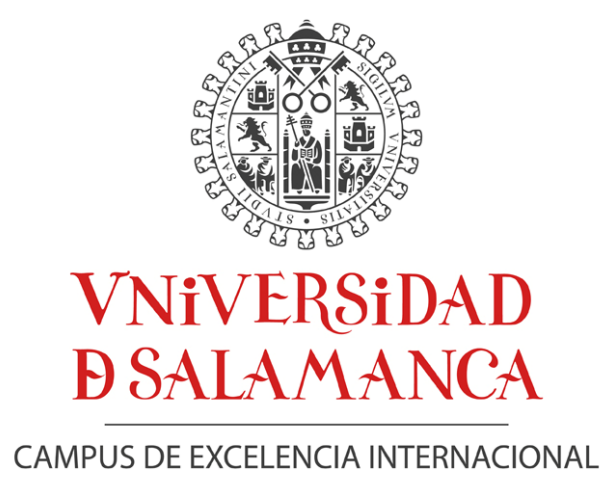

Facultad de Geografía e Historia

Departamento de Historia Medieval, Moderna y Contemporánea

TESIS DOCTORAL

\title{
TÓPICOS Y CONTINUIDADES EN EL DISCURSO SOBRE LA EXPANSIÓN Y EN LA REAFIRMACIÓN DE LA MONARQUÍA CASTELLANA (SIGLOS XII Y XIII): UNA PROPUESTA DE ANÁLISIS DE LA CRONÍSTICA EN LA RECONQUISTA
}

Autor:

Raimundo Meneghello Matte

Directores:

Dr. José Luis Martín Martín

(U. de Salamanca)
Dr. Diego Melo Carrasco

(U. Adolfo Ibáñez) 
A Consuelo que comenzó junto a mí este camino.

A Leonor que llegó al final para darle sentido a todo. 


\section{Prefacio y Agradecimientos}

Cuando el 2008 inicié mis estudios doctorales, jamás dimensioné el enorme compromiso que estaba adquiriendo. No se trataba solamente de la confección de una tesis (la que demoró mucho más de lo que planeé en un principio) sino el reconocerme como devoto a una disciplina y una temática, no siempre grata, pero siempre gratificante.

A lo largo de estos años han existido muchos sinsabores y desventuras, así como momentos de felicidad y de logros. En especial por la dificultad de compaginar este trabajo con la vida familiar y profesional y todo ello sumado a las dificultades de trabajar desde un país muy alejado de las fuentes, bibliotecas y archivos españoles. Pero todo ello confluyó para el logro de este producto de la globalización, una tesis sobe la Castilla Medieval escrita por un chileno con apellido italiano.

Al llegar al final de este camino son muchas las personas a las cuales debo mi reconocimiento, por su guía, consejos o simplemente por estar ahí.

En primer lugar, al Dr. José Luis Martín que desde un principio estuvo dispuesto a guiar esta tesis, aun cuando no era más que una idea muy alejada de lo que ahora es, y yo apenas un estudiante de posgrado al que acababa de conocer. A Diego Melo, un amigo que se comprometió en el momento más oportuno y dio todo de sí en forma totalmente desinteresada. Ambos, mis Directores, fueron quienes dedicadamente orientaron y revisaron este trabajo una y otra vez y me tuvieron una infinita paciencia para corregirme

$y$ levantarme en cada uno de mis tropiezos. A Ángel Gordo, que siempre estuvo presto a extenderme su mano y darme sus consejos y palabras de apoyo. A Ítalo Fuentes, de quien aprendí ese extraño amor a la Edad Media.

No puedo dejar de agradecer a Francisco Belmar y a Mathias Mellado, quienes tuvieron el ingrato trabajo de hacer las transcripciones y pasar en limpio miles de fichas, un trabajo lento y tedioso, pero que supieron hacer con meticulosidad y compromiso.

También existen otros tantos que de forma consciente o no fueron claves para la culminación de este trabajo. El personal de la biblioteca de la Universidad de Salamanca y tantos profesores con los que intercambié opiniones y recibí consejos.

Por último a mi familia, en especial a mis padres, que siempre han creído en mí y que sin ellos no sería la persona que soy.

A todos ellos mis más profundas gratitudes, puesto que sin ellos estas 663 páginas, 316.076 palabras y 6.044 párrafos nunca hubiesen visto la luz.

Santiago de Chile, diciembre de 2014 
Y después de que lo haya leido y se haya enterado de todo, colóquelo en su lugary permanezca allí para siempre y ninguno de alli lo robe ni se lo lleve por medio del fraude

o la artimaña.

Y si alguno lo hiciera o sin saberlo lo robara o por medio de algún engaño lo destruyera, por la autoridad de Dios omnipotente y de la bienaventurada Virgen María y de los santos apóstoles Pedro y Pablo y del gloriosísimo Santiago y de todos los santos de Dios y por nuestra propia autoridad, sea maldito y excomulgado y condenado en el infierno para siempre junto con Judas, el traidor del Señor, y con Datán y Abirón, a los que tragó la tierra estando aún vivos. Amén, amén. Y quien lo guarde y custodie bien, sea bendito por Dios Padre omnipotente y por su discípulo el santo apóstol Santiago y santificado por los siglos de los siglos. Amén.

Historia Compostelana, Libro I. 


\section{ÍNDICE}

Fuentes y Abreviaturas

p. 8

Introducción

$\begin{array}{ll}\text { I. De las motivaciones de esta tesis } & \text { p. } 12\end{array}$

$\begin{array}{ll}\text { II. Sobre la Metodología de análisis } & \text { p. } 17\end{array}$

$\begin{array}{ll}\text { III. Hipótesis y objetivos } & \text { p. } 24\end{array}$

$\begin{array}{ll}\text { IV. Estado de la cuestión } & \text { p. } 27\end{array}$

$\begin{array}{ll}\text { VII. Estructura } & \text { p. } 51\end{array}$

\section{PRIMERA PARTE: CONTEXTO HISTÓRICO}

\section{I.1.- El Cristianismo y el Islam dos culturas enfrentadas en el marco peninsular}

I.1.a.- El Cristianismo y el Islam en Castilla y León:

$\begin{array}{ll}\text { del discurso a la práctica p. } 58 & \text { p }\end{array}$

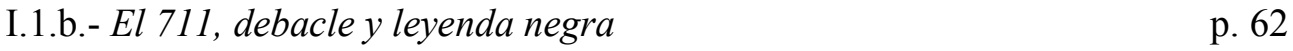

I.1.c.- Siglo XI. Se inicia la Reconquista, el moro enemigo o $\begin{array}{ll}\text { aliado tolerado } & \text { p. } 67\end{array}$

I.1.d.- Siglos XII-XIII. Avanza la reconquista y la intolerancia p. 70

\section{I.2.- Guerra santa y cruzada: la instrumentalización religiosa} de la práctica bélica

I.2.a.- La guerra justa: de la Antigüedad tardía a la Alta Edad Media p. 88

$\begin{array}{lr}\text { I.2.b.- De la Guerra santa a la Cruzada p. } 99 & 99\end{array}$

\section{I.3.- La Guerra Santa y la Cruzada, el caso hispano medieval}

I.3.a.- Discusiones en torno al uso de los conceptos:

De Asturias a la Reconquista

p. 116

I.3.b- Reconquista, Monarquía e Iglesia

p. 123 


\section{SEGUNDA PARTE: LAS FUENTES: LA CONSTRUCCIÓN DE INSTRUMENTOS IDEOLÓGICOS}

\section{II.1.- La historiografía medieval, fusión de lo clásico y lo "bárbaro":}

el caso hispano.

II.1.a.- Panorama general.

p. 147

II.1.b.- La historiografía de la Reconquista: Siglos VIII-X

p. 153

II.1.c.- La historiografía de la Reconquista: Siglos XI-XIII

p. 158

\section{II.2.- Las Crónicas y la hagiografía en el discurso de la Reconquista}

II.2.a.- Cronistas, crónicas: vidas y contextos

p. 164

II.2.b.- La hagiografía, la mano de Dios

p. 188

II.2.c.- La demonización del Islam: proceso ideológico y realidad práctica

p. 192

II.2.d.- El caso de Mahoma: la construcción de una imagen malévola

p. 198

II.2.e.- El escenario fronterizo y algunos intentos de comprensión del Islam p. 201

II.2.f.- Las matanzas: la muerte instrumentalizada

p. 207

II.2.g.- Botín, aspectos materiales y humanos

p. 223

II.2.h.- La imagen de los musulmanes y el ordenamiento de la

frontera en Alfonso X: Realidad y práctica

p. 234

\section{II.3.- La figura del rey y la Reconquista}

II.3.a.- La figura del monarca, orígenes y evolución. p. 243

$\begin{array}{ll}\text { II.3.b.- El caso hispano, los monarcas visigodos } & \text { p. } 251\end{array}$

$\begin{array}{ll}\text { II.3.c.- Los monarcas de la Reconquista } & \text { p. } 261\end{array}$

\section{II.4.- Las virtudes del rey: Construcción de un ideal monárquico}

$\begin{array}{ll}\text { II.4.a.- Linaje visigodo y continuidad } & \text { p. } 267\end{array}$

$\begin{array}{ll}\text { II.4.b.- Virtudes religiosas } & \text { p. } 283\end{array}$

$\begin{array}{lr}\text { II.4.c.- Validación Bélica } & \text { p. } 289\end{array}$

$\begin{array}{ll}\text { II.4.d.-Validación jurídica } & \text { p. } 298\end{array}$

$\begin{array}{ll}\text { II.4.e.- Virtudes morales } & \text { p. } 305\end{array}$ 


\section{TERCERA PARTE: LOS TÓPICOS}

\section{III.1.- EI Dios de la guerra}

III.1.a.- Providencialismo: Dios, juez y parte en los hechos de los hombres p. 313

III.1.b.- Providencialismo hispano-visigodo p. 317

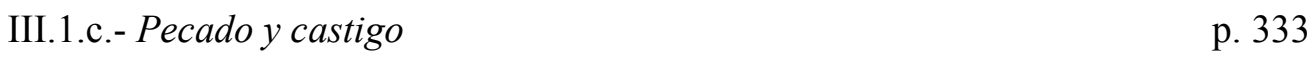

III.1d.- El siglo XIII. Dios y los hombres, consolidación y cambios p. 343

III.2.- Los santos guerreros al servicio de la causa cristiana

III.2.a.- Los Mensajeros celestes: de oriente a occidente p. 354

III.2.b.- Los mensajeros celestes en Hispania p. 362

$\begin{array}{ll}\text { III.2.c.- Santiago p. } 368 & \text { po }\end{array}$

$\begin{array}{ll}\text { III.2.d.- San Isidoro } & \text { p. } 387\end{array}$

III.2.e.- Santa María p. 397

$\begin{array}{ll}\text { III.2.f.- Santos de la frontera } & \text { p. } 404\end{array}$

III.2.g.- Santo Domingo de Silos p. 405

III.2.h.- San Millán de la Cogolla p. 410

$\begin{array}{ll}\text { III.2.i.- Otros santos y mensajeros celestes } & \text { p. } 412\end{array}$

III.3.- Las dadivas divinas y los rituales de la guerra

III.3.a.- Las dádivas divinas: recompensas espirituales, indulgencias $\quad$ p. 419

III.3.b.- Martirio p. 430

III.3.c.- Rituales bélico-religiosos en occidente p. 435

III.3.d.- Ritos de preparación al combate p. 438

III.3.e.- Ritos de Victoria p. 448

III.3.f.- Ritos de purificación de los lugares conquistados p. 455

III.4.- Los Reyes modélicos: Siglos XII y XIII

III.4.a.- Alfonso $V I \quad$ p. 463

III.4.a.- Alfonso VII p. 475

III.4.a.- Alfonso VIII p. 481

III.4.a.- Fernando III p. 486

$\begin{array}{ll}\text { III.4.a.- Alfonso } X & \text { p. } 494\end{array}$

$\begin{array}{ll}\text { Conclusiones } & \text { p. } 507\end{array}$

$\begin{array}{ll}\text { Bibliografía } & \text { p. } 518\end{array}$

$\begin{array}{ll}\text { Anexos } & \text { p. } 558\end{array}$ 


\section{Siglas y Abreviaturas}

\begin{tabular}{|c|c|}
\hline $\begin{array}{l}\text { "Annales Toledanos", en Las crónicas latinas de la Reconquista, } \\
\text { estudios prácticos de latín medieval por A. Huici, España, } \\
\text { Establecimiento Tip, Hijos de F. Vives Mora, 1913, } \\
\text { Volumen I. }\end{array}$ & AT 1913 \\
\hline $\begin{array}{l}\text { Los anales toledanos I y II, Edición de Julio Porres Martín-Cleto, } \\
\text { Toledo, Instituto provincial de Investigaciones y Estudios } \\
\text { Toledanos, Diputación Provincial de Toledo, } 1993 .\end{array}$ & AT 1993 \\
\hline $\begin{array}{l}\text { Crónica del Obispo de Oviedo don Pelayo, en Casariego, J.A., } \\
\text { Crónicas de los Reinos de Asturias y León, León, Everest, } \\
1985 .\end{array}$ & COP \\
\hline $\begin{array}{l}\text { Chronica latina regum castellae, Corpus Christianorum, } \\
\text { Continuatio Mediaevalis, LXXIII, Chronica Hispana } \\
\text { Saecvli XIII, Turnholti, Typographi Brepols Editores } \\
\text { Pontificii, MCMXCVII. }\end{array}$ & CLRC \\
\hline $\begin{array}{l}\text { Crónica Latina de los Reyes de Castilla, edición de Luis Charlo } \\
\text { Brea, Madrid, Akal, } 1999 .\end{array}$ & CLRC 1999 \\
\hline $\begin{array}{l}\text { Chronica Adefonsi Imperatoris, Edición y estudio por Luis } \\
\text { Sánchez Belda, Madrid, CSIC., Escuela de Estudios } \\
\text { Medievales, 1950. }\end{array}$ & CAI \\
\hline $\begin{array}{l}\text { Crónica del Emperador Alfonso VII, Introducción, traducción, } \\
\text { notas e índices por Maurilio Pérez González, León, } \\
\text { Universidad de León, } 1997 .\end{array}$ & CEA \\
\hline $\begin{array}{c}\text { Chronica Naierensis, Chronica Hispana saeculi XII. Pars II, Cura } \\
\text { et studio Juan A. Estévez Sola, Brepols, Turnhout, } 1995 .\end{array}$ & CN 1995 \\
\hline $\begin{array}{l}\text { Crónica Najerense, Edición de Juan A. Estévez Sola Tres Cantos, } \\
\text { Madrid, Akal, } 2003 .\end{array}$ & CN 2003 \\
\hline $\begin{array}{l}\text { Crónica de Alfonso X, según el Ms. II/2777 de la Biblioteca del } \\
\text { Palacio Real, edición, trascripción y notas por Manuel } \\
\text { González Jiménez, Madrid, Real Academia de Alfonso X } \\
\text { el Sabio, } 1999 \text {. }\end{array}$ & CAX \\
\hline Crónica de Veinte Reyes, Burgos, Ayuntamiento de Burgos, 1991. & CXXR \\
\hline $\begin{array}{l}\text { Crónica mozárabe de 754, Edición crítica y traducción por José } \\
\text { Eduardo López Pereira, Zaragoza, Anubar, } 1980 .\end{array}$ & CM 754 \\
\hline $\begin{array}{l}\text { Crónicas Anónimas de Sahagún, Edición crítica, nota e índice por } \\
\text { Antonio Ubieto Artera, Zaragoza, Anubar, } 1987 .\end{array}$ & CAS \\
\hline $\begin{array}{l}\text { Crónicas asturianas: Crónica de Alfonso III (Rotense y "A } \\
\text { Sebastián"), Crónica albeldense (y "profética"), } \\
\text { Introducción y edición crítica de Juan Gil Fernández; } \\
\text { traducción y notas de José L. Moralejo, estudio preliminar } \\
\text { de Juan I. Ruiz de la Peña, Oviedo, Universidad de } \\
\text { Oviedo, 1985. }\end{array}$ & CAIII \\
\hline $\begin{array}{l}\text { El Cronicón del Silense, en Las Crónicas Latinas de la } \\
\text { Reconquista, Tomo II, Estudios prácticos de latín } \\
\text { medieval por Ambrosio Huici, Valencia, Establecimiento } \\
\text { tipográfico Hijos de F. Vives Mora, 1913. }\end{array}$ & $\mathrm{CS}$ \\
\hline $\begin{array}{l}\text { Historia Silense, Edición crítica e introducción por Dom Justo } \\
\text { Pérez de Urbel y Atilano González Ruiz-Zorrilla, Madrid, } \\
\text { Escuela de Estudios Medievales, } 1959 .\end{array}$ & $\mathrm{HS}$ \\
\hline
\end{tabular}




\begin{tabular}{|c|c|}
\hline $\begin{array}{l}\text { "Chronicon Sampiri Episcopi Asturicensis", en Las crónicas } \\
\text { latinas de la Reconquista, estudios prácticos de latín } \\
\text { medieval por A. Huici, España, Establecimiento Tip, Hijos } \\
\text { de F. Vives Mora, 1913, Volumen I. }\end{array}$ & CSEA \\
\hline $\begin{array}{l}\text { Historia Compostelana, Edición de Emma Falque, Madrid, Akal, } \\
1994 .\end{array}$ & HC 1994 \\
\hline $\begin{array}{l}\text { Historia Compostella, Cura et Studio Emma Falque Rey, Brepols, } \\
\text { Turnholti, } 1988 .\end{array}$ & HC 1988 \\
\hline $\begin{array}{l}\text { Ibn 'Idari al-Marrakusi, La caída del Califato de Córdoba y los } \\
\text { reyes de Taifas, estudio, traducción y notas de Felipe } \\
\text { Maillo Salgado, Salamanca, Universidad de Salamanca, } \\
\text { 1993. }\end{array}$ & $\mathrm{CCC}$ \\
\hline $\begin{array}{l}\text { Jiménez de Rada, Rodrigo, Historia Arabvm, Introducción, } \\
\text { Edición crítica, notas e índice de José Lozano Sánchez, } \\
\text { Sevilla, Universidad de Sevilla, } 1993 .\end{array}$ & HA \\
\hline $\begin{array}{l}\text { Jiménez de Rada, Rodrigo, Historia de los hechos de España, } \\
\text { Introducción, traducción, notas e índices de Juan } \\
\text { Fernández Valverde, Madrid, Alianza, } 1989 .\end{array}$ & HHE \\
\hline $\begin{array}{l}\text { Jiménez de Rada, Rodrigo, Opera Omnia, Pars I, Historia de } \\
\text { rebus Hispaniae, Corpus Christianorum, Continuatio } \\
\text { Mediaevalis, LXXII, Turnholti, Typographi Brepols } \\
\text { Editores Pontificii, MCMLXXXVIII. }\end{array}$ & $\mathrm{HRH}$ \\
\hline $\begin{array}{l}\text { Liber Sancti Jacobi “Codex calixtinus", Traducción de Abelardo } \\
\text { Moralejo, Casimiro Torres y Julio Feo, Galicia, Xunta de } \\
\text { Galicia, 2004. }\end{array}$ & LSJ 2004 \\
\hline $\begin{array}{l}\text { Liber Sancti Jacobi: Codex Calixtinus, Edición de K. Herbers y } \\
\text { M. Santos Noia, Galicia, Xunta de Galicia, D.L. } 1998 .\end{array}$ & LSJ 1998 \\
\hline $\begin{array}{l}\text { López Guil, Itzíar, Libro de Fernán Gonçález, Madrid, CSIC., } \\
\text { Instituto de la Lengua española, 2001. }\end{array}$ & LFG \\
\hline $\begin{array}{l}\text { Lucae Tudensis, Opera Omnia, Chronicon Mundi, Cura et studio } \\
\text { Emma Falque, Corpus Christianorum, Continuatio } \\
\text { Mediaevalis, LXXIV, Bélgica, Brepols Publishers, 2003. }\end{array}$ & $\mathrm{CM}$ \\
\hline $\begin{array}{l}\text { Tuy, Lucas de, Crónica de España, Primera edición del texto } \\
\text { romanceado, conforme a una copia de la Academia } \\
\text { preparada y prologada por Julio Puyol, Madrid, } 1926 .\end{array}$ & $\mathrm{CE}$ \\
\hline $\begin{array}{l}\text { Primera Crónica General de España, Editada por Ramón } \\
\text { Menéndez Pidal con un estudio actualizador de Diego } \\
\text { Catalán, } 2^{\circ} \text { tomo de la tercera reimpresión, Madrid, } \\
\text { Gredos, } 1977 .\end{array}$ & CGE \\
\hline $\begin{array}{l}\text { Alfonso X el Sabio, Cantigas de Santa María. Códice Rico de El } \\
\text { Escorial, Ms. escurialense T.I.1. Introducción, versión } \\
\text { castellana y comentarios de José Filgueira Valverde, } \\
\text { Madrid, Castalia, } 1985 .\end{array}$ & CSM 1985 \\
\hline $\begin{array}{l}\text { Alfonso X el Sabio, Cantigas de Santa María, editadas por } \\
\text { Walter Mettmann, Madrid, Ediciones Xerais de Galicia, } \\
\text { 1981. }\end{array}$ & CSM 1981 \\
\hline $\begin{array}{l}\text { Cantigas de Santa María de Alfonso X el Sabio, Rey de Castilla, } \\
\text { Estudio Preliminar por Matilde López Serrano, Madrid, } \\
\text { Editorial Patrimonio Nacional, } 1974 .\end{array}$ & CSM 1974 \\
\hline
\end{tabular}




\begin{tabular}{|c|c|}
\hline $\begin{array}{l}\text { Gonzalo de Berceo, Milagros de Nuestra Señora; Vida de santo } \\
\text { Domingo de Silos; Vida de san Millán de la Cogolla; Vida } \\
\text { de santa Oria; Martirio de san Lorenzo, Prólogo y versión } \\
\text { moderna de Amancio Bolaño e Isla, México, Porrua, } 1969 .\end{array}$ & MNS \\
\hline $\begin{array}{l}\text { La "Vita Dominici Siliensis" de Grimaldo, estudio, edición crítica } \\
\text { y traducción de Vitalino Valcarcel. Logroño, Instituto de } \\
\text { Estudios Riojanos, } 1982 .\end{array}$ & VDS \\
\hline $\begin{array}{l}\text { Los "Miraculos romançados" de Pero Marín, edición crítica, } \\
\text { introducción e índices por Karl-Heinz Antón, Abadía de } \\
\text { Silos, } 1988 .\end{array}$ & MR \\
\hline $\begin{array}{l}\text { Tuy, Lucas de, Milagros de san Isidoro, traducción de Juan de } \\
\text { Robles (1525), Trascripción, prólogo y notas de Julio } \\
\text { Pérez Llamazares (1947), León, Universidad de León, } \\
1992 .\end{array}$ & MSI \\
\hline $\begin{array}{c}\text { Alfonso X el Sabio, Fuero Real, Edición, estudio y glosario de } \\
\text { Azucena Palacios Alcaine, Barcelona, PPU, } 1991 .\end{array}$ & FR \\
\hline $\begin{array}{l}\text { El Fuero de Coria, Estudio histórico-jurídico por José Maldonado } \\
\text { y Fernández del Torco; trascripción y fijación del texto } \\
\text { por Emilio Sáez; con prólogo del Excmo. Sr. D. José } \\
\text { Fernández Hernando, Instituto de Estudios de } \\
\text { Administración Local, } 1949 .\end{array}$ & $\mathrm{FC}$ \\
\hline $\begin{array}{c}\text { El fuero de Cuenca, } 2^{\mathrm{a}} \text { Edición, Introducción, traducción y notas } \\
\text { de Alfredo Valmaña Vicente, Cuenca, Torno, } 1978 .\end{array}$ & FCc \\
\hline $\begin{array}{c}\text { Las siete partidas del rey don Alfonso el Sabio, Cotejadas con } \\
\text { varios códices antiguos por la Real Academia de la } \\
\text { Historia, Tomo III, Madrid, Imprenta Real, } 1807 .\end{array}$ & LSP \\
\hline $\begin{array}{l}\text { Lumbreras Valiente, Pedro, Los fueros municipales de Cáceres su } \\
\text { derecho publico, Cáceres, Ayuntamiento de Cáceres, } \\
\text { 1974. }\end{array}$ & FCs \\
\hline $\begin{array}{l}\text { Aquino, Tomas de, Suma Teológica, Parte II-II (a), Madrid, } \\
\text { Biblioteca de Autores Cristianos, } 1990 .\end{array}$ & ST 1990 \\
\hline $\begin{array}{l}\text { Aquino, Tomas de, Suma Teológica, Traducción y Anotaciones } \\
\text { de Francisco Barbado Viejo O.P., Madrid, Biblioteca de } \\
\text { Autores Cristianos, } 1959 .\end{array}$ & ST 1959 \\
\hline $\begin{array}{l}\text { Cantar de Mío Cid, edición, prologo y notas de Alberto } \\
\text { Montaner, Estudio preliminar de Francisco Rico, } \\
\text { Barcelona, Centro para la Edición de los Clásicos } \\
\text { Españoles, } 2007 .\end{array}$ & $\mathrm{CMC}$ \\
\hline $\begin{array}{l}\text { Claraval, Bernardo de, Elogio de la Nueva milicia templaria, } \\
\text { Madrid, Siruela, } 2005 .\end{array}$ & ENMT \\
\hline $\begin{array}{l}\text { El libro de los doze sabios o Tratado de la nobleza y lealtad [ca. } \\
\text { 1237], Real Academia Española de la Lengua (Anexos del } \\
\text { Boletín de la RAE, XXIX), Madrid 1975, páginas 71-118, } \\
\text { en: http://www.filosofia.org/aut/001/12sabios.htm. }\end{array}$ & LDS \\
\hline $\begin{array}{l}\text { Gil de Zamora, Juan, De preconiis Hispanie o Educación del } \\
\text { príncipe, traducción y estudio José-Luis Martín, Jenaro } \\
\text { Costas, Ayuntamiento de Zamora, 1996. }\end{array}$ & $\mathrm{DPH}$ \\
\hline $\begin{array}{l}\text { Hipona, Agustín de, De civitate Dei, en } \\
\text { http://www.augustinus.it/latino/cdd/index2.htm. }\end{array}$ & DCD \\
\hline
\end{tabular}




\begin{tabular}{|c|l|}
\hline $\begin{array}{c}\text { Hipona, Agustín de, La Ciudad de Dios, traducción de Santos } \\
\text { Sartamarta del Río, Madrid, Biblioteca Homo Legens, } \\
2006 .\end{array}$ & DCD 2006 \\
\hline $\begin{array}{l}\text { Orosio, Paulo, Historia contra los paganos, Estudio preliminar, } \\
\text { versión y notas de Enrique Gallego-Blanco, Barcelona, } \\
\text { Puvill Libros, 1983. }\end{array}$ & HCP \\
\hline $\begin{array}{c}\text { Sevilla, Isidoro de, Las historias de los godos, vándalos y suevos, } \\
\text { Estudio, edición crítica y traducción de Cristóbal } \\
\text { Rodríguez Alonso, León, Centro de Estudios e } \\
\text { investigación "San Isidoro", 1975 }\end{array}$ & HGVS \\
\hline $\begin{array}{l}\text { Aquino, Tomas de, Suma Teológica, Parte II-II (a), Madrid, } \\
\text { Biblioteca de Autores Cristianos, 1990. }\end{array}$ & ST 1990 \\
\hline
\end{tabular}




\section{INTRODUCCIÓN}

\section{De las motivaciones de esta tesis}

El periodo de la Reconquista, comprendido entre los siglos XII y XIII, ha sido uno de los temas predilectos de la historiografía hispánica, en razón de que, junto con el siglo anterior, comprenden una de las etapas de mayores transformaciones en el escenario peninsular. Como consecuencia se ha producido un abundante cuerpo bibliográfico que ha abordado las áreas más diversas, como la historia militar, la frontera, el comercio, las treguas, las relaciones entre los distintos estamentos sociales, la construcción de la monarquía y el rol de la Iglesia, entre otros. Todos ellos trabajos que en distintas medidas han contribuido a construir un completo panorama del periodo.

Desde esta perspectiva puede parecer arriesgado el estudiar esta época a partir de fuentes tradicionales como son las crónicas y hagiografías, en el entendido de que el discurso de las mismas ya ha sido estudiados incluso, en este momento, por medievalistas como Carlos de Ayala, Amancio Isla, Ana Rodríguez, Martín Ríos Saloma, Margarita Torres Sevilla, Inés Calderón Medina, José Manuel Nieto Soria y Carlos Estepa, solo por nombrar algunos. No obstante ello, es nuestro interés concentrarnos en esta época con la intención de, a través de una mirada amplia intentar sintetizar parte de este saber, con el fin de ayudar a la categorización del conocimiento del periodo, contribuyendo a la disciplina por medio de la sistematización de una información contenida en las crónicas y que constituye parte de un relato compuesto de un significativo lenguaje simbólico, elemental para la comprensión del discurso cronístico en Castilla, y secundariamente en León, durante los siglos XII y XIII.

Nuestro eje de análisis se remite al reino castellano en razón de que si bien, durante parte importante de nuestro periodo de estudio, se encontró unido con León, en sus momentos independientes se convirtió en un eje central del avance hacia el sur y construyó su propio discurso validador, basado en el linaje de sus monarcas y la victoria militar sobre sus enemigos, cristianos y musulmanes. 
Es en ese contexto en que la cronística consolidó una serie de tópicos ${ }^{1}$ que se mantuvieron y perfeccionaron a lo largo de esos doscientos años, y que reflejaron el modelo de monarquía y de reino que se estaba configurando. Estos tópicos se concentraron en torno a la figura del monarca, de la guerra contra el Islam, las prácticas religiosos y el providencialismo, constituyendo un todo ideológico que podía ser aplicable a distintos reyes y épocas, adaptando el uso de los mismos, según las necesidades y contexto del momento.

Es así como nuestro trabajo se concentra en el uso de estos tópicos en el discurso cronístico y como estos pueden ser contrastados en su uso con la realidad práctica ${ }^{2}$. Por ello hemos buscado identificar los conceptos más amplios posibles, con el fin de que reflejen su uso y significancia. De esta manera hemos podido dividir nuestros tópicos en aquellos vinculados directamente al monarca, lo que hemos llamado las virtudes reales, siendo estas religiosas, militares, jurídicas y morales. Las que a su vez se ven complementadas con otros conceptos constitutivos del discurso y que reflejan la forma en que el monarca relacionaba los elementos culturales y prácticos, como el providencialismo, la Iglesia y la idea de cruzada. Construyéndose así, por parte de los cronistas, un relato coherente y unitario, que si bien es atestiguable en los siglos anteriores, se encuentra claramente perfilado en los siglos XII y XIII.

Para que el discurso cronístico pudiese llevar a cabo estos objetivos, era necesario, en palabras de Margarita Torres Sevilla, cumplir con cinco reglas: la simplificación, es decir que el mensaje sea breve, claro y centrado en un objetivo preciso; que recurra a la desfiguración o engrandeciendo, que exagere y repita para exacerbar las filias y fobias comunes del receptor; que tenga una orquestación, es decir que el mismo mensaje se

\footnotetext{
${ }^{1}$ Por tópico acogemos la acepción del termino para la retórica según la RAE que lo define como: "Lugar común que la retórica antigua convirtió en fórmulas o clichés fijos y admitidos en esquemas formales o conceptuales de que se sirvieron los escritores con frecuencia." (http://lema.rae.es/drae/?val=topicos. 31 de julio de 2014) En otras palabras nos referimos a los términos más utilizados por los cronistas y que prácticamente no experimentaron variaciones en su significado en el trascurso de nuestro periodo de estudio, constituyéndose en una suerte de lugar común en el discurso cronístico.

${ }^{2}$ Respecto al uso de las crónicas y su impacto en el conjunto de la sociedad peninsular, es importante establecer que, siguiendo los postulados de Ladero Quesada, para el contexto en que nos movemos, es en extremo complejo separar lo oral de lo escrito en razón de que hablamos de una sociedad mayoritariamente analfabeta y donde la trasmisión del conocimiento era vertical. Misma razón que explica la importancia del peso de los conceptos y las formas de trasmisión de los acontecimientos, ya que es muy distinta la comprensión actual de esos testimonios al significado que pudo tener en su época de origen. Para más referencias sobre esta problemática ver Ladero Quesada, Miguel Ángel, "Comunicación y propaganda de creencias, opiniones e ideas en la Europa de los siglos XIV y XV", en Revista de la Universidad Complutense de Madrid, $\mathrm{N}^{\circ}$ 3, 1981, pp. 193-211.
} 
trasmita por diversos cauces paralelos con el fin de saturar al público objetivo; que posea mecanismos de contagio o unanimidad, para ello debe impactar primeramente a las elites y luego esparcirse por las masas; y finalmente ejercer como contra propaganda para contrarrestar el discurso del oponente, al que se caricaturiza, menosprecia y ridiculiza para neutralizarlo"3. Elementos que se pueden observar en la cronística y hagiografías a través de instrumentos como la repetición constante, mediante un lenguaje directo y claro, de episodios en los cuales son frecuentes las exageraciones, mismas que se pueden encontrar en distintas fuentes, siempre procurando exaltar a las elites del reino y descalificando a los enemigos, musulmanes o cristianos, acusándoseles de traidores, mentirosos, lujuriosos, cobardes, etc.

Dado lo anterior, nuestro trabajo puede encuadrarse, en parte, dentro del área metodológica del análisis de contenido, específicamente dentro del ámbito cronístico, en el entendido de que refleja la mentalidad del autor de la obra, es decir como el cronista comprende e interpreta su realidad, a la vez que proyecta una imagen idealizada de la misma ${ }^{4}$. Es de destacar que la mentalidad debe ser comprendida, según Bouthoul, como un elemento común a los miembros de una civilización y uno de los lazos identitario y de unión más poderosos ${ }^{5}$. Para nuestro caso de estudio, parte significativa de esta mentalidad estaba compuesta por el pensamiento cristiano providencialista, el que permeó todos los aspectos del discurso e incluso de la realidad, desde las instituciones como la monarquía hasta los personajes individuales, sin que existiesen verdaderas divisiones entre lo sagrado y lo profano ${ }^{6}$. Lo que se evidencia en las crónicas y en similar medida en las hagiografías, obras que deben ser entendidas como un recipiente de los mensajes simbólicos de y para una sociedad ${ }^{7}$.

\footnotetext{
3 Torres Sevilla, Margarita, "La propaganda y sus técnicas en las crónicas leonesas y castellanas (siglos IX-XIII)", en Aragón en la Historia, N 18, 2004, Universidad de Zaragoza, [pp. 57-82], p. 66.

${ }^{4}$ En lo posible queremos evitar el uso del concepto de propaganda para referirnos a este discurso. Ello en razón de la carga ideológica que tiene este concepto, no obstante reconocemos que en algunos aspectos este discurso cronístico puede ser interpretado de esta forma, en especial por su característica de editar y manipular los hechos de forma premeditada, omitiendo acontecimientos o exagerándolos, con el fin de adaptar el relato a las intenciones del autor. En ese sentido es que compartimos los postulados de Margarita Torres Sevilla en su articulo "La propaganda y sus técnicas... op. cit., p. 58.

${ }^{5}$ Bouthoul, Gastón, Las Mentalidades, ¿Qué sé?, No 21, Barcelona, Oikos-tau, 1971, p. 31.

${ }^{6}$ Bertelli, Sergio, “«Religio Regis» la propaganda del poder real”, en Medievalismo, Año 8, N 8, Madrid, 1998, [pp. 9-18], p. 12.

${ }^{7}$ Tuliani, Mauricio, "La idea de Reconquista en un manuscrito del la Crónica General de Alfonso X el sabio”, en Studia Historica. Historia Medieval, Vol. 12, 1994, Salamanca, [pp. 3-23] pp. 6, 7.
} 
Visto lo anterior fue necesario que este discurso crease tópicos que se convirtieron en parte integral de la interpretación de la sociedad, con el fin de crear instancias identitarias $^{8}$ que sirvieran a los propósitos reconquistadores de la elite, a la que pertenecían los cronistas, y desde allí permeasen, mediante la oralidad, a las restantes capas sociales, para lo cual era necesario contar con cierto grado de complicidad por parte del público objetivo, es decir que este se encontraba dispuesto a creer en los relatos, en parte gracias a la existencia de creencias, lenguaje y tópicos comunes ${ }^{9}$. Estos tópicos, pueden ser asimilados a los que Bouthoul, parafraseando a Fouillée, refiere como las "ideas-fuerza", palabras que en una sociedad determinada pueden llegar a tener una potencia objetiva cuando su valor y credibilidad han sido aceptados por $\operatorname{todos}^{10}$. Es decir se trata de conceptos fácilmente identificables y asimilables por todos los componentes sociales que reconocen en ellos un valor intrínsico y prácticamente incuestionable. A nuestro entender, tales serian los casos de conceptos como rey, justicia, castigo, guerra, religión, etc... Conceptos y realidades que revelan, según Má́llo Salgado, el hecho de que todo discurso esta penetrado por una ideología ${ }^{11}$ de clase -las elites en nuestro caso- razón por la cual las palabras pierden su neutralidad

\footnotetext{
${ }^{8}$ Estas instancias son parte de lo que nosotros identificamos como un Ideal identitario, lo que entendemos como el conjunto de ideas que, observables en las fuentes, sirven para caracterizar la concepción que de si mismo tenían los hispanos, o al menos las que los cronistas pretendían imponer como una visión de su propia sociedad.

El origen de este ideal se remonta a los tiempos visigodos y a pensadores como Isidoro de Sevilla que a través de sus obras establecieron la creencia de que los visigodos constituían un pueblo señalado por la providencia y destinado a regir Hispania. Una autoconcepción, que luego de la irrupción islámica fue asociada al convencimiento de la necesidad de recuperar las tierras ancestrales para los descendientes de los godos y la cristiandad. Convicción que se reflejó en las crónicas castellanos y leonesas, a través de la descripción de los hispanos como un pueblo de guerreros cristianos, valientes y esforzados, que pese a sus pecados luchan por la recuperación de la tierra santa peninsular, bajo el liderazgo de sus reyes.

${ }^{9}$ Torres Sevilla, Margarita "La propaganda y sus técnicas... op. cit., p. 65.

${ }^{10}$ Bouthoul, Gastón, Las Mentalidades... op. cit., p. 60.

${ }^{11}$ Respecto al concepto de ideología, aceptamos la caracterización de Nieto Soria que dice "Siempre supone un sistema completo en sí mismo que provoca cierta seguridad en el individuo, así como una visión más o menos deformada de las realidades que produce la incuestionabilidad de determinadas creencias esenciales en el sistema ideológico de que se trate. Tienden a la búsqueda de formas de estabilización o, más raramente, de limitada transformación siempre controlada, siendo ello consecuencia de que toda ideología se asienta sobre un determinado sistema de valores que se pretende inmutable. Las mutaciones que se producen en las realidades concretas siempre se reflejan con extraordinario retraso en los sistemas ideológicos, teniendo, por tanto, toda ideología, por definición, un importante componente conservador. Una ideología política tiene, como uno de sus caracteres esenciales, la disponibilidad de un amplio conjunto de signos y símbolos que actúan como formas elementales de comunicación y propagación de los contenidos propios de esa ideología, aunque en su forma más simplificada. Entre sus funciones se encuentra la de justificar determinados comportamientos, jugando en ello un papel muy importante la utilización del tópico y del lugar común, disponiendo de un cierto abanico de fórmulas retóricas. En todos estos aspectos de comunicación, justificación y explicitación desarrollan un papel muy importante los denominados aparatos ideológicos, cuyos caracteres contribuyen significativamente a definir un sistema político." (Nieto Soria, José Manuel, "La ideología política bajomedieval en la historiografía española", en Hispania, Revista española de historia, Vol. 50, № 175, 1990 [pp. 667-681] p. 668)
} 
ideológica, tornando las palabras mismas en estereotipos significativos, que revelan la ideología del autor ${ }^{12}$. Una ideología, que además, debe servir para integrar, identificar y promover los sentimientos de pertenecía de los miembros de una comunidad, al mismo tiempo que sirve para que esta se justifique como sociedad ${ }^{13}$. Es por ello que para el estudio de este discurso se debe considerar que los aspectos de lo material y lo mental se encuentran relacionados, influenciándose mutuamente, por lo que se hace necesario conocer a los productores del discurso y el contexto que los influyó para así poder comprender sus actitudes mentales y como esta fue expresada en las crónicas ${ }^{14}$.

En vista de lo anterior, el marco cronológico de nuestra investigación se concentra en el periodo comprendido entre la etapa final del reinado de Alfonso VI (1065-1109) y el reinado de Alfonso X (1252-1284), esto, en razón de que sus reinados coinciden con el periodo central de la Reconquista.

Los años comprendidos entre 1065 y 1284 corresponden a un periodo de gran actividad militar y política. Es una época donde los reinos cristianos peninsulares iniciaron su consolidación política y social, al mismo tiempo que se veían afectados por los procesos de cambio que ocurrían en Europa. El aumento de la influencia del Papado, la reforma eclesiástica y monacal, las cruzadas, los cambios sociales; en suma todas aquellas transformaciones vinculadas a la Plena Edad Media.

Para el caso particular de los reinos de León y Castilla, los reinados de Alfonso VI y Alfonso $\mathrm{X}$, son una etapa fundamental, puesto que vemos la consolidación de procesos iniciados en los periodos anteriores, así como las bases de las siguientes etapas del desarrollo hispánico de modelos, tal es el caso de los modelos monárquicos, en torno a los cuales los cronistas consolidaran un discurso validador basado en la tradición

12 Má́llo Salgado, Felipe, Un análisis del discurso histórico: La ideología. (Lección teóricometodológica), Salamanca, Imprenta Comercial Salmantina, 1980, pp. 9-11.

${ }^{13}$ García Fitz, Francisco, "La conquista de Andalucía en la cronística castellana del siglo XIII: Las mentalidades historiografías en los relatos de la conquista", en Emilio Cabrera (coordinador), Andalucía entre oriente y occidente (1236-1492) Actas del V Coloquio internacional de historia medieval de Andalucía, Córdoba, Excma. Diputación Provincial de Córdoba, 1988, pp. 59-61. Nieto Soria, José Manuel, Propaganda y opinión pública en la historia, Valladolid, Universidad de Valladolid, 2007, pp. $15-17$.

${ }^{14}$ Nieto Soria, José Manuel, "La ideología política bajomedieval... op. cit., pp. 667, 668. 
cristiana, el linaje, la guerra y las virtudes. Creando un bloque ideológico fundamental en la posterior consolidación global de España.

La ocupación de Toledo (1085) se convirtió en uno de los principales hitos de la Reconquista y del goticismo que se vera fortalecido entre los siglos XII y XIII. En tanto que las conquistas de Córdoba (1236) y Sevilla (1248) señalaron el mayor avance territorial y prácticamente dieron por terminada la etapa más intensa del largo conflicto contra el Islam peninsular. Finalmente, las reformas legales de Alfonso X vinieron a señalar la reorganización del territorio, pero, además, evidenciaron claramente las influencias políticas europeas en la corte castellano-leonesa, así como las proyecciones de esta en el escenario político del Mediterráneo occidental.

\section{Sobre la Metodología de análisis.}

Para abordar la problemática de nuestro estudio, fue imperiosa la revisión del amplio repertorio bibliográfico existente, esencialmente para lograr elaborar una visión integral del periodo de estudio y los enfoques historiográficos desde los cuales ha sido estudiado.

A continuación nos dimos al trabajo de ordenar las fuentes que fueron nuestro principal insumo de trabajo, con este fin se seleccionaron las principales crónicas del periodo, entendiendo por ellas las que fueron elaboradas en los ambientes cortesanos o que tratasen la narración de los hechos desde una perspectiva amplia, razón por la cual textos muy regionalistas o particulares, como la Crónica de la Población de Ávila, fueron reducidos a material de referencia, pero no de análisis. Junto con las crónicas se elabora una selección de hagiografías y obras piadosas, con el objeto de que complementasen el análisis de las crónicas, teniendo en consideración aquellos textos que trataban problemáticas similares y útiles a nuestros propósitos, como aquellos donde la guerra, el cautiverio o la figura de los monarcas, fuesen tema central de sus relatos y que además pudiesen identificarse claramente a sus autores, para así poder dilucidar su contexto e intenciones.

Finalmente seleccionamos algunos documentos jurídicos referenciales, tales como los Fueros de Cáceres, Cuenca y Coria, con el fin de extraer en ellos algunos aspectos 
prácticos y contrastar estos con los elementos ideales observables en el discurso cronístico. Con el fin de que esta operación escapase a las particularidades locales, es que también se incorporaron los textos jurídicos alfonsíes, por sus intenciones aglutinadoras y ordenadoras del aparato jurídico del reino.

Todas estas fuentes fueron estudiadas a partir de sus versiones editadas, buscando siempre en la medida de que fue posible trabajar con textos en latín y romance en forma conjunta con sus versiones en castellano. Razón por al cual, en el trascurso de nuestro trabajo se han citado los textos en su idioma original y al pie la traducción contemporánea.

En su conjunto las crónicas, hagiografías y textos jurídicos conforman el reflejo de la sociedad de los reinos de Castilla y León en los siglos XII y XIII, por lo que no son excluyentes, sino que complementarias en cuanto que todas ellas contienen, en distintas proporciones, elementos discursivos y prácticos. Consideramos que el estudio parcelado de las mismas nos impediría obtener la visión global que buscamos y que por el contrario, esta solo es posible de observar a través de una dinámica de interacción, complementación y contraste entre las diversos tipos de fuentes.

Esta metodología nos acerca a la técnica metodológica de análisis de contenido y dentro de esta parte de lo que se conoce como análisis del discurso ${ }^{15}$. No obstante nuestro enfoque no puede ser totalmente inserto en estas disciplinas analíticas, puesto que ellas pretenden un análisis íntegramente cuantitativo o cualitativo normalmente asociado a estadísticas, mientras que nosotros nos hemos enfocado al estudio de una cantidad limitada de casos.

\footnotetext{
${ }^{15}$ Como definición genérica del análisis de contendido adoptamos la de José Luis Piñuel, que si bien pertenece al enfoque de la Sociología, consideramos ilustra a groso modo sus principales características: "Se suele llamar análisis de contenido al conjunto de procedimientos interpretativos de productos comunicativos (mensajes, textos o discursos) que proceden de procesos singulares de comunicación previamente registrados, y que, basados en técnicas de medida, a veces cuantitativas (estadísticas basadas en el recuento de unidades), a veces cualitativas (lógicas basadas en la combinación de categorías) tienen por objeto elaborar y procesar datos relevantes sobre las condiciones mismas en que se han producido aquellos textos, o sobre las condiciones que puedan darse para su empleo posterior. El análisis de contenido, de hecho, se convirtió a finales del siglo XX en una de las técnicas de uso más frecuente en muchas ciencias sociales, adquiriendo una relevancia desconocida en el pasado a medida que se introdujeron procedimientos informáticos en el tratamiento de los datos." (Piñuel Raigada, José Luis, "Epistemología, metodología y técnicas del análisis de contenido", en Estudios de Sociolingüística, 3(1), 2002, [pp. 1-42], p. 2)
} 
Sin perjuicio de lo anterior nosotros adoptamos de estas técnicas su intención de buscar los significados expresos y latentes de un relato, mediante la observación de su contexto explicativo, intencionalidad y omisiones del mismo, a través del recogimiento de información mediante un análisis que pretende identificar parámetros o tópicos objetivos y sistemáticos que pueden ser categorizados siendo posible su replicación y validación posterior. Todo ello sin perder de vista la importancia de la elaboración de una categorización sistemática cuya amplitud permita la replicación del modelo de análisis, asumiendo que esta práctica metodológica siempre podrá ser criticada en razón de la selección de los criterios utilizados, por su posible tendencia a la subjetividad e inexactitud $^{16}$.

El cúmulo documental por nosotros seleccionado, más los problemas propios del análisis del contenido nos obligó a crear una metodología de trabajo, que, en un primer lugar, requirió del establecimiento de parámetros de análisis considerando los tópicos y periodo de uso, para ver así si podíamos identificar unas determinadas series o continuidades, todo lo cual permitiría establecer una cronología que situara los contenidos en una dimensión temporal, observando de esta forma la existencia de agrupaciones, evoluciones y rupturas. Ello nos permitió concluir la necesidad de visualizar esta información a través del uso de gráficos, mediante los cuales se puede hacer evidente la relación entre los tópicos, su uso y el contexto cronológico que los explica.

Como se indicó anteriormente, el discurso para que sea efectivo debe buscar la creación de un lenguaje común que sea simple, directo y que cumpla con los propósitos de exaltar, identificar, orquestar y crear unanimidad. Para ello nosotros identificamos una serie de tópicos presentes en las fuentes, los cuales fueron seleccionados por su amplitud y flexibilidad significativa, así como por su reiteración, es decir por el hecho

${ }^{16}$ Al respecto de otras disciplinas ver Andréu Abela, Jaime (2001). "Las técnicas de Análisis de Contenido: Una revisión actualizada.", en http://public.centrodeestudiosandaluces.es/pdfs/S200103.pdf (Consultado 29 marzo 2010), Bardin, Laurence, El análisis de contenido, Madrid, Akal, 2002. López Noguero, Fernando, "El análisis de contenido como método de investigación", en Revista de Educación, 4, 2002, [pp. 167-179]. Fernández Chaves, Flory, "El análisis de contenido como ayuda metodológica para la investigación”, en Ciencias Sociales, Junio, Vol. II, Número 96, Universidad de Costa Rica [pp. 35-54], y Piñuel Raigada, José Luis, "Epistemología, metodología... op. cit.

En cuanto a lo que se refiere a su uso en la disciplina historiográfica, imprescindibles nos resultaron los trabajos de Felipe Maíllo Salgado, Un análisis del discurso histórico: La ideología (Lección teórico-metodológica), Imprenta Comercial Salmantina. Salamanca, 1980. y Torres Sevilla, Margarita "La propaganda y sus técnicas... op. cit. 
de que pueden ser aplicados a distintos personajes y en distintos periodos. Por razones prácticas estos conceptos fueron vertidos al castellano, principalmente porque ello nos permitía el poder usarlos en su significado más amplio y porque así nos asegurábamos de poder incorporar tanto las fuentes escritas en latín, como aquellas en castellano y gallego medieval. Todo ello sin perder de vista el significado contextual de cada uno de los conceptos seleccionados.

Nosotros pudimos establecer que el discurso de los siglos XII y XIII, centrado en la figura del monarca, el providencialismo y la Reconquista, se podían subdividir en distintos aspectos complementarios. En primer lugar el linaje, esto es la intención de los autores por resaltar la sangre de los monarcas, haciéndolos herederos directo de los visigodos y por lo tanto de una estirpe marcada por una especia de "virtus", o bien de reyes pretéritos que por sus victorias parecieron señalados por la Providencia. En ambos casos la intención es señalar la idea de una continuidad sanguínea, lo que se expresa en conceptos como heredero, continuador y restaurador.

A continuación los cronistas procuraron caracterizar a los soberanos con una serie de virtudes que reforzaban la validación de los mismos, así como de sus actos. Nosotros dividimos estas virtudes en religiosas, militares, jurídicas y morales. Para el caso de las virtudes religiosas, estas son la suma de los conceptos de piadoso (que sintetiza las ideas de devoción, temor de Dios y la práctica y aplicación de normas religiosas); restaurador (como aquel que funda o refunda iglesias y monasterios en las zonas reconquistadas, recuperando así el espacio para la Iglesia); protegido o auxiliado por Dios (expresiones que trasmiten la noción de que el rey está amparado por Dios); instrumento o poseído por Dios (concepto amplio que engloba ideas como el actuar poseído por Dios o el Espíritu Santo, estar al servicio de Dios, o ser impulsados por el Señor. En general expresiones que nos dicen que las acciones del soberano son fruto de la acción divina. En esta categoría también incluimos la Inspiración Divina que tiene muy pocas menciones en las crónicas); finalmente incluimos el concepto de estar al servicio de Dios (que los cronistas utilizan para justificar algunas acciones y decisiones de los monarcas).

En lo que respecta a las virtudes militares estas se componen del concepto de guerrero (compuesta de calificativos como combativo, luchador, esforzado o que se 
enfrenta al Islam); valiente o bravo (que generalmente se usa en forma literal o bien afirmándose que el monarca no tenía temor ante sus enemigos); y victorioso (concepto que podía ser usado en forma literal o bien indicando que se obtuvo una victoria, pero siempre aplicado en el sentido militar).

Jurídicamente, los principales conceptos fueron la expresión de justo o justiciero (expresiones vinculadas a la capacidad del rey para crear leyes y ejecutarlas); pacificador (todas aquellas ideas relacionadas con la capacidad de imponer la paz al interior de un territorio, a través de lograr la armonía, el orden, y la concordia); por último encontramos las expresiones de piadoso, clemente y misericordioso, las que consideramos como una sola idea vinculada a la capacidad del monarca de perdonar a sus enemigos cristianos y que suele verse utilizada en relación a soberanos que enfrentaron rebeliones o querellas internas.

Finalmente en lo referido a las virtudes morales, estas agrupan una diversidad de atributos como virtuoso (un concepto genérico muchas veces mencionado sin mayores detalles); hermoso o fermoso (también usado literalmente y referido a la proporción y características físicas); casto (que si bien no es una idea muy utilizada si aparece como una virtud deseada); sabio (es quizás el concepto más difuso, puesto que viene a englobar calificativos como conocedor, sabidor, instruido, conocedor y prudente. Todas ellas se refieren principalmente a las acciones de un monarca más que a sus capacidades intelectuales o académicas); y generoso (en el que hemos incluido los actos de hacer donaciones religiosas, otorgamiento de favores, así como las ideas de humildad y bondad).

Junto a lo anterior existen aquellos tópicos que hemos considerado "universales" en el sentido de que no solo se limitan al monarca sino que a otros personajes y a veces al conjunto de la comunidad, siendo el principal el del providencialismo, el cual dividimos según se refiera al monarca, a un grupo especifico o bien algún individuo. En este caso los tópicos seleccionados fueron el de castigo divino (el que suele referirse a calamidades provocadas por Dios en respuesta a los pecados, la impiedad, avaricia, lujuria, soberbia o la imprudencia); protegido o ayudado por la Providencia (que engloba a distintas manifestaciones que expresan la noción de que se está amparado por Dios, como es la expresión rex gratia. En el mismo apartado se incluyen las ideas de ser 
un instrumento de la voluntad divina y la victoria como recompensa divina); auxilio (un tópico en extremo amplio que engloba los distintos episodios favorables explicados como intervención de la Providencia como situaciones climáticas, otorgamiento de virtudes o actitudes, facilidades en la organización, entre otras); y bendito (una expresión que suele aparecer de forma explicita, pero que también engloba otras expresiones como gracia y beneficiado, siendo muy común en el pensamiento isidoriano en relación a los visigodos).

Nuestro interés no fue solo identificar los tópicos directamente vinculados a las estructuras de poder, sino que también aquellos que reforzaban la mentalidad providencialista y a través de ella las figuras del monarca y la Reconquista. Fue por ello que incorporamos en nuestro análisis la figura de los, a nuestro juicio, principales santos en el ámbito de la Reconquista: Santiago, San Isidoro, la Virgen María, y santos fronterizos como Santo Domingo de Silos, San Millán de la Cogolla y otras figuras celestes menores como apariciones angelicales. Para su análisis dentro del discurso cronístico y hagiográfico se les categorizó según las acciones que les atribuyeron los autores, siendo las principales la de castigador (concepto que engloba todas las acciones donde se atribuyen a los santos el envío de enfermedades, muertes, pesadillas contra algún individuo); defensor o protector (es decir cuando se le atribuye al santo la protección de un lugar o persona. El concepto suele aparecer vinculado al anterior); mensajero (referido a la entrega de mensajes mediante apariciones y sueños); guerrero (donde englobamos todos los relatos que describen algún santo combatiendo directamente a sus enemigos); rescatador (una de las funciones más comunes); y legitimador (otro concepto amplio que agrupa las distintas manifestaciones de santos o ángeles que con su actuar vienen a reforzar la figura o decisiones de un personaje).

Junto con los santos, otro de los aspectos del providencialismo, pero más práctico y cuantificativo, fueron las entregas de indulgencias y la difusión de las ideas de martirio. Sobre estos conceptos no es necesario profundizar, puesto que a diferencias de los otros reseñados se trata de tópicos que no generan mayores controversias.

Un poco más complicado son los tópicos vinculados a los ceremoniales y rituales bélicos, los cuales clasificamos como rituales de preparación para el combate, ritos de preparación para la muerte, ritos de victoria y ritos de purificación de lugares conquistados. Su dificultad, más que por su significado, se debe a la forma en que las 
tratan las fuentes puesto que no son categorías propias de ellas, por lo que fue necesario identificar los episodios y las distintas ceremonias o rituales descritos en ellos para luego categorizarlos. Fue así que los rituales de preparación para el combate se desprenden de las liturgias, oraciones, confesiones y actos de arrepentimiento realizados por las huestes antes de emprender el combate, en tanto que los ritos de preparación para la muerte son aquellos que se desprenden de los actos de construcción realizados por los guerreros ante lo que podría parecer una muerte inminente.

Los ritos de victoria son aquellos efectuados luego de que las huestes cristianas derrotasen a sus enemigos y se componían de oraciones, liturgias formales y desfiles triunfales. Como parte de estos rituales se podían realizar también los de purificación de lugares conquistados, consistente en la ocupación de edificaciones o asentamientos y se componían del acto de purificar con agua bendita esos lugares, el encumbramiento de signos religiosos y políticos como estandarte y cruces.

La última parte de nuestro estudio consistió en el análisis detallado de lo que llamamos los reyes modélicos, Alfonso VI, Alfonso VII, Alfonso VIII, Fernando III y Alfonso X, por considerarlos figuras centrales en la Reconquista en su periodo de mayor actividad y referentes obligados en las fuentes cronísticas, donde los autores centraron en ellos las virtudes propias del ideal de la monarquía. Sus acciones y virtudes fueron categorizadas según el modelo de monarquía basado en el linaje y virtudes, con el fin de ver como los cronistas hicieron uso de los tópicos y crearon un ideal que se convirtió en parte integral del discurso de la Reconquista.

Todo lo anterior fue complementado con el estudio de monografías y artículos especializados que nos sirvieron para contextualizar nuestro análisis, así como incorporar distintos enfoques al mismo.

Toda esta información fue vertida en tablas, que ordenadas cronológicamente en periodos de una década, durante los siglos XII y XIII, servían para identificar la presencia de un determinado tópico en una fuente en particular. Ello desde una perspectiva general, puesto que la cuantificación del uso de tópicos en cada una de las fuentes hubiese significado un trabajo fuera de los alcances de nuestra investigación. De 
esta forma las tablas evidencian la presencia constante de un tópico en un periodo de tiempo claramente identificable.

Una vez que esta información fue sistematizada en las tablas, los datos de las mismas fueron graficados para ilustrar así la información en ellas contenidas. Fue así como se elaboraron principalmente gráficos de dispersión y de barras, siendo los primeros los más utilizados, debido a que por sus características se ajustaban mejor a nuestros datos y la forma en que queríamos mostrarlos, esto es, una visión completa de la progresión en el uso de determinados tópicos en relación al marco temporal de la Reconquista.

Todo lo anterior nos ha permitido configurar una herramienta integrada en base al uso de una tabla de hoja de cálculo asociada al análisis gráfico, que nos ha permitido extraer, sintetizar y representar una información, que sirve para ilustrar los elementos constitutivos de la construcción del discurso en general, facilitando así su posterior estudio en particular para aquellos investigadores que lo consideren pertinente.

\section{Hipótesis y objetivos}

\section{Hipótesis}

A partir de los problemas planteados, nosotros hemos generado la siguiente hipótesis, la cual trataremos de demostrar a lo largo de nuestra investigación: que durante los siglos XII y XIII, en el marco de la Reconquista, es posible identificar, en la cronística castellana, un discurso de reafirmación de la monarquía y por extensión del reino, compuesto de una serie de tópicos que sirvieron para el establecimiento y continuidad de un ideal identitario, algo que sería constatable a través de un estudio del lenguaje cronístico y las formas en las cuales este se refiere a las características que debía poseer el monarca comprendido como un modelo real.

En un segundo nivel la hipótesis a demostrar pretende lograr ilustrar el cómo se sustentó este discurso en medio de la realidad fronteriza donde los contactos y relaciones entre los reinos cristianos de la Península y el al-Andalus obligaban a adaptar las prácticas y costumbres en razón de las particularidades de la frontera y las influencias externa que confluían sobre esta, tales como los intereses del Papado y la Iglesia y las ideologías de guerra santa. 
En un tercer nivel, y subordinado a los dos anteriores, la hipótesis pretende ilustrar el rol que le cupo a la Iglesia, a través de algunos de sus obispos y otras autoridades, en la creación, divulgación y sustentación del discurso cronístico mediante la elaboración y patrocinio de crónicas y hagiografías destinadas a la exaltación de algunos monarcas en particular y la guerra contra el Islam.

\section{Objetivo General}

Con la intención de demostrar algunas de las cuestiones plateadas en la hipótesis propuesta, es que hemos establecido el siguiente objetivo general.

Constatar y comprender a través de fuentes directas, en especial crónicas, hagiografías y textos jurídicos, cómo entre los siglos XII y XIII, en Castilla se desarrollaron una serie de tópicos, que contribuyeron a conformar un discurso destinado a la reafirmación del modelo monárquico y la expansión territorial de la Reconquista, con el fin de establecer un ideal identitario.

Desde esta perspectiva se analizarán las características de las principales fuentes cronísticas del periodo y sus autores, combinándolas con el estudio contextual del periodo para dilucidar las influencias y elementos que pudieron afectar al desarrollo y motivaciones del discurso cronístico.

\section{Objetivos específicos}

En función de la hipótesis y objetivo general que nos hemos propuesto, es que se pueden desprender los siguientes objetivos específicos:

En primer lugar, aproximarnos al contexto general de la Reconquista en Castilla, identificando los marcos políticos, culturales y militares en los que se escribieron las crónicas y demás fuentes de nuestro estudio y en el cual se gestó y desarrolló el discurso cronístico, en el contexto del enfrentamiento entre cristianos y musulmanes. Ello en el entendido de que tanto los cronistas como sus producciones son el reflejo de su realidad y de los intereses y necesidades propios de su entorno. 
Lo anterior sin perder de vista que algunos de estos tópicos corresponden a concepciones producto de influencias foráneas, tales como las ideas de guerra santa y cruzada, y que por ende debieron ser adaptados a la realidad peninsular. Por lo que se hace necesario conocer las formas mediante las cuales se introdujeron estas ideas y la manera en que impactaron en la mentalidad cronística hispánica.

Para lograr lo anterior es necesario exponer las diversas fuentes cronísticas, y en menor medida hagiográficas y jurídicas, en relación a como expresaron los elementos esenciales de este discurso, teniendo como fin último contrastar este con los aspectos prácticos y cotidianos de la Reconquista.

Ello en vista de identificar y explicar el uso de los diversos tópicos, a través de los siglos XII y XIII, especialmente centrándonos en los tópicos providencialistas, militares y "morales" en relación a la figura del monarca como modelo práctico e ideal del discurso de la Reconquista.

En directa relación con lo anterior se buscar integrar la construcción de la figura del monarca según la historiografía con la imagen que de él se da en las fuentes a través de los diversos tópicos, analizando la construcción de la figura del rey como un modelo ideal, validado por su linaje y actos, centrándonos para ello en los casos particulares de Alfonso VI, Alfonso VII, Alfonso VIII, Fernando III y Alfonso X.

Junto con desglosar y explicar el uso y continuidades de los tópicos, para poder visualizar de mejor forma los datos sistematizados y su uso durante los siglos XII y XIII, junto se confeccionaran tablas y gráficos de dispersión y de barras, que sirvan para ilustrar y explicitar el uso y desarrollo de los tópicos en relación a su contexto histórico y desarrollo. 


\section{Estado de la cuestión}

En virtud de los objetivos de la presente investigación es necesario enfocarnos en el estudio de diversas fuentes cronísticas y hagiográficas. El criterio para selección de las mismas se basaron en sus temáticas y periodos de elaboración, todo ello con el objeto de obtener una visión lo más amplia posible sobre los problemas que nos abocan con el fin de poder realizar una dinámica comparativa entre los tópicos discursivos y la práctica.

Respecto al discurso, sus distintos tópicos integradores se obtuvieron de la revisión de crónicas y hagiografías. Respecto a las crónicas se dio especial atención a aquellas que, elaboradas, durante los siglos XII y XIII representaban la visión de las elites del reino. En ese sentido es importante considerar que las crónicas que utilizamos para los años centrales de nuestro estudio, pueden ser divididas en oficiales y oficiosas. Siendo las primeras aquellas que fueron producidas en los ambientes cortesanos o directamente promocionadas por algún monarca y aquellas que, en cambio, responden a una producción local o particular no necesariamente vinculada a las grandes esferas de poder real. No obstante en ambos casos existen elementos discursivos comunes, tópicos, que constituyen parte importante de sus narraciones e interpretaciones.

Es así como podemos calificar, para los siglos XII y XIII, de oficiosas a las Crónicas anónimas de Sahagún (I Parte), edición crítica, nota e índice por Antonio Ubieto Artera, Zaragoza, Anubar, 1987; Historia Compostelana, edición de Emma Falque, Madrid, Akal, 1994; Crónica del Obispo de Oviedo don Pelayo, en Casariego, J.A., Crónicas de los Reinos de Asturias y León, León, Everest, 1985; Crónica Najerense, edición de Juan A. Estévez Sola Tres Cantos, Madrid, Akal, 2003; el Liber Sancti Jacobi/ Codex calixtinus, traducción de Abelardo Moralejo, Casimiro Torres y Julio Feo, Galicia, Xunta de Galicia, 2004 ${ }^{17}$; los Annales Toledanos I - II, en Las crónicas latinas de la Reconquista, estudios prácticos de latín medieval por Antonio Huici, España, Establecimiento Tip, Hijos de F. Vives Mora, 1913. En tanto que entre las oficiales encontramos la Historia Silense/Legionense, Historia Silense, edición crítica e introducción por Don Justo Pérez de Urbel y Atilano González Ruiz-Zorrilla, Madrid,

\footnotetext{
${ }^{17}$ Sobre la calificación de esta obra, ver el apartado Cronistas, crónicas: vidas y contextos, en el capítulo II.2. Las Crónicas y la hagiografía en el discurso de la Reconquista, de la II Parte de la presente tesis.
} 
Escuela de Estudios Medievales, 1959; la Chronica Adefonsi Imperatoris, edición y estudio por Luis Sánchez Belda, Madrid, CSIC., Escuela de Estudios Medievales, 1950; la Crónica latina de los reyes de Castilla, edición de Luis Charlo Brea, Madrid, Akal, 1999; la magna obra de Lucas de Tuy el Cronicon Mundi, cura et studio Emma Falque, Corpvs Christianorvm, Brepols, 2003; de Rodrigo Jiménez de Rada su Historia de Rebus Hispanie, cura et studio Juan Fernández Valverde, Corpvs Christianorvm, Brepols, 1987; la Crónica General de España, editada por Ramón Menéndez Pidal con un estudio actualizador de Diego Catalán, $2^{\circ}$ tomo de la tercera reimpresión, Madrid, Gredos, 1977; y la Crónica de veinte reyes, Burgos, Ayuntamiento de Burgos, $1991^{18}$.

No obstante, en virtud de nuestra intención de presentar una perspectiva global de los procesos también hicimos uso de crónicas fuera de nuestro eje cronológico central. Es por ello que a modo de referencia se incluyen textos pertenecientes a los primeros siglos de la Reconquista, concretamente la Crónica Mozárabe de 754, edición crítica y traducción por José Eduardo López Pereira, Zaragoza, Anubar, 1980; la Crónica Albeldense y Crónica Profética y la Crónica de Alfonso III en sus dos versiones Rotense y A Sebastián, las tres obras publicadas en conjunto con introducción y edición crítica de Juan Gil Fernández; traducción y notas de José L. Moralejo; estudio preliminar de Juan I. Ruiz de la Peña, Oviedo, Universidad de Oviedo, 1985. Junto a ellos se incluyeron algunas crónicas y textos de los siglos XIV y XV, a modo de referencia en cuanto a las siguientes etapas de evolución del discurso, concretamente se trato la Crónica de Alfonso X, edición, trascripción y notas por Manuel González Jiménez, Real Academia Alfonso X el Sabio, Murcia, $1998^{19}$.

En cuanto a las hagiográficas utilizadas, estas se restringieron a los siglos centrales de nuestro estudio y corresponden a una pequeña, pero a nuestro juicio, significativa muestra de este tipo de obras. Si bien, por lo general, los textos hagiográficos no tienen pretensiones directamente políticas, si son difusores del aspecto religioso del discurso. En los textos elegidos, como la Vita Dominici Silensis de Grimaldo, estudio, edición crítica y traducción de Vitalino Valcarcel, Logroño, Instituto de Estudios Riojanos, 1982; de Gonzalo de Berceo la Vida de Santo Domingo de Silos,

18 Para un conocimiento más completo de estas obras, autores y características, ver el subcapítulo Cronistas, crónicas: vidas y contextos, en el capítulo II.2. Las Crónicas y la hagiografía en el discurso de la Reconquista, de la II Parte de la presente tesis.

${ }^{19}$ Idem. 
los Milagros de Nuestra Señora, la Vida de San Millán de la Cogolla, y la Vida de Santa Oria y Martirio de San Lorenzo, prólogo y versión moderna de Amancio Bolaño e Isla, México, Porrua, 1969. Así como los Miraculos romançados de Pero Marin, edición crítica, introducción e índices por Karl-Heinz Anton, Stvdia Silensia, Abadía de Silos, 1988. Los Milagros de San Isidoro de Lucas de Tuy, transcripción, prólogo y notas de Julio Pérez Llamazares, León, Universidad de León, Secretariado de Publicaciones, Cátedra de San Isidoro de la Real Colegiata de León, 1992 y la alfonsí Cantigas de Santa María, introducción, versión castellana y comentarios de José Filgueira Valverde, Madrid, Castalia, $1985^{20}$. En ellas observamos una intención consciente por exaltar el cristianismo y denostar a sus rivales, musulmanes y judíos, trasmitiendo una imagen por lo general bastante "maniquea" de la realidad fronteriza. Además, en las hagiografías, se desarrollan con más detalles aspectos de la cotidianidad hispánica que no se ven reflejadas en las grandes crónicas, puesto que a diferencia de los cronistas los hagiógrafos parecían dirigirse a un público mucho más amplio, que abarcaba desde los monjes y clérigos menores a los simples campesinos.

A través de sus relatos milagrosos se pueden observar aspectos del cautiverio, comercio, peregrinaje, la guerra, la justicia y la administración, siendo muchos de estos episodios protagonizados por personajes simples, alejados de las grandes esferas del poder. Lo que no significa que omitan a los protagonistas de los grandes procesos, puesto que no será extraño que en ellas también se mencionen y exalten a algunos monarcas y magnates.

Por lo anterior, las hagiografías, aportan importantes datos complementarios a los grandes sucesos cronísticos y junto a ellos son claves en la difusión de un discurso identitario basado en el providencialismo y la confrontación contra el Islam.

Con respecto a aquellas fuentes que sirven para el estudio de las condiciones prácticas, nos concentramos en textos jurídicos. Los cuales dividimos en dos grandes grupos, los textos forales y los diversos códigos elaborados bajo la iniciativa de Alfonso $\mathrm{X}$. Estamos concientes de que los textos jurídicos también expresan un discurso, puesto que representan los ideales y principios de la sociedad que los producen, pero no

\footnotetext{
${ }^{20}$ Idem.
} 
debemos olvidar que las leyes y códigos son elaborados a partir de una realidad práctica y cotidiana, por lo que reflejan las necesidades y problemas de una comunidad.

Esto es más evidente en los textos forales, dado que, en muchos casos, respondieron a la realidad concreta de una comunidad especifica. Sabemos que estos ordenamientos contaron con el respaldo de las monarquías que los otorgaban o ratificaban, pero nos aparece evidente que respondían a las necesidades de normar la convivencia de las comunidades, más que a las necesidades políticas y militares de las elites del reino.

Nosotros nos concentraremos en los fueros de Cuenca, Coria y Cáceres, por considerar que son homogéneos en cuanto a su época y contexto, concentrándonos en aquellos aspectos que nos parecían un fiel reflejo de las necesidades reales de las comunidades que los utilizaron, tales como las normas vinculadas a la guerra, el botín, el comercio y la convivencia entre credos distintos.

En cuanto a la obra jurídica alfonsí, conformada por el Espéculo, el Fuero Real y las Siete Partidas, es evidente que esta posee importantes elementos discursivos, en especial vinculados a la consolidación de la figura del monarca. No obstante, los códigos seleccionados, también se veían en la necesidad de normar sobre aspectos cotidianos, por lo que entre sus aspectos discursivos, es posible observar prácticas y costumbres vinculadas a problemas concretos propios de la convivencia.

Junto a estos textos, que utilizaremos de forma transversal en nuestro trabajo, también haremos uso de otras fuentes para algunos aspectos en particular. Ese fue el caso de Paulo Orosio y su Historiae Adversus Paganos en cuanto a la historiografía medieval y de San Agustín y sus textos Contra Faustum, y De Civite Dei, respecto a las dimensiones de la violencia y guerra santa cristiana. Sobre estos mismos problemas también nos fueron útiles las partes II y III de la Suma Teológica de Tomas de Aquino y las Etimologías y la Historia Gothorum, Vandalorum et Suevorum de Isidoro de Sevilla y del mismo autor, con respecto a las implicancia del poder real, sus Sentencias.

Para aspectos variados referentes a la violencia, el poder político y el providencialismo también reconocemos la pertinencia de la Biblia, incluidos los dos 
Testamentos y los Hechos de los Apóstoles ${ }^{21}$, y el Corán ${ }^{22}$. En cuanto a la relación del Papado con la Reconquista fundamental resulta la Colección de Documentación Pontificia Referente a España recopilada por Demetrio Mansilla y Santiago Domínguez Sánchez. A ellos se suman otros autores y recopilaciones que por su limitado uso no consideramos necesario mencionar en este apartado.

Con respecto a la bibliografía historiográfica que hemos revisado es innegable que muchos autores han dedicado estudios respecto a la comprensión de los principales aspectos de los siglos XII y XIII, produciendo un corpus académico difícilmente abordable. Por ello y reconociéndonos tributarios de muchos de sus planteamientos trataremos de abordar de la manera más completa posible algunas de los principales estudios que nos han servido para nuestro trabajo, por lo que consideramos prudente ordenarla según las principales partes de nuestro trabajo.

Para ello hemos calificado las obras según la presencia que en ellos tengan los temas por nosotros estudiados. Es así como para la primera parte de nuestra investigación, dedicada a elaborar un contexto histórico y conceptual, nos hemos visto obligados a tratar los conceptos de discurso, Ideología, Goticismo, Guerra Santa y Cruzada, entre otras.

En cuanto al discurso nuestro enfoque se concentró en lograr una conceptualización general del término como parte de la visión de una cultura, para ello el trabajo de Michel Vovelle, Ideologías y mentalidades, Barcelona, Ariel, 1985, nos sirvió para una aproximación general al tema, en tanto que para un conocimiento más acabado en cuanto al discurso en el escenario peninsular, imprescindible nos resultaron los trabajos de Emilio Mitre y Martín Alvira "Ideología y guerra en los reinos de la España Medieval": Revista de Historia Militar, 2001, № 1 Extraordinario, pp. 291-334; José Manuel Nieto Soria, "Ideología y poder monárquico en la Península": en La Historia medieval en España. Un balance historiográfico (1968 - 1998) XXV Semana

21 Biblia de Jerusalén, Bilbao, Desclée de Brouwer, 1975; Santa Biblia, Reina-Valera, Edición de Estudio, Bogotá, Sociedades Bíblicas Unidas, 1995.

${ }^{22}$ El Corán, Edición preparada por Julio Cortés, Barcelona, Herder, 2009. 
de Estudios Medievales Estella, Pamplona, Gobierno de Navarra, 1999; los que a su vez se completan con los trabajos vinculados al concepto de Ideología, como son los trabajos de Nieto Soria, "La ideología política bajo medieval en la historiografía española": Hispania, revista española de historia, L/2, $\mathrm{N}^{\circ}$ 175, 1990, pp. 667-681; y Propaganda y opinión pública en la historia, Valladolid, Universidad de Valladolid, 2007; de Rogelio Rubio Hernández, Antropología: Religión, mito y ritual, Madrid, Universidad nacional de Educación a Distancia, 1988; y más recientemente de Francisco García Fitz en su aporte "La conquista de Andalucía en la cronística castellana del siglo XIII: Las mentalidades historiografías en los relatos de la conquista": Andalucia entre Oriente y Occidente (1236-1492), Actas del V coloquio internacional de historia medieval de Andalucía. Todas ellas obras que intentan contextualizar las mentalidades de los cronistas y de las elites en el marco de la Reconquista y el fortalecimiento de las instituciones monárquicas y nobiliarias en distintas etapas de la Edad Media Peninsular.

En cuanto al goticismo, lo hemos desarrollado a través de los textos de José Antonio Maravall, El concepto de España en la Edad Media, Madrid, Centro de Estudios Constitucionales, 1997; y Estudios de Historia del Pensamiento Español, Madrid, Ediciones Cultura Hispánica, 1983; el trabajo de Emilio Mitre "Alfonso X: historiografía y tradiciones compilatorias del medievo europeo": Curso de Cultura Medieval. Repoblación y reconquista, Centro de Estudios Románicos Aguilar del Campoo, 1991; y de Luis González Antón, España y las Españas, Madrid, Alianza, 1997, interesante texto que desde una mirada global de la historia española trata de explicar la configuración política de los estados peninsulares.

La guerra y sus acepciones como guerra justa, guerra santa y cruzada son objeto de diversos análisis y polémicas, razón por la cual existe una extensa bibliografía al respecto, entre la cual nosotros destacamos respecto a los aspectos generales de la guerra y su rol cultural los trabajos de Arnold Toynbee, Guerra y Civilización, Buenos Aires, Alianza, 1952; de Gaston Bouthol, El Fenómeno Guerra, Barcelona, Plaza \& Janes, 1971; y del mismo autor La Guerra, Barcelona, Oikos-tau, 1971; textos escritos a mediados del siglo XX, pero que exponen el fenómeno de la guerra desde una perspectiva cultural aplicable a distintas épocas. 
Ya acercándonos a la problemática de las guerras justas y santas son recomendables los textos de Jean Flori, Guerra Santa, Yihad, Cruzada. Violencia y Religión en el Cristianismo y el Islam, Granada, Universidad de Granada y Universitat de València, 2004; La Guerra Santa. La formación de la idea de cruzada en el Occidente cristiano, Granada, Trota, Universidad de Granada, 2003; Caballeros y caballería en la Edad Media, Barcelona, Paidos Ibérica. 2001; y La caballería, Barcelona, Alianza, 1998. Además podemos mencionar los trabajos de Francisco García Fitz, La edad Media. Guerra e ideología, justificaciones jurídicas y religiosas, Madrid, Silex, 2003; a José Fernández Ubiña y su libro Cristianos y militares. La iglesia antigua ante el ejército y la guerra, Granada, Universidad de Granada, 2000; a José Marín, Cruzada, Guerra santa y Yihad, Valparaíso, Pontificia Universidad Católica de Valparaíso, 2003, de Peter Partner, El Dios de las batallas: Las guerras santas desde la Biblia hasta nuestros dias, Madrid, Anaya, 2002; el trabajo de Philippe Contamine, La guerra en la Edad Media, Barcelona, Labor, 1984; y el estudio de Frederick Russell The Just War in the Middle Ages, Cambridge University Press, Londres, 1977, quizás una de las obras más importantes escritas sobre la materia.

Más próximos al tema de las cruzadas son destacables las obras de Geoffrey Hindley, Las cruzadas. Peregrinaje armado y guerra santa, Ediciones B, Buenos Aires, 2004; Jonathan Riley-Smith y su libro ¿Qué fueron las cruzadas?, Barcelona, Acantilado, 2012; de Maurice Keen, La caballería, Barcelona, Ariel, 2008; de Luis, García-Guijarro Papado, cruzadas y órdenes militares, siglos XI-XIII, Madrid, Cátedra, 1995, y de Francisco García Fitz su trabajo "El discurso militar en la historiografía de las cruzadas: la ideología patente", presente en la obra colectiva de Juan Carlos Iglesias Zoido (ed.), Retórica e Historiografía. El discurso militar en la historiografía desde la Antigüedad hasta el Renacimiento, Madrid, Ediciones Clásicas, Cáceres, Universidad de Extremadura, 2007.

En cuanto a estas problemáticas aplicadas a la Península Ibérica, necesariamente estos conceptos se confunden con la Reconquista, siendo estudiada así en obras como los trabajos de José Antonio Maravall La idea de Reconquista en España durante la Edad Media, Arbor $\mathrm{N}^{\circ}$ 28, 1954, pp. 1-37; de Joseph O'Callaghan, Reconquest and Crusade in Medieval Spain, Philadelphia, University of Pennsylvania Press, 2003; de Alexander Pierre Bronisch, su amplio estudio titulado Reconquista y guerra santa: La 
concepción de la guerra en la España cristiana desde los visigodos hasta comienzos del siglo XII, Granada, Universidad de Granada, 2006; de Francisco García Fitz sus trabajos La Reconquista, Granada, Universidad de Granada, 2010; y Las Navas de Tolosa, Ariel, Madrid, 2005; así como también Emilio Mitre y Martín Alvira, en su articulo ya mencionado "Ideología y guerra en los reinos de la España Medieval” y de Derek Lomax, La Reconquista, Barcelona, Crítica, 1978. Imprescindible resulta además, por su recopilación documental y análisis de la misma, el trabajo de José Goñi Gaztambide Historia de la Bula de Cruzada en España, Vitoria, Editorial del Seminario, 1958.

Junto a estos autores también destacan las monografías y artículos de Martín Alvira Cabrer, que ha dedicado diversos estudios a estos temas, entre otros "Guerra e ideología en la España del siglo XIII: la conquista de Mallorca según la crónica de Bernat Desclot": En la Edad Media, 19, 1996, pp. 37-50; y de Carlos de Ayala "Fernando I y la sacralización de la Reconquista": Anales de la Universidad de Alicante, Historia Medieval, 17, 2011, pp. 67-115; y "Fernando III: Figura, significado y contexto en tiempo de cruzada", en la obra colectiva de Ayala y Martín Ríos Saloma (eds.), Fernando III, tiempo de cruzada, Silex, Madrid, 2012. Finalmente incluimos los trabajos de Ana Belén Sánchez Prieto, Guerra y guerreros en España según las fuentes canónicas de la Edad Media, Madrid, Servicio de Publicaciones del E.M.E., 1990, una obra un tanto general pero muy ilustrativa; y de David Porrinas González, "La caballería y la guerra en la Edad Media castellano-leonesa: El libro del caballero Zifar y su contexto". Medievalismo 15, 2005, pp. 39-70.

De forma complementaria, para esta primera parte fue necesario también construir un contexto general en el cual se enmarcaran los conceptos mencionados, para ello trabajamos con las obras de autores de diversas épocas y posiciones, con el fin de lograr un panorama lo más amplio posible. Al respecto debemos mencionar los trabajos de Francisco García Fitz, Castilla y León frente al Islam: Estrategias de expansión y Tácticas militares (Siglos XI-XIII), Sevilla, Universidad de Sevilla, 2001; y Relaciones Políticas y Guerra. La experiencia castellano - leonesa frente al Islam. Siglos XI-XIII, Sevilla, Universidad de Sevilla, 2002, que tratan la Reconquista en los siglos pleno medievales a partir de sus aristas militares y las implicancias de esta para la configuración de la sociedad hispana. En un plano más analítico, en especial en cuanto al estudio de las estructuras de dominación, ocupación del espacio y feudalización, 
encontramos los trabajos de José María Mínguez, La España de los siglos VI al XIII: Guerra Expansión y Trasformaciones. En busca de una frágil unidad, Donostia, Nerea, 1994; y de Luis Miguel Villar García La Extremadura Castellano-Leonesa, guerreros, clérigos y campesinos (711-1252), Valladolid, Junta de Castilla y León, Consejería de Educación y Cultura, 1986.

Junto a estos trabajos, también es necesario referirse a la serie de biografías dedicadas a los monarcas de León y Castilla, entre las cuales utilizamos el trabajo de Mínguez, Alfonso VI. Poder, expansión y reorganización interior, Donostia, Nerea, 2000; sobre el mismo monarca Bernard Reilly, El Reino de León y Castilla bajo el Rey Alfonso VI, 1065-1109, Toledo, Instituto Provincial de Investigaciones y Estudios Toledanos, 1987; de Pallares y Portela, La Reina Urraca, Donostia, Nerea, 2006; el texto de Manuel Recuero Astray Alfonso VII (1126-1157), Burgos, La Olmeda, 2003; los importantes y completos estudios de Julio González, El reino de Castilla en la época de Alfonso VIII, 3 vols., Madrid, Escuela de Estudios Medievales, $1960 \mathrm{y}$ Reinado y Diplomas de Fernando III, Córdoba, Publicaciones del Monte de Piedad y Caja de Ahorros de Córdoba, 1983; y de Manuel González, Alfonso X el Sabio 1252 1284, Palencia, Diputación Provincial de Palencia, La Olmeda, 1993. Consientes que estos trabajos son solo una pequeña muestra sobre la amplia producción biográfica sobre estos personajes, nuestro interés radicó en usarlos como complementarios al contexto histórico de nuestros años de estudio.

Con respecto a la imagen de los musulmanes y su evolución a partir del 711, utilizamos una variada bibliografía entre la que se cuentan la imprescindible obra de Ron Barkai, El enemigo en el espejo, Madrid, Rialp, 2007; y los trabajos de John Tolan, Sarracenos. El Islam en la imaginación medieval europea, Valencia, Publicaciones de la Universitat de Vàlencia, España, 2007; y Richard Fletcher, La cruz y la media luna, Barcelona, Península, 2005, que si bien tratan el tema de las relaciones entre cristianos y musulmanes desde una perspectiva general, permiten colocar el problema peninsular en una perspectiva amplia. También son útiles, desde la perspectiva hispánica, los trabajos de Ana Belén Paniagua Lortau, "Consideraciones sobre la imagen de los musulmanes en la Gran Crónica de Alfonso XI": IV Estudios de Frontera, Historia, Tradiciones y leyendas en la Frontera, Jaén, Diputación Provincial de Jaén, 2002; Martín Alvira Cabrer, "La muerte del enemigo en pleno medioevo cifras e ideología (el modelo de las 
Navas de Tolosa)": Hispania, Revista Española de Historia. Vol. LV/ II, No 190, 1995, pp. 403-423; y José María Soto Rábanos "Reflexiones sobre el discurso cristiano a judíos y musulmanes en los sínodos castellanos, siglos XIII-XV”: IV Jornadas de Historia en la Abadía de Alcalá la Real, Alcalá la Real, 2002; así como el texto de Thomas Glick Islamic and Christian Spain in the Early Middle Ages: Comparative Perspectives on Social and Cultural Formation, Princeton, Universidad de, 1979. Por ultimo el interesante articulo de Cristina Granda Gallego "Otra imagen del guerrero cristiano (su valoración positiva en testimonios del Islam)": En la España Medieval, 8, 1986, pp. 471-480.

Complementando los temas y sus respectivas bibliografías, tratados en la primera parte de la tesis, es necesario contemplar un conjunto de obras que, creemos, sirven para ilustrar los aspectos prácticos de estas problemáticas y que versan sobre la sociedad de frontera y las relaciones entre las distintas estructuras que la componen, tales como la Iglesia, la Monarquía y los Concejos Urbanos. Es así como contemplamos para los temas concejiles los trabajos de James F. Powers, A society organized for war. The Iberian Municipal Militias in the Central Middle Ages, 1000-1284, University of California Press, 1999; de Antonio Palomeque Torres. "Contribución al estudio del ejército en los estados de la Reconquista": Anuario de historia del derecho español, Tomo XV, 1944, pp. 205-351, de José Rodríguez Molina, “Alcalá la Real. Comunicación, Defensa y Convivencia en la Frontera": III Estudios de Frontera. Convivencia, Defensa y Comunicación en la Frontera, Alcalá la Real, Diputación Provincial de Jaén, 2000; de Santiago Palacios Ontalva "Fortalezas y Guerra Santa. Un estudio comparado de algunos aspectos de su funcionalidad en las fronteras de la Cristiandad": Espacio, Tiempo y Forma, Serie III, H. Medieval, Tomo 14, 2001, pp. 193-217. Respecto a los aspectos jurídicos los trabajos de Pedro Andrés Porras Arboledas, "Derecho a Guerra y paz en la España medieval": Revista de Historia Militar, 2001, No Extraordinario, Instituto de Historia y Cultura militar, pp. 335-359; de Enrique Gacto Fernández, Temas de Historia del derecho: Derecho Medieval, Sevilla, Universidad de Sevilla, 1977; y de Diego Melo Carrasco, "Las treguas entre Granada y Castilla durante los siglos XIII a XV": Revista de Estudios Históricos-Jurídicos, XXXIV, 2012, pp. 237-275. Sobre la monarquía y la Iglesia, entre muchos otros son recomendables de Evelyn Procter su esclarecedor libro Curia y Cortes en Castilla y León 1072-1295, Madrid, Cátedra, 1988; el trabajo de Jesús M. Mollero García, "La 
Frontera Castellana en tiempos de Alfonso VII: Nobleza y organización del espacio": II Estudios de Frontera. Actividad y Vida en la Frontera, Alcalá la Real, Diputación Provincial de Jaén, 1997; y los libros de Peter Linehan La Iglesia Española y el Papado en el S. XIII, Salamanca, Universidad Pontificia de Salamanca, 1975 y de Antonio García y García, Iglesia, Sociedad y Derecho, Salamanca, Publicaciones Universidad Pontificia de Salamanca, 2000.

Para la segunda parte, "La construcción de instrumentos ideológicos", dado que nuestro trabajo se basa en el estudio de fuentes, es imprescindible adentrarse en el análisis de la historiográfica medieval y luego en las particularidades de la misma para el escenario hispánico. Desde una perspectiva general útiles son los trabajos de Emilio Mitre Historiografía y mentalidades históricas en la Europa Medieval: Actas del III Curso de Cultura Medieval. Repoblación y reconquista, Centro de Estudios Románicos Aguilar del Campoo, Septiembre de 1991; y de Nilda Guglielmi y Adeline Rucquoi en su obra colectiva El discurso político en la Edad Media = Le discours politique au Moyen Age, Buenos Aires, CONICET, Paris, Centre National de la Recherche Scientifique, 1995; así como también el articulo de Eloy Benito Ruano, "La historiografía de la alta edad media. Ideología y Estructura": Cuadernos de Historia de España, XVII, Buenos Aires, Universidad de Buenos Aires, Instituto de Investigaciones Históricas, 1952, pp. 50-104; y el aporte, que aunque sintético ilustrador, de Bernard Guenée, "Historia”, presente en el Diccionario razonado del Occidente Medieval de Le Goff, y Schmitt, Madrid, Akal, 2003.

Estos trabajos, que son solo la referencia de un universo más amplio, sirvieron como complemento para el estudio de la historiográfica hispana de la Reconquista, iniciándose con el trabajo de Díaz y Díaz, De Isidoro al siglo XI. Ocho estudios sobre la vida literaria peninsular, Barcelona, El Albir, 1976, texto antiguo pero aún vigente, así como los estudios más recientes de Eustaquio Sánchez Salor, "El Providencialismo en la Historiografía Cristiano-Visigótica en España”, Anuario de Estudios Filológicos V, Universidad de Extremadura, Cáceres, 1982, pp. 179-192; de Ariel Guiance, "Morir por la patria, morir por la fe: La ideología de la muerte en la Historia de Rebus Hispaniae": Cuadernos de Historia de España, LXXIII, 1991, pp. 75-104; de Emilio Mitre, ¿Un 
sentimiento de comunidad hispánica? La historiografía peninsular": Historia de España Menéndez Pidal, Tomo XVI, Madrid, Espasa Calpe, 1994; el articulo de Manuel Rodríguez de la Peña, "Ideología política y crónicas monásticas: La concepción cluniacense de la realeza en la España del siglo XII": Anuario de Estudios Medievales, 30/2, 2000, pp. 681-734, Y los artículos de Fernando Arias Guillén, "Honor y Guerra. La tensión entre realidad bélica y el discurso ideológico en la cronística castellana de la primera mitad del siglo XIV”: Hispania, vol. LXIX, N²32, 2009, pp. 307-330; de José Luis Martín Martín, "La Frontera como entorno legendario": IV Estudios de Frontera. Historia, Tradiciones y leyendas en la Frontera, Jaén, Diputación Provincial de Jaén, 2002; el aporte de Martín Alvira Cabrer, “'Senhor, per les nostres peccatz'. Guerra y pecado en la Edad Media”, en el trabajo colectivo de Ana Isabel Carrasco Manchado y María del Pilar Rábade Obradó, Pecar en la Edad Media, Madrid, Silex, 2008; y finalmente Carlos Reglero de la Fuente, "Restauración diocesana y memoria regia en León y Castilla”, en Pascual Martínez Sopena y Ana Rodríguez, La construcción medieval de la memoria regia, Valencia, Universidad de Valencia, 2011.

Centrándonos en la historiográfica de la Reconquista, en especifico, para sus primeros siglos consideramos esenciales los trabajos ya mencionados de José Antonio Maravall, "La idea de Reconquista en España durante la Edad Media" y El concepto de España en la Edad Media; y en el texto de Andrés-Gallego, Historia de la historiografía española el aporte de Emilio Mitre Fernández, "La historiografía sobre la Edad Media”. Así como los libros de Sánchez Alonso, Historia de la historiografía española. Tomo I. Hasta la publicación de la Crónica de Ocampo (...-1543), Madrid, CSIC., 1947; y de Serafín Bodelón, Literatura latina de la Edad Media en España, Madrid, Akal, 1989. Complementario a estos trabajos, debemos considerar también el tratamiento que del tema hace Felipe Maíllo Salgado en su estudio Un análisis del discurso histórico: La ideología (lección teórico-metodológica), Salamanca, Imprenta Comercial Salmantina, 1980; el trabajo colectivo editado por Amancio Isla y Ana Rodríguez La construcción medieval de la memoria regia y los artículos de Margarita Torres Sevilla, "La propaganda del poder y sus técnicas en las crónicas leonesas y castellanas (Siglos IX-XIII)" y Alexander, Bronisch, "La ideología asturiana y la historiografía en la época de Fernando III", Valencia, Universitat de Valencia, 2011. 
La historiográfica en la etapa central del proceso de Reconquista en los siglos pleno medievales es tratada en el trabajo de Ana Rodríguez López, "Sucesión regia y legitimidad política en Castilla en los siglos XII y XIII. Algunas consideraciones sobre el relato de las crónicas latinas castellano-leonesas" como parte del texto coordinado por Isabel Alfonso, Julio Escalona y Georges Martin, Lucha Política. Condena y legitimación en la España medieval, Annexes des Cahiers de linguistique et de civilisation hispanique medievales, Volume 16, Ens éditions 2004. La colaboración de Amaia Arizaleta, "Topografías de la memoria palatina: los discursos cancillerescos sobre la realeza (Castilla, siglos XII y XIII)", en Fernández de Larrea, Jon Andoni y José Ramón Díaz de Durana, Memoria e Historia. Utilización política en la Corona de Castilla al final de la Edad Media, Madrid, Silex, 2010. De Inés Calderón Medina, "La Memoria de los reyes de León (1157-1230)" y de Carlos Estepa Díez, "El Reino de Castilla de Alfonso VIII (1158-1214)", en el Poder real y sociedad: estudios sobre el reinado de Alfonso VIII (1158-1214), León, Universidad de León, 2011; así como el artículo de Francisco Bautista, "Genealogía y leyenda. El surgimiento de los reinos de Castilla y Aragón": e-Spania, 7, junio 2009. Junto a ellos también destacamos a Juan Gil, "La Historiografía”, en Historia de España Menéndez Pidal, Tomo XI, Madrid, Espasa Calpe, 1995; a Carmen Benítez Guerrero, La imagen del rey en la cronística castellana. Propaganda y legitimación durante la primera mitad del siglo XIV, Madrid, La Ergástula, 2014; y de Martín Alvira Cabrer, su tesis doctoral Guerra e ideología en la España medieval: cultura y actitudes históricas ante el giro de principios del siglo XIII: batallas de Las Navas de Tolosa (1212) y Muret (1213), Universidad Complutense, 2003.

También complementan la perspectiva general sobre el tema el texto de Daniel Baloup y Philippe Josserand. “Du Jourdain au Tage” en Regards Croisés sur la Guerre Sainte. Guerre, Idéologie et Religion Dans L'espace Méditerranéen Latin (XI-XIII Siècle), Toulouse, CNRS-Université de Toulouse-Le Mirail, 2006; el aporte de José Manuel Nieto Soria, "Ideología y poder monárquico en la Península" presente en La Historia medieval en España. Un balance historiográfico (1968 - 1998) XXV Semana de Estudios Medievales Estella, Pamplona, Gobierno de Navarra, Departamento de Educación y Cultura, 1999. El articulo de Juan Antonio Estévez Sola, "Chronica Naierensis e Historia Silensis": e-Spania, 7, junio 2009; y de García Fitz, "La Conquista de Andalucía en la Cronística Castellana del siglo XIII: las mentalidades 
historiográficas en los relatos de la reconquista": Andalucía entre Oriente y Occidente (1236-1492), Actas del V Coloquio internacional de historia medieval de Andalucía, Córdoba, Excma. Diputación Provincial de Córdoba, 1988.

En cuanto al análisis de las crónicas y sus autores, aparte de los textos mismos y sus diversos estudios críticos, nos parece imprescindible el trabajo de Peter Linehan, Historia e historiadores de la España medieval, Salamanca, Universidad de Salamanca, 2011; lo mismo que su versión original en ingles, considerada una pieza esencial para comprender el aspecto global de la cronística hispana. En cuanto a trabajos más monográficos, sobre la Historia Compostelana, además de las ediciones de Emma Falque, consideramos prudente mencionar las referencias que de ella se hacen en el trabajo de Evelyn Procter, Alfonso X of Castile, patron of literature and learning, Oxford, Oxford University Press, 1941. La Historia Silense/Legionense también ha sido objeto de diversos estudios, en especial los últimos años por la polémica de su titulo, entre los cuales destacamos los artículos de Amancio Isla en su artículo "Una historia leonesa, su perfil y sus costuras": Edad media. Rev. Hist., 12, 2011, pp. 143-157; de Raquel Alonso, "La obra histórica del obispo Pelayo de Oviedo (1089-1153) y su relación con la Historia legionensis (llamada silensis): e-Spania, 14, 2012; de Gaël le Morvan, "Reinos e imperio: la Historia legionensis (llamada silensis) y la reivindicación leonesa de la herencia visigótica", e-Spania, 14, 2012; de Georges Martin "La Historia legionensis (llamada silensis) como memoria identitaria de un reino y como autobiografía", y de Fernando Luis Corral "Y sometió a sus autoridad todo el reino de los leoneses"": formas de ejercicio del poder en la Historia Silense o cómo Alfonso VI llegó al trono", ambos en e-Spania, 14, 2012 . Junto a ellos se debe considerar también a José María Canal Sánchez-Pagín, “CCrónica Silense o Crónica Domnis Sanctis?": Cuadernos de Historia de España, LXIII-LXIV, 1980; así como a Claudio Sánchez-Albornoz, Investigaciones sobre historiografía hispana medieval (siglos VIII al XII), Buenos Aires, Instituto de Historia de España, 1967.

Sobre la Chronica Adefonsi Imperatoris, si bien existe mucha bibliografía, nos fueron de utilidad los artículos de José María Canal Sánchez-Pagín, "Elías, canónigo rótense, posible autor de la Chronica Adefonsi Imperatoris": Anuario de Estudios Medievales, 30/2, 2000, pp. 735-757; y de Emmanuelle Klinka, "Protagonismos y relación historiográfica en la Chronica Adefonsi Imperatoris": e-Spania, 15, junio 2013; 
así como el trabajo más general de Ester Echegaray que también la referencia, Guerra y pacto en el siglo XII. La consolidación de un sistema de reinos en Europa Occidental, Madrid, Biblioteca de Historia: 31, CSIC., 1996.

Respecto a la Crónica del Obispo Pelayo, existen menos trabajos monográficos, pero entre ellos destacamos el articulo ya mencionado Raquel Alonso "La obra histórica del obispo Pelayo de Oviedo (1089-1153) y su relación con la Historia legionensis (llamada silensis)".

En comparación con el periodo inmediatamente anterior, la producción cronística de los siglos XII y XIII ha sido estudiada en profundidad, existiendo una gran abundancia de material dedicado en forma monográfica a las principales crónicas del periodo. Entre estos trabajos, para la Crónica Latina de los reyes de Castilla destacamos a Ana Rodríguez y sus artículos "Modelos de legitimidad política en la Chronica regum Castellae de Juan de Osma": e-Spania, 2 diciembre 2006 y "De rebus Hispaniae frente a la Crónica latina de los reyes de Castilla: virtudes regias y reciprocidad política en Castilla y León en la primera mitad del siglo XIII": Cahiers de linguistique et de civilisation hispaniques medievales, $\mathrm{N}^{\circ}$ 26, 2003, pp. 133-150; también destaca el trabajo de Julio González, "La Crónica Latina de los Reyes de Castilla" en Homenaje a Don Agustín Millares Carlo, 2 V, Gran Canaria, Caja Insular de Ahorros de Gran Canaria, 1975. Por ultimo son relevantes las aportaciones más recientes de Francisco Bautista, "Escritura cronística e ideología histórica"; de Inés Fernández Ordóñez, "La composición por etapas de la Chronica latina regum Castellae (1223-1237) de Juan de Soria" y de Amaia Arizaleta, "La Chronica regum Castellae: aledaños de la ficción", estos últimos como parte del numero especial de diciembre de 2006 de la revista digital e-Spania.

Referentes a las crónicas de Lucas de Tuy y Rodrigo Jiménez de Rada sus trabajos son ineludibles en cualquier estudio referente a la cronística del periodo, razón por la cual nos servimos mayoritariamente de textos globales, entre los que destacamos los aspectos tratados por Ambrosio Huici Miranda, en su ya clásico Las grandes batallas de la Reconquista durante las invasiones africanas (Almorávides, Almohades y Benimerines), Madrid, s.n., 1956. El aporte de Adeline Rucquoi, "Cultura y poder en la monarquía medieval castellana": Actas del III Curso de Cultura Medieval. Repoblación 
y reconquista, Centro de Estudios Románicos Aguilar del Campoo, 1991; y el más reciente trabajo de Georges Martin, “La invención de Castilla. Rodrigo Jiménez de Rada, Historia de rebus Hispaniae, V. Identidad patria y mentalidades políticas" en el marco del Séminaire interdisciplinaire de recherches sur'l Espagne medievales (SIREM), 2006.

La Crónica de Alfonso X es quizás uno de los textos más estudiados de la cronística del siglo XIII, por lo que solo nos remitimos algunos de estos trabajos. En primer lugar el texto más general de Emilio Mitre, "Historiografía y tradiciones compilatorias del medioevo europeo" en Actas del III Curso de Cultura Medieval. Repoblación y reconquista, Centro de Estudios Románicos Aguilar del Campoo, Septiembre de 1991; así como las monografías de Diego Catalán La estoria de España de Alfonso X: creación y evolución, Universidad Complutense de Madrid, Seminario Menéndez Pidal, 1992; de María del Carmen Jiménez Vicente, La razón de Estado en Alfonso X el Sabio. Paulo Orosio en la Primera Crónica General, Salamanca, Universidad de Valladolid, 1993; y de Leonardo Funes, El modelo historiográfico alfonsí: Una Caracterización, London, Department of Hispanic Studies, Queen Mary and Westfield Collage, 1997. Así como el articulo de Raquel Homet, "Caracteres de la conciencia histórica: los sueños y visiones en la Estoria de España": En la España Medieval, 25, 2002, pp. 85-112. Junto a los anteriores es especialmente valiosa y útil la obra colectiva dirigida por Inés Fernández - Ordóñez, Alfonso X el Sabio y las crónicas de España, Valladolid, Universidad de Valladolid, 2000, en especial las aportaciones de Fernando Gómez Redondo, "La construcción del modelo de Crónica real”, de Juan Bautista Crespo, “La 'Estoria de España' y las crónicas generales” y de Georges Martín, "El modelo historiográfico alfonsí y sus antecedentes".

La hagiografía también constituye una fuente invaluable para el conocimiento de los discursos de la Reconquista, puesto que si bien no se trata de textos puramente políticos, en ellos se expresan las ideologías de la elite y tienen un objetivo de difusión más amplio que las crónicas. Para el conocimiento de este fenómeno, nosotros consideramos útiles, entre otras, los trabajos de Ángeles García de la Borbolla, "Santo Domingo de Silos, el santo de la frontera: La imagen de la santidad a partir de las fuentes hagiográficas castellano-leonesas del siglo XIII": Anuario de Estudios Medievales, 31-1, 2001 pp. 127-145; sobre los textos de Berceo destacamos a Juan 
Pedro Rodríguez Hernández, "El Diablo en 'Los Milagros de Nuestra Señora' de Gonzalo de Berceo": Espacio, Tiempo y Forma, Serie III, H/ Medieval, t. 17, 2004, pp. 519-532; y a José Luis Martín, "Los milagros de la Virgen: Versión latina y romance”, Espacio, Tiempo y Forma, Serie III, H. Medieval, t, 16, 2003, pp. 177-214.

Sobre la figura de San Isidoro existe una abundante bibliografía, pero especialmente orientativa nos resuelto el articulo de José Carlos Martín, "El corpus hagiográfico latino en torno a la figura de Isidoro de Sevilla en la Hispania tardoantigua y medieval (SS. VII-XIII)": Veleria. Revista de Prehistoria, Historia Antigua, Arqueología y Filología Clásicas, Vitoria, Universidad del País Vasco, 2005, pp. 187228.

Esta bibliografía contribuye a comprender parte importante del contexto de las fuentes, así como los principales elementos que contribuirán a la composición de su discurso. En relación a la imagen del Islam particularmente expresada en crónicas y hagiografías consideramos ilustrativos los textos de José Manuel Rodríguez García, "Fernando III y sus campañas en el contexto cruzado europeo, 1217-1252": Archivo Hispalense, Revista Histórica, Literaria y Artística, 2.a Época, año 1994, Tomo LXXVII, Núms. 234-235-236, pp. 205-217; el interesante texto de Marta Madero, Manos Violentas, Palabras Vedadas. La injuria en Castilla y León (siglos XIII-XV), Madrid, Taurus, 1992; la contribución de Palacios Ontalva al trabajo colectivo ya referenciado Ayala y Ríos Saloma, "Imagen e identidad del musulmán en tiempos de Fernando III. El enemigo desde la perspectiva cruzada" y finalmente el articulo de Francisco García-Serrano, "La creación de identidad en la frontera medieval hispana y la visión del otro: mudéjares y judíos”, presente en el texto de Alejandro Rodríguez de la Peña, Hacedores de Frontera. Estudios sobre el contexto social de la frontera en la España medieval, Madrid, CEU Ediciones, 2009.

En cuanto a los intentos de comprender al Islam peninsular, así como los aspectos prácticos de la realidad fronteriza y la guerra podemos dar cuenta de los trabajos de Martín Alvira Cabrer "El desafio del Miramamolín antes de la Batalla de las Navas de Tolosa (1212), fuentes, datación y posibles orígenes”, Al-Qantara, Vol. XVIII, Fasc. 2, 1997, pp. 463-490; las aportaciones contenidas en El cuerpo derrotado: Cómo trataban los musulmanes y cristianos a los enemigos vencidos (Península Ibérica, SS. VIII-XIII) editado por Maribel Fierro y Francisco García Fitz, entre las que destacamos a David 
Porrinas González, “¿Masacre o Clemencia? La conducta del Cid hacia los enemigos vencidos”, de José Manuel Rodríguez García, "Cabezas cortadas en Castilla - León, 1100-1350", de Isabel Alfonso Antón, "El cuerpo del delito y la violencia ejemplar” y de Francisco García Fitz, “ ¿’De exterminandis sarracenis’? El trato dado al enemigo musulmán en el reino de Castilla-León durante la plena edad media" y directamente complementario a este el trabajo de Manuel Alejandro Rodríguez de la Peña, "Añadiendo muertos a los muertos: el destino de los vencidos en la frontera Al Andalus en la cronística latina plenomedieval", en el texto ya mencionado Hacedores de Frontera. Junto a ellos también consideramos importantes el texto de José Manuel Calderón Ortega y Francisco Javier Díaz González, Vae Victis: Cautivos y prisioneros en la Edad Media hispánica, Alcalá de Henares, Universidad de Alcalá, 2012; y el articulo de Martín Alvira Cabrer, "La muerte del enemigo en pleno medioevo cifras e ideología (el modelo de Las Navas de Tolosa)", Hispania, Revista Española de Historia, Vol. LV/ II, No 190, 1995, pp. 403-423.

Complementario a los autores mencionados, para una aproximación general al fenómeno del cautiverio como característico de las dinámicas de frontera, consideramos ilustrativos los aportes de Francisco Vidal Castro, "El Cautivo en el Mundo Islámico: Visión y vivencia desde el otro lado de la frontera andalusí” y Manuela García Pardo, "La Redención de Cautivos: Una muestra de la religiosidad popular medieval en Úbeda" publicados en los II y V Estudios de Frontera respectivamente.

La distinta bibliografía referida corresponde a los aspectos más contextuales de la presente tesis, correspondiéndonos ahora la descripción de los textos que consideramos más acotados a nuestro tema central de estudio y sus distintas aristas, partiendo por el discurso en torno a la monarquía. En esta parte muchos de los textos utilizados lo fueron para distintos capítulos, por lo que para evitar las reiteraciones procuraremos referirnos a ellos en forma trasversal y señalando claramente aquellos de carácter más monográfico.

Sobre las características generales de la monarquía y su desarrollo histórico, especialmente importantes nos resultaron algunos trabajos ya clásicos como el libro de Marc Bloch, Los reyes taumaturgos, México DF, FCE, 1993; de Jean De Pange, Le roi très Chretien, Paris, Librairie Arthème Fayard, 1949; así como el estudio esencial sobre 
las dimensiones de la monarquía de Ernst Kantorowicz, Los dos cuerpos del rey: un estudio de teología política medieval, Madrid, Alianza, 1985. Junto a ellos los trabajos de Manuel García Pelayo, El Reino de Dios, Arquetipo Político, Revista de Occidente, Madrid, 1959; de Walter Ullmann, Historia del pensamiento político en la Edad Media, Barcelona, Ariel, 2006; finalmente los primeros capítulos del trabajo de Alejandro Rodríguez de la Peña, Los Reyes sabios. Cultura y poder en la Antigüedad Tardía y la Alta Edad Media, Madrid, Editorial Actas, 2008. Buena parte de las principales conclusiones de algunos de estos textos se encuentran sintetizados en el artículo de Patricio Zamora "El Rey Sagrado, Arquetipo Político-Religioso. Concepción y Representación en las fuentes del poder sagrado de la Edad Media": Intus Legere, $\mathrm{N}^{\circ} 4$, 2001, pp. 123-139.

Ya aproximándonos a las generalidades de las monarquías hispanas, son de utilidad los artículos de José Manuel Nieto Soria, "Imágenes religiosas del rey y del poder real en la Castilla del siglo XIII": En la España Medieval, Tomo V, 1986, pp. 709-729; "Del rey oculto al rey exhibido: Un síntoma de las trasformaciones políticas en la castilla bajo medieval": Medievalismo 2, 1992, pp. 5-27; y del mismos autor el libro Fundamentos Ideológicos del Poder Real en Castilla (Siglos XIII-XVI), Madrid, Eudema, 1988 y de José Luís Villacañas Berlanga, La Formación de los Reinos Hispánicos, Madrid, Espasa Calpe, 2006.

En esta línea de aproximación a la monarquía hispana, es necesario remitirnos a las características de los monarcas visigodos, para lo cual nos servimos de los trabajos de Luis Suárez Fernández “Los fundamentos medievales de la nación española” en Eloy Benito Ruano (coord.) Tópicos y realidades de la Edad Media. Volumen III, Madrid, Real Academia de la Historia, 2000-2002; el trabajo ya referido de Eustaquio Sánchez Salor, el libro de Amancio Isla, Ejército, Sociedad y Política en la Península Ibérica entre los siglos VII y XI, Madrid, CSIC., 2010, que aborda de forma contextual este tema. También destacamos el aporte de Cristina Godoy y Josep Vilella, "De la Fides Ghotica a la Ortodoxia Nicena: Inicio de la Teología Política Visigótica”, en Actas de la Semana Internacional de Estudios Visigóticos, Antigüedad y Cristianismo, Monografías históricas sobre la Antigüedad Tardía: Los Visigodos, Historia y Civilización, Actas de la Semana Internacional de Estudios Visigóticos, Madrid-Toledo-Alcalá de Henares, 1986. 
Ya adentrándonos en los ideales monárquicos presentes en los discursos de las crónicas de los siglos XII y XIII, nuestro primer interés radica en aquellos textos que abordan el problema del linaje y el origen visigodo de los monarcas de la Reconquista. Desde una perspectiva general es importante mencionar los trabajos ya referenciados de Barkai y Tolan, así como el artículo de José Luis Martín, "La pérdida y reconquista de España a la luz de las crónicas y del romancero": Actas del III Curso de Cultura Medieval. Repoblación y reconquista, Centro de Estudios Románicos Aguilar del Campoo, 1991. Complementarios a estos autores son los trabajos en torno al concepto de Reconquista y sus usos en relación a la monarquía, entre otros aspectos, de Martín Ríos Saloma, "Usos políticos e historiográficos del concepto de Reconquista", Anales de la Universidad de Alicante. Historia Medieval, N. 17, 2011, pp. 41-65; y La reconquista. Una construcción historiográfica (siglos XVI-XIX), Madrid, Marcial Pons, 2001. Y sobre el goticismo en este particular son de utilidad el texto de Maravall ya mencionado El concepto de España en la Edad Media, de José María Monsalvo, "Notas sobre los primeros espacios de la Reconquista (Primera Mitad S. VIII) en la cronística cristiana pleno medieval: De la Historia Silense a la Estoria de España" en José María Mínguez y Gregorio del ser Quijano (Eds.), La Península en la Edad Media treinta años después. Estudios dedicados a José Luis Martín, Salamanca, Ediciones Universidad de Salamanca, 2006; y de Luis de Valdeavellano, El Feudalismo Hispánico, Barcelona, Crítica, 1981.

En cuanto a estudios pormenorizados del problema del linaje, en los últimos años se han publicado importantes aportaciones, entre las que destacan Isabel Beceiro Pita "La legitimación del linaje a través de los ancestros", presente en Fernández de Larrea y Díaz de Durana (eds.), Memoria e Historia: utilización política en la Corona de Castilla al final de la Edad Media, Madrid, Silex, 2010; de Amancio Isla Frez, "La construcción de la monarquía en León, siglos X y XI: Historia y Leyes” y Ana Rodríguez, "Memoria y curia regia en Castilla en la primera mitad del siglo XIII", ambos contenidos en Pascual Martínez y Ana Rodríguez, La construcción medieval de la memoria regia, Valencia, Universitat de Valencia, 2011.

Sobre las virtudes religiosas del rey, esta característica puede ser referida a partir de la suma de la bibliografía anterior, pero en especifico podemos mencionar el texto de 
Carlos Reglero "Restauración diocesana y memoria regia en León y Castilla", presente en el trabajo colectivo de Martínez y Rodríguez ya mencionado.

La relación entre los monarcas y la guerra como fuente de validación ha sido el objeto de estudio de distintos artículos, entre los que destacamos el de Nieto Soria, "Imágenes religiosas del rey y del poder real en la Castilla del siglo XIII", publicado en España Medieval, Tomo V, Universidad Complutense, Madrid, 1986. Además de las reflexiones que sobre el tema hacen María del Carmen Pallares y Ermelindo Portela en su libro La Reina Urraca, Madrid, Nerea, 2006. Indispensable resulta el texto ya mencionado La construcción medieval de la memoria regia, en particular el trabajo ya referido de Carlos Reglero de la Fuente, "Restauración diocesana y memoria regia en León y Castilla" y los artículos de Pascual Martínez "Los concejos, la tradición foral y la memoria regia en Castilla y León", de Caldero "La memoria de los reyes de León", de Carlos Estepa "Memoria y poder real bajo Alfonso VIII y de Ana Rodríguez "La preciosa transmisión, memoria y curia regia en Castilla en la primera mitad del siglo XIII". Junto a ellos encontramos también en el texto colectivo Poder real y sociedad: estudios sobre el reinado de Alfonso VIII, el articulo de Carlos Estepa "El Reino de Castilla de Alfonso VIII", y Hélène Sirantoine, "La Cancillería regia en época de Fernando III: Ideología, discurso y práctica", en el trabajo ya referido de Carlos de Ayala y Ríos Soloma, Fernando III: Figura, significado y contexto en tiempo de cruzada.

Finalmente, algunas de las referencias en cuanto a las virtudes jurídicas y morales del monarca fueron extraídas, además de la bibliografía ya citada, de los trabajos de Adeline Rucquoi, "El Rey Sabio: Cultura y Poder en la Monarquía Medieval Castellana", Repoblación y reconquista (III Curso de Cultura Medieval, 1991), Aguilar de Campoó, 1993; José Orlandis, "Legados de la España Visigótica", II Curso de Cultura Medieval: Alfonso VIII y su Época, Centro de Estudios del Románico, Aguilar del Campoo, 1990; de José Luis Bermejo su libro Máximas, Principios y Símbolos Políticos, Madrid, Centro de Estudios Constitucionales, 1986; y del mismo autor el articulo "Orígenes Medievales en la Idea de Soberanía": Revista de Estudios Políticos, 200-201, 1975, pp. 283-290. Finalmente destacamos el estudio de Ángel Gordo, “Estructuras Regias en el Reino de León. La Preparatio en la Elevación al Trono Imperial de Urraca I y Alfonso VII. Factores diferenciadores y de estabilidad en el 
gobierno", en José Manuel Cerda (editor), El Mundo Medieval, Legado y Alteridad, Santiago de Chile, Universidad Finis Terrae, 2009.

La tercera parte de la presente tesis, "Los tópicos", en esencia, pretende centrarse en los aspectos más prácticos del discurso y por ende se concentra en el uso de fuentes directas comentadas y contextualizadas a partir de los textos anteriormente mencionados. Por esta razón mucha de la bibliografía utilizada ya fue mencionada previamente, existió relativamente pocos textos novedosos, no obstante procuraremos mencionar los más importantes, aunque asumiendo como inevitables algunas reiteraciones.

Para aproximarnos a los aspectos generales del providencialismo utilizamos los textos ya mencionados de Rogelio Rubio, Eustaquio Sánchez, Manuel García Pelayo y de García Fitz, su artículo también ya citado "La Conquista de Andalucía en la Cronística Castellana del siglo XIII: las mentalidades historiográficas en los relatos de la reconquista". A los que complementamos con el estudio de Mircea Eliade, Lo Sagrado y lo Profano, Barcelona, Labor, 1985; el aporte de Carla Casagrande y Silvana Vecchio, "Pecado", presente en el Diccionario razonado del occidente medieval de Le Goff y Schmit y el texto de Le Goff, Lo maravilloso y lo cotidiano en el Occidente medieval, Barcelona, Gedisa, 2002; Junto a ellos y más concentrado en la situación ibérica esta la aportación ya mencionada de Martín Alvira Cabrer, "Senhor, per les nostres peccatz'. Guerra y pecado en la Edad Media”.

El problema del providencialismo en la realidad hispánica fue abordado a través de los artículos de Ariel Guiance, "Morir por la patria, morir por la fe: la ideología de la muerte en la Historia de Rebus Hispaniae": Cuadernos de Historia de España, LXXIII, Buenos Aires, Instituto de Historia de España, 1991, pp. 75-104; José Rodríguez Molina, "Historia, tradiciones y leyendas en la frontera" y Manuela Gracía Pardo, "El pastor de Las Navas de Tolosa. La realidad y la leyenda", ambos en IV Estudios de Frontera, Historia, Tradiciones y leyendas en la Frontera, Jaén, Diputación Provincial de Jaén, 2002; además de Bautista, Francisco, “Genealogía y leyenda. El surgimiento de los reinos de Castilla y Aragón”: en e-Spania, 7 junio 2009. Directamente vinculado a 
lo anterior encontramos el desarrollo de las dinámicas de pecado y castigo, las cuales son tratadas en textos como El enemigo en el espejo de Barkai, el articulo de Mitre y Alvira "Ideología y guerra en los reinos de la España medieval”, además de los artículos ya referidos de José Luis Martín, "La pérdida y reconquista de España a la luz de las crónicas y del romancero” y de Martín Alvira Cabrer, “'Senhor, per les nostres peccatz'. Guerra y pecado en la Edad Media" y del mismo autor "Del sepulcro y los sarracenos meridionales a los herejes occidentales": Baloup, Daniel y Philippe Josserand (éd.). Regards Croisés sur la Guerre Sainte.

Respecto a la participación de los santos en la causa de la Reconquista existe una abundante bibliografía, tanto de carácter general como en particular sobre algunas figuras celestes. Entre ambas consideramos necesarios los textos de Sofía Boesch, "Santidad" en el Diccionario razonado de Le Goff, Schmitt, de Mircea Eliade, Mito y Realidad, Barcelona, Labor, 1991; de Carlos de Ayala en su articulo "Fernando I y la sacralización de la Reconquista"; de Ángela Muñoz Fernández, "Cultos, Devociones y Advocaciones Religiosas en los Orígenes de la Organización Eclesiástica Cordobesa (siglos XIII-XIV)": Andalucía entre Oriente y Occidente (1236-1492) Actas del V coloquio internacional de historia medieval de Andalucía.; y los textos ya citados de Keen y Flori, sobre la caballería y la Guerra santa, así como el trabajo de Javier Domínguez García, Del Apóstol matamoros a Yllapa mataindios. Dogmas e ideologías medievales en el (des)cubrimiento de America, Salamanca, Universidad de Salamanca, 2008.

Junto a los anteriores trabajos debemos considerar los textos ya citados de Linehan, sobre La Iglesia Española, de Francisco Javier Fernández Conde, sobre La religiosidad medieval en España, el trabajo de Martín Martín sobre las practicas clericales en la frontera y además de los artículos de José Rodríguez Molina, "Santos Guerreros en la Frontera", en los IV Estudios de Frontera, de Antonio García Flores, “"Fazer batallas a los moros por las vecindades del reyno'. Imágenes de enfrentamientos entre cristianos y musulmanes en la Castilla medieval": Identidad y representación de la frontera en la España medieval: (siglos XI - XIV); seminario celebrado en la Casa de Velázquez y la Universidad Autónoma de Madrid, 1998; y de Ángeles García de la Borbolla, "La Espiritualidad de los Cautivos de Santo Domingo en la obra de Pero 
Marín": II Estudios de Frontera. Actividad y Vida en la Frontera, Diputación Provincial de Jaén, 1998.

Sobre algunos santos en particular son de interés los escritos de Francisco Márquez Villanueva, Santiago: trayectoria de un mito, Barcelona, Bellaterra, 2004; de Klaus Herbers, Política y veneración de santos en la Península Ibérica: desarrollo del "Santiago político”, Pontevedra, Fundación Cultural Rutas del Románico, 2006; y de Luis Fernández Gallardo, "Santiago Matamoros en la historiografía medieval origen y desarrollo de un mito nacional”, Medievalismo, № 15, 2005, pp. 139-174; además de el aporte de Luis Suárez Fernández, "Santiago: Camino y 'Matamoros”, en Eloy Benito Ruano, Tópicos y realidades de la Edad Media, Volumen II. Para la figura de Isidoro son útiles los artículos ya referenciados de José Carlos Martín, "El corpus hagiográfico latino en torno a la figura de Isidoro de Sevilla en la Hispania tardoantigua y medieval (SS. VII-XIII)"; y Ángela Muñoz Fernández, "Cultos, Devociones y Advocaciones Religiosas en los Orígenes de la Organización Eclesiástica Cordobesa (siglos XIIIXIV)".

En cuanto a otras figuras celestes y santos, destacamos los textos ya mencionados, de Ángeles García de la Borbolla, "Santo Domingo de Silos, el santo de la frontera. La imagen de la santidad a partir de las fuentes hagiográficas castellanoleonesas del siglo XIII" y de la misma autora "La Espiritualidad de los Cautivos de Santo Domingo en la obra de Pero Marín", así como el trabajo de Manuela Gracía Pardo, "El pastor de Las Navas de Tolosa. La realidad y la leyenda".

Referentes a los problemas en torno a los ritos, el martirio y las recompensas espirituales respecto a la Reconquista, no nos fue posible encontrar muchos trabajos monográficos, pero suficientes para ayudar a contextualizar las fuentes a ese respecto, por lo que la mayoría de ellos también nos fueron útiles en otros apartados . Destacamos especialmente de José Manuel Rodríguez García, “Cruzados y fronterizos. Discusión sobre el Carácter Cruzado de la Guerra en la Frontera, 1214-1314" en III Estudios de frontera. Convivencia, Defensa y Comunicación en la Frontera, Alcalá la Real, Diputación Provincial de Jaén, 2000; de Martín Alvira Cabrer, "Guerra e ideología en la España del siglo XIII: la conquista de Mallorca según la crónica de Bernat Desclot”, y 
de Francisco García-Serrano, "La creación de identidad en la frontera medieval hispana y la visión del otro: mudéjares y judíos".

Finalmente, con respecto a los reyes modélicos y sus virtudes, la mayor parte de la bibliografía ya ha sido reseñada en las paginas anteriores, no obstante consideramos necesario incluir los siguientes trabajos, útiles para este apartado en especifico, de Carlos Estepa, "Memoria y poder real bajo Alfonso VIII (1158-1214)" y del mismo autor "El Reino de Castilla de Alfonso VIII (1158-1214)" y de Ana Rodríguez, "Memoria y curia regia en Castilla en la primera mitad del siglo XIII". Junto a ellos encontramos a José Manuel Nieto Soria y su articulo "Imágenes religiosas del rey y del poder real en la Castilla del siglo XIII", a Manuel Alejandro Rodríguez de la Peña, "Rex institutor scholarum: La dimensión sapiencial de la realeza en la cronística de LeónCastilla y los orígenes de la Universidad de Palencia”: Hispania Sacra, LXII, 126, 2010, pp. 491-512; de Adeline Rucquoi, "El Rey Sabio: Cultura y Poder en la Monarquía Medieval Castellana" y de Leonardo Funes, El modelo historiográfico alfonsi: una caracterización.

Si bien este listado no esta completo, consideramos que hemos podido reseñar los textos que más nos han contribuido a la elaboración de nuestro trabajo, dando cuenta, sin ser exhaustivos, de los materiales y aportes existentes de forma panorámica.

\section{Estructura}

En vista del cumplimiento de los objetivos planteados, es que hemos dividido nuestro análisis en tres partes, cada una dedicada a abordar los principales aspectos del problema del discurso y sus tópicos, así como su evolución.

En la primera parte "Contexto Histórico", el primer capítulo "El Cristianismo y el Islam dos culturas enfrentadas en el marco peninsular" tal como su nombre lo indica se pretende describir el contexto general de la Reconquista, con énfasis en los siglos XII y XIII, en el marco de las relaciones entre las sociedades hispano cristina y el Islam, así como reseñar la evolución de los conceptos de Guerra Santa y Cruzada y su aplicación en el escenario peninsular, dándonos los principales hitos cronológicos, políticos, militares y religiosos de la Reconquista, permitiéndonos así comprender como las 
diversas fuentes fueron respondiendo a estos eventos y adaptándose a sus nuevas realidades.

Por último, este capítulo describe de forma más o menos general, los grandes tópicos de la frontera entre los reinos en construcción de Castilla y León y el mundo del al-Andalus en crisis. La intencionalidad de este apartado es describir algunos aspectos prácticos de la convivencia fronteriza, destacando la dinámica de relaciones que evidencian la existencia de una doble realidad, por una parte la construcción de estereotipos del otro, "el moro", y por el otro observar como este discurso debía adaptarse a la realidad práctica de la frontera.

Este capítulo también cumple el rol de materializar a través de ejemplos concretos como en la realidad práctica de la frontera, pese a la presencia del discurso oficial, era necesario buscar otros estímulos para la actividad bélica, apelando a necesidades y aspiraciones más concretas como fueron esencialmente el botín, el poder y la riqueza que se podían conquistar a través de la guerra.

En su conjunto esta primera parte nos permite identificar los pilares que servirán de base contextual a la segunda etapa de nuestro trabajo, donde procuraremos analizar en forma conjunta las formas en que, a partir de los elementos ya mencionados, se procuró crear herramientas que permitían dirigir y orientar las necesidades e intereses de la sociedad hispánica hacia la satisfacción de los objetivos de la reconquista, el empoderamiento de la monarquía y la unidad y sometimiento de la sociedad a la Iglesia.

El capítulo segundo, "Guerra santa y Cruzada: la instrumentalización religiosa de la práctica bélica", en ningún caso pretende ser una visión rupturista sobre temas que ya han sido trabajados y sobre los cuales existen corrientes y posturas historiográficas bien definidas. Simplemente pretende relatar como la idea de la guerra religiosa se encuentra en las raíces de las culturas mediterráneas y que por lo tanto el cristianismo simplemente adapto una tradición común para los pueblos a los que evangelizó y que era necesaria para logra la alianza con los poderes políticos de ese momento.

En ese contexto, en el tercer capítulo "La Guerra Santa y la Cruzada, el caso hispano medieval", describiremos como la Península Ibérica no estuvo alejada de este proceso y fue influenciado por él, con la salvedad que para el caso hispano, el 
enfrentamiento con Islam y en defensa del solar cristiano, venía dándose con anterioridad a la consolidación del discurso bélico del Papado, aunque inicialmente carecía de los elementos ideológicos que posteriormente la Iglesia y la influencia europea introducirían en la Reconquista. Por lo que nuestro estudio se concentra en como la Iglesia participó activamente en la construcción del discurso, pero también como los poderes monárquicos y la Iglesia, dentro de la cual hay que distinguir a la Iglesia hispánica y al Papado, no siempre actuaron en concordancia, entregándose a una lucha de poderes en los cuales el Papado pretendió aumentar el control sobre los soberanos, al mismo tiempo que estos procuraban acrecentar la autonomía de sus reinos y el control sobre el clero local.

En la segunda parte, titulada "Las fuentes: la construcción de elementos ideológicos", a través de dos grandes ejes temáticos se abordan primeramente las fuentes cronísticas del periodo y sus características, en segundo lugar su relación con la construcción de un ideal monárquico. Todo ello en vista de lograr una descripción del discurso teórico y sus principales componentes.

Es así como en los tres primeros capítulos de esta parte se realiza una revisión muy general de las principales directrices de la concepción y comprensión histórica medieval, es decir la convicción de que los hechos del hombre estaban insertos en un plan divino superior que daba sentido a todos los acontecimientos humanos ${ }^{23}$. Partiendo de esa base general, se procede a describir las principales crónicas de la Reconquista, desde la cronística mozárabe, pero concentrándose en torno a los textos y autores de los siglos XII y XIII. Junto a ello se presentan alguna hagiografías hispánicas, obras clásicas y bien conocidas, que no obstante nos interesa presentar en cuanto a su función de reflejos de la cosmovisión cristiana de la sociedad que las produjo y finalmente y solo de manera muy general, nos detenemos en algunos textos jurídicos, del escenario castellano y leones, esencialmente los fueros de Cuenca, Coria y Cáceres y en la obra jurídica alfonsina, en el entendido de que las tres primeras nos presentan una concepción jurídica esencialmente práctica y local, motivada por la realidad fronteriza, en tanto que los textos alfonsíes nos revelan una concepción más teórica e ideologizada de los ordenamientos jurídicos del reino.

\footnotetext{
${ }^{23}$ Eliade, Mircea, Lo Sagrado y lo Profano... op.cit., p. 64.
} 
De esta manera en los primeros capítulos de esta segunda parte se introduce el hecho de que las fuentes demuestran una intencionalidad de exaltación de la identidad castellano, basada en las prácticas cristianas, la guerra y la figura del monarca. Así como también nos sirve para constatar como las fuentes revelan, entre su discurso, algunos aspectos cotidianos de la reconquista, que viene a reforzar la idea de la convivencia práctica entre los distintos grupos religiosos y culturales que habitaban la Península.

El segundo eje temático se aborda a partir de los capítulos "La figura del rey y la Reconquista" y "Las virtudes del rey: Construcción de un ideal monárquico". En ellos se describirá la evolución cronística y su relación con los poderes políticos y religiosos a los que servían. Pero también se analizara como algunas ideas foráneas, en especial las relacionadas con la guerra santa, se introdujeron en la Península y permearon las fuentes cronísticas y hagiográficas, convirtiéndose en un elemento más del discurso al servicio de la creación de un ideal modélico de soberano.

Con el fin de comprender este proceso, en el capítulo "La figura del rey la Reconquista”, nos remitimos a tiempos más pretéritos para describir la conformación de la idea de monarquía en el occidente medieval, todo ello con el fin de recalcar el hecho de que desde sus orígenes el poder político y religioso se encontraban profundamente relacionados, confluyendo en torno a la figura real, creando así un modelo reconocible en toda Europa, lo que Bertelli llama religio regis ${ }^{24}$. Una posición que nos sirve de punto de partida y que nos permite afirmar que el proceso en España fue un símil de lo ocurrido en el resto de occidente, como la guerra - entendida como parte integral del ejercicio del poder $^{25}$ - aunque con ciertos elementos que fueron exacerbados o adaptados por las particularidades de la Península.

\footnotetext{
${ }^{24}$ Bertelli, Sergio, "Religio Regis la propaganda del poder real”, En Medievalismo, Año 8, N VIII, 1998 (9-18). Respecto al concepto utilizado por Bertelli, en nuestro trabajo nos hacemos parte del mismo, pero optamos por no desarrollarlo en profundidad ya que si bien existió una concepción común del monarca europeo, nosotros nos centramos exclusivamente en el caso hispano y sus propias particularidades.

${ }^{25}$ Rodríguez Lopéz, Ana, "Légitimation Royale Et Discours Sur La Croisade En Castille Aux XII Et XIII Siecles”, en Journal des savants, 2004, N¹ (129-163) p. 161. González Jiménez, Manuel, "Historia política y estructura de poder. Castilla y León. La Historia medieval en España. Un balance historiográfico (1968 - 1998)", XXV Semana de Estudios Medievales Estella, 14 a 18 de julio de 1998. p. 202.
} 
Aclarado estos aspectos, en el capítulo "Las virtudes del rey: Construcciones de un ideal monárquico", se describe cómo dentro de la mentalidad hispana medieval, desde las primeras crónicas astures, la figura del rey se tornó inseparable de la misión de recuperar los antiguos territorios visigodos y devolverlos a la fe cristiana ${ }^{26}$. Esto se tradujo en el convencimiento de una herencia visigoda y en la trasmisión de una misión justa de recuperación territorial. A partir de este momento los monarcas, primero astures y luego castellano leoneses, tenían presente que una de sus formas de validar su poder era demostrar que contaban con el respaldo divino, cuya mejor manifestación era la victoria sobre los enemigos de la Iglesia.

En la tercera y última parte, "Los Tópicos", se identifican elementos integrales trasversales del discurso a través del uso de imágenes modélicas omnipresentes como son los santos y los rituales religioso-políticos, así como los intentos por aumentar la concepción sacra de la Reconquista a través de la creencia en recompensa y estímulos divinos. Finalmente nos centrarnos en los tópicos discursivos que constituyen lo que hemos llamado los "monarcas modélicos" y como estos fueron utilizados en la ilustración de los aspectos prácticos de la narración de la Reconquista a través del análisis de casos concretos vinculados a la práctica religiosa, la política y la guerra en el escenario castellano, estableciendo como estos elementos respondían a un orden descendente, debiendo ser permanentemente reforzados para asegurar su utilidad a los intereses de los poderes reales y religiosos.

En el primer capítulo de esta tercera parte, "El Dios de la Guerra", se describen los principales elementos constitutivos del providencialismo, centrándonos específicamente en su vertiente militar y el desarrollo de la idea del pecado, que se ve acompañada de la descripción de como este discurso se introdujo en los relatos y fue evolucionando durante los siglos XII y XIII hasta convertirse en una presencia permanente, aunque progresivamente menos utilizada a medida que los protagonistas de los eventos, los monarcas, acrecentaban su poder ${ }^{27}$.

\footnotetext{
${ }^{26}$ Rodríguez Lopéz, Ana, "Légitimation Royale... op.cit., p. 156. Mitre Fernández, Emilio, Martín Alvira Cabrer. "Ideología y guerra... op.cit., p. 301

${ }^{27}$ Eliade, Mircea, Lo Sagrado y lo Profano...op.cit., p. 18-20, 66.
} 
En el segundo capítulo "Los santos guerreros al servició de la causa cristina" se analiza, a través de la selección de algunas figuras celestes destacadas, principalmente Santiago, Isidoro, San Millán, Domingo de Silos y la Virgen, como de forma consciente se utilizaron estas figuras ejemplares, que materializaban la protección de los cristianos y a través de sus obras se convertían en paladines, pero también vigilantes de la piedad de los castellanos y leoneses.

En el tercer capítulo "Las dádivas divinas y los rituales de la guerra", se estudian las principales recompensas espirituales y la forma en que se difundían, así como los rituales destinados a empapar de providencialismo los distintos aspectos de la realidad bélica. Para ello se describen los antecedentes pretéritos de la ritualidad en el Mediterráneo, para destacar, como en otras ocasiones, como lo ocurrido en Hispania es la adaptación local y particular de un proceso mayor.

Todo lo anterior pretende demostrar como estas prácticas permitieron el fortalecimiento del discurso bélico y político de la reconquista al materializar, de forma metódica y organizada los símbolos que demostraban la vinculación entre la guerra, sus protagonistas y la voluntad de Dios.

Finalmente, en el capítulo "Los Reyes modélicos" analizaremos en concreto la figura del monarca en Castilla -y León- durante los siglos XII y XIII, a través de un estudio focalizado en lo que hemos llamado los reyes modélicos, Alfonso VI, Alfonso VII, Alfonso VIII y Fernando III, además de Alfonso $\mathrm{X}^{28}$, sobre los cuales las crónica se explayan y convierten en arquetipos virtuosos que sintetizaban los ideales del buen rey, a través de la ejecución de distintas acciones que simbolizaban las virtudes políticas, militares, judiciales y cristinas de aquel que regía a su pueblo como representante de la Providencia.

\footnotetext{
${ }^{28}$ Alfonso X no fue exactamente un modelo real, en esencia debido al trágico fin de su reinado. No obstante su relevancia y el motivo por el cual lo asociamos a esta lista, es que el rey fue clave en la consolidación del modelo real, gracias a su obra jurídica y cronística. Alfonso fue el heredero y continuador de un proceso discursivo cronístico destinado a la exaltación del monarca como figura virtuosa, en el entendido, y aquí compartimos lo expresado por el profesor Emilio Mitre en su trabajo "Alfonso X: historiografía y tradiciones compilatorias del medievo europeo", de que las alabanzas a los reinos de Castilla y León eran una exaltación del monarca que los precedía y a su vez, la gloria de este era una alabanza para sus reinos, creándose así una dinámica destinada a la consolidación de la figura real.
} 
PRIMERA PARTE:

CONTEXTO HISTÓRICO 


\title{
PRIMERA PARTE: CONTEXTO HISTÓRICO
}

\section{I.1.- El Cristianismo y el Islam dos culturas enfrentadas en el marco peninsular}

\author{
I.1.a.- El Cristianismo y el Islam en Castilla y León: del discurso a la práctica
}

En el siguiente capítulo abordaremos las relaciones entre musulmanes y cristianos en la Península, centrándonos en el caso castellano ${ }^{29}$, y en dos aspectos: el discurso y la práctica $^{30}$. Esto en razón de que en las crónicas se manifiestan una serie de tópicos que

\footnotetext{
${ }^{29}$ El Reino de León será tratado en la medida que el contexto histórico así lo justifique, como fueron los períodos en que ambos reinos estuvieron unidos bajo una misma corona o bien, cuando los enfrentamientos entre Castilla y León afectaron directamente al desarrollo de los acontecimientos históricos.

${ }^{30}$ Nosotros entendemos el discurso como la expresión de un conjunto de ideas y principios que al ser ordenados constituyen una unidad ideológica cuyo objetivo es ser trasmitido e interiorizada por un grupo con el fin de orientar la voluntad y acción de un colectivo hacia fines claramente identificables. En función de esta caracterización es que en nuestra comprensión del discurso, incorporamos a la propaganda como medio de difusión del mismo y a la "ideología", como aquello que se utiliza para crear una visión de la realidad, necesaria para motivar al grupo en la culminación del objetivo.
}

Para explicar mejor estas palabras consideramos necesario enumerar algunas características del concepto de Discurso: Es elaborado concientemente por los sectores más preparados de la sociedad, incluidos cronistas, para representar su forma de concebir su realidad y cuyo fin es orientar la conducta general con el fin de lograr la realización de esta visión. Por ello el discurso debe ser relativamente fácil de comprender, no obstante puede tener segundas lecturas. (Vovelle, Michel, Ideologías y mentalidades, Barcelona, Ariel, 1985, p. 8; Mitre Fernández, Emilio y Martín Alvira Cabrer, "Ideología y guerra... op. cit., p. 292; Nieto Soria, José Manuel, "Ideología y poder monárquico... op.cit., pp. 342, 343).

Es en ese sentido que el discurso se encuentra profundamente vinculado al concepto de ideología, puesto que ella viene a sintetizar esta visión de las elites. Por la complejidad del término el concepto de ideología no puede ser descrito de forma simple, siendo, por lo tanto, necesario aproximarnos a estos conceptos en forma conjunta. En ese sentido podemos afirmar que las ideologías sirven para la trasmisión de visiones y objetivos que se utilizan para ordenar la sociedad. Una concepción del mundo en la cual, según Nieto Soria, se unen lo material y lo mental, lo que no significa una armonía, pero si la intencionalidad de lo mental por influenciar y orientar lo material. Y dado que lo material cambia, puesto que es sujeto de procesos, los discursos también deben adaptarse según la realidad práctica, puesto que de lo contrario perderían vigencia, resultando del todo inefectivos, misma razón por la cual el discurso ideológico es inseparable del hecho social y colectivo. De ello se desprende que la ideología y el discurso que la representa, siguiendo la línea de Michel Vovelle, es el fruto de un acto consiente, planificado y ordenado. (Ver Nieto Soria, José Manuel, "La ideología política bajo medieval... op. cit., p. 668; García Fitz, Francisco, "La conquista de Andalucía... op. cit., pp. 59-61; Mitre Fernández, Emilio y Martín Alvira Cabrer, "Ideología y guerra... op. cit., p. 292).

La ideología sobre la cual se estructura el discurso, a su vez cumple con una serie de funciones, siendo la que más nos interesa su rol como ente identificador de un grupo determinado. A través de ella la elite no solo establece objetivos, sino que crea certezas que fortalecen al grupo al cual esta dirigida, dotándolo así de un aparato doctrinal que favorece la estabilidad interior, razón por la cual la ideología debe ser evidente y comprensible a todos. Lo primero se logra a través de ritos y actos simbólicos que se convierten en la materialización y recordatorio permanente de los ideales del grupo, mientras que lo segundo y en relación a los ritos, obliga a crear un lenguaje común y recurrente (manifestado en símbolos, discursos y ritos) que sean comprensibles por todos los miembros de esa comunidad, sin importar su posición. 
pueden ser el reflejo un discurso agresivo y poco tolerante, vinculado a las ideas de la guerra, Reconquista y religión ${ }^{31}$, en tanto que las fuentes jurídicas, como los fueros, nos

Es así como la ideología y sus discursos se muestran como necesarios para el orden social, razón por la cual innegablemente pueden presentar una tendencia a volverse conservadores, lo que no debe ser confundido con inmutables, puesto que en esos casos es posible afirmar que lo que observamos es el uso constante de ciertos elementos estructurales, a los cuales se les van adaptando nuevos elementos impulsados por realidades prácticas, que permiten que estos elementos subsistan como eje discursivo de fondo (Nieto Soria, José Manuel, "La ideología política bajo medieval... op. cit., p. 668). Es en ese sentido que, en parte, consideramos que la ideología puede ser asimilada a la religión, puesto que esta permite la identificación de un grupo, orientado por ideales comunes, pero ordenados por una elite, que procura el reforzamiento de los mismos a través de una serie de ritos, rituales y discursos que impregnan a todos los sectores de esa comunidad. Emile Durkheim, en su trabajo Las formas elementales de la vida religiosa, caracteriza la religión a partir de elementos como el ser algo inminentemente social, una representación colectiva de una expresión colectiva, donde los ritos son una forma de actuar para grupos reunidos. Razón por la cual los hechos religiosos son también sociales ya que son frutos del pensamiento colectivo. (Durkheim, Emile, Las formas elementales de la vida religiosa. El sistema totémico en Australia, Madrid, Akal, 1992, pp. 8, 9, 388). Por lo que sirve de forma similar que otras manifestaciones ideológicas, como las que nos atañen: el mito visigodo, la lucha religiosa, el providencialismo, etc...

Es precisamente por estas características, en el especial su rol identificador, que las ideologías suelen tender a la exclusión dividiendo la concepción de la realidad según la adopción de determinadas ideas y creencias, lo que en el mundo medieval se materializo en la estructuración de Occidente en torno al cristianismo, lo que les permitía identificarse y al mismo tiempo idealizarse en torno a su concepción del bien, distanciándose así de aquellos que no compartían esta misma visión y por lo que naturalmente se les identificó con lo maligno y malvado (Nieto Soria, José Manuel, Propaganda y opinión pública... op. cit., pp. 15-17; Rubio Hernández, Rogelio, Antropología: Religión, mito y ritual, Madrid, Universidad Nacional de Educación a Distancia, 1988, pp. 38, 39 y 44, 45).

Pieza fundamental de la difusión del discurso fueron las crónicas, en especial las compuestas en el entorno del poder, y que estando a su servicio recurrían a la edición de los hechos para ponerlos al servicio de los intereses y fines de los monarcas y mandantes (Funes, Leonardo, "La crónica como hecho ideológico: el caso de la Estoria de España de Alfonso X", en La Corónica, A journal of medieval hispanic languages: Literatures \& Cultures, Vol. XXXII, N³, 2004, [pp. 69-90], pp. 84, 85).

En España, la Reconquista significo la aceptación de una interpretación ideológica total que identificaba a los cristianos con las fuerzas del bien, insertos en una lucha contra el Islam. Era una visión mística fatalista que promovía el conflicto permanente entre dos opuestos irreconciliables, y donde solo uno representaba la justicia y el favor de la Providencia. La lucha era entonces símbolo del enfrentamiento eterno que se inicio con el Génesis y debería extenderse hasta el final de los tiempos (García Fitz, Francisco, "La conquista de Andalucía... op. cit., p. 53). Esta era una cosmovisión que implicaba la creación y trasmisión de una idea distorsionada de la realidad, puesto que esta era interpretada y manipulada según la ideología de los cronistas, con el objeto de que se adaptase a su particular visión del mundo (Linehan, Peter, Historia e historiadores de la España Medieval, Salamanca, Universidad de Salamanca, 2011, pp. 30, 31). Lo que no implica que aquellos difusores de la ideología, en esté caso los cronistas, fuesen promotores y valedores de una mentira, puesto que si bien sus escritos se pueden basar en falsedades o versiones sesgadas, esto no significaba que lo hiciesen de forma totalmente conciente, puesto que pudieron obrar bajo una influencia cultural de la que eran parte y que condicionaba sus pensamientos y acciones (García Fitz, Francisco, "La conquista de Andalucía... op. cit., pp. 59-61).

A nuestro entender todos estos factores implican que el discurso no puede ser comprendido como una mera ideología inmutable, y en concordancia con Foucault, entendemos el discurso como el reflejo de una ideología viva, que se adapta y evoluciona a sus circunstancias y que impregna a toda la sociedad, al punto que se convierte en parte de ella. Esto a su vez implica que el discurso puede terminar por desprenderse de sus autores originales, cobrando una vida propia y enriqueciéndose con las experiencias comunes y aporten individuales. Pese a lo cual tenderá a conservar sus ideas matrices, puesto que estas serán las que servirán de base a la misma sociedad que las sostiene en una relación de retroalimentación y autovalidación constante. En esencia, entendemos los discursos como concepciones "vivas" que evolucionan y se adaptan, cobrando una autonomía que trascendía a sus autores.

${ }^{31}$ El concepto de tolerante (del latín tolerans, que sobrelleva, que soporta) o de tolerancia (tolerantia, paciencia, sufrimiento) suele usarse a menudo para referirse a la dinámica de coexistencia en la España medieval, frecuentemente tomando un cariz positivo y a veces hasta idealizado. Nosotros preferimos usar 
revelan una realidad diferente, basada en situaciones más cotidianas y prácticas que rara vez dan espacio a algún tipo de discurso ideológico o religioso. Si bien es posible que estos temas no sean novedosos, nos parece prudente referirnos a ellos con el fin de ilustrar y contextualizar los restantes apartados de esta investigación. Motivo por el cual, a partir de una descripción histórica procuraremos abordar la teoría y la práctica de la coexistencia entre el reino de Castilla y el al-Andalus ${ }^{32}$.

el término en su sentido original latino; es decir, el simple hecho de soportar, en este caso las prácticas y creencias del otro. Ello en el entendido de que esta "tolerancia" para el caso peninsular no puede ser definida con un carácter constantes y que además sus motivaciones muchas veces se debían a razones prácticas o instrumentales, mas que por la búsqueda de una idílica armonía. Es por esto que también utilizaremos, cuando las circunstancias lo ameriten, el concepto de convivencia. Esto en razón de que según su su concepción más amplia, convivencia significa vivir en compañía de otro, sin que esto implique una relación armónica, pacífica o tolerante. Simplemente es un concepto que se aplica cuando personas o comunidades comparten el mismo espacio y es con esa premisa que adoptamos de forma preferente este concepto para nuestro trabajo. (Al respecto de estas definiciones ver Diccionario de la Lengua Española, XXII Edición, Madrid, Real Academia Española, 2001).

32 A partir del siglo XI comienza un proceso definitivo de recuperación del territorio, el que posteriormente sería denominado "Reconquista". Este esfuerzo tuvo su eje central primero en el Reino de León, y posteriormente en el de Castilla. Luego del establecimiento de la frontera en el Duero, los reinos del norte debieron soportar las incursiones de al-Mansur, que pese a su intensidad no eran más que los últimos estertores del Califato de Córdoba que acabaría por desaparecer a comienzos del siglo XI. La aparición del los reinos de Taifas y el fortalecimiento leonés dieron inicio a un avance cristiano que, pese a retrocesos ocasionales, se tornaría imparable a lo largo de los siglos siguientes. En ese contexto, que en 1085 Alfonso VI se apodero de Toledo, estableciendo la frontera en el río Tajo. De esta forma, la posesión de la antigua capital señala el rol de heredero y continuador del linaje visigodo y la misión unificadora y restauradora del territorio por parte de los monarcas castellano-leoneses. Un avance que fue posible gracias al desgaste y rivalidades entre los reinos de Taifas, que presionados por el sistema de Parias, se encontraban demasiado agotados para oponer una resistencia a la presión de Alfonso VI.

En 1086 el arribo de los almorávides, implicó una fuerte derrota para los cristianos y una pausa momentánea en del desarrollo de la Reconquista. Paralelamente, a la muerte de Alfonso VI, su reino fue azotado por los conflictos derivados del matrimonio de su hija Urraca con Alfonso I de Aragón. Por casi veinte años el reino estuvo a merced de los conflictos internos, hasta la coronación de Alfonso VII (11261127), quien bajo el título de emperador reinició la ofensiva contra los musulmanes. A su muerte en 1157 , el reino fue divido entre sus hijos Sancho III de Castilla (1157-1158) y Fernando II de León (1157-1188). Este periodo de relativa inestabilidad de los cristianos fue aprovechado por una tercera oleada africana, entre 1145 y 1147, cuando los almohades unificaron el al-Andalus bajo su dominio, el que comenzó a declinar a partir de 1212, cuando la alianza cristiana liderada por Alfonso VIII de Castilla (1158-1214) derrotó a los africanos en la batalla de las Navas de Tolosa (Ver García Fitz, Francisco, Las Navas de Tolosa, Barcelona, Ariel, 2008).

En 1230 se produjo la unión definitiva de Castilla y León bajo la corona de Fernando III (12171252), fecha que coincide con el colapso de los almohades y la restauración de los reinos de Taifas. Durante este reinado, la Reconquista tomó nuevos bríos y logró casi la total recuperación del territorio, salvo por el extremo sur; el Reino de Granada y el control de Estrecho de Gibraltar que queda encomendado a su hijo, Alfonso X que reino entre 1221-1284.

Sobre el periodo reseñado existen muchas obras en las que nos hemos basado para confeccionar esta breve síntesis. Para un estudio más acabado del periodo recomendamos los siguientes trabajos. De Francisco García Fitz, sus obras dedicadas a los aspectos bélicos y políticos; Castilla y León frente al Islam: Estrategias de expansión y Tácticas militares (Siglos XI - XIII) y Relaciones Políticas y Guerra. La experiencia castellano - leonesa frente al Islam. Siglos XI-XIII. Los textos de Angus Mackay, La España de la Edad Media: Desde la Frontera hasta el Imperio (1000-1500), José Luis Martín, La Península en la Edad Media y José María Mínguez, La España de los siglos VI al XIII: Guerra Expansión y Trasformaciones. En busca de una frágil unidad, todos estos trabajos nos planten una mirada general de la época, desde distintas y complementarias perspectivas historiográficas. Por ultimo cabe destacar las distintas biografías y textos dedicados a los reyes mencionados, entre los que destacan: 
Como es sabido, el Islam hizo su entrada en la realidad hispánica en el siglo VIII, contribuyendo a la desaparición del Reino Visigodo. Esto produjo, tanto política como culturalmente, un cambio trascendental en la historia de la Península ante el cual los hispanos debieron adaptarse, al mismo tiempo que intentaban comprender las causas que generaron la transformación total de su mundo.

Por ello no fue extraño que con respecto al Islam asumiesen la misma visión que previamente habían tenido los bizantinos, la idea del castigo de Dios en manos de un pueblo hereje, un instrumento del mal y del Anticristo. Pero este fue sólo el inicio de la relación y convivencia entre ambas culturas, puesto que lo prolongado de la presencia musulmana en la Península provocaría una dinámica compleja en las relaciones, la que también estaría influenciada por los acontecimientos foráneos ${ }^{33}$.

Sin embargo, no hay que engañarse por estas dinámicas de coexistencia propias de la realidad de frontera. Para los hispano-cristianos, en el discurso, el "moro" fue siempre un invasor, un advenedizo, que injustamente había usurpado las tierras de sus ancestros y cuyo fin último era ser expulsado de las tierras peninsulares; podía existir coexistencia, pero no aceptación. En la cosmovisión cristiana medieval primaban los absolutos y no existían términos medios; así, el Islam era el enemigo de Dios y de la Iglesia, la materialización del mal y por tanto, los cristianos tenían la obligación de derrotarlo. Ese es el discurso que estará presente en las crónicas desde el siglo VIII en adelante; no obstante, este modo argumentativo experimentó variaciones durante la Reconquista, pasando por períodos de mayor tolerancia, hasta adoptar la idea de derrota y expulsión total, visible de forma patente a partir del siglo XII.

Veremos con más detalle, cómo se fue construyendo este discurso y cómo evolucionó en la práctica, teniendo en consideración que las crónicas constituyen una

Mínguez, Alfonso VI, Pallares y Portela, La Reina Urraca, Manuel Recuero Astray. Alfonso VII (11261157), Julio González. Reinado y Diplomas de Fernando III y Manuel González J, Alfonso X el Sabio $1252-1284$.

${ }^{33}$ Hemos de tener siempre presente que para los cristianos peninsulares su visión del musulmán cambiara dependiendo de si se trata desde la perspectiva de mozárabes o de cristianos del norte, así como también a medida que se produzcan nuevas oleadas invasoras los cristianos distinguirán entre andalusíes y africanos. En esencia la presencia islámica en la Península creó dos sociedades particulares que se enfrentaron por el control del mismo territorio. Con los siglos se produjo una doble modalidad de convivencia; por un lado una vida fronteriza con intercambios comerciales y culturales frecuentes, y por otro, periódicas campañas militares en las que los cristianos llevaron la iniciativa en forma casi permanente a partir del XI.

Por su parte, la sociedad árabe-islámica peninsular, los andalusíes, también evolucionaron, adoptando un sentimiento de independencia o quizás más correctamente, particularidad, - influenciada por las tradiciones occidentales y cristianas - con respecto a la tradición islámica del norte de África. Esta característica les permitía acercarse y comprender mejor a sus vecinos cristianos, sin que por ello los andalusíes renunciaran a tener una conciencia de pertenencia común con el resto del Islam, la umma universal. Este fenómeno es lo que José Antonio Maravall ha llamado el "Islam Occidental". 
versión parcializada de la realidad, escritas y dirigidas para la élite con el fin de establecer paradigmas, ideologías y modelos ${ }^{34}$. Por ello, pese a que fueron compuestos en épocas distantes, los términos para referirse al Islam escasamente varían, dado que principalmente se destacó su rol como enemigo de la cristiandad. Por este motivo, consideramos necesario hacer una revisión general de otras fuentes, aquellas originadas en la costumbre - como los fueros - a fin de intentar rescatar la imagen, de quien hemos llamado el vecino enemigo.

\section{I.1.b.- El 711, debacle y leyenda negra}

En el año 711, la crisis en torno a la asunción de Rodrigo permitió la irrupción de las huestes de Tarik en Hispania contribuyendo al colapso del Reino Visigodo, ya sacudido por sus propios conflictos internos ${ }^{35}$.

Para el siglo IX, las élites y los cronistas intentaron explicar estos hechos interpretándolos como una forma castigo divino ${ }^{36}$; paralelamente, desde un principio demonizaron a los musulmanes, en un intento de justificar la lucha en su contra. Es así como la Crónica del 741, considera a los musulmanes como uno de los tantos pueblos que se habían levantado contra Bizancio, destacando su crueldad, caracterizando a Mahoma como a su caudillo, sin mayores referencias religiosas ${ }^{37}$.

\footnotetext{
${ }^{34}$ Paniagua Lortau, Ana Belén, "Consideraciones sobre la imagen de los musulmanes en la Gran Crónica de Alfonso XI" en Toro Ceballos, Francisco y José Rodríguez Molina (Coordinadores), IV Estudios de Frontera, Historia, Tradiciones y leyendas en la Frontera, Jaén, Diputación Provincial de Jaén, 2002, [pp. 417-430], p. 420.

${ }^{35}$ Con respecto al 711 y su impacto, Peter Linehan, nos recuerda como algunos autores son enfáticos en afirmar que no se puede hablar de una verdadera catástrofe, hecho evidenciado en que la supervivencia cultural e institucional y que no es posible observar una completa ruptura entre una etapa y otra. No obstante, según el parecer del autor, los cronistas del norte peninsular realizaron un trabajo consiente de magnificación de lo ocurrido, con el fin de crear la ideología reconquistadora, legitimar a los monarcas del norte y justificar los cambios sociopolíticos que la expansión producían en la sociedad cristiana de la Península (Linehan, Peter, Historia e historiadores...op. cit., p. 37).

${ }^{36}$ La idea del castigo divino es de antigua data y no solo se vincula a los reyes visigodos, puesto que los cronistas lo hacen extensivo a diversos personajes de la antigüedad, como emperadores romanos, que fueron sancionados por Dios, entre otras razones, por la persecución a los cristianos. En cuanto a los visigodos, la Chronica Naierensis, elabora una "genealogía" de la monarquía, construyendo una historia de traiciones, injusticias, rebeliones y pecados, que explicarían las distintas desgracias que afectaron a los monarcas y que culminaría con la muerte de Rodrigo y la conquista musulmana del 711 (Klinka, Emmanuelle, "Chronica naiarensis: de la traición a la exaltación”, en e-Spania [En línea], 7 / juin 2009, http://e-spania.revues.org/18934 ; DOI : 10.4000/e-spania.18934. (octubre de 2013).

${ }^{37}$ Barkai, Ron, El enemigo en el espejo. Cristianos y musulmanes en la España medieval, Madrid, Rialp, 2007, pp. 21, 24-28. Sánchez Alonso, B. Historia de la historiografía española. Tomo I. Hasta la publicación de la Crónica de Ocampo (...-1543), Madrid, CSIC, 1947, pp. pp. 100-101.
} 
En la misma línea, la Crónica Mozárabe del 754, relata la destrucción y devastación que los árabes hicieron en las tierras de Hispania, destacando la crueldad desplegada hacia todos los sectores de la sociedad:

"Sicque non solum ulteriores Spaniam, sed etiam et citeriores usque ultra Cesaragustam antiquissimam ac florentissiman, seniores et potentes seculi cruci aiudicat, iubenes atque lactantes pugionibus trucidat. Sicque dum tali terrore cunctos stimulat pacem nonnulle ciutates que residue erant iam coacte proclamitant adque suadendo et inridendo astu quoddam nec mora petita condonat. Sed ubi enpetrata territi metu recalcitrant, ad montana temti iterum effugientes fame et diversa morte periclitant. Adque in eandem infelicem Spaniam Cordoba in sede dudum Patricia, que semper extitit pre ceteras adyacentes ciuitates opulentissima et regno Uuisegothorum primitibas inferebat delicias, regnum efferum conlocant. ${ }^{, 38}$

A estos relatos de barbarie, se suman múltiples referencias que aluden a que las victorias obtenidas por los musulmanes eran fruto del engaño y la traición ${ }^{39}$. Asimismo, destacan las menciones sobre la existencia de "colaboracionistas" con los invasores, personajes que pactaron con los musulmanes y traicionaron así a su pueblo. Entre estos últimos se mencionan a los antiguos partidarios de Witiza y en particular a los judíos, quienes nunca gozaron de una completa aceptación por parte de los visigodos ${ }^{40}$.

\footnotetext{
${ }^{38}$ Crónica mozárabe de 754, Edición crítica y traducción por José Eduardo López Pereira, Zaragoza, Anubar, 1980, $\mathrm{N}^{\circ}$ 54, pp. 70, 72 (En adelante CM 754). "Y así, con la espada, el hambre y la cautividad devasta no sólo la España ulterior sino también la citerior hasta más allá de Zaragoza, ciudad muy antigua y floreciente, poco ha desprovista de defensas porque asi lo quiso Dios. Con el fuego deja asoladas hermosas ciudades, reduciéndolas a cenizas; manda crucificar a los señores y nobles y descuartiza a puñaladas a los jóvenes y lactantes. De esta forma, sembrando en todos el pánico, las pocas ciudades restantes se ven obligadas a pedir la paz, e inmediatamente, complacientes y sonriendo, con cierta astucia conceden las condiciones pedidas. Pero asustados, rechazan la paz lograda, huyen por segunda vez en desbandada a las montañas y mueren de hambre y otras causas.

Así, sobre esta España desdichada, en Córdoba, ciudad que de antiguo llevaba el título de Patricia, que siempre fue la más rica entre otras ciudades próximas y que dio al reino visigodo los primeros frutos delicados, establecen un reino bárbaro." CM 754, $\mathrm{N}^{\circ} 54$, op. cit., pp. 71, 73.

${ }^{39}$ La Crónica Mozárabe de 754, destaca el hecho de que Rodrigo accedió al trono mediante una revuelta y que luego fue derrotado por lo musulmanes debido a que "fugatum omnnem Gothorum exercitum, qui qui cum eo emulanter fraudulenterque ob ambitionem regni eduenerant, cecidit", así como también afirma que Muza arrasó Toledo y ejecutó a algunos ancianos nobles, gracias a la ayuda de Opas, hijo de Egica (CM 754, $\mathrm{N}^{\circ}$ 52, op. cit., pp. 68 y 70) Similar relato se observa en las versiones Rotense y A Sebastian de la Crónica de Alfonso III, donde se hace referencia a la derrota de los godos producto del la traición de los hijos de Vitiza (CAIII, "Rotense" N 7 y “A Sebastian" No7, op. cit. pp. 200 y 201).

${ }^{40}$ García Sanjuán, Alejandro, "Formas de sumisión del territorio y tratamiento de los vencidos en el derecho islámico clásico" en Fierro, Maribel y Francisco García Fitz (Editores), El cuerpo derrotado: Cómo trataban musulmanes y cristianos a los enemigos vencidos (Península Ibérica, SS. VIII-XIII), Madrid, CSIC, p. 102.
} 
Pese a resaltar las características arteras de los árabes, la Crónica omite referencias negativas a Mahoma, refiriéndose a él simplemente como un "caudillo" de los musulmanes y como líder de una rebelión exitosa contra Bizancio. En contraposición, relata la batalla de Poitiers sin ocultar sus simpatías hacia Carlos Martel y su victoria ${ }^{41}$.

En ambas crónicas las referencias al Islam son étnicas y políticas, evitando las críticas a su religión ${ }^{42}$. Al parecer, para los cronistas, en esta primera etapa, fueron más importantes los hechos ocurridos en torno a la conquista que la comprensión o crítica hacia la religión de los conquistadores ${ }^{43}$.

En el mismo siglo IX, particularmente en las crónicas del ciclo Astur ${ }^{44}$, veremos un cambio respecto a esa postura, tornándose las referencias al Islam cada vez más críticas y cercanas a la "leyenda negra", en la que se explica el origen mítico de los "sarracenos", negando que fuesen descendientes de Saray y por el contrario, destacando que fueron fruto de la relación entre Abraham y Agar, introduciendo así la idea de la raza bastarda ${ }^{45}$.

Asimismo, en la Crónica de Alfonso III (compuesta a finales del siglo IX) se aprecian claramente una serie de denominaciones peyorativas para referirse a los musulmanes, relacionadas con los orígenes míticos del pueblo árabe. Es así como se les llama caldeos, sarracenos, árabes, ismaelitas y paganos ${ }^{46}$.

Por su parte, la Crónica Profética (posiblemente compuesta en torno a la década de 880) utiliza las ideas de culpa y castigo divino, a la vez que anuncia una pronta

Para el siglo XIII, Lucas de Tuy y Jiménez de Rada, destacan la colaboración de los judíos en la captura y ocupación de las ciudades visigodas, como el caso de Toledo, Córdoba, Málaga y Murcia (CE, Libro III, cap. LXVII, op. cit., p. 270; y HEE, Libro III, cap. XXIII, XXIV, op. cit., p. 154, 155).

${ }^{41}$ CM 754, N 80, op. cit., pp. 99, 101; y Flori, Jean, La Guerra Santa. La formación de la idea de cruzada en el Occidente cristiano, Granada, Trota, Universidad de Granada, 2003, p. 234.

${ }^{42}$ Redondo Jarillo, María Cristina, "La Confección de la Figura del Rey guerrero en las Crónicas Asturleonesas (Siglos VIII-XII)", en Miscelánea Medieval Murciana, 2008, XXXII, [pp. 131-141], pp. 132, 133; y Barkai, Ron, El enemigo en el espejo. Cristianos y musulmanes en la España medieval, Madrid, Rialp, 2007, pp. 24-28.

${ }^{43}$ No debemos peder de vista el hecho de que nos estamos refiriendo a obras mozárabes y por lo tanto elaboradas por autores que procuraban no ofender a los musulmanes dominantes.

${ }^{44}$ Evidentemente, esta diferencia en el discurso se debe a que estas crónicas fueron compuestas en el norte peninsular, en las tierras cristianas y al servicio de los monarcas astures y sus descendientes.

${ }^{45}$ Chronica Naierensis, Chronica Hispana saeculi XII. Pars II, Cura et studio Juan A. Estévez Sola, Brepols, Turnhout, 1995, Liber I, N²5, op. cit., p. 46. (En adelante CN 1995) Cronicón Albeldense en Huici M., Ambrosio, Las crónicas latinas ...op. cit., Tomo I, p. 188.

${ }^{46}$ Destaca especialmente el uso del nombre caldeo, puesto que este pueblo referido en el Antiguo Testamento fue un enemigo tradicional de los israelitas, y es frecuentemente mencionado como un instrumento de castigo divino, Por extensión se entiende que para estos cronistas, los visigodos son el pueblo de Dios castigado a través de estos "nuevos caldeos" (Bronisch, Alexander Pierre, Reconquista y guerra santa: La concepción de la guerra en la España cristiana desde los visigodos hasta comienzos del siglo XII, Granada, Universidad de Granada, 2006, p. 189). 
derrota y expulsión de los musulmanes. En su conjunto, las crónicas sobre Alfonso III involucran los aspectos religiosos en la conceptualización de los árabes, relacionándolos con la herejía y el error. Comenzaron entonces a masificarse los términos peyorativos, terminando finalmente por catalogar a Mahoma como un falso profeta ${ }^{47}$. Al mismo tiempo, la imagen de los musulmanes se tornó cada vez más diabólica, acusándoseles de actos como el canibalismo y destacando sus características físicas, "feos y de piel oscura", como símbolos de su maldad ${ }^{48}$. Un cambio de actitud que puedo responder al incremento de la actividad bélica fronteriza durante la segunda mitad del siglo IX y reveses cristianos como las batallas de Guadalacete (852) y Morcuera (865), que aumentaban la necesidad de justificar el enfrentamiento entre cristianos y musulmanes peninsulares.

En definitiva, estas crónicas marcarían una tendencia que definiría los arquetipos peninsulares, los que se fueron tornando más extremos, con el fin último de fortalecer el discurso de la Reconquista y en particular presentar la figura del monarca como símbolo de la lucha cristiana y antitesis de la "perfidia de los moros"49.

Estos cambios no solo son atestiguables entre los cristianos. Los musulmanes, inicialmente, también debían adaptarse para facilitar la ocupación de sus conquistas ${ }^{50}$. Lo anterior tuvo varias consecuencias, entre ellas que los conquistados comenzaran un proceso de aculturación con los musulmanes y muchos terminasen por convertirse a la fe de sus conquistadores. Sin duda, esto implicaba una seria amenaza para las autoridades eclesiásticas sobrevivientes sometidas a la superioridad islámica, que veían en ello el fin de la influencia y poder de la Iglesia hispana. Lo anterior se veía agravado por la actitud de muchos cristianos, que temerosos de perder sus libertades, prerrogativas e incluso influencias, evitaban criticar a los musulmanes y sus creencias, facilitando así el camino a la aculturación. Esto generó el surgimiento de grupos

\footnotetext{
${ }^{47}$ Bronisch, Alexander Pierre, ibid., p. 213; y Barkai, Ron, El enemigo en el espejo... op. cit., pp. 34-39.

48 Gárate Córdoba, José María, Espíritu y milicia en la España medieval, Madrid, Publicaciones Españolas, 1967, pp. 56, 57.

${ }^{49}$ Redondo Jarillo, María Cristina, "La Confección de la Figura del Rey... op. cit., pp. 132, 133.

${ }^{50}$ Siguiendo sus practicas de expansión, los musulmanes incluían a los cristianos y mozárabes sometidos en la categoría de dhimmies, gozando de cierto grado de respeto y libertades, pero limitando sus prácticas religiosas y obligándolos a usar señas distintivas para evitar que se mezclasen con los musulmanes o intentasen convertirlos a su fe. Lo que no significo una separación total entre ambos grupos, puesto que los árabes necesitaban de la colaboración de los hispanos conquistados para poder controlar el territorio. (Fletcher, Richard, La cruz y la media luna. Las dramáticas relaciones entre el cristianismo y el Islam desde Mahoma hasta Isabel la Católica, Barcelona, Península, 2005, p. 34).
} 
cristianos radicales que comenzaron a criticar directamente al Islam, produciéndose el episodio de los Mártires de Córdoba a mediados del siglo $\mathrm{IX}^{51}$.

A partir de este suceso, la posición cristiana se radicalizó aún más, haciéndose muy frecuentes las referencias peyorativas hacia Mahoma. Personajes como Eulogio de Córdoba y su discípulo Álvaro en el siglo IX, comenzaron a relacionar a los musulmanes con las Escrituras, y a buscar explicaciones providenciales sobre la conquista de España, otorgándoles un lugar negativo dentro del plan de la Salvación. Según Ron Barkai, estas ideas habrían llegado a la Península desde el exterior, habiéndose originado en Oriente durante el siglo VIII por Juan Damasceno ${ }^{52}$.

Igualmente, los musulmanes, también se referían peyorativamente a los cristianos, en especial a partir de la última parte del siglo IX y $\mathrm{X}$ cuando se incrementaron los enfrentamientos con los astures ${ }^{53}$. Las fuentes andalusíes se refieren al norte peninsular como tierra de "idólatras" o de "paganos" y llaman a Ordoño II “enemigo de Alá”. Del mismo modo, sus victorias se atribuyen a la voluntad de Dios ${ }^{54}$.

De esta forma se observa cómo ambas culturas, pasada la sorpresa inicial y la etapa de adaptación mutua, comenzaron a extremar sus posturas con respecto al otro, a medida que lo fueron considerando una amenaza. La religión tuvo un papel importante en esta evolución, puesto que sirvió como clara señal diferenciadora entre un grupo y otro; así, los cristianos crearon una autoimagen basada en su fe y en la necesidad de recuperar sus tierras, al mismo tiempo que construían una imagen del musulmán como el antagonista por naturaleza, el invasor y el enemigo de Dios. Algo similar ocurrió con los musulmanes, que procuraron conocer la religión de los occidentales, la que si bien no llegaron a demonizar, no tardaron en identificar como los enemigos de Allah, caracterizados por sus costumbre idolatras y comprendiéndolos como a sus enemigos

\footnotetext{
51 Tolan, John, Sarracenos. El Islam en la imaginación medieval europea, Valencia, Universitat de Vàlencia, 2007, pp. 115, 116; Flori, Jean, Guerra Santa...op. cit., pp. 118, 119; y Fletcher, Richard, La cruz y la media luna... op. cit., p. 57.

${ }^{52}$ Barkai, Ron, "Diálogo Filosófico-Religioso en el seno de las tres culturas ibéricas", en Santiago-Otero, Horacio (Editor), Diálogo Filosófico-Religioso entre Cristianismo, Judaísmo e Islamismo durante la Edad Media en la Península Ibérica, Actes du Colloque international de San Lorenzo de El Escorial, Société Internationale pour l'Étude de la Philosophie Médiévale, Brepols, 1994, p. 6; Tolan, John, Sarracenos ... op. cit., p. 109; y Flori, Jean, Guerra Santa, ...op. cit., pp. 130, 131.

${ }^{53}$ Ejemplos de este incremento de enfrentamientos fueron el avance de la frontera hasta el Duero, bajo el reinado de Alfonso III de León, las batallas de Batalla de Valdejunquera (920) Simancas (939) y las expediciones de Al-Mansur en las últimas décadas del siglo X.

54 Tolan, John, Sarracenos... op. cit., p. 70.
} 
naturales $^{55}$. Sin embargo, debemos recordar que estas imágenes son parte de un discurso, y que la realidad cotidiana tendió a matizar estas ideas.

\section{I.1.c.- Siglo XI. Se inicia la Reconquista, el moro enemigo o aliado tolerado}

Sabemos que a comienzos del siglo XI el Califato de Córdoba colapsó producto de una serie de dinámicas internas que llevaron a la aparición de los distintos reinos de Taifas. Dicha situación fue bien aprovechada por Fernando I, quien comenzó a aplicar una política de presiones y expansiones territoriales materializadas en las parias, debilitando seriamente a los nuevos poderes musulmanes ${ }^{56}$.

Este sistema fue seguido por los herederos de Fernando I y llevado a su máximo desarrollo por Alfonso VI, que combinó esta estrategia de desgaste con la acción militar directa contra los "reyezuelos" andalusíes. Esto le dio un nuevo impulso a la

\footnotetext{
${ }^{55} \mathrm{Al}$ respecto de las visiones de los musulmanes con respecto a los cristianos y su evolución, ver Barkai, Ron, El enemigo en el espejo... op. cit. Capítulo II.

${ }^{56}$ Como se sabe, las parias fueron un sistema, consagrado, por Fernando I, mediante el cual, el soberano cristiano extorsionaba a los distintos reinos de Taifas con el objeto de obtener de ellos concesiones territoriales y tributos monetarios, a cambio de no atacarlos. Esta estrategia, también incluía la explotación de las rivalidades internas de las Taifas y la intromisión en los conflictos locales a través de la ayuda militar cristiana y la realización de cabalgatas de amedrentamiento, todo ello con el objeto de mantener debilitados a los reinos musulmanes y lograr, sin grandes esfuerzos bélicos y económicos, la ampliación del reino cristiano. Entre más débiles estuviesen los Reyes de Taifas, mayores eran los tributos que cobraban los cristianos, una estrategia que resulto tan exitosa que el dinero de las parias comenzó a llegar a Europa en la forma de donaciones para Cluny y al morir el rey, las parias se convirtieron en pieza clave de su repartición testamentaria entre sus hijos.

Por lo anterior, esencialmente consideramos a las Parías como una forma de relación, a través de la cual se imponía la negociación entre los cristianos y musulmanes, donde primaban los intereses estratégicos, políticos y económicos, por sobre las ideas religiosas. Fernando I y sus sucesores deseaban la consolidación de su reino, el aumentó de sus riquezas y la obtención de tierras, por sobre cualquier otro objetivo.

Si bien los andalusíes conocían la estrategia de los cristianos, no se encontraban en condiciones de impedirla; tal como lo revela con juicio bastante crítico la tardía crónica de Ibn 'Idari, en relación a la amenaza sobre Santarén y la conquista de Coimbra por Fernando I. En esta ocasión los caudillos musulmanes y cristianos, intercambiaron el siguiente diálogo: "Hablaron ambos largamente acerca de lo que [era] su oferta de paz y del tributo (itāwa). Al-Muzaffar negase a aquello hasta que convino con él, después de forcejeos y fatigas, [una cantidad de] cinco mil dinares, que le entregaría cada año desde el comienzo de esta tregua.

Y así continuó el enemigo de Dios, Fernando, fortaleciéndose, mientras los musulmanes de debilitaban con el pago de parias (ŷizya) a los cristianos, hasta que el maldito sitió la ciudad de Coimbra [...] El maldito Fernando ahora la asedió hasta que la conquistó. Y eso fue porque su caid [...] habló secretamente con Fernando [para] que le diera el amán a él mismo y a su familia y se pasaría a él desde la ciudad de noche. Entonces le dio el maldito amán y se pasó el maldito secretamente al ejército de los cristianos. [...]

Mientras, continuó la frontera de al-Andalus debilitándose, el enemigo fortaleciéndose y la guerra civil entre los emires de al-Andalus - Dios los censure - ardiendo, hasta que el enemigo ansió [dominar] a todos ellos y se hastió de recibir parias (ŷizya), y no se contentó más que con la toma del país y arrancarlo de las manos de los muslimes." (Ibn "Idari al-Marrakusi, La caída del Califato de Córdoba y los reyes de Taifas, estudio, traducción y notas de Felipe Maillo Salgado, Salamanca, Universidad de Salamanca, 1993, II Parte, pp. 198, 199 (En adelante CCC)).
} 
Reconquista, caracterizada en esta etapa por la guerra y ocupación efectiva de los espacios, aunque manteniendo cierto grado de tolerancia con respecto a los musulmanes sometidos $^{57}$.

La expansión territorial sin precedentes que implicó la ocupación de Toledo, sumado a la explotación de las parias y las constantes intromisiones de los cristianos en sus asuntos internos, entre otros factores, terminó por agotar a los reyes de Taifas que llamaron en su auxilio a los almorávides. Esto rompió todo el equilibro militar y político de la Península ${ }^{58}$, cambiando totalmente la relación entre musulmanes y cristianos y dando pie para el desarrollo de la dinámica de interacción que trataremos a continuación $^{59}$.

Los monarcas hispanos como Alfonso VI, preferían la convivencia al exterminio de los musulmanes. En general mantenían un grado de tolerancia en relación a los musulmanes vencidos, a quienes incluso se les otorgaban algunas garantías de protección. En este sentido, el sentimiento de animadversión hacia a los musulmanes, aunque se mantuvo constante, experimentó variaciones según la época. En general, los hispanos acostumbraban a negociar y pactar con sus vecinos, inclusive en tiempos de guerra. Incluso, era frecuente que un cerco terminase mediante una capitulación ${ }^{60}$. Pese

\footnotetext{
${ }^{57}$ Mínguez, José María, La España de los siglos VI al XIII: Guerra Expansión y Trasformaciones. En busca de una frágil unidad, Donostia, Nerea, 2008, pp. 200-202.

${ }_{58}^{58}$ Mínguez, José María, La España de los siglos VI al XIII... op. cit., pp. 244, 255.

${ }^{59}$ Paralelo a este incremento de la guerra peninsular, en Europa se experimentaban las trasformaciones políticas producto de la Reforma Gregoriana. Este hecho fue importante en el cambio de percepción hacia los musulmanes, produciéndose en este tema, una dualidad conceptual. Esto porque, por un lado, en León-Castilla se encontraban los cluniacenses - y francos en general - que compartían ideas de intolerancia y lucha sin cuartel en relación al Islam, y en otro extremo se encontraba el propio rey Alfonso VI y gran parte de los magnates del reino, acostumbrados a un trato "más tolerante" y práctico hacia el Islam (Barkai, Ron, El enemigo en el espejo... op. cit., p. 160) De cualquier manera, la Reforma impuso una suerte de maniqueísmo en toda la cristiandad, dividiéndose ésta entre los que apoyaban al Papa, o a sus enemigos. Lo mismo ocurrió respecto del Islam, que se convirtió en ícono de todo lo maligno, demoníaco e impuro; una imagen que contrastaba con aquella que la Iglesia daba de sí misma, símbolo de Dios y de todo lo bueno (Flori, Jean, Guerra Santa, Yihad, Cruzada. Violencia y Religión en el Cristianismo y el Islam, Granada, Universidad de Granada, Universitat de València, 2004, p. 201)

Un ejemplo de esta dualidad la podemos observar en el Pseudo-Turpin, que si bien es un texto del siglo XII, sirve para reflejar claramente la mentalidad franca, dejando en claro que el objetivo de los ejércitos de Carlomagno era la liberación total de las tierras de Hispania y la aniquilación de los musulmanes sin mayores contemplaciones, como se relata luego de la captura de Agen: "Die vero secuenti Karolus urbem cum magno trumpho intravit. Tunc quidam ex Sarracenis gladio occisi sunt, quidam per Garonam cum magno impetu evaserunt. Decem tamen milia Sarracenorum gladio perempti sunt-" (LSJ 1998, Liber IV, cap. IX, op. cit. p. 206. "Pues al día siguiente Carlomagno entró triunfalmente en la ciudad. Entonces parte de los sarracenos fueron acuchillados, otros se evadieron a través de Garona con gran ímpetu. Sin embargo, diez mil sarracenos fueron pasados a cuchillo." (Liber Sancti Jacobi "Codex calixtinus", traducción de Abelardo Moralejo, Casimiro Torres y Julio Feo, Galicia, Xunta de Galicia, 2004, Libro IV, cap. IX, p. 441. (En adelante LSJ 2004))

${ }^{60}$ Para un estudio detallado respecto a la conquista de ciudades y puntos fuertes, así como las dinámicas de lucha y negociación ver García Fitz, Francisco, Castilla y León frente al Islam: Estrategias de expansión y Tácticas militares (Siglos XI-XIII), Sevilla, Universidad de Sevilla, 2001, pp. 223-277.
} 
a ello, recordemos que en las crónicas se seguía sosteniendo la necesidad de derrotar y expulsar a los sarracenos de la Península, para así liberarla totalmente. Observándose una coincidencia, al menos teórica, con los postulados del Pseudo-Turpin.

En palabras de distintos autores, lo que sucedía en la Península respecto a la lucha entre musulmanes y cristianos, es que estos últimos distinguían entre el colectivo de los musulmanes -que eran los enemigos a derrotar-, y sus miembros -es decir los individuos-. Esta disociación permitía amplios márgenes de coexistencia, puesto que cada musulmán recibía un trato distinto de acuerdo a su relación y utilidad para los cristianos. A ello debían agregarse los intereses de los reyes cristianos por no perder a la población andalusí, a la que necesitaban para poblar los espacios y mantener de los territorios anexados, dadas las dificultades que implicaba la repoblación total solo con cristianos $^{61}$.

Esto nos lleva a revisar el concepto de "moro" - en el período de los siglos X y XI - entendido como el enemigo por antonomasia del cristianismo.

En los siglos siguientes, la imagen del "moro" experimentó algunas variaciones, que coinciden con un incremento en la actividad de Reconquista. Se le seguía considerando un invasor y usurpador, aunque ya habían desaparecido las referencias a la antropofagia. Las crónicas demostraban un mejor conocimiento del Islam y sus prácticas, incluso en ambos bandos aparecen "estudios críticos" sobre el adversario ${ }^{62}$. Aún así, lo realmente interesante es que en esta época, el surgimiento de las primeras Taifas permitió aumentar los lazos políticos entre cristianos y musulmanes, puesto que los primeros supieron aprovechar las querellas intestinas de los segundos, para realizar pactos y alianzas que les asegurasen la anexión de nuevos territorios. Ello, pese a que la Iglesia romana no favorecía este tipo de contactos y por el contrario, insistía en aplicar

\footnotetext{
${ }^{61}$ Martín, José Luis, La Península en la Edad Media, Barcelona, Teide, 1976, p. 404; y Maravall, José Antonio, "La idea de Reconquista en España durante la Edad Media", en Arbor: Ciencia, pensamiento y cultura, 28, 1954, [pp. 1-37], p. 18.

62 Maravall, José Antonio, "La idea de Reconquista... op. cit., pp. 4 y 16. Entre los distintos acercamientos al Islam, el que es más destacado por los autores, es que a partir del siglo XII se realizan las primeras traducciones del Corán al latín, lo que acercó el texto a la elite ilustrada occidental (Partner, Peter, El Dios de las batallas: Las guerras santas desde la Biblia hasta nuestros días, Madrid, Anaya, 2002, p. 98; y Barkai, Ron, "Diálogo Filosófico-Religioso...op. cit., p. 10.). En una línea similar se encuentran los diversos "diálogos", ensayos literarios que comenzaron a difundirse por Europa y que representaban debates teológicos entre cristianos, judíos y musulmanes, destacando entre estos textos el Sefer ha-kuzari, que fue compuesto por un judío en la Península Ibérica (Barkai, Ron, "Diálogo Filosófico-Religioso...op. cit., p. 13).
} 
una política de hostilidad hacia el Islam; proyectos que chocaban con la realidad peninsular $^{63}$.

En el mismo período, la comprensión de los andalusíes respecto de los hispanos también evidenció una evolución. Si bien en su conjunto las referencias a los cristianos siguen siendo peyorativas, se hace levemente más común encontrar ciertos comentarios positivos sobre los enemigos del Islam, particularmente en relación a la figura de Alfonso VI, quien es criticado a la vez que admirado por sus enemigos. Según Cristina Granda, los andalusíes reconocen a los cristianos su valentía y arrojo en la lucha, pero también critican sus prácticas o llaman a Alfonso "tirano" 64 .

Recordemos que los musulmanes peninsulares vivían en una situación muy similar a la de sus vecinos cristianos. Para ambos la frontera era una realidad cotidiana, es decir, la guerra y la violencia eran sólo una parte de su coexistencia, mientras que el comercio, las treguas y el traspaso de influencias mutuas, era una realidad mucho más común y frecuente, aumentando progresivamente hasta el siglo XIII. De esta manera, los habitantes del sur peninsular vivían la misma dualidad que los cristianos del norte, generada por las realidades propias de una tierra de frontera, es decir, un discurso político de rivalidad e intolerancia que convivía con una práctica mucho más tolerante.

\section{I.1.d.- Siglos XII-XIII. Avanza la reconquista y la intolerancia}

A partir del siglo XII y puntualmente durante el siglo XIII, la coexistencia entre musulmanes y cristianos experimentó profundos cambios, debido a la radicalización de las ideas religiosas en ambos credos. A partir de la Primera Cruzada, en 1096, se estableció una nueva ideología bélica en la cristiandad, ligando la realidad de la Península con las luchas en las lejanas tierras de Oriente. Esto repercutió en una paulatina pérdida de la ya frágil tolerancia por parte de los hispanos hacia los musulmanes, pero sin llegar a extremos, puesto que si bien se comenzaron a ver nuevas prácticas - como la expulsión de los habitantes de las ciudades conquistadas - las matanzas o exterminio de poblaciones civiles seguirán siendo un fenómeno por lo general extraño.

\footnotetext{
${ }^{63}$ Le Goff, Jacques, La civilización del occidente medieval, Barcelona, Paidos, 1999, p. 124.

${ }^{64}$ Granda Gallego, Cristina, "Otra imagen del guerrero cristiano (su valoración positiva en testimonios del Islam)”, en En la España Medieval, 8, 1986, [pp. 471-480], pp. 446, 447.
} 
A su vez el Islam peninsular también sufrirá períodos de radicalización, en los que la idea del yihad imperará fuertemente de la mano de las nuevas oleadas de invasiones norafricanas de almorávides y almohades; sin embargo, en el caso andalusí, existirá una cierta disociación entre las acciones y creencias de africanos y musulmanes peninsulares, éstos últimos acostumbrados a la vida con los cristianos, lo que no significo que los andalusíes no participasen en las campañas de los norteafricanos.

La llegada de los almorávides en 1086, precipitada por el cambio de equilibrios en la lucha peninsular, significó un importante retroceso en las estrategias de expansión de Alfonso VI. Luego de la muerte del soberano en 1109, el reino entró en una etapa de dificultades vinculadas al reinado de Urraca $(1109-1126)^{65}$. Lo que implicó que la lucha contra el Islam se ralentizara. Es significativo que mientras esto ocurría, en el resto de Europa se experimentaba la consolidación de las ideas de cruzadas, gracias a la captura de Jerusalén en 1099 y el establecimiento de los Estados Latinos en Tierra Santa.

Progresivamente, las ideas de cruzada se hicieron cada vez más influyentes en el discurso cronístico hispano. Los autores apelarán a las raíces cristianas y las prácticas religiosas para reflotar la idea del pueblo visigodo castigado por Dios y perseguido por pueblos paganos, al igual que lo fueron los israelitas según las Escrituras. Así, la idea de vengar estas ofensas se convirtió en un importante estímulo para los cruzados de uno y otro lado de los Pirineos ${ }^{66}$.

${ }^{65}$ La heredera de Alfonso VI, mantuvo una serie de conflictos con su segundo esposo, Alfonso de Aragón, así como también con una parte de los magnates leoneses. Ello sumado al freno que experimento la Reconquista durante su reinado (una situación relacionada con la irrupción almorávides, que había puesto en jaque la expansión llevada a cabo por Alfonso VI) han contribuido a que los cronistas contemporáneos la hayan relegado a un lugar muy secundario en sus narraciones. Especialmente duros son la Historia Compostelana y algunas secciones de la Adefonsi Imperatoris, en tanto que autores como Lucas de Tuy y Jiménez de Rada, se limitan a reverenciarla, sin atribuirle una mayor importancia.

Si bien sus relaciones con magnates como Diego Gelmírez y su difícil relación con su hijo y heredero, Alfonso VII, la reina gobernó León y Castilla por más de 15 años, logrando mantener la frontera del sur, al mismo tiempo que aseguraba la continuación del linaje de Alfonso VI.

Por el trato que la reina ha recibido de parte de las fuentes, es que se nos hace difícil remitirnos con mayor atención a su persona, puesto que un estudio pormenorizado y objetivo de su reinado se escapa a las pretensiones de nuestro trabajo. Para un conocimiento más acabado de esta figura recomendamos, entre otros textos, Del Carmen Pallares, María y Ermelindo Portela, La Reina Urraca, Donostia, Editorial Nerea, 2006; Gordo, Ángel, "Estructuras Regias en el Reino de León. La Preparatio en la Elevación al Trono Imperial de Urraca I y Alfonso VII. Factores diferenciadores y de estabilidad en el gobierno", en Cerda, José Manuel (Editor), El Mundo Medieval, Legado y Alteridad, Santiago de Chile, Universidad Finis Terrae, 2009; y Gordo, Ángel, "El reinado de la 'indomable' reina Urraca I de León. El mito que hace historia. Fuentes, soberanía, prejuicios y religión”, parte de la investigación patrocinada por el Instituto de Estudios Zamoranos "Florián de Ocampo" titulado: "La Reina Urraca I (1109-1126) La práctica del concepto de Imperium Legionense en la primera mitad del siglo XII".

${ }^{66}$ Alvira Cabrer, Martín, "La muerte del enemigo en pleno medioevo cifras e ideología (el modelo de las Navas de Tolosa)", en Hispania, Revista Española de Historia. Vol. LV/ II, No 190, 1995, [pp. 403-423] p. 414; y Soto Rábanos, José María, "Reflexiones sobre el discurso cristiano a judíos y musulmanes en 
Con la coronación de Alfonso VII en 1126, la actitud belicista se vio reforzada, al mismo tiempo que se aprecia una mayor radicalización de la misma, producto de las influencias de Roma y la instalación de las ideas de cruzada en la Península. En rigor, los paradigmas experimentaron una nueva evolución, donde se enfrentaban las formas de trato y convivencia tradicionales con las exigencias de un nuevo tipo de guerra, inspirada discursivamente en causas totalmente religiosas, al punto que veremos nuevamente una demonización del Islam y una mayor frecuencia a la apelación de causas sacras e intervenciones providencialistas en la lucha ${ }^{67}$.

Después de los espectaculares avances de Alfonso VI, la irrupción de los norafricanos -caracterizados por su fanatismo dogmático y esfuerzo bélico- fue vista como una seria amenaza para todos los reinos cristianos; adicionalmente, los recién llegados también sometieron a los andalusíes, por lo que se generaron tensiones entre ambos grupos musulmanes ${ }^{68}$.

Los cristianos supieron aprovechar estas diferencias y usarlas a su favor, algo que se puede observar en el trato distinto que daban a andalusíes y almorávides. Esto debido a que los cristianos separaban claramente a los andalusíes -enemigos habituales y con quienes compartían el territorio- de los invasores de allende el estrecho, a quienes acusaban de radicalizar la lucha y de obligar a los musulmanes peninsulares a extremar sus ideas y tendencias bélicas ${ }^{69}$. En consecuencia, se puede decir que para los hispanos los almorávides eran un elemento negativo que ponía serios obstáculos a los modos de vida fronterizos y a los planes de las coronas cristianas. Debido a ello, luego de una cabalgata o batalla, los castellano-leoneses solían ejecutar a los almorávides capturados, mientras que los andalusíes eran sometidos al cautiverio, preservando sus vidas y valor económico $^{70}$.

los sínodos castellanos, siglos XIII-XV”, en IV Jornadas de Historia en la Abadía de Alcalá la Real, Jaén, Diputación Provincial de Jaén, 2003, pp. 489, 490.

${ }^{67}$ Es importante recordar que durante el reinado de Alfonso VII, si bien no se produjeron grandes conquistas o avances territoriales significativos, fue durante este periodo que se fundaron o consolidaron importante asentamientos fronterizos que servirían como plataforma para la expansión de cristiana de los años siguientes.

${ }^{68}$ Fletcher, Richard, La cruz y la media luna... op. cit., p. 84.

${ }^{69}$ Gárate Córdoba, José María, Espíritu y milicia ... op. cit., pp. 137 y 211.

${ }^{70}$ García Fitz, Francisco, Relaciones politicas y guerra ... op. cit., p. 89. Ejemplos de lo anterior se pueden observar en la CAI, donde, entre otros episodios, se narra la cabalgata que Alfonso VII, junto con Zafadola, realizaron contra el valle del Guadalquivir. En esa campaña los andalusíes se dirigieron al caudillo musulmán y le rogaron: "Loquere cum rege christianorum et cum eo libera nos de manibus Moabitarum, et dabimus regi Legionensi tributa regalia amplius quam patres nostri dederunt patribus suis, et tecum secure serviemus illia, et tu regnavis super nos, et filli tui." (Chronica Adefonsi Imperatoris, Edición y estudio por Luis Sanchez Belda, Madrid, CSIC., Escuela de Estudios Medievales, 1950, CAI, Liber I, $N^{\circ} 41$, p. 33. (En adelante CAI). Otro caso similar se puede observar en el relato de la 
Las crónicas que más destacan estas diferencias son las ya mencionadas Historia Compostellana y la Chronica Adefonsi Imperatoris; ambas obras se centran en la época en que Alfonso VII reiniciaba las campañas contra el al-Andalus. En la obra de Gelmírez se relatan algunos encuentros con las fuerzas almorávides. Entre ellos resalta la narración de la batalla de Sagrajas y la muerte del Infante Sancho, donde se identifica claramente al grupo invasor, destacando la oscuridad de su piel, pero también su bravura:

\begin{abstract}
"Transacto abhinc ferme triennio Moabite, quos estus solis facit Ethiopibus similes, castra et oppida Toledo subiacentia acrius solito inuaserunt et, interfectis hominibus, qui forum abstabant fortitudini, quia robore militum suorum uallati nulla hostium spicula formidabant, ibi quasi in summa positi trasquillitate sua tentoria firmauerunt." ${ }^{, 71}$
\end{abstract}

Si bien la Historia Compostellana relata otros sucesos ilustrativos de esta práctica, a nuestro juicio una de las obras más importantes para comprender esta dinámica entre cristianos y almorávides, es la Chronica Adefonsi Imperatoris. En ella se aprecia una clara distinción entre los distintos tipos de musulmanes, llamando a los andalusíes “agarenos" y dividiendo a los beréberes entre almorávides y moabitas ${ }^{72}$. Esta diferenciación se diluye cuando se habla de sus costumbres, puesto que el cronista los engloba en un todo ${ }^{73}$.

Así, en la Chronica se da a entender que los andalusíes toleraron el rigorismo almorávide, mientras les proporcionaron seguridad ante los embates cristianos. Pero cuando éstos se hicieron imparables y los andalusíes empezaron a perder sus tierras y

rebelión de los andalusíes contra los almorávides (episodio al que nos referiremos luego), que habría sido precipitada por la acción de las huestes de Alfonso VII (Crónica del Emperador Alfonso VII, Introducción, traducción, notas e índices por Maurilio Pérez González, León, Universidad de León, 1997, Libro II, $\mathrm{N}^{\circ} 188$, pp. 123, 124 (En adelante CEA)).

${ }^{71}$ HC 1988, Liber I, cap. XXIX, op. cit., p. 57. "Pasados desde entonces casi tres años, los almorávides, a los que el calor del sol hace semejantes a los etíopes, atacaron con más fuerza de lo acostumbrado los campamentos y poblaciones cercanas a Toledo y, muertos los hombres que se oponían a su bravura, puesto que defendidos por la fuerza de sus soldados no temían a las flechas de los enemigos, plantaron allí su campamento como si estuvieran colocados en lugar seguro." (Historia Compostelana, Edición de Emma Falque, Madrid, Akal, 1994, p. 9). (En adelante HC 1994).

${ }_{72}^{72}$ Barkai, Ron, El enemigo en el espejo...op. cit., pp. 137-139.

73 Por ejemplo, en la Chronica se llama a las mezquitas sinagogas, mientras a que los clérigos musulmanes se les nombra como sacerdotes o doctores legis. Lo mismo ocurre cuando se habla del conjunto de los musulmanes, donde la crónica se refiere a ellos únicamente como sarracenos. No obstante, en líneas generales el relato describe dos formas muy distintas en el trato dado a andalusíes y a almorávides. Los primeros son tratados de mejor forma y en ocasiones más como aliados que como enemigos, actitud originada en la animadversión compartida hacia los norafricanos. (Garate Córdoba, José María, Espíritu y milicia... op. cit., p. 211) 
vidas, decidieron romper con los africanos y buscar la paz separada con Alfonso VII, reanudando el sistema de parias y tributos para así asegurar su libertad ${ }^{74}$ :

"Moabitae medullas terrae comedunt et posesiones nostras; aurum et argentum nobis tollunt; uxores nostras et filios nostros opprimunt: pugnemus ergo contra eos et occidamus eiiciamusque dominium forum a nobis, quia non est nobis pars in domo regisTexufini neque hereditas in filiis Ali et patris eius Iuzeph'. Alii autem dicebant: 'Faciamus in primis pactum et pacem cum imperatore Legiones et Toleti et demus ei tributa regalia sicut patres nostri dederunt patribus suis'. Quod bonum visum est in occulis forum, et ut essent parati in proemio contra Marrochinos. Deinde, conversi in synagogis suis, orabant patentes miserationes Mahometis pseudoprophetae eorum, ut adiuvaret coeptus et actus eorum; et mittentes nuntios, vocabant regem Zafadolam et omnem semen regum Agarenorum ut venirent et bellarent contra Moabitas" ${ }^{, 75}$.

Si bien el relato es claramente favorable a los cristianos, que son presentados como "el mal menor", y se destaca el protagonismo de Alfonso VII, también se revelan las intensiones propagandísticas del autor en cuanto se refiere a Mahoma como falso profeta. Aunque el testimonio puede ser muy cuestionable, lo cierto en que para mediados del siglo XII el poder almorávide estaba en decadencia, y pronto colapsaría dando origen a las segundas Taifas, entre los años 1144 y 1203.

Pero no sólo en las crónicas advertimos esta distinción entre almorávides y andalusíes; también la observamos en la literatura, como en del Cantar del Mio $\mathrm{Cid}^{76}$.

\footnotetext{
${ }^{74} \mathrm{Si}$ bien el relato es narrado por una fuente cristiana, que difícilmente pudo haber sido testigo de las tratativas entre los andalusíes no olvidemos que estamos analizando como los cristianos veían a sus distintos adversarios.

${ }^{75}$ CAI, Liber II, $\mathrm{N}^{\circ} 188$ op. cit., pp. 148, 149. “"Los moabitas consumen las entrañas de la tierra nuestras posesiones, nos quitan el oro y la plata, oprimen a nuestras esposas y a nuestros hijos. Luchemos, pues, contra ellos, matémoslos y sacudámonos su dominio, puesto que no tenemos parte en el palacio del rey Texufin ni herencia entre los hijos de Ali y de su padre Yusef'. Por su parte, otros decian: 'Ante todo hagamos una alianza de paz con el Emperador de León y Toledo y démosle tributos reales, de la misma manera que nuestros padres se los dieron a sus padres'. Les pareció bien a sus ojos esto y el hecho de estar preparados para una guerra contra los de Marrakech. Después, tras dirigirse a sus mezquitas, oraban pidiendo la compasión de Mahoma, su falso profeta, para que les ayudase en sus empresas y acciones. Y mediante embajadas llamaban al rey Zafadota y a toda la estirpe de los reyes agarenos para que viniesen y guerreasen contra los moabitas." CEA, Libro II, Nº 92 (188) op. cit., pp. 123, 124.

${ }^{76}$ Cantar de mió Cid, Edición, prólogo y notas de Alberto Montaner, estudio preliminar de Francisco Rico, Barcelona, Centro para la Edición de los Clásicos Españoles, Galaxia Gutenberg, 2007, p. CXXV, CXXVI.

Según el Cantar, el Cid es sumamente hostil hacia los almorávides, a quienes desprecia y ve como una simple fuente de recursos, tal como parecen indicarnos los versos 1620 al 1800 que narran el ataque de los almorávides recién llegados de Marruecos a la ciudad de Valencia (Poema de Mio Cid, canto 8795, edición, introducción y notas de José Jesús de Bustos Tovar, Madrid, Alianza, 1988, pp. 118-125). En cambio el Campeador tiene un trato notoriamente mejor hacia los andalusíes, con lo que elabora alianzas
} 
A nuestro entender, estas categorizaciones de musulmanes que nos muestran las crónicas, son el reflejo de las complicaciones de la vida fronteriza en la Península ${ }^{77}$. Debemos recordar que para los siglos XII y XIII, cristianos y musulmanes llevaban coexistiendo alrededor de cuatro siglos, en los que ambos grupos se conocieron, comerciaron y lucharon por el control de una tierra que consideraban propia. También revela cómo las nuevas ideologías ligadas a las ideas de cruzada afectaron esta realidad, obligando a los hispanos a adaptar su comportamiento con respecto a los musulmanes, distinguiendo entre aquellos a los que se podía tolerar y subyugar y a quienes eran una amenaza por sus creencias y conductas.

Paralelamente el incremento de la actividad bélica obligó a redefinir la frontera, reforzando las urbes y su organización a través de los fueros y concejos urbanos ${ }^{78}$. En general el derecho foral respondía a las necesidades de la Reconquista, principalmente en lo referido a la repoblación; sin embargo, los fueros no sólo se limitaban a esta

y además acepta que convivan junto a los cristianos como "moros de paz", como se relata en diversas partes del cantar, como por ejemplo en el canto 24 (Ibíd., canto 24, pp. 66, 67).

77 Hay que mencionar que además de la diferenciación que hacían los cristianos entre andalusíes y africanos, también existía otra categorización más general para los musulmanes, dada por el lugar en que habitaban y reconociéndose dos grandes grupos. Primero, los musulmanes que vivían en las tierras cristianas y permanecían allí después de su Reconquista; los mudéjares, y luego, aquellos que se hallaban al otro lado de la frontera, en el al-Andalus (Soto Rábanos, José María, "Reflexiones sobre el... op. cit., pp. 481-484). Para ambos grupos existían formas de trato muy distintas, puesto que los primeros eran considerados como parte de la sociedad hispana, aunque reducidos a una categoría separada e inferior como los judíos, mientras que los segundos eran tenidos por enemigos hostiles; es decir, sujetos de guerra, saqueo y cautiverio.

${ }^{78}$ En Castilla y León los Concejos urbanos se convirtieron en una pieza clave para el ordenamiento de la vida en la frontera. A grandes rasgos, estas reuniones de vecinos, tenían la obligación de elegir o designar a las autoridades locales encargadas de administrar la justicia, mediar en conflictos, fiscalizar los mercados, dirigir la defensa y organizar la guerra (O'Callaghan, Joseph, Las Cortes de Castilla y León. 1188-1350, Valladolid, Ámbito, Cortes de Castilla y León, 1989, p. 11). Todo ello regulado por los Fueros locales, que como ya hemos visto, eran la pieza clave en el ordenamiento de la vida urbana.

El rol de los concejos se basaba en la realidad de la vida fronteriza. Es decir operando a través de la práctica de la vida cotidiana, quizás por esa misma razón, ni los fueros ni los concejos, tenían alguna injerencia en temas religiosos y sólo se limitaban a ordenar la convivencia entre los distintos credos de una localidad. En cuanto a la guerra y la política, sus funciones eran bastante concretas y de vital importancia, en especial en cuanto a organizar las cabalgatas y el reparto del botín. No obstante, al avanzar la Reconquista y en especial a partir del reinado de Alfonso VII, debieron ceder parte de su poder e iniciativa al monarca, que para el siglo XII protagonizaba la mayoría de las campañas militares. Esto repercutió en limitar la autonomía del Consejo, así como su libertad de hacerse con el botín, elementos que desincentivaron la función militar urbana. En vista de esta situación es que, según Luis Miguel Villar, la evolución de los concejos como órganos reguladores de la vida fronteriza, se puede resumir en las siguientes etapas: Entre fines del siglo XI a mediados el siglo XII la frontera se caracterizo por concejos altamente militarizados que permitieron el empoderamiento y enriquecimiento de los caballeros. A partir de mediados del siglo XII y hasta el siglo XIII el consejo mutó a un órgano administrativo de sus términos, dirigido por el colectivo de los caballeros. Finalmente, a partir de mediador del siglo XIII, sus funciones militares estaban cada vez más limitadas, en tanto que su control ha pasado a depender totalmente de los caballeros más poderosos (Villar García, Luis Miguel, La Extremadura CastellanoLeonesa, guerreros, clérigos y campesinos (711-1252), Valladolid, Junta de Castilla y León, 1986, p. 552). 
función; en la práctica regulaban todos los aspectos de la vida en las localidades cristianas, y por lo tanto - con mayor énfasis en las zonas fronterizas - dedicaban una parte importante de sus normas a la convivencia con musulmanes y judíos, y a todo lo relativo a la guerra ${ }^{79}$. Este tipo de códigos conocidos como "Fueros de Frontera", "Derecho de Extremadura" o "Derecho de Frontera", tenían el claro propósito de normar la vida tanto en los períodos de paz como en los de guerra, considerando aspectos como el comercio, el cautiverio y los derechos jurídicos de cada uno de los credos que conformaban una comunidad ${ }^{80}$. ${ }^{79}$ Un buen ejemplo de la cotidianidad de la guerra para las sociedades de frontera y su impacto, se puede
constatar en los fueros; en ellos se delata la preocupación que la guerra causaba en la población, no solo
en materias como el botín, sino que también en situaciones mucho más prácticas como era el caso de las
indemnizaciones que debían entregarse a quienes resultasen heridos o perdiesen equipos o caballos
durante algún enfrentamiento (Powers, James F., A society organized for war. The Iberian Municipal
Militias in the Central Middle Ages, 1000-1284, California, University of California Press, 1999, p. 164).
Fueros como el de Coria son extremadamente exhaustivos en esta parte, describiendo cada uno de los
tipos de heridas que podía sufrir el guerrero y cual era la compensación que debía recibir. Otro fuero
destacado en este sentido es el de Cuenca. En él se estipula la indemnización que recibían los dueños de
los animales heridos y también por la perdida de las armas, específicamente en el caso de las lanzas,
donde se llegaba al detalle de que se pagaban de manera distinta dependiéndose de si llevasen o no
pendón. (El Fuero de Coria, Estudio histórico-jurídico por José Maldonado y Fernández del Torco;
trascripción y fijación del texto por Emilio Sáez; con prólogo del Excmo. Sr. D. José Fernández
Hernando, Instituto de Estudios de Administración Local, 1949, Libro III, No 173, op. cit., p. 57. (En
adelante FC). Lumbreras Valiente, Pedro, Los fueros municipales de Cáceres su derecho publico,
Cáceres, Ayuntamiento de Cáceres, 1974, cap. XXX, pp. 226 - 228 (En adelante FCs).
80 Porras Arboledas, Pedro Andrés, "Derecho a Guerra y paz en la España medieval", en Revista de
Historia Militar, N $\mathrm{N}^{\circ}$ Extraordinario, Instituto de Historia y Cultura militar, 2001, [pp. 335-359], pp. 342,
343 .

Respecto a las fuentes jurídicas aunque aparentemente no tienen la intención de difundir un discurso, corresponden a la aplicación concreta y real de muchas ideas y corrientes de pensamiento de la época, en especial sobre la relación entre los diversos grupos sociales, así como también la convivencia con el Islam. No es exagerado afirmar que cada uno de los pueblos que se asentaron en la Península Ibérica dejó una huella en su "cultura jurídica"; de esta forma, en la Edad Media, el ordenamiento jurídico tuvo raíces hispanoromanas, romanogóticas, germánicas e incluso islámicas, pero por sobre todas, se vio influenciado por el Liber Iudiciorum o Lex Visigothorum.

Con la irrupción musulmana del 711 la población hispanogoda intento mantener sus costumbres y tradiciones, incluyendo la vigencia del Liber Iudiciorum. Esta situación se tradujo en que entre los mozárabes, al menos durante las primeras épocas, se mantuviese vivo el antiguo derecho visigodo, aunque posteriormente su influencia se fuese diluyendo en los siguientes años. (Para una mayor comprensión de este proceso recomendamos consultar el trabajo de Cyrille Aillet, Les Mozarabes. Christianisme, islamisation et arabisation en péninsule ibérique (IXe - XIIe siècle), Madrid, Casa de Velázquez, 2010).

Conforme se iniciaba el proceso de Reconquista, en el Reino Astur-leonés de Alfonso II se oficializó la vigencia del Liber, lo que se enmarcaba en su discurso de continuador y heredero del Reino Visigodo, convirtiendo el código legal en una herramienta política que resaltaba la memoria de los visigodos (Isla Frez, Amancio, "La construcción de la monarquía en León, siglos X y XI: Historia y Leyes”, en Martínez Sopena, Pascual, Ana Rodríguez (Editores), La construcción medieval de la memoria regia, Valencia, Publicacions de la Universitat de València, 2011, p. 42; y Gacto Fernández, Enrique, Temas de Historia del derecho: Derecho Medieval, Sevilla, Universidad de Sevilla, 1977, pp. $28,48)$.

En los siglos XII y XIII, el avance significativo de la Reconquista y la incorporación de nuevos territorios y habitantes a los reinos cristianos produjo que las distintas villas, pueblos y ciudades comenzaran a redactar sus propios ordenamientos jurídicos. Éstos, que anteriormente se habían basado en la tradición y antiguas costumbres, incorporaban ahora nociones del derecho romano y canónico, a la vez 
La necesidad de estos códigos se dio por el significativo aumento de contactos interculturales, a causa de la expansión cristiana y el incremento de la actividad bélica ${ }^{81}$. De esta forma, se construyó una sociedad de frontera regida por estructuras sociales y económicas homogéneas y sometidas al control de los monarcas; elementos que fueron clave cuando el modelo fue amenazado por los almorávides. Otro factor a considerar para comprender el éxito de este modelo, es que la repoblación se realizó utilizando los asentamientos tradicionales y no teniendo como prioridad la fundación de nuevas poblaciones $^{82}$. En forma complementaria en el mismo período, muchos de los fueros se redactaron directamente en los concejos urbanos para luego ser sometidos a la aprobación real. Esto demuestra la autonomía que tenían los concejos de frontera, obligados a actuar rápidamente para organizar la ocupación y aprovechar sus oportunidades $^{83}$.

que cobraba impulso la reimplantación del Liber Iudiciorum. Este proceso recibió su impulso definitivo una vez que Alfonso VI proclamó la vigencia del ordenamiento visigodo para la recién reconquistada ciudad de Toledo (Lumbreras Valiente, Pedro, Los fueros municipales de Cáceres su derecho publico, Cáceres, Ayuntamiento de Cáceres, 1974, p. 3. (En adelante FCs); Isla Frez, Amancio, "La construcción de la monarquía... op. cit., p. 42).

La forma en que este ordenamiento jurídico se plasmó y organizó fue a través de los llamados fueros, que pueden ser definidos según Gacto Fernández como "acepción de ordenamiento jurídico propio de una comunidad local o comarcal, con un ámbito de vigencia, por tanto, reducido a los límites en que tal comunidad se desenvuelve, o bien para designar los textos en que tal ordenamiento jurídico resulta fijado por escrito" (Gacto Fernández, Enrique, Temas de Historia del Derecho... op. cit., pp. 60, 61). El otorgamiento de un fuero, generalmente por disposición del rey, se producía luego de la conquista de una población con el objetivo de regular la vida en la localidad, crear una ley conocida por todos y otorgarle ciertos privilegios económicos, judiciales y militares que favorecieran su repoblación y mantención, en especial en los territorios de frontera. (Gacto Fernández, Enrique, Temas de Historia del Derecho... op. cit., pp. 61-65; El Fuero de Coria, Estudio histórico-jurídico por José Maldonado y Fernández del Torco; trascripción y fijación del texto por Emilio Sáez; con prólogo del Excmo. Sr. D. José Fernández Hernando, Instituto de Estudios de Administración Local, 1949, p. XXV. (En adelante FC); y Procter, Evelyn, Curia y Cortes en Castilla y León 1072-1295, Madrid, Cátedra, 1988, p. 117).

Para ilustrar este proceso, a lo largo de nuestro trabajo haremos uso de algunos fueros locales, por considerarlos representativos, estos son: el Fuero de Cuenca (segunda mitad del siglo XII), el Fuero de Coria (comienzos del siglo XIII) y el Fuero de Cáceres (primera mitad del siglo XIII)

${ }^{81}$ En el aspecto militar, los fueros destacan por su minuciosidad, tanto con respecto a su lenguaje, como a los distintos aspectos bélicos, convirtiéndose en una fuente vital para el conocimiento de las prácticas bélicas fronterizas. Llama la atención las partes donde los fueros distinguen la lucha entre cristianos y el combate contra los musulmanes. A la primera le llaman guerra (del germano werra) y se entiende que se encontraba sujeta a las limitaciones de la paz y tregua de Dios, en cambio a la segunda se refieren con el concepto latino de bellum, sin que se aprecien las mismas restricciones religiosas que en el caso anterior.

${ }^{82}$ Villar García, Luis Miguel, La Extremadura Castellano-Leonesa... op. cit., p. 91; y Mollero García, Jesús M., "La Frontera Castellana en tiempos de Alfonso VII: Nobleza y organización del espacio", en II Estudios de Frontera. Actividad y Vida en la Frontera, Alcalá la Real, Diputación Provincial de Jaén, 1997, p. 586.

${ }^{83}$ En Hispania los fueros y concejos se vinculaban estrechamente con el concepto de milicia. Los términos milicias, concejos o milicias concejiles, son ampliamente usados por los cronistas para referirse a una sola institución: las fuerzas de combate y defensa conformadas por los habitantes de un núcleo urbano, que convocadas y controladas por el Concejo de la ciudad o poblado, contaba con su propia estructura de mando. Estas milicias debían obediencia a la monarquía del reino, pero tenían una cierta autonomía para iniciar sus propias acciones; esta independencia relativa les venía dada por los fueros y cartas pueblas de la localidad a la que pertenecían. 
Así, los cristianos ocuparon un espacio ya "urbanizado" con sus defensas y tierras productivas, lo que abarató, facilitó y aceleró el sistema de poblamiento, lo que no significaba la creación de una política de integración entre los nuevos y antiguos habitantes; dadas las distintas realidades de los credos y etnias que conformaban el escenario fronterizo, no existía lo que podríamos llamar una "igualdad jurídica"concepto alejado de la mentalidad medieval- sino que cada grupo mayoritario imponía sus condiciones en el territorio, situación que se hace evidente, por ejemplo, en los fueros de frontera ${ }^{84}$.

Esto provocó grandes desplazamientos humanos, en los cuales los musulmanes derrotados abandonaban las zonas conquistadas, mientras que cristianos del norte peninsular se instalaban en las nuevas tierras; no obstante, en contadas ocasiones los conquistadores disponían de los recursos humanos suficientes para asentarse en sus conquistas - algo fundamental para consolidar la ocupación del espacio - agravado por la huida de los musulmanes ${ }^{85}$.

Independientemente de como se ocupara el espacio, era vital atraer a la gente para repoblar; la táctica más utilizada fue pregonar por todo el reino las ventajas de los nuevos territorios y al mismo tiempo, ofrecer ciertas garantías a los nuevos pobladores. Una estrategia que fue fundamental, dado que no debemos perder de vista que en el fondo la frontera seguía siendo una zona de guerra ${ }^{86}$. Así fue como a los colonos cristianos, e incluso judíos y musulmanes que acudiesen a poblar las tierras y asentamientos conquistados, se les ofrecían amnistías y garantías legales, como también tierras, viviendas y siervos, con el objeto de acelerar la ocupación de la frontera y consolidar la conquista ${ }^{87}$.

\footnotetext{
${ }^{84}$ Ejemplos ilustrativos de como se dividía y categorizada a la población son los Fueros de Cáceres, de Coria y de Cuenca, entre otros, donde se regulaban con detalles aspectos como el comercio, e incluso el uso de los baños.

85 Martínez Díez, Gonzalo, "Las capitulaciones de Fernando III con las ciudades musulmanas conquistadas", en Archivo Hispalense Revista Histórica, Literaria y Artística, 2.a Época, 1994, Tomo XXXVII, Núms. 234-235-236, [pp. 267-286], pp. 278-286; Martín, José Luis, La Península ... op. cit., pp. 403, 404; Fernández Conde, Javier, Historia de la Iglesia en España. II-2 ${ }^{\circ}$ La iglesia en la España de los siglos VIII al XIV, Madrid, Ed. Católica, 1982, p. 504; Carrasco, Juan y otros, Historia de las Españas Medievales, Barcelona, Ed. Crítica, 2002, p. 150; Villacañas Berlanga, José Luis, La Formación de los Reinos Hispánicos, España, Ed. Espasa Calpe, 2006, pp. 620, 621; y Álvarez Borge, Ignacio, La Plena Edad Media, Siglos XII-XIII, Madrid, Ed. Síntesis, pp. 291, 292.

${ }^{86}$ González Jiménez, Manuel, Fernando III... op. cit., p. 242.

${ }^{87}$ Fernández Conde, Javier, Historia de la Iglesia en España, II-2 ${ }^{\circ}$... op. cit., pp. 502, 504; Procter, Evelyn, Curia y Cortes en Castilla y León... op. cit., p. 117.

Una señal clara de la importancia que tenían los fueros en la frontera y que además se encontraban dirigidos hacia una población heterogénea, es que a partir de los siglos XII y XIII, precisamente los de mayor actividad reconquistadora, los códigos comenzaron a redactarse en romance y no en latín, lengua restrictiva de las elites religiosas e intelectuales.
} 
Al respecto, el "privilegio de los pobladores" del Fuero de Cuenca, según la traducción de Alfredo Valmaña, es elocuente:

"Concedo también a todos los pobladores esta prerrogativa: que cualquiera que venga a vivir a Cuenca, sea de la condición que sea, cristiano, moro o judio, libre o siervo, venga con seguridad y no responda a nadie por razón de enemistad, deuda, fianza, herencia, mayordomía, merindad ni de cualquier otra cosa que haya hecho antes de la conquista de Cuenca". ${ }^{88}$

La actividad comercial también era un importante estímulo para la repoblación cristiana de la frontera, puesto que los privilegios que rodeaban al comercio fronterizo eran un atractivo para aquellos que buscaban fortuna y tenían el valor para arriesgarse e instalarse en la frontera. Por ello era tolerado el intercambio de productos con los andalusíes, salvo algunas excepciones, puesto que aseguraba la supervivencia de la población y permitía adquirir bienes del otro lado de la frontera material y religiosa. Es así que el libre tránsito de los comerciantes musulmanes estaba asegurado por algunos ordenamientos forales, como ocurría en el caso de Cuenca, donde además se prestaba especial atención a la protección durante las ferias ${ }^{89}$.

La importancia del comercio queda de manifiesto al ver las altas multas y castigos que implicaba el agredir o entorpecer a los comerciantes, sin importar su origen. Sin el comercio la colonización hubiese sido inviable, algo que hasta la Iglesia de Roma debió reconocer como una realidad; como cuando Gregorio IX autorizó a los habitantes de Quesada a comercial con los musulmanes, situación que según Jiménez de Rada, era la única manera de asegurar la posesión y ocupación de la urbe recién conquistada ${ }^{90}$.

\footnotetext{
${ }^{88}$ FCc, cap. I, $\mathrm{N}^{\circ} 10$, op. cit., p. 41.

89 "24.- El que venga a esta ciudad con mercancías. - A todo el que venga a Cuenca con mercancías, sea cristiano, judio o moro, nadie le tome prendas, salvo que sea deudor o fiador. El que tome prendas a otro, pague al Concejo cien maravedís y al demandante, el doble de las prendas.

25.- El otorgamiento de ferias.- [...]

Cualquiera que, sea cristiano, moro o judio, venga a estas ferias, venga seguro. El que se lo impida o le cause algún daño, pague mil maravedís de multa para la parte del rey y al demandante, el doble del daño que le haya hecho; si no tiene con qué pagar, sea ahorcado" (FCc, cap. I, $\mathrm{N}^{\circ} 24,25$, op. cit., p. 46) ${ }^{90}$ Goñi Gaztambide, José, Historia de la Bula de Cruzada en España, Vitoria, Editorial del Seminario, 1958, p. 155; y Domínguez, Santiago, Documentos de Gregorio IX (1227 - 1241) Referentes a España, León, Universidad de León, Secretariado de Publicaciones, 2004, p. 330.

Paralelo a este comercio lícito y controlado de frontera también se desarrolló el contrabando, en donde las limitaciones religiosas o estratégicas no existían. De esta actividad participan moros, judíos y cristianos, que buscaban el beneficio económico rápido e inescrupuloso. Precisamente para controlar este flujo ilegal, se levantaron muchas fortificaciones en los pasos fronterizos ilegales, lo que también contribuyó al poblamiento de la frontera, puesto que la edificación de un castillo convertía el paso en un lugar de transito legal, que atraía a los comerciantes, propiciaba la creación de mercados oficiales y el surgimiento de poblaciones que vivían a su alrededor. (Al respecto ver Rodríguez Molina, José, “Alcalá
} 
No obstante todas estas garantías, a partir del siglo XII hubo una falta permanente de población cristiana en la frontera. Esta situación se volvió crítica con las conquistas de Fernando III y la necesidad de repoblar grandes núcleos urbanos como Córdoba y Sevilla. Si bien nunca escasearon las tropas de conquistadores -en definitiva, hombres dispuestos a enriquecerse con el saqueo y el botín-, la situación cambiaba dramáticamente cuando se trataba de radicarse y sobrevivir en las duras condiciones de la frontera ${ }^{91}$.

La falta de pobladores pudo deberse a la realidad fronteriza y sus riesgos, los cuales no podían ser minimizados por ningún discurso religioso o promesas de recompensas espirituales ${ }^{92}$. Por este motivo fue necesario generar una serie de incentivos mundanos y aceptar la creación de una frontera donde se permitiera la convivencia entre los habitantes de los distintos credos peninsulares, dispuestos a asentarse en los nuevos territorios.

Por lo anterior, se puede afirmar que la relación entre la corona y los concejos era constante, al punto de estar altamente normada a través de los fueros locales ${ }^{93}$,

la Real. Comunicación, Defensa y Convivencia en la Frontera", en Toro Ceballos, Francisco y José Rodríguez Molina (Coordinadores), III Estudios de Frontera. Convivencia, Defensa y Comunicación en la Frontera, Alcalá la Real, Diputación Provincial de Jaén, 2000, pp. 590, 591; Palacios Ontalva, J. Santiago, "Fortalezas y Guerra Santa. Un estudio comparado de algunos aspectos de su funcionalidad en las fronteras de la Cristiandad", en Espacio, Tiempo y Forma, Serie III, H. Medieval, t. 14, 2001, [pp. 193-217], p. 209. Para una aproximación a las dinámicas del comercio vinculadas a los períodos de treguas, recomendamos el artículo de Melo Carrasco, Diego, "Las treguas entre Granada y Castilla durante los siglos XIII a XV", en Revista de Estudios Históricos-Jurídicos, XXXIV, Pontificia Universidad Católica de Valparaíso, Valparaíso, 2012, [pp. 237-275].

${ }^{91}$ A modo de ejemplo podemos recordar que el "Rey Santo", pese a sus pregones y promesas de repartimientos, apenas contó con gente dispuesta a instalarse en Sevilla, lo que se tradujo no sólo en la falta de colonos, sino también de guerreros que defendieran la conquista. Esto obligaba a aceptar la permanencia de musulmanes en el campo y judíos en las ciudades, única forma de garantizar la sobrevivencia económica de las urbes conquistadas (Linehan, Peter, España, 1157-1300. Una sociedad desorganizada por la guerra, Historia de España, VII, Barcelona, Crítica, 2008, pp. 102, 105).

${ }^{92}$ Se debe tener presente que la frontera era un espacio de conflictos, donde los asentamientos y sus alrededores eran escenarios de frecuentes incursiones y enfrentamientos. Las cabalgatas que buscaban destruir los recursos enemigos y hacer cautivos eran una amenaza latente, razones por las cuales era importante atraer pobladores mediante promesas materiales, como tierras, comercio e incluso amnistías, así como también a través de recursos piadosos como las promesas de indulgencias para aquellos que ayudases a la repoblación.

${ }_{93}$ Para un conocimiento más amplio de los diversos tipos de fueros, recomendamos la obra de Gacto Fernández, Enrique, Temas de Historia del derecho... op. cit.

El llamado a incorporarse a la hueste real, conocido como Fonsado, si bien en sus inicios era bastante amplio, a partir del siglo XI fue cada vez más frecuente que se impusieran limitaciones al tipo de servicio, la cantidad de hombres y los costos de la campaña. De hecho fue común que las ciudades alejadas de la frontera e incluso particulares afectados por el llamado real, permutaran su servicio por un impuesto especial llamado Fonsadera. Estas limitaciones terminaron por restringir la obligación del Fonsado, solo a las poblaciones fronterizas, las cuales debían servir por un periodo limitado de tiempo, por lo general entre 45 días a tres meses, durante los cuales el Concejo debía subsanar los gastos de sus hombres. Acabado ese tiempo, si el rey quería conservar las tropas debía pagar su mantención con el 
incluyendo algunas restricciones como que la campaña se realizara a cierta distancia de la población, o que solamente fuese obligatoria la asistencia si es que el rey mismo encabezaba la expedición. Esta reglamentación se tradujo en una creciente falta de hombres para algunas campañas, particularmente desde el siglo XIII, lo que obligó a la corona a conceder fueros más generales y a reglamentar el llamado de las milicias ${ }^{94}$. Un testimonio de aquello lo encontramos en la Crónica de los Reyes de Castilla, que con posterioridad a los hechos, nos narra las dificultades de Alfonso X para reclutar a los concejos de frontera, destacando las medidas que el rey debió tomar para solucionar este problema $^{95}$.

dinero de las arcas reales. También se hicieron frecuentes las limitaciones sobre el número de hombres obligados a acudir, por ejemplo solo uno por cada casa o solo los caballeros.

94 O'Callaghan, Joseph, Reconquest and Crusade in Medieval Spain, Philadelphia, University of Pennsylvania Press, 2003, p. 125; MacKay, Angus, La España de la Edad Media... op. cit., p. 67; Palomeque Torres, Antonio, "Contribución al estudio del ejército en los estados de la Reconquista", en Anuario de historia del derecho español, Tomo XV, Madrid, 1944, [pp. 205-351], pp. 232, 233; y Powers, James F., A society organized for war ... op. cit., p. 113).

95 "E veyendo este rey don Alfonso esta guerra que tenía comenzada con los moros en que se gastaban muchos caballos, é otrosí commo muchos de las villas se excusaban de lo servir por el llamamiento que les facia de cada año para la frontera, é en que aquel tiempo iva cada uno á servir tres meses por lo que avia, ca el Rey non les daba nada de las fonsaferas, é porque de las extremaduras avia más gentes para su servicio que de las otras villas de su reino, é porque oviesen razon de mantener é criar los caballos é estubiesen prestos cada que los él llamase, ordenó que oviesen los alcaldes en toda la Extremadura en esta manera: que cualquier home que mantoviese caballo é armas, que fuese excusado de la martiniega é fonsadera, é que oviese excusado sus amos é molineros é hortelanos é yugueros é mayordomos é apaniaguados, é por esto que fuese tenudo de ir a servir á la frontera cada que el Rey le llamase sin le dar el Rey otra cosa ninguna por los tres meses del servicio. Este ordenamiento fizo el Rey con acuerdo de los de las Extremaduras que eran y con él, é enviole a las cibdades é villas é logares de la Extremadura: é este ordenamineto fue fecho por los labradores é caballeros ó por otros cualesquier que quisieren mantener los caballos é aver la franqueza par sí é para sus excusados" CRC, cap. XII, op. cit., p. 10.

En la Crónica de Alfonso $X$, se relata otro episodio relacionado con la dificultad de mantener a las milicias en campaña. Cuando el rey decidió poner cerco a Algeciras envió contra la ciudad una fuerza compuesta por una flota e infantes; debido a que el cerco se extendió más de lo previsto, las milicias exigieron su licenciamiento por haberse cumplidos los tres meses de servicio estipulados en el fuero. Por su parte el rey, al carecer de de recursos se vio imposibilitado de retenerlos, situación que terminó por afectar a la flota, puesto que sus tripulantes no recibieron su paga ni sus provisiones. Además, fueron afectados por enfermedades, ante lo cual la flota perdió sus capacidades y fue destruida por los musulmanes (CAX, cap. LXXII, op. cit., pp. 200-203). Esto demuestra, el celo con el cual las milicias procuraban el cumplimiento de los compromisos forales por sobre cualquier otro aspecto, incluido el discurso de guerra justa o religiosa.

Por estas razones, las dificultades que este tipo de tropas ofrecían eran frecuentemente destacadas por los cronistas, que incluso dejan ver un cierto tono de reproche hacia estos hombres que por haber cumplido su tiempo de servicio foral podían retirarse en mitad de una campaña, pese a que esta pudiese no haber concluido. Como ocurrió durante el cerco de Úbeda, donde acudieron los Concejos de Toro, Zamora, Salamanca y Ledesma, bajo el mandado de Fernando III. Estas recriminaciones no deben extrañarnos si recordamos que la gran mayoría de los cronistas eran clérigos convencidos de ser participes de una guerra santa, una misión divina más importante que cualquier norma hecha por los hombres: "[S]equenti uero hyeme sub era MCCLXXI, in festo Epiphanie, obsedit dominus rex Vbedam cum nobilibus et populis quibusdam non multis de regno Legionis et populi Taurinenses, Zamorienses, Salamantini, Ledesmenses, qui iuxta mandatum regis ad absidiomen predicte uille in multitudine magna et apparatu multo occurrerunt.Adueniente uero termino usque ad quem tenebantur seruire regi secundum forum suum, sicut ipsi dicebant, ante captionem uille ad propia sunt reuersi." " (Chonica latina regum 
Pese a todas las dificultades y limitaciones que las milicias concejiles podían implicar, eran tropas bastantes apreciadas por los reyes castellanos ${ }^{96}$.

Aparte de su servicio en la hueste real, las milicias concejiles eran libres de realizar sus propias acciones de guerra contra los musulmanes -frecuentemente motivadas por el deseo de obtener botín-, siempre y cuando estos actos bélicos no fuesen contrarios a los intereses de la corona ${ }^{97}$. Y era precisamente por ello que las milicias se convirtieron en tropas de gran experiencia y de utilidad para los monarcas ${ }^{98}$.

Si bien la hueste concejil la conformaban la mayoría de los guerreros de la ciudad, es significativo que los fueros establecieran una serie de precauciones para no dejar los poblados expuestos durante la época de guerras ${ }^{99}$.

castellae, Corpus Christianorum, Continuatio Mediaevalis, LXXIII, Chronica Hispana Saecvli XIII, Turnholti, Typographi Brepols Editores Pontificii, MCMXCVII, N 64, pp. 105, 106. (En adelante CLRC 1997)).

${ }^{96}$ Esto debido a su experiencia militar, su conocimiento del enemigo y geografía de la zona de conflicto, así como por su bajo costo (siempre y cuando la campaña no durase demasiado) y su estado de preparación casi permanente, permitiendo formar un cuerpo de combate en poco tiempo.

${ }^{97}$ En cuanto a los motivos para hacer una cabalgata se refería, pese al discurso religioso, la práctica demuestra que los concejos tenían una fuerte tendencia a priorizar las razones económicas frente a las religiosas, al punto que, para las cabalgatas concejiles, es extraño ver un lenguaje extremo como el que era propio de las Cruzadas orientales. Como ejemplo de ello se puede colocar la Crónica de la Población de Ávila, donde no se aprecian grandes discursos religiosos o episodios directamente impulsados por ese factor.

${ }^{98}$ Villar García, Luis Miguel, La Extremadura Castellano-Leonesa ... op. cit., p. 163.

Para ilustrar lo anterior podemos citar la Chonica Adefonsi que afirma: "Sed quamvis Sarraceni magna bella faciebant, consuetudo semper fuit christianorum qui habitabant Trans Serram et in tota Extremadura, saepe per singulos annos congregare se in cuneos, qui erant quandoque mille milites aut duo milia aut quinque milia aut decem milia, aut plus, aut minus, et ibant in terram Moabitarum et Agarenorum et faciebant multas caedes et captivabant multos Sarracenos et multam praedam, multaque incendia faciebant et occidebant multos reges et duces Moabitarum et Agarenorum, et bellando destruebant castella et villas, et malora faciebant quam accipiebant a Sarracenis." (CAI, Liber II, N ${ }^{\circ}$ 115, op. cit., p. 90. "Pero aunque los musulmanes hacian grandes guerras, siempre fue costumbre de los cristianos que habitaban la Transierra y en toda Extremadura reunirse cada año frecuentemente en formaciones, que a la postre eran de mil, dos mil, cinco mil o diez mil caballeros, más o menos, e iban al territorio de los moabitas y de los agarenos, efectuaban numerosas matanzas, capturaban muchos musulmanes, conseguian mucho botín y causaban numerosos incendios, mataban muchos reyes y caudillos de los moabitas y de los agarenos, peleando destruían castillos y villas e infligían más daño que el que recibían de los musulmanes". CEA, Libro II, N² 20 (115), op. cit., pp. 101, 102.)

En el caso de los cristianos se establecieron las normas que aseguraban el sometimiento y control de "moros" y judíos. Existía el permanente temor a ser traicionados por ellos, razón por la cual se les limitaban sus derechos en lo referido a aspectos administrativos y judiciales más no en lo económico, puesto que se les consideraba pieza clave de la economía fronteriza. Sobre estas medidas de desconfianza los fueros nos dan algunas señas. Por ejemplo el Fuero de Cuenca dispone que mientras los guerreros estén en campaña, debía existir la obligación de dejar guardias en las murallas, la expulsión de los extranjeros y la prohibición de circular de noche. Pero más interesante es el caso de los incendios, ordenando a los guardianes que en caso de iniciarse un fuego, debían primero asegurar las puertas de la ciudad y luego combatir las llamas, puesto que "porque muchas veces ha acontecido que algunos, queriendo traicionar a la ciudad, produjeron un incendio de manera, que mientras todos andaban ocupados en su extinción, ellos mismos abrieron las puertas más libremente y recibieron dentro a los enemigos" (FCc, cap. XXX, $\mathrm{N}^{\circ}$ 1, op. cit., pp. 221, 222).

${ }_{99}$ Bonassie, Pierre y otros, Las Españas Medievales... op. cit., p. 206. Estas medidas y exceso de celo nos hablan de un cierto clima de inseguridad o desconfianza que existía en las localidades fronterizas, 
En cuanto a las acciones propiamente ofensivas, las milicias urbanas -así como el resto de las fuerzas combatientes de la frontera- realizaban distintos tipos de actividades o servicios bélicos, que se fueron incrementando a partir del siglo XII. Entre ellas

caracterizado por un fuerte temor a la traición, miedo fundamentado en la presencia de musulmanes y judíos en las zonas fronterizas; personajes que aunque viviesen en la misma ciudad, debían soportar sobre ellos la sospecha permanente por parte de los cristianos. Esto, ya que en la práctica las ciudades hispanas de frontera eran la suma de distintos barrios segregados. La mayoría del espacio estaba ocupado por los cristianos, en tanto que las comunidades judías y musulmanas eran limitadas a sus propios distritos, siempre bajo vigilancia. Esta realidad se reflejaba en la distribución del poder local, puesto que solo los cristianos podían ocupar los cargos en el Consejo. Los judíos debían limitarse a sus juderías y desarrollar aquellos oficios que les fueran permitidos, gozando de cierta autonomía jurídica, pero en el entendido de que sobre ellos estaba la ley del reino. Por su parte los musulmanes que permanecían en las ciudades conquistadas o en sus alrededores podían hacerlo bajo un régimen de esclavitud o en el mejor de los casos en una situación similar a la de los judíos (FC, op. cit., pp. XVI, XVII; Lacarra de Miguel, José María, "Acerca de la atracción de pobladores en las ciudades fronterizas de la España cristiana 'siglos XI-XII", en En la España Medieval, № 2, Madrid, 1982, [pp. 485-498], p. 494). No obstante la situación de los musulmanes fue siempre más precaria, puesto que por su número se les veía como una potencial amenaza, sin embargo esa misma situación los hacia necesarios para el trabajo agrícola, lo que permitía a los cristianos dedicarse a actividades como la ganadería y la guerra. A ello debe sumarse que en las localidades cristianas fronterizas el comercio era fundamental y en la práctica los asentamientos musulmanes y cristianos tenían una relación de interdependencia, razón por la cual los comerciantes de uno y otro bando solían desplazarse con relativa facilidad y protección.

A los musulmanes que permanecían con los cristianos o participaban del comercio, se les encuadraba bajo el concepto genérico de "moros de paz", que si bien debían vivir segregados, se les reconocía un rol social vinculado a su actividad económica. En virtud de ella que estaban protegidos por los fueros (FCc, cap. XI, n ${ }^{\circ}$ 20, op. cit., p. 111). Puesto que el abuso contra un "moro de paz", ponía en riesgo el delicado equilibrio étnico fronterizo. Los Concejos no podían arriesgarse a crear un ambiente demasiado hostil hacia los mozárabes, puesto que si huían del territorio se podría producir un fuerte daño al conjunto de la economía.

Distinto era el caso de los conocidos como "moros de guerra", aquellos cautivados en la guerra y considerados parte del botín, por lo que podían ser esclavizados y vendidos. (Fierro, Maribel y Francisco García Fitz (Editores), El cuerpo derrotado... op. cit. p. 50).

Es importante destacar que esta división en la práctica no siempre fue tan clara, puesto que, pese a las prohibiciones, no fue extraño que algunos capturasen moros de paz para comerciar con ellos. Además en caso de sublevaciones, estos pasaban a ser moros de guerra y perdían todas sus garantías legales. Sin embargo los fueros no parecen testimoniar una intención por evitar que ambos grupos de moros se mezclasen, aunque si se diferencia entre los cautivos y los que no lo eran. Una división que de todas maneras se debían a razones principalmente prácticas y judiciales, (Álvarez Borge, Ignacio, La Plena Edad Media ... op. cit., pp. 291, 292).

En cuanto a las practicas religiosas para los mudéjares, su situación era bastante similar a la de los cristianos en tierras andalusíes. Los musulmanes vivían entre los cristianos intentaban mantener su lengua y cultura. Y las leyes del reino procuraban protegerlos de forma similar a como se hacia con los judíos (Las siete partidas del rey don Alfonso el Sabio, Cotejadas con varios códices antiguos por la Real Academia de la Historia, Tomo III, Madrid, Imprenta Real, 1807, Partida VII, Titulo XXV, Ley I, p. 676 (En adelante LSP)). Junto a ello, en especial a partir del siglo XIII, los musulmanes al igual que los judíos se vieron sometidos a periódicas campañas de conversión, las cuales procuraban evitar la violencia y en cambio se enfocaban en prédicas y sermones (LSP, Partida VII, Titulo XXV, Ley I, op. cit., p. 676; Glick, Thomas, Islamic and Christian Spain in the Early Middle Ages, Leiden, Koninklijke Brill NV, 2005, p. 8).

En su conjunto estas medidas fueron toleradas por los musulmanes, pero en muchos casos sirvieron para provocar una paulatina migración hacia las tierras del sur. No obstante es sintomático el hecho de que para el siglo XIII, pese a los discursos bélicos, en la práctica se tratase de evitar los conflictos religiosos y étnicos en las zonas fronterizas, con excepción de lo sucedido con Alfonso X, que con sus políticas término de provocar las hostilidades con los mudéjares. 
destacan la Hueste ${ }^{100}$, el Fonsado o fonsadera que podía implicar el servicio militar personalizado, y finalmente la Cabalgata, que sin duda fue la más destacada por su frecuencia ${ }^{101}$.

Los distintos tipos de expediciones y prácticas bélicas no implicaban una renuncia al botín, puesto que la depredación y la captura de cautivos y riquezas seguían siendo una de las principales motivaciones para la reunión de las huestes, funcionando como un estímulo aparte del discurso religioso y restaurador oficial.

Más rentable, desde el punto de vista de la estrategia de aproximación indirecta, fue la cabalgata llevada a cabo por Fernando el Magno contra Sevilla:

"E después quél ouo todas sus cosas hordenadas e asosegadas por todo su rreyno allegó muy grant huste e fue correr tierra de moros, e començó de destruyr a fierro e a fuego villas e castillos, aldeas, e todo caunto fallaua, e tanto mal les fizo que por fuerça ouo de venir a él Abenhabet, rrey de Córdoua e de Seuilla, con grandes aueres, rrogándole que tomase aquel auer e que por onrra de su rreyno non quisiese más mal fazerle en la tierra de lo que avía fecho, mas quell tomase por su vasallo e su pechero asy commo tomara a los otros reyes moros d'España." 102

Las cabalgatas lideradas por los monarcas recibieron especial atención por parte de los cronistas, que se concentraban particularmente en las consecuencias de las incursiones, entendidas como la sistemática labor de destrucción de las tierras enemigas; los autores dan muchos detalles que ilustran las devastaciones de la guerra y los éxitos

${ }^{100}$ Entendida como la acción militar ofensiva de gran envergadura, durante un tiempo largo y que solía buscar la conquista de un territorio o una batalla campal.

${ }^{101}$ Sobre este concepto -que por lo demás era de un uso muy difundido y común en toda Europa- existe abundante bibliografía, sin embargo, siguiendo nuestra pauta de trabajo, nos aventuraremos a realizar una pequeña caracterización del significado de la idea de Cabalgata, entendida como una estrategia ofensiva de carácter estacional, de corta duración y que por sus características solía tener una logística mínima, basándose en el autoabastecimiento. (En vista de lo anterior no se debe confundir la cabalga con el Apellido, puesto que este era siempre una acción de respuesta a un ataque directo, por lo tanto no tenia mayor planificación y respondía a una situación puntual. En cambio la cabalgata era una maniobra planificada con anterioridad, con un cierto grado de logística y que respondía a una estrategia global). Por las mismas características mencionadas la cabalgata no se veía afectada por las limitaciones forales respecto a la duración del servicio. Por todo lo anterior era un modo de lucha que no requería grandes inversiones para su realización, ni grandes avances en materia armamentística. A lo anterior se sumaba el hecho de que era sumamente rentable en el corto y mediano plazo, ya que se financiaba con la obtención de botín y aseguraba la destrucción de los bienes y tierras enemigos con un mínimo margen de riesgo, lo que a largo plazo debilitaba al adversario y facilitaba la anexión de territorios (García Fitz, Francisco, Castilla y León frente al Islam...op. cit., p. 54, 55). En esencia era una forma de guerra, cómoda y barata, que se adaptaba muy bien a las características de una economía agraria que producía pocos excedentes con los que financiar grandes esfuerzos bélicos.

${ }^{102}$ Crónica de Veinte Reyes, Burgos, Ayuntamiento de Burgos, 1991, Libro VIII, cap. VIII, p. 170. (En adelante CXXR). 
de los caudillos cristianos, probablemente para demostrar el respaldo implícito de la Providencia a las acciones guerreras ${ }^{103}$. Una vez más la Chronica Adefonsi Imperatoris, por su forma y estilo, nos sirve para ilustrar las características y consecuencias de un hecho bélico:

"Et inde rex movit castra et coepit ire per campaniam Codubae[sic], a dextris et a siniestris preadando, et occupavit totam illam terram et praedavit eam, et misit post se ignem et fecit magnam captivationem et pervenit ad fluvium qui dicitur Goadalquivir, quo transfretato, ex altera parte dimiserunt Cordubam et Carmonam a sinistra, Sibiliam vero, quam antiqui vocabant Hispalim relinquentes a dextera. Eratque in diebus messis unde et succendit omniasata, et omnes vineas et oliveta et ficulnea fecit incide; [...]",104.

Se desprende del testimonio de los cronistas, que en estas incursiones se buscaba realizar el mayor daño posible, convirtiéndose en verdaderas campañas de terror. Un ejemplo, en extremo gráfico, nos es revelado en el relato del ataque de Fernando III a Jaén, en el que la magnitud de la devastación fue tal que "Denigrata est facies illius nobilis civitatis, florentis et uirentis, super carbones; emarcuit terra; squalebant arua;

\footnotetext{
${ }^{103}$ Junto con las cabalgatas reales los cronistas dan especial énfasis a las batallas campales. Estas eran un suceso muy excepcional, debido a una serie de razones prácticas, como la enorme logística que se necesitaba para movilizar un gran ejército hacia un punto determinado. Pero, sin duda alguna, lo que convertía en un fenómeno tan extraño, era que en general los líderes medievales las evitaban mientras les fuera posible. Esto en razón de su alto riesgo político, puesto que un encuentro campal implicaba que jugarse la suerte del reino en un solo golpe, con muy inciertos resultados. Si el resultado resultada adverso el rey podía morir o ser capturado y el reino completo perderse - ejemplos sobran como las batallas de Hastings y de Hattin -, a ello se sumaba el hecho de que por las características antes mencionadas, la batalla campal podía ser interpretada como una Ordalía, lo que implicaba que en caso de derrota esta se debía a que Dios castigaba al vencido y por lo tanto podía deslegitimar a un monarca.

Por todas estas razones los contendientes trataban de evitarla las grandes batallas y en la mayoría de los casos su realización era producto de un acto desesperado (como la ruptura de un cerco) o fortuito y solo excepcionalmente preparado con anticipación como fue el caso de las Navas de Tolosa. Fue por sus características de excepcionalidad que los cronistas suelen llenar varias páginas con el relato de un enfrentamiento campal, ilustrándolo con todos sus detalles, reduciendo, en cambio, las cabalgatas y cercos, a algunas cuantas líneas, lo que nos habla de lo frecuente que eran esté tipo de operaciones.

${ }^{104}$ CAI, Liber I, $\mathrm{N}^{\circ} 35$, op. cit., p. 32, "El rey levanto alli el campamento, empezó a moverse por la campiña de Córdoba saqueando a diestro y sinistro, ocupó todo aquel territorio, lo saqueó, lo incendio a sus espaldas, hizo gran número de prisioneros y llegó al río llamado Guadalquivir. Después de atravesarlo, desde la otra orilla se alejaron dejando a la izquierda Córdoba y Carmona y a la derecha Sevilla, que los antiguos llamaban Hispalis. Era la época de la recolección, por lo que hizo incendiar todos los sembrados y cerrar todas las viñas, olivos e higueras. El temor a él se apoderó de todos los habitantes del territorio de los moabitas y agarenos, más también los aludidos moabitas y agarenos, invadidos por un gran temor, abandonaron las ciudades y castillos secundarios y se refugiaron en los castillos más fortificados y en las ciudades amuralladas; se escondieron en las montañas, en las cuevas de las montañas, en las cavernas de las rocas y en las islas del mar" CEA, Libro I, N 35, op. cit., pp. 74, 75 .
} 
decidit, decidit gloria prima ${ }^{\text {} 105}$. Este tipo de lenguaje retórico era de uso común entre algunos cronistas, conscientes de su deber de exaltar las glorias de los monarcas y atemorizar a sus adversarios.

Asimismo, a nuestro entender, los relatos ilustran la manera en que las cabalgatas reales respondían a estrategias mayores, las cuales implicaban el enriquecimiento de la corona, el debilitamiento de los enemigos y la ampliación de los territorios; factores que fortalecían la posición del monarca como máximo conductor militar y político del reino. A su vez, episodios como los relatados nos revelan algo que ya hemos mencionado, y es cómo los intereses económicos -en este caso la obtención de parias- en muchas ocasiones se superponían al discurso de derrota total y "exterminio de los moros".

Si bien la devastación y la búsqueda de botín son las temáticas más destacadas por los cronistas, existe también un tema al que ya nos hemos referido y que no es tan destacado por los cronistas pese a ser uno de los principales objetivos de toda acción bélica y el que a largo plazo puede tener más consecuencias para la conquista de un territorio. Nos referimos al temor y al daño sicológico que podía causar en una comunidad el miedo constante de vivir bajo la amenaza de sus enemigos. Un testimonio gráfico de ello se aprecia en la narración recién transcrita de la expedición realizada por Alfonso VII contra la población de la campiña de Córdoba:

"[...] et cecidit timor illius super omnes habitantes in terra Moabitarum et Agarenorum, sed et ipsi Moabitae et Agareni, praeoccupati timore magno, reliquerunt civitates et castella minora et miserunt se in castellis fortissimis et in civitatibus munitis; in montibus et speluncis montium et in cavernis petram, et in insulis maris absconderunt se." 106

El relato es muy ilustrativo en cuanto al sentimiento de temor que cundió entre los habitantes de la zona, quienes huyeron de sus tierras buscando mejores refugios, llegando incluso a esconderse en cuevas e islas. A pesar de estos vívidos relatos, recordemos que, en palabras de Maribel Fierro y García Fitz, hubo una serie de

${ }^{105}$ CLRC 1997, $\mathrm{N}^{\circ}$ 46, op. cit., p. 89. "La faz de aquella noble ciudad, floreciente y vigorosa, se ennegreció como el carbón; la tierras se marchitó y los campos languidecieron: cayó, cayó su gloria primera" CLRC 1999, $\mathrm{N}^{\circ} 46$, op. cit., p. 78.

${ }^{106}$ CAI, Liber I, N 36, op. cit., p. 32. "El temor a él se apoderó de todos los habitantes del territorio de los moabitas y agarenos, mas también los aludidos moabitas y agarenos, invadidos por un gran temor, abandonaron las ciudades y castillos secundarios y se refugiaron en los castillos más fortificados y en las ciudades amuralladas; se escondieron en las montañas, en las cuevas de las montañas, en las cavernas de las rocas y en las islas del mar." CEA, Libro I, $\mathrm{N}^{\circ} 36$, op. cit., p. 74. 
garantías -aunque no siempre respetadas- que consideraban su religión y condición socioeconómica, y que eran reguladas por principios éticos y jurídicos ${ }^{107}$.

Un hecho que nos parece muy llamativo sobre los diferentes testimonios referentes a cabalgatas, así como de la estructura jurídica que se elaboró para reglamentarla, es el enfoque altamente pragmático que se le dio a esta costumbre bélica. Las fuentes forales describen a los organizadores, la composición de las huestes, sus itinerarios, desventuras y logros; sin embargo, escasamente hacen referencia a aspectos religiosos, incluso el providencialismo aparece tan sólo como una referencia coloquial.

Es importante señalar, que si bien las cabalgatas estaban insertas en la estrategia general de la Reconquista, muchas de ellas no tenían relación con una estrategia mayor, y por el contrario solían responder a las necesidades de alguna localidad o a razones prácticas, como conseguir abastecimientos para una guarnición. Fue común que esta actividad bélica, se viese motivada por la búsqueda de botín y cautivos, los cuales nutrían los mercados y formaban parte fundamental de la actividad económica de las ciudades de frontera ${ }^{108}$.

En vista de lo anteriormente expuesto, nosotros podemos afirmar que, en general las prácticas bélicas de los concejos y milicias fronterizas, así como las de los monarcas, nos permiten extraer varias conclusiones. Primeramente, destaca el sentido práctico de la convivencia en estas urbes, puesto que se procuró que los fueros legislaran sobre la cotidianidad y no sobre discursos ideológicos o religiosos. En ese mismo sentido, se puede considerar que los cristianos de la frontera se encontraban impulsados a la guerra, principalmente motivados por la defensa de sus propiedades e intereses además de la obtención de botín. La guerra era una actividad económica más de la frontera, si no la principal, y el botín permitía la movilidad social y nutría los mercados. A nuestro entender esto contribuye a diferenciar entre discurso cronístico y prácticas fronterizas, ya que a pesar de la radicalización ideológica de los siglos XII y XIII, ésta no fue un móvil relevante para la actividad concejil.

\footnotetext{
${ }^{107}$ Fierro, Maribel y Francisco García Fitz (Editores), El cuerpo derrotado... op. cit., p. 20.

${ }^{108}$ García Fitz, Francisco, Castilla y León frente al Islam ... op. cit., p. 69.

Es de notar que los mercaderes, banqueros y comerciantes en general lucraban con el fruto de estas guerras, siendo ellos los que prestaban el dinero para financiar las campañas o transaban con el botín y los cautivos - pero no pareciera que su piedad los llevase a ser donaciones para apoyar la lucha desinteresada contra el Islam, al menos las crónicas no dan cuenta de ello. En relación a lo anterior es destacable la preocupación general que las fuentes otorgan al tema de la logística bélica. Algo que parece tener intenciones pedagógicas en vista de futuras campañas, como si se quisiera prevenir a los guerreros de que si bien Dios estaba su parte, no debían confiarse totalmente y que era responsabilidad de ellos procurar su sustento.
} 


\title{
I.2.- Guerra santa y cruzada: la instrumentalización religiosa de la práctica bélica
}

\author{
I.2.a.- La guerra justa: de la Antigüedad tardía a la Alta Edad Media
}

A lo largo de la historia, la guerra ha sido un fenómeno de gran connotación social, política, económica y religiosa. En la Edad Media occidental esta fue una figura omnipresente, pero que se distanció de la concepción de la guerra en el mundo clásico, fundamentalmente, por la cosmovisión cristiana de la sociedad que la protagonizaba ${ }^{109}$.

${ }^{109}$ La guerra es parte integral de la historia, y es innegable ha contribuido a la creación del mundo actual, puesto que no solo debe ser considerada como una acción destructora, sino que no se debe perder de vista su función como articuladora de la sociedad e impulsora de procesos y cambio. Al respecto de estas visiones de la guerra como un elemento constructor de la sociedad, podemos encontrar los trabajos de Arnold Toynbee, (Guerra y Civilización, Buenos Aires, Alianza, 1952, p. 31); Gaston Bouthol (El Fenómeno Guerra, Barcelona, Plaza \& Janes, 1971, p. 44); y, del mismo autor, (La Guerra, Barcelona, Oikos-tau, 1971, p. 34, 35).

La guerra, además se convierte en parte importante de los discursos e ideologías, puesto que la victoria y la derrota son incorporadas al subconsciente colectivo, dejando una profunda marca que influencia sus futuras acciones y posiciones frente a sus rivales o aliados, a partir de la interpretación que la sociedad afectada y sus líderes hacen de estos eventos (Sánchez Prieto, Ana Belén, Guerra y guerreros en España según las fuentes canónicas de la Edad Media, Madrid, Servicio de Publicaciones del E.M.E., 1990, p. 15).

Nosotros compartimos estas percepciones, siendo nuestro interés comprender este proceso como parte del escenario de la Reconquista castellana en relación a las intenciones ideológicas-discursivas de sus elites dirigentes y como supieron orientarla hacia la satisfacción de sus intereses. Algo para lo cual les fue sumamente útil el uso de las creencias y prácticas religiosas. Siendo entonces la guerra un elemento constituyente de la historia y conciencia de los pueblos y no se puede obviar su relevancia para el caso de la España medieval, puesto que esta fue una sociedad fuertemente marcada por su relación conflictiva con el Islam. Es bajo esta premisa, que siguiendo los planteamientos de Braudel, entendemos la guerra como una estructura integral de larga duración. Nosotros creemos que la guerra es permanente dentro de la civilización y un ente formador, a la vez rupturista y continuador, y no pocas veces vinculado a la religión. Lo que en el fondo, a nuestro entender, significa que la violencia religiosa medieval no es una novedad en sí misma, sino que es el producto de una herencia cultural anterior que es necesario conocer y comprender.

Si bien sería un error considerar que todos los territorios hispánicos se vieron afectados de igual forma por la frontera y la guerra, lo cierto es que ninguno de los estados cristianos pudo abstraerse totalmente del problema. De tal forma que la guerra se convirtió en parte integral de la sociedad hispánica, al punto de la guerra se convirtió en una presencia discursiva permanente y omnipresente en las crónicas, las hagiografías y el derecho de los reinos cristianos (Palomeque Torres, Antonio, "Contribución al estudio del ejército en los estados de la reconquista", en Anuario de historia del derecho español, Tomo XV, Madrid, 1944, [pp. 204-351], p. 205; y Alvira Cabrer, Martín, "Guerra e ideología en la España del siglo XIII: la conquista de Mallorca según la crónica de Bernat Desclot”, en En la España Medieval, 19, 1996, [pp. 37-50], p. 37). Siendo además, una pieza clave, en las relaciones sociales y en la construcción de las estructuras de poder, que continuamente se aprovecharon de estar realidad como medio de satisfacción de sus intereses territoriales y políticos.

Por este estado casi permanente de guerra y la forma en que se desenvolvió el conflicto no es de extrañar que en el conjunto de la sociedad hispana desarrollara una doble mentalidad respecto al hecho bélico. Por un lado se organizaba para la guerra, la instrumentalizaba y lucraba con ella a través de la siempre tentadora presencia del botín y las conquistas territoriales, pero por otra parte debía sufrir las consecuencias de muerte y destrucción que la contienda causaba. Al respecto don Juan Manuel, en el siglo XIV, no dudaba en calificar la guerra como el peor mal que podía afectar al reino: "Señor infante, segund dizen los sabios todos, y es verdat, en la guerra ay tantos males que non solamente el fecho, mas aun el dicho, es muy espantoso, et por palabra non se puede decir quánto mal della nasçe et por ella viene. Ca por la guerra viene pobreza et lazeria et pesar, et nasçe della desonra et muerte, et quebranto et dolor, et deserviçio de Dios et despoblamiento del mundo, et mengua de derecho et de justiçia" (Don 
Previo al cristianismo, en las antiguas culturas del Mediterráneo, existía una visión religiosa de la guerra. Esto se reflejo en la costumbre de que el botín obtenido, o al menos una parte de él, debía consagrarse a los dioses. En el caso de los hebreos, su monoteísmo marcaba algunos rasgos diferenciadores con respecto a sus vecinos politeístas. El principal de estos rasgos es la característica "teocéntrica" de la guerra; ésta, como fenómeno socio-económico siempre era comprendida como deseada $\mathrm{u}$ ordenada por Dios; por ende, sagrada ${ }^{110}$.

El Antiguo Testamento, en especial el Pentateuco, Deuteronomio y los Libros históricos $^{111}$, es extremadamente pródigo en relatos bélicos ${ }^{112}$. Para los hebreos la guerra fue un instrumento político-religioso que legitimaba sus actos en pos de conquistar un territorio o vencer a sus enemigos; sin embargo, después de la conquista babilónica y la captura de Jerusalén por Nabucodonosor II en el 587 a.C., los judíos cambiaron su forma de concebir la guerra. A ella se le agregó la noción de que la derrota era un castigo divino, un instrumento utilizado por Dios para sancionar los pecados de su pueblo ${ }^{113}$.

Ambas nociones de guerra, fueron reinterpretadas por los teólogos de la antigüedad tardía para justificar la violencia ejercida por los cristianos, en especial luego de la alianza entre la Iglesia y Constantino, siendo necesario combinar la

Juan Manuel, El Libro de los Estados, Edición de Ian R. Macpherson y Robert Brian Tate, Madrid, Editorial Castalia, 1991, p. 207).

La guerra, tan dramáticamente expuesta por don Juan Manuel, sin embargo, fue un elemento integrador para los reinos de Castilla y León, sobre el cual la monarquía y la Iglesia elaboraron un discurso validador que fue esencial para la consolidación de los reinos cristianos. En esencia la guerra fue una actividad cotidiana que marcó todos los aspectos de la cultura hispánica, señalando los grandes valores y principios sobre los cuales se construyó una sociedad particular. Una particularidad no dada por el hecho bélico en sí, sino que por las características de la guerra peninsular: la lucha contra el infiel y el desarrollo de una dinámica de fronteras.

${ }_{110}$ García Fitz, Francisco, La Edad Media. Guerra e ideología, justificaciones jurídicas y religiosas, Madrid, Silex, 2003, p. 93; y Sánchez Prieto, Ana Belén, Guerra y guerreros... op. cit., p. 23.

${ }^{111}$ Dentro de los libros del antiguo testamento destacan por su violencia o temática bélica el Éxodo, Josué, Jueces, Samuel $1^{\circ}$ y $2^{\circ}$, Segundo Libro de Reyes, Judit, Primer y Segundo Libro de los Macabeos, a los que deben sumarse los actos y discursos violentos de muchos profetas contenidos en los Libros Proféticos.

${ }^{112}$ José Fernández Ubiña en su libro Cristianos y militares. La iglesia antigua ante el ejército y la guerra, realiza un recuento de los actos violentos mencionados en el Antiguo Testamento, concluyendo que en el texto aparecen seiscientas referencias sobre pueblos o individuos que realizan actos criminales y de exterminio, mil donde Dios se encoleriza y se venga sangrientamente, y cien donde Yahaveh ordena directamente a uno de sus seguidores el asesinato de otra persona. (Fernández Ubiña, José, Cristianos y militares. La iglesia antigua ante el ejército y la guerra, Granada, Universidad de Granada, 2000, pp. $112,113)$

${ }^{113}$ Bouthoul, Gaston, La Guerra... op .cit., p. 11. 
concepción bélica bíblica con la compresión latina de la guerra ${ }^{114}$, para así poder ordenar la guerra cristiana sobre sólidas bases jurídicas y religiosas ${ }^{115}$.

Ello nos lleva a reafirmar la concepción de que el hecho bélico cumplía un rol de organizador y estructurador de la sociedad, ayudándolas a desarrollar una identidad común, muchas veces amparada por la concepción religiosa de la violencia organizada. La guerra era una actividad común para casi todas las sociedades y sobre la cual se basaba parte de la legitimidad de los líderes, en especial a partir del momento en que la dimensión religiosa de la guerra cobró importancia, convirtiendo la violencia en un signo del favor o castigo de los dioses. La sumatoria de estos ingredientes trascendería en los siglos venideros y paulatinamente impregnaría al cristianismo, el que a partir de finales del siglo III comenzará un largo camino de aceptación de la violencia justificada.

En este recorrido, inicialmente, durante los siglos I al IV d.C., los cristianos, fueron objeto de persecuciones debido a su negativa a rendir los cultos imperiales y

${ }^{114}$ La contribución latina se basó en la tradición romana y su adaptación de la dimensión teológica de la guerra desarrollada por los griegos, así como su papel en la formación de una identidad colectiva, a ello los romanos le aportaron una nueva dimensión jurídica, perfeccionando el concepto de guerra justa. Para el derecho romano la guerra defensiva era un derecho natural, bajo el cual se entendía que una nación podía actuar como juez y parte en caso de ser agredida, y que la respuesta militar era la única acción posible para vengar una afrenta o reivindicar un daño hecho. Cicerón fue uno de los pensadores que ayudó a organizar las ideas romanas sobre la guerra justa (Ver Cicerón, Los oficios o los deberes, México D.F., Porrúa, 1998, pp. 13 y ss). Para el autor, la guerra era considerada como un mal que se debía evitar y solo se podía recurrir a ella como un último recurso (Kakarieka, Julios, "Los orígenes de la doctrina de la guerra justa. Cicerón y la tradición romana", en Arbea, Antonio, Giuseppina Grammatico y Héctor Herrera Cajas, Cicerón, un alma ardiente, Santiago de Chile, Universidad Metropolitana de Ciencias de la Educación, Centro de Estudios Clásicos, 1994, p. 267). Era por ello que la guerra justa era entendida jurídicamente y sometida a una serie de reglas, especificando que estos conflictos eran los que hacían en auxilio de los aliados o en defensa del propio territorio; contra los bárbaros; o si en su ejecución se evitaban los excesos y se cumplían los pactos acordados con el enemigo. A ello debían sumarse ciertos aspectos rituales propios de la religión romana que aseguraban el favor de los dioses en el conflicto por iniciarse, el que sólo se aseguraba si el ritual era realizado de la forma adecuada, puesto que de lo contrario, la contienda sería considerada sacrílega, injusta y por ende destinada al fracaso (Fernández Ubiña, José, Cristianos y militares... op. cit., p. 515; García Fitz, Francisco. La Edad Media ... op. cit., p. 25; Bouthoul, Gaston, La Guerra ... op. cit., p.18; y Kakarieka, Julios, "Los orígenes... op. cit., pp. 269276).

${ }^{115}$ Recordemos que la tradición latina, a su vez se basa en el Helenismo. Para los griegos la guerra era una actividad relativamente frecuente. Inicialmente fue la literatura la que se preocupó más del fenómeno bélico, el cual era trasmitido como parte de la formación de la sociedad y un componente esencial del orden provincial (Bouthoul, Gaston, La Guerra... op. cit., p. 14). Para los helenos la guerra era importante para la conformación e identificación de una sociedad y que, por ello se le admitía como algo lícito en cualquiera de sus formas., como se observa en algunos textos como los Nueve libros de la Historia de Herodoto, la Historia de la Guerra del Peloponeso de Tucídides o Anábasis de Jenofonte.

Fue Aristóteles en su obra La Política, el que introdujo el concepto de Guerra Justa para referirse a aquella librada contra los no helenos, los bárbaros fuera de la Helade. Para el filósofo, la guerra era una forma natural de expedirse sobre pueblos menos dignos que, adicionalmente, podían ser esclavizados; en tanto, los griegos debían procurar mantener su libertad, para lo cual les era legítimo luchar. En ambos casos -según Frederick Russell- la guerra, más que un fin en sí misma, era comprendida como un medio para alcanzar objetivos más altos como la paz y la gloria (Aristóteles, Política, Libro I, capítulo II, III. Russell, Frederick, The Just War in the Middle Ages, Cambridge, 1975, pp. 3, 4). 
posteriormente, a partir del siglo III, por negarse a enrolarse en el ejército. Era por tanto una religión pacífica, cuya absoluta negación de la violencia se tradujo en una causa de persecución y martirio. El cristiano ansiaba morir por su fe, pero no matar por ella ${ }^{116}$.

El mensaje cristiano es rupturista en ese aspecto al promover un total rechazo a la violencia; sin embargo, es importante recordar que, tanto para los judíos como para los primeros cristianos, el Antiguo Testamento tenía una especial relevancia; se le consideraba un libro iluminado y por tanto incuestionable ${ }^{117}$. Para los cristianos, este hecho creaba conflictos con su doctrina pacifista, ya que la primera parte de la Biblia, cargada con hechos de violencia, estaba relacionada al proceso de formación e individualización de un pueblo. Además, dicha conducta estaba estrechamente relacionada con la voluntad de Yahaveh, lo que explicaría que en el Nuevo Testamento se encuentran muchas referencias a los soldados y la actividad militar, hacia quienes no se formulan verdaderas condenas o prohibiciones ${ }^{118}$. Por el contrario, Cristo alaba al centurión que buscaba la sanación de su criado, y posteriormente San Pablo, en sus cartas a Timoteo, no duda en exhortar a conformar la noble milicia y a soportar las fatigas como un soldado de Cristo ${ }^{119}$. Esta utilización de conceptos militares, si bien no pueden ser considerados una exaltación de la violencia, sí confirman la utilización del soldado como un modelo a imitar, por sus características de obediencia, esfuerzo y entrega $^{120}$.

Los primeros cristianos interpretaron esta tradición como una condena a la violencia individual, la que debía ser rechazada, pero debieron enfrentarse con un vacío doctrinal en cuanto a la guerra, ya que ésta no fue condenada explícitamente por

\footnotetext{
${ }^{116}$ La progresiva imposición del culto al Emperador en Roma, se topó con la férrea oposición de los cristianos, que se negaban a adorar a otro dios. Dicha situación, dada en el contexto de la creciente unión política y religiosa del poder en Roma, los puso en el punto de mira de las autoridades imperiales, que los acusaron de lesa majestad argumentando que su negativa perjudicaba al Estado y que su postura contraria a los ritos oficiales significaba la traición.

${ }^{117}$ Fernández Ubiña, José, Cristianos y militares... op. cit., pp. 119, 147-150.

118 Marín, José, Cruzada, Guerra santa y Yihad. La Edad Media y Nosotros, Valparaíso, Instituto de Historia, Pontificia Universidad Católica de Valparaíso, 2003, p. 65.

119 II Timoteo 2: $1,10$.

${ }^{120}$ Flori, Jean, Guerra Santa, Yihad, Cruzada..., op. cit., p. 15; Fernández Ubiña, José, Cristianos y militares... op. cit., p. 119, 147, 180, 182; Partner, Peter, El Dios de las batallas... op. cit., pp. 48-49; Sánchez Prieto, op.cit., p. 24; y Demurger, Alain, Caballeros de Cristo. Templarios, hospitalarios, teutónicos y demás órdenes militares en la Edad Media (Siglos XI a XVI), Granada, Universidad de Granada, Universitat de Valencia, 2005, p. 23.

Para ilustrar lo anterior, se pude recordar el caso de Juan el Bautista que si bien criticó duramente a la cultura judía de su tiempo, es más bien cauto al momento de aconsejar a un grupo de soldados, a quienes en vez de reprochar su actividad, sólo les ordena evitar los excesos propios de la guerra y su oficio para así lograr la salvación: "Preguntáronle también unos soldados: 'Y nosotros ¿qué debemos hacer?' Él les respondió: 'No hagáis extorsión a nadie, no hagáis denuncias falsas y contentaos con vuestra soldada" (Lucas 3:15).
} 
Cristo $^{121}$. Ello obligó a los cristianos a buscar alguna solución respecto a cómo enfrentarse a la guerra, problemática que se vio agravada cuando en el siglo III la crisis imperial propició las levas, que obligaban a los cristianos a luchar y eventualmente matar en la defensa de un imperio pagano.

En este estado de cosas, el cristianismo sufrió un cambio radical a partir del reinado de Constantino (306-337) y la proclamación en el año 313 del Edicto de Milán. Ahora, los cristianos gozaban de los beneficios y obligaciones del poder político, convirtiéndose en un aliado al servicio de Constantino y sus sucesores que buscaban la estabilidad del decadente Imperio. Situación que se ve consolidada durante el reinado de Teodosio I (379-395), cuando es promulgado el Edicto de Tesalónica en el año 380.

Constantino y Teodosio, con las normas que establecieron, causaron un cambio radical en la relación entre cristianismo y violencia, pues ya no se trataba de un imperio pagano, sino de la defensa de un estado cristiano ${ }^{122}$. Los emperadores tardoromanos tomaron en sus manos el deber de promover, expandir y defender la cristiandad, lo que era imposible de realizar sin ejercer algún grado de violencia. Por otra parte, estaba el problema de la defensa de las fronteras ante los germanos paganos o herejes, ante lo cual los cristianos se vieron obligados a tomar las armas para defender Roma y sus instituciones, entre las que se encontraba la Iglesia $^{123}$. Lo que significaba que los soldados cristianos podían ampararse en la guerra defensiva para justificar el uso de la violencia y la muerte ${ }^{124}$.

\footnotetext{
${ }^{121}$ García Caneiro y Vidarte en su obra Guerra y Filosofia: concepciones de la guerra en la historia del pensamiento, nos recuerdan que desde los orígenes del cristianismo existieron personajes influyentes, como Tertuliano, que condenaron de manera absoluta la guerra y el servicio militar. Así como otros posteriores como fue San Ambrosio que en el 381 excomulgó y negó a Teodosio la entrada al concilio de Constantinopla en castigo por la matanza de los rebeldes de Tesalónica.

${ }^{122}$ Fernández Ubiña, José, Cristianos y militares... op. cit., p. 428; Flori, Jean, La Guerra Santa..., op. cit., pp. 34-38.

${ }^{123}$ Si bien sobre este proceso hay abundante material escrito, recomendamos algunas obras que sintetizan bastante bien las principales ideas a este respecto. Nos referimos a las obras de Jean Flori, La Guerra Santa y Guerra Santa, Yihad, Cruzada. Violencia y Religión en el Cristianismo y el Islam, Granada, Universidad de Granada, Universitat de València, 2004; y de Bronisch, Alexander Pierre, Reconquista y guerra santa ... op. cit. Finalmente de García Fitz, Francisco, La Edad Media ... op. cit.

${ }^{124}$ Esto en razón de que para el cristianismo el matar se encontraba completamente fuera del mensaje de Cristo y la aceptación de la violencia contradecía sus mismas palabras cuando dijo: "No penséis que he venido a abolir la Ley y los Profetas. No he venido a abolir sino a dar cumplimiento" (Partner, Peter, El Dios de las batallas... op.cit., pp. 76, 77; y Mateo 5:17). Por ello, la muerte de un enemigo en guerra se siguió considerando un asesinato y, en consecuencia, un pecado que debía ser sujeto de penitencia. Pero las necesidades defensivas obligaron a buscar una forma de legitimar el derramamiento de sangre y convertirlo en un pecado menos grave. La solución de los teólogos para este conflicto fue buscar justificaciones en las Sagradas Escrituras, en especial en el Antiguo Testamento y, en la tradición clásica (Flori, Jean, Guerra Santa, Yihad, Cruzada ... op. cit., pp. 46-50).
} 
Este cambio en la postura original del cristianismo hubiese sido imposible de no haber existido el precedente cultural de los rituales religiosos previos a la ejecución de la violencia institucionalizada y a la aceptación teologal del Antiguo Testamento ${ }^{125}$. Ambos elementos permitían aceptar la violencia dentro de determinados márgenes, dados por la voluntad de Dios o bien dirigidos a la defensa de sus siervos; no obstante, para los dirigentes cristianos, el aceptar la violencia no fue un proceso fácil ${ }^{126}$. En razón de ello también se busco sustento en el Nuevo Testamento ${ }^{127}$, en especial en Los Hechos de los Apóstoles y en las cartas de Pablo de Tarso, quien sentó las bases para el acatamiento de las órdenes provenientes de las autoridades civiles, incluidas, entre ellas, la guerra, argumentando que todo poder dado por Dios se ajusta a sus designios ${ }^{128}$.

Posteriormente las migraciones germanas y el colapso romano vinieron a complicar aun más el escenario cristiano. Para que la Iglesia sobreviviera a esta nueva circunstancia, fue necesario que adoptara y adaptara las costumbres germánicas, en especial las relativas a la guerra. Para estos pueblos la guerra era una actividad social cotidiana, repleta de rituales y simbolismos que la sacralizaban, en donde la participación en ella significaba alcanzar un posicionamiento social. En respuesta, el cristianismo atrajo a los germanos a través de la exaltación de la imagen de un Cristo

\footnotetext{
${ }^{125}$ García Fitz, Francisco, La Edad Media... op. cit., p. 116.

${ }^{126}$ Producto de todas estas circunstancias, comenzó un paulatino proceso de aceptación de la violencia en su expresión de guerra defensiva, la que a su vez se basaba en las nociones de la guerra justa latina. A esta se le incorporaron nuevos elementos propios de la teología cristiana, planteados por autores como Eusebio de Cesarea (c.275-339), San Atanasio (296-367), Ambrosio de Milán (c.340-397) y Agustín de Hipona (354-430). San Atanasio afirmo que era legítimo eliminar a un enemigo en el contexto de una guerra justa. Un pensamiento similar al de San Ambrosio de Milán que sostiene que es justo tomar las armas para defender la patria y defender la justicia. (Marín, José, Cruzada, Guerra santa y Yihad.... op. cit., p. 66). Incuso en el Concilio de Arles del año 314, convocado por Constantino, se estableció la excomunión para los cristianos que desertasen la milicia en tiempos de paz; de esta manera se daba un barniz religioso a las necesidades militares del Imperio (García Fitz, Francisco, "La Reconquista: un estado de la cuestión", en Clio \& Crimen, $\mathrm{N}^{\circ}$ 6, Extremadura, 2009, [pp. 142-215], pp. 174, 175; Fernández Ubiña, José, Cristianos y militares... op. cit., pp. 476, 477; y Cardini, Franco, "Guerra y cruzada", en Le Goff, Jacques y Jean-Claude Schmitt (Editores), Diccionario razonado del occidente medieval, Madrid, Akal, 2003, p. 310).

${ }^{127}$ Expresiones atribuidas a Cristo conteniendo conceptos violentos, fueron utilizadas para validar la violencia, no obstante que muchos de estos dichos fueron extraídos de su contexto. A modo de ejemplo, se puede citar el evangelio de Mateo 10, 34: "No penséis que he venido a traer paz a la tierra. No he venido a traer paz, sino espada. Sí, he venido a enfrentar al hombre con su padre, a la hija con su madre, a la nuera con su suegra; y enemigos de cada cual serán los que conviven con él’.

${ }^{128}$ García Caneiro, José y Francisco Javier Vidarte, Guerra y filosofía: concepciones de la guerra en la historia del pensamiento, Valencia, Tirant lo Blanch, 2002, p. 37.

"Sométanse todos a las autoridades constituidas, pues no hay autoridad que no provenga de Dios, y las que existen, por Dios han sido constituidas. De modo que, quien se opone a la autoridad, se rebela contra el orden divino, y los rebeldes se atraerán sobre si mismos la condenación" (Romanos 13: 1, 2)
} 
triunfante, el fortalecimiento de los santos como manifestaciones menores de la divinidad y de la exaltación de los sacramentos ${ }^{129}$.

Aun así, estas ideas no significaron la aceptación de la totalidad de la violencia; por el contrario, la Iglesia sostuvo que la paz era el estado natural del hombre y que la violencia era parte del pecado original. El hombre debía vivir en paz, la misma que caracterizaba a la Ciudad de Dios, ya que la violencia era propia de la Ciudad Terrenal, donde los hombres estaban obligados a vivir ${ }^{130}$.

Estas reformas, empujadas por la coyuntura histórica, se tradujeron en un alto costo para la ortodoxia cristiana: el abandono del mensaje pacifista de Cristo y la adopción de una visión más guerrera, que la acercó a la idea de la Guerra Sacralizada ${ }^{131}$.

Esta evolución político-teológica hubiese sido imposible sin la intervención de una nueva corriente de pensadores, propensos a captar la nueva realidad del cristianismo de corte más terrenal que espiritual $^{132}$.

Quien sintetizó estas ideas y permitió su aceptación por parte de la jerarquía eclesiástica fue Agustín de Hipona, a quien se le debe la formulación de lo que podríamos llamar una "teología bélica"133.

${ }^{129}$ Flori, Jean, Guerra Santa, Yihad...op. cit., pp. 56-58.

${ }^{130}$ Flori, Jean, La Guerra Santa ... op. cit., p. 37.

${ }^{131}$ Partner, Peter, El Dios de las batallas... op. cit., pp. 76, 77; Flori, Jean, La Guerra Santa ... op. cit., p. 40, 41; y Fernández Ubiña, José, Cristianos y militares ... op. cit., p. 552, 553.

${ }^{132} \mathrm{Ya}$ en época temprana existieron algunos pensadores cristianos más proclives a la violencia en su faceta defensiva, entre los que destacó Eusebio de Cesárea, quien en su papel de consejero del Emperador Constantino reafirmó la idea de que era una tarea del Imperio el asegurar la paz. A esta misión estaban obligados los laicos, pero no así los clérigos, que debían entregarse a Dios y la oración para asegurar la protección espiritual del emperador, sus territorios y súbditos. En vista de ello, Eusebio no dudó en alabar las victorias guerreras de Constantino sobre sus enemigos paganos, y en difundir la justicia de su causa. En el siglo IV las ideas de Eusebio se vieron complementadas con los postulados de Ambrosio de Milán, cuyas motivaciones ideológicas se relacionaban con la amenaza de las incursiones de los germanos paganos. Según su concepción era necesario y justo defender al Imperio, argumento sustentado en la combinación de las ideas de Cicerón sobre la guerra justa y las del Antiguo Testamento, planteamientos que además podían ser utilizados en el combate hacia los herejes, considerados como traidores a la doctrina oficial del Imperio y la Iglesia (Bronisch, Alexander Pierre, Reconquista y Guerra santa ... op. cit. pp. 38, 39; Partner, Peter, El Dios de las batallas... op. cit., p. 75).

${ }^{133}$ Marín, José, Cruzada, Guerra santa y Yihad.... op. cit., p. 66; y Russell, Frederick, The Just War... op. cit., pp. 16 y ss.

El pensamiento de San Agustín se basaba en la guerra justa latina, en el Antiguo Testamento y en los Evangelios (Russell, Frederick, The Just War... op. cit., p. 16). Básicamente, sus planteamientos se enfocaban en la guerra justa, que para obtener esa calificación debía sintetizar una serie de características, entre las que se contaban: el responder a una agresión injustificada y, por ende, actuar en legítima defensa; recuperar bienes o tierras usurpadas; reponer un estado de justicia quebrantado por el enemigo; no responder a motivaciones personales y evitar los abusos y pillajes -esto último en la línea con las palabras de Juan Bautista - y por último, que la guerra fuese convocada por una autoridad pública y legítima (Marín, José, Cruzada, Guerra santa y Yihad.... op. cit., p. 67). En razón de lo anterior es que Cardini sostiene que San Agustín, en su filosofía, distingue claramente la diferencia entre las causas para luchar una guerra, jus ad bellum y la conducta que se debe adoptar durante su transcurso, jus in bello (Cardini, Franco, "Guerra y cruzada", en Le Goff, Jacques y Jean-Claude Schmitt (Editores), Diccionario 
Para Agustín la guerra, si bien es nociva, no es mala por sí misma, sino por los actos excesivos que podían realizarse durante su trascurso; he ahí la importancia de regular la actividad militar ${ }^{134}$. En este contexto, Agustín reconoce la guerra como una necesidad, pero sólo considera lícitas y permisibles las guerras justas, que son aquellas que los hombres sabios libran contra la injusticia de sus enemigos ${ }^{135}$.

razonado... op. cit., p. 312). En esencia, estos postulados giran sobre el sentido de justicia de la res publica, a lo que se suman las ideas del Nuevo Testamento que afirman que todo poder político viene dado por Dios (Juan 18:10), de lo que se desprende que si el Imperio es cristiano, su defensa está garantizada por la voluntad divina y por consiguiente, se trata de una causa santa (Ortega, Juan Fernando, "La paz y la guerra en el pensamiento agustiniano", en Revista Española de Derecho Canónico, Vol XX, $\mathrm{N}^{\circ}$ 58, Enero-Abril, 1965, [pp. 5-35], p. 22; Fernández Ubiña, José, Cristianos y militares... op. cit., pp. 539, 540; Bronisch, Alexander Pierre, Reconquista y Guerra santa...op. cit., pp. 42, 43; Flori, Jean, Guerra Santa, Yihad..., pp. 37-39, 262, 263; Demurger, Alain, Caballeros de Cristo... op. cit., p. 23; Bouthoul, Gaston, La Guerra, op. cit. pp. 12, 13; Russell, Frederick, The Just War... op. cit., p. 18; Bronisch, Alexander Pierre, "En Busca de la Guerra Santa", en Baloup, Daniel y Philippe Josserand (Editores), Regards Croisés sur la Guerre Sainte. Guerre, Idéologie et Religion Dans L'espace Méditerranéen Latin (XI-XIII Siècle), CNRS-Université de Toulouse-Le Mirail, 2006, p. 105; y Cardini, Franco, "Guerra y cruzada", en Le Goff, Jacques y Jean-Claude Schmitt (Editores), Diccionario razonado... op. cit., p. 312).

La esencia del "pensamiento militar" de Agustín se encuentran en sus obras Contra Faustum, dedicadas a combatir la herejía maniquea, y posteriormente en su De Civite Dei. El primer escrito pretende negar los extremismos de los maniqueos, que rechazaban toda violencia, incluida la veterotestamentaria. Esto, para el Obispo de Hipona, implicaba una amenaza directa para la seguridad del Imperio cristiano. En respuesta, sostiene que si bien la guerra no es algo bueno, es necesaria cuando sirve de herramienta para el servicio de Dios, postulado que se sostiene en múltiples ejemplos extraídos del Antiguo Testamento. En esencia, lo que propone San Agustín, es que la guerra es algo intrínsicamente malo y ligado a lo terrenal, pero necesario. No obstante, el hombre debe aspirar a la paz, al amor y a lo espiritual. La guerra únicamente se justificaba cuando, querida por Dios, servía para asegurar la paz, el amor y regresar al orden (Ortega, Juan Fernando, "La paz y la guerra... op. cit., pp. 17-19; Fernández Ubiña, José, Cristianos y militares... op. cit., pp. 547; García Caneiro, José y Francisco Javier Vidarte, Guerra y filosofía... op. cit., 38, 39; y O'Callaghan, Joseph, Reconquest and Crusade... op. cit., p. 13). Sobre ello Agustín afirma: "Pacis igitur intentione geruntur et bella, ab his etiam, qui virtutem bellicam student exercere imperando atque pugnando. Unde pacem constat belli esse optabilem finem. Omnis enim homo etiam belligerando pacem requirit; nemo autem bellum pacificando" (Hipona, Agustín de, De civitate Dei. Liber XIX, Cap. XII, en http://www.augustinus.it/latino/cdd/index2.htm. 11 de noviembre de 2010 (En adelante DQD). "Con miras a la paz se emprenden las guerras, incluso por aquellos que se dedican a la estrategia bélica, mediante las ordenes y el combate. Está, pues, claro que la paz es el fin deseado de la guerra. Todo hombre, incluso en el torbellino de la guerra, ansía la paz, así como nadie trabajando por la paz busca la guerra”. Hipona, Agustín de, La ciudad de Dios, Libro XIX, Cap. XII, Madrid, Homo Legens, 2006, p. 837. (En adelante LCD).

Bajo esta concepción, la guerra forma parte de la naturaleza humana $\mathrm{y}$ frecuentemente se manifestaba en la obligación de los buenos de castigar a los malvados y sus vicios; en otras palabras, el pecado (Russell, Frederick, The Just War... op. cit., p. 25). Si la guerra era por esta causa, los soldados no cometían faltas, puesto que obedecían el mandato de una autoridad superior. De esta forma, Agustín, basándose en la interpretación del Nuevo Testamento, avalaba el servicio militar y lo libraba de las manchas del pecado y, de paso, obligaba al respeto de las jerarquías militares y civiles (Obras completas de San Agustín. XXXI. Escritos antimaniqueos $\left(2^{\circ}\right)$ Contra Fausto. Introducción, Traducción, Notas e Índices de Pío de Luis, Madrid, Biblioteca de Autores Cristianos, 1993. pp. 604, 605. (En adelante CF)

No contento con estas afirmaciones, Agustín continúa sus meditaciones, distinguiendo entre las guerras de los hombres y las ordenadas por Dios, aclarando que estas últimas son incuestionables y quienes participasen de ellas estaban absolutamente libres de toda culpa o reproche (CF, op. cit., pp. 605, 606).

${ }^{134}$ Bronisch, Alexander Pierre, Reconquista y guerra santa..., op. cit., p. 41.

${ }^{135}$ LCD, Libro XIX, cap, VII, op. cit., p. 832. 
Durante los siglos V al VII, la Península Ibérica no escapó a este proceso de trasformaciones políticas, teológicas y sociales. En el trascurso del periodo arriano del Reino Visigodo, se obtuvieron importantes victorias militares contra los bizantinos y otros pueblos germanos ${ }^{136}$. Todo ello, sumado al relativo aislamiento geográfico de la Península, contribuyó a que la monarquía visigoda mantuviera su doctrina herética sin ser mayormente importunados por la Iglesia de Roma, no obstante la importante presencia de población católica en el reino. Ello significó que el arrianismo nunca fue mayoritario en la Península, pero al ser la creencia de los vencedores, fue también la fe del Estado; de suerte que en el reino convivieron las dos Iglesias rivales, intentando ambas alcanzar la máxima influencia política ${ }^{137}$.

Estas diferencias terminaron cuando Recaredo (586-601) se convirtió al catolicismo en el año 587, lo que implicó la creación de una poderosa alianza entre la Iglesia Católica y la monarquía visigoda. Para mantener la estrecha relación entre la jerarquía eclesiástica y el poder político, así como solucionar conflictos que pudiesen mermar esa alianza, se fortaleció el sistema de los Concilios -las grandes asambleas del reino donde autoridades civiles y religiosas legislaban sobre materias civiles-, de esta manera el poder del alto clero se acrecentaba, extendiendo su influencia a áreas netamente políticas al mismo tiempo que el monarca se aseguraba que la Iglesia respaldase y legitimase sus acciones, incluido en el aspecto militar ${ }^{138}$.

Esta dinámica de relaciones fue abordada desde las ideas de San Isidoro. Al igual que San Agustín, Isidoro estuvo impulsado por el contexto de su época, en que vio a un reino germano que consolidaba sus fronteras, en proceso de adoptar la ortodoxia

Se puedes concluir que con sus postulados Agustín no pretendió formular una teología bélica, ni menos un panegírico a la guerra justa; sus ideas respondieron más bien a una coyuntura histórica concreta y a un contexto determinado por un Imperio cristiano amenazado desde el interior por los herejes y desde el exterior por las migraciones de bárbaros paganos. Por esas mismas razones, las ideas del Obispo de Hipona, aunque conocidas, no se convirtieron en una norma inmediata, pero en cambio quedaron latentes e influenciaron a pensadores posteriores, hasta ser aceptadas plenamente por la Iglesia Occidental (Flori, Jean, La guerra santa... op. cit., pp. 261-264; y Russell, Frederick, The Just War... op. cit., pp. 16-39, 213-257).

${ }^{136}$ Todo ello ocurrió en una época de convulsiones en la cual Europa y la Iglesia estaban en pleno proceso de reestructuración política y cultural, luego del colapso del Imperio Romano occidental. Es la época en que las tradiciones cristiano latinas se combinaron con las germanas y desde el patriarcado de Roma, se intentaba organizar esta nueva realidad, a través de la imposición de la doctrina católica, gracias a las reformas y la intención evangelizadora de pontífices como León I (440-461), Gelasio I (492-496) y Gregorio Magno (590-604).

${ }^{137}$ Mitre, Emilio, La España medieval, Madrid, Istmo, 1999, pp. 37-39.

138 García y García, Antonio, Iglesia, Sociedad y Derecho, Salamanca, Publicaciones Universidad Pontificia de Salamanca, 2000, p. 184. 
católica y que frecuentemente se veía sacudido por conspiraciones, asesinatos y guerras de diversa índole. Era una sociedad inestable donde la violencia política era común, lo que obligaba a la Iglesia a pronunciarse sobre el tema ${ }^{139}$.

La violencia se encuentra tratada en los primeros concilios hispanos donde se le condenaba sin importar si era política o individual; no así la guerra, hacia la cual no se hacían mayores reproches ${ }^{140}$. Los postulados de Isidoro se basan en la ya tradicional definición de guerra justa, inspirándose esencialmente en los postulados de Cicerón ${ }^{141}$ : “Guerra justa es la que se hace por acuerdo, a causa de hechos muy repetidos, o para arrojar al invasor. Es guerra injusta la que no se apoya en legitima razón, sino que en el furor" ${ }^{\prime 142}$.

Claramente, estas distinciones se deben comprender dentro de las necesidades por evitar la violencia al interior de un reino frecuentemente perturbado por ella. Esta tendencia se explica mejor a través de las subdivisiones referentes a la guerra que estableció Isidoro en su Etimologías, donde dedica un apartado a los conflictos intestinos. En su conjunto las guerras podían ser "justas, injusta, civil y plus cuam civile" "143. A su vez, Isidoro, las divide en guerras “internas" y "externas", precisando, adicionalmente, que las "internas" podían ser civiles o entre parientes, siendo necesario, en ese caso distinguir entre guerra, bellum, que se hace contra los enemigos y ajustada al derecho, es decir la guerra justa y los tumultos "que se forma por sedición civil" y que quedaban desprovistos de toda justificación ${ }^{144}$. Una señal más que reafirmaba su preocupación por los conflictos sucesorios al interior de la monarquía visigoda ${ }^{145}$.

Las ideas de Isidoro sobrevivieron a la caída del Reino Visigodo y durante los siglos XII y XIII cobraron gran vigencia e influencia, convirtiéndose en las bases para el

\footnotetext{
${ }^{139}$ Entre los años 560 y 636, en los que vivió Isidoro, once reyes se sucedieron; de ellos siete llevaron a cabo guerras contra bizantinos, francos y otras amenazas y cinco fueron asesinados o expulsados del trono mediante conjuras.

${ }^{140}$ Sánchez Prieto, Ana Belén, Guerra y guerreros... op. cit., p. 28.

${ }^{141}$ Isidoro de Sevilla, Etimologías, Versión castellana total, por vez primera, e introducciones particulares de don Luis Cortés y Góngora, Introducción general e índices científicos del prof. Santiago Montero Díaz, Biblioteca de Autores Cristianos, Madrid, 1951, p. 441. (En adelante Etimologías). García Fitz, Francisco, Las Navas de Tolosa... op. cit., p. 403.

${ }^{142}$ Etimologías, Libro XVIII, cap. I, ... op. cit., p. 440.

${ }^{143}$ Etimologías, Libro XVIII, cap. I,... op. cit., pp. 441, 442.

${ }^{144}$ Etimologías, Libro XVIII, cap. I, ... op. cit., p. 442.

145 Sánchez Prieto, op. cit., pp. 28, 38. A continuación Isidoro continua desarrollando los aspectos militares en su obra, pero ya desde una perspectiva práctica, procurando describir las distintas partes de la guerra, las armas, insignias y armaduras (Etimologías, Libro XVIII, Cap. I a XIV,... op. cit., pp. $442-$ 449).
} 


\section{llamado goticismo ${ }^{146}$ propugnado por personajes como Lucas de Tuy y Rodrigo Jiménez de Rada, promotores de la Reconquista y la guerra contra el Islam. Esto}

146 Para el caso hispano este discurso, al servicio de los monarcas, tenia como piezas esenciales la concepción de España como una entidad unida y gloriosa, fuertemente identificada por su pasado visigodo y su tradición cristiana. Este ideal es lo que suele llamarse goticismo. Un concepto de larga data, que si bien no es parte del vocabulario cronístico ha servido ha investigadores posteriores para identificar a este ideal común al que nos estamos refiriendo.

Sabemos de que el concepto de goticismo no siempre genera consensos y que algunos autores suelen diferenciarlo identificándolo con las interpretación del discurso godo desde San Isidoro a los primeros reinos de la Reconquista y el "neogoticismo" que correspondería al uso del concepto durante los siglos XII y XIII, cuando la cronística lo revitaliza y estructura sus distintos componentes de forma más coherente a las necesidades de la Reconquista. Si bien aceptamos esta división, nosotros hemos optado por utilizar la categorización más genérica de goticismo, puesto que consideramos que se trata, esencialmente, del mismo principio ideológico que no cambia en su sustancia y que esta puede ser fácilmente rastreable e identificable desde los primeros años de la Reconquista hasta los siglos de nuestro estudio. Misma razón que nos ha llevado a pensar que los cronistas pleno medievales de Castilla eran consientes de la existencia y utilidad del goticismo como una herramienta al servicio de la construcción de una identidad hispánica y que no tuvieron una real intención de trasformar el ideal, sino que simplemente se abocaron a utilizarlo según su propia visión y su contexto. En otras palabras consideramos que el neogoticismos responde más a una interpretación de estudiosos modernos, que a una intencionalidad de los autores de las fuentes, razón por la que preferimos no hacer mayores diferenciaciones en el uso del concepto.

A modo de caracterización, el goticismo representó una autoconcepción hispano-visigoda que encuentra sus raíces en San Isidoro y su alabanza a los godos, especialmente visible en su Historia Gothorum, Vandalorum et Suevorum. Una visión que fue mantenida por los cronistas posteriores y que luego de la invasión musulmana del 711 fue revitalizada y adaptada como una forma de validación para los reinos que en el norte peninsular

Los textos de San Isidoro son parte de una serie de fuentes cronísticas que cumplieron la misión de consolidar un sentimiento de unidad hispánica, basada en el cristianismo y la oposición con otras culturas que intervinieron en la Península, un proceso que también contribuiría a la creación de símbolos ideológicos particulares como Santiago y la guerra santa (Suárez Fernández, Luis, "Santiago: Camino y «Matamoros»", en Eloy Benito Ruano (Coordinador), Tópicos y realidades de la Edad Media, II, Madrid, Real Academia de la Historia, 2002, p. 309; Maravall, José Antonio, "La idea de Reconquista... op. cit., p. 250; Valdeón Baruque, Julio, La Reconquista. El concepto de España: unidad y diversidad, Madrid, Espasa, 2006, p. 13; Barkai, Ron, El enemigo en el espejo... op. cit., p. 285; y Linehan, Peter, Historia e historiadores... op. cit., p. 31).

El ideal godo isidoriano comenzó ha ser reinterpretado e incorporado por los cronistas a partir del siglo IX. Siendo rastreables en textos, incluso anteriores, como la Crónica Mozárabe de 754, la Crónica Albeldense y la Crónica Rotense (Crónicas asturianas: Crónica de Alfonso III (Rotense y "A Sebastián"), Crónica albeldense (y "profética"), Introducción y edición crítica de Juan Gil Fernández; traducción y notas de José L. Moralejo; estudio preliminar de Juan I. Ruiz de la Peña, Oviedo, Universidad de Oviedo, 1985, p. 126. (En adelante CAIII, versión... y CA). Linehan, Peter, Historia e historiadores ... op. cit., p. 133).

Es así como en el contexto de la Reconquista, la memoria de la antigua Península unida y cristiana no se perdió, sino que fue evolucionando hasta convertirse en una clara noción de herencia común, una ideología que se consolidaría en los siglos XII y XIII.

Para la Plena Edad Media, el ideal de restauración visigoda, el "goticismo" se convirtió en parte esencial del discurso cronísticos y demostró una sorprendente supervivencia a los distintos avatares de la Reconquista, puesto que con más o menos intensidad la idea de la recuperación del territorio y de la unidad visigoda se mantuvo, con matices, en los distintos territorios cristianos (Al respecto ver Maravall, José Antonio, El concepto de España en la Edad Media, Madrid, Centro de Estudios Constitucionales, 1997, p. 346; Maravall, José Antonio. Estudios de Historia del Pensamiento Español, Madrid, Ediciones Cultura Hispánica, 1983, pp. 18, 19; y González Antón, Luis, España y las Españas... op. cit., pp. 114, 115).

Ejemplos paradigmáticos fueron Lucas de Tuy y Rodrigo Jiménez de Rada. El primero refuerza concepción de una España como una tierra única, enmarcada dentro del plan de Dios. (Lucas de Tuy, Crónica de España, Primera edición del texto romanceado, conforme a una copia de la Academia preparada y prologada por Julio Puyol, Madrid, 1926, pp. 4-7). En tanto que Jiménez de Rada, propone la 
independiente incluso del factor religioso, puesto que la recuperación de las tierras arrebatadas y la restauración de los derechos violados eran causas más que legítimas para la violencia organizada ${ }^{147}$.

\section{I.2.b.- De la Guerra santa a la Cruzada}

Para el siglo XI, la Iglesia estaba en pleno proceso de consolidación como la principal institución política y religiosa de Europa Occidental. Es el siglo de la Reforma Gregoriana, de la independencia e imposición del Papado por sobre los poderes

noción de una unidad hispánica basada en la herencia visigoda común a todos los reinos peninsulares. Ideas que expone en su De rebus Hispaniae, siendo uno de los baluartes del "goticismo" del siglo XIII.

Es por lo tanto que el goticismo debemos comprenderlo como la materialización ideológica de un ideal de hispánico, una mentalidad común, que es compartida por todos los miembros de una civilización, siendo este el elemento que identifica a una comunidad y se convierte parte integral del sentido de pertenencia a un colectivo. Es así como en un mismo territorio o incluso al interior del mismo grupo étnico podemos ver el desarrollo de grupos diferenciados en razón de compartir mentalidades diferentes. (Bouthoul, Gaston, Las Mentalidades... op. cit., p. 31). Es decir la conciencia de las elites de ser parte de una cultura y realidad distinta al enemigo musulmanes, pero también diferente al resto de la Europa cristiana.

No tenemos forma de saber si este ideal permeó a los restantes grupos sociales peninsulares, no al menos para los siglos medievales que hemos estudiado, pero si sabemos, gracias a las fuentes cronísticas, que existió una intencionalidad permanente por interiorizar estas ideas entre las clases dirigentes y que para el siglo XII y XIII los monarcas de Castilla y León fueron promotores de la elaboración de textos que sostenían esta hipótesis, exaltando el goticismo, como parte de la "particularidad hispánica", entendida como las características distintivas de la Península durante la Edad Media en virtud de ser una tierra de frontera y coexistencia, sumado a la creencia de tratarse de una "tierra santa" (Para el desarrollo de estas características ver Maravall, José Antonio, "La idea de Reconquista..., op. cit., pp., 1, 2-27; García Fritz, Francisco, Las Navas de Tolosa... op. cit., p. 396; y Mitre Fernández, Emilio, "Alfonso X: historiografía y tradiciones compilatorias del medievo europeo", en III Curso de Cultura Medieval. Repoblación y reconquista, Centro de Estudios Románicos Aguilar del Campoo, 1991, p. 110).

De forma complementaria, concordamos con los planteamientos de Francisco Javier Fernández Conde, en cuanto a la relación entre la política y la guerra en la España medieval (Fernández Conde, Francisco Javier, La Religiosidad Medieval en España. Plena Edad Media (siglos XI-XIII), Oviedo, Trea, 2005 , pp. 88, 89). Es cierto que las motivaciones económicas y sociales fueron importantes estímulos del avance hispano hacia el sur, pero ese hecho es inseparable del factor ideológico que relacionaba este avance, o "reconquista" con un concepto de recuperación de un espacio ancestral, amparado en la lucha religiosa contra el infiel. Sin perjuicio de los análisis de la historiográfica moderna, es innegable que para los cronistas y dirigentes hispanos medievales, el factor religioso era un elemento integral y verdadero de su lucha, lo que la convertía en una guerra santa (En esto no hacemos más que seguir los planteamientos de Mircea Eliade cuando afirma que "Cualquiera que sea el grado de desacralización del Mundo al que haya llegado, el hombre que opta por una vida profana no logra abolir del todo el comportamiento religioso" (Eliade, Mircea, Lo Sagrado y lo Profano... op.cit., p. 27).

147 Suárez Fernández, Luis, "Santiago: Camino... op. cit., p. 309; Maravall, José Antonio, "La idea de Reconquista..., op. cit., p. 250; Valdeón Baruque, Julio, La Reconquista ... op. cit., p. 13; Barkai, Ron, El enemigo en el espejo... op. cit., p. 285; Linehan, Peter, Historia e historiadores... op. cit., p. 31.

En los siglos siguientes a Agustín e Isidoro se sumaron nuevos pensadores. Para el siglo IX, el uso del Antiguo Testamento para legitimar la acción violenta se había convertido en un recurso común, estableciendo la aceptación de la violencia bajo ciertos parámetros. A partir del siglo XII la doctrina cristiana en trono a la guerra, se tornara progresivamente más compleja gracias a tratadistas como Ivo de Chartres (c.1040-1116), Graciano (c.1140) y finalmente Tomás de Aquino (c. 1225-1247) que se convirtió en el nuevo referente de la violencia justa y religiosa Marín, José, Cruzada, Guerra santa y Yihad.... op. cit., p. 64). Un proceso que llegaría a su máximo desarrollo durante el período de las cruzadas, cuando la guerra se tornó en una forma de expiar los pecados. 
señoriales; un proceso no sin oposición y dificultades, en el cual los pontífices fueron venciendo las resistencias y adaptándose a las condiciones particulares de la sociedad milenarista $^{148}$

Paulatinamente, y pese a algunos tropiezos, la Reforma logró el reconocimiento de Europa a la voluntad del Pontífice Romano y a los intereses de la Iglesia, la misma que había ido abandonando su pacifismo original e incorporado una "filosofía de la violencia”, usada primero contra sus enemigos internos, -las herejías-, y luego contra los bárbaros paganos, ahora, esta filosofía estaba al servicio del nuevo mal que, a su juicio, acechaba a la cristiandad: el Islam ${ }^{149}$. Contra esta creencia se dirigieron los esfuerzos del Papado, y la guerra contra ella sirvió para probar qué tan hondo habían calado las lealtades hacia el Papa en los corazones y fe de los hombres de armas. En vista de lo anterior creemos que las cruzadas, iniciadas formalmente en Oriente y luego presentes en Europa, fueron la prueba de fuego para las aspiraciones político-sociales de la Iglesia; una prueba que pese a su aparente fracaso militar, demostró los verdaderos alcances del poder papal.

Para el siglo XI la idea de la guerra $\operatorname{santa}^{150}$ ya se encontraba mayormente aceptada en Occidente; un antecedente importante para ello fueron las guerras sacralizadas del Imperio Carolingio ${ }^{151}$.

\footnotetext{
${ }^{148}$ Parte esencial de este proceso fue el uso de la violencia, la cual, como ingrediente omnipresente de la historia, fue sometida y reglamentada por la religión. Primero fueron la Paz y Treguas de Dios, movimientos que pretendieron "domesticar" la violencia feudal, protegiendo de paso los intereses de una Iglesia ya cansada de los descalabros que las constantes disputas señoriales producían en sus bienes, intereses y feudatarios. Ahora, los guerreros debían limitar sus actividades a los lugares y días estrictamente permitidos, y a su vez, reconocer en la Iglesia y sus representantes la suprema autoridad a la que se debía obedecer y proteger. El paso siguiente sería dirigir a esos guerreros hacia donde el Papado lo considerase útil y necesario. Elemento clave para lograr la sumisión de los bellatores y del conjunto de la sociedad, fue la excomunión: el control sobre el monopolio del exilio de la congregación de fieles y la virtual condena al infierno. Estas medidas fueron reafirmadas posteriormente por distintas disposiciones y concilios, como el III Lateranense en 1179 que aseguraba sanciones espirituales a cualquiera que durante un conflicto atacase a los eclesiásticos, comerciantes, campesinos o a cualquiera que no estuviese relacionado con las hostilidades (Duby, Georges, La Época de las Catedrales, arte y sociedad 980-1420, Madrid, Cátedra, 1993, pp. 46, 47; García Fitz, Francisco, La Edad Media... op. cit., p. 61).

No obstante, todas estas medidas quedaban anuladas cuando el enemigo a enfrentar se encontraba fuera de la cristiandad; es decir, si era pagano, hereje o musulmán; en cuyo caso cualquier época, arma y estrategia eran lícitas, bastando solamente con rezar antes del combate y en lo posible, evitar el exterminio de los vencidos. Todo ello en el entendido de que la prioridad era derrotar a los enemigos de Dios (Flori, Jean, La Guerra Santa ... op. cit., p. 223; García Fitz, Francisco, La Edad Media ... op. cit., p. 61).

${ }^{149}$ Keen, Maurice, La caballería, Madrid, Alianza, 2001, p. 70; García-Guijarro Ramos, Luis, Papado, cruzadas y órdenes militares, siglos XI-XIII, Madrid, Cátedra, 1995, pp. 42,43; y Porrinas González, David. "La caballería y la guerra en la Edad Media castellano-leonesa: El libro del caballero Zifar y su contexto", en Medievalismo, $\mathrm{N}^{\circ} 15,2005$, [pp. 39-70], pp. 62, 63.

${ }^{150}$ Sabemos que el concepto de Guerra Santa, al igual que el de Cruzada no son frecuentes en el vocabulario medieval contemporáneo y que entonces no existía un sólo término preciso para referirse a estos eventos. No obstante decidimos utilizar el término por ser el más comúnmente utilizado.
} 
Ya durante los pontificados de Gregorio Magno (590-604) y posteriormente de León IV (847-855), los pontífices no sólo no renegaron de la guerra, sino que incluso llegaron a prometer la salvación eterna a quienes muriesen luchando por la defensa de la Iglesia contra los paganos ${ }^{152}$. Por lo que se puede concluir que las acciones de Carlomagno, ocurridas entre ambos pontificados, solamente venían a ratificar lo que ya era una costumbre. Las tropas marchaban a la guerra luego de asistir a los santos oficios, los clérigos rezaban por la obtención de la victoria y las mismas espadas símbolo del guerrero y de la muerte-, junto con las banderas y enseñas, solían ser previamente bendecidas. Es evidente, por tanto, la implicación religiosa en la legitimación y justificación de la violencia institucionalizada por parte de los reyes cristianos en la lucha contra los enemigos de la cristiandad ${ }^{153}$.

${ }^{151}$ En esencia Carlomagno significó el resurgimiento de la idea imperial y la consolidación de una alianza política con la Iglesia. El rey franco consideraba que su poder venía dado por Dios y que eso era lo que lo validaba para emprender campañas contra los paganos sajones y avaros, a los que sometió mediante una serie de guerras de conquistas en las cuales la cruz acompañaba a la espada (Flori, Jean, La guerra santa... op. cit., pp. 33, 34). De esta forma, la acción militar quedaba justificada por la conversión y salvación de las almas de los vencidos.

${ }^{152}$ Bronisch, Alexander Pierre, Reconquista y guerra santa ... op. cit., pp. 55, 56.

${ }^{153}$ En vista de lo anterior, es posible consensuar qué significaba y qué hacía falta para que una acción bélica, en ese momento, se pudiese considerar una guerra santa. Acerca de esto ha corrido bastante tinta y no es de nuestro interés reseñar todas las discusiones sobre el tema, pero sí referirnos a algunas de las principales posturas al respecto. Con este propósito nos remitiremos al trabajo de síntesis realizado por Bronisch en su ya referida obra y en su texto "En Busca de la Guerra Santa", publicado como parte de los Estudios de Frontera Alcalá La Real y el Arcipreste de Hita.

Bronisch divide las distintas concepciones de guerra santa según autores y tesis. En un primer grupo se encuentra Carl Erdmann y Albrecht Noth, cuyas ideas se pueden sintetizar en la creencia de que la guerra santa es toda aquella guerra al servicio de la religión. Asimismo, no realizan una diferenciación entre cruzada y guerra santa, considerándolas sinónimos. Un segundo grupo lo componen los autores Michel Villey y Paul Rousset, que se caracterizan por oponerse a la postura de Erdmann, criticándole su falta de diferenciación entre los dos conceptos. Villey postula, a su vez, que la guerra santa sería la adaptación cristiana a las antiguas luchas romanas contra los bárbaros. Rousset complementa estas ideas afirmando que las guerras santas pueden ser tanto ofensivas como defensivas, y que su diferencia con las cruzadas radica en que en ésta se pueden observar elementos exclusivos como la indulgencia, la cruz, la dirección de la Iglesia y especialmente el cuidado por la Tierra Santa.

Un tercer grupo, según Bronisch, es el compuesto por Frederik Russel y Jonathan Riley-Smith. El primero se concentra en la relación y diferenciación entre guerra justa y guerra santa, diferencia que radica en el carácter secular de la primera, y en la falta de restricciones para el uso de la violencia en la segunda. Riley-Smith, por su parte, postula la falta de diferencias entre ambos conceptos sosteniendo que la guerra santa se hace sobre las bases jurídicas de la guerra justa (Vara Thorbeck, Carlos, El lunes de Las Navas, Jaén, Universidad de Jaén, 1999, p. 117; Bronisch, Alexander Pierre, Reconquista y guerra santa ...op. cit., pp. 281-295. Para más detalles respecto a estos autores ver: Erdman, Carl, The origin of the idea of Crusade, Oxford, 1977; Noth, Albrecht, Heiliger Krieg und Heiliger Kampf in Islam und Chistetum. Breiträge zur Vorgeschchte und Geschichte der Kreuzzüge, Bonn, 1966; Villey, Michel, La cruisade. Essai sur la formation d'une théorie juridique, París, 1942; Rousset, Paul, Historie d'une idéologie. La Croisade, Lausanne, 1983; y del mismo autor Les origins et les caracteres de la première croisade, Neuchatel, 1945. Russell, Frederik, The Just War in the Midle Ages, Cambridge, 1975; RileySmith, Jonathan, Simon Cristopher y Marie-Loise Jeanetta (Editores), The Crusades: Idea and Reality 1095-1274, Londres, 1981; y Riley-Smith, Jonathan, The first crusade and the idea of crusading, Philadelphia, University of Pennsylvania Press, 1997). 
Respecto al problema de la caracterización de la guerra santa, nosotros consideramos, que buena parte de las definiciones vistas o enunciadas versan sobre el elemento religioso, dejando en claro que su único denominador común es el hecho de que se ordenaban, organizaban y libraban bajo la creencia o discurso de que eran una

Desde otro enfoque se encuentran los aportes de Jean Flori y James Brundage. El primero considera que es posible encontrar elementos constituyentes del concepto tanto en los escritos del Obispo de Hipona, como en los de los papas Esteban II, León IV y Juan VIII. Por lo anterior, este autor prefiere el concepto de "guerra sacralizada" y concluye que en el medioevo coexistieron diferencias entre guerras justas, santas y cruzadas. Para Brundage, la única distinción entre estos conceptos es que la guerra santa, a partir de Gregorio VIII, era considerada como una forma de salvación individual. Sus ideas se pueden resumir en que toda guerra santa es justa, y que no habría mayores diferencias con el concepto de cruzada (Para más detalles respecto a estos autores ver: Flori, Jean, Guerra Santa... op. cit. y del mismo autor Guerra Santa, Yihad, Cruzada. Violencia; Brundage, James, "Holy War and the Medieval Lawyers", en Murphy, Thomas Patrik, (Editor), The holy war, Ohio, Columbus, 1976).

Finalmente existe un último grupo, bastante crítico, conformado por John Gilchrist y Hanas Eberthard Mayer. Gilchrist critica la importancia que se ha dado a San Agustín y a los papas reformistas, afirmando que luego de la Reforma Gregoriana no existieron verdaderos cambios en la posición de la Iglesia ante la guerra. Mayer, por su parte, califica la cruzada como un nuevo tipo de guerra santa, dirigida y orquestada por la Iglesia (Gilchrist, "Holy war and the Medieval Lawyers" International History Rewiew, 10,2 (1988); Mayer, Hans, Historia de las cruzadas, Madrid, 2007).

Bronisch, por su parte, promueve su propia definición, partiendo de la base de que el concepto de guerra santa es una elaboración reflexiva posterior y necesaria para el estudio de un fenómeno concreto, que básicamente se trata de una empresa militar, ordenada por Dios a su pueblo y que obedece al plan de Salvación, por ello es Dios dirige la campaña a través del monarca, que actúa como un instrumento (Bronisch, Alexander Pierre, Reconquista y guerra santa ... op. cit., p. 309).

José Marín en su trabajo ya citado sintetiza los elementos constitutivos de la guerra santa en diez puntos, para lo cual se basa principalmente en los trabajos de J.T. Johnson, The Holy War Idea in Western ad Islamic Traditions, Pennsylvania, The Pennsylvania State University Press, 1997; García Fitz, Francisco, La Edad Media... op. cit.; Erdmann, Carl, The origin of the idea of Crusade... op. cit.; Runciman, S., Historia de las Cruzadas, Madrid, Alianza, 1994; Brundage, James, "Holy War... op. cit.; Canard, M, Byzance et les musulmans du Proche Orient, Londres, Variorum Reorints, 1973; y Partner, Peter, El Dios de las batallas... op. cit.

De acuerdo a estos autores, según Marín estos aspectos propios de la guerra santa son: Una guerra hecha bajo la guía divina; cuando se combate por la fe a partir de la convocatoria de una autoridad representativa; una guerra en la que Dios mismo combate, según el modelo del Antigua Testamento; cuando se lucha contra los enemigos de la religión, en un sentido defensivo; cuando su fin es imponer la verdadera religión; cuando su objetivo es imponer la recta doctrina y castigar las desviaciones; sus participantes son, ritual y moralmente, "santos"; también puede ser santa una guerra entendida como un esfuerzo en la progresión de la fe por medios no violentos; así como cuando la lucha se libra bajo la guía de un líder inspirado religiosamente; finalmente cuando se reconocen, durante o después de su trascurso, como un "absoluto milagro". A estos diez puntos, Marín incorpora como elemento fundamental la idea del martirio y perdón de los pecados, siendo esta la principal diferencia entre "guerra santa, guerra de religión y guerra religiosa" (Marín, José, Cruzada, Guerra santa y Yihad .... op. cit., pp. 74-78).

Por ultimo debemos hacer nota el parecer de José Manuel Rodríguez García, en su tesis doctoral de 2010, Idea y realidad de cruzada en tiempos de Alfonso X El sabio (1252-1284), que sintetiza los distintos pareceres sobre el tema de guerra santa y cruzada, defendiendo la primera como aquella en que las partes creen tener Dios de su lado y están convencidos de luchar por Él. En tanto que la principal característica de la Cruzada seria su motivación en defensa de la Iglesia, además de otros componentes tradicionales, a las que nos referiremos en las líneas siguientes. (Rodríguez García, José Manuel, Idea y realidad de cruzada en tiempos de Alfonso X El sabio (1252-1284), Tesis doctoral, Salamanca, 2010, pp. 124-126: http:/gredos.usal.es/jspui/bitstream/10366/76558/2/DHMMC_Rodriguez_Garcia_JM_Idea_y_ realidad_2.pdf (septiembre 2014). 
acción bélica querida por Dios, si es que no ordenada por Él a través de la Iglesia ${ }^{154}$; sin embargo, creemos que, prácticamente dejan de lado el elemento político y económico. La guerra, en todas sus variantes, se relaciona con la imposición sobre un adversario, y en la apropiación de sus bienes y recursos. Las guerras relatadas en el Antiguo Testamento son básicamente de dos tipos: la conquista de la Tierra prometida - la apropiación violenta de un territorio-, o bien la defensa de esta conquista, como son las guerras contra filisteos, babilonios y seléucidas. La vertiente clásica de este tipo de conflictos también se vinculaba a la defensa de los bienes y territorios propios. En todos estos antecedentes, el factor económico, expresado en la apropiación de bienes, es omnipresente. A la luz de ello, podemos afirmar que la guerra santa es producto de la evolución de las motivaciones bélicas. Para los pueblos primitivos, la tierra que habitaban solía ser un legado de los dioses o de Dios, y por lo tanto, poseían una implícita dimensión religiosa ${ }^{155}$. Esta creencia, hábilmente expresada por los primeros textos religiosos, fue perpetuada por los primitivos cronistas que, además, para mayor sustento incorporaron el culto a los ancestros allí sepultados. Con el triunfo de las religiones monoteístas y en especial el cristianismo en el siglo IV, se produjo una natural combinación ente las costumbres romanas de la guerra justa -basada en la defensa de las tierras ancestrales o conquistadas por derechos divinos- con la tradición judeo cristiana de la tierra prometida dada por Dios a su pueblo.

En razón de lo planteado, postulamos que la guerra santa es inseparable de una dimensión política; constituye un discurso creado por los sectores dirigentes de una sociedad pía destinado a asegurar, mediante un vínculo divino, la posesión y seguridad de diversos bienes, especialmente de la tierra, base de la economía y subsistencia. Esta dimensión fue el fruto de un largo proceso de definiciones socio-culturales que alcanzó su máximo desarrollo durante la Edad Media, cuando convergieron diversas tradiciones, a las que se sumaron nuevos planteamientos teológicos y políticos.

Por lo anterior, y considerando las distintas definiciones expuestas, consideramos que la guerra santa corresponde al resultado de un largo proceso evolutivo que se afirmo en la combinación de tradiciones hebreas y clásicas (guerras de Dios y guerras justas), utilizado por un sector dirigente de una sociedad y sustentado en una interpretación religiosa, destinado a la conquista o defensa de bienes materiales mediante el uso de

\footnotetext{
${ }^{154}$ Russell, Frederick, The Just War... op. cit., p. 2; y Cipollone, Giulio, "Esclavitud y Liberación en la Frontera"... op. cit., p. 79.

${ }^{155}$ Un ejemplo es Roma, fundada debido a la voluntad de los dioses que guiaron el viaje de Eneas a Italia.
} 
armas. En vista de ello, cabe aclarar que el factor religioso es fundamental en esta estructura de pensamiento, reconociendo, además, que para muchas de estas sociedades la religión correspondía a una realidad verdadera y ubicua, que no obstante fue instrumentalizada, por las elites intelectuales -con qué grado de intencionalidad es algo que está por verse- para cumplir determinados objetivos relacionados con los intereses terrenales de una sociedad determinada.

La aparición del hecho de la cruzada es inseparable de la Reforma Gregoriana recientemente mencionada. Fue en este contexto de avasallamiento de la sociedad civil que el Papado comenzó el proceso de someter a los bellatores y convertirlos en miles Christi; es decir, en guerreros al servicio de la causa cristiana y componentes de la militia Christi ${ }^{156}$. Este sometimiento que se veía compensado con una creciente exaltación de la figura del caballero como siervo de la Iglesia, amparado en el ejemplo de los santos, en especial los mártires soldados que ahora reaparecían como activos guerreros para proteger reliquias, Santos Lugares o propiedades eclesiásticas ${ }^{157}$.

Este culto a los santos y su defensa se vinculaba directamente con otro de los antecedentes de la cruzada: la peregrinación ${ }^{158}$.

Si bien Europa se vio repleta de lugares santos a los que peregrinar, el lugar por excelencia para hacer el viaje expiatorio que constituía la peregrinación era Jerusalén, y el resto de lugares mencionados en el Nuevo Testamento. En el siglo XI estas sendas se vieron interrumpidas por el avance del Islam, que arrebató los territorios al cada vez

\footnotetext{
${ }^{156}$ García Villoslada, Ricardo, Historia de la Iglesia Católica en sus cuatro grandes edades: Antigua, Media, Nueva y Moderna, Madrid, Biblioteca de Autores Cristianos, 1958, p. 429, 436.

${ }^{157}$ El origen de los mártires soldados se encontraría en las persecuciones llevadas a cabo durante el reinado de Diocleciano - finales del siglo III y principios del IV- cuando, debido a las levas forzosas, miles de cristianos fueron obligados a servir en las legiones. Estos reclutas ante la disyuntiva de matar en defensa del imperio o negarse a cumplir sus órdenes, optaron por la desobediencia siendo martirizados. Cosa similar ocurrió con aquellos legionarios que posteriormente adoptaron el cristianismo. Tiempo después, la Iglesia revivió la figura de estos mártires para convertirles en modelos de virtud guerrera, trasformando así las causas últimas de sus ejecuciones.

${ }^{158}$ Este fenómeno, iniciado entre los siglos X y XI, prontamente se convirtió en una especie de moda transversal en Europa, multiplicándose las reliquias milagrosas y creándose rutas especiales para acceder a ellas. Por estos caminos circularon peregrinos, productos, riquezas e ideas. El concepto de Tierra Santa tomaba una nueva dimensión, a la vez que lugares como Roma y Santiago de Compostela, se vieron directamente beneficiados por esta necesidad de los hombres medievales por tocar, ver y sentir lo maravilloso (Le Goff, Jacques, La civilización... op. cit., pp. 114, 118; y Marín, José, Cruzada, Guerra santa y Yihad.... op. cit., pp. 58, 59). Pero los caminos no eran lugares seguros, y la Iglesia procuró que los bellatores asegurasen la protección de los peregrinos contra salteadores y otras amenazas, en tanto que monasterios y conventos debían procurar el cuidado de sus almas y atender sus cuerpos durante sus travesías (Bernardo de Claraval, Elogio de la Nueva milicia templaria, Madrid, Siruela, 2005, p. 10-13 (En adelante ENMT). Iradiel, Paulino y otros, Historia Medieval de la España Cristiana, Madrid, Ed. Cátedra, 1989, p. 138; y Martín, José Luis, La Península ... op. cit., p. 386).
} 
más decadente Imperio Bizantino ${ }^{159}$. Previamente en el siglo VIII los musulmanes irrumpieron en Europa Occidental apoderándose de la Península Ibérica, asolando el sur de Francia e incursionando por Italia, lo que obligó al Papa León IV a mediados del siglo IX, a solicitar la ayuda de los francos ${ }^{160}$. Esta fue una de las primeras ocasiones en que se ofrecieron recompensas espirituales a los guerreros que acudiesen a la defensa de la Iglesia. Sólo la consolidación del Imperio Carolingio contuvo nuevas incursiones islámicas por Europa continental, pero para el siglo XI el Islam, gracias al empuje de los turcos -recientemente conversos- se había apoderado nuevamente de la Tierra Santa en el año 1070 -arrebatándosela a los bizantinos que pocos años antes la habían logrado reconquistar-. Esta vez los invasores no parecían dispuestos a aplicar una política de tolerancia hacia los peregrinos cristianos ${ }^{161}$.

Esta era la coyuntura histórica necesaria para que el Papado pusiese a prueba los éxitos de la Reforma Gregoriana. La carta del Emperador Alejo I (1081-1118) solicitando ayuda fue la excusa que necesitaba el Papa Urbano II (1088-1099) para orientar las trasformaciones de la Reforma, a través de una instrumentalización de la costumbre de las peregrinaciones y de la devoción popular. A ello se sumó la ya larga tradición bélica de la Iglesia, materializada en la mencionada guerra santa. Nacía así un nuevo fenómeno bélico-religioso: la cruzada ${ }^{162}$.

\footnotetext{
${ }^{159}$ Como se explicó en una cita anterior, desde el siglo VII que el Islam se encontraba en pugna con el cristianismo, primero con el Imperio Bizantino y luego, a partir del siglo VIII con Occidente. Desde su irrupción en el Mediterráneo, los musulmanes fueron identificados como enemigos de la cristiandad, practicantes de una herejía pecaminosa relacionada con el diablo, al punto que pronto surgió la creencia de que los musulmanes eran aliados o instrumentos del demonio para destruir a los cristianos. Esta ideología encontró justificativos en su rápida expansión, sus costumbres e incluso en sus características raciales, puesto que la oscuridad de su piel se veía como un símbolo de su condición semidiabólica. En esencia, siguiendo los planteamientos de Má́llo Salgado, con respecto al Islam se construyó un estereotipo basado en una ideologización discursiva del cristianismo, que se estructuraba en base a la diferenciación del otro, según una comprensión de los musulmanes como un colectivo. En palabras simples, Islam era el enemigo por antonomasia de Dios y los cristianos, la verdadera religión, y la lucha contra él se convierte en una misión divina.

${ }^{160}$ Ante las incursiones de los moros en costas italianas, León IV solicitó la ayuda de los guerreros francos a quienes prometió que "quienes muriesen en la lucha no se les negará el reino de los cielos". Este ejemplo fue seguido por el Papa Juan VIII en el año 878. Nuevamente la amenaza era las incursiones sarracenas y de forma similar a la anterior ocasión, el Papa prometió la vida eterna para los que muriesen en su defensa y la absolución de los pecados para todos aquellos que respondieran a su llamado.

${ }^{161}$ Heers, Jacques, La primera Cruzada, Barcelona, Andrés Bello, 1997, pp. 34-39; y Marín, José, Cruzada, Guerra santa y Yihad.... op. cit., p. 58.

${ }^{162}$ Para este trabajo solamente nos concentraremos en la Cruzada en su acepción de lucha contra el Islam, dejando para otra ocasión las cruzadas contra los herejes, paganos y otros enemigos de la Iglesia en Occidente. Sin perjuicio que con respecto a la idea de cruzada, lo primero que hay que aclarar es que no es un concepto de uso general en el medioevo, sino que su masificación se remonta al periodo que corre entre siglos XVI y XVIII, cuando el término empezó a ser popular en Francia e Inglaterra -no obstante, se reconoce que el concepto fue utilizado por primera vez en el siglo XII, aunque de forma limitada(Hindley, Geoffrey, Las cruzadas. Peregrinaje armado y guerra santa, Argentina, Ediciones B, 2004, p. 25). Por tanto, destacamos que no es fácil localizar el término "cruzada" en las crónicas medievales,
} 
En la actualidad existe un gran debate entre los expertos en torno a la conceptualización de "guerra santa" y cruzada, en especial respecto a si realmente existe una diferenciación entre ambas formas de ejercicio de la violencia, o si bien son parte del mismo proceso. Independiente de esta disputa, consideramos sensato señalar algunos elementos distintivos de la cruzada que ayudan a diferenciarla, mas no separarla, de la guerra santa ${ }^{163}$.

Respecto a la definición exacta de este concepto, existe gran cantidad de bibliografía $^{164}$. Hallándose muchas definiciones, algunas de ellas bastante amplias,

donde comúnmente se refieren a este acontecimiento como "Pasaje general", "viaje", "expedición de la cruz" o "peregrinación", entre otras denominaciones (Marín, José, Cruzada, Guerra santa y Yihad.... op. cit., p. 50) Marín, en la página 59 de su trabajo, nos recuerda que si bien el termino cruzada no es propiamente medieval, si lo fue el concepto de cruzado, entendido como aquel que portaba la marca de la cruz (crucesignatus). De la misma idea es Jonathan Riley-Smith en su libro ¿Qué fueron las cruzadas? (Barcelona, Acantilado, 2012, pp. 24, 25).

En vista de lo anterior, creemos que es prudente puntualizar que para los pensadores medievales la cruzada, con cualquiera de sus nombres, era una realidad sobre la cual, aparentemente, no se realizó una discusión teológica al nivel de la efectuada en torno a la guerra santa. Por lo mismo, aventuramos que para los intelectuales contemporáneos la cruzada fue interpretada como la evolución o la continuación de la guerra santa, más que un fenómeno totalmente nuevo, al menos para los siglos estudiados. Un planteamiento que creemos compartir con Riley-Smith cuando afirma que "Desde luego, el problema radicaba en que las cruzadas se convirtieron en un elemento tan conocido del paisaje medieval que no requería una descripción detallada. Las personas que vivieron en esa época sabían perfectamente lo que era una cruzada. En los escritos de los cronistas, de los apologistas y los canonistas, así como en las expresiones empleadas por quienes redactaban cartas papales, podemos identificar las señales que informaban a los fieles de que se estaba predicando una cruzada" (Riley-Smith, Jonathan, ¿Qué fueron las cruzadas... op. cit., p. 25).

163 Posiblemente la dificultad de analizar esta problemática radica en el hecho de que los estudiosos actuales deben a atrabajar con conceptos, que en su época no fueron claramente definidos y delimitados, lo que ha obligado a intentar caracterizarlos en base a la poca claridad de las fuentes contemporáneas.

164 Para una panorámica general en torno a estas discusiones y las distintas posturas, recomendamos ver, entre otros textos relacionados al tema, los trabajos de Frederick Russell y su texto clásico The Just War in the Middle Ages, página 2, donde la Cruzada es comprendida como un híbrido entre la Guerra Justa y la Guerra Santa, cada vez más controlado y que como tal, será tratado como un todo por la filosofía cristiana: "Hence the crusade became a strange hybrid of holy war and just war marked by an increasingly explicit chain of command. The holy war and the crusade will here be considered only as a part of the general medieval debate of the right to war rather than as an independent phenomenon". Junto a él y ya tratando de elaborar una definición más compacta, encontramos a Antonio García y García, Iglesia, Sociedad y Derecho, que en su página 222 define cruzada como "una guerra promovida o bendecida por el Papa o por su representante, cualificada de espiritualmente meritoria y, por ende, premiada con la indulgencia plenaria de los pecados de quienes cumplieran su voto de cruzados en alguna de las expediciones para la recuperación de los Santos Lugares de Palestina o de la Península Ibérica o para otras causas declaradas por los papas como cruzadas". Destacando, adicionalmente, que este autor postula la importancia del I y II Lateranense en caracterización formal del término y agregando, al mismo tiempo, a su difusión original la afirmación de que el fenómeno se origina a partir de Urbano II y que, por lo tanto, es inseparable de la iniciativa pontificia. Complementando a García, podemos identificar a Ricardo García Villoslada y su Historia de la Iglesia Católica en sus cuatro grandes edades: Antigua, Media, Nueva y Moderna, página 433, donde presenta una definición muy similar pero, destacando el carácter pontificio y supranacional de la campaña: "el nombre de 'Cruzada' se debe reservar exclusivamente a aquellas guerras santas predicadas y en cierto modo dirigidas por el Papa en cuanto cabeza y jefe de toda la cristiandad. Tienen, consiguientemente, un carácter supranacional y universal, y por eso suelen participar en ellas soldados de diversas naciones cristianas". Extendiendo su ejecución más allá de Jerusalén, están autores como Geoffrey Hindley en su texto Las Cruzadas, peregrinaje armado y guerra santa, que destaca cómo la cruzada fue utilizada contra el conjunto de los enemigos de la Iglesia, 
como por ejemplo la que la caracteriza como "Expedición militar contra los infieles, especialmente para recuperar los Santos Lugares, que publicaba el Papa concediendo indulgencias a quienes en ella participaran"165, o como "Un enfrentamiento, espiritual o material, contra el mal, las creencias anticristianas o los enemigos de la cristiandad"166.

En razón de lo anterior, es que a partir de nuestras lecturas podemos concluir que existe cierta dificultad para definir el concepto, y aún más para diferenciarlo de la guerra santa, al punto que hay acuerdo en definir la cruzada a partir de sus elementos integrantes, más que como una idea por sí sola. Pero antes, es importante aclarar que también hay consenso referente a que la cruzada fue una continuación o, por lo menos, una nueva manifestación de la guerra santa.

En vista de lo recién afirmado, es que para analizar estos elementos, sintetizaremos las posturas de distintos autores. Para Jean Flori, la cruzada es una expedición armada asimilada a la peregrinación, a la que se le otorgaron los privilegios de la indulgencia vinculados al viaje a Tierra Santa ${ }^{167}$. Esta peregrinación armada le fue prescrita a los milites para el perdón de sus pecados, prometiéndoles que en caso de morir serían considerados mártires. El objetivo final de esta expedición, era en definitiva, la reconquista de los Santos Lugares ${ }^{168}$. Por su parte, José Goñi, quien estudió el fenómeno para la Península Ibérica -pero cuyas conclusiones se pueden extrapolar a todos los territorios de cruzada- considera que una guerra es una cruzada si

sean estos cismáticos, herejes, paganos o musulmanes. En tanto que José Manuel Rodríguez García, en su articulo dedicado a Fernando III "Fernando III y sus Campañas en el Contexto Cruzado Europeo 12171252", realiza una definición bastante amplia donde procura incorporar la Reconquista dentro del contexto ideológico cruzado: "Una cruzada era una guerra santa autorizada por el Papa, quien la proclamaba en el nombre de Dios o Cristo. Se creía que era una empresa emprendida por Cristo, legitimizada por su mandato personal. Propuesta, como todas las acciones cristianas de violencia justa, como una respuesta defensiva a la injuria o a la agresión o como un intento de recobrar territorios cristianos perdidos a manos de los infieles, contestaba a las necesidades de la Iglesia de toda la Cristiandad, concebida como un estado único, universal y transcendente, más que una nación o región particular: muchas de las campañas de la Reconquista española, que se lucharon en nombre no sólo de España sino de la Cristiandad al fin y al cabo y que se abastecieron de hombres provenientes de toda Europa, eran cruzadas." Finalmente, Franco Cardini en el capítulo "Guerra y Cruzada" de la obra colectiva dirigida por Le Goff y Schmitt, Diccionario razonado del occidente medieval, no realiza una definición concreta de cruzada y de hecho afirma que la Iglesia nunca elaboro una propia, pero analiza el tema desde sus orígenes en la guerra santa, la paz y tregua de Dios y la Reforma gregoriana, agregando al discurso religioso los factores políticos, sociales y económicos que contribuyeron a su popularidad en el medioevo.

${ }^{165}$ Real Academia de la Lengua. http://buscon.rae.es/draeI/SrvltConsulta? TIPO_BUS=3\& LEMA= Cruzada, 5 de diciembre de 2010, 12:15.

${ }_{166}^{16}$ Cook, Chris; Diccionario de términos históricos, Segunda Edición, Madrid, Alianza, 2006, p. 165.

${ }^{167}$ Sobre las indulgencias como electos distintivo de la Cruzada, Rodríguez García nos recuerda que no fue sino hasta el año 1215, que se establece claramente que solo el Papa tiene la potestad para emitirlas, razón por al cual en los siglos XI y XII existió cierta ambigüedad respecto a quienes podían otorgarlas y bajo que autoridad. Al respecto ver Rodríguez García, José Manuel, Idea y realidad... op. cit., p. 128.

${ }^{168}$ Flori, Jean, Caballeros y caballería en la Edad Media, España, Paidos Ibérica, 2001, pp. 194-197. 
cuenta con el reconocimiento oficial de la Iglesia y trae consigo el otorgamiento de indulgencias; además, ambos factores deben estar expresados en una Bula de Cruzada. Para este autor, todos los demás componentes comúnmente aceptados como la Tierra Santa o la peregrinación, son agregados que pueden variar de acuerdo con la ocasión ${ }^{169}$. En la misma línea se encuadra Fernández Conde, quien afirma que una guerra santa se convierte en cruzada cuando es promovida por la jerarquía eclesiástica, respaldada por indulgencias y promesas de martirio ${ }^{170}$. Junto a los autores mencionados también encontramos a Riley-Smith que caracteriza la cruzada a partir de cinco principios: que los cruzados estaban atados por un juramento; que sólo el Papa podía convocarla; que en virtud de su juramento y votos los cruzados contaban con ciertas garantías y protecciones especiales; la entrega de indulgencias a los expedicionarios. Esto último implica que la cruzada siempre tenía un carácter penitencial; y que finalmente existía el convencimiento de estar cumpliendo la voluntad de Dios ${ }^{171}$.

En vista de lo anterior, nos es posible aventurar una definición de la cruzada como una acción armada (originalmente una peregrinación), invocada o respaldada directamente por el Papado mediante una bula que otorga beneficios de indulgencia, acompañada de la promesa del martirio para quienes acudían al llamado. Esta acción bélica podía, además, ir dirigida contra los enemigos de la Iglesia, fueran paganos o herejes, o tener como fin recuperar algún santo lugar injustamente arrebatado. De forma similar que la guerra santa, la cruzada era presidida por rituales religiosos de bendición de armas y estandartes, y frecuentemente se le vinculaba con acontecimientos providencialistas como la aparición de santos, guerreros celestiales y otras manifestaciones divinas ${ }^{172}$.

La guerra contra el Islam debía ser presentada, entonces, como una causa divina; el cumplimiento de una misión religiosa contra los enemigos de Dios, para lo cual era esencial demonizar al rival, haciéndolo despreciable y convirtiéndolo en un símbolo de lo maligno o amenazante. Como sabemos, no existe un registro ciento por ciento fidedigno del discurso del Papa en Clermont en 1095, pero las distintas versiones del mismo que han sobrevivido coinciden en que el Pontífice utiliza una serie de epítetos

\footnotetext{
${ }^{169}$ Goñi, José, Historia de la Bula ... op. cit., pp. 44-46.

${ }^{170}$ Fernández Conde, Francisco Javier, La religiosidad medieval ... op. cit., p. 96.

${ }^{171}$ Riley-Smith, Jonathan, ¿Qué fueron las cruzadas... op. cit., pp. 25, 26, 31.

${ }^{172} \mathrm{~A} 1$ respecto de las fuentes para esta definición, recomendamos referirse especialmente a los textos de Jean Flori, Francisco García Fitz, Jacques Heers y José Marín, supra páginas 7, 12, 2, 4, 57, 36. Así como al trabajo de Cardini, Franco, "Guerra y Cruzada", en Le Goff, Jacques y Jean-Claude Schmitt (Editores), Diccionario razonado... op. cit., pp. 310-318.
} 
peyorativos para referirse a los musulmanes, todo ello con el fin de hacerlos despreciables a los francos y así exaltar su ardor guerrero ${ }^{173}$. Por ejemplo, en la versión de Roberto el Monje, Urbano se refiere a los musulmanes como gens maledicta e inmundus gentibus ${ }^{174}$. No muy distinta es la versión de Guibert de Nogent, en la cual se trata a los musulmanes de "païennes" y se los vincula directamente al anticristo ${ }^{175}$. En tanto que, según Foucher de Chartres, el Papa tacha a los turcos de "race impie des dévastateurs" $" 176$, para continuar haciendo una dura comparación entre los creyentes de Allah y los cristianos ${ }^{177}$. En la misma línea se encuentran las versiones de Guillermo de Tiro $^{178}$ y Orderic Vital ${ }^{179}$.

Estos discursos claramente recogen la "leyenda negra" que ya se había asentado en Bizancio y en parte de Europa occidental. Una percepción que sólo se centraba en destacar al Islam como un enemigo de la verdadera fe y una amenaza para la cristiandad y que, por ende, apelaba directamente a los sentimientos religiosos de los fieles.

Pese a lo anterior, sería iluso restringir la cruzada solamente a sus motivaciones espirituales, puesto que al igual que todo conflicto incluía aspectos más amplios, incluyendo por supuesto los económicos. La conquista de fama y fortuna, siempre ha sido un estímulo para los guerreros, algo de lo que Urbano II estaba muy conciente; al menos así se desprende según la versión de Roberto el Monje, que afirma que el Pontífice, también procuro estimular las ambiciones materiales de los francos, puesto

${ }^{173}$ García Fitz, Francisco, "El discurso militar en la historiografía de las cruzadas: la ideología patente", en Iglesias Zoido, Juan Carlos (Editor), Retórica e Historiografía. El discurso militar en la historiografía desde la Antigüedad hasta el Renacimiento, Madrid, Ediciones Clásicas, Cáceres, Universidad de Extremadura, 2007, p. 442; y Fletcher, Richard, La cruz y la media luna... op. cit., p. 89.

174 Robert le Moine, Histoire de la Première Croisade, Paris, Ed. Guizot, 1825. En http://remacle.org/bloodwolf/historiens/robertlemoine/croisade1.htm (enero de 2014).

175 Guibert de Nogent, Histoire des Croisades, II, Paris, Éd. Guizot, 1825, pp. 46-52. En http://books.google.cl/books?id=GkQPAAAAQAAJ\&printsec=frontcover\&source=gbs_ge_summary_r\& $\mathrm{cad}=0 \# \mathrm{v}=$ onepage $\& \mathrm{q} \& \mathrm{f}=$ false (enero de 2014.).

176 Foucher de Chartres, Histoire des Croisades, Chap. 1, Paris, Ed. Guizot, 1825, pp. 7-10. http://books.google.cl/books?id=J00PAAAAQAAJ\&pg=PA7\&focus=viewport\&output=text. (enero de 2014).

177 "Quelle honte ne serait-ce pas pour nous si cette race infidèle si justement méprisée, dégénérée de la dignité d'homme, et vile esclave du démon, l'emportait sur le peuple élu du Dieu tout-puis« sant, ce peuple qui a reçu la lumière de la vraie foi, et sur qui le nom du Christ répand une si grande splendeur!". Foucher de Chartres, Histoire des Croisades, Chap. 1, Paris, Ed. Guizot, 1825, pp. 7-10. http://books.google.cl/books?id=J00PAAAAQAAJ\&pg=PA7\&focus=viewport\&output=text. (enero de 2014).

${ }^{178}$ Guillaume de Tyr, Histoire des Croisades, vol. I, Paris, Éd. Guizot, 1824, pp. 38-45. Trad. del francés por José Marín R. En http://jmarin.jimdo.com/fuentes-y-documentos/las-cruzadas/el-llamado-a-laprimera-cruzada-seg\%C3\%BAn-diversos-autores/. (noviembre de 2011).

${ }^{179}$ Orderic Vital, Histoire de Normandie, Libro IX, Ed. Guizot, 1826, Paris, vol. III, pp. 410-413. Trad. del francés por José Marín R. En http://jmarin.jimdo.com/fuentes-y-documentos/las-cruzadas/el-llamadoa-la-primera-cruzada-seg\%C3\%BAn-diversos-autores/. (noviembre de 2011). 
que se refirió a Tierra Santa como un lugar de riquezas en comparación con las tierras de Francia:

"Non vos protrahat ulla possessio, ulla rei familiaris sollicitudo, quoniam terra haec quam inhabitatis clausura maris undique et jugis montium circumdata, numerositate vestra coangustatur; nec copia divitiorum exuberat; et vix sola alimenta suis cultoribus administrat. Inde est quod vos invicem mordetis, et comeditis; bella movetis, et plerumque mutuis vulneribus occiditis. [...] Viam sancti sepulcri incipite, terram illam nefariae genti auferte, eamque vobis subjicite. Terra illa filiis Israel a Deo in potestatem data fuit, sicut Scriptura dicit quae lacte et melle fluit." 180

Si bien, ésta es la única de las versiones que menciona explícitamente el tema de las bondades materiales de Oriente, en las otras versiones se hace referencia a los conflictos que afectaban a la nobleza franca en lucha por acrecentar sus recursos ${ }^{181}$. En virtud de ello, nosotros concluimos que, de esta manera, Urbano parece querer recordarles a los guerreros la precariedad de su situación y las bondades que podían obtener al abandonar sus tierras por "causas más nobles", y dirigir sus esfuerzos hacia las posibilidades que ofrecían los territorios en manos musulmanas.

Por todo lo anterior, es claro que el sermón de Clermont fue en esencia una verdadera arenga y un claro acto de propaganda. Urbano exhortó a los francos apelando a la gloria de sus ancestros, a la fortaleza de su raza, a la justicia de la causa, a sus sentimientos religiosos y a sus ambiciones mundanas. El Pontífice los convocaba a una guerra justa en defensa de su religión, prometiéndoles también la gloria espiritual y el perdón de sus faltas. Pero el Papa también supo apelar a razones de índole más mundana, sabiendo que era un estímulo tan poderoso como la Salvación. Estas fueron

\footnotetext{
${ }^{180}$ Robert le Moine, Histoire de la Première Croisade... op. cit., "Que no os retenga ningún afán por vuestras propiedades y los negocios de vuestra familia, pues esta tierra que habitáis, confinada entre las aguas del mar y las alturas de las montañas, contiene estrechamente vuestra numerosa población; no abunda en riquezas, y apenas provee de alimentos a quienes la cultivan: de allí procede que vosotros os desgarréis y devoréis con porfía, que os levantéis en guerras, y que muchos perezcan por las mutuas heridas. [...] Tomad la ruta del Santo Sepulcro, arrancad esa tierra de las manos de pueblos abominables, y sometedlos a vuestro poder. Dios dio a Israel esa tierra en propiedad, de la cual dice la Escritura que mana leche y miel." Trad. del francés por José Marín R., en http://jmarin.jimdo.com/fuentes-ydocumentos/las-cruzadas/el-llamado-a-la-primera-cruzada-seg\% $\%$ C3\%BAn-diversos-autores/. ( noviembre del 2011).

181 Cardini, Franco, "Guerra y cruzada", en Le Goff, Jacques y Jean-Claude Schmitt (Editores), Diccionario razonado...op. cit., p. 312; y García Fitz, Francisco, "El discurso militar... op. cit. p. 435; "El llamado a la cruzada según diversos autores", en http://jmarin.jimdo.com/fuentes-y-documentos/lascruzadas/el-1lamado-a-la-primera-cruzada-seg\%C3\%BAn-diversos-autores/ (diciembre de 2012).
} 
las promesas de gloria y fortuna ${ }^{182}$. En suma, el llamado a la Primera Cruzada fue un discurso que hábilmente supo sintetizar las costumbres, creencias, necesidades y temores de la cristiandad, ordenándolos en pos de un objetivo que serviría a la Iglesia, y que en los años siguientes se convertiría en un modelo para las demás campañas contra el Islam, incluida Península Ibérica, donde es especialmente apreciable en la cronística castellana de los siglos XII y XIII ${ }^{183}$

Definitivamente, la cruzada y sus acepciones obligaron a revisar los planteamientos teológicos respecto a la guerra y a la muerte en batalla. Después de 1096 era claro que la Iglesia había adoptado totalmente la violencia como parte de su accionar mundano, en parte gracias a la evolución y adaptación de los conceptos de la guerra justa -tal era el caso de las guerras contra el Islam que ocupaba los Santos Lugares-. Esas tierras tradicionalmente pertenecían al cristianismo, en consecuencia, para la Iglesia, su ocupación por parte del Islam era un hecho ilegítimo, una usurpación meritoria de una respuesta violenta, pero justificada ${ }^{184}$. Esta forma de concebir la guerra, si bien fue el fruto de un largo proceso, no significaba su total aceptación. La

${ }^{182}$ García Fitz, Francisco, "El discurso militar... op. cit. p. 435, 443-448.

183 Independiente de las diversas motivaciones existentes, reales o discursivas, es importante aclarar que la cruzada, al igual que la guerra santa, experimentó una evolución a medida que trascurrió el tiempo, incorporando nuevos elementos y posturas ideológicas. Se observa en la incorporación de cierta tendencia legalista; es decir, la intención de la Iglesia por normar su uso y condiciones con el fin de hacerla más dúctil para el servicio de los intereses del Papado. Debemos recordar que el éxito de la llamada Primera Cruzada entre 1096 y 1099 causó una verdadera conmoción, demostrando a la Iglesia la utilidad de su uso contra todo tipo de enemigos, incluidos aquellos dentro de la misma cristiandad que se opusieran a los intereses de la sede apostólica.

Complementario a lo recién expresado, consideramos relevante mencionar que técnicamente hablando, la primera vez que se realizó una campaña militar con todos los componentes de la Cruzada, incluyendo la convocatoria papal, la bula y las indulgencias, fue la conquista de Barbastro, en la Península Hispánica, el año 1064, durante el pontificado de Alejandro II. Cuando una fuerza de ultramontanos y aragoneses capturaron la ciudad, arrebatándosela a los musulmanes. (Para un mayor desarrollo de este episodio ver nota 253).

También es importante considerar que junto con la evolución formal de la cruzada, ésta también propició cambios prácticos y filosóficos. Entre los cambios prácticos destacó la novedad de las Órdenes militares, siendo estas en esencia, una nueva forma de canalizar la violencia a través de hombres consagrados que no tenían impedimentos para derramar sangre en nombre de la fe y la religión. Las Órdenes fueron la culminación del proceso de domesticar a la caballería; ahora, el guerrero no solamente obedecía a la Iglesia, sino que se entregaba totalmente a ella. Este nuevo tipo de guerrero se convirtió en un modelo virtuoso al cual imitar, pero más importante aún, se trasformó en una herramienta totalmente disponible para el Papa; sólo a él debían su obediencia, totalmente independientes de los poderes e intereses locales, replicando así, el modelo del Císter en cuanto a su obediencia única al pontífice (Para una aproximación general respecto al problema de las Órdenes militares, sus influencias y modelos, recomendamos remitirse a las obras ya citadas: Demurger, Alain, Caballeros de Cristo ... op. cit.; GarcíaGuijarro Ramos, Luis, Papado, cruzada... op. cit.; así como el trabajo de Pernoud, Régine, Los Templarios, Madrid, Siruela, 2005. Para un conocimiento especifico del ámbito hispánico es recomendable el trabajo conjunto coordinado por Ricardo Izquierdo Benito y Francisco Ruiz Gómez (Las órdenes militares en la Península Ibérica, volumen I. Edad Media, Cuenca, Ediciones de la Universidad de Castilla-La Mancha, Cortes de Castilla-La Mancha, 2000) y el texto de Carlos de Ayala Martínez (Las órdenes militares hispánicas en la Edad Media 'siglos XII-XV', Madrid, Marcial Pons Historia, 2007).

${ }^{184}$ Contamine, Philippe, La Guerra en la Edad Media, Barcelona, Labor, 1984, p. 349. 
muerte en batalla seguía siendo un asesinato, un acto repudiado por el mismo Cristo y una amenaza para la salvación del alma; era pues necesario continuar desarrollando una filosofía que regulase la violencia. La que terminó por convertir en algo legítimo la muerte violenta de un enemigo de la fe, y el asesinato en un acto de piedad cristiana. De esta forma, gracias a la legitimación de la guerra santa y la cruzada, el antiguo pecado de homicidio se convirtió en una herramienta al servicio de Dios y un medio válido para expiar otros pecados ${ }^{185}$.

Uno de los primeros pensadores a este respecto fue Bernardo de Claraval (10901153), entusiasta defensor de las órdenes de caballería y en especial del Temple, a la que redactó su regla. En sus textos Bernardo plantea la legitimidad de la ofensiva cristiana sobre la Tierra Santa, apelando al argumento de que pertenecía a la cristiandad, y que le fue injustamente arrebatada por los musulmanes. En ese aspecto el principal escrito del cisterciense fue su Elogio de la Nueva Milicia Templaria, en el cual, al mismo tiempo que elogia al Temple como una novedad, al combinar la espada con la piedad cristiana, el monje convoca a la orden a exterminar a los infieles. En esencia, este nuevo tipo de guerreros representaban la consolidación del miles: el guerrero al servicio de Dios y la Iglesia ${ }^{186}$. Un fenómeno, que fue incorporado profusamente en la

185 Alvira Cabrer, Martín, “Senhor, per les nostres peccatz'. Guerra y pecado en la Edad Media”, en Carrasco Manchado, Ana Isabel y María del Pilar Rábade Obradó (Coordinadores), Pecar en la Edad Media, Silex, Madrid, 2008, p. 99.

${ }^{186}$ ENMT, I, op .cit., p. 40; Cardini, Franco, "Guerra y cruzada", en Le Goff, Jacques y Jean-Claude Schmitt (Editores), Diccionario razonado... op. cit., p. 312; y Fernández Conde, Francisco Javier, La religiosidad medieval... op. cit., p. 71.

Es de notar que dentro de su elogio Bernardo deja en claro que aún más dichosa que la victoria es la muerte en batalla, ya que convierte el caballero en mártir y lo coloca inmediatamente en presencia del Señor. Este nuevo modelo de caballero-monje es un ejemplo de virtudes que se diferencia de la milicia laica -la "malicia" como la llama el cisterciense - cargada de lujos, ciega de botín y gloria y, por ello, alejada de Dios y en pecado. En esencia, el texto resume las virtudes guerreras y sintetiza las motivaciones que debe tener un caballero al servicio de la causa de Dios: "Además, consiguen dos cosas: muriendo sirven a Cristo, y matando, Cristo mismo se les entrega como premio. El acepta gustosamente como una venganza la muerte del enemigo y más gustosamente aún se da como consuelo al soldado que muere por su causa. Es decir, el soldado de Cristo mata con seguridad de conciencia y muere con mayor seguridad aún" (ENMT, III, op. cit., p. 45).

En el escrito del cisterciense no hay ningún reproche a las muertes causadas por esta milicia cristiana; por el contario, se exhorta el derramamiento de sangre infiel y se prometen recompensas espirituales por este acto que se consideraba un servicio a Dios, puesto que constituía un "malicidium". Esta era una postura muy distinta a las ideas respecto a la violencia de los primeros filósofos cristianos: "Marchad, pues, soldados, seguros al combate y cargad valientes contra los enemigos de la cruz de Cristo, ciertos de que ni la vida ni la muerte podrá privarnos del amor de Dios que está en Cristo Jesús, quien os acompaña en todo momento de peligro, diciéndoos: Si vivimos, vivimos para el Señor, y si morimos, morimos para el Señor. ¡Con cuánta gloria vuelven los que han vencido en una batalla! ;Qué felices mueren los mártires en el combate! Alégrate, valeroso atleta, si vives y vences en el Señor; pero salta de gozo y de gloria si mueres y te unes íntimamente con el señor. Porque tu vida será fecunda y gloriosa tu victoria; pero una muerte santa es mucho más apetecible que todo eso. Si son dichosos los que mueren en el Señor, ¿no lo serán mucho más los que mueren por el Señor?”. ENMT, I, op. cit., p. 41. 
realidad peninsular, mediante la presencia de Órdenes de caballería orientales y también autóctonas, como Calatrava y Santiago.

Posteriormente, fue Santo Tomás de Aquino quien desarrolló una filosofía más crítica respecto a la guerra, más en la línea de pensadores anteriores ${ }^{187}$. En su Suma Theologiae no duda en calificar todas las guerras como pecado, a pesar de reconocer la existencia de las guerras justas ${ }^{188}$. Respecto a éstas, no las critica abiertamente ni condena, sino que se limita a exigir que sean dirigidas por una autoridad legítima, en pos de una causa justa y con una recta intención como trasfondo ${ }^{189}$. Para el dominico, entonces, la guerra es una calamidad; sin embargo, debía ser aceptada bajo algunas circunstancias, siempre y cuando se ciñera a ciertos parámetros que evitasen los excesos.

Queda claro entonces que la aceptación de la guerra y específicamente de la cruzada, si bien contó con importantes defensores, no logró un respaldo universal. A pesar de las distintas oleadas de fanatismo o, si se prefiere, de extremismo, finalmente

Se hace notorio después de un análisis general del Elogio de la nueva Milicia Templaria, que para San Bernardo el cristianismo no era el agresor; por el contrario, era el agredido por los infieles y paganos y por tanto estaba obligado a defenderse. Estas ideas están en la misma línea que los planteamientos acerca de la Guerra justa y la legitimación de la reclamación cristiana sobre los territorios de Tierra Santa (ENMT, III, op. cit., pp. 45, 46.)

${ }^{187}$ En forma sintética Santo Tomás clasifica la guerra como un mal, afirmando al respecto: " $1 . \mathrm{Ad}$ primum sic proceditur. Videtur quod bellare semper sit peccatum. Poena enim non infligitur nisi pro peccato. Sed bellantibus a domino indicitur poena, secundum illud Matth. XXVI, omnis qui acceperit gladium gladio peribit. Ergo omne bellum est illicitum.

2. Praeterea, quidquid contrariatur divino praecepto est peccatum. Sed bellare contrariatur divino praecepto, dicitur enim Matth. V, ego dico vobis non resistere malo; et Rom. XII dicitur, non vos defendentes, carissimi, sed date locum irae. Ergo bellare semper est peccatum.

3. Praeterea, nihil contrariatur actui virtutis nisi peccatum. Sed bellum contrariatur paci. Ergo bellum semper est peccatum" ("1. No se inflige pena más que por el pecado. Ahora bien, a quienes pelean el Señor les tasa pena, a tenor de estas palabras: Todo el que empuñare la espada, morirá (Mt. 26,52). Por tanto, toda guerra es ilícita. 2. Es pecado cuanto contraría al mandamiento divino. Pues bien, guerrear contraría al precepto divino, pues se dice: Yo os digo: no resistáis al mal (Mt. 5,39), y también: No defendiéndoos, carísimos, sino dando lugar a la ira (Rom. 12,19). Guerrear, pues, siempre es pecado. 3. Nada sino el pecado contraría a la acción virtuosa. Ahora bien, la guerra contraría a la paz. Luego la guerra siempre es pecado". Aquino, Tomas de, Suma Teológica, Parte II-II (a), Tomo III, Cuestión 40, Articulo 1, Madrid, Biblioteca de Autores Cristianos, 1990, p. 337. (En adelante ST 1990).

${ }^{188}$ Santo Tomás tomó las ideas de Agustín y las sintetizó en tres principios: aquella librada por un poder público y legítimo cuando sus causas eran justas; que se dirigía contra un adversario culpable, merecedor de castigo; siendo su fin último alcanzar la paz, detener el mal y favorecer a los rectos. (ST 1990, Parte IIII (a), Tomo VII, Cuestión 40, Artículo 1, Madrid, Biblioteca de Autores Cristianos, 1959, pp. 1074-1076 (En adelante ST 1959).

En contexto histórico en el que se expresaron las ideas tomistas, la guerra no era vista como algo positivo, y contrariamente a los postulados de Agustín, el hecho de matar en guerra era siempre un pecado reprobable y no libre de culpa, independiente de quien ejecutase u ordenase la acción. Keen, Maurice, $L a$ caballería... op. cit., p. 72; García Fitz, Francisco, La Edad Media... op. cit., p. 32; y García Caneiro, José y Francisco Javier Vidarte, Guerra y filosofia ... op. cit., pp. 40-42.

${ }^{189}$ ST 1959 op. cit., pp. 1074 a 1077; Bouthoul, Gastón, La guerra ... op. cit. pp. 12, 13; y García Caneiro, José y Francisco Javier Vidarte, Guerra y filosofía... op. cit., pp. 41, 42. 
continuó siendo vista como algo contrario al mensaje de Cristo y el modo de vida cristiano $^{190}$.

Estos hechos, sumados a los acontecimientos peninsulares, permiten observar que para el siglo XII, al menos en algunos sectores, se produce un cierto cambio en la concepción que se tenía del Islam. Podríamos decir que se estableció una imagen menos negativa hacia los musulmanes, sin que por ello se les dejase de considerar enemigos de Dios, o se hiciesen grandes esfuerzos por comprender su $\mathrm{fe}^{191}$. Es decir, seguía existiendo una visión arbitraria de ellos, pero un poco más tolerante ${ }^{192}$.

${ }^{190}$ No obstante lo anterior, las circunstancias en Tierra Santa obligaron a adoptar otras formas de convivencia. Es de conocimiento general que la conquista de Jerusalén en 1099 permitió la formación de cuatro principados cristianos en Oriente, inaugurándose una nueva zona de fronteras en la cristiandad, donde la convivencia entre musulmanes y cristianos dio paso a nuevos contactos culturales y económicos. Allí se convivía en un ambiente en el que se intercalaban las treguas y las guerras, estas últimas casi siempre en perjuicio de los cristianos (Bresc, Henri, Pierre Guichard y Robert Mantran, Europa y el Islam en la Edad Media, Barcelona, Crítica, 2001, pp. 156-158; Hindley, Geoffrey, Las cruzadas... op. cit., pp. 77-97).

${ }^{191}$ Ejemplo de ello son las primeras traducciones del Corán al latín realizadas en Occidente, pero cuyo principal objetivo era demostrar, a través de comentarios, los errores y falacias del Islam. En 1210 Marcos de Toledo -a instancias del Arzobispo Jiménez de Rada- terminaba su traducción del Corán al latín. En el prefacio del texto, el traductor introdujo una biografía de Mahoma, en que lo presenta como un mago, influenciado por judíos y cristianos. Luego agrega que debió decidirse entre el cristianismo y el judaísmo, rechazando el primero por parecerle que los Evangelios eran muy estrictos al exigir el perdón y negar los placeres, por lo que habría optado por el judaísmo. No obstante, al darse cuenta que los judíos eran despreciados en todas partes, decidió crear su propia religión combinando las dos anteriores y "sus propias fantasías". Entonces se proclamó profeta, reunió a los árabes en La Meca donde, según Marcos, fingió una crisis epiléptica y anunció que el arcángel Gabriel le había revelado una nueva ley. A continuación, el autor hace una descripción certera de la doctrina islámica en relación a la unidad de Dios, el papel de Cristo y los cinco pilares (Tolan, John, Sarracenos... op. cit., pp. 216, 217). El relato de Marcos, si bien busca desacreditar a Mahoma y su religión, también tiene una clara intención pedagógica, al pretender reseñar las bases de la doctrina Islámica -dejando siempre en claro su origen pernicioso y erróneo-, en especial si se considera que las traducciones del Corán no estaban destinadas a la totalidad de la élite, sino que a un reducido número de teólogos e intelectuales.

La descripción de Marcos tendrá un símil en otras obras del período. En la misma época, Lucas de Tuy en su crónica, dedicó sendos capítulos al Islam, para lo cual elaboro una biografía de Mahoma. En ella aparecen algunos hechos historiográficamente aceptados sobre la vida de Mahoma, como que fue un hombre inicialmente de escasos recursos económicos, dedicado al comercio, su matrimonio con Jadiya y sus relaciones con judíos y cristianos mediante los cuales conoció las Escrituras (CE, Libro III, cap V, op. cit., p. 203). Por su parte, Jiménez de Rada complementa mucha de esta información en su Historia Arabvm (Jiménez de Rada, Rodrigo, Historia Arabvm, Introducción, Edición crítica, notas e índice de José Lozano Sánchez, Sevilla, Universidad de Sevilla, 1993); sin embargo, ambos cronistas coinciden en dar una visión negativa del Profeta, resumida en que Mahoma fue un embaucador que obraba milagros gracias a la magia, que era un falso mesías, que estaba afectado por la epilepsia, que era esencialmente cobarde y que utilizaba a las mujeres para expandir su herejía. En esta misma línea, se puede mencionar el caso de las Siete Partidas y la Crónica General, donde Alfonso X narra la historia del Islam, pero destacando por sobre todo el error de su religión.

${ }^{192}$ Lo anterior, se explica, según Tolan, se explicaría por diversas razones: por una parte por la aparición del catarismo, que como herejía cristiana representó una amenaza más seria para los poderes de la Iglesia y de la monarquía francesa que el Islam. Además, comenzaron a reconocerse los aportes de la cultura islámica a Occidente, en relación a la filosofía, las ciencias y el comercio; contribuciones que de todas formas no limpiaban al Islam de su interpretación como una simple herejía.

Esencialmente, la relativa mejora de la imagen del Islam sólo afectó a algunos intelectuales y cruzados, puesto que para la gran mayoría de la población europea seguían siendo simples paganos y enemigos, esto en razón de que si bien ya se habían realizado las primeras traducciones del Corán, éstas 
El Papado supo sacar provecho de esta percepción cultural en vista de sus objetivos cruzadistas ${ }^{193}$. Un hábil manipulador de esta situación fue Inocencio III (1198- 1216), que las utilizó para atacar al Islam desde todos los frentes posibles, promoviendo contra ellos la IV y V cruzada, además de apoyar la campaña de las Navas de Tolosa (1212); también impuso restricciones a los musulmanes que habitaban en los territorios cristianos y favoreció la predicación a los musulmanes donde sea que estuviesen, razón por la cual apoyó a los franciscanos en ese esfuerzo ${ }^{194}$.

Pese a las discusiones filosóficas y las prácticas de la frontera, lo cierto es que la guerra religiosa y la cruzada conformaban una realidad tangible y, por lo tanto, se hacía necesario que estuviese normada para asegurar una real utilidad para los intereses de la Iglesia. Esto se logró en el IV Concilio de Letrán de 1215, donde el llamado a cruzada fue dotado de un aparato legal definido ${ }^{195}$. Se puede concluir que este conjunto de medidas fueron el reflejo y fruto de una larga evolución ideológica que consolidó la regulación y normalización de la violencia, en su acepción cruzada, al servicio de los intereses de la Iglesia.

solamente llegaban a un pequeño sector de la élite intelectual y las colaboraciones propias de la convivencia en zonas de frontera -como Sicilia o España- se restringían a esos territorios, sin que lograran permear las fronteras de otros Estados cristianos. (Tolan, John, Sarracenos... op. cit., p. 201; Partner, Peter, El Dios de las batallas... op. cit., p. 98).

${ }^{193}$ Riley-Smith, Jonathan, ¿Qué fueron las cruzadas... op. cit., p. 28.

194 Tolan, John, Sarracenos... op. cit., p. 231.

195 En su canon 71, el Concilio establece la imposibilidad de renunciar al voto de cruzada formalmente realizado. Además, se establece que la cruzada sólo debe ser convocada por el Papa para la defensa de los santos lugares o de la Iglesia en su conjunto; la Iglesia debía colaborar con el financiamiento de la campaña, y ésta debía contar con la presencia de un Legado papal. Asimismo, el ejército debía encomendarse a Dios y mantener su pureza; en la misma línea, quienes participasen en ella, estando confesados y arrepentidos de sus faltas, recibían la indulgencia plenaria, beneficio que se hizo extensible a aquellos que, al no poder concurrir personalmente, financiaban a un tercero para que cumpliera sus votos. De la misma forma, se establecía el pago de ciertos montos de dinero a cambio de la redención del voto y, a manera de incentivo, se consagraban una serie de garantías destinadas a proteger a los cruzados, como la congelación de sus deudas o el posicionamiento de sus personas, familias y propiedades bajo la protección de la Iglesia (Rodríguez García, José Manuel, Idea y realidad de cruzada en tiempos de Alfonso X el sabio. Metodología, historiografia y contexto histórico... op. cit., pp. 121-123; De Ayala Martínez, Carlos, Las órdenes militares... op. cit., p. 429; y Goñi Gaztambide, José, Historia de la Bula... op. cit., p. 133, 134). 


\section{I.3.- La Guerra Santa y la Cruzada, el caso hispano medieval}

\section{I.3.a.- Discusiones en torno al uso de los conceptos: De Asturias a la Reconquista}

En la Península Ibérica, el uso religioso de la violencia tuvo un importante rol en la consolidación de la realidad política y cultural de la sociedad hispano cristiana ${ }^{196}$. La característica peninsular, de ser una tierra de frontera con el mundo islámico, se tradujo en una rápida aplicación de las ideas de la violencia religiosa. Si bien se evidencia que, no existe un consenso actual respecto a si el proceso hispano puede ser considerado una cruzada o al menos una guerra santa, lo cierto es que hay ciertos episodios en los cuales podemos observar claramente características de ambas situaciones ${ }^{197}$.

A partir de lo anteriormente expuesto, en las próximas líneas, nosotros pretendemos señalar que en el aspecto de las ideas y el discurso, la llamada Reconquista, fue una guerra de fronteras, que en determinados momentos tomó las características de una guerra religiosa o santa. Sin embargo, sólo a partir del siglo XII existió una "popularización” de ello, que se vio materializada en la revitalización de un discurso de reivindicación de las tierras cristianas -ilegítimamente arrebatadas- y en la creencia de estar luchado contra los enemigos de la fe y de la Iglesia. En suma, la guerra hispánica fue un conflicto político-territorial en el cual, en distintos períodos de tiempo, se sucedieron momentos que podríamos considerar de guerra santa y cruzada.

\footnotetext{
${ }^{196}$ En aspectos prácticos e independientes de los hechos ocurridos en Asturias, la consecuencia más inmediata de la invasión musulmana para la Iglesia hispana, fue la ruptura casi total con Roma. El estado de caos en que quedaron inmersas las diócesis peninsulares, sumado al hecho de su tradicional distanciamiento con la Santa Sede implicó el virtual cese de todo tipo de comunicaciones, que repercutió luego en el proceso de reorganización del clero hispano. Sólo a partir del pontificado de Alejandro II (1061-1073), se retomarían los contactos con Roma de manera más o menos fluida, aunque, sólo se restaurarían de forma plena y total durante el pontificado de Gregorio VII (Previamente habían existido sólo algunos contactos esporádicos. Carlos de Ayala en su artículo ya citado "Fernando I y la sacralización de la Reconquista" las resumen en las siguientes: en 1047, Clemente II concedió una bula a favor del monasterio de Oña, una reconvención contra la pretensión apostólica del obispo de Compostela, emitida en 1049 por León IX. En tanto, Alejandro II inició su aproximación enviando a un legado a Aragón entre 1064 y 1065 y una posible embajada, enviada en la época final del reinado de Fernando I, cuyo objetivo era verificar la ortodoxia de algunos textos litúrgicos hispanos).

Lo anterior implicó que la Iglesia Hispana quedara bajo el control de los monarcas asturianos y sus descendientes, ya que fueron ellos los que pasaron a controlar a la institución y a su alta jerarquía (Bronisch, Alexander Pierre, Reconquista y guerra santa... op. cit., pp. 64, 70; Tuliani, Mauricio, "La idea de Reconquista... op. cit., p.13).

${ }^{197}$ La discusión en torno a la cruzada en el caso hispano ha producido una abundante bibliografía, la cual procuraremos ir analizando en las siguientes páginas. Sin embargo en gran parte de nuestras conclusiones reconocemos la influencia de Francisco García Fitz y sus trabajos La Reconquista, Granada, Universidad de Granada, 2010, y los ya citados Las Navas de Tolosa y La Edad Media. Guerra e ideología, justificaciones jurídicas y religiosas. Así como también en Emilio Mitre y Martín Alvira, principalmente en su articulo "Ideología y guerra... op. cit., pp. 291-334; y Joseph O'Callaghan con su libro Reconquest and Crusade in Medieval Spain.
} 
Teniendo en cuenta lo anterior, la guerra peninsular desde un comienzo reprodujo el proceso evolutivo de la violencia religiosa al igual que el resto de la cristiandad occidental, puesto que, antes que todo -según los lineamientos para este tipo de conflicto establecidos en los comienzos de la Edad Media- se trató de una guerra justa, ya que de manera temprana, y siguiendo los planteamientos de García Fitz sobre esto, el Reino Asturiano apeló como causa de la guerra la necesidad de recuperar el territorio perdido $^{198}$. Habiendo sido un bien injustamente arrebatado por los invasores musulmanes, había que recuperar el daño inferido a los predecesores visigodos ${ }^{199}$. Un hecho, que en el aspecto discursivo, consideramos que se encontraba, agravado en razón de que los nuevos conquistadores no compartían la religión de los hispanos; eran musulmanes y, por tanto, considerados totalmente opuestos a los cristianos según el imaginario medieval.

Este discurso, junto con enlazarse con la tradición gótica, encajaba con la concepción de guerra justa, percepción reforzada a su vez al tratarse de la defensa del solar asturiano contra las incursiones andalusíes ${ }^{200}$. De esta forma, el discurso de la guerra justa fue un continuo a lo largo de toda la Reconquista, incluso en los episodios en que ésta se tornaba en cruzada, como fue en el siglo XIII. Hacia ese entonces, las fuentes sostienen una y otra vez la injusticia de la dominación musulmana y el derecho de los cristianos de recuperar las tierras de sus "ancestros"

Es por lo anterior que es posible postular que la idea de una guerra sacralizada es de temprana data en las crónicas hispanas, en razón de una interpretación providencialista de la historia. Primero, en la cronística asturiana, la conquista musulmana se convirtió en un instrumento divino para castigar los pecados de los $\operatorname{godos}^{202}$. Luego, la victoria contra el Islam se tornó en una señal de la reconciliación y perdón de Dios, que ahora protegía los esfuerzos del pueblo cristiano, convirtiendo la totalidad del conflicto en una lucha espiritual -querida y dirigida por Dios- entre los

\footnotetext{
${ }^{198}$ García Fritz, Francisco, La edad media ...op. cit., pp. 194, 195.

${ }^{199}$ Un elemento discursivo e ideológico que fue valido, independientemente de lo verdadero o no de esta premisa.

${ }^{200}$ García Fritz, Francisco, Las Navas de Tolosa... op. cit., pp. 404-407; y García Fitz, Francisco, "La Reconquista: un estado de la cuestión... op. cit., pp. 171-173.

${ }^{201}$ Entre los siglos XII y XIII, se hace común que las fuentes aludan a la pérdida del Reino Visigodo, la restauración católica en España y la justicia de la causa cristiana. Ejemplo claro de ellos lo podemos observar en los relatos vinculados a la figura de Pelayo y la batalla de Covadonga. A modo de referencia puede consultarse el de Rebus Hispaniae, en sus Libros I, capítulo IX, Libro III, capítulos XX y XII y Libro IV, capítulo II; el texto de Lucas de Tuy, en su Libro IV. Cap. IV, también la Crónica General de España en su capítulo 568. Destacamos, en forma complementaria, la Crónica Silense/Legionense y su genealogía de Alfonso VI.

${ }_{202}$ Al respecto se puede consular la CAIII, versión Rotense, N 7, op. cit., pp. 120, 122.
} 
creyentes y los enemigos de la Iglesia; señales claras de la sacralidad del conflicto peninsular. Algo que se puede observar en las crónicas asturianas, siendo el caso de la Crónica de Sampiro, que enfoca la lucha entre los soberanos astur-leoneses contra el Islam como la restauración de la Iglesia y del antiguo orden cristiano. Lo anterior debe ser comprendido dentro de un contexto cultural occidental; los cronistas asturianos y europeos en general, mantenían como referente permanente el Antiguo Testamento y sus episodios bélicos; con ello podían construir discursos propagandísticos que se basaban en una conciencia religiosa compartida, que lo hacía más fácil de difundir y “popularizar" entre los nobles y guerreros ${ }^{203}$.

En vista de lo recién señalado, es posible observar que, ya para el siglo IX se hacía una clara identificación entre la resistencia de los reinos del norte, la restauración visigoda y la recuperación de la Iglesia Católica, por lo que no es de extrañar el temprano surgimiento de la figura de la Virgen de Covadonga, que con su aparición en la batalla homónima, validaba de forma providencial la lucha de los norteños. A esta primera intervención divina se debe agregar el surgimiento y fortalecimiento del culto jacobeo, puesto que la creencia de que los restos del santo descansaban en Galicia convirtió a toda la Península en una Tierra Santa, lugar de maravillas y objeto de la devoción popular ${ }^{204}$. A las apariciones de la Virgen y Santiago se sumaron también las de Isidoro de Sevilla, que convertido en santo protector tomaba la espada para combatir a los musulmanes que injustamente usurpaban la tierra de los visigodos. A estos grandes santos se fueron agregando numerosas figuras providenciales; gran parte de ellas santos varones hispanos muertos años antes. Entre ellos destacan personajes como Santo Domingo de Silos o San Millán; fieles reflejos de los ideales cristianos de vida contemplativa y que después de sus muertes sirvieron como instrumentos de exaltación militar $^{205}$.

Con respecto a la construcción de un discurso de sacralización territorial en la Península, uno de los mejores ejemplos se puede observar en el Prohemio de la crónica de Lucas de Tuy. Allí el cronista realiza un exhorto a la tradición piadosa peninsular, apelando a que es el lugar de descanso de Santiago, pero también de otros personajes

\footnotetext{
203 García Fritz, Francisco, Las Navas de Tolosa... op. cit., pp. 409, 410-412; y Bronisch, Alexander Pierre, "En Busca de la Guerra Santa”... op. cit., pp. 95, 96.

${ }^{204}$ García Fitz, Francisco, La Edad Media... op. cit., pp. 140, 194; y Fernández Conde, Francisco Javier, La Religiosidad Medieval ... op. cit., pp. 39, 40.

205 Testimonio de aquello lo podemos observar al comparar las primeras crónicas posteriores al 711, como la Crónica mozárabe de 754, Crónica de Alfonso III y Crónica albeldense, con las crónicas de períodos posteriores.
} 
autóctonos que por sus actos alcanzaron la santidad. Dentro de ese grupo, el "Tudense" destaca, entre otros, a Isidoro de Sevilla, los mártires Laurente, Vicente y Marcelo, al Papa Dalmacio, así como a otros más recientes como Santo Domingo de Silos ${ }^{206}$. Esta construcción discursiva sirvió para estimular la participación de guerreros en las campañas y facilitar a su vez, el otorgamiento de bulas de cruzada y otros privilegios a la guerra peninsular, reforzando los estímulos espirituales, además de las motivaciones puramente políticas y económicas de la Reconquista.

Si la Península era Tierra Santa, entonces, era merecedora del esfuerzo militar de la Iglesia, de los hispanos y de la cristiandad general; por ello es significativo que la relación Reconquista-cruzada fuese utilizada indistintamente por los monarcas, Roma y la Iglesia hispana ${ }^{207}$. Una situación que se hizo cada vez más frecuente a partir del siglo XII, cuando las invasiones norafricanas de almorávides y almohades, y más tardíamente los merenidas, hicieron retroceder o frenaron la expansión de los reinos cristianos de la Península, poniendo en jaque la defensa del flanco occidental de Europa ${ }^{208}$.

De esta manera, la guerra hispana se consolidaba como una guerra justa, santa y también, esporádicamente, cruzada. Este estatus sagrado del conflicto, que fue en aumento a partir del siglo XII, se ve patente en los momentos más extremos de la lucha; cuando existió un claro propósito por imponer y señalar la restauración del cristianismo en las tierras reconquistadas. Esto se realizó básicamente a través de la reconstrucción de iglesias, restauración y fundación de monasterios, el establecimiento de nuevas sedes episcopales y la demolición o transformación de las mezquitas, además de la pretensión de destruir tanto física y simbólicamente aquello considerado como "moro"209. En estas

${ }^{206}$ CM, Prohemio, op. cit., pp. 4-7.

${ }^{207}$ La Iglesia necesitaba al "Estado", el que estaba materializado en el rey, a la vez que éste necesitaba a la Iglesia. El soberano era quien, gracias a sus conquistas, le otorgaba las tierras sobre las cuales la Iglesia reorganizaba sus diócesis y obtenía sus recursos económicos, a cambio de la ya consabida legitimación religiosa del poder terrenal. Esto en el contexto de enfrentar a un enemigo común, el Islam. En pocos territorios de la cristiandad se dio una relación tan estrecha entre Iglesia y monarquía, pero también tan llena de tensiones; no obstante, la alianza entre ambos perseveró durante todo el proceso reconquistador (Sánchez-Albornoz, Claudio, España, un Enigma Histórico, Tomo I... op. cit., pp. 320, 321).

${ }^{208}$ No obstante, esto no implicó que para Roma la guerra peninsular dejase de ser considerada como secundaria en relación a las campañas en Oriente, hacia donde la Iglesia dirigía la mayoría de sus recursos y atenciones. (Fernández Conde, Francisco Javier, La Religiosidad Medieval... op. cit., p. 334, 335).

${ }^{209} \mathrm{Si}$ bien es cierto que en distintas épocas los hispanos prefirieron negociar antes que masacrar a los musulmanes, periódicamente existieron olas de fanatismo donde se buscó el abierto exterminio del infiel y todo lo que éste representaba, en especial sus líderes y textos religiosos, con los que no se tenía piedad. Así lo atestigua la Chronica Adefonsi: "Sed et omnes synagogae forum, quas inveniebant, destructae sunt; sacerdotes vero et legis suae doctores, quoscumque inveniebant, gladio trucidabant. Sed et libri legis suae in synagogis igne combusti sunt" (CAI, Liber I, op. cit., №37, p. 33). ("Y también destruyeron todas las mezquitas que encontraban. Pasaban a cuchillo a los sacerdotes y doctores de su religión que encontraban al paso, e igualmente quemaron los libros de su religión en las mezquitas". CEA, Libro I, $\mathrm{N}^{\circ} 37$, op. cit., p. 75). 
etapas de inflexión, los hombres de la Iglesia no dudaban en extremar sus métodos teniendo en cuenta que, con respecto al musulmán no existían las salvaguardas que había en las luchas entre cristianos: el exterminio, el botín y el cautiverio eran la norma, y no había pecado en estos excesos, puesto que era el deseo de Dios y era la justa retribución ante las provocaciones de los musulmanes. Esto se puede ver graficado en la siguiente referencia de la Historia Compostellana: "[...] nec parcit gladius eorum a maiori usque ad minorem: templa quoque eorum comburere ac diruere et in eis feda relatu facere non erubescunt" ${ }^{210}$.

A esta política de aniquilación, que, insistimos, no fue permanente, se deben agregar otros rasgos de la guerra santa que sí fueron más constantes, en especial a partir del siglo XII. Nos referimos especialmente a la absolución de los pecados y a las recompensas espirituales para aquellos que luchaban bajo las banderas de la cristiandad; ejemplo de ello podemos verlo en la campaña de Almería cuando los obispos de Toledo y León -bajo incitación de Alfonso VII- ofrecieron indulgencias a quienes se sumasen físicamente o materialmente a la expedición, indulgencia que al mismo tiempo, venía acompañada de la promesa de recompensas espirituales y materiales ${ }^{211}$.

Otro ejemplo también significativo, en cuanto a la capacidad de movilización producto de estas promesas, ocurre en relación a la campaña de las Navas de Tolosa; Jiménez de Rada nos relata que, multitudes de hombres acudieron al llamado de Alfonso VIII. Venían de todos los rincones de España y del otro lado de los Pirineos, "Et quia de die in diem crescebat numerus stigmata Domini in corpore suo portancium $[\ldots]^{\prime 212}$.

Testimonios como éstos dejan claro la comprensión de la cruzada como un instrumento de propaganda al servicio de la causa cristiana, pero estrechamente ligado

\footnotetext{
${ }^{210} \mathrm{HC}$ 1988, Liber I, CIII, 3, op. cit., p. 176. “[...] y su espada no perdona desde el mayor al más pequeño; tampoco se avergüenzan de quemar y derruir sus templos y de hacer en ellos cosas indignas de ser relatadas". HC 1994, Libro I, CIII, 3, op. cit., p. 246.

${ }^{211}$ CAI, Poema de Almería, op. cit. p. 132

${ }^{212}$ Roderici Ximenii de Rada, Opera Omnia, Pars I, Historia de rebus Hispaniae, Corpus Christianorum, Continuatio Mediaevalis, LXXII, Turnholti, Typographi Brepols Editores Pontificii, MCMLXXXVIII, Liber II, Cap. XVII, p. 259 (En adelante HRH). "Y como aumentaba por días el número de los que lucían en su cuerpo la señal del Señor" (Jiménez de Rada, Rodrigo, Historia de los hechos de España, Introducción, traducción, notas e índices de Juan Fernández Valverde, Madrid, Alianza, 1989, Libro VIII, cap. I, p. 308 (En adelante HHE.))
} 
al poder político que, según el relato, parece ser el mayor protagonista y promotor de su uso $^{213}$.

Por ello es posible decir que la evolución de la guerra peninsular corrió paralela a la evolución del pensamiento bélico del cristianismo, pero desarrollándose de forma análoga al proceso en el resto de Europa.

Es importante no perder de vista que la Reconquista hispánica fue una empresa paulatina que se dio en varias etapas y que experimentó trasformaciones y evoluciones. No obstante, entre sus móviles profundos existieron causas de orden político y

${ }^{213}$ En contraste con los altibajos de las ideas de cruzada en Hispania, se encuentra lo ocurrido en el alAndalus. Aunque no es el objeto de esta tesis profundizar sobre el Islam peninsular, si nos interesan algunos fenómenos precisos que afectaron a ambas culturas.

En primer lugar, en relación a la cruzada, es interesante observar que los musulmanes conocían su significado, y por supuesto, sus consecuencias. José Manuel Rodríguez rescata algunos ejemplos de esta realidad, como la "carta de la ciudad de Ceuta al Califa Almohade", donde se dice que Alfonso X ha convocado a curas y frailes levantando cruces que impulsan al pueblo para que ayuden al rey en su cruzada (Rodríguez García, José Manuel, "El Yihad: Visión y respuesta andalusí a las campañas cristianas en la época de Alfonso X, el sabio", en Medievalismo, 10, 2000, [pp. 69-98], p. 79).

Como es conocido, la idea de la guerra religiosa es parte importante de la tradición coránica, por lo que el concepto no sólo no era desconocido, sino que además, era aplicado. La principal diferencia en ese sentido, es la ausencia de lo que podríamos llamar una estructura religiosa islámica comparable con la Iglesia Católica. Igualmente, hay que recordar que la guerra santa islámica se originó junto con la religión, a diferencia del cristianismo, que la fue construyendo a medida que la Iglesia se consolidaba como institución religiosa y política. En vista de lo anterior, se puede afirmar que en el Islam la guerra santa era un recurso bastante utilizado y su declaración era una de las atribuciones del califa como máximo líder religioso y político, dado lo cual su uso no fue extraño en el Califato cordobés. Una práctica que se agudizó, a partir de las invasiones de almorávides y almohades, a partir de finales del siglo XI. Ambos grupos destacaron por su rigorismo religioso y actividad militar, así como su apego a la tradición coránica, por lo que hicieron un constante uso de la guerra santa como herramienta en su expansión territorial y guerras contra los cristianos. Factores que se acrecentaban por la aplicación del derecho malikí en la Península (Sobre este último aspecto, ver el artículo de Penelas, Mayte, "Introducción a la doctrina malikí sobre el martirio", en Fierro, Maribel (Editora), De muerte violenta. Política, religión y Violencia en el al-Andalus, Madrid, Consejo Superior de Investigaciones Científicas, 2004, pp. 454, 455 y el texto Maillo Salgado, Felipe, "La Guerra santa según el derecho malikí. Su preceptiva. Su influencia en el derecho de las comunidades cristianas del medioevo hispano", en Stvdia Historica. H ${ }^{a}$ Medieval. Vol I, No 2, 1983, [pp. 29-66]. También es recomendable la aportación de Manuel Rodríguez de la Peña, "Añadiendo muertos a los muertos: el destino de los vencidos en la frontera al-Andalus en la cronística latina pleno medieval", presente en la obra colectiva Hacedores de Frontera. Estudios sobre el contexto social de la frontera en la España Medieval, Madrid, CEU Ediciones, 2009).

Paradójicamente, según la tradición coránica, lo que estaban haciendo los musulmanes peninsulares era la defensa de sus tierras y su religión. Por lo que su guerra estaba completamente justificada según los preceptos coránicos: “190. Combatid por Dios contra quienes combatan contra vosotros, pero no os excedáis. Dios no ama a los que se exceden.

191. Matadles donde deis con ellos, y expulsadles de donde os hayan expulsado. Tentar es más grave que matar. No combatáis contra ellos junto a la Mezquita Sagrada, a no ser que os ataquen allí. Así que, si combaten contra vosotros, matadlos: ésa es la retribución de los infieles.

192. Pero, si cesan, Dios es indulgente, misericordioso.

193. Combatid contra ellos hasta que dejen de induciros a apostatar y se rinda culto a Dios. Si cesan, no haya más hostilidades que contra los impios" (Corán, 2: 190-193).

No obstante estos factores religiosos, para los andalusíes la guerra también tenía motivos económicos, no solamente defender sus tierras, sino también el botín y la captura de cautivos eran importantes estímulos, al igual que lo fueron para los cristianos. 
económico; la ocupación y recuperación de las fértiles tierras del centro y sur de la Península fue un proceso enmarcado dentro del contexto de organización de los reinos cristianos peninsulares. Esta realidad se encontraba matizada por la construcción de un discurso por parte de los poderes cristianos que, apelando a las ideas de guerra sacralizada, guerra santa y posteriormente cruzada, lograban conmover a los guerreros y dirigirlos contra los musulmanes bajo la convicción de que estaban cumpliendo la voluntad de Dios; discurso que, si bien no siempre tuvo la misma intensidad, es observable en las obras cronísticas del periodo ${ }^{214}$.

Esta realidad, que combinaba necesidades políticas con un discurso religioso, en el contexto de una época particular ${ }^{215}$, ha contribuido a que algunos autores prefieran hablar de una "guerra sacralizada" o "religiosa", antes que santa para referirse a la Reconquista. Según autores como Sánchez Albornoz y Joseph O'Callaghan, en Hispania faltaron elementos claves de la guerra santa, como son la búsqueda del martirio y la conversión del enemigo vencido ${ }^{216}$. En cambio, sí existía el convencimiento de estar luchando por la recuperación de la tierra y la protección de la familia y bienes ${ }^{217}$. Una apreciación que puede ser constatada en las crónicas y textos jurídicos, desde el Reino de Asturias hasta la unificación castellano-leonesa con Fernando III, donde la idea del martirio es apenas mencionada y la entrega de indulgencias papales o locales sólo se vuelve relevante a partir del siglo XIII. También es cierto que el conflicto contó con algunas características propias de la guerra contra los enemigos de la Iglesia, como el hecho que rescata Jean Flori, cuando en el Concilio de Elna en 1027, mucho antes de la cruzada de Urbano II, permitió a los catalanes luchar contra los moros el domingo y fiestas de guardar, pues al ser estos "paganos" no estaban protegidos por la Paz de $\operatorname{Dios}^{218}$.

\footnotetext{
${ }^{214}$ Fernández Conde, Francisco Javier, La Religiosidad Medieval... op. cit., pp. 89; O'Callaghan, Joseph, Reconquest and Crusade... op. cit., p. 9; Sánchez-Albornoz, Claudio, España, un enigma histórico, Tomo I... op. cit., pp. 308, 309; García Fitz, Francisco, "La Reconquista: un estado de la cuestión... op. cit., pp. $180-182$

${ }^{215}$ Este discurso se habría definido durante el reinado de Alfonso II entre los siglos VIII y IX e incorporado a la cronística de forma definitiva con Alfonso III, ya en el siglo X. Siendo durante el reinado de Fernando I, cuando el discurso religioso se habría asentado en el conjunto social, e indudablemente reforzado gracias a los aportes de Cluny primero y luego, con el arribo de las ideas de cruzada. De manera que, la instrumentalización de la causa religiosa, puede ser constatada de forma muy temprana en los reinos cristianos, independiente de las verdaderas motivaciones de la reconquista. Al respecto ver García Fritz, Francisco, Las Navas de Tolosa... op. cit. p. 411; y Carlos de Ayala Martínez con su obra Sacerdocio y Reino en la España Alto medieval, páginas 124, 282 y 131, entre otros.

${ }^{216}$ Para los elementos que se han considerado propios de la guerra santa ver notas número 133 y 153.

${ }^{217}$ O'Callaghan, Joseph, Reconquest and Crusade... op. cit., pp. 10, 11; y Sánchez-Albornoz, Claudio, España, un Enigma Histórico, Tomo I... op. cit., pp. 308-311.

${ }^{218}$ Flori, Jean, Guerra Santa, Yihad, Cruzada ... op. cit., p. 177.
} 
Sin embargo, lo cierto es que rara vez una campaña fue iniciada arguyendo motivos puramente religiosos; en todas las crónicas estudiadas los monarcas que convocaron a sus consejeros lo hicieron por distintas causas, como razones políticas, para conquistar o recuperar territorios y vengar las incursiones musulmanas. No obstante, cuando se convocaba a las huestes se enarbolaba la bandera de la religión y el perdón de los pecados que, junto con el botín, eran los incentivos más efectivos para reunir a las tropas. De esta forma se atestiguaba la existencia de una causa común, propiciada por una cosmovisión religiosa que servía de ente unificador para toda la sociedad cristiana peninsular.

Es importante destacar que, muchas veces, estas convocatorias bélicas no contaban con el respaldo directo de Roma, como ocurría en el caso de las cruzadas; pero a pesar de ello, surtían el mismo efecto, en razón de que los largos años de dinámica fronteriza habían terminado por convertir cualquier guerra contra los musulmanes en una guerra santa, y posteriormente en una cruzada ${ }^{219}$.

\section{I.3.b- Reconquista, Monarquía e Iglesia}

Desde mediados del siglo XI el Papado se abocó a la Reforma Gregoriana, lo que repercutió en el fortalecimiento del discurso religioso de la guerra peninsular y en su posterior radicalización ${ }^{220}$. Un proceso que se explica, en especial debido a que el control de la monarquía y el patronazgo que tenían sobre la Iglesia local se convertían

\footnotetext{
${ }^{219}$ Flori, Jean, Guerra Santa... op. cit., p. 270; O'Callaghan, Joseph, Reconquest and Crusade... op. cit., p. 7; y Rodríguez García, José Manuel, "Cruzados y fronterizos. Discusión sobre el carácter cruzado de la guerra en la frontera, 1214-1314”, en Toro Ceballos, Francisco y José Rodríguez Molina (Coordinadores), III Estudios de Frontera ... op. cit., p. 570.

${ }^{220}$ O'Callaghan, Joseph, Reconquest and Crusade... op. cit., p. 24.

Como sabemos, la Reforma vino a reorganizar la Iglesia en relación a su misión apostólica y visión política; en ese marco, continuó con su labor de ordenar la violencia feudal a través de las Treguas y Paz de Dios, a través de las cuales dirigía la acción violenta para asegurar sus intereses. Antonio García y García en su obra ya citada, Iglesia, sociedad y derecho, páginas 217 a 219, señala que uno de los grandes impulsores de la implantación de la Paz y Tregua de Dios fue el Arzobispo compostelano Diego Gelmírez. El 20 de abril de 1124, en un concilio compostelano, se dieron varias constituciones sobre la materia, siendo la primera vez que el tema se trataba con profundidad en los concilios y sínodos castellanos leoneses, implementándose de esta manera este instrumento papal de control de la violencia entre cristianos. En líneas generales, en ellas se estipulaban los mismos aspectos que en el resto de Europa, con la salvedad que en la disposición sexta se estipulaba que si alguno saliese a castigar a los infractores de estas disposiciones y muriese en el proceso, "sea absuelto de todos sus pecados (de los cuales ya hubiere recibido o recibiera penitencia), como si hubiese muerte en el viaje a Jerusalén". La primera de indulgencias plenaria, inédita y no común para otros territorios de la cristiandad, más cuando esta atribución no correspondía a los obispos y arzobispos. Por lo que no seria extraño que, en este caso particular, seamos testigos de un aprovechamiento de las disposiciones papales por parte de Gelmírez para acrecentar su poder e influencia.
} 
en un obstáculo para las intenciones del Papado. Como en otros lugares de Europa, el instrumento de la Santa Sede para ingresar en los reinos hispanos fue el uso de la diplomacia y el envío de legados, entre los que destacaron algunos monjes de Cluny ${ }^{221}$ que comenzaron a arribar al territorio junto con los primeros expedicionarios francos, atraídos por el botín de la Reconquista ${ }^{222}$. Todo ello en alianza con los poderes políticos locales, que estaban deseosos de la validación que podían obtener del Papado y la justificación religiosa para sus conquistas. No obstante, no se debe exagerar la influencia cluniacense, puesto que la radicalización de las ideas religiosas fue un fenómeno común en Europa que obedeció a las intenciones del Papado, del que la orden borgoñona fue un instrumento más en el aumento de su influencia ${ }^{223}$.

En este contexto, la independencia de la Iglesia hispana se convirtió en un foco de atracción para los reformadores romanos; por primera vez desde el 711 el Papado comenzó a observar detenidamente los asuntos peninsulares, y al mismo tiempo, en León, Fernando I (1037 - 1065) consolidaba su poder a través del ya tradicional control de la Iglesia. En 1055, el rey convocó el concilio de Coyanza con el objetivo de resolver los problemas que afectaban a los distintos estamentos clericales del reino ${ }^{224}$, para lo cual el buscó la ayuda de Cluny ${ }^{225}$.

\footnotetext{
${ }^{221}$ En el año 910 fue fundada en Francia la Orden de Cluny. Esencialmente, la orden fue una reforma de la regla benedictina, cuya motivación era volver a los orígenes humildes de la orden, alejándose de las distracciones mundanas que afectaban a gran parte de la Iglesia, para lo cual defendían la autonomía del monasterio y una dependencia directa del Papado, lejos de cualquier influencia señorial. Con el arribo de los papas reformistas, adquirió gran relevancia y se convirtió en la punta de lanza de la reestructuración eclesiástica. Los monjes negros, populares por sus conocimientos intelectuales y formas de vida, se tornaron en el instrumento mediante el cual la Iglesia podía llegar a las distintas esferas del poder laico. Tal fue el caso Castilla y León, donde los cluniacenses, en alianza con Alfonso VI, recibieron el control de importantes diócesis, entre las cuales destacan Toledo, Segovia, Palencia, Sigüenza, Zamora y Salamanca (Mackay, Angus, La España de la Edad Media ... op. cit., pp. 34).

${ }^{222}$ Flori, Jean, La Guerra Santa... op. cit., 267-285; y Mackay, Angus, La España de la Edad Media... op. cit., pp. 32-36.

${ }^{223}$ Flori, Jean. La Guerra Santa... op. cit., p. 98; Bronisch, Alexander Pierre, Reconquista y guerra santa ... op. cit., pp. 52, 53; García Fitz, Francisco, La Edad Media ... op. cit., pp. 156, 157; Flori, Jean, La caballeria, Barcelona, Alianza, 1998, p. 126; Heers, Jacques, La primera Cruzada ... op. cit., pp. 53-57; y Fernández Conde, Francisco Javier, La Religiosidad Medieval... op. cit., pp. 104-151.

${ }^{224}$ Reilly, Bernard, El Reino de León y Castilla bajo el Rey Alfonso VI, 1065-1109, Toledo, Instituto Provincial de Investigaciones y Estudios Toledanos, 1987, p. 114; Mínguez, José María, Alfonso VI. Poder, expansión y reorganización interior, Donostia-San Sebastian, Nerea, 2000, p. 213; Lomax, Derek, La Reconquista... op. cit., p. 78; y Díez Borque, José María (Editor), Historia de las literaturas hispánicas no castellanas, Madrid, Taurus, 1980, p. 61.

${ }^{225}$ La orden ya había sido introducida en Hispania durante el reinado de su padre Sancho III de Navarra. Hacia el 953 arribó a Cataluña y desde el 1025 había comenzado a extender su influencia por los restantes reinos peninsulares.
} 
Debe destacarse que Fernando I fue clave en los cambios ideológicos de la guerra peninsular ${ }^{226}$. Ante el derrumbe del Califato y la aparente disminución de la amenaza musulmana, el rey necesitaba de recursos que le sirviesen para aunar esfuerzos en la guerra; la religión fue el argumento que el monarca y sus consejeros reforzaron como estímulo, y fue así como el discurso oficial comenzó a apelar a la idea de la lucha y restauración religiosa más que a la ocupación territorial. Este es un hecho que se hace visible en la Crónica Silense/Legionense por medio del uso de un lenguaje e interpretación providencialista como eje del relato ${ }^{227}$. En este proceso, Fernando I acrecentó su acercamiento con los cluniacenses, materializado en la entrega de un considerable censo anual obtenido de las parias $^{228}$. De esta manera, Fernando demostraba su astucia, ya que no solamente, mantenía alineada a la iglesia local, sino que se aseguraba -a través de la creación de vínculos económicos- que la Orden más influyente del momento reconociese y validase su corona ante el resto de Europa.

Sin embargo, la operación de Fernando I también tenía sus desventajas, puesto que abrió las puertas de su reino a la influencia de Cluny, que representaba los intereses de los papas reformadores ${ }^{229}$. A ello se debe agregar que, en esta época, la "extorsión" de las parias había hecho del rey de León un hombre riquísimo, cuyas donaciones fluían por Europa demostrando sus tesoros y atraían aún más la atención sobre la Península

\footnotetext{
${ }^{226}$ De forma paralela, a partir del siglo XI se vio un incremento exponencial de las "peregrinaciones penitenciales" hacia la Península y la entrega de absoluciones para aquellos que luchasen contra los musulmanes o prestasen algún servicio a la Iglesia ${ }^{226}$. Dichos beneficios contribuyeron a aumentar la presencia franca en Hispania (Fernández Conde, Javier, Historia de la Iglesia en España, II- $2^{\circ}$... op. cit., p. 297).

${ }^{227}$ Carlos de Ayala Martínez a estudiado el rol de Fernando I en la sacralización de la guerra peninsular en su articulo "Fernando I y la sacralización de la Reconquista" (Anales de la Universidad de Alicante, Historia Medieval, 17, 2011, [pp. 67-116], pp. 67-115). Nos reconocemos deudores de este articulo, no obstante para nuestro análisis hemos dividido sus aportes en razón de nuestro propio orden de trabajo, por lo que el tema de los santos y su accionar en la Reconquista lo analizaremos en un próximo capítulo de esta tesis.

${ }^{228}$ A ello se sumaba la concesión, por parte de Fernando y sus sucesores, de importantes centros religiosos peninsulares como los monasterios de Sahagún y San Juan de la Peña, además de destacadas sedes obispales (Díez Borque, José María, Historia de las literaturas... op. cit., p. 61; y Álvarez Borge, Ignacio, La Plena Edad Media ... op. cit., p. 312).

Es de destacar que si bien la influencia de la orden borgoñona no fue un factor determinante en los reinos de Fernando I, el rey estaba al tanto del poder de la orden en Europa. Durante el siglo XI, Cluny, representaba las aspiraciones reformistas de la Iglesia y sus fundaciones se extendían por el continente, poseyendo gran cantidad de tierras y atrayendo las donaciones de la nobleza laica. Todo ello al mismo tiempo que sus monjes se instalaban en Roma y se convertían en pieza clave del Papado, como quedaría posteriormente demostrado con la elección pontificia del cluniacense Urbano II en 1073.

${ }^{229} \mathrm{Si}$ bien, como ya mencionamos, la influencia de Cluny no fue un factor tan determinante como anteriormente se creía, es innegable el hecho que al ser ésta la orden más influyente del continente y en estrecha relación con Roma, el estrechar lazos con ella implicaba permitir a la maquinaria romana poner su atención sobre la Península.
} 
por parte del clero y de los caballeros francos ${ }^{230}$. De este modo, Fernando, posiblemente sin pretenderlo, creó las condiciones propicias para que el pontífice Alejando II pudiese comenzar su programa reformador en la Península y se introdujesen en la misma, nuevas ideologías acerca de la guerra ${ }^{231}$.

A la muerte de Fernando I, bajo el reinado de su hijo Alfonso VI, Cluny y la Reforma Gregoriana ingresaron plenamente en León ${ }^{232}$. Estos acontecimientos convirtieron a Alfonso VI en el principal promotor de la orden en Hispania, y en gran parte, responsable de la influencia de los cluniacenses sobre la Iglesia local. Esta situación respondía a una estrategia política, y no sólo a la simple devoción. Alfonso, al igual que su padre, comprendía la utilidad de mantener alianzas y obtener el reconocimiento de la Orden más influyente de Europa, como otra forma de validar su trono y controlar a sus vasallos. ${ }^{233}$.

De forma paralela, desde Roma se aumentaba la presión sobre toda Europa para introducir los objetivos de la Reforma; en esencia, la centralización y sumisión de la totalidad de la jerarquía eclesiástica a la autoridad del Pontífice ${ }^{234}$. En el caso hispano,

${ }^{230}$ Tuliani, Mauricio, "La idea de Reconquista... op. cit., p. 13.

${ }^{231}$ Previamente la participación de Roma había sido débil e indirecta, limitándose a la aprobación de la guerra y a realizar sus primeras reclamaciones tentativas sobre las tierras reconquistadas. Durante este período, el Papado se limitó a apoyar la guerra contra el al-Andalus a través de cartas que alababan las victorias de los monarcas cristianos, como la enviada por Juan VIII a Alfonso III en el siglo IX. Poco después, la acción de Roma se tornaría más activa con el patrocinio al camino de Santiago y la promoción de la llegada de francos a la Península, que venían tras la gloria y el botín.

${ }^{232}$ Alfonso mantuvo sus relaciones con Cluny, e incluso aumentó al doble el censo que su padre daba a la Orden. Gracias a esto Cluny aumentaba sus riquezas y poder en Europa y en forma paralela acrecentaba su influencia en León.

${ }^{233}$ Alfonso era receptivo a las influencias de Cluny y con ellas las de la Reforma, pero solamente en el ámbito eclesiástico y clerical, puesto que no estaba dispuesto a aceptar las prerrogativas pontificias de la Dictatus Papae de Gregorio VII que, utilizadas en su contra, podían desestabilizar toda la construcción política llevada a cabo por sus predecesores. No obstante, el rey estrechó aún más sus lazos con la Orden francesa, al punto que respaldó el nombramiento de Bernardo de Sédirac como abad de Sahagún y posteriormente, lo nombró Arzobispo de Toledo, en 1085. Este fue un hecho determinante, dado que el rey había puesto a la cabeza de la antigua capital visigoda a un extranjero fuertemente vinculado con el Papa. Bernardo no fue el único cluniacense, ni franco, que arribó a León en esos años. Durante el reinado de Alfonso, se produjo una importante migración de allende los Pirineos, monjes y caballeros cruzaron las montañas para radicarse en Hispania, llamados por las glorias y el botín de la Reconquista. Incluso, el mismo rey contrajo nupcias con una borgoñona, Constanza de Borgoña, en 1079 (Rodríguez de la Peña, Alejandro, Añadiendo muertos a los muertos... op. cit., p. 690). En el caso de los clérigos, éstos constituirían una nueva élite religiosa e intelectual con amplias influencias políticas - algo atestiguable en la Historia Compostellana y sus distintos autores - en cuanto a los caballeros, pronto ocuparon puestos destacados en la Corte y en la lucha contra el Islam. Algunos de ellos formarían parte del círculo íntimo del monarca destacando, especialmente, Raimundo de Borgoña quien se casó con Urraca la hija del soberano.

${ }^{234}$ Las Iglesias locales debían obedecer en primer lugar el sucesor de Pedro y luego responder a los intereses de los poderes seculares locales. A su vez, el Papado pedía que los poderes reales y señoriales reconociesen al pontífice como la máxima autoridad espiritual y moral de la sociedad cristiana. Esta postura causó distintas reacciones, algunas muy graves como la Querella de las Investiduras, puesto que muchos monarcas consideraban que los planes papales mermaban sus bases de poder pero, en otros casos, 
se dio la postura opuesta aceptándose las demandas pontificias, siempre en el marco de algún tipo de negociación y búsqueda de beneficios.

Fue en ese contexto que se produjo la conocida querella por la liturgia visigoda. La independencia de la Iglesia Hispana y las prerrogativas del rey sobre ésta, no podían ser toleradas en el nuevo escenario de la supremacía papal. De tal manera que el pontífice recurrió al reclamo del Patrimonio Petri sobre las tierras peninsulares (Flori, Jean, Guerra santa, yihad, cruzada... op. cit., pp. 228-229; y De Ayala Martínez, Carlos, Sacerdocio y Reino...op. cit., p. 307).

Las acciones de Gregorio implicaron un giro total en las relaciones entre los reinos hispánicos y el Papado, puesto que hasta ese momento ningún pontífice había intervenido de manera tan directa en los acontecimientos peninsulares. Creemos que es posible que Gregorio se atreviese a romper el statu quo, debido a estar fortalecido por su reciente triunfo sobre Enrique IV, en la llamada "Humillación de Canossa" (febrero de 1077).

Ante las presiones papales los reyes peninsulares podían optar por pactar con Roma declarándose sus vasallos, como ocurrió en el caso de Aragón. O también podían resistir y buscar una salida negociada, mientras respondían con sus propias acciones de fuerza, como fue el caso de Alfonso VI, que en esas fechas se hizo proclamar Imperator totus hispaniae (Mínguez, José María, Alfonso VI... op. cit., pp. 217, 226; Flori, Jean, La Guerra Santa...op. cit. pp. 204-213; Gordo Molina, Ángel, "Papado y monarquía... op. cit., p. 10, 16; y Goñi Gaztambide, José, Historia de la bula... op. cit., pp. 54, 55).

Si bien oficialmente el Papa exigía los territorios reconquistados, al parecer su verdadera intención era terminar con la independencia de la iglesia local. Por ello Gregorio exigió el fin de la liturgia visigoda y el cese del patronazgo exclusivo del soberano. Prontamente, el tema de la liturgia se convirtió en el centro de la disputa (Reilly, Bernard, El Reino de León y Castilla... op. cit., p. 135). Entre los años 1074 y 1081, Gregorio VII despachó distintas epístolas y exhortaciones destintas a los reyes hispánicos y en especial a Alfonso VI, exigiendo la imposición del rito romano. Al respecto ver Mansilla, Demetrio, La documentación pontificia hasta Inocencio III (965-1216), Roma, Instituto Español de Estudios Eclesiásticos, 1955, pp. 15-36).

Alfonso sabía de la importancia del rito mozárabe en el reino, pero el rey también conocía las intensiones y alcances de los nuevos poderes del Papado, por lo que hábilmente utilizó la cuestión de la liturgia como herramienta de negociación con Gregorio (La lucha a favor o en contra del rito mozárabe es un tema bastante conocido y del cual las crónicas nos han legado abundantes testimonios. Al respecto ver: Mínguez, José María, Alfonso VI... op. cit., pp. 215, 216; García y García, Antonio, Iglesia, Sociedad y Derecho... op. cit., p. 27-31; Villacañas Berlanga, José Luis, La Formación...op. cit., p. 293; Flori, Jean, Guerra Santa, Yihad, Cruzada.... op. cit., pp. 221-223; De Ayala Martínez, Carlos, Sacerdocio y Reino...op. cit., pp. 306-309; y la crónica de Rodrigo Jiménez de Rada).

En definitiva, Gregorio y Alfonso sabían que el tema de la liturgia era en realidad el reconocimiento de la unidad y sometimiento a la potestad romana y el fin de la independencia de la Iglesia hispana. Significaba también, reconocer que las tierras reconquistadas quedarían bajo la tutela de la Iglesia Romana (De Ayala Martínez, Carlos, Sacerdocio y Reino...op. cit., p. 307). Pero Alfonso no estaba dispuesto a renunciar a sus conquistas, pero sí era partidario de la reforma del clero hispano; por ello, sus esfuerzos se centraron en la renuncia de las aspiraciones territoriales de Gregorio VII. Finalmente el Papa renunció a sus reclamos a cambio de la sustitución del rito mozárabe y la aceptación de las influencias de la reforma, además de importantes donaciones a la Sede Apostólica (Sánchez Albornoz, Claudio, Estudio sobre las Instituciones... op. cit., p. 800; De Ayala Martínez, Carlos, Sacerdocio y Reino...op. cit., pp. 309-323; García y García, Antonio, Iglesia, Sociedad y Derecho... op. cit., p. 32; Villacañas Berlanga, José Luis, La Formación...op. cit., p. 295; y Goñi Gaztambide, José, Historia de la bula...op. cit., pp. 54, 55). De esta manera, ambos lograron sus objetivos, aunque quien resultó más beneficiado fue el rey leonés, que mantuvo su independencia al mismo tiempo que lograba el respaldo del Papa en sus planes reconquistadores y en la consolidación política de su reino.

Sin embargo, un asunto eran los acuerdos diplomáticos y otra distinta la forma en que los cronistas presentaron estos sucesos en sus escritos, representándolos como una lucha de poderes e influencias que enfrentan al rey con el "pueblo" hispano que rechazaba el cambio litúrgico (HRH, Liber VI, cap. XXV, op. cit. p. 208, CGE, cap. 872, op. cit., pp. 542, 543. CXXR, Libro X, cap. XXXIV, op. cit., pp. 219, 220).

En esencia, y a nuestro parecer, los movimientos de Alfonso le permitieron consolidar una alianza mucho más poderosa que la que obtuvieron sus predecesores, puesto que esta vez, la contraparte era la máxima autoridad religiosa de la cristiandad, la única que en los siglos siguientes podría incluso afectar el esfuerzo bélico de la Reconquista, favoreciéndolo abiertamente según las necesidades de los monarcas cristianos. 
obteniéndose buenos resultados en Navarra y Aragón y acercamientos provechosos con Castilla $^{235}$. En todo este juego diplomático fue importante el trabajo previo realizado por los cluniacenses, puesto que ya se habían ganado la confianza de los magnates e iniciado sus propias reformas a nivel de los cleros locales ${ }^{236}$.

Casi en paralelo, el reino se veía afectado por las consecuencias de la sucesión de Alfonso VI, la Iglesia continuó su proceso de reorganización según los lineamientos gregorianos. Este proceso de reforma debía llevarse a cabo junto con los avances de la Reconquista; como parte de la ideología de la misma, se pretendía restaurar las antiguas diócesis del tiempo de los visigodos, lo que en la práctica no resultaba siempre realizable, tanto por las luchas de poder al interior de la misma Iglesia como por el hecho concreto de que los límites geográficos de la expansión no siempre coincidían

${ }^{235}$ En 1068, Sancho Ramírez de Aragón se declaró vasallo de Alejandro II, comprometiendo el pago de un tributo anual a Roma. A continuación, en 1071, el aragonés introdujo el cambio de liturgia en sus dominios, demostrando así su sumisión a los planes de la Santa Sede, a cambio de la protección de ésta (Flori, Jean, Guerra santa, Yihad, Cruzada... op. cit., pp. 228, 229).

${ }^{236}$ Gordo Molina, Ángel, "Papado y monarquía en el Reino de León. Las relaciones político religiosas de Gregorio VII y Alfonso VI en el contexto del Imperium Legionense y la implantación de la reforma pontifical en la Península Ibérica”, en Studi_medievali, Anno 49, Fasc. 2, 2008 [pp.519-559], p. 519, 520. Iradiel, Paulino y otros, Historia Medieval... op. cit., p. 132.

Respecto de la orden borgoñona, debemos recordar que su influencia no fue solamente política, sino que también implicó grandes aportes culturales que cambiaron el panorama peninsular; quizás, una de sus principales contribuciones fue el apoyo directo a las peregrinaciones a Santiago de Compostela. Los monjes supieron usar la ruta jacobea y el culto al Apóstol como un foco de atracción de peregrinos y guerreros, convirtiendo la ruta en una vía para el intercambio de ideas y movimiento de capitales que, en parte, ayudaron a romper el "aislamiento" que hasta ese momento había caracterizado las relaciones entre los reinos peninsulares y la Iglesia occidental. Cluny promovió y utilizó el camino como una forma de aumentar su propia influencia, a través del establecimiento de monasterios en la ruta y fomentando la idea de la Península como una segunda Tierra Santa con mayores posibilidades de éxito que la lucha en las lejanas tierras de Oriente (Márquez Villanueva, Francisco, Santiago: trayectoria de un mito, Barcelona, Bellaterra, 2004, p. 16; García y García, Antonio, Iglesia, Sociedad y Derecho... op. cit., p 12; Álvarez Borge, Ignacio, La Plena Edad Media... op. cit., p. 313). Lo que queda en evidencia en el siguiente extracto del Liber Sancti Jacobi: "Felix es, Hispania, rerum plurimarum copia, sed felicior es beati Iacobi presencia. Felix es, quia in temperie similis es paradiso, sed felicior es, quia commissa es celi paranimpho. Olim quidem pro columnas Herculis fama vane opinionis fueras gloriosa, sed nunc beato Jacobo firmissima columna feicius es subnixa. Ille perniciosa supersticiones te illexerunt diabolo, hec pia intercessione te innexuit Creatori tuo, Ille lapidee team augebant infidelitatem, hec spiritualis adquisivit tibi gratiam salutem." (LSJ 1998, Liber I, Cap. XV, op. cit., p. 82. "Dichosa eres España por la abundancia de muchos bienes; pero eres más dichosa por la presencia de Santiago. Eres feliz, porque en el clima eres semejante al Paraíso; pero eres más dichosa, porque has sido encomendada al paraninfo del cielo. En otro tiempo fuiste célebre por las columnas de Hércules, según las vanas leyendas, más ahora con más felicidad te apoyas en la columna fortísima de Santiago. Aquellas, por el error pernicioso de la superstición, te ligaron al diablo; ésta, por su piadosa intercesión, te une a tu creador; aquellas, como eran de piedra, aumentaban tu obcecación; ésta, puesto que es espiritual, adquirió para ti la gracia saludable." LSJ 2004, Libro I, Cap. XV, op. cit., pp. 168, 169).

Textos como este -que, como sabemos, posiblemente corresponden a una falsificación del siglo XII- que centraban el laudus de España en la presencia de un cuerpo santo, tenían una clara intención propagandística: la de atraer peregrinos y guerreros a la Península, los cuales debían hacer escala en los monasterios cluniacenses de la ruta, dejando allí sus donaciones (Domínguez García, Javier, Memorias del futuro: Ideología y ficción en el símbolo de Santiago Apóstol, Madrid, Iberoamericana, 2008, pp. 76, 80). 
con los de las antiguas jurisdicciones visigodas. Situaciones como ésta obligaban a la Iglesia a vigilar de cerca el proceso, puesto que no sólo producía conflictos, sino que podía prestarse para la creación de parroquias demasiado independientes ${ }^{237}$.

El proceso de reorganización de la Iglesia hispana continuó sin grandes sobresaltos hasta mediados del siglo XIII, cuando desde Roma se decidió normalizar en forma definitiva el estado de la institución en Hispania. Lo que nos lleva a pensar, que no fue casualidad este renovado interés en vista de que en ese mismo período el Papado observaba con preocupación el fracaso de las últimas cruzadas en Tierra Santa y la continúa expansión albigense, entre otros problemas. Además, en forma paralela, los monarcas castellanos leoneses reafirmaban su poder, iniciando la etapa más activa de la Reconquista, adquiriendo más territorios, autonomía y preponderancia política y religiosa ${ }^{238}$.

Por otra parte, la cruzada también servía a los reyes como instrumento discursivo para controlar y disciplinar a los nobles locales, o como herramienta de presión contra sus propios vecinos cristianos. En el primer caso, gracias a las bulas, los monarcas podían hacer exigencias extraordinarias a la nobleza, a la Iglesia y a las ciudades de su reino, que estaban obligadas a obedecer y prestar los auxilios requeridos. Incluso podía obligarlos a romper pactos o treguas contrarios a los intereses reales. Respecto al segundo aspecto, la cruzada también servía como instrumento de política exterior. Alfonso VIII fue muy conciente de ello cuando en 1212, la Bula de cruzada otorgada por Inocencio III le sirvió para contener -al menos parcialmente- la agresión de León, al mismo tiempo que le permitió formar una alianza con Navarra y Aragón ${ }^{239}$.

\footnotetext{
${ }^{237}$ Linehan, Peter, La Iglesia Española y el Papado en el S. XIII, Salamanca, Universidad Pontificia de Salamanca, 1975, p. 2; García y García, Antonio, Iglesia, Sociedad y Derecho... op. cit., pp. 14, 167.

${ }^{238} \mathrm{El}$ aumento de la influencia romana, así como el culto jacobeo, entre otros elementos, contribuyeron a darle un carácter mas sacralizado a la guerra peninsular. Con el fortalecimiento del poder del pontificado y la Reforma Gregoriana, sabemos que la Iglesia se preocupó más de los acontecimientos peninsulares, en especial cuando, a partir del siglo XII, la idea de cruzada ya se encontraba firmemente arraigada en el imaginario político y religioso europeo. Aún así, los reyes peninsulares acostumbrados al control sobre todos los aspectos de la vida en sus reinos, no serían muy receptivos a la intromisión de poderes extranjeros en sus territorios, aunque se tratase del Papado o de los cluniacenses, lo que en la práctica se tradujo en una introducción más lenta y significativa de estas instituciones en la lucha peninsular. (Goñi Gaztambide, José, Historia de la bula ... op. cit., pp. 48, 49).

${ }^{239}$ Rodríguez López, Ana, "La política eclesiástica de la monarquía castellano-leonesa durante el reinado de Fernando III (1217-1252)", en Hispania Revista Española de Historia, ํ 168, Madrid, 1988, [pp. 748], p. 19; y Rodríguez García, José Manuel, “Cruzados y fronterizos... op. cit., p. 582.

Durante el reinado de Alfonso VIII, luego del espectacular triunfo de las Navas de Tolosa en 1212, según Linehan, se produjo un cambio fundamental en la relación entre el monarca y la Iglesia, puesto que su triunfo convirtió al rey en rex christianus; en otras palabras, el soberano era ante todo un defensor de la fe y líder de la causa cristina en la Península, incluso con proyecciones en Europa (Rodríguez García, José Manuel, Idea y realidad de cruzada en tiempos de Alfonso X el sabio. Metodología, historiografia y contexto histórico... op. cit., pp. 173, 174). Algo que se encuentra en directa relación al hecho de que las
} 
Con posterioridad a las Navas, Fernando III también haría buen uso de la cruzada, al convertirla en pieza clave en la consolidación de su poder sobre el reino unido de León y Castilla, y como elemento fundamental en la organización y financiación de sus exitosas campañas andalusíes ${ }^{240}$. Todo ello bajo su control directo,

victorias cristianas en la Península venían a compensar los reveses sufridos en las cruzadas orientales, especialmente luego de la Cuarta Cruzada. Alfonso había demostrado que era el único soberano europeo con la capacidad de reunir un gran contingente militar y propinar una dura derrota a los enemigos de la Iglesia, logrando la validación de ésta en su papel como caudillo de la cristiandad hispana. Misma razón por la cual Roma pasó de su tibio apoyo inicial a celebrar el triunfo como una victoria propia (Sobre el apoyo papal a la campaña de la Navas de Tolosa, recomendamos los siguientes textos ya citados en esta tesis: el clásico trabajo de Goñi Gaztambide, José, Historia de la Bula de Cruzada en España; el texto de García Fitz, Las Navas de Tolosa; y Demetrio Mansilla con La documentación pontificia hasta Inocencio III).

Por otro lado, la función bélica de los monarcas también era una constante preocupación para el pontificado, puesto que las continuas rencillas entre los reyes cristianos obstaculizaban los avances de la Reconquista. Por ello, no fue extraño que desde Roma se intentase mediar en reiteradas ocasiones para restablecer la paz entre los cristianos. En referencia a las distintas exhortaciones para la paz entre los reinos cristianos, la documentación pontificia nos brinda distintos ejemplos, aunque hay que hacer notar que dichas intervenciones se hicieron más numerosas en el siglo XIII, coincidiendo con las primeras etapas de la reactivación de la Reconquista. Sólo a modo de muestra, podemos citar los casos de Inocencio III, quien en 1198 manda a su legado a procurar que se observe la paz entre Castilla y Portugal, en 1205 intercede por la unión entre los monarcas de Castila y Navarra, en 1210 Inocencio III mandó a Jiménez de Rada exhortar a Alfonso VIII para a seguir el ejemplo de Pedro II, en su lucha contra los "moros" y en 1211 a través de Jiménez de Rada, media entre Alfonso VIII y Alfonso IX, por un acuerdo de paz y alianza contra los musulmanes, en 1212 manda a los arzobispos de Toledo y Compostela a ordenar a los reyes acordar la paz y apoyarse mutuamente contra los musulmanes. En 1214, Inocencio III mandó a su legado Arnaldo ponerse de acuerdo con el rey de Aragón para que éste concertase treguas y dirigiese sus esfuerzos a la guerra contra los sarracenos (Mansilla, Demetrio, La documentación pontificia hasta Inocencio III... op. cit., pp. 85, 347, 436, 480, 501, 555). Por su parte, Honorio III en 1218, mandó a Alfonso IX a obedecer al arzobispo de Toledo, en cuanto a hacer la guerra a los musulmanes y conservar la paz entre los cristianos (Mansilla, Demetrio. La documentación pontificia de Honorio III (1216 - 1227), Roma, Instituto Español de Historia Eclesiástica, 1965. pp. 124); y en 1237, Gregorio IX intervino para procurar que Fernando III no iniciase la guerra contra Navarra (Domínguez, Santiago, Documentos de Gregorio IX... op. cit., p. 499).

Con respecto a la intervención pontificia para que las órdenes de caballería realizasen campañas y otras actividades bélicas, independientemente de las políticas de los reinos peninsulares, también existen abundantes ejemplos, de los cuales sólo mencionamos algunos casos: En 1155, Adriano IV respalda al cardenal legado Jacinto, en su exhorto a los arzobispos, templarios, hospitalarios y demás prelados de España para que luchasen contra los sarracenos (Demetrio Mansilla, La documentación pontificia hasta Inocencio III... op. cit., p. 116); y en 1220, Honorio III manda a los reyes hispanos que permitan a los calatravos realizar campañas contra los musulmanes (Mansilla, Demetrio, La documentación pontificia de Honorio III... op. cit., p. 251).

Al mismo tiempo, el pontífice también presionaba a los soberanos para no interrumpir sus campañas contra los musulmanes, y evitar que estos pactasen treguas con los enemigos de la Iglesia. Con este propósito incluso llegó a ordenar la ruptura de pactos y treguas, incitando a las órdenes de caballería a actuar por su cuenta (se solía exhortar primero a los soberanos para que no impidiesen su actividad), o llegando al extremo de ordenar a Jiménez de Rada iniciar una campaña por sus propios medios, ante la imposibilidad de romper las treguas que Fernando III mantenía con los musulmanes. Sobre este asunto se puede agregar que entre enero de 1218 y febrero de 1219, Honorio III envió distintas exhortaciones a los prelados y miembros de las órdenes religiosas hispanas, para que se pusieran a disposición o auxiliasen al arzobispo de Toledo, en su campaña contra los musulmanes. (Mansilla, Demetrio. La documentación pontificia de Honorio III... op. cit., pp. 119-207).

${ }^{240}$ Al respecto ver en Archivo Hispalense Revista Histórica, Literaria y Artística. 2.a Época, Año 1994. Tomo LXXVII. Núms. 234-235-236, los artículos de Carrillo de Albornoz y Galbeño, Juan, "Fernando III. Sus Campañas. (El Conquistador y la conquista)", en Archivo Hispalense Revista Histórica, Literaria y Artística, 2.a Época, Tomo LXXVII, Núms. 234-235-236, 1994, [pp. 137-155], pp. 137-155; y de 
con lo que se consolidaba el proceso de control político de la cruzada, independiente de la voluntad de Roma ${ }^{241}$.

En forma conjunta a este uso de la cruzada, se produjo la aparición de una nueva institución que sería un factor relevante en la Reconquista: nos referimos al surgimiento de las Órdenes militares hispánicas, que con su presencia en las huestes reales, reforzaban la figura del monarca como siervo de los intereses de la Iglesia, una realidad que, parafraseando a Carlos de Ayala, los monarcas supieron instrumentalizar en su discurso propagandístico político y religioso ${ }^{242}$.

Es en este contexto que, según Flori, se dieron dos discursos paralelos. El primero, ideológico, vinculado con la defensa de la fe, era propiciado por el Papado y aceptado por los reyes; el otro, más pragmático, apuntaba a la recuperación de los territorios, y a la obtención de botín, aunque también limitaba el revanchismo contra los musulmanes por razones prácticas de coexistencia ${ }^{243}$.

Para el Papado, el triunfo cruzado peninsular era una necesidad política, aún más después del estrepitoso fracaso de la IV Cruzada en 1204; cada vez se veía más lejana la posibilidad de recuperar Jerusalén, y por momentos parecía tambalear la capacidad de convocatoria de los papas. Ante estos temores, la lucha en Hispania se veía como algo

Rodríguez García, José Manuel, "Fernando III y sus campañas en el contexto cruzado europeo, 12171252”, Archivo Hispalense, N 234-236, 1994, [pp. 205-217].

En relación al aspecto de las relaciones entre el poder político y la Iglesia, podemos afirmar que durante gran parte de la Edad Media castellano-leonesa no se puede hablar de una verdadera independencia del poder espiritual, esto porque las condiciones particulares de la Reconquista obligaban a una fuerte conexión entre la Iglesia y la monarquía. En el fondo, los obispos y abades, aparte de sus funciones clericales, eran agentes políticos, y por tanto piezas fundamentales en la administración del reino y en la legitimación mutua que se brindaban ambos poderes frente al conjunto de la población. Para todos debía ser evidente que los representantes de Dios, tanto los civiles como los religiosos, luchaban unidos contra los enemigos de la Iglesia por la recuperación de las tierras peninsulares.

${ }^{241}$ Ayala Martínez, Carlos, "Fernando III: Figura, significado y contexto en tiempo de cruzada", en Ayala Martínez, Carlos y Martín Ríos Saloma (Editores), Fernando III, tiempo de cruzada, Madrid, Silex, 2012, pp. 25, 26.

${ }^{242}$ Los freires de Calatrava, Santiago, entre otros, se convirtieron en un elemento de vanguardia en la lucha, con el cual los monarcas podían contar tanto en el aspecto militar como en el material, dados los cuantiosos recursos que poseían. No sólo eso, sino que además las Órdenes, debido a sus características espirituales, constituían un potente símbolo de la causa justa y divina de la Reconquista. (de Ayala Martínez, Carlos, "Las órdenes militares castellano-leonesas y la acción de frontera en el siglo XIII", en Identidad y Representación de la Frontera en la España Medieval (siglos XI-XIV), Seminario celebrado en la Casa de Velázquez y la Universidad Autónoma de Madrid, Madrid, 2001, pp. 152, 153; O'Callaghan, Joseph, Reconquest and Crusade... op. cit., p. 52).

Pese a su origen cruzado, las Órdenes hispánicas limitaron, mayormente, su actuar bélico a la Península, no interviniendo en los acontecimientos de ultramar, así como tampoco existe mayor evidencia de que intentasen influenciar a los monarcas peninsulares en ese respecto. Esto incluso afecto a Órdenes orientales instaladas en la Península, como fue el caso de llamamiento general de Gregorio IX, en 1239, que no fue atendido por los templarios hispanos (Ayala Martínez, Carlos, "Fernando III: Figura... op. cit., pp. 21, 22).

${ }^{43}$ Flori, Jean, Guerra Santa, Yihad, Cruzada... op. cit., p. 225. 
seguro, un proceso lento pero victorioso que venía a demostrar las virtudes de la causa cristiana $^{244}$.

Dentro de algunos de los temas mencionados con anterioridad, hay dos que consideramos merecen una descripción más acabada; el primero de ellos es el rol del Papado en la Reconquista, en relación a su asimilación con el concepto de cruzada, y el segundo, la recepción de estos esfuerzos por parte de los hispanos.

En cuanto al primero, si bien para los guerreros francos y otros cruzados europeos la guerra peninsular era un conflicto demasiado cercano, quizás poco exótico, en comparación con el místico viaje a Oriente; no obstante, para la Iglesia la lucha peninsular era un asunto de vital relevancia. Existía el temor de que la caída de la Península abriese el flanco occidental de Europa para las incursiones sarracenas, tal como había ocurrido durante los siglos VII y IX; temor exacerbado por algunos notables retrocesos hispánicos como las batallas de Sagrajas (1086), Ucles (1108) y Alarcos $(1195)^{245}$. Si bien es cierto que para el siglo XII el empuje islámico occidental se encontraba debilitado, y las posibilidades de amenazar al resto de Europa era bastante lejanas, para la cúpula de la Iglesia ésta era una amenaza real. El infiel norafricano era un enemigo al que había que neutralizar, y cuya peligrosidad era comparable con aquellos musulmanes que ocupaban la Tierra Santa en Oriente. Para el Papado, la guerra peninsular era el segundo frente del gran conflicto contra los seguidores de Mahoma: una campaña global dirigida por una Iglesia fuertemente organizada bajo el alero del sucesor de Pedro ${ }^{246}$.

\footnotetext{
${ }^{244}$ Linehan, Peter, España, 1157-1300 ... op. cit., p. 37; y Tuliani, Mauricio, "La idea de Reconquista... op. cit., p. 16.

${ }^{245}$ Para ilustrar los temores de Roma respecto a los peligros de desproteger la Península, podemos citar la carta que, en 1109, Pascual II dirigió a la Iglesia peninsular, donde conmina a los guerreros a no abandonar sus tierras por temor a que la frontera se debilitase: "Scripsimus enim uobis preterito tempore, ne Iherosolimitane expeditionis occasione partes uestras desereretis, que Maurorum et Mohabitarum cotidianis incursionaribus impugnantur; non parum enim in discessu uestro illorum tyrannidem occidentalibus partibus formidamus" (HC 1988, Liber I, XXXIX, op. cit., pp. 77, 78). Un documento que coincidentemente se elaboro un año después de la derrota de Ucles, cuando Jerusalén ya llevaba una década en manos cristianas.

${ }^{246}$ A pesar que esta visión de guerra "global" puede parecer exagerada, no debemos olvidar que existen abundantes testimonios respecto a los planes pontificios para expandir la guerra. Ejemplo de ellos fueron los enviados papales a la Corte mongola a mediados del siglo XIII en la búsqueda de crear una alianza contra sus enemigos comunes, los musulmanes orientales. Un suceso notable, si consideramos las diferencias culturales y religiosas existentes entre los asiáticos paganos y occidentales, pero que demuestra hasta qué punto el Papado estaba dispuesto a transar, en búsqueda de la victoria contra el Islam y la recuperación de los Santos Lugares.

No obstante lo anterior, Carlos de Ayala, nos recuerda que para mediados del siglo XIII, paulatinamente el Papado fue renunciando a sus intereses en Oriente, y en cambio trato de fortalecer la cruzada en Hispania, lo que no impide que monarcas como Fernando III termines utilizando la lucha
} 
Es por lo anterior que a partir de las cruzadas convocadas por Urbano II, Roma comenzó a interesarse cada vez más por la guerra en la Península, lo que se evidenció en un intento consciente de asimilar la guerra peninsular al concepto de cruzada. Junto a lo anterior Roma intervino directamente, mediando entre los monarcas hispanos para que terminasen sus rencillas y dirigiesen sus esfuerzos contra los musulmanes ${ }^{247}$. En esta línea, el Papado no dudó en aceptar el vasallaje de algunos reinos, como Navarra y Aragón, y enviar legados a interceder ante los distintos monarcas ${ }^{248}$.

Pero el auge cruzado en Oriente trajo un riesgo asociado para los intereses hispanos; el peligro de sufrir una merma constante de guerreros, que abandonaban la Península en búsqueda de los beneficios espirituales de la guerra en ultramar. En vista de ello, Roma desarrolló una política de dos frentes; por un lado, y afirmándose en la tradición jacobea, elevó el estatus de la guerra peninsular a cruzada, puesto que al ser una Tierra Santa, era justo luchar por ella y recibir las recompensas espirituales correspondientes. Así, desde Roma se inició una verdadera campaña de propaganda que colocaba a los reyes hispanos y sus dominios bajo la protección de la Santa Sede, lo que a su vez incentivaba a los ultramontanos a cumplir sus votos en Hispania ${ }^{249}$. Aún así el atractivo oriental era superior, y si bien la Península fue reconocida como tierra de cruzada, ésta fue relegada a un segundo lugar; un destino para aquellos cruzados que

contra el Islam como un instrumento a su servicio (Ayala Martínez, Carlos, "Fernando III: Figura... op. cit., pp. 62, 63)

${ }^{247}$ Sobre estos temas hay una muy abundante bibliografía entre las que destacamos la obra de José Goñi Historia de la bula de cruzada en España, Las Navas de Tolosa de Francisco García Fitz, de Francisco Javier Fernández Conde La Religiosidad Medieval en España, el articulo de Alain Demurger "La papauté entre croisade et guerre sainte" presente en la obra colectiva Regards Croisés sur la Guerre Sainte, la obra de Joseph O'Callaghan Reconquest and Crusade in Medieval Spain, Cristianos y Musulmanes 1031 - 1157 de Bernard Reilly y la obra de Carlos de Ayala Martínez, Sacerdocio y Reino en la España Altomedieval. Iglesia y poder político en el Occidente peninsular, siglos VII-XII, entre otras, además del trabajo recopilatorio de Demetrio Mansilla, La documentación pontificia hasta Inocencio III (965-1216).

${ }^{248}$ Cuando los reyes de Castilla y Aragón, Fernando III y Jaime I, alcanzaron la consolidación de su poder, Honorio III y sus sucesores decidieron apoyarlos directamente en sus esfuerzos de cruzada, lo que implicaba intervenir en sus decisiones y acciones en este aspecto. En este sentido, la prioridad del pontificado fue lograr la paz entre los reinos cristianos, para lo cual no titubeó en utilizar todos los recursos a su alcance. Tal fue el caso de Navarra, que junto al rey Teobaldo I, en 1237, fueron puestos bajo la protección de la Santa Sede por decisión del Papa Gregorio IX, en previsión de los deseos expansionistas castellanos. A cambio, el soberano navarro reforzó su lucha contra los musulmanes, que había iniciado tiempo antes. (Fernández Conde, Javier, Historia de la Iglesia en España, II-2 $2^{\circ}$...op. cit., pp. 34, 35; Goñi Gaztambide, José, Historia de la bula ...op. cit., p. 174; Flori, Jean, Guerra santa, Yihad, Cruzada... op. cit., pp. 228, 229).

249 Guichard, Pierre, "Islam", en Le Goff, Jacques y Jean-Claude Schmitt (Editores), Diccionario razonado... op. cit., p. 393; Tuliani, Mauricio, "La idea de Reconquista... op. cit., p. 16; y Linehan, Peter, España, 1157-1300... op. cit., p. 37. 
por diversos motivos no podían realizar el pasaje a Oriente, o como destino obligatorio para purgar penitencias ${ }^{250}$.

Por otra parte, y de manera complementaria, se prohibió a los hispanos abandonar sus tierras para emprender el viaje a oriente, ya que su obligación era cumplir sus votos en la Península. A cambio se les aseguraba la obtención de los privilegios cruzados, llegando al punto de ordenar el regreso de quienes ya habían partido ${ }^{251}$.

A mediados del siglo XII, Alejandro II (1061-1073) fue el primer pontífice en otorgar indulgencias a quienes combatiesen en la Reconquista. El problema fue que sus bendiciones no solamente estaban dirigidas a los peninsulares, sino que a los francos que se dirigían a capturar Barbastro (1063). Antes de Alejandro, los pontífices habían prestado poca atención a la guerra peninsular, siendo éste el primer Papa en darle importancia a la estrecha relación entre guerra, política y religión en la Península; por lo tanto, se hacía indispensable utilizar esta realidad para lograr la imposición de la Reforma en los territorios hispanos ${ }^{252}$. Sumado a lo anterior, Alejandro II fue también el primer pontífice en plantear la Reconquista como parte de una estrategia global de la lucha contra el Islam ${ }^{253}$.

${ }^{250}$ Tuliani, Mauricio, "La idea de Reconquista... op. cit., p. 16; y Linehan, Peter. España, 1157-1300... op. cit., p. 37.

${ }^{251}$ Goñí Gaztambide, José, Historia de la bula... op. cit., pp. 60, 61. Sobre la participación de hispanos en las cruzadas orientales ver el artículo de Rodríguez López, Ana, "Légitimation Royale... op. cit., pp. 129-163.

${ }^{252}$ Asimismo, Alejandro II veía con extrema preocupación la independencia del clero peninsular, de allí su interés y paulatina intervención en los asuntos locales. Una de las situaciones que molestó al pontífice y que trascendería a su sucesor, fue la posición del Arzobispo de Santiago. La Sede de compostelana había adquirido bastante influencia e independencia en su calidad de custodia de los restos de Santiago, pero fue el hecho de que su titular se arrogara el título de "Obispo de la Sede Apostólica", en abierta competencia con el patriarca de Roma lo que causó mayor molestia (Sánchez-Albornoz, Claudio, España un enigma histórico, Tomo I... op. cit., p. 354). Esta situación no podía ser tolerada dentro de los planes de la Reforma eclesiástica que había puesto en marcha el Papado, e implicó amenazas y sanciones contra el Compostelano. Este es un ejemplo más de las acciones de fuerza que Roma estaba dispuesta a tomar para imponer su programa en la Península.

${ }^{253}$ Lomax, Derek, La Reconquista... op. cit., pp. 81, 82. Fue en este contexto que la captura de Barbastro es uno de los primeros episodios de cruzada conocidos; una acción bélica completamente apoyada y protegida por la Iglesia romana y protagonizada por huestes provenientes de Normandía y Aquitania. Si bien los francos capturaron la ciudad, al poco tiempo esta fue reconquistada por los musulmanes. Sin embargo, el objetivo estratégico se había logrado: el Pontífice ratificaba su poder de convocatoria, el botín obtenido se convertía en un importante estímulo para los francos, y se daba el paso definitivo para la sacralización de la Reconquista (Flori, Jean, Guerra santa, Yihad, Cruzada ... op. cit., p. 275, 276). Todo ello sin que los monarcas hispanos hubiesen tenido una mayor participación en los hechos.

En un estudio reciente Carlos de Ayala ("Fernando I y la sacralización de la Reconquista") afirma que, en Barbastro, se puede observar claramente la radicalización ideológica de la guerra, en especial, en dos aspectos; el primero de ellos atribuido al Pontificado, corresponde a la responsabilidad del Papado en el primer llamado, claramente definido, a una cruzada con todos sus elementos característicos, como la iniciativa pontificia, la entrega de absoluciones y las recompensas espirituales. El segundo elemento es presentado en contraposición y corresponde el Yihad; para los musulmanes, la caída de Barbastro fue una calamidad, un castigo divino y por ende, su reacción estuvo imbuida de estas ideas. Los islámicos 
El paso definitivo que vendría a señalar la acción directa del Papado sobre la guerra peninsular, ocurriría durante el pontificado de Urbano $\mathrm{II}^{254}$, cuando éste equipararía la lucha en la Península con la Cruzada oriental, pero restringiéndola exclusivamente a los hispanos y aquellos ultrapirinéicos que, por distintas razones, no pudiesen emprender la larga travesía a Tierra Santa, posteriormente, para la conquista de Tarragona, Urbano promovió la campaña prometiendo a los participantes las mismas indulgencias que a una peregrinación ${ }^{255}$.

Varios años después, Gelasio II apoyó directamente la campaña de Alfonso de Aragón, para la conquista de Zaragoza en 1118, otorgando una bula de cruzada para ese propósito, la cual fue predicada por el Arzobispo Bernardo de Toledo, el Obispo Guido de Pescar y el Cardenal Bosón. La captura de la ciudad a los almorávides implicó un hito importante en la guerra, puesto que demuestra cómo se estrecharon los lazos entre el Papado cruzado y los monarcas de la Reconquista ${ }^{256}$.

Respecto a otras formas de estimular la lucha peninsular, el sucesor de Urbano, Pascual II (1099-1118), renovó la prohibición explícita de los hispanos de acudir a la cruzada en Jerusalén, pero en compensación, concedió indulgencias a aquellos que lucharan en Hispania. Al respecto, tenemos el notable testimonio de la Historia Compostellana, que cita una carta del Papa, fechada en $1109^{257}$, apenas diez años de culminada exitosamente la Primera Cruzada:

"P. episcopus seruus seruorum Dei clericis et laicis Al. Regnum habitantibus salutem et apostolicam benedictionem.

Magnum uestre salutis dispendium facitis, quod Apostolice Sedis preceptos obedire contempnitis. Scripsimus enim uobis preterito tempore, ne Iherosolimitane expeditionis occasione partes uestras desereretis, que Maurorum et Mohabitarum cotidianis incursionaribus impugnantur; non parum enim in discessu uestro illorum tyrannidem occidentalibus partibus formidamus. Qua de re nos partium uestratum tam clericos quam laicos, quos lidere potuimus, a Ierosolimitana profectione desistere et ad patriam suam

\footnotetext{
reaccionaron en forma conjunta a esta amenaza y fue bajo un discurso de unidad y redención que emprendieron la pronta reconquista de la ciudad. En otras palabras, la lucha por Barbastro fue el primer enfrentamiento efectuado bajo el discurso religioso-militar entre el Islam y los cristianos en la Península.

${ }^{254}$ En el intertanto, durante el reinado de Alfonso VI, Gregorio VII envío a su legado Hugo Cándido, para reactivar la Reconquista a través de la imposición de las ideas de cruzada.

${ }^{255}$ Flori, Jean, La Guerra Santa ... op. cit., 281, 282; Flori, Jean, Guerra Santa, Yihad,... op. cit., pp. 232, 315; y Goñi Gaztambide, José, Historia de la Bula... op.cit., pp. 60, 61.

${ }^{256}$ Martín, José-Luis, "Reconquista y cruzada... op. cit., p. 218; y De Ayala Martínez, Carlos, Sacerdocio $y$ Reino...op. cit. p. 396-398.

${ }^{257}$ Respecto a la datación del documento, ver nota 357, en HC 1994, Libro I, XXXIX, op. cit., p. 147.
} 
redire precipimus. Latores quoque presentium, Munionem et Didacum et Nunonem cum sequacibus suis, a nobis coactos redire sciatis. Vnde etiam uestre dilectioni precipimus, ne quis eos pro reditu hoc infamare aut calumpniis aliquibus presuma tempere. Vobis ergo omnibus iterata preceptione precipimus, ut in uestris partibus persitentes Mahobitas et Mauros totis uiribus impugnetis, ibi largiente Deo uestras penitentias peragatis, ibi sanctorum apostolorum Petri et Pauli et apostolice eorum ecclesie remissionem et gratiam percipiatis. Datum Laterani VIII Kal. Aprilis" ${ }^{258}$.

La medida pontificia logró bastantes resultados, ya que mantuvo a los hispanos en su tierra y lograr desviar una porción del esfuerzo bélico cruzado de los francos; a pesar de ello, la Reconquista siempre mantuvo un rol secundario en el imaginario cruzado occidental.

En este sentido, la imposición de penitencias se convirtió en un instrumento ideal, para incentivar la participación de ultramontanos en la Reconquista, aunque recién en 1123, algunos años antes de la invasión almorávide de 1145, Calixto II (1119-1124) declarará abiertamente la paridad total entre las cruzadas orientales y la Reconquista ${ }^{259}$. Junto a ello, en el I Concilio de Letrán (1123), se estableció como sanción canónica, para los guerreros laicos, la imposición penitencial del voto de cruzada a Oriente, o bien el servicio de las armas en Hispania, asignando duras penas a quienes incumpliesen sus $\operatorname{votos}^{260}$ :

${ }^{258}$ HC 1988, Liber I, XXXIX, op. cit., pp. 77, 78. "Pascual, obispo, siervo de los siervos de Dios, a los clérigos y laicos que viven en el reino de Alfonso, salud y bendición apostólica.

Gran daño hacéis a vuestra salvación porque os negáis a obedecer los preceptos de la sede apostólica. Pues os hemos escrito hace tiempo que no abandonaseis vuestras tierras, las cuales son atacadas por las frecuentes incursiones de moros y almorávides, para peregrinar a Jerusalén; pues en vuestra ausencia, no poco tememos la tirania de aquellos sobre las regiones occidentales. Por lo cual hemos ordenado, tanto a los clérigos como a los laicos de vuestras tierras que hemos podido ver, que desistan de la marcha a Jerusalén y que regresen a su patria. Sabed también que los portadores de la presente, Munio, Diego y Nuño con sus compañeros, han sido obligados por nosotros a regresar. Por ello, ordenamos a vuestra caridad que ninguno se atreva a infamarlos por este regreso o a acusarles con alguna reclamación. Así pues, ordenamos a todos vosotros con repetido precepto que permanezcáis en vuestras tierras y luchéis con todas vuestras fuerzas contra los almorávides y moros, y alli por la generosidad de Dios, hagáis vuestras penitencias y alli recibáis el perdón y la gracia de los apóstoles Pedro y Pablo y de su apostólica Iglesia. En Letrán a 25 de marzo". HC 1994, Libro I, XXXIX, op. cit., pp. 146, 147.

${ }^{259}$ LSJ, Liber IV, Apendix D, op. cit., pp. 228, 229; García y García, Antonio, Iglesia, Sociedad y Derecho... op. cit. p. 34; O'Callaghan, Joseph, Reconquest and Crusade..., op. cit., p. XI; y Riley-Smith, Jonathan, ¿Qué fueron las cruzadas... op. cit., p. 28.

${ }_{260}$ Aún así, como ya mencionamos, la participación extranjera fue limitada y relacionada con acontecimientos puntuales. A modo de ejemplo podemos recordar que la participación de un número contingente de cruzados nórdicos en la conquista de Lisboa en 1147, se debió al hecho fortuito de que su expedición se vio obligada a recalar en tierras lusas. En 1212 durante la campaña de las Navas de Tolosa, inicialmente, la presencia de ultramontanos fue muy numerosa, pero antes de la batalla decisiva, el grueso de esas tropas habían abandonado la expedición, dando por cumplidos sus votos. 
"En cuanto a los que se han puesto las cruces en los vestidos haciendo voto de ir a Jerusalén o a España y después las han dejado, les ordenamos en virtud de la autoridad apostólica, que vuelvan a tomarlas y se pongan en ruta desde la Pascua próxima hasta la siguiente; de lo contrario, les prohibimos la entrada en la iglesia y la celebración de todo servicio divino en sus tierras, excepto el bautismo de los niños y la penitencia de los moribundos."261

Esta asimilación fue bien recibida por los reyes peninsulares, puesto que impedía una merma de sus guerreros, y por otra parte, les permitía contar con periódicos refuerzos venidos desde Europa. No obstante, se cuidaron de mantener bajo su control las campañas y dirigir la guerra según sus propios intereses, incluido el pactar treguas periódicas y cobrar parias a los musulmanes cuando acaso les conviniese ${ }^{262}$.

Según Antonio García, fue en 1125, mediante un sermón del Arzobispo Diego Gelmírez, donde por primera vez se puede identificar un discurso claramente cruzadista. El prelado exhorta a combatir a los sarracenos peninsulares, al igual que lo han hecho los cristianos en Tierra Santa, dando a entender que ambos frentes de combate eran parte de un único esfuerzo bélico ${ }^{263}$.

El sermón del compostelano enuncia el principal cambio ideológico de la guerra peninsular. Hasta ese momento, el discurso hispano era entendido como la lucha de un conflicto propio, dirigido a la recuperación de las tierras de sus antepasados y a la restauración de su Iglesia perdida; es decir, la Reconquista era vista como algo particular de alcances locales; algo diametralmente opuesto al espíritu de cruzada, que era inclusivo y universal ${ }^{264}$. A pesar de ello, a nuestro juicio, es posible concluir que la

\footnotetext{
${ }^{261}$ Primer Concilio de Letrán, Canon XIII, en Goñi Gaztambide, José, Historia de la Bula...op. cit., pp. $76,77$.

${ }^{262}$ La incomodidad del Papado ante la independencia política de los reyes hispanos, en distintas, épocas queda en evidencia en la documentación pontificia, cuando diversos papas intentaron forzar a la ruptura de treguas o bien promovieron campañas a través del envío de legados o por medio de las Ordenes de caballería. Ejemplo de ello se puede observar en la carta de 1155, del legado cardenal Jacinto exhortando a las ordenes militares y a los prelados hispanos a luchar contra los sarracenos; la carta de Inocencio III, de febrero de 1210, mandando a Jiménez de Rada que exhorte a Alfonso VIII a iniciar la guerra contra los musulmanes, o que al menos no impida a sus súbditos unirse a la campaña iniciada por Aragón, (Mansilla, Demetrio, La documentación pontificia hasta Inocencio III... op. cit., pp. 116, 117, 437). Más potente es la intervención de Honorio III que en diciembre de 1220 manda a los reyes peninsulares autorizar a los calatravos a emprender campañas contra los musulmanes (Mansilla, Demetrio, La Documentación pontificia de Honorio III... op. cit., p. 251).

${ }^{263}$ García y García, Antonio, Iglesia, Sociedad y Derecho... op. cit., p. 35; y Martín Martín, José Luis. “Algunas prácticas clericales... op. cit., p. 410.

${ }^{264}$ García Fritz, Francisco, Las Navas de Tolosa ... op. cit. p. 436. El mismo autor desarrolla de forma más acabada este paralelismo entre la cruzada y la reconquista en su texto, también ya citado, "la Arenga militar en la historiografía de las cruzadas".
} 
idea de cruzada fue aceptada en la Península en razón de sus ventajas, puesto que ahora, para sus campañas, los monarcas podían gozar de los recursos humanos y económicos que Roma podía movilizar.

Por otra parte, esta actividad bélica promovida por la Iglesia requería de un importante esfuerzo económico. Si bien es efectivo que normalmente el botín de una campaña exitosa cubría los gastos de la misma, también era cierto que la preparación de una expedición, así como de las constantes cabalgatas, conllevaba períodos de agitación y tensiones fronterizas. Además, la convocatoria a una cruzada significaba un gasto extraordinario, que exigía a las arcas reales a su máxima capacidad. En estas circunstancias, los monarcas recurrieron a los dineros de la Iglesia. El problema radicaba en que no siempre las autoridades religiosas estaban dispuestas a entregar estos fondos, puesto que las conquistas territoriales y el botín no les generaba el mismo retorno que a los monarcas. De esta manera, en más de una ocasión fue necesaria la intermediación de Roma para financiar las campañas peninsulares. Esto resulta paradójico, ya que anteriormente era Roma la que exigía fondos a los monarcas y a la Iglesia Hispana para financiar las cruzadas de ultramar ${ }^{265}$.

En vista de lo anterior es que se puede concluir que la relación económica entre Castilla y el Papado dependía en gran parte de la coyuntura política y militar que enfrentasen $^{266}$. En general, los aportes económicos de la Iglesia a la guerra podían realizarse producto de una decisión de Roma o de los primados de Hispania, o bien de la acción unilateral de algún monarca que se apoderaba de los bienes de la Iglesia o que coaccionaba a las autoridades eclesiásticas para que se los facilitasen ${ }^{267}$. En esas

\footnotetext{
${ }^{265}$ Fernández Conde, Javier, Historia de la Iglesia en España, II-2 ${ }^{\circ}$...op. cit., pp. 33, 34; García Fitz, Francisco, Relaciones políticas y guerra ... op. cit. p. 149.

${ }^{266}$ Por ejemplo, durante el reinado de Alfonso VI -cuando la irrupción almorávide prácticamente paralizó la Reconquista, produciendo asimismo una fuerte crisis económica, política y militar en León- el Papado declaró la guerra peninsular como cruzada, igual que las destinadas a Tierra Santa, con lo que fomentó el envío de refuerzos militares y obligó a la Iglesia local a contribuir espiritual y materialmente al esfuerzo bélico de Alfonso VI.

${ }^{267}$ Gracias a los avances de la guerra, la Iglesia hispana y en especial la castellano-leonesa, contaba con gran cantidad de riquezas, producto de las donaciones, diezmos y botín recaudados. Situación que aumentaba aún más el interés del Papado por los fondos hispanos. A ojos de Roma, la Iglesia hispana no debía estar exenta de colaborar cuando se trataba de apoyar las Cruzadas orientales. Fiel defensor de esta idea fue Inocencio III, que en razón de sus iniciativas de cruzadas, en 1215 se negó a promulgar la Cruzada en Hispania y por consiguiente, exigió la entrega de las vigésimas, como resultado de esto, los clérigos hispanos obstaculizaron todo lo posible la recaudación de los tributos. Similar fue lo sucedido con el sucesor de Inocencio, Honorio III, que en el IV Concilio de Letrán convocó a la V Cruzada, confirmando el cobro de vigésimas en Hispania. Al mismo tiempo, y en aparente contradicción - aunque quizás siguiendo una estrategia de acercamiento a los hispanos - conmutó a solicitud del Arzobispo Jiménez de Rada, el voto de cruzada oriental a quienes dirigieran su esfuerzo militar a la Reconquista,
} 
ocasiones solían producirse fuertes altercados diplomáticos con Roma, los que sin embargo, rara vez terminaban en algún tipo de sanción contra el monarca o en la devolución de los capitales expoliados, contentándose la Iglesia local con la ampliación de sus dominios sobre las nuevas tierras reconquistadas ${ }^{268}$.

En virtud de lo anteriormente expresado, nosotros creemos que la aceptación de las ideas de cruzada en la Península, en particular entre dirigentes los castellanos y leoneses, se trato de un proceso relativamente rápido. Aunque el uso de la cruzada no fue de carácter permanente, debido, en parte, a las condiciones prácticas dadas por la convivencia entre cristianos y musulmanes. En virtud de ello la introducción de este concepto no significó una trasformación radical en la coexistencia peninsular; al menos no en una primera etapa. Los hispano-cristianos ya conocían al Islam y a los musulmanes, por lo que se puede afirmar que verdadero aporte de la cruzada fue de corte propagandístico, puesto que permitía a los dirigentes cristianos encauzar y

nombrando al "Toledano" como legado de cruzada (Fernández Conde, Javier, Historia de la Iglesia en España, II-2 ${ }^{\circ} \ldots o p$. cit., pp. 33, 34; y García Fitz, Francisco, Relaciones políticas y guerra... op. cit. p. 149).

${ }^{268}$ García y García, Antonio, Iglesia, Sociedad y Derecho... op. cit., p. 13. Como ejemplo de esta situación se puede recordar el caso de Fernando III. Durante su reinado, el Papa Honorio III y sus inmediatos sucesores respaldaron económicamente la lucha en Hispania, eximiendo a Castilla del pago de la vigésima para las Cruzadas orientales. Junto con ello, entregaron al rey las Tercias de Fábrica, o sea, la tercera parte de los diezmos que estaba destinada para la construcción y mantención de las iglesias (Carrillo de Albornoz y Galbeño, Juan, "Fernando III. Sus Campañas... op. cit., p. 138).

Algunos años después, para financiar sus campañas, el "Rey Santo" obtuvo del Papa Inocencio IV un subsidio de 20 mil monedas de oro durante un trienio, provenientes de los monasterios e iglesias de Castilla, además de otorgar indulgencias de cruzada para los participantes ("Litterae executoriae (3 de septiembre de 1236), en Domínguez, Santiago, Documentos de Gregorio IX... op. cit., pp. 474, 475; y Goñi Gaztambide, José, Historia de la Bula ... op. cit., pp. 155, 156).

Aunque la recaudación de estos recursos implicaban una merma para las Iglesias hispanas, no siempre fue objeto de disputas entre los poderes seculares y seglares, puesto que, al menos para el caso de Fernando III, el soberano se preocupó de recompensar de otra manera a los prelados por sus aportes económicos. En especial a Jiménez de Rada por su ayuda no sólo monetaria, sino por su labor guerrera, por la que recibió la villa de Quesada y veinte castillos. Otro beneficiado fue el Obispo de Cuenca, a quién Fernando otorgó el diezmo del almojarifazgo de la recién conquistada ciudad de Córdoba (Fernández Conde, Javier, Historia de la Iglesia en España, II-2...op. cit., pp. 30, 31).

No obstante estas recompensas, en general los aportes económicos de la Iglesia hispana rara vez eran retribuidos, y por lo general, los prelados perdían más de lo que ganaban. En el mediano plazo esto causó una crisis económica en la Iglesia peninsular, que ya se hacía notoria para mediados del siglo XIII y que afectó las relaciones entre los poderes políticos y religiosos.

En ese escenario, uno de los grandes puntos de conflicto entre Roma y la Iglesia Hispana reformada fue la cuestión económica, puesto que demostró el lugar secundario que el Papado daba a la lucha en la Península en relación a las cruzadas en Oriente. El fin del estatus de relativo "aislamiento" que había tenido la Península antes de las reformas implicó que ahora debía aportar parte de sus ingresos al Papado, al igual que el resto de Europa. Esta situación no era bien vista por las autoridades del alto clero hispano, que no querían ver mermados sus recursos, más aún cuando las guerras de reconquista exigían periódicamente la entrega de capitales a los monarcas. El clero castellano protestaba cada vez que tenía ocasión frente a las exigencias económicas romanas, incluso no dudaba en hacerlo cuando estas exigencias estaban dirigidas a financiar alguna campaña de Reconquista, puesto que los clérigos consideraban que este modo de actuar fortalecía al monarca, en detrimento de su propia autoridad (Fernández Conde, Javier, Historia de la Iglesia en España, II-2 ${ }^{\circ}$...op. cit., pp. 46-53). 
reorganizar el esfuerzo bélico, a través del aprovechamiento de un discurso que apelaba a un sentimiento común, una visión integradora, que podía movilizar a los distintos sectores de la sociedad y que además traía aparejado una serie de garantías ideológicas, espirituales y económicas.

Junto a lo anterior, a partir del siglo XII, las intervenciones papales en la Península se hicieron cada vez más frecuentes e influyentes ${ }^{269}$. Por lo que no es de extrañar que en el agitado siglo XIII, cuando se experimentaron avances sin precedentes y se conquistaron grandes territorios musulmanes, las relaciones entre el pontificado y los monarcas más importantes en este proceso, Fernando III y Jaime I de Aragón (12131276), fuesen sumamente activas ${ }^{270}$.

${ }^{269}$ En ocasiones, las acciones pontificias fueron mucho más radicales. Aunque se escapa de nuestro marco geográfico, se puede citar el caso de Celestino III, que exigió a Sancho de Navarra romper sus treguas con los almohades y renunciar al tributo que recibía de ellos, otorgándole a cambio el reconocimiento de su título real. Más cercano a nuestro contexto, está la acción del mismo Papa contra Alfonso IX de León, a quien amenazó con excomulgar si no renunciaba a sus alianzas e intercambios con los almohades y no dejaba de hostigar a Castilla. Finalmente, en 1197 el Pontífice declaró la cruzada contra el rey de León y prometió indulgencias a aquellos que respondiesen a su llamado (Goñi Gaztambide, José, Historia de la bula ... op. cit., pp. 100-102). En este último caso, la intención del Papa fue la neutralización de un reino y de su soberano, ya que no sólo estaba pactando con los enemigos de la Iglesia, sino que además entorpecía el esfuerzo bélico de otros reinos cristianos.

No siempre esta intervención pontificia era favorable para la Península, puesto que a veces las intenciones del Papado eran opuestas a los intereses de los monarcas. Un caso representativo de esto fue el matrimonio entre Berenguela -hija de Alfonso VIII- con su rival Alfonso IX. Fue un enlace concertado para sellar la paz entre ambos monarcas, pero pese a que la alianza no sólo aseguraba la paz, sino que permitiría a ambos reinos concentrarse en los asuntos de la Reconquista, en junio de 1203 Inocencio III les ordenó divorciarse, aludiendo al grado de parentesco de los cónyuges, a pesar de que para esa fecha ya había engendrado a cinco hijos (Ver Mansilla, Demetrio, La documentación pontificia hasta Inocencio III... op. cit., pp. 168, 305). El divorcio sirvió de excusa para que los monarcas reiniciaran sus hostilidades, produciendo una complicada situación en el equilibrio de poderes en la Península, justo en el momento en que ésta estaba a punto de entrar en un serio conflicto contra los almohades. La Iglesia hispana trató por todos los medios de cambiar la decisión papal, y en general las crónicas son bastantes duras con respecto a la intransigencia de Inocencio (Linehan, Peter, España, 1157-1300... op. cit., p. 70).

La explicación para este proceder parece generar consenso en los historiadores actuales. La política papal con respecto a la consanguinidad para los matrimonios se habría convertido en una herramienta fundamental para el control de las monarquías y dinastías de Europa, ya que de esta forma el Pontífice podía intervenir en la formación de alianzas políticas y fomentar aquellas que directamente atendían a sus intereses o que beneficiaban la Iglesia (Pérez de Tudela Velasco, María Isabel, "El concepto de pecado como arma de control político: el matrimonio de Alfonso IX de León y Berenguella de Castilla", en Carrasco Manchado, Ana Isabel y María del Pilar Rábade Obradó (Coordinadores), Pecar en la Edad Media... op. cit., p. 35). En conclusión, la Iglesia supo utilizar la norma de parentesco como una herramienta de coerción política que aseguraba la lealtad de los soberanos.

${ }^{270}$ Debemos destacar que, como factor de esta cada vez más creciente sacralización de la Reconquista, podemos observar cómo, a partir del siglo XIII, se ha producido una consolidación del poder de los monarcas peninsulares, quienes hacen de la restauración de su herencia visigoda y la recuperación de sus territorios ocupados por los enemigos de la Iglesia, su principal bandera de lucha y más efectivo método de legitimar su poder. En esencia los monarcas estaban cumpliendo una misión divina y sus victorias demostraban al conjunto de la sociedad que Dios estaba con ellos y aprobaba sus actos (Goñi Gaztambide, José, Historia de la Bula... op. cit., pp. 15, 16; Maravall, José Antonio, El concepto de España...op. cit., p. 262). 
Ambos monarcas marcaron una nueva etapa en la guerra de Reconquista, puesto que ambos dirigieron con éxito una serie de campañas que lograron grandes conquistas territoriales y la consolidación de sus reinos como "potencias peninsulares". Para ello contaron con la activa participación y apoyo del Papado, que bajo Honorio III (12161227), Gregorio IX (1227-1241) e Inocencio IV (1243-1254), confirmaron la homologación entre sus campañas y las cruzadas orientales, dándole así los estímulos espirituales y materiales para sostenerlas ${ }^{271}$.

En buenas cuentas, la acción del Pontífice inició una nueva etapa en la relación de Roma con la guerra de Reconquista, en la que el Papa actuaría con más independencia respecto de los intereses de los monarcas hispanos ${ }^{272}$. Fue en esta línea que el sucesor de Inocencio, Honorio III nombró en 1217 a Jiménez de Rada como Legado papal, encargado de dirigir una nueva cruzada en Hispania, omitiendo las treguas existentes entre los reyes cristianos y los almohades. ${ }^{273}$ Este hecho inédito

\footnotetext{
${ }^{271}$ Fernández Conde, Javier, Historia de la Iglesia en España, II-2 ${ }^{\circ}$...op. cit., p. 35.

272 Pese a que es cierto que los acontecimientos europeos disminuyeron la atención de los cruzados extranjeros en Hispania, la historia registra algunos episodios notables como el ocurrido en 1217, cuando una flota de cruzados alemanes y flamencos debió buscar refugio en Lisboa, durante su camino a Tierra Santa. Allí fueron convencidos para que capturasen la fortaleza musulmana de Alcacer do Sal. Las autoridades eclesiásticas de la Península aprovecharon la ocasión para pedir a Honorio III que autorizase a los alemanes a permanecer un año en Hispania y colaborar en la Reconquista, además de solicitar el uso de las vigésimas para la guerra peninsular. El pontífice negó la petición en cuanto a la permanencia de los nórdicos, pero si otorgó indulgencias de cruzada a quienes ayudasen a la defensa de la fortaleza recién ocupada. (Mansilla, Demetrio, La Documentación pontificia de Honorio III... op. cit., pp. 76, 78, 106). La decisión del Papa reflejaba la oscilación experimentada en cuanto a la importancia de la lucha en Hispania; muy probablemente, en 1217, Honorio tenía en vista la importancia de la V cruzada debido a los reveses sufridos en Tierra Santa y el fiasco absoluto de la IV cruzada, razones suficientes para no querer restar tropas a la campaña en Oriente. En cambio, en Hispania los esfuerzos parecían rendir frutos y todavía estaba vivo el recuerdo a la gesta de 1212, situaciones que posiblemente impulsaron al pontífice a adoptar una decisión intermedia, es decir, no prescindir de sus tropas, a la vez que estimular el esfuerzo bélico de los hispanos, a través de promesas espirituales.

${ }^{273}$ Lomax, Derek, La Reconquista... op. cit., pp. 173; y González Jiménez, Manuel, Fernando III... op. cit. p. 65.

La preocupación de Honorio respecto a la necesidad de enfrentar al Islam peninsular se hace evidente cuando se constata que, en enero del año siguiente, el pontífice ordenó a importantes prelados, entre otros a los obispos de Tarragona, Burgos y Ávila, ponerse bajo las ordenes del Arzobispo de Toledo, en su rol de legado, en la lucha contra los musulmanes. A ello se suma que, en apoyo de Jiménez de Rada, el Papa también despachó cartas a diversos obispos, ordenándoles reconocer sus derechos, reclamaciones y primacía; el 9 de febrero 1219, le concede a su legado la mitad de las vigésimas de Toledo y Segovia para financiar sus campañas y poco después, en marzo lo autoriza a hacer uso de las tercias con el mismo objetivo. No obstante, el 4 de julio de 1220, Honorio reclama al Arzobispo el pago de las vigésimas, en razón de que éste no habría realizado la campaña ordenada (Mansilla, Demetrio, $L a$ documentación pontificia de Honorio III... op. cit. pp. 119, 124, 125, 160, 226).
} 
implicó que Honorio III pasara por sobre las autoridades regias, rompiendo así toda una tradición diplomática de larga data ${ }^{274}$.

Posteriormente, en 1224, Fernando III acompañó a Jiménez de Rada a capturar la localidad de Quesada. Por ello Honorio no sólo congratuló al monarca, sino que además tomó al rey bajo su protección junto con su familia y la totalidad del reino. Además, ordenó a los arzobispos de Toledo y Burgos predicar la indulgencia para aquellos que acompañasen al soberano en su campaña ${ }^{275}$. De esta forma, premiaba al castellano por el reinicio de la actividad bélica, e intentaba estimular al resto de los magnates hispanos para que siguiesen su ejemplo ${ }^{276}$.

Es importante no perder de vista el hecho de que uno de los objetivos centrales de la Reforma Gregoriana fue el alineamiento de los poderes seculares con el pontificado

\footnotetext{
${ }^{274}$ Si bien inicialmente la decisión de Honorio puede sorprender, lo cierto es que el Pontífice no actuaba de forma precipitada. El plan de Roma y las funciones del Legado trasgredían el aspecto puramente militar; parte importante de la misión de Jiménez de Rada era lograr la paz definitiva, o al menos concertar treguas duraderas entre los monarcas peninsulares y así orientar el esfuerzo bélico de éstos hacia los debilitados almohades (Mansilla, Demetrio, La Documentación pontificia de Honorio III... op. cit., pp. 119, 207, 430). No obstante, Jiménez de Rada obtuvo parcos resultados en su misión, en parte debido a lo limitado de sus recursos; por ello, en 1219, solicitó al Pontífice fondos extraordinarios, así como el otorgamiento de una Bula de Cruzada. Concretamente el Arzobispo solicito al Pontífice que eximiera a Hispania de las vigésimas demandas para la cruzada en Tierra Santa - que habían sido exigidas en el IV Lateranense- y que le permitiese usar ese dinero para financiar la guerra peninsular. Según Francisco García Fitz en la página 149 de su libro Relaciones políticas y guerra. La experiencia castellano-leonesa frente al Islam. Siglos XI-XIII, Sevilla, Universidad de Sevilla, 2002, ya citado en este trabajo, el tema de las vigésimas se convirtió en una frecuente fuente de tensiones entre la Iglesia peninsular y el Papado puesto que, pese a la concesión dada a "el Toledano", el resto de las diócesis estaba obligada a entregar el impuestos para las cruzadas orientales, algo que rechazaban, en demanda de las necesidades de la guerra peninsular, por lo que optaron por poner todo tipo de escollo a la entrega de las vigésimas a Roma, entorpeciendo así los planes del Papado (Goñi Gaztambide, José, Historia de la bula ...op. cit., pp. 144-146).

${ }^{275}$ Goñi Gaztambide, José, Historia de la bula ... op. cit., p. 151.

${ }^{276}$ Luego de una serie de campañas, en 1236 Fernando se apoderó de Córdoba, hecho al que le sucedió un período de paz que se extendió hasta 1240. Durante este lapso, el monarca se concentró en repoblar su más reciente conquista, consciente de la importancia estratégica de la ciudad como punto de penetración en el cada vez más debilitado al-Andalus. Debido al estado del reino, solicitó ayuda a Gregorio IX, quien le otorgó al rey una serie de Bulas y le entregó una importante ayuda económica, consistente en 20.000 áureos o maravedíes durante tres años. Dichas cantidades debían ser pagadas por las iglesias y monasterios de la localidad (Domínguez, Santiago, Documentos de Gregorio IX... op. cit., pp. 474, 475), es decir, que el pontífice si bien estaba ayudando al monarca, no lo hacía recurriendo a sus propios recursos, ya que no se desprendía de los medios entregados por la iglesia castellana.

En 1240, la actividad bélica se reanudó, coincidiendo con la entrega de indulgencias especiales a los caballeros de Alcántara y a los calatravos, así como a quienes los acompañasen en su lucha contra los andalusíes (Goñi Gaztambide, José, Historia de la bula... op. cit., p. 178). Posteriormente, en 1247, Inocencio IV dio un enfático respaldo a las guerras de Fernando III al concederle una parte de las tercias diezmales para financiar sus campañas (Ayala Martínez, Carlos, "Fernando III: Figura... op. cit., p. 85). En ese contexto, en 1248, Fernando III alcanzó su máximo logro al apoderarse de la ciudad de Sevilla. En esta ocasión también contó con el beneplácito de la Iglesia, que celebró su triunfo. El rey murió cuatro años después, habiendo logrado reducir significativamente los estados musulmanes en la península y consolidando el reino unido de Castilla y León. Por sus logros, pese a haber tenido más de algún roce con la Iglesia, por motivos políticos y económicos, el Papa Gregorio IX le llamó "atleta de Cristo" y posteriormente Inocencio IV le otorgó el título de "campeón invicto de Cristo". Finalmente en 1671 fue llevado a los altares, al ser nombrado santo durante el pontificado de Clemente X.
} 
romano; en ese contexto, las cruzadas fueron una de las herramientas que utilizó Roma para demostrar su poder e influencia. Es en razón de ello que, a nuestro juicio, se explica el porque hubo papas bastante reticentes a otorgar las bulas respectivas ante las peticiones de los poderes reales. La cruzada fue una herramienta que debía ser útil al pontífice, ya que mediante ella se jugaba el prestigio e influencia de la Iglesia. Por ello, para el caso hispano la cruzada no está siempre presente, y solamente la vemos aparecer con todas sus características en contadas ocasiones, en especial a partir de los siglos XII y XIII, coincidentemente las etapas de mayor actividad reconquistadora, misma época en que la concepción de cruzada ya se encontraba institucionalizada y difundida. Para ilustrar lo anterior, es posible constatar lo ocurrido durante el reinado de Fernando III, cuando pese a sus múltiples campañas y éxitos militares, recién en 1225 obtuvo la Bula de Cruzada para respaldar sus acciones. En esa ocasión, el Pontífice utilizó la particular formula de quamdiu in minori etate iuerit Rex predictus ${ }^{277}$; es decir, que la Iglesia pasaba a tutelar el reino mientras durase la campaña, asegurándose de esta forma que pese a los éxitos del soberano, este continuaría totalmente sometido a la obediencia romana. Las cosas no fueron muy distintas con Alfonso X, quien debió solicitar una bula para enfrentar la rebelión mudéjar; y mientras ésta le era otorgada, se vio obligado a improvisar en base a bulas anteriores ${ }^{278}$.

$\mathrm{Si}$ bien es cierto que durante el reinado de Alfonso $\mathrm{X}$ la Reconquista experimentó una ralentización, el proceso no se detuvo. El rey tuvo que hacer frente a una serie de dificultades internas, como la rebelión mudéjar, el enfrentamiento con la nobleza local que se resistía a las reformas que quería implementar el rey, y las amenazas externas como el desembarco de los benimerines, a lo que deben sumarse los problemas causados por las ambiciones imperiales del rey. Pese a todo lo anterior, el "Rey sabio", por lo menos en la etapa inicial de su reinado, enfrentó seriamente la guerra contra el Islam, continuando los planes de su padre de controlar el Estrecho y atacar el Norte de África y así neutralizar futuras amenazas. En estos planes contó con el apoyo decidido de la Iglesia ${ }^{279}$.

\footnotetext{
${ }^{277}$ Villacañas Berlanga, José Luis, La Formación ...op. cit., p. 537.

${ }^{278}$ Fernández Conde, Javier, Historia de la Iglesia en España, II-2 ${ }^{\circ}$... op. cit., p. 37; y Mackay, Angus, La España ...op. cit., p. 78.

${ }^{279}$ Al respecto del apoyo papal a las campañas de Alfonso X, a modo de ejemplo se pueden citar las Litterae exsecutoriae del 23, 26, 31 marzo de 1265, (Domínguez, Santiago, Documentos de Clemente IV (1265 - 1268) Referentes a España, León, Universidad de León, 1996, pp. 111, 112, 118, 119), así como la Litterae gratiosae de Gregorio X, de septiembre de 1275, la Litterae secretae dirigida al infante don
} 
Por lo demás, los planes africanos de Alfonso X, interesaron de sobremanera al Papado, en especial debido al fracaso de las últimas cruzadas orientales. Por ello Inocencio IV expidió varias bulas otorgando privilegios espirituales a los que se unieran a la campaña, encomendando también a Franciscanos y Dominicos ${ }^{280}$ que predicasen la cruzada en los reinos hispanos. Por último, concedió al rey las tercias de las rentas de las diócesis de Sevilla y Compostela para que financiaran la expedición.

Finalmente, como ya sabemos, la rebelión del infante Sancho y la posterior división del reino terminó por frustrar los planes cruzadistas de Alfonso X, y creó una situación general que contribuyó a la ralentización de la Reconquista.

Su bisnieto Alfonso XI lograría, con la ayuda papal, el control del Estrecho en el siglo XIV con la conquista de Algeciras en $1344^{281}$. Pero el impulso de la cruzada hispana, nunca volvería a tener la importancia que alcanzó con Fernando III. Después de Alfonso X, los reyes hispanos se concentraron más en la consolidación de sus reinos y en los problemas europeos que en la Reconquista, lo que permitió la supervivencia del al-Andalus hasta el siglo XV, cuando los Reyes Católicos se apoderaron de Granada, con el apoyo de Roma.

En vista de todo lo anterior, podemos sostener que la Reconquista no fue una cruzada continúa, ni una guerra de exterminio; en cambio podemos caracterizarla como un conflicto contra al-Andalus, en la cual se recurrió con cierta frecuencia al argumento cruzadista como forma de promover la conquista territorial. Los soberanos de Castilla y León supieron hacer uso de este hecho de forma prudente, puesto que sabían que junto a cada bula se abría la posibilidad de una mayor intervención pontificia en sus reinos.

En contraparte, el otorgamiento de éstas significaba un importante aporte económico a la guerra, siempre costosa. En esta ayuda eran esenciales las tercias reales, las décimas o vigésimas de la Iglesia y las limosnas solicitadas ex profeso; todas ellas ayudas que venían a reforzar las que la Iglesia Hispana solía aportar tradicionalmente al esfuerzo bélico. A estos estipendios había que agregar las ganancias propagandísticas: sin duda, la cruzada aumentaba el prestigio de los soberanos, puesto que los ligaba

Manuel de septiembre de 1275, y la Litterae solemnes, de octubre de 1275, todas ellas referidas a la invasión merenida (Domínguez, Santiago, Documentos de Gregorio X (1272 - 1276) Referentes a España, León, Universidad de León, 1997, pp. 343, 348, 369).

${ }^{280}$ Ambas órdenes religiosas, de reciente fundación, para mediados del siglo XIII se habían convertido en pieza clave del ejercicio del poder papal, siéndole delegadas varias misiones claves como la evangelización de los paganos y persecución de las herejías europeas, en especial la de los Albigenses.

${ }^{281}$ Mackay, Angus, La España... op. cit., p. 78. 
directamente a lo querido por Dios. Esta fue razón suficiente para apelar a ella con cierta frecuencia como un elemento más en la construcción del poder real, a lo que contribuía su connotación "universal" demostrada en las obras trovadorescas que circulaban por Francia y otros reinos que alababan a los monarcas cruzados hispanos ${ }^{282}$. Por supuesto, esta era una labor que era reconocida por la nobleza europea y el Papado, y que convertía a los hispanos en los defensores de la Iglesia y de Europa. Todo ello sin olvidar que la guerra contra el Islam era ya parte integral de la vida peninsular, esencial en la conformación de su estructura socio-económica.

La Península Ibérica, gracias a sus particulares condiciones durante la Antigüedad tardía y la Edad Media, permite observar este proceso de larga duración. Su pasado glorioso, construido y alabado por los cronistas latinos, fue sucedido por la invasión visigoda, un pueblo cristiano que, de la mano de Isidoro de Sevilla, se consideró bendito por Dios. Sin embargo, en un determinado momento dicha bendición pareció extinguirse y verterse en castigo luego de la invasión del 711 y la destrucción del Reino Visigodo, que dio paso a la creación de nuevos reinos en un principio relativamente aislados del resto de la cristiandad, y en permanente contacto con el Islam.

Es así como en las antiguas tierras de los visigodos convergieron las antiguas y nuevas teorías sobre la guerra; fue como un campo de pruebas donde, de manera temprana, los santos cabalgaron junto con los vivos en la lucha contra los enemigos de la fe, donde la tumba de un apóstol sacralizó toda la tierra y donde el Papado dirigió las primeras huestes de combatientes en una ofensiva bajo las promesas de indulgencia y salvación.

Definitivamente, la particularidad hispana contiene, dentro de sus características, los elementos de la instrumentalización de la religión al servicio de la guerra. En los siguientes apartados de este trabajo ahondaremos sobe la relación entre la política, la religión y la guerra para el caso específico de los reinos de Castilla y León en los siglos XII y XIII, y de qué manera se fue construyendo este discurso instrumentalizado, visible en las crónicas y demás fuentes del período.

${ }^{282}$ Rodríguez García, José Manuel, “Cruzados y fronterizos.... op. cit., pp. 574, 575, 585. 
SEGUNDA PARTE: LAS FUENTES, LA CONSTRUCCIÓN DE INSTRUMENTOS IDEOLÓGICOS 


\section{SEGUNDA PARTE: LAS FUENTES, LA CONSTRUCCIÓN DE INSTRUMENTOS IDEOLÓGICOS}

\section{II.1.- La historiografía medieval, fusión de lo clásico y lo "bárbaro": el caso hispano. \\ II.1.a.- Panorama general.}

La "historiografía medieval", heredera de los estilos y modos de las grandes obras de la antigüedad clásica y tardo romana, presenta sus propias particularidades producto del mundo cambiante en el que se desenvolvió. A partir del siglo V d.C., con el derrumbe definitivo del Imperio Romano y el asentamiento de los llamados pueblos bárbaros en territorios del Mediterráneo, se iniciaron una serie de procesos históricos de largo aliento, en especial, el fenómeno mediante el cual la cultura de los "invasores" se combinó con la de los conquistados ${ }^{283}$.

Por ello fue normal que estos pueblos, pese a ciertas tensiones, se consideraran continuadores de Roma, herederos de su cultura y sus dominios. En la primera parte de este capítulo, pretendemos analizar la historiografía hispana que, partiendo de estas raíces germano romanas, fue evolucionando producto de sus propias particularidades y por la influencia de los distintos grupos humanos que participaron en la conformación de lo que podríamos llamar la España Medieval. Y, en especial, a partir del "quiebre" que significó la invasión musulmana del siglo VIII y la conformación de una nueva sociedad a partir de este hecho, fundamental para la comprensión de la España actual.

Durante el Medioevo, el estudio de la historia era comprendido como inseparable del plan de Dios. La historia era entendida como el relato de la Salvación, una línea recta que comenzaba con la creación del mundo y terminaba con la Parusía, siendo el nacimiento de Cristo un hito que servía de eje articulador en el plan divino. En otras palabras, todos los acontecimientos humanos estaban señalados por el providencialismo, siendo Dios el principal actor y director de la Historia. Esta concepción fue inaugurada por San Agustín (354-430) en su De Civitate Dei, que buscaba una explicación para los

283 Díaz y Díaz, Manuel, De Isidoro al siglo XI. Ocho estudios sobre la vida literaria peninsular, Barcelona, El Albir, 1976, p. 13.

Hay que recordar que en el caso particular de los visigodos, estos habían sido convertidos al arrianismo durante la primera mitad del siglo IV. 
grandes sucesos de su tiempo a la vez que exculpaba a los cristianos de la caída de Roma. Las ideas agustinianas fueron trasmitidas e interpretadas por su discípulo, el hispano Paulo Orosio (c.383-c.420) en su Historiarum adversus paganos ${ }^{284}$, en un sentido político, en el que afirma que todo poder proviene de Dios. Relaciona, por tanto, el pecado de los hombres -en especial el de los gobernantes- con los castigos divinos:

“En verdad, ¿quién puede regular y ordenar nuestras acciones más sabiamente y con más firmeza que Aquel que previó lo que tenía que hacerse y ejecutó lo previsto? Por esto, el hecho de que todo poder y todo gobierno proceden de Dios es sentido por los que no son ilustrados, y reconocido por los que lo son." 285

Estas ideas estarán presentes a lo largo de toda la Edad Media, entendiendo que todos los hechos acontecidos a los hombres se explican por los designios divinos, ya que son parte de un plan de Salvación. Lo anterior lo explica Eloy Benito Ruano de la siguiente manera:

"Toda la historia del Occidente medieval está traspasada de providencialismo. La herencia patrística en la Escolástica que se da en Filosofía tiene su perfecto correlato para la Edad Media en el campo histórico. El mundo historiográfico, aun sin la elaboración de contenidos que realizan los filósofos con su legado, se impregna también, a través de Orosio e Isidoro precisamente, de agustinismo. La magna Filosofía de la Historia alzada en la Ciudad de Dios se hace idea central y permanente en los historiadores del medioevo cristiano. No en una consciente e inteligente apropiación, no en un hábil manejo de tan excelente medio, sino como determinante instintivo, esencial y constante del pensamiento histórico. La Historia medieval no reflexiona, no puede reflexionar hondamente sobre sí misma; acepta los postulados que se le han marcado y, en general, no lo hace por un acto expreso y formulado: de vez en cuando aflora ese ánima interna que vive en ella y se manifiesta como un saber - no ya como un creer (existente sin embargo) y mucho menos como un pensar (que prácticamente no existe) — de sí misma. Cuando el

\footnotetext{
${ }^{284}$ Orosio escribió su obra a incitación de San Agustín, que le encomendó la elaboración de un texto que explicase que las desgracias y calamidades que azotaban al Imperio Romano no se debían a la influencia del cristianismo, sino que correspondía a un Iudicium Dei en respuesta a los actos de los hombres. Por otro lado Orosio plantea que la creación está sujeta a un orden cósmico sostenido por la Providencia, y que solo el respeto a ese orden garantiza la paz y seguridad. Posteriormente Alfonso X retomaría estas ideas en su Crónica General. Para un mayor conocimiento sobre estos temas recomendamos las obras de Luis Gracia Moreno, El fin del Reino Visigodo de Toledo. Decadencia y catástrofe. Una contribución a su crítica y de María del Carmen Jiménez Vicente, La razón de Estado en Alfonso X el Sabio. Paulo Orosio en la Primera Crónica General.

${ }^{285}$ Orosio, Paulo, Historia contra los paganos, Libro II, cap. I, estudio preliminar, versión y notas de Enrique Gallego-Blanco, Barcelona, Puvill Libros, 1983, p. 65. (En adelante HCP).
} 
cronista dice que Dios envió los bárbaros para que pusieran fin a la maldad de los romanos, o permitió la llegada de los árabes como castigo a la lujuria de Vitiza y de Rodrigo, o azotó con las plagas y el hambre a las regiones pecadoras, tal afirmación se consigna como un hecho objetivo más: Dios es entonces tan actor de la historia humana como el monarca que gana una batalla a los moros. Ninguna circunstancia diferencia una noticia de la otra" 286 .

De esta forma, la historia se convierte en un relato ordenado, lógico y racional, enmarcado dentro del plan de la Salvación en el que Dios es el sujeto principal. Él es quien impulsa los acontecimientos y juzga a los hombres, distribuyendo castigos o premios a sus acciones, interviniendo directamente en el desarrollo de los acontecimientos humanos e históricos. Es importante destacar que esta concepción providencialista fue fruto de la herencia y combinación de distintas tendencias de pensamientos, entre los que se deben considerar la tradición judeo-cristiana, los pensadores clásicos y su influencia en los intelectuales cristianos, y la reacción ante el colapso del mundo antiguo con la intromisión de los pueblos bárbaros. Es así como el providencialismo fue la principal ideología que influenció en la casi la totalidad de los de autores medievales cristianos ${ }^{287}$.

Es por ello que, basándonos en los planteamientos de Eustaquio Sánchez, trataremos de generar una caracterización más precisa del providencialismo en su acepción historiográfica. Para este autor toda obra historiográfica cristiana tiene cuatro finalidades: testimonial, es decir, constatar la intervención divina en los hechos humanos; edificadora, en el sentido de que Dios ensalza a los santos y dirige los acontecimientos humanos para edificar a los hombres; apologética, cuyo objetivo es legitimar y exaltar el cristianismo, y finalmente terapéutica, puesto que la narración del pasado ayuda a olvidar el presente ${ }^{288}$. Estos cuatro elementos se pueden observar en la cronística medieval europea e hispana; se desprende entonces, que el providencialismo fue un discurso construido por los cronistas, cuyo fin era trasmitir la idea de la omnipresencia divina y mostrar cómo todos los eventos humanos se encontraban

\footnotetext{
${ }^{286}$ Benito Ruano, Eloy, "La historiografía de la alta edad media. Ideología y Estructura", Cuadernos de Historia de España, XVII, Buenos Aires, Universidad de Buenos Aires, Instituto de Investigaciones Históricas, 1952, [pp. 50-104], p. 55.

${ }^{287}$ Mitre Fernández, Emilio, Historiografía y mentalidades históricas en la Europa Medieval, Madrid, Universidad Complutense, 1982, pp. 27-36.

288 Sánchez Salor, Eustaquio. "El Providencialismo en la Historiografía Cristiano-Visigótica en España" en Anuario de Estudios Filológicos V Universidad de Extremadura, Cáceres, 1982, [pp. 179-192], pp. $180,181$.
} 
sometidos a su voluntad. Así, las acciones de los líderes de la sociedad -como los monarcas, por ejemplo- se amparaban en la convicción de tener un respaldo divino, que explicaba los distintos avatares que los afectaban.

Esta primacía del pensamiento providencialista aplicado a la historia, se traducía en una cierta rigidez al momento de referirse a las fuentes ${ }^{289}$. La historiografía medieval carecía de una verdadera crítica de fuentes y la interpretación de las mismas era prácticamente nula, limitándose solamente a la identificación de aquellos elementos que pudiesen revelar la intervención de Dios en los hechos relatados ${ }^{290}$.

A lo dicho anteriormente es importante agregar que para los primeros estudiosos de la historia -casi exclusivamente miembros del clero- ${ }^{291}$, ésta debía ser entendida como universal, puesto que al ser parte del plan de Salvación se encontraba profundamente ligada a la Iglesia y su "misión universal"292. Por ende, debemos entender que para ellos el objeto de trabajo se refería a todo el orbe conocido, que puede ser resumido como los antiguos dominios del Imperio Romano. Es por ello que muchas de las obras históricas medievales se inician con la creación del mundo, o bien desde Abraham, para luego extenderse en torno al pueblo de Israel y luego Roma ${ }^{293}$. Esta concepción universal fue cambiando a partir del siglo X, cuando el fracaso de las ideas imperiales renacidas por la dinastía Carolingia y luego germánica, dieron paso a una concepción más regionalista del pasado, hasta llegar a lo siglos de la baja Edad Media cuando se produce un renacimiento de las temáticas locales, circunscritas a un territorio delimitado ${ }^{294}$.

\footnotetext{
${ }^{289}$ Según Bernard Guenée, el cronista medieval, condicionado por su época y sociedad, basaba sus escritos en tres fuentes principales: lo que el mismo hubiese presenciado; lo que le fuese relatado por testigos directos de los hechos; las fuentes escritas, en especial documentos de las cancillerías o crónicas anteriores, a las cuales solo recurre en casos de carecer de los dos primeros tipos de fuentes. Además era común el uso de las Sagradas Escrituras como fuente transversal y modelo narrativo (Guenée, Bernard, "Historia", en Le Goff, Jacques y Jean-Claude Schmitt, Diccionario razonado... op. cit., pp. 340, 341).

${ }^{290}$ Orcástegui, Carmen y Esteban Sarasa, La historia en la Edad Media. Historiografia e historiadores en Europa Occidental: siglos V-XIII, Madrid, Cátedra, 1991, p. 18.

${ }^{291}$ Guenée, Bernard, "Historia", en Le Goff, Jacques y Jean-Claude Schmitt, Diccionario razonado... op. cit., pp. 340, 341.

${ }^{292}$ Entendemos por misión universal de la Iglesia, el mandato entregado por Cristo a sus apóstoles durante su ascensión. "Id por todo el mundo y proclamad la Buena Nueva a toda la creación". Marcos 15: 16.

${ }^{293}$ Algunos ejemplos de esta tendencia son la obra Paulo Orosio, Historiarum adversum paganos (siglo V), la Historia Francorum de Gregorio de Tours (siglo VI), Sigeberto de Gembloux y su Chronicon sive Chronographia (siglo XII), Vicente de Beauvais y su Speculum historiale (parte del más amplio Speculum majus del siglo XIII).

${ }^{294}$ Mitre Fernández, Emilio, Historiografía ... op. cit., p. 18.

El hecho de que los "historiadores" medievales fuesen miembros del clero o cercanos a la Iglesia se traducía en que intentasen aplicar su conocimiento respecto a las Sagradas Escrituras en su quehacer cronístico (Guglielmi, Nilda y Adeline Rucquoi (Coordinadoras), El discurso político en la Edad Media
} 
El providencialismo medieval se tradujo, según Eloy Benito Ruano, en un “optimismo metafísico", que se explica como el entendimiento y confianza por parte del cronista de ser parte de un orden superior, donde los acontecimientos escapan del control de los hombres, pero que en cambio están sujetos a la misericordia de Dios ${ }^{295}$.

Es así como se desarrolló una visión sagrada de la historia, que permeaba todas las esferas del relato. De esta manera, para el caso de la Penisula Ibérica, por ejemplo, el rey era un instrumento al servicio de Dios, las guerras contra al-Andalus representaban la lucha contra los enemigos de la cristiandad (al menos en el discurso), y Dios decidía el resultado de las batallas, las que sin importar los bandos, se convertían en verdaderas ordalías donde la Providencia bendecía a los buenos con la victoria y castigaba con la derrota a los pecadores ${ }^{296}$. Bajo este precepto, para los cronistas -según Fernández Conde- todo debía ser interpretado en clave religiosa, predominando la explicación universal para todos los eventos o procesos, aunque detrás de ellos existiesen evidentes motivaciones políticas o socioeconómicas ${ }^{297}$.

No obstante la concepción providencialista, la historiografía medieval no se encontraba limitada en cuanto a la expresión de otras ideas y discursos. Al igual que en otras épocas posteriores, la actividad historiográfica servía para difundir ideas políticas o culturales, del mismo modo que las leyendas o mitos eran usados para trasmitir modelos idealizados que debían servir de inspiración para el público al que iba dirigido la obra, cumpliendo así un rol que podríamos denominar de "propaganda"298. En razón de ello, los relatos históricos, solía girar en torno a la exaltación de Dios, la figura del rey o príncipe, y posteriormente la idea o sentido de pertenencia a un territorio o patria $^{299}$. Al respecto compartimos plenamente las ideas expresadas por José Luis

= Le discours politique au Moyen Age, Buenos Aires, Consejo Nacional de Investigaciones Científicas y Técnicas, Paris, Centre National de la Recherche Scientifique, 1995. pp. 121, 122) De esta forma, es frecuente encontrar parafraseos y citas de la Biblia, e incluso comparaciones más o menos sutiles entre personajes del Antiguo Testamento con aquellos contemporáneos a los cronistas.

${ }_{295}$ Benito Ruano, Eloy, "La historiografía... op. cit., p. 61.

${ }^{296}$ Alvira Cabrer, Martín, "Senhor, per les nostres peccatz', Guerra y pecado en la Edad Media", en Carrasco Manchado, Ana Isabel y María del Pilar Rábade Obradó (Coordinadores), Pecar en la Edad Media, Madrid, Silex, 2008, p. 99; Flori, Jean, La caballeria ... op . cit., 87.

${ }_{297}$ Fernández Conde, Francisco Javier, La religiosidad medieval... op. cit., pp. 91, 92.

${ }^{298}$ Guiance, Ariel, "Morir por la patria, morir por la fe: La ideología de la muerte en la Historia de Rebus Hispaniae", en Cuadernos de Historia de España, LXXIII, Buenos Aires, Instituto de Historia de España, 1991, [pp. 75-104], p. 84; Linehan, Peter, Historia e historiadores ... op. cit., p. 31.

${ }^{299}$ Mitre Fernández, Emilio, “¿Un sentimiento de comunidad hispánica? La historiografía peninsular”, en Historia de España Menéndez Pidal, Tomo XVI, Madrid, Espasa Calpe, 1994, p. 411. 
Martín M., quien se refiere al uso de muchas crónicas y otros textos contemporáneos, como propaganda al servicio de la monarquía, los señores y sus intereses ${ }^{300}$.

Es importante destacar que los textos cronísticos medievales no se definen a sí mismos como políticos, ni siquiera los “espejos de príncipe”, esto es porque la política no se entendía como una disciplina separada, y es por eso que las crónicas se encuentran salpicadas de ideas políticas y morales ${ }^{301}$. En el caso hispánico esta tendencia se acrecentó con la influencia de la Orden de Cluny, que en conjunto con los autores hispanos, convirtieron a los reyes Alfonso VI (1065-1109) y Alfonso VII (1126-1157) en modelos virtuosos de monarcas, exaltándolos no solo a ellos, sino que también a sus $\operatorname{reinos}^{302}$.

Es precisamente en relación a la figura real que las crónicas europeas cumplían el papel fundamental de ser las custodias y trasmisoras de la memoria, entendida como la construcción de un recuerdo identitario que a través de relatos y también omisiones, contribuían a la creación de un discurso legitimador e identificador. Es por ello que el principal protagonista de la cronista occidental será el monarca, dado su rol simbólico de ente ordenador de un territorio, en esencia lo que algunos autores llaman una "memoria regia" 303 .

En líneas generales, la historiografía hispana medieval siguió las mismas pautas que en el resto de Europa, salvo por algunas características propias del desarrollo

\footnotetext{
300 “Quizá de todos los aspectos que se han analizado aquí, uno de los calificativos que mejor designe el sentido que desempeñaron muchas tradiciones y leyendas sea el de propaganda. De manera que se difundian porque ayudaban a dar cohesión a los señores y a sus mesnadas en torno a proyectos del monarca; porque justificaban la actividad militar de los caballeros y contribuían a darles relevancia social; porque fortalecian el sentido de unidad entre poblaciones que, a veces, tenían pocos elementos comunes y las vinculaban en torno a un santuario. Dados los objetivos, parece claro que la influencia de los relatos resulta proporcional al éxito o difusión que lograran entre el público al que estaban destinados" (Martín Martín, José Luis, "La Frontera como entorno legendario", en Toro Ceballos, Francisco y José Rodríguez Molina (Coordinadores), IV Estudios de Frontera. Historia, Tradiciones y leyendas en la Frontera, Jaén, Diputación Provincial de Jaén, 2002, p. 25).

${ }^{301}$ Guglielmi, Nilda y Adeline Rucquoi, El discurso político... op.cit., p. 117; Rodríguez de la Peña, Manuel A., "Ideología política y crónicas monásticas: La concepción cluniacense de la realeza en la España del siglo XII", Anuario de Estudios Medievales, 30/2, 2000, [pp. 681-734], pp. 684-723.

${ }^{302}$ Es por esta particularidad de la historiografía medieval que las cronistas se han convertido en una excelente herramienta para conocer el pensamiento político de sus autores y los sectores socioculturales a los que ellos pertenecían.

${ }^{303}$ Reglego de la Fuente, Carlos, "Restauración diocesana y memoria regia en León y Castilla", en Martínez Sopena, Pascual y Ana Rodríguez (Editores), La construcción medieval de la memoria regia, Valencia, Publicacions de la Universitat de València, 2011. p. 87; Arias Guillén, Fernando, "Honor y Guerra. La tensión entre realidad bélica y el discurso ideológico en la cronística castellana de la primera mitad del siglo XIV", en Hispania, vol. LXIX, N² 232, 2009, [pp. 307-330], p. 307; Le Goff, Jacques, “Rey”, en Le Goff, Jacques y Jean-Claude Schmitt, Diccionario razonado... op. cit., p. 685.
} 
peninsular $^{304}$. Destacando el aporte de Isidoro de Sevilla respecto a la idea de la "unidad hispana". El obispo en su Etimologías ${ }^{305}$ plantea la idea de que Hispania era una unidad integrada, unida por su tradición y pueblo, en esencia una idea "nacional" o local, protagonizada por los visigodos como un pueblo independiente de la tradición romana $^{306}$.

\section{II.1.b.- La historiografía de la Reconquista: Siglos VIII-X}

El impacto de la victoria musulmana produjo profundos cambios en la forma de escribir la historia en la Península. A finales del siglo VIII aparecen los primeros trabajos históricos que responden al Islam, específicamente en Asturias. Estas crónicas se caracterizarán por una clara intención de revelar las causas de la caída de los visigodos, apelando a la explicación del castigo divino por los pecados de los últimos reyes, y por tratar de validar a los monarcas asturianos a través de los hechos de armas, ensalzando su papel de restauradores de la tradición en una clara reducción temática que se aleja de la anterior tendencia universalista ${ }^{307}$.

${ }^{304}$ El objetivo de su estudio del pasado era el de servir de "preparación para la vida", y su redacción estaba en manos de religiosos que se inspiraban en los clásicos de la antigüedad y en las Sagradas Escrituras. Tempranamente fue influenciada por San Isidoro de Sevilla (556-636), quien incluso dividió el quehacer histórico en tres ramas: la Crónica, las Historias y los Anales, división que se mantendrá a lo largo de la Edad Media, aunque no así sus definiciones, que variarán al punto de que finalmente la Crónica englobará a los otros dos géneros (Orcástegui, Carmen y Esteban Sarasa, La historia en la Edad Media... op. cit., p. 28).

${ }^{305}$ Isidoro, Santo, Arzobispo de Sevilla, Etimologías, Versión castellana e introducciones particulares de Luis Cortés y Góngora, Madrid, Biblioteca de Autores Cristianos, 1951; Sánchez Salor, Eustaquio. "E1 Providencialismo... op. cit., pp. 180-184.

${ }^{306}$ Maravall, José Antonio, El concepto de España en la Edad Media, Madrid, Centro de Estudios Constitucionales, 1997, pp. 22, 23.

No obstante, este ideal de unidad debía superar la realidad de que desde la ocupación del territorio por parte de los visigodos, los habitantes se dividieron en dos tendencias: los descendientes de los hispano-romanos, poseedores de la tradición y cultura clásica, y los godos arrianos, propietarios del poder político y bélico. Ambas sociedades coexistieron, pero fue la tradición clásica la que predominó, al lograr imponer la ortodoxia romana y el latín como lengua oficial.

Junto a lo anterior, pese a las ideas de Isidoro, hay que tener presente que para los historiadores medievales europeos e hispanos la historia debía ser comprendida como parte de un todo mayor, cuya función era solo el relato y no la interpretación. A este respecto consideramos prudente citar la concepción de la historia y los historiadores medievales dada por Orcástegui y Sarasa en la página 29 de su libro ya citado: "Todas las diferencias señaladas por los historiadores de la historia medieval en cuanto se refiere a Historia y Crónica no son de naturaleza, sino de grado cuantitativo, en cuanto a la extensión dada al relato. Tanto una como otra se hacen con fines narrativos, y en ningún caso pretende explicar las causas de los hechos sino simplemente contarlos. La razón de este postulado puede estar en la misma mentalidad medieval, en la que cada acontecimiento es un hecho aislado cuya causa es particular, siendo inútil explicarlo de otra manera que no sea por la arbitrariedad de la voluntad humana o divina".

307 Con respecto a lo anteriormente dicho, es importante destacar que los cambios ideológicos que experimentó la Península luego de la invasión del 711, también se relacionan con el hecho de que a partir de ese momento el territorio pasó a estar influenciado por la cultura musulmana, que para ese entonces se extendía desde el al-Andalus hasta el actual Irán. Una cultura islámica que también experimentó 
Es en este marco que se desprenden nuevos temas en la historiográfica hispana. El primero que lamenta la "pérdida de España" ${ }^{, 308}$; el segundo que apela al fin del dominio musulmán, muchas veces combinando ambos temas, y el tercero construye el mito del reino de Asturias como heredero de los Visigodos ${ }^{309}$. Ejemplos de estos nuevos tópicos los podemos observar en diversas obras, algunas de las cuales reseñaremos a continuación.

\section{Crónica Mozárabe de 754}

Respecto a las obras que lamentan la pérdida de España, destaca la Crónica Mozárabe de 754, escrita anónimamente a mediados del siglo VIII y que se basa en las ideas de Isidoro de Sevilla respecto a la concepción de Hispania como unidad cultural $^{310}$. Esta es la primera obra en explicitar una "lamentación por la perdida de España", equiparándola con otros grandes desastres de la historia como las caídas de Babilonia, Jerusalén y Roma ${ }^{311}$. Se inaugura así un tópico muy popular que perduró a lo largo de toda la Edad Media y que no tardará en ser interpretado como un castigo divino por los pecados de los últimos soberanos visigodos 312 . Este "lamento" es un hito en la creación de una concepción histórica en Hispania, y por ello consideramos prudente citarlo in extenso:

"55.- Quis enim narrare quet tanta pericula? Quis dimunerare tam infortuna naufragio? Nam si omnia menbra uerterentur in linguam, omnino nequaquam Spanie ruinas uel eius coth tanque mala dicere poterit humana natura. Sed ut in brebi cuncta legenti renotem pagella, relictis seculi inumerabilibus ab Adam usque

trasformaciones que se relacionan con los ejes de poder que la influenciaron (Mitre Fernández, Emilio, "La historiografía sobre la Edad Media", en Andrés-Gallego, J. (Coordinador), Historia de la historiografía española, Madrid, Encuentro, 1999, p. 68).

${ }^{308}$ Maravall, José Antonio, "La idea de Reconquista en España durante la Edad Media", en Arbor: Ciencia, pensamiento y cultura, 28, 1954, [pp. 1-37], pp. 30, 31.

309 Al respecto del rol del rey dentro del pensamiento reconquistador y el goticismo ver Bronisch, Alexander, "La ideología asturiana y la historiografía en la época de Fernando III", en De Ayala Martínez, Carlos y Martín Ríos Saloma (Editores), Fernando III... op, cit., p. 419.

${ }^{310}$ Según Díaz y Díaz y Mommsen, su autor debió ser un clérigo toledano, en cambio Dozy se decanta por Córdoba como lugar de origen del autor, del mismo parecer es Richard Fletcher. Aparte de eso no existe ninguna otra certeza respecto al autor de la Crónica Mozárabe, aunque se especula que pudo haber sido influenciado por la Crónica de 741 y que el hecho que evitase hacer referencias negativas en cuanto a los musulmanes podría evidenciar un posible origen mozárabe. (Díez Borque, José María (Editor), Historia de las literaturas hispánicas no castellanas, Madrid, Taurus, 1980, pp. 49, 50).

311 Mitre Fernández, Emilio, "La historiografía sobre la Edad Media", en Andrés-Gallego, J., (Coordinador), Historia de la historiografia española, Madrid, Encuentro, 1999, pp. 68-69; Mitre Fernández, Emilio y Martín Alvira Cabrer, "Ideología y guerra... op.cit., p. 301; Sánchez Alonso, B., Historia de la historiografía española. Tomo I. Hasta la publicación de la Crónica de Ocampo (...-1543). Madrid, Consejo Superior de Investigaciones Científicas, 1947, pp. 101-102.

312 Fletcher, Richard, La cruz y la media luna... op. cit., p. 39. 
nunc claribus, quas per infinitis regionibus et ciuitatibus crudelis intulit mundus iste inmundus, quidquid historialiter capta Troia perrulit, quidquit Iherosolima predicta per prophetarum eloquia baiulabit, quidquid Babilonia per scripturarum eloquia substulit, quidquid postremo Roma apostolorum nouilitate decorta martirialiter confecit, omnia et coth ut Spania comdam deliciosa et nunc misera effecta tam in honore quam etiam in dedecore experibit ${ }^{313}$.

\section{Crónica Albeldense y Crónica Profética}

Una crónica que combinaba las tres temáticas mencionadas fue la llamada Albeldense, escrita entre el 881 y el 883 , que relata los acontecimientos previos y posteriores a la invasión islámica ${ }^{314}$. Entre sus particularidades está ser la primera escrita en el norte cristiano, pero su principal aporte radica en ser promotora de la idea de que el Reino Astur es la continuación del desaparecido Reino Godo, concepción patrocinada por el rey Alfonso II (783/791-842), quien restauró en Oviedo los usos y costumbres de la antigua Corte toledana ${ }^{315}$. Para el anónimo autor de la Crónica, la ocupación islámica era un acontecimiento pasajero y los musulmanes pronto serían expulsados de la Península con la ayuda de Dios: "Sarraceni euocati Spanias occupant regnemque Gotorum capiunt, quem aduc usque ex parte pertinaciter possedunt. Et cum eis Xpiani die noctuque bella iniunt et cotidie conflictur, dum predestinatio usque diuina dehinc eos expelli crudelit iubeat."

A la Crónica Albeldense le fue incorporada la Crónica Profética, cuyo autor, inspirado en la profecía de Ezequiel, anunciaba el fin del dominio árabe para el año 883,

\footnotetext{
313 Crónica mozárabe de 754, Capítulo VII, Edición crítica y traducción por José Eduardo López Pereira, Zaragoza, Anubar, 1980, pp. 72, 74 (En adelante CMz). "55.- ¿¿Quién podrá, pues, narra tan grandes peligros?! ¿¿Quién podrá enumerar desastres tan lamentables?! Pues aunque todos sus miembros se convirtiesen en lengua, no podría de ninguna manera la naturaleza humana referir la ruina de España ni tantos y tan grandes males como ésta soportó. Pero para contar al lector todo en breves páginas, dejando de lado los innumerables desastres, que desde Adán hasta hoy causó, cruel, por innumerables regiones y ciudades, este mundo inmundo, todo cuanto según la historia soportó la conquistada Troya, lo que aguantó Jerusalén, según vaticinio de los profetas, lo que padeció babilonia, según el testimonio de las Escrituras, y, en fin, todo cuanto Roma enriquecida por la dignidad de los apóstoles alcanzó por sus mártires, todo esto y más lo sintió España tanto en su honra, como también de su deshonra, pues antes era atrayente, y ahora está hecha una desdicha" CMz, op. cit., pp. 73, 75.

${ }^{314}$ Sánchez Alonso, Benito, Historia de la historiografía... op. cit., pp. 104, 105.

315 Maravall, José Antonio, El concepto de España... op. cit., p. 304. Bodelón, Serafín, Literatura latina de la Edad Media en España, Madrid, Akal, 1989, p. 62.

316 Chronica Albendensia, Cap. XIV, 34, en Crónicas asturianas... op. cit., p. 171. "Los sarracenos ocupan España y se apoderan del reino de los godos, que todavía retienen en parte de manera pertinaz. $Y$ con ellos los cristianos día y noche afrontan la batalla y cotidianamente luchan, hasta que la predestinación divina ordene que sean cruelmente expulsados de aqui" Cronica Albeldense, Cap. XIV, 34, op. cit., p. 244.
} 
una vez pasados ciento setenta años desde la invasión ${ }^{317}$. El hombre designado para el cumplimento de la profecía era el rey Alfonso III (866-910), en cuyo reinado se produjeron importantes victorias y avances territoriales ${ }^{318}$. Por ello no es extraña la aparición de una crónica que profetizara estos éxitos, de tal forma que queda patente la intención de legitimar la monarquía por parte de esta corriente ideológica.

\section{Crónica de Alfonso III}

El rey Alfonso III habría sido el autor o patrocinador de la Crónica que lleva su nombre. De ella existen dos versiones, que Linehan nos recuerda son bastante divergentes en sus contendido ${ }^{319}$. La primera llamada Rotense escrita entre el 883 y el 884, según los autores de la edición de 1985, es de un estilo tosco y poco cuidado, en cambio la versión conocida como A Sebastián es una elaboración más cuidada de la primera; pese a ello, fue la versión Rotense la más difundida y usada como fuente en las crónicas posteriores $^{320}$. La importancia de esta obra radica en la consolidación de la idea de la "pérdida de España" y la continuidad del Reino Visigodo en Asturias ${ }^{321}$. Ambos hechos usados para validar el poder del rey, justificar su papel de defensor de la Iglesia y sancionar la expansión territorial del reino, lo que permite, además, encuadrar la obra como una "historia oficial" de temática "nacional"322.

Esta obra también nos recuerda que a partir de las primeras crónicas asturianas, y en menor medida en los anales, la historiografía hispánica tendrá como protagonista recurrente a los reyes y sus actos, en especial en el marco bélico, debido a las particulares circunstancias relacionadas con la presencia árabe en la península ${ }^{323}$. Los

\footnotetext{
${ }^{317}$ Orcástegui, Carmen y Esteban Sarasa, La historia en la Edad Media ... op. cit., p. 131.

${ }^{318}$ Es importante recordar que este monarca marcó un hito en la lucha contra el Islam, al derrotar en distintas ocasiones a los andalusíes, consolidar la frontera hasta el Duero y trasladar la Corte hasta León.

${ }^{319}$ Linehan, Peter, Historia e historiadores... op. cit., p. 123.

${ }^{320}$ Ruiz de la Peña, Juan Ignacio, "La cultura en la corte ovetense del siglo IX”, en Crónicas asturianas... op. cit., p. 34.

${ }^{321}$ Barbero y Vigil, en su texto La formación del feudalismo en la Península Ibérica son enfáticos en afirmar que el discurso neogótico se convirtió en un tópico cronístico a partir del reinado de Alfonso III, siendo un recurso discursivo utilizado para explicar la caída del reino toledano y la conformación del Reino Astur. No obstante, según los autores, al hacerlo los cronistas cayeron en un círculo de incoherencia y contradicciones, dadas por el hecho de que el reino Astur se localizó en las regiones del norte, donde los astures habían luchado contra los visigodos y mantenido su independencia de ellos, algo que evidentemente entraba en conflicto con las intenciones de sostener una continuidad gótica. Este problema no pudo ser resuelto por los cronistas, que pese a ello, lo continuaron utilizando y perpetuaron.

${ }^{322}$ Sánchez Alonso, Benito, Historia de la historiografia... op. cit., p. 107; Orcástegui, Carmen y Esteban Sarasa, La historia en la Edad Media ... op. cit., p. 130.

${ }^{323}$ Respecto a la idea de discurso oficial nos basamos en el trabajo del profesor Maílo Salgado, $U n$ análisis del discurso histórico: La ideología (lección teórico-metodolólogica), en el sentido de que en las fuentes tan importante como lo que se encuentra explicito es lo que no se dice, dada que las omisiones o exaltaciones responden a las necesidades del momento y las intenciones de o los autores en relación a la
} 
monarcas tuvieron desde temprano un papel fundamental en torno al cual se aglutinaron valores y tradiciones que sumados a la misión de reconquista y a la concepción de que su poder terrenal venía dado por Dios -y por lo tanto estaba en estrecha relación con la Providencia, ante quien eran responsables-. Fue así que los cronistas, siguiendo la tradición historiográfica visigoda, dotaron a las figuras reales de características particulares que los convirtieron en imágenes unificadoras y de fácil identificación, en torno a los cuales era posible desarrollar los relatos argumentales de las crónicas ${ }^{324}$.

Es importante señalar que entre los siglos IX y XIII la cronística hispana fue adoptando sus características discursivas definitivas, en especial en cuanto a las ideas de restauración y consolidación monárquica. Se trató de un proceso evolutivo que podemos ordenar, basándonos en la clasificación hecha por Torres Sevilla, esencialmente en cuatro etapas, con sus respectivas obras cronísticas representativas. La primera de estas etapas correspondería al siglo IX, expresada en el llamado "Ciclo de Alfonso III" y por lo tanto vinculado al escenario asturiano. En una segunda etapa, durante los siglos $\mathrm{X}$ al XII, el foco historiográfico se traslado a León expresando en textos como la Crónica Silense/Legionense y la Crónica del Obispo Pelayo de Oviedo ${ }^{325}$. En esta etapa, el siglo XII fue fundamental en cuanto a la introducción de la cronística castellana, además de un incremento de la actividad historiográfica en general, reflejada en obras como la Historia Compostelana, el Liber Sancti Iacobi, la Crónica Anónima de Sahagún, la

trasmisión de ciertas idas. De esta manera se establece que todo texto tiene un discurso enmarcado dentro de una ideología y que solo es totalmente descifrado cuando consideramos también lo que podríamos llamar lagunas intencionadas. Una ideología entendida, según el autor, de forma amplia, como constituida por un conjunto de opiniones, gustos, prejuicios, lealtades, valores y diversos estándares incluso estéticos y morales. En esencia la ideología, entendida como reflejo de una sociedad, su autocomprensión y la visión del otro $\mathrm{Y}$ que es trasmitida a través de un sistema de valores contendidos en los diversos conceptos vinculados a las palabras utilizadas para la trasmisión del discurso. Estos conceptos, más concretamente su significado, permiten la construcción de tipos ideales, o estereotipos que por sus alcances facilitan la trasmisión y comprensión del mensaje discursivo.

${ }^{324}$ Barkai, Ron, El enemigo en el espejo... op. cit., p. 80; García Fitz, Francisco, Castilla y León... op. cit., pp. 279, 280; Isla Frez, Amancio, "La construcción de la monarquía en León, siglos X y XI: Historias y Leyes”, en Martínez Sopena, Pascual y Ana Rodríguez (Editores), La construcción medieval de la memoria regia, Valencia, Universitat de Valencia, 2011, p. 37.

Es importante señalar que esta caracterización del monarca no era totalmente exclusiva de la Península. En toda Europa los monarcas se convirtieron en los protagonistas de la historia y en imágenes modélicas, que encabezaban las construcciones ideológicas que servían de inspiración para los magnates europeos. Una situación que George Duby sintetiza notablemente en la página 23 de su libro La Época de las Catedrales, arte y sociedad 980-1420 “Modelo de la perfección terrenal, la figura real se instaló en la cima de todas las construcciones mentales que pretendian entonces dar un orden al universo visible. Arturo, Carlomagno, Alejandro, David, todos los héroes de la cultura caballeresca fueron reyes y todos los hombres de la época, ya fuesen sacerdotes, guerreros o incluso campesinos, pretendian asemejárseles. Es necesario ver en la permanencia del mito de la realeza uno de los caracteres más definitorios de la civilización medieval."

${ }^{325}$ Torres Sevilla, Margarita, "La propaganda del poder y sus técnicas en las crónicas leonesas y castellanas (Siglos IX-XIII)", en Aragón en la Historia, N 18, 2004, [pp. 57-82], pp. 61, 62. 
Crónica Najerense y la Adelfonsi Imperatoris. Es a partir de estas obras, donde se observa una fusión de las temáticas castellanas y leonesas, y se establecen las pautas que regulan la cuarta etapa cronística en el siglo XIII, donde observamos un discurso ideológico y propagandístico prácticamente definido ${ }^{326}$.

En función de lo anterior en los próximos apartados procuraremos caracterizar las principales obras entre los siglos IX y XIII ${ }^{327}$.

\section{II.1.c.- La historiografía de la Reconquista: Siglos XI-XIII}

Mientras que en la Península ocurrían estos cambios políticos y estratégicos, la historiografía también experimentaría algunas trasformaciones. En el siglo XI, a partir de la expansión hacia el sur, el foco del quehacer historiográfico se trasladará desde Asturias al Reino de León, que en el siglo XII compartirá este espacio con la pujante Castilla, sin lograr recuperar el espíritu universal de las primeras crónicas godas. A partir de este momento y hasta el siglo XIII, la llamada "época de oro" de la historiografía hispana medieval, se comenzaran a ver obras de carácter "hispánico", - en especial Juan de Osma, Lucas de Tuy, Rodrigo Jiménez de Rada y los talleres Alfonsíes -, que sin embargo retoman el relato universal como punto de partida para la trasmisión de los acontecimientos particulares de los reinos peninsulares ${ }^{328}$. Un fenómeno que puedes ser explicado, a nuestro entender por el contexto de la Reconquista, sus grandes avances territoriales y la reorganización de los equilibrios políticos ejemplificados en la unión de Castilla y León.

Junto a lo anterior, la actividad cronística de ese siglo vino a compensar la poca producción historiográfica que había caracterizado a los cronistas hispanos desde la elaboración de la Crónica Najerense a finales del siglo XII, razón por la cual cobra más

\footnotetext{
${ }^{326}$ Torres Sevilla, Margarita, "La propaganda del poder... ibidem.

${ }^{327}$ Si bien la Historia Compostelana, el Liber Sancti Iacobi, la Crónica Anónima de Sahagún, la Crónica Najerense y la Adelfonsi Imperatoris, son textos leoneses, escritos en la época en que Castilla conformaba parte de ese reino, consideramos importante su estudio, puesto que fundamentales para comprender las raíces del discurso, sus características e evolución posterior en el escenario castellano.

328 Juan de Osma, Lucas de Tuy y Rodrigo Jiménez de Rada, fueron parte de la misma generación de autores, que escribieron sus crónicas en la misma época, distanciándose alrededor de una década en la elaboración de sus trabajos. Coincidentemente los tres cronistas, si bien tienen algunas particularidades en sus ejes narrativos, comparten el mismo hito de cierre de sus trabajos, que son los episodios relativos a la conquista de Córdoba por Fernando III. Al respecto ver Bautista, Francisco, "Genealogía y leyenda", en e-Spania [En línea], 7 | juin 2009, Puesto en línea el 16 agosto 2010, URL: http://espania.revues.org/18086; DOI: 10.4000/e-spania.18086, (octubre 2013).
} 
importancia el estudio de las intenciones y discursos detrás de cada una de las crónicas $^{329}$.

Con respecto a los temas tratados en las crónicas y demás textos históricos, se verá la introducción de otros personajes como guerreros y religiosos, sin que ello significara un desmedro por la figura del monarca, que seguirá siendo un importante símbolo político y "nacional"330. En tanto que la guerra y la lucha contra el Islam continuara siendo uno de los ejes centrales de los relatos cronísticos, estrechamente vinculados a la trasmisión de las atribuciones y poderes de la monarquía ${ }^{331}$.

En forma paralela a lo anteriormente dicho, los relatos se tornarán más dinámicos y literarios ${ }^{332}$. Más importante es que los textos comenzarán a reflejar un pensamiento

${ }^{329}$ Crónica del Emperador Alfonso VII, Introducción, traducción, notas e índices por Maurilio Pérez González, León, Universidad de León, 1997, pp. 9, 10 (En adelante CEA); Sánchez Alonso, Benito, Historia de la historiografia...op. cit., p. 92; Baloup, Daniel y Philippe Josserand, "Du Jourdain au Tage”, en Baloup, Daniel y Philippe Josserand (Editores), Regards Croisés sur la Guerre Sainte. Guerre, Idéologie et Religion Dans L'espace Méditerranéen Latin (XI-XIII Siècle), Toulouse, CNRS-Université de Toulouse-Le Mirail, 2006, p. 294; Rodríguez López, Ana, "Sucesión regia y legitimidad política en Castilla en los siglos XII y XIII. Algunas consideraciones sobre el relato de las crónicas latinas castellano-leonesas", en Isabel Alfonso, Julio Escalona y Georges Martin (Coordinadores), Lucha Política. Condena y legitimación en la España medieval, Annexes des Cahiers de linguistique et de civilisation hispanique medievales, Vol. 16, 2004, p. 204; Bautista, Francisco, "Genealogía y leyenda", op. cit.; Arizaleta, Amaia, "Topografías de la memoria palatina: los discursos cancillerescos sobre la realeza (Castilla, siglos XII y XIII)”, en Fernández de Larrea, Jon Andoni y José Ramón Díaz de Durana (Editores), Memoria e Historia. Utilización politica en la Corona de Castilla al final de la Edad Media, Madrid, Silex, 2010, p. 48.

Es importante recordar que ya para el siglo XIII cobran importancia las fuentes escritas, apreciándose un aumento de referencias documentales. Esto, sin embargo, no significó el desarrollo de un trabajo crítico de fuentes del tipo científico, el que sólo aparecerá a partir del Renacimiento (Orcástegui, Carmen y Esteban Sarasa, La historia en la Edad Media... op. cit., pp. 45-48). Esta transformación se produjo debido a la creciente organización estatal y la consolidación de las Cancillerías Reales tanto en España como en el resto de Europa. En su conjunto, estos factores impulsaron a la historiográfica peninsular, que hasta ese momento se encontraba en franco atraso en relación al resto del continente, lo que habria expresdo en una menor producción de obras históricas y en un escaso uso de fuentes (Barkai, Ron, El enemigo en el espejo... op. cit., pp. 203; Fernández Conde, Francisco Javier, La religiosidad medieval... op. cit., p. 358).

En cuanto al rol de las cancillerías, en los últimos años han aparecido una serie de trabajos que estudian la relación entre las cancillerías y la creación de un discurso histórico, destinado a exaltar la memoria regia. Según esos autores las cancillerías fueron una importante herramienta de legitimación real, en especial a través de la intitulación, puesto que allí se destacaba linaje, posesiones, aspiraciones y logros del monarca. No siendo casualidad, además que algunos cronistas del siglo XIII hayan estado involucrados con las Cancillerías reales. Para una comprensión más acabada de estos planteamientos dirigirse a Calderón Medina, Inés, "La Memoria de los reyes de León (1157-1230)", en Martínez Sopena, Pascual y Ana Rodríguez (Editores), La construcción medieval ... op. cit., p. 175, 180-184; y Estepa Díez, Carlos, "El reino de Castilla de Alfonso VIII (1158-1214)", en Estepa Díez, Carlos y otros, Poder real y sociedad: estudios sobre el reinado de Alfonso VIII (1158-1214), Universidad de León, León, 2011, p. 49.

${ }^{330}$ Nieto Soria, José Manuel, "Ideología y poder monárquico en la Península”, en La Historia medieval en España. Un balance historiográfico (1968 - 1998), XXV Semana de Estudios Medievales Estella, 14 a 18 de julio de 1998, Pamplona, Gobierno de Navarra, Departamento de Educación y Cultura, 1999, p. 346.

331 Arias Guillén, Fernando, "Honor y Guerra... op. cit., p. 309

${ }^{332}$ Estévez Sola, Juan Antonio, “Chronica Naierensis e Historia Silensis”, en e-Spania [En línea], 7 | juin 2009, puesto en línea el 21 noviembre 2011, URL: http://e-spania.revues.org/18048 ; DOI : 10.4000/espania.18048 (octubre 2013) 
más crítico y cuestionador, menos providencial o determinista. Hará su aparición un modelo más filosófico claramente inspirado en las obras del periodo clásico, lo que ha llevado a algunos autores a referirse a la aparición de un "humanismo" medieval reflejado en la literatura de carácter histórico ${ }^{333}$. Estos cambios también son observables en otros territorios europeos, no obstante en la Península se experimentó este proceso con algunas particularidades, en especial en lo referente a los autores, que continuaban siendo en su mayoría anónimos y miembros de la Iglesia. Paralelamente, en este periodo los monjes cluniacenses cederán paso a autores hispanos, muchos de los cuales también habían sido educados en el extranjero y pertenecían al clero ${ }^{334}$.

Es, sin embargo, en el elemento ideológico donde podremos presenciar trasformaciones de mayor relevancia. Atestiguable en la revitalización del pensamiento de San Isidoro, así como un nuevo interés por la historia local, e incluso "nacional", tomando como punto de partida la antigüedad clásica -en especial en relación a los emperadores romanos de origen hispánico, Trajano, Adriano y Teodosio- se postulará la existencia de una unidad cultural y territorial, a la que se suma el lamento por el territorio perdido y el llamado a su recuperación. Se produce entonces una exacerbación hacia lo que se considera propio, en contraposición con lo extranjero. Serán notorios los ejemplos por diferenciarse de los territorios francos, exaltando los particularismos hispanos $^{335}$. Todo ello mientras el trabajo de los cronistas sigue respondiendo a

\footnotetext{
${ }^{333}$ Orcástegui, Carmen y Esteban Sarasa, La historia en la Edad Media ... op. cit., pp. 198, 199. En su trabajo "La ideología asturiana...", Bronisch sostiene que durante el siglo XIII los cronistas continuaron teniendo un discurso providencialista, pero que cambiaron el sentido del hecho providencial, adoptando una visión más general del problema y menos concreta, reflejando así como esta creencia se encontraba incorporadas a la cultura y discurso cronístico, no obstante que ya se habían definido otros ideales como el goticimo. Según el autor, en casos como el Chonicon Mundi, se trata de un cambio en la cosmovisión providencialista, asumiendo aspectos como la defensa del catolicismo, la Gracia que favorece a la Península y la idea de la recuperación del solar godo, como parte de una cultura ya establecida y que por lo tanto no requería de mayores justificaciones discursivas (Bronisch, Alexander, "La ideología asturiana..., op. cit., pp. 438-441, 443).

${ }^{334}$ Gil, Juan, "La Historiografía", en Historia de España Menéndez Pidal, Tomo XI, Madrid, Espasa Calpe, 1995, p. 83; y Fernández Conde, Francisco Javier, La religiosidad medieval... op. cit., pp. 358, 359.

No obstante las innovaciones cronística de los siglos XII y XIII, concordamos con Estévez Sola, cuando en su articulo "Chronica Naierensis e Historia Silensis" nos recuerda que por lo general la cronística peninsular se basada en la compilación de obras anteriores - normalmente carentes de una verdadera intención narrativa o critica - muchas de las cuales eran copiadas, casi de forma textual, con la salvedad que se le incorporaban nuevos episodios, ocurridos con posterioridad. En otras palabras, en muchos casos los cronistas actualizaban textos más antiguos o en el mejor de los casos adaptaban parte de su contendido para adaptarse mejor a las intenciones del autor.

${ }^{335}$ Mitre Fernández, Emilio, Historiografia ... op. cit., pp. 88-90; Maravall, José Antonio, El concepto de España ... op. cit., pp. 22, 23; y Orcástegui, Carmen, op. cit., p. 227.
} 
utilidades políticas de legitimación y justificación de las acciones de las monarquías a las que sirven ${ }^{336}$.

Esta diferenciación discursiva tambien se hallaba presente al interior de los territorios hispano-cristianos, como fue el caso de Castilla y León, a partir de su separación XII y sus frecuentes enfrentamientos. El reino castellano construyó su discurso identitario a partir de una raíz común con la tradición leonesa, pero en forma paralela elaboro una identidad propia basada en la exaltación de sus héroes locales, algunos míticos y otros reales (similar a la tradición de Pelayo) como fueron los casos de Fernán Gonçalez, los Jueces de Castilla y el Cid, a los que se fueron uniendo los reyes castellanos, teniendo todos ellos como denominador común el ser presentados como grandes guerreros, vencedores de los musulmanes, piadosos y favorecidos por Dios, justicieros y legítimos rivales ante las injusticias cometidas por otros reyes cristianos, especialmente León. Se trataba entonces de construir un discurso propio y diferenciador de la tradición asturiana y leonesa, para así recalcar la independencia castellana, lo que viene a explicar, para el siglo XII y XIII, el fortalecimiento de figuras providenciales castellanas, como San Millán o grandes héroes como el Cid y nuevos hitos de la Reconquista castellana como es el caso de las Navas de Tolosa, que los cronistas del siglo XIII describen en profundidad y de forma extensa, ocupando un lugar destacado en los relatos cronísticos y en ocasiones eclipsando victorias pretéritas vinculadas a la tradición leonesa, como fue el caso de la batalla de Covadonga ${ }^{337}$.

Dos crónicas fueron ejemplares respecto a este giro castellanista, la Chronica Naierensis y la Historia Silensis/Legionense, sobre las que volveremos luego ${ }^{338}$.

\footnotetext{
${ }^{336}$ Benítez Guerrero, Carmen, La imagen del rey en la cronística castellana. Propaganda y legitimación durante la primera mitad del siglo XIV, Madrid, La Ergástula, 2014, pp. 49, 50.

${ }^{337}$ La batalla de Las Navas tiene una figuración destacada en los Anales Toledanos, en la Historia de Rebus Hispaniae que le dedica a la batalla y a Alfonso VIII los capítulos 35 y 36 del libro VII y la totalidad del libro VIII (mientras que a Covadonga solo dedica los capítulos 1 y 2 del libro III, en tanto que la dedicación a Las Navas y Alfonso VIII es solo comparable con el espacio dedicado a Alfonso VI que abarca todo el Libro VI) Lucas de Tuy por su parte dedica menos espacio a la batalla, centrándose más en las relaciones entre León y Castilla, en cambio se extiende sobre episodios mas antiguos. La Crónica Latina de los Reyes de Castilla también dedica a Alfonso VIII y Las Navas un espacio considerable, por su parte en la Crónica de veinte reyes la batalla también destaca en el relato, extendiéndose entre los capítulos 27 y 38 del Libro XIII. Finalmente la Crónica General de España, siguiendo el relato de Jiménez de Rada, le dedica a Las Navas los capítulos 1008 al 1021, mientras que a Covadonga le da una importancia menos, reseñándola en los capítulos 566 al 568, algo similar a lo ocurrido con la batalla de Clavijo y la aparición de Santiago narradas en los capítulos 628 a 630 . Todo lo que nos lleva a resaltar la batalla de las Navas como uno de los electos más importantes en el discurso validador de Castilla en vista de su union con el Reino de León.

${ }^{338}$ Francisco Bautista, recordando el trabajo de Ramos y Loscertales, recuerda la interpretación de estas dos fuentes como representantes de los intentos de validación real. Es así como la Chronica Naierensis tendría el objetivo de justificar la sucesión de Fernando en Castilla, mistras que la Historia Silense
} 
En síntesis, es durante el siglo XIII cuando se alcanza un momento cúlmine en la historiografía castellana, en que se observa una gran producción literaria que pugnará por ser independiente de las influencias foráneas. Es una historiografía mixta que combinará los acontecimientos universales con los locales. Ejemplo de ellos serán Rodrigo Jiménez de Rada y Lucas de Tuy ${ }^{339}$.

Es así como las crónicas hispanas, sin olvidar su carácter de oficiales u oficiosas $^{340}$, construyeron un discurso destinado a legitimar la Reconquista, como una campaña dirigida por los monarcas bajo el auspicio de la Providencia, con el objeto de recuperar las tierras de los godos y derrotar al Islam en su interpretación como enemigos del cristianismo ${ }^{341}$. En ese sentido, el discurso de las crónicas es inseparable del tema islámico. Los cronistas definieron la identidad hispánica a través del conflicto con el Islam, creando una idea de unidad basada en la herencia goda y en la lucha contra los enemigos de Dios. En otras palabras, y siguiendo los postulados de Barkai, el discurso cronístico se construyó, entre otros elementos, sobre la concepción ideológica del “otro", el opuesto. Razón por la cual se aprovecharon todas las instancias posibles para

pretenderia poner en duda la legitimidad real de Aragón (Bautista, Francisco, "Genealogía y leyenda", op. cit...)

${ }^{339}$ En vista de todo lo anterior, las crónicas son una fuente indispensable para el estudio de las mentalidades e ideologías en la España medieval. Barkai las define como las fuentes más adecuadas, por ser obras escritas por las elites intelectuales y dirigidas a la elite política, lo que reflejaría las ideas de las clases dirigentes de la sociedad (Barkai, Ron, El enemigo en el espejo... op. cit., pp. 14, 15). Sin embargo, concordamos con Ana Belén Paniagua y Martín Alvira, que si bien rescatan la importancia de las crónicas como fuentes, difieren en cuanto a su utilidad tomando una postura más cauta, ya que las mismas características que nos hacen alabarlas como fuentes deben causarnos desconfianza en cuanto a su objetividad e intenciones, puesto que es indiscutible que las crónicas son idealizaciones de la realidad, visiones parciales que además contienen discursos claramente identificables con intenciones pedagógicas y políticas, que no necesariamente responden a la realidad de las sociedades que las crearon, sino más bien al modelo idealizado al cual aspiraban (Paniagua Lortau, Ana Belén, "Consideraciones sobre la imagen de los musulmanes en la Gran Crónica de Alfonso XI", en Toro Ceballos, Francisco y José Rodríguez Molina, (Coordinadores), IV Estudios de Frontera... op. cit., p. 420; Alvira Cabrer, Martín, Guerra e ideología en la España medieval: cultura y actitudes históricas ante el giro de principios del siglo XIII: batallas de Las Navas de Tolosa (1212) y Muret (1213), Tesis inédita, Madrid, Universidad Complutense, 2003, p. 15)

${ }^{340}$ Entendemos por crónicas oficiales aquellas que fueron escritas bajo el alero de la monarquía y por autores cercanos a algún monarca en particular. En estos textos existe un discurso claramente identificable dedicado a la exaltación del monarca, su linaje y su reino, siendo común, en especial durante el siglo XIII, que el cronista reconozca estas motivaciones. Ese es el caso de la Chronica Adefonsis Imperatoris, los textos de Jiménez de Rada, la Crónica Latina de los Reyes de Castilla o la obra cronística alfonsí, entre otras.

Por oficiosas comprendemos aquellos textos que si bien tienen una función discursiva y muchas veces de abierta exaltación a un monarca, reino u otro personaje, no responden a una patrocinio directo del aludido, siendo el producto de una iniciativa particular que a través del texto busca la alabanza como medio de conquistar o fortalecer alianzas, Un ejemplo bastante claro de ello es la Crónica Anónima de Sahagún, como veremos más adelante.

${ }^{341}$ García Fritz, Francisco, Las Navas de Tolosa ... op. cit., p. 389-391. 
la exaltación del conflicto, siempre procurando mantener una línea argumentativa legitimadora. Ejemplo claro de ello es la obra de Jiménez de Rada, que dedica distintos espacios a la descripción del Islam, su historia y características, destacando los aspectos más negativos de sus adversarios ${ }^{342}$. En el mismo sentido, no es de extrañar que el relato de la batalla de las Navas de Tolosa sea el de mayor extensión en los Anales Toledanos, siendo un texto donde el foco parece estar en la descripción de fenómenos naturales llamativos $^{343}$.

Todo lo anterior, debe ser comprendido sin perder de vista que este discurso o actividad propagandística fue llevada a cabo por miembros de la Iglesia, hombres concientes de la necesidad de triunfar sobre los enemigos de su fe, para lo que se hacía necesario fortalecer la concepción ideológica de la monarquía como brazo secular en esta lucha; la misma que debía ser comprendida como la ejecución de la voluntad divina, convirtiendo todo el asunto en un tema providencial ${ }^{344}$.

\footnotetext{
${ }^{342}$ A modo de ejemplo, podemos señalar la primera mención que "el Toledano" hace de Mahoma y el Islam: "Huius temporibus nephandus Mahomat nequiciam secte sue stultis populis predicauit" (HRH, Liber II, Cap. XVII... op. cit., pp. 65, 66). "Durante su reinado el maldito Mahoma predicó la maldad de su secta a los pueblos de poco seso.” HHE, Libro II, Cap. XVII... op. cit., p 111.

Una afirmación que servirá de pauta para las restantes menciones que el autor realiza en el resto de su obra. Es decir un discurso de denotación permanente que buscaba menoscabar la imagen de los musulmanes, su religión y cultura.

${ }^{343}$ Fernández Conde, Francisco Javier, La Religiosidad Medieval ... op. cit., p. 103.

${ }^{344}$ Pizarroso Quintero, Alejandro, Historia de la Propaganda, notas para un estudio de la propaganda política y de guerra, Madrid, Eudema, 1993, pp. 67, 68; García Fitz, Francisco, "La Conquista de Andalucía... op. cit., p. 59.
} 


\section{II.2.- Las Crónicas y la hagiografía en el discurso de la Reconquista}

II.2.a.- Cronistas, crónicas: vidas y contextos

Expuesto de forma general el contexto historiográfico europeo e hispano, reseñaremos las principales crónicas utilizadas para este estudio y sus contextos particulares, sin olvidar referirnos a sus autores cuando éstos no sean anónimos ${ }^{345}$.

\section{Historia Compostelana}

Otro texto que destaca por su tema y originalidad es la Historia Compostelana, dedicada y patrocinada por el Arzobispo de Santiago de Compostela, Diego Gelmírez. Una de las principales características de la obra es que, junto a la Historia Roderici, inauguran una nueva tendencia cronística, donde el personaje principal no es el soberano, sino que un miembro de la aristocracia. Además, son obras escritas por contemporáneos de los protagonistas, a lo que se agrega la incorporación de elementos autobiográficos $^{346}$.

345 Dada la distinción realizada en páginas anteriores, entre las crónicas oficiales y oficiosas, consideramos prudente referirnos brevemente a las Crónicas anónimas de Sahagún, como ejemplo de la segunda categoría, misma característica, sumada a su enfoque leonista, que la coloca en un lugar secundario en cuanto a otras fuentes utilizadas y por la cual solo nos referiremos a ella de forma general.

Cronológicamente hablando, la primera de las crónicas del siglo XII que nos interesa es la llamada Crónicas anónimas de Sahagún, que se compone de dos partes diferentes. La más antigua fue escrita, posiblemente, por un monje que - pese a su época - la plasmó en castellano en el monasterio homónimo entre los años 1109 y 1117 (Crónicas Anónimas de Sahagún, edición crítica, nota e índice por Antonio Ubieto Artera, Zaragoza, Anubar, 1987, p. 5. (En adelante CAS) Su trama se inicia con el martirio de Facundo y Primitivo y la fundación del monasterio por Alfonso III. Posteriormente relata el reinado de Alfonso VI, sobre cuya persona se hacen muchas alabanzas y elogios, subrayando sus virtudes como monarca.

Destaca el relato de los dones que concedió al monasterio y los halagos realizados a los monjes de Cluny, que acudieron al llamado de Alfonso VI y en especial a Bernardo, primer abad cluniacense de Sahagún (CAS, I Crónica, $\mathrm{N}^{\circ}$ 7, op. cit., pp. 12 - 15) Respecto a las guerras contra los musulmanes, la Crónica sólo hace unas pocas referencias, ya que su tema central son las luchas ocurridas entre los frailes y burgueses de la localidad, en el contexto de las guerras entre Urraca y Alfonso I el Batallador (Torres Sevilla, Margarita, "La propaganda del poder... op. cit., p. 63) De hecho a lo largo del relato se describen alrededor de veinte acciones de violencia de los burgueses contra el monasterio, en algunos casos apoyados por fuerzas aragonesas; el autor de la crónica no duda en relatar con lujo de detalles los abusos y vejámenes que sufren los monjes, incluida la tortura, sin olvidar mencionar de vez en cuando los daños que sufrían los aldeanos. Todo ello sirve para mostrar a los monjes como víctimas de los burgueses, atrapados en medio de las guerras civiles y permite descubrir una trama de lucha de poderes entre la creciente burguesía en expansión y el poder económico que representaba el monasterio. Es por ello que a nuestro juicio, la crónica tiene claras intenciones propagandísticas en el sentido de que defiende la causa de los monjes y legitima sus acciones, al mismo tiempo que exalta la memoria de Alfonso VI, al contrastar su reinado con el de su hija.

La segunda parte de la Crónica es una versión del siglo XIV de escaso valor para los fines de este estudio, por lo que hemos decido no profundizar en ella.

346 Procter, Evelyn. Alfonso $X$ of Castile, patron of literature and learning, Oxford, Oxford University Press, 1941, p. 79; Díez Borque, José M. (Editor), Historia de las literaturas... op. cit., pp. 64 a 66; y Fernández Conde, Francisco Javier, La Religiosidad Medieval... op. cit., p. 369. 
Gelmírez, presenta una serie de particularidades definidas por su relación con el poder. Señor de un extenso territorio y custodio de las reliquias del Apóstol Santiago, a lo largo de su vida pugnó por mantener su poder e influencia, conservando una relación tormentosa con la corona de León, a la que pertenecían sus dominios ${ }^{347}$.

A la par de ello, el arzobispo cultivó cercanas relaciones con Cluny, haciéndose rodear por clérigos francos o educados en la abadía borgoñona. Con ello consolidaba una alianza que, entre otras ventajas, le permitía gozar de fluidos contactos con los pontífices antes mencionados ${ }^{348}$. La simpatía del arzobispo respecto a los cluniacense, explica el porque a lo menos dos de los autores confirmados de la Historia Compostelana fueron franceses, y que el capítulo XIV de la obra sea un verdadero panegírico a Cluny ${ }^{349}$.

Por todo lo anterior no es de extrañar que Gelmírez fuera el principal protagonista de la Historia Compostelana, obra que él mismo mandó a componer y que tenía como objetivo la exaltación de su figura personal, sus éxitos y la importancia de su diócesis ${ }^{350}$. El mismo autor lo afirma sin reservas de ningún tipo:

\footnotetext{
${ }^{347}$ Gelmírez habría nacido entre 1065 y 1070 en Galicia, su padre habría sido un miles que gobernó el castillo de Torres, al servicio del Obispo Diego Peláez. Fue educado en la escuela de la catedral de Compostela y por un tiempo sirvió en la Corte de Alfonso VI. Fue canónigo de la iglesia de Santiago y confesor de Raimundo de Borgoña entre 1090 y 1094. Asumió la administración de la diócesis compostelana a la muerte del Obispo Dalmacio en 1096, cargo que mantuvo hasta 1110, año en que fue elegido Obispo. (Historia Compostelana, Edición de Emma Falque, Madrid, Akal, 1994, p. 9). (En adelante HC 1994).

En julio de 1100, Gelmírez, fue consagrado Obispo de Compostela, y veinte años después es elevado a Arzobispo de su diócesis, cuando logra el traslado de la dignidad metropolitana desde Mérida (HC 1994, op. cit., pp. 8, 9) Dicho estatus lo llevó a negociar directamente con varios papas, como Gelasio I y Calixto II, al mismo tiempo que se enfrentaba con sus pares peninsulares, en especial con el Primado de Toledo, con el que disputaba áreas de influencia y poder.

Durante su vida Gelmírez no sólo mantuvo fuertes lazos con los poderes religiosos, sino que también mantuvo vínculos con algunos de los monarcas más importantes de la Península como Alfonso VI, Urraca, Alfonso I de Aragón y Alfonso VII, lo que lo coloca en una posición de testigo privilegiado y protagonista de una etapa clave en el proceso de la constitución de la monarquía castellano-leonesa, y la reconquista territorial. En el desarrollo de las luchas entre Urraca y "El Batallador" tomó partido por la reina, con quien posteriormente mantendría intensas disputas en pos de mantener su poder e influencia en la Corte. Así entonces, durante la minoría de edad de Alfonso VII, Gelmírez se convirtió en su protector, utilizándolo como arma para asegurarse el favor de la reina. En los conflictos ocurridos en esta época, se alió con el Conde de Traba, y tal fue su influencia, que en 1111 proclamó al infante Alfonso como rey en Compostela (Recuero Astray, Manuel, Alfonso VII (1126-1157), Burgos, Serie de los Reyes de León y Castilla, Vol. XIX, 2004, pp. 25-41).

En 1127 Alfonso VII, ya coronado rey de Castilla y León, nombra a su antiguo tutor jefe de la Cancillería Real. Su brillante carrera política declinó hacia el final de su vida, y en 1130 su influencia en la Corte se había debilitado al punto de prácticamente desaparecer de la documentación real.

${ }^{348}$ Rodríguez de la Peña, Manuel A., "Ideología política... op. cit., pp. 708-710.

${ }^{349}$ Rodríguez de la Peña, Manuel A., "Ideología política... ibidem.

${ }^{350}$ La obra está dividida en tres libros, dedicados, el primero a los orígenes de la sede compostelana, el segundo, se centra en la ascensión a sede metropolitana de Compostela, y el tercero, relata los hechos ocurridos entre los años 1128 y 1139 (Historia Compostella, Libro I, cap. III, Cura et Studio Emma Falque Rey, Brepols, Turnholti, 1988, p. 17). (En adelante HC 1988).
} 
"Nun cuero ipsius reuerendi episcopi successus, quos in hoc honore habuit, et aduersa, que in eodem uiriliter pertulit, atque ea, que ipse ad Dei honorem et sue ecclesie utilitatem Domino cooperante discrete et sapienter peregit, describere et ad posterorum memoriam reucare diuina preueniente gratia aggrediar, ${ }^{351}$.

Sus distintos autores procuraron escribir una obra de intencionalidad política, primero exaltando la figura de Alfonso VI y su nieto Alfonso VII, ambos mostrados como ejemplos del buen gobernante, y luego justificando el poder del arzobispo al documentar la relevancia de sus obras. Lo anterior, haciendo uso de abundantes referencias bíblicas, utilizadas para reafirmar los dichos del cronista de turno; por ejemplo, asimilando las figuras de Alfonso VII y "el Batallador" con David y Saúl, respectivamente ${ }^{352}$.

También destaca por el relato de hechos contemporáneos, que salvo por el frecuente uso de expresiones providencialistas, se hacen pocas referencias a explicaciones de tipo mítico o fantástica; se refiere, en cambio, a algunos autores clásicos e intelectuales cristianos, como San Agustín ${ }^{353}$.

La composición de la obra estuvo a cargo de varios autores sucesivos, Nuño o Munio Alfonso, el francés Hugo, y Giraldo, también francés, Además de ellos se supone que hubo otros autores no confirmados (Nuño o Munio Alfonso, fue tesorero de la iglesia de Santiago y en 1112 fue consagrado Obispo de Mondoñedo; Hugo, autor confirmado del capítulo quince del libro I, posteriormente fue nombrado Obispo de Oporto; y Giraldo, fue canónigo de la Iglesia de Santiago, a quien le cupo terminar el libro II y redactar gran parte del libro III. (HC 1994, op. cit., pp. 11 - 15).

${ }^{351}$ Historia Compostella, Libro I, cap. III, Cura et Studio Emma Falque Rey, Brepols, Turnholti, 1988, p. 17. (En adelante HC 1988) " $Y$ ahora con la ayuda de la divina gracia empezaré a describir y recordar a las generaciones venideras los éxitos que el reverendo obispo tuvo en el desempeño de su cargo y las adversidades que sufrió con valentía en el mismo y lo que él en persona con la cooperación del Señor llevó a cabo con discreción y sabiduría para honor de Dios y utilidad de su iglesia." HC 1994, Libro I, cap. III, 3, op. cit., p. 79.

${ }_{352}^{353}$ Rodríguez de la Peña, Manuel A., "Ideología política... op. cit., pp. 718, 719, 723, 724.

${ }^{353}$ HC 1994, op. cit., pp. 28, 29. 
Historia Silense/Legionense $(1109 \text { y } 1126)^{354}$

La Crónica, al parecer, pretendía ser una historia de la vida y reinado de Alfonso

VI, pero su autor no la habría concluido, por lo que solo nos legó su parte introductoria

dedicada a estudiar el linaje del rey leonés. El anónimo autor enlazó a algunos de sus ascendientes con los extintos soberanos visigodos, planteando así la idea de la continuidad del Reino Visigodo en la corona de León. Junto a ello, en la Crónica, se observa la primera aparición del Apóstol Santiago como paladín cristiano en la lucha

${ }^{354}$ Escrita aproximadamente entre los años 1109 y 1126 por un anónimo posiblemente originario de León -o por lo menos de fuertes ideas "leonisistas"-, con un destacable conocimiento de los clásicos latinos - en especial Salustio -, de la Crónica de Alfonso III y de la historia arábigo-española, que escribe en estilo realista y cargado de anécdotas y noticias (Historia Silense, Edición crítica e introducción por Dom Justo Pérez de Urbel y Atilano González Ruiz-Zorrilla, Madrid, Escuela de Estudios Medievales, 1959, pp. 69 y 97. (En adelante HS 1959). Procter, Evelyn, Alfonso X of Castile... op. cit., p. 79)

Respecto a la autoria de la Historia Silense, su denominación y composición, en los últimos años se ha dado una interesante polémica. Amancio Isla en su articulo "Una historia leonesa, su perfil y sus costuras" (Edad media. Rev. Hist., 12, 2011, [pp. 143-157]) reniega del titulo Silense, en razón de que el texto no seria originario del Monasterios de Silos, y por el contrario su origen estaría en León, razón por la cual el autor prefiere referirse a ella como Historia Legionesis, y adjudicando su autoría a el PseudoPedro. En cuanto a su composición, Isla, afirma que el texto original sufrió una mutilación en tiempos remotos y que copistas posteriores habrían intentado "parchar" la Historia incorporándole el texto de Sampiro, lo que a la postre genero un cuerpo documental confuso, discontinuo y desarticulado. No obstante, Isla, afirma que quizás el texto no es tan caótico como parece y que por el contrario su composición respondería a un acto intencionado: dar un énfasis más providencialista a la Historia, siguiendo el modelo de San Agustín, en torno a evitar las luchas entre los reyes cristianos y advirtiendo de las graves consecuencias que estas podían acarrear para el conjunto del pueblo. Todo ello con el fin de convertir a la "mal llamada Silense" en un texto educativo para las elites hispanas.

Referente a la misma polémica, Raquel Alonso, en su articulo "La obra histórica del obispo Pelayo de Oviedo (1089-1153) y su relación con la Historia legionensis (llamada silensis) (e-Spania [En línea], $14,2012)$ no atribuye un autor especifico a la Silensis, pero sostiene que posiblemente perteneció al alto clero, que debió escribir el texto en León o sus alrededores y debió conocer a Pelayo de Oviedo y su obra, descartando de plano su composición en Silos y datándola alrededor del año 1115.

Por su parte Gaël le Morvan, sigue la misma tesis de Isla y Alonso en cuanto a la autoria de la Silensis, incorporando un mayor énfasis en la intencionalidad política de la obra como valedora de un discurso legitimador inspirado por Urraca y Alfonso VII (Gaël le Morvan, "Reinos e imperio: la Historia legionensis (llamada silensis) y la reivindicación leonesa de la herencia visigótica, en e-Spania [En línea], 14, 2012). En la misma línea se encentran los artículos de Georges Martin "La Historia legionensis (llamada silensis) como memoria identitaria de un reino y como autobiografía" y de Fernando Luis Corral "'Y sometió a sus autoridad todo el reino de los leoneses": formas de ejercicio del poder en la Historia Silense o cómo Alfonso VI llegó al trono. (e-Spania [En línea], 14, 2012. http://e-spania.revues.org/21696 10.4000/e-spania.21696. (10 de junio de 2013).

Junto a lo anterior, la admiración que el autor manifiesta hacia la figura del rey Alfonso VI ha llevado a pensar que debió ser un miembro de la Corte real (Canal Sánchez-Pagín sostiene que el autor debió ser un cluniacense que escribió la crónica como un homenaje póstumo a Alfonso VI, de quien fue muy cercano, llegando a aventurar que el autor debió ser el Vicario real Pedro Muñoz. Canal SánchezPagín, José M., “¿Crónica Silense o Crónica domnis sanctis?”, en Cuadernos de Historia de España, LXIII-LXIV, 1980. p. 100) Destaca además una fuerte tendencia anti-franca y una crítica explícita a las versiones de la conquista de Hispania por parte de Carlomagno, a la influencia de Cluny en la Península y a los privilegios que gozaban sus monjes en Hispania (Sánchez-Albornoz, Claudio, Investigaciones sobre historiografía hispana medieval (siglos VIII al XII), Buenos Aires, Instituto de Historia de España, 1967, pp. 228, 229; Gil, Juan, "La Historiografía"... op. cit., pp. 11, 12; y Torres Sevilla, Margarita, "La propaganda del poder... op. cit., p. 63). 
contra los musulmanes ${ }^{355}$. Ambos elementos se combinan con un marcado espíritu providencialista que explica que los godos - pueblo elegido por Dios- fueron castigados con la invasión musulmana por culpa de los pecados de sus reyes. Por su parte, el surgimiento del Reino de Asturias y las posteriores victorias de Alfonso VI señalarían el retorno del favor divino, un hecho que serviría como discurso legitimador para Urraca y su hijo, insertos en los conflictos que se sucedieron a la muerte del conquistador del Toledo $^{356}$. De esta manera, la Historia Silense/Legionense combina los principales tópicos ideológicos de la cronística medieval, los mismos que se irán perfeccionado y afianzando en las obras siguientes hasta definir una identidad particular hispánica.

\section{Chronica Adefonsi Imperatoris}

Escrita a mediados del siglo XII, este relato se concentró de forma excepcional en una sola persona, Alfonso VII, y en los acontecimientos de su reinado ${ }^{357}$.

Desde un punto de vista político la obra tiene una clara intención de reafirmar la corona de Alfonso VII luego del difícil reinado de su madre y su complicada ascensión al trono ${ }^{358}$. Es clara la intención apologética del autor, que traza las líneas rectoras de la

${ }^{355}$ Domínguez García, Javier, Memorias del Futuro... op. cit., p. 81; HS, op. cit., pp. 14 y 16; y Rodríguez de la Peña, Manuel A., "Ideología política... op. cit., pp. 708, 709, 710.

${ }^{356}$ Bronisch, Alexander Pierre, Reconquista y guerra santa... op. cit. p. 232; Corral, Fernando Luis, "Y sometió a sus autoridad... op. cit., http://e-spania.revues.org/21696 (junio 2013); Martin, Georges, "La Historia legionensis... op. cit., http://e-spania.revues.org/21568 (junio de 2013); y Le Morvan, Gaël, "Reinos e imperio: la Historia legionensis... op. cit., http://e-spania.revues.org/21681 (junio de 2013).

${ }^{357}$ Respecto a su autoría, se supone que su autor fue contemporáneo a los hechos relatados, y que posiblemente escribió por encargo del rey o de la Corte basando su narración en su propia memoria, los relatos de otros testigos y en algunas fuentes de la Cancillería Real. Esto en razón de su estilo literario y dominio del latín, así como su conocimiento de autores clásicos como Virgilio y Ovidio, las constantes referencias bíblicas y un marcado providencialismo hacen suponer que fue escrita por un miembro del alto clero, posiblemente Arnaldo, Obispo de Astorga (CEA, op. cit., pp. 13 y 19. (En adelante CEA). Gárate Córdoba, José María, Espíritu y Milicia en la España Medieval, Madrid, Publicaciones Españolas, 1967, pp. 201, 202) Esta hipótesis se sustenta, entre otros motivos, por el desconocimiento del autor con respecto a los hechos de Castilla y la especial atención que dedica a los acontecimientos de León.

Estamos al corriente de los planteamientos de José M. Sánchez-Pagín en cuanto a una posible autoría de Elías canónigo rotense, no obstante preferimos la versión de la autoría del Obispo de Astorga, por ser más universalmente aceptada. Para más detalles sobre este asunto ver: Canal Sánchez-Pagin, José María, "Elías, canónigo rótense, posible autor de la Chronica Adefonsi Imperatoris," en Anuario de Estudios Medievales, 30/2, 2000, [pp. 735-757].

En cuanto a la estructura de la obra, esta se encuentra dividida en tres partes que en su conjunto narran el reinado de Alfonso VII entre los años 1126 y 1147 (Bodelón, Serafín, Literatura latina ... op. cit., p. 105) La primera parte describe el arribo al poder del rey y y el proceso de consolidación y restauración que siguieron a los al reinado de doña Urraca. La segunda parte se concentra en sus campañas de reconquista y finalmente encontramos el "Poema de Almería", que a diferencia del resto de la obra está escrita en verso y constituye la parte más llamativa de la crónica, al convertirla en el único texto que combina prosa y verso en el mismo cuerpo.

358 Domínguez García, Javier, De Apóstol matamoros a Yllapa mataindios: dogmas e ideologías medievales en el (des)cubriminsto de América, Salamanca, Universidad de Salamanca, 2008, pp. 54, 55; y Pascua Echegaray, Ester, Guerra y pacto en el siglo XII. La consolidacion de un sistema de reinos en 
política del emperador, convirtiéndose el relato prácticamente en un discurso político de validación del reinado de Alfonso. Por esta misma razón, el autor es sumamente duro con los enemigos de emperador, en especial con Alfonso I de Aragón a quien tacha reiteradamente de pecador ${ }^{359}$. La Crónica también es severa contra los enemigos del cristianismo y es la primera del periodo en demonizar a los musulmanes de forma directa y sin alegorías, al mismo tiempo que valida espiritualmente la lucha que contra ellos hacen los cristianos $^{360}$. Esta última caracteristica dota a a la crónica de un importante elemento providencialista, poseyendo ademas una clara inspiración en las Escrituras, todo lo que contribuye a una interpretación basada en modelos de bien y mal, vicios y virtudes, que justifica las acciones de Alfonso VII y explica los éxitos del soberano, así como los reveses de sus adversarios ${ }^{361}$.

Esta obra, fiel representante de los estilos historiográficos del siglo XII, posee características que la colocan en una etapa de transición hacia los cambios del siglo XIII, centrados especialmente en su carácter local y nacional y en su alianza con la política reconquistadora.

\section{Crónica del Obispo de Oviedo don Pelayo ${ }^{362}$}

La también conocida como Crónica de Pelayo es bastante breve y relata los reinados desde Vermudo II a Alfonso VI (982-1109), siendo en general su información pobre y esquemática ${ }^{363}$. Prácticamente la mitad de la obra se dedica a la biografía de Vermudo II (982-999), a quien acusa de pecador y le responsabiliza de las incursiones de al-Mansur; en cambio, sus referencias a Alfonso VI son de alabanza, no obstante que

Europa Occidental, Madrid, Biblioteca de Historia: 31, Consejo superior de Invetsigaciones Cientificas, 1996, pp. 32, 33.

${ }^{359}$ CEA, Libro I, op. cit., pp. 80, 81; y Guglielmi, Nilda y Adeline Rucquoi (Coordinadoras), El discurso politico... op. cit., 118.

${ }^{360}$ Gárate Córdoba, José María, Espíritu y Milicia... op. cit., pp. 201, 202.

${ }^{361}$ Klinka, Emmanuelle, "Protagonismos y relación historiográfica en la Chronica Adefonsi Imperatoris", en e-Spania [En línea], 15 | juin 2013, Puesto en línea el 21 junio 2013. URL : http://espania.revues.org/22279; DOI : 10.4000/e-spania.22279 (05 de octubre 2013)

${ }^{362} \mathrm{La}$ Crónica del Obispo de Oviedo don Pelayo, fue posiblemente escrita en torno a los años 1118 a 1130. Su autor, Pelayo, Obispo de Oviedo, asumió la cátedra el año 1101 y la conservó hasta su retiro en 1128 o 1130, falleciendo en 1153. Lo "delicado" de su crónica se debe a que si bien durante el medioevo sus contenidos fueron juzgados como fidedignos, a partir del siglo XVI comienza a ser duramente criticada, ya que su autor, en un afán por enaltecer su diócesis habría manipulado los archivos diocesanos e incluso inventado documentos que colocó en el texto ("Crónica del Obispo de Oviedo don Pelayo", en Casariego, J. A., Crónicas de los Reinos de Asturias y León, León, Everest, 1985, pp. 160, 161. (En adelante COP). Bodelón, Serafín, Literatura latina ... op. cit., pp. 113, 114).

363 Sánchez Alonso, Benito, Historia de la historiografia...op. cit., pp. 116, 117; Gil, Juan, "La Historiografía"... op. cit., pp., p. 8; y Torres Sevilla, Margarita, "La propaganda del poder... op. cit., p. 63. 
no oculta su tortuosa llegada al poder, calificando como traicionera la muerte de su hermano Sancho y afirmando que se apoderó de Galicia "mediante artimañas"364. Pese a lo anterior Pelayo procura exaltar la figura de Alfonso VI, trasmitiendo un discurso político propagandístico a favor del monarca Leones y su estirpe, a través de la exaltación de las virtudes guerreras, religiosas y jurídicas del conquistador de Toledo ${ }^{365}$.

\section{Crónica Najerense}

Ya adentrándonos a las postrimerías del siglo XII encontramos la Crónica Najerense, cuya fecha de redacción se sitúa entre los años 1157 y $1176^{366}$. Esta crónica manifiesta una clara tendencia castellanista, creando un verdadero discurso en favor del reino, lo que la hace destacar entre las crónicas que incorporan un discurso históricopolítico en su contenido ${ }^{367}$. En líneas generales, el texto es un relato desde la Creación hasta mediados del siglo XII, siendo sus fuentes otras crónicas anteriores, abarcando desde las obras de San Isidoro hasta la Crónica de Pelayo. El cronista destaca las persecuciones cristinas y, tempranamente, muestra una visión dicotómica del pasado, basada en una vinculación entre lo celeste y lo profano y el enfrentamiento entre bien y mal, el pecado y el castigo ${ }^{368}$.

Sus principales novedades historiográficas radican en una narración más "limpia" de la cual se procuró eliminar aquello que no fuese propio de la narración histórica; en segundo lugar, su intención por crear un relato completo desde la Creación hasta el siglo XII, dividiendolo en tres partes: desde la creación al fin del Reino Visigodo; desde Asturias al reinado de Vermudo III de Léon y finalmente desde Sancho III a Alfonso VI. Todo lo anterior, que aleja, parcialmente, a la crónica de la simple reiteración y compilación de textos anteriores, lo que se convierte en su tercera innovación, dotándola de un sentido más crítico e historiográfico, con una intención ideológica clara en torno

\footnotetext{
${ }^{364}$ COP, op. cit., p. 178.

365 Alonso Álvarez, Raquel, "La obra histórica del obispo Pelayo de Oviedo (1089-1153) y su relación con la Historia legionensis (llamada silensis)", en e-Spania [En linea], 14, diciembre2012, mis en ligne le 13 septembre 2012. URL: http://e-spania.revues.org/21586; DOI: 10.4000/e-spania.21586. (junio de 2013).

${ }^{366}$ De su autor sólo sabemos que debió ser un monje, o una persona próxima a los ámbitos eclesiásticos, cercano a Cluny (Crónica Najerense, edición de Juan A. Estévez Sola Tres Cantos, Madrid, Akal, 2003, pp. 31, 32). (En adelante CN 2003).

${ }^{367}$ Lacarra, María Eugenia, El poema de Mio Cid: realidad histórica e ideología, España, José Porrúa Turanzas imp, 1980. p. 2; y Bautista, Francisco, "Genealogía y leyenda", op. cit.

${ }^{368}$ Klinka, Emmanuelle, "Chronica naiarensis: de la traición... op. cit.
} 
al pensamiento goticista ${ }^{369}$. Es así como el texto divide la historia hispánica comenzando por el Reino Visigodo, seguido del surgimiento de Asturias y el fortalecimiento de León y, finalmente, centrándose en el ascenso de Castilla, destacando la importancia de la batalla de Atapuerca y una postura "anti Navarra" como uno de los hitos fundamentales en la construcción del reino castellano ${ }^{370}$. Esta cronología sería posteriormente utilizada por Rodrigo Jiménez de Rada y Lucas de Tuy. Destaca, además, el hecho de que en el relato, se mencionen los hechos de otros personajes, distintos a los monarcas, y se incorporen narraciones de origen épico ${ }^{371}$.

A partir del año 711 la narración tiende a centrarse en los acontecimientos en torno a los territorios y personajes castellanos, razón por la cual algunos autores la consideran la primera crónica castellana ${ }^{372}$. Esto debido a que en obras previas el relato histórico había tenido un marcado acento leonés. A partir de la composición de la Najerense se comienza a reflejar el auge de Castilla y su influencia en la Península, desplazando el foco de atención que hasta entonces había retenido León. En relación a este mismo hecho, el autor continuó con la tendencia cluniacense de exaltación del linaje monárquico ${ }^{373}$, pero orientándola hacia un fuerte castellanismo, rescatando la memoria de Fernando I, su enlace con Sancha de León, y sus buenas obras, así como las de sus sucesores, al mismo tiempo que parece querer evitar cualquier elogio hacia la figura de Alfonso VI, que hasta ese entonces era frecuentemente representado como un modelo monárquico ${ }^{374}$.

\footnotetext{
${ }^{369}$ Estévez Sola, Juan Antonio, "Chronica Naierensis e Historia Silensis"... op. cit. No obstante, pese a las innovaciones de la Naierensis, el mismo Estévez Sola, es enfático en afirmar que la crónica mantiene la costumbre de hacer uso literal de textos anteriores, a los que sin embargo se les da una interpretación y uso original.

${ }^{370}$ Chronica Naierensis, Chronica Hispana saeculi XII. Pars II, Cura et studio Juan A. Estévez Sola, Brepols, Turnhout, 1995, pp. XCIII, XCIV. (En adelante CN 1995) Klinka, Emmanuelle, "Chronica naiarensis: de la traición... op. cit.,

${ }^{371}$ Respecto a su contenido, se puede afirmar que la Crónica Najerense si bien pretende ser universal, sólo se limita, en este sentido, a la parte que concierne a la antigüedad, ya que su relato del Reino Visigodo es de tenor "nacional".

${ }^{372}$ Orcástegui, Carmen y Esteban Sarasa, La historia en la Edad Media ... op. cit., p. 202; y Gil, Juan, "La Historiografía"... op. cit., pp. 15-17.

${ }^{373}$ Una acción que debemos recordar no era gratuita, sino que buscaba fortalecer las alianzas políticas y económicas entre Cluny y el poder monárquico. Para el caso de la Crónica quedan claras las intenciones del Monasterio de Santa María la Real de Nájera por recibir las donaciones de los reyes castellanos.

${ }^{374}$ Benito Ruano, Eloy, "La historiografía de la alta edad media...” op. cit., pp. 102, 103; Rodríguez de la Peña, Manuel A., "Ideología política... op. cit., pp.730, 731; Klinka, Emmanuelle, "Chronica naiarensis: de la traición... op. cit.; y Bautista, Francisco, "Genealogía y leyenda", op. cit.
} 


\section{Liber Sancti Jacobi/ Codex calixtinus}

La ultima fuente del siglo XII a la que nos referiremos no es exactamente una crónica, sino más bien una colección de textos, pero que por sus características preferimos analizar como obra historiográfica, en razón del discurso e ideología que representa. Nos referimos al Liber Sancti Jacobi, obra que caracteriza la concepción de la política, la religiosidad y la guerra en la Península según la visión de los francos, así como también la postura de algunos cronistas hispanas posteriores con respecto a los mismos elementos y tipos relatados. El mismo texto, que atribuye al Papa Calixto II su composición - algo actualmente descartado -, consta de cinco libros ${ }^{375}$.

En relación a los fines que perseguimos los libros más interesantes son el tercero y el cuarto. El relato de la traslación del cuerpo de Santiago viene a consolidar una tradición, y muestra las distintas versiones que giraban sobre ese hecho, logrando legitimar el mito y con él su importante carga política y económica, puesto que el mito de Santiago convirtió a Hispania en una Tierra Santa. A partir de lo anterior, nosotros aventuramos que el autor del texto quizás no era consciente de las múltiples facetas del mito que estaba plasmando, pero es casi seguro que sí sabía que la presencia del cuerpo de un apóstol de Cristo en tierras hispanas constituía un foco de prestigio religioso para el territorio y de riquezas para aquellos encargados de recibir a los peregrinos y sus donaciones.

El quinto capítulo, más que por su contenido, destaca por las reacciones que produjo en Hispania. La expedición Carolingia - un hecho histórico comprobado, pero de alcances mucho más limitados que los que pretende el texto- adquiere características fantásticas extremas, abundando los relatos de milagros, personajes míticos e

\footnotetext{
${ }^{375}$ El libro primero y más extenso es una recopilación de sermones y homilías dedicadas a Santiago, además de dos relatos de su martirio; la segunda parte reúne veintidos milagros del santo; la tercera y más breve es el relato de la traslación del cuerpo del Jacobo desde Jerusalén a Galicia; el libro cuarto es la "Crónica de Turpin" que narra la expedición hispánica de Carlomagno y la batalla de Roncesvalles entre otros episodios épicos; finalmente el libro quinto consiste en una "guía" para peregrinos, detallando el camino, la ciudad y la catedral de Santiago. (Liber Sancti Jacobi "Codex calixtinus", traducción de Abelardo Moralejo, Casimiro Torres y Julio Feo, Galicia, Xunta de Galicia, 2004, p. XVII. Liber Sancti Jacobi: Codex Calixtinus, edición de K. Herbers y M. Santos Noia, Xunta de Galicia, D.L. 1998, p. XIX (En adelante LSJ 2004).

Dando por hecho que la autoría pontificia del texto es una falsificación, y por la importancia que se da al libro cuarto y las características del quinto, se piensa que el verdadero autor debió ser un franco avecindado en Galicia, que escribió el texto entre los años 1139 y 1173 con una clara intención propagandística, buscando promover el culto jacobeo con el fin de beneficiar a los monasterios cluniacenses que se encontraban en "el camino francés" (Domínguez García, Javier, Memorias del futuro... op. cit., p. 76 y 80; Gil, Juan, "La Historiografía”... op. cit., pp. 34, 35; y Rodríguez de la Peña, Manuel A., "Ideología política... op. cit., pp.730, 731). De esta manera, se convierten en depositarios de las limosnas y donaciones de los peregrinos, transformando a la Península Ibérica en una tierra santa, en un foco de atracción para la cristiandad.
} 
intervenciones divinas. En relación a esto, el autor no duda en inventar personajes y batallas, así como exagerar las cifras a números imposibles. Todos estos factores no son extraños en otras fuentes similares, sin embargo en esta obra se incluye la reacción de los hispanos a estos relatos. Para muchos cronistas peninsulares alejados del área de influencia carolingia, la afirmación de que Carlomagno "invadió” toda Hispania fue objeto de críticas, ya que desmerecía el esfuerzo bélico de los peninsulares y echaba por los suelos sus propios mitos en relación a la guerra contra el Islam $^{376}$.

Como mencionamos anteriormente, el siglo XIII es testigo de cambios en la forma de escribir y concebir la historia. Es considerada "una época de oro" para la historiografía hispana, donde se pueden ver textos caracterizados a grosso modo por un carácter más "hispánico" o protonacional; un regreso a las temáticas universalistas, pero esta vez utilizadas como punto de partida para la narración de los hechos peninsulares; un mayor uso de las fuentes escritas -lo que en parte se relaciona con la consolidación del poder de los reyes y por ende el ordenamiento de las cancillerías reales-; un mayor uso de fuentes "no históricas", como relatos épicos y tradicionales ${ }^{377}$; la aparición de

\footnotetext{
${ }^{376}$ Evidencia de lo anterior se puede observar en algunas crónicas de los siglos XII y XIII, que tienden a restar importancia a las incursiones carolingias en la Península o bien relatan estos episodios de forma parca, concentrándose en cambio en la derrota de Roncesvalles y por lo general no trasmiten una imagen favorable de Carlomagno. Podemos encontrar ejemplos de ello en algunas de las obras cronificas más importantes del siglo XIII. Lucas de Tuy en su Cronicon Mundi, en el libro IV, capítulos XV y XXI, reduce la intervención carolingia en Hispania a unas pocas líneas, donde afirma que el rey franco fue a España a combatir "tan bien a los cristianos como a los moros", pero que fue detenido en las montañas por Bernardo y Muza, rey de Zaragoza, haciendo huir desordenadamente a los francos y dando muerte a muchos hombres "tan bien de los romanos, como de las Galias, así de los christianos, como de los moros". En el capítulo X, del libro IV, del Rebus Hispaniae, de Jiménez de Rada, se cuenta un supuesto pacto entre Alfonso "el casto" y Carlomagno, en el cual el primero le ofreció el trono al rey franco. Pero cuando el hispano se retractó por la presión de sus magnates, por lo que Carlomagno habría dejado de luchar contra los musulmanes para atacar y subjugar el reino de Alfonso. El cronista trasmite una imagen de Carlomagno como un hombre ambicioso, que con sus ataques fue peor que los musulmanes. Razón por la cual los habitantes de Asturias, Alava, Vizcaya, Navarra, Ruconia y Aragón se unieron para expulsar al invasor. Jiménez narra la batalla de Roncesvalles como una lucha entre los hispanos contra los francos, a quiénes vencieron "por la fuerza de las armas, o mejor, por la del Señor" y reduce la intervención de los musulmanes a un lugar muy secundario, afirmando que tropas árabes combatieron junto a Alfonso. Finalmente "el toledano" termina su relato narrando como Carlomagno y sus huestes fueron fruto del miedo y abandonaron la Península y que su supuesta conquista, solo puede restringirse a las zonas de Cataluña, donde el conde de Barcelona es su vasallo. Finalmente en la Crónica General, en su capítulo 619 se narra la derrota de los carolingios afirmando que el Emperador franco intento someter a los hispanos cristianos y que cuando se retiraba, en Roncesvalles, sus huestes fueron derrotadas por Marssil, rey de Zaragoza, al mando de una "hueste muy grande de moros et de nauarros". Del relato destacan la falta de elogios a Carlomagno o su hueste y por el contrario su derrota es relatada como un acto heroico, sin reproches o lamentos de ningún tipo.

${ }^{377}$ Según Peter Linehan, esto se debió a que entre los años 1127 y 1220 no se dispone de ninguna obra de carácter historiográfico que relate los acontecimientos de los reinos centrales de la Península Ibérica, lo que obligó a los autores del siglo XIII a buscar información por otras vías para llenar este vacío. Este
} 
otros protagonistas, distintos de los reyes, en el cuerpo de los relatos; y el paulatino abandono del latín y su reemplazo por el castellano. A ello debemos sumar la introducción de la autoría en algunas obras, lo que además de permitirnos identificar a los autores, nos permite conocer la mentalidad histórica de los grupos sociales a los que pertenecían $^{378}$.

En consideración de lo anterior, quizás la trasformación más grande fue la consolidación de dos ideas fundamentales. La primera es el rescate de la tesis isidoriana de la unidad hispánica; la Península entendida como una unidad religiosa y cultural, pese a las divisiones político-territoriales. De esta idea derivó un tema común en las crónicas de este siglo: el lamento por la pérdida de Hispania y el deseo de recuperar su antigua gloria. La segunda idea es la convicción de que los reyes asturianos eran los legítimos herederos del Reino Visigodo y, por tanto, los soberanos castellano-leoneses serían los continuadores de la tradición y legitimidad gótica. Ésta es la base del pensamiento goticista. Ambos temas son desarrollados y están presentes en la obra de los tres autores más importantes de este periodo: Lucas de Tuy, Rodrigo Jiménez de Rada y el rey Alfonso X. Estos personajes también serán los promotores de una nueva forma de concebir las crónicas; las llamadas "Crónicas Reales", escritas por intermediación directa del monarca y puestas al servicio de sus intereses ${ }^{379}$.

La suma de estos cambios contribuyó a que la historiografía hispana, a partir del siglo XII, se recuperara del atraso que experimentaba en relación al resto de Europa Occidental $^{380}$. Durante este periodo se produce una consolidación de las ideas de los cronistas, existiendo una clara intención de reunir y ordenar el pasado de España con el fin, según José Antonio Maravall, de crear una unidad histórica que sirviera para los objetivos políticos en torno a la idea de "unidad hispánica". 381

A modo de síntesis, se puede afirmar que el rescate de las ideas de San Isidoro sirvieron para crear un discurso político que glorificaba un pasado perdido y señalaba la obligación de recuperar esa memoria, misión que los cronistas parecen encomendar a

fenómeno sería exclusivo de los reinos del centro de la península y no se observa en regiones como Aragón y Cataluña. (Linehan, Peter, España, 1157-1300... op. cit., p. 25).

${ }^{378}$ García Fitz, Francisco, "La conquista de Andalucía... op. cit., pp. 51, 52.

${ }^{379}$ Gómez Redondo, Fernando, "La construcción del modelo de Crónica real”, en Fernández Ordóñez, Inés, Alfonso X el Sabio y las crónicas de España, Valladolid, Universidad de Valladolid, 2000, pp. 133, 134. La diferencia de estas crónicas con las anteriores estaría en que sus autores son miembros activos de la Corte, que escriben en vida del monarca y que cuentan con acceso a fuentes reales.

${ }^{380}$ Rodríguez de la Peña, Manuel A., "Ideología política... op . cit., pp. 688, 689.

${ }^{381}$ Maravall, José Antonio, El concepto de España... op. cit., p. 31. 
los reinos de Castilla y León, y en específico a sus soberanos, entendidos como modelos virtuosos, símbolos de la alianza con Dios y de la restauración de un Reino Visigodo.

\section{Annales Toledanos Iy II}

En este nuevo horizonte, la primera obra que reseñaremos son los Annales Toledanos I y II, escritos en la primera mitad del siglo XIII, que sin ser una crónica aporta interesantes datos que complementan los que nos entregan las obras "historiográficas" 382 .

Su autor procuró dejar constancia de cuanto fenómeno natural pareciera relevante, pero más nos interesa la preocupación que mostró en relación a los acontecimientos en los Santos Lugares y en especial sobre las guerras peninsulares contra el Islam $^{383}$. Destaca especialmente el espacio dedicado a la campaña de las Navas de Tolosa, uno de los más extensos relatos del texto ${ }^{384}$.

\section{Crónica latina de los reyes de Castilla}

Ya adentrándonos de lleno en el siglo XIII, nos encontramos con la Crónica latina de los reyes de Castilla, posiblemente escrita por etapas, entre el decenio de 1223 y 1237. Se cree que su autor fue castellano y no muy adepto a León ni a Alfonso IX $(1188-1230)^{385}$. En su relato el autor centra su atención en Castilla, relegando los acontecimientos de los restantes reinos a meras referencias. De esta forma la crónica se

\footnotetext{
${ }^{382}$ Por lo general los anales son un género distinto en el contexto medieval, y solían ser recopilaciones de acontecimientos de diversa índole tales como sucesos climáticos o astronómicos, así como diversos episodios políticos y religiosos, muchas veces de carácter local. En el caso hispano esta situación se repite, pero sin eclipsar la figura del rey, que solo que en este caso debe compartir su protagonismo con las semánticas ya mencionadas.

En el caso particular de la obra que reseñamos, esta se encuentra dividida en dos partes, es de autor desconocido, pero existen fundadas razones para creer que el compositor de la primera parte fue un clérigo, mientras que el de la segunda habría sido un seglar o miembro del bajo clero, existiendo entre ambos textos unos treintaiún años de diferencia. Su contenido puede ser descrito como un conjunto de anotaciones ordenadas cronológicamente y fechadas según la Era Hispánica. La primera parte, sin contar las anotaciones de hechos bíblicos, abarca desde el año 714 hasta el 1219, y el segundo desde el año 712 hasta 1250 (Los anales toledanos I y II, edición de Julio Porres Martín-Cleto, Toledo, Instituto provincial de Investigaciones y Estudios Toledanos, Diputación Provincial de Toledo, 1993, pp. 11-15. (En adelante AT 1993). "Annales Toledanos" en Las crónicas latinas de la Reconquista, estudios prácticos de latín medieval por A. Huici, España, Establecimiento Tip, Hijos de F. Vives Mora, 1913, Volúmenes I, II. (En adelante AT 1913).

${ }^{383}$ Fernández Conde, Francisco Javier, La religiosidad medieval ... op. cit., p. 103.

${ }^{384}$ Ver "Anales Toledanos", en Huici, Ambrosio, Las Crónicas latinas..., op. cit., Tomo I, pp, 350, 351.

385 Del texto se desprende que su autor fue un conocedor de algunos clásicos como Lucano, Virgilio, Horacio y Séneca, de las Escrituras y el Derecho Canónico, lo que apunta a que fue miembro del alto clero. También sabemos de él que asistió al IV Concilio de Letrán, y que presenció la consagración del Patriarca de Constantinopla. Por sus conocimientos de ciertos detalles íntimos de la Corte se deduce que debió ser bastante cercano a la familia real.
} 
aleja del goticismo, para centrarse en la historia castellana y especialmente en la figura de Fernando III, a quien procura exaltar y validar, haciendo, ademas, uso de un lenguaje propio de las ideas de cruzada ${ }^{386}$. Por lo anterior es claro que el autor debió ser testigo directo de muchos de los acontecimientos que narra, lo que ha llevado a los estudiosos de la crónica a plantear con bastante certeza una autoría de Juan, Obispo de Osma $(† 1246)^{387}$. Producto de esta probable autoría es que la Crónica Latina tiene la particularidad de narrar episodios ocurridos en vida del autor, salvo por algunas reseñas a temas anteriores como los orígenes de Castilla, y algunas referencias a fuentes proporcionadas por los registros de Cancillería, lo que la distingue de otras crónicas del periodo que se basan en la reproducción de textos anteriores ${ }^{388}$. Esto, según Ana

\footnotetext{
${ }^{386}$ Rodríguez, Ana, "Modelos de legitimidad política en la Chronica regum Castellae de Juan de Osma", en e-Spania [En línea], 2 | décembre 2006, Puesto en línea el 25 junio 2007, consultado el 04 octubre 2013. URL: http://e-spania.revues.org/433; DOI: 10.4000/e-spania.433; y Bautista, Francisco, "Escritura cronística e ideología histórica", en e-Spania [En línea], 2 | décembre 2006, Puesto en línea el 16 agosto 2010. URL: http://e-spania.revues.org/429; DOI: 10.4000/e-spania.429 (04 de octubre 2013).

Según Bautista, por estas mismas características es difícil precisar las influencias y recepción que tuvo el texto en su época, la cual corresponde a un momento de incertidumbres e inquietudes. Siendo su relato castellanista y contrario a Alfonso IX coincidente con la etapa previa a la unión de Castilla y León. En cambio la Chronica exalta la tradición castellana, colocando a Castilla como el nuevo eje de la Reconquista, un reino cruzado, independiente de León y que encuentra sus raíces en la influencia del Liber Regnum de Navarra y la leyenda de Fernán González. Razones por la cual los eventos "extranjeros" solo son relatados a medida que exaltan a Castilla, un hecho que se hace más claro a partir del relato de las Navas de Tolosa, la gran victoria cruzada de Castilla.

Según el mismo autor, fue el castellanismo de la obra y su postura antileonesa los responsables que la CLRC perdiese vigencia e influencia en los años posteriores, puesto que este discurso no tenia mayor sentido y utilidad luego de la unión de los reinos de Castilla y León.

${ }^{387}$ Juan de Osma, aparece como canciller de Fernando III en 1217, cargo que conservo hasta su muerte. Pero es posible que anteriormente fuese notario regio de Alfonso VIII y Enrique I. En su carrera eclesiástica fue abad de Valladolid entre 1219 y 1231, electo de Osma en 1232 y obispo de Burgos desde 1241 hasta su muerte. (Rodríguez, Ana, "De rebus Hispaniae frente a la Crónica latina de los reyes de Castilla: virtudes regias y reciprocidad política en Castilla y León en la primera mitad del siglo XIII", en Cahiers de linguistique et de civilisation hispaniques medievales, $\mathrm{N}^{\circ} 26,2003$, [pp. 133-150], p. 144); Crónica Latina de los Reyes de Castilla, edición de Luis Charlo Brea, Madrid, Akal, 1999, p. 14. (En adelante CLRC 1999); Chonica latina regum castellae, Corpus Christianorum, Continuatio Mediaevalis, LXXIII, Chronica Hispana Saecvli XIII, Turnholti, Typographi Brepols Editores Pontificii, MCMXCVII, p. 11. (En adelante CLRC 1997); González, Julio, "La Crónica Latina de los Reyes de Castilla", en Homenaje a Don Agustín Millares Carlo, 2 V, Gran Canaria, Caja Insular de Ahorros de Gran Canaria, 1975, p. 58; y Costas Rodríguez, Jenaro, Fernando III a través de las crónicas medievales, Zamora, Ayuntamiento de Zamora, Centro de la UNED de Zamora, 2001. p. 12.

${ }^{388}$ Fernández Ordóñez, Inés, "La composición por etapas de la Chronica latina regum Castellae (12231237) de Juan de Soria", en e-Spania [En línea], 2 | décembre 2006, Puesto en línea el 02 septiembre 2010. URL: http://e-spania.revues.org/283; DOI: 10.4000/e-spania.283 (5 de octubre 2013); y Bautista, Francisco, "Escritura cronística e ideología histórica"... op. cit.

Es de destacar el hecho de que el autor no solo alabe a los monarcas, sino que también dedique especial atención a los clérigos que los aconsejan. Así como también el que su estilo y narración habrían influenciado los posteriores trabajos de Lucas de Tuy y Jiménez de Rada (quienes posteriormente retomaron el goticismo como discurso legitimador), no obstante Juan de Osma escribió sobre los hechos contemporáneos, en tanto que Lucas y Jiménez, en gran parte, dedican sus crónicas a relatar los hechos pretéritos (Arizaleta, Amaia "La Chronica regum Castellae: aledaños de la ficción", en e-Spania [En línea], 2 | décembre 2006, Puesto en línea el 16 agosto 2010. URL: http://e-spania.revues.org/517; DOI : 10.4000/e-spania.517) (4 de octubre 2013).
} 
Rodríguez, también podría explicar algunas inconsistencias y omisiones en el texto en razón de cierta intencionalidad discursiva de su autor ${ }^{389}$.

Respecto al contenido de la Crónica, ésta relata los acontecimientos ocurridos en Castilla, a partir de la muerte de Fernán González, pasando brevemente por los distintos monarcas hasta alcanzar y explayarse sobre los reinados de Alfonso VIII, Enrique I y Fernando III, hasta la conquista de Córdoba ${ }^{390}$.

A nuestro parecer dos elementos destacan en el conjunto del relato: un marcado providencialismo, visible en la atribución a la inspiración divina de los principales acontecimientos históricos, y la intención de mostrar los logros y legitimidad de Castilla en uno de sus periodos de mayor expansión y avance frente al Islam. Lo que implica que la crónica posee un marcado lenguaje providencialista y cruzado, que centra uno de sus focos discursivos en la relación con la Iglesia y el Papado ${ }^{391}$. Todo ello, posiblemente como una estrategia en torno a la unión castellana con León, en 1230 y los intentos por reforzar, validar y legitimar a Fernando III como soberano del nuevo reino unido $^{392}$.

\footnotetext{
389 Según Ana Rodríguez, la obra de Juan de Osma, pareciera no tener intenciones por establecer un modelo regio, esto debido a su falta de prologo, carecer de una declaración de intenciones y no tener un destinatario claramente identificado. No obstante, según la misma autora un estudio más acabado de la fuente revela que su autor utiliza un lenguaje de fuerte simbolismo político regio y dedica especial atención en la narración de los procesos políticos, ejemplificados a través de la narración de virtudes y vicios asociados a la imagen real. Por lo que la Crónica Latina, podría enmarcarse junto con los textos en Lucas de Tuy y Jiménez de Rada, en lo que se refieren a la construcción de una imagen y discurso reales. (Rodríguez, Ana, "La preciosa trasmisión. Memoria y curia regia en Castilla en la primera mitad del siglo XIII", en Martínez Sopena, Pascual y Ana Rodríguez (Editores), La construcción medieval... op. cit., pp. 315, 316 y 321; y Rodríguez, Ana, "De rebus Hispaniae frente a la Crónica latina ... op. cit., p. 138). Según Francisco Bautista, en su artículo ya citado, sería esta misma característica de contemporaneidad lo que dificulta el conocer cuales fueron las fuentes utilizadas por el cronista, especialmente en la primera parte que presenta una síntesis de la historia castellana.

${ }^{390}$ Fernández Ordóñez, Inés, "La composición por etapas de la Chronica latina regum Castellae... op. cit. La Crónica se encuentra dividida en tres partes: la primera tiene un rol introductorio y reseña a los soberanos castellanos desde la muerte de Fernán González hasta Sancho III; la segunda esta dedicada al reinado de Alfonso VIII, con menciones a reinos relacionados con el fenómeno de las cruzadas como Francia, Inglaterra, Flandes y el Imperio Bizantino; finalmente, la última parte, está dedicada a Fernando III, siendo, además, la única que se respalda en una amplia cronología. (González, Julio, "La Crónica Latina... op. cit., pp. 55, 56; Mitre Fernández, Emilio, “¿Un sentimiento... op. cit., p. 411; y Sánchez Alonso, Benito, Historia de la historiografia ... op. cit., pp. 124, 125).

${ }^{391}$ Fernández Ordóñez, Inés, "La composición por etapas...op. cit.

${ }^{392}$ A lo anterior hay que agregar lo planteado por Fernández Ordóñez, con respecto a la influencia e impacto que tuvo esta crónica en su época, el cual se vio limitado por no haber sido parte de las fuentes utilizadas por Alfonso X para su Historia General, lo que en la práctica implicó relegar prácticamente al olvido a la Crónica Latina (Fernández Ordóñez, Inés, “La composición por etapas... op. cit.).
} 


\section{Cronicon Mundi}

Como ya mencionamos, dentro de los autores del siglo XIII destacan las figuras de dos prominentes clérigos; el primero de ellos fue el Obispo Lucas de Tuy, "el Tudense",393.

El Cronicon Mundi fue un claro ejemplo de la historia al servicio de la política, y es inseparable del proceso que llevó a la unión definitiva de Castilla y León en 1230 bajo el reinado de Fernando III. Para Lucas, un "patriota” leonés, ésta unión no era bien vista y no ocultó sus intenciones de reivindicar la grandeza leonesa. En la primera parte de su Cronicon Mundi, "De Excellentia Hispanie”, coloca a León como un ejemplo virtuoso de patria y civitas $^{394}$; incluso, en su relato, la toma de posesión de la corona leonesa por parte del rey castellano es descrita como un episodio distante, casi con desinterés. Es en vista de lo anterior que a nuestro juicio, para este caso, las ideas políticas del autor pesaron más que la de su "mecenas", dándole a su obra un cariz particular que la convierte en una interesante fuente del período.

Relacionado con los aspectos políticos, está también la concepción moralista que Lucas tiene de la historia ya que en su crónica plantea a Fernando III una serie de preceptos morales, una especie de "espejo de príncipe" que aconseja sobre los distintos aspectos del buen gobierno ${ }^{395}$. Esta característica de la obra del "Tudense" no debe sorprendernos, menos cuando sabemos que su patrocinadora fue Berenguela de Castilla

393 Originario de León, nació a mediados del siglo, entre 1221 y 1239, fue canónigo de San Isidoro de León y Obispo de Tuy entre 1239 y 1249, año de su muerte. Durante su vida viajó a Jerusalén, Grecia, Constantinopla, Tarso de Cilicia, Armenia, París y Roma. Fue un combativo opositor de la herejía albigense, contra la cual redactó varios escritos basados en San Isidoro y San Jerónimo. (Lucae Tudensis, Opera Omnia, Chronicon Mundi, Cura et studio Emma Falque, Corpus Christianorum, Continuatio Mediaevalis, LXXIV, Bélgica, Brepols Publishers, 2003, pp. VII, VIII (En adelante CM).

Cercano a la Corte real, gozó de bastantes influencias; esta pudo ser la razón que explica que en 1236 la reina Berenguela le encomendase la elaboración de una obra historiográfica, el Cronicon Mundi, que dicho sea de paso, es la primera obra de este tipo compuesta por encargo. Ésta abarca desde la creación del mundo hasta la época del autor, extendiéndose hasta 1236, en el reinado de Fernando III. Su intención era la composición de una historia universal, y a la vez peninsular. Dividida en cuatro partes, denota la influencia de autores anteriores como San Isidoro, Orosio, Alfonso III, el Silense, entre otros (CM, op. cit., pp. XIX a XXV, Costas Rodríguez, Jenaro, op. cit., p. 13. Según Peter Linehan, Lucas de Tuy no habría concluido su obra en la fecha comúnmente aceptada, sino que para el año 1239 todavía habría estado escribiéndola. Ver el artículo del autor "Fechas y sospechas sobre Lucas de Tuy", en Anuario de Estudios Medievales. No32, 2002, [pp. 19-38]; y Procter, Evelyn, Alfonso X of Castile... op. cit., p. 80). Destaca a su vez por el uso de fuentes juglarescas y legendarias; y es menos innovadora en su postura frente al providencialismo propio de su época, careciendo de un "espíritu critico" en la evaluación de sus fuentes. Lo anterior, llevó a dar crédito a relatos fantásticos y milagros mezclados con hechos históricos (Alvira Cabrer, Martín, Guerra e ideología... op. cit., pp. 123-125).

${ }^{394}$ Linehan, Peter, "Lucas de Tuy, Rodrigo Jiménez de Rada y las Historias alfonsíes", en Fernández Ordóñez, Inés, Alfonso X el Sabio... op. cit., pp. 22, 23.

${ }^{395}$ Rucquoi, Adeline, "Cultura y poder en la monarquía medieval castellana", en III Curso de Cultura Medieval, Repoblación y Reconquista, Aguilar de Campo, Centro de Estudios del Románico, 1993, p. 83. 
(1180-1246), que en su papel de madre siempre mantuvo una estricta vigilancia moral sobre su hijo.

\section{Historia de Rebus Hispanie}

Como contraparte al "Tudense", encontramos la figura del Arzobispo de Toledo Rodrigo Jiménez de Rada, "el Toledano"396. Su gran obra historiográfica fue la Historia de Rebus Hispanie, escrita entre mediados de 1241 y 1242 (pese a que la obra se autofecha en marzo de 1243). Las intenciones de su autor, según Georges Martin, fueron las de componer un texto de historia nacional, centrada en la Península y en particular en Castilla. Teniendo como base los trabajos de Juan de Osma y Lucas de Tuy, el "Toledano" es el primero en plantear la historia de Hispania como una unidad geográfica y cultural coherente que va desde la Creación hasta la Conquista de Córdoba, a través de una reinterpretación de las fuentes - y no de su simple trascripción como era habitual -. Ello en la línea del pensamiento goticista y la correspondiente exaltación de la unidad y grandeza hispánica ${ }^{397}$.

\footnotetext{
${ }^{396}$ De origen navarro, nació en 1170 y fue educado en la Corte de Sancho IV. Continuó sus estudios en Bolonia y en Paris, donde cursó cátedras en Derecho Canónico y Teología. De regreso a España, en el año 1207, medió un acuerdo de paz entre Alfonso VIII de Castilla y Sancho VII de Navarra. Cercano al rey castellano, éste lo nombró su consejero, y en 1209 lo hace elegir Arzobispo de Toledo sin importar que para ese entonces Rodrigo aún no hubiese sido ordenado sacerdote. Pese a ello, la decisión regia es confirmada por Inocencio III. A partir de entonces el principal objetivo de Jiménez fue lograr que Roma ratificase la supremacía de Toledo sobre toda la Península (HHE, op. cit., pp. 16 - 20) Por su experiencia, Alfonso VIII le envía como embajador a Francia para reclutar tropas para la campaña de las Navas de Tolosa. Regresa para participar en la batalla, de la cual nos dejó un vívido relato en su obra. A la muerte del rey fue nombrado albacea de su testamento, decantando su apoyo hacia la reina Berenguela. En 1215, en el IV Concilio de Letrán logró un tibio apoyo papal para sus planes de primacía para Toledo, aunque siguió contando con importantes opositores en el clero peninsular. En 1217, al ser coronado Fernando III, se confirmó su cargo de Canciller Mayor del reino.

Al año siguiente fue nombrado Legado Pontificio para la Reconquista, debiendo realizar campañas contra los musulmanes pese a existir una tregua vigente firmada por Fernando III y que solo expiraron en 1224. Finalizada esta tregua, Jiménez acompañó al rey en varias campañas, e incluso dirigió la conquista de la Villa de Quesada que le fue posteriormente donada por el monarca. En 1236 viajó a Roma para solucionar una disputa de jurisdicción con las órdenes militares, ocasión en que fue acusado de irregularidades por parte de dos racioneros de la Catedral de Toledo. Si bien la acusación no prosperó, dañó la credibilidad del Arzobispo, quien a partir de ese momento comenzó a defender más duramente la primacía de su diócesis.

Durante sus últimos años se distanció del rey y parece haber perdido el favor real. Murió en 1247 en el Ródano, cuando regresaba de entrevistarse con Inocencio IV en Lyón (HRH, op. cit., pp. IX, X).

${ }^{397}$ HHE, op. cit., p. 47. Mitre Fernández, Emilio, “¿Un sentimiento... op. cit., pp. 412, 413; y Fernández Ordóñez, Inés, "La composición por etapas... op. cit.

No obstante las intenciones "hispánicas" de Jiménez de Rada, es importante recordar que se trato de un autor leal a Castilla, característica que lo llevo a procurar la exaltación de ese reino en particular, al punto que Georges Martin sostiene que el Arzobispo fue quien "le atribuyo a Castilla su primera identidad política". Ejemplo de ello se puede observar en episodios como la campaña de las Navas de Tolosa. Según (Martin, Georges, "La invención de Castilla. Rodrigo Jiménez de Rada, Historia de rebus Hispaniae, V. Identidad patria y mentalidades políticas", en Séminaire interdisciplinaire de recherches sur'l Espagne medievales (SIREM), 2006, p. 1).
} 
Esta nueva "metodología" revela al autor como un símbolo de los cambios ideológicos del siglo XIII; su intención es identificar raíces comunes que sirvan para los grandes objetivos políticos del reino y la Iglesia: la Reconquista y la cruzada ${ }^{398}$. Aquí puede observarse la influencia de San Isidoro. Rodrigo, al igual que Lucas de Tuy, fue influenciado por el Obispo de Sevilla, de quien obtuvo la idea de una España unida, sumada al lamento por el territorio perdido y el llamado para su recuperación ${ }^{399}$.

La obra de Jiménez de Rada no sólo posee un providencialismo más matizado, sino que también posee un espíritu más crítico que le sirve para explicar, la rápida caída del Reino Visigodo. Para ello enumera las causas de este hecho, desde el desarme militar del reino ordenado por Witiza, las pestes, y otras causas materiales que explican racionalmente el desastre. De esta manera pudo combinar sin dificultades la explicación racional con la providencialista, que interpretaba los acontecimientos como un castigo divino por los pecados de los reyes visigodos ${ }^{400}$.

De esta obra es de destacar que el autor se refiere extensamente a los acontecimientos por él visto o vividos. Muchos de estos relatos, incluso, se hacen en primera persona, destacando los acontecimientos bélicos. Esto no es de extrañar puesto que Jiménez fue un activo promotor de la Reconquista en el siglo XIII ${ }^{401}$. En relación a lo anterior, esta obra posee, al igual que los escritos del "Tudense", un marcado carácter político. La lucha por la Reconquista y los constantes mensajes morales expresados en relación a los reyes nos hablan de una intención por sacralizar la guerra y apresurar la recuperación territorial lo que es coherente con el patrocinio que recibió de Fernando III. Su misión era por tanto, servir a la corona justificando los actos del soberano.

Asimismo, el Arzobispo procuró ignorar o "retocar" algunos hechos relatados en su crónica. Ése fue el caso de su relato sobre los preparativos para la campaña de las

Según Martin los aportes de Jiménez de Rada a la identidad castellanista se pueden sintetizar en la concepción de un territorio determinado y de raíces étnicas, la identificación de sus orígenes poderosos, basados en los báculos y la distanciación de León. Todo lo anterior implicaría, según Jiménez de Rada, la existencia de un linaje y tradición propios de Castilla. (Martin, Georges, "La invención de Castilla... op. cit., pp. 4 y 11).

${ }^{398}$ Guiance, Ariel, "Morir por la patria... op. cit., p. 76; Rucquoi, Adeline, “El Rey Sabio... op. cit., p. 83; y Orcástegui, Carmen y Esteban Sarasa, La historia en la Edad Media ... op. cit., p. 227.

399 Aparte de Isidoro sus principales fuentes fueron Jordanes y Lucas de Tuy, además de las Crónicas Mozárabe, de Alfonso III, Sampiro, Najerense, de Pelayo y la Silense, a los que se suman algunos relatos árabes y épicos franceses y españoles.

${ }^{400}$ García Moreno, Luis A., El fin del Reino Visigodo de Toledo: decadencia y catástrofe, una contribución a su crítica, Madrid, Universidad Autónoma, 1975, pp. 28, 29.

${ }^{401}$ Esta característica de "el Toledano" no solo hace referencia a su participación en la batalla de las Navas de Tolosa y el cariz de su crónica, sino que también a su rol de difusor de la cruzada en tierras francesas, sus contactos con Roma y su designación como legado de Honorio III para la cruzada hispánica, entre otros episodios relacionados. 
Navas de Tolosa, al aminorar e incluso omitir los conflictos y desórdenes que causaron los ultramontanos en Toledo. También atribuyó a la intervención diabólica el que éstos abandonaran la campaña, para así no culpar directamente a ninguno de los caudillos involucrados ${ }^{402}$.

Otro ejemplo de su carácter político versa sobre el delicado tema de la unión de Castilla y León: Jiménez, al contrario que Lucas, celebrará y destacará el hecho, y para ello no dudará en restar importancia a los acontecimientos leoneses ${ }^{403}$.

Esta crónica es un ejemplo de como la alianza entre historia y política se consolidará a lo largo del siglo XIII y más durante el reinado de Alfonso X, quien necesitará justificar su legitimidad más que ninguno de los monarcas que lo antecedieron, a raíz de las revueltas nobiliarias y el enfrentamiento con su propio hijo, el infante Sancho.

\section{Crónica General de España}

Asimismo dentro de los principales autores del siglo XIII se encuentra el rey Alfonso X (1252-1284) 404 . El llamado "Rey Sabio", tuvo un reinado marcado por distintos problemas. De su padre, Fernando III, heredó un Reino Castellano-Leonés unificado y un proceso de Reconquista que había experimentado grandes avances territoriales, pero también un Estado que comenzaba a fracturarse políticamente y una economía sobreexigida debido al esfuerzo bélico desplegado. A ello deben sumarse las pretensiones imperiales del rey, que sólo contribuyeron a dividir aún más a la alta jerarquía del reino y a exigir económicamente cada vez más a sus habitantes para financiar los proyectos reales. Fue, por tanto, un reinado de contrastes, donde los grandes avances del los monarcas anteriores se vieron ensombrecidos por las disputas internas y la guerra civil.

En el ámbito cultural, el reinado de Alfonso X fue más exitoso, famosas son sus obras las Cantigas a Santa María, las Siete Partidas, etc. También destaca su labor historiográfica. Alfonso patrocinó la elaboración de una magna obra, la Crónica

\footnotetext{
${ }^{402}$ HHE, op. cit., Libro VIII. Cap. I., p. 308 y Libro VIII, Cap. VI, p. 314.

${ }^{403}$ Linehan, Peter, "Lucas de Tuy, Rodrigo Jiménez... op. cit., pp. 30, 31; Adeline Rucquoi, "El Rey Sabio... op. cit., p. 83; Barkai, Ron, El enemigo en el espejo... op. cit., p. 296; y Huici Miranda, Ambrosio, Las grandes batallas de la Reconquista durante las invasiones africanas (Almorávides, Almohades y Benimerines), Madrid, s.n., 1956, p. 304.

${ }^{404}$ Por ser la biografía de este rey bastante conocida consideramos innecesario reseñar su vida en el presente trabajo y preferimos centrarnos en su obra historiográfica.
} 
General de España, también llamada la Primera Crónica General ${ }^{405}$; un texto de carácter general dedicado a exaltar los hechos de España y de sus reyes. Ello en directa relación con el contexto del momento, marcado por el Fecho imperio ${ }^{406}$.

La Crónica, en su primera parte, se basa en las obras anteriores de Paulo Orosio, Paulo Diácono, Eusebio de Cesarea, San Jerónimo, San Isidoro, Justino entre otros, en tanto que para la segunda usa los trabajos de Lucas de Tuy y Jiménez de Rada, de cuyas obras extrae gran cantidad de episodios, prácticamente sin ningún tipo de edición. A esto sumó el uso de leyendas heroicas, literatura popular y fuentes árabes, además de clásicos latinos, europeos contemporáneos, todo ello en pos de alcanzar las aspiraciones

${ }^{405}$ A lo largo de nuestro trabajo nos referiremos a esta obra por cualquiera de sus dos denominaciones, la ultima correspondiente al nombre con el cual fue editada por Ramón Menéndez Pidal. No obstante estamos concientes que esta edición es el resultado de numerosas refundiciones medievales y posteriores a la obra original del "Rey Sabio". Para mayor información al respecto recomendamos la Presentación del trabajo de Inés Fernández Ordóñez (Alfonso X el Sabio y las crónicas de España, España, Universidad de Valladolid, 2000); y Procter, Evelyn. Alfonso X of Castile... op. cit., p. 82.

${ }^{406}$ Respecto a la autoria de la Crónica General, habría sido iniciada por Alfonso X en 1270, quien intervino, supervisando el trabajo de los escribas, en la redacción de la primera parte -que abarca desde los orígenes de Hispania hasta la invasión musulmana-. Sin embargo, el rey murió antes de terminar la obra, y la segunda parte fue finalizada durante el reinado de su hijo Sancho IV, en 1289. Este hecho explicaría los distintos estilos de redacción de la misma. (Primera Crónica General de España, Editada por Ramón Menéndez Pidal con un estudio actualizador de Diego Catalán, $2^{\circ}$ tomo de la tercera reimpresión, Madrid, Gredos, 1977, pp. 855-870. (En adelante CGE).

La base de lo que conocemos como Primera Crónica General se compone de la refundición del texto en dos etapas distintas de elaboración. Durante la vida de Alfonso X se había compuesto una primera versión conocida como Regia o Primitiva que abarcaría desde los orígenes hasta, quizás, el reinado de Fernando I. Luego de la muerte del "Rey Sabio", se habría elaborado la segunda parte de la crónica conocida como Versión Vulgar o Concisa. A estas versiones se fueron agregando nuevas ediciones y correcciones, pero sin que se lograse llevar a cabo la idea original de Alfonso X que era la composición de una historia general desde los orígenes hasta su propio reinado. Para una cabal comprensión de la elaboración de la Primera Crónica General, recomendamos las colaboraciones de Fernando Gómez Redondo, "La construcción del modelo de Crónica real” y Juan Bautista Crespo, "La 'Estoria de España' y las crónicas generales"; contenidos en el texto de Fernández Ordóñez Alfonso X el Sabio y las crónicas de España; además del trabajo de Leonardo Funes, El modelo historiográfico alfonsí: Una Caracterización, London, Department of Hispanic Studies, Queen Mary and Westfield College, 1997.

La Crónica general es una obra en extremo particular dentro de la historiografía hispana medieval, puesto que no sólo recopila y sintetiza los antiguos tópicos cronísticos, sino que combina cuatro elementos nuevos o reinterpretados: el uso de fuentes de forma crítica y en vista de un plan global de la obra; el uso de temas provenientes de la poesía y tradición popular; la utilización de fuentes árabes y musulmanas y, finalmente, la utilización de la lengua vulgar a lo largo de todo el texto.

Respecto al uso del romance -quizás la principal innovación del texto y según Diego Catalán, hecho inaugural de una nueva era en la historiografía peninsular-, la Crónica pretendía institucionalizar el uso de la lengua vulgar con el fin de facilitar su divulgación entre la población medianamente instruida como los señores, caballeros y burgueses, a la vez que difundir la cultura castellana en contraposición a la cultura árabe. Este esfuerzo estaba impulsado por el patrocinio real, ayudando financieramente a las escuelas de traductores que se esforzaban por verter al latín y castellano las grandes obras del pasado clásico (Catalán, Diego, La estoria de España de Alfonso X: creación y evolución, Madrid, Universidad Complutense de Madrid, Seminario Menéndez Pidal, 1992, p. 143. Mitre Fernández, Emilio, "Historiografía y tradiciones compilatorias del medioevo europeo", en Actas del III Curso de Cultura Medieval. Repoblación y reconquista, Centro de Estudios Románicos Aguilar del Campoo, Septiembre de 1991, pp. 107-114). 
del rey de elaborar un relato histórico total ${ }^{407}$. En otras palabras la obra alfonsí es esencialmente una compilación de obras anteriores, a la que los cronistas del rey procuraron dar un sentido discursivo preciso en favor del soberano.

Es así como en sus aspectos puramente políticos, la obra se hace parte de la corriente ideológica del siglo XIII influenciado por San Isidoro, en cuanto muestra a España como una unidad política que clama por la recuperación de su territorio. $\mathrm{Su}$ principal innovación es considerar que tanto la dominación romana como la musulmana son parte integrante de la historia hispánica, separando los hechos peninsulares de la historia general ${ }^{408}$. Respecto a las intenciones reales, la obra no escatima elogios hacia la corona, la nobleza y la Iglesia. La escuela alfonsí no dudó en difundir la idea de que la monarquía era el reflejo terrenal del orden divino, donde el rey recibe sus poderes de Dios y es su representante en la tierra, siendo este el eje conductor de la narración ${ }^{409}$. Esta postura era parte de los planes de Alfonso X para la obtención del Imperio, pero los esfuerzos del monarca no tuvieron los resultados esperados. Aún así, la obra es un excelente reflejo de la mentalidad del rey que la patrocinó y un claro ejemplo de las intenciones políticas que caracterizaban a la historiografía del siglo XIII.

A modo de síntesis, se puede afirmar que la obra historiográfica de Alfonso X tenía varios objetivos políticos y propagandísticos; el primero de ellos, el de fortalecer la figura del monarca como legitimo regente, para lo cual incorporó las ideas neogoticistas de Isidoro y el providencialismo de Paulo Orosio; en segundo lugar y en relación a lo anterior, el de exponer un discurso destinado a deslegitimar las reclamaciones de los magnates del reino y justificar sus intenciones jurídicas de centralizar el poder - pudiendo incluso contener un mensaje velado contra las acciones del Infante Sancho -. Por último, pretende ilustrar ejemplos y modelos a seguir por los sucesores del rey, y señalar la necesidad de la Reconquista ${ }^{410}$.

\footnotetext{
${ }^{407}$ Georges Martín, "El modelo historiográfico alfonsí y sus antecedentes”, en Fernández Ordóñez, Inés, Alfonso X el Sabio y las crónicas de España, España, Universidad de Valladolid, 2000, p. 94; PCG, op. cit., pp. 871; Gárate Córdoba, José María, Espíritu y Milicia... op. cit., pp. 231; Tuliani, Mauricio, "La idea de Reconquista en un manuscrito de la Historia General de Alfonso X", Studia historica. Historia medieval. Universidad de Salamanca, 12, 1994, [pp. 3-23], p. 4; Sánchez Alonso, Benito, Historia de la historiografia ... op. cit., p. 216; y Procter, Evelyn, Alfonso X of Castile... op. cit., p. 96-104.

${ }^{408}$ CGE, op. cit., Apéndice, pp. 888, 889.

${ }^{409}$ Catalán, Diego, La estoria de España ... op. cit., p. 30; y Tuliani, Mauricio, "La idea de Reconquista... op. cit., pp. 6, 7.

${ }^{410}$ Respecto a los aspectos discursivos e ideológicos de la Primera Crónica General recomendamos los textos de Funes, Leonardo, El modelo historiográfico alfonsí... op. cit.; Jiménez Vicente, $\mathrm{M}^{\mathrm{a}}$ del Carmen, La razón de Estado en Alfonso X el Sabio. Paulo Orosio en la Primera Crónica General, Salamanca, Universidad de Valladolid, 1993; y Homet, Raquel, "Caracteres de la conciencia histórica: los sueños y visiones en la Estoria de España”, en En la España Medieval, 25, 2002, pp. 85-112.
} 
Crónica de veinte reyes

Con posterioridad a la Crónica general de Alfonso X, se produjo de forma anónima la actualmente llamada Crónica de veinte reyes. La obra, escrita en romance, abarca unos tres siglos de historia, comenzando con el reinado de Fruela II (924-925) hasta el fin del reinado de Fernando III (1217-1252). Posiblemente fue escrita entre los años 1270 y 1289, entre los reinados de Alfonso X y Sancho IV (1284-1295) ${ }^{411}$.

En cuanto a contenido, la crónica se centra principalmente en lo concerniente al Reino de Castilla, destacando a personajes nobiliarios como Fernán Gonçález, los Infantes de Lara, Sancho el Fuerte, y el Cid. De los personajes reales, Fernando I, Alfonso VI, Alfonso VII, Alfonso VIII y Fernando III son los tratados con mayor profusión, llegando a ocupar la mayor parte de la obra. Debido a su eje castellano, la crónica deja en un lugar secundario los acontecimientos de los restantes reinos hispanos y musulmanes, y sólo se refiere a ellos cuando se relacionan directamente con Castilla $^{412}$.

\footnotetext{
${ }^{411}$ Su título original nos es desconocido, y el que actualmente utilizamos se lo debemos a Menéndez Pidal, quien se basó en el número de reinos que abarca la obra para su denominación: Fruela II, Alfonso IV, Ramiro II, Ordoño III, Sancho I, Ramiro III, Vermudo II, Alfonso V, Vermudo III, Fernando I, Sancho II, Alfonso VI, Urraca y Alfonso I, Alfonso VII, Sancho III, Fernando II, Alfonso VIII, Alfonso IX, Enrique I, y Fernando III (Al parecer el autor omitió intencionalmente a Ordoño por considerarlo un usurpador dentro del reinado de Sancho I). Se supone que originalmente la obra consistía en la llamada Crónica de Once Reyes, a la que posteriormente se le agregaron los reinados de Fernando I, Sancho II y Alfonso VI y en una segunda etapa le fueron sumados los reinados de Alfonso VII, Sancho III, Fernando II y parte del de Alfonso IX. Finalmente, algunos años después, la obra se dio por terminada con el añadido del reinado de Fernando III (Crónica de Veinte Reyes, Burgos, Ayuntamiento de Burgos, 1991, pp. 13 - 20. (En adelante CXXR). Inés Fernández Ordóñez sostiene que la Crónica es una rama de los manuscritos de la llamada Versión Crítica de la Primera Crónica General. (Fernández Ordóñez, Inés, Alfonso X el Sabio y las crónicas de España, op. cit., p. 254).

Las fuentes sobre las que se basó la compilación y redacción de la Crónica fueron principalmente, la Primera Crónica General de Alfonso X, el De Rebus Hispaniae e Historia Arabvm de Jiménez de Rada, el Cronicon Mundi de Lucas de Tuy, y la Historia Roderici, a las que se suman algunas obras árabes y cantares de gesta como el Cantar del Rey Fernando y el Cantar del Mío Cid, además de los Annales Compostellani y los Annales Portugalenses Veteres. Al parecer, el o los autores ordenaron su compilación usando como referencia la Crónica de Alfonso X, siendo los primeros once reinados anteriores a la Crónica general, en tanto que los relatos de los reinados de Alfonso VII, Sancho III, y Fernando II serían posteriores a la crónica alfonsina. Finalmente, gran parte del reinado de Fernando III es una transcripción literal de la parte correspondiente de la Crónica General (CXXR, op. cit., p. 16)

${ }^{412}$ Ibídem, p. 33.
} 
La Crónica de veinte reyes mantiene varias de las innovaciones de los talleres alfonsíes, pero en ningún caso alcanza la profundidad discursiva e ideológica de sus antecesoras, sin que por ello deje de ser una obra valiosa para los investigadores ${ }^{413}$.

${ }^{413}$ Durante el siglo XIII y complementario a la cronística harían su irrupción los Espejos de príncipes. Un nuevo género, compuesto por tratados morales y didácticos que aquí incluiremos como complementarios a las crónicas debido a que en sus orígenes compartían varias de las características de éstas en lo que se refiere a su intención didáctica, formativa y ejemplar ${ }^{413}$. Inicialmente los "espejos de príncipe", fueron originarios de Bizancio y fueron difundidos entre los musulmanes, pero también están presentes en varios países europeos, surgieron como una forma de expresión de determinados círculos intelectuales y cortesanos que buscaban influenciar en los grandes señores. La idea de sus autores era continuar con la idea de larga tradición de que la historia debía ser una magistra vitae, pero además buscaban trasmitir consejos valóricos, políticos y morales de forma clara para que sirvieran de referencia a los monarcas, por ello no fue infrecuente que muchos espejos de príncipe fueran compuestos a petición de algún soberano para ser entregados a sus herederos, trasformando así las obras en textos didácticos además de manuales políticos. (Rodríguez Velasco, Jesús D., "La historia como base argumentativa de la literatura éticopolítica en Europa, ca. 1100-1350", Epos. Revista de Filología, 12, 1996, [pp. 177-205], pp. 179-195; y Pizarroso Quintero, Alejandro, Historia de la Propaganda ... op. cit., p. 67).

En el ámbito hispánico uno de los primeros espejos de príncipe en ser compuesto fue el que ahora conocemos como El libro de los doze sabios o Tratado de la nobleza y lealtad, mandado a componer por el rey Fernando III alrededor del año 1237, y que posiblemente estaba destinado a la formación del infante Alfonso. En su comienzo el texto relata un cónclave de doce sabios, convocados por Fernando III para: "[...] dar consejo en lo espiritual y temporal: en lo espiritual para salud y descargo de la vuestra anima, y de la vuestra esclarecida y justa conciencia, en lo temporal para vos decir y declarar lo que nos parece en todas las cosas que nos dijistes y mandastes que viésemos... Y otrosi de como debe regir, y castigar, y mandar, y conocer a los del su reino, para que vos y los nobles señores infantes vuestros hijos tengáis esta nuestra escritura para estudiarla y mirar en ella como en espejo" (El libro de los doze sabios o Tratado de la nobleza y lealtad [ca. 1237], Real Academia Española de la Lengua (Anexos del Boletín de la RAE, XXIX), Madrid 1975, páginas 71-118. en: http://www.filosofia.org/aut/001/12sabios.htm. 2 de abril de 2010 (En adelante LDS); Rucquoi, Adeline y Hugo Bizzarri, "Los Espejos de Príncipes en Castilla: entre Oriente y Occidente", en Cuadernos de Historia de España, LXXIX, 2005, [pp.7-30] p. 12).

El texto está dividido en LXVI títulos dedicados a diversos temas políticos y morales, entre los que destacan la virtud, la honra, la lealtad, la justicia, cómo tratar al pueblo y a los señores, la forma de ir a la guerra, entre otros (Bizzarri, Hugo Oscar. "La idea de Reconquista en el Libro de los doze Sabios", en Revista de Filología Española, Tomo LXXVI, Enero-Junio, 1996, Fascículos 1²-2 , CSIC, Madrid, 1996, [pp. 5-29], pp. 5, 14).

Otro texto a destacar es el De Preconnis Hispanie de Juan Gil de Zamora (Nacido alrededor del año 1240, miembro de la orden Franciscana, fue scriptor de Alfonso X, quien le encomendó la educación de su hijo, el futuro Sancho IV) Quien También habría sido el autor del Tractatus Historiae Canonicae et Civilis o Liber Illustrium Personarum, con toda certeza del De preconiis civitatis Numantinae y posteriormente del ya mencionado De Preconnis Hispanie, dedicado a su pupilo Sancho IV (Gil de Zamora, Juan, De preconiis Hispanie o Educación del príncipe, traducción y estudio José-Luis Martín, Jenaro Costas, Ayuntamiento de Zamora, 1996, p. 12 (En adelante DPH); Díez Borque, José M. (Editor), Historia de las literaturas... op. cit., p. 82; y Fernández Conde, Francisco Javier, La Religiosidad Medieval... op. cit., p. 474).

El De Preconnis se encuentra dividida en tres partes, siendo una combinación de resumen histórico de Hispania -basado principalmente en Jiménez de Rada-, un tratado sobre los príncipes y su pueblo, y un manual militar. Siendo su primera parte una combinación de una síntesis histórica con un tratado político destinado a presentar modelos de conducta ideal al príncipe heredero; su segunda parte es básicamente un resumen -en especial de los libros XI y XII- del Epitome Rei Militaris de Vegecio, y por último la tercera parte esta dedicada a relatar la historia de Zamora (Rucquoi, Adeline, "Cultura y poder en la monarquía...op. cit., p. 84; DPH, op. cit., p. 22; García Fitz, Francisco, "La didáctica militar en la literatura castellana (Segunda mitad del siglo XIII y primera del XIV)", en Anuario de Estudios Medievales, 19, Consejo superior de Investigaciones Científicas, 1989, [pp. 271-283], p. 271; y Rodríguez Velasco, Jesús D., "La historia como base argumentativa... op. cit., p. 198).

Cada una de estas secciones responde a una finalidad didáctica y política distinta. En la primera se justifica y valida el papel del monarca como representante de Dios y columna vertebral de la sociedad. 
Fuentes posteriores: la Crónica de Alfonso X.

Junto a los textos reseñados también nos serán útiles algunas obras posteriores para el objeto de contextualizar las conclusiones de parte de nuestro trabajo ${ }^{414}$. Entre ellas destacamos la Crónica de Alfonso $X$, que fue mandada componer por el rey Alfonso XI (1312-1350) alrededor del año 1344. Si bien su autor material es desconocido, existe cierto consenso respecto a una posible autoría de Fernán Sánchez de Tovar y Fernán Sánchez de Valladolid. Las intenciones de la obra, según su mismo prólogo, son recordar y perpetuar los hechos del pasado, que deben quedar escritos como testimonio. De esta forma, se deben relatar los actos de los reyes de Castilla y León, representantes terrenales de Dios y que luchan para recuperar España: "[...] conuiene que los fechos de los reyes, que tienen lugar de Dios en la tierra, sean fallados en escripto, señaladamente de los reyes de Castilla e de León, que por la ley de Dios e por acrecentamiento de la santa fee católica tomaron muchos trabajos e se posyeron a grandes peligros en las lides que ouieron con los moros echándolos de Espanna." ${ }^{415}$

Recordemos que Gil escribe en momentos en que las luchas entre los nobles y Alfonso X hacían tambalear a la monarquía y es clara su intención de inculcarle valores al Infante que asegurasen la continuidad del modelo monárquico. La segunda parte responde a las necesidades bélicas de una sociedad marcada por la lucha y la Reconquista, para lo cual el autor seleccionó los libros más prácticos del Epitome Rei Militaris y los adaptó ligeramente a la situación hispánica. Por último, la tercera parte responde más a motivaciones personales del autor, que siendo originario de Zamora, quería rendir un homenaje a su tierra y quizá también granjearle el favor real.

414 Junto a los textos cristianos, consideramos interesante incluir alguna fuente musulmana, solo como referencia y a veces para contrastar algunos de los relatos de las fuentes hispanas. Para ello utilizamos principalmente el trabajo del autor origen magrebí Abu 1-Abbas Ahmad b. Muhammad b. 'Idari al-Marrakusi (Ibn 'Idari), conocido en castellano como La caída del califato de Córdoba y los reyes de taifas. De su autor, sabemos que vivió entre fines del siglo XIII y comienzos del siglo XIV, que pasó gran parte de su vida en el actual Marruecos y que habría muerto alrededor del año 1320. Esto ha permitido datar la composición de su obra entre el año 1313 y la muerte de su autor.

La crónica se encuentra dividida en tres partes; la primera dedicada a relatar la historia de los territorios del actual Túnez y sus monarcas hasta la llegada de los almorávides; la segunda a contar la historia del al-Andalus, el auge del emirato de Córdoba y su posterior caída, el surgimiento de los reyes de taifas y sus guerras intestinas, finalizando con el arribo de los almorávides a la Península. De esta parte destaca el relato de la captura de Barbastro por parte de una expedición de cristianos ultramontanos y su posterior recuperación por los andalusíes, además de la descripción de las campañas de Fernando I. La tercera y última parte de la obra pretendía tratar la historia de almorávides, almohades, hafsies, hudies y los nasríes en el al-Andalus, pero su autor sólo pudo escribir sobre los dos primeros pueblos, dejando inconcluso el resto de la obra. (Ibn 'Idari al-Marrakusi, La caída del Califato de Córdoba y los reyes de Taifas, estudio, traducción y notas de Felipe Maillo Salgado, Salamanca, Universidad de Salamanca, 1993, p. V y ss. (En adelante CCC).

Para nosotros la utilidad de esta crónica está en que, pese a ser del siglo XIV, fue compuesta en una fecha no tan lejana de nuestro marco cronológico de estudio, siendo especialmente interesante la imagen que trasmite de los cristianos y de la ideología que los motiva a luchar: deja patente y sin reproches que los hispanos estaban combatiendo por la recuperación de lo que ellos consideraban sus tierras ancestrales.

${ }^{415}$ Crónica de Alfonso X, según el Ms. II/2777 de la Biblioteca del Palacio Real, edición, trascripción y notas por Manuel González Jiménez, Murcia, Real Academia de Alfonso X el Sabio, 1999, p. 3. (En adelante $\mathrm{CAX}$. 
El objetivo de esta crónica es el de relatar los reinados de Alfonso X, Sancho IV y Fernando IV (1295-1312), completando así Crónica General ${ }^{416}$.

Es importante destacar que en la Crónica se observa una tendencia a centrarse esencialmente en la narración de los sucesos, dada la virtual ausencia de elementos explicativos externos o justificaciones superiores, como el providencialismo, a diferencia de como ocurría en los textos de los siglos anteriores ${ }^{417}$.

\footnotetext{
${ }^{416}$ Según los expertos, la obra parece haber sido compuesta en distintas etapas, lo que explicaría sus frecuentes errores cronológicos, en especial en su primera parte, que es la más antigua. Su parte segunda es la mejor informada y coherente, y se dedica a relatar las revueltas nobiliarias de los años 1272-1273. $\mathrm{Su}$ tercera y última parte mantiene la apariencia de una composición descuidada, patente en la permanencia de los errores cronológicos (CAX, op. cit., pp. XIV a XXXVII.)

${ }^{417}$ Por razones similares a las referidas a los "Espejos de Príncipe", es que consideramos necesario remitirnos de forma general a los Cantares de Gesta y en especial a algunos de ellos que serán utilizados a manera referencial en nuestros análisis. Consideramos que este género posee algunas características comunes a ciertas crónicas y espejos de príncipe, en lo que se refiere a su aspecto ejemplificador y moralizante.
}

Los "cantares de gesta" pueden ser identificados como pertenecientes a la épica, es decir, una poesía compuesta de versos largos con cesura, agrupados en tiradas monorrimas de distinta longitud. En la alta Edad Media su composición en lengua vernácula servía para facilitar su difusión y exaltar los ideales caballerescos (Cantar de Mio Cid, edición, prologo y notas de Alberto Montaner, Estudio preliminar de Francisco Rico, Barcelona, Centro para la Edición de los Clásicos Españoles, 2007. p. XCIX; y Pizarroso Quintero, Alejandro, Historia de la Propaganda ... op. cit., p. 67). Lo cantares pueden ser divididos en varios géneros, siendo los principales los de épica interior y los de exterior. Los primeros relatan episodios dentro de una comunidad, principalmente venganzas personales o familiares, a veces recurriendo a la imagen de un héroe que se rebela contra la injusticia por parte del poder establecido. Los exteriores, en cambio, tratan sobre conflictos entre una sociedad y sus enemigos externos, que en el mundo medieval suelen ser los infieles, generalmente el musulmán, y en algunas regiones de Europa las tribus bárbaras o estepáricas no cristianizadas. Cuando el conflicto con los elementos externos se trasforma en guerra santa, entonces se habla de cantares de cruzada; no obstante, a veces el enfrentamiento no es radical y se caracteriza por cierto grado de comprensión, convivencia y admiración hacia el enemigo, produciéndose así los llamados cantares de frontera, frecuentes en la España medieval y muy distintos a los "cantares de cruzada" en los que la intolerancia hacia el enemigo es total (Cantar de Mio Cid. op. cit., pp. CII, CIII.)

El primero de los textos a reseñar es el muy conocido Cantar del Mio Cid. Sobre su fecha de composición y autoria no hay certeza, aunque existe cierto consenso de que fue compuesto entre finales del siglo XII y la primera década del siglo XIII por un autor anónimo. Sin embargo, algunos estudiosos han identificado como posible compositor del cantar a Pero Abad, canónigo de Osma (Gárate Córdoba, José María, Espíritu y Milicia... op. cit., p. 21; Lacarra, María Eugenia, El Poema de Mío Cid: Realidad histórica e ideología, Madrid, Ediciones José Porrúa Turanzas, 1980, p 6; y Riano Rodríguez, Timoteo, "Propósito de Pero Abat al escribir el Cantar de Mío Cid: Motivaciones geopolíticas", en Actas del Congreso Internacional del Cid, poema e historia (12-16 de julio, 1999), Coordinador Cesar Hernández Alonso, p. 279). Respecto al Cantar debemos referirnos a la polémica iniciada no hace mucho por Dolores Oliver Pérez y su trabajo El Cantar de Mio Cid: Génesis y autoria árabe (Almería, Fundación Ibn Tufayl de Estudios Árabes, 2008), libro en el que postula una posible autoria árabe para el Cantar, el cual habría sido escrito con anterioridad al siglo XIII, por Abu-l-Walid al-Waqqaši. Ello, según la autora, en razón de la forma en que se describe al personaje central, siguiendo un modelo de "héroe" islámico, así como la falta de demonización hacia los musulmanes y las estrategias militares atribuidas al Cid, pero que serian propias de los bereberes. Para mayor claridad sobre esta teoría, recomendamos referirse a la obra en cuestión y a la reseña de Luis Molina y Alberto Montaner, el "Cantar de Mio Cid y su supuesta autoría árabe" (Al-Qantara, XXXI, 1, 2010, pp. 311-323).

Respecto al contenido del Cantar, éste es de sobra conocido, por lo que sólo destacaremos su tendencia castellanista, expresada en las virtudes de su protagonista Rodrigo Díaz de Vivar y el ambiguo trato que recibe el rey Alfonso VI respecto a la forma en que se relaciona con el héroe. Además la obra 


\section{II.2.b.- La hagiografía, la mano de Dios}

Otro tipo de textos a los que haremos referencia a lo largo de este estudio corresponde al grupo de obras hagiográficas y obras líricas de carácter sacro, compuestas entre los siglos XII y XIII. En su conjunto estas obras nos trasmiten diversos aspectos de la religiosidad popular y “oficial” de la cultura hispánica, y si bien los temas puramente políticos no se encuentran presentes de forma directa, sí se pueden desprender de un fenómeno omnipresente en la mayoría de estas obras: la vida fronteriza, el contacto intercultural y el enfrentamiento entre musulmanes y cristianos. Es por ello que las obras seleccionadas que serán reseñadas a continuación, han sido incorporadas a nuestro estudio por el hecho de presentarnos otra perspectiva de la problemática que afrontamos; una perspectiva centrada en el hecho religioso y menos políticas, pero quizás igual de instrumentalizada que las crónicas.

\section{Vita Dominici Silensis de Grimaldo}

La primera de las obras que reseñaremos corresponde a la Vita Dominici Silensis de Grimaldo, esta fue compuesta entre los años 1088 y 1109 por un autor anónimo, pero se supone que fue contemporáneo al protagonista de la obra, Santo Domingo de Silos

puede enmarcarse en los llamados "Romances de Frontera", pero con algunas características particulares, puesto que es un problema interno lo que obliga al Cid a migrar al exterior, donde su conducta y acciones se desarrollan acorde con la vida y espíritu fronterizos, evidenciando una primacía de los intereses económicos y políticos respecto al trato con los musulmanes, por sobre el espíritu religioso, por lo que es difícil confundirlo con un "romance de cruzada" (Cantar de Mío Cid... op. cit., pp. CVII, CVIII).

El segundo texto que reseñaremos corresponde al conocido como Poema de Fernán Gonçález. La identidad de su autor sigue siendo un misterio, pero se presume que fue un clérigo ilustrado que habría compuesto el poema entre 1250 y 1275. El autor habría sido contemporáneo a Gonzalo de Berceo, por quien sentía admiración, al punto de que copia algunos versos de los Lores de Nuestra Señora y de la Vida de Santo Domingo. El poema narra los hechos protagonizados por Fernán Gonçález, conde de Castilla, entre la batalla de Osma en el año 934 hasta la muerte del conde en el año 970, sin olvidar una narración respecto a hechos anteriores como la conquista de Hispania por los godos y la invasión de los norafricanos en el 711 (López Guil, Itzíar, Libro de Fernán Gonçález, Madrid, Consejo Superior de Investigaciones Científicas, Instituto de la Lengua española, 2001, pp. 25-36, 125, 126 (En adelante PFG); y Sánchez, Tomas Antonio, Poetas castellanos anteriores al siglo XV, Madrid, Biblioteca de Autores Españoles, Atlas, 1966, p. XLIV).

Junto con exaltar al Conde, también es una oda a Castilla, sugiriendo que los castellanos son los legítimos herederos del Reino Visigodo, y motores de la Reconquista. También destaca en la obra una profunda presencia religiosa presente a través de apariciones de santos, oraciones, y discursos piadosos, además de las constantes referencias a Dios. Queda manifiesto además, su profundo sentido religioso en la manera en que el poema asume el hecho fronterizo: a diferencia del Cid, aquí no existe la tolerancia hacia los musulmanes. En este poema se reduce la relación intercultural al enfrentamiento entre los castellanos creyentes y los "moros" paganos, que son representados de forma negativa, como antropófagos, bárbaros, salvajes, sucios, y otros tantos epítetos descalificativos (Gárate Córdoba, José María, Espíritu y Milicia ... op. cit., pp. 41-57). Lo anterior aleja al poema de los cantares y otro tipo de literatura calificada de fronteriza, y lo acerca más a aquellos llamados de cruzada, sin que llegue a pertenece completamente a ese genero en particular. 
(1000-1073). La obra, escrita en latín, tendría dos grandes objetivos: en primer lugar, la clara intencionalidad propagandística de extender y fomentar el culto al santo, teniendo como uno de sus objetivos que la abadía donde está sepultado Domingo se convirtiera en lugar de peregrinación y recibiese donaciones y favores de los peregrinos. Una segunda intención que se puede desprender de la obra es la pedagógica, ya que convierte Santo Domingo en un modelo a seguir, repleto de virtudes, entrega y sacrificio $^{418}$. Quizás la parte más promocional de la obra es aquella que relata los milagros del protagonista después de su deceso, hechos principalmente relacionados con la sanación de enfermos y posesos, pero especialmente con la liberación de cautivos.

\section{Vida de Santo Domingo de Silos}

También relacionada con la figura del santo de Silos está la segunda obra a analizar, aquella compuesta por Gonzalo de Berceo y que suele agrupar los Milagros de Nuestra Señora, Vida de Santo Domingo de Silos, Vida de San Millán de la Cogolla, Vida de Santa Oria y Martirio de San Lorenzo. De este conjunto a nosotros nos interesa particularmente la Vida de Santo Domingo de Silos. El autor riojano (1198-1265 aprox.) habría compuesto su obra siendo monje en San Millán de la Cogolla, a petición de sus pares de la abadía de Silos que deseaban la elaboración de una biografía que exaltara y difundiera el culto a su patrono. La obra tiene claras intenciones propagandísticas, para lo cual el autor se sirvió de la figura de la Virgen y su relación con Silos. Ya que María mediante sus atributos de madre y señora, según Fernández Conde, sintetiza las funciones teológico-salvíficas que caracterizarán su figura como presencia celeste gravitante en la Reconquista $^{419}$.

\section{Miraculos romançados de Pero Marin}

Santo Domingo fue el protagonista de una serie de textos hagiográficos; el último de ellos corresponde a los Miraculos romançados de Pero Marin. Su autor es anónimo, pero se cree con certeza que debió ser monje en Santo Domingo de Silos, y

\footnotetext{
${ }^{418}$ La "Vita Dominici Siliensis" de Grimaldo, estudio, edición crítica y traducción de Vitalino Valcarcel. Logroño, Instituto de Estudios Riojanos, 1982, pp. 98-107 (En adelante VDS).

${ }^{419}$ Gonzalo de Berceo, Milagros de Nuestra Señora; Vida de Santo Domingo de Silos; Vida de san Millán de la Cogolla; Vida de santa Oria; Martirio de san Lorenzo, Prólogo y versión moderna de Amancio Bolaño e Isla, México, Porrua, 1969, p. XV (En adelante VSD); García de la Borbolla, Ángeles, "Santo Domingo de Silos, el santo de la frontera: La imagen de la santidad a partir de las fuentes hagiograficas castellano-leonesas del siglo XIII", en Anuario de Estudios Medievales, 31-1, 2001, [pp. 127-145], pp. 128, 129; y Fernández Conde, Francisco Javier, La Religiosidad Medieval... op. cit., p. 472.
} 
que habría escrito su obra alrededor del año $1285^{420}$. El texto, escrito en romance, es el relato de una sucesión de liberaciones milagrosas de cautivos hechas por el santo después de su muerte. En ellas, observamos, se repite casi siempre el mismo patrón: un cristiano -hombre o mujer- es apresado por los musulmanes, encerrado en calabozos y sometido a vejámenes. El cautivo desesperado reza a Santo Domingo, quien acude a su rescate apareciéndosele al devoto en sueños para indicarles la forma de escapar. Luego los cautivos ya libres se dirigen al Monasterio de Silos a dejar sus cadenas u ofrendas ante la tumba del santo. Demás está decir que la obra, al igual que las anteriormente descritas, tiene claras intenciones propagandísticas, en el sentido de exaltara la figura del santo y con él, el del monasterio que guarda sus reliquias y que es el depositario de las limosnas y donaciones de los fieles. Razón, entre otras que implican que la obra sigue el mismo modelo narrativo que la Vita Dominici y los textos de Berceo.

\section{Milagros de Nuestra Señora}

Respecto a Gonzalo de Berceo, vale la pena reseñar otro de sus trabajos ya nombrado: los Milagros de Nuestra Señora. En esta obra Berceo, no oculta sus intenciones catequísticas. El texto está escrito en romance con la intención de llegar a un público más amplio, y con ello logra su finalidad de difundir el culto mariano, convirtiendo a la Virgen en un ejemplo de virtudes dignas de imitar. En la obra se relatan múltiples milagros e intervenciones divinas de la Virgen, que una y otra vez vence el mal, y en algunos casos hasta al mismo demonio. Sin embargo, en otras ocasiones el mal esta representado por personas deshonestas que perjudican a la Iglesia, o judíos que cometen sacrilegios; todo ello con el objetivo de demostrar la grandeza de la Iglesia y exhortar a los fieles a su obediencia ${ }^{421}$. Es por este motivo que nos interesamos en este texto, no sólo por sus intenciones propagandísticas respecto de la Virgen y la Iglesia, sino que también por su relación temática con otra obra que estudiaremos, las Cantigas de Santa María de Alfonso X. En ambas obras se puede observar una serie de tópicos relacionados con el servicio a Dios, las relaciones interculturales y el papel de la religiosidad en la vida cotidiana de las personas.

\footnotetext{
${ }^{420}$ Los "Miraculos romançados" de Pero Marín, edición crítica, introducción e índices por Karl-Heinz Antón, Abadía de Silos, 1988, pp. 11, 12 (En adelante MR).

${ }^{421}$ Rodríguez Hernández, Juan Pedro, “El Diablo en 'Los Milagros de Nuestra Señora' de Gonzalo de Berceo", en Espacio, Tiempo y Forma, Serie III, H/ Medieval, t. 17, 2004, p. 520; y Martín, José Luis, "Los milagros de la Virgen: Versión latina y romance", en Espacio, Tiempo y Forma, Serie III, H. Medieval, t. 16, 2003, [pp. 519-532], p. 177.
} 


\section{Milagros de San Isidoro}

Otra obra hagiográfica digna de rescatar son los Milagros de San Isidoro, escrita por Lucas de Tuy alrededor del año $1223^{422}$. El texto fue escrito originalmente en latín, posteriormente fue traducido a lengua vulgar para facilitar su difusión. En su conjunto, la obra está dividida en ochenta y siete capítulos, cada uno dedicado a relatar un milagro o intervención del santo. Entre las sanaciones y otros milagros efectuados por el santo de Sevilla destacan sus luchas contra los musulmanes, a quienes confunde, presagia desgracias, elimina por su propia mano o castiga. El autor también procura trasmitir una imagen negativa del rey aragonés Alfonso el Batallador, en un intento por exaltar su propio reino, el de León ${ }^{423}$.

Las intenciones de los Milagros de San Isidoro, a nuestro entender, son evidentes: el "Tudense" no sólo busca difundir el culto al santo, sino que lo convierte en un activo combatiente de los musulmanes, creando así un vínculo entre el santo baluarte de la Iglesia hispano visigoda- y la España de Lucas, enfrascada en la lucha por la Reconquista. Esto que debe ser enmarcado dentro de las ideas neogoticistas que el autor también expresa en su Cronicon Mundi.

\section{Cantigas de Santa María}

El último texto que analizaremos corresponde a las muy conocidas Cantigas de Santa María, obra atribuida a Alfonso X "el sabio" y que fueron compuestas a mediados del siglo XIII ${ }^{424}$. En su composición, aparte de Alfonso X, también se atribuye la coautoría a Juan Gil de Zamora, Bernardo de Brihuela y al clérigo Arias Nunes, además de distintos poetas gallegos y portugueses ${ }^{425}$. No obstante, existe certeza de que Alfonso $\mathrm{X}$ fue autor de varias de las cántigas, y que guardó especial afecto a esta obra, mucho más emocional y menos práctica que las obras de tipo histórico que

\footnotetext{
${ }^{422}$ Tuy, Lucas de, Milagros de san Isidoro, traducción de Juan de Robles (1525), Trascripción, prólogo y notas de Julio Pérez Llamazares (1947), León, Universidad de León, 1992, p. IX (En adelante MSI).

${ }^{423}$ Martín, José Carlos, "El corpus hagiográfico latino en torno a la figura de Isidoro de Sevilla en la Hispania tardoantigua y medieval (SS. VII-XIII)", en Veleria. Revista de Prehistoria, Historia Antigua, Arqueología y Filología Clásicas, Vitoria, Universidad del País Vasco, 2005, [pp. 187-228], p. 225.

${ }^{424}$ En su conjunto, el texto consiste en un cancionero religioso conformado por cuatrocientas veintisiete composiciones en honor a la Virgen, escritas en galaico-portugués, que relatan distintos milagros e intervenciones divinas realizadas por la Virgen. Las composiciones carecen de ordenación temática, existiendo sólo un orden a nivel macro: el primer centenar de relatos son de temáticas universal, y las restantes de carácter local, hispano, en los que predominan los apartados con participación o relación con el "Rey Sabio" (Alfonso X el Sabio, Cantigas de Santa María. Códice Rico de El Escorial... op. cit., p. LIX; y Fernández Conde, Francisco Javier, La Religiosidad Medieval... op. cit., p. 149).

${ }^{425}$ Alfonso X el Sabio. Cantigas de Santa María. Códice Rico de El Escorial... op. cit., pp. XXXI, XXXII.
} 
patrocinó. Junto a la ayuda de los autores mencionados, la obra también se nutrió de distintas fuentes, entre las que se han identificado el Speculum historíale de Vicente de Beauvais (1200-1264), las Gesta Romanorum; Les miracles de la Sainte Vierge de Gautier de Coincy; y el Liber Mariae. A esto se debe agregar que posiblemente conoció las obras de Gonzalo de Berceo, sin que por ello haya intentado copiarlas o utilizarlas como modelo ${ }^{426}$.

La temática mariana de las Cantigas corresponde al contexto de su época, en el que la lucha contra el Islam había experimentado importantes avances y cuando el culto a la Virgen se encontraba muy difundido gracias a las influencias del $\mathrm{Cister}^{427}$.

Desde la Vita Dominici Silensis hasta las Cantigas de Santa María, los textos hagiográficos o de temática religiosa nos hablan desde la perspectiva de los simples hombres de la frontera y no desde la doctrina oficial de la Iglesia. Es por ello que sus textos nos sirven para descubrir cómo sus autores manifestaban las creencias providencialistas de la época, y también cómo utilizaban esas creencias en beneficio de localidades, monasterios e ideas políticas. Queda así patente la utilización -no tanto política, pero sí moral y económica- de la literatura sacra durante el medioevo hispano.

\section{II.2.c.- La demonización del Islam: proceso ideológico y realidad práctica}

La evolución de la cronística hispana fue un proceso paralelo al incremento de la actividad reconquistadora durante los siglos XII y XIII. Época en la cual a través de las fuentes se hace evidente la consolidación de las percepciones ideológicas en torno a la guerra, religiosidad y poder. Fue así como para el siglo XII la guerra peninsular y el discurso cronístico vinculado, sufrió un proceso de radicalización, un fenómeno relacionado con las ideas de guerra religiosa en España, influencia que provino del otro lado de los Pirineos donde los preceptos de cruzada eran mucho más influyentes ${ }^{428}$. Por ello no extraña que los francos vieran a los hispanos como débiles, debido a su larga

\footnotetext{
${ }^{426}$ Cantigas de Santa María de Alfonso X el Sabio, Rey de Castilla, Estudio Preliminar por Matilde López Serrano, Madrid, Editorial Patrimonio Nacional, 1974, p. 12, 15, 16.

427 Domínguez Rodríguez, Ana y Pilar Treviño Gajardo, Las Cantigas de Santa María Formas e imágenes, España, AyN Ediciones, 2007, p. 57; y Alfonso X el Sabio. Cantigas de Santa María. Códice Rico de El Escorial... op. cit., p. XLII.

${ }^{428}$ Ejemplos de esta influencia fue la llegada caballeros de borgoñones durante el reinado de Alfonso VI y junto a ellos el aumento de la influencia de Cluny en la Península. Junto a lo anterior, hay que recordar que después de la conquista de Jerusalén en 1099, el espíritu de cruzada se popularizó entre los francos y se convirtió en un recurso frecuentemente utilizado por el Papado, afectando así los acontecimientos peninsulares.
} 
convivencia con el Islam y su aparente incapacidad para derrotarlos. Para los cronistas ultramontanos, la guerra en la Península era una alternativa al viaje a Oriente, por lo cual no sorprende que a partir del siglo XII comenzaran a aparecer obras que hacían referencia a los acontecimientos allende los Pirineos, vinculándolos con la tradición cruzada franca ${ }^{429}$.

Si bien ésta era la concepción de los francos acerca de la guerra peninsular, la realidad era muy distinta para los hispanos, puesto que para ellos la Reconquista no era una actividad esporádica o recreativa -como podía interpretarse que lo fue para los ultrapirenaicos-; por el contrario, era una lucha por la recuperación de las tierras del centro-sur peninsular y el retorno del control sobre importantes recursos, amparada bajo las banderas de la lucha religiosa, cada vez más importantes como discurso propagandístico $^{430}$.

\footnotetext{
${ }^{429}$ En el Pseudo-Turpin se relata la ficticia liberación de Hispania por Carlomagno, que rescató esa tierra "vergonzosamente oprimida por los sarracenos" gracias al consejo y auspicio de Santiago que le ordenó combatir a "las pérfidas gentes paganas" (LSJ 2004, Libro IV, cap. I, op. cit., pp. 413-415) Relato en el cual los hispanos prácticamente no tienen ninguna participación destacable, y se les acusa de cobardía e incompetencia para derrotar a los enemigos de la Iglesia. Al respecto podemos señalar algunos ejemplos. En el Libro V del Codex Calixtinus el autor reseña distintos pueblos hispanos, por lo general de forma poco halagüeña. Por ejemplo, de los vascos dice que son feroces y que su lenguaje bárbaro parecen gruñidos que intimidan a quienes los oyen. A los navarros los asimila a los vascos, agregando que comen y visten puercamente y que al verlos comer más parecen cerdos o perros, en tanto que su lenguaje se asemeja a ladridos. Finalmente, y sólo como muestra, sobre Castilla dice que esa tierra está llena de hombre malos y viciosos y que los gallegos, si bien son más civilizados, a semejanza de los galos, son iracundos y conflictivos (LSJ 2004, Libro V, cap. VII, op. cit., pp. 549-556).

${ }^{430}$ No obstante la realidad cotidiana de la Reconquista, en la práctica obligaba a los hispanos a adoptar algunas políticas que podríamos llamara de "tolerancia". Mismas que causaban extrañeza entre los combatientes de allende los Pirineos, y fue una de las causas de la deserción de los ultramontanos luego de la captura de Calatrava -durante la campaña de las Navas de Tolosa-; al menos así se puede concluir del relato de la Crónica general, basada en la crónica de Jiménez de Rada (CGE, cap 1015, op. cit., p. 696).
}

Este episodio se debió a las diferentes concepciones que tenían los hispanos y los francos sobre el concepto de cruzada y sobre los musulmanes. Los primeros, como ya hemos dicho, poseían un pensamiento marcado por su historia de convivencia con el Islam el cual fue permeado por las ideas de cruzada, en que matar y morir por la fe se convirtieron en un paradigma ideológico matizado por las razones antes descritas; de esta manera el musulmán no era visto como una figura aniquilable a la cual había que borrar de la faz de la tierra, como sí lo entendían los caballeros francos que periódicamente entraban en la Península para cumplir sus votos de cruzada. Los ultramontanos traían sus propias concepciones de cruzada -concebidas a partir de su participación en las guerras de Tierra Santa y más recientemente, en el conflicto contra la herejía albigense-, que eran mucho más extremistas y violentas, chocando con las costumbres hispanas en relación a los enemigos de la fe; es decir, musulmanes y judíos (Rodríguez García, José Manuel, "Fernando III y sus campañas en el contexto cruzado europeo, 12171252", en Archivo Hispalense, Revista Histórica, Literaria y Artística, 2.a Época, año 1994, Tomo LXXVII, Núms. 234-235-236, [pp. 205-217], p. 215). Una situación que tambien se pudo observar cuando los guerreros ultramontanos atacaron a los judíos de Toledo: “[...] é este perdon fue poque el rey de Marruecos dixo que lidiaria con cuantos adoraban cruz en todo el mundo, é moviendose los dultra puertos, é vinieron a Toledo en dia de Cinquesma, é volvieron todo Toledo, é mataron de los Judíos dellos muchos, é armaronse los Caballeros de Toledo é defendieron a los Judios" ${ }^{430}$ (AT. I, op. cit., p. 172). 
De esta manera se aprecia que para los siglos XI al XIII, el lenguaje de las fuentes, relativo a los musulmanes se hiciese cada vez más agresivo. Lejos quedaron las sutilezas de las primeras crónicas que evitaban los temas doctrinales; ahora el Islam y sus seguidores eran derechamente aliados del demonio. Un ejemplo paradigmático de ello fue lo ocurrido con la figura de al-Mansur, sobre el cual distintas crónicas relatan cómo fue llevado al infierno después de su muerte e incluso cómo el mismo demonio lloraba su pérdida. Al respecto el Cronicón Burgense nos dice "Era millesima cuadragesima; mortuus est Almanzor et est sepultus in inferno ${ }^{„ 431}$. La Crónica Silense/Legionense va mas allá afirmando que el caudillo cordobés había estado poseído por el demonio, además de repetir la idea de su sepultación en el infierno ${ }^{432}$. Esta tradición continuó y es mencionada en las posteriores crónicas de Lucas de Tuy y en la de Veinte Reyes, agregando al relato el episodio de un misterioso personaje que lloraba la muerte de al-Mansur, quien no sería otro que el diablo ${ }^{433}$.

Las crónicas de este período, si bien demonizan a la religión islámica, mantienen la tendencia a no denostar a los musulmanes como individuos; más bien, se les consideraba gente ignorante y cobarde que seguía una religión maligna y supersticiosa. Una forma de expresarse que hacía eco de las palabras de Urbano II (1088-1099), quien tildaba a los seguidores de Mahoma de bárbaros, se rescata en la Crónica Silense, en la que se agrega que su dominio sobre Hispania era pérfido ${ }^{434}$.

Sorprende cómo a partir de los siglos mencionados, los cronistas construyen una nueva imagen del musulmán, basándose en estereotipos antiguos, como si los siglos de coexistencia no hubiesen dejado ninguna huella ${ }^{435}$. Esto quizás se explica por el desinterés, de parte de la masa de los cristianos por comprender a sus adversarios. La élite ilustrada, posiblemente conocedora de las realidades del Islam, tampoco

\footnotetext{
${ }^{431}$ Cronicón Burguense, en Huici M., Ambrosio, Las crónicas latinas...op. cit., Tomo I, p. 34. "Era milésima cuadragésima; murió Almanzor y esta sepultado en el infierno", ibidem.

${ }^{432}$ El cronicón del Silense, en Huici M., Ambrosio, "Las crónicas latinas...op. cit., Tomo II, p. 106.

${ }^{433} \mathrm{CM}$, Liber IV, $\mathrm{N}^{\circ} 39$, op. cit., p. 270, 271. Otro ejemplo más explicito aparece en la Crónica de Veinte reyes: "Ese día que Almançor fue vençido andaua vn omne en guisa de pescador por rribera de Guadalquivir dando bozes, llorando e faziendo duelo e diziendo asy vna vegada por aráuigo e otra por lenguaje castellano: 'En Canatanaçor e quien esto decir asy / quien en Canatanaçor perdió Almançor el su poder e el su brío e la su alegría' [...] E bien creemos que este omne era el diablo que lloraua e se dolie del quebrantamiento e astragamiento de los moros, su gente, que zufrieron de alli adelante." (CXXR, Libro V, cap. XXI, op. cit., p. 129).

${ }^{434}$ Barkai, Ron, El enemigo en el espejo... op. cit., pp. 132, 133; Mitre Fernández, Emilio y Martín Alvira Cabrer, "Ideología y guerra...op. cit., p. 307; Tolan, John V., Sarracenos... op. cit., pp. 182, 183; y "El cronicón del Silense”, en Huici M., Ambrosio, Las crónicas latinas...op. cit., Tomo II, p. 20.

435 Palacios Ontalva, Santiago, "Imagen e identidad del musulmán en tiempos de Fernando III. El enemigo desde la perspectiva cruzada", en Ayala Martínez, Carlos y Martín Ríos Saloma (Editores), Fernando III... op. cit., pp. 270, 271.
} 
demostraba mucha disposición a trasmitir sus conocimientos, puesto que la imagen maléfica de los musulmanes servía a sus propósitos. Era importante que el conjunto de la población cristiana identificara a los andalusíes como sus enemigos, pero también como los adversarios de la Iglesia.

Así se explica que se crearan una serie de relatos destinados a trasmitir una imagen negativa y hasta maligna de musulmanes y judíos. Ya hemos mencionado cómo la creencia popular atribuyó los éxitos de al-Mansur a una supuesta protección demoníaca y cómo las primeras crónicas describen a los "moros" como bárbaros crueles y hasta antropófagos. Sobre ello cabe preguntarse cómo fue posible que estas imágenes se impusieran en una sociedad de frontera, donde musulmanes, judíos y cristianos coexistían cotidianamente; es más, los fueros no hacen referencia a este tipo de imágenes, algo que se puede constatar en la ausencia de normas al respecto, como por ejemplo: "al moro que sea sorprendido devorando a un cristiano o al judío que envenene los pozos quémeseles vivos". La ausencia de este tipo de leyes en documentos que pretendían normar la vida cotidiana nos permite afirmar que tales situaciones no ocurrían; no obstante, sabemos que estaban presentes en el imaginario popular de los cristianos.

Consideramos que, una posible explicación a este fenómeno podría ser que las peores prácticas atribuidas a musulmanes y judíos, según los cronistas, siempre se realizaban en privado, de noche y al interior de sus barrios o casas; es decir, en lugares donde los cristianos no solían entrar, lo que facilitaba que se produjesen todo tipo de historias. Esta situación, atribuida al sistema de segregación impuesto por los cristianos, permitió a ciertos autores y líderes propagar falsas creencias entre la población cristiana y asegurar que ésta desconfiara de sus vecinos. De esta forma, se impuso la convicción general de que tanto musulmanes como judíos tenían dos facetas; una pública y diurna, y otra nocturna más siniestra y privada. Todo ello con el fin último de mantener separadas a las distintas etnias y asegurar entre los cristianos un desprecio y desconfianza hacia los musulmanes y judíos, sentimientos sustentados en la manipulación de las prácticas y creencias religiosas por parte de las élites cristianas, para asegurar la lealtad de sus súbditos y mantener vivo el esfuerzo bélico de la Reconquista. 
Es en ese contexto que uno de los más hábiles promotores de la cronística hispana, el Arzobispo de Santiago Diego de Gelmírez ${ }^{436}$, realiza su descripción de los musulmanes, destacando el color de la piel de los almorávides, sobre quienes dice: "quos estus solis facit Ethiopibus similes" el color del mal y de lo demoníaco. Sobre los andalusíes tampoco tiene buenas impresiones, puesto que los considera falsos, crueles, astutos y traidores: “[...] ne forte Hismahelitarum subdola uersutia qualibet machinatione seu ingenii calliditate [...] ${ }^{, 438}$. Incluso, "El compostelano" menciona antiguas creencias con respecto a la doctrina islámica, que hacen dudar al lector moderno sobre si el cronista era realmente ignorante en esa materia, o si era su propósito mantener el error, haciendo parecer a los musulmanes aún más desagradables ${ }^{439}$. A modo de ejemplo, en varios pasajes Gelmírez hace referencia al supuesto politeísmo de los musulmanes: "Regnum etenim Toleti, castella, ciuitates et oppida, que ultra decursum Dorri fluminis esse noscuntur, in quibus christiane professionis religio tenetur et obseruatur, a cultura Pentium numina iana colentium penitus euacuauit ${ }^{, 440}$.

En este caso particular se refiere a las victorias de Alfonso VI, respecto a quien destaca como aquel que ha sometido el Reino de Toledo y ha implantado la observancia católica al otro lado del Duero. En otro pasaje, la crónica explica la actitud de los musulmanes debido a su propia ignorancia: "uerissimis atque euidentissimis argumentis astruebat gentiles ignorantie nube cecatos uarioque desusos errore,441.

A modo de explicación a la posición del arzobispo, es significativo recordar que la Historia Compostelana no fue una crónica centrada en los hechos de frontera; de hecho al momento de su redacción, la guerra contra el Islam se libraba muy lejos de los territorios compostelanos. Esta fue la razón, a nuestro entender, por la cual el tema de

\footnotetext{
${ }^{436}$ Como ya se explicó en el capítulo I, Gelmírez no fue el autor material de la Historia Compostelana, pero si fue su promotor y director.

${ }^{437}$ HC 1988, Liber I, cap XXIX, op. cit., p. 57. "A los que el calor del sol hace semejantes a los etiopes". HC 1994, Liber I, cap XXIX, op. cit., p. 125. Sobre los aspectos relacionados a las injurias y descalificativos otorgados al Islam recomendamos consultar el trabajo de Marta Madero, Manos Violentas, Palabras Vedadas. La injuria en Castilla y León (siglos XIII-XV), Madrid, Taurus, 1992.

${ }^{438}$ HC 1988, Liber I, cap. XXXIII, op. cit., p. 63. "Para evitar que la malicia astucia de los ismaelitas pudiera tomarla con alguna maquinación o engaño de su ingenio...” HC 1994, Libro I, cap. XXXIII, op. cit., p. 132.

${ }^{439}$ Barkai, Ron, El enemigo en el espejo... op. cit., p. 135.

${ }^{440}$ HC 1988, Liber I, cap. XLVI, op. cit., p. 84. "Pues apartó por completo del culto de los gentiles, que adoran dioses vacios, el reino de Toledo, los castillos, las ciudades y fortalezas que están más allá del río Duero, en los cuales se profesa y observa la religión cristiana”, HC 1994, Libro I, cap. XLVI, op. cit., p. 152.

${ }^{441}$ HC 1988, Liber II, cap. L, op. cit., p. 308. "Con muy veraces y evidentes argumentos afirmaba que los gentiles estaban cegados por la nube de la ignorancia y que estaban engañados por muchos errores", HC 1994, Libro II, cap. L, op. cit., p. 384.
} 
los musulmanes fue un aspecto secundario, que aparece para celebrar la lucha contra ellos por parte del arzobispo, o bien para legitimar la acción bélica de los cristianos. Es por ello que, aquella lejana y esporádica amenaza, cuando aparece, lo hace rodeada de todo tipo de estereotipos negativos. En esa misma línea, otra obra del siglo XII, la Crónica Najerense explicaba el éxito de la prédica de Mahoma, aludiendo a la ayuda del demonio y la superstición de los árabes: "[...] set, ut uariis demonum erroribus nonnulli illaqueantur mahometica supersiticiosa secta [... $]^{p 442}$.

Un autor más cercano a la frontera y a la guerra, siendo protagonista en muchos de sus principales hechos durante el siglo XIII, fue Rodrigo Jiménez de Rada. En su obra De Rebus Hispaniae, plantea variadas críticas a los musulmanes peninsulares. En ella llama la atención un pasaje donde explica el éxito de la predicación de Mahoma, aludiendo a la falta de inteligencia de los árabes: "Huius temporibus nephandus Mahomat nequiciam secte sue stultis populis predicauit" ${ }^{, 433}$.

Junto a estos testimonios, encontramos la obra de Lucas de Tuy, Milagros de San Isidoro, que destaca por sus críticas al Islam, al cual califica de "rito abominable" y cuyos practicantes están destinados a perecer, dando distintos ejemplos de la manera en que San Isidoro, como representante de Dios, castigaba a los musulmanes ${ }^{444}$.

En la Crónica de Veinte Reyes, se continúa con la práctica de denostar al Islam, esta vez exaltando a los musulmanes en su calidad de siervos del demonio, de quien recibían favores y mediante el cual podían realizar encantamientos. Ejemplo de ello se aprecia en el capítulo IV, cuando en el preludio de una batalla entre las huestes de Fernán Gonçález y los andalusíes, apareció en el cielo una gran serpiente o dragón que sembró el miedo entre los cristianos. Ante ello el conde realizó la siguiente arenga:

“Amigos, los moros son omnes que saben muchos escantamentos e llaman los diablos por esperimentos que fazen, e algun moro astroso que sabe fazer aquestas cosas fizo aquella visión venir por espantarnos con esta artería. E mas, como sodes omnes entendidos, bien deuedes saber que el diablo non nos puede fazer ningund mal, ca le tolló el poder nuestro señor Ihesu Christo, e acomendémonos

\footnotetext{
${ }^{442} \mathrm{CN}$ 1995, Liber II, $\mathrm{N}^{\circ} 17$, op. cit., pp. 110, 111. “...como otros tantos que por las diferentes argucias de los demonios caían en la trampa de la supersticiosa secta de Mahoma...” CN Libro II, $\mathrm{N}^{\circ}$ 17, op. cit., p. 123.

${ }^{443}$ HRH, Liber II, Cap. XVII, op. cit., pp. 65, 66. "Durante su reinado el maldito Mahoma predicó la maldad de su secta a los pueblos de poco seso." HHE., Libro II, Cap. XVII, op. cit., p. 111. Jiménez de Rada, junto a su rol de líder cristiano y activo combatiente contra los musulmanes, también fue el autor de la Historia Arabum, uno de los primeros textos hispanos dedicados a explicar el origen del Islam, donde no obstante, el autor reproduce muchos de los estereotipos y discursos que figuran en las crónicas contemporáneas y anteriores.

${ }^{444}$ A modo de ejemplo ver en MSI, cap. XX, op. cit., pp. 34, 35.
} 
[a] aquel solo Dios que fizo todas las cosas del mundo, que es poderoso de dar e de toller a quien él quiere, e non demos nada por tales cosas (e) desde oy. ${ }^{445,}$

Es de notar, en este episodio, la aparición de la serpiente como manifestación de lo demoníaco. Una figura que podemos encontrar dentro de la tradición bíblica y el imaginario religioso bizantino en relación a San Jorge. En este caso particular la apelación a la religiosidad es directa, puesto que se utilizan imágenes de un imaginario común; la serpiente, ser maligno pero inofensivo, puesto que los demonios no tienen poder ante Dios y es precisamente Él quien acompaña a los cristianos en su lucha ${ }^{446}$.

Complementario a lo anterior, podemos observar que, en su conjunto, las crónicas de los siglos XII y XIII, como en el período anterior, hacen referencia a los musulmanes a través de diversos nombres, tales como "moro", "sarraceno", "pagano", "ismaelita", "agareno", "pérfido", "enemigo de la cruz", "impío", "incrédulo" e "infiel”, entre otras. Todas ellas resaltan el hecho de que pertenecen a una cultura y religión distinta, siendo lo que permitía agruparlos como una sola comunidad, pasando por alto otro tipo de diferencias como políticas o geográficas. Por parte de los musulmanes la situación era similar, puesto que solían enmarcar a los hispanos bajo la categoría de cristianos, sin hacer mayor distinción entre los habitantes de los distintos reinos, como castellanos, leoneses, aragoneses, etc ${ }^{447}$; es decir, que la religión y la forma de practicarla se convirtieron en el factor de mayor diferenciación entre ambas comunidades, pasando por alto la ya larga coexistencia que venían experimentando.

\section{II.2.d.- El caso de Mahoma: la construcción de una imagen malévola}

En el contexto de los siglos XII y XIII, cuando la guerra de Reconquista tomó un fuerte impulso y se produjo un aumento creciente del rechazo hacia el Islam propiciado principalmente por un discurso religioso- se comienza a apreciar una clara intención de denigrar el origen mismo del Islam; a partir de este momento los cronistas

\footnotetext{
${ }^{445}$ CXXR, Libro III, cap. IV, op. cit., p. 99.

${ }^{446}$ Cooper, J.C., Diccionario de símbolos, Barcelona, Gustavo Gili, 2007, p. 164.

${ }^{447}$ García-Serrano, Francisco, "La creación de identidad en la frontera medieval hispana y la visión del otro: mudéjares y judíos”, en Rodríguez de la Peña, Alejandro, Hacedores de Frontera. Estudios sobre el contexto social de la frontera en la España medieval, Madrid, CEU Ediciones, 2009, p. 81; y García Fitz, Francisco, "La conquista de Andalucía en la cronística castellana del siglo XIII: Las mentalidades historiográfícas en los relatos de la conquista", en Cabrera, Emilio, Andalucía entre Oriente y Occidente (1236-1492), Actas del V Coloquio Innternacional de Historia Medieval de Andalucía, Córdoba, Excma. Diputación Provincial de Córdoba, 1988, p. 57.
} 
empiezan a referirse directamente a la figura de Mahoma, personaje sobre el cual las crónicas anteriores ya habían hecho menciones indirectas, haciendo insinuaciones respecto a sus lazos con el demonio y principalmente explicando sus éxitos en razón a la ignorancia y barbarie de los árabes. Desde entonces, las crónicas se referirían directamente al profeta del Islam llamándolo "falso", "hereje", "endemoniado", "pérfido", "epiléptico" y "nefasto", entre otros epítetos insultantes ${ }^{448}$.

Especialmente durante el siglo XIII, veremos aparecer biografías de Mahoma, donde se le representa de manera repulsiva y como un condenado. Se trata de verdaderos ejercicios discursivos donde se pretende hacer un paralelismo entre Cristo y Mahoma, con el objeto de demostrar la falsedad del segundo ${ }^{449}$. A nuestro entender, esta demonización del enemigo responde en parte a las influencias de las ideas de cruzada, puesto que al deshumanizar a los musulmanes se hacía más fácil hacer contra ellos una guerra total, convirtiendo la lucha en un símil del enfrentamiento bíblico entre las fuerzas del bien y las del anticristo, por ende cumpliendo designios divinos. Veamos a continuación algunos ejemplos de este proceso de demonización del adversario.

En el siglo XII los Annales Complutenses se refieren escuetamente al origen del Islam relatando que: "In era sexcentesima quinquagesima sexta prophetavit Mafomet pseudos-propheta $[\ldots]^{, 450}$. Se observa una cita prácticamente igual en el Crónicon Burguense $^{451}$, y en ambos casos se destaca la falsedad de Mahoma y su revelación, tratándolo de embustero y sirviendo como punto de partida para acusaciones más graves, como las que aparecen en el siglo XIII, y que podemos observar en las obra de Lucas de Tuy, que trata a Mahoma de traidor, embustero y a los árabes de "animalias brutas, 452 .

\footnotetext{
${ }^{448} \mathrm{Al}$ respecto de la forma de referirse al Profeta del Islam, recomendamos dirigirse a los trabajos de Ron Barkai, El enemigo en el espejo y de John Tolan, Sarracenos; ambos ya citados en este trabajo.

${ }^{449}$ Goñi Gaztambide, José, Historia de la Bula ... op. cit., pp. 235, 236; y Barkai, Ron, El enemigo en el espejo...op. cit., pp. 214, 215.

450 "Anales Complutenses", en Huici, Ambrosio, Las Crónicas latinas..., op. cit., Tomo I, pp. 40. "En la seiscentésima quincuagésima sexta profetizó Mahoma, falso profeta [...] Ibidem.

451 "Cronicón Burguense", en Huici, Ambrosio, Las Crónicas latinas..., op. cit., Tomo I, pp. 32.

${ }^{452}$ En primer lugar, el Obispo inicia su relato sobre Mahoma situándolo en el contexto del reinado de Heraclio (610-641) y dando a entender que originalmente, el Profeta se había levantado en rebelión contra Bizancio aprovechando la debilidad del Imperio en ese entonces (CE, Libro III, cap. V, op. cit., pp. 202, 203). En el mismo párrafo está explicitada la idea de que Mahoma era un caudillo, cuya principal finalidad era alejar a los árabes del cristianismo. Demostrando la intencionalidad del cronista por hacer parecer al Islam como enemigo de la cristiandad desde sus orígenes, esto pese a que la Península Arábiga no era parte del Imperio Bizantino y que para el siglo VII el territorio estaba poblado por tribus nómadas paganas. Además, los cristianos que allí habitaban eran una minoría principalmente herética.

A continuación se nos relata como Mahoma utilizaba trucos y artes mágicas para simular milagros, aprovechándose de la ignorancia de los árabes, a quienes tilda de "animalias brutas", una clasificación que se repite en crónicas anteriores. Agregando además al relato que Mahoma, quien era "hermoso y bien
} 
En obras posteriores los relatos destinados a destruir la imagen de Mahoma continúan, aunque con biografías menos extensas y limitándose a destacar la falsedad de la revelación islámica. Por ejemplo, en el Libro de Fernán Gonçález se afirma que "Mahoma era de mala creencia y que predicó mala sentencia"453 y Juan Gil de Zamora se refiere a Mahoma como "nefasto", destacando su huida de Hispania y su posterior predicación maliciosa entre "pueblos necios" 454 .

Excepcional en cuanto al espacio dedicado a la descripción y comprensión del Islam es la Crónica General, puesto que Alfonso X reproduciría una extensa reseña de Mahoma, pero que al igual que en casos anteriores, toma hechos históricos y los utiliza para denostar al profeta y su $\mathrm{fe}^{455}$.

razonado", fue elegido rey gracias a sus engaños, demostrando así sus ambiciones. Una situación que bien podría servir a la élite para comparar la actitud el profeta del Islam con la humildad de Cristo " $E$ como estas cosas y otras semejables les predicase con palabras de amonestamiento, como paresçiese fazer algunas virtudes fingidas y algunos miraglos con arte magica, luego los ysmaelitas, asi como animalias brutas que no han entendiminsto, (y) poco a poco començaron a caer del bien en mal, desamparando la fee catholica, (y) començaron creerlo e allegarse a él, en tanto honrramiento, que le dixesen propheta de Dios, y escogeronlo por rey para sí, engañados por sus fingidos miraglos y por su buen razonamiento, e porque él era fermoso y bien razonado e fuerte e conplido de artes magicas." (CE, Libro III, cap. V, op. cit., p. 203).

El relato del "Tudense" es en realidad un discurso sobre la "maldad" del Islam, puesto que el cronista destaca una y otra vez las características heréticas de Mahoma y de su mensaje, con la finalidad de deshumanizar cada vez más a su biografiado (CM, Liber III, $\mathrm{N}^{\circ}$ 5, op. cit., p. 167).

El cronista continúa narrando cómo Mahoma sufría de ataques de epilepsia y cómo explicaba éstos a su esposa, diciéndole que eran por efecto de la aparición del ángel Gabriel que le hablaba. Algo que el cronista explica haciendo referencia a la Segunda Epístola a los Corintios ${ }^{452}$. Luego menciona parte de las creencias del Islam, que si bien son correctas en relación a la doctrina coránica, para los cristianos de la época era una ofensa directa, ya que negaba la divinidad de Cristo: "Dicebat enim Ihesum Christum Dominum de uirgine esse natum operatione Spiritus Sancti, non tamen esse Deum”( CM, Liber III, N 5 , op. cit., p. 168. "Dezia el Señor Ihesu Christo ser naçido de virgen por operamiento de Espiritu Sancto, mas no ser Dios." CE, Libro III, cap V, op. cit., p. 205.)

Ya finalizada su descripción de Mahoma, Lucas se hace parte de la leyenda medieval al señalar que el profeta viajó a Hispania, pero huyó rápidamente de allí cuando los demonios le advirtieron de que a su encuentro se dirigía Isidoro de Sevilla. El epílogo de la biografía viene a resumir la esencia de la figura de Mahoma según el cronista, puesto que se dice que muere traicionado y envenenado y en vez de resucitar como él había dicho, -según el "Tudense"- su cuerpo termina devorado por perros (CM, Liber III, $\mathrm{N}^{\circ}$ 6, op. cit., p. 169).

${ }^{453}$ PFG, op. cit., p. 245.

${ }^{454} \mathrm{DPH}$, Tratado V, $\mathrm{N}^{\circ} 10$, op. cit., p. 73.

${ }^{455}$ Dentro del espacio dedicado a este tema en la Crónica General destaca la biografía de Mahoma, de la cual reproducimos un extracto: "Este Mahomat era omne fermoso et rezio et muy sabidor en las artes a que llaman magicas, e en aqueste tiempo era el ya uno de los mas sabios de Arauia et de Affrica. Este Mahomat otrossi uinie del linnage de Ysmael, fijo de Abraham, assi como lo auemos ya contado ante desto en esta estoria, e començo de seer mercador, ca era omne pobre et lazrado, e yua muy a menudo con sus camellos a tierra de Egipto et de Palestina; et moraua alla con los judios et los cristianos que y auie una sazon dell anno, e mayormientre con un monge natural de Anthiochia, que auie nombre Johan, que tenie el por su amigo et era herege; e daquel monge malo aprendió el muchas cosas tan bien de la nueua ley como de la uieia pora deffender se contra los iudios et los cristianos quando con ellos departiesse, ca todo lo que aquel monge le demostraua, todo era contra Dios et contra la ley, et todo a manera de heregia. [...] diziendol con tod esto que ell era Messias, el que los judios atendien que auie de uenir. Los judios, quando oyron et supieron aquello que el dizie, uinien se pora ell a compannas de cada logar, et aguardauan lo et creyen le de quanto les el dizie; otrossi los ysmaelitas et los alaraues uinien se 
En síntesis, a partir del siglo XII, pero aún más en el siglo XIII, los autores pierden todo pudor en cuanto a la figura de Mahoma y lo convierten en el centro de sus ataques con la intención de que su demonización sirviera para debilitar la fe entre los musulmanes y también para inducir el rechazo hacia el Islam en los cristianos, para así evitar las conversiones e incentivar el ardor bélico de los guerreros ${ }^{456}$.

\section{II.2.e.- El escenario fronterizo y algunos intentos de comprensión del Islam}

El trato dado a la figura de Mahoma fue parte de una visión general europea que se desarrollo en torno al Islam $^{457}$. Pero este discurso debía coexistir con la realidad de la frontera. Precisamente fue esta larga coexistencia la que llevó a que junto con este discurso de permanente hostilidad, también se desarrollasen algunos pequeños intentos por comprender o explicar algunas características de los musulmanes. Particularmente, en virtud de los pactos que se realizaban entre los monarcas y señores de ambos bandos frecuentemente los cronistas alaban ciertos aspectos de los "moros", en especial cuando estos luchaban del lado cristiano ${ }^{458}$. Una intención que, sin embargo, se englobaba

pora ell, et acompannauan le et aguardauan le, ca tenien por marauilla lo quell oyen dezir et fazer. [...] Quando la reyna Cadiga uio que assil onrrauan yl aguardauan todos, cuedo ella en su corazon que yazie en el ascondido el poder de Dios, e por quel auie muy grahd amor cassosse con ell et tomol por marido; e dalli adelant fue Mahomat rico et poderoso et rey et sennor de tierra. Este Mahomat era mal dolient duna emfermedad a que dizien caduco morbo et de epilesia, e acaesció assi un dia quel tomo aquella emfermedad et quel derribo en tierra. La reyna Cadiga quando lo uio ouo ende muy grand pesar; e pues que uio la emfermedad partida del, preguntol que dolencia era aquella tan mala et tan lixosa; e dixol Mahomat: 'amiga, non es enfermedad, mas el ángel sant Gabriel es que uien a mi et fabla comigo demientre que yago en tierra; e por que nol puedo catar en derecho nin puedo sofrir su uista, tanto es claro et fremoso, por que so omne carnal, fallesce me ell spiritó et cayo assi como ueedes por muerto en tierra'. Luego que estol ouo dicho trabaiosse por sus encantamientos et sus artes mágicas, et con la ayuda del diablo por quien se el guiaua, de fazer antella assi como sennales et miraglos, e por que las uezes se torna el diablo assi como diz la Escriptura en figura de ángel de lux; entraua el diablo en ell a las uezes et faziel dezir algunas cosas daquellas que auien de uenir, e por esta manera le auien de creer todas las yehtes de lo que les dizie" (CGE, cap. 478, op. cit., pp. 265, 267). Del texto destaca el hecho de que, pese a la cercanía de Alfonso X con los musulmanes y sus pretensiones de ser rey de los tres credos, el soberano se limite a repetir estereotipos, priorizando así el discurso tradicional por sobre cualquier otro elemento en su obra.

${ }^{456}$ Esta concepción de Mahoma no es exclusiva de la Península Ibérica, al contrario estuvo presente en todo occidente, donde el Islam y su fundador fueron vistos como el gran enemigo de la Iglesia. Testimonio de ello es el Canto vigésimo octavo de la Divina comedia, donde Dante coloca a Mahoma y a su sucesor Alí en el Octavo Círculo del infierno, destinado a los sembradores de discordias, donde sufren terribles tormentos a manos de diablos que continuamente los despedazan (Alighieri, Dante, La divina comedia, Madrid, Millenium, 1999, pp. 92, 93). Un castigo religioso, para un enemigo de la religión y relatado como parte de la mitología cristiana, es decir, apelando a las bases de la religiosidad cristiana europea.

457 Al respecto recomendamos revisar íntegramente las obras de John Tolan, Sarracenos y Richard Fletcher, La cruz y la media luna.

${ }^{458}$ Un ejemplo de esta situación son las referencias que en la CAI se hacen a Zafadola, destacandolo como un hombre recto y leal a Alfonso VII (CEA, Libro I, N²7-29, op. cit., pp. 72, 73) 
dentro de una concepción mucho más general del Islam como enemigo, vinculada específicamente a episodios bélicos. ${ }^{459}$.

Estas características podían estar relacionadas con la espiritualidad islámica o

bien destacar algunas virtudes de los musulmanes siempre y cuando fuesen útiles para

los discursos de Reconquista.

\begin{abstract}
${ }^{459}$ En la Península, esta realidad de coexistencia, obligó, a los tres credos a elaborar una serie de trabajos intelectuales destinados a imponerse sobre los restantes. Si bien estos "estudios" buscaban probar la superioridad de una u otra religión, también implicaban que era necesario conocer las creencias ajenas para oponerse a ellas. Paradójicamente, estos trabajos polemistas llevaron a una mejor comprensión de los credos y al reconocimiento de algunos elementos comunes, como las Escrituras, pero no significaron el fin de ciertos estereotipos que eran necesarios mantener para fortalecer la religión propia; por ello, los estudiosos cristianos no dejaron de referirse al Islam como herejía y a Mahoma como un falso profeta (Tolan, John V., Sarracenos ... op. cit., pp. 182, 183; García Fitz, Francisco; Cristianos y Musulmanes en la Península Ibérica... op. cit., p. 401). De hecho la Iglesia oficialmente no hizo gran cosa para comprender la esencia del Islam, al punto de que en los Sínodos Hispanos el asunto no era un tema frecuente. Al parecer, para el alto clero el problema estaba más que claro en materia teológica y por lo tanto, la reglamentación práctica de la convivencia era un tema jurídico y político en el cual la Iglesia no se entrometía directamente, en el entendido que para los cristianos toda norma debía basarse en sus creencias religiosas. Así se observa que los Sínodos generalmente intervenían en esta materia cuando creían que la convivencia se había relajado y los contactos se había hecho demasiado laxos, en cuyo caso
\end{abstract} se solía recomendar endurecer las normas o bien solamente recordarlas.

Con respecto a la coexistencia, la Iglesia consideraba su obligación fiscalizar que el poder político tomase las medidas para evitar el exceso de contactos que pudiese contaminar a los cristianos, por lo cual un objetivo siempre presente fue limitar y restringir las prácticas religiosas de musulmanes y judíos, mas no su vida en tierras cristianas. Lo que si era una preocupación constante de las asambleas sinodales, era la liberación de los cautivos y la guerra de Reconquista (Soto Rábanos, José María, "Reflexiones sobre el discurso cristiano a judíos y musulmanes en los sínodos castellanos, siglos XIII-XV", en IV Jornadas de Historia en la Abadía de Alcalá la Real... op. cit., pp. 474-490). Lo que sucediera con los musulmanes bajo control cristiano no era un asunto que les preocupase sobremanera, puesto que se asumía que junto con la conquista vendría la cristianización de los territorios y mientras tanto, eran las leyes civiles las que deberían preocuparse de los mudéjares según fuesen las condiciones de paz o de guerra.

La actitud de los Sínodos nos demuestra cómo el asunto de la convivencia, si bien tenía un trasfondo religioso, se asumía como una realidad cotidiana e inevitable, por lo que era necesario regularizarla con normas claras pero adaptadas a las necesidades políticas, económicas y militares, que no siempre acompañaban al discurso religioso.

Por su parte, Roma periódicamente enviaba instrucciones a España, con el fin de que allí se respetasen las disposiciones en cuanto a la coexistencia con musulamnes y judíos. Este último aspecto se vio incrementado luego del IV Lateranense, cuando el pontífice reclamó en forma reiterada que se cumpliesen las medidas de segregación dispuestas por el Concilio. Ejemplo de ellos son las cartas de Honorio III en enero de 1217 y marzo de 1218, en cuanto se obligase a los judíos a obedecer los mandatos conciliares referentes a la segregación y el pago de diezmos y otros impuestos. (Mansilla, Demetrio, La documentación pontificia de Honorio..., op. cit., pp. 22, 163). En la misma línea se encuentran los mandatos enviados por Gregorio IX en mayo y junio de 1233, ordenando a Fernando III y a autoridades eclesiásticas reprimir a los judíos y obligarlos a vivir separados de los cristianos (Domínguez, Santiago, Documentos de Gregorio IX..., op. cit., pp. 273, 274).

En menor medida los pontífices también tuvieron intercambio diplomático con las autoridades musulmanas, particularmente con el fin de obtener permisos para enviar predicadores a África o bien, para garantizar la libre práctica religiosa de los cristianos en los territorios musulmanes, como fue el caso de la petición de Honorio III a Miramamolín, en septiembre de 1219, solicitando se permitiera a los cristianos la práctica de sus cultos en sus dominios. (Mansilla, Demetrio, La documentación pontificia de Honorio..., op. cit., p. 184). 
Sobre los intentos de comprensión por parte de los cristianos, destacamos el caso de Jiménez de Rada, que mientras explica el origen y creencias de los almohades, realiza una comparación entre el califa de Bagdad y el Sumo Pontífice romano:

"Auentumerth autem asciuit quendam, qui Almohadi uocabatur et erat in Machometi doctrina ualde peritus, et cepit librum Machometi, qui dicitur Alchoranus, exponere et docere et caliphe de Baldac, qui est Papa Arabum et descendit generationis linea de semine Machometi, contraria predicare, similiter contra Almorauides, qui tunc culmen regni in Affrica optinebant, rebellia adhortari." 460

La cita puede ser tachada de explicación burda y pintoresca, pero sin embargo refleja un intento por dar a comprender a sus lectores la estructura política y religiosa de sus adversarios. El mismo cronista destaca las virtudes de uno de los caudillos musulmanes -Abenthut-, un andalusí que dirigió un levantamiento contra los almohades: "Erat autem Abenhut de genere Abohaget olim regis Cesarauguste, et cum fere monarchus in cismarina Vandalia haberetur, audacia, largitate, justicia, ueritate, prout gentis eius infedelitas seu uersucia tolerat, preminebat."461

A nuestro parecer, este es un claro ejemplo de lo que podríamos llamar un "buen moro", puesto que su lucha contra los almohades lo convertía en un aliado potencial para los cristianos, o al menos servía a sus propósitos al debilitar al enemigo común. Lo que en ningún caso implicó que se dejase de ver al musulmán como un ser por lo general despreciable, como se desprende del relato.

En principio se puede afirmar que los siglos de convivencia previos a la introducción de las ideas cruzadistas en la Península, dejaron una marca indeleble en la mentalidad bélica-religiosa de los hispanos. El musulmán era el enemigo, pero también el vecino, y más importante aún, una fuente de recursos que debía ser tratada de acuerdo a los principios prácticos de la vida fronteriza, lo que implicaba un esfuerzo por

\footnotetext{
${ }^{460}$ HRH, Liber VII, cap. X, op. cit., p. 231. “Aventumerth se ganó a un tal Almohadi, persona muy docta en la doctrina de Mahoma, y comenzó a predicar y enseñar el libro de Mahoma, que se llama Alcorán, y a defender ideas opuestas a las del califa de Bagdad, que es el Papa de los árabes y desciende de Mahoma por línea directa, y de la misma forma comenzó a instigar levantamientos contra los almorávides, que entonces poseían el poder en Africa” HHE, Libro VII, cap. X, op. cit., p. 277.

${ }^{461}$ HRH, Liber IX, cap. XIV, op. cit., p. 294. "Por su parte Abenhut pertenecía a la familia de Abohaget, otrora rey de Zaragoza, y considerándose como monarca en la Andalucía peninsular, hacía gala de generosidad, justicia y verdad, en la medida en que lo permite la deslealtad y la artería de ese pueblo" HHE, Libro IX, cap. XIV op. cit., p. 346.
} 
comprenderlos $^{462}$. No obstante, por razones estratégicas, se mantuvo un discurso provocador destinado a exaltar los ánimos de los cristianos contra sus enemigos, como

${ }^{462}$ Sólo a modo de referencia, creemos necesario mencionar la opinión de los musulmanes con respecto a
sus antagonistas, para constatar que no era muy distinta a las que tenían éstos sobre los "moros". Según
Rodríguez García, la mayoría de los textos musulmanes -que eran por cierto, tan propagandísticos como
los cristianos- demuestran un relativo desconocimiento con respecto a los motivos y aspectos de la fe
cristiana, reduciéndolos a politeístas, infieles o adoradores del crucificado, refiriéndose a sus caudillos
con el genérico de "malditos". Al mismo tiempo, en sus motivaciones suelen ignorar los argumentos de la
Reconquista para explicar las agresiones, acusándolos de avaricia, usurpación de tierras o simple
venganza. En resumen, se podría pensar que hasta el siglo XI la postura general entre los musulmanes era
la de despreciar a los cristianos y sus causas, situación que cambia a partir del siglo XII cuando las
ofensivas hispanas se convierten en una amenaza casi imparable. Dicho escenario convirtió a los
cristianos en el enemigo exterior y temido, el cual era además demonizado de forma progresiva a las
victorias que obtenían. Victorias cristianas que los musulmanes no tardaron en interpretar como castigos
divinos (Rodríguez García, José Manuel, "El Yihad: Visión y respuesta... op. cit., pp. 80-82).
Religiosamente hablando a diferencia de las fuentes cristianas, los autores andalusíes no se
preocuparon de desarrollar explicaciones en torno a los orígenes y creencias del cristianismo, algo por lo
demás lógico si consideramos la postura general del Islam y el Corán con respecto a Cristo. En cambio
sus ataques se vinculaban más con las conductas cristianas, en la lógica de distinguirse de ellos por su
religión. Habitualmente, los autores musulmanes tachaban a los cristianos de bárbaros y a sus líderes de
tiranos, con el fin de crear un discurso diferenciador y trasmitir la idea de superioridad respecto de sus tiranos, con

Una curiosa síntesis sobre la concepción que tenían los musulmanes respecto de los cristianos, la encontramos en el cronista magrebí Ibn 'Idari y su obra al-Bayan al-Mugrib (La caída del Califato de Córdoba y los reyes de Taifas) compuesta entre finales del siglo XIII y comienzos del siglo XIV. Allí el autor describe un diálogo entre el rey Fernando I y un grupo de embajadores toledanos, enviados a buscar la paz ante las arremetidas del cristiano: "Cuando los toledanos vieron eso enviaron emisarios al tirano Fernando, el auxiliar de Ibn Hud, para pactar con él la paz para su ciudad, Toledo, y sus alrededores, por una suma que le entregarían, y así se marcharía de [donde] ellos. Entonces [él] les dijo: 'No os concederé paz ni os libraré de guerra hasta que hagáis esto y esto', y les exigió unas condiciones que no podian cumplir. Le respondieron: 'Si tuviéramos capacidad para [conseguir] esas cosas y esas sumas, ciertamente las hubiéramos gastado con los beréberes y los hubiéramos llamado a fin de alejar esta desgracia'.

Fernando les replicó: 'En cuanto a vuestras palabras: 'no tenemos capacidad para [conseguir] esas sumas', eso es absurdo, pues si se derribaran los tejados de vuestras casas a buen seguro resplandecería el oro por su abundancia. Y en cuanto a vuestra llamada a los beréberes es una cosa que nos la repetís mucho y con la que nos amenazáis, pero con la que no podéis por el odio que os tienen. Nosotros hemos dirigido hacia vosotros [los sufrimientos] que nos procuraron aquellos de los vuestros que vinieron [antes contra] nosotros, y solamente pedimos nuestro país que nos lo arrebatasteis antiguamente, al principio de vuestro poder, y lo habitasteis el tiempo que os fue decretado; ahora os hemos vencido por vuestra maldad. ;Emigrad, pues, a vuestra orilla [allende el Estrecho] y dejadnos nuestro pais!, porque no será bueno para vosotros habitar en nuestra compañia después de hoy; pues no nos apartaremos de vosotros a menos que Dios dirima el litigio entre nosotros y vosotros'. Asi, los enviados de los toledanos no hallaron, ante Fernando y sus compañeros cristianos, acogida para lo que les propusieron [acerca] de la paz". (CCC, op. cit., p. 233).

En el texto se puede apreciar cómo el rey cristiano es representado como un hombre ambicioso, que extorsiona a los musulmanes y se dirige a ellos en un tono intransigente y vengativo, apelando a la restitución de las tierras arrebatadas a los visigodos por los ancestros de los musulmanes de Toledo.

En síntesis, los musulmanes peninsulares desarrollaron en relación a los cristiano una imagen muy similar a la que éstos desarrollaron sobre el Islam, creándose un discurso basado en la incomprensión y exageración, así como en la búsqueda de explicaciones religiosas o providenciales para los éxitos de sus enemigos y que justificasen sus derrotas, independientemente de los procesos de crisis y debilitamientos internos que afectaron a al-Andalus en sus distintas etapas. 
por ejemplo, es el caso del mítico desafió de Miramamolín que describen los cronistas en torno a la cruzada de las Navas de Tolosa ${ }^{463}$.

No obstante lo anterior, como veremos a continuación, los discursos de ambos bandos irremediablemente chocaban con la realidad práctica, siendo el comercio una señal ostensible de ello. Es allí donde nuevamente vemos cómo los intereses seglares o mundanos primaban sobre las creencias religiosas. Es por ello que prevalecieron las normas y costumbres que regulaban las transacciones, centrándose en el libre intercambio de productos, aunque sin perder de vista otros asuntos prácticos como la guerra.

Como es sabido, en centros urbanos de frontera el comercio era una actividad esencial, que se nutría mediante el intercambio libre de productos o bien con el botín de la guerra. En ambos casos los bienes eran transados en los mercados, el verdadero epicentro de la ciudad ${ }^{464}$. Ganados, cueros, telas y otros productos de lujo eran intercambiados en una actividad donde participaban musulmanes, judíos y cristianos. El contacto con el mundo musulmán convertía a la Península en un atractivo centro económico para comerciantes europeos como los genoveses, que a través de la ruta jacobea exportaban los paños de Castilla al Mediterráneo ${ }^{465}$.

El conjunto de la actividad mercantil se encontraba regulada por los concejos locales que prohibieran la comercialización de ciertos productos que podrían ser catalogados de estratégicos, tales como armas, hierros, caballos, entre otros de utilidad bélica $^{466}$. Es aquí donde la realidad bélica de la frontera se hace presente, puesto que se

\footnotetext{
${ }^{463}$ Alvira Cabrer, Martín, "El desafío del Miramamolín antes de la Batalla de las Navas de Tolosa (1212), fuentes, datación y posibles orígenes", Al-Qantara, Vol. XVIII, Fasc. 2, 1997, [pp. 463-490], pp. 470, 471.

Según diversas crónicas, previo al inicio de la cruzada de 1212 el líder musulmán habría desafiado al conjunto de la cristiandad. El episodio es recogido en distintas crónicas, pero no hay ninguna evidencia de que el hecho realmente hubiese ocurrido. El Cronicon Mundi nos dice al respecto: "Rex Miramamolinis, ut haec audivit, valde pertimuit, et doluit se verbum superbiae protulisse, scilicet quod vinceret in campo omnes adorantes crucem Christi" (CE, Liber IV, cap. LXXXIII, op. cit., p. 414). El episodio también es rescatado en los Anales Toledanos: "[...] é este perdon fue poque el rey de Marruecos dixo que lidiaria con cuantos adoraban cruz en todo el mundo, é moviendose los dultra puertos, é vinieron a Toledo en dia de Cinquesma" (AT. I, op. cit., p. 172). En todos estos casos podemos observar que no se revela la fuente del desafío, pero se insiste en utilizarlo para explicar la gran convocatoria que obtuvo el llamado a cruzada.

464 Juan Baró Pozos, "El Consejo de la Villa de Santander en la Baja Edad Media", en El Fuero de Santander y su Época, Actas del Congreso Conmemorativo de su VIII Centenario, pp. 244, 254; y Villar García, Luis Miguel, La Extremadura Castellano-Leonesa ... op. cit., pp. 302, 303.

${ }^{465}$ Mackay, Angus, La España de la Edad Media... op. cit., pp. 88, 89.

${ }^{466}$ Es notorio que este ordenamiento con respecto al tipo de productos que podían ser transables con los musulmanes, no sólo fue elaborado por los juristas hispanos, sino que el Papado también procuró normar este aspecto de la coexistencia peninsular, a través de distintas prohibiciones y mandatos que emanaron los pontífices al respecto, aunque cabe señalar que muchas de estas normativas estaban destinadas a otros
} 
prohibía vender a los andalusíes todo aquello que podría serles útil para la guerra, como alimentos, caballos y armas. Las penas por trasgredir estas normas iban desde la expropiación de todos los bienes, hasta la muerte del vendedor. Al respecto los fueros de Cuenca y Coria nos dicen:

"234. Qui pan levar a tierra de moros.

Todo ome que pan llevar a tierra de moros, ho miel, ho queso, ho manteca, ho armas, ho cavallo, qui lo fallar tomelle quanto truxier sin calonna, e adula el cuerpo a los alcaldes, e fagan delle justiçia, e pierda quanto ovier ${ }^{, 467}$.

"4.- El que venda alimentos a los sarracenos.- Cualquiera que venda o suministre armas o alimentos a los moros, sea despeñado, si se le puede probar; pero si no, sálvese con doce vecinos y sea creído; o juré él solo y responda el reto, lo que más le plazca al Consejo. Llamamos alimentos al pan, al queso y a todo lo que se pueda comer, excepto los ganados vivos" ${ }^{\text {468 }}$.

Estas prohibiciones respondían a las estrategias de la Reconquista. Recordemos que las cabalgatas tenían como objetivo el depredar y destruir los recursos de los andalusíes, para así debilitarlos y facilitar la posterior conquista, siendo por lo tanto totalmente incongruente venderle alimentos a ese mismo enemigo. Lo mismo ocurría respecto a la venta de caballos y armas, lo que se consideraba como un acto de traición, pese a lo cual, no parece que las penas por esto fuesen realmente graves en proporción a otros tipos de faltas ${ }^{469}$. Todo lo anterior contribuyó a la existencia de un contrabando constante en ambos lados de la frontera ${ }^{470}$.

territorios cristianos, pero que mantenían algún tipo de comercio con los musulmanes. Ejemplos destacados de ello fueron algunos documentos emitidos por Gregorio IX; en diciembre de 1228 el pontífice autorizó al Obispo de Génova a excomulgar a aquellos que vendiesen armas, hierro o madera a los musulmanes. Misma prohibición que en febrero de 1229 se hizo extensiva a los genoveses, pisanos y marselleses que enviasen vituallas, armas, caballos y naves a los musulmanes, especialmente en Hispania. En oposición, el 24 de julio de 1234, Gregorio emitió un mandato destinado a Rodrigo Jiménez de Rada para que permitiera que los habitantes de Quesada (recientemente reconquistada por los cristianos) pudiesen mantener comercio con los musulmanes, a excepción de armas, caballos, hierros y maderas, en el entendido de que, dada la situación de la villa, este comercio le era indispensable para su subsistencia. (Domínguez, Santiago, Documentos de Gregorio IX... op. cit., pp. 105, 114, 330).

467 FC, Libro III, No 234, op. cit., p. 71. En el Fuero de Cáceres, en su titulo 237, encontramos prácticamente esta misma disposición.

${ }^{468}$ FCc, cap. XIII, n 4, op. cit., p. 124.

${ }^{469}$ Al respecto el Fuero de Cuenca nos dice: "29.- Que nadie saque de la ciudad armas para venderlas.Establecemos por fuero, para provecho y defensa de la ciudad, que ni cristiano, ni moro, ni judio saquen de la ciudad armas de madera o hierro. Y todo el que las saque para venderlas, pague veinte maravedis. El que le violente y se las quite, no pague pena alguna por ello" (FCc, cap. XXIX, № 29, op. cit., p. 220). ${ }^{470}$ Para una información más precisa al respecto, ver Melo Carrasco, Diego, "Las treguas entre Granada y Castilla... op . cit. 


\section{II.2.f.- Las matanzas: la muerte instrumentalizada}

Tanto en lo que respecta a las capitulaciones como a las cabalgatas, existían dos temores permanentes por parte de las poblaciones afectadas: la muerte y el cautiverio. En relación al primero, vale la pena detenerse para ver cuál era el real alcance de estos actos respecto al impacto que podían causar y la forma en que los cronistas hicieron uso de estas acciones.

Al respecto García Fitz acota que las masacres peninsulares solían tener distintos tipos y motivaciones. Por ejemplo, las ocurridas luego de alguna batalla campal, producto de la euforia de los vencedores, o la captura por asalto de una fortificación. Estas podrían ser interpretadas como señales de macabra propaganda o advertencia a posibles adversarios, o bien como estrategias para eliminar potenciales amenazas en la retaguardia antes de un enfrentamiento ${ }^{471}$. A ello se sumaba el exterminio estratégico de ciertos tipos de combatientes como los adalides, o la muerte de campesinos durante una cabalgata con el fin de mermar la voluntad de la población atacada ${ }^{472}$. En su conjunto, cada una de estas acciones respondía a objetivos particulares, más motivados por las razones estratégicas que religiosas.

A la luz de lo anterior, pretendemos revisar estas y otras situaciones de masacre en las fuentes que hemos seleccionado. Partiendo de una categorización amplia, los cronistas hispanos nos refieren dos tipos de matanza: aquellas que afectaban a los cristianos, y aquellas que tenían como víctimas a los musulmanes. En las primeras, las razones para describirlas pudieron tener a una intención pedagógica, puesto que el autor siempre trata de explicar los hechos que llevaron a la aniquilación de los guerreros cristianos. Un ejemplo de ello lo podemos observar en la tardía Crónica de los Reyes de Castilla, donde se nos relata el exterminio de más de dos mil caballeros santiaguistas, junto con la plana mayor de la orden, que fue derrotada por la imprudencia de su líder:

"[...] é á ellos que se tornaban ya, parecieron cerca del castillo de Moclin, cient caballeros de moros, é desque los vido este maestre don Gonzalo Ruiz Giron, commo era ome de grand corazon, non atendio ninguno de los otros, ni áun á la su gente mesma, é frésenlos acometer con muy poca gente, é los moros, que los vieron, comenzaron de fuir, é leváronle á una celada en que estaban dos mill

\footnotetext{
${ }^{471}$ García Fitz, Francisco, “¿’De exterminandis sarracenis’? El trato dado al enemigo musulmán en el Reino de Castilla-León durante la plena edad media”, en Fierro, Maribel y Francisco García Fitz, El cuerpo derrotado... op. cit., pp. 116-127.

472 Ibidem.
} 
caballeros de moros. É desque fué descubierta la celada, acogieron en pos dellos, é diéronle feridas á este Gonzalo Ruiz, de que murió después, é fueron en pos de la otra gente, é llegaron cerca de las tiendas del rey, é mataron ese día entre caballeros é omes de pié dos mill é ochocientos, é murieron y todos los más de los frailes de la órden de Santiago [...]" ${ }^{\text {"473. }}$

De la cita se desprende el reproche del cronista hacia la actitud de Gonzalo Ruiz, quien por su falta de humildad llevó a sus hombres a la muerte. Podemos aventurar que este relato buscaba aconsejar a los lectores sobre la prudencia y bondades de oír a los consejeros y ceñirse a las órdenes del jefe de la campaña, en este caso concreto, del rey. En otras ocasiones, la intención del autor parece ser la de incentivar el ardor guerrero de los cristianos y justificar acontecimientos posteriores. Como ocurre con el relato de la convocatoria de campaña de Alfonso VII contra Texulin, en que se narra la masacre de caudillos y de guerreros que lucharon hasta el fin:

“[...] et habuit cum eis misterium consilii sui, dixitque omnem intentionem suam in eo esse ut iret in terram Sarracenorum ad debellandum eos et accipere sibi vindictam de rege Texufino et de caeteris regibus Moabitarum, qui venerant in terram Toleti el occiderant multos duces chistianorum et destruxerant castellum quod dicitur Acecha usque ad fundamentum, et omnes cristianos quos ibi invenerant, perdiderant gladio." ${ }^{, 74}$.

No se puede descartar que este episodio cumpliera con otras finalidades además de estimular el ardor de los guerreros, entre las que podemos aventurar la intención de mostrar el conflicto como una guerra justa; puesto que se nos dice que la campaña real era en respuesta a la agresión que previamente habían hecho los musulmanes, por lo que la expedición tenía como motivación el legítimo derecho de vengar un daño.

Pese a estos testimonios, los relatos de masacres son bastante parcos y poco numerosos. Autores modernos sostienen que estos acontecimientos no eran tan frecuentes como se cree, y que cuando ocurrían, solían ser parte de una campaña de

\footnotetext{
${ }^{473}$ CRC, cap. LXXIV, op. cit., p. 58.

${ }^{474}$ CAI, Liber I, N 33, op. cit., p. 30, 31. "[...] y trato con ellos su plan secreto diciendo que toda su intención estaba en ir al territorio de los musulmanes para vencerlos y tomarse venganza del rey Texufin $y$ de los demás reyes moabitas, que incluso en persona habían venido al territorio de Toledo, matando a muchos caudillos de los cristianos, destruyendo hasta los cimientos el castillo llamado Aceca y pasando a chuchillo a todos los cristianos de alli habian encontrado" CEA, Libro I, N 33, op .cit., p. 74.
} 
terror para intimidar a los adversarios ${ }^{475}$. En el caso peninsular, a lo anterior se suma que el musulmán, aparte de su rol de enemigo de la fe también era un "objeto" valorado comercialmente, haciendo poco rentable su exterminio.

Por su parte, los cronistas musulmanes también mencionan las matanzas en forma similar a sus pares cristianos; es decir, que cuando mencionan masacres cuyas víctimas son musulmanes lo hacen por razones didácticas o para exaltar a los guerreros a la venganza, y cuando relatan las matanzas de cristianos, la intención puede ser la destacar la victoria por razones propagandísticas y levantar el ánimo de los combatientes de Allah, a quien los cronistas siempre recordaban agradecer y otorgar las victorias. Ejemplo de ello es el relato de Ibn 'Idari sobre la conquista del castillo de San Martín por parte de al-Muzaffar, en la que se narra la forma de proceder del caudillo hacia los defensores cristianos: luego de varios días de lucha solicitaron rendirse con la condición de que se les respetase la vida y se les dejase partir, lo que les fue denegado y se les exigió la rendición incondicional, luego de lo cual el caudillo 'Abd al-Malik, ordenó separar a los hombres de las mujeres y los niños:

"Detuvo su corcel en el patio de la fortaleza que miró con atención; luego llegase al lugar en el que se habia separado a las gentes [23] de la fortaleza. Se dirigió hacia [el grupo formado por] los hombres, que ya se habian levantado en consideración a él, mientras esperaban su de clemencia que los llevaría cautivos. [Él] los miró y les aplicó la sentencia con el [mismo] veredicto [emitido contra] Sa'd b.Mu'ād - Dios esta satisfecho con él -. Hizo un signo a los soldados que estaban a su alrededor; [estos] entonces los pasaron a cuchillo y los hicieron perecer en un momento. Enseguida ordenó la distribución de los prisioneros a los fronterizos voluntarios de la guerra santa (ah lar-ribāt) y a los cabalgadores de los grupos irregulares (fursāan al-wufüd), conforme a la costumbre ${ }^{, 476}$.

Nótese que los hechos narrados ocurren en el año islámico de 398 (equivalente a septiembre de 1007 y 1008, en el calendario cristiano), período en el cual el Califato aún subsistía y se habían comenzado a producir los primeros enfrentamientos serios de la Reconquista antes de establecerse la dinámica de frontera ya señalada. Razones que

475 Flori, Jean, Caballeros y caballería... op. cit., pp. 158, 159; y Rodríguez de la Peña, Manuel Alejandro, "Añadiendo muertos a los muertos: el destino de los vencidos en la frontera Al Andalus en la cronística latina plenomedieval", en Rodríguez de la Peña, Manuel, Hacedores de frontera ... op. cit., pp. $33,34$.

${ }^{476}$ CCC, op. cit., pp. $29,30$. 
quizás explicarían la aparente crueldad con la que actuaron los musulmanes en este caso.

Con respecto a los relatos que nos hablan de matanzas contra los musulmanes, estos son un poco más frecuentes que aquellos relacionados con la muerte de cristianos, si bien son igualmente parcos. Ya hemos mencionado que con respecto a los no combatientes, la Iglesia había intentado normar el uso de la violencia; algo que no ocurría en el caso de la lucha contra paganos o infieles, puesto que en este caso se luchaba una guerra por la defensa de la fe y la religión, y por tanto era lícito el uso de todo tipo de armas y estrategias ${ }^{477}$.

En el marco de esta concepción de guerra santa, los cronistas nos relatan que los guerreros hispanos muchas veces se ensañaban contra los religiosos islámicos, sus textos sagrados y mezquitas. La Historia Compostelana nos relata: "tampoco se avergüenzan de quemar y derruir sus templos y de hacer en ellos cosas indignas de ser relatadas". De forma similar la Chronica Adefonsi Imperatoris afirma: "omnes viri doctores legis quicumque inventi sunt, gladio trucidati sunt ${ }^{, 478}$. Este modo de acción se debía a que los religiosos islámicos eran el símbolo del enemigo de la fe y por ende, su muerte simbolizaba el triunfo del cristianismo frente a lo que podríamos resumir como la "herejía mahometana" 479 .

En el mismo marco ideológico, eran lícitos actos de terror, cuyo principal fin era la desmoralización del enemigo ${ }^{480}$. Como ejemplo de ello podemos citar las acciones de Alfonso VI durante el cerco de Córdoba, donde el rey cristiano no dudó en quemar vivos a algunos prisioneros para forzar a los sitiados a negociar una rendición y a entregar tributos:

"Sequenti uero die ipsum Abaldella iussit rex Adefonsus uidentibus Mauris qui erant super murum Cordube, frustratim (s)cindi et igne cremari, quia occiderat Benabet socerum regis. De illis etiam qui capti fuerant cum illo et erant familiares eius, igne comburi iussit. Vnde territi Sarraceni de soliendo tributo cum rege Adelfonso firmiter pepigerunt et illi et argenti, lapidum preciosorum et

\footnotetext{
${ }^{477}$ Flori, Jean, Guerra Santa, Yihad, Cruzada... op. cit., p. 177.

${ }^{478}$ CAI, Liber II, $\mathrm{N}^{\circ} 131$, op. cit., p. 103. "Mataron a golpe de espada a todos los doctores de la ley que encontraron" CEA, Libro II, N³6 (131), op. cit., p. 106.

${ }^{479}$ HC 1988, Liber I, cap. CIII, op. cit., pp. 174-146; y CEA, Libro II, No 36 (131), op. cit., p. 106.

${ }^{480}$ Para una contextualización del uso del temor como parte de las estrategias militares ver, Calderón Ortega, José Manuel y Francisco Javier Díaz González (Compiladores), Vae Victis: Cautivos y prisioneros en la Edad Media hispánica, Alcalá de Henares, Universidad de Alcalá, 2012, pp. 93 y ss.
} 
sericarum uestium, inmensos thesauros abtulerunt, et reuersus est rex Adefonsus

in patriam cum multis opibus et gloria magna"481.

La mayoría de las matanzas destacadas en las crónicas no se encuentran sujetas a explicaciones concretas, como la venganza o actos religiosos, y sólo se comprenden a través del estudio del contexto en que se generaron. Por ejemplo, Rodrigo Jiménez de Rada nos relata una matanza ordenada por Ordoño I, durante su campaña contra Albelda: "Et sic uictor et inclitus ad eos quos in obsidione dimiserat, est reuersus, et VII die postquam rediit, irruptione municionem accepit; omnibus qui inerant interfectis et ciuitate usque ad fundamenta subuersa, ad propria rediit cum triumpho ${ }^{, 482}$.

Recordemos que este rey asturiano sostuvo varios combates contra los musulmanes; proceso mediante el cual logró consolidar la frontera en torno a puntos fuertes como León, Astorga, Amaya y Tuy. El caso de Albelda se produjo cuando el gobernador musulmán de Zaragoza intentó fortificar la ciudad luego de que Ordoño derrotase una expedición cordobesa a orillas del Ebro ${ }^{483}$. La acción del gobernador afectaba los intereses del monarca y era una clara amenaza para sus planes; en vista de ello, la matanza sólo respondió a razones prácticas; es decir, un mensaje a los musulmanes sobre los peligros de amenazar Asturias.

Similares intenciones son las que habría tenido el nieto de Ordoño (850-866), Ordoño II (914-924), cuando después de cercar Talavera y derrotar una columna de socorro, ejecutó a todos los defensores:

"In inicio autem regni rex Ordonius collecto exercitu Talaueram oppidum animosus obsedit; uenientesque Arabes ut obsessis fierent in succursum, et ipsi pugna prostrati et obsessi frustrati utrique gladio perierunt; et directo oppido que ibi erant regis Ordonii prede cesserunt, et principem exercitus Cordubensis

\footnotetext{
${ }^{481} \mathrm{CM}$, Liber IV, $\mathrm{N}^{\circ} 71$, op. cit., p. 307. “...e entonçes, al dia siguiente, mando el rey Alfonso, veyendolo los moros que estauan sobre el muro de Cordoua, fazer en pedaços y quemarlo, porque auia muerto a Benabeth, y de aquellos que auian seydo captiuos en la batalla, que eran sus familiares, mandolos quemar en fuego; onde espantados los moros, pleytaron firmemente con el rey de pagar los tributos, y offresçieronle grandes tesoros de oro y plata y de piedras preçiosas y de vestiduras de seda, y tornose a su tierra con muchas riquezas y gran gloria." CE, Libro IV, cap. LXXI, op. cit., p. 380.

${ }^{482} \mathrm{HRH}$, Liber IV, cap. XIV, op. cit., 135. "Y de esta forma, victorioso y enaltecido, volvió junto a los que habia dejado en el asedio, y a los siete días de su regreso conquistó al asalto la fortaleza; una vez ejecutados todos los que la ocupaban y arrasada la ciudad hasta los cimientos, regresó triunfalmente a su tierra." HHE, Libro IV, cap. XIV, op. cit., p. 179.

${ }^{483}$ HHE, Libro IV, cap. XIV, op. cit., p. 179.
} 
captum adduxit, qui multis predis et captiuorum catheruis eius gloriam subsequentibus in regnum suum reuertitur gloriose ${ }^{, 484}$.

Ordoño II, al igual que su abuelo, sostuvo importantes campañas contra el Islam, llegando a atacar la ciudad de Mérida y a enfrenarse a los musulmanes en dos ocasiones; en ambas fue derrotado durante la batalla campal contra las huestes andalusíes. En vista de ello, nos parece prudente concluir que la matanza de los derrotados respondía a la necesidad de intimidar a los musulmanes, pero también de consolidar sus victorias frente a sus propios soldados a través de la teatralidad demostrada en la ejecución de los enemigos. En ambos casos destacamos dos hechos: primero, que el cronista comienza los capítulos en cuestión realizando una semblanza de los monarcas, destacado sus múltiples virtudes como el valor, la mesura, la piedad y prudencia. Por lo tanto, mostrándolos como ejemplos de hombres de los que no se esperarían actos crueles, en el entendido de que estos sean dirigidos contra cristianos. El segundo aspecto, es que no se hace referencia a razones religiosas para justificar las matanzas ni a la reivindicación de las tierras ancestrales, así como tampoco se nota un lenguaje demasiado peyorativo hacia el Islam, salvo por algunas expresiones como sarracenos, que se vinculan más con la identificación del enemigo que con sus creencias religiosas.

Años después, Fernando I protagonizaría otro episodio similar luego de capturar Lamengo en 1057: "Lameccenses quoque Mauri partim gladiis obtruncati, partim uero ob diuersa ecclesiarum opera ansis ferreis sunt constricti ${ }^{, 485}$. En esta ocasión, la acción del soberano debe ser entendida en el contexto del colapso del Califato de Córdoba, el nacimiento de las Taifas y la imposición de las parias; es decir, el cambio radical en los equilibrios de poderes en la Península y la necesidad de enviar claros mensajes políticos a los adversarios.

Los relatos con respecto al Cid Campeador son bastante gráficos en lo que se refiere a la muerte de los enemigos; sin embargo, no olvidemos el contexto de $E l$

\footnotetext{
${ }^{484} \mathrm{HRH}$, Liber IV, cap. XXII, op. cit., p. 145. "Al comienzo de su reinado el rey Ordoño, formado un ejército, sitió con gran coraje la fortaleza de Talavera; y cuando llegaron los árabes para socorrer a los sitiados, no sólo fueron éstos derrotados en combate y quedaron los asediados sin esperanzas, sino que unos y otros fueron pasados a cuchillo, y, saqueada la fortaleza, los que alli vivían engrosaron el botín del rey Ordoño, y se llevó prisionero al jefe del ejército cordobés y regresó cubierto de gloria a su reino con ingente botín y largas columnas de prisioneros que rubricaban su gloria." HHE, Libro IV, cap. XXII op. cit., p. 188.

${ }^{485} \mathrm{CN}$ 1995, Liber III, $\mathrm{N}^{\circ}$ 6, op. cit., p. 157. "Los moros de Lamengo fueron en parte decapitados con las espadas, y en parte atados con cadenas de hierro para los trabajos en la construcción de iglesias." CN 2003, Libro III, $\mathrm{N}^{\circ}$ 6, op. cit., p. 164
} 
Cantar y las mismas circunstancias que rodearon la vida del Cid. Se trata de un momento de gran agitación bélica, cuando la Reconquista de Alfonso VI sufría un duro revés y el reino comenzaba a experimentar los temores por la falta de un sucesor masculino. En este escenario es que el Campeador inició sus campañas, sirviendo a un amo u otro; sin embargo, la mayoría de sus actos más brutales sucedieron cuando el guerrero luchó movido por sus propios intereses y ambiciones. Es así que durante el cerco de Valencia ordeno capturar, torturar y ejecutar a quienes intentasen abandonar la ciudad $^{486}$ : "Et aquel que el Çid podie fallar que salie de la villa, mandaual quemar ante todo el pueblo en lugar o lo viessen los moros; et quemo en vn dia XVII dellos. Et echaua otros a los perros que los despedaçauan biuos."

A nuestro entender, la violencia del Cid no era gratuita, sino que obedecía a razones pragmáticas. Su intención era ahorrar esfuerzo y no tomar la ciudad por asalto, sino que forzarla a rendirse por hambre, lo que exigía que la población a permaneciese en ella para acelerar el agotamiento de sus recursos. A ello se sumaba la presión sicológica que significaba para los defensores el ver masacrar a los valencianos frente a los muros de la ciudad ${ }^{488}$.

Es de notar que independiente de los relatos cronísticos peninsulares, la acción violenta contra los musulmanes se encontraba auspiciada, legitimada e incluso fomentada por las autoridades religiosas. Sin ir más lejos, el pontífice Celestino III (1191-1198) declaró que perseguir y exterminar sarracenos no era contrario a la fe católica, puesto que al igual que los Macabeos, los cristianos estaban luchando por recuperar sus tierras ancestrales usurpadas por los enemigos de Cristo ${ }^{489}$. Este tipo de declaraciones legitimaba, al menos ideológicamente, la violencia de reyes y magnates; sin embargo, como ya hemos dicho, esta obedecía a motivos prácticos, los mismos que servían para evitar el uso de la violencia cuando no era estrictamente necesario. Es por ello que se prefirió hacer pactos y alianzas con el enemigo siempre que fuese posible. Una postura que también era compartido por los musulmanes, que al igual que los cristianos trataban de adaptarse a las diversas situaciones y contextos de la Reconquista.

\footnotetext{
486 Porrinas González, David, “¿Masacre o Clemencia? La conducta del Cid hacia los enemigos vencidos”, en Fierro, Maribel y Francisco García Fitz, El cuerpo derrotado... op. cit., p. 169.

${ }^{487}$ CGE, cap. 915, op. cit., p. 586.

${ }^{488}$ Es interesante destacar que en el caso del Cid, tampoco encontramos un discurso de cruzada o de lucha religiosa como temática principal. No obstante, sí existen referencias a la causa cristiana y a la necesidad de enfrentar a los musulmanes como enemigos de Dios, siendo este un tema secundario en relación a la narración de las aventuras de Rui Días, sus victorias y actividades políticas, sobre las cuales se levantó un modelo de guerrero y líder (Cantar de Mío Cid, op. cit., pp, CXXV, CXXVI).

${ }^{489}$ García Fitz, Francisco, ‘¿’De exterminandis sarracenis’?... op. cit., pp. 113-115.
} 
Fernando III, pese a su actitud por lo general "tolerante" y al igual que sus sucesores, también haría uso de la matanza como instrumento de propaganda. Durante sus primeras campañas contra los andalusíes, cuando recién había sido coronado rey de Castilla y con una clara intención de validarse a través de la victoria militar, capturó las fortalezas de Priego y Alhama, las cuales arrasó hasta los cimientos, ejecutando a sus defensores:

"[...] alia uice duxit exercitum per Giennum circa festum sancti Iohannis, quod propter sui fortitudinem non potuit expugnari; et inde procedens cepit Pegum et captis incolas et occisis munitionem funditas desolauit, et ueniens ad oppidum quod Alhama dicitur, captis habitatoribus et occisis locum destruccione simili dissipauit ${ }^{, 490}$.

Más dramático aún es el relato de la Crónica de veinte reyes, que narra cómo Fernando III atacó Baeza y luego Jaén. En esta última localidad, luego de dejar un camino de destrucción a su paso, el monarca ordenó incendiar una torre donde se refugiaban algunos musulmanes. Lo que sucedió nos es vividamente relatado por el cronista: "E llegó a Jahén e pusieron y luego fuego a vna torre, e murieron y muchos moros quemados e despeñáuanse e rrecogienlos en las lanças"491.

La narración resalta por su crudeza, y aunque en otros relatos se habla de las intenciones de Fernando para "exterminar a esa gente maldita" o que actúa movido por “el espíritu del señor”, en este caso, a nuestro parecer, la narración de la matanza no parece estar enmarcada por esta aura mística religiosa ${ }^{492}$. Por el contrario, parece ser que su único objetivo es el de describir las virtudes guerreras del soberano y destacar su fiereza, trasmitiendo así una advertencia a sus oponentes al mismo tiempo que les infunde terror en cuanto a su destino en caso de resistencia. Sin duda, estos son elementos importantes para la validación de un monarca que accedió al trono de manera

\footnotetext{
${ }^{490}$ HRH, Liber IX, cap. XII, op. cit., p. 293. “[...] en otra ocasión condujo a su ejército hacia Jaén por la festividad de San Juan, pero no pudo conquistarla a causa de sus grandes defensas; y partiendo desde allí tomó Priego y, apresados y pasados a cuchillo sus moradores, demolió la fortaleza hasta los cimientos, y dirigiéndose al castillo que se llama Alhama, arrasó el lugar con el mismo sistema tras apresar y pasar a cuchillo a sus habitantes.” HHE, Libro IX, cap. XII, op. cit., p. 345.

${ }^{491}$ CXXR, Libro XIV, cap. VIII, op. cit., p. 300.

492 Ver CXXR, Libro XIV, cap. VII-X. Consideramos que en forma complementaria a lo arriba expresado, estos capítulos contienen otro elemento importante en cuanto a la exaltación de Fernando III, puesto que se insertan a continuación del relato de la ascensión al trono castellano de Fernando, su matrimonio con Beatriz y como el nuevo soberano sometió a sus enemigos al interior del reino (Cap. I al VI), para luego hacer la narración de las campañas victoriosas contra los moros, como paso previo a relatar la muerte de Alfonso de León y la sucesión de Fernando como rey de ambos reinos, en los capítulos XVI a XVIII.
} 
tortuosa. Además, el relato descrito se enmarca dentro del pragmatismo de la guerra contra el Islam, donde la derrota del enemigo era más importante que las motivaciones religiosas, y que por otra parte, la victoria era un hecho fundamental en la validación del poder de los monarcas. Esto porque el triunfo venía a demostrar el apoyo tácito de Dios hacia el rey y su reino.

Otro caso de pragmatismo, esta vez como una advertencia hacia el enemigo, es el que involucró a Alfonso X cuando aún era infante. La Crónica General nos narra cómo el futuro rey -mientras encabezaba una cabalgata junto con Alvar Pérez, en la que habían hecho muchos cautivos- se vió superado por las tropas del rey Abenhut; entonces, Alfonso y Pérez decidieron enfrentar a su rival, tomando para ello una medida estratégica: ordenaron que fuesen decapitados los 500 "moros" que se tenían cautivos $^{493}$.

La acción del Infante bien pudo responder a dos razones; la primera, erradicar un potencial peligro en su retaguardia, representado por los prisioneros que podían aprovechar el combate para huir o atacar a sus captores. La segunda es que pudo responder a la doble necesidad de levantar y exaltar el ánimo a sus tropas con la matanza y a la vez atemorizar a las huestes atacantes ${ }^{494}$.

Si bien las matanzas parecen ser actos calculados y alejados de las pasiones religiosas, está clara su importancia estratégica, y en ese contexto es que nos llama la atención el trato que se daba a los cuerpos masacrados, siendo distinto si se trataba de los caudillos o de los simples guerreros. En las primeras crónicas de la Reconquista no abundan testimonios al respecto, pero la situación cambia en los relatos de los siglos XII

\footnotetext{
${ }^{493}$ CGH, cap. 1043 , op. cit., p. 726.

${ }^{494}$ Hasta el momento nos hemos referido a matanzas en general, pero qué sucedía cuando lo que se buscaba era la muerte de un individuo en particular, dentro de las necesidades de la guerra. Este es el caso de algunos personajes típicos de la frontera, que por sus habilidades eran considerados una amenaza de primer orden, siendo el caso más identificable el de los adalides.

En el Fuero de Cuenca, por ejemplo, si bien se diferencia entre espías y adalides "moros", ambos están sujetos a las mismas amenazas. En su aparado dieciocho del capítulo XXXI, se especifica que el consejo recompensa con cinco maravedíes a quien traiga la cabeza de un espía y con el doble, es decir diez, por una cabeza de adalid. Lo que señala una clara jerarquización de las amenazas, dadas por el valor de las piezas capturadas. En el caso de que el adalid haya sido capturado vivo, llama la atención de que en el mismo fuero se de prioridad a su muerte por sobre su intercambio, cautividad o incluso la obtención de información. Simplemente se dice que el consejo puede darle muerte como quiera (FCc, op. cit., p. 238). Este tipo de disposiciones también se encuentran en otros fueros como el de Cáceres, Coria y las Partidas.

En síntesis el adalid era una amenaza por su sola presencia y debía ser exterminado, según los fueros sin contemplaciones de ningún tipo. Sin embargo, esto no significa que se le tuviese un odio o saña particular por ser "moro", sino que su muerte se debía a la necesidad de privar al adversario de un valioso recurso bélico, sin que al parecer, pesaran otro tipo de razones del tipo políticas o religiosas.
} 
y XIII donde se encuentran distintas narraciones respecto de la forma de tratar a un rival caído.

En las crónicas de los siglos mencionados se puede observar cómo se había impuesto la costumbre entre ambos bandos de hacerse con macabros trofeos luego de los combates, específicamente las cabezas de los caudillos enemigos ${ }^{495}$. Si bien la costumbre de decapitar a los vencidos y exponer sus cabezas como señal de victoria forma parte de una tradición muy antigua, llama la atención la forma en que eran tratados los despojos. Por ejemplo, la Crónica Adefonsis Imperatoris nos narra cómo después de que Munio Alfonso (†1143), alcalde de Toledo, derrotase y diese muerte a dos caudillos musulmanes, ordena decapitarlos; no obstante, sus cuerpos son envueltos en sedas y entregados a los musulmanes. Sus cabezas sufren una suerte distinta, puesto que colocadas en lanzas son exhibidas en la entrada triunfal de Munio en Toledo, acompañadas por una procesión de cautivos ${ }^{496}$ :

"Capita vero regue suspenderunt in summitate hastarum in quibus erant vexilla regalia, et capita ducum et principum suspensa sunt in singulis hastis. Corpora regum iussit Munio Adefonsi involvi in pannis sericis optimis, et posuit ea in quoddam campo viridi, et reliquia cum eis Sarracenos qui ea custodirent usque inde tollerentur. ",497

\footnotetext{
495 De acuerdo con Rodríguez García, una costumbre muy común entre los musulmanes - aunque presente también entre los cristianos, pero en una escala menor - era la práctica de decapitar masivamente a los enemigos vencidos. Esto se debía a varias razones, entre las que podemos destacar las propagandísticas, puesto que las cabezas eran expuestas amontonadas en grandes pilas. Una imagen macabra y de gran impacto, que incluso podía ir acompañada de un ritual donde el iman o clérigo musulmán subía al montículo de testas cortadas para llamar a la oración y agradecer a Allah por la victoria (Rodríguez García, José Manuel, "Cabezas cortadas en Castilla - León, 1100-1350”, en Fierro, Maribel y Francisco García Fitz, El cuerpo derrotado...op. cit., p. 365). Sin duda una acción de fuerte carga simbólica, tanto para los cristianos como para los musulmanes. Otra razón era más mundana y básicamente consistía en cercenar las cabezas como forma de contar la cantidad de enemigos caídos - una práctica que se remonta a las primeras civilizaciones y común en muchas partes del Mediterráneo -. Las narraciones sobre estas costumbres abundan en las fuentes andalusíes, no así en las cristianas (Fierro, Maribel y Francisco García Fitz, "Introducción”, en Fierro, Maribel y Francisco García Fitz, El cuerpo derrotado... op. cit., pp. 43, 44). De hecho en grandes batallas, como las Navas de Tolosa, no se hace mención a una acción similar por parte de los cristianos victoriosos, por ejemplo en ese caso particular, las crónicas ni siquiera nos hablan de algún procedimiento para contar los cadáveres. Esta situación no implica que la decapitación fuese una costumbre inexistente entre los cristianos peninsulares, pero que posiblemente no era una práctica común o al menos relevante de narrar para los cronistas. En su artículo recién referenciado, Rodríguez García incluye un interesante listado descriptivo de distintos episodios de matanzas y decapitaciones ente los siglo X y XIV, del cual se desprende que la práctica de "descabezar" a los adversarios fue mucho más común en el mundo andalusí, que en los reinos cristianos peninsulares.

496 Alfonso Antón, Isabel, "El cuerpo del delito y la violencia ejemplar”, en Fierro, Maribel y Francisco García Fitz, El cuerpo derrotado... op. cit., p. 425.

${ }^{497}$ CAI, Liber II, $\mathrm{N}^{\circ} 168$, op. cit., pp. 131, 132. "Colgaron las cabezas de los reyes en la punta de las lanzas, en las que estaban los estandartes reales, y en cada una de las lanzas se suspendieron las cabezas de los caudillos y jefes militares. Munio Alfonso mando envolver los cuerpos de los reyes en espléndidos
} 
El relato continúa narrando que las testas son colocadas en la parte alta de la ciudadela para ser exhibidas y sólo ante los ruegos de la emperatriz son bajadas, ornamentadas y enviadas a sus viudas ${ }^{498}$. Un acto de piedad, descrito por el cronista, que creemos, pudo tener la intención de exaltar la figura de la reina como ejemplo de virtud cristiana, una especia de antítesis del guerrero que se regocijaba en su victoria.

Sin embargo, la victoria de Munio sería temporal, puesto que el caudillo no tardaría en encontrar un trágico fin. Derrotado por los norafricanos, su cuerpo fue mutilado y repartido para que su muerte fuese conocida por todos los musulmanes ${ }^{499}$ :

"Venit autem Farax adali et amputavit caput eius et brachium dextrum cum humero, et manun et pedem eius dextrum, cum tibia, et expoliavit eum armis; et truncum corporis eius involvit in linteaminibus mundis; et multa capita militum christianorum praeciderunt. Et miserunt capuz Munionis Adefonsi in Cordubam, in domun uxoris Azuel, et in Sibiliam, in domun regis Abencetae; deinde trans mare, in domun regis Texufini, ut annuntiaretur in omnen terram Moabitarum et Agarenorum. Brachium et pedem Munionis Adefonsi, et capita aliorum militum suspenderunt super excelsam turrem quae est super Calatravam."

El texto explica la muerte del caudillo por causas religiosas, puesto que su derrota se interpreta como un castigo de Dios debido a la violencia que Nuño ejecutó en contra de su hija a causa de unos amoríos. De esta forma se da a entender que la falta de piedad del guerrero fue la que lo llevó a su trágico final.

La crónica de Alfonso $X$ nos entrega relatos similares, pero en este caso asumiéndolos desde la perspectiva de los musulmanes. Ambos relatos se basan en los mismos hechos: la invasión de los benimerines en alianza con Granada. Ante la ausencia del rey, salió a su encuentro Nuño González de Lara (†1275), que fue

paños de seda, los puso en una llanura verde y dejó con ellos a los musulmanes para que los custodiasen hasta que fueran retirados de allí." CEA, Libro II, $\mathrm{N}^{\circ} 73$ (168) op. cit., pp. 117, 118.

${ }^{498}$ CEA. Libro II, $\mathrm{N}^{\circ} 79$ (174), op. cit., p. 118.

499 Alfonso Antón, Isabel, "El cuerpo del delito y la violencia ejemplar" en Fierro, Maribel y Francisco García Fitz, El cuerpo derrotado...op. cit., p. 427.

${ }^{500}$ CAI Liber II, N 183. op. cit., p. 142. "El adalid Farax llegó y cortó su cabeza, el brazo derecho con el hombro, la mano y su pie derecho con la pierna, le despojó de sus armas y envolvió su cuerpo mutilado en lienzos limpios. Cortaron muchas cabezas de los caballeros cristianos, y enviaron la cabeza de Munio Alfonso a Córdoba, al palacio de la esposa de Azuel, y a Sevilla, al palacio del rey Avenceta, después al otro lado del mar al palacio del rey Texufin, con el fin de que se conociese en todo el territorio de los moabitas y de los agarenos. El brazo y el pie de Munio Alfonso y las cabezas de los demás caballeros los colgaron sobre una alta torre que hay en Calatrava." CEA, Libro II, № 88 (183), op. cit., pp. 121, 122. 
derrotado y muerto. Una muerte que, según la Crónica, fue profundamente lamentada por sus enemigos -se entiende por el valor simbólico y monetario de capturarlo con vida-, quienes pese a decapitarlo, regresaron su cabeza a los cristianos:

"Et Aben Yuçaf mostró que le pesaua de la muerte de don Nuño, ca dezié que lo quisiera tomar biuo. Et mandól cortar la cabeça e enbióla al rey de Granada, et enbióle dezir que tomase su parte de aquella cabalgada. Et el rey de Granada enbiól dezir que era pagado con aquella parte que él le enbiaua, pero quel pesó mucho con la muerte de don Nuño, ca éste fizo mucho porque él fuese rey. E esta cabeça enbiólla (sic) a Córdoua e enbió dezir que la enterrasen con el cuerpo." $" 501$

Ante la derrota de Nuño, don Sancho, Arzobispo de Toledo, reunió a sus huestes y sin esperar refuerzos, se lanzó contra los invasores en una acción precipitada que le valió la derrota y captura. Mientras los líderes musulmanes discutían respecto a si el arzobispo debía ser entregado a los granadinos o a los africanos, uno de ellos lo mató para evitar las pugnas entre los musulmanes. A continuación su cabeza y la mano, donde llevaba el anillo, les fueron cercenadas y llevadas como trofeo, aunque fueron devueltas tiempo después:

"E fue preso el arzobispo e muertos muchos de los cristianos. E teniendo[lo] desnudo de las armas e de las otras vestiduras que leuaua, aquellos moros que eran los mayoles dixeron que lo leuarían al rey de Granada. Et Hamejamalit e Vzmén dixieron que ellos lo leuarían [a] Abén Yuçaf, ca, fasta que ellos pasaron aquende la mar, nunca el rey de Granada nin los suyos supieron por quáles partes pasaua el rio de Gualdalquivir. Et sobre esto fueron los moros en tiempo de aver muy grant pelea entre sí. Et quanto esto vió el arrayaze Abén Macar, dio de las espuelas al caballo e fue al arzobispo do estana desnuyo (sic) e diól con vna azagaya por ençima del onbro que le entró el cuerpo e matoló. Et dixo:

- 'Non quiera Alá que por vn perro se maten tantos buenos commo aqui están' E cortáronle la cabeça e la mano en que tenié el aniello e mouieron ende con su presa et fuéronse."

Podemos extraer varias conclusiones de estos relatos. La primera es que las crónicas incluyen una narración de índole pedagógica. Concretamente se nos da a

${ }^{501}$ CAX, cap. LXII, op. cit., p. 179.

${ }^{502}$ CAX, cap. LXIII, op cit., p. 182. 
entender que el arzobispo actuó de manera irresponsable, puesto que salió a enfrentar a los invasores sin esperar que se reuniesen las tropas necesarias. Dicha acción pudo responder al temor del clérigo ante la amenaza, o bien a su deseo de lograr un triunfo que lo glorificase, puesto que según el mismo relato, el caudillo actuó atolondradamente porque estaba seguro de sorprender a los musulmanes y obtener una fácil victoria. Destaca también el hecho de que la captura del alto clérigo sirvió al autor de la crónica para ejemplificar las divisiones al interior de las huestes musulmanas, puesto que los norafricanos reprochan a los granadinos su falta de valor y pasividad bélica.

Otra idea a destacar, en el caso de don Nuño, es la supuesta tristeza de los caudillos musulmanes por su muerte. Este hecho sumado al trato dado a sus restos, bien puede reflejar la intención del cronista por enaltecer la figura del líder caído, mostrándolo como un hombre cuya excelencia era reconocida por sus enemigos.

En los distintos relatos estudiados, resalta la idea del respeto por el enemigo caído y la falta de denostaciones. También parecen poco relevantes las explicaciones de tipo providencialista para justificar la muerte de los caudillos cristianos. Es por ello que creemos que en conjunto las narraciones tienen una intención ejemplificadora para los cristianos, puesto que al demostrar el trato dado a los caudillos caídos de ambos bandos se intentaba reflejar una práctica fronteriza que afectaba a los líderes cristianos y musulmanes, en relación a reconocerse como pares y enemigos dignos de ser admirados por su valor.

Este mismo sentido de respeto y falta de motivaciones religiosas para el derramamiento de sangre será una de las características más particulares de la guerra peninsular, lo que provocará más conflictos con los aliados cristianos venidos del otro lado de los Pirineos. Como veremos a continuación, este es un hecho especialmente reconocible en los episodios de Barbastro y las Navas de Tolosa.

El primero de estos episodios nos interesa por el hecho de ser una expedición conformada mayoritariamente por francos, los cuales pusieron cerco a la ciudad y la capturaron en 1064, realizando toda clase de atropellos contra la población derrotada. Todos estos sucesos fueron narrados, entre otros, por Ibn 'Idari en el siglo XIII. Primero los musulmanes ofrecieron rendirse a cambio de salvar sus vidas, pero los francos rechazaron la oferta y prefirieron conquistar la ciudad a sangre y fuego, matando a todos los guerreros y apoderándose de sus mujeres y niños, que junto con las viviendas fueron repartidos entre los conquistadores. El relato continúa de forma dantesca, narrando cómo la ciudad fue saqueada y las mujeres ultrajadas, en una orgía de destrucción: 
“[...] tomando todo lo que se le presentaba y castigando por lo que se le ocultaba, y a veces perdió la vida el musulmán por esto y así descansó; otras veces su término lo retrasó para una situación peor que esa, dado que los enemigos de Dios, entonces, apetecían violar a las mujeres de sus prisioneros y a sus hijas en su presencia, extremándose en las ofensas; abusaban de la casada y desfloraban a la virgen ante el marido de aquélla y el padre de ésta aherrojado, y el que no se complacía de entre ellos en hacer eso las daba a sus esclavos para que se divirtieran con ellas."

Al año siguiente, según la crónica, los andalusíes respondieron a la agresión y recapturaron la ciudad con facilidad, según el narrador, impulsados por el comportamiento violento, corrupto y viciado de los cristianos ${ }^{504}$. Los musulmanes ejecutaron a todos los francos y restituyeron al Islam. Para los andalusíes el ataque a Barbastro causó una gran conmoción dada la participación de tropas extranjeras y la crueldad de los hechos, muy distinta a la forma de luchar de los hispanos. Es por ello que clasifican a los ultramontanos como una plaga cruel que castigaba a los musulmanes por sus pecados ${ }^{505}$. Por esa misma razón, la reconquista de la ciudad debía ser efectuada de forma rápida, brutal y piadosa para demostrar a Dios el arrepentimiento y devoción de los musulmanes:

"Cuando los cristianos vieron eso con sus propios ojos salieron desde otro lado, por otra puerta, y cargaron como un solo hombre contra el campamento de los musulmanes; pero los muslines los persiguieron y los mataron como quisieron, $y$ no se salvó de ellos sino poca gente de aquellos cuyo fin se aplazó. Hicieron prisioneros a todos los que estaban en ella, sus familiares e hijos, y se mató, de los enemigos de Dios, a unos mil caballeros y a cinco mil infantes, y no fueron alcanzados de la comunidad musulmana sino unos cincuenta. Los musulmanes se adueñaron de la ciudad y la lavaron de la suciedad del politeísmo y la pulieron de la herrumbre de la mentira."

En este caso particular, la matanza sí estuvo justificada por razones religiosas; para los francos los andalusíes no eran más que paganos y blasfemos, enemigos de Dios y de la Iglesia -una mentalidad que también podemos observar en las cruzadas a Tierra

\footnotetext{
${ }^{503}$ CCC, op. cit., p. 189.

${ }^{504}$ CCC, op. cit., pp. 189, 190.

${ }^{505}$ Rodríguez García, José Manuel, “El Yihad: Visión y respuesta... op. cit., p. 70.

${ }^{506}$ CCC, op. cit., p. 190.
} 
Santa-, por ello no merecían piedad, y darles muerte les parecía correcto. A ello debemos sumar las causas más mundanas para acometer la destrucción, como el deseo de botín y gloria, que para el cronista musulmán serían la única causa de la agresión cristiana.

En cambio, bajo su perspectiva, la contraofensiva andalusí se hizo bajo la bandera del yihad; los cristianos derrotados fueron masacrados en represalia a sus actos previos y quizás, como mensaje de advertencia contra futuras incursiones cristianas; pero esto es sólo conjetura, puesto que Ibn 'Idari, destaca por sobre cualquier razón las motivaciones religiosa. Así se evidencia cuando afirma que la victoria musulmana significó lavar la ciudad del politeísmo y limpiarla de la mentira cristiana, en un tono discursivo muy similar a que veremos por parte de los cristianos en las crónicas del siglo XIII ${ }^{507}$.

Si bien durante los siguientes años existió una permanente influencia y presencia franca en la Península, especialmente durante el reinado de Alfonso VI, sus acciones militares se limitaron a la participación de algunos señores en las mesnadas reales bajo órdenes y costumbres hispanas. Por ende no volveremos a ver una gran intervención militar franca hasta comienzos del siglo XIII, cuando Alfonso VIII convoque a los ultrapirenaicos a la cruzada de las Navas de Tolosa.

Como ya hemos mencionado anteriormente, los francos tenían una concepción muy distinta y mucho más extrema de lo que significaba la guerra contra el Islam. Lo anterior explica su actitud durante la campaña de 1212: los cruzados francos, pese a la bienvenida brindada por Alfonso VIII, entraron en rápido conflicto con los hispanos, primero por la convivencia que existía con los judíos de Toledo, y luego por la forma en que debían ser tratados los musulmanes ${ }^{508}$. Para ellos, según su experiencia en las cruzadas orientales y contra los albigenses, la matanza de herejes o musulmanes, no sólo era un acto natural sino que legítimo, una acción deseada por Dios y así lo demostraron camino a la batalla cuando capturaron la fortaleza de Malagón. Todos sus defensores y habitantes fueron masacrados, en un acto que los cronistas hispanos

${ }^{507}$ En la Crónica el autor trata a los cristianos, entre otros epítetos, como "maldito caudillo" para referirse a Robert Crispín, o "politeístas", “infieles”, además de acusarlos de violadores y mentirosos. (CCC, op. cit., p. 189, 190).

${ }^{508}$ Estos guerreros, que se habían criado en una Francia donde las ideas de cruzada campeaban en la música y literatura y además, eran exaltados por la lucha que se llevaba en el reino contra los albigenses, eran portadores de una percepción del Islam absolutamente radical e intolerante, los enemigos de Dios que debían ser exterminados, de igual forma que lo hicieron sus ancestros cuando expedicionaron contra Barbastro o capturaron Jerusalén en 1099. 
justifican en excesiva piedad de los francos, y aun así lo narran con un aire de reproche a la luz de los acontecimientos posteriores.

Es así como la Crónica Latina nos dice al respecto, que los francos “[...] quod in momento et uelud in ictu oculi rapuerunt de manibus Maurorum, concidentes in frusta quotquot ibi reperti sunt ${ }^{, 509}$. Jiménez de Rada -que precisamente fue el encargado de reclutar estas tropas- sobre el mismo episodio nos da a entender que la acción de los ultramontanos fue inusitada, aunque la justifica aludiendo a su exceso de pasión religiosa: "[...] licet qui erant in arce satis uiriliter se defenderent, instancia temen ultramontanorum, que magna strenuitate feruebat, pro Christi nomine mori desiderans uirtutem resistencium et munitionis presidium in nomine Domini minorauit cepitque Malachonem, omnibus qui inerant interfectis" ${ }^{" 510}$. Otra versión no muy distinta de la que trasmite la Crónica General - tributaria del texto de "el Toledano" - que al igual que éste, se centra en el excesivo celo religioso de los francos pero sin dejar de destacar los detalles de la masacre ${ }^{511}$.

Para los francos, la matanza intolerante era una práctica común, pero muy distante de la realidad hispana en la que, como ya hemos señalado en páginas anteriores, pese a las banderas de cruzada y de guerra religiosa primaban las razones prácticas en el trato hacia los enemigos. Esencialmente, si no existía una razón estratégica la masacre se evitaba, y al contrario, se prefería la negociación que era menos arriesgada y además permitía obtener los asentamientos sin destruirlos, facilitando así su repoblación. Complementariamente estaba la posibilidad de lograr cautivar a los defensores, lo que implicaba un recurso económico adicional que era muy valorado.

\footnotetext{
${ }^{509}$ CLRC 1997, Liber II, $\mathrm{N}^{\circ} 22$, op. cit., p. 58. "[...] que en un momento y como en un abrir y cerrar de ojos tomaron de la mano de los moros, matando inútilmente a cuantos alli encontraron." CLRC 1999, Libro II, $\mathrm{N}^{\circ} 22$, op. cit., p. 50.

${ }^{510}$ HRH, Liber VIII, cap. V, op. cit., p. 264. "[...] aunque los que estaban en la fortaleza se defendieron muy bravamente, sin embargo el empuje de los ultramontanos, que ardía de valerosa pasión, en su afán por morir por la fe de Cristo quebrantó el valor de los defensores y la solidez de la fortificación en nombre del Señor y se apoderó de Malagón, matando a todos los de adentro." HHE, Libro VIII, cap. V, op. cit., p. 313.

${ }^{511}$ La matanza de Malagón fue rechazada por los caudillos hispanos, puesto que contravenía la forma de lucha tradicional de la península y privaba a los castellanos de los cautivos y sus recursos. En el siguiente enfrentamiento de la campaña, las diferencias en la manera de concebir a los enemigos de Dios quedaron sumamente claras. Los cruzados, directamente bajo las órdenes de Alfonso VIII, se apoderaron de la fortaleza de Calatrava, la cual les fue entregada previa negociación con los musulmanes que la defendían. A estos se les respetó sus vidas y se les permitió marcharse bajo la protección de una escolta cristiana. Un acto incomprensible para los expedicionarios francos, que protestaron por ello e incluso acusaron a los hispanos de traicionar los votos de cruzada (Márquez Villanueva, Francisco, Santiago: trayectoria de un mito ... op. cit., p. 209). Finalmente, la situación sirvió de excusa para que los ultrapirenaicos abandonaran en maza la expedición, salvo pocas excepciones.
} 
Si bien existen autores como Alvira Cabrer que sostienen la existencia de una política de exterminio hacia el Islam en la Península Ibérica, creemos, a la luz de nuestra aproximación al tema, que no se puede hablar de tal cosa de forma absoluta. Si bien es cierto, como lo expresa Alvira, que la guerra contra paganos o herejes tenía una intención exterminadora y que el fin lógico del musulmán era la muerte violenta y el castigo infernal, en la realidad hispánica esas ideas estaban sólo presentes en el discurso y no siempre en la práctica ${ }^{512}$.

En vista de lo anteriormente expuesto, concordamos con Fierro y García Fitz, que hubo actos de extrema violencia y matanzas, pero éstos se dieron en el contexto de acciones puntuales, como la captura de alguna fortaleza, o bien fueron actos de descontrol incitados por odios coyunturales o situaciones de desesperación ${ }^{513}$. Estos acontecimientos fueron excepcionales y episódicos, puesto que lo que primó durante los siglos XI al XV fue la guerra de desgaste, el cautiverio y los pactos. Estos estaban motivados por razones prácticas, como conservar la infraestructura de las localidades conquistadas y hacerse de cautivos. A nuestro entender, para la mentalidad hispánica, no era lógico destruir las ciudades que se pretendían repoblar por cristianos, y aún más contraproducente asesinar a su población, cuando se consideraba un bien capital más. Por todo ello -a pesar de la presencia de un doble discurso, que por un lado promovía la guerra total contra los enemigos de Cristo, pero que priorizaba la ocupación pactada de los espacios- es que consideramos que en la guerra peninsular las razones religiosas se sometían a las necesidades económicas y políticas, lo que descarta la existencia de una política de exterminio permanente en lo que a las relaciones entre cristianos y musulmanes se refiere.

\section{II.2.g.- Botín, aspectos materiales y humanos}

Al igual que en la época antigua, el concepto de guerra era inseparable de la idea del botín. La obtención de beneficios económicos a través de un conflicto bélico era una de las causas que podían llevar al estallido de hostilidades. En la España medieval, esta idea es clave para comprender la actividad de los guerreros y milicias en la frontera,

\footnotetext{
${ }^{512}$ Alvira Cabrer, Martín, "La muerte del enemigo en pleno medioevo cifras e ideología (el modelo de las navas de Tolosa)", en Hispania, Revista Española de Historia, Vol. LV/ II, No 190, 1995, [pp. 403-423], pp. 405-420, 421.

513 Fierro, Maribel y Francisco García Fitz, "Introducción”, en El cuerpo derrotado: cómo trataban musulmanes y cristianos a los enemigos vencidos (Península Ibérica, ss. VIII-XIII), op. cit., pp. $24,25$.
} 
donde las incursiones en busca de botín eran consideradas una actividad económica regular y un modo de vida en sí mismo. Las ciudades extremeñas contaban con este flujo de objetos expoliados a los enemigos para solventar la inexistencia de una comunidad artesanal desarrollada. Así, los mercados donde se vendían las rapiñas se convirtieron en focos de desarrollo económico, institucional y demográfico para las ciudades $^{514}$.

El acto de expoliar los recursos al enemigo en el marco de una guerra justa era considerado absolutamente legítimo, e incluso se asumía que era casi inevitable no destruir los bienes de los campesinos en el proceso. Tal era la importancia del botín, que existían distintas normativas que aseguraban su justa repartición. Estas pautas son posibles de encontrar en los fueros urbanos y documentos reales como las Partidas, donde se especificaba que siempre se debía reservar una parte del botín para el rey, y que las dos restantes se debían dividir entre el Concejo de la ciudad y los participantes de la hueste ${ }^{515}$.

${ }^{514}$ Villar García, Luis M, op. cit., p. 162; y García Fitz, Francisco, Castilla y León Frente al Islam...op. cit., p. 78.

${ }^{515}$ Flori, Jean, Caballeros y caballería...op. cit., p. 156. El repartimiento se solía realizar una vez que los hombres hubiesen regresado a la población de origen, allí existía la obligación de entregar todo lo obtenido, para que los cuadrilleros lo contasen y repartieran de acuerdo a la condición social de los guerreros, es decir, diferenciando a los caballeros y a los hombres montados, de los peones. La parte entregada al Concejo de la ciudad era usada para indemnizar a aquellos que hubiesen salidos heridos, muertos o los animales perdidos, además de pagar los servicios de especialistas como los médicos y pastores que participaron de la cabalgata. Al respecto, recomendamos consultar el apartado 176 del Fuero de Cáceres, que contiene un detallado listado de las heridas y sus respectivas indemnizaciones.

Los documentos también mencionan duras penas para aquellos que intentasen esconder o robar parte del botín, lo que demuestra la importancia que se le daba al fruto de las cabalgatas como parte de una economía urbana que beneficiaba a todos los lugareños. A modo de ejemplo, el Fuero de Cuenca establece para aquellos que hurtasen parte del botín, o bien intentasen recibir más de lo que les correspondía mediante engaños, se les castigaría con la amputación de sus orejas o trasquilándolos en forma de cruz (FCc, $\mathrm{N}^{\circ}$ 37, 38, 42, op. cit., p. 229).

Además, los distintos fueros aseguraban la obtención de recompensas particulares, no sujetas al reparto. A modo de ejemplo, en el navarro Fuero de Peralta, se dice que quien diese muerte a un enemigo podía quedarse con su montura y vestidos; en los fueros de Cuenca, Plasencia, Teruel y Albarracín entre otros, se dispone que aquellos que fuesen los primeros que causasen confusión en las tropas enemigas tenían el derecho de hacerse con las ganancias que esto produjese. (Palomeque Torres, Antonio, “Contribución al estudio... op. cit., pp. 286, 287).

Finalmente respecto a la parte del botín que correspondía al monarca -una costumbre de herencia islámica que entregaba una quinta parte de lo obtenido al Califa-, conocida como "el quinto real", era una práctica bien arraigada en Castilla y Aragón. Aunque no siempre se le respetaba, se encontraba normalizada en todos los documentos forales y reales de los reinos. A ello se agregaba además, que todas las tierras conquistadas eran entregadas en propiedad al rey, quien a su vez las dispensaba a sus vasallos y allegados -incluidas órdenes de caballería-. En esto cambiaba la tradición original islámica, puesto que en ese caso las tierras conquistadas pertenecían a la umma (Maillo Salgado, Felipe, "La Guerra santa... op. cit., p. 46; Vaca Lorenzo, Ángel, "La guerra en la historia”, Décimas Jornadas de Estudios Históricos, organizadas por el departamento de Historia Medieval, Moderna y Contemporánea, Universidad de Salamanca, Salamanca, 1999, p. 86; y Fernández Conde, Javier, Historia de la Iglesia en España. II- $2^{\circ}$... op. cit., p. 30). Situación que de paso reafirma lo dicho sobre la autoridad de los monarcas hispanos, 
Recordemos que pese a los discursos cronísticos en torno a liberar la Península de la "blasfemia de Mahoma" y todos los demás argumentos religiosos utilizados para justificar los conflictos, lo cierto es que el botín y las restantes riquezas obtenidas en estas luchas eran parte fundamental del sistema económico peninsular, y un importante estímulo para los guerreros de toda condición social y origen nacional. Las parias, que convertidas en donaciones llegaban al Reino Franco, revelaron a Europa las enormes riquezas del al-Andalus y sirvieron de incentivo para que el Papado y los francos se interesasen en la guerra de Reconquista. Por ello se explica su participación en batallas posteriores, como en Barbastro, las campañas de Alfonso VI y las Navas de Tolosa, sólo por mencionar algunas.

Sobre las formas y tipos de botín, los cronistas suelen ser bastante precisos, quizás debido a que el detalle de las especies obtenidas reflejaba el éxito de la lucha contra los infieles y estimulaba la ambición de los guerreros. En líneas generales, el botín podría ser dividido en animales, metales preciosos, vestidos, textiles y cautivos, de los cuales hablaremos luego. Al respecto, la Chronica Adefonsi Imperatoris nos relata los tipos de ganancias que se podían obtener en una incursión de gran magnitud, como eran las llevadas a cabo por el rey:

"[...] et reversae sunt universae praedatoriae cohortes cum magnis victoriis, portantes secum multa milia Sarracenorum captivorum et maximam multitudinem camelorum, equorum et equarum, boum et vaccarum, arietum et ovium, hircorum et caprarum, quae erant regum et regitarum, et alias opes plurimas" ${ }^{216}$.

En la misma crónica -que narra los acontecimientos de una etapa de reactivación de la Reconquista- se relata la victoria de Rodrigo Fernández (c.1090 - c.1142) sobre un importante contingente almohade. El caudillo cristiano obtiene un ingente botín que es llevado en triunfal procesión a Toledo, acompañado de loas de gratitud a Dios ${ }^{517}$.

puesto que estos podían reclamar parte del botín y la totalidad de las tierras obtenidas, aun cuando el rey no hubiese participado de ninguna manera de su conquista.

${ }^{516}$ CAI, Liber I, N 39, op. cit., p. 34. "Y todas las tropas dedicadas al pillaje regresaron con grandes victorias llevando consigo muchos miles de prisioneros musulmanes y un número muy grande de camellos, de cabras, y yeguas, de bueyes, vacas, carneros y ovejas, de machos cabríos y cabras, que eran de los reyes y reinas, y otras muchísimas riquezas." CEA, Libro I, N 39, op. cit., p. 76.

En la misma crónica, en su libro II, entre los apartados 118 a 122, se relatan diversas victorias de las huestes cristianas sobre las musulmanas, destacando en todas ellas el botín obtenido, resaltando bienes como tiendas, vestidos, animales, oro, plata, además de hombres, mujeres y niños. (CEA, Libro II, $\mathrm{N}^{\circ} 118$ a 122, op. cit., pp. 102, 103.

${ }^{517}$ CAI, Liber II, N 128, op. cit., pp. 99, 100. 
En este caso, tanto el botín como su exhibición pública servían como elemento de propaganda, para señalar la magnitud de la victoria y las riquezas obtenidas; las que además eran consideradas concedidas por Dios, dotándolas así de un elemento religioso de legitimación para la acción bélica de los cristianos ${ }^{518}$.

Además de su utilidad netamente económica, el botín también tenía una significación política. Primero, como motor de las periódicas cabalgatas concejiles que desgastaban la frontera con el al-Andalus, y luego como incentivo para forjar alianzas militares. Un ejemplo de esto último lo encontramos en la campaña de Alfonso VII contra Almería $^{519}$. Si bien algunos cronistas difieren en los términos de la repartición de las riquezas de la ciudad, parece concluyente que el botín fue uno de los principales estímulos para la campaña:

"Erat quedam nobilissima et opulentissima ciuitas barbarorum in maritimis Mediterranei maris Almeria, quam imperator Adefonsus depredatis omnibus aliis opidis barbarorum obsedit et etiam Ianuenses et Venetos per mare ad obsidionem illius urbis conuocauit. Cepit eam imperator catholicus in ore gladii et omnes thesauros ipsius dedit Venetis et Ianuensibus et ciuitatem retinuit sibi. Captiuos autem Sarracenos dedit Raymundo comiti Barchilonensi, qui uenerat ad absidionem urbis, et licet thesauri essent infiniti, imperator nichil sibi retinuit" ${ }^{520}$

\footnotetext{
${ }^{518}$ Esta aparente impunidad para expoliar al enemigo musulmán, contrastaba con las normas que regían la guerra entre cristianos, destacando la inviolabilidad de las propiedades de la Iglesia y la absoluta prohibición de saquear y reducir a botín o soldada los templos, monasterios y sus pertenecías. Incluso los cronistas, basándose en la mentalidad contemporánea, no dudan en atribuir como castigo divino las derrotas militares de quienes incurrían en estos actos: "Aragonenses autem de Castelle uictoria eleuati, Doriam transeuntes per Campos Gothicos adeunt Legionem, intermedia irruptionibus et incendiis deuastantes; et licent incliti essent predis, tamen ceperunt deffectu pecunie stipendia minorari; unde et rex Aragonum ed sanctuaria misit manum et thesauros auri et argenti et preciosorum lapidum, quos rerum et reginarum deudotio dedicaract, manu sacrilega usurpauit et etiam posesiones oblatas a regibus infiscauit" (HRH, Liber VIII, cap. II, op. cit., p. 222). Posteriormente, Jiménez de Rada, nos relata que el rey aragonés, Alfonso I, "pagó el castigo del sacrilegio que había cometido en León” al encontrar la derrota y la muerte a manos de los musulmanes en la batalla de Fraga (HHE, Libro VIII, cap. II, op. cit., p. 270).

${ }^{519}$ Desde ese puerto musulmán, los corsarios musulmanes asolaban el comercio del Mediterráneo, lo que afectaba los intereses económicos de los mercaderes italianos. Por ello los genoveses, aliados con los catalanes y písanos, ofrecieron realizar una campaña conjunta con el emperador para acabar con el distante bastión musulmán. Al parecer el acuerdo implicaba que el soberano castellano-leonés adquiriría el control del puerto, mientras que sus aliados obtendrían el fin de los piratas y parte del botín.

${ }^{520} \mathrm{CM}$, Liber IV, $\mathrm{N}^{\circ}$ 74, op. cit., p. 311. "Hera vna muy noble y muy abastecida çibdad de los barbaros, en los mares mediterraneos, que se dize Almería, la cual çcercó el emperador Alfonso robando los otros villajes de los barbaros; y llamó para la çerca de aquella çibdad a los genoueses y veneçianos por la mar; y tomo el emperador en boca de cuchillo, todos sus tesoros y diolos a los veneçianos y gonoueses, y retubo para sí la çibdad; mas los captiuos moros diolos a Remon, conde de Barçelona, que auia venido a la çerca de la çibdad, y maguera que tesoros sin cuento auia auido, el emperador no tomó para sí cosa." CE, Libro IV, cap. LXXVIII, op. cit., pp. 392, 393.
} 
Un caso particular respecto de la importancia del botín y su papel en la negociación política, es el episodio relatado por el autor de la Crónica Latina de los Reyes de Castilla referente al cerco de Córdoba por parte del Fernando III. Allí se narra que después de varios meses de asedio, cuando ambos bandos estaban al límite de sus fuerzas, los cordobeses ofrecieron la rendición de la ciudad a cambio de preservar sus vidas y las pertenencias que pudiesen cargar. En el bando cristiano las opiniones se dividieron entre los que proponían asaltar la ciudad y "decapitar" a los defensores, y aquellos que abogaban por aceptar las condiciones de los cordobeses; más aún cuando corría el rumor de que los sitiados estaban dispuestos a destruir el oro y la plata, quemar la ciudad y suicidarse para así reducir al mínimo las ganancias de los cristianos. Ante tal amenaza el rey y sus consejeros aceptaron las condiciones impuestas por los $\operatorname{sitiados}^{521}$ :

"E contrario suadebatur regi ut acceptaret conditionem et non curaret de personis Maurutum uel de mobilibus dummodo ciuitatem posset habere sanam et integram, siquidem quasi pro certo sciebatur, quia Cordubenses conduxerant, quia si dominus noster Fernandus rex nollet acceptare conditionem, desperantes de uita, omne preciosum, quod esset in ciuitate, destruerent, mezquitam scilicet et pontem, aurum et argentum absconderent, panos sericos ymo totam ciuitatem igni succederent, semetipsos morti traderent ${ }^{3522}$.

La amenaza de suicidio de los cordobeses, nos lleva a uno de los fenómenos más interesantes de la Reconquista y muy vinculado al botín, puesto que la muerte de los defensores de la ciudad también es vista como una merma para Fernando III. Esto se debe a que parte del botín corresponde a la figura del cautivo, término que hace referencia a las personas -musulmanas o cristianas- capturadas en el transcurso de una campaña. En algunas ocasiones, cuando el cautivo era una persona rica o poderosa, era

\footnotetext{
${ }^{521}$ Un episodio similar ocurrió en el año 1187, cuando Balián de Ibelín forzó a Saladino a aceptar sus condiciones para la entrega de Jerusalén, amenazando con matar a todos los cautivos musulmanes y destruir todos los santos lugares del Islam y del Cristianismo, para que luego los defensores de la ciudad se inmolasen en una salida suicida, destruyendo así todo el botín material y espiritual que ambicionaban Saladino y sus tropas (Hindley, Geoffrey, Las cruzadas... op. cit., p. 135). Ignoramos si los hechos de Córdoba, en relación a la amenaza de los "moros", realmente ocurrieron como son relatados o bien el cronista conocía el episodio recién narrado y lo adaptó a su obra para darle un carácter más dramático al relato.

${ }^{522}$ CLRC 1997, № 73, op. cit., p. 116. “Otros, al contrario, insinuaban al rey que aceptara la condición y no se preocupase de las personas de los moros ni de los bienes muebles con tal de que pudiera obtener la ciudad sana e íntegra, pues de cierto se sabía que los cordobeses habian decido que, si nuestro rey Fernando no quería aceptar la condición, desesperados de la vida, destruirían todo lo que de valor hubiese en la ciudad, a saber, la mezquita y el puente, esconderían el oro y la plata y quemarían las telas de Siria, es más, toda la ciudad, y a sí mismos se darían la muerte." CLRC 1999, N 73, op. cit., p. 101.
} 
posible que fuese liberado a cambio de una suma de dinero o intercambiado por alguien de igual estatus capturado por el otro bando ${ }^{523}$.

La costumbre de reducir a la servidumbre a prisioneros de guerra tenía una larga data, siendo común en la antigüedad y una práctica ampliamente difundida en casi todas las culturas mediterráneas. En la Edad Media europea la práctica continuó vigente, con la salvedad de que la Iglesia prohibió esta costumbre entre cristianos, limitándola solamente a los paganos e infieles ${ }^{524}$. En el caso peninsular, los cautivos eran considerados una parte importante del botín, que se transaba en los mercados como cualquier otro objeto, siendo por ende, un bien económico más ligado a la economía de frontera. Un ejemplo de la importancia mercantil de los prisioneros la observamos en la frase atribuida al Cid: "a más moros, más ganancia", lo que no deja lugar a dudas respecto a la apreciación que se daba a este tipo de botín ${ }^{525}$.

Es importante aclarar, a la luz de las palabras del Cid, que en la Península Ibérica el cautiverio fue un factor importante de la guerra de Reconquista, y también una de las particularidades de la Hispania medieval ${ }^{526}$. Los territorios peninsulares fueron uno de los pocos lugares en Europa donde fue necesario hacer la diferencia entre cautivo -que podía ser reducido a la esclavitud por su calidad de no cristiano- y prisionero cristiano, debido a las rencillas entre los distintos reinos cristianos de la Península ${ }^{527}$.

\footnotetext{
${ }^{523}$ García Fitz, Francisco, “¿’De exterminandis sarracenis’?... op. cit., pp. 128-142.

${ }^{524}$ Contamine, Philippe, La guerra en la Edad Media... op. cit., p. 334; y Flori, Jean, La Caballería... op. cit., p. 84.

${ }^{525}$ Gárate Córdoba, José María, Espíritu y Milicia... op. cit., p. 135; García Pardo, Manuela. "La Redención de Cautivos: Una muestra de la religiosidad popular medieval en Úbeda", en $V$ Estudios de Frontera, funciones de la red castral fronteriza, Alcalá la Real, Diputación Provincial de Jaén, 2003, p. 275; y Keen, Maurice, op. cit., pp. 323-325.

${ }^{526}$ Recordemos que los cautivos eran sólo una parte de los habitantes musulmanes en tierras cristianas. Un hecho que daba pie a distintas situaciones puesto que, pese a lo anterior y no obstante las regulaciones y la convivencia, no se ocultaba la desconfianza recíproca que existía entre ambos grupos. Nótese que las condiciones de la coexistencia debieron ser más tensas en los períodos de guerra, cuando era frecuente que los expedicionarios regresaran trayendo consigo andalusíes cautivos, los cuales quedaban sometidos a la servidumbre y desprovistos de todos sus derechos ante la mirada de los mudéjares.

527 Fierro, Maribel y Francisco García Fitz, "Introducción”, en El cuerpo derrotado: cómo trataban musulmanes y cristianos a los enemigos vencidos (Península Ibérica, ss. VIII-XIII)...op. cit., p. 47; y Torró, Joseph, "De Bona Guerra. El ambiguo estatuto del cautivo musulmán en los países de la corona de Aragón (Siglos XII-XIII)”, en Fierro, Maribel y Francisco García Fitz, El cuerpo derrotado: cómo trataban musulmanes y cristianos a los enemigos vencidos (Península Ibérica, ss. VIII-XIII..., op. cit., p. 436.

A estos -en teoría, pero no siempre en la práctica- no se les podía someter a trabajos forzados, vender, lastimar o matar de forma arbitraria; en otras palabras, no eran un bien comercial o una propiedad, sino que por el contrario, debía respetárseles su estatus social y atender sus necesidades. En resumen, la diferencia entre un prisionero cristiano y uno que no lo fuese era que este último quedaba reducido a la condición de bien transable.

Por lo tanto, económicamente hablando, el cautivo era un bien que podía ser vendido, intercambiado y utilizado a criterio de su cautivador. En ese sentido, los fueros nos revelan que no era extraño que se le alquilase para realizar distintos deberes. Al respecto, el Fuero de Cuenca nos dice cual
} 
En síntesis, y a la luz de estudios modernos, el cautiverio debe ser visto como una actividad económica propia de la vida fronteriza, y el hecho de que poblaciones enteras quedasen reducidas a esta condición se explica por el temor a un destino peor validado por la guerra religiosa: la matanza. Los cautivos cumplían un rol económico como mano de obra esclava, y además -dependiendo de su estatus social- tenían un valor monetario importante, puesto que el pago de rescates se convirtió en una industria por sí misma. Al respecto, Vidal, cita los 2705 dinares de oro pagados por Sevilla para el rescate de setecientos de sus vecinos capturados por los cristianos ${ }^{528}$. Por lo mismo, no era extraño que la captura de personas, a través de cabalgatas e incursiones, fuese una de las actividades bélicas más frecuentes llevadas a cabo por milicias urbanas, como las de Ávila, dando así origen a personajes dedicados a la negociación de estos rescates: los "alfaqueques" $" 529$. A los factores económicos mencionados se suman los políticos,

era la forma en que debía ser tratado este particular bien: "15.- El alquiler de un moro o de un siervo.- El que alquile a un moro o un siervo, guárdelo hasta que sea devuelto a su dueño, porque si se le escapa, está obligado a pagar su precio por juramento de su señor. Asimismo, si lo mata o lo lesiona, págueselo. Si lo azota o lo hiere, pague la multa del delito que haya cometido, según el Fuero de Cuenca." (FCc, Cap XXXIII, $\mathrm{N}^{\circ} 15$, op. cit., p. 247).

En el Fuero de Cuenca se establece una multa de cinco sueldos al que hiera a un "moro" ajeno y quince si es que lo mataba (FCc, cap XI, $\mathrm{N}^{\circ}$ 19, op. cit., p. 111). Es decir que el dueño del "moro", como ocurre con todo bien, debía ser indemnizado por el perjuicio económico que significaba la pérdida de su propiedad. Esta situación se agravaba si el "moro" en cuestión estaba destinado a la redención, pues en ese caso el homicida del "moro" debía pagar el rescate prometido. Otro ejemplo de lo anterior se puede ver en el Fuero de Cáceres donde en su apartado 126 se establecen las indemnizaciones por dañar un "moro" ajeno: "126. Qui firier moro ageno. Todo me que firiere moro ageno o mora, o messare, pectel II morabetis domino suo. Et si liuores fezier, pectet IIII morabetis domino suo, et si non, iure siue V de uezinos, si firmare non ge lo pudieren" (FCs, $\mathrm{N}^{\circ} 126$, op. cit., p. XXXVII). En el Fuero de Coria, en su Libro II, se es mucho más especifico al respecto: "119. Qui ferir moro o mora. Qui ferir moro ageno, o mora, o los mesar, peche dos maravedis a su señor. E si fezier livores, peche IIII maravedis a su señor; si non, jure con IIII e elle el $V^{o}$, Qui ferir moro o mora ageno, jure solo que no lo ferio por su desonra de su señor; e si no jurar, o de plazo cayre, peche la calonna doblado a su señor.

[...]

121. Qui matar moro ho mora. Qui matar moro de lavor o mora de serviçio, peche quinze maravedis a su sennor. E si matar moro de merçede, lo alcaldes e los VI apreçien quanto peche a su sennor" (FC, Libro II, $\mathrm{N}^{\circ} 119,121$, op. cit., p. 45).

En el Fuero de Cáceres se da testimonio de la otra cara de esta situación, es decir, qué pasaba si un "moro" cautivo agredía a un cristiano. En estos casos se seguía una lógica bastante práctica y que no difería demasiado con respecto a lo que ocurría si cualquier animal atacaba a una persona, lo que venía a reafirmar la condición de bien económico que tenía el cautivo: "128. Moro o mora que feriere chistiano. Todo moro o mora que firiere christiano o christiana, so sennor pectet la calopna al uizino como al uizino, al morador assi como a morador" (FCs, No 128, op. cit., p. XXXVIII. Según el Fuero de Cuenca si un animal mataba o hería a una persona, el dueño de la bestia debía indemnizar al afectado o a su familia, extinguiéndose de esta manera las responsabilidades y evitándose otro tipo de penas).

${ }_{528}$ Vidal Castro, Francisco, "El Cautivo en el Mundo Islámico: Visión y vivencia desde el otro lado de la frontera andalusí", en II Estudios de Frontera, Actividad y Vida en la Frontera, Alcalá la Real, Diputación Provincial de Jaén, 1998, pp. 794, 795; y García Fitz, Francisco, “¿’De exterminandis sarracenis'?... op. cit., pp. 128-142.

${ }_{529}$ Vallvé Bermejo, Joaquín, "El tiempo de los moros", en Eloy Benito Ruano (Coordinador), Tópicos y realidades de la Edad Media, Volumen III, Madrid, Real Academia de la Historia, 2000-2002, p. 99. 
puesto que los cautivos más importantes podían convertirse en moneda de cambio para negociaciones entre los caudillos y monarcas de ambos bandos ${ }^{530}$.

Tempranamente se procuró definir y normar la figura del cautivo para evitar los abusos y complicaciones que podría producir. Es así como en las Partidas lo encontramos definido en relación a una serie de parámetros, como son la diferencia de credos, la falta de libertad, el sometimiento a tormentos, el trabajo servil y en general un estado de miseria:

"Mas cativos son llamados por derecho aquellos que caen en prisión de homes de otra creencia; ca estos los matan despues que los tienen presos por despreciamineto que han á su ley, ó los tormentan de muy cruas penas, ó se sirven dellos como siervos metiéndolos á tales servicios que querrian ante la muerte que la vida: et sin todo esto non son señores de los que han pechándolo á aquellos que les facen todos estos males ó los venden quando quieren"

Es de notar que esta definición es tardía en comparación al fenómeno mismo del cautiverio, ya que para el siglo XIII la práctica llevaba siglos de evolución y su inclusión en las Partidas se explica dentro del contexto de una obra que pretendía normalizar todo el sistema jurídico del reino. Por lo mismo, sintetiza una serie de prácticas y tradiciones que la convierte, a nuestro juicio, en un texto clave para comprender esta problemática.

En las Partidas destaca lo que podríamos llamar "el aspecto emocional”, puesto que se refiere al cautiverio como una de las peores cosas que le pueden ocurrir a un individuo -sin hacer distinción entre musulmanes y cristianos -. También es notoria la diferencia que hace entre cautivos y presos, revelando lo común que eran ambas prácticas en el escenario peninsular. En cuanto a la liberación de cautivos, el "Rey Sabio" no deja dudas de que es un tema profundamente mezclado con la religión, puesto

\footnotetext{
${ }^{530}$ Directamente vinculado al fenómeno del cautiverio en la Península se encuentra la fundación de las Órdenes religiosas redentoras, destacando las de la Trinidad y de Merced, fundadas por San Juan de Mata en 1188 y por San Pedro Nolasco en 1218, respectivamente. El objetivo principal de estas órdenes fue la dedicación exclusiva a la liberación de cautivos en manos de los musulmanes. Lo que hacían a través de la recaudación de dineros mediante donaciones, negociando e incluso intercambiando frailes por cautivos. El surgimiento y crecimiento sostenido de las órdenes en la Península, durante los siglos XII y XIII, y el apoyo que recibieron por parte de autoridades políticas y religiosas nos hablan de la importancia del fenómeno del cautiverio en la Reconquista y la necesidad de ordenar el mismo, en especial en consideración de aquellos más débiles que veían dificultada la posibilidad de costear su propia liberación. (Para una panorámica general de estas órdenes y su actividad recomendamos ver la Parte IV del trabajo de Calderón Ortega y Díaz González (Vae Victis... op. cit., pp. 230 y ss.)

${ }^{531}$ LSP, Partida II, Titulo XXIX, Ley I, op. cit., p. 327.
} 
que dentro de las tres razones que da para su liberación, solamente la cuarta responde a razones prácticas. Las demás se vinculan con virtudes y creencias religiosas.

"Quitar deben los homes á los que yacen en cativo por quatro razones: la primera porque place mucho á Dios de haber home dolor de su cristiano, ca segunt él dixo asil debe home amar como á sí mesmo quanto a la fe: la segunda por mostrar hi piedad natural que deben los homes haber daquellos que mal reciben, porque son de una natura et de una forma: la tercera por razon de haber gualardon de Dios et de los homes quandol fuere meester; ca bien asi como él querri seer acogido si yoguiese en cativerio; otrosí debe él acorrer al que en él fuese: la quarta por facer daño a sus enemigos cobrando los que tienen preso de su parte sácandolos de su poder; ca esta cosa en que yace pro et honra á los que lo facen, et los otros reciben en ello perdida et mengua." 532

En esencia, para los juristas alfonsíes la liberación de los cautivos cristianos era un acto de piedad religiosa amparado en las enseñanzas de Cristo, y por lo tanto una obligación para todo buen creyente. Pero también se le reconocía como parte de las estrategias de la guerra peninsular, puesto que se entendía que cualquier cautivo liberado era un siervo menos para los adversarios, al mismo tiempo que les restaba una herramienta de negociación. Así, para los redactores de las Partidas el fenómeno debía ser entendido como una realidad cotidiana, enmarcada dentro de una dinámica religiosapolítica propia de la realidad peninsular.

En el caso de las narraciones de cabalgatas, la descripción de los cautivos suele estar incluida dentro de la enumeración del botín, limitándose a mencionarlos casi al pasar. Sin duda, esta era una práctica bastante antigua, como lo atestigua el relato de la Crónica de Veinte reyes con respecto a una expedición del rey Ramiro: "E leuaron los cristianos muchos catiuos e muchos despojos, e tornáronse para sus tierras rricos e honrrados" $" 533$. Otras alusiones a ellos se pueden apreciar en la Chronica Adefonsi Imperatoris, que describe el fruto de una correría por tierras de Jaén, Baeza, Úbeda y Andujar:

"Vineas et oliveta et ficulneas et omnes arbores fecerunt incidi, et emnis locus quemcumque pedes forum calcaverunt vastatus remansar. Post multos vero dies reversi sunt ad imperatorem in castra, portantes secum magnam multitudem captivorum virorum ac mulierum et parvolorum, munera auri et argenti el vestes

${ }^{532}$ LSP, Partida II, Titulo XXIX, Ley II, op. cit., p. 328.
${ }^{533}$ CXXR, Libro I, Cap V, op. cit., p. 83 . 
pretiosissimas et omnes locupletationes forum et totam supellectilem et magnos

greges equarum et equarum et boum et vaccarum et ovium et caprarum" ${ }^{, 534}$.

En estos casos destaca el detalle del cronista para describir la cantidad y calidad del botín, algo muy propio de una crónica, como la Chronica Adefonsi que está destinada a proclamar la gloria del soberano y legitimar su figura través de sus acciones militares. En este contexto, los cautivos forman parte del aparato propagandístico de la crónica.

Debido a la extensión de sus conquistas y trascendencia histórica, consideramos relevante destacar la figura de Fernando III. Debemos recordar que durante el reinado del "Rey Santo" se conquistaron numerosas y populosas ciudades, así como gran cantidad de aldeas, asentamientos y fortalezas. Por lo que las campañas reales incorporaron gran cantidad de personas al control cristiano, en un momento - mediados del siglo XIII- que existía una fuerte influencia de las ideas de cruzada y un progresivo aumento de la intolerancia por parte de los hispanos.

No obstante, Fernando III tenía una clara concepción del valor político, económico y religioso de los cautivos. Al respecto sabemos que el rey inició una cabalgata contra Granada y pactó con los granadinos el cese de hostilidades, a cambio de la liberación de los cautivos cristianos que tenían en su poder, que llegaban a 1.300 almas. Además el rey conservó el botín ya capturado, en el que se contaba la enorme cifra de 17.000 cautivos musulmanes ${ }^{535}$. La narración del episodio revela una exaltación a la piedad del monarca, que prioriza la liberación de los cautivos cristianos. Asimismo, se devela la intención propagandística con que se presenta la figura del cautivo, puesto que a la liberación de cristianos se suma la captura de los musulmanes en una cantidad tan elevada que parece increíble, tanto que es probable que obedezca al proselitismo de los cronistas, esto porque, en la mentalidad cronística, entre más cautivos se capturasen, mayor era la victoria y mayor la acumulación de riquezas, además de ser una prueba

\footnotetext{
${ }^{534}$ CAI, Liber II, N 131, op. cit., p. 104. "Hicieron cortar las viñas, olivos, higueras y todos los árboles, $y$ todo el lugar que hollaron sus pies quedó devastado. Y después de muchos días regresaron al campamento ante el emperador llevando consigo una gran multitud de cautivos, hombre, mujeres y niños, regalos de oro y plata, vestidos muy valiosos, todas sus riquezas, todo su ajuar y grandes rebaños de caballos, yeguas, bueyes, vacas, ovejas y cabras." CEA, Libro II, 36 (131), op. cit., p. 106.

${ }^{535}$ González Jiménez, Manuel, Fernando III el Santo..., op. cit., pp. 92, 93.
} 
tangible de la superioridad del cristianismo. De esta manera, se revelaría el apoyo tácito de la divinidad a las acciones del monarca ${ }^{536}$.

Es notable el hecho de que estas realidades sean apenas explotadas por los cronistas, puesto que si bien se solían hacer recuentos de botín y cautivos, estos quedan opacados por la descripción general de las campañas. En general las narraciones procuran exaltar al monarca, agradecer a Dios y luego describir el botín, aunque esta descripción siempre está subyugada a los dos elementos mencionados.

Junto a lo anterior, es innegable que el botín fue uno de los principales motores de la Reconquista -aun cuando la idea de la defensa de la Iglesia es omnipresente- y que bajo ese discurso se escondía una verdadera industria bélica. Entonces, ¿Por qué no defender a la Iglesia a la vez que obtener recompensas materiales? Esta es una pregunta, que nosotros creemos, que probablemente los hombres de la Reconquista ni siquiera se plantearon, puesto que, según nuestras conclusiones, ellos consideraban la captura de botín como una actividad natural, meritoria e inseparable de la acción militar. En este sentido, es interesante observar cómo los caudillos y cronistas supieron equilibrar esta balanza ideológica para que primase la motivación discursiva por sobre la material. Como hemos podido apreciar hasta ahora, en ellos permanentemente se recuerda sobre los riesgos de la ambición desmedida, que podía materializarse en contraofensivas musulmanas que sorprendían y masacraban a las huestes cristianas sobrecargadas por su pillaje. Aun así, encontramos un testimonio explícito sobre los esfuerzos que debían hacer los caudillos por contener las ansias de botín de sus tropas y evitar desbordes que podían llevarlos al fracaso. Un buen ejemplo de ello se puede ver en el siguiente extracto que relata la jornada de las Navas de Tolosa:

"In campo autem qui uoluerunt rapere plurima inuenerunt, aurum, scilicet, argentum, uestes preciosas, suppellectilia serica et multa alia preciosísima ornamenta, necnon et pecunias multas et uasa preciosa, que omnia pro maiori parte pedites et aliqui milites de Aragonia habuere. Maiores enim et quos fidei zelus et legis reurencia et amor strenuitatis nobilitauerat, hec omnia contempnentes usque ad noctem persecucioni uiriliter intenderunt, presertim cum precedente die Toletanus pontifex sub interminatione anathematis

\footnotetext{
${ }^{536}$ Debemos aclarar, que en este punto sólo nos basaremos en las obras cristianas, puesto que son las que se adaptan mejor a nuestros objetivos, por lo explícito de sus relatos. También consideramos prudente advertir, que en un próximo capítulo regresaremos a tratar este tema, cuando hablemos específicamente del providencialismo.
} 
inhibuisset, ne quis prede campi insisteret, si diuina providencia uictoriam concedere dignaretur." 537

El episodio deja en claro que el botín era un importante acicate, en especial para los peones, quienes en general permanecían alejados de los ideales caballerescos y de las contingencias políticas. Bajo esta visión, la victoria final y el exterminio de los sarracenos debía ser el objetivo de todos los guerreros, y se hacía necesario recordárselos y apremiarlos a ello. De allí la necesidad de reafirmar en las crónicas, una y otra vez, que se estaba librando una guerra por la defensa de la fe; dando origen a los discursos propagandísticos que instrumentalizaban la religiosidad, poniéndola al servicio de la conquista de tierras y la obtención de recompensas materiales por el esfuerzo bélico.

\section{II.2.h.- La imagen de los musulmanes y el ordenamiento de la frontera en Alfonso X:}

\section{Realidad y práctica}

El reinado de Alfonso X, a nuestro parecer, evidencia claramente la evolución que hubo respecto a la imagen que se formó en torno a los musulmanes, durante de los siglos XII y XIII. Nos referimos al doble discurso que se advierte en la relación entre musulmanes y cristianos, puesto que el "Rey Sabio" había heredado de su padre, Fernando III, la misión de continuar con la Reconquista y expulsar a los musulmanes de la Península; objetivo que el soberano intentó cumplir - al tiempo que enfrentaba una nueva invasión norafricana - aplastando la revuelta de los mudéjares y utilizando para ello el recurso de la cruzada. Esto se evidencia en textos como la Crónica General; en ella, Alfonso complementó sus ideas con acciones concretas, puesto que frecuentemente rompió los acuerdos y pactos hechos por su padre con los mudéjares. No obstante, bajo su reinado fue frecuente observar la presencia de musulmanes en la Corte, y especialmente en la legislación, como por ejemplo en las Siete Partidas, en la que se expresa una clara intención de regular la coexistencia de ambos grupos. En definitiva, se

${ }^{537}$ HRH, Liber VIII, cap. XI, op. cit., p. 275. “A su vez, los que quisieron pillar encontraron muchísimas cosas en el campo, esto es, oro, ricos vestidos, atalajes de seda y muchos otros ornamentos valiosísimos, y además mucho dinero y vasos preciosos, de lo que en su mayor parte se apoderaron los infantes y algunos caballeros de Aragón. Pues los grandes y aquellos a los que había ennoblecido el amor a la fe, el respeto a la ley y el afán de valentía, continuaron bravamente la persecución hasta la noche dando de lado a todo eso, debido sobre todo a que el día anterior el Arzobispo de Toledo había prohibido, bajo amenaza de excomunión, dedicarse al saqueo del campo si la divina providencia se dignaba a conceder la victoria." HHE, Libro VIII, cap. XI, op. cit., p. 324. 
advierte una contradicción al combinar una imagen negativa del Islam con el intento de regular la vida en común con los cristianos ${ }^{538}$.

A la situación anterior se suma la presión ejercida por el Papado, que impregnado de las ideas de cruzada- trataba de imponer un mayor control sobre las poblaciones musulmanas y judías en los reinos cristianos. Se aprecia en ello una evidente radicalización por parte de la Iglesia en su trato a estas minorías, a las que aparentemente consideraban una especia de "quinta columna" medieval. De ahí su interés por imponer, a través de los concilios, medidas de segregación como la obligatoriedad de utilizar prendas distintivas, así como presiones directas a soberanos como Jaime I (1213-1276) y Alfonso X - para que terminasen con sus políticas de "tolerancia" y expulsaran o convirtiesen a los no cristianos en sus reinos, o bien, que cesaran todo tipo de pacto, tregua o negociación con los musulmanes ${ }^{539}$. Estas presiones pontificias debían ser equilibradas con los intereses de Alfonso X, particularmente con sus intensiones de verter al castellano el saber musulmán, empleando para ello a traductores musulmanes. Esto no impidió que el rey aplicase una política de expulsión de los musulmanes en las ciudades y localidades capturadas, incrementada luego de la revuelta mudéjar. En palabras de José Luis Villacañas, la solución a la disyuntiva real se plasmó en la siguiente idea: "Su saber pasaría a los castellanos, desde luego, pero ellos no serían castellanos jamás"

En síntesis, el reinado de Alfonso X ilustra la disyuntiva de la sociedad castellanoleonesa en los siglos XII y XIII con respecto al Islam. Puesto que nos permite observar la búsqueda del delicado equilibrio en la dinámica de fronteras y como esta se vio afectada por las ideologías bélico-religiosas que impregnaban la Península.

Veremos ahora cómo ambas prácticas convivieron durante el reinado de Alfonso $\mathrm{X}$ desde la perspectiva de los escritos cronísticos y legislativos del soberano.

Para ello nos centraremos en la Crónica General, en gran medida tributaria de las obras de "el Tudense” y “el Toledano". Bajo estas concepciones, el musulman era el enemigo de la cristiandad, que había usurpado las tierras de Hispania y a quien era justo combatir para lograr la liberación del antiguo solar de los visigodos. Es decir, la

\footnotetext{
${ }^{538}$ Fernández Conde, Francisco Javier, La Religiosidad Medieval ... op. cit., pp. 394, 395.

539 Villacañas Berlanga, José Luis, La Formación de los Reinos Hispánicos... op. cit., pp. 620, 621; y Rodríguez García, José Manuel, Idea y realidad de cruzada ... op. cit., p. 144.

${ }^{540}$ Villacañas Berlanga, José Luis, La Formación de los Reinos Hispánicos... op. cit., p. 619.
} 
Crónica posee todos los elementos relacionados con la demonización del Islam ${ }^{541}$, junto con reflejar algunas antiguas creencias al respecto, tales como los orígenes bíblicos de los árabes ${ }^{542}$.

La crónica dedica varios capítulos a narrar la biografía de Mahoma, usando como fuente principal la realizada por Lucas de Tuy, a la que se agregan episodios relatados en los Milagros de San Isidoro del mismo autor. También se agregan episodios que son parte de la tradición musulmana, a los que procura desmentir o trastocar ${ }^{543}$. Entre estas últimas, destaca la historia de un astrólogo judío que habría vaticinado el futuro del recién nacido Mahoma y cómo esto influyó en el líder islámico, que inventó mentiras para construir su imagen de Profeta. La Crónica rechaza completamente la tradición que cuenta cómo unos ángeles lavaron el corazón de Mahoma cuando aún era un niño, reduciendo toda la historia a una simple invención del ya mencionado judío:

"Esse anno dozeno del regnado del rey Leouegildo, auiendo ya Mahomat quatro annos de su nascencia, dixo aquel iudio estrellero mintiendo, que uinieron dos angeles et que sacaran el coraçon a Mahomat et ge lo fendieran por medio, et quel tiraran dell un quaio de sangre negra, et dise que ge lo lauaran muy bien con agua muy clara et flemosa [...] e que ell un angel daquellos dixo all otro: 'si este coraçon fuere puesto en peso con los corazones de quantos omnes a en Arauia, mas pesara el solo que todos ellos". E el judio mintiendo dixo quel dixiera esto sant Grabiel arcangel en uision" ${ }^{\text {,54 }}$.

En esta parte de la biografía de Mahoma se destacan dos elementos: en primer lugar, el rol del judío - representante de una etnia despreciada por los cristianos y culpable de deicidio - quien sería el artífice del origen mítico del falso profeta. De esta manera vincula a la nueva religión con un antiguo rival del cristianismo, haciendo a los musulmanes parte de un imaginario común de desprecio basado en las creencias religiosas. En segundo lugar, tilda de falsa una antigua tradición que para los musulmanes representa, un símbolo indiscutido de la pureza de Mahoma, y señal inequívoca de ser elegido de Allah.

El relato continúa relatando cómo el Profeta fue instruido en la lectura por el malicioso judío, quien le enseñó la ley de los cristianos y hebreos, para luego narrar la

\footnotetext{
${ }^{541}$ Barkai, Ron, El enemigo en el espejo..., op. cit., pp. 234, 235.

${ }^{542}$ CGE, cap. 466, op. cit., p. 261.

${ }^{543}$ Goñi Gaztambide, José, Historia de la Bula de Cruzada... op. cit., p. 248.

${ }^{544}$ CGE, cap. 469, op. cit., p. 262.
} 
vida de Mahoma, copiando casi textualmente los relatos de Lucas de Tuy. A éstos agrega otros episodios, como el cuasi enfrentamiento entre el líder musulmán y San Isidoro, así como también su matrimonio, sus luchas y prédicas; siempre destacando la mentira y falsedad como elementos esenciales de la vida y obra del Profeta ${ }^{545}$.

Pese a esta imagen negativa de Mahoma, la Crónica General deja entrever que sus autores y promotor tenían amplios conocimientos sobre la religión islámica, a la cual permanentemente procuraban desprestigiar. Evidentemente, este conocimiento era el fruto de la coexistencia y cercanía con los musulmanes, y tal vez por ello, los relatos reflejan una comprensión del Islam, con el fin de desacreditarlo como una falsa revelación con argumentos fundamentados. Un ejemplo de ello es la explicación que se hace sobre la composición del Corán:

"E despues que se leuantarua dalli predigauales et dauales leys que touiessen, las que ellos llamaron por au arauigo zoharas, que son tanto como 'mandamientos', e destas zoharas les fizo ell un grand libro departido por capitulos, al que ellos llaman alcoran, et tanta nemiga et tanta falsedad escriuio ell en aquellas zoharas, esto es mandamientos, que uerguença es a omne de decirlo nin de oyrlo, et mucho mas de seguirlo; e pero estas zoharas le recibieron aquellos pueblos malauenturados seyendo beldos de la ponçon del diablo et adormilados en el peccado de la lujuria, e oy en dia los tienen et estan muy firmes en su porfia e non se quieren llegar nin acoger a la carrera de la verdadera fe nin ayer en si la ley de Dios nin el su enseñamiento."

Finalmente, la biografía de Mahoma termina con su muerte por envenenamiento, dando "ell alma al diablo" mientras su cadáver es devorado por perros ${ }^{547}$, y sus restos finalmente sepultados ${ }^{548}$. Así, podemos concluir que la Crónica General sigue los pasos de sus antecesoras en el sentido de desprestigiar completamente al Islam y su fundador; sin embargo, introduce el intento de explicar algunos aspectos de su religión, aunque, finalmente su propósito sea el mismo que el conjunto de los pasajes referidos a los musulmanes: la denostación.

Con respecto a los musulmanes en su conjunto, el texto reitera los mismos episodios de crónicas anteriores, relatando eventos y personajes ya conocidos, como la

\footnotetext{
${ }^{545}$ CGE, cap. 478-493, op. cit., pp. 265-273.

${ }^{546}$ CGE, cap. 493, op. cit., p. 274.

${ }^{547}$ El hecho de que los perros sean considerados animales impuros en el Islam, hacia más denigrante el relato.

${ }^{548}$ CGE, cap. 494, op. cit., p. 274.
} 
figura demoníaca que lamenta la muerte de al-Mansur, o el paralelismo entre el Califa de Bagdad y el Papa. A su vez, menciona sucesos destinados a mostrar una imagen más benigna de los musulmanes -cuando esto era útil a los intereses cristianos- como por ejemplo, cuando se califica a Abenhut de "sabio"549.

Sin embargo, este tipo de relatos es solamente una parte de la imagen del musulmán, un aspecto proselitista destinado a señalarlo como enemigo y objeto de guerra. En contraposición, Alfonso X debió afrontar la realidad de la coexistencia entre ambos grupos. Esto se refleja en la obra legislativa del monarca, principalmente en las Siete Partidas. Veremos a continuación la imagen del "moro" que nos trasmite esta magna obra jurídica.

Como sabemos, en las Partidas se tratan una infinidad de temas, dejando el asunto de los musulmanes para la Partida Séptima, compartiendo lugar con los judíos y herejes. En el Titulo XXV, se procuran describir y explicar qué es un "moro" y cuáles son sus orígenes, caracterizándolos como: "una manera de gentes que creen que Mahomat fue profeta et mandadero de Dios; et porque las obras et los fechos que él fizo non muestran del tan grant santidad por que a tan santo estado pudiese llegar, por ende la su ley es como denuesto de Dios" ${ }^{250}$. El mismo apartado regula aspectos de convivencia como la manera en que deben ser convertidos, cómo deben ser tratados los conversos, qué penas afectan a los cristianos que se tornan musulmanes y cómo deben ser tratados los embajadores, entre otros temas.

Destaca de esta primera aproximación, la afirmación de que la ley de Mahoma es un insulto a Dios; idea con la cual se pretende expresa el rechazo tajante hacia el Islam, afirmando que no existe punto de comparación entre éste y el cristianismo y apelando a esa razón como la principal causa de animadversión hacia ellos. Se le presenta como un argumento religioso contundente, que puede ser fácilmente entendido por el conjunto de la población cristiana ${ }^{551}$. A continuación, la Ley I nuevamente hace referencia al origen bíblico de los musulmanes en el relato de Abraham, Agar y Saray, remarcando que los sarracenos no descienden de Saray sino de Agar y por ende, el nombre que ellos mismos se dan no es correcto, subrayando así el origen bastardo de la etnia ${ }^{552}$. En la misma ley se deja entrever el equilibrio buscado entre el discurso y la realidad práctica, puesto que - pese a las denostaciones - se especifica la manera en que los "moros" que

\footnotetext{
${ }^{549}$ CGE, cap. 755, 979, 998, op. cit., , pp. 449-678.

${ }^{550}$ LSP, Partida VII, Titulo XXV, op. cit., p. 675.

${ }^{551}$ Tolan, John V., Sarracenos... op. cit., pp. 209, 223.

${ }^{552}$ LSP, Partida VII, Titulo XXV, op. cit., p. 675.
} 
viven entre cristianos, pueden vivir su fe y bajo qué garantías, enfatizando el hecho de que no podían hacer manifestación pública de su religiosidad y que se les prohibía poseer mezquitas. En otras palabras, se toleraba su presencia -por razones económicas, como el comercio-, pero no su religión:

"Et decimos que deben vevir los moros entre los cristianos en aquella misma manera que deximos en el titulo ante deste que lo deben facer los judios, guardando su ley et non denostando la nuestra. Pero en las villas de los cristianos non deben haber los moros mezquita, nin facer sacrificios públicamente ante los homes: et las mezquitas que habien antiguamente deben seer del rey, et puédelas él dar a quien quisiere. Et como quier que los moros non tengan buena ley, pero mientras vivieren entre los cristianos en seguranza dellos, non les deben tomar ni robar lo suyo por fuerza; et cualquier que contra esto ficiere mandamos que peche doblado todo lo que les asi tomaren." 553

Especialmente interesante, con respecto a aspectos puramente vinculados con la religión y la forma de vivirla es la Ley II, que describe cómo se debe procurar la conversión de los musulmanes, sugiriendo que debía ser mediante palabras y no la fuerza. El argumento que se presentaba para ello era que si Dios quisiese la conversión de todos los musulmanes Él mismo lo haría, sin embargo, valora más la conversión voluntaria:

"Por buenas palabras et convenibles predicaciones se deben trabajar los cristianos de convertir a los moros para facerles creer la nuestra fe et para aducirlos a ella, et non por fuerza nin por premia; ca si voluntad fuese de nuestro señor Dios de los aducir a ella o de gela facer creer por fuerza, él los apremiare, que ha poder acabado de lo facer; mas el non se paga del servicio que facen los homes amidos, sinon de aquel que lo face de su grado et sin premia ninguna: et pues que el non les quiere apremiar nin forzar, por esto defendemos que ninguno non los apremie nin les faga fuerza ninguna sobre esta razon." 554

Se observa entonces, que existía un marco "tolerancia práctica" hacia el otro, que se demuestra en las disposiciones de la Ley I. Sin embargo, situación cambiaba radicalmente cuando el que se convertía era cristiano, ya que era considerado un acto gravísimo y prohibido, que era descrito por la Ley IV como algo que ocurría a hombres

${ }^{553}$ LSP, Partida VII, Titulo XXV, Ley I, op. cit., pp. 675, 676.
${ }^{554}$ LSP, Partida VII, Titulo XXV, Ley II, op cit., p. 676. 
que "perdían el seso", y que traicionaban la fe de Cristo, y por ello debían ser exiliados y eliminados $^{555}$. Incluso, la Ley $\mathrm{V}$ establece que aquellos cristianos que se convertían al Islam y luego se arrepentían, no podrían reincorporarse a sus comunidades, puesto que habían perdido toda credibilidad y honra ${ }^{556}$. El objetivo de esto era evitar las conversiones y la mezcla racial, en definitiva impedir la contaminación sexual ${ }^{557}$.

En esencia estas leyes -que eran el reflejo de una realidad cotidiana y popular alejada de los discursos cronísticos y religiosos-, si bien permitían cierto grado de coexistencia, no reflejan una mayor intención por comprender a los musulmanes, a quienes les seguía considerando "adversarios". Por esta misma razón se pretendía evitar el mestizaje. El musulmán, como colectivo humano, era el enemigo de la cristiandad, y bajo ninguna circunstancia debía contaminar a los cristianos mezclando su sangre con los cristianos.

${ }_{555}^{55}$ LSP, Partida VII, Titulo XXV, Ley IV, op. cit., pp. 677, 678.

${ }^{556} \mathrm{La}$ legislación sexual alfonsina no era nueva, sino que se basaba en normas previas incluidas en el derecho foral. Al respecto el Fuero de Cuenca demuestra claramente esta situación al condenar a la hoguera a los amantes de distintos credos. Sin importar si el hombre fuese "moro" o judío, tanto él como la mujer cristiana con la que fue sorprendido debían ser quemados vivos (FCc, Cap. XI, $\mathrm{N}^{\circ} 48$, op. cit., p. 116). Una sentencia, que se entiende debía ser pública y por lo tanto, servir de escarmiento para toda la sociedad, de modo que no olvidasen que la mezcla étnica y la "perversión" del alma no sería tolerada. Demás esta decir que esta disposición iba de la mano con una cierta interpretación del rol de la mujer dentro de la sociedad, considerándola como inferior al hombre y con una inclinación natural hacia el pecado, según el ejemplo bíblico de Eva.

La situación era distinta si era un hombre cristiano el que mantuviese relaciones con una "mora". En los fueros consultados este problema sólo se trata en relación a las cautivas musulmanas. Por su condición, ellas eran consideradas bienes y por lo tanto, eran protegidas como tal; sin embargo, en caso de violación, el Fuero de Cuenca específica que la indemnización debe ser para la víctima y no para su dueño. En tanto, si un cristiano engendraba un hijo con una cautiva ajena, el niño debía ser considerado propiedad del dueño de la mora y permanecer como tal hasta que su padre lo redimiese: "23.- El que tenga un hijo con una mora ajena.- Cualquiera que tenga un hijo con una mora ajena, este hijo sea siervo del señor de la mora, hasta que su padre lo redima." (FCc, cap. XI, $\mathrm{n}^{\circ} 22,23$, op. cit., p. 111).

Es notorio el hecho de que en estos casos no se sancione tan duramente la ruptura de la segregación sexual. Quizás esto se debía a la concepción del hombre que se tenía en la sociedad medieval o bien por el hecho de considerarse que los actos cometidos contra una cautiva, no eran tan perjudiciales como la entrega voluntaria de una mujer cristiana a un infiel, lo que bien podía ser una traición a su familia, linaje y religión.

Es en esta misma línea que las leyes procuraban mantener las prácticas religiosas de los musulmanes y judíos, reducidas a su minima expresión. Ya que como hemos dicho con anterioridad, existía el permanente temor de que a través de ellas "contagiaran su error" al pueblo cristiano.

${ }^{557}$ Ejemplos al respecto abundan en las partidas, Ley X penalizaba las relaciones sexuales entre miembros de ambos grupos, castigando con lapidación al "moro" que yaciera con una virgen cristiana, mientras que la mujer perdía la mitad de sus bienes y la totalidad de ellos si reincidía en la misma falta. Penas similares eran aplicadas si la relación se daba con una mujer casada; en este caso, ella podía ser entregada a su marido para que él la castigase como quisiese. Más aún, se prohibía el contacto sexual entre los "moros" y las prostitutas, acto que se castigaba con azotes si era la primera vez, y la muerte si se repetía la falta (LSP, Partida VII, Titulo XXV, Ley V, op. cit., pp. 678, 681). Curiosamente, según se infiere de su ausencia en las leyes, no parece haber habido una prohibición expresa de contacto sexual entre un cristiano y mujeres moras o judías, entendiéndose que existía una tolerancia tácita sobre estas relaciones (Tolan, John V., Sarracenos... op. cit., pp. 224, 225; y Madero, Marta, Manos Violentas, Palabras Vedadas... op. cit., p. 123). Esta distinción se podría deber a las distintas concepciones que se tenían sobre el rol del hombre y la mujer en cuanto a la fecundación y a la transmisión de linajes y herencias. 
Como ya mencionamos, producto de sus políticas de gobierno, en 1264, Alfonso $\mathrm{X}$, debió hacer frente a la rebelión Mudéjar. El saldo de esta rebelión fue la ruptura definitiva de todos los pactos y políticas de convivencia con los "moros", lo que quedó de manifiesto con la expulsión de los mudéjares de Sevilla y Murcia ${ }^{558}$. Sin embargo, es sugerente que Alfonso no exterminó a las poblaciones sublevadas, sino que las expulsó a otros territorios musulmanes. Al respecto, la Crónica de Alfonso $X$ deja un testimonio en relación a los rebeldes mudéjares de Jerez, asentamiento que se había entregado a Castilla bajo un pacto de coexistencia:

"E commo quier que el rey tenía dellos muy gran sanna por lo que finieron, pero [por] la gran guerra que tenía començada con el rey de Granada et con los moros de aquén la mar [et] otrosy que avía nuevas que Jaco[b] Abuyuçaf, rey de Marruecos, se aperçibía para pasar aquén la mar con todo su poder, e por cobrar esta villa ante que aquello fuese, touo por bien de cobrar aquella villa e dexar salir los moros a saluo." 559

Como se aprecia, pese a que los mudéjares eran técnicamente rebeldes y traidores -y por tanto sujetos a las más duras penas-, el rey optó por dejarlos ir como si se tratase de una capitulación tradicional. Si bien en esos momentos Alfonso se veía presionado por las circunstancias, mantuvo la costumbre de concertar una salida pactada en lugar de exterminar a los sublevados. De esta manera, la razón de la benevolencia del monarca no se debía sino a una nueva adaptación a las circunstancias prácticas; ya que el rey deseaba finiquitar pronto el asunto de Jerez para destinar su esfuerzo bélico a la guerra contra Granada, optó por una salida negociada y no arriesgarse a un cerco largo. Al mismo tiempo, la revuelta le sirvió a Alfonso para eliminar a buena parte de los mudéjares y así acceder a sus tierras y recursos económicos, erradicando la potencial amenaza que esta población significaba. Por ello es que no resulta aventurado postular que la revuelta terminó para beneficiar a Alfonso, y quizás incluso se puede inferir que esa había sido su intención desde un principio.

Las imágenes hacia el Islam, trasmitidas por las crónicas, fueron fomentadas durante el reino de Alfonso X y las ideas que apelaban a las nociones religiosas y populares se perpetuaron durante los siglos siguientes, siendo las crónicas herederas de los textos alfonsíes -como por ejemplo la Crónica de Alfonso XI del siglo XIV- en los

\footnotetext{
558 Villacañas Berlanga, José Luis, La Formación de los Reinos Hispánicos... op. cit., pp. 620, 621; y García Fitz, Francisco, Cristianos y Musulmanes en la Península Ibérica ... op. cit., pp. 422, 423.

${ }^{559}$ CAX, cap. XIV, op. cit., p. 38.
} 
cuales se continúa demonizando al musulmán, exaltando su peligrosidad para los cristianos y destacando la relación entre el botín, el cautiverio y destrucción como parte de un mismo fenómeno. Mientras que en las escasas ocasiones en que se les alaba como valientes y grandes guerreros, se tenía como intención glorificar las victorias cristianas ante tan grandes enemigos ${ }^{560}$. De esta manera, durante el reinado de Alfonso X en el siglo XIII quedó establecida una imagen o concepción del musulmán caracterizada por el doble discurso antes referido, o bien por la adaptación entre la teoría y la práctica en la vida fronteriza.

\footnotetext{
${ }^{560}$ Paniagua Lortau, Ana Belén, "Consideraciones sobre la imagen de los musulmanes en la Gran Crónica de Alfonso XI”, en Toro Ceballos, Francisco y José Rodríguez Molina, op. cit., pp. 424-426.
} 


\section{II.3.- La figura del rey y la Reconquista}

\section{II.3.a.- La figura del monarca, orígenes y evolución.}

La figura del rey es una pieza clave en la historia de la Reconquista, pues en ella confluyen las responsabilidades religiosas, políticas y militares de la sociedad medieval. Por ello, antes de estudiar la figura del monarca para el caso particular de Castilla y León, realizaremos una breve reseña de la figura del rey como arquetipo del medioevo.

La figura del rey medieval es el resultado de una construcción basada en la tradición hebraica y cristiana (que a su vez es oriental), la herencia romana, y parte de la tradición germana. Es en esencia una figura de síntesis muy propia del crisol medieval, en la que, no obstante, primó como principal fuente la tradición bíblica veterotestamentaria. Gracias a ello, los pensadores tardo romanos y medievales como Eusebio de Cesarea (ca. 275-339), Juan Crisóstomo (347-407), Ambrosio de Milán (340-397), Agustín de Hipona, Gregorio Magno (590-604) e Isidoro de Sevilla, entre otros, postulaban que el orden político debía ser una emulación del reino de Dios en la tierra, para que así, al ser un régimen justo, se restaurase el estado de gracia perdido por el pecado original ${ }^{561}$.

Esta concepción ideológica, según Manuel García Pelayo, se tradujo en un ordenamiento en el cual se mezclaban los aspectos políticos con los religiosos, de tal manera que la política se sacralizaba y se politizaba la imagen religiosa ${ }^{562}$. Es lo que Ernest Kantorowicz definió como una "persona mixta", en la que el rey junto con sus competencias políticas, poseía ciertas capacidades espirituales ${ }^{563}$. El resultado de esto fue que el rey o el emperador debía ser una imagen de Cristo con todos sus atributos de justicia, valor y piedad.

En la tradición hebrea del Antiguo Testamento, los reyes debían ser líderes, jueces y guerreros victoriosos, todo ello partiendo de la creencia de que el monarca había sido elegido por $\operatorname{Dios}^{564}$ y en parte era un representante de la divinidad ${ }^{565}$.

\footnotetext{
${ }^{561}$ Zamora, Patricio, "El Rey Sagrado, Arquetipo Político-Religioso. Concepción y Representación en las fuentes del poder sagrado de la Edad Media", Intus Legere, N ${ }^{\circ} 4,2001$, [pp. 123-139], pp. 136-138.

562 De Pange, Jean, Le roi très Chretien, Paris, Librairie Arthème Fayard, 1949, pp. 89 y ss; García Pelayo, Manuel, El Reino de Dios, Arquetipo Político, Revista de Occidente, Madrid, 1959, p. 1; y Nieto Soria, José Manuel. "Imágenes religiosas del rey y del poder real en la Castilla del siglo XIII", en La España Medieval, Tomo V, Ed. Universidad Complutense, Madrid, 1986. p. 713.

${ }^{563}$ Kantorowicz, Ernst H., Los dos cuerpos del rey: un estudio de teología política medieval, Madrid, Alianza, 1985, pp. 55, 56.

${ }^{564}$ Patricio Zamora, en su artículo ya citado, caracteriza al antiguo Israel como una Teocracia, puesto que permanentemente se expresa la visión de Yahveh como verdadero soberano, juez y conductor de su pueblo. Él es el que rige sobre toda la creación y de quién emana todo poder y en torno a su creencia es
} 
Por su parte, el principal aporte romano provino desde la fuente del derecho. La tradición romana y clásica en general, indirectamente, dotó a las monarquías de un lenguaje jurídico que ayudó a definir algunas de sus funciones y alcances ${ }^{566}$. El poder real se definió a partir de los principios romanos de autoritas, dignitas y majestad, por lo que éste no era ilimitado; por el contrario, el gobernante debía regirse según estos principios $^{567}$. En forma paralela, con la introducción del cristianismo a la estructura oficial del Imperio en el siglo IV, comenzó el proceso que combinó las ideas cristianas

que se ordenaba la cosmovisión política, jurídica y social del reino. El autor nos recuerda que el mismo Gedeón afirmo: "No seré yo el que reine sobre vosotros ni mi hijo; Yahveh será vuestro rey" (Jueces 8: 23) y que expresiones similares podemos encontrarlas previamente en Éxodo 15: 18 ";Yahveh reinará por siempre jamás!"”, así como también en Números 23: 21, Samuel I, 8: 7, Reyes I, 22: 19 e Isaías 6: 5.

${ }^{565}$ Los hebreos originalmente estuvieron regidos por caudillos tribales, luego a la muerte de Moisés y su sucesor Josué, el poder pasó a manos de los Jueces, que ostentaban el poder político y religioso. A ellos les sucedieron los profetas que lideraron al pueblo como mensajeros de Dios. Recién a fines del siglo XI a.C., y debido a la presión bélica de los filisteos, apareció la figura del rey entre los judíos, materializada en la persona de Saúl. Estos acontecimientos son relatados en el Primer libro de Samuel, donde se pueden observar los principales tópicos relacionados con la tradición monárquica hebraica. Aquí es el pueblo el que le exige al profeta Samuel para que designe un rey: "Tendremos un rey y nosotros seremos también como los demás pueblos: nuestro rey nos juzgara, irá al frente de nosotros y combatirá nuestros combates" (Samuel I, 8: 5).

Samuel entonces ungió a Saúl, lo que apunta hacia una idea de poder descendente, pero también deja claro que el nuevo rey, si bien es sagrado, no es divino, ya que sobre él está Dios ${ }^{565}$. Es así como la unción convertía al rey en una figura protegida por Dios, en un ser señalado y por lo tanto intocable y fuertemente vinculado a la divinidad. Razón por la cual inicialmente se le considero poseedor y representante de los misterios sagrados y por lo tanto síntesis de dos dimensiones de poder: el poder político y espiritual, el rey y sacerdote. Aunque esta ultima manifestación rápidamente se fue limitando a una función más simbólica que efectiva, lo que no significo que no hubiesen conflictos entre los sacerdotes y el poder político, en cuanto a la supremacía entre ambas potestades, los que sabemos que serán un tema frecuente de discusión en la Edad Media (Bloch, Marc, Los reyes taumaturgos, México DF, FCE, 1993, pp. 57-78, 175-177; Kantorowicz, Ernst H., Los dos cuerpos del rey... op. cit., pp. 42 y ss; De Pange, Jean, Le roi très Chretien... op. cit., pp. 98 y ss; y Zamora, Patricio, "El Rey Sagrado... op. cit., p. 133).

El primer acto de validación no religioso de Saul y con ello de la monarquia hebrea, se produjo cuando el rey "invadido por el espíritu de Dios" derrotó a los ammonitas. Gracias a esta victoria, el rey fue aceptado por todos los habitantes de Israel que nuevamente lo aclamaron y ofrecieron sacrificios a Yahveh (Samuel I 11: 12, 15).

Las virtudes reales hebreas fueron sinettizadas en la figura de David: el ungimiento, la victoria y la justicia. De esta manera, el rey se convierte en el garante de su pueblo y en instrumento de Dios. Así lo revelan los Salmos 5 y 72, en que David representa la esencia de la figura del monarca ya que es el delegado de Dios para guiar y proteger y dar justicia a su pueblo (Salmos 72: 1, 4).

${ }^{566}$ Los romanos, en esta materia, al igual que tantas otras, era tributarios del pensamiento político griego. Aristóteles en su Política, capítulos IX al XI, desarrolló el tema de la monarquía, a la cual categoriza, pero no denosta. En cambio el filósofo si menciona que el rey debe ser un hombre justo, sin potestad sobre la vida o muerte, valiente, educado, ser un general para sus tropas y un sacerdote para su pueblo. En categorización Aristóteles distingue la figura del monarca absoluto como único ejemplo deleznable y por el contrario afirma que todo hombre que rija a la comunidad, independiente de su categoría, debe estar sometido a la ley, siendo esta la principal referente y única norma por sobre todo. En otras palabras es la ley, el respeto y aplicación de esta, lo que separaba al rey del tirano.

${ }^{567}$ Le Goff, Jacques, "Rey", en Le Goff, Jacques y Jean-Claude Schmitt, Diccionario razonado del occidente medieval... op. cit., p. 677. 
con la visión imperial romana, combinación que se estableció como referencia para la comprensión del poder en adelante ${ }^{568}$.

Gracias a esta combinación de tradiciones se impuso la idea de que el Imperio no sólo era legítimo, sino que además poseía un origen divino, en virtud de que todo poder y autoridad provenía de Dios. Esto según los Evangelios y las epístolas de San Pablo y San Pedro, en base a la creencia de que en esencia existían dos potestades; el poder de Dios y el de los hombres, estando el segundo siempre subordinado al primero ${ }^{569}$. De esta forma, el poder político era legitimado, aunque solamente en una escala material, sin que se le considerase divino, lo que permitia que este fuese obedecido pero no adorado $^{570}$.

Todo lo anterior se puede resumir en que el cristiano debía servir a ambas potestades; al Dios de los cielos y al soberano terrestre, sin importar cómo obrase este último, pues sus acciones eran un reflejo de la voluntad del Altísimo, y contradecirlas implicaba la condenación del alma ${ }^{571}$. De esta forma, la aplicación del poder real y su funcionamiento no sólo quedaba legitimado, sino también protegido por Dios ${ }^{572}$.

${ }^{568}$ Flori, Jean, La guerra santa... op. cit., p. 33-36; y Fernández Ubiña, José, Cristianos y militares... op. cit., pp. 494-501. Un ejemplo contemporáneo de este proceso de comprensión del poder de acuerdo a los nuevos ideales cristianos lo podemos observar en el pensamiento de San Agustín, presente en algunas de sus obras como la Civitas Dei y Diálogos, en sus apartados dedicados al hombre y la libertad.

${ }^{569}$ En los evangelios si bien no abundan las referencias al poder político en cuanto a sus normas o funciones, si se aprecia la trasmisión de una concepción del poder basado en la existencia de una potestad superior. El episodio mas referenciado es la famosa frase de Cristo "dad al César lo que es del César ya Dios lo que es de Dios" (Mateo, 22: 21) donde la idea de la existencia de las dos potestades es enunciada y luego reforzada en Juan 19: 11.

${ }^{570}$ Una idea que se desprende de la epístola de Pablo a los romanos: "Sométanse todos a las autoridades constituidas, pues no hay autoridad que no provenga de Dios, y las que existen, por Dios han sido constituidas. De modo que, quien se opone a la autoridad, se rebela contra el orden divino, y los rebeldes de atraerán sobre si mismos la condenación. En efecto, los magistrados no son de temer cuando se obra el bien, sino cuando se obra el mal. ¿Quieres no temer a la autoridad? Obra el bien, y obtendrás de ella elogios, pues es para ti un servidor de Dios para el bien. Pero, si obras el mal, teme: pues no en vano lleva espada: pues es un servidor de Dios para hacer justicia y castigar al que obra mal. Por tanto, es preciso someterse, no solo por temor al castigo, sino también en conciencia. Por eso precisamente pagáis los impuestos, porque son funcionarios de Dios, ocupaos asiduamente en ese oficio. Dad a cada cual lo que se debe: a quien impuestos, impuestos: a quien tributo, tributo: quien respeto, respeto: a quien honor, honor." (Romanos 13: 1, 7).

${ }^{571}$ Zamora, Patricio, "El Rey Sagrado... op. cit., pp. 135, 136.

${ }^{572}$ En un sentido más profundo, los pensadores cristianos sostuvieron que el Imperio Romano, incluso en su etapa pagana, fue producto de la voluntad de Dios, ya que al coincidir la era de Augusto con el nacimiento de Cristo, la divinidad creaba un contexto en el cual el mensaje cristiano podía difundirse por todo el orbe conocido. Desde Roma se establecería entonces el reino celestial en la tierra. Por lo demás, si el Imperio era reflejo de la voluntad divina, también lo era el emperador, quien debía guiar a los hombres de acuerdo a los designios de la Providencia. Es más, Dios lo "había elegido" para realizar el Reino en la tierra, lo que lo convertía en un vicario del mismo. Esta fue una interpretación del poder que se consolidó gracias a pensadores cristianos como Eusebio de Cesárea y a los padres de la Iglesia como Juan Crisóstomo y San Ambrosio (García Pelayo, Manuel, El Reino de Dios,...op. cit., pp. 24, 25, 30; y Zamora, Patricio, “El Rey Sagrado... op. cit., pp. 137, 138). 
Los germanos por su parte, también contribuyeron al desarrollo de la imagen regia; en su caso particular gracias a la introducción de la idea del ban, el poder de los caudillos, que luego evolucionó hacia la idea del carisma en la concepción del rey como un nuevo hombre, elegido por y al servicio de la Providencia. En este sentido, se hacía responsable ante ella por sus actos y reconociendo en Dios al legítimo soberano ${ }^{573}$.

En la concepción germana, el rey era el líder de su reino, comprendido éste como el conjunto de su pueblo y no necesariamente como un territorio especifico. Por ello es que era esencial la capacidad del monarca-caudillo de liderar a su comunidad, incluso por sobre otras competencias como serían las vinculadas a la administración de un espacio geográfico ${ }^{574}$. Todo ello acompañado de una reedición de la concepción del soberano como guerrero; un pensamiento que si bien era parte de la tradición romana, fue revitalizado por los germanos y su fuerte tradición militar, que exigía a sus caudillos el destacar por sobre el resto de los combatientes y ser un modelo de valor y coraje ${ }^{575}$. Virtudes y carisma que acabarían por comprenderse como algo trasmisible a través de la sangre, consolidando entre los germanos la idea del linaje como una de las fuentes primarias de validación real ${ }^{576}$.

En esencia, el pensamiento político medieval se basaba en las Escrituras ${ }^{577}$, por lo que fue necesario armonizar la figura de Yhaveh, el juez supremo y a la vez señor de los ejércitos, con la de Cristo, una manifestación de la divinidad de carácter universal y difusor de un mensaje más pacifico e integrador. Es por ello que la política medieval inicialmente fue inseparable del pensamiento eclesiástico ${ }^{578}$.

Luego del colapso del Imperio Romano Occidental, comenzó a definirse la figura del caudillo-rey de acuerdo a los parámetros veterotestamentarios y romanos, que ya hemos mencionado, incorporando la cosmovisión del poder cristiano en detrimento de sus antiguas tradiciones paganas que se basaban en los aspectos guerreros y

\footnotetext{
${ }^{573}$ García Pelayo, Manuel, El Reino de Dios, ...op. cit., pp. 50, 51.

${ }^{574}$ De Pange, Jean, Le roi très Chretien... op. cit., p. 90.

${ }^{575}$ Rodríguez de la Peña, Manuel A., Los Reyes Sabios. Cultura y poder en la Antigüedad Tardía y la Alta Edad Media, Madrid, Actas, 2008, p. 19. Bloch, Marc, Los reyes taumaturgos... op. cit., p. 61.

${ }^{576}$ De Pange, Jean, Le roi très Chretien... op. cit., p. 90; y Zamora, Patricio, "Espejos de lo sagrado: Genealogía y antropología del poder en la monarquía francesa (Siglos VI-IX)”, Intus-Legere, 8, 2005, en http://edadmedia.cl/wordpress/wp-content/uploads/2011/04/ReySagradoIIEspejos.pdf (abril de 2013)

${ }^{577}$ Nieto Soria, José Manuel, Fundamentos Ideológicos del Poder Real en Castilla (Siglos XIII-XVI), Madrid, Eudema, 1988, p. 50.

${ }^{578}$ Ullmann, Walter, Historia del pensamiento político en la Edad Media, Barcelona, Ariel, 2006, p. 16, 23.
} 
carismáticos de sus líderes, lo que conllevó a que vincularan a sus reyes directamente a la divinidad ${ }^{579}$.

La suma de todas estas tradiciones permitió que tempranamente en la Edad Media surgiesen algunas teorías referentes al origen del poder real. La principal de ellas fue introducida a Occidente por Eusebio de Cesarea, y esgrimida por San Agustín, que estaba basada en las ideas de San Pablo. Este último se había inspirado en las palabras de Cristo ante Pilatos, que postulaban un origen descenderte del poder ${ }^{580}$; es decir, que Dios era quien elegía y delegaba parte de su potestad en los reyes para que éstos, ungidos, rigiesen a los hombres en su representación ${ }^{581}$. Esta idea descendente encajaba

${ }^{579}$ Rodríguez de la Peña, Manuel Alejandro, Los reyes sabios... op. cit., pp. 23, 31; y Bloch, Marc, Los reyes taumaturgos... op. cit., pp. 61-65.

${ }^{580}$ Ullmann, Walter, Historia del pensamiento... op. cit., p. 15.

${ }^{581}$ Según el Libro Primero de Samuel, la costumbre de ungir a los reyes de Israel se habría iniciado con el profeta homónimo, que por instrucciones de Yahvé ungió a Saúl como rey de los israelitas, "Tomó Samuel el cuerno de aceite, lo derramó sobre la cabeza de Saúl, y después le besó diciendo: ‘No es Yahvé quien te ha ungido como jefe de su pueblo Israel? Tú regirás al pueblo de Yahvé y le librarás de la mano de los enemigos que le rodean. Y ésta será para ti la señal de que Yahvé te ha ungido como caudillo de su heredad [...]" (Primer libro de Samuel 10.1). Esta cita no solo hace referencia a la elección divina, sino que a la función guerrera de los reyes. No obstante en la tradición medieval, el rey por excelencia fue David, sucesor de Samuel, quien fue electo por Yahvé, ungido por el profeta Samuel y validado frente al pueblo de Israel gracias a su victoria sobre Goliat. Pasados los años se distanció de Dios y pecó, pese a lo cual y gracias a su arrepentimiento fue perdonado por Yahvé. Este conjunto de acontecimientos convirtieron a David en un paradigma a seguir por los reyes medievales y en un recurso discursivo permanente que recordaba los castigos divinos, pero también la misericordia de Dios hacia aquellos que demostraban su arrepentimiento.

Este ritual venía a señalar al soberano como vicario de Cristo y a consagrar la unión entre el poder político y el poder espiritual, aunque también implicaba que el rey como representante de Dios debía servir a los intereses de la Iglesia y respetar sus preceptos (De Pange, Jean, Le roi très Chretien... op. cit., p. 98 y ss, 381, 382; Le Goff, Jacques, "Rey", en Le Goff, Jacques y Jean-Claude Schmitt, Diccionario razonado... op. cit., pp. 678, 679; Ullmann, Walter, Historia del pensamiento... op. cit., pp. 15, 33-79; y García Pelayo, Manuel, El Reino de Dios, op. cit., pp. 101-107). Pero, pese a todos los atributos y privilegios que recibía el ungido, siguiendo la tradición bíblica, éste no se convertía en un personaje sagrado, ni tampoco la unción aseguraba su inviolabilidad, puesto que a diferencia que para el caso de los sacerdotes, ésta no era indeleble, y sólo podía considerarse válida mientras el soberano se comportase como un rey cristiano. (Sobre este tema, Bloch nos recuerda que si bien la práctica de la unción, estuvo bastante difundida, no tuvo un alcance universal y en algunos lugares como Bizancio su introducción fue tardía. De acuerdo al autor el origen de la unción se hunde en las culturas de Mesopotamia y de allí paso a las culturas semíticas y al Mediterráneo. Si bien inicialmente convertía al ungido en un personaje divino, en el mundo medieval el ritual paso a simbolizar la protección de Dios con respecto al soberano, el elegido si bien no era convertido en divino, si quedaba cubierto de la Gracia, lo que significaba que cualquier ataque a su persona era un acto profanatorio que contradecía la voluntad de Dios. Una concepción del poder que finalmente terminaría por incomodar a la Iglesia, puesto que colocaba a los monarcas a la misma altura que las autoridades religiosas, avalando así las pretensiones del poder político sobre la potestad religiosa (Bloch, Marc, Los reyes taumaturgos ... op. cit., pp. 69-78, 184-189). Bajo esta concepción, el rey se transforma en símbolo con dos dimensiones; un cuerpo físico y corruptible y una expresión superior, un "cuerpo místico", sagrado representado por el título y no por la persona (García Pelayo, Manuel, Mitos y símbolos políticos... op. cit., pp. 151, 152; y Kantorowicz, Ernst H., Los dos cuerpos del rey... op. cit., pp. 65-68).

La existencia de estas dos dimensiones significa que la figura del rey estaba legitimada por su título y no por la persona que lo ostentase. Es decir, que independiente de las conductas de un monarca en particular, incluso si fuese una persona nociva, la institución era considerada benigna (Nieto Soria, José 
con la tradición hebraica y el sistema jurídico romano, por lo que no tardó en imponerse y ser aceptada por los germanos, que la adoptaron en el proceso de conformación de sus reinos.

En esencia, en la figura del rey convergen las dimensiones política y religiosasacerdotal -no obstante que el cuerpo político pareció primar sobre el sacerdotal-, lo que contribuyó a dotar al rey de un aura mística, propia de quien es elegido por Dios, ungido y por lo tanto, considerado imagen de $\mathrm{Cristo}^{582}$. De esta forma se estableció, en muchas partes de Europa, lo que podríamos llamar un culto real, que sirvió para unificar los distintos estamentos sociales que componían el reino, agrupándose en torno al rey, que si bien no era un sacerdote, estaba dotado de atributos religiosos que los colocaban por sobre los simples laicos ${ }^{583}$. Así vemos cómo tempranamente la fe y la política conformaron una fuerte alianza mediante la cual la devoción religiosa fue orientada hacia una autoridad única y unificadora. Esta idea, promovida por Eusebio de Cesarea y Paulo Orosio, entre otros, acabó por convertir al rey en un vicario de Dios, un hombre sagrado, pero no divino. Esta idea fue posteriormente perfeccionada por Gregorio Magno, a quien se el atribuye la creación de la teoría del derecho divino de los monarcas $^{584}$.

Así, es posible aventurar que la construcción de la figura del rey en el escenario medieval fue una acción conciente realizada por las elites religiosas que necesitaban un nuevo aliado político poderoso después de la caída del Imperio. No obstante, ésta alianza pareció favorecer una "santificación" de los reyes en los nuevos reinos germánicos -quizás como una forma de asegurarse su alianza-, lo que al sumarse a la tradición propia de estos pueblos terminó por convertir a la monarquía, según José Manuel Nieto Soria, en componente de una estructura simbólico-moral que trascendía las meras funciones políticas-administrativas. En definitiva, el rey se convirtió en una figura representativa de los intereses y necesidades de su colectividad ${ }^{585}$, lo que sólo fue posible gracias la elaboración de un discurso propagandístico y legitimador que asegurase la supremacía del soberano.

\footnotetext{
Manuel, "Imágenes religiosas del rey... op. cit., p. 710). Esta concepción ponía a salvo la figura de la monarquía y aseguraba su continuidad como forma de organización política.

${ }_{582}$ Nieto Soria, Fundamentos Ideológicos ... op. cit., pp. 55-57.

${ }^{583}$ Bertelli, Sergio, op. cit., pp. 10-12; Rodríguez de la Peña, Manuel Alejandro, Los reyes sabios... op. cit., pp. 24, 25; y Bloch, Marc, Los reyes taumaturgos... op. cit., pp. 175, 176, 212.

${ }^{584}$ Zamora, Patricio "El Rey Sagrado..., op. cit., pp. 136-138.

${ }^{585}$ Nieto Soria, José Manuel, "Del rey oculto al rey exhibido: Un síntoma de las trasformaciones políticas en la castilla bajo medieval”, en Medievalismo, 2, 1992, [pp. 5-27], pp. 6,7.
} 
En esencia, bajo esta teoría política, el soberano se consideraba elegido por Dios, cumpliendo el rol de vigilante y protector de una comunidad encomendada a él por el Creador $^{586}$. De esta forma, la monarquía se convirtió en una institución imprescindible para la sociedad, idea que se vio respaldada además, en el mencionado siglo por la introducción de las ideas aristotélicas a Occidente, que postulaban una concepción naturalista del poder monárquico ${ }^{587}$. En vista de ello, a nuestro entender, de forma similar al relato bíblico de Samuel, la institución de un monarca se instituyó como la respuesta natural e instintiva de un colectivo humano necesitado de liderazgo ${ }^{588}$.

Por estas mismas razones, el rey no sólo debía ser justo y piadoso, sino que también un líder militar excepcional. Uno de sus principales deberes era el de mantener la paz y proteger su reino, a la Iglesia y a sus súbditos ${ }^{589}$. En esa misma línea, se encontraba la lucha contra los herejes, que por su rechazo a la Iglesia se consideraban traidores y enemigos políticos del monarca. Así se establecía la última dimensión de la figura del rey: el líder, el "sacerdote", y el guerrero. Esta concepción, que Kantorowicz expresa como "monarquía clerical”, continuó evolucionando durante el medioevo ${ }^{590}$.

En el siglo XIII, con la difusión de los Espejos de Príncipe, en Occidente es posible apreciar la incorporación y consolidación de una serie de otros elementos

\footnotetext{
${ }^{586}$ Recientemente, el Papa Benedicto XVI, se refirió a la esencia del verdadero poder real según el Nuevo Testamento. El Sumo Pontífice afirma en el capítulo II, página 64 de su libro Jesús de Nazaret, que: "El Señor tiene poder en el cielo y en la tierra. Y sólo quien tiene todo ese poder posee el autentico poder, el poder salvador. Sin el cielo, el poder terreno queda siempre ambiguo y frágil. Sólo el poder que se pone bajo el criterio y el juicio del cielo, es decir, de Dios, puede ser un poder para el bien. Y sólo el poder que está bajo la bendición de Dios pude ser digno de confianza." De las palabras de Benedicto XVI se puede concluir que si solo aquel que cuente con la bendición de Dios puede aspira al poder terrenal y que dicha condición obliga a actuar para el bien, tanto de su reino como de la humanidad toda. Lo que demuestra la continuación evolutiva de la alianza entre el poder político y el religioso al interior de la sociedad cristiana.

${ }^{587}$ Para una comprensión sintética del aristotelismo en relación al poder político en la Edad Media aconsejamos revisar el breve pero explicativo apartado que Walter Ullmann dedica al tema, en su texto ya citado, Historia del Pensamiento político en la Edad Media, capítulo VI "Los principios aristotélicos".

${ }^{588}$ Basándonos en lo expresado por Villacañas, podemos afirmar que esta comprensión del poder real se sustentaba sobre un discurso construido por los teólogos y juristas europeos de la época. Ambos oficios se encontraban profundamente ligados dada la comprensión de la justicia como un concepto divino, dotando al rey de todo un aparato legitimador que se mantuvo a lo largo de la Edad Media y que fue expandiéndose paulatinamente desde las esferas señoriales al resto de los concejos y comunidades del reino. (Villacañas Berlanga, José Luís, La Formación de los Reinos Hispánicos, España, Espasa Calpe, 2006, p. 637, 638.)

${ }^{589}$ Kantorowicz, Ernst H., Los dos cuerpos del rey... op. cit., p. 252; Le Goff, Jacques, "Rey” en Le Goff, Schmitt, Diccionario razonado del occidente medieval... op. cit., p. 683; Bloch, Marc, Los reyes taumaturgos... op. cit., p. 74; y Rodríguez de la Peña, Manuel Alejandro, Los reyes sabios... op. cit., p. 58.

${ }^{590}$ Fue que a partir de la Reforma Gregoriana que el Papado terminó por negar la acepción clerical del rey y limitó sus poderes sólo a algunos elementos honoríficos. No obstante esto, la misma Iglesia reconocía que el soberano no era un laico más, y que se encontraba en una posición superior a la del resto de los mortales (Kantorowicz, Ernst H, Los dos cuerpos del rey... op. cit., pp. 55, 56; y Bloch, Marc, Los reyes taumaturgos... op. cit., pp. 183-189)
} 
utilizados para validar a los monarcas y que complementaban sus roles de juez y guerrero $^{591}$. En ellos se enumeran una serie de virtudes y vicios que el rey debía poseer y evitar en el correcto ejercicio de su oficio. La primera de las virtudes deseadas era la piedad, seguida del temor de Dios, al igual que la prudencia, la justicia y el valor. En definitiva, el buen monarca era aquel que poseía una serie de virtudes opuestas a una lista similar de vicios ${ }^{592}$.

De acuerdo a lo expuesto, podemos inferir que la construcción de la figura del rey durante los siglos medievales fue producto de la necesidad de crear la figura de un líder que rigiera con éxito las nuevas comunidades que se asentaban en Europa. En tanto que la Iglesia, consciente de aquello, en forma paralela al proceso de evangelización de los germanos, sentó las bases para la institucionalidad de la monarquía basándose en diversas tradiciones del mundo antiguo y germano. De acuerdo a esta noción, se consideraba que nada era más poderoso que la voluntad divina, por lo que nadie podía ser superior a quien la Providencia había elegido como líder de su comunidad; un liderazgo que la Iglesia se encargaba de legitimar a través de la unción y coronación del elegido. Esta fue una tradición que se consolidó durante el medioevo, y que resultó

${ }^{591}$ En su libro sobre los Reyes Sabios, Rodríguez de la Peña, afirma que desde el mundo antiguo se identifican distintas virtudes propias de aquellos que ostentasen el poder político, entre las cuales el autor destaca la Sapiencia, comprendida como un amor a la sabiduría, posteriormente combinada con la concepción cristiana de la "búsqueda de la Verdad iluminada por la Fe". El autor califica esta sapiencia en distintas categorías, en forma paralela que relata los distintas manifestaciones del poder real, según sus tipos (Realeza sacerdotal, Realeza triunfal, rey guerrero, rey sacerdote, etc) (Ver Rodríguez de la Peña, Los reyes sabios... op. cit., Introducción) Aceptando los postulados de Rodríguez, nosotros no profundizaremos en el problema de los reyes sabios, limitándonos a desarrollar las características más políticas y discursivas del poder real y comprendiendo el concepto de sabiduría como una virtud moral determinada por las ideas cristinas de rectitud y justicia.

${ }^{592}$ Nogales Rincón, David, "Los espejos de príncipe en Castilla (Siglos XIII-XV): Un modelo literario de la realeza bajo medieval”, en Medievalismo 16, 2006, [pp. 9-39] pp. 21-37, 38.

Pese a que la institución monárquica fue comúnmente aceptada en Europa, no debemos olvidar que en algunos territorios como Francia, Inglaterra y el Sacro Imperio, el rey se encontró muchas veces limitado por el sistema feudal, quedando sujeto a la voluntad de los señores locales. Comúnmente eran éstos quienes ostentaban el verdadero poder, ya que concentraban la posesión de las tierras, lo que limitaba la acción real al papel de aglutinante y mediador entre los poderes señoriales.

En torno a los siglos XII y XIII, es posible apreciar un fortalecimiento de la figura del monarca, ya no tanto por su función simbólica, sino por la construcción de instituciones tendientes a consolidar su poder político por sobre el sistema feudal y vasallático. Una de estas instituciones, aunque de orígenes anteriores, fue la Corte, comprendida como el conjunto de personas directamente ligadas al monarca para la administración del reino y de sus rentas.

Fue así como el fortalecimiento del poder real ocurrió de forma paralela al desgaste del sistema feudal, situación que fue favorecida por la Iglesia cuando aumentó su respaldo a la monarquía y a la idea del rey vinculado a la voluntad de Dios. De esta forma, para el pontificado fue más fácil tratar con el soberano que con un conjunto de señores (ref. Ver Jose-Luis Martin, sobre el origen de las Cortes). A esta situación también se debe agregar el factor burgués, la nueva clase social urbana que respaldó económicamente al rey a cambio de su protección contra los abusos señoriales. 
imprescindible para lograr la creación de dinastías monárquicas o instituciones imperiales, como la carolingia o la del Sacro Imperio.

\section{II.3.b.- El caso hispano, los monarcas visigodos}

A partir del 711, con la invasión islámica a la Península, se incorporaron otros elementos de validación real, propios del cristianismo peninsular, manteniéndose también algunos de los elementos de la tradición europea y visigoda ${ }^{593}$. Es para entender esto que se hace necesario referirse brevemente a algunas de las características de la monarquía visigoda, en especial en su relación con la religión.

Con anterioridad nos referimos al papel de Isidoro de Sevilla como creador de una identidad goda a través de sus obras, en especial Historia Gothorum, Vandalorum et Suevorum, donde relata los orígenes míticos de los godos y sus victorias sobre Roma. En ellas además se explaya sobre la idea de una unidad hispana gracias a una suerte de "proto nacionalismo" godo ${ }^{594}$. Sin duda, las ideas isidorianas se encuentran

${ }^{593}$ En el caso de Castilla y León se mantuvieron los sistemas de relación con los poderes eclesiásticos locales. Esta era una forma de interactuar que encontraba sus raíces en el antiguo Reino Visigodo, y que según Nieto Soria, puede sintetizarse como la aceptación de la Iglesia de la concepción corporativa de poder real; la función protectora del rey respecto a la Iglesia de su reino; la legitimación ideológica recíproca entre monarquía e Iglesia, y en algunos casos, el reconocimiento de una cierta dimensión sacerdotal en la figura del monarca (Nieto Soria, José Manuel, Fundamentos Ideológicos... op. cit., p. 198). En esencia, los poderes reales y espirituales debían respaldarse mutuamente, como parte de un sistema integrado, sobre el cual se estructuraba la sociedad completa.

${ }^{594}$ A partir de estas ideas, creemos necesario referirnos a algunos conceptos que consideramos esenciales para ilustrar nuestro análisis. Nos referimos a las concepciones de patria, frontera, territorio y unidad, que por estar estrechamente relacionados, los presentaremos en forma combinada.

Sobre el uso de la palabra patria, consideramos necesario explicarla a partir de una comprensión general del concepto para el medioevo europeo. Entendemos el concepto de patria, según la acepción dada por Ariel Guiance en su articulo "Morir por la patria o morir por la fe", basadas en las definiciones de Ernest Kantorowicz, para quien el concepto de Patria en la Edad Media tenía distintos significados: 1.como invocación al Paraíso, la patria celestial común a todos los cristianos 2.- el lugar natal 3.- la comunidad mayor de la que se es originario. Esta última acepción había perdido el contenido emocional que tenía en la antigüedad y para mediados de la edad media, todavía ese sentimiento no se identificaba con un territorio o estado nacional. Fue en el S.XII, en Francia, que el concepto patria evolucionó y se ligó con la idea de guerra santa pero secularizada, ya no como defensa de la Fe sino que como defensa del reino. Se traslada la noción de "morir por la patria celeste a la de morir por la patria terrestre" (Guiance, Ariel, "Morir por la patria, morir por la fe: La ideología de la muerte en la Historia de Rebus Hispaniae", en Cuadernos de Historia de España, LXXIII, 1991, [pp. 75-104], pp. 91, 92).

En la misma línea se encuentra la caracterización del concepto de nación medieval que elabora Suárez Fernández, que afirma que el término es de uso impreciso y que se vinculaba al origen o lugar de nacimiento y a los derechos y obligaciones que emanaban de dicha realidad. Un aspecto que la monarquía solía respetar, pero dividiendo a quienes gobernaba entre naturales y súbditos. Siendo los primeros los nacidos en el reino, pero que no gozaban de todos los derechos y deberes, como era el caso de musulmanes y judíos en Hispania. En tanto que los súbditos eran aquellos, que incluso habiendo nacido en otro lugar, se encontraban reconocidos íntegramente por el monarca, debiendo honrar las obligaciones 
que ello implicaba (Suárez Fernández, Luis, "Los fundamentos medievales de la nación española" en Benito Ruano, Eloy (Coordinador), Tópicos y realidades de la Edad Media, Volumen III, Madrid, Real Academia de la Historia, 2000-2002, p. 121).

Con respecto a la frontera hispano medieval, por ser un tema bastante estudiado, nosotros solo esbozaremos el concepto en función de su relación con la idea de unidad y territorio.

Frontera y límite son dos conceptos sumamente asociados y para el caso son usados como sinónimos. Sin embargo sabemos que etimológicamente tienen significados diferentes, puesto que mientras límite procede del concepto latino Limes, entendido como la división entre dos lugares, el concepto de Frontera, fronte, hace referencia a la división y enfrentamiento. Básicamente, en su acepción mas simple, la frontera se trata de una: "Línea real o imaginaria que separa dos terrenos, dos países, dos territorios" (RAE, http://buscon.rae.es/drael/SrvltConsulta?TIPO_BUS=3\&LEMA=frontera, 16-3-2012). En esencia es se trata de la necesidad de separar dos grupos humanos que se consideran distintos debido a su historia, cultura, etnia o intereses. En el mundo hispano medieval todos estos elementos eran considerados, pero además se agregaba la particularidad de que se asumían que este limite no era estático, sino que flexible, dinámico y además permeable.

Esta manera de entender el limite, fue un cambio radical en cuanto a su concepción original romana, el limes. Durante el Imperio romano, la frontera era una barrera fija, estable y fortificada, incluso amurallada, como en Inglaterra, fuertemente controlada y supervisada, que en la mentalidad latina, separaba al mundo civilizado de la barbarie y los enemigos. No obstante esto no implicaba una separación total, puesto que los romanos se cuidaron de no convertir el limes en una barrera infranqueable, siendo comunes los contactos y los intercambios con aquellos ubicados fuera de el (Le Goff, Jacques, "Centro/Periferia", en Le Goff, Jacques y Jean-Claude Scmitt (Editores), Diccionario razonado del Occidente medieval, Madrid, Akal, 2003, p. 150; y Gozalbes Cravioto, Enrique, "Reflexiones sobre el concepto Antiguo y Medieval de Frontera", en Toro Ceballos, Francisco y José Rodríguez Molina (Coordinadores), III Estudios de Frontera. Convivencia, Defensa y Comunicación en la Frontera, Jaén, Diputación Provincial de Jaén, 2002, pp. 362-363) Los visigodos, en parte heredaron esta concepción de frontera en relación a los territorios norteños a manos de cantabros y vascones. El Reino de Toledo, erigió una línea de atalayas y barreras para separar esos territorios, al mismo tiempo que no renunciaba a su conquista. En ambos casos, el romano y el visigodo, la línea de demarcación, también traía implícita una concepción de quién estaba del otro lado, el bárbaro, el hostes, el primitivo. Existía, por tanto, la necesidad de separase de ese colectivo atrasado, que nada podía aportar a la propia cultura, pero no obstante se ambicionaban sus recursos. Esta concepción es la que veremos cambiar en la Hispania de la Reconquista. Allí, como ya dijimos, el concepto termino por mutar a una caracterización marcada por la permeabilidad y la movilidad. El límite ya no era una línea clara y fortificada, más bien era un amplio espacio salpicado de castillos y aldeas, donde la división estaba presente a través de las diferencias religiosas y culturales, pero pese a lo cual existía un nutrido intercambio ente ambos bandos, el cual se veía alterado por los sucesivos periodos de guerra y paz (Cipollone, Giulio. "Esclavitud y Liberación en la Frontera", en Toro Ceballos, Francisco y José Rodríguez Molina (Coordinadores), Estudios de Frontera Alcalá La Real y el Arcipreste de Hita... op. cit., pp. 59, 72 a 75; De la Montaña Conchiña, Juan Luis, "Frontera y Sociedad en la Transtierra Extremeña (siglos XII-XIII)", ibid, p. 135; y Palacios Martín, Bonifacio, "Las Milicias de Extremadura y la Conquista de Andalucía", en Cabrera, Emilio, Andalucía entre Oriente y Occidente... op. cit., p. 81).

En general en Europa medieval, la frontera fue percibida como un espacio amplio, difuso y poco limitado. Incluso cuando campeaban las ideas radicales de división cultural, como fueron las cruzadas incluida Hispania - la frontera era vista como un punto de contacto e intercambio, por donde se filtraban las influencias culturales. En el caso peninsular, en palabras de Milouda Charouiti Hasnaoui, la frontera fue "puente más que barrera" esto en razón, que pese a la frecuente actividad bélica rara vez se rompió el contacto comercial y económico entre ambos bandos (Charouiti Hasnaoui, Milouda, "El Dualismo conceptual de la frontera legendaria e histórica en las fuentes árabes" en Toro Ceballos, Francisco. José Rodríguez Molina. (Coordinadores), IV Estudios de Frontera. Historia, Tradiciones y leyendas en la Frontera. Jaén, Diputación Provincial de Jaén, 2003, p. 131, Mackay, Angus, La España de la Edad Media... op. cit., p. 92).

Junto a lo anterior debemos considerar que no existía una frontera, sino que múltiples, partiendo por el hecho de que cada reino cristiano tenía sus propios límites y que además esos límites eran difíciles de imponer a los demás reinos y a los mismos súbditos de cada monarca. En ese sentido, si bien es cierto que existían verdaderas redes cástrales fronterizas, estas no constituían una muralla infranqueable, más bien era un conjunto de hitos, entre los cuales circulaban los productos y gran variedad de tipos humanos, que lo hacían a través de caminos conocidos (Rodríguez Molina, José "Alcalá la Real. Comunicación, Defensa y Convivencia en la Frontera", en Toro Ceballos, Francisco y José Rodríguez Molina 
profundamente ligadas a un sentimiento de religiosidad, ya que para el santo sevillano el pueblo de los visigodos había obtenido todos sus triunfos gracias a la ayuda de Dios, quien legitimaba sus actos. Lo anterior permitió que Isidoro postulase la existencia de una unidad política, religiosa y territorial del Reino Visigodo -fuertemente ligado a un espacio geográfico favorecido, el que además se presenta como una entidad fuerte, unida, dueña de su territorio y gloriosa ${ }^{595}$.

Por lo demás, las conclusiones isidorianas están presenten en distintos textos contemporáneos, que postulan la presencia de la Providencia en cada uno de los principales episodios de la historia visigoda, como por ejemplo en sus victorias sobre Roma, sobre los Hunos y sobre los Vándalos. Es importante destacar que estos triunfos se lograron durante el periodo en que los visigodos eran arrianos, y por tanto heréticos, asunto que Isidoro solucionó apelando a la existencia de una suerte de Virtus goda, que exaltaba su esfuerzo, valor, capacidades militares y piedad, atributos nobles que eran del agrado de Dios ${ }^{596}$. En este contexto los postulados isidorianos, aunque no llegan al punto de convertir a los visigodos en un nuevo Israel, sí lo consideró un pueblo elegido por Dios, quien los condujo, protegió y premió con la nueva tierra prometida: Hispania. De esta forma, según esta línea de pensamiento, la conversión de Recaredo fue la conclusión de un proceso y el sello definitivo de una alianza ente los monarcas visigodos y $\operatorname{Dios}^{597}$.

(Coordinadores), III Estudios de Frontera. Convivencia, Defensa y Comunicación en la Frontera. op. cit., p. 587; y Rodríguez Molina, José, "La Frontera de Granada, siglos XIII-XV", ibid., p. 514). No obstante lo anterior, a partir del siglo XIII, los cronistas hispanos, utilizaron con más frecuencia la expresión "España" - que a su vez proviene del antiguo nombre dado por los romanos al territorio - para referirse a la Península Ibérica, lo que según Julio Valdeón, habría tenido la intención de identificar un concepto de unidad para los habitantes peninsulares, dándoles un referente para un pasado perdido o bien como una expiativa de un futuro identitario (Valdeón Baruque, Julio, La Reconquista. El concepto de España: unidad y diversidad, Madrid, Espasa, 2006, p. 13).

En esencia la frontera hispana y por lo tanto la castellana leonesa, no era, ni pretendía ser una especie de muralla China, destinada a evitar entradas y salidas, simplemente era un hito que señalaba donde comenzaba la zona de influencia de los cristianos y donde terminaba la de los andalusíes, sin que por ello se pretendiese separar totalmente ambas sociedades. Algo que en la práctica era imposible, puesto que la frontera surgió de forma paralela a la conformación de ambos grupos humanos

${ }^{595}$ Sevilla, Isidoro de, Las historias de los godos vandalos y suevos, Estudio, edición crítica y traducción de Cristobal Rodriguez Alonso, León, Centro de Estudios e investigación "San Isidoro", 1975, pp. 61-63 (En adelante HGVS); y Sánchez Salor, Eustaquio, "El Providencialismo en la Historiografía CristianoVisigótica en España", en Anuario de Estudios Filológicos V, 1982, [pp. 179-192], p. 184.

596 Bronisch, Alexander Pierre, Reconquista y guerra santa... op. cit., pp. 79, 81; Sánchez Salor, Eustaquio, "El Providencialismo en la... op. cit., p. 192; y Mitre Fernández, Emilio. Historiografia y mentalidades... op. cit., p. 59, 60.

${ }^{597}$ Las relaciones formales entre los monarcas y la Iglesia de Roma se iniciaron oficialmente con la conversión de Recaredo en el año 586 durante el III Concilio de Toledo. A partir de ese momento, las relaciones entre la monarquía y la Iglesia cambiaron, puesto que ello significaba el reconocimiento de la autoridad del Papa. Esto llevaría a Hispania a ingresar a la dinámica doctrinal de las "dos espadas" (Rodríguez de la Peña, Manuel Alejandro, Los reyes sabios... op. cit., pp. 245, 246). 
El hecho es destacado por diferentes testimonios que resaltan la idea de que el reino entraba en una etapa de comunión con la Iglesia Católica llevada a cabo por un rey virtuoso y piadoso que demostraba poseer la Gracia a través de la fortuna evidente en sus actos y las victorias contra sus enemigos; a diferencia de sus antecesores, y en especial de su padre Leovigildo, a quien algunos cronistas han caracterizado como impío y violento. De esta forma, queda clara la relación entre la sumisión a la Iglesia y la imagen del poder político investido de una nueva virtud; la piedad, característica de los soberanos de la Reconquista ${ }^{598}$.

Los testimonios del III Concilio de Toledo, en boca de Recaredo (586-601), resaltan aún más el elemento religioso en relación al rechazo del arrianismo y a la “comunión" con Roma y la verdadera fe:

"Por lo mismo, santísimos Padres, ofrezco al eterno Dios, por vuestra mano, como un santo y expiatorio sacrificio, a estos nobilísimos pueblos, que por nuestra diligencia se han ganado para el Señor, pues será para mí una inmarcesible corona y gozo en la retribución de los justos, si estos pueblos que por nuestros ciudadanos corrieron a la unidad de la Iglesia, permanecen firmes y constantes en la misma. Y así como disposición divina nos fue dado a nosotros traer estos pueblos a la unidad de la Iglesia de Cristo, del mismo modo os toca a vosotros instruirlos en los dogmas católicos, para que instruidos totalmente con el conocimiento de la verdad, sepan rechazar acertadamente el error de la perniciosa herejía y conservar por la caridad en camino de la verdadera fe, abrazando con deseo cada día más ardientemente la comunión de la Iglesia católica."

Es decir, el acto de Recaredo selló la alianza entre los visigodos y la divinidad, culminando el proceso que llevó a este pueblo a ser, según Isidoro, bendecido por

\footnotetext{
598 “Aera DCXXIIII, anno III imperio Maurici, Leunigildo defuncto filius eius Recaredus regno est coronatus, cultu praeditus religiones et paternis moribus longe dissimilis: namque ille inrreligiosus et bello promptissimus, hic fide pius et pace praeclarus, ille armorum artibus gentis imperium dilatans, hic gloriosus eandem gentem fidei trophaeo sublimans. In ipsis enim regni sui exordios catholicam fidem adeptus totius Gothicae gentis populos inoliti errores labe deterja ad cultum rectae fidei reuocat." HGVS, $\mathrm{N}^{\circ}$ 52, op. cit., p. 260. "En la era DCXXIIII, en el año tercero del imperio de Mauricio, muerto Leovigildo, fue coronado rey su hijo Recaredo. Estaba dotado de un gran respeto a la religión y era muy distinto de su padre en costumbres, pues el padre era irreligioso y muy inclinado a la guerra; él era piadoso por la fe y preclaro por la paz; aquél dilataba el imperio de su nación con el empleo de las armas, éste iba a engrandecerlo más gloriosamente con el trofeo de la fe. Desde el comienzo mismo de su reinado, Recaredo se convirtió, en efecto, a la fe católica y llevó al culto de la verdadera fe a toda la nación gótica, borrando asi la mancha de un error enraizado.” HGVS, $\mathrm{N}^{\circ}$ 52, ibid., p. 261.

599 "Concilio de Toledo III", en Concilios visigóticos e hispanoromanos, ed. J. Vives, C.S.I.C., Barcelona Madrid, 1963, pp. 110-111, extraído de Mitre Fernández, Emilio, Iglesia y vida religiosa en la Edad Media, Madrid, Istmo, pp. 84, 85.
} 
$\operatorname{Dios}^{600}$. No obstante, luego de la conversión de Recaredo, los lazos entre la Península y Roma no se estrecharon significativamente, y la Iglesia Visigoda mantuvo gran parte de la independencia que la había caracterizado. Esto se puede explicar entre otras razones, debido a que a partir del 587, la monarquía se convirtió en garante de la ortodoxia católica y protectora de la Iglesia romana, incorporando a la alta jerarquía eclesiástica a la estructura política y administrativa del reino ${ }^{601}$.

Recaredo y sus sucesores sabían la importancia de tutelar o al menos influenciar a la Iglesia, ya que era pieza fundamental para la administración del reino, para lograr el control social y por sobre todo, para validar el poder político. Por ello no es de extrañar que los monarcas no quisiesen renunciar al control que tenían sobre la institución, por lo que procuraron controlar las influencias foráneas sobre la Iglesia local, temiendo que fuesen una amenaza para sus intereses y de paso, rompieran la ya tradicional autonomía de la corona visigoda ${ }^{602}$.

En esencia, la monarquía se alió con la Iglesia Católica peninsular y no directamente con el Papado, con el cual mantuvo un flujo de relaciones similar al que había tenido en el período anterior.

A partir de lo anterior, veamos algunos de estos planteamientos expresados en la obra isidoriana sobre la comprensión del poder y la religión en el Reino Visigodo y que continuaron manifestándose en la producción cronística y jurídica posterior. Sobre el territorio de la Península Ibérica y su posesión por parte de los godos, el sevillano destaca que fue fruto de la victoria sobre los romanos, y una justa recompensa por el esfuerzo realizado por los germanos:

"Iure itaque te iam pridem aurea Roma caput gentium concupiuit et liceo te sibimet eadem Romuela uirtus primun uictrix desponderit, denuo tamen Gothorum florentissima gens post multiplices in orbe uictorias certatim rapit et amauit,

\footnotetext{
600 Durante el período arriano no se aprecia una ruptura con Roma, pero sí un distanciamiento interrumpido por esporádicos, pero cordiales contactos. El clero arriano reconocía al pontífice como al sucesor de Pedro y por lo tanto, lo consideraba una autoridad legítima a la cual dirigir sus dudas y consultas sobre aspectos de fe, sin que esto implicase un sometimiento de la Iglesia visigótica arriana a la potestad papal.

${ }^{601}$ Mitre Fernández, Emilio, Iglesia, herejía y vida politica en la Europa Medieval, Madrid, Biblioteca de Autores Cristianos, 2007, pp. 40, 41; Bronisch, Alexander Pierre, Reconquista y guerra santa... op. cit., p. 64, 70; y Linehan, Peter, Historia e historiadores ... op. cit., pp. 56, 57.

${ }^{602}$ En el marco doméstico, el cambio de doctrina implicó la erradicación del arrianismo, así como un mayor celo para acabar con los cultos paganos que aún subsistían. Con respecto a los judíos, que hasta el momento habían sido bien tolerados, se les aumentaron las restricciones y las medidas de control, en parte coartando los espacios de libertad que hasta el momento habían tenido.
} 


$$
\begin{aligned}
& \text { fruiturque hactenus inter regias infulas et opes largas imperri felicitate } \\
& \text { securas. }{ }^{603}
\end{aligned}
$$

Respecto a la devoción de los godos, Isidoro también destaca sus virtudes cristianas, incluso cuando todavía profesaban el arrianismo, por haber respetado los lugares sagrados durante el saqueo de Roma. De esta forma, el santo demuestra que el pueblo godo, pese a sus prácticas heréticas, poseía una serie de virtudes como la piedad, la compasión y el temor a Dios, características que justificaban que la Providencia los bendijese con la victoria sobre los romano-cristianos:

"Post hoc igitur uotum adgressi urbem ómnibus et mors et captiuitas indulta est, qui ad sanctorum limina confugerunt. Sed et qui extra loca martyrum erant et nomen Chisti et sanctorum nominauerunt, et ipsis simili misericordia pepercerunt."

A partir del abandono del arrianismo por parte de los visigodos, Isidoro introdujo la idea -cada vez más frecuente en la teoría política medieval- de que el poder real provenía directamente de Dios, y que por tanto el rey estaba obligado a actuar bajo un profundo sentido de justicia, defendiendo a sus súbditos y a la Iglesia ${ }^{605}$.

En sus sentencias, Isidoro, resalta el concepto del rey como figura moral regida por la idea de una justicia basada en un orden providencial. En forma conjunta, el rey siempre debía reconocer su sometimiento a la Providencia y hacia sus representantes, sirviendo como su garante y poniendo su poder a su servicio ${ }^{606}$.

\footnotetext{
${ }^{603}$ HGVS, op. cit., pp. 170. "Y por ello, con razón, hace tiempo que la áurea Roma, cabeza de las gentes, te desé y, aunque el mismo Poder Romano, primero vencedor, te haya poseido, sin embargo, al fin, la floreciente nación de los godos, después de innumerables victorias en todo el orbe, con empeño te conquistó y te amó y hasta ahora te goza segura entre ínfulas regias y copiosísimos tesoros en seguridad y felicidad de imperio." HGVS, op. cit., p. 171.

${ }^{604}$ HGVS, op. cit., p. 194. "Y así, después de esta promesa, cuando atacaron la ciudad, concedieron el indulto de la muerte y del cautiverio a todos los que se refugiaron en los lugares sagrados, y también perdonaron con igual misericordia a los que se hallaban fuera de los templos martiriales y pronunciaron el nombre de Cristo o los santos." HGVS, N 15, op. cit., p. 195.

605 "[...] el justo Dios, sin embargo, diferenció la vida en los hombres instituyendo a los unos siervos, a los otros señores, con el fin de que la licencia para obrar mal de los siervos sea reprimida con el poder de los que dominan. Porque si todos estuviesen sin miedo, ¿quién sería al que otro prohibiera obrar mal? De ahí que aún los gentiles han elegido reyes y príncipes para que contuviesen de lo malo por terror a sus pueblos y con leyes los sometiesen a bien vivir." Isidoro de Sevillas, Sentencias, 1035, en Marín R., José, Textos históricos: desde el Imperio Romano hasta el siglo VIII, Santiago de Chile, Ril, 2003, p. 177. 606 “(1065) Los príncipes seculares algunas veces conservan dentro de la Iglesia los honores de la potestad recibida, a fin de que por la misma defiendan la disciplina eclesiástica. Por lo demás, dentro de la Iglesia son innecesarias tales potestades, si no es para que impongan con el terror de la disciplina lo que el obispo no puede lograr por medio de la enseñanza y el discurso.
} 
Esencialmente, para Isidoro, el soberano debía ser un reflejo de Dios y actuar movido por el temor a Él, venciendo su propia inclinación al mal y anteponiendo el bien; de lo contrario podría atraer sobre él y su pueblo el castigo de Dios, de la misma manera que un mal rey podía ser un instrumento de la Providencia para escarmentar a un pueblo pecador ${ }^{607}$. De esta forma, Dios era el verdadero garante y regulador de todo el sistema político; una idea que continuaría evolucionando y a la que nos seguiremos refiriendo más adelante.

Asimismo, existieron razones históricas que explican la conformación de las ideas de unidad hispana expresadas por Isidoro, y que son sintetizadas por José Antonio Maravall $^{608}$. Con el arribo de los visigodos a la Península, estos se mezclaron, en un largo proceso, con los hispano-romanos, con quienes compartían creencias y costumbre adoptadas de Roma. Durante esta etapa, los recién llegados derrotaron a los suevos, repelieron a los bizantinos y finalmente adoptaron el catolicismo romano, abandonando su arrianismo original (siglo VI). Todo ello realizado por grandes personajes de la Iglesia visigoda, que reunidos en sínodos y concilios en la ciudad de Toledo dieron forma a un importante sentimiento de unidad basado en el liderazgo guerrero de los reyes -vestigio de su pasado germano-, en la fe en común y en su herencia germánica. Todo esto contribuyó a crear una figura monárquica fuerte sobre la cual se ordenara la sociedad $^{609}$.

(1066) A las veces el reino de los cielos adelanta por medio del reino de la tierra, como cuando los que están colocados dentro de la Iglesia maquinan contra la fe y la disciplina de la misma, para que sean desbaratados por el rigor de los príncipes: y la misma disciplina eclesiástica que por la humildad de la Iglesia no pueda ejercitarse, sea impuesta a las orgullosas cervices por la potestad de los príncipes; y para que merezca veneración, la da en fuerza de la potestad.

(1067) Sepan los príncipes seculares que han de dar a Dios cuenta de la Iglesia, que reciben de Cristo en encomienda para defenderla. Pues ora se aumente la paz y la disciplina de la Iglesia por los príncipes fieles, ora se pierda, Cristo les pedirá cuenta y El es quien entregó su Iglesia al poder de ellos." Isidoro de Sevillas, Sentencias, 1065, 1066, 1067, en Marín R., José, Textos históricos ... op. cit., p. 177.

${ }^{607}$ Bronisch, Alexander Pierre, "En Busca de la Guerra Santa”, en Baloup, Daniel y Philippe Josserand (Editores), Regards Croisés... op. cit., p. 98; y Maravall, José Antonio, Estudios de Historia... op. cit., p. 38.

${ }^{608}$ Maravall, José Antonio, El concepto de España...op. cit., pp. 22-35.

${ }^{609}$ Isla, Amancio, Ejército, Sociedad y Política en la Península Ibérica entre los siglos VII y XI, CSIC, Madrid, 2010, p. 219; Godoy, Cristina y Josep Vilella, "De la Fides Ghotica a la Ortodoxia Nicena: Inicio de la Teología Política Visigótica", en González Blanco, Antonio, Antigüedad y Cristianismo, Monografias históricas sobre la Antigüedad Tardía: Los Visigodos, Historia y Civilización, Actas de la Semana Internacional de Estudios Visigóticos, Madrid-Toledo-Alcalá de Henares, 1986, p. 124; y Maravall, José Antonio, El concepto de España... op. cit., p. 198.

Sobre este punto, nos parece prudente remitirnos a la observaciones de Linehan, en cuanto que la alianza entre la Iglesia y los Visigodos, luego de la conversión de Recaredo, no construyó una estructura totalmente sólida, lo que en parte explicaría algunos de los problemas internos del reino y las trasformaciones que experimento la Iglesia luego del colapso del reino a partir del 711 (Linehan, Peter, Historia e historiadores ... op. cit., pp. 58, 59, 73). 
Es posible afirmar entonces, que Isidoro fue consciente de esta realidad, por lo que elaboró un discurso unitario que se impusiese sobre los distintos factores que dividían el reino. Esta construcción es un tema casi permanente en la obra isidoriana, y que podemos apreciar, entre otros textos, en su ya referida obra Etimologías. Es importante destacar que todo ello fue puesto en práctica a través de los Concilios provinciales, mediante los cuales la Iglesia mantuvo una permanente influencia sobre el Reino Visigodo, a la vez que la participación de la nobleza laica en ellos aseguraba el respaldo y colaboración del poder político ${ }^{610}$.

A nuestro juicio, Isidoro llevó a su máxima expresión la idea de la unidad hispánica ligada a la grandeza de los godos, en que la legitimidad de los monarcas y de su pueblo, fueron inseparables de la creencia en Dios y en el favor que se creía que Éste otorgaba a la comunidad.

Esta relación entre los monarcas y la divinidad se manifestaba a través del rito de la unción al que éstos eran sometidos ${ }^{611}$. Debemos recordar que los visigodos establecieron un sistema monárquico basado en la costumbre germana de la elección de los reyes, la cual era realizada por los magnates del reino ${ }^{612}$. Por ello fue esencial que el elegido fuese ungido por la Iglesia y luego aclamado para lograr su validación. Pero este sistema no funcionó del todo, ya que la unción no consiguió la inmunidad de los soberanos, ni logró asegurar la transmisión ordenada y pacífica del poder. Mientras existió el Reino Visigodo Católico de Toledo, no fue extraña la deposición o asesinato del rey de turno, así como la existencia de varias revueltas contra el soberano, en las que en no pocas ocasiones participaron miembros del alto clero visigodo ${ }^{613}$. Esto deja claro que la tradición bíblica de la inviolabilidad del cuerpo místico del rey no era impedimento para las ambiciones de sus adversarios. Por su parte, el juramento de

\footnotetext{
${ }^{610} \mathrm{La}$ forma de interacción entre las instituciones monárquicas y eclesiásticas fue a través de dos tipos distintos de asambleas: el Concilio y la Curia. Las primeras debían ser presididas por un legado papal, mientras que las curias eran encabezadas por el rey. Si bien en ambas instancias se trataban temas vinculados a la administración y control de la Iglesia, el monarca procuró ejercer la mayor influencia en ellas. No obstante, ambas prácticas no eran periódicas, ni contaban con una regularidad determinada, lo que en parte restringía su accionar e influencia. (Rodríguez de la Peña, Manuel Alejandro, Los reyes sabios... op. cit., pp. 281, 282; y Procter, Evelyn, Curia y Cortes... op. cit., p. 38).

${ }^{611}$ Para una discusión del uso y pervivencia de la unción en el caso hispano medieval, remitirse a la exposición de Linehan, en su Historia e Historiadores, páginas 150-153, 157.

${ }^{612}$ En la práctica este sistema convivía con la costumbre de que el rey asociaba a su sucesor al gobierno, de manera que se convirtiese en su heredero natural y que al momento de su muerte fuese ratificado sin inconvenientes por la asamblea. (Bonassie, Pierre y otros, Las Españas Medievales, Barcelona, Crítica, 2001, pp. 160-271).

${ }^{613}$ Entre los años 531 y 711, en el Reino Visigodo de Toledo, se sucedieron unos veintitrés reyes, de los cuales aproximadamente diez fueron asesinados, eliminados o depuestos por conjuras nobiliarias, a través de métodos como la mutilación o tonsura forzosa.
} 
lealtad que los nobles debían prestar al rey, y que los comprometían con él y el reino tampoco fue garantía de estabilidad ${ }^{614}$. Una situación que por momentos se vio agravada por la actitud de la Iglesia, la cual no siempre cumplió con su rol de garante del orden y estabilidad del reino ${ }^{615}$. En su conjunto, y en esto somos tributarios de Rodríguez de la Peña, la Iglesia visigoda tuvo un rol fundamental en la constitución de la realeza visigoda, puesto que no sólo ungía al soberano, sino que en la práctica cogobernaba el reino $^{616}$.

Lo anterior se explica debido a que el reino constantemente se encontraba dividido en facciones, producto del sistema electivo de los reyes, provocando frecuentes luchas políticas, disputas y conjuras entre los diferentes grupos, por lo que fueron frecuentes los pequeños enfrentamientos locales, y en menor medida conflictos más serios, como algunas "guerras civiles". La Iglesia católica visigoda tenía clara conciencia de este problema, razón por la cual en el IV Concilio de Toledo (633), y bajo la influencia de San Isidoro, se incorporó la protección a la monarquía a través de decretos específicos, estableciéndose la inviolabilidad de la figura del rey, haciendo de cualquier ataque al monarca un acto sacrílego que podía afectar al conjunto del pueblo ${ }^{617}$.

A continuación, el Concilio establecía la forma de sucesión real, destacando la importancia de la transición pacífica, para lo cual era necesario lograr un acuerdo entre la nobleza y la Iglesia ${ }^{618}$.

Para fortalecer estos postulados, el Concilio, en el texto, formuló y repitió tres veces la sentencia de que quien conspirase, traicionase, atacase o agrediese al rey, sufriría el anatema. En contraparte a esta protección, se recordaba al rey y a sus

\footnotetext{
${ }^{614}$ Barbero, Abilio y Marcelo Vigil, La Formación del Feudalismo en la Península Ibérica, Barcelona, Crítica, 1978, p. 128.

${ }^{615}$ Ejemplo de ello fueron algunos episodios en que el alto clero tuvo un papel activo en las pugnas de poder, y que incluso llevaron a la caída de monarcas como Suintila (631) y Wamba (680), al ungir sin mayores oposiciones a los usurpadores Sisenando y Ervigio. O episodios abiertamente subversivos como la conspiración del Obispo Sisberto contra Egica en el 693.

${ }^{616}$ Rodríguez de la Peña, Manuel Alejandro, Los reyes sabios... op. cit., pp. 273, 274.

617 “Aquéllos, como es sabido, se matan con su propia mano olvidándose de su propia salvación, cuando dirigen sus fuerzas contra sí mismos o contra sus reyes, diciendo el Señor: 'No toquéis a mis ungidos', David añade: ‘Quién extenderá la mano contra el ungido del Señor y será inocente?’ [...] Sin duda que es un sacrilegio el violar los pueblos la fe prometida a sus reyes, porque no sólo se comete contra ellos una violación de lo pactado, sino también contra Dios, en el nombre del cual se hizo la dicha promesa. De aqui procede el que la ira del cielo haya trocado muchos reinos de la tierra de tal modo que a causa de la impiedad de su fe y de sus costumbres, ha destruido a unos por medio de otros." ("Teoría política en el IV Concilio de Toledo", en Marín R., José, Textos históricos... op. cit., p. 179).

618 "Que nadie prepare la muerte de los reyes, sino que muerto pacificamente el rey, la nobleza de todo el pueblo, en unión de los obispos, designarán de común acuerdo al sucesor en el trono, y no se origine alguna división de la patria y del pueblo a causa de la violencia y de la ambición." "“Teoría política en el IV Concilio de Toledo", en Marín R., José, Textos históricos... op. cit., p. 180).
} 
sucesores que su poder le había sido otorgado por Dios, y que por ello estaban obligados a regir a su pueblo de forma justa y piadosa ${ }^{619}$.

En esta misma línea, sabemos que la forma más práctica de enfrentar el problema de la sucesión y legitimidad fue la evolución del sistema electivo a un sistema de asociación, donde el rey en ejercicio compartía poderes con su posible sucesor, quien era generalmente un hijo que a su muerte ocuparía el trono previa aclamación de los magnates $^{620}$. De esta manera se mantenía simbólicamente el sistema electivo y se pretendía limitar las ambiciones de las distintas facciones nobiliares, que veían reducido su papel al de la confirmación del nuevo soberano ${ }^{621}$. Pero este sistema tampoco dio resultados, y como ejemplo de ello sólo basta recordar el conflicto que sucedió, entre los hijos de Witiza y Rodrigo, luego de la muerte del primero.

En base a lo anterior, podemos afirmar que la relación entre el rey, la nobleza y la Iglesia era de mutua dependencia, aunque no era de carácter horizontal, puesto que si bien el monarca tenía la facultad de nombrar los cargos civiles y religiosos del reino, lo que le permitía reforzar alianzas y lealtades-, lo cierto es que el monarca necesitaba contar con el favor de los magnates para asegurarse en el trono, y por lo tanto estaba sometido a sus exigencias con el riesgo de desencadenar un conflicto en caso de negarse. De esta forma, cada nuevo rey era más débil y dependiente de los señores que el anterior.

Las frecuentes revueltas no hacían más que empeorar la situación, ya que aunque el rey se impusiese, debía repartir las propiedades de los vencidos entre quienes lo habían respaldado, haciéndolos más ricos. De esta manera, el soberano perdía el control de dichas tierras, a la vez que disminuía su libertad de acción frente a sus aliados. En

\footnotetext{
619 “Teoría política en el IV Concilio de Toledo”, en Marín R., José, Textos históricos... op. cit., p. 181. A partir de la Influencia Isidoriana y Conciliar, Rodríguez de la Peña, nos recuerda que el monarca visigodo debía ser un rey cristiano, movido por las virtudes cardinales de prudencia, magnanimidad, continencia y justicia, las cuales se mantendrán como una constante histórica. Junto a ellas estaban además su función guerrera, que también se consideraba una virtud, pero que debía estar subordinada a la piedad y los modelos cristianos. En el fondo el rey debía ser un cristiano guerrero y no un guerrero cristiano. Así se consolidaba la idea de que la Iglesia era la rectora última del reino, misma razón, por la cual, según el autor, los reyes visigodos no desarrollaron un discurso Sapiencial, puesto que no era necesario ya que era la Iglesia la que asumió la construcción del aparato ideológico del reino. (Rodríguez de la Peña, Manuel Alejandro, Los reyes sabios... op. cit., pp. 252, 274, 276, 284).

${ }^{620}$ El principio de elección se puede encontrar en las crónicas más antiguas, pero su presencia tiende a disminuir a medida que la práctica fue siendo remplazada por el sistema de sucesión dinástica. No obstante la elección todavía sigue siendo mencionada en algunas fuentes de los siglos XII y XIII, como la Historia de rebus Hispaniae, pero para hacer referencias a tiempos pasados. (Martin, Georges, "Linaje y legitimidad en la historiografía regia hispana de los siglos IX al XIII”, en e-Spania [En línea], $11 \mid$ juin 2011, Puesto en línea el 06 junio 2011, consultado el 04 octubre 2013. URL: http://espania.revues.org/20335; DOI: 10.4000/e-spania.20335)

${ }^{621}$ Lomax, Derek W., La Reconquista... op. cit., p. 22; Martín, José Luis, La Península... op. cit., p. 62.
} 
definitiva, el rey visigodo no contó con una sólida base de validación, puesto que careció del "misticismo dinástico", un hecho agravado por la falta de una teoría política del tipo cesaropapista ${ }^{622}$. Por ello debía legitimarse mediante símbolos externos como la unción o la victoria militar, para lo cual dependía de la Iglesia y de los magnates laicos respectivamente ${ }^{623}$.

\section{II.3.c.- Los monarcas de la Reconquista}

Este estado de permanentes divisiones es una de las causas del rápido colapso del Reino Visigodo, que derivó en el sometimiento de la mayoría del territorio. En consecuencia, un grupo importante de cristianos se dirigió hacía el extremo norte de la Península, a las regiones de la Cordillera Cantábrica. Allí se produjo la primera batalla de la resistencia; el leyendario encuentro de Covadonga, donde Pelayo -a quien muchos cronistas dan un origen noble visigodo- derrotó a las avanzadas musulmanas enviadas a la zona. Este fue el origen del Reino Astur, donde los recién llegados se mezclaron con los nativos y comenzaron a reorganizar sus dominios siguiendo el modelo de los visigodos $^{624}$. De esta combinación de culturas se derivarían los reinos y guerreros que protagonizarían las siguientes etapas históricas de la Península.

Del "trauma" producto de la irrupción islámica surgirá una nueva corriente de pensamiento que buscaría explicar las causas de la caída de los visigodos, y a su vez validar a los nuevos monarcas del norte a través de sus victorias militares realizadas en pos de restaurar el reino perdido. Es en este contexto en que las crónicas desarrollan los tres tópicos que caracterizarán a la cronística: el lamento por la pérdida de España, la búsqueda del fin del dominio musulmán y el mito del Reino de Asturias como heredero de los visigodos.

Cinco son, a nuestro parecer, los elementos claves que permiten a la construcción de este nuevo modelo validador de la monarquía, y que estudiaremos para el caso

\footnotetext{
${ }^{622}$ Rodríguez de la Peña, Manuel Alejandro, Los reyes sabios... op. cit., p. 273.

${ }^{623}$ Isla, Amancio, Ejército, Sociedad y Política... op. cit., p. 219; Martín, José Luís, La Península ... op. cit., p. 59; Rodríguez de la Peña, Manuel Alejandro, Los reyes sabios... op. cit., p. 273; y Bloch, Marc, Los reyes taumaturgos... op. cit., pp. 72-74.

${ }^{624}$ Para un conocimiento más acabado sobre este tema recomendamos la ya clásica obra de Abilio Barbero y Marcelo Vigil (Sobre los orígenes sociales de la Reconquista, Barcelona, Ariel, 1988) y la de Manuel José Recuero Astray (Orígenes de la Reconquista en el occidente peninsular, Coruña, Universidade da Coruña, 1996, p. 56).
} 
castellano-leonés $^{625}$. En primer lugar se trata del linaje, concepto con el que los cronistas trataron de vincularse con los antiguos godos y su gloria. Luego vendrían las virtudes militares, las judiciales, las religiosas y las morales. Dichos elementos sentarían las bases del discurso real de fuertes raíces religiosas y militares.

En este capítulo analizaremos cada uno de estos componentes de este discurso y su evolución en los siglos XII y XIII, aunque sin olvidar sus raíces anteriores, por lo que las referencias al antiguo Reino Astur y los siglos previos serán necesarias para la obtención de una visión global del proceso en su conjunto, todo ello sin olvidar que junto con el discurso, la validación real también se construyó sobre los actos de los monarcas, es decir mediante el ejercicio efectivo del poder, sin perder de vista, además, la importancia que este ejercicio se sometiese a las normas religiosas cristinas ${ }^{626}$. Junto a lo anterior, para los siglos en cuestión, hay que tener presente que no todos los elementos se dieron de forma simultánea y hubo monarcas en los que confluyeron más atributos que en otros ${ }^{627}$. Es así como hemos podido identificar a cuatro reyes a los que hemos llamado "modélicos" y sobre los cuales las crónicas coinciden al identificar sus virtudes $^{628}$. Se trata de Alfonso VI, Alfonso VII, Alfonso VIII y Fernando III. Estos

${ }^{625}$ Georges Martin afirma que para los siglos IX al XIII, según las crónicas, la legitimación del poder real provenía de cuatro principios: Dios, la ética, la elección y el linaje, mientras que la fuerza no seria un principio legitimador, a menos que se apoyase en alguno de los cuatro ya mencionados (Martin, Georges, "Linaje y legitimidad en la historiografía... op. cit.) Se trata de una categorización que solo compartimos parcialmente, por considerarla demasiado amplia, razones por la cual hemos elaborado nuestras propias categorías, por lo que es posible encontrar coincidencias entre el trabajo de Martín y el nuestro.

En el mismo trabajo referido, Martin, establece que los cuatro principios de legitimación se asocian a ámbitos complementarios de la realidad humana, tales como las creencias religiosas, las valoraciones sociales, el derecho político y el derecho parental, lo que se hace patente en las evocaciones a los reyes pretéritos hechas por los cronistas. Pero por sobre todos los principios, el autor destaca el de Dios como el más potente. El providencialismo empapa todos los acontecimientos históricos y todas las formas de poder a lo largo de los siglos (Martin, Georges, "Linaje y legitimidad en la historiografía... op. cit.)

${ }^{626}$ Rodríguez, Ana, "Modelos de legitimidad política... op. cit.

${ }^{627}$ En cuanto alas virtudes reales, Rodríguez identifica una correspondencia entre la Chronica Regum Castellae, el Chronicon Mundi y el De Rebus Hispaniae, que asocian a distintos monarcas con diversas características, algunas virtuosas, como en el caso de Alfonso VIII y Fernando III, y otras negativas, aunque estas ultimas se utilizan para referirse a personajes distintos a los reyes o bien extranjeros, como Federico II, Raimundo y Enrique de Borgoña o los almorávides (Rodríguez, Ana, "Modelos de legitimidad política... op. cit.)

${ }^{628}$ Respecto a la obra de Lucas de Tuy, Ana Rodríguez sostiene que en su Proemio, el obispo identifica cinco requisitos para gobernar: conocer a Dios, confesar su fe, mantener la paz en su reino, impartir justicia para todos y luchar contra los enemigos. En tanto que Jiménez de Rada también enumera distintas virtudes la aplicación de la justicia, la sapiencia y la generosidad, mientras que la Crónica latina de los reyes de Castilla, aunque no tiene un apartado para detallar las virtudes, estas se pueden desprender de la narración general. (Ver Rodriguez, Ana, "De Rebus Hispaniae frente a la Crónica latina de los reyes de Castilla: virtudes regias y reciprocidad política en Castilla y León en la primera mitad del siglo XIII", en Cahiers de linguistique hispanique médiévale, Volumen 26, $N^{\circ} 26,2003$, [pp. 133-149], $p$. 134-138).

La misma autora destacad el concepto de generosidad como uno de los principales ejes en los trabajos de Jiménez de Rada y Juan de Osma, no obstante en nuestro análisis, desarrollado en las 
cuatro monarcas servirán, en un próximo capítulo, para ilustrar el uso y evolución del discurso legitimador monárquico, razón por la cual los trataremos de forma individual en el siguiente análisis ${ }^{629}$.

La irrupción musulmana del 711 trasformó radicalmente la situación en la Península Ibérica, el Reino Visigodo colapsó y, según algunos cronistas, sus antiguas autoridades y habitantes quedaron señaladas como responsables de la catástrofe en razón de sus pecados ${ }^{630}$. El trastorno fue total y fue así como luego de la invasión musulmana los cristianos del norte debieron afrontar una doble tarea: organizar sus territorios y comprender las razones que condujeron al Reino Visigodo a su fin. Para ello recurrieron a sus antiguas creencias religiosas y antiguas tradiciones providenciales, como las ideas de San Isidoro ${ }^{631}$. Las Escrituras relatan que el pueblo elegido, Israel, fue castigado por Dios debido a sus pecados, por lo que no fue extraño para los astures aplicar la misma lógica a la desgracia de los visigodos, más en vista de los disturbios y pecados que habían caracterizado la última etapa del reino. Sobre ella se había construido una especie de leyenda negra, que convertía a Witiza en un libertino y pecaminoso rey, que por sus actos había atraído la ira de Dios.

"Era DCCXXXVIIII post Egicani discessum Uutiza ad solium patris reuertitur Toleto. Iste quidem probrsus et moribus flagitiosus fuit, et 'sicus equus et mulus, in quibus non est intellectus', cum uxoribus et concubinis plurimis se coinquinauit. Et ne aduersus eum censura eclesiastica consurgeret, concilia dissoluit, canones obserauit omnemque religiones ordinem depranarit. Episcopis, presbiteris et diaconibus uxores habere preceptos. Istud quidem scelus Yspanie causa pereundi fuit. Et quia reges et sacerdotes legem Domini derelinquerunt, Omnia agmina

\footnotetext{
siguientes páginas, no otorgamos un rol esencial a esta característica, puesto que no consideramos que fuese de uso trasversal en nuestro periodo de análisis, por lo que le asignamos una relevancia secundaria con respecto a otros valores monárquicos de uso más difundido en el discurso cronístico.

${ }^{629}$ Alfonso VII, a diferencia de los otros tres monarcas no fue un arquetipo tan poderoso, no obstante lo hemos incluido en esa lista en razón de ser el único que cuenta con una obra exclusivamente dedicada a su persona, la Chronica Adefonsi Imperatoris y porqué las crónicas posteriores suelen detenerse en su reinado, en especial para levantarlo como un modelo en oposición a sus rivales peninsulares y reforzar así la identidad leonesa. En cuanto a Alfonso X el rey sabio también será objeto de análisis, pero en virtud a la forma en que sus talles rescataron esta tradición y sus arquetipos y los incluyeron en su discurso, sintetizando para ello distintas versiones cronísticas anteriores.

${ }^{630}$ Podemos observar ejemplos de ello en la CAIII, versión A Sebastián, N5, op. cit., pp. 199, 200; CN, Libro I, op. cit., p. 107; CS, op. cit., p. 40; CE, Libro III, Cap. LXIII, op. cit., p. 264; HHE, Libro III, Cap. XVI, op. cit., p. 141; y CGE, Cap. 592, op. cit., pp. 337, 338.

${ }^{631}$ De Ayala Martínez, Carlos. Sacerdocio y Reino en la España Altomedieval... op. cit., p. 287.
} 
Gotorum Sarracenorum gladio perierunt. Interea Uuittiza post regni an. X morte

propria Toleto discessit era DCCXLVIIII.",632

Entonces, los cronistas postulaban que los godos estaban siendo castigados por sus pecados y los de su rey; pero al igual que Israel, que había sido castigada por Babilonia, ellos estaban destinados a ser perdonados y a restaurar su grandeza perdida. Esto, sin embargo, sólo sería posible mediante la realización de grandes sacrificios ${ }^{633}$.

Como se ve, la idea del castigo y por ende del próximo perdón y retorno a la Gracia está presente en los cronistas asturianos, que detallan las razones que atrajeron la furia divina, entre los que destacan los actos pecaminosos del rey, el abandono de las armas por parte del pueblo y la pérdida de su espíritu característico, que en antaño los había llevado a imponerse a sus enemigos. Todo ello, quizás, como parte de un esfuerzo discursivo didáctico orientado a las elites, destinado a plasmar los pecados cometidos, casi a modo de confesión, para asegurar el conocimiento público de las faltas y así evitar que fuesen olvidadas y repetidas ${ }^{634}$.

Las crónicas también dan indicios sobre los actos por los cuales el pueblo y sus líderes podían recuperar la Gracia divina. Primero, repudiando a aquellos que pactaron con los invasores, a los que se clasifica como traidores, como en el caso del Obispo Opas, y segundo, haciendo un llamado a recuperar las tierras perdidas; las mismas que, según Isidoro, son como un paraíso, un territorio fértil y agradable, distinto a las agrestes y frías montañas del norte peninsular ${ }^{635}$. A nuestro juicio, estos aspectos del

${ }^{632}$ CAIII, versión Ad Sebastianvm...op. cit., pp. 119, 121. "En la era 739, tras el fallecimiento de Egica, Vitiza vuelve a Toledo para ocupar el trono de su padre. Este fue en verdad un hombre deshonesto y de escandalosas costumbres, y cual el caballo o el mulo, en los que no hay entendimiento, se contaminó con numerosas esposas y concubinas. Y para que no se levantara la censura eclesiástica contra él, disolvió los concilios, cerró los cánones, y vició todo el orden religioso. A los obispos, presbiteros y diáconos les ordenó que tuvieran esposas. En verdad este crimen fue la causa de la perdición de España. Y puesto que reyes y sacerdotes abandonaron la ley del Señor, todos los ejércitos de los godos perecieron por la espada de los sarracenos. Entretanto Vitiza, tras diez años de reinado, falleció de muerte natural en Toledo, en la era 749.” CAIII, versión A Sebastián... op. cit., p. 199.

${ }^{633}$ Testimonio temprano de esto es el relato del encuentro entre Pelayo y Opas. Allí el caudillo cristiano del que se recalca su origen cortesano y visigodo - expresa la idea del castigo divino, pero también recurre a las escrituras para comparar su situación con la de Israel y afirmar que aún cuentan con el favor divino y que por ello la victoria será suya (CAIII, versión Rotense, op. cit., pp. 200 - 204; Isla Frez, Amancio, "La construcción de la monarquía en León, siglos X y XI: Historia y Leyes", en Martínez Pascual, Rodríguez, Ana, La construcción medieval de la memoria ... op. cit., p. 36; y De Ayala Martínez, Carlos, Sacerdocio y Reino en la España Altomedieval... op. cit., p. 133).

${ }^{634}$ Buena parte de estos relatos fueron sintetizados por Rodrigo Jiménez de Rada en su Historia De Rebus Hispaniae.

${ }^{635}$ Pérez de Tudela Velasco, María Isabel, "La consideración ética de la guerra y el uso de la violencia en la España Medieval”, en En La España Medieval, 2007, vol. 30, 7-25, [pp. 7-25], pp. 13-15; Mitre Fernández, Emilio y Martín Alvira Cabrer, "Ideología y guerra... op.cit., p. 301; y Bronisch, Alexander, "La ideología asturiana..., op. cit., p. 436. 
relato cronístico son los que imperan en los primeros tiempos de la Reconquista. Si bien aún en ellos no se observa una motivación religiosa mayor -la idea de la guerra santa-, sí manifiestan que los líderes de los astures debían ser piadosos y recuperar las tierras de sus ancestros; sólo esto los legitimaría ante Dios, y obtendrían su perdón.

Es en ese sentido, según el discurso cronístico, que se explica que el conjunto de la comunidad sintiese el derecho a recuperar las tierras de sus ancestros visigodos, puesto que también recaía sobre ellos el castigo divino que habían adquirido sus antepasados por sus pecados ${ }^{636}$. Las primeras crónicas insisten en ello; si bien se concentran en las figuras monárquicas, procuran diluir la culpa entre el conjunto de la población, evitando focalizarla totalmente en las figuras reales, puesto que tampoco convenía a sus intereses destruir la institución regia. La argumentación sugería entonces que el pueblo en su conjunto había caído en excesos y en el pecado y, aunque lo hicieron siguiendo el ejemplo de sus soberanos, no estaban exculpados, puesto que el cristianismo es claro en torno al tema de las libertades y responsabilidades individuales.

Es así como el colectivo de los visigodos habría pecado en conjunto, habiéndose entregado a la pereza y a los placeres mundanos, mientras sus dirigentes luchaban por el poder, ciegos de ambición y traicionándose mutuamente hasta llegar a la máxima felonía: pactar con los musulmanes y entregarse a ellos ${ }^{637}$. Si el pecado fue colectivo, común debía ser castigo; pero también común debía ser el perdón y la redención. Así parece atestiguarlo la Crónica de Alfonso III, cuando al relatar la derrota de Rodrigo explica el suceso por la falta de piedad del pueblo godo: "Et quia derelinquerunt Dominum ne seruirent ei in justicia et ueritatem, derelicti sunt a Domino ne auitarent terram desiderauilem ${ }^{\prime 638}$. Esta convicción de la necesidad de redención continuaría estando presente en los siglos siguientes, siendo incluso uno de los fundamentos para

\footnotetext{
${ }^{636}$ Pérez de Tudela Velasco, María Isabel, "La consideración ética... op. cit., pp. 13-15.

${ }^{637}$ La idea de la traición de algunos visigodos como causa de la caída del reino es mencionada en algunas crónicas antiguas, como Crónica Mozárabe, $\mathrm{N}^{\circ}$ 54, donde se mencionan a personajes como el obispo Opas, pero es en la cronística posterior, a partir del siglo XIII cuando el tópico es desarrollado de forma más extensa. Lucas de Tuy también se refiere a Opas, pero directamente acusa a los judíos se haber ayudado a los invasores musulmanes a capturar Toledo (CM, Libro III, cap. LXVIII), mientras que Jiménez de Rada se explaya aun más en el asunto, mencionando la actitud de los judíos, pero resaltando la traición del conde Julián y afirmando que solo el señor de Córdoba fue capturado en combate, puesto que el resto de los magnates del reino se entregaron mediante rendición o pacto (HRH, Libro III, cap. XXIII, XIV). Es importante destacar que estos relatos de traición se desarrollan en torno a la narración de la caída de Rodrigo y como paso previo a la historia de Pelayo, teniendo una importante carga simbólica en su constaste entre aquellos que se entregaron al invasor y los que lucharon contra ellos.

${ }^{638}$ CAIII, versión Rotensis, N7, op. cit., pp. 120, 122. "Y como abandonaron al Señor, para no servirle en justicia y en verdad, fueron abandonados por el Señor, de manera que no habitaran la tierra deseable" CAIII, versión Rotense, N7, op. cit., p. 200.
} 
legitimar a los monarcas y la guerra de Reconquista. Por ello se hacía imprescindible la realización de actos y conductas que permitiesen el retorno a la Gracia divina. 


\title{
II.4.- Las virtudes del rey: Construcción de un ideal monárquico
}

\author{
II.4.a.- Linaje visigodo y continuidad
}

Uno de los componentes más importantes y permanentes del discurso validador de los cronistas fue la apelación a la continuidad del linaje visigodo ${ }^{639}$. Ya las primeras crónicas asturianas presentaban a los monarcas como herederos directos del extinto reino, aunque siempre procurando limitar las vinculaciones con los últimos monarcas germanos, a quienes se responsabilizaba por el colapso del reino. La idea era expresar una convicción en torno la herencia transmitida sanguíneamente, para demostrar que, en el marco de la Reconquista, los hispanos y sus reyes sólo estaban recuperando lo que les correspondía: las tierras de sus ancestros ${ }^{640}$.

Es en ese contexto que la figura de Pelayo es especialmente importante, en razón de que tradicionalmente fue el primer rey asturiano: un reino nuevo, pero que se postulaba como continuador de los visigodos. De allí que la mayoría de las primeras crónicas destaquen el origen germano de este personaje -sin dar pie a la justa pregunta sobre un posible origen cantábrico- ya que sólo de esta manera se podía sostener la legitimación por herencia de la nueva monarquía ${ }^{641}$. Según el discurso tradicional, la sangre visigoda de Pelayo lo convertía en el legítimo receptor de las virtudes godas, las

\footnotetext{
639 Según Martin la voz linaje, de origen francés, comenzó a usarse en la historiografía real hispana alrededor del año 1200, no obstante su significado ya era conocido y utilizado por los hispanos, significando una unión de parentesco que vinculaba a los miembros de una familia con un antepasado primordial fundador de las grandezas de la familia, teniendo un componente más místico que físico. Una concepción que paulatinamente fue ganando terreno en relación al poder real y la legitimación del príncipe, lo que se manifestó en la preocupación cronística por desarrollar las genealogías regias y nobiliares entre los siglos X al XIII, siendo esta práctica la que nos permite identificar las raíces del goticismo y del discurso restaurador visigodo (Martin, Georges, "Linaje y legitimidad en la historiografía... op . cit.).

${ }^{640} \mathrm{La}$ formulación de este discurso se enlaza con la antigua tradición germana del linaje (De Pange, Jean, Le roi très Chretien... op. cit., pp. 90; y Zamora, Patricio, "Espejos de lo sagrado... op. cit.). Gracias a Isidoro los visigodos habían construido un ideal colectivo gótico, la idea de un linaje común para todo el pueblo. A partir de la Reconquista y el mito de Pelayo veremos como este linaje ideal y colectivo es revitalizado y convertido en parte esencial del discurso de legitimación monárquico y nobiliar.

En relación al linaje, es prudente recordar que, en palabras de Isabel Beceiro, "La reivindicación de los ancestros constituye un instrumento fundamental para justificar una posición hegemónica a fines de la Edad Media", una práctica, vinculada a las capas nobiliares, que en distintas medidas puede extenderse a la totalidad del medioevo, siendo un componente esencial en la construcción del poder político (Beceiro Pita, Isabel, "La legitimación del linaje a través de los ancestros", en Fernández de Larrea, Jon Andoni y José Ramón Díaz de Durana (Editores), Memoria e Historia... op. cit., pp. 77 y ss).

${ }^{641}$ Sobre el tema de los verdaderos origen del Reino de Asturias y el rol de los cántabros en su conformación es recomendable revisar las ya clásicas obras de Abilio Barbero y Marcelo Vigil, Sobre los orígenes sociales de la reconquista y La Formación del feudalismo en la península Ibérica, que aunque actualmente sus conclusiones han sido matizadas por investigadores más recientes fue inaugural en el cuestionamiento de las raíces étnicas del reino asturiano.
} 
mismas que alabó San Isidoro y que aseguraban el perdón y el favor divino ${ }^{642}$. Las crónicas exacerbaron esta postura al convertir a Pelayo en mucho más que un visigodo cualquiera, sino en un miembro de la nobleza, de linaje real, aunque distante de los últimos soberanos y sus pecados ${ }^{643}$. Es importante recordar que Pelayo fue encumbrado como rey por sus huestes, y que según las crónicas, a este acontecimiento le siguió la batalla de Covadonga, en la que el nuevo soberano obtuvo el triunfo militar por la intervención divina. De esta forma Pelayo quedaba consagrado como monarca, puesto que había sido legitimado por su ascendencia, su victoria y el favor de Dios. En esencia, Pelayo se convirtió en un nuevo tipo ideal de visigodo, repleto de las virtudes isidorianas: cristiano piadoso y alejado de los vicios de sus antecesores ${ }^{644}$.

En síntesis, nosotros consideramos que la alianza entre los godos y Dios fue parte del discurso isidoriano para legitimar a su pueblo y crear en él un sentimiento de unidad y superioridad. Estas ideas sobrevivieron al 711 cuando fueron adaptadas para los mismos fines, pero centrándose en las nuevas monarquías asturianas. Estos reyes no eran hispano-visigodos, sino que eran el resultado del mestizaje con los cántabros y astures del norte peninsular, lo que ponía en duda sus derechos sobre el resto de la Península. Se hacía necesario entonces enlazarlos con aquella tradición isidoriana y de paso explicar porqué un pueblo elegido por Dios había sido tan aplastantemente derrotado. El goticismo fue la respuesta a estas necesidades; un pensamiento que basado en las creencias religiosas y genealógicas se convirtió en parte de la tradición hispano

\footnotetext{
${ }^{642}$ Ver gráfico y tabla $\mathrm{N}^{\circ} 1$.

${ }^{643}$ Le Morvan, Gaël, Reinos e imperio: la Historia legionensis... op. cit., http://e-spania.revues.org/21681 (junio de 2013). En este mismo trabajo, Le Morvan, postula que fue con Alfonso I (693-757), yerno de Pelayo, que discursivamente se confirmo la continuidad regia visigoda. Puesto que en la Historia Silensis se afirma que Alfonso, al ser hijo de Pedro duque de Cantabria, sería descendiente directo de Recaredo, estableciéndose una línea dinástica directa entre los monarcas visigodos-católicos y el linaje de Pelayo en Asturias.

${ }^{644}$ En ello hacemos eco de lo afirmado por José Luis Martín: "Si los asturianos han de expulsar a los musulmanes, habrá que convertirlos en herederos de los visigodos y así se hace desde las primeras líneas de la crónica dirigida a Sebastián para que conozca 'la historia de los godos' a partir del momento en que la dejó San Isidoro hasta el reinado de Alfonso III: no hay ruptura sino continuidad histórica que se logra convirtiendo a Pelayo en miembro de la familia real visigoda y en víctima, al mismo nivel que Rodrigo, de Vitiza: la Rotense lo convierte en 'espatario de los reyes Vitiza y Rodrigo' y la de Sebastián en 'hijo del antaño duque Favila, de linaje real' y la Albeldense va más lejos al convertirlo en 'hijo de Bermudo, nieto de Rodrigo, rey de Toledo', y por si este entronque no bastara se hace emparentar a Pelayo con la familia del duque Pedro de Cantabria, 'de regio linaje', 'descendiente del linaje de los reyes Leovigildo y Recaredo." (Martín, José Luís, "La perdida y reconquista de España a la luz de las crónicas y del romancero", en Actas del III Curso de Cultura Medieval. Repoblación y reconquista, Centro de Estudios Románicos Aguilar del Campoo, septiembre de 1991, p. 12). Una postura similar a la de Klinka que coincide en señalar, que según la Chronica Naierensis, Pelayo viene a sintetizar las ideas de castigo, reivindicación y continuidad de los visigodos (Klinka, Emmanuelle, "Chronica naiarensis: de la traición... op. cit.)
} 
cristiana de León y Castilla ${ }^{645}$. Una construcción ideológica dirigida a las elites del reino y cuyo principal objetivo fue legitimar a los soberanos y su expansión hacia el sur peninsular $^{646}$.

Estas convicciones llevaron a los astures a mantener vivo el modelo de los visigodos y a idealizarlo, conjugándolos con elementos del mundo hispano-latino. Todo ello en la línea del pensamiento isidoriano. Esta idea sobrevivió a la debacle del 711 encontrándola incluso, aunque matizada, en relatos posteriores como en el Poema de Fernán Gonçález, en el que se narra el origen de los godos, que siendo guiados por Dios se convirtieron por el Espíritu Santo ${ }^{647}$ :

"Escogyeron España toda de mar a mar, nin vylla nin castello no s' pudo anparar. Áfryca e Turonia ovyeron por mandar: omnes fueron arteros, Dios los quiso guïar.

Fueron de Sancty Spýritus los godos espyrados, los malos argumentos todos fueron fallados: conosçieron que eran los ýdolos pecados, cuantos creién por ellos eran mal engañados. $[\ldots]$

Resçibyeron los godos del ánima vautysmo,

Fueron luz e estrella de tod' el cristianismo;

645 Nosotros creemos que la situación de los reyes de Asturias se puede interpretar, como que los monarcas sabían de la utilidad de la Iglesia como instrumento de control social, pero ésta no podía ser la misma iglesia que había servido a los monarcas de Toledo y que había acabado por sucumbir a la corruptela de estos últimos: era inadmisible que la misma Iglesia que se había entregado a los invasores musulmanes tuviese un rol destacado en la nueva sociedad asturiana, y por lo mismo los monarcas decidieron controlarla directamente. Fue una iglesia cristiana, pero no pontificia, puesto que la autoridad suprema recayó sobre el monarca y no sobre el Papa, situación que se vio favorecida por el estado de aislamiento antes descrito

${ }^{646}$ Al respecto de la construcción ideológica de la reconquista, recientemente Martín Ríos Saloma, publicó una monografía al respecto La reconquista. Una construcción historiográfica (siglos XVI-XIX), donde se analiza este problema. En forma complementaria el mismo autor produjó el interesante articulo "Usos políticos e historiográficos del concepto de Reconquista", en el cual plantea que desde época temprana la Reconquista fue instrumentalizada, creándose un discurso a partir de la lucha contra el Islam peninsular. Pero no fue sino hasta la llegada de los Reyes Católicos que este discurso fue ordenado en post de dos objetivos centrales: como arma de propaganda política contra lo enemigos de la monarquía y como elemento unificador en torno a una identidad colectiva para todos los súbditos de los Reyes Católicos. Bajo estos principios, el concepto se convirtió en parte importante del discurso del poder político en la historia de España, pasando por distintas etapas hasta finalizar convertido en un argumento del nacionalismo franquista en el siglo XX (Ríos Saloma, Martín, "Usos políticos e historiográficos del concepto de Reconquista", en Anales de la Universidad de Alicante, Historia Medieval, $\mathrm{N}^{\circ}$ 17, 2011, pp. 41-65)

${ }^{647}$ Maravall, José Antonio, Estudios de Historia... op. cit., pp. 40, 41; y Recuero Astray, Manuel José, Orígenes de la Reconquista... op. cit., pp. 62, 63 у 69. 
alçaron cristiandad, vaxaron paganismo:

el cond' Ferrán Gónçález fyzo aquesto mismo" ${ }^{\text {648 }}$.

Bajo estas creencias, y con el deseo de reforzarlas, es que Alfonso II el Casto (791-842) trasladó la capital del reino a Oviedo, donde había levantado edificaciones según los antiguos modelos visigodos ${ }^{649}$. Se mantuvo también, por lo menos en los primeros tiempos de la Reconquista, la tradición de la monarquía electiva, aunque en la práctica encubría un principio hereditario ${ }^{650}$. Esto en la práctica monopolizó la sucesión de los linajes de Pelayo y del duque Pedro de Cantabria, de tal manera que la "elección" siempre recayó en los miembros de la misma familia. Esta situación continuó hasta el reinado de Ramiro I (842-850), en el que se impuso la sucesión patrilineal y se eliminó definitivamente el rito de la elección. Según Emilio Mitre, para el siglo X la sucesión real directa de un miembro de un mismo linaje era considerada ya como algo natural, consolidándose así la sucesión del primogénito ${ }^{651}$.

De esta manera, el extinto reino germánico sobrevivió como un modelo ideal basado en la posesión de las tierras de la Península, asentándose sobre la idea de unidad y en la de una pasada gloria guerrera. Las crónicas, que en su gran mayoría fueron escritas por miembros del clero, fueron las responsables de plasmar este discurso. Los cronistas supieron rescatar el "espíritu visigodo" que les había legado el Obispo de Sevilla, y utilizarlo para justificar la conquista territorial y la creación de un nuevo sistema político. A través de crónicas como la Profética, Alfonso III o la Albeldense, se trazó una línea de continuidad genealógica entre los monarcas astures y los últimos visigodos, comenzando por Pelayo y dejando fuera a Witiza y a Rodrigo ${ }^{652}$. Podemos observar como una y otra vez las crónicas mencionan las hazañas de los monarcas visigodos con el fin de un crear un discurso que rememoraba los modelos virtuosos de antaño, a la vez que justificaban la derrota del 711 como un castigo pasajero, una prueba de Dios que los monarcas astures debían superar para así recuperar la gloria y favor divino del cual habían gozado sus ancestros visigodos.

\footnotetext{
${ }^{648}$ PFG, (19 - 24) op. cit., p. 247.

649 De Valdeavellano, Luis, El Feudalismo Hispánico, Barcelona, Crítica, 1981, pp. 78, 79; Mitre Fernández, Emilio, La España Medieval... op. cit., pp 147, 148; y Valdeón Baruque, Julio, La Reconquista... op. cit., p. 57.

${ }^{650}$ Martín, José Luis, La Península en la Edad Media ..., op. cit., pp. 201, 202.

${ }^{651}$ Mitre Fernández, Emilio, La España Medieval... op. cit., p. 153; Martín, José Luis, La Península en la Edad Media... op. cit., p. 199-202; y García-Guijarro Ramos, Luis, Papado, cruzadas... op. cit., p. 19.

${ }^{652}$ Barbero, Abilio y Marcelo Vigil. La Formación del Feudalismo... op. cit., p. 233.
} 
La creencia en estos principios valido a los soberanos germanos, por lo tanto si los astures buscaban justificar el dominio sobre los remanentes visigodos y los nuevos componentes cantábricos, debían convertirse en descendientes directos de los monarcas visigodos $^{653}$. Una política que se hizo extensiva al conjunto de la nobleza, puesto que los magnates también debían legitimar su posición en los nuevos reinos, y en especial en el contexto en que el monarca era encumbrado por los nobles. De esta forma se trasmitía la idea de que los descendientes de la nobleza visigoda eran los únicos con el derecho de administrar el reino y la corona ${ }^{654}$.

Un claro ejemplo de lo anterior se puede observar en las primeras líneas de la Crónica de Alfonso III, en sus dos versiones, pero en especial en la "A Sebastian", donde expresa su intención de contar la crónica de los visigodos desde Wamba hasta García, es decir desde finales del siglo VII hasta comienzos del siglo $\mathrm{X}^{655}$. Como mencionamos anteriormente, esta crónica puede ser considerada como una "historia oficial", por el patrocinio que recibió directamente de la monarquía y por sintetizar los ideales de ésta en cuanto a la continuidad visigoda, defensa de la fe y expansión del reino $^{656}$ :

\section{"IN NOMINE DOMINI NOSTRI IHESU XẼI INCIPIT CRÓNICA UISEGOTORUM A TEMPORE UUAMBANI REGIS USQUE NUNC IN}

\footnotetext{
${ }^{653}$ Barbero y Vigil en su obra recién citada establecieron la paradoja que significo que los territorios del extremo norte, que solo parcialmente fueron sometidos por los visigodos, se convirtieron en el eje "restaurador" de ese reino. Una situación que como sabemos se debe a una construcción intencionada por parte de las elites del norte, necesitadas de argumentos para consolidar su poder y eventualmente reclamar las tierras en manos de los árabes.

${ }^{654}$ Isla Frez, Amancio, "La construcción de la monarquía en León, siglos X y XI: Historia y Leyes.”, en Martínez Sopena, Pascual y Rodríguez, Ana, La construcción medieval de la memoria ... op. cit., pp. 34, 35; González Antón, Luis, España y las Españas, Madrid, Alianza, 1997, pp. 121, 122; Rodríguez, Ana, "Memoria y curia regia en Castilla en la primera mitad del siglo XIII", en Martínez Pascual y Ana Rodríguez, La construcción medieval de la memoria ... op. cit., p. 294; y Barbero, Abilio y Marcelo Vigil, La Formación del Feudalismo... op. cit., pp. 292, 293.

${ }^{655}$ Sobre la idea de un temprano discurso neogoticista existe una abundante bibliografía, ente la que destacamos Barkai, Ron, El enemigo en el espejo... op. cit., pp. 29, 40-42; Tolan, John V., op. cit., pp. 130-136; Maravall, José Antonio, El concepto de España ... op. cit., p. 300; Mitre Fernández, Emilio, Iglesia, herejía y vida política en la Europa Medieval, Madrid, Biblioteca de Autores Cristianos, 2007, p. 44; Maravall, José Antonio, "La idea de Reconquista..., op. cit., p. 8; Monsalvo, José María, "Notas sobre los primeros espacios de la Reconquista (Primera Mitad S. VIII) en la cronística cristiana pleno medieval: De la Historia Silense a la Estoria de España”, en Mínguez Fernández, José María y Gregorio del Ser Quijano (Editores), La Península en la Edad Media treinta años después. Estudios dedicados a José Luis Martín, Salamanca, Ediciones Universidad de Salamanca, 2006, p. 254; Bodelón, Serafín, Literatura latina ... op. cit., p. 62; Martín, José Luis, "La perdida y reconquista de España a la luz de las crónicas y del romancero", en Actas del III Curso de Cultura Medieval. Repoblación y reconquista, Centro de Estudios Románicos Aguilar del Campoo, septiembre de 1991, p. 12; Orcástegui, Carmen y Esteban Sarasa, La historia en la Edad Media... op. cit., p. 128; Martín, José Luis, "Reconquista y cruzada", en Studia Zamorensia, Segunda Etapa, Volumen III, UNED, Zamora 1996, [pp. 215-241], pp. 222-226; y Benito Ruano, Eloy, "La historiografía... op. cit., pp. 74, 75.

${ }_{656}$ Menéndez Pidal, Ramón, Los Españoles en la Historia, Madrid, Espasa Calpe, 1991, p. 173; y O'Callaghan, Joseph. Reconquest and Crusade... op. cit., pp. 4, 6.
} 
TEMPORE GLORIOSI GARSEANI REGIS DIUE MEMORIE ADEFONSI FILIO

COLLECTA ${ }^{\text {,657. }}$

De esta forma, el goticismo estuvo presente desde la conformación de los reinos hispanos, ya que para el siglo IX, aunque los territorios cristianos se encontraban fragmentados en distintos reinos y condados, compartían el mismo origen, el cual fue profusamente explotado por los cronistas ${ }^{658}$. Un origen que sólo podía ser reivindicado si se relacionaba con la idea de que los visigodos habían estado "en gracia" con Dios. Sólo eso podía explicar su trayectoria dentro de un plan providencial y que los validaba como un modelo digno sobre el cual construir una nueva estructura política y militar. En otras palabras, podemos afirmar que los cronistas crearon -con claras intenciones legitimadoras- un linaje continuo, expresado en una construcción genealógica, exaltando las glorias de los reyes del pasado y así encumbrar a sus descendientes. Fue así que convirtieron a Pelayo y su presunto origen godo en el nexo de unión entre los visigodos, los astures y los futuros monarcas de Castilla y León.

Pero la sola idea de la herencia no bastaba para la validación de la monarquía, y era necesario demostrarla por hechos concretos. Durante los siglos IX y X, cuando del Reino Astur habían surgido distintos reinos y condados independientes, el goticismo fue acompañado por los avances de la ocupación hacia el Duero, que cuando chocó con la resistencia musulmana se convirtieron en Reconquista. Así, el avance cristiano y sus primeros triunfos bajo el mando de Alfonso III sirvieron de sustento para la idea de la restauración gótica, ya que parecían demostrar la recuperación del antiguo favor divino con el que había contado ese pueblo en el pasado ${ }^{659}$. A ello debe agregarse que las campañas de Alfonso III implicaron una renovación del "espíritu gótico", ya que a los territorios del rey llegaron gran cantidad de mozárabes -muchos de ellos religiosos y nobles- que conservaban aún una fuerte tradición goda, la que rápidamente fue asimilada por la Corte de asturleonesa como parte de un programa mayor iniciado por

${ }^{657}$ CAIII, versión "Ad Sebastianvm”... op. cit., p. 115. "EN NOMBRE DE NUESTRO SEÑOR JESUCRISTO, EMPIEZA LA CRÓNICA DE LOS VISIGODOS, COMPILADA DESDE EL TIEMPO DEL REY WAMBA HASTA AHORA, EL TIEMPO DEL GLORIOSO REY GARCIA, HIJO DE ALFONSO, DE SANTA MEMORIA" CAIII, versión "A Sebastian"... op. cit., p. 195.

${ }_{658}^{658}$ Ver gráfico y tabla $\mathrm{N}^{\circ} 1$.

${ }^{659}$ Mitre Fernández, Emilio, "La historiografía... op. cit., p. 69; Bonassie, Pierre Las Españas Medievales, op. cit., pp. 192-194; Martín, José Luis, La Península ... op. cit., p. 199; y Lomax, Derek W., La Reconquista... op. cit., 44, 45. 
Alfonso II y destinado a restaurar en el reino los modelos arquitectónicos, burocráticos, de asambleas, y otros elementos de la antigua Corte de Toledo ${ }^{660}$.

Los monarcas asturleoneses mantuvieron el discurso visigodo porque mediante su uso podían presentar la Reconquista como una restauración, una continuidad con el reino extinto, que se manifestaba en la recuperación de las ciudades y territorios de manos de los musulmanes ${ }^{661}$. En esencia, las ideas propuestas por la monarquía, apoyadas por la Iglesia y expresadas en las crónicas, sostenían el discurso de que los cristianos del norte peninsular eran los legítimos herederos de las tierras e instituciones de las que se apoderaban, justificando de esta manera su actuación militar y convirtiéndola en una guerra justa. Además de esto también se construía una base sólida sobre la cual los reyes podían establecer su poder político y social. En definitiva, una base cimentada en la idea de la existencia de una comunidad heredera, puesto que todos los astures compartían el linaje godo. Es así como se instaura la idea de que es el pueblo entero el que está luchando por la restitución de sus legítimos derechos ${ }^{662}$.

Como parte de la noción de la continuidad gótica, los reyes astures no sólo procuraron reproducir la Corte goda en Oviedo, sino que también apelaron a la tradición jurídica del extinto reino. En el siglo IX, Alfonso II oficializó la vigencia del Liber Iudiciorum, el antiguo código legal visigodo proclamado durante el reinado de Recesvinto (586-601) en el siglo VII. De esta manera, el rey asturiano apelaba a las raíces legales godas - que eran de orígenes romanos- como símbolo de continuidad, dándole importancia a la ley escrita como base del legítimo poder del soberano "godo" sobre su reino. No obstante, esto no significó que el código fuese universalmente aceptado o conocido, ya que su uso fue más simbólico que real ${ }^{663}$. De esta forma, en palabras de José Antonio Maravall, en la España cristiana se plasmó la convicción de una teoría jurídico-política que sostenía la herencia y la restauración de las instituciones anteriores a la invasión musulmana ${ }^{664}$. A partir de ello nosotros podemos afirmar que el

\footnotetext{
${ }^{660}$ Barbero y Vigil, La Formación del Feudalismo... op. cit., p. 233, 236; Bronisch, Alexander Pierre, Reconquista y guerra santa... op. cit., p. 213; Orcástegui, Carmen y Esteban Sarasa, La historia en la Edad Media ... op. cit., p. 128; Martín, José Luis, La Península ... op. cit., p. 199; y Lomax, Derek W., La Reconquista... op. cit., p. 57.

${ }^{661}$ Maravall, José Antonio, El concepto de España...op. cit., p. 279; y García Fitz, Francisco, La edad Media... op. cit., pp. 194, 195.

${ }^{662}$ Benito Ruano, Eloy, "La historiografía... op. cit., pp. 74, 75.

${ }^{663}$ Isla Frez, Amancio, "La construcción de la monarquía en León, siglos X y XI: Historia y Leyes", en Martínez Sopena, Pascual y Rodríguez, Ana, La construcción medieval de la memoria ... op. cit., p. 42.

${ }^{664}$ Maravall, José Antonio, "La idea de Reconquista... op. cit., p. 24. Según Bizzarri y Rucquoi en su texto "Los espejos de Príncipes en Castilla: entre Oriente y Occidente", el Liber no solo era un conjunto de normas, sino que además, en sus primeras partes, indicaba al soberano como actuar con respecto a la
} 
goticismo dejaba de ser una idea abstracta, para convertirse en una realidad palpable, una indiscutida señal de que el Reino Visigodo aún se encontraba vigente. De esta manera se legitimaba por la ley lo que antes había sido sacralizado por la religiosidad, la idea de un pueblo unido, civilizado y poseedor de las virtudes que alguna vez lo habían hecho agradable a Dios.

A este hecho se agrega que en los territorios bajo el control musulmán, los cristianos que siguieron viviendo entre los musulmanes, convirtiéndose en mozárabes, mantuvieron durante algún tiempo el Liber como parte de su derecho tradicional e independiente de la sharia, como una manera de autorregular sus comunidades ${ }^{665}$. Esto permitió que, cuando se produjeron los primeros avances norteños hacia el sur, en torno al siglo XI, existiese un derecho común entre todos los cristianos, lo que exacerbó la noción de un pasado colectivo y renovó la idea de restauración de los antiguos modelos germanos. De ello fue consiente Alfonso VI, cuando después de la conquista de Toledo confirmó la vigencia del Liber Iudiciorum, basándose en la presencia de mozárabe en la población. Así se entiende que la ley visigótica se mantuviera durante los siglos siguientes, incluso coexistiendo con los modelos jurídicos de influencia franca que se introdujeron posteriormente en la Península ${ }^{666}$.

Gracias al establecimiento de las ideas goticistas y providencialistas, especialmente durante el reinado de Fernando I $(1037-1065)^{667}$, cuando pocos años

justicia, junto con otros consejos prácticos relacionados con su conducta. De esta manera, los autores afirman la vinculación entre la ley y el rey y como podía servir como modelo de comportamiento y aplicación del poder.

${ }^{665}$ Gacto Fernández, Enrique, Temas de Historia... op. cit., pp. 17, 25.

${ }^{666}$ Palacios Alcaine, Azucena, en Fuero Real... op. cit., pp. VIII, IX; y Gacto Fernández, Enrique, Temas de Historia... op. cit., pp. 17, 25, 28.

${ }^{667}$ En la Historia Silense/Legionense se procura alabar a los monarcas de Castilla y León, en oposición a sus rivales peninsulares. Es así como el cronista relata los enfrentamientos de Fernando I contra los navarros, elogiando al rey como un hombre piadoso, obligado a luchar pese a su naturaleza benigna y piadosa. Así nos lo recuerda Klinka, según el siguiente episodio de la Silensis en torno a los antecedentes de la batalla entre Fernando y García: "Ceterum Fernandus cum per omnia mansuetus et pius inueniretur, a naturali benignitate et solita pietate segmentarii aborrens; proposuerat in corde simulantes et fratris inuidiam utcumque ferret; ita quod nec ad iracundiam quidem ab eo prouocari potuisset, ratus sua scilicet gloria quandoque fraternam inuidiam sincere." (HS, 1959, op. cit., p. 185). Un episodio donde lo que se pretende es exaltar las virtudes religiosas de Fernando en oposición de García, que vendría a representar el modelo monárquico contrario. (Klinka, Emmanuelle, "Chronica naiarensis: de la traición... op. cit.)

Un relato que se cierra con la piadosa muerte del rey, narrada en la Historia Silense y la Chronica Naierensis. Fernando I sabiendo que pronto moriría pide ser trasladado a la iglesia, donde se postra en oración, se despoja de sus insignias reales, se somete simbólicamente a la autoridad de Dios, pide perdón por sus pecados y así, estando rodeado de un aura de piedad, muere rodeado de sacerdotes (HS, 1959, op. cit., pp.. 208, 209; y CN 1995, Liber II, $\mathrm{N}^{\circ}$ 1, op. cit., pp. 169-170). Es así entonces como el buen rey tiene una buena muerte, con lo que se entiende que su reino continuara por la senda cristiana y próxima a la Iglesia que Fernando señalo. 
después se produjo el arribo de los almorávides y el consecuente restablecimiento de la potencia islámica en la Península, los cronistas simplemente tuvieron que adaptar y revitalizar el discurso previamente creado $^{668}$. Pieza clave en esta nueva etapa de construcción del discurso fue la Historia Silense/Legionense, que postulaba la existencia de una continuidad con el pasado visigodo, al mostrar a la monarquía leonesa como descendiente directa de Recaredo y de paso validando los orígenes navarros de Alfonso $\mathrm{VI}^{669}$. La conversión de este rey había señalado una nueva etapa en el Reino Visigodo, ya que permitió fortalecer la creencia del pueblo bendecido, permitiendo a Isidoro y a otros cronistas tejer un halo de religiosidad sobre todas las instituciones, tradiciones e historias godas. A nuestro parecer, este fue el mismo discurso que se mantuvo luego de la invasión del 711. Por ello no es extraño que el cronista de la Silense/Legionense empalmara a los monarcas leoneses con aquel rey que había refundado el reino de los godos y sellado la alianza definitiva con la Iglesia. Hechos que además son respaldados por los relatos de las apariciones de Santiago e Isidoro para guiar a los monarcas y auxiliar al pueblo cristiano en su lucha contra sus enemigos. Es por ello que creemos que la aceleración de la Reconquista y la expansión territorial del reino coincide con un mayor esfuerzo cronístico por establecer un discurso legitimador basado en el linaje, de manera de trasmitir la idea de que Alfonso VI y sus descendientes no hacían más que reclamar lo que era suyo por derecho.

Para nosotros es evidente que, en su conjunto a partir del siglo XIII, las crónicas nos narran una relación cada vez más estrecha entre los soberanos y Dios, un hecho

Junto a lo anterior, Fernando I, por su vinculación con los siguientes reyes, en especial Alfonso VI y posteriormente el origen independiente de Castilla, fue una figura de relevancia en las crónicas de los siglos XII y XIII. La Historia Silense e incluso el Chronicon Mundi, procuraron destacar su linaje y legitimar a su descendencia, destacando para ello la ascendiente visigoda del rey (Martin, Georges, "Linaje y legitimidad en la historiografía... op. cit.)

${ }^{668} \mathrm{La}$ explicación para esta matización del discurso hay que buscarla en el contexto. Para el siglo XI el Califato de Córdoba llegaba a su fin, pero antes en sus últimos estertores, Al-Mansur había dado certeros golpes a los cristianos. En los años siguientes y mientras los lideres musulmanes se dividían en Taifas enfrentadas la guerra expansionista de los estados cristianos quedo semiparalizada en virtud del sistema de parias, en tanto que monarcas como Fernando I procuraban la consolidación de su poder y la reorganización política e ideológica de sus reinos. En otras palabras el siglo XI fue un periodo de transición en la península, donde las ideas políticas y religiosas se perfeccionaron y adaptaron a las nuevas circunstancias para reflotar con nuevos brios en el siglo siguiente, coincidiendo con los primeros grandes avances territoriales y las nuevas oleadas africanas.

${ }^{669}$ Isla Frez, Amancio, "La construcción de la monarquía en León, siglos X y XI: Historia y Leyes.", en Martínez Sopena, Pascual y Rodríguez, Ana, La construcción medieval de la memoria... op. cit., p. 35; Domínguez García, Javier, De Apóstol matamoros a Yllapa mataindios: dogmas e ideologías medievales en el (des)cubriminsto de América, Salamanca, Universidad de Salamanca, 2008, pp. 52, 53; Domínguez García, Javier, Memorias del futuro... op. cit., p. 83; y Bautista, Francisco, "Genealogía y leyenda", op. cit. 
fundamental si se piensa que estas crónicas estaban dirigidas a la elite del reino, la misma que con relativa frecuencia desafiaba a sus soberanos, en especial durante los periodos de minoría, como por ejemplo el de Alfonso VIII o de ascensos al trono, como los de Alfonso VI y Fernando III. Cada vez más, la figura del rey se convirtió en un símbolo religioso de justicia. Los reyes hispanos, en la línea del pensamiento isidoriano, habían renovado su alianza con Dios, y por ello sus reinos nada debían de temer mientras que ellos y sus monarcas no se desviaran del justo camino.

En relación a esta alianza renovada, las crónicas del "Toledano" y del "Tudense" supieron aunar el mito godo con los aspectos religiosos culturales para demostrar el abolengo de sus respectivos reinos, pero también crear puntos en común que ayudasen a la consolidación de un reino unido. En el caso de Lucas de Tuy, la idea goticista no fue algo nuevo, ya que como hemos dicho, la supuesta continuidad visigoda en León era un tópico antiguo ${ }^{670}$. En cambio, Jiménez de Rada debió tomar el mito, que si bien no era ignorado en Castilla, no contaba con el prestigio que tenía en los territorios leoneses. Es fundamental comprender que ambos reinos llevaban décadas de fiero antagonismo y que, por lo tanto, en un esfuerzo consciente, estos cronistas reforzaron la idea de un pasado común en un reino visigodo unido en la fe y en la victoria contra sus enemigos.

También es de destacar, por lo menos para el caso del "Toledano", que el mito visigodo se encontraba bastante más elaborado y perfeccionado -incluido el relato de Covadonga y Pelayo-. Si bien Jiménez de Rada fue el gran promotor de esta ideología, parece ser que consideraba que el pasado visigodo era más un modelo ideal que una realidad a restaurar. Por lo tanto, su discurso más que exponer un tema de linaje, se relaciona con una ideología política. Es en esta línea que procura describir y exaltar las virtudes guerreras y piadosas de los visigodos, siguiendo para ello las ideas que había expuesto Isidoro de Sevilla.

Es así como Jiménez de Rada en el capítulo IX de la De Rebus Hispaniae, explica los orígenes visigodos y hace de ellos una alabanza en la que destaca su bravura, su inteligencia y su amor por la libertad, sin olvidar atributos físicos, como la piel clara, quizás como una forma de diferenciarlos de los andalusíes:

"Libertatem semper bello quam pace pocius seruauerunt. In bellandi necessitate uires precibus pretulerunt, et in armis spectabiles, hastis et iaculis, arcubus et sagitis, ensibus atque clauis, equestri et pedestri prelio confligebant. Cura tamen

\footnotetext{
${ }^{670}$ Maravall, José Antonio, El concepto de España... op. cit., pp. 321-323; Mitre Fernández, Emilio, ¿Un sentimiento... op. cit., pp. 412, 413; y Guiance, Ariel, “Morir por la patria... op. cit., pp. 76, 77.
} 
equorum carior illis fuit. Telis et iaculis pro recreatione preludere affectabant. Ludorum certamina usu gerebant in armorum experiencia. Solo naualis belli exercicio caruerunt usque ad tempora Sisebuti, sub quo ad tantam gloriam peruenerunt ut uictoriarum insigniis non solum terras, set et ipsa maria subsulcarent. Fuerunt autem naturaliter magnanimi et audaces, ingenio faciles et subtiles, in proposito prouidi et constantes, gestu et habitu aprobandi, uiribus prepollentes, statura ardui et proceri, duri unlneris, manu prompti, corpore ualidi, menbris apti, disposicione compositi, coloris albi. ${ }^{, 671}$

El cronista de Toledo incluso llegó más lejos en su exaltación, al atribuir la derrota de Rodrigo no a los árabes, sino a los godos que luchaban junto a ellos. Postula entonces una interpretación que afirma que los godos sólo pudieron ser derrotados por ellos mismos, restándoles a los musulmanes toda virtud guerrera. No obstante, para "el Toledano", los visigodos no sólo eran un modelo virtuoso, ya que también describe algunos de sus defectos; los mismos que los llevaron a alejarse de Dios y a ser castigados. En este ejercicio, el cronista hace un trabajo de comparación, relatando el castigo divino, pero a la vez, también señalando la grandeza de los germanos: "Et quia diuina gracia protectionis manum elongauerant ab Hispanis, gens illa uitrix, gens illa nobilis, gens Gothorum cui se dederant Asia et Europa et eius fugacibus Vandalis Orbis cesserat Africanus, triumphis Arabicis incuruatur."

\footnotetext{
${ }^{671}$ HRH, Liber I, cap. IX, op. cit., p. 24. "Protegieron siempre su libertad más con la guerra que con la paz. En el trance del combate preferían la fuerza a las negociaciones, y al luchar eran de admirar manejando todo tipo de armas: lanzas y picas, arcos y flechas, espadas y mazas, a pie y a caballo. Sentían, con todo, una mayor predilección hacia los caballos. Con los dardos y las picas se divertían simulando los prolegómenos de la lucha. La experiencia de estos juegos la aplicaban luego al ejercicio de las armas. Solamente les faltó práctica en el combate naval hasta la época de Sisebuto, bajo el que alcanzaron tal gloria que recorrieron no sólo las tierras sino también los mares con las hazañas de sus victorias. Pese a todo fueron de un natural generoso y valiente, de inteligencia rápida y profunda, de intención precavida y tenaz, de maneras y porte más que regular, de fuerza sobresaliente, de estatura elevada y esbelta, resistentes a las heridas, rápidos de acción, poderosos de cuerpo, hábiles de manejo, proporcionados de figura, de tez clara.” HEH, Libro I, cap. IX, op. cit., p. 75.

${ }^{672}$ HRH, Liber III, cap. XX, op. cit., p. 103. "Y como la gracia de Dios había apartado de los hispanos su mano protectora, aquel pueblo triunfador, aquel pueblo noble, el pueblo de los godos a quien se habian rendido Asia y Europa y que habia hecho huir a los vándalos, ante quienes se había inclinado las tierras de África, es doblegado por la victoria de los árabes." HHE, Libro III, cap. XX, op. cit., p. 147.
} 
Junto con lo anterior, Jiménez de Rada señala también otros defectos de los visigodos, frente a los cuales no presenta mayores excusas, como es la narración de la violencia de Sancho contra sus hermanos, situación que se atribuye a su sangre goda ${ }^{673}$.

En definitiva, la obra del "Toledano" consagró las ideas del goticismo, y junto con Lucas de Tuy, se convirtió en la base de las posteriores crónicas, siendo ambas sintetizadas en la Historia General de Alfonso $\mathrm{X}^{674}$, en la que se integra plenamente al discurso oficial de validación de la monarquía hispana. Se cierra así un ciclo discursivo iniciado por los astures y consolidado como una de las herramientas más importantes para la validación monárquica y la expansión militar hacia el sur.

Junto a lo anterior, podemos constatar que para mediados del siglo XIII, que si bien los visigodos se mantuvieron como parte importante del discurso cronístico de la Reconquista, no fueron la única fuente de validación, como se desprende del siguiente gráfico:

\section{Gráfico 1: Linaje visigodo y linajes posteriores}

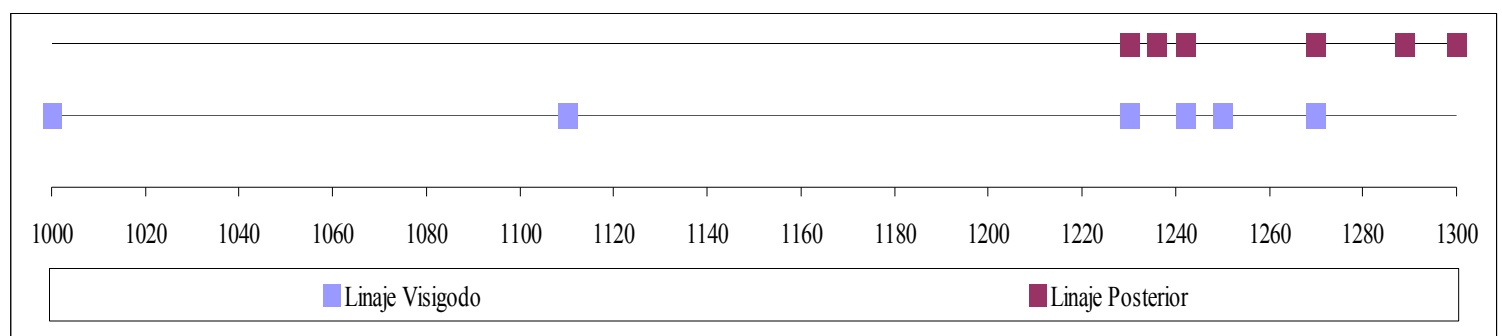

A partir de la elaboración de la Crónica Latina de los reyes de Castilla en la década de 1230, se puede observar cómo, sin perder de vista el linaje visigodo, los cronistas comenzaron a resaltar otras formas de legitimación por herencia ${ }^{675}$. En este caso concreto, el cronista inicia su relato aludiendo directamente a la tradición castellana:

"Defuncto comite Fernando Gundissalui, qui Primus tenuit comitatum in Castella post subuersionem populi Christiani tempore Roderici, regis Gotorum, factam in Yspaniis, succesit ei filius eius, comes Garsias Fernandi, cui succesit filius, comnes Sancius, cuius filius, Garsias infans, interfectus fuit apud

\footnotetext{
${ }^{673}$ HRH, Liber VI, cap. XIV, op. cit., p. 194.

${ }^{674}$ Martín, José Luis; "Reconquista y cruzada...op. cit., pp. 232, 333.

${ }^{675}$ Ver gráfico y tabla $\mathrm{N}^{\circ} 1$.
} 
Legionem, cum iuisset ut duceret in uxorem filiam regis uel cuiusdam comitis,

per quosdam Legionenses"

El episodio narrado sintetiza la historia de España sin hacer una extensa narración de los sucesos históricos anteriores, aunque rescatando lo esencial: la caída de los visigodos, el origen del condado castellano y la rivalidad de éste con León.

De manera menos castellanista, podemos observar la tendencia a recordar el linaje inmediato en textos como el Cronicon Mundi y el De Rebvs Hispaniae, donde Jiménez de Rada realiza una prolongada alabanza a Fernando I, antes de narrar el reinado de su hijo Alfonso $\mathrm{VI}^{677}$. El arzobispo pone además especial cuidado en constatar en apartados diferentes las virtudes de algunos reyes, trasmitiendo la idea de una sucesión de monarcas virtuosos ${ }^{678}$.

En la misma línea también destaca la Crónica General, que basándose en los textos del "Tudense" y "el Toledano", incorpora un evento nuevo vinculado a la exaltación del linaje. Se trata de los capítulos 1131, 1132 y 1133 donde se exalta la figura de Fernando III y se narra su piadosa muerte y cómo entregó el reino a Alfonso $\mathrm{X}$, encomendándole la protección del mismo y de su gente. Es así que se entiende la existencia de expresiones como: "en los quales fechos et en la qual uida el mientras visco siempre seruio a Dios lealmiente ${ }^{, 679}$.

${ }^{676}$ CLRC, 1997, № 1, op. cit., p. 35. “Cuando murió Fernán-González, el primer conde de Castilla después de la derrota que los cristianos sufrieron en España en tiempos de Rodrigo, rey de los godos, le sucedió su hijo el conde Garcia-Fernández; a éste el suyo, el conde Sancho. Un hijo de este Sancho, el infante García, cuando fue a León para casarse con una hija del rey o de un conde, cayó muerto a mano de ciertos leoneses." CLRC, 1999, $\mathrm{N}^{\circ}$ 1, op. cit., p. 25.

677 "El Toledano", en el libro VI, capítulo XIII, de su crónica, realiza una semblanza de Fernando I centrándose especialmente en su piedad y devoción, describiéndonos como realizó obras piadosas y donaciones, para terminar narrándonos como el mismo San Isidoro se le apareció para vaticínales su pronta muerte a fin de que se aprontase a morir de forma cristiana: "Sed iam uite sibi termino inminente apparuit ei beatus Isidorus et diem suit obitus intimauit" (HRH, Liber VI, cap. XIII, opcit., p. 193). No deja de ser significativo el hecho que a continuación en cronista nos narre como el reino se vio aquejado por las luchas entre Sancho, García y Alfonso y como el reinado de este ultimo estuvo precedido por distintas señales provisorias, que señalaban de forma temprana como la Providencia velaba por el futuro rey, previniendo lo que serian sus futuras glorias.

En relación a lo anterior Beceiro Pita destaca que en su conjunto las fuentes de los siglos XII y XIII resaltaron a Alfonso VI, Alfonso VIII y Fernando III, como grandes monarcas que por sus logros fueron utilizados para validar el linaje de sus descendientes, al tiempo que también servían como modelos de conducta para el conjunto de la nobleza de sus reinos (Beceiro Pita, Isabel, "La legitimación del linaje... op. cit., pp. 96, 97).

${ }^{678}$ Ejemplo de ello lo podemos ver claramente en el: Libro IV, capítulos 8, 12, 14, 15, 16; Libro V, capítulos 19, 21, 24; Libro VI, capítulos 1, 5, 9, 13, 16, 21; Libro VII, capítulos 4, 5, 12, 17, 18, 19; Libro VIII, capítulos 4, 15; Libro IX, capítulos 10, 12.

${ }^{679}$ CGE, cap. 1131 , op. cit., p. 770. 
Además, lo califica de "muy iustiçiero", de "buen entendimiento, muy sabidor; et muy brauo et muy sannudo", destacando también que fue "enxalçador de cristianismo, abaxador de paganismo, mucho omildoso contra Dios" у "muy catholico, muy ecclesiastico, mucho amador de la yglesia" ${ }^{680}$. A continuación narra cómo el rey encomendó el reino a su hijo, haciéndole jurar respetar a sus vasallos y sus leyes ${ }^{681}$ para finalmente realizar una serie de actos de penitencia rogando a Dios el perdón de sus pecados y entregándole humildemente su alma ${ }^{682}$. Un relato que no sólo exaltaba al difunto rey, sino que sirve para señalar la continuidad de las obras de Fernando III, ahora bajo el liderazgo de Alfonso X.

Finalmente, en la Crónica de Veinte reyes, se sigue la misma pauta del texto alfonsino, reuniendo en su interior muchos de los episodios de las crónicas anteriores, destacando entre otras, los ocurridos en torno a la figura del castellano Fernán Gonçalez, para terminar con una alabanza a Fernando III ${ }^{683}$.

Por lo general, se trata de referencias acotadas tendientes a destacar los ascendientes directos de los monarcas, sus padres y abuelos, apelando así a una tradición más cercana y conocida ${ }^{684}$. Posiblemente este hecho se deba, en primer lugar a la unión de Castilla y León en 1230, y a la necesidad de legitimar este acto a través de la exaltación de los antepasados directos de Fernando III. Era necesario que los padres y abuelos del rey fuesen destacados en forma equitativa, para así equilibrar la tradición e importancia de ambos reinos. Ambos linajes estaban cubiertos de gloria y habían compartido la misión de la Reconquista, por lo que el nuevo reino y su rey, venía a simbolizar la alianza entre ambas tradiciones gloriosas.

Quizás el caso más evidente es el de Lucas de Tuy, quien en su Cronicon Mundi, alaba la figura de Fernando III, haciendo referencia a su ascendencia directa: "[...] quod

\footnotetext{
${ }^{680}$ CGE, cap. 1131 , op. cit., p. 771.

${ }^{681}$ Entre otros aspectos en el mencionado juramento Fernando hizo prometer a Alfonso el cuidado y honra de sus hermanos y su madre, así como del hermano del rey don Alfonso de Molina y sus hermanas. Que respetase a sus caballeros y vasallos, así como guardase bien sus fueros y libertades. Agregando que si esto cumplía recibiría su bendición o de lo contario se haría merecedor de su maldición. (CG. cap. 1132, op. cit., p. 772).

${ }^{682}$ CGE, cap. 1133 , op. cit., p. 773.

${ }^{683}$ CXXR, Libro II, capítulos 1 al 12 y Libro XV, capítulos 82, 83, 84 y 85. Es importante recordar que esta crónica copia, en distintas partes, casi de forma textual a la Crónica General, por lo que discursivamente no representa un aporte novedoso.

${ }^{684}$ Esta exaltación dinástica fue un elemento común en la cronística del periodo. Para el siglo XII la idea del linaje se había introducido como uno de los elementos que aseguraban la legitimidad del soberano. Así los cronistas procuraron exaltar los matrimonios reales y su descendencia como parte de su discurso. Un caso especialmente claro al respecto fue el del autor de la Crónica Latina, que destaca la concepción de que el poder de reinar se trasmitía de padres a hijos, producto de un matrimonio canónicamente legitimado (Rodríguez, Ana, "Modelos de legitimidad política... op. cit.)
} 
requieuerit super eum spiritus sapiencie, qui in Adefonso rege Castelle auo suo, et spiritus fortitudinis et clemencie, qui erat in Adefonso rege Legionense patre ipsius" ${ }^{\prime 65}$. De esta forma, procuraba igualar y hermanar a su padre y abuelo, pese a las rivalidades que marcaron la existencia de ambos monarcas.

Una segunda razón que explicaría este fenómeno, es que para el siglo XIII el estado de avance de la Reconquista permitió a los cronistas recurrir a modelos reales más cercanos y recientes, cuyas acciones eran fácilmente identificables y conocidas. Tampoco es casualidad que los personajes referenciados en ellas, como Alfonso VI, Alfonso VII y Fernando III, no sólo fuesen conquistadores, sino que gobernaron sobre los reinos unidos de Castilla y de León. Creemos que tampoco es coincidencia que que esta tendencia se hiciera más patente bajo la influencia de Alfonso X.

De esta manera, nosotros consideramos, que los cronistas supieron aprovechar y tornar a su favor las distintas tradiciones castellanas y leonesas para aunarlas y reforzar la función de ambas monarquías. Todo ello sin perder de vista el tronco común que las unía: su sangre visigoda y la misión de recuperar las tierras de España para la cristiandad.

\footnotetext{
${ }^{685} \mathrm{CM}$, Liber IV, $\mathrm{N}^{\circ}$ 93, op. cit., p. 333. “[...] assi que fue visto que folgó sobrél [el] spiritu de sabiduria que fue en Alfonso rey de Castilla, su abuelo, y el espiritu de fortaleza y clemençia que era en Alfonso su padre, rey de León." CE, Libro IV, cap. LXXXV, op. cit., p. 418.
} 
Tabla 1: Linaje visigodo y linajes posteriores

\begin{tabular}{|c|c|c|c|}
\hline & Linaje Visigodo & Linaje Posterior & Fuente \\
\hline 1000 & $\mathrm{X}$ & & $\begin{array}{l}\text { - CAIII Rotense } \mathrm{N}^{\circ} 10 \text { p. 204. CAIII Sebastian } \mathrm{N}^{\circ} 8 \\
\text { p. } 201, \mathrm{~N}^{\circ} 9 \text { p. } 205, \mathrm{~N}^{\circ} 13 \text { p. } 207 .\end{array}$ \\
\hline \multicolumn{4}{|r|}{$\mathrm{F}^{\mathrm{n}}$} \\
\hline \multicolumn{4}{|l|}{1100} \\
\hline 1110 & $\mathrm{X}$ & & - CS/L p. 21.22 \\
\hline \multicolumn{4}{|l|}{1120} \\
\hline \multicolumn{4}{|l|}{1130} \\
\hline \multicolumn{4}{|l|}{1140} \\
\hline \multicolumn{4}{|l|}{1150} \\
\hline \multicolumn{4}{|l|}{1160} \\
\hline \multicolumn{4}{|l|}{1170} \\
\hline \multicolumn{4}{|l|}{1180} \\
\hline \multicolumn{4}{|l|}{1190} \\
\hline \multicolumn{4}{|l|}{1200} \\
\hline \multicolumn{4}{|l|}{1210} \\
\hline \multicolumn{4}{|l|}{1220} \\
\hline 1230 & $\mathrm{X}$ & $\mathrm{X}$ & $\begin{array}{l}\text { - CM Liber IV, Cap. } 85 \text { p. } 417,418 \\
\text { - CLRC N} 1 \text { p. } 25\end{array}$ \\
\hline 1240 & $\mathrm{X}$ & $\mathrm{X}$ & $\begin{array}{l}\text { - HRH Liber I, Cap. } 9 \text { p. } 74,75 . \text { Liber VI Cap. } 14 \text { p. } \\
237 \text { Liber VII Cap 21. p. } 290\end{array}$ \\
\hline 1250 & $\mathrm{X}$ & & - PFG No $15-25$ p. 246,247 \\
\hline \multicolumn{4}{|l|}{1260} \\
\hline 1270 & $\mathrm{X}$ & $\mathrm{X}$ & $\begin{array}{l}\text { - ICG Cap. 566, } 567 \text { p. 321, 322, Cap. } 1132 \text { p. } 772 \text {, } \\
773 \\
\text { - CXXR Liber II Cap. } 6 \text { p. } 89\end{array}$ \\
\hline 1280 & & & \\
\hline 1290 & & & \\
\hline 1300 & & $\mathrm{X}$ & - II CS No 84 p. 140 \\
\hline
\end{tabular}




\section{II.4.b.- Virtudes religiosas}

Como hemos podido constatar, los cronistas se esforzaron por vincular a los monarcas leoneses y castellanos con los reyes visigodos, Recaredo y Pelayo, siendo evidente que las virtudes religiosas debían ocupar un rol esencial en dicho discurso. Fue así como dentro de la temática religiosa se pueden identificar varios tópicos, siendo el primero y el más utilizado, la imagen el rey como un protegido o auxiliado por Dios, que entre sus principales funciones estaba velar por la restauración de la Iglesia en la Península, y vivir bajo sus preceptos. Razón por la cual se mostraba al monarca como un individuo al servicio de Dios, e incluso en ocasiones, como un instrumento directamente manejado por la Providencia.

Estas distintas categorías no siempre se daban simultáneamente en todos los reyes, y en algunos casos su aparición cronística fue más tardía. Es así como el tópico del rey como un protegido o auxiliado por Dios lo podemos observar entre los años de 1110 y 1280, principalmente en las crónicas Silense/Legionense, Compostelana, Anónima de Sahagún, Pelayo, Adefonsi Imperatoris, Najerense, Latina, el Cronicon Mundi, De Rebus Hispaniae, Crónica general, de Veinte reyes y en otras obras como las Cantigas, como se evidencia en el siguiente gráfico. Así como la existencia de un importante vacío literario entre 1180 y 1210 , que coincide con una menor actividad cronística y el estancamiento de la Reconquista luego de la invasión almorávide.

\section{Gráfico 2: Virtudes religiosas}

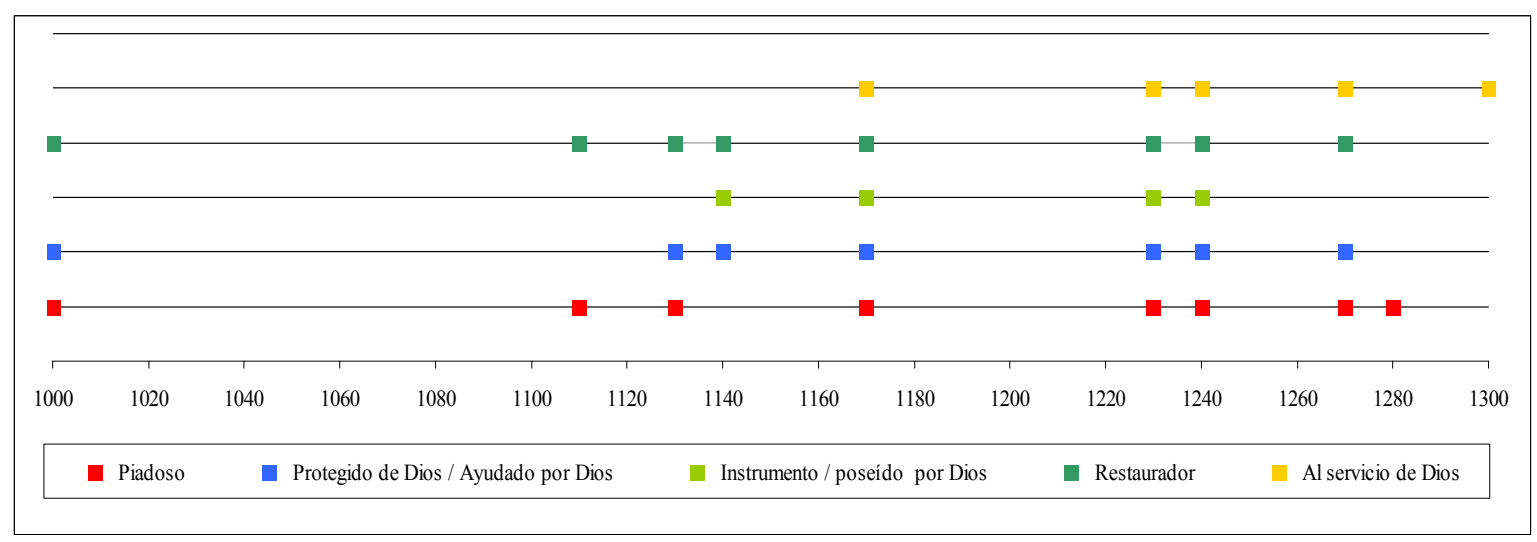

Por su parte, el arquetipo del rey como ejemplo de piedad tuvo un uso frecuente en los mismos años y se observa prácticamente en todas las crónicas mencionadas, a 
excepción de la Adefonsi Imperatoris, en que el tema de la piedad del soberano no es tratado como un factor relevante y sólo se insinúa en oposición a los actos de su adversario Alfonso de Aragón. Nosotros entendemos que el uso del concepto hacía referencia al monarca como un fervoroso practicante de la religión y muy respetuoso de la Iglesia y del cristianismo en general, algo que según los autores, hubiese sido imposible sin una especial comunión con Dios. Este hecho evidentemente reforzaba la imagen del monarca como líder de una sociedad creyente ${ }^{686}$.

No obstante, como se observa en el gráfico, el rey presentado como aquel que estaba al servicio de Dios, sólo aparece de forma tardía, en las crónicas desde 1170 e intensificándose a partir de 1230; es decir, coincidiendo con el periodo de mayor expansión y consolidación monárquica y coincidiendo con la corriente ideológica europea que estaba construyendo una nueva imagen real. El rey al servicio de Dios venía a reforzar la idea de un monarca piadoso y humilde, que se entregaba completamente a una causa superior y que a cambio recibía del Altísimo una legitimación ante sus adversarios y el respaldo a sus decisiones. Es así, como se evidencia en el gráfico anterior, como las crónicas que explícitamente incluyen este tópico son la Najerense, el Cronicon Mundi, De Rebus Hispaniae y la Crónica General. Cuatro obras que, como sabemos, representan una clara continuidad ideológica a la vez que la consolidación del discurso validador.

De forma complementaria, a partir de la evidencia graficada, hemos podido constatar que el uso del tópico del rey como un instrumento utilizado directamente por Dios es el menos frecuente, y sólo aparece directamente en relación a los monarcas Alfonso VII, Alfonso VIII y Fernando III. Tres reyes también definidos como guerreros, y en el caso de los dos últimos, también protagonistas de acciones militares decisivas contra el Islam. Concretamente podemos observar este uso en las crónicas Adefonsi Imperatoris, Najerense y De Rebus Hispaniae ${ }^{687}$. Esto no significa que no se utilice o insinúe en otras, pero es en éstas obras donde se relatan episodios que manifiestan expresamente las ideas antes referidas ${ }^{688}$. Así, estas obras trasmitían la idea de una comunión máxima entre el rey (el poder político) y la divinidad (el poder espiritual), unidos en la lucha contra el enemigo común y llamados a regir al pueblo cristiano.

\footnotetext{
${ }^{686}$ Ver gráfico y tabla $\mathrm{N}^{\circ} 2$.

${ }^{687}$ Ver gráfico y tabla $\mathrm{N}^{\circ} 2$.

${ }^{688}$ Entre las otras obras en que existe una idea de un Dios que influenciaba los actos del monarca se puede destacar la Crónica Latina de los Reyes de Castilla, al respecto ver Bronisch, Alexander Pierre, "La ideología asturiana... op. cit., p. 450.
} 
Hemos dejado para el final el tópico de la restauración eclesiástica, el segundo de más incidencia en las fuentes. Ello en razón de que simboliza la aplicación práctica del discurso religioso de unión entre la Iglesia y la monarquía, así como una vinculación directa con el atributo del linaje. Este tópico hace referencia a las acciones monárquicas destinadas a la fundación y refundación de diversas instituciones cristianas en los territorios arrebatados al Islam. Nos referimos al establecimiento de diócesis, obispados, monasterios y parroquias, basándose en los antiguos ordenamientos eclesiásticos visigodos, que a la vez servían de instrumento propagandístico para exaltar el triunfo del cristianismo y el restablecimiento del antiguo orden ${ }^{689}$. Dicha función restauradora es frecuentemente referenciada, aunque no son muchos los testimonios específicos sobre la organización de la Iglesia asturiana, en los años inmediatos al $711^{690}$. Fuentes, como la Crónica Mozárabe, Profética, Crónica de Alfonso III, la Crónica Albeldense y la Crónica de Sampiro, coinciden en situar a los soberanos como responsables del nombramientos de obispos, diócesis y de construir o reconstruir iglesias y monasterios $^{691}$. A modo de ejemplo, en la Crónica de Alfonso III se nos dice de Pelayo que "restauratur ecclesia" y se narra cómo Favila manda construir una basílica en honor de la Santa $\mathrm{Cruz}^{692}$. También Alfonso II es descrito como un constructor de iglesias, repitiéndose casi el mismo relato en las crónicas de Alfonso III y en la

\footnotetext{
689 Martínez Sopena, Pascual, “Introducción”, en Martínez Sopena, Pascual y Ana Rodríguez, La construcción medieval de la memoria regia, Valencia, Publicacions de la Universitat de València, 2011, p. 15. De la misma obra tambien citamos Reglero, Carlos, "Restauración diocesana y memoria regia en León y Castilla", pp. 93, 97, 102. También ver Bronisch, Alexander Pierre, "La ideología asturiana..., op. cit., p. 434

${ }^{690}$ Creemos que esto puede deberse a diversas razones, quizás porque fue una época donde lo que importaba a los autores era relatar el papel de los guerreros y de los líderes que fundaron el Reino Astur. Así como también es posible que los primeros cronistas, en forma intencionada evitasen referirse a la Iglesia para omitir el hecho de que muchas de sus autoridades se habían entregado o pactado con los musulmanes. En ese sentido, no deja de ser significativo que en los relatos de las primeras luchas, en especial en la batalla de Covadonga, no se destaque la presencia de clérigos entre la hueste de Pelayo, pero en cambio, sí se destaque la figura del Obispo Opas de Toledo, el traidor, que en nombre de los árabes llamó a los cristianos a rendirse. Más significativo aún es el hecho de que en la batalla, la ayuda divina se produce sin la intercesión de los clérigos, demostrando así la unión directa entre el nuevo rey y Dios.

Sobre la situación de la iglesia visigoda, en relación a su estado de desorganización, la Crónica Najerense nos da una significativa pista. Según este texto, Pelayo urde su rebelión pensando en la Iglesia, como si ésta sintetizase la cristiandad y el Estado visigodo: "Set quod iam cogitauerat de saluatione ecclesie cum omni animositate agere festinauit" (CN 1995, Liber II, $\mathrm{N}^{\circ}$ 2, op. cit., p. 98.)

$\mathrm{Si}$ bien es cierto que este es un relato indirecto y posterior a los hechos, es posible intuir que la intención del mismo fue la de demostrar la unión de los poderes políticos y religiosos en el Reino Astur, para sostener la idea de la continuidad goda y el sometimiento de la Iglesia a la figura del monarca, al que debía su supervivencia.

${ }^{691}$ Ver gráfico y tabla $\mathrm{N}^{\circ} 2$.

${ }^{692}$ CAIII, versión Rotensis y ad Sebastianum, $\mathrm{N}^{\circ} 11$, op. cit., pp. 130, 131.
} 
Albeldense $^{693}$. Por su parte, en la Crónica de Sampiro, se identifica claramente a Alfonso III con la restauración eclesiástica "Quoque tempore ejes est ampliata ecclesia; namque populantur a christianis urbes portugallensis, bracharensis, vesensis, flaviensis, auriensis et secundum sententiam canonicam ordinantur episcopi et producitur populando usque ad flumen Tagum" ${ }^{\text {,94. }}$.

La misma fuente cita el caso de Ordoño II con respecto a la reorganización de la sede episcopal de León y a la construcción de varias iglesias ${ }^{695}$. A partir de estos relatos y otros similares, se puede constatar la intención cronística de mostrar a los reyes como los constructores de la nueva Iglesia. Esto no solamente significaba edificar los templos, puesto que cada nueva fundación se traducía en la designación de los clérigos que la tendrían a su cargo ${ }^{696}$. Una tendencia narrativa que continuó en las obras de los siglos siguientes, destacando el rol restaurador como una de las funciones de los monarcas de Castilla y León. Una idea que aparece expresada a partir del relato de Covadonga con las palabras de Pelayo que prometen la restauración eclesiástica ${ }^{697}$. Un discurso que sería repetido por los cronistas de los siglos XII y XIII (Lucas de Tuy, Jiménez de Rada y Alfonso $\mathrm{X}$, solo por mencionar algunos), coincidiendo con la conquista de importantes territorios musulmanes en el sur de la Península.

${ }^{693}$ CAIII, versión Rotensis y ad Sebastianum, $\mathrm{N}^{\circ}$ 21, op. cit., pp. 138, 139; y CA, Cap. XV, No 9, op. cit., pp. 174,175

${ }^{694}$ Chronicon Sampiri Episcopi Asturicensis, en Crónicas Latinas de la Reconquista, Tomo I, op. cit., pp. 243, 245 (En adelante CSEA). "También en tiempo de él fue ampliada la iglesia; pues se pueblan por los cristianos las urbes de Oporto, Braga, Viseo, Chaves, Orense y según la sentencia canónica se ordenan obispos y se extiende poblando hasta el río Tajo." CSEA, op. cit., pp. 244, 246.

${ }^{695}$ CSEA, op. cit., pp. 273, 275.

${ }^{696}$ Esta función restauradora no estuvo exenta de conflictos, puesto que si bien los obispos seguían sujetos al patronazgo real, comenzaron a demostrar su independencia, tratando de limitar las injerencias del monarca. Caso emblemático fueron las pugnas con Bermudo III, en las cuales los obispos se inclinaron por la causa de Sancho de Pamplona, y posteriormente se aliaron con Fernando I (De Ayala Martínez, Carlos, Sacerdocio y Reino... op. cit., p. 259). Si bien, en ningún caso esto demuestra que la Iglesia asturiana-leonesa podía considerase autónoma en relación a los monarcas, sí señala que los obispos tampoco se mostraron del todo dóciles y obedientes, y que por el contrario, se oponían a aquellos monarcas que amenazaran sus intereses.

Por estas razones es que la monarquía procuró controlar a la iglesia local. Debemos recordar que esta relación no se dio únicamente en la Península, sino que fue una situación común en la mayoría de los territorios de la cristiandad, donde era frecuente que los monarcas y otros poderes seculares interviniesen en la Iglesia, especialmente, mediante la designación de los obispos y abades, dada su importancia dentro de las dinámicas de vasallaje. Para el caso particular del Reino Astur-Leonés, los monarcas inicialmente comenzaron la práctica del patronato, siguiendo el modelo visigodo; es decir, designando a un candidato ante la asamblea eclesiástica para su aprobación. Este sistema, sumado al poder efectivo del monarca, aseguraba la elección del favorito del rey, otorgándole a este un amplio poder sobre la estructura y decisiones de la Iglesia (O'Callaghan, Joseph, Las Cortes de Castilla y León. 1188-1350, Valladolid, Ámbito, Cortes de Castilla y León, 1989, p. 10; Vara Thorbeck, Carlos, El lunes...op. cit., pp. 128, 129).

${ }^{697}$ CAIII, versión Rotense, № 9, op. cit., pp. 202, 204; y CAIII, versión A Sebastian, № 9, op. cit., pp. $203,205$. 
Tabla 2: Virtudes religiosas

\begin{tabular}{|c|c|c|c|c|c|c|}
\hline & Piadoso & $\begin{array}{l}\text { Protegido } \\
\text { de Dios / } \\
\text { Ayudado } \\
\text { por Dios }\end{array}$ & \begin{tabular}{|l|}
\multicolumn{2}{|l|}{ Instrumento $/$} \\
Poseído por \\
Dios
\end{tabular} & Restaurador & $\begin{array}{l}\text { Al servicio } \\
\text { de Dios }\end{array}$ & Fuente \\
\hline 1000 & $X$ & 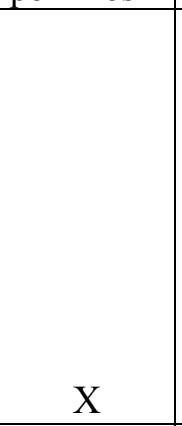 & & $X$ & & $\begin{array}{l}\text { - CAIII Rotense } \mathrm{N}^{\circ} 1 \text { p. } 196, \\
\mathrm{~N}^{\circ} 13 \text { p. } 206, \mathrm{~N}^{\circ} 15 \text { p. } 208, \\
\mathrm{~N}^{\circ} 21 \text { p. } 212, \mathrm{~N}^{\circ} 25 \text { p. } 218 . \\
\text { CAIII Sebastian } \mathrm{N}^{\circ} 1 \text { p. } 197, \\
\mathrm{~N}^{\circ} 13 \text { p. } 207, \mathrm{~N}^{\circ} 15 \text { p. } 209 \\
\mathrm{~N}^{\circ} 21, \text { p. } 213, \mathrm{~N}^{\circ} 22, \text { p. } 215 . \\
\mathrm{CA} \mathrm{N}^{\circ} 2, \mathrm{~N}^{\circ} 3 \text { p. } 247, \mathrm{~N}^{\circ} 3 \\
\text { p. } 248, \mathrm{~N}^{\circ} 12 \text { p. } 252 \\
\text { - CSEA pp. } 244,272,274, \\
275,286,288\end{array}$ \\
\hline \multicolumn{7}{|l|}{1090} \\
\hline \multicolumn{7}{|l|}{1100} \\
\hline 1110 & $X$ & & & $X$ & & $\begin{array}{l}\text { - CAS N } 6 \text { p. } 13 \\
\text { - CS/L p. } 26.56 .82 .132 .152\end{array}$ \\
\hline \multicolumn{7}{|r|}{ P. } \\
\hline 1130 & $X$ & $X$ & & $X$ & & $\begin{array}{l}\text { - HC Liber I Cap. } 46 \text { p. } 152 . \\
153 \\
\text { - COP p. } 179,180.181\end{array}$ \\
\hline 1140 & & $X$ & $X$ & $X$ & & $\begin{array}{l}\text { - CAI Prefacio p. } 61 \text {, Liber I } \\
\mathrm{N}^{\circ} 1 \text { p. } 63, \mathrm{~N}^{\circ} 10 \text { p. } 67 \mathrm{~N}^{\circ} 15 \\
\text { p } 68, \mathrm{~N}^{\circ} 27 \text { p. } 72, \mathrm{~N}^{\circ} 29 \text { p. } 73, \\
\mathrm{~N}^{\circ} 71 \text { p. } 85\end{array}$ \\
\hline 1150 & & & & & & \\
\hline \multicolumn{7}{|l|}{1160} \\
\hline 1170 & $X$ & $X$ & $X$ & $X$ & $X$ & $\begin{array}{l}\text { - CN Liber II } \mathrm{N}^{\circ} 2 \text { p. } 113, \mathrm{~N}^{\circ} \\
20 \text { p. } 129, \mathrm{~N}^{\circ} 25 \text { p. } 136 . \mathrm{N}^{\circ} \\
29 \text { p. } 141 . \mathrm{N}^{\circ} 39 \text { p. } 151 . \text { Liber } \\
\text { III } \mathrm{N}^{\circ} 7 \text { p. } 164, \mathrm{~N}^{\circ} 3 \text { p. } 159\end{array}$ \\
\hline \multicolumn{7}{|l|}{1180} \\
\hline \multicolumn{7}{|l|}{1190} \\
\hline \multicolumn{7}{|l|}{1200} \\
\hline \multicolumn{7}{|l|}{1210} \\
\hline \multicolumn{7}{|l|}{1220} \\
\hline 1230 & $X$ & $X$ & $X$ & $X$ & $X$ & $\begin{array}{l}\text { - CM Prologo p. 1, 2, Liber } \\
\text { IV, Cap. } 4 \text {, p. } 276 \text {, Cap. } 14 \text {, p. } \\
\text { 284, Cap. } 60 \text { pag. } 361 \text {, Cap. } \\
68 \text { p. } 372, \text { Cap. } 85 \text { p. } 417-419 \text {, } \\
\text { Cap. } 91 \text { p. } 424, \text { Cap. } 95 \text { p. } \\
431 . \\
\text { - CLRC } N^{\circ} 2 \text { p. } 27, N^{\circ} 18 \text { p. } \\
46, N^{\circ} 48 \text { p. } 79, N^{\circ} 61 \text { p. } 92 \text {, } \\
N^{\circ} 70 \text { p. } 98, N^{\circ} 72 \text { p. } 100\end{array}$ \\
\hline & & & & & & \\
\hline
\end{tabular}




\begin{tabular}{|c|c|c|c|c|c|c|}
\hline & Piadoso & $\begin{array}{l}\text { Protegido } \\
\text { de Dios / } \\
\text { Ayudado } \\
\text { por Dios }\end{array}$ & $\begin{array}{l}\text { Instrumento } / \\
\text { Poseído por } \\
\text { Dios }\end{array}$ & Restaurador & $\begin{array}{l}\text { Al servicio } \\
\text { de Dios }\end{array}$ & Fuente \\
\hline 1240 & X & $X$ & $X$ & $X$ & $X$ & $\begin{array}{l}\text { - HRH Liber II Cap. } 15 \\
\text { p.108, Liber III Cap. IX } \\
\text { p.132. Liber IV Cap } 1 \text { p. } 159 \text {, } \\
\text { Cap } 2 \text { p. } 161 \text {, Cap. } 5 \text { p. } 165, \\
\text { Cap. } 6 \text { p. } 167 \text {, Cap } 8 \text { p. } 169 . \\
\text { Cap } 13 \text { p } 176,177 \text {, Cap. } 15 \\
\text { p. } 181 \text {, Cap } 5 \text { p. 197, Liber VI } \\
\text { Cap. } 10 \text { p. } 232 \text {, Cap. } 13 \text { p.236, } \\
\text { Cap. } 21 \text { p. } 246 . \text { Liber VII Cap } \\
19 \text { p. } 289 \text {, Cap } 24 \text { p.296, Cap. } \\
27 \text { p.297 }\end{array}$ \\
\hline \multicolumn{7}{|l|}{1250} \\
\hline \multicolumn{7}{|l|}{1260} \\
\hline 1270 & $X$ & $X$ & & $X$ & $X$ & $\begin{array}{l}\text { - CGE. Cap } 580 \text { p. } 330 \text {, } \\
\text { Cap.614-616 p } 348-349 \text {, Cap. } \\
\text { 629 p 359, Cap. } 782 \text { p. } 467 \text {, } \\
\text { Cap. } 846 \text { p.520, Cap } 1038 \text { p } \\
\text { 722, Cap. } 1131 \text { p. } 771 \text {, Cap. } \\
\text { 1133 p.773. } \\
\text { - CXXR Liber II Cap. } 4 \text { p. } 88 \text {, } \\
\text { Liber VIII Cap } 1 \text { p.165, Liber } \\
\text { X Cap. } 1 \text { p. } 201 \text {, Cap. } 25 \text { p. } \\
\text { 214, Liber XV Cap } 80 \text { p. } 346- \\
\text { 347 }\end{array}$ \\
\hline 1280 & & & & & & \\
\hline \multicolumn{7}{|l|}{1290} \\
\hline 1300 & & & & & $X$ & $\begin{array}{l}\text { - CAX Cap } 3 \text { p. 12, Cap } 6 \text { p. } \\
\text { 16, Cap } 74 \text { p. } 210\end{array}$ \\
\hline
\end{tabular}




\section{II.4.c.- Validación Bélica}

Como ya hemos señalado anteriormente, la herencia visigoda y la conducta religiosa eran una de las principales vertientes de validación de los monarcas castellanoleoneses, pero no las únicas. También jugaban un rol fundamental en el imaginario legitimador, las victorias que el rey lograse contra sus enemigos -en especial los musulmanes- presentándose como un activo "reconquistador". El rey tenía la misión prioritaria de proteger su reino, a lo que con el pasar del tiempo se agregó la función discursiva de recuperar los territorios visigodos. Estos ideales convivían con la realidad que ya hemos mencionado, impulsando la guerra y la captura de los bienes del enemigo.

La sociedad andalusí se había enseñoreado sobre las tierras más fértiles de Hispania y su sociedad urbana y mercantil era prodiga en riquezas ${ }^{698}$. Todo ello la hacía atractiva para los reyes del norte que ambicionaban sus recursos ${ }^{699}$. Es decir, según nuestras conclusiones, que la guerra de reconquista comenzó motivada por razones políticas y económicas, expresadas a través, primero, de la paulatina ocupación de las tierras del Duero, en paralelo a la aplicación de diversas formas de expoliar los recursos andalusíes. No fue sino con posterioridad, entre otros gracias a Fernando I, que el elemento religioso fue cobrando mayor importancia, como parte de un discurso propagandístico que reforzaba la acción guerrera de los soberanos.

Sin embargo, como veremos a continuación, las ideas religiosas estuvieron presentes en menor medida, casi desde un comienzo y con ellas la concepción de la validación del caudillo a través de las victorias militares que representaban el apoyo divino a su causa. El primer ejemplo resaltado por los cronistas y el que marcó la pauta a seguir fue el, ya mencionado, episodio de Pelayo y la batalla de Covadonga ${ }^{700}$. Las crónicas, los relatos épicos, la literatura y las cancillerías fueron las encargadas de crear

\footnotetext{
${ }^{698}$ Sobre las bases de la economía andalusí, Felipe Maíllo Salgado en su articulo "De la formación social tributaria ¿y mercantil? Andalusí”, postula que esta se construyó sobre una base agraria y mercantil, basada en las activas redes de comercio entre los distintos territorios musulmanes, donde las ciudades funcionaban como focos de atracción y en torno a las cuales se ordenaba la vida de los campesinos que constituían la mayoría de la población. Este comercio significó importantes ingresos para los estados musulmanes, gracias al cobro de tributos específicos, que sabemos abundantes, aunque difícil de cuantificar debido a la posible manipulación de los registros. No fue sino hasta el siglo XIII, según el autor, esta actividad comercial comenzó a disminuir debido a las presiones y pérdidas de territorios a manos de los cristianos, en el contexto de la Reconquista. (Má́llo Salgado, Felipe, "De la formación social tributaria ¿y mercantil? Andalusí”, en Anales de Historia antigua, medieval y moderna, $\mathrm{N}^{\mathrm{o}} 35-36$, 2003, Universidad de Buenos Aires, [pp. 175-184]).

${ }^{699}$ Flori, Jean, “Guerra Santa, Yihad... op. cit., p. 220, 270-271.

${ }^{700}$ Bronisch, Alexander, "La ideología asturiana..., op. cit., p. 431.
} 
el discurso de validación bélica ${ }^{701}$. Así el discurso de la guerra peninsular fue adquiriendo una connotación religiosa cada vez mayor, centrándose en la figura del monarca $^{702}$. Se creó así una alianza entre el soberano, heredero de los visigodos y Dios, que en la mentalidad y en el sentir religioso de los cristianos peninsulares era un estimulo para luchar, al menos según el discurso cronístico, tanto o más poderoso, quizás, que el botín que se podía obtener de las victorias y conquistas.

Como se puede observar en el tercer gráfico, los cronistas de los siglos XII y XIII sintetizaron las virtudes militares permitiéndonos identificar tres grandes tópicos que se distribuyen con igual importancia en las crónicas el rey comprendido como: guerrero; bravo o valiente y victorioso. La primera, el rey guerrero, será una de sus características más recurrentes ${ }^{703}$. Junto a ella la descripción del rey como bravo o valiente, la cual también puede referirse a sus acciones a la cabeza de sus tropas. Finalmente la caracterización del soberano como victorioso, el cual, por un lado, venía a sintetizar todas las virtudes guerreras, pero también simbolizaba la relación de un monarca con Dios, puesto que sólo Él podía otorgar la victoria, una creencia que los cronistas

\footnotetext{
${ }^{701}$ Con respecto a las cancillerías estas representan una política de estado vinculada a la creación de un discurso legitimador. Por ejemplo la intitulación solía iniciarse con la habitual formula de religiosa política, para luego continuar señalando los dominios del monarca, pero también sus aspiraciones territoriales y zonas de influencia. Todo ello como símbolo palpable de su poder. Fue también habitual que en los documentos cancillerescos se soliese hacer referencias a grandes victorias o hitos del reinado, tales como tratados, matrimonios, alianzas, pero en contraste se silenciaran episodios ignominiosos como las derrotas, todo ello en la línea de reforzar la imagen de soberano mediante una memoria selectiva.

Las Cancillerías no solo se limitaron a destacar los hitos políticos, puesto que también procuraron incluir en su documentación referencia a las virtudes del monarca o de sus antecesores, contribuyendo así a crear una línea de continuidad virtuosa. Para un estudio más profundo de estos temas se puede consulta en la obra colectiva coordinada por Martínez y Rodríguez La construcción medieval de la memoria regia, los artículos de Carlos Reglero de la Fuente, "Restauración diocesana y memoria regia en León y Castilla", de Pascual Martínez "Los concejos, la tradición foral y la memoria regia en Castilla y León”, de Inés Caldero "La memoria de los reyes de León", Carlos Estepa "Memoria y poder real bajo Alfonso VIII y de Ana Rodríguez "La preciosa transmisión, memoria y curia regia en Castilla en la primera mitad del siglo XIII", así como también el articulo de Carlos Estepa "El Reino de Castilla de Alfonso VIII" en el texto colectivo Poder real y sociedad: estudios sobre el reinado de Alfonso VIII, el trabajo de Amaia Arizaleta, "Topografías de la memoria palatina... op. cit. y la colaboración de Hélène Sirantoine, "La Cancillería regia en época de Fernando III: Ideología, discurso y práctica", en Ayala Martínez, Carlos, "Fernando III: Figura... op. cit., pp. 175-203.

${ }^{702}$ Redondo Jarillo, María Cristina, "La Confección de la Figura del Rey... op. cit., pp. 141; y Fernández Conde, Francisco Javier, La Religiosidad Medieval en España ... op. cit., pp. 91, 92.

${ }^{703}$ En esta categoría hemos colocado todas aquellas expresiones que abarcaban el rol bélico del monarca contra el Islam, como por ejemplo cuando se afirma que durante su vida un rey combatió o llevó a distintas expediciones contra los musulmanes, o cuando se le describe como conquistador, o que arrebató territorios a los andalusíes, etc.
} 
supieron instrumentalizar sabiamente como forma de legitimar a sus monarcas y demostrara la perfidia de sus enemigos ${ }^{704}$.

Si bien las virtudes militares tienen una presencia casi constante, adolecen del mismo problema que otros conceptos cronísticos, nos referimos a la notable disminución de fuentes, debido a los eventos contextuales, entre los años 1150 y 1210. No obstante en el periodo general de los siglos XII y XIII, es posible detectar dos momentos donde se observan las tres características. El primero en torno a la década de 1090, coincidente con el reinado de Alfonso VI y el segundo, mucho más extenso, entre 1220 y 1270, incluyendo las crónicas Latina, Cronicon Mundi, De Rebus Hispaniae, Crónica General y la de Veinte reyes; es decir, los reinados comprendidos entre Alfonso VIII y Alfonso X, la etapa de mayor actividad bélica y coincidentes con el proceso de consolidación del poder real. Sin olvidar además el aumento de la actividad cronística y la tendencia de las fuentes del siglo XIII por repetir los mismos eventos en su relato ${ }^{705}$.

Como mencionamos, estos tres tópicos aparecen virtualmente en todas las crónicas, siendo la de guerrero una de las categorías más estables de la cronística hispana, reforzando así que la lucha contra el Islam era una misión divina que exaltaba a toda la sociedad, pero en especial a los reyes que los dirigían en la lucha y la eventual victoria contra los enemigos de Dios ${ }^{706}$.

A ese respecto es significativo que en algunas crónicas las victorias contra otros tipos de enemigos como eran los demás reinos cristianos peninsulares, caudillos o comunidades sublevadas e incluso invasores externos como los normandos, eran retratadas como victorias de segundo orden en comparación a la lucha contra los musulmanes. Dando la impresión que incluso para los mismos soberanos tales acciones bélicas no los validaban y que sólo la lucha contra los enemigos de Dios cumplía ese rol. Una situación que seguramente se vinculaba más con las posibilidades de grandes botines y conquistas territoriales que sirviesen para aumentar el poder político y los lazos vasalláticos, que por motivaciones puramente religiosas. A este respecto tenemos el interesante, aunque tardío, testimonio de Jiménez de Rada en relación a Ramiro I.

\footnotetext{
${ }^{704}$ En las crónicas del siglo XIII también se suele encontrar la expresión de rey glorioso, no obstante la hemos apartado de nuestra categorización ya que por lo general el uso del concepto se reduce a la figura de Alfonso VIII y la batalla de las Navas de Tolosa, por lo que se dificulta considerarla una categoría comparativa.

${ }^{705}$ Ver gráfico y tabla $\mathrm{N}^{\circ} 3$.

${ }^{706}$ Ver gráfico y tabla $\mathrm{N}^{\circ} 3$.
} 
El cronista nos relata que el soberano, al comienzo de su reino, debió enfrentar la sublevación de Nepociano a quien derrotó en un encuentro campal. A continuación Ramiro debe repeler en Galicia una incursión de normandos, gente "crudelissima et pagana" a quienes venció con "la ayuda del Señor", sólo para tener que enfrentarse inmediatamente a otra sublevación por parte del conde Alderedo. Vencidos todos estos enemigos, el rey parece considerar que no han sido victorias suficientes y "Post hec autem rex Ranimirus nolens ociosus a Dei seruicio inueniri, aggressus est loca Arabum et tam in uillis quam in agris cuncta que reperiit, etiam Anagarum incencio concremauit."

Es de destacar la expresión "Dei seruicio", como si la lucha contra otros enemigos del reino no fuese suficiente para validar al rey como guerrero y protector de la Iglesia. Al parecer, los normandos no eran una amenaza tan grave como los árabes a los que Ramiro atacó. Es en esta última incursión en la que se habría producido la batalla de Clavijo, donde la aparición de Santiago apóstol se convirtió en la señal visible de que la Gracia acompañaba al rey ${ }^{708}$.

Este tipo de testimonios nos permiten concluir que la figura del rey pasó a validarce en razón de sus éxitos militares y la conquista de las antiguas tierras visigodas, las que serían una señal evidente de la Gracia de Dios. En Castilla y León esto se tradujo en la formación de una ideología guerrera, que obligaba al soberano a probarse en el campo de batalla y que se tradujo en una militarización de la figura real, visible según García Fitz- en los sellos y otras formas de representación, donde el soberano era caracterizado montado y $\operatorname{armado}^{709}$.

Los cronistas, principales agentes en la divulgación del modelo regio, procuraron, seguir la tradición bíblica y destacar la función guerrera del monarca. Si los reyes

707 HRH, Liber IV, cap. XIII, op. cit., p. 133. "Tras estos hechos, el rey Ramiro, que no quería permanecer inactivo en el servicio de Dios, atacó los dominios de los árabes e incendió todo lo que encontró a su paso, tanto poblados como sembrados, incluida Nájera." HHE, Libro IV, cap. XIII, op. cit., p. 177.

${ }^{708}$ Luego de este testimonio, Jiménez de Rada no constata más hechos de armas y termina su relato recordando cómo el rey mandó a construir una iglesia dedicada a Santa María en Oviedo, para terminar sus días muriendo de forma natural (HRH, Liber IV, cap. XIII, op. cit., p. 133).

${ }^{709}$ García Fitz, Francisco, "Las guerras de cada día en la Castilla del siglo XIV”, en Edad Media. Revista de Historia, 8, 2007, [pp. 151-181], p. 164; Pallares, María del Carmen y Ermelindo Portela, La Reina Urraca, España, Nerea, 2006, p. 57; y González Antón, Luis, España y las Españas... op. cit., p. 120.

No obstante esta concepción bélica, Ana Rodríguez, basandose en el estudio de la Chronica Regum Castellae, afirma que el monarca debía pasar por una serie de etapas, asociadas a los ciclos de la vida, antes de poder gobernar y luchar. El poder real se construía a partir de un proceso de crecimiento físico y de madurez que comenzaba en la infancia y donde el deseo de acudir a la guerra señalaba el inicio de la edad adulta y por lo tanto el momento propicio para que el rey empezase a ejercer su "legitimo poder regio" (Rodríguez, Ana, "Modelos de legitimidad política... op. cit.) 
visigodos había derrotados a todos sus enemigos -romanos, hunos, vándalos, suevos, bizantinos, etc.- era necesario que esa virtud también fuese asociada a quienes se postulaban como sus sucesores, que de esta forma podían contar con una prueba irrefutable del favor de Dios. La victoria militar no sólo era del rey, sino que también de su pueblo; y más importante aún, de la Iglesia, que a través de los guerreros recuperaba sus posesiones e influencias en los territorios peninsulares. Por todo ello no es inusual, según Redondo Jarillo, que el Dios de la Reconquista fuese más cercano a su imagen veterotestamentaria: un Dios militar que guiaba las espadas de sus siervos ${ }^{710}$.

\section{Gráfico 3: Validación bélica}

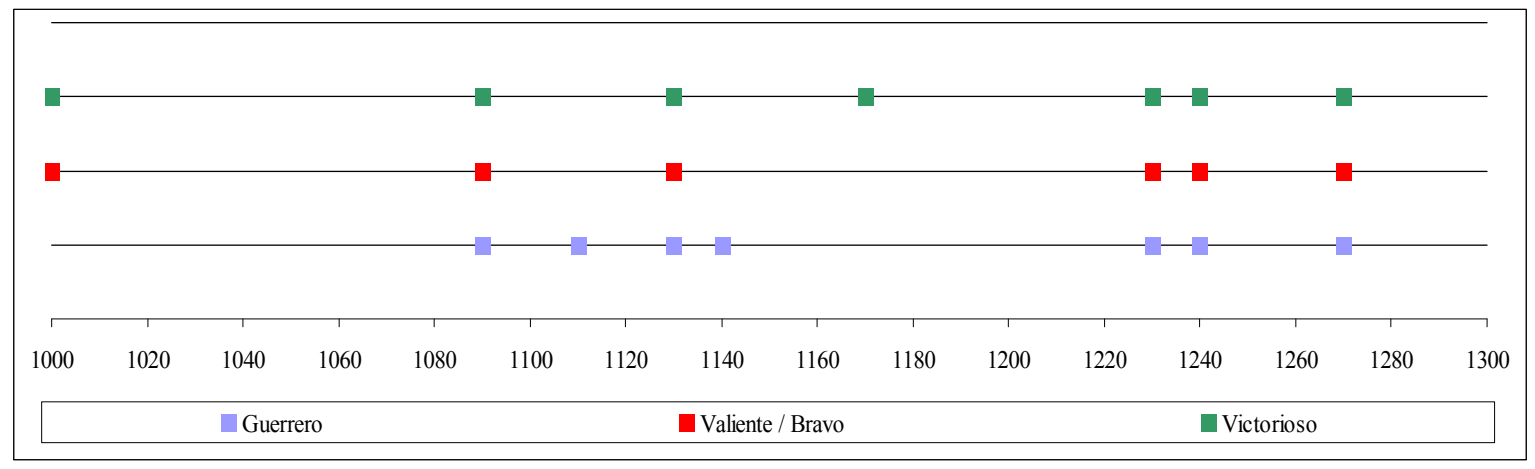

En esencia, los reyes en el ámbito asturiano leonés y posteriormente castellano, debían ser guerreros al servicio de Dios, de la Iglesia, y por tanto, de las virtudes cristianas. Se podría afirmar entonces que la lucha contra el Islam se convirtió en el primer deber de todo rey cristiano ${ }^{711}$. Razón por la cual la mayoría de los soberanos de los siglos XII y XIII procuraron alcanzar la victoria en el campo de batalla. A nuestro parecer existen dos casos que ejemplifican bien esta situación. El primero se trata de Alfonso VIII de Castilla que, si hemos de creer a los cronistas, después del desastre de Alarcos concentró todas sus energías en lavar su derrota hasta lograrlo en la jornada de las Navas de Tolosa, hecho que no sólo lo validó ante su pueblo, sino que también lo convirtió en un paladín de la cruz y en la figura política más poderosa de la Península. Otro modelo muy comúnmente reconocido se formó a partir de la figura de Fernando

\footnotetext{
${ }^{710}$ Redondo Jarillo, María Cristina, "La Confección de la figura del rey... op. cit., p. 138; y García Pelayo, Manuel, El Reino de Dios... op. cit., pp. 7, 8.

${ }^{711}$ Rodríguez García, José Manuel, “Cruzados y fronterizos... op. cit., pp. 572, 577; Nieto Soria, José Manuel, "Imágenes religiosas del rey y del poder real en la Castilla del siglo XIII", en la España Medieval, Tomo V, Universidad Complutense, Madrid, 1986, pp. 717, 718; Nieto Soria, José Manuel, Fundamentos Ideológicos... op. cit., pp. 80, 81; y González Antón, Luis, España y las ... op. cit., p. 120.
} 
III, al que sus importantes victorias, sumadas a su comportamiento piadoso y devoto, convirtieron en un modelo de rey reconocido por todos, al punto que mucho después de su muerte, en el siglo XVII, sería oficialmente elevado a la santidad. Sobre ambos nos referiremos en profundidad más adelante.

La importancia de la guerra es un elemento que podemos observar desde las primeras crónicas, que relatan una y otra vez numerosos episodios bélicos; muchos de ellos evidentemente frutos de la exageración propagandística. Los cronistas convirtieron cada pequeña escaramuza en una batalla épica, en una lucha sin cuartel entre el bien cristiano y el mal islámico. Estos relatos, claramente intencionados, convirtieron a los soberanos en paladines, en héroes virtuosos semejantes a los modelos clásicos ${ }^{712}$. El buen rey cristiano debía ser un guerrero, pero también un hombre sabio, justo y mesurado, virtudes que podemos rastrear culturalmente hasta figuras heroicas como Héctor, héroe de Troya ${ }^{713}$. Con la salvedad de que el rey, a diferencia de los héroes trágicos, logra finalmente sus cometidos -triunfar sobre sus enemigos y libera las tierras cristianas-, con la ayuda de Dios ${ }^{714}$.

En ese sentido existe una intencionalidad de mostrar a los caudillos cristianos dotados de virtudes clásicas, tales como la elocuencia, belleza (en el sentido de la proporción y armonía del cuerpo) y por supuesto dotes guerreras como el valor, pero también la templanza para ser un líder mesurado ${ }^{715}$. Virtudes a las que se suman descripciones de sus victorias sobre los musulmanes, que aparecen a modo de epílogo para el relato virtuoso de su persona y hazañas. Un ejemplo de ello lo podemos ver en la más tardía Vita Dominici Silensis en relación a su descripción del rey García (10351054), hijo de Sancho el Mayor:

"Igitur in eo tempore Garsias rex, filius Sancii regis Maioris, frater Fredelandi regis tenentis imperium prouincie Legionensium, obtinebat regnum prouincie

\footnotetext{
${ }^{712}$ Recuero Astray, Manuel José, Orígenes de la Reconquista... op. cit., 79; y Redondo Jarillo, María Cristina, "La Confección de la figura del rey... op. cit., pp. 131-138.

${ }^{713}$ En la Iliada, Homero, describe dos modelos de héroe, el primero representado por Aquiles el guerrero brutal, dominado por sus pasiones y su ira, defectos que apenas son compensados por su valor y liderazgo. El otro modelo es el representado por Héctor, defensor de Troya, de su hogar y su estirpe. El troyano es presentado, especialmente en el canto VI, como un hombre piadoso, devoto de su familia, padre y esposo amoroso, pero también como un gran guerrero, el mejor y más valiente de su pueblo. Los arquetipos heroicos de Homero trascenderán durante toda la duración del mundo antiguo, siendo heredados por los romanos y a través de estos pasaron a los germanos en el proceso de conformación del mundo medieval. Por ello no es de extrañar que las virtudes, propias de la arete griega, puedan ser rastreadas en otros modelos políticos como son los monarcas, aunque claro, como virtudes cristianizadas.

${ }^{714}$ Bloch, Marc, Los reyes taumaturgos... op. cit., p. 65 y ss.; y Rodríguez de la Peña, Manuel Alejandro, Los reyes sabios... op. cit., pp. 23, 24.

${ }^{715}$ Un modelo ideal que recuerda a la kalokagathía de la cultura clásica.
} 
Nagarensis; uir certe corpore decorus, actibus clarus, sermone directus, armis strenuus et usu milicie bellicosus, ut testantur frecuentes et nobiles ac memorabiles ipsius uictorie super spurcissiman gentem Agarenorum facte et insuper restitutio Calagurritane ciuitatis, que quondam fuit, auctoritate scripturarum, sedes pontificalis."

El rey García no fue la excepción; por el contario, según los cronistas, estos atributos debían ser la norma. Los relatos sobre virtudes militares son una constante en las crónicas, y si bien no siempre se utilizan las tres categorías antes mencionadas, lo cierto es que el discurso en su conjunto presenta estas características vinculantes, puesto que no se podía ser un rey valiente si no se había probado antes en combate, y sólo podía ser llamado victorioso aquel al que la Providencia premiaba con la victoria sobre los verdaderos enemigos de la $\mathrm{fe}^{717}$.

A la luz de lo ya descrito, nosotros, podemos afirmar, que el argumento bélico se convirtió en uno de los elementos más destacables de las monarquías en Castilla y León. Por lo general, los cronistas de los siglos XII y XIII, al igual que sus predecesores, convirtieron a los reyes guerreros en los protagonistas de sus textos, relegando a un plano secundario a aquellos soberanos que no habían destacado en la lucha contra los musulmanes, o bien sus victorias habían sido sobre otros cristianos. Es así que concluimos, que sólo la lucha contra los enemigos de Dios, los mismos a los que el mito de la Reconquista había convertido en los usurpadores de las tierras godas, podía glorificar a un soberano. Al vencer a los musulmanes, los reyes castellanoleoneses se emparentaban con los antiguos reyes de Israel, y se alzaban ante sus pares europeos, pensando en el modelo carolingio, como protectores de la cristiandad. Ellos eran los que, con sus conquistas, permitían la restauración religiosa y la anexión de nuevas tierras. Eran sus conquistas las que permitían apoderarse de las riquezas del alAndalus y distribuirlas a través de donaciones, cesiones y botín, entre la Iglesia, los nobles y el pueblo.

\footnotetext{
${ }^{716}$ VDS, Liber I, cap. V, op. cit., 216, 218. "Es el caso que, por aquel entonces, el rey García, hijo del rey Sancho el Mayor, hermano del rey Fernando, que regía el Reino de León, ocupaba el trono de Nájera; hombre, ciertamente, de belleza corporal, esclarecido en sus hechos, claro en su modo de hablar, soldado activo y valiente en la práctica de la guerra, como atestiguan sus frecuentes, célebres y famosas victorias obtenidas sobre la infame gente de los agarenos, asi como la reconquista de la ciudad de Calahorra, que otrora fue sede episcopal, según consta en escrituras." VDS, Libro I, cap. V, op. cit., pp. 217, 219.

${ }^{17}$ Ver gráfico y tabla $\mathrm{N}^{\circ} 3$.
} 
Como veremos más adelante, cuando analicemos algunas figuras reales en detalle, la guerra fue una de las principales herramientas de poder político al servicio de la monarquía, puesto que gracias a ella, el rey se convertió en el eje central de sus reinos, organizando en torno a él a los restantes grupos sociales. Algo que, por lo demás, se sustentó en el convencimiento de que la victoria era un don de Dios, una idea más poderosa que cualquier otro símbolo exterior de poder. Estos fueron signos a los que los cronistas no dieron mayor importancia, como por ejemplo la corona, el cetro o el ungimiento en comparación con la imagen del rey dirigiendo a las huestes cristianas. 
Tabla 3: Validación bélica

\begin{tabular}{|c|c|c|c|c|}
\hline & Guerrero & Valiente/Bravo & Victorioso & Fuente \\
\hline 1000 & & 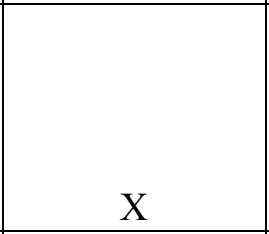 & $\mathrm{X}$ & $\begin{array}{l}\text { - CAIII Rotense } \mathrm{N}^{\circ} 11, \text { p. } 206, \mathrm{~N}^{\circ} 16 \text { p. } 210 \\
\mathrm{~N}^{\circ} 23 \text { p. } 216, \mathrm{~N}^{\circ} 25 \text { p. } 218 . \text { CAIII Sebastian } \\
\mathrm{N}^{\circ} 13 \text { p. } 207, \mathrm{~N}^{\circ} 16 \text { p. } 211, \mathrm{~N}^{\circ} 24 \text { p. } 217, \mathrm{~N}^{\circ} \\
25 \text { p. } 219 . \text { CA N}^{\circ} 9 \text { p. } 249, \mathrm{~N}^{\circ} 12 \text { p. } 250 . \\
\text { - CSEA p. } 272,286 .\end{array}$ \\
\hline 1090 & $\mathrm{X}$ & $\mathrm{X}$ & $\mathrm{X}$ & - VDS Cap IV, N³35, 340 p. 217, 219. \\
\hline 1100 & & & & \\
\hline 1110 & $\mathrm{X}$ & & & - CAS N 6 p. 13 \\
\hline 1120 & & & & \\
\hline 1130 & $\mathrm{X}$ & $\mathrm{X}$ & $\mathrm{X}$ & $\begin{array}{l}\text { - HC Liber I Cap. } 83 \text { p. 201. Liber II Cap. } \\
50 \text { p.384 } \\
\text { - COP p. 177. } 179\end{array}$ \\
\hline 1140 & $\mathrm{X}$ & & & $\begin{array}{l}\text { CAI. Liber I No } 33-38 \text { p. } 74,75[\mathrm{PA}] \mathrm{N}^{\circ} 5 \\
\text { p. } 131\end{array}$ \\
\hline 1150 & & & & \\
\hline 1160 & & & & \\
\hline 1170 & & & $\mathrm{X}$ & - CN Libro II, N² 25 p. 136 \\
\hline 1180 & & & & \\
\hline 1190 & & & & \\
\hline 1200 & & & & \\
\hline 1210 & & & & \\
\hline 1220 & & & & \\
\hline 1230 & $\mathrm{X}$ & $\mathrm{X}$ & $\mathrm{X}$ & $\begin{array}{l}\text { - CM Prologo, p. 1, 2, Liber III, Cap. } 64 \text {, } \\
\text { p. } 266 . \\
\text { - CLRC No5 p. } 31, \mathrm{~N}^{\circ} 13 \text { p. } 39, \mathrm{~N}^{\circ} 25,26 \text { p. } \\
56\end{array}$ \\
\hline 1240 & $\mathrm{X}$ & $\mathrm{X}$ & $\mathrm{X}$ & $\begin{array}{l}\text { - HRH Liber II Cap. } 15 \text { p.108, Liber IV } \\
\text { Cap. } 5 \text { p.166, cap. } 12 \text { p. } 175 \text {, Cap. } 13 \text { p.177, } \\
\text { Cap } 14 \text { p.179, Cap. } 22 \text { p. 188, Liber VI Cap } \\
11 \text { p. } 232 \text {, Cap XXI p. } 246 \text {, Liber VII Cap. } \\
24 \text { p. } 293 .\end{array}$ \\
\hline 1250 & & & & \\
\hline 1260 & & & & \\
\hline 1270 & $\mathrm{X}$ & $\mathrm{X}$ & $\mathrm{X}$ & $\begin{array}{l}\text { - CGE. Cap. } 580 \text { p. } 330 \text {, Cap. } 612 \text { p. } 347 \text {, } \\
\text { Cap. } 643-651 \text { p. } 367-371 \text {, Cap. } 846 \text { p. } 520 \text {, } \\
\text { Cap. } 1131 \text { p. } 771-772 . \\
\text { - CXXR Liber X Cap } 1 \text { p. } 201 \text { Lber XII, } \\
\text { Cap. } 1 \text { p. } 259 \text {, Liber XV Cap. } 80-81 \text { p. } 346 \text {, } \\
347 .\end{array}$ \\
\hline 1280 & & & & \\
\hline 1290 & & & & \\
\hline 1300 & & & & \\
\hline
\end{tabular}




\section{II.4.d.-Validación jurídica}

Además de sus virtudes guerreras y su herencia, era necesario que el rey demostrase ser un buen cristiano y estar en comunión con Dios, lo que se manifestaba gracias a sus victorias y actitudes piadosas ${ }^{718}$. Junto a lo anterior existe otro tópico que debía caracterizar al buen rey: nos referimos a la potestad real de hacer y aplicar justicia, lo que también se vinculaba con su relación con sus súbditos y vasallos, no obstante las crónicas rara vez dicen cuáles eran estas normas, o cómo se elaboraban; aunque sí nos dan a entender que debían estar en comunión con los preceptos del cristianismo, siendo frecuente que sus atributos de justiciero fuesen acompañados de la descripción del rey como piadoso (en su raíz latina de pietās), por lo que se entiende que todas las leyes se basaron en la aplicación de modelos socio-religiosos.

En conjunto con el rol de juez, los cronistas también dan una significativa importancia a la función del rey como pacificador; esto es, como garante de la paz al interior de su reino. Posiblemente, siguiendo la tradición isidoriana recogida de las Sentencias y Etimologías, así como en los cánones del IV Concilio Toledano, se atendía que sólo un rey justo podría proteger a su pueblo de forma ecuánime, y que la paz que lograra era un símbolo de la bendición de Dios hacia el reino. ${ }^{719}$ Por ello no es de extrañar, como se observa en el siguiente gráfico, que este tópico aparezca en diversas crónicas asturianas y se mantenga en los textos de los siglos XII y XIII, como en las crónicas Silense/Legionense, de los Reyes de León, Compostelana, Anónima de Sahagún, Pelayo, Adefonsi Imperatoris, Najerense, Latina, Cronicon Mundi, De Rebus Hispaniae, Crónica general, de Veinte reyes y en otras obras como la Vita Dominici Silensis.

\footnotetext{
${ }^{718}$ Bronisch, Alexander, "La ideología asturiana..., op. cit., p. 421.

719 Debemos recordar que en las Escrituras, a partir de los textos de Isaías, la paz era entidad como un estado de gracia y que si bien simbolizaba la próxima venida del Mesías, frecuentemente fue interpretado como la bendición de Dios a su pueblo.
} 
Gráfico 4: Validación jurídica

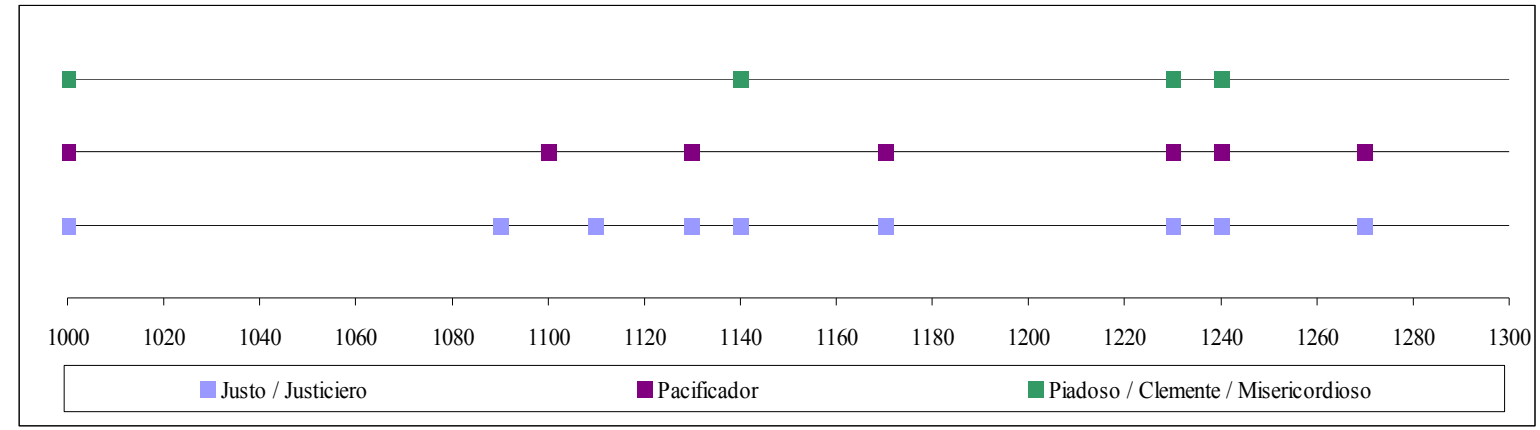

Por último, y con una incidencia mucho menor, se puede constatar el ideal del rey como hombre piadoso, clemente o misericordioso. Tres conceptos que consideramos como símiles y que los cronistas solían usar para referirse al perdón real hacia algún noble rebelde. Por ello es común que se usen en crónicas como la Adefonsi Imperatoris, o se haga más frecuente a partir de 1230, cuando se relatan los esfuerzos de Fernando III por unificar sus reinos y someter a los nobles castellanos y leoneses para asegurar su trono. La razón para incluirla en esta categoría es que los cronistas vinculaban estos actos a un sentido superior de justicia del soberano, relacionado a la cosmovisión religiosa del poder, que además permitía al rey fortalecer sus relaciones con los restantes poderes y asegurar la paz interior en su reino.

Con respecto a la primera función al rey, que debía ser juez y justiciero, esencialmente se le entendía como un hombre justo, un don propio de los grandes personajes bíblicos como Salomón, y muy apreciado por el conjunto de la sociedad, siendo una de las virtudes más importantes, ya que demostraba que el soberano estaba en comunión con el juez supremo, Dios, y que actuaba según sus preceptos y guía ${ }^{720}$. Y

\footnotetext{
${ }^{720}$ Rodríguez de la Peña, caracteriza el modelo real bíblico a partir de dos categorías, la realeza davídica y la salomónica. La primera se centra en el principio de que el rey sabio gobierna conforme a las leyes divinas, a las que además debe defender. Su sabiduría le es otorgada en virtud de obediencia y sumisión a Dios. El ideal salomónico, por su parte, corresponde al rey poseedor de conocimiento intelectual, virtud de la cual se puede tornar soberbio y desafiar a Dios. Según el mismo autor ambos modelos se sucedieron en el medioevo. En una primera instancia primó el ideal davídico, pero a partir del siglo XIII, cobró importancia el modelo salomónico (Rodríguez de la Peña, Manuel Alejandro, Los reyes sabios... op. cit., pp. 28-30). Es importante aclarar que el mencionado autor analiza estos modelos a partir del problema de la sapiencia medieval. Por nuestra parte, nosotros, aludimos a la figura de Salomón en referencia a la creencia común vinculada directamente a su interpretación como un rey sabio en razón de la sabiduría que le fue otorgada por Dios y las diversas historias vinculadas a su sentido de justicia "Dijo Dios: 'Pídeme lo que quieras que dé'. Salomón dijo: 'Tú has tenido gran amor a tu siervo David mi padre, porque él ha caminado en tu presencia con fidelidad, con justicia y con rectitud de corazón contigo. Tú le has reservado este gran amor y le has concedido que se siente en su trono un hijo suyo Ahora Yahveh mi Dios, tú has hecho rey a tu siervo en lugar de David mi padre, pero yo soy un niño pequeño que no sabe salir ni entrar. [...] Concede, pues, a tu siervo corazón que entienda para juzgar a
} 
para el caso hispano, el rey justiciero venía a simbolizar la restauración del equilibrio perdido por los reyes visigodos, que por su injusticia e inequidad condenaron a su reino. Es así como el rey es descrito como el máximo juez, cuyo accionar venía a restaurar el estado de injusticia que llevó a su fin el Reino Visigodo ${ }^{721}$. Sobre ello la Crónica de Alfonso III nos ha legado un decidor testimonio referente a la muerte de Alfonso I, soberano destacado por su lucha contra los musulmanes, y de quien se decía estar tocado por la Gracia divina por ser un valiente y exitoso guerreo, además de hombre piadoso y respetuoso de Dios y de la Iglesia, al punto que los mismos ángeles alabaron su alma:

"Nec hoc miraculum silebo, quod uerius factum esse cognosco. Quumque spiritum emisisset intempeste noctis silentia *** [sic] cum officiis palatinis corpus custodissent, subito in aera auditur a cunctis uox angelorum psallentium: 'Ecce quomodo tollitur iustus et nemo considerat; et uiri iusti tolluntur et nemo percibit corde. A facie iniquitatis sublatus est iustus; erit in pace sepultura eius'. Hoc uerum esse cognoscite et nec fabulosum putetis:' alioquin tacere magis quam falsa promere maluissem,.,"722

Posteriormente, Lucas de Tuy, enumeró cinco virtudes o características que debía poseer un buen rey, destacando principalmente el conocimiento de Dios, la mantención de la paz, la aplicación de la justicia y la lucha contra los enemigos ${ }^{723}$. Pero además advirtió sobre los peligros de un mal rey, puesto que el castigo por sus actos sería extensivo a todo el reino:

tu pueblo, para discernir entre el bien y el mal, pues ¿quién será capaz de juzgar a este pueblo tuyo tan grande?' Plugo a los ojos del Señor esta suplica de Salomón, y le dijo Dios: 'Porque has pedido esto, y en vez de pedir para ti larga vida, riquezas, o la muerte de tus enemigos, has pedido discernimiento para saber juzgar, cumplo tu ruego y te doy un corazón sabio e inteligente como no lo hubo antes ni lo habrá después [...] (Reyes I, 3: 5, 12).

En relación a lo anterior, Carmen Benítez nos recuerda que si bien la justicia era uno de los símbolos más potentes de la delegación del poder por parte de Dios, ello no implicaba la renuncia de la justicia divina, la cual siempre estaba por sobre el soberano (Benítez Guerrero, Carmen, La imagen del rey... op. cit., p. 75).

${ }^{721}$ Reglero de la Fuente, Carlos, "Restauración diocesana y memoria regia en León y Castilla", en Martínez Sopena, Pascual y Ana Rodríguez, La construcción medieval de la memoria..., op. cit., p. 102; Morán, Remedios, y Eduardo Fuentes, "Ordenamiento, legitimación y potestad normativa: Justicia y moneda", en Nieto Soria, José Manuel, Orígenes de la monarquía hispánica ... op. cit., p. 211-213.

${ }^{722}$ CAIII, versión Rotensis, $\mathrm{N}^{\circ} 15$, op. cit., pp. 132, 134. "Y no callaré un milagro que en verdad sé que ocurrió. Como hubiera exhalado su espíritu durante el silencio de la noche cerrada ***, y como los oficiales palatinos velaban su cuerpo, súbitamente se oyó por todos en los aires la voz de los ángeles que cantaban: 'He aqui cómo desaparece el justo y nadie repara en ello; y los varones justos desaparecen y nadie se da cuenta en su corazón. De la presencia de la iniquidad ha sido apartado el justo; en la paz estará su sepultura'. Sabed que esto es verdad, y no lo reputéis fabuloso; de otro modo hubiera preferido callar antes que contar falsedades." CAIII, versión Rotense, $\mathrm{N}^{\circ}$ 15, op. cit., p. 208.

${ }^{723}$ Rodríguez, Ana, "De rebus Hispaniae frente... op. cit., p. 134. 
"Rex dicitur a regendo, quod se et alios bene regat; cui specialius quinque sunt necesaria: primo uidelicet creatorem et regem suum, Patrem et Filium et Spiritum sanctus, unum uerum Deum in unitate subtancie et in trinitate personarum agnoscere; secundo fidem catholicam moribus et uerbis confiteri; tercio regnum in pace omnimode conseruare; cuarto sine acceptione personarum unicuique iusticiam exibere; quinto uero hostes uiriliter, contemptis cunctis laboribus, expugnare. Princeps enim dalicatus pocius flectitur ad carnis ludibrio preagenda, quam ad hostium onstinatam fortitudinem feriendam. Princeps delicatus uino madet, lenitur blandiciis meretricum, dissoluitur luxuria et susurronibus libenter aponit aurem [...] Semper sollicitatur princeps sapiens, ne suis excessibus in temporalibus aut spiritualibus paciatur populus sibi subditus detrimentum; nam plerumque pro peccatis principum ira Dei in populos incandescit, et quotquot eius culpa dilapsi fuerint in peccatum, de illis Deo redditurus est rationem.",724

Casi contemporánea a la obra del "Tudense", El libro de los doze sabios, contribuyó a la consolidación de la imagen del rey como una personalidad virtuosa dotado de múltiples características cristianas -entre ellas la idea de que el soberano, al igual que Cristo es el buen pastor que guía a su pueblo-, pero especialmente, capaz de ejercer la justicia, de castigar a los malos y además siendo valiente en la lucha:

"Que el príncipe o rey o regidor que no es sañudo a los malos ni muestra los yerros a los que lo merecen, y no da por el mal pena y por el bien galardón no es digno de regimiento, que regidor de reino tanto quiere decir como pastor de las ovejas, que ha de dar vía por donde usen y vayan, destruidor de los malos, enmendador de los malos usos y costumbres, rehacedor de los bienes, igualador de las discordias, veces con saña, veces con buena palabra, enseñador de las virtudes, destruidor de los pecados, y pena de la maldad y gloria de la bondad, defendimiento de pueblo, poblador de tierra, pértiga de justicia. Y por ende le es

${ }^{724}$ CM, Praefatio, op. cit., pp. 3, 4. "El rey se diriua o desciende desta palabra regir, porque bien rija a sí ya los otros; al qual, más especialmente que a otro, çinco cosas son necesarias, conuiene a saber: primeramente, conosçer al criador y a su Rey, padre y fijo y spiritu sancto, vn viuo Dios en vnidad de sustancia e trinidad de personas; segundamente, les es necesario confesar la fee católica por costumbres y palabras; terceramente, le es necesario que de todo en todo guarde su reyno en paz; lo cuarto, dar justicia a cada vna de las personas sin afección; lo quinto, varonilmente despreciando sus enemigos, con todos trabajos batallar, porque el principe delicado más ayna se inclina a tractar los escarnios e los ruegos de la carne, que a ferir la fortaleza de los enemigos. El principe delicado mójase con vino, afalágase con blanduras de malas mugeres, sueltase por lujuria, de buena mente da la oreja a los maldicientes parleros [...] El prinçipe sabio siempre es cydadoso que el pueblo subiecto a él, por sus excesos en las cosas temporales o spirituales non padezca daño, porque muchas vezes, por los peccados de los principes, la yra de Dios escomiença a caer (y) [en] los pueblos y qualquier cosa de peccado en que por su culpa cayeren dara dello cuenta." CE, Prologo, op. cit., pp. 1, 2. 
cumplidera la saña contra los malos y crueles y desordenados en sus hechos, que el príncipe o señor en quien no hay saña o crueldad cuando cumple no puede bien regir reino, que cada uno se atreve a mal obrar en esfuerzo de no ser castigado. Y más temor pone la saña del rey o del regidor que es conocido por justicia que la justicia que hace o manda hacer, y más la debe mostrar a los grandes que a los pequeños, que ganado lo más, lo menos es cosa vencida. Y muy gran castigo es al pueblo ver quebrantada la soberbia de los grandes que ser sometidos a justicia. Razón clara y muy conocida es de que las obras pasadas dan testimonio. IX

\section{$[\ldots]$}

El miedo no es yerro mas naturaleza derecha: publicarlo es gran mengua, encubrirlo es nobleza de corazón. Antes hablando con las sus compañas y esforzándolos como compañero, debe ser el primero que tomare la lanza, y decir decires de osadía. Y como ya habemos dicho, y el esfuerzo tuvo las glorias mundanales y es hermano de la fortuna. Pero no sea tanto compañero que se atrevan a él y con palabra grida y sañuda deseche a los que se atrevieren a él fuera de razón, que de todas las cosas el medio y templanza es la mejor, según antes dijimos en el tratado de templanza. XI, ${ }^{, 725}$

Como mencionamos anteriormente, buena parte de las virtudes atribuidas al rey se vinculaban a la idea de la sabiduría, entendida como reflejo de la sapiencia divina. El rey debía ser sabio para poder gobernar a su pueblo con mesura, hacer leyes y buscar buenos consejeros que le ayudasen a gobernar rectamente ${ }^{726}$.

Esencialmente, un buen rey era aquel que honraba sus pactos, defendía sus tierras, engrandecía su reino a través de obras arquitectónicas y piadosas, extendía sus dominios en detrimento de sus enemigos, y defendía a la Iglesia ${ }^{727}$. Este tipo de acciones le significaban el directo reconocimiento de Dios, y ninguna de ellas era tan importante como su capacidad de impartir justicia ${ }^{728}$.

\footnotetext{
${ }^{725}$ LDS, op. cit., IX, XI.

${ }^{726}$ Rucquoi, Adeline, "El Rey Sabio: Cultura y Poder en la Monarquía Medieval Castellana”, Actas del III Curso de Cultura Medieval. Repoblación y reconquista, Centro de Estudios Románicos Aguilar del Campoo, 1991, pp. 83, 84; y Orlandis, José, “Legados de la España Visigótica”, en Nuño González, Jaime (Coordinador), II Curso de Cultura Medieval: Alfonso VIII y su Época, Centro de Estudios del Románico, Aguilar del Campoo, 1990, p. 154.

${ }^{727}$ Pérez de Tudela, María Isabel, "La consideración ética... op. cit., p. 18.

${ }^{728}$ Morán, Remedios y Eduardo Fuentes, “Ordenamiento, legitimación y potestad... op. cit., pp. 209-221; Bizzarri, Hugo y Adeline Rucquoi, "Los espejos de Príncipes en Castilla.... op. cit., p. 21; y Le Goff, Jacques, "El rey", en Le Goff, Jacques y Jean-Claude Schmitt, Diccionario razonado ...op. cit., p. 683.
} 
La administración de la justicia, con su importante carga simbólica dentro del cristianismo -en que Dios es el juez de los hombres y el Apocalipsis tiene como pieza central el juicio final con Cristo como juez-, es una de las principales atribuciones del soberano, y manifestación evidente de la orientación de Dios en sus acciones. De acuerdo a esto, las leyes debían proteger a los súbditos y al mismo tiempo ser reflejo de las virtudes y la piedad cristiana, y por lo tanto no podían contradecir los fundamentos teológicos del cristianismo ${ }^{729}$. Esencialmente, siguiendo la idea de ser una Imago Dei, el soberano era rey y juez, de la misma forma que lo es el Señor, pero con la salvedad de que estaba sometido a Él.

Consecuentemente, la función judicial del rey será uno de los temas centrales en los relatos de "Espejos de Príncipes", que nos permiten observar el fenómeno ya desarrollado. Así, se hacen claramente identificables las intenciones pedagógicas de inculcar al monarca los ideales, haciendo de su facultad de "hacer justicia" parte de los medios de validación ${ }^{730}$.

En esencia, en lo que a la cronística y textos políticos y judiciales hispanos se refiere, existía la convicción de que el rey justificaba su poder a través del cumplimento cabal de su rol como juez y protector de la justicia ${ }^{731}$. Bajo esta concepción, el soberano debía regir su reino como un modelo del orden celestial, garantizando así el orden cósmico en la tierra y la defensa tanto de su reino como la de la civitas $D e i^{732}$. Una misión justiciera que, para el caso hispano se combinaba con la derrota de los enemigos de Dios; la expulsión del Islam.

\footnotetext{
729 Bermejo, José Luis, Máximas, Principios y Símbolos Políticos, Madrid, Centro de Estudios Constitucionales, 1986, p. 51; Nieto Soria, José Manuel, Orígenes de la Monarquía Hispánica ... op. cit., p. 225; y Nieto Soria, José Manuel, Fundamentos Ideológicos... op. cit., pp. 157-161.

${ }^{730} \mathrm{El}$ género de los espejos fue desarrollado en las cortes y por lo tanto reflejan los postulados ideológicos de la elite jurídica y religiosa del reino, que proponía un discurso propagandístico que colocaba al monarca en una posición de superioridad con respecto al resto de los mortales. Son la manifestación de las principales ideas políticas y su evolución, en especial en relación a la imagen idealizada del rey como representante de Dios, a quien debe su poder, y como modelo de virtudes y de justicia. Siendo la justicia uno de los tópicos permanentes y sobre el cual se insiste, pues solo aquel verdaderamente justo podía apelar a ser representante de la divinidad. Nogales Rincón, David, "Los espejos de príncipe en Castilla...op. cit, pp. 30, 37, 38.

${ }^{731}$ Bermejo, José Luis, "Orígenes Medievales en la Idea de Soberanía”, en Revista de Estudios Políticos, 200-201, 1975, [pp. 283-290], p. 284; y García Pelayo, Manuel, El Reino de Dios... op. cit., p. 143.

${ }^{732}$ Zamora, Patricio, "El rey sagrado.... op. cit., p. 137.
} 
Tabla 4: Validación jurídica

\begin{tabular}{|c|c|c|c|c|}
\hline & $\begin{array}{l}\text { Justo } \\
\text { Justiciero }\end{array}$ & Pacificador & $\begin{array}{l}\text { Piadoso / Clemente } \\
\text { / Misericordioso }\end{array}$ & Fuente \\
\hline 1000 & $\mathrm{X}$ & $\mathrm{X}$ & $\mathrm{X}$ & $\begin{array}{l}\text { - CAIII Rotense } \mathrm{N}^{\circ} 3 \mathrm{~N}^{\circ} 4 \text { p. } \\
198, \mathrm{~N}^{\circ} 11 \text { p. } 206, \mathrm{~N}^{\circ} 15 \text { p. } 208 . \\
\text { CAIII Sebastian } \mathrm{N}^{\circ} 15 \text { p. } 209 . \\
\text { - CA N }{ }^{\circ} 10 \text { p. } 249, \mathrm{~N}^{\circ} 11 \text { p. } 250 \\
\text { - CMz. C.VI, N44, p. } 63\end{array}$ \\
\hline 1090 & $\mathrm{X}$ & & & $\begin{array}{l}\text { - VDS Cap XXVI, N¹5-25 p. } \\
377\end{array}$ \\
\hline 1100 & & $\mathrm{X}$ & & - CRL p. 330 \\
\hline 1110 & $\mathrm{X}$ & & & - CAS N ${ }^{\circ} 6$ p. 13 \\
\hline 1120 & & & & \\
\hline 1130 & $\mathrm{X}$ & $\mathrm{X}$ & & $\begin{array}{l}\text { - HC Liber I Cap. } 46 \text { p. } 153, \\
154 \\
\text { - COP p. } 179,180 .\end{array}$ \\
\hline 1140 & $\mathrm{X}$ & & $\mathrm{X}$ & $\begin{array}{l}\text { - CAI. Liber I } N^{\circ} 23 \text { p. } 71, \mathrm{~N}^{\circ} \\
71 \text { p. } 85\end{array}$ \\
\hline 1150 & & & & \\
\hline 1160 & & & & \\
\hline 1170 & $\mathrm{X}$ & $\mathrm{X}$ & & - CN Liber III No 23 p. 183 \\
\hline 1180 & & & & \\
\hline 1190 & & & & \\
\hline 1200 & & & & \\
\hline 1210 & & & & \\
\hline 1220 & & & & \\
\hline 1230 & $\mathrm{X}$ & $\mathrm{X}$ & $\mathrm{X}$ & 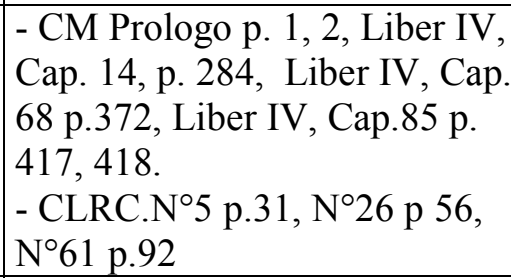 \\
\hline 1240 & $\mathrm{X}$ & $\mathrm{X}$ & $\mathrm{X}$ & $\begin{array}{l}\text { - HRH Liber II Cap. } 15 \text { p.108, } \\
\text { Liber III Cap. } 8 \text { p. } 130-131 . \\
\text { Liber IV Cap. } 13 \text { p. } 176 \text { Liber } \\
\text { VI, Cap. } 21 \text { p. } 246 \text { Liber VII } \\
\text { Cap. } 21 \text { p. 290, Liber Liber } \\
\text { VIII, Cap. } 4 \text { p. 311, Cap X } \\
\text { p.341 }\end{array}$ \\
\hline 1250 & & & & \\
\hline 1270 & $\mathrm{X}$ & $\mathrm{X}$ & & $\begin{array}{l}\text { - CGE. Cap. } 782 \text { p. } 467, \text { Cap } \\
\text { 846 p. } 520-521, \text { Cap } 980 \text { p. } \\
\text { 659, Cap. } 1131 \text { p. } 771 \\
\text { - CXXR Liber VIII Cap } 1 \text { p. } \\
\text { 165, Liber X Cap. } 1 \text { p 201, } \\
\text { Liber XII Cap } 16 \text { p. } 265\end{array}$ \\
\hline 1280 & & & & \\
\hline 1290 & & & & \\
\hline 1300 & & & & \\
\hline
\end{tabular}




\section{II.4.e.- Virtudes morales}

En las páginas anteriores hemos hecho referencia a varias características regias, complementarias a las que nos han servido de eje de análisis. Son aquellas a las que hemos llamado "virtudes morales", un concepto amplio en que se han incluido otros conceptos vinculados al monarca, tales como sabio, hermoso o fermoso, casto, virtuoso y generoso ${ }^{733}$. En su conjunto estas "virtudes morales" tienen una mención mucho menor en las crónicas, por lo que podemos clasificarlas como secundarias y subordinadas a otras virtudes, que incluso parecen englobarlas, como son las virtudes guerreras, religiosas y judiciales. A partir de la observación del siguiente gráfico, es destacable es el hecho que además estas características se encuentran concentradas en las crónicas elaboradas a partir de la década de 1220, esencialmente las obras de Lucas de Tuy, Jiménez de Rada y el Ciclo Alfonsí; es decir, cuando el discurso cronístico ya estaba consolidado.

\footnotetext{
733 A este respecto Ana Rodríguez, realizó una interesante recopilación de reyes con sus respectivas virtudes, según el Chronicon mundi, que consideramos prudente citar en extenso. Es de destacar que, según la autora, que si bien el cronista asocia a los distintos monarcas con sus virtudes, no hace lo mismo con los vicios los cuales si bien son enumerados en el proemio, rara vez aparecen asociados a un monarca en especifico. Quizás por las intenciones del "Tudense" de escribir una obra con fines pedagógicos en lo que realmente importaba era demostrar modelos virtuosos que sirviesen de ejemplo: "Algunas de estas virtudes van adornando a los reyes leoneses y castellanos a lo largo del relato del Chronicon mundi: Fernando II de León fue "pius et hilaris [...] armis strenuus, in belli victoriosus, circa omnes pius, benignus, liberalis et largitate preclarus», su hijo Alfonso IX «fuit pulcher, eloquens, clemens, fortis viribus et armis strenuus et in fide Catholica solidatus». Alfonso VIII de Castilla es caracterizado como «sapientia magnus, consilio prouidus, armis strenuus, largitate precipuus et fide Catholica roboratus»." (Rodríguez, Ana, "Modelos de Legitimidad Política en la Chronica regum Castellae de Juan de Osma", en e-Spania 2/2006, p. 3. En forma complementaria consideramos el trabajo de la misma autora "De rebus Hispaniae frente... op. cit., p. 139).

Sobre los reyes de León mencionados, Fernando II (1157 y 1188) y su hijo Alfonso IX (11881230), es importante tener en consideración que ambos convivieron con Alfonso VIII de Castilla, y por lo tanto son contemporáneos y protagonistas del periodo de expansión territorial. En líneas generales los reyes leoneses debieron hacer frente a una realidad militar y política similar a la castellana, en otras palabras impulsar la expansión territorial hacia el sur, al mismo tiempo que luchaban por consolidar su poder en sus reinos. Ejemplo gráfico de ello fue el hecho que durante el reinado de Fernando II, el monarca sostuviese dos conflictos contra Castilla (el primero entre 1162 y 1166 , y entre 1178 y 1180 el segundo), al mismo tiempo que realizaba alianzas matrimoniales con Portugal y arrebata a los musulmanes Badajoz y favoreciera la creación de la Órden de Santiago en 1170.

Por su parte Alfonso IX mantuvo una serie de disputas con Alfonso VIII, lo que los llevó a enfrentarse en diversas ocasiones, incluso el leonés se resto de la campaña de las Navas de Tolosa y en cambio aprovechó la situación para recuperar territorios que previamente le había arrebatado Castilla. Lo que no impidió que el monarca también fuese un activo reconquistador, apoderándose de las plazas de Valencia de Alcántara y Cáceres. Todo ello plasmado, entre otras fuentes en la Crónica General. Junto a lo anterior el monarca leonés debió enfrentarse con Portugal por la posesión de territorios en la frontera y pactar la paz con Castilla por medio de su matrimonio con Berenguella, el cual si bien fue posteriormente disuelto, permitió el nacimiento de Fernando III, que terminaría por unificar los reinos de Castilla y León en 1230 .
} 


\section{Gráfico 5: Virtudes morales}

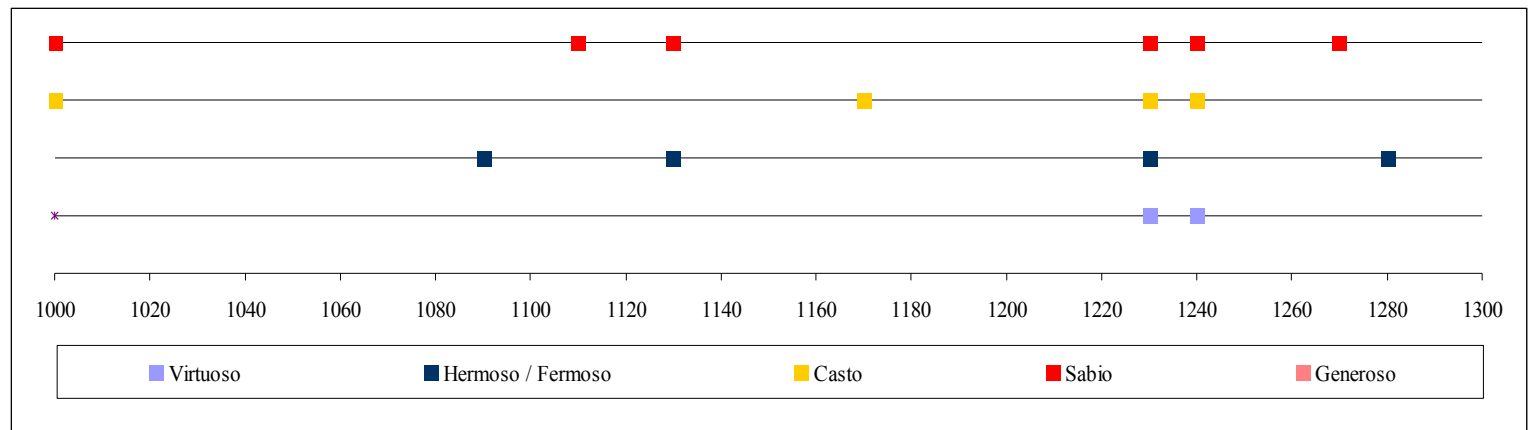

A partir del gráfico se puede concluir que, dentro de estas "virtudes" referidas a la figura del rey, la que más se repite es la de Sabio, que aparece en textos como la Crónica Anónima de Sahagún, la Historia Compostelana, la Crónica de Pelayo, la Adefonsi Imperatoris, la Crónica Latina, y en los textos del "Tudense" y "el Toledano". En ellos se incluyen una serie de otros atributos, como es el ser conocedor de Dios y de los hombres, ser instruido y prudente. En otras palabras, no necesariamente hace referencia al conocimiento intelectual, sino que más bien a la sapientía, o lo que podríamos entender como un combinación entre el conocimiento (de Dios y los hombres) y la inteligencia.

Siguiéndole en importancia están las expresiones "fermoso/hermoso",734 y "casto". Este ultimo concepto es más genérico, entendido como la fidelidad conyugal y la recta vida privada, y se le atribuye a distintos monarcas; pero el segundo se suele referir a dos personajes en específico: Alfonso II el Casto (791-842) y Fernando III (1217-1252) ${ }^{735}$. No obstante diversos autores, en especial Lucas de Tuy y Jiménez de Rada, la mencionan como una virtud aconsejable, pero muy raramente aplicada ${ }^{736}$.

Los últimos dos apelativos observables, aunque no muy recurrentes, son "generoso" -siendo el mayor ejemplo, como luego veremos, el caso de Alfonso VIII- y “virtuoso", principalmente restringido a las décadas de 1220 y 1240, pero siendo de uso recurrente en las crónicas de este período ${ }^{737}$.

\footnotetext{
${ }^{734}$ Una caracterización, que como ya mencionamos se refiere a la proporción y armonía del cuerpo, en relación a reflejar una proporcionalidad equivalente a la dimensión espiritual, más que a un parámetro de belleza especifico.

${ }^{735}$ Pese a que en la práctica el concepto se restringe a estos dos personajes los hemos incluido como categoría debido a que son variadas las crónicas que citan estos casos, las mismas que en contraste lo omiten para otros monarcas que además sabemos incurrieron en conocidas prácticas de adulterio.

${ }^{736}$ Ver gráfico y tabla $\mathrm{N}^{\circ} 5$.

${ }^{737}$ Ver gráfico y tabla $N^{\circ} 5$.
} 
En su conjunto, estas últimas tres virtudes, si bien no son de un amplio uso en cuanto a su aparición en las crónicas, ayudan a elaborar una imagen más acabada de los monarcas, en especial a partir del siglo XIII cuando el discurso está prácticamente consolidado.

Como hemos visto, estas características significaron la elaboración de un discurso que proyectó, desde las primeras crónicas del ciclo astur, la idea de que los reyes del norte estaban involucrados en una guerra contra los enemigos de la cristiandad y, por lo tanto, poseían un aura de santidad y un temor de Dios que los protegía y conduciría a la victoria $^{738}$. En esencia, se muestran como campeones de la fe, una imagen que destaca por sobre los intereses económicos o territoriales que las crónicas apenas insinúan. Es evidente que las crónicas poseen un marcado espíritu providencialista, inspirado en el Antiguo Testamento y en la tradición visigoda, el cual estaba destinado a conmover a las elites a quienes iba dirigido el relato, y así ayudar a unificar estos sectores bajo las órdenes de los monarcas y la Iglesia. A este respecto, crónicas como la Albeldense son categóricas al afirmar que el surgimiento del Reino Astur se debió a la reacción de la gracia divina que protegió e inspiró a sus fundadores. Este pensamiento continuó evolucionado a lo largo de la Reconquista y se vio fortalecido con el ingreso de la Orden de Cluny a la Península, con sus ideas de orden y respeto a las instituciones monárquicas.

Para el siglo XIII se había consolidado la idea de que los reyes eran un instrumento al servicio de la divinidad, y que ésta manifestaba su voluntad a través de ellos, premiando o castigando sus actos. Esta relación entre la religión y la política -con su arista neogótica- se convirtió en un método común de propaganda mediante el cual se validaba al soberano y se criticaba a sus adversarios. En este sentido, las crónicas debían hacer ostentación de esta cercanía con la divinidad, tildando al soberano de piadoso y cristiano, entre otros apelativos, en tanto que solían criticar en el mismo tono a sus adversarios, llamándolos "malditos" o "impíos", entre otros calificativos ${ }^{739}$. Debemos recordar que nos referimos a un grupo humano -en especial al conjunto de la población y a la elite- profundamente creyente y poseedora de cierto dominio del lenguaje

\footnotetext{
${ }^{738}$ Flori, Jean, Guerra Santa, Yihad, Cruzada... op. cit., p. 245; Bronisch, Alexander Pierre, Reconquista y guerra santa... op. cit., 189, 194, 195, 213-232.

${ }^{739}$ El antiguo testamento se convirtió en una fuente de modelos regios, entre los que se contaban Moisés, Saúl, David y Salomón. Del mismo lugar provenían los modelos del mal rey, caracterizados por la impiedad y la injusticia, destacando por sobre todos Nabuconodosor. Nieto Soria, José Manuel, Fundamentos Ideológicos... op. cit., p. 43-105; y Bertelli, Sergio, "Religio Regis..., op. cit., p. 12.
} 
religioso, pero al mismo tiempo poco crítica con respecto a sus creencias; es por esto que este tipo de acciones propagandísticas resultaban ser de fuerte impacto.

En el caso castellano fue la propia monarquía la que procuró fomentar estas creencias a través de textos legales y las crónicas ${ }^{740}$, en la convicción de que la creación de una retórica que reforzara una alianza político-religiosa era la principal herramienta para controlar a sus vasallos, apelando a su religiosidad. Una construcción que utilizaba como punto de partida la batalla de Covadonga y la imagen de Pelayo, el nuevo caudillo que restablecería la alianza entre los visigodos y Dios, imagen que luego sería trasmitida a sus sucesores a lo largo de la guerra de Reconquista.

A nuestro juicio, el rey hispano era entonces representante de la potestad divina, pero curiosamente esta característica no le era conferida por la Iglesia, sino que la recibía en función del cumplimento de la tradición y de sus deberes. Sobre estos últimos ya hemos hablado; en cuanto a la tradición, recordemos que esta hace referencia al linaje del rey, a su posición de heredero y continuador de los reyes de antaño, que también habían sido instrumentos al servicio de Dios ${ }^{741}$. Esto implicaba que el rey recibía su potestad directamente de Dios a través de su linaje, y por lo tanto su poder era independiente de otras voluntades como el Papado o las figuras imperiales. El rey es entonces un delegado de Dios, un vicario y por lo tanto sólo reconoce a Dios mismo como su superior y fuente de su poder ${ }^{742}$. Este hecho se sintetiza en la expresión -

\footnotetext{
${ }^{740}$ Sobre este punto existe una abundante bibliografía, entre la que destacamos, entre muchas otras, el articulo de María Isabel Pérez de Tudela Velasco "La consideración ética de la guerra y el uso de la violencia"; el texto de Walter Ullmann Historia del Pensamiento Político en la Edad Media; los ya mencionados trabajos de Nieto Soria, "Fundamentos Ideológicos del Poder Real en Castilla" e "Imágenes religiosas del rey y del poder real en la Castilla del siglo XIII"; y el también mencionado "El Reino de Dios, Arquetipo Político" de Manuel García Pelayo. Así como Las España medievales de Pierre Bonassie y la obra de José Luis Villacañas La Formación de los Reinos Hispánicos.

${ }^{741}$ Maravall, José Antonio, Estudios de Historia ...op. cit., p. 51.

${ }^{742} \mathrm{La}$ suma de todas estas distintas formas de legitimación, contribuyeron a que para el caso castellanoleones, se produjera otra de las particularidades hispánicas. En las crónicas se constata la ausencia de uno de los más tradicionales rituales de legitimación y muy común en otros reinos europeos, nos referimos a la ya mencionada bíblica costumbre de la unción de los reyes.

Como ya mencionamos anteriormente en la Hispania Visigoda la unción era una costumbre habitual, pero después del 711 su uso se fue haciendo cada vez menos frecuente, al punto de que en Castilla y León prácticamente desapareció, salvo por unas contadas excepciones, como los casos de Alfonso VII y Alfonso IX. Como sabemos la unción es la forma en la que el soberano, como representante de Dios, recibía de manos de la Iglesia una señal física y constatable de la Gracia. Un acto que colocaba al soberano bajo la protección divina y le obliga a actuar como rey cristiano y defensor de la fe y que por lo tanto era fundamental en la concepción religiosa del poder real. En palabras de Joseph Ratzinger, Benedicto XVI, "la unción era el signo visible de la concesión de los dones [al rey] requeridos para su tarea, del Espíritu de Dios para su misión" (Ratzinger, Joseph, Benedicto XVI, Jesús de Nazaret, Buenos Aires, Planeta, 2010, p. 49).

La ausencia del rito en estos territorios ha sido explicada a través de dos formas, que consideramos complementarias, la primera de ellas es que para la mentalidad hispánica la consagración del soberano no venía dada por un ritual simbólico, sino que por sus conquistas y victorias (Linehan, Peter, España, 1157$1300 \ldots$ op. cit., p. 138; y Nieto Soria, José Manuel, "Del rey oculto... op. cit., p. 9). Al ser el dirigente de
} 
presente en distintas crónicas- de Dei Gratia, que no sólo servía para recodar a los súbditos el origen de las prerrogativas reales, sino que también cumplía la función de recordar al soberano que su poder era un don, y que por lo tanto estaba sujeto a la voluntad divina $^{743}$. En base a esta teoría política, que defendía la independencia de los reyes hispanos, no es extraño que en determinadas ocasiones los soberanos leoneses utilizasen el título de emperador ${ }^{744}$. No obstante, esta condición sólo tuvo un efecto

la guerra contra los musulmanes, las victorias sobre ellos demostraban que Dios estaba con el monarca. De esta forma para el grueso de la población castellano-leonesa sus reyes estaban ungidos por la sangre de los musulmanes y el polvo de los territorios conquistados, ello era suficiente prueba del favor de Dios y quizás también era una señal mucho más poderosa y física que un antiguo ritual. Esta forma de "unción" también obligaba al rey a validarse constantemente a través de nuevas conquistas y demostrando sus virtudes de justicia y piedad. Al mismo tiempo, la ausencia del ritual también permitía al soberano demostrar cierto grado de independencia en relación a la Iglesia, puesto que se daba a entender que no necesitaba de la Institución para legitimarse, en el contexto de la ya mencionada superioridad de los monarcas castellano-leoneses sobre sus vasallos (Rucquoi, Adeline, "El Rey Sabio... op. cit., pp. 77; y Sánchez-Albornoz, Claudio, España, un Enigma Histórico, Tomo I, Buenos Aires, Sudamericana, 1971, p. 284).

La segunda explicación versa sobre la concepción que sobre si mismos tenían los reyes castellanoleoneses. Debido a su función como defensores de la fe y herederos de los visigodos, existía entre ellos mismos y a parecer entre sus súbditos la creencia de que contaban con una unción directamente otorgada por Dios de forma privada e individual y que era tan aceptada como aquella otorgada de forma pública y ritual (Nieto Soria, José Manuel, Fundamentos Ideológicos... op. cit., pp. 61, 62). En esta idea se expresaba la particularidad del monarca por ser el rector de los súbditos y soberanos peninsulares. Él como Imago Dei, rey victorioso y piadoso era directamente legitimado por el Creador y por lo tanto hacía innecesario cualquier otro ritual, en el que hubiese mediadores que controlasen esta forma de legitimación.

Es posible que la falta de unción se relacionase con la aparente falta de poderes especiales en los monarcas castellano y leoneses, puesto que pese a las influencias francas los reyes hispanos parece ser que no tuvieron poderes taumatúrgicos evidentes, limitando sus "milagros" al contacto con la divinidad, en especial con los santos como Santiago, en el contexto de la guerra de Reconquista (Bermejo Cabrero, José Luis, Máximas, Principios... op. cit., p. 81). Es decir que sus poderes sobrenaturales se veían en su labor de combatir a los musulmanes y al mal en general.

La ausencia de la unción no es la única particularidad para el caso castellano, ya que según Nieto Soria, la corona real también tenía un trato especial. Si bien la corona fue considerada un objeto bendito entregado al monarca mediante una ceremonia eclesiástica, la misma pareció no tener un significado trascendente en si misma puesto que no pasaba de un soberano a otro y en cambio parece ser que fue tratada como un objeto personal, al punto que a partir del siglo XIII debió compartir protagonismo con la espada como símbolo del poder real. Una evolución que parece corresponder al simbólico del papel del rey como protector de la Iglesia, impartidor de justicia y máximo dirigente en la guerra contra el Islam y la recuperación de las tierras, todas ellas acciones simbolizadas de forma universal por la espada y no necesariamente por la corona.

Estas particularidades no significaban la ausencia de rituales religiosos cristianos en la ascensión de un nuevo rey, pero si es posible observar que el ceremonial castellano era una combinación de nuevas y antiguas tradiciones. Por ejemplo se mantenía la costumbre visigoda de alzar al rey luego de su proclamación, para acto seguido ser coronado por un obispo, que a su vez era el encargado de juramentar al soberano en el compromiso de defender la fe, la Iglesia y la justicia. Hechos este juramento la asamblea procedía a jurar su lealtad al nuevo soberano según los compromisos vasalláticos (Bonassie, Pierre y otros, Las Españas Medievales... op. cit., 270).

${ }^{743}$ Gordo, Ángel, "Alfonso VII, Sucesión e Imperium”, en Tiempo y Espacio, Universidad del Bio-Bio, Chillán, 18, 2007, p. 19. (http://www.ubiobio.cl/miweb/webfile/media/222/Tiempo/2007/ ALFONSO\% 20VII,\%20 SUCESI\%C3\%93N\%20E\%20IMPERIUM.pdf. (julio de 2012). Bermejo, José Luis. “Orígenes Medievales... op. cit., p. 287; y Mitre Fernández, Emilio, La España Medieval... op. cit., p. 152.

${ }^{744}$ Sobre los usos del titulo imperial Ángel Gordo León ha publicado una serie de artículos ("Las intitulaciones y expresiones de la 'Potestas' de la reina Urraca I de León: trasfondo y significado de los 
circunscrito a los territorios de León, y apenas considerado por los restantes monarcas peninsulares. Debemos recordar que cuando los reyes de León se arrogaron la máxima autoridad política no se observó ningún cambio en la relación con los demás reinos, y el Papado, único garante del título imperial, tampoco hizo reconocimiento de la titularidad leonesa $^{745}$. De esta forma, el título imperial leonés quedó reducido a un formalismo simbólico de limitados alcances reales, pero que sin embargo, expresa las intenciones de los reyes de demostrar la independencia y grandeza de su poder.

vocativos 'Regina' e 'imperatrix' en la primera mitad del siglo XII’, Intus - legere, Vol. 1, No 9, 2006, pp. 77-92; “Alfonso VII, Sucesión e Imperium”, en Tiempo y Espacio, Universidad del Bio-Bio, Chillán, 18, 2007; y "Papado y monarquía en el Reino de León. Las relaciones político religiosas de Gregorio VII y Alfonso VI en el contexto del Imperium Legionense y la implantación de la reforma pontifical en la Península Ibérica", Studi medievali, Anno 49, Fasc. 2, 2008, pp. 519-559). en los que propone que los reyes leones utilizaron el título como una forma de establecer y marcar su dominio sobre las tierras peninsulares, imponiéndose sobre los restantes señoríos peninsulares en la lógica del "rey de reyes". Por lo tanto no existía una intencionalidad universal detrás de esta forma de intitulación, como ocurría en el Sacro Imperio, sino que más bien se trataba de un argumento de empoderamiento local.

De forma complementaria se encuentran los planteamientos de Gaël Le Morvan, que a partir del estudio de Alfonso VI y la Historia Silensis explica que el monarca se atribuyó el título imperial para legitimar su dinastía. Él gobernada sobre la patria de los visigodos, Hispania, sostenido por la fe, la Iglesia y las armas, todos ellos elementos constituyentes de la dignidad imperial. (Le Morvan, Gaël, Reinos e imperio: la Historia legionensis... op. cit., http://e-spania.revues.org/21681 (junio de 2013).

Por su parte la Iglesia desde Roma tampoco respaldó las ambiciones imperiales en Castilla y León. Un caso representativo fue el de los títulos imperiales solicitados por Alfonso VII y Fernando III. El pontificado, si bien reconocía la supremacía de ambos reyes sobre el resto de sus pares peninsulares, nunca realizó ningún tipo de reconocimiento oficial a esos títulos, que en el caso de Alfonso fueron utilizados por el soberano (Gordo, Ángel, “Alfonso VII, Sucesión e Imperium... op. cit., p. 13; y González Jiménez, Manuel, Fernando III... op. cit., pp. 131, 132).

El mencionado reconocimiento hubiese reforzado la posición política de los monarcas castellanoleoneses, no sólo en la Península sino que en todo Occidente. Su rechazó se debió entre otros factores al hecho de que desde el pontificado de Gregorio VII, Roma se encontraba en una disputa con el Sacro Imperio, y en tales circunstancias es lógico que el patriarcado romano no quisiese favorecer la entronización de otro emperador, que a la larga podría convertirse en un nuevo rival político, más si consideramos los antecedentes particulares y autonómicos de los magnates peninsulares (Gordo, Ángel, "Alfonso VII, Sucesión e Imperium... op. cit., p. 14).

745 Gordo, Ángel, "Estructuras Regias en el Reino de León. La Preparatio en la Elevación al Trono Imperial de Urraca I y Alfonso VII. Factores diferenciadores y de estabilidad en el gobierno", en Cerda, José Manuel (Editor), El Mundo Medieval, Legado y Alteridad, Santiago de Chile, Universidad Finis Terrae, 2009, pp. 178, 179. 
Tabla 5: Virtudes morales

\begin{tabular}{|c|c|c|c|c|c|c|}
\hline & Virtuoso & $\begin{array}{l}\text { Hermoso } \\
/ \\
\text { Fermoso }\end{array}$ & Casto & Sabio & Generoso & Fuente \\
\hline 1000 & & & X & X & & $\begin{array}{l}\text { - CAIII Rotense } \mathrm{N}^{\circ} 3, \mathrm{~N}^{\circ} 4 \text { p. } 198, \\
\mathrm{~N}^{\circ} 22 \text { p. } 214 \text {. CAIII Sebastian } \mathrm{N}^{\circ} 22 \\
\text { p.215. CA } \mathrm{N}^{\circ} 9, \mathrm{~N}^{\circ} 10 \text { p. } 249\end{array}$ \\
\hline 1090 & & X & & & & $\begin{array}{l}\text { - VDS Cap IV, N³35, } 340 \text { p. } 217 \text {, } \\
219 .\end{array}$ \\
\hline 1100 & & & & & & \\
\hline 1110 & & & & $\mathrm{X}$ & & - CAS N 6 p. 13 \\
\hline 1120 & & & & & & \\
\hline 1130 & & X & & $\mathrm{X}$ & & $\begin{array}{l}\text { - HC Liber I Cap. } 46 \text { p.153 } \\
\text { - COP p. } 178\end{array}$ \\
\hline 1140 & & & & & & \\
\hline 1150 & & & & & & \\
\hline 1160 & & & & & & \\
\hline 1170 & & & $\mathrm{X}$ & & & - CN Liber II $N^{\circ} 15$ p. 121 \\
\hline 1180 & & & & & & \\
\hline 1190 & & & & & & \\
\hline 1200 & & & & & & \\
\hline 1210 & & & & & & \\
\hline 1220 & & & & & & \\
\hline 1230 & $\mathrm{X}$ & $\mathrm{X}$ & X & X & $\mathrm{X}$ & $\begin{array}{l}\text { - CM Prologo p. 1, 2, Liber IV, } \\
\text { Cap. } 14 \text { p. } 284 \text {, Cap. } 60 \text { p. } 361 \text {, Cap. } \\
85 \text { p. } 417,418 \text {, Cap. } 90 \text { p. } 423 \\
\text { - CLRC N² p. } 27, N^{\circ} 21 \text { p.50, } \\
\text { N}^{\circ} 46 \text { p. } 77\end{array}$ \\
\hline 1240 & $\mathrm{X}$ & & X & X & $\mathrm{X}$ & $\begin{array}{l}\text { - HRH Liber II Cap. } 15 \text { p. } 108,109 . \\
\text { Liber IV Cap. 5, Liber } 8 \text { Cap } 169 \text {, } \\
\text { Cap. } 13 \text { p. } 176,177 . \text { Cap. } 15 \text { p. } 181 . \\
\text { Liber VI Cap } 21 \text { p. } 246 \text {, Liber VII } \\
\text { Cap. } 24 \text { p. } 293 \text {, Liber VIII Cap. } 4 \text { p. } \\
\text { 312, Cap. } 15 \text { p. } 329 \text {, Liber IX Cap. } 6 \\
\text { p. } 339 \text {, Cap } 13 \text { p. } 346\end{array}$ \\
\hline 1250 & & & & & & \\
\hline 1260 & & & & & & \\
\hline 1270 & & & & $\mathrm{X}$ & $\mathrm{X}$ & $\begin{array}{l}\text { - CGE Cap. } 846 \text { p. } 520 \text {, Cap. } 998 \text { p. } \\
\text { 678, Cap. } 1113 \text { p. } 694 \text {, Cap. } 1131 \\
\text { p. } 770-771 . \\
\text { - CXXR Liber XIII Cap } 28 \text { p. } 282\end{array}$ \\
\hline 1280 & & & & & & \\
\hline 1290 & & & & & & \\
\hline 1300 & & & & & & \\
\hline
\end{tabular}


TERCERA PARTE:

LOS TÓPICOS 


\section{TERCERA PARTE: LOS TÓPICOS}

\section{III.1.- El Dios de la guerra}

III.1.a.- Providencialismo: Dios juez y parte en los hechos de los hombres

"En el principio era el Verbo, y el Verbo era con Dios, y el Verbo era Dios.

Este era en el principio con Dios.

Todas las cosas por él fueron hechas, y sin él nada de lo que ha sido hecho, fue hecho.

En él estaba la vida, y la vida era la luz de los hombres. La luz en las tinieblas resplandece, y las tinieblas no prevalecieron contra ella"746.

Según el Diccionario de la Real Academia Española, providencialismo se define como: "Doctrina según la cual todo sucede por disposición de la Divina Providencia" 747. Si bien esta definición es exacta, no alcanza a describir la enorme influencia de esta doctrina ya que la sociedad medieval, y por ende su historiografía, tenía el fuerte convencimiento de que Dios actuaba de forma directa y explícita en los hechos de los hombres, ya sea influenciando, interviniendo o incluso castigando a colectivos enteros $^{748}$.

Toda la historia del Occidente medieval está marcada por el providencialismo, siendo esto especialmente evidente en las obras cronísticas, puesto que la historiografía medieval -desde San Agustín- comprendía su labor como la de manifestar la evidencia de la actuación divina en todos los hechos de los hombres. De esa forma, todo lo

\footnotetext{
${ }^{746}$ Juan 1: 1, 5.

${ }^{747} \mathrm{http}$ ///buscon.rae.es/draeI/SrvltConsulta?TIPO_BUS=3\&LEMA=providencialismo. (octubre de 2012).

${ }^{748}$ Es importante notar que el providencialismo -entendido ampliamente como la intervención de Dios en los hechos de los hombres- no fue sólo un fenómeno cristiano, puesto que también estaba presente en el Islam con sus propias características. Ambos grupos, cristianos y musulmanes, se identificaban a sí mismos por su religión y denostaban a sus adversarios a raíz de sus creencias; es por ello que en las contiendas en las que se enfrentaron, ambos bandos sostenían ser instrumentos de Dios en su lucha contra los infieles. Tanto los musulmanes como los cruzados e hispanos enarbolaban estandartes y pendones con símbolos religiosos e invocaban a la divinidad antes de entrar en combate. Al respecto, José Manuel Rodríguez nos recuerda que autores musulmanes como Ibn al-Kardabus consideraban -de forma similar a los teólogos cristianos- que la historia de la humanidad era la historia de la religión de los hombres (Rodríguez García, José Manuel, "El Yihad: Visión y respuesta... op. cit., p. 72; y Barkai, Ron, El enemigo en el espejo... op. cit., p. 277).

Esta situación se explica en razón de que ambos credos comparten una raíz común, el Antiguo Testamento; así, cristianos y musulmanes aceptaban y respetaban a los mismos profetas y reyes de la antigüedad, que al igual que ellos, combatían en nombre de Dios. En definitiva, eran instrumentos y defensores del mensaje divino, lo que contribuyó a la sacralización del conflicto y a dotarlo de una evolución única en Occidente.
} 
ocurrido y por ocurrir podía ser explicado como parte de un plan maestro gestado por la Providencia, el cual incluía las grandes trasformaciones socioculturales, como el colapso del Imperio Romano y la introducción de los reinos bárbaros medievales, por ejemplo. Así Dios se introduce como el principal actor de la historia, la que además sigue un orden lógico que excluye las arcanas creencias en la fortuna o los astros. Por su parte, los hombres, aunque libres, deben ceñirse a los parámetros del Plan de Salvación y evitar el pecado, puesto que su cometimiento acarrea la sanción de la Providencia $^{749}$.

Es así como podemos afirmar que el providencialismo era parte integral del discurso de la Iglesia, que lo utilizaba como instrumento de control sobre aspectos políticos y morales, extensivos a todos los estamentos de la sociedad. No obstante, es importante destacar que en el caso de la cronística medieval, no debemos juzgar todos los relatos providenciales como meras invenciones propagandísticas, dado que las apariciones de santos y otros milagros eran parte del imaginario colectivo de la sociedad medieval $\mathrm{y}$, fruto de una tradición oral que rara vez era rebatida por los contemporáneos.

No obstante lo anterior, ello no implica que no existiera un providencialismo pagano, judío o musulmán, en el caso de estos dos cultos monoteístas, el

749 Benito Ruano, Eloy, "La Historiografía...op.cit, pp. 55, 56; y Sánchez Salor, Eustaquio, "E1 Providencialismo en la Historiografía... op. cit., pp. 181.

Es importante notar que el providencialismo no fue un fenómeno exclusivo de los cristianos; también se pueden observar episodios similares en el Islam, aunque al parecer fue un argumento menos utilizado que en el caso cristiano. Un ejemplo de ello lo encontramos en una crónica islámica de comienzos del siglo XIV: “Los relámpagos continuaban sin interrupción mientras los fragores [de la tormenta], inspirando temor, seguian sus trazas. Las gentes se [re]vistieron de sumisión y humildad y temieron la venida del castigo; entonces clamaron a Dios suplicando reconociese lo que [de bueno] habia en ellos y que no [permitiera] se alegrasen con su mal los enemigos, a los que había venido a hacer la guerra santa por él. [Dios] - alabado sea - [les] concedió eso prontamente, se apiadó de [ellos por] sus súplicas y desplegó su misericordia sobre ellos. La gente dio las gracias a su Dueño por la merced que nuevamente les hizo y por hacerles ver signos de su poder." (CCC, op.ci, p. 20).

El relato, si bien tardío, nos muestra un tipo de providencialismo que también está presente entre los cristianos, y que es frecuente de encontrar en las Escrituras; la creencia de que Dios controla la naturaleza a su antojo, y por tanto la interpretación de cualquier tipo de desastre natural en un acto providencialista, sólo posible de revertir mediante la oración y las súplicas.

Para el Islam peninsular, a medida que sus derrotas fueron cada vez más frecuentes y los cristianos comenzaron a demostrar una clara superioridad militar, comenzó a ser necesario buscar explicaciones para estos reveses. Según Rodríguez García, dos fueron las posibles explicaciones halladas. La primera de tipo político y racional, señala que los musulmanes estaban siendo derrotados debido a su falta de organización política y a sus divisiones y luchas intestinas. Pero la segunda explicación respondía a un modelo de interpretación netamente religioso y de larga tradición: Dios o Alá estaba castigando a los malos e impuros creyentes. Una explicación no muy distinta a la que en su momento esgrimieron los hispano-cristianos y que venía a explicar los reveses militares apelando a la religión y la religiosidad. La fe debía servir para reorganizar a la sociedad y unirla en torno a un objetivo común, es decir, la supervivencia de una comunidad política y social amenazada por sus enemigos (Rodríguez García, José Manuel, "El Yihad: Visión y respuesta... op. cit., pp. 81, 82). 
providencialismo era similar a la concepción cristiana, en cuanto la comprensión de Dios como señor de toda la existencia. Entre los paganos también existía esta concepción, pero con dimensiones distintas propias como el politeísmo ${ }^{750}$. Ambas creencias convivirían durante el Imperio Romano, influenciando y definiendo al cristianismo, que de la mano de la construcción de la Iglesia creó una nueva concepción providencial. Esta corresponde a la creencia de que al Dios único y trino se puede acceder a través de "representantes menores"; es decir, los santos; quienes cumplen diferentes roles asociados a distintos aspectos de la vida cotidiana, a semejanza de los primitivos "poderes invisibles".

Es así como la cosmovisión cristiana fue construyéndose durante siglos, gracias a la actividad intelectual de personajes como San Agustin $^{751}$, que esencialmente aborda el problema del libre albedrío de los hombres. Por lo tanto, pese a la existencia de una voluntad superior, las personas son responsables de sus actos y de sus desgracias; siendo así, no se podía culpar a Dios ni al cristianismo de la caída del antiguo orden

\footnotetext{
${ }^{750}$ Según Rogelio Rubio, en las sociedades primitivas el mundo sobrenatural era inseparable del mundo real, el cual se explicaba a través de los designios de los "poderes invisibles" (Rubio Hernández, Rogelio, Antropología: Religión... op. cit., p. 15). Estos poderes, a grandes rasgos, corresponden a las distintas deidades que servían para explicar aquellos fenómenos que el hombre primitivo no estaba en condiciones de comprender, siendo el origen de los espíritus o dioses que habitaban o controlaban en el agua, los terremotos, volcanes, la muerte, el sexo, los animales, etc. Esta cosmovisión, presente en prácticamente todos los pueblos primitivos del globo, fue perfeccionada por las primeras civilizaciones y a partir de ella crearon dioses antropomorfos, quienes intervenían y convivían con los hombres. El judaísmo convivió con este tipo de creencias, pero desarrolló una concepción teológica distinta al instaurar el culto a un solo Dios omnipresente y todopoderoso.

${ }^{751}$ Fue a partir del Edicto de Milán (313) cuando el cristianismo se incorporó oficialmente al culto religioso romano, siendo necesario construir una doctrina al alcance de todos y que, a su vez, pudiese resistir los ataques de los intelectuales paganos. Esto especialmente a partir del siglo IV, cuando la decadencia romana era evidente y surgían voces que señalaban al cristianismo como el responsable del colapso imperial; Según esta visión, la nueva fe había debilitado los cimientos del poder político y ahora el mundo colapsaba víctima de la debilidad cristiana. En respuesta a esas voces los teólogos cristianos configuraron su versión providencialista de la historia (García Moreno, Luis A., El fin del Reino Visigodo... op. cit., pp. 23, 24), en la que destaca la figura de San Agustín de Hipona, quien basándose en las Escrituras sintetizó la esencia del providencialismo cristiano. Para el santo, la presencia de Dios es una constante en la historia, y por lo tanto siempre interviene, siendo Él el único capaz de establecer reinos en la tierra, incluso paganos, puesto que todo es parte del Plan de Salvación. Por esa misma razón rechaza las creencias paganas en el destino y los astros -por su aparente absolutismo- y por el contrario, afirma que el hombre es libre para decidir sus actos dentro de la creación divina; es decir, tiene libertad de acción y pensamiento, aunque restringidos dentro de los márgenes dados por la voluntad de Dios y los Planes de Salvación: "Nos aduersus istos sacrilegos ausus atque impios et Deum dicimus omnia scire antequam fiant, et uoluntate nos facere, quidquid a nobis non nisi uolentibus fieri sentimus et nouimus. Omnia uero fato fieri non dicimus, immo nulla fieri fato dicimus; quoniam fati nomen ubi solet a loquentibus poni, id est in constitutione siderum cum quisque conceptus aut natus est, quoniam res ipsa inaniter asseritur, nihil ualere monstramus. [...] Non est autem consequens, ut, si Deo certus est omnium ordo causarum, ideo nihil sit in nostrae uoluntatis arbitrio. Et ipsae quippe nostrae uoluntates in causarum ordine sunt, qui certus est Deo eiusque praescientia continetur, quoniam et humanae uoluntates humanorum operum causae sunt; atque ita, qui omnes rerum causas praesciuit, profecto in eis causis etiam nostras uoluntates ignorare non potuit, quas nostrorum operum causas esse praesciuit." (DQD, V, IX, http://www.thelatinlibrary.com/augustine/civ5.shtml. (abril de 2012).
} 
romano. En ese mismo sentido, Agustín rescata la idea veterotestamentaria del castigo divino $^{752}$. Dios podía sancionar a los hombres por sus actos y particularmente a los gobernantes que se hubieran desviado del justo camino, en cuyo caso la acción punitiva se hacia extensiva al conjunto del pueblo ${ }^{753}$.

Siguiendo las ideas del santo de Hipona, encontramos al hispano Paulo Orosio, quien a nuestro juicio las sintetizó a partir de la siguiente frase:

“En verdad, ¿quién puede regular y ordenar nuestras acciones más sabiamente y con más firmeza que Aquel que previó lo que tenía que hacerse y ejecutó lo previsto? Por esto, el hecho de que todo poder y todo gobierno proceden de Dios es sentido por los que no son ilustrados, y reconocido por los que lo son"754.

Orosio perfecciona la interpretación providencialista de la historia, definiendo que el punto de partida para todas las calamidades es el pecado original de Adán; un acto de libre albedrío que trajo desgracia para el conjunto de la humanidad. A ello se suma la interpretación de la profecía de Daniel sobre los imperios, que explica la caducidad de Roma, reduciéndola a un instrumento más al servicio del Plan de Dios; el mismo que ordena las guerras, plagas y todo tipo de infortunios ${ }^{755}$.

De esta forma, según San Agustín y Orosio, se puede concluir que el providencialismo cristiano a comienzos de la Edad Media se basaba en la suposición de la existencia de un Plan Divino -que incluía la designación de los poderes políticos- que permitía a los hombres actuar con cierta libertad dentro de sus límites, aunque éstos, de ser trasgredidos, podían producir una sanción divina sobre el soberano y su pueblo ${ }^{756}$.

\footnotetext{
${ }^{752}$ LCD, Libro I, cap. IX, op. cit., p. 14, 15.

${ }^{753}$ Un pensamiento que se puede ejemplificar en la obra de San Jerónimo, que al relatar el saqueo de Roma por los visigodos, lo hace ver como consecuencia de los pecados de los romanos, que entregados a los lujos habían olvidado la piedad y la caridad cristiana. ("Saqueo de Roma según San Jerónimo", en Marín, José, Textos Históricos. Del Imperio Romano hasta el siglo VIII, Santiago de Chile, Ril, 2003, pp. 67, 68).

${ }^{754}$ HCP, Libro II, cap. I, op. cit., p. 65.

755 Jiménez Vicente, María del Carmen, La razón de... op.cit, p. 89; y García Pelayo, Manuel, El Reino de Dios... op. cit., pp. 34, 35.

${ }^{756}$ Esta concepción de la divinidad se observó en la interpretación de la historia, la cual se convirtió en el reflejo del Plan de Dios. El cronista debía por lo tanto, buscar y plasmar en su obra los elementos providenciales que confirmasen los designios del Todopoderoso en los acontecimientos históricos narrados (Orcástegui, Carmen y Esteban Sarasa, La historia en la Edad Media ... op. cit., pp. 20, 21). De esta manera, según Mircea Eliade, Dios irrumpe en la historia universal y todos los hechos del pasado, del presente y del futuro, quedan sujetos a los designios de la Providencia, la que a su vez es jueza y protagonista de la historia (Eliade, Mircea, Lo Sagrado y lo Profano, Barcelona, Labor, 1985, p. 99; García Fitz, Francisco, "La Conquista de Andalucía en la Cronística Castellana del siglo XIII: las mentalidades historiográficas en los relatos de la reconquista", en Cabrera, Emilio, Andalucía entre Oriente y Occidente $(1236-1492) \ldots$ op. cit., pp. 53, 54). Entonces, todo se podría explicar a través de esta creencia, y la utilización de la misma serviría a su vez para legitimar a los soberanos y sus actos.
} 
El providencialismo agustiniano fue continuado por Isidoro de Sevilla, quien en sus obras, y especialmente en sus Etimologías, reafirmaba la idea de que toda la historia era parte del Plan de Salvación, y que la Providencia no determinaba los actos humanos, aunque sí los permitía. Así, el hombre era libre de equivocarse y pecar, pero también era responsable de sus acciones ${ }^{757}$. Esta convicción fue la que durante la Edad Media introdujo un elemento providencialista novedoso: la idea cristiana del pecado.

De la cronística se desprende que la fortuna bélica era el mejor indicador de la gracia de un soberano o su nación, debido a que Dios sólo otorgaba la victoria a quienes mantenían pureza y caridad en sus actos y pensamientos; únicamente el temeroso de Dios obtendría la victoria militar y la legitimación por sus actos ${ }^{758}$.

Esta forma de pensar fue fomentada por la Iglesia, que supo instrumentalizarla a través de un discurso teológico y cronístico destinado a asegurar que las acciones de los poderosos se ciñeran a los principios de la fe y que estuvieran en línea con la obediencia papal, particularmente luego de la Reforma Gregoriana ${ }^{759}$.

\section{III.1.b.- Providencialismo hispano-visigodo}

En Hispania, el providencialismo medieval cristiano se encuentra estrechamente vinculado con Isidoro de Sevilla, que jugó un papel fundamental en la conversión del reino al catolicismo y en la creación de un mito legitimador visigodo, que convirtió a los godos en un pueblo favorito de la Providencia, y por ende destinado a regir la Península Ibérica ${ }^{760}$.

Basado en esta cosmovisión, los cronistas postreros explicarían el colapso del Reino godo en el siglo VIII como parte del ciclo providencial del pueblo elegido, que por sus pecados cayó en desgracia, fue castigado por Dios y que debió iniciar el

\footnotetext{
${ }^{757}$ HGVS, op.cit, p. 22; y Etimologias, Libro II, op. cit., pp. 57, 58.

758 Alvira Cabrer, Martín, “Senhor, per les nostres peccatz'. Guerra y pecado en la Edad Media”, en Carrasco Manchado, Ana Isabel y María del Pilar Rábade Obradó (Coordinadores), Pecar en la Edad Media ... op. cit., p. 98; y Russell, Frederick, The Just War... op. cit., p. 22.

Al respecto Casagrande y Vecchio nos dicen: "Los hombres de la Edad Media vivían subyugados por el pecado. La concepción del tiempo, la organización del espacio, la antropología, la noción de saber, la idea de trabajo, las relaciones con Dios, la construcción de los lazos sociales, la institución de las prácticas rituales, toda la vida y la visión del mundo del hombre medieval gira en torno a la presencia del pecado.

El tiempo histórico es un tiempo medido por la noción del pecado: existe un antes y un después de la Caída, existe un antes y un después de la venida de Cristo, existe un antes y un después del Juicio Final" (Casagrande, Carla y Silvana Vecchio, "Pecado", en Le Goff, Jacques y Jean-Claude Scmitt (Editores), Diccionario razonado... op. cit., p. 637).

${ }_{759}$ García Fitz, Francisco, La edad Media. Guerra e ideología ... op. cit., pp. 39, 40.

${ }^{760}$ Bronisch, Alexander Pierre, Reconquista y guerra santa... op. cit., pp. 79, 117, 119.
} 
tortuoso camino de la redención. Así lo confirma la cronística y la literatura posterior como el Libro de Fernan Gonçalez, que con respecto a los visigodos nos dice que pese a no ser cristianos, sus victorias y conquistas se explican debido a que "Dios los quiso guiar ${ }^{, 761}$.

Más representativa es la leyenda recogida en la Crónica General respecto a la profecía sobre el fin del Reino Visigodo, que narra cómo Rodrigo, después de asumir el trono ya contaminado por la corrupción de Witiza, hizo abrir un palacio que había estado clausurado por años. En su interior sólo se encontraba un arca cerrada, que al ser abierta reveló un lienzo donde estaban dibujadas "gentes vestidas de árabes" y una inscripción que decía que cuando el sello del arca se rompiese y se revelase su contenido, hombres como los de la ilustración invadiría Hispania y se convertiría en sus señores ${ }^{762}$.

Este episodio, aunque tardío y no originalmente visigodo, representa la faceta profética del providencialismo: el pueblo elegido cuya indiferencia ante el pecado de sus reyes fue sancionado por Dios -quien había escrito este destino desde siempre- , convirtiéndolo en un hecho de la fatalidad divina. Alfonso X tomó esta leyenda y la incorporó a su Historia General como una señal providencialista para validar su reinado y linaje.

Gracias a lo anterior se puede afirmar que fue la conquista árabe del 711 lo que marcó un hito en la concepción providencialista hispana, puesto que a partir de ese momento se fortaleció la creencia de ser el pueblo elegido y castigado. Es así como el tema del pecado de los visigodos se convirtió en una narrativa constante en la literatura, manifestándose como una advertencia para las futuras generaciones. Sin embargo, también se estableció la noción de la redención, la cual se evidenciaba en la victoria militar contra el infiel ${ }^{763}$. Por ende es posible afirmar que los cronistas astures fueron los primeros en fortalecer el providencialismo hispano $\mathrm{y}$ en darle sus nuevas características, las que posteriormente serían perfeccionadas y complementadas por los autores castellanos y leoneses.

\footnotetext{
${ }^{761}$ López Guil, Itzíar, Libro de Fernán Gonçález... op. cit., p. 247.

${ }^{762} \mathrm{CGH}$, cap. 553, op.cit, p. 307.

${ }^{763}$ COP, op.cit, pp. 10, 11; Barkai, Ron, El enemigo en el espejo... op. cit., p. 44; y Flori, Jean, Guerra Santa, Yihad, Cruzada... op. cit., pp. 135 y 163.
} 
En las crónicas de León y Castilla estudiadas por nosotros ${ }^{764}$, el providencialismo se observa frecuentemente ligado a los siguientes elementos: intervenciones directas de Dios o del Espíritu Santo para favorecer o castigar a los hombres y apariciones de santos, mensajeros luminosos o ejércitos celestiales participando directamente en las batallas del bando cristiano ${ }^{765}$. En cualquiera de estos casos, concordamos con Jean Flori, en que el fenómeno del providencialimso, en general, tiene una relación evidente con el Antiguo Testamento. En la primera parte de la Biblia, son frecuentes las intervenciones directas de personajes celestes que aparecen para entregar mensajes, juzgar a los hombres o para intervenir en los acontecimientos humanos ${ }^{766}$.

Sin embargo, no debemos juzgar todos los relatos providenciales como meras invenciones propagandísticas, puesto que las apariciones de santos y otros milagros eran parte del imaginario colectivo de la sociedad medieval, fruto de una tradición que rara vez era cuestionada. El conjunto del pueblo cristiano creía firmemente en estos portentos, que muchas veces combinaban interpretaciones cristianas con antiguas costumbres y creencias paganas ${ }^{767}$. Razón por la cual la mayoría de estos relatos maravillosos fuesen conocidos y creídos por buena parte de la población, no solamente por las élites a quienes iban dirigidas las crónicas y la literatura en general.

Respecto a lo anterior y la labor cronística, en el siguiente gráfico podemos apreciar, como para el caso hispánico, el providencialismo se extendió al conjunto del pueblo. Centrándose especialmente en los tópicos del castigo divino, mediante el cual se podía explicar distintos infortunios y reveses; el auxilio de Dios o alguno de sus

764 Entre otras nos referimos a las crónicas Najerense, Silense/Legionense, Chronica Adefonsi Imperatoris, Cronicon Mundi, De Rebus Hispaniae, Crónica Latina de los Reyes de Castilla, Crónica General y Crónica de veinte reyes.

${ }^{765}$ Sin perjuicio de lo anterior, Ariel Guiance, en su articulo "Morir por la patria, morir por la fe: la ideología de la muerte en la Historia de Rebus Hispaniae", publicado en Cuadernos de Historia de España, LXXIII, nos recuerda que en la obra de "el Toledano" se pueden identificar cuatro grupos de hechos maravillosos: la participación de lo celestial junto a lo humano en casos concretos, como las apariciones de santos; el castigo divino; acontecimientos asombrosos, como hechos aparentemente inexplicables; y los mensajes de trasmundo.

${ }^{766}$ A modo de referencia, basta recordar episodios como el sacrificio de Abraham, los ángeles de Sodoma o las campañas de Josué, en las que se pueden apreciar hechos fantásticos como la detención del caudal de ríos, el derrumbe de murallas y hasta la paralización de sol en el cielo (Génesis 22:1-19 y 19:1-12; y Josué 1: 22).

${ }^{767} \mathrm{Al}$ respecto es importante recordar que el mundo medieval fue el fruto de la combinación de diversas tradiciones, entre las cuales el cristianismo fue la que terminó por predominar, pero sin anular las profundas huellas dejadas por latinos y germanos. En ese sentido es que la mitología y la religión eran parte fundamental de la cotidianidad, lo maravilloso impregnaba todas las esferas de la sociedad, misma razón por la cual la Iglesia procuró domesticar y servirse de estas costumbres. Para un mayor desarrollo de estas ideas recomendamos remitirse, entre otros, a los textos: Le Goff, Jacques, Lo maravilloso y lo cotidiano en el Occidente medieval, Barcelona, Gedisa, 2002, pp. 9-17; Le Goff, Jacques, La civilización del occidente medieval... op. cit., pp. 131-137, 141, 142; y Flori, Jean, La guerra santa ... op. cit., pp. 99149. 
mensajeros; complementario a ello la idea de la protección de la Providencia; y finalmente la creencia de ser un pueblo bendecido por la divinidad. Tópicos que si bien están presentes en las crónicas anteriores al año 1000, se hacen más presentes a partir de la década de 1110 cuando la Reconquista comenzó a intensificarse.

Es en este contexto cuando los tópicos de castigo divino y protección providencial se hacen más usuales, al punto de prácticamente equilibrase en torno al periodo entre 1220 y 1280, cuando la Reconquista experimento significativos avances, haciéndose más necesario el mantener la idea de la protección divina a la causa cristiana y los riesgos de atraer la desaprobación de Dios y el consecuente castigo.

\section{Gráfico 6: Providencialismo referido al conjunto del pueblo godo-hispano}

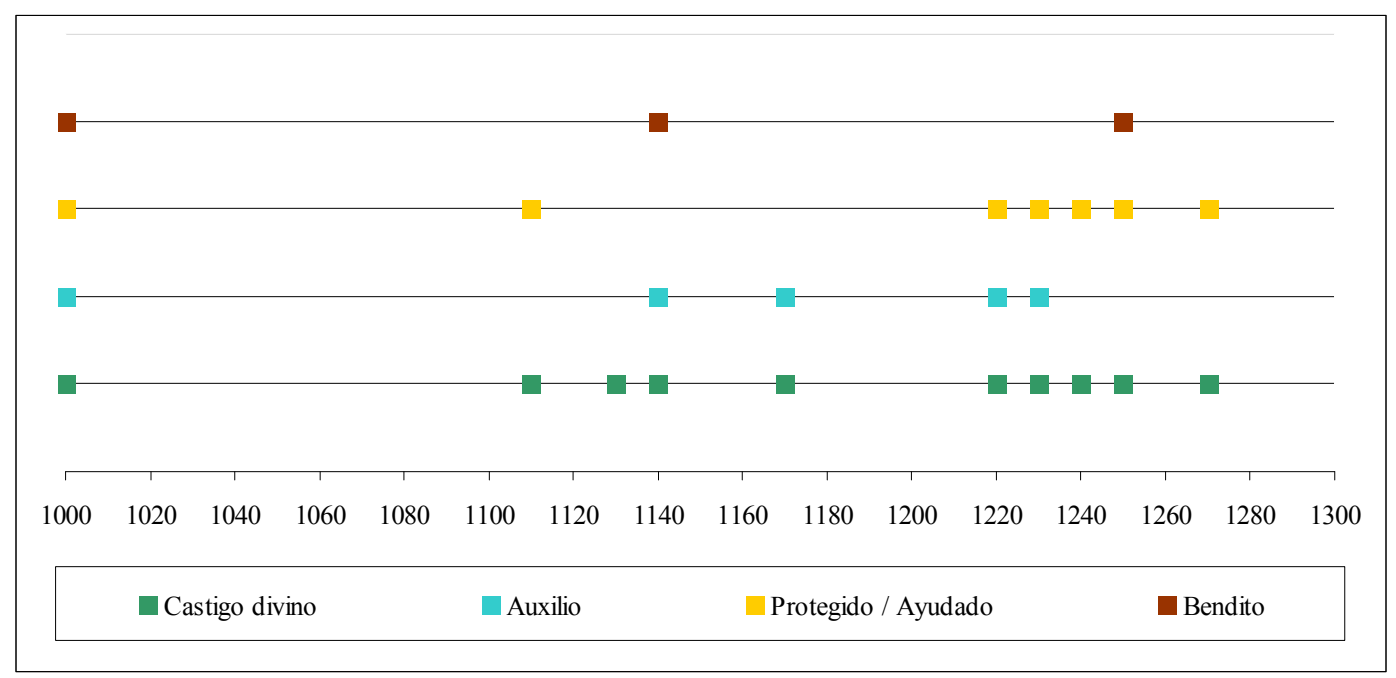

Puede afirmarse entonces, que la historia de la Reconquista, según los cronistas, se interpreta como la narración de la intervención divina en la lucha de los hispanos contra el Islam y, en consecuencia, el relato de cómo la Providencia protegió o castigó a los protagonistas de este conflicto ${ }^{768}$. Esta mentalidad no fue sino el reflejo de una cosmovisión cristiana que sostenía que todo había sido ordenado según el Plan de Dios, entendida como una creación ordenada por la Justicia Divina, donde todo tenía una explicación dentro de la dinámica del pecado, el perdón y la redención.

Es así como podemos observar que las intervenciones providenciales en las narraciones comentadas se hicieron más frecuentes después de la invasión islámica a la Península, primero asumiéndola como un castigo divino por los pecados de los

\footnotetext{
${ }^{768}$ García Fitz, Francisco, “La conquista de Andalucía... op. cit., p. 53.
} 
visigodos, y luego como señal de reconciliación a partir de los relatos míticos de victorias como las batallas de Covadonga y Clavijo. De esta manera, una de las formas de providencialismo que más se expresan en las crónicas es la protección o castigo divino respecto a ciertos personajes en función de sus actos y su importancia para el desarrollo de la historia. Esto en razón de que la intervención divina señalaba claramente las virtudes y facultades de un individuo para llevar a cabo acciones relevantes o bien, sugería un castigo con la intención de señalar un acto ejemplificador.

A medida que se fue configurando la frontera entre los cristianos y al-Andalus, esta se convirtió rápidamente en un lugar propicio para la manifestación del providencialismo. Allí era precisamente donde Dios se revelaba para apoyar a su pueblo, acosado por amenazas y enemigos; visión que era compartida a ambos lados de la frontera, con obvios matices diferenciadores dependiendo de si se era musulmán o cristiano $^{769}$.

Además, en la cronística castellana existió un destacado protagonismo de los monarcas, siendo ellos el eje sobre el cual se aticulaban los relatos. Así, no es de extrañar que los reyes y caudillos fueran los más beneficiados por la instrumentalización del providencialismo, dado que los argumentos religiosos los legitimaban a ellos y a sus campañas al tiempo que validaban los réditos económicos de las operaciones como parte de la lucha contra el Islam ${ }^{770}$.

Es así como se aprecia una tendencia de los cronistas a destacar a algunos monarcas por sobre otros, como Alfonso VI, Alfonso VII, Alfonso VIII y Fernando III, que son los principales protagonistas de los relatos providencialistas en los siglos XII y $\mathrm{XIII}^{771}$. A su vez, como la intención de los cronistas era validar linajes y reinos, en las crónicas también se destacan algunos otros reyes anteriores tales como Pelayo, Alfonso el Casto, Alfonso V y Fernando I, entre otros; a los que se sumará el más tardío Alfonso $\mathrm{X}$. Incluso, se incluyen personajes que, sin ser reyes, fueron de gran importancia en el período, tales como al-Mansur, Diego Gelmírez, Muño Alfonso y Rodrigo Díaz de Vivar, además de otros que sólo se mencionan ocasionalmente ${ }^{772}$.

\footnotetext{
${ }^{769}$ Rodríguez Molina, José, "Historia, tradiciones y leyendas en la frontera" y Manuela Gracía Pardo, "El pastor de Las Navas de Tolosa. La realidad y la leyenda”, en Toro Ceballos, Francisco y José Rodríguez Molina (Coordinadores), IV Estudios de Frontera ... op.cit, pp. 11, 13-215, 216.

${ }^{770}$ Tuliani, Mauricio, "La idea de Reconquista... op. cit., p. 11.

${ }^{771}$ Ver gráfico y tabla ${ }^{\circ} 2$.

772 Fuera de la lista de personajes hemos dejado a Fernán Gonçalez, por considerarlo parte de los monarcas en su rol de fundador de Castilla y al Cid, puesto que tiene su propio género literario y su presencia no es contante en las crónicas estudiadas.
} 


\section{Gráfico 7: Providencialismo referido al monarca}

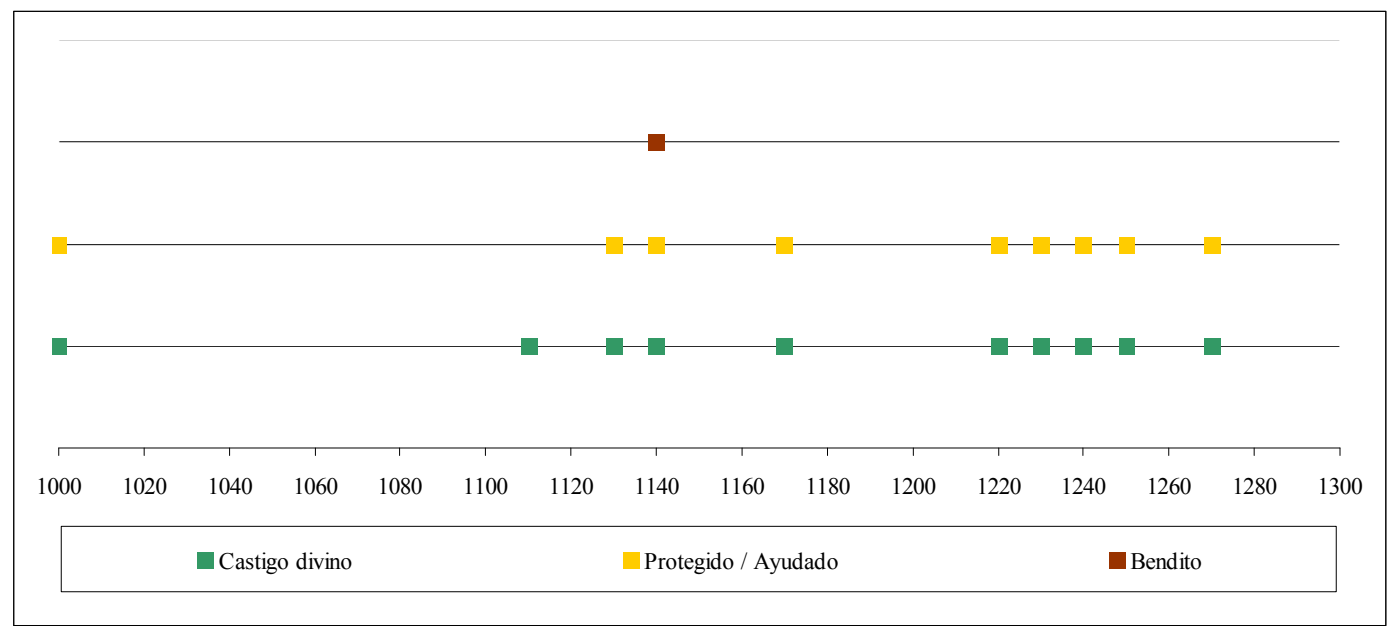

La aparición de estos reyes y grandes hombres en las principales fuentes del período muestran cómo los autores los convierten en sujetos del binomio de protección y castigo ${ }^{773}$, siendo dos elementos que, como se observa en el gráfico, se encuentran prácticamente equilibrados en las fuentes a partir de 1220 en adelante, especialmente en las Crónica Latina de los reyes de Castilla, Cronicon Mundi, de Rebus Hispaniae y la

\footnotetext{
${ }^{773}$ En función de nuestro análisis hemos agrupado las distintas manifestaciones de la Gracia de Dios en una sola gran categoría, la del Protegido o Ayudado por Dios. Conceptos amplios, que sin embargo engloban distintas manifestaciones providenciales. En tanto que en la categoría de castigo se han incorporado todos aquellos elementos que sirven a los cronistas para responsabilizar a un soberano, individuo o la totalidad del pueblo de algún revés o desgracia que los afligiese.

En cuanto al concepto de bendito o bendecido - tan propio del pensamiento Isidoriano con respecto al pueblo visigodo - si bien esta categoría se puede rastrear en las crónicas en referencia a algunos monarcas como Alfonso VII, así como vinculada a algunos personajes y el conjunto del pueblo cristiano, su uso se encuentra bastante restringido a ocasiones muy específicas, razón por la cual no es un elemento fundamental en nuestro análisis.

Mas limitado es el concepto de auxilio divino, el cual sólo se aplica en relación al pueblo cristiano y muy estrechamente a unos pocos episodios muy localizados y particulares. Esencialmente las fuentes repiten - sin darle mucha importancia y casi al pasar - el mismo milagro, que narra cómo previo a la batalla entre Ramiro II Abderramán, Dios mostrando una gran señal hizo que el sol se volviera tinieblas durante una hora. Luego del portento, el rey de León obtuvo gracias a Dios la victoria." (CN 1995, Liber II, $\mathrm{N}^{\circ} 29$, op. cit., p. 131).

No obstante este episodio, el concepto, de forma más amplia, también puede referirse al hecho de que Dios no abandona a su pueblo y le ayuda de diversas formas, en cuyo caso el término se utiliza frecuentemente en los episodios ocurridos luego de la invasión musulmana, como es la aparición de Pelayo.

En las fuentes los relatos providencialistas suelen combinar distintos protagonistas, así como hacer fuertes contrastes entre los episodios de protección o castigo, razones por las cuales es difícil realizar categorizaciones tajantes. La misma dificultad ocurre en cuanto a los sujetos de las acciones providenciales, puesto que salvo algunos casos precisos, estos episodios son narrados como parte de eventos mayores, por lo cual la índole del relato, en relación al providencialismo, no siempre coincide con el final del mismo. Por todo ello, nuestro análisis no se basará en categorías estrictas, sino que en algunos casos particulares que permiten observar mejor, a nuestro juicio, la forma en que se construían estos relatos.
} 
Crónica General ${ }^{774}$. Si bien estos elementos estaban presentes antes, se observa en ellas una inclinación a dar más importancia al castigo divino que a la protección o ayuda providencial. Algo que posiblemente responde a la situación general de la Península, que durante el siglo XII debió hacer frente a dos invasiones norafricanas y sufrir largos períodos de crisis -según los cronistas- tales como el reinado de Urraca y las pugnas que precedieron a la coronación de Alfonso VII. Es por esta razón que los cronistas tuvieron que endurecer su discurso, en tanto que para el siglo siguiente se tendió a generar nociones positivas que contribuyesen a la consolidación del sistema.

El primer personaje relevante protegido por la Providencia fue Pelayo, quien como continuador del linaje visigodo representa a un nuevo tipo de hombre, un modelo virtuoso alejado del pecado de sus ancestros, y por tanto, es descrito como un símbolo de la nueva alianza entre los hispanos y Dios. Este hecho queda demostrado en la providencial batalla de Covadonga ${ }^{775}$, en la que se cuenta que Dios eliminó a los musulmanes haciendo retornar sus proyectiles para luego aplastarlos con una montaña, mientras que previamente Pelayo, en su dialogo con Opas, introduce los conceptos de castigo divino, pero también de reconciliación con la divinidad ${ }^{776}$.

Es así como las crónicas asturianas y luego las leonesas son las más pródigas en la creación de relatos providencialistas. Esto porque era necesario crear en las élites la idea de que únicamente se alcanzaría la victoria contra el Islam con la ayuda de Dios y que ésta sólo se lograría mediante vidas ejemplares, oraciones, penitencias y limosnas, elementos importantes dentro de la ritualidad cristiana que eran supervisados por la Iglesia $^{777}$. Es más, las señales divinas no siempre tenían que ser magníficas o ligadas a grandes acontecimientos, sino que también podían corresponder a episodios más simples, aunque no por ello menos significativos. Veamos, por ejemplo el caso de la cruz de Alfonso el Casto, en un relato de la Crónica General ${ }^{778}$ :

"E el uiniendo pora su palacio de la iglesia o fuera a oyr misa, fallosse con dos angeles que uinien en guisa de peregrino quel dixieron que eran orebzes. El rey quando lo oyo plogol mucho con ellos, et dixole que fiziessen una cruz la mas fremosa que ellos pudiesen; et dioles oro et piedras preciosas et casa apartada en que labrassen. [...] El rey, luego que lo sopo, fue pora ella corriendo, e quando uio

\footnotetext{
${ }^{774}$ Ver tabla $\mathrm{n}^{\circ} 2$

775 Isla Frez, Amancio, Ejército, Sociedad y Política en la Península Ibérica entre los siglos VII y XI... op. cit., p. 127; y O'Callaghan, Joseph, Reconquest and Crusade... op. cit., p. 5.

${ }^{776}$ CAIII, versión Rotense, $N^{\circ}$ 9, op.cit, pp. 204; y CN 2003, Libro II, op. cit., pp. 115, 116.

${ }^{777}$ Goñi Gaztambide, José, Historia de la Bula de Cruzada ... op. cit., p. 26.

${ }^{778}$ El mismo relato se puede observar en la Historia Silense, que si bien es anterior a la obra Alfonso, es posterior al reinado de Alfonso el Casto.
} 
aquella claridad tan grand et la cruz fecha et acabada tan ayna et de tan alta obra et tan maravillosa, et non estando y los orebzes, rendio gracias a Dios por ende, ca entendio que fecho de Dios era"779.

La cita nos recuerda que Alfonso fue un activo luchador contra los andalusíes y una pieza clave en la organización del Reino Astur. Es por ello que el relato de los ángeles orfebres cumple con varios objetivos: primero, demostrar la piedad del soberano que destina oro y joyas a la confección de una cruz; en segundo lugar señala el favor divino hacia Alfonso, puesto que Dios premia su piedad a través de sus mensajeros y también con las victorias ante los musulmanes. Así, la cruz de Alfonso se convierte en una señal de Gracia y legitimidad.

De manera similar se narra otro caso de protección, cuando Alfonso V entregó a su hermana como tributo al rey moro de Toledo. Cuando éste intentó poseerla, ella se negó por ser cristiana, advirtiéndole de que Dios lo castigaría si la forzaba. El moro ignoró sus advertencias y la violó, pero pronto se sintió enfermo y temeroso, la devolvió a Alfonso cargada con oro y joyas ${ }^{780}$. El episodio tiene la particularidad de centrar el castigo divino en el rey de Toledo y no en Alfonso, quien había entregado a su hermana a un "enemigo de la fe". Es posible que el cronista no quisiera interpelar la figura del rey para evitar ponerlo en entredicho y a su linaje y en cambio, prefiriendo utilizar el episodio para demostrar la protección divina sobre la familia real, al tiempo que denosta a los musulmanes como impíos y lujuriosos.

Es importante destacar que, si bien la Iglesia estaba detrás de gran parte de estos relatos y los ponía al servicio de una causa mayor, también hay episodios providencialistas que parecen responder a los intereses de autores particulares. Es el caso de la Historia Compostelana, donde vemos los esfuerzos de su promotor, Gelmírez, por validar la dignidad de su cargo ${ }^{781}$.

\footnotetext{
${ }^{779}$ CGE, cap. 616, op. cit., p. 349.

${ }^{780}$ El episodio se encuentra relatado en distintas fuentes, nosotros optamos por reseñarlo a partir de las siguientes crónicas: COP, op. cit., pp. 174, 175; CGE, cap 761, op. cit., p. 452; y CXXR, Libro VI, cap. III, p. 134.

${ }^{781}$ Con este objetivo incluye relatos como el del Adaulfo II, obispo de Compostela, falsamente acusado por sus enemigos durante el reinado de Bermudo II (985-999) y condenado a muerte por el rey. A pesar de ello Dios lo protege haciendo que el toro que debía acabar con su vida se sometiese mansamente y ofreciese sus cuernos al obispo: "Sed ille, qui occulto indicio statum iustitie equali lance ponderat, non permittens radium ueritatis mendacii umbra obscurari sic ferocitatem furentis tauri mittigauit, quod quamuis a canibus irritaretur, eidem religioso uiro nichil impedimenti inferre auleret" (HC 1988, Liber I, cap. II, op.cit, p. 10). Este acontecimiento es narrado como señal inequívoca de la dignidad de los antecesores de Gelmírez, y a la vez, como un ejemplo demostrativo de que Dios - en este caso particular a través de Santiago - protegía a sus servidores. Es por ello que en la misma crónica se hacen referencias directas al patrocinio divino de Gelmírez a través de distintos episodios, como cuando después de sufrir
} 
En el contexto de las primeras crónicas de la Reconquista, posteriores al siglo $\mathrm{XI}$, entre los personajes relatados aparece la figura de Fernan Gonçalez, quien al igual que Pelayo cumplió el rol de simbolizar la unión política-militar con la Gracia Divina.

Gonçalez fue uno de los principales protagonistas en el fortalecimiento del condado de Castilla, y por ello no extraña que sobre él se tejiera un aura mística providencialista destinada a validar su linaje. Para el siglo XII Castilla se consolidaba como un reino independiente de León, razón por la cual fue necesario dotar a sus monarcas, originarios de Navarra, de un pasado glorioso que los validara ante los restantes reinos peninsulares. Así los cronistas castellanos se dieron a la tarea de enlazar a sus soberanos con los visigodos, tal como se puede observar en la Historia Naierensis, al mismo tiempo que junto a la épica creaban a sus propios héroes contemporáneos para que pudiesen equiparar las glorias de los leoneses, navarros y aragoneses ${ }^{782}$.

Este discurso quedó registrado en el Poema dedicado a Fernán Gonçalez y en crónicas posteriores, que en su afán recopilatorio insertan a Gonçalez en la historia hispana ${ }^{783}$. En el relato, se nos narra como el Conde, previo a la batalla se encuentra con un monje -coincidentemente llamado Pelayo- que le vaticina la victoria sobre sus enemigos presentes y futuro ${ }^{784}$. De esta manera, el Conde de Castilla se consolidó como un señalado por la Providencia y en un ejemplo a seguir, puesto que al relato de sus victorias se suman los actos piadosos que realizó. Así, su linaje y sus dominios eran validados; un hecho especialmente relevante, dada la historia castellana y su relación con León.

A grandes rasgos estos relatos providenciales centrados en personajes son más bien esporádicos y a veces anecdóticos, centrándose especialmente en lo referido al castigo divino, más que en la protección o auxilio providencial ${ }^{785}$. Y al igual que para el

una grave enfermedad experimenta una "milagrosa" recuperación puesto que "Dios omnipotente no quería en modo alguno privar a la Iglesia de la presencia de tan gran pastor”. Está claro el afán propagandístico de los autores de la Historia Compostelana que mediante este episodio pretenden señalar al Arzobispo como un elegido de Dios, y por ende poseedor se una autoridad casi irrebatible. HC 1994, Libro I, cap. XXIX, op. cit., p. 125.

${ }^{782}$ Bautista, Francisco, "Genealogía y leyenda. El surgimiento de los reinos de Castilla y Aragón”, en http://e-spania.revues.org/18086, 7 | juin 2009 (octubre de 2013); y Klinka, Emmanuelle, "Chronica naiarensis: de la traición... op. cit.

${ }^{783}$ El mismo Poema atribuye a Gonçalez el ser descendiente de los Jueces de Castilla, mismos personajes sobre los cuales los castellanos construirán el mito originario de su reino.

784 “Por çierto sepas que guiará Dios la tu fazianda; asy vençerás todo el poder de Almaçor, auerás grand batalla con los moros e vençerlos has, e mataras y tantas que non avrá cuenta, e cobrarás vna grand partida de la tierra, e verterás mucha sanghe de rreyes e de grandes omes. E la tu buena andaca será tan grande que por todo el mun/do será sonada la tu caballería." CXXR, Libro II, cap VI, op. cit., pp. 89.

${ }^{785}$ Ver gráfico y tabla ${ }^{\circ} 3$. 
caso del providencialismo referente al conjunto del pueblo y los monarcas, los relatos se hacen más abundantes en torno a los años de mayor actividad bélica y actividad fronteriza.

En ese sentido es que muchos de estos personajes suelen ubicarse en un tiempo pretérito, previos al gran avance de la Reconquista de los siglos XII y XIII, parecen tener -respecto a soberanos y magnates- una intención pedagógica y validadora. Pedagógica porque relatan hechos relacionados con la piedad y la conducta de un buen cristiano, y validadoras, en cuanto en estos acontecimientos la mano de Dios señala y protege a sus siervos.

\section{Gráfico 8: Providencialismo referido a personajes particulares}

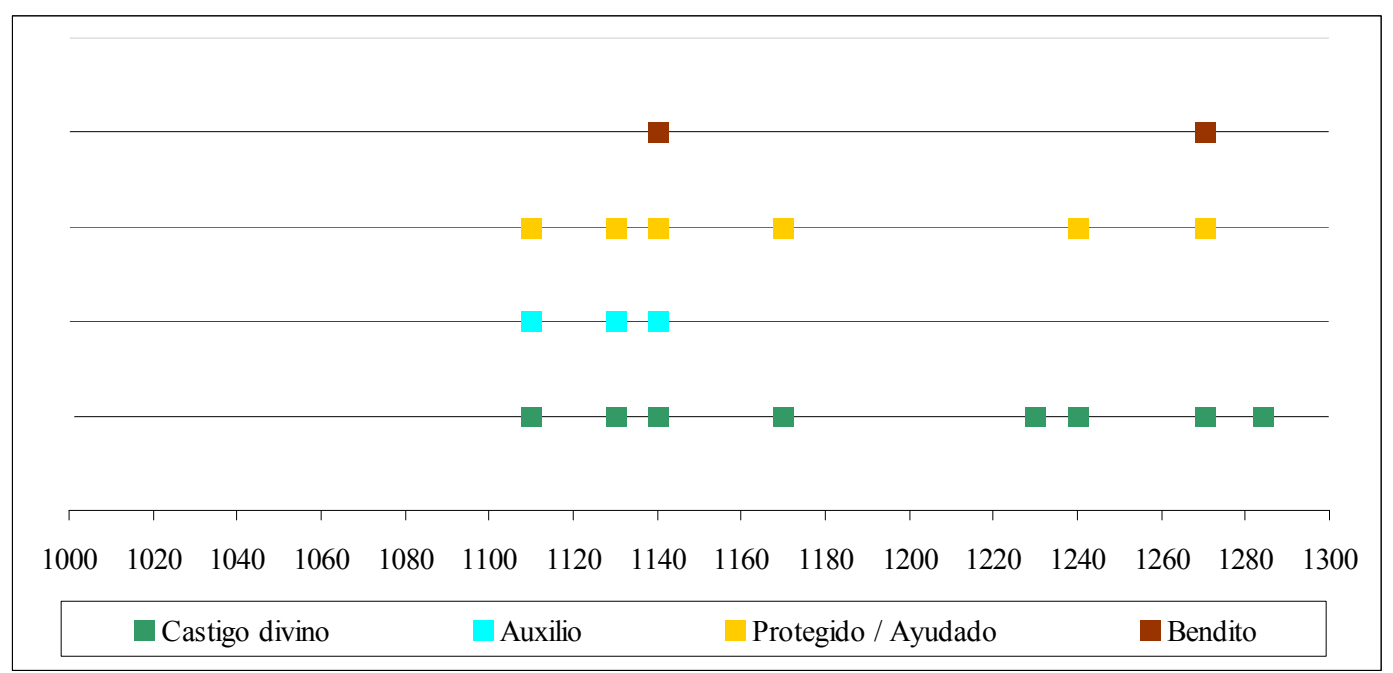

Para el siglo XII, y particularmente en el siglo XIII, los cronistas repiten esquemas y relatos de textos anteriores, a los que en algunos casos suman nuevos elementos, enriqueciendo los relatos de acuerdo a las tendencias y necesidades políticas y culturales del momento. Es así como en crónicas del siglo XIII encontramos narraciones de hechos previos donde se muestra de forma explícita aspectos que antes sólo se insinuaban. Ejemplo de ello es la figura de Alfonso VI, puesto que fue el protagonista de una serie de procesos militares -como el primer gran avance hacia el río Tajo y la anexión de Toledo-, sociales y religiosos, como por ejemplo el patrocinio a los francos que se instalaron en la Península, la revitalización de las relaciones con Roma y el cambio de rito religioso. Todos estos eventos, que además sintetizan los elementos políticos, religiosos y militares del monarca, impulsan a los cronistas a glorificar su figura al destacar sus grandes obras y minimizando otras un tanto incómodas, como las 
vinculadas a su tortuoso acceso al trono leonés o la existencia de su concubina mora. En cuanto a las glorificaciones, éstas versan principalmente sobre la conquista de Toledo, la cual no sólo es relatada muchas veces, como si se hubiese tratado de una gran expedición militar y un cerco épico, sino que además es narrada como un acontecimiento con claras señales celestiales, al punto que en una crónica tardía la campaña militar queda disminuida frente a la afirmación de que la ciudad se rindió porque Dios hizo que los toledanos la entregasen sin más oposición ${ }^{786}$.

Por su parte, el nieto de Alfonso, Alfonso VII, tampoco estuvo lejos de la mano divina. El soberano pasó años luchando contra su madre y los aragoneses para asegurar su corona, por lo que al menos en la primera parte de su reinado relegó a un lugar secundario la lucha contra el Islam. No obstante, este período tampoco estuvo exento de providencialismo, ya que los cronistas supieron encontrar la intervención divina en la lucha entre cristianos, convirtiendo a Alfonso en un modelo virtuoso en tanto que su rival, Alfonso "el batallador" simbolizaba lo contrario ${ }^{787}$.

También en la Chronica Adefonsi Imperatoris se relatan distintos episodios, donde los enemigos cristianos y musulmanes del rey son quienes reconocen en él la mano protectora de Dios. Esto hace que la Chronica sea una de las fuentes más ricas en hechos providencialistas y en descripciones de su protagonista como un protegido de $\operatorname{Dios}^{788}$.

786 "Recepto nuncio, predictus rex in continenti reuersus est et, disponente Deo, regnum paternum plene adeptus est. Inspirauit ei Dominus consilium salutare ut obsideret Toletum, cuius statum ad plenum nouerat, utpote qui eius interiora et secretiora, dum ibi moram faceret, non perfuctiore fuerat perscrutatus. Multis igitur annis eam impugnauit prudenter, singulis annis segetes uastando et fructus omnes destruendo. Tandem uirtute diuina compulsi, Mauri Tolletani tradiderunt ciuitatem suam predicto regi Alfonso, ipsum recipientes honorifice in dominum et in regem, adiecta conditione quod liceret eis remanere in ciuitate, retinere domos et possessiones suas, et quod seruirent ei sicut regi" CLRC 1997, $\mathrm{N}^{\circ}$ 2, op.cit, p. 36. "Cuando recibió el mensaje, el rey Alfonso volvió con toda rapidez y, por la providencia de Dios, obtuvo en su totalidad el reino paterno. El Señor Dios le inspiró el saludable consejo de que sitiara Toledo, cuya situación conocía perfectamente, puesto que, mientras vivió allí, había escudriñado totalmente a fondo sus interiores y lugares apartados. Durante muchos años la impugnó juiciosamente, devastando y destruyendo año tras año las mieses y los frutos todos. Finalmente, los moros toledanos, movidos por la virtud divina y con la condición de que les fuera permitido permanecer en la ciudad, retener sus casas y posesiones y que le sirvieran como rey, entregaron la ciudad al rey Alfonso, a quienes recibieron con honor como rey y señor." CLRC 1999, N², op.cit, p. 27.

De hecho, el fragmento citado ilustra una verdadera secuencia providencialista en torno a Alfonso. Providencial es su rápido arribo a León, que le permite hacerse con el trono de su difunto hermano; la campaña de Toledo es fruto del consejo de Dios -aprovechando el hecho de que el leonés conocía la ciudad debido a su destierro en ella-, y finalmente los musulmanes se rinden movidos por la virtud divina. De esta manera, se nos presenta un escenario en que el soberano es un instrumento al servicio de Dios, pero también un elegido destinado a grandes actos bajo el amparo de la divinidad.

${ }^{787}$ Ver gráfico y tabla $\mathrm{N}^{\circ} 2$.

${ }^{788}$ Por ejemplo, en el libro primero se nos dice: “Cognovit autem rex Aragonensis quod Dominus esset cum rege Legionensi et avertit faciem suam ne pugnaret cum illo, et recessit in castra sua [...]" "788. CAI, Liber I, $\mathrm{N}^{\circ}$ 10, op. cit., p. 13. "Mas el rey de Aragón comprendió que el Señor estaba con el rey de León, se apartó para no luchar con él, se retiró a su campamento...” CEA, Libro I, N 10, op. cit., p. 67. 
Los cronistas también vieron la mano de Dios en hechos aparentemente fortuitos, como la muerte de Rodrigo Martínez durante el cerco de Coria o el fallecimiento de Sancho III de Castilla. En el primero de los casos, el "gran señor" fue abatido por una flecha, que después de rebotar y romperse se clavó en su cuello; todo ello "en castigo por sus pecados". El hecho nos habla -con cierta fatalidad- de la omnipresencia divina y lo ineludible del castigo a quienes ofendían a Dios. En el caso del rey Sancho, de quien se habla elogiosamente, pareció morir prematuramente por un designio divino sin relación aparente con su actuar en vida. Al parecer, la conclusión que se puede desprender del relato, es que Dios deseaba acelerar la llegada al trono de Alfonso VIII. Situaciones similares aparecen en distintos relatos -como la recuperación de Beatriz de Suabia, madre de Alfonso X, de la enfermedad que la aquejaba-, siempre siguiendo la idea de que todos estos hechos eran señales del favor divino ${ }^{789}$.

Los reyes y caudillos cristianos -y en menor medida musulmanes- necesitaban de estas señales divinas, que trasmitiesen a sus súbditos la certeza de estar luchando por una causa justa bajo el mando de un "elegido", ambos elementos que aseguraban la victoria. Es por ello que dichos signos aparecen reiteradamente, y cuando no eran del todo claros, los cronistas se encargaban de darle la interpretación deseada, apelando a las costumbres y prácticas de la religiosidad de su público. Fue en ese mismo sentido que el pecado y la idea del castigo divino se comenzaron a expresar en las fuentes de la época. Al igual que la victoria o las gracias, el castigo también constituía una señal divina que servía para marcar a los enemigos o bien advertir al pueblo o a su líder de la necesidad de enmendar su conducta ${ }^{790}$.

En el mismo sentido validador se nos relata otro enfrentamiento del emperador con el rey aragonés; en esta ocasión el leonés estaba en clara desventaja numérica, sin embargo, "el Batallador" duda en entablar combate y reúne a sus consejeros sólo para oír de boca del obispo de Pamplona una dura sentencia providencialista, que le advierte que su enemigo está protegido por Dios y que por ende, su victoria estaba asegurada "victoria belli non est in multitudine exercitus, sed de coelo fortitudo est." CAI, Liber I, $\mathrm{N}^{\circ} 15$, op. cit., p. 17. "La victoria en la guerra no reside en la multitud de un ejército, sino que la fuerza procede del cielo." CEA, Libro I, N 15, op. cit., p. 69.

${ }^{789}$ CAI, Liber II, $\mathrm{N}^{\circ} 137$, op. cit., p. 108; CLRC 1997, $\mathrm{N}^{\circ}$ 9, op. cit., p. 34; y Procter, Evelyn, Alfonso X of Castile... op. cit., p. 33.

790 En forma paralela al providencialismo político, es posible atestiguar un amplio uso de éste para ordenar aspectos más cotidianos de la realidad cristiana peninsular. Nos referimos a la presencia en los fueros de juramentos y juicios de Dios, que como fuentes jurídicas no olvidan que la estructura legal debía someterse a las leyes de Dios y a las costumbres de los cristianos, según las prácticas de la religiosidad.

Los habitantes de las villas peninsulares tenían el convencimiento de que Dios era el Juez Supremo de los hombres, y por ello -al igual que en el resto de Europa- fue usual que se buscase probar la inocencia o culpabilidad de las personas a través de actos milagrosos que demostrasen si la persona se encontraba en estado de Gracia. En los fueros consultados, el tipo de prueba más utilizado en estas ordalías era la del hierro, el juramento y el duelo 
De esta forma, queda en claro cómo las creencias religiosas impregnaban todas las esferas de la sociedad, siendo por lo demás utilizadas con distintos fines, especialmente para ordenar las conductas sociales y fortalecer el poder de los monarcas y autoridades. Ellos debían dirigir al pueblo en la búsqueda del cumplimiento de los mandatos divinos; es decir, del discurso político-religioso.

Al parecer la prueba del hierro estaba destinada principalmente a las mujeres y los débiles. La acusada debía tomar un hierro, previamente calentado al rojo y además bendecido por un sacerdote, bajo la supervisión del alcalde y el clérigo, la persona debía caminar cierta cantidad de pasos y soltar el metal. Luego su mano debía ser cubierta y al cabo de tres días examinada. Si la mano presentaba lesiones por quemadura la acusada debía ser llevada a la hoguera o sufrir las penas prescritas por el fuero (FCc, cap. XI, N 46. op. cit., p. 116).

El proceso relatado se encontraba lleno de elementos providenciales y también supersticiosos. El hierro debía ser bendecido y el fuego protegido para evitar "maleficios", además del hecho de suponer que una persona inocente al estar protegida por Dios no sufriría daño físico por la prueba.

Otra forma habitual de entregar la justicia a la Providencia, eran los duelos judiciales, batallas a pequeña escala donde, al igual que en la guerra, Dios protegería al luchador justo. Por su parte los juramentos, mucho menos espectaculares que los anteriores ejemplos, se solían utilizar para corroborar la declaración de los acusados o testigos. Lo significativo es que se contemplaba que los cristianos jurasen sobre las Escrituras y los judíos ante la Tora. Es decir juramentos religiosos, donde además se reconocían las creencias de los juramentados. 
Tabla 6: Providencialismo referido al conjunto del pueblo godo-hispano

\begin{tabular}{|c|c|c|c|c|c|}
\hline & Castigo divino & Auxilio & Protegido / Ayudado & Bendito & Fuentes \\
\hline 1000 & $\mathrm{X}$ & $\mathrm{X}$ & $\mathrm{X}$ & $\mathrm{X}$ & $\begin{array}{l}\text { - CAIII Rotense } \mathrm{n}^{\circ} 5 \text { p. } 198, \mathrm{~N}^{\circ} 7 \text { p } 200, \mathrm{n}^{\circ} \\
10 \text { p. } 204 \text { CAIII Sebastian } \mathrm{n}^{\circ} 5199, \mathrm{~N}^{\circ} 7 \text { p. } \\
201, \mathrm{n}^{\circ} 9 \text { p. } 205 \text { ) } \\
\text { - CA n }{ }^{\circ} \text { p. } 247 \text {, Cap. XVI } \mathrm{N}^{\circ} 1 \text { p. } 257 \\
\text { - CMz n } 92 \text { p. } 125 \\
\text { - CP n }{ }^{\circ} 1 \text { p. } 261 \\
\text { - CSEA p. } 304\end{array}$ \\
\hline \multicolumn{6}{|r|}{ 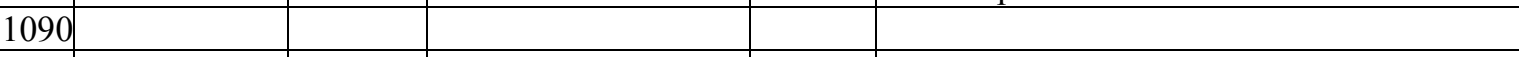 } \\
\hline \multicolumn{6}{|l|}{1100} \\
\hline 1110 & $\mathrm{X}$ & & $\mathrm{X}$ & & $\begin{array}{l}\text { - CS/L p. } 36,40,52,98,99,100,136 . \\
\text { - CAS n } 3 \text { p. } 10, N^{\circ} 19 \text { p. } 28\end{array}$ \\
\hline \multicolumn{6}{|r|}{ ( } \\
\hline 1130 & $\mathrm{X}$ & & & & - HC Libro I Cap. II p. 75 COP p. 172, 175 \\
\hline 1140 & $\mathrm{X}$ & $\mathrm{X}$ & & $\mathrm{X}$ & $\begin{array}{l}\text { - CAI Libro I n }{ }^{\circ} 15 \text { p. } 68,69 \mathrm{~N}^{\circ} 60 \text { p. } 82 \\
\text { Libro II n } 6 \text { p. } 97 \mathrm{n}^{\circ} 42 \text { p. } 108 \\
\text { - LSJ Libro IV Cap } 21 \text { p. } 489 . \text { Cap. } 25 \text { p. } \\
517\end{array}$ \\
\hline \multicolumn{6}{|l|}{1150} \\
\hline \multicolumn{6}{|l|}{1160} \\
\hline 1170 & $\mathrm{X}$ & $\mathrm{X}$ & & & $\begin{array}{l}\text { - CN Libro I n } 209 \text { pp. } 107,108 \text { n }^{\circ} 211 \text { p. } \\
109 \text { Libro II n }{ }^{\circ} 29 \text { p. } 140 \text { n }^{\circ} 32 \text { p. } 145-147 \\
n^{\circ} 36 \text { p. } 149 \text { n}^{\circ} 39 \text { pp. } 151,152 .\end{array}$ \\
\hline \multicolumn{6}{|r|}{ (1, } \\
\hline \multicolumn{6}{|l|}{1190} \\
\hline \multicolumn{6}{|l|}{1200} \\
\hline \multicolumn{6}{|l|}{1210} \\
\hline 1220 & $\mathrm{X}$ & $\mathrm{X}$ & $\mathrm{X}$ & & - AT I p. 347 \\
\hline 1230 & $\mathrm{X}$ & $\mathrm{X}$ & $\mathrm{X}$ & & $\begin{array}{l}\text { - CM Libro III Cap. } 11 \text { p. } 210, \text { Cap } 63 \text { p. } 264 \\
\text { Cap. } 58 \text { p. } 271 \text {, Libro IV Cap. } 3 \text { pp. } 275, \\
276 \text { Cap. } 38 \text { p. } 329 \\
\text { - CLRC n }{ }^{\circ} 13 \text { p. } 39, n^{\circ} 19 \text { p. } 47, n^{\circ} 25 \text { p. } 55, \\
n^{\circ} 43 \text { p. } 74\end{array}$ \\
\hline 1240 & $\mathrm{X}$ & & $\mathrm{X}$ & & $\begin{array}{l}\text { - HRH Libro III Cap. } 16 \text { p. 141, Cap } 20 \text { p. } \\
\text { 147, Cap. } 22 \text { p. } 152 \text {, Libro V Cap. } 15 \text { p. } 207 \text {, } \\
\text { Cap } 13 \text { pp. } 236,237 \text {, Libro VII Cap. } 2 \text { p. } \\
\text { 268, Cap. } 3 \text { pp. } 269 \text {, 270. Libro VIII Cap } 6 \\
\text { p. } 313 \text {, Cap. } 12 \text { p. } 325 \text {, Cap. } 23 \text { p. } 328 .\end{array}$ \\
\hline 1250 & $\mathrm{X}$ & & $\mathrm{X}$ & $\mathrm{X}$ & $\begin{array}{l}\text { - PFG n }{ }^{\circ} 16,20,23 \text { p. } 247, \mathrm{~N}^{\circ} 40,41 \text { p. } 249, \\
\mathrm{n}^{\circ} 59 \text { p. } 251 .\end{array}$ \\
\hline \multicolumn{6}{|l|}{1260} \\
\hline 1270 & $\mathrm{X}$ & & $X$ & & $\begin{array}{l}\text { - CGE Cap } 551 \text { p. } 305 \text {, Cap. } 553 \text { p. } 307 \text {, Cap. } \\
754 \text { pp. } 448,449 \text {, Cap. } 1014 \text { p. } 695 \text {, Cap. } \\
1021 \text { p. } 705 \\
\text { - CXXR Libro III Cap. } 4 \text { p. } 99 \text {, Libro V } \\
\text { Cap. } 19 \text { p. } 127 \text {, Libro X Cap. } 39 \text { p. } 222 \text {, } \\
\text { Libro XIII Cap. } 25 \text { p. } 280 \text {, Cap. } 32 \text { p. } 284 \text {, } \\
\text { Cap. } 38 \text { p. } 287\end{array}$ \\
\hline \multicolumn{6}{|r|}{ 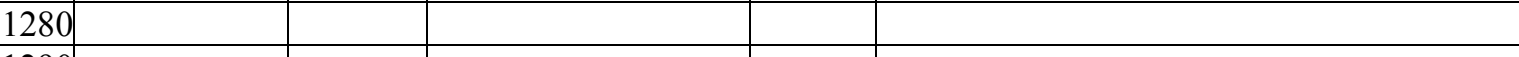 } \\
\hline \multicolumn{6}{|l|}{1290} \\
\hline 1300 & & & & & \\
\hline
\end{tabular}


Tabla 7: Providencialismo referido al monarca

\begin{tabular}{|c|c|c|c|c|}
\hline 1000 & Castigo divino & Protegido / Ayudado & Bendito & $\begin{array}{l}\text { Fuentes } \\
\text { - CAIII Rotense } \mathrm{n}^{\circ} 5 \text { p. } 198, \mathrm{n}^{\circ} 7200, \mathrm{n}^{\circ} \\
16 \mathrm{p} 210, \mathrm{n}^{\circ} 24 \mathrm{p} 216, \mathrm{n}^{\circ} 25 \mathrm{p} 218 . \\
\text { CAIII Sebastian } \mathrm{n}^{\circ} 5 \text { p. } 199, \mathrm{n}^{\circ} 7 \text { p. } 201, \\
\mathrm{n}^{\circ} 16 \text { p. } 211 \\
\text { - CA Cap. XIV n }{ }^{\circ} 161 \text { p. } 241 \\
\text { - CSEA pp. } 244,286,288\end{array}$ \\
\hline \multicolumn{5}{|l|}{1090} \\
\hline \multicolumn{5}{|l|}{1100} \\
\hline 1110 & $\mathrm{X}$ & & & $\begin{array}{l}\text { - CS/L p. } 36,46 \\
- \text { CAS n }^{\circ} 3 \text { p. } 10, n^{\circ} 20 \text { p. } 33 \text {. }\end{array}$ \\
\hline \multicolumn{5}{|r|}{ 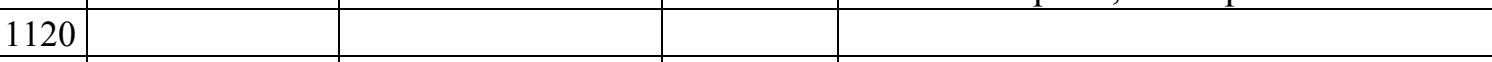 } \\
\hline 1130 & $\mathrm{X}$ & $\mathrm{X}$ & & - COP p. $172,175,176,179,181$ \\
\hline 1140 & $\mathrm{X}$ & $\mathrm{X}$ & $\mathrm{X}$ & $\begin{array}{l}\text { - CAI Libro I n }{ }^{\circ} 10 \text { pp. } 67 \text { n }^{\circ} 15 \text { pp. } 68, \\
69 \text { N }^{\circ} 55 \text { p. } 80 \text { Libro II n } 54 \text { p. } 111 \\
\text { - LSJ Libro IV Cap. } 22 \text { p. } 499\end{array}$ \\
\hline \multicolumn{5}{|l|}{1150} \\
\hline \multicolumn{5}{|l|}{1160} \\
\hline 1170 & $X$ & $\mathrm{X}$ & & $\begin{array}{l}\text { - CN Libro I n }{ }^{\circ} 110-112 \text { p. } 61 n^{\circ} 184 \text { p. } \\
89 \text { n }^{\circ} 209 \text { p. } 107 \text { Libro II n }{ }^{\circ} 5,6 \text { pp } 115 \\
116 . n^{\circ} 25 \text { p. } 137 \text { n }^{\circ} 29 \text { p. } 141 \text { n }^{\circ} 36 \text { p. } \\
149 \text { n }^{\circ} 39 \text { p. } 152 \text { Libro III n }^{\circ} 3 \text { p. } 159\end{array}$ \\
\hline \multicolumn{5}{|l|}{1180} \\
\hline \multirow{2}{*}{\multicolumn{5}{|c|}{1190}} \\
\hline & & & & 1200 \\
\hline \multicolumn{5}{|l|}{1210} \\
\hline 1220 & $\mathrm{X}$ & $\mathrm{X}$ & & - AT I p. 343 \\
\hline 1230 & $\mathrm{X}$ & $\mathrm{X}$ & & $\begin{array}{l}\text { - CM Libro IV Cap } 32 \text { p } 316 \text {, Cap } 71 \text { p. } \\
381 \text {, Cap } 76 \text { p. } 390 \\
\text { - CLRC n } 2 \text { p. } 27 \text { n } 3 \text { p. } 28, n^{\circ} 10 \text { p. } 35, \\
\text { n }^{\circ} 14 \text { p. } 40, n^{\circ} 18 \text { p. } 46, n^{\circ} 22 \text { pp. } 50,51, \\
n^{\circ} 34 \text { p. } 67, n^{\circ} 48 \text { p. } 79,67, n^{\circ} 70 \text { p. } 98 \\
\text { - MSI Cap. } 27 \text { p. } 45, \text { Cap. } 20 \text { p. } 47\end{array}$ \\
\hline 1240 & $\mathrm{X}$ & $\mathrm{X}$ & & $\begin{array}{l}\text { - HRH Libro II Cap. } 13 \text { p. } 104 \text {, Cap. } 15 \\
\text { pp. } 108 \text {, 109, Libro III Cap. } 16 \text { p. } 141 \text {, } \\
\text { Cap } 22 \text { p.152, Libro IV Cap.2 pp. 161, } \\
\text { 162, Libro V Cap. } 6 \text { pp.196, } 197 \text {, Cap. } 14 \\
\text { p. 205, Cap. } 15 \text { p.207, Cap. } 17 \text { p. } 209, \\
\text { Libro VI Cap.13 pp.236, 237, Libro VII } \\
\text { Cap. } 2 \text { p. 268, Cap } 3 \text { pp.269, } 270 .\end{array}$ \\
\hline 1250 & $\mathrm{X}$ & $\mathrm{X}$ & & - PFG n 83 p. 254 \\
\hline \multicolumn{5}{|l|}{1260} \\
\hline 1270 & $\mathrm{X}$ & $\mathrm{X}$ & & $\begin{array}{l}\text { - CGE Cap. } 551 \text { p. } 305 \text {, Cap. } 629 \text { p. } 359 \text {, } \\
\text { Cap. } 1131 \text { p. } 771 \\
\text { - CXXR. Libro X Cap. } 39 \text { p. } 222 \text {, Libro } \\
\text { XI Cap. } 6 \text { p. } 257\end{array}$ \\
\hline \multicolumn{5}{|r|}{ 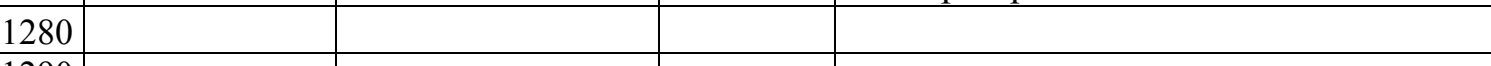 } \\
\hline 1290 & & & & \\
\hline 1300 & & & & \\
\hline
\end{tabular}


Tabla 8: Providencialismo referido a personajes particulares

\begin{tabular}{|c|c|c|c|c|c|}
\hline & $\begin{array}{l}\text { Castigo } \\
\text { divino }\end{array}$ & Auxilio & $\begin{array}{l}\text { Protegido } \\
\text { Ayudado }\end{array}$ & /Bendito & Fuentes \\
\hline \multicolumn{6}{|c|}{1000} \\
\hline \multicolumn{6}{|l|}{1090} \\
\hline \multicolumn{6}{|l|}{1100} \\
\hline 1110 & $\mathrm{X}$ & $\mathrm{X}$ & $\mathrm{X}$ & & - CS/L p.106 \\
\hline \multicolumn{6}{|l|}{1120} \\
\hline 1130 & $\mathrm{X}$ & $\mathrm{X}$ & $\mathrm{X}$ & & $\begin{array}{l}\text { - HC Libro I p. 66, Cap. } 2 \text { pp. } 70 \text {, } \\
\text { 71-75. Cap. } 15 \text { pp. } 96,97 \text { Cap. } 16 \\
\text { p.101 Cap. } 29 \text { pp. } 125,267 . \text { Libro } \\
\text { II Cap. } 53 \text { p. } 391 \\
\text { - COP p. } 172,175\end{array}$ \\
\hline 1140 & $\mathrm{X}$ & $\mathrm{X}$ & $\mathrm{X}$ & $X$ & $\begin{array}{l}\text { - CAI Libro I n } 38 \text { p. } 75 \text { Libro II } \\
n^{\circ} 7 \text { pp. } 97 \text { n }^{\circ} 10 \text { p. } 98 \text { n }^{\circ} 29 \text { p. } \\
104 \text { n}^{\circ} 42 \text { p. } 108 \text { n }^{\circ} 86 \text { p } 121 \text { n }^{\circ} 90 \\
\text { p. } 122 .\end{array}$ \\
\hline \multicolumn{6}{|l|}{1150} \\
\hline \multicolumn{6}{|l|}{1160} \\
\hline 1170 & $\mathrm{X}$ & & $\mathrm{X}$ & & $\begin{array}{l}\text { - CN Libro II n }{ }^{\circ} 26 \text { p. } 137, n^{\circ} 32 \\
\text { p. } 145, n^{\circ} 34 \text { p. } 148\end{array}$ \\
\hline \multicolumn{6}{|l|}{1180} \\
\hline \multicolumn{6}{|l|}{1190} \\
\hline & & & & & \\
\hline \multicolumn{6}{|l|}{1200} \\
\hline \multicolumn{6}{|l|}{1210} \\
\hline \multicolumn{6}{|l|}{1220} \\
\hline 1230 & $\mathrm{X}$ & & & & - CLRC n ${ }^{\circ} 38$ p. 70 \\
\hline 1240 & $\mathrm{X}$ & & $\mathrm{X}$ & & $\begin{array}{l}\text { - HRH Libro V Cap. } 18 \text { p.210, } \\
\text { Libro VIII Cap. } 10 \text { pp. } 321-323 .\end{array}$ \\
\hline \multicolumn{6}{|l|}{1250} \\
\hline \multicolumn{6}{|l|}{1260} \\
\hline 1270 & $\mathrm{X}$ & & $\mathrm{X}$ & $\mathrm{X}$ & $\begin{array}{l}\text { - CGE Cap. } 698 \text { pp. } 400-402 \text {, Cap } \\
699 \text { pp. } 402,403 \text {, Cap. } 700 \text { pp. } \\
\text { 403-406, Cap. } 727 \text { p. } 425 \text {, Cap. } \\
761 \text { p. } 452 \text {, Cap. } 1019 \text { p. } 702 . \\
\text { - CXXR Libro II Cap6 p. } 89, \\
\text { Libro VI Cap. } 3 \text { p. } 134\end{array}$ \\
\hline 1280 & $\mathrm{X}$ & & & & $-\mathrm{CSM} \mathrm{n}^{\circ} 83$ p. 340 \\
\hline 1290 & & & & & \\
\hline 1300 & & & & & \\
\hline
\end{tabular}


III.1.c.- Pecado y castigo

Para la sociedad cristiana medieval, el pecado y el castigo eran ideas tan poderosas y permanentes como los símbolos de favor divino y al igual que éstos, fueron hábilmente utilizados para señalar los defectos y debilidades de los enemigos, o educar a la comunidad de creyentes.

Del mismo modo que muchos otros elementos de la religiosidad medieval, la idea de pecado y del castigo divino consecuente encuentra sus raíces en las Escrituras, puntualmente en el Antiguo Testamento. Allí abundan ejemplos de personas o agrupaciones que por diversos motivos pecaron y fueron objeto de la ira divina. Por lo general, la peor falta era dudar de Dios y de sus promesas, lo que significaba una verdadera traición a la divinidad y a la comunidad de fieles. En las Escrituras, la opresión en Babilonia y la maldición de Yahvé contra Moisés y su pueblo fueron los episodios que más hondo calaron en el imaginario cristiano medieval, pues en ellas la furia de Dios se hizo palpable, pero sin que por ello se rompiera la alianza con Israel, por lo que estos episodios servían tambien para ilustra la misericordia de Dios ${ }^{791}$.

Por su parte, los padres de la Iglesia -en especial San Agustín- reforzaron esta tradición argumentando que eventos desastrosos como el saqueo de Roma se debieron a los pecados cometidos por los cristianos, al tiempo que introducían la poderosa idea de que un pueblo completo podía ser castigado por la acción de unos pocos, incluso tan sólo por las de sus gobernantes. Sin embargo, esto debe ser interpretado como una prueba destinada a fortalecer la fe de la comunidad, la que de superar la prueba vería recompensada su devoción a través de dones y otras señales ${ }^{792}$.

\footnotetext{
791 “ ¿Hasta cuándo esta comunidad perversa, que está murmurando contra mi? He oído las quejas de los israelitas, que están murmurando contra de mi. Diles: Por mi vida-oráculo de Yahveh-que he de hacer con vosotros lo que habéis hablado a mis oídos. Por haber murmurado contra mi, en este desierto caerán vuestros cadáveres, los de todos los que fuisteis revistados y contados, de veinte años para arriba." (Números 14: 27-29).

792 Sánchez Prieto, Ana Belén, Guerra y guerreros en España ... op. cit., p. 30.

"Non mihi itaque uidetur haec parua esse causa, quare cum malis flagellentur et boni, quando Deo placet perditos mores etiam temporalium poenarum adflictione punire. Flagellantur enim simul, non quia simul agunt malam uitam, sed quia simul amant temporalem uitam, non quidem aequaliter, sed tamen simul, quam boni contemnere deberent, ut illi correpti atque correcti consequerentur aeternam, ad quam consequendam si nollent esse socii, ferrentur et diligerentur inimici, quia donec uiuunt semper incertum est utrum uoluntatem sint in melius mutaturi. [...]Deinde habent aliam causam boni, quare temporalibus affligantur malis, qualem habuit Iob: ut sibi ipse humanus animus sit probatus et cognitus, quanta uirtute pietatis gratis Deum diligat." DCD, Liber I, cap. IX, en http://www.thelatinlibrary.com/augustine/civ1.shtml. 19.05.2012. "Asi que, a mi modo de ver, no es despreciable la razón por la que pasan penalidades malos y buenos juntamente, cuando a Dios le parece bien castigar incluso con penas temporales la corrompida conducta de los hombres. Sufren juntos no porque juntamente llevan una vida depravada, sino porque juntos aman la vida presente. No con la
} 
Posteriormente, la cronística medieval se amparó en la idea del castigo divino para ir construyendo una nueva historia de Salvación, destinada a glorificar al conjunto del pueblo cristiano a la vez que denostar a sus enemigos. En el caso particular de la Península Ibérica, la idea del castigo divino repercutió profundamente, ya que a partir de la tradición isidoriana existía ya la noción de que eran un pueblo beneficiado y castigado por Dios ${ }^{793}$.

Pareciera que la noción de castigo divino fue extremadamente popular en las crónicas, siendo una de las ideas más presentes en este tipo de fuentes ${ }^{794}$. Un ejemplo de ello se aprecia en la Crónica Najerense, que como tributaria de una larga tradición, afirmaría que la mano de Dios fue la responsable de la muerte de los emperadores Valeriano y Aureliano, ambos castigados por haber perseguido a los cristianos ${ }^{795}$.

En la sociedad cristiana peninsular, al igual que en muchas otras sociedades influencidas por la religión y enfrentadas a periodos de crisis, fue frecuente mantener un discurso político y moral estricto que procurase intimidar y advertir permanentemente a su público de los peligros de incurrir en alguna falta. Los castellanos no debían olvidar que luchaban contra los enemigos de Dios, en una contienda justa por la recuperación de su reino arrebatado. Dios había castigado a los israelitas por sus faltas, sancionado a los visigodos por los pecados de sus reyes, y también castigaría a los soberanos contemporáneos si no seguían sus preceptos. Es por ello que los cristianos siempre debían estar atentos para contentar a la Providencia y no acarrear penas que afectarían no sólo a los monarcas, sino que al conjunto del pueblo.

Curiosamente, pese a la importancia del castigo en el discurso cronístico, no siempre se aclara cuál fue el pecado cometido, y en ocasiones ni siquiera se hace

misma intensidad, pero sí juntos. Y los buenos deberían menospreciarla para que los otros, enmendados con la represión, alcancen la vida eterna. Y si sus enemigos se niegan a acompañarlos en conseguir la vida eterna, deberían ser soportados y amados, ya que, mientras están viviendo, nunca se sabe si darán un cambio en su voluntad para hacerse mejores. [...] Tiene, además, otra razón los buenos para sufrir males temporales. Es la misma que tuvo Job: someter el hombre a prueba su mismo espíritu y comprobar qué hondura tiene su postura religiosa y cuánto amor desinteresado tiene a Dios. " LCD, Libro I, cap. IX, op. cit., pp. 14, 15.

${ }^{793}$ Barkai, Ron, El enemigo en el espejo... op. cit., p. 31; y Martín, José Luis, "La pérdida y reconquista de España a la luz de las crónicas y del romancero", en Actas del III Curso de Cultura Medieval. Repoblación y reconquista... op. cit., pp. 9, 12.

${ }^{794}$ La idea del castigo expresada de forma explícita y compacta, es decir, sin dar pie a ambigüedades, tanto para los siglos XII y XIII como anteriores la podemos observar, entre otras, en las siguientes fuentes, Crónica Mozárabe de 754, Crónica Profética, Crónica de Alfonso III, Chronicon Regum Legionensium, Crónicas anónimas de Sahagún, Historia Silense, Historia Compostelana, Crónica del Obispo de Oviedo don Pelayo, Liber Sancti Jacobi o Codex Calixtinus, Chronica Adefonsi Imperatoris, Crónica Najerense, Crónica latina de los reyes de Castilla, Cronicon Mundi, Historia de Rebus Hispanie, Crónica General de España y la Crónica de veinte reyes.

${ }^{795}$ CN 1995, Liber I, N¹10-112, op. cit., p. 41. 
referencia a alguna falta concreta. Pero en los episodios en que las fuentes sí desarrollan la causa de la ira divina, ésta suele radicarse principalmente en la codicia, la actitud impía o la licencia sexual. Todas ellas faltas comunes a todos los hombres sin importar su condición y por lo tanto -al menos en estos casos- el mensaje era comprensible para todos los sectores de la sociedad; así, evidenciándose un uso de las creencias religiosas para mantener el control social, en relación a algunos actos que podían conmover al conjunto del pueblo cristiano ${ }^{796}$.

Es en ese sentido que para los autores medievales las intervenciones de Dios no se limitaban a acciones puntuales y específicas contra ciertas personas; por el contrario, la divinidad actuaba para alterar el curso de la historia en beneficio o perjuicio de grupos completos, puesto que el castigo de un sector beneficiaba a otro. Cuando Dios castigaba a un pueblo, era por el conjunto de sus pecados, y la forma más habitual de infligirle daño era por medio de pueblos invasores. Este modelo, proveniente del Antiguo Testamento, fue usado por los cronistas para explicar fracasos militares mayores y hechos trascendentales tan profundos como la conquista del año $711^{797}$. Es importante destacar, que tanto en la Biblia como en la mentalidad de los intelectuales medievales, estos castigos divinos no eran permanentes, y que consistían en pruebas de fe enviadas por Dios a su pueblo para luego redimirlos ${ }^{798}$. Fue así como la invasión musulmana y la caída de Reino Visigodo fueron tempranamente interpretadas como un castigo divino ${ }^{799}$.

Los godos fueron castigados por los pecados de sus reyes -particularmente Witiza y en menor medida Rodrigo-, quienes con sus actos corrompieron al conjunto de del pueblo, haciéndolo merecedor de la sanción providencial por no haberse opuesto y

\footnotetext{
${ }^{796}$ Tanto el conjunto del pueblo como los monarcas podían ser objeto del castigo divino. Esto en razón de que Dios podía castigar a toda la comunidad por los pecados de uno de sus reyes. Esto incluye la derrota militar o la muerte del soberano, puesto que en ambos casos era evidente la pérdida de la gracia ante Dios. En otras ocasiones también se podía castigar al pueblo en su conjunto, sin que necesariamente este hecho esté vinculado directamente a alguna falta del soberano. Todo ello en el entendido de que el soberano era el garante de su pueblo, para lo bueno y lo malo y por lo tanto, las faltas de uno o del otro podían convertirlos en merecedores comunes de la sanción providencial.

${ }^{797}$ En el antiguo testamento Yahvé castiga al pueblo de Israel en varias ocasiones producto del pecado de sus soberanos y del conjunto de la sociedad. Es en el Libro de los Profetas en donde se ven los ejemplos más dramáticos debido a la invasión, conquista y posterior exilio del pueblo elegido, de parte del imperio de Babilonia.

${ }^{798}$ Flori, Jean, La guerra santa... op. cit., p. 225.

799 "Sed suorum peccatorum classe oppressi et filiorum Uitizani fraude delecti in fuga sunt uersi. Quo exercitus fugatus usque ad internicionem eo pene est deletus. Et quia derelinquerunt Dominum ne seruirent ei in iustitia et ueritatem, derelicti sunt a Domino ne auitarent erram desiderauilem." CAIII, versión Rotense, 7, op. cit., pp. 120, 122. "Pero, aplastados por la muchedumbre de sus pecados y traicionados por el fraude de los hijos de Witiza, fueron puestos en fuga. Puesto en fuga el ejército, fue destruido casi hasta el exterminio. Y como abandonaron al Señor, para no servirle en justicia y en verdad, fueron abandonados por el Señor, de manera que no habitaran la tierra deseable." CAII, versión Rotense, 7, op. cit., p. 200.
} 
por convertirse en cómplice de los pecados del rey. De este modo es como lo transmiten los cronistas de la Reconquista, que enmarcan este episodio dentro del relato general de la "pérdida de España" ${ }^{800}$. La Crónica Najerense alude directamente a la lujuria del monarca y su alejamiento de la Iglesia como responsables directos de la catástrofe; lo mismo hacen "el Toledano" y "el Tudense"; el primero extiende el pecado de Witiza al conjunto de su pueblo "hasta el punto de que tal como obraba el pueblo, así también el sacerdote, y como los pecadores, así también el rey" $", 01$, mientras que el segundo resalta la corrupción del clero y la separación de Roma como agravantes ${ }^{802}$. Ideas que la Crónica General sintetiza:

"Assi en esta guisa como dezimos fue toda Espanna llena de nemiga et de peccado et de sobeiania de mal por el rey Witiza que mouio los oios de Nuestro Sennor Dios a sanna, ca todos los omnes de la tierra auien corrompida su carrera et ensuçiada su uida; e al que era bueno nol preciauan una paia, et al derechurero quanto a una espina de sebe, esto es sarça" ${ }^{\prime 03}$.

Esa cita ilustra la idea del pecado y redención a la que anteriormente nos hemos referido, pero que es importante recordar, puesto que la cronística hispana permanentemente mantendrá vivo este recuerdo y construirá un discurso legitimador a partir de ella, expresando constantemente la necesidad de que el pueblo cristiano-ibérico enmiende su actitud y evite el pecado para obtener la victoria sobre sus enemigos. De este modo es posible observar en aquellos textos claras intenciones pedagógicas, en el énfasis por resaltar que la derrota de los visigodos no fue un suceso causado solamente por los pecados de Witiza, sino que se debió a una tradición pecaminosa llevada a cabo por los reyes visigodos. Incluyendo además una serie de defectos que habrían carcomido las bases del poder, la legitimación de los monarcas y el favor divino ${ }^{804}$.

\footnotetext{
${ }^{800}$ Martín, José Luis, "La pérdida y reconquista de España... op. cit., pp. 9, 11.

${ }^{801}$ HRH, Liber III, cap. XVI, op. cit., pp. 97, 98.

${ }^{802}$ De hecho la idea del castigo divino a los visigodos se convirtió en un tópico transversal de la cronística hispana, que a través del ejemplo de Witiza explicaba como los pecados del rey se proyectaban en su pueblo y como éste podía ser cómplice de las faltas de su monarca, de forma que la sanción providencial afectaba al conjunto de la comunidad. (PFG, 83, op. cit., p. 254; CN 1995, Liber I, 209, op. cit., pp. 94, 95; HRH, Liber III, cap. XVI, op. cit., pp. 97, 98; y CM, Liber III, Nº 61, p. 217-219).

${ }^{803}$ PCG, cap. 551, op. cit., p. 305.

${ }^{804}$ Bronisch, Alexander Pierre, Reconquista y guerra santa ... op. cit., pp. 126, 158.

Es así como en el De Rebus Hispaniae se enumeran los pecados de la estirpe goda, en un texto que luego vemos reproducido, casi textualmente, en el De Preconiis Hispanie DPH, Tratado IX, $\mathrm{N}^{\circ}$ 11, op. cit., p. 186). Según estas versiónes, los pecados de los godos literalmente colmaron la paciencia de Dios: "Set quia 'regis ad exemplum totus componitur orbis', peccata Witize et ultimi Roderici et aliorum regum qui precesserant, quorum aliqui factione, aliqui fraticidio seu parricidio regni usurpauerant potestatem, successione legitima non seruata, incanduit ira Dei et Gothorum gloriam, quam hactenus sustentarat, eiecit a facie" HRH, Liber III, cap. XXII, op. cit., p. 108. "Pero como 'todo el mundo se ordena a
} 
Estas ideas se repiten una y otra vez en distintas crónicas y relatos, siempre como explicación contextual a los trágicos lamentos por la pérdida de España. En ellas se aprecia como denominador común la idea de que la península le fue entregada a los visigodos por Dios, y que fue Él quien castigó a su pueblo por sus pecados, por intermedio de los musulmanes ${ }^{805}$.

A la par con el relato del castigo, los cronistas destacan el hecho de que Dios sanciona pero no abandona a su pueblo, y que pronto se vería liberado de los invasores, como vaticinaba la Crónica Profética. Una señal inequívoca de ello sería el advenimiento de Pelayo, quien como "pequeña ascua" 806 lideró a su pueblo, y con la ayuda de la Providencia obtuvo la mítica victoria contra los sarracenos ${ }^{807}$.

Así, a medida que avanzaba la Reconquista el tópico del castigo divino se hizo cada vez más potente en las crónicas, especialmente en momentos de crisis, con la salvedad de que, de forma progresiva, los relatos experimentaron un pequeño giro y comenzaron a evitar responsabilizar a los monarcas de estos infortunios, atribuyéndolos en cambio a la debilidad del pueblo en su conjunto, o bien a que los enemigos contaban con el apoyo de fuerzas oscuras y sobrenaturales, como el demonio. Este fue el caso de los relatos referidos al-Mansur, los mismos que fueron utilizados para amedrentar a los cristianos, para recalcar la visión de que toda amenaza no es más que una prueba de $\operatorname{Dios}^{808}$.

semejanza del rey', por los pecados del rey Witiza y del postrer Rodrigo y de otros reyes anteriores, algunos de los cuales se apropiaron de la dignidad del trono con una conjura, otros por fratricidio o parricidio, sin respetar la sucesión establecida, estalló la ira de Dios y apartó de la presencia de su Majestad a la gloria de los godos, a los que hasta entonces habia tolerado." HHE, Libro III, cap. XXII, op. cit., p. 152.

${ }^{805}$ CA, op. cit., pp. 192, 193. CS, op. cit., p. 40. En el mismo sentido la Crónica Anónima de Sahagún es clara al afirmar: "Mas mereçiéndolo los grandes pecados de la gente gótica e permitiémdolo la justa sentençia del muy alto señor, España fue ferida e metida al cuchillo muy cruel de los ynfieles, por lo qual el dicho lugar e capilla, en la que los miembros de los dichos santos mártires folgavan, fasta el suelo derrivada." CAS, Crónica I, n 3, op. cit., p. 10.

${ }^{806}$ HRH, Liber IV, cap. I, op. cit., 114.

${ }^{807}$ Mitre Fernández, Emilio y Martín Alvira Cabrer, "Ideología y guerra en los reinos... op. cit., pp. 301; y Weber, Max, Economía y Sociedad. Esbozo de sociología comprensiva, México, Fondo de Cultura Económica, 1983, p. 354.

${ }^{808}$ Distintas crónicas, como la Najerense o la De Rebus Hispaniae, nos narran cómo el caudillo cordobés arrasó las tierras cristianas con el permiso de Dios, que de esta manera castigaba los pecados del pueblo cristiano, aunque sólo lo suficiente para que se enmendara, puesto que al cabo de algunos años levantó el castigo, permitiendo la derrota y la retirada de los invasores (CN 2003, Liber II, $\mathrm{N}^{\circ} 39$, op. cit., pp. 151, 152; HHE, Libro V, cap XIV, op. cit., p. 205). Al respecto la Najerense dice: "Tandem diuina miserante pietate et tam diram calamitatem a ceruicibus Christianorum auferre dignante ipse Almazor, quamuis permittente Deo peccatis Christianorum exegentibus per duodecim continuos annos terram deuastasset, XII regni sui anno post multas et horriferas Christianorum strages cum predicto comite Sancio confligens et fugam arripiens per medium crepuit et mortuus est in uilla que dicitur Graliare et sepultus est apud Medina Celem era MXL." CN 1995, Liber II, № 39, op. cit., p. 146. "Finalmente la misericordia divina se apiadó y se dignó levantar tan cruel calamidad del cuello de los cristianos y ese Almanzor, aunque había devastado la región durante doce años seguidos, porque así lo permitió Dios y lo exigían los 
La figura de al-Mansur es interesante debido a la doble interpretación que se le dio en las crónicas; por una parte, sus victorias sirvieron para sancionar a los cristianos, y en consecuencia se presenta como un instrumento divino al servicio de un plan superior. Simultáneamente, su retirada y posterior muerte lo muestran como un enemigo de Dios, y por tanto, objeto del castigo divino. Estos relatos cumplieron el rol de cerrar el ciclo del pecado y castigo, señalando la redención de los creyentes y demostrando cómo Dios se imponía frente a los enemigos de su pueblo, sin importar lo fuertes que fuesen, reafirmando así la fe de los cristianos. Respecto del caudillo cordobés, es particularmente significativo que el principio de su fin comienza cuando sus huestes atacaron el sepulcro de Santiago en Compostela, el corazón de la espiritualidad hispana ${ }^{809}$. El ataque al sepulcro del santo habría desencadenado la ira de Dios, que castigó a los musulmanes con disentería, ceguera y muerte, obligándolos a replegarse ${ }^{810}$.

En cuanto a los cristianos, es revelador que -según los cronistas de los siglos XII y XIII- Dios los castigase con bastante frecuencia. En distintos episodios se explican los reveses sufridos, y casi siempre destacando que eran producto de los pecados del conjunto de la población. No obstante, en algunos casos parece existir una intención de encubrir con esta fórmula algún aspecto negativo, o incluso lanzar una velada crítica hacia algún monarca. Por ejemplo, Alfonso VI, el conquistador de Toledo, llegó al trono luego de la muerte de Sancho y de haber encarcelado de por vida a su hermano García; y si bien fue un firme luchador contra el Islam, mantuvo una larga relación con la "mora" Zaira, con quien incluso engendró al infante Sancho Alfónsez. No obstante, pese a las faltas del monarca fuentes como la Cronica de veinte reyes, evitan responsabilizarlo por su derrota ante los Almorávides: "Mas al cabo, por los pecados de la Christiandat, fueron los christianos vençidos e fuxeron muchos dellos, non los persiguiendo

pecados de los cristianos, en el décimo tercer año de su reinado, tras muchos horribles estragos causados a los cristianos, luchó con el conde Sancho y, emprendió la huida, reventó por medio y murió en el pueblo que llaman Grajal de Campos y fue enterrado en Medinaceli en la era 1040." CN 2003, Liber II, N 39, op. cit., p. 152.

${ }^{809}$ Guiance, Ariel, "Morir por la patria, morir por la fe: La ideología de la muerte en la Historia de Rebus Hispaniae", en Cuadernos de Historia de España, LXXIII, 1991, pp. 100, 102.

810 Ejemplos de este relato se pueden encontrar en textos tan distintos como el Chronicon Sampiri Episcopi Asturicensis, el Codex Calixtinus y la crónica de Lucas de Tuy (LSJ 2004, Libro IV, cap. XXV, op. cit., p. 517; CN 1995, Liber II, $\mathrm{N}^{\circ}$ 32, op. cit., p. 140; y CM, Liber IV, $\mathrm{N}^{\circ}$ 38, op. cit., p. 70). Es asi como el Chronicon Sampiri Episcopi Asturicensis dice: "Ergo uoluit accedere ad ecclesiam et sive ad sepulchrum beati Jacobi cum magna audacia, sed renuente Deo rediit territus; sed noster rex coelestis nos est oblitus plebem christianam; misit in agarenos infirmitatem ventris et nemo ex eis remansit uius qui rediret in patriam unde venerat." Chronicon Sampiri, en Crónicas Latinas de la Reconquista, Tomo I, op. cit., p. 304. "Pues quiso llegar a la iglesia y también al sepulcro del beato Jacobo con magna audacia, pero reprobándolo Dios regresó aterrado; pero nuestro rey celeste no olvidó á la plebe cristiana; envió á los agarenos una enfermedad de vientre y nadie de ellos quedó vivo que volviese a la patria de donde viniera." CSEA, en Crónicas Latinas de la Reconquista, Tomo I, op. cit., p. 304. 
ninguno. El rrey don Alfonso mantouo la batalla él solo, synon con muy pocos, fasta la noche e tan de rrezio lidiaua que moro ninguno non se le osaua parar delante $[\ldots]^{811}$. El relato demuestra que pese a sus pecados la legitimidad del monarca no era cuestionada, a la vez que reafirmaba la importancia de la piedad para el conjunto de la cristiandad peninsular.

La protección de los cronistas a la honra de Alfonso VI desaparece con respecto a su sucesora, Urraca, quien es muy criticada por la mayoría de los autores, quienes introducen la idea de que los ocurridos en su reinado, y en especial su matrimonio con Alfonso de Aragón, se debieron a un castigo divino ${ }^{812}$. No obstante, dado el contexto de las crónicas posteriores, es posible inferir que las críticas a la reina pudieron tener la intención de construir un discurso que "demonizara" al rey aragonés en su rol de rival del futuro rey Alfonso VII ${ }^{813}$.

Crear una imagen vil del enemigo era también parte de la utilización de la religiosidad, puesto que sobre el adversario se construía una estampa plagada de características y comportamientos malignos y pecaminosos, que servían para ilustrar su condición de antagonista y justificar la lucha contra él. El rival "demonizado" era por ende, símbolo del mal y contrario a todo lo bueno; en consecuencia, era un enemigo de Dios contra quien era legítimo enfrentarse. Un ejemplo de ello lo podemos observar en la descripción física y moral que se hace de Geraldo, lugarteniente -según la crónicadel también "malvado" Alfonso de Aragón ${ }^{814}$ :

"Su cara era arrugada e magra; los dientes, escabrosos e ormientos; e sus ojos, turbados manantes sangre; la su barba, pelada en la haz e pocos pelos e quasi ferida e quemada. E como fuese así de feo en la figura de la cara, mui más feo era en el corazón e voluntad, ca los sus mesmos cavalleros que le seguían, afirmavan que escondidamente avía dado fee al demonio, e el ánima con el cuerpo al diablo avía dado [...]",15

\footnotetext{
${ }^{811}$ CXXR, Libro X, cap. XXXIX, op. cit., p. 222.

${ }^{812}$ Como ejemplo se ello se puede mencionar la explicación dada por el cronista de Sahagún: "Mas como el poderoso Dios dispusiese de querer açotar a Espanna con el bastón de su sanna, consintió e pirmitio que los yniquos e malos consejos prebaleçiesen, ca venidos los condes e nobles al castillo que diçen Munnón, allí casaron e ayuntaron a la dicha doña Urraca con el rei de Aragón." CAS, Crónica I, № 19, op. cit., p. 28.

${ }^{813}$ Es de hacer notar que según distintas fuentes y autores actuales, el matrimonio de Urraca y el Batallador fue arreglado por Alfonso VI antes de su muerte y no se debió a una decisión personal de la futura reina.

${ }^{814}$ De forma similar a lo que ocurría con Geraldo, los musulmanes también eran frecuentemente vilipendiados e injuriados, acusándoseles sobre todo de lujuriosos y viciosos, y por tanto símbolos del pecado; este era un agravante más que justificaba y legitimaba la lucha contra ellos (CAS, Crónica I, $\mathrm{N}^{\circ}$ 59, op. cit., p. 87).

${ }^{815}$ CAS, Crónica I, N ${ }^{\circ}$ 59, op. cit., p. 87.
} 
En una línea similar, en la Crónica de Alfonso VII, a través del providencialismo se realiza un notable juego comparativo entre el soberano leonés y su rival aragonés. Mientras el emperador es representado como un restaurador de la armonía y justicia, "el Batallador" es descrito como un traidor, embustero y pecador, y por ende muy alejado de la "protección divina" que legitimaba a los soberanos. Esta concepción queda patente en la narración en torno a la derrota y posterior muerte del rey de Aragón. La Chronica Adefonsi nos relata -en un párrafo que sintetiza la esencia del providencialismo- cómo el rey se enfrentó, en la batalla de Fraga, a fuerzas musulmanas superiores y que ignoró el consejo de sus asesores: "Verumtamen noluit eam recipere, quia Deus induraverat cor eius ut venirent super eum omnia mala quae ipse fecerat super cristianos in terra Legionis et Castellae et super gentem suam, sicut et postea venerunt ${ }^{\prime 816}$. El rey continuó con su línea de acción, y se enfrentó a sus enemigos con resultados catastróficos:

"Hoc videntes episcopi et clerici et omnis populus christianorum, coeperunt rogare Dominum Deum ut eos eriperet de manibus Sarracenorum et ne reminisceretur peccatorum regis nec parentum suorum vel qui cum eo erant, et ut ab ipso mitius corriperentur. Sed, peccatis exigentibus, orationes eorum non sunt exauditae ante Deum, quia Gabriel Archangelus, summus nuntius Dei, non tulit eas ante tribunal Christi nec Michael, princeps militae caelestis, misus est a Deo ut eos adiuvarent in bello" ${ }^{\text {} 817}$.

Este relato es un magnífico ejemplo del uso de los elementos legitimadores providencialistas. El rey, movido por su soberbia, ignora a los buenos consejeros. Por su parte, sus allegados reconocen la mano de Dios en la derrota y claman por misericordia, pero no son escuchados, puesto que Dios no envió ninguna ayuda celestial a socorrerlos

\footnotetext{
${ }^{816}$ CAI, Liber I, N 53, op. cit., p. 44. "Sin embargo, él no quiso aceptarla porque Dios había endurecido su corazón para que cayeran sobre él, como después cayeron, todos los males que él había hecho contra los cristianos en el territorio de León y Castilla y contra su propio pueblo." CEA, Libro I, N 53, op. cit., p. 80 .

${ }^{817}$ CAI, Liber I, No 55, op. cit., pp. 45, 46. “Al ver esto, los obispos, clérigos y todo el pueblo de los cristianos empezaron a rogar a Dios Nuestro Señor que los arrancase de las garras de los musulmanes, que no se acordarse de los pecados del rey, de sus parientes o de quienes estaban con él y que los castigase con suficiente benignidad. Pero, en castigo por sus pecados, sus oraciones no fueron atendidas ante Dios, porque el arcángel Gabriel, el más importante mensajero de Dios, no le llevó ante el tribunal de Cristo, ni Miguel, príncipe de la milicia celeste, fue enviado por Dios para ayudar en la guerra." CEA, Libro I, N 55, op. cit., p. 80.
} 
y dejó que perecieran en manos de sus enemigos, que en este caso actuaron como instrumentos de la Providencia ${ }^{818}$.

Como se puede observar, la Chronica Adefonsi Imperatoris es pródiga en episodios providenciales, y creemos que esto se debe al contexto del reinado de Alfonso VII. El monarca había accedido al trono luego de amplias perturbaciones políticas y conflictos intestinos, por lo que sus primeras acciones miliares fueron dirigidas contra sus rivales cristianos, lo que según la tradición no bastaba para validar a un monarca. Es por ello que en una segunda etapa y ya neutralizados sus enemigos internos, el emperador comenzó la guerra contra el Islam. En ambos momentos el autor de la Chronica hace un constante uso del providencialismo, para demostrar las virtudes del monarca, injuriar a sus enemigos o simplemente explicar diversas situaciones que afectaban al soberano. Todo ello con el fin de hacer evidente la cercanía del rey con la Providencia y validar al monarca.

En la misma línea estaba la idea de la acción punitiva individual, la que es descrita en la Chronica mediante casos concretos, en los que grandes caudillos cristianos encuentran una muerte abrupta como causa de sus actos. Son los casos de Rodrigo Martínez, -cuya muerte se explica debido a los pecados por él cometidos- y Munio Alfonso, muerto a manos de los musulmanes como castigo por el hecho de haber asesinado a su propia hija ${ }^{819}$.

El relato de estas muertes bien pudo cumplir distintas funciones, tales como demostrar que la justicia divina no tenía límites, así como también señalar a estos personajes y su desgracia en oposición a Alfonso VII, quien es descrito como un buen rey que no es afectado por sanciones providenciales.

Relacionado con el providencialismo encontramos también las apariciones del demonio, comprendido como el opuesto de Dios. Este dualismo propio de la mentalidad medieval también se refleja en las crónicas, donde ciertos hechos son atribuidos a la influencia del "enemigo de los hombres". En general, estos episodios se relacionan con la explicación de sucesos que debilitaban a los cristianos o que les causaban duros

\footnotetext{
${ }^{818}$ La posterior muerte de "el Batallador" fue interpretada -según los cronistas adversarios, como el autor de la Chronica Adefonsi y Jiménez de Rada- como parte del castigo divino por los pecados y abusos del soberano, los cuales se hacían extensivos al conjunto de los aragoneses. Razón por la cual su pueblo realizó actos de dolor y penitencia, en búsqueda del perdón de Dios y el cese del castigo (CAI, Liber I, $\mathrm{N}^{\circ}$ 61, op. cit., p. 49; HHE, Libro VII, Cap. III, op. cit., p. 223; y CXXR, Libro XI, Cap. VI, op. cit., p. 257). ${ }^{819}$ CEA, Liber II, $\mathrm{N}^{\circ} 43,185$, op. cit.. pp. 36, 37, 144, 145.
} 
reveses; por ejemplo, las leyendas en torno al-Mansur que los describían como aliado del demonio y que narraban cómo el diablo lloró su muerte ${ }^{820}$.

No obstante, estos sucesos, si bien debilitaban y hacían tambalear a los cristianos, no logran hacerlos fracasar, lo que pretende demostrar que la lucha contra el infiel se daba en dos dimensiones; una divina y otra humana, donde el bien y el mal se enfrentan a través de los hombres. En esta lógica, el guerrero cristiano se trasformaba en un instrumento al servicio de la Providencia, con el aliciente de que era una guerra querida por Dios, y que con Su ayuda podrían vencer a los musulmanes, aliados del demonio y enemigos de la fe. Por ello es que los guerreros y el conjunto del pueblo cristiano debían guardar una vida piadosa, ya que su conducta ejemplar y devoción los libraría del pecado y su consecuente castigo ${ }^{821}$.

En esta corriente de pensamiento podemos identificar nuevamente una reminiscencia bíblica - especialmente en el Nuevo Testamento - donde el duelo entre el bien y el mal está representado en diversos episodios; por ejemplo, en el relato que muestra los intentos del diablo por tentar a Cristo durante su retiro en el desierto; ocasión donde el demonio esgrimió como armas de tentación el poder, la riqueza y la gloria, mismos pecados sobre los cuales los cronistas advierten reiteradamente ${ }^{822}$. Siendo más precisos, la soberbia, la lujuria, la avaricia y el orgullo fueron los pecados sobre los cuales se formularon más advertencias en los textos estudiados ${ }^{823}$. El primero de ellos era un claro desafío a Dios, puesto que el soberbio creía poder vencer por sí mismo, y por ende negaba la intervención de la Providencia. Una situación altamente riesgosa y que regularmente -según las fuentes- solía atraer sendos castigos, que tendían a empañar alguna gran victoria previa.

La soberbia también era un pecado usualmente atribuido a los musulmanes, lo que servía a los cronistas para ilustrar los alcances de la falta; no sólo ofendía a Dios, sino que además acercaba al pecador a la conducta de los infieles. Por su parte, la avaricia o codicia también son tópicos bastante frecuentes, debido a que a través de estos pecados se buscaba impedir actos de indisciplina - como el abalanzarse sobre el botín antes de

${ }^{820}$ Cronicón Burguense, en Huici M., Ambrosio, Las crónicas latinas...op. cit., Tomo I. p. 34; El Cronicón del Silense, en Huici M., Ambrosio, "Las crónicas latinas...op.cit." Tomo II, p. 106; CM, Liber IV, N 39, op. cit., p.270, 271; y CXXR, Libro V, cap. XXI, op. cit., p. 129.

${ }^{821}$ Goñi Gaztambide, José, Historia de la Bula ... op. cit., p. 26. García Fritz, Francisco, Las Navas de Tolosa ... op. cit., pp. 410, 413.

${ }_{822}^{823}$ Mateo 4: 1,11. Lucas 4: 1,13.

${ }^{823}$ Alvira Cabrer, Martín, "'Senhor, per les nostres peccatz'. Guerra y pecado en la Edad Media”, en Carrasco Manchado, Ana Isabel y María del Pilar Rábade Obradó (Coordinadores), Pecar en la Edad Media... op. cit., pp. 102-109. 
lograr la victoria- que podían poner en riesgo el triunfo de la hueste cristiana. Por último, la lujuria -que también era atribuida a los musulmanes- era un pecado que se narraba principalmente en relación a los monarcas, recordándoles que había sido uno de los pecados más característicos de los visigodos, y en consecuencia causa de la pérdida del reino. Los monarcas hispanos no debían olvidar los pecados de sus antepasados, puesto que su misión era precisamente reconquistar las tierras que se habían perdido por esas faltas.

\section{III.1.d.- El siglo XIII. Dios y los hombres, consolidación y cambios}

A partir del siglo XIII, las crónicas muestran una consolidación de los tópicos providencialistas, en especial en torno a uno de los acontecimientos más importantes de la Reconquista: la batalla de Las Navas de Tolosa del 16 de julio de 1212. Para los autores medievales, este evento reúne todos los elementos constituyentes del providencialismo: fue una batalla campal entre la alianza de los reyes cristianos contra el Islam "soberbio", que mostró las pericias de de un rey pecador y castigado, Alfonso VIII, que buscó y logró la redención. Por lo demás, los relatos son abundantes en milagros, apariciones de mensajeros providenciales y otros sucesos sobrenaturales que sirvieron para convertir a la batalla en un icono del providencialismo y en la legitimación de la guerra en manos de la monarquía castellana. No obstante, debemos destacar que estos episodios providenciales evidencian algunos cambios, en relación a la forma en que habían sido presentados anteriormente, dado que se trataría de portentos menos espectaculares y más sencillos. En general, relatan pequeños milagros que en su conjunto componen una gran historia providencial; a su vez la mano de Dios es menos directa, resaltando en su lugar las acciones de los grandes líderes, como Alfonso VIII, siempre bajo la premisa de que sus actos eran impulsados por la Providencia. En razón de lo anterior, consideramos prudente referimos al encuentro de las Navas en sus aspectos providencialistas.

En 1195, los Almohades, al mando de Abu Yusuf Ya'qub al Mansur, iniciaron una serie de ofensivas contra tierras castellanas. Ante la gravedad de la amenaza, al auxilio de Alfonso VIII acudieron los monarcas de Navarra, Aragón y León. Pero el castellano decidió no esperar a los refuerzos y se enfrentó en solitario a los musulmanes, resultando la operación en un total desastre. Para los cronistas, en cambio, la derrota tuvo explicaciones más simbólicas y providencialistas. El rey había cometido dos 
graves pecados que le restaban la Gracia de la Providencia y precipitaron su infortunio $^{824}$ : el primero fue la soberbia, ya que se había atrevido a creer que podía prescindir de la ayuda de los otros reinos cristianos y en un impulso de orgullo injustificado, se lanzó imprudentemente a conquistar la gloria; fue un acto de desprecio a la humildad y piedad que debían caracterizar a un rey cristiano. Al respecto la Crónica Latina señala "Ignis ascensus uidebatur in furore Domini et elationem animi, si qam conceperat rex nobilis ex gloria precedenti, deprimere uidebatur, ut intelligeret rex prudens et nobilis quod regnum filiorum hominum in manu Dei est et cuicumque uoluerit dabit illud" ${ }^{\$ 25}$. Esta versión es reforzada por el autor de la Crónica de veinte reyes, quien no duda en afirmar que "mas non quiso Dios que los chistianos saliesen ende onrrados, que non eran de vn coraçón nin ayudaron a su señor commo deuían, $e$ fueron vençidos e malandantes e murieron y muchos cristianos" 826 .

En ambos casos los testimonios no dejan dudas, Alfonso y sus huestes no contaron con la protección de la Providencia, que airada por la actitud del monarca, dejó que éste fuese vencido por sus enemigos.

Asimismo, podemos observar en las mismas fuentes que Alfonso no sólo atrajo la ira divina sobre él mismo, sino también sobre toda la comunidad. El castigo fue para el conjunto de los castellanos que no lucharon o auxiliaron a su señor como debían hacerlo. Esto se hace extensivo para el resto de los cristianos, como lo indica la Crónica Latina, que afirma que Alfonso de León no llegó con ayuda a la batalla de Alarcos, debido al "consejo de algunos satélites de Satanás" ${ }^{27}$. Esta es una explicación providencialista y política a la vez, puesto que justifica la derrota de Castilla apelando a la intervención del Mal y al mismo tiempo, acusa al rival de Alfonso VIII de traicionar a su primo, al dejarse influenciar por el demonio. Dicha acusación equivale a señalar al rey de León como un hombre traicionero, entendido en el contexto de disputas que afectaba a ambos reinos y al interés de los cronistas por favorecer a los bandos según su origen.

Junto a la soberbia, el segundo pecado del rey castellano, fue el hecho de que se encontraba en falta en el momento de iniciar la campaña, por haber engañado ${ }^{828}$ a su

\footnotetext{
${ }^{824}$ García Fitz, Francisco, "La conquista de Andalucía... op. cit., pp. 54, 55.

${ }^{825}$ CLRC 1997, No 14, op. cit., p. 48. "El fuego de la ira del Señor parecía crecer y abatir la soberbia, que quizá tuviese el noble rey por su gloria anterior, para que entendiera el prudente y noble rey que el reino de los hombres está en manos de Dios y lo da a quien quiere." CLRC 1999, No 14, op. cit., p. 40.

${ }^{826}$ CXXR, Libro. XIII, cap. XXV, op. cit., p. 280.

${ }^{827}$ CLRC 1997, No 14 , op. cit., p. 47.

${ }^{828} \mathrm{Si}$ bien la posesión de concubinas no era extraño en los reyes cristianos, siempre fue una situación incómoda, que se trataba de no ventilar, puesto que era una grave falta al sacramento matrimonial.
} 
legítima esposa, Leonor de Plantagenet con una amante judía ${ }^{829}$. Una falta agravada por el hecho de que su favorita era miembro de un pueblo hacia el cual solían dirigirse recelos y acusaciones de corte religioso. En otras palabras, el rey se encontraba en pecado y había atraído la ira de Dios, que lo había castigado con la derrota militar, al igual que lo había hecho con los reyes del antiguo Israel ${ }^{830}$.

Los pecados del rey, la soberbia y lujuria, incluso trascendieron de la Península y atrajeron voces críticas contra la actitud del soberano, que por sus actos ponía en riesgo la muy noble misión de combatir al Islam, y permitía el aumento de las fuerzas de los poderosos almohades. Esto se evidencia en una de las obras del trovador y posterior Obispo, Fulco de Marsella, quien amonesta al rey por su conducta ${ }^{831}$.

Como confirmación del castigo de Dios, la derrota de Alfonso VIII desató una serie de acontecimientos perjudiciales. En 1197 los almohades asaltaron sin éxito Toledo y Madrid. Además de ello, la debilidad castellana fue aprovechada por Navarra y León, que presionaron al atribulado reino con la recuperación de los territorios en disputa. Esto inició una serie de enfrentamientos entre ellos, que entorpecieron aún más la guerra contra el Islam ${ }^{832}$.

La idea de un castigo divino como explicación al desastre de Alarcos encontró eco en el mismo Alfonso VIII. Según García Fitz, el rey cambió su actitud luego de la derrota, enmendando su conducta y renegando de sus pecados. Ello en la lógica cristiana de que si una mala acción era motivo de castigo divino, su enmienda atraería el favor de la Providencia ${ }^{833}$.

Paralelamente a estos hechos, Alfonso VIII había logrado restablecer el orden en su reino y firmado una tregua con los almohades. Aún así - en versión de distintos cronistas - el rey se encontraba profundamente afectado por su descalabro en Alarcos, al punto de que la idea de una revancha se había convertido prácticamente en una

\footnotetext{
${ }^{829}$ Este episodio es rescatado por García Fitz en su texto "La conquista de Andalucía en la cronística castellana del siglo XIII: Las mentalidades historiográficas en los relatos de la Conquista". Allí el autor expone que en la edición de la Primera Crónica General de Florián Ocampo, se rescata el episodio de la amante judía de Alfonso VIII, que no aparece en la edición de Pidal. En el episodio se narra como la amante fue ultimada por los hombres del rey, que consideraban que dicha relación era perjudicial para todo el reino. Un acto que entristeció al rey, lo que implicó que un ángel le advirtiera que sus actos y actitud atraerían el castigo divino. (García Fitz, Francisco, "La Conquista de Andalucía... op. cit., p. 54, $55)$.

${ }^{830}$ En el Antiguo Testamento existen diversos episodios en los que se relata como Dios castigo a los soberanos de Israel por sus pecados, emblemáticos son los casos de Saúl y David.

${ }^{831}$ Un reproche no menor viniendo de él, que como obispo a partir de 1205, jugó un rol importante en la lucha y persecución contra los albigenses en Francia. (Alvar, Carlos, La poesía trovadoresca en España y Portugal, Madrid, Cupsa, D.L, 1977, p. 95).

${ }^{832}$ García Fitz, Francisco, "Las Navas... op. cit., pp. 134-137.

${ }^{833}$ García Fitz, Francisco, "La Conquista de Andalucía... op. cit., p. 54, 55.
} 
obsesión $^{834}$. Algo que no es de extrañar, si recordamos que para la visión providencialista la derrota era interpretada como el fracaso ante un juicio divino. Parecía entonces que Dios había abandonado al monarca por sus pecados, y por ello había sido puesto en entredicho por sus enemigos. En consecuencia el rey debía probar que era digno de su alto cargo, y sólo una victoria podría demostrar su reconciliación con la Providencia y legitimarse ante sus enemigos y súbditos.

Por todo ello, Alfonso comenzó a preparar su desagravio militar, empezando por crear un escenario favorable en la Península y en Europa. El castellano procuró difundir los peligros de la amenaza almohade por el continente, sirviéndose de una verdadera campaña de propaganda ${ }^{835}$.

Para 1212 los planes de Alfonso VIII habían alcanzado su éxito, puesto que gracias a la promulgación de la cruzada, el rey había logrado formar una alianza con los monarcas de Navarra y Aragón, además de reunir un importante contingente de guerreros ultramontanos.

Se iniciaba así la campaña, y con ella, una serie de milagros. Ya en marcha hacia la batalla, los cronistas procuraron demostrar cómo la Providencia protegió a los guerreros, como en el caso del cruce del río Guadiana, que los cristianos sortearon sin sufrir grandes percances, a pesar de haber sido sembrado de abrojos por los almohades ${ }^{836}$. Esto sirvió a los cronistas para afirmar que Dios protegía a los cruzados, y que ningún instrumento humano podría dañar a quienes contasen con su protección, como nos relata Jiménez de Rada: "Set quia humana artificia contra Dei prouidenciam nichil ualent, sic Deus uoluit ut paucissima uel nulli fere illis tribulis lederentur; et gracie Dei manu supposita transiuimus flumen Anam et castramentati fuimus in circuitu Calatraue 837 . Nótese que el arzobispo no afirma la inutilidad de los abrojos y que por

\footnotetext{
${ }^{834} \mathrm{Al}$ respecto la Crónica Latina nos dice "Manebat in alta mente regis positum, quod nunquam de ipsa exciderat: infortunium quod passis fuerat in bello de Alarcos. Sepe reuocabat ad animun diem illam, habens desiderium uicem reddere regi Marroquitano et pro hac re sepe Dominum deprecabatur." CLRC 1997, op. cit., $\mathrm{N}^{\circ} 18$, p. 53.

${ }^{835}$ Entre los instrumentos que utilizó Alfonso se destacaron el capítulo general del Cister y los trovadores. La orden monástica con sus redes de influencia política e intelectual ayudó a difundir el mensaje en las esferas de poder europeas, apelando a la lucha contra los enemigos de Dios. En tanto que los trovadores, con sus obras, conmovieron a las Cortes de Francia, recalcando el peligro del avance moro en Hispania. Así, los guerreros francos eran exhortados desde los altares y los palacios para ir a buscar la gloria al servicio de Dios. Una táctica que al parecer surtió efectos, como veremos más adelante, cuando Alfonso dé inicio formal a la campaña de las Navas. (Alvira Cabrer, Martín, "Del sepulcro y los sarracenos meridionales a los herejes occidentales", en Baloup, Daniel y Philippe Josserand (Editores), Regards Croisés sur la Guerre Sainte... op. cit., p. 193).

${ }^{836}$ CGE, cap. 1015 , op.cit, p. 695.

${ }^{837}$ HRH, Liber VIII, cap. V, op. cit., p. 264. "Pero como las invenciones de los hombres nada pueden hacer contra la providencia de Dios, la voluntad de Dios fue que escasísimos, o casi ninguno, se hiriera
} 
el contrario, reconoce que algunos guerreros resultaron lastimados, lo que hace más interesante su discurso, puesto que intenta dar a cada dificultad una explicación providencial que refuerce las motivaciones ideológicas de la campaña.

Posterior a las capturas de Malagón y Calatrava se produjo la deserción de los cruzados extranjeros, un episodio que también fue interpretado en forma providencial por los cronistas, en especial por Jiménez de Rada ${ }^{838}$. Según los testimonios, la deserción fue causada por acción del demonio, quien contaminó el corazón de los ultramontanos, haciéndolos abandonar la causa divina:

"Set quoniam humani generis inimicus nos cessat christianis actibus inuidere, misit Sathan in exercitum caricatis et corda emulancium conturbauit, et qui ad certamen fidei se accinxxerant, retrorsum a bono proposito abierunt. Omnes enim fere ultramontani comuni proposito statuerunt ut relictis crucis signaculis, omissis etaim belli laboribus, ad propria remearent ${ }^{\prime 239}$.

Luego, Alfonso X incluyó el relato en su Crónica General, agregándole más detalles en relación a que los ultramontanos, influenciados por el diablo, conspiraron para desertar de la campaña:

"Entre tod esto, porque ell enemigo de los omnes, et este el diablo, que nunca queda de inuidiar los buenos fechos de los omnes, metiosse en la huste de los fieles de Cristo et de la su caridad, et conturuio los coraçones de los enuidiosos que se auien guisado pora yr a esta batalla. Et fizolos arredar de yr, et fizoles desuiar de la buena postura que auien fecha: ca por la mayor parte todos los trasmontanos de comunal postura establesçieron que tolliessen las sennales de la cruç que auien tomadas de que se cruçaran pora esta batalla, et que dexassen los trabaios de su lit, et se tornassen pora sus tierras" ${ }^{\prime 40}$.

con aquellos abrojos; y sobre la mano de la Gracia de Dios, a modo de puente, atravesamos el río Guadiana y acampamos en derredor de Calatrava." HHE, Liber VIII, cap. V, op. cit., p. 313.

${ }^{838}$ Como ya hemos mencionado en capítulos anteriores, la retirada de los ultramontanos puede explicarse por distintas causas, entre las que se pueden mencionar las carestías que estaba sufriendo la expedición, el clima y las diferencias con respecto a la forma de conducir la campaña, en especial lo referido al trato dado a los vencidos.

${ }^{839}$ HRH, Liber VIII, cap. VI, op. cit., p. 265. "Pero como el enemigo del género humano no deja de malquerer las obras cristianas, introdujo a Satán en el ejército de caridad y encizaño los corazones envidiosos; y quienes se habian aprestado para la contienda de la fe dieron marcha atrás en sus buenas intenciones. Pues casi todos los ultramontanos, dejadas las enseñas de la cruz, abandonados también los trabajos de la batalla, tomaron en común la determinación de regresar a sus tierras." HHE, Libro VIII. cap. VI. p. 314.

${ }^{840}$ CGE, cap. 1015, op. cit., p. 696. 
Estas explicaciones providencialistas deben ser comprendidas en razón de algunos hechos que se infieren de las crónicas, y que se encuentran relacionados con el discurso validador de la guerra y la política peninsular. Primero, destacar el providencialismo presente en la campaña, ya que sólo una obra querida por Dios podría ser sujeto de una acción tan claramente diabólica, como la deserción de la cruzada, con la cual el "Mal" debilitaba a los cristianos. Al mismo tiempo, es posible concluir que la deserción de los ultramontanos sirvió a los intereses hispanos, puesto que sin ellos la victoria fue de exclusiva responsabilidad de los peninsulares -en especial de Castilla y su rey-, que habían organizado y financiado la campaña, conformando ahora el grueso de las tropas. La gloria sería así para Alfonso VIII y su reino, desligando su triunfo de la participación extranjera y desmereciendo a los francos, que en el Pseudo Turpin despreciaron a los peninsulares $^{841}$. Luego de la retirada de los ultramontanos, la campaña prosiguió sorteando diversos obstáculos, como el bloqueo del paso de La Loza, salvado gracias a la milagrosa intervención del "pastor de las Navas" ${ }^{\prime 42}$.

Ya en el campo de batalla y previo al combate, la característica providencialista de la próxima lucha fue recalcada por un hecho que, aunque no es compartido en todas las fuentes, no admite dudas respecto a cómo los cronistas construyeron un discurso que apelaba a la devoción y religiosidad de los hispanos. La Crónica de veinte reyes afirma que el domingo "aparesçió en el çielo vna cruz muy fermosa de oro de muchos colores e vieron los cristianos e touiéronlo por buena señal [...]"843.

De esta manera, la jornada fue una victoria completa para los cristianos, aunque parecía que ésta por sí misma no bastaba para resarcir a Alfonso de su anterior derrota; fue así que los relatos se complementaron con distintos portentos que resaltaban las características providenciales del triunfo ante los poderos almohades. De esa forma, el triunfo sería de Dios, por intermedio de los hombres. A su vez, Jiménez de Rada y otros cronistas narran cómo el estandarte del "Toledano" cruzó las líneas musulmanas sin que su portador recibiese daños ${ }^{844}$.

\footnotetext{
${ }^{841}$ Destacamos que, según las crónicas, los ultramontanos no fueron objeto de algún tipo de castigo divino por su deserción. Pareciera que toda su sanción fue no haber participado de la victoria y quedar señalados como traidores a sus votos y ajenos a la gloria alcanzada por los hispanos.

${ }^{842}$ Para los detalles del avance de las huestes ver el texto ya citado de García Fitz, Las Navas de Tolosa.

${ }^{843}$ CXXR, Libro XIII, cap. XXXII, op. cit., p. 284.

844 "Crux uero Domini, que coram Toletano pontifice consueuerant baiulari, preferente eam Dominico Pascasii canonico Toletano, per agarenorum acies miraculose transiuit, et ibidem illeso baiulo sine suis usque finem belli, Sicut Domino placuit, perdurauit" HRH, Liber VIII, cap. X, op. cit., p. 273. "La cruz del Señor, que solía tremolar delante del arzobispo de Toledo, pasó milagrosamente entre las filas de los agarenos llevada por el canónigo de Toledo Domingo Pascasio, y allí, tal como quiso el Señor, permaneció hasta el final de la batalla sin que su portador, solo, sufriera daño alguno" HHE, Libro VIII.
} 
Junto a ello se cuentan otros milagros, como que pese a la multitud de muertos, mutilados y despojados, no se encontró en el campo una sola gota de sangre ${ }^{845}$. Esto último, a nuestro entender, podría significar la intención de los cronistas por demostrar que fue una victoria limpia y pura, puesto que la sangre de los enemigos de Dios no contaminó la tierra cristiana.

Asimismo, las crónicas también atribuyen a la intervención de la Providencia las exageradas cifras de muerte de musulmanes - en algunas fuentes más de cien mil- en comparación a los pocos caídos en el bando cristiano -no más de cien- ${ }^{846}$. Los cronistas ven en estas cifras la intervención protectora de Dios y las utilizan para reforzar el discurso que convertía a los guerreros cristianos en paladines de la fe, en oposición a los musulmanes, que producto de su maldad, sufrieron el castigo espiritual, como lo relata la Crónica Latina, los “moros" caídos "in profundum inferni descenderunt"

Luego de la batalla, las huestes cruzadas se adentraron en territorio enemigo, sitiando Úbeda el día 22 de julio. Allí los habitantes ofrecieron una fianza de piezas de oro para levantar el cerco; los monarcas se vieron tentados a aceptarla y poner fin a la campaña, pero los clérigos no lo permitieron, recriminando a los reyes por su ambición y prohibiéndoles seguir con las negociaciones. Finalmente, la ciudad fue tomada por asalto y su población fue muerta o esclavizada ${ }^{848}$.

Luego de la captura de Úbeda una plaga azotó a las huestes cristianas, causando enfermedad y mortandad a hombres y bestias. Los cronistas no dudaron en atribuir el suceso a la ira divina, que castigaba a los cruzados por su orgullo y codicia ${ }^{849}$. El primer pecado correspondía al hecho de que se ufanaban de su victoria, sin reconocer ni agradecer suficientemente a Dios, olvidando que sólo Él podía otorgar el triunfo a quien lo merecía. En tanto, la flaqueza demostrada ante el rescate ofrecido por los

Cap. X, op. cit., p. 322. El mismo episodio lo podemos observar tambien en la Crónica General, cap. 1019, página 702.

${ }^{845}$ CGE, cap. 1019, op. cit., pp. 702, 703.

${ }^{846}$ HHE, Libro VIII, cap. X, op. cit., p. 323; y Alvira Cabrer, Martín, "La muerte del enemigo... op. cit., p. 414.

Aunque esta desproporción, se puede explicar por la costumbre de contabilizar únicamente a los nobles y caballeros caídos, quienes sólo representaban entre un tercio y un cuarto de las tropas; por ende, se infiere que el número de bajas cristianas fuera mucho mayor.

${ }^{847}$ CLRC 1997, No 25. op. cit., p. 62.

${ }^{848}$ HHE, Libro VIII, cap. XII, op. cit., p.325; CLRC 1997, N²5, op. cit., p. 63; y CGE, cap. 1021, op. cit., p. 705.

${ }^{849}$ HHE, Libro VIII, cap. XII, op. cit., p. 325; y CGE, cap. 1021, op. cit., p. 705. 
musulmanes fue interpretado como un banal acto de codicia que desmereció la causa cristiana y estuvo cerca de traicionar sus valores ${ }^{850}$.

Pese a este último revés, las crónicas cierran el capítulo de Las Navas señalándolo como una gran victoria cristiana, y una señal inequívoca de la justicia providencial de la causa de Reconquista.

Junto a lo anterior, respecto a la concepción providencialista de la guerra, Las Navas nos demuestra importantes cambios, principalmente en lo referido a las figuras celestes. En batallas anteriores de la Reconquista, los cronistas solían incluir la participación de mensajeros divinos o guerreros santos, como los ya conocidos casos de Santiago e Isidoro. También eran comunes los sueños premonitorios, donde los enviados de Dios advertían o instruían a los líderes cristianos. En resumen, entre los siglos VIII y X, y en menor medida en el siglo XI, las intervenciones providencialistas fueron directas y presentadas de manera indiscutible. Por el contrario, en el caso de las Navas, la intervención providencialista es mostrada de manera distinta; ejemplo de ello es que el gran milagro de la batalla, el episodio del pastor, no genera consenso en los cronistas en cuanto a su naturaleza. Sus interpretaciones van desde su consideración como un hombre humilde, hasta la de un ángel, versión que gana adeptos a medida que

850 "Proposuerant ulterius procedere, sed Deus, cuius uoluntati resistere nemo potest, impediuisse uidebatur. Occulta quidem sunt iudicia Dei: Fortase aliquid elationis et superpie contraxerunt Christiani ex victoria supradicti belli, cum soli Deo, non sibi, atribuere debuissent. Nam cum aliquot diebus moram fecissent in obsidione predicte uille, tot et tantos de Christianis inuasit multiplex infirmitatum uarietas et precipue fluxus uentrium, quod Pauli remanserunt sani, qui, si necessitas postularet, contra hostes se defendere possent. Eadem et tempestate tanta mortalitas accidit in hiis qui remanserant de bello, quod in autumno illo magna pars maiorum et seniorum in uillis et ciuitatibus uite terminum dederunt" CLRC 1997, N 25, op. cit., p. 63. "Habian determinado avanzar más, pero Dios, cuya voluntad nadie puede resistir, lo impidió. Ocultos son en verdad los juicios de Dios. Quizá los cristianos pecaron de vanagloria y soberbia atribuyéndose a ellos mismos y no a Dios el mérito de la victoria en la guerra. Y así, cuando descansaban algunos días en el asedio de la citada villa, a tales y tantos cristianos invadió una múltiple variedad de enfermedades y principalmente un flujo de vientre que quedaron pocos sanos para defenderse de los enemigos si la necesidad lo requiriera." CLRC 1999, № 25, op. cit., p. 55.

Posiblemente el suceso de la peste fuese verdadero, pero su explicación se encuentra lejos de la visión providencialista que le atribuyen intencionadamente las crónicas. Recordemos que la hueste se encontraba escasa de alimentos antes de la batalla, situación que según las crónicas, no mejoró mucho después de la victoria; ello sumado a que era un verano bastante caluroso, y que después de la batalla muchos de los caídos quedaron insepultos. Estas condiciones debieron ser conocidas por los cronistas, particularmente por Jiménez de Rada. Por ello se puede inferir la manipulación de los hechos con la intención de enriquecer el discurso religioso y político

A continuación de este episodio, Jiménez de Rada y la Crónica de veinte reyes afirman que después de finalizada la totalidad de la campaña de Las Navas y una vez restablecida la paz, la España cristiana fue afectada por una terrible hambruna, ante la cual la Iglesia no pudo hacer nada. Lo curioso del relato es que ninguno de los cronistas aventura una explicación a este suceso, ni lo relaciona con ninguna falta producida durante o después de la guerra, limitándose a decir que Dios castigó a España con el hambre. Es decir, se trata de una explicación providencialista que se validaba por sí misma y que seguramente, no fue más que una pequeña crisis ocurrida en los tiempos de la cruzada de 1212 y que los cronistas simplemente se limitaron a constatar en su tono ideológico habitual. 
las crónicas se alejan del suceso ${ }^{851}$. Donde sí coinciden los cronistas, es en que la afortunada intervención se debió a un designio divino. Sin embargo, lo realmente interesante a nuestro parecer, es que este "mensajero" solamente se limita a señalar un camino, dejando a los cruzados la decisión de tomarlo y proseguir la campaña ${ }^{852}$.

Entonces, la batalla de las Navas refleja una nueva visión del providencialismo de cruzada, ya que si bien los cronistas insisten sobre la intervención divina, a fin de cuentas, son los hombres quienes deciden los cursos a seguir, siendo ellos los que luchan contra los enemigos de Dios, aunque inspirados por sus señales.

A nuestro juicio, esta concepción va en la misma línea que los otros portentos observados en la batalla de Las Navas, puesto que los milagros quedan reducidos prácticamente a hechos anecdóticos, como los abrojos que no dañan, la aparición de una cruz en el cielo, el estandarte invicto de la catedral, o la ausencia de sangre en el campo de batalla ${ }^{853}$; es decir, se trata de hechos secundarios que no afectan el desarrollo del combate ni las decisiones estratégicas de los combatientes. De esta forma, la interpretación de la victoria nos lleva a conjeturar que es una intención por parte de los cronistas de mantener el discurso providencialista, pero dirigiendo el peso de las acciones a la voluntad humana. Dios y su poder rodea toda la narración de la batalla, pero en su centro se encuentra Alfonso VIII, que como simple hombre es el encargado de dirigir la cruzada.

El rey es mostrado como una criatura sujeta al pecado, y en especial a la vanidad, puesto que los cronistas no ocultan sus flaquezas -como sus dudas ante el bloqueo del paso de la Losa-, aunque al mismo tiempo narran sus virtudes, su generosidad y valor. Entonces el eje de la acción ya no es la Providencia sino el rey, que como mortal debe elegir los caminos que Dios pone a su disposición. El monarca se convierte así en un nuevo modelo a seguir, en un hombre inspirado por Dios, pero esencialmente un mortal

${ }^{851}$ CE, Libro IV, cap. LXXXIII, op. cit., p. 415; HHE, Libro VIII, cap. VIII. op. cit., p. 318; CLRC 1999, $\mathrm{N}^{\mathrm{o}}$ 23, op. cit., p. 52; CGE, cap. 1016, op. cit., p. 698; y CXXR, Libro XIII, cap. XXXI, op. cit., p. 283.

${ }^{852}$ A diferencias de otras apariciones celestes, el pastor no da instrucciones ni consejos, ni siquiera dirige palabras de ánimo a los apesadumbrados reyes cristianos, como por ejemplo, lo hacía Isidoro o Santiago.

Al respecto reiteramos que no es nuestra intención afirmar que el providencialismo desapareció de las crónicas y creencias populares en el siglo XIII, sino que éste fue mutando. Los santos siguieron apareciendo -como en el caso de la ayuda que Santiago otorgó a Alfonso IX en la batalla de Alfanje (CE, Libro IV, cap. XCI, op. cit., p. 425), pero sus apariciones directas como blancos guerreros se hicieron cada vez más esporádicas. En cambio, se refuerza la imagen del soberano, que poseído por el espíritu de Dios, o siguiendo los consejos de la Providencia, realiza actos gloriosos, como la conquista de Córdoba por Fernando III.

${ }^{853}$ CGE, cap. 1015 y cap. 1019, op.cit, pp. 695, 702, 703; CXXR, Libro XIII, cap. XXXII, op. cit., p. 284; y HRH, Liber VIII, cap. X, op. cit., p. 273. 
con virtudes y defectos que enfrenta obstáculos que es capaz de superar gracias a la ayuda de la potestad divina.

En síntesis, se puede afirmar que a partir del siglo XII, y ya decididamente en el siglo XIII, las crónicas restringen cada vez más los episodios providencialistas. En textos como las crónicas de "el Tudense", "el Toledano" o la Crónica General se puede apreciar este cambio, puesto que en los episodios anteriores a su redacción se narran acciones providencialistas directas, como las apariciones de santos, mensajeros y combatientes divinos. Sin embargo, cuando los autores narran episodios contemporáneos a ellos, estas acciones directas se reducen, al punto que en sucesos como las conquistas de Fernando III, los milagros y otros prodigios prácticamente desaparecen o no son relevantes.

De esta manera, el rey se presenta como el sujeto principal de la narración, trasmitiéndose la idea de que sus acciones eran validadas y legitimadas por la Providencia. Así, la instrumentalización de la religiosidad al servicio de los fines políticos y militares de la Reconquista castellana se mantenía, aunque de un modo que se adaptaba mejor a los nuevos tiempos de fortalecimiento del poder de las monarquías.

Ejemplos de la nueva comprensión providencial de la imagen del rey se pueden encontrar en las crónicas de mediados del siglo XIII, sobre todo en relación a la figura de Fernando III. Dicho monarca fue protagonista de importantes victorias, no obstante, en los relatos de las mismas no aparecen con frecuencia grandes milagros; en cambio, sí se hacen referencias a que el rey actuaba movido por Dios o "poseído por el espíritu del señor", resaltando las excepcionales virtudes del "Rey Santo" y reforzando su alianza con la Providencia ${ }^{854}$.

Por todo lo anteriormente señalado, los monarcas hispanos procuraron obtener la victoria sobre los sarracenos para validar sus anexiones territoriales y tomar control sobre el conjunto de la sociedad hispana. En este aspecto Alfonso X fue un hábil usuario de la religiosidad de su pueblo, puesto que a través de este instrumento atraía pobladores a las zonas de la frontera donde faltaban, o bien reclutaba tropas cuando hacia falta ${ }^{855}$. Las herramientas usadas por el soberano para este propósito fueron sus obras literarias, como las Cantigas, donde los relatos de las apariciones de la Virgen protegiendo a personas o ciudades, o bien la exaltación de los milagros en las rutas de

${ }^{854}$ CLRC 1999, No 70, op. cit., p. 98; y CLRC 1997, No 70, op. cit., p. 111. En la misma crónica se hacen también varias alusiones a la relación entre Alfonso VIII y la divinidad. Entre otros ejemplos, se llama al rey "Glorioso" y al menos en una ocasión se dice de él que está "revestido del poder de lo alto", todos ellos apelativos que directamente se relacionaban con su victoria de 1212.

${ }^{855}$ Linehan, Peter, España, 1157-1300 ... op. cit., p. 196. 
peregrinaje, tuvieron por propósito enaltecer la piedad de sus súbditos y dirigir su devoción hacia donde era necesario: a los intereses de la corona y las necesidades de la Reconquista.

En la mentalidad cristiana medieval, el providencialismo era una realidad omnipresente que trascendió a los conflictos bélicos, en especial cuando los rivales también lo eran en el ámbito religioso. Así, en la guerra se fusionaba lo sagrado y lo profano; los guerreros, según el discurso cronístico, luchaban bajo el convencimiento de ser instrumentos de Dios y de que Él era quien dirigía las huestes y decidía su destino. Es por ello que en las crónicas se suele hacer uso de distintos apelativos, destinados a enlazar a los combatientes con su función religiosa.

De esta forma, es evidente que el providencialismo era un hecho vivo y real en la mentalidad de los guerreros cristianos. Asimismo, se constituye como una necesidad antropológica reconvertida en una fuente del poder político, una construcción necesaria para consolidar la estructura político-militar de los reinos hispanos y elaborar un ideal de poder basado en las creencias del conjunto de la sociedad.

Esta creencia de estar cumpliendo la voluntad de Dios pasará de las crónicas al subconsciente de la cultura hispánica. Se considera que es Dios quien da la victoria a Pelayo, protege al Cid, guía a Alfonso VIII en las Navas y dirige a Fernando III en su conquista de Andalucía. Luego, según Menéndez Pidal ${ }^{856}$, ese mismo providencialismo será atestiguado por los hispanos en su expansión atlántica, donde la cruz y la espada marcharían juntas en la conquista de nuevos territorios para la grandeza de Dios y de España.

\footnotetext{
${ }^{856}$ Menéndez Pidal, Ramón, Los Españoles en la Historia ... op. cit., p. 225.
} 


\section{III.2.- Los santos guerreros al servicio de la causa cristiana}

\section{III.2.a.- Los Mensajeros celestes: de oriente a occidente}

Los santos de la Reconquista fueron parte del rico imaginario medieval y el fruto de una larga tradición religiosa que se remontaba a las escrituras. Desde esa perspectiva se les puede enmarcar dentro de una realidad cultural europea, muy abundante en ese aspecto y por lo tanto un tanto alejada de otras particularidades hispánicas. No obstante, el uso que se dio de ellos en la Península, es inseparable de su peculiar realidad militar y cultural, puesto que estos personajes celestes quedaron estrechamente ligados a la lucha contra el Islam. Fueron además, elementos de unión regional o protonacional, el caso de Castilla y León, Santiago, Isidoro, Millán, Domingo y la Virgen María, se convirtieron en piezas activas del discurso de validación real, ellos eran los que guiaban y protegían a los reyes y a los habitantes de la frontera. Sobre ellos cayó parte del peso de la legitimación del sistema político que aseguraba la legitimidad real basada en su herencia, sus victorias y su cercanía a Dios, como se esforzaron en establecerlos los cronistas. Pese a ello, nosotros reiteramos que para mediados del siglo XIII se puede constatar una progresiva disminución de la participación de los santos en los sucesos militares, lo que bien puede ser explicado por el hecho de que a partir de mediados de ese siglo se ve una consolidación en la Reconquista y también del poder real a través de la unificación castellano leonesa. El rey cobra cada vez mayor protagonismo en la guerra, como lo demuestran las crónicas referentes a Fernando III, quien lucha directamente influenciado por Dios. De manera que los santos legitimadores pierden importancia - aunque no desaparecen - puesto que ahora es el soberano el que protagoniza las victorias y a él y a su piedad se deben los triunfos y su propia validación.

La guerra, el poder y la religión fueron los pilares sobre los que se construyó la Reconquista. Dicha triada fue fundamental para la elaboración de un discurso consecuente y efectivo que sirviese a los propósitos de la recuperación de las tierras peninsulares y a la derrota del Islam. La consigna principal del discurso se basó en la demostración de que el poder político, Dios y la guerra, eran parte de un todo superior y para ello fue necesario adaptar las prácticas religiosas ajustándolas a los propósitos planteados. En este contexto es que los cronistas, desde su rol de difusores de un discurso identitario, recurrieron a uno de los símbolos más primitivos de validación del poder político: los mensajeros celestes. 
Enviados celestiales que portaban mensajes, protegían, aconsejaban o ayudaban efectivamente a los cristianos en su lucha. Apariciones que fueron parte de la imaginacón popular medieval y comunes en toda Europa e incluso en Tierra Santa ${ }^{857}$. Esta tradición, que puede tener sus raíces en los ángeles mensajeros del Antiguo y Nuevo Testamento, toma un matiz distinto en las crónicas, al ser los enviados personajes relacionados con la propia historia peninsular. Las crónicas nos relatan las milagrosas apariciones, entre otras, de San Isidoro y el Apóstol Santiago, ambos profundamente vinculados con la religiosidad hispánica.

Estas apariciones a las que llamamos mensajeros celestes, podían ser generalmente de dos tipos: ángeles o santos. Es decir criaturas que siempre han estado vinculadas a las esferas celestes o bien hombres cuya vida ejemplar los llevo a la santidad. Es este último caso el que más nos interesa a la luz de nuestro trabajo, puesto que sobre los santos varones se tejieron toda una suerte de mitos destinados a exaltar aun más su figura, al mismo tiempo que los mutaba en figuras ejemplificadoras, sobre las cuales se dictaban las pautas de conducta a seguir para ser considerado un buen cristiano y por lo tanto merecedor de la recompensa espiritual ${ }^{858}$. No obstante los ángeles también son figuras sobre las que se construyen mitos, pero de un matiz distinto, puesto que al estar alejados de las tentaciones, sus vidas no son lo importante, sino cómo estos influyen en los actos de los mortales ${ }^{859}$.

En su conjunto, ambos tipos de figuras corresponden a una tradición, que en el caso hispano, partió de un sustrato común cultural en el Mediterráneo y que influenciado por la tradición bíblica se tradujo en la construcción de una tradición creada, enriquecida y reinventada para adaptarse a las circunstancias históricas y ser útil

\footnotetext{
857 Esta tradición no es excluyente del cristianismo, puesto que también podemos observar estos mensajeros en las otras dos religiones inspiradas en la tradición veterotestamentaria, el judaísmo y el islamismo.

${ }^{858}$ Según Sofía Boesch en Occidente medieval la santidad es un fenómeno multidimensional de relevancia cultural. Esto ya que se trata de un fenómeno espiritual, por su búsqueda de lo divino, teológico en razón de representar la manifestación de Dios en lo terrenal. También es religioso por simbolizar la relación con lo sobrenatural y social puesto que los santos se convierten en un factor de unidad para distintas comunidades. Finalmente, según la misma autora, también es un fenómeno institucional por estar en las bases de las estructuras eclesiásticas y además tiene una dimensión política por el uso que se le puede dar a este fenómeno religioso. En síntesis las distintas dimensiones del fenómeno afectaban a todas las esferas de la sociedad y cultura medievales, sirviendo de instrumento para conocer las visiones morales y éticas de los grupos humanos, siendo además un fenómeno instrumentalizado por los distintos grupos de poder medievales, lo que lleva a Boesch a afirmar que la santidad cristiana es ante todo una construcción. (Boesch, Sofía, "Santidad", en Le Goff, Jacques y JeanClaude Schmitt, Diccionario razonado... op. cit., p. 711).

${ }^{859}$ Le Goff, Jacques, La civilización del Occidente medieval... op. cit., pp. 141, 142.
} 
a las necesidades político, religiosas y militares de la Reconquista. Es lo que Hobsbawam y Ranger definen como la "tradición inventada" 860 .

Esto, a nuestro parecer, es lo que sucede en Hispania, con figuras como Santiago o Isidoro. Personajes propios de la historia y la tradición peninsular que son rescatados para el conjunto de los cristianos peninsulares y especialmente en Castilla y León, con el fin de convertirse en ejemplos profundamente enlazados con una herencia históricocultural. Es decir eran símbolos de un pasado glorioso que debía ser revivido.

Ambos, Santiago e Isidoro, al igual que otros mensajeros celestes, como la Virgen María, San Jorge y San Pedro, son parte del mito de la nueva Era cristiana, formando parte de los fundamentos de la construcción religiosa de Occidente. Cumplen así una función inaugural y creadora. Es en ese sentido que se crean mitos permanentes, debido a que estos personajes aparecen una y otra vez bajo parámetros comunes, al punto que se convierten en parte de la vida y de la conciencia cotidiana de la sociedad. De esta forma el objeto del mito termina por convertirse en un hecho histórico incuestionable ${ }^{861}$.

Como ya mencionamos, estos mensajeros celestes, dentro de la realidad hispánica, son los herederos de una larga tradición que hunde sus raíces en los pueblos semitas de las Escrituras. Es pues necesario referirnos a estos orígenes bíblicos, para poder comprender a cabalidad las dimensiones del fenómeno en la Península Ibérica, pues como ya hemos dicho la religiosidad peninsular se construyó sobre las bases de las Escrituras, conocidas a través del púlpito, las lecturas o el simple intercambio de historias, crearon un sustrato cultural del que todos los cristianos beberían, conscientes o no de ello. Una situación que no fue muy distinta en otras partes de Europa occidental como veremos a continuación.

Nosotros hemos podido observar que en las Escrituras se afirma que Dios tenía, esencialmente, tres maneras de comunicarse con los hombres. La primera, de forma directa, es decir Él se le manifestaba a un individuo en particular, como ocurrió en los

\footnotetext{
860 "Un grupo de prácticas, normalmente gobernadas por reglas aceptadas abierta o tácitamente y de naturaleza simbólica o ritual, que buscan inculcar determinados valores o normas de comportamiento por medio de su repetición, lo cual implica automáticamente continuidad con el pasado. De hecho, cuando es posible, normalmente intentan conectarse con un pasado histórico que le sea adecuado" (Hobsbawm, Eric y Terence Ranger (Editores), La invención de la tradición, Barcelona, Crítica, 2002, p. 8).

${ }^{861}$ Abellán, José Luis, Historia critica del pensamiento español, Tomo I, Metodología e introducción histórica, Madrid, Espasa-Calpe, 1979. p. 240; y Elíades, Mircea, Mito y Realidad, Barcelona, Labor, 1991, pp. 12, 13.
} 
casos de Noé, Abraham y Moisés ${ }^{862}$. La segunda, a través de enviados mortales, es decir personas elegidas para hablar en nombre de Él, que además se comunicaba directamente con estos elegidos. A esta categoría pertenecen los profetas como Isaías, Samuel, y otros $^{863}$. Finalmente, la tercera fórmula era a través de ángeles que se aparecerían ante los hombres como heraldos, para ejecutar, por sí mismos, los deseos de Dios ${ }^{864}$.

En este último caso, las acciones de estos enviados celestiales, que casi siempre son representados como ángeles, solían trasmitir las órdenes de Dios y guiar a los hombres, probándolos o castigándolos. En razón de lo anterior, es necesario aclarar que en el Antiguo Testamento la aparición de los ángeles suele no ser del todo clara, puesto que en muchas ocasiones éstos parecen representar al Espíritu de Dios o bien son encarnaciones del mismo, confundiéndose con la divinidad. Es así como a veces los ángeles hablan como si fuesen Yahvé y en otras ocasiones dicen hacerlo en nombre de Él, como sus mensajeros, dificultando la distinción entre el heraldo y el productor del mensaje. Sin embargo, es el rol de transmisor de las palabras de la divinidad, en el que más comúnmente aparecen los ángeles en las escrituras. A modo de ejemplo podemos mencionar el episodio bíblico de Abraham y el sacrificio de Isaac ${ }^{865}$.

Los mensajeros celestes en el Antiguo Testamento también están vinculados a acciones más directas, como probar o desafiar a los hombres. En ese sentido las Escrituras relatan casos como los ángeles de Sodoma, los que son identificados como tales sin dar pie a mayores confusiones ${ }^{866}$. Más ambiguo es el relato de la lucha de Jacob/Israel contra el ángel, del cual no se da su nombre, pero se da a entender que es el “espíritu” de Dios que prueba la fortaleza del hijo de Isaac ${ }^{867}$.

En cuanto a los castigos, los ejecutores de éstos también se confunden con el mismo Yahvé, como son los casos la expulsión del paraíso y de las plagas de Egipto, en especial la última que elimina a los primogénitos ${ }^{868}$. En ambos episodios, Dios obra como castigador por las faltas cometidas ${ }^{869}$.

\footnotetext{
${ }^{862}$ Entre otros ejemplos ver Génesis Génesis 6: 13, 22. 7:1, 22. 12: 1,3. 15:1, 21. Éxodo 3: 1, 20. 4:1,31.

${ }^{863}$ Libros Proféticos

${ }^{864}$ Entre otros ejemplos ver Génesis 16: 7, 12. 21: 17, 18.

${ }^{865}$ Génesis 22: 11, 13.

${ }^{866}$ Génesis 19: $1,22$.

${ }^{867}$ Génesis 32: 23, 31 .

${ }^{868}$ Génesis 3: 1, 20; y Éxodo 11: 1, 9.

${ }^{869}$ No obstante la ambigüedad de las figuras celestiales, en el Antiguo Testamento se identifican algunas personalidades angelicales concretas, que además cumplen roles específicos. Ese es el caso del Arcángel Rafael, quien enviado por Dios, guía a Tobías en la búsqueda de una mujer piadosa, simbolizando así la función de protector y consejero. Otro ejemplo es el Arcángel Miguel, vinculado directamente con la guerra y la protección, puesto que él es el que anuncia a Josué la victoria sobre Jericó y el que protege a Daniel cuando es probado en Babilonia (Josué 5: 13, 15; y Daniel 10: 13,14)
} 
Es en el Nuevo Testamento donde se distinguirá nítidamente la diferencia entre la divinidad y los ángeles, ésto quizás en razón de que en los Evangelios se pretende relatar las vivencias del Dios hecho hombre, pero además único y trino, por lo que es necesario diferenciar su actuación de la de otras manifestaciones divinas menciondas en relación directa con Jesucristo, que aparecen cumpliendo los roles de mensajeros o protectores. Ese es el caso de la Natividad, donde los ángeles rodean a los pastores mientras alaban al Señor. Así como es “el ángel del Señor” el que se aparece en sueños a José para advertirle sobre los peligros e indicarle que debía huir con su familia a Egipto $^{870}$. También es una multitud de ángeles la que aparece para consolar y servir a Cristo luego de que este venciera las tentaciones en el desierto ${ }^{871}$.

Es en vista de lo anterior, por lo que es posible aventurar que en su conjunto, los mensajeros celestes de las Escrituras, además de sus roles específicos, cumplen el papel de comprobar el poder de Dios a través de la manifestación de su voluntad. Ellos sólo se aparecían a quienes estaban señalados para grandes actos, es decir, a los favorecidos por la Divinidad. Es por ello que los heraldos del Cielo se convirtieron en una pieza importante de la dinámica política, puesto que en el imaginario simbolizaban la victoria contra los enemigos o simplemente el favor divino. Es bajo estas ideas que esta tradición pasa al mundo cristiano medieval, donde será reinventada, convirtiendo a los ángeles en mensajeros celestes encarnados en figuras históricas o propias de la mitología religiosa de cada región.

El cristianismo trajo consigo estas creencias cuando se fusionó con el poder político de Roma. La leyenda une a Constantino con la tradición de los mensajeros cuando se crea el mito de su famoso sueño antes de la batalla del puente Milvio. Posteriormente los germanos también aceptaron la existencia de estos mensajeros celestes, de manera que durante la Edad Media se popularizó la creencia en estos entes celestiales $^{872}$.

El mensajero celeste por excelencia y que servirá de ejemplo arquetípico es el ángel Gabriel, el que anunció el nacimiento de Juan el Bautista y más importante aún, es el encargado de anunciar a María su papel en la historia sagrada (Lucas 1: 11,38). Cabe señalar que en el Islam, Gabriel o Yibril es el jefe de los ángeles, el mensajero de Alá, quien se le aparece a Mahoma y le revela el Corán. Gabriel también protege al profeta y según la tradición, a él se le deben algunas de las victorias obtenidas por las huestes mahometanas (Domínguez García, Javier, De Apóstol matamoros a Yllapa ... op. cit., p. 65). Por lo tanto, entre los musulmanes, el mito de los mensajeros celestes también es una parte integral de sus creencias religiosas, en donde cumplen un rol de legitimadores del poder, indicando cuando este sea querido por Alá.

${ }^{870}$ Mateo 2: 13, 14.

${ }^{871}$ Lucas 2: 8, 15; Mateo 4: 11; y Marcos 1: 13.

${ }^{872}$ Sánchez-Albornoz, Claudio, España, un Enigma Histórico, Tomo I.,... op. cit., p. 272. 
Por su parte, la figura de los santos fue evolucionando para adaptarse a las costumbres y tradiciones de cada pueblo, convirtiéndose en una de las principales y más características manifestaciones del cristianismo. Una creencia que fue desarrollándose a lo largo del medioevo hasta constituir una verdadera jerarquía celeste encabezada por Dios, Cristo y la Virgen, seguidos de los apóstoles y evangelistas y finalmente mártires, doctores y clérigos en general, teniendo cada uno de ellos una función dentro del imaginario colectivo de la sociedad cristiana ${ }^{873}$. Funciones entre las que tempranamente destacaron los roles militares, que respondían a la necesidad del Imperio Romano Cristiano de defender sus fronteras sin trasgredir la mística no violenta del cristianismo, para lo cual se asimilaron algunas figuras religiosas a la guerra defensiva ${ }^{874}$. Una práctica que sería heredada por los germanos, dadas sus tradiciones guerreras ${ }^{875}$.

Según Paulino Iradiel, la extensión y popularidad del culto a los santos, se debió a las necesidades del hombre medieval, por contar con patronos más poderosos que sus señores, y que a diferencia de ellos, pudiesen protegerlos de aquellas amenazas materiales que escapaban del control humano, como plagas, enfermedades, hambrunas, inclemencias climáticas, así como también de enemigos más mundanos, invasores o los mismos señores cuando abusaban de su poder. Es decir, el hombre común buscaba en los santos un protector sobrenatural contra las amenazas mundanas. Es importante destacar, que una característica fundamental de estos patrones era su cercanía para con sus fieles. Para el común de las personas, Dios se presentaba como un ser demasiado poderoso y distante, que inspiraba temor y respeto, más que cercanía. Una imagen que bien puede responder al Dios del Antiguo Testamento, y por lo tanto era necesario que existiesen figuras que intercediesen ante él, pero que también permitiesen que los simples mortales se identificasen con ellas ${ }^{876}$. Esa sería una de las dimensiones que ayudan a comprender como se popularizaron los cultos a los santos, puesto que en el fondo habían sido hombres, sujetos a los mismos temores que el común de las personas.

En relación al culto a la Virgen, nos atrevemos a afirmar, que la Edad Media fue una época "Mariana". El culto a María esta presente en casi todos los aspectos de la vida religiosa europea y fue además fomentado fuertemente por la Iglesia y algunas

\footnotetext{
${ }^{873}$ Muñoz Fernández, Ángela, "Cultos, Devociones y Advocaciones Religiosas en los Orígenes de la Organización Eclesiástica Cordobesa (siglos XIII-XIV)”, en Cabrera, Emilio (Coordinador), Andalucía entre Oriente y Occidente... op. cit., p. 136; y Le Goff, Jacques, Lo maravilloso y lo cotidiano... op. cit., pp. 13, 14.

${ }^{874}$ Fernández Ubiña, José, Cristianos y militares... op. cit., pp. 480, 481.

${ }^{875}$ Sobre las características de la guerra para el mundo romano y temprano medieval ver la primera parte de esta tesis.

${ }^{876}$ Iradiel, Paulino y otros, Historia Medieval de la España Cristiana ... op. cit., pp. 189, 199.
} 
órdenes monásticas como los cistercienses. La Virgen María era considerada como protectora, sanadora, jueza, consejera y redentora, entre otras virtudes que una y otra vez aparecen en la literatura medieval y en obras hispanas tan emblemáticas como Las Cantigas de Santa María o Los Milagros de Nuestra Señora, de Gonzalo de Berceo ${ }^{877}$.

Los santos se convirtieron en parte del aparato mitológico del Occidente cristiano, en parte de un mundo mágico, pero a la vez real, presente y vivo, en la mentalidad de los europeos de la Alta Edad Media. Dicha mentalidad combinaba las siguientes tres visiones: las costumbres y tradiciones del mundo clásico, donde los dioses descendían del Olimpo e interactuaban con los hombres, la tradición guerrera germana y la cosmovisión judeo-cristiana ${ }^{878}$. Como producto de esta combinación, se generaron arquetipos religiosos sumamente versátiles y adaptables.

$\mathrm{Y}$ es precisamente la característica de adaptabilidad la que lleva a los santos a desarrollar un rol cada vez más beligerante, acorde al contexto de las tradiciones guerreras germánicas. Los santos ya no sólo eran defensores y mediadores entre Dios y los hombres, sino que también eran guerreros con el poder de dañar a quienes desafiasen sus potestades. La Iglesia, en su rol evangelizadora, supo aprovechar esta nueva situación, puesto que los germanos querían santos guerreros, se les darían en la forma de obispos y autoridades religiosas, que pasaron de ser santos varones en estado de gracia, a ser espíritus protectores que combinaban la fe y la fuerza en la figura de un nuevo tipo de santo, muy distante de su concepción originaria. Sin embargo, la esencia del santo seguía siendo la paz y la protección desarmada. Más adelante, en el siglo X, se consolidó la figura del "Santo Militar", un soldado justo, que originalmente alcanzó la santidad a través del martirio por negarse a usar las armas, que se vio trasformado en un arquetipo de santo armado, un guerrero de Dios, que ahora usaba las armas para la defensa y protección de la Iglesia. Tales fueron los casos de San Benito, San Severo, San Denis, y otros, que por toda Europa pasaron de los altares a los campos de batalla $^{879}$.

\footnotetext{
${ }^{877}$ El culto mariano es una de las herencias medievales más potentes entre las que los conquistadores implantaron en América. En el nuevo mundo la idea de la diosa madre estaba bastante difundida entre las culturas prehispánicas, razón por la cual la imagen de María alcanzo una rápida difusión y popularidad que se mantiene hasta el día de hoy, como se puede apreciar en las distintas representaciones marianas, que además, en muchos casos cumplen la función de patronas nacionales. Como son los casos de la Virgen del Carmen en Chile, Virgen del cobre en Cuba y la Virgen de Guadalupe en México, solo por nombrar algunos casos.

${ }^{878}$ García Pelayo, Manuel, Mitos y Símbolos Políticos... op. cit., pp. 185, 186; y Homet, Raquel, "Caracteres de la conciencia... op. cit., pp. 101, 102.

${ }^{879}$ Flori, Jean, Guerra Santa, Yihad, Cruzada... op. cit., p. 181-184; Martín, José Luis, La Península... op. cit., p. 133; Márquez Villanueva, Francisco, Santiago: trayectoria de un mito... op. cit., p. 200
} 
Es probable que la evolución de las figuras santas haya sido influenciada por Bizancio $^{880}$. Tanto en Oriente como en Occidente, estos nuevos santos cumplían un doble propósito. Por un lado, convertirse en modelos orientados a "domesticar" a los señores y guerreros, dándoles un ejemplo a seguir para que compartiesen algunas de sus virtudes, llamándolos a una vida más devota. Por otro lado, estos santos también debían cumplir un rol de amedrentar a estos mismos guerreros que frecuentemente amenazan los intereses, propiedades y vidas de los hombres de la Iglesia. La idea era hacerles creer que la Iglesia no estaba sola y que contaba con fuertes defensores que además de invencibles, podían darles caza a sus enemigos y llevarles al peor de los castigos: la muerte y la condenación ${ }^{881}$.

Los Santos Guerreros se popularizaron rápidamente extendiéndose por Europa, donde fueron asociados a rituales y fórmulas que constituían parte integral de la, cada vez más aceptada, concepción de guerra santa. De esta forma, estos Santos Guerreros se tornaron en patronos, que servían como una idea de unión, de solidaridad y de pertenencia, puesto que su protección cubría a todos los habitantes de una localidad, parroquia, monasterio o reino ${ }^{882}$. Es por ello que fue necesario procurar que estos patronos se vinculasen con los lugares que protegían, ya sea por haber habitado allí alguna vez, o por guardar ahí sus reliquias ${ }^{883}$.

\footnotetext{
${ }^{880}$ En Oriente la figura del santo militar se encontraba arraigada hace siglos. Los Santos Armados, se encontraban en los estandartes imperiales y su protección cubría a las tropas griegas en su lucha contra los paganos, que amenazaban al imperio. De esta forma, las guerras bizantinas solían tener un matiz religioso, donde era esencial fortalecer los símbolos sobre los cuales se fortalecía la lealtad de los soldados hacia la Iglesia y el emperador. Fue así como, tanto San Jorge, San Mauricio y el Arcángel Gabriel, entre otros, eran parte esencial del imaginario religioso-militar de los ejércitos de Constantinopla, durante su expansión por el Mediterráneo. Más adelante, en Occidente, se sumarían nuevos guerreros celestes, como fue Santiago (Keen, Maurice, La Caballería... op. cit., pp. 72, 73; y Flori, Jean. Guerra Santa, Yihad, Cruzada... op. cit., pp. 189, 190).

${ }^{881}$ Jean Flori postula que la militarización de los santos, a partir del siglo XI, fue una de las estrategias vinculadas al establecimiento de la Paz y Tregua de Dios por parte de la Iglesia (Flori, Jean, La Guerra Santa... op. cit., pp. 99-156).

${ }^{882}$ Flori, Jean, La Guerra Santa... op. cit., p. 99; y Sánchez Prieto, Ana Belén, Guerra y guerreros en España... op. cit., p. 60.

${ }_{883}$ Carlos de Ayala en su articulo "Fernando I y la sacralización de la Reconquista" (Anales de la Universidad de Alicante, Historia medieval, 17. 2011, p. 78) explica la importancia de las reliquias en civilización medieval, según el texto Furta Sacra de Patrick Geary, afirmando que las reliquias suscitaban la automática creencia de la gente y por otro lado la certeza de sus carácter milagroso como manifestación de la presencia de los santos se supone aun permanecían en ellas. Eran entonces un medio para comunicarse con una divinidad abstracta que les era difícil de comprender, por lo que poseerlas o incluso tocarlas era acercarse a la divinidad y gozar de su protección.

Por estas mismas razones eran importantes para los monarcas poseer reliquias, que así demostrarían sus cercanías con la Providencia. Además se entendía que las reliquias no protegían a un solo individuo, sino que blindaban al pueblo, iglesia, monasterio, comunidad o incluso al territorio donde se encontraban. Razón por la cual, según Carlos de Ayala, los reyes procuraron reunir el mayor numero posible de reliquias, para así validar su autoridad, proteger a sus reinos y asegurar el éxito de sus iniciativas.
} 
Fue con las cruzadas que la figura del Santo Guerrero terminó por alcanzar su máxima definición. Las características de este conflicto, comprendido como guerra santa, facilitaron el fortalecimiento de las ideas providencialistas y permitió una mayor permeabilización del mundo real con el sobrenatural. De esta forma, se multiplicaron las señales divinas, los "Mensajeros Celestes" y los "Guerreros Celestiales", consolidándose la imagen del o "los caballeros blancos" que descendían de los cielos en ayuda de los cristianos ${ }^{884}$. Todos ellos portentos, que no solo sacralizaban el combate, sino que también lo validaban ${ }^{885}$.

\section{III.2.b.- Los mensajeros celestes en Hispania}

Como es de esperar, la Península Ibérica, por sus condiciones de tierra de frontera y lucha religiosa, fue uno de los lugares donde la figura del Santo Guerrero y el Mensajero Celestial alcanzaron una mayor difusión e instrumentalización.

Como sabemos, luego del colapso del Reino Visigodo, los cristianos del norte peninsular comenzaron un proceso de progresiva sacralización de su realidad. La derrota era un castigo de Dios y era pues necesario alcanzar el perdón. Fue por ello que en forma temprana los cronistas comenzaron a relatar portentos milagrosos que parecían señalar la reconciliación del Pueblo Astur-Visigodo con la divinidad. Señales materializadas en algunos milagros, pero esencialmente en la aparición de Mensajeros Celestes que auxiliaban a los cristianos en su lucha contra el Islam. Fue de esta manera como pronto, la historia de la Reconquista fue convirtiéndose en un relato sagrado ${ }^{886}$.

Es así, como se observa en el gráfico número 4, que su presencia es prácticamente trasversal a los relatos de la Reconquista en sus distintas épocas, existiendo, eso si, una preponderancia a atribuir las intervenciones providencialistas a Santiago, San Isidoro y

\footnotetext{
${ }^{884}$ García Fitz, Francisco, La edad Media. Guerra e ideología... op. cit., p. 173; y Sánchez Prieto, Ana Belén, Guerra y guerreros en España ... op. cit., pp. 132, 133.

${ }^{885}$ Dentro de esta dinámica, fue que el poder político supo aprovechar esta nueva forma de religiosidad y surgió la necesidad de elevar a los altares a reyes y caudillos del pasado. Puesto que en ellos se fundían: las aspiraciones políticas, las necesidades militares y las creencias religiosas, siendo estas tres las bases del poder medieval. Es así como en el siglo XI Esteban de Hungría se convirtió en el primer rey medieval llevado a los altares, luego le sucederían otros como Luis IX de Francia, canonizado en 1297 y Fernando III, que habiendo recibido honores de parte de los pontífices en el siglo XIII, tardíamente ascendió a los altares en el siglo XVII (Linehan, Peter, La Iglesia Española ... op. cit., pp. 291-194; y Martín, José Luis, La Península ... op. cit., p. 132).

${ }^{886}$ Fernández Conde, Francisco Javier, La religiosidad medieval... op. cit., p. 39; y Goñi Gaztambide, José, Historia de la Bula de Cruzada ... op. cit., pp. 31-33.
} 
la Virgen María, y en segundo lugar figuras más locales como Domingo de Silos y Millán de la Cogolla ${ }^{887}$.

\section{Gráfico 9: Santos de la Reconquista}

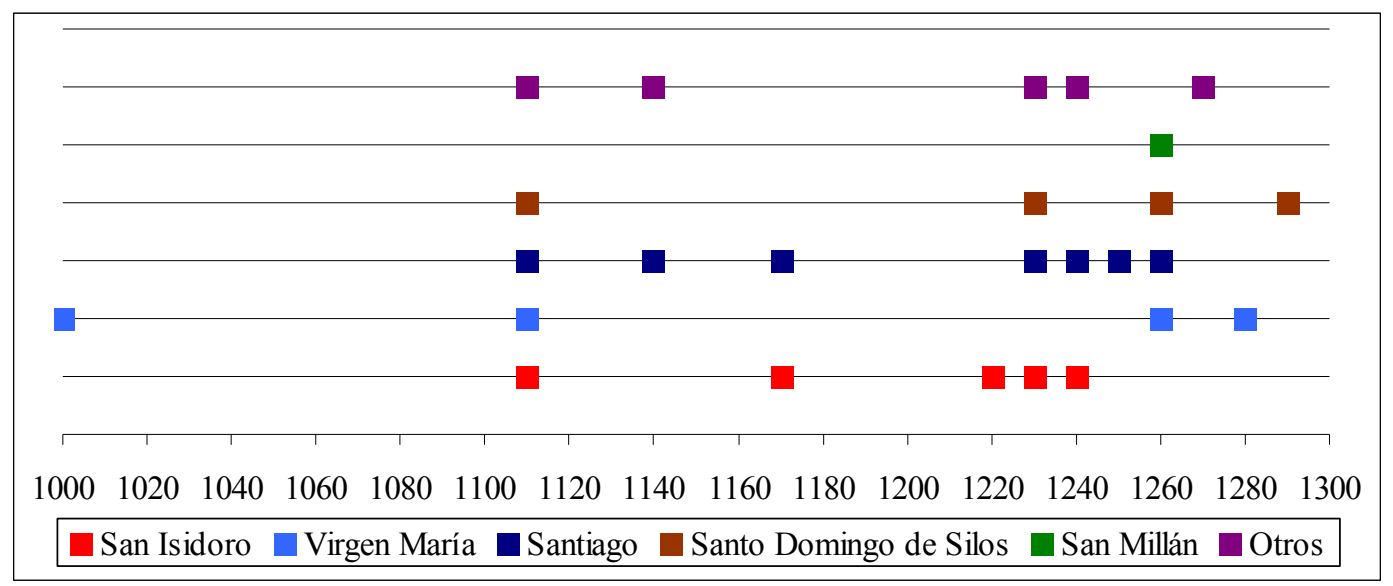

A nuestro entender, en el ámbito peninsular la actividad providencial de los santos se concentró especialmente en seis aspectos. El primero de ellos visualiza a los santos como protectores, que tanto a través de su presencia directa, como por medio de una imagen suya, protegía una localidad o individuos. Una segunda función sería su intervención como mensajeros celestes, que se aparecían a los mortales para advertir de un peligro, ordenar acciones o bien anunciar algún acontecimiento. El tercer rol tiene relación con la función militar, la cual no necesariamente se relacionaba con la vida del santo, puesto que, al menos en el caso hispano, fueron hombres de fe los que mutaron en guerreros, como Santiago o San Isidoro, pero siempre con el deber de luchar junto a los combatientes cristianos contra los enemigos de la fe. Otra de sus funciones fue la redención de cautivos - un fenómeno muy propio de la realidad peninsular - y que permitió la consolidación de santos tipicamente hispanos ${ }^{888}$. Una quinta atribución fue la capacidad punitiva, es decir aquellas ocasiones en que el santo sancionaba a individuos que de una forma $u$ otra lo habían ofendido o bien abusado de sus creyentes. Finalmente, pero no menos importante, encontramos la función validadora, que se vinculaba directamente al discurso cronístico de sacralización de las tierras peninsulares a través de las reliquias que en ellas descansaban.

\footnotetext{
${ }^{887}$ Ver tabla ${ }^{\circ} 4$

${ }^{888}$ Respecto a las formas de liberación de cautivos recomendamos revisar el texto ya citado de Calderón Ortega, José Manuel y Francisco Javier Díaz González (Compiladores), Vae Victis... op. cit., pp. 111-287.
} 
Por lo general, según se desprende de las crónicas, los receptores de los mensajes y mensajeros divinos fueron los reyes y magnates cristianos. De esta manera, se fortalecía el discurso de validación religiosa del poder político hispano, puesto que la supuesta comunión del soberano o caudillo con los enviados de Dios era mostrada como una señal inequívoca de sus virtudes, gracias y potestades. Así, en el imaginario colectivo se implantaba la idea del rey como un elegido de la Providencia, primando esta idea por sobre otras motivaciones más mundanas para el esfuerzo de la Reconquista $^{889}$. Esta comunión entre los soberanos y la Providencia en la Península, venía a remplazar otras formas de providencialismo político presentes en Europa, como los reyes taumaturgos en Francia, cualidad que constituía en una señal clara de la alianza entre el soberano y Dios ${ }^{890}$. En Hispania en cambio, esta alianza se testimoniaba por otras fuentes, especialmente vinculadas a la victoria militar, la cual muchas veces, se entendía que se debía a la intersección, consejo o intervención de los enviados celestes y por consiguiente, a Dios.

Por su parte, los soberanos y magnates fomentaban estas creencias al patrocinar a la Iglesia Hispana y a los cronistas. Recordemos pues que las riquezas de la Reconquista alimentaban las arcas de los monasterios y catedrales peninsulares ${ }^{891}$. Mismos lugares de donde salían los cronistas que relataban los portentos divinos en comunión con el poder político. Es así como la Iglesia y corona sabían que era necesario apelar a la religiosidad popular para mantener el impulso de la guerra, era pues necesario santificar las tierras de Hispania, convertirlas en patrimonio de la cristiandad, para que la cristiandad la protegiera ${ }^{892}$.

En otras palabras, a medida que se comenzaba a configurar la frontera, también se construía un espacio providencial, donde los personajes celestes se manifestaban permanentemente ${ }^{893}$. Estas apariciones originalmente eran protagonizadas por figuras comunes a la cristiandad, como la Virgen María. Sin embargo fueron ganado terreno aquellos personajes involucrados con el pasado histórico de la Península y que contribuirán a formar un sentimiento de unidad entre los cristianos apelando a su

\footnotetext{
${ }^{889}$ Martín Martín, José Luis, “Algunas prácticas clericales en ámbitos fronterizos”, en Iglesia y frontera. $V$ Jornadas de Historia en la Abadia. Homenaje a José Rodríguez Molina, Alcalá la Real, Diputación de Jaén, Servicio de Publicaciones, 2005, pp. 411, 412.

${ }^{890}$ Bermejo Cabrero, José Luis, Máximas, Principios y Símbolos Políticos ... op. cit., p. 81.

${ }^{891}$ Sánchez-Albornoz, Claudio, Estudios sobre las instituciones ... op. cit., pp. 802, 803.

892 Para una aproximación al problema de la "sacralización" peninsular, recomendamos ver, entre otros los trabajos de Flori, Jean, Guerra Santa, Yihad, Cruzada... op. cit., cap. 12; Linehan, Peter, Historia e historiadores... op. cit., cap. 7; y Bronisch, Alexander Pierre, Reconquista y guerra santa... op. cit., Partes II y III.

${ }^{893}$ Rodríguez Molina, José, “Historia, tradiciones y leyendas... op. cit., pp. 11-13.
} 
tradición y creencias ${ }^{894}$. Se trataba de santos visigodos o fuertemente ligados a la tradición hispánica, como San Isidoro de Sevilla y Santiago apóstol. Un proceso similar experimentaron algunas personalidades eclesiásticas contemporáneas, que a su muerte fueron convertidos en santos por la devoción popular. Tales fueron los casos de San Froilán de León $(† 905)$, San Rosendo $(† 977)$ y San Pedro Mezonzo († 1003), todos ellos destacados miembros de la jerarquía eclesiástica asturiana y piezas importantes en los procesos de repoblación, es decir promotores de la recuperación para la Iglesia y el reino de las tierras que habían caído en manos de los musulmanes ${ }^{895}$.

Fue así como, junto con el culto jacobeo, comenzaron a surgir otros santos peninsulares. Se trataba de personajes más recientes y vinculados a la frontera. Monjes o eremitas que habían dado testimonio de gran piedad durante sus vidas y que además habían convivido con la realidad fronteriza. A ellos se dedicaron templos y también historias que exaltaban la piedad y devoción de los hispanos, apelando además a su rivalidad natural con los musulmanes ${ }^{896}$. Ejemplo esta tendencia fueron autores como Gonzalo de Berceo, Grimaldo y otros, quienes ayudaron a popularizar a personajes como San Millán, de la Cogolla y Santo Domingo, de Silos, entre otros "santos de la frontera" 897 .

Es en este contexto donde la frontera también fue un terreno propicio para los guerreros celestiales, los ángeles y santos que descendían del cielo para luchar y dar la victoria a los cristianos, convirtiendo de esta manera, las conquistas en triunfos de la $\mathrm{Fe}$ por sobre el Islam. Por esta razón, los relatos cronísticos incluían distintos portentos milagrosos y solían exagerar desproporcionadamente las muertes enemigas, simbolizando así la magnitud de una victoria que sólo era posible gracias a la intercesión divina ${ }^{898}$.

La constancia de los santos y enviados celestes se encuentra presente en las crónicas y hagiografías a lo largo del periodo de la Reconquista, concentrándose durante los siglos XII y XIII en dos epocas distintas, entre las decadas de 1090 y 1170 y luego

${ }^{894}$ Rodríguez Molina, José, "Santos Guerreros en la Frontera”, en Toro Ceballos, Francisco y José Rodríguez Molina (Coordinadores). IV Estudios de Frontera ... op. cit., p. 447.

${ }^{895}$ Fernández Conde, Javier, Historia de la Iglesia en España. II-2… op. cit., pp. 312; y García Fitz, Francisco, "La Conquista de Andalucía... op. cit., p. 55.

${ }^{896}$ Sánchez-Albornoz, Claudio. Estudios sobre las instituciones ... op. cit., pp. 802, 803.

${ }^{897}$ Llamamos Santos de la Frontera a aquellos personajes que a través de crónicas o hagiografías fueron vinculados con la actividad bélica fronteriza a partir del siglo XI, no obstante que sus orígenes se remontaban a épocas anteriores. Ver gráfico y tabla $n^{\circ} 4$.

${ }^{898}$ García Flores, Antonio, “'Fazer batallas a los moros por las vecindades del reyno'. Imágenes de enfrentamientos entre cristianos y musulmanes en la Castilla medieval", en Identidad y Representación de la Frontera... op. cit., p. 269; y Alvira Cabrer, Martin, "La muerte del enemigo... op. cit., p. 410. 
entre 1220 y 1280, coincidiendo así con las etapas de mayor actividad fronteriza, avances territoriales e inseguridad. No obstante lo anterior, no se debe perder de vista que el tema de los santos es parte de una realidad cultural mucho más profunda y que en este caso se trata de cómo ésta fue aplicada en Castilla y secundariamente en León a través de prácticas y creencias, las cuales se fueron acrecentando a medida que se intensificó la Reconquista y sus diversos elementos, como la guerra, la consolidación del sistema político, la convivencia y el cautiverio.

En vista de este proceso, nos centraremos especialmente en las figuras de Santiago, San Isidoro de Sevilla, San Millán de la Cogolla, San Domingo de Silos, la Virgen María y algunas manifestaciones divinas de menor relevancia en las fuentes, como San Pedro y diversos tipos de manifestaciones angelicales ${ }^{899}$.

${ }^{899}$ Consideramos prudente referirnos brevemente al cautiverio en su acepción providencial, puesto que,
prácticamente, todos los santos mencionados estuvieron relacionados con este fenómeno tan propio del
escenario fronterizo de la Reconquista.
Habitualmente los relatos cristianos sobre el cautiverio versan sobe la liberación a través de elementos
providencialistas, concretamente sobre la intercesión o ayuda de santos o la Virgen para que acudiesen a
rescatar a estos "desgraciados" cristianos (Para este acercamiento al tema nos hemos basado en los textos
Vita Dominici Silensis, las obras de Gonzalo de Berceo, el Liber Sancti Jacobi y las Cantigas de Alfonso
$X$, entre otras) En estas narraciones se suele hacer una introducción que nos cuenta cómo fue cautivado el
cristiano, lo que solía ocurrir de dos maneras: durante una cabalgata de los musulmanes, o bien cuando un
cristiano que incursionaba en tierras andalusíes era capturado por sus enemigos. En ambos casos el
cautiverio era interpretado como una prueba de fe para los capturados, quienes se veían expuestos a duras
condiciones, incluso sin poder comunicarse con sus captores por no entender su idioma. Todo ello
provocaba, lo que el profesor Martín ha denominado una "nostalgia", que debilitaba aún más al prisionero
y tornaba más dura la prueba a la que era sometido (Martín Martín, José Luis, "Algunas prácticas
clericales... op. cit., pp. 420 , 421, 422 ; y García de la Borbolla, Ángeles, "La Espiritualidad de los
Cautivos de Santo Domingo en la obra de Pero Marín", en II Estudios de Frontera. Actividady Vida en la Frontera, Diputación Provincial de Jaén, 1998, p. 260).

A continuación, los relatos describen las condiciones en la que era mantenido el prisionero, repitiéndose casi siempre el mismo patrón: el cautivo era encadenado y encerrado en algún lugar inmundo como una mazmorra o una torre, o simplemente arrojado al fondo de algún pozo seco y nauseabundo (incluso la situación de los cautivos podía volverse aún más lastimera si es que eran vendidos como esclavos y llevados al norte de África, donde sus posibilidades de liberación o rescate se volvían prácticamente nulas. Todo ello mientras esperaban que algún familiar o conocido pagase el rescate). De su prisión solían ser sacados para realizar trabajos pesados, haciendo de sus vidas un estado de miseria permanente (estos relatos de malos tratos hacia los cautivos, eran parte de la visión negativa que las crónicas procuraban trasmitir con respecto a los musulmanes. En textos como la Historia Compostelana y la Chronica Adefonsi, se describe a los musulmanes como violadores en sus incursiones y torturadores de sus cautivos. También se les acusa de ejecutar a los prisioneros y obligar a otros a convertirse mediante tormentos, así como se describen múltiples abusos a los que son sometidos los cautivos, como golpes, cadenas, etc... En su conjunto, la intención es convertir a los moros en símbolos de la crueldad y el abuso, con el objeto de estimular a los cristianos al combate). Ejemplo de ello y otros casos similares se pueden podemos apreciar en la Vida de Santo Domingo de Berceo: "355 Metiéronlo en fierros, en dura cadena,/ De lazrar, é fanme dábanle fiera pena,/ Dábanle yantar mala, é non buena la çena,/ Cambríe si gelo diesen, de grado pan d'avena”.

"356 Aquel es bien mezquino que caye en tal mano:/ En cosiment de canes quando yaz el chistiano;/ En dicho, é en fecho afróntolo cutiano,/ Anda mal en yvierno, non mejor en verano” (VSD, II, 355, 356, op. cit., p. 246).

En su conjunto, estos relatos pretenden mostrar una imagen en extremo negativa del cautiverio. Destacamos que hay episodios en los que se explica la cautividad de un cristiano como resultado de sus pecados, y por lo tanto, el relato tiene la función explicita de servir de advertencia o ejemplo didáctico 
Tabla 9: Santos de la Reconquista

\begin{tabular}{|c|c|c|c|c|c|c|}
\hline & Santiago & San Isidoro & Virgen María & $\begin{array}{l}\text { San Domingo } \\
\text { de Silos }\end{array}$ & San Millán & $\begin{array}{l}\text { Otros (Pastor de las Navas, } \\
\text { San Pedro, San Facundo, } \\
\text { Ángeles, Arcángel Miguel) }\end{array}$ \\
\hline 1000 & & & $\mathrm{X}$ & & & \\
\hline 1190 & & & & & & \\
\hline 1110 & $\mathrm{X}$ & $\mathrm{X}$ & $\mathrm{X}$ & $\mathrm{X}$ & & $\mathrm{X}$ \\
\hline 1120 & & & & & & \\
\hline 1130 & & & & & & \\
\hline 1140 & $\mathrm{X}$ & & & & & $\mathrm{X}$ \\
\hline 1150 & & & & & & \\
\hline 1160 & & & & & & \\
\hline 1170 & $\mathrm{X}$ & $\mathrm{X}$ & & & & \\
\hline 1180 & & & & & & \\
\hline 1190 & & & & & & \\
\hline 1200 & & & & & & \\
\hline 1210 & & & & & & \\
\hline 1220 & & $X$ & & & & \\
\hline 1230 & $\mathrm{X}$ & $X$ & & $X$ & & $X$ \\
\hline 1240 & $X$ & $X$ & & & & $X$ \\
\hline 1250 & $X$ & & & & & \\
\hline 1260 & $X$ & & & & & \\
\hline 1260 & $X$ & & $X$ & $X$ & $X$ & \\
\hline 1270 & & & & & & $\mathrm{X}$ \\
\hline 1280 & & & $X$ & & & \\
\hline 1290 & & & & $X$ & & \\
\hline 1300 & & & & & & \\
\hline
\end{tabular}

para la comunidad, como, por ejemplo sucede en la en la Cantiga 83 (Alfonso X, Cantigas de Santa María, Cantiga 83, editadas por Walter Mettmann, Madrid, Ediciones Xerais de Galicia, 1981, p. 340). En estos casos sólo el arrepentimiento y la devoción piadosa podía salvar al cautivo. Por eso los relatos de cautiverio también servían como una especie de parábola, destinada a amedrentar a la población graficando los castigos a los que se exponían por sus actos desviados.

De la misma manera, se destacan algunas narraciones que dan cuenta cómo muchos cautivos eran sometidos a una intensa presión por parte de sus captores para que alcanzasen la libertad mediante la apostasía y su conversión al Islam. Esta situación solamente era posible en el contexto del cautiverio fronterizo, en que los cristianos eran capturados por los "enemigos de Dios", los sirvientes del demonio, el enemigo ancestral que siempre procuraba corromper las almas de los cristianos y demostrar su superioridad. Una superioridad que para los cautivos podía parecer evidente, en vista de su situación, y que funcionaba a falta de una explicación mejor que justificase su suerte. Un hecho relevante si consideramos que por lo general las fuentes no dan cuenta de los pecados que pudiesen explicar estos infortunios.

En esas circunstancias la salida más fácil para el cautivo era aceptar la oferta de sus captores y entregarse al Islam (Cipollone, Giulio, "Esclavitud y Liberación en la Frontera... op. cit., p. 77, 85). Esta era una posibilidad que los relatos sobre el cautiverio trataban de evitar a toda costa, mediante la narración de distintos episodios donde el apóstata, aunque lograba su libertad, perdía su alma, ya que cuando algún santo aparecía para rescatar a sus compañeros, el "traidor" a la fe era abandonado en tierras musulmanas o incluso, moría de manera fulminante. En este último caso se le consideraba como una víctima de un castigo divino inmediato, y la condenación de su alma aparecía como algo inevitable. En consecuencia, el mensaje que se pretendía entregar era la no claudicación de los principios y valores cristianos y la fe en un futuro rescate. 


\section{III.2.c.- Santiago}

Sin lugar a dudas, el personaje providencial más destacado en el imaginario hispano medieval fue Santiago de Compostela, originalmente el apóstol y discípulo de Jesús, según la leyenda, le correspondió evangelizar Hispania y que a su regreso a Judea fue apresado y decapitado. Luego su cuerpo y cabeza fueron llevados por las corrientes, desde Judea hasta Compostela donde fueron sepultados. Este mito - relatado a muy grandes rasgos - fue una historia popular en Galicia, León, Castilla y el resto de la Península y su importancia central radica en que convirtió la gallega tumba de Santiago en Tierra Santa, categoría que por extensión abarcaba toda Hispania ${ }^{900}$.

El mito ya lo vemos definido en la Historia Compostelana, es por ello que no debe sorprender que el texto comience explicando cómo llegaron los restos del "Hijo del Trueno" a Galicia:

"[...] sed sicut Leo Papa in epistola, quam de eius passione et ipsius corporis in Hispaniam translatione, ad Hispanos destinauit, affirmat: Integrum corpus cum capite extra ciuitatem proiicientes canibus auibusque atque feris deuorandum consumendumque exposuerunt. Sed illis discipuli ab illo uiuente premoniti quatenus corpus suum in Hispánicam regionem transferrent tumulandum, totum corpus cum capite, teste Leone Papa, concturno tempore arrepientes litus adusque maris citato calle peruenerunt; dumque ibi de auigio, quo in Hispaniam transmearent, solliciti essent, nauim sibi diuinitus apparatam in littore maris inuenerunt, quam Deo gratias unanimiter referentes, sacratísimo corpore imposito, ouanter conscederunt et, Scilla cum Caribdi atque periculosis Sirtibus, manu Domini gubernante, deuitatis, primum ad Hiriensem portum felici nauigio peruenerunt, deinde uenerabile corpus ad lucum, qui tunc Liberum domun uacabatur, nunc autem Compostella dicitur, deferentes ipsum corpus sub marmoreis arcubus eclesiástico more ibidem sepelierunt." ${ }^{\prime 91}$

\footnotetext{
${ }^{900}$ Sobre la historia de la evangelización de Hispania, la muerte y el periplo del cuerpo de Santiago existen abundantes fuentes medievales, entre las que se cuentan, solo por nombrar algunas, el Liber Sancti Jabobi. Codex Calixtinus o el Cronicon Mundi de Lucas de Tuy.

${ }^{901}$ HC 1988, Liber I, cap I, op.cit... pp. 7, 8. “[...] según afirma el Papa León en la carta dirigida a los hispanos en la que habla de su pasión y traslado de su cuerpo a Hispania: Arrojando el cuerpo entero con la cabeza en las afueras de la ciudad, lo dejaron a merced de los perros, las aves y las fieras para que fuera devorado y consumido. Pero sus discípulos, a los que él había ordenado en vida que llevaran su cuerpo a Hispania para enterrarle, recogieron el cuerpo con la cabeza durante la noche, según atestigua el Papa León, llegaron hasta la orilla del mar con paso apresurado y, al buscar alli un barco para hacer el viaje a Hispania, encontraron en la playa una nave que les habia sido preparada por Dios, en la cual se hicieron a la mar llenos de gozo dando gracias a Dios de manera unánime tras embarcar el sacratísimo cuerpo, y después de evitar Escila y Caribdis junto con las peligrosas Sirtes, siguiendo el rumbo de la mano del Señor, arribaron a bordo del afortunado navio primero al puerto de
} 
En este extracto de relato, a nuestro parecer, destacan varios hechos que parecen querer demostrar ex profeso la veracidad de la narración. Primero, se afirma que la historia del viaje de Santiago fue narrada por el Papa León a través de una carta, es decir que cuenta con el aval de la más alta autoridad eclesiástica. En segundo lugar, se destaca y afirma en al menos dos ocaciones, que los despojos que llegaron a Compostela estaban completos, es decir, que la cabeza y el cuerpo del santo, se encontraban juntos, con lo que se pretendía negar la existencia de otras reliquias de Santiago, puesto que esto mermaría el poder y grandeza de los restos en Compostela. Por último, se destacan los elementos providencialistas, como la afortunada aparición de la embarcación que trasladó las reliquias, los peligros que sortearon y cómo hallaron finalmente su lugar de descanso bajo la protección de Dios. Todo ello, en un esfuerzo por reafirmar la validez de la historia y del cuerpo sepultado en la Catedral de Santiago.

El rol santificador de Santiago lo convirtió en un personaje fundamental en las crónicas peninsulares, pudiéndose rastrear su presencia tempranamente en los textos del Reino de Asturias. Las referencias al Apóstol son una constante, no obstante, como parte del fenómeno providencialista sus apariciones tenderán a perder importancia a partir de las crónicas del siglo XIII, cuando los autores empiecen a centrarse en episodios contemporáneos ${ }^{902}$. Pese a ello, Santiago reunirá en su persona todas las categorías o funciones anteriormente descritas, pero con algunas como principal eje de acción. Ante todo, su figura fue la de guerrero y protector, apareciendo como tal en las crónicas Silense, Compostelana, el Codex Calixtinus, la Najerense, Cronicon Mundi, De Rebus Hispaniae, Cerratense, la Crónica General y de Veinte reyes, además de los textos hagiográficos de Berceo.

Es así como el conocido mito jacobeo fue una pieza fundamental del discurso y la propaganda política, miliar y religiosa en la Hispania Medieval y que alcanzó a los más diversos rincones de Europa. La presencia de Santiago en la Península se convirtió en un foco de atracción para una sociedad necesitada de patronos y que hizo de las peregrinaciones una verdadera moda a partir del siglo $\mathrm{X}^{903}$.

Iria y luego llevaron el venerable cuerpo al lugar que entonces se llamaba Liberum donum y que ahora se llama Compostela, donde lo sepultaron siguiendo el rito eclesiástico bajo unos arcas de mármol" $\mathrm{HC}$ 1994, Libro I, cap I, op.cit... pp. 67, 68.

${ }^{902}$ Ver gráfico y tabla $\mathrm{N}^{\circ} 5$.

${ }^{903}$ Aunque en el siglo VIII existen testimonios asturianos referentes a la tumba de Santiago, es durante los siglos X al XII que se consolidó la leyenda. (Sot, Michel, "Peregrinaciones", en Le Goff, Jacques y JeanClaude Scmitt (Editores), Diccionario razonado... op. cit., p. 651). 
En su conjunto, gracias al discurso jacobeo, Hispania se convirtió en una tierra bendita por la Providencia, exaltada por sobre toda la cristiandad y razón de loas que aseguraban su prosperidad, por encima de cualquier otra razón económica o política:

"Sed nec preces matris, quibus sedem regni fillis poposcerat, cassate sunt, quia ut quidam sapiens in himnidicis laudibus astruit, Iohanni Asia que est a dextera, beato vero Iacobo Hispania que est a sinistra, in divisione provinciarum contigerunt. Unde beatus Iacobus, ut creditur, sua ammonicione post passionem suma a discipulis in Hispania est transvectus, et in fine Gallecie, qui nunc Compostella nuncupatur, honorifice est sepultus, ut non solum Hispanos, qui sibi in sorte contigerant suo patrocinio regerent, verum etiam corporis sui thesauro confortaret. Gaude ergo Hispania tanto illustra iubare, tripudia, supersticiones exuta errore. Gaude, quia per adventum tanti hospitis beluinam ferocitatem deposuisti et humilis Christi iugo cervices prius indomitam supposuisti. Plus enim tibi contulit beati Iacobi humilitas, quam omnium regum tuorum immanitas. Illa etinem te sublevavit ad celum; isti te depresserunt ad baratrum. Illi te coinquinaverunt idolis sacrificando; illa te mundificavit cultum veri Dei tradendo". ${ }^{904}$

En ese contexto, para el siglo XI la peregrinación a Compostela ya era reconocida y comparada con otros grandes destinos piadosos, como Tierra Santa y Roma.

La difusión y popularidad del camino, en parte, fueron posibles gracias a que la descomposición del Califato de Córdoba y los avances militares cristianos hicieron más segura la ruta. A lo que debe sumarse la intervención cluniacense que ayudó a difundir el mito jacobeo atrayendo a los peregrinos. Junto a ello, también se debe considerar, las acciones de Alfonso VI y Sancho Ramírez de Aragón (1063-1094) que contribuyeron a la fijación oficial de la ruta, eximiendo a los peregrinos de peajes y otras cargas,

\footnotetext{
${ }^{904}$ LSJ 1998, Liber I, cap. XV, op. cit., pp. 81, 82. "Pero aun la petición de su madre de una sede especial en el reino, para sus hijos, no fue en vano, pues como dijo un sabio poeta en los versos del himno en su honor, a Juan le tocó Asia, que está a la derecha; a Santiago, España, que está a la izquierda en la división de las provincias. Por lo cual Santiago, según es tradición, por su indicación fue trasladado después de su martirio por sus discípulos a España y en la extremidad de Galicia, que ahora se llama Compostela, fue honorificamente sepultado, no solo para regir con su patrocinio a los españoles que le habian tocado en suerte, sino por confortarlos con el tesoro de su cuerpo. Regocíjate, España, ensalza con semejante fulgor; salta de gozo, pues has sido salvada del error de la superstición. Alégrate, ya que por la visita de este huésped dejaste la ferocidad de las bestias y sometiste tu cerviz, antes indómita, al yugo de la humildad de Cristo. Mayores bienes te proporciono la humildad de Santiago que la ferocidad de todos tus reyes. Aquella te levantó hasta el cielo; éstos te hundieron en el abismo. Ellos te mancillaron con el sacrificio de los ídolos; aquélla te purificó, enseñándote el culto al verdadero Dios." LSJ 2004, Liber I, cap. XV, op. cit., p. 168.
} 
asegurando la protección del camino y haciendo mejoras en el mismo, lo que además contribuyó al desarrollo de las ciudades y aldeas aledañas ${ }^{905}$.

Contribuyendo con lo anterior se creo una literatura completa relacionada con Santiago y que ayudo a expandir la creencia de las virtudes, especialmente taumatúrgicas de sus reliquias ${ }^{906}$. En ese aspecto, sin duda alguna, el principal texto que contribuyó a la fama de Compostela fue el Liber Sancti Jacobi o Codex Calixtinus, que, en parte, relataba la fantástica expedición de Carlomagno a Hispania, donde, a petición del mismo Santiago, el emperador derrotó a los musulmanes y recuperó la Península para la cristiandad ${ }^{907}$.

Debido a la suma de todo lo anterior, muchos peregrinos también fueron atraídos por la guerra contra los musulmanes, una situación que se fue acrecentado a medida que se popularizaban las cruzadas contra el Islam. La Iglesia Reformista supo utilizar el camino y culto jacobeo para atraer a su dominio a la otrora distante Iglesia Hispana y además contribuir a la sacralización de la guerra contra el Islam Occidental ${ }^{908}$.

Fue así como la ruta jacobea se extendió, incluso, hasta los lejanos reinos nórdicos, construyendo un camino salpicado de monasterios, iglesias, poblados y mercados. Una senda por donde iban y venían los peregrinos, los mercaderes, los productos, las ideas, así como también el botín de al-Andalus, convertido en donaciones, junto a los guerreros deseosos de servir a la cruz, en la guerra contra los musulmanes $^{909}$.

Pero la instauración del mito y culto jacobeo no fue un suceso espontáneo, por el contrario, fue el resultado de un largo proceso y la construcción de un relato que fue mutando y adaptándose según las necesidades de la realidad peninsular y los intereses de la Iglesia y de la monarquía local. Según diversos autores, los orígenes del mito jacobeo se entrelazan con la política. Al parecer, las primeras noticias sobre el tema se remontan al siglo VII, intensificándose hacia el siglo VIII, haciéndose prontamente

\footnotetext{
${ }^{905}$ Iradiel, Paulino y otros, Historia Medieval de la España Cristiana, op. cit., pp. 138, 139; Martín, José Luis, La Península ... op. cit., pp. 35; Márquez Villanueva, Francisco, Santiago: trayectoria de un mito... op. cit., p. 16; y Valdeón Baruque, Julio, La Reconquista: El concepto de España: unidad y diversidad, Pozuelo de Alarcón, Espasa Calpe, 2006, p. 57.

${ }^{906}$ Iradiel, Paulino y otros, Historia Medieval de la España Cristiana ... op. cit., pp. 136, 137.

${ }^{907}$ Márquez Villanueva, Francisco, Santiago: trayectoria de un mito... op. cit., pp. 168, 169.

${ }^{908}$ Domínguez García, Javier, Memorias del Futuro... op. cit., pp. 67, 68.

909 Al respecto, entre otros autores recomendamos ver los capítulos del 3 al 6 del trabajo de Francisco, Márquez Villanueva (Santiago: trayectoria de un mito... op. cit., pp. 79-173); y el de Pierre Bonassie y otros, Las Españas Medievales... op. cit., p. 192).
} 
popular en el Reino Astur ${ }^{910}$. Un reino que se consideraba heredero de los visigodos y para ese momento se encontraba en plena etapa de organización y reconstrucción de la alicaída moral hispano-cristiana. Una situación donde una figura que santificaba la tierra peninsular venía a ser en extremo útil, puesto que rápidamente se convirtió en protector del reino y principal mediador ante Dios, para el perdón de los pecados del pueblo.

Fueron los monarcas Astur-leoneses los primeros en exaltar el culto jacobeo. Para ellos, los restos de Santiago eran el símbolo religioso más importante de la Península y por lo tanto el patrono más poderoso. Es por ello que desde su afortunado "descubrimiento" a comienzos del siglo IX, los monarcas procuraron enaltecer la figura del santo y convertirlo en una señal de la reconciliación entre los hispanos y la Providencia. El santo se convirtió así, en un potentísimo símbolo político que sacralizaba la acción de los monarcas en la construcción del Reino Astur y protegía sus campañas militares. Además, los restos del Apóstol implicaban la posesión de unas importantísimas reliquias, que permitían a los hispanos rivalizar con Roma en cuanto a la relevancia de sus patronos ${ }^{911}$, razón por la cual reyes como Alfonso II impulsaron la política de ennoblecer la sede de Compostelana a través de la construcción de iglesias y ligando la localidad al poder real utilizando el lugar para realizar las coronaciones y atribuyendo sus victorias a la protección del santo, ante cuya tumba se oraba antes de las campañas, se bendecían los estandartes y se le ofrecía como donación parte del botín. Esto contribuyó a que a medida que la monarquía se fortalecía, Compostela se enriquecía y aumentaba su fama e influencia en Hispania ${ }^{912}$.

En un principio, durante el período Astur-leones, la principal función del Apóstol fue la de santificar la tierra e interceder por el perdón de los pecados de aquellos que morían luchando contra el Islam. Era por lo tanto, todavía una figura pacífica, un predicador y misionero; posteriormente, con el pasar del tiempo su función de patrono cobró cada vez más relevancia, experimentando una progresiva militarización de su imagen, pero todavía como protector y no como guerrero. Santiago será el que proteja a los hispanos contra sus enemigos, siendo éstos no sólo musulmanes, sino también

\footnotetext{
${ }^{910}$ Herbers, Klaus, Política y veneración de santos... op. cit., pp. 27-31; Fernández Conde, Javier, Historia de la Iglesia en España, II-1 ${ }^{\circ}$... op. cit., p. 78; y Domínguez García, Javier, Memorias del Futuro... op. cit., pp. 50, 51.

${ }_{911}$ Sánchez-Albornoz, Claudio, España, un Enigma Histórico, Tomo I, ... op. cit., p. 268.

912 Lomax, Derek, La Reconquista... op. cit., pp. 47, 137; y Bonassie, Pierre y otros, Las Españas Medievales... op. cit., p. 192.

Estas prácticas fueron continuadas por Fernando I, que las complemento con la reunión de reliquias, como las de San Isidoro. Al respecto recomendamos referirse al texto ya citado de Carlos de Ayala Martínez ("Fernando I y la sacralización.... op. cit., pp. 67-115).
} 
vikingos y cualquier otro que atacase la Península. La figura de Santiago prosiguió evolucionando en ese sentido, en especial cuando la Reconquista se aceleró ${ }^{913}$. A partir del siglo XI se instaura la creencia en la mítica batalla de Clavijo y el Voto de Santiago, ello al mismo tiempo que por vez primera el Apóstol comienza a ser asociado a la función de combatiente activo. A partir de este momento, Santiago se transforma en un baluarte de la monarquía. Es con la aceleración del proceso reconquistador, entre el siglo XI y el XII, en combinación con la idea de la cruzada y la costumbre del peregrinaje, que la figura del Santo Guerrero se consolida, adquiriendo así las características que lo identificarán durante el resto del medioevo y los siglos siguientes $^{914}$.

El rol protector de Santigo es complementario a sus descripciones como guerrero, que son las que le dieron más fama. Santiago cabalgando, espada en mano y derribando "moros", está claramente presente en el Codex Calixtinus, las obras de "el Tudense" y “el Toledano”, el Poema de Fernán Gonçalez, la Crónica General y de Veinte reyes. El santo también se apareció para entregar mensajes y advertencias a los protagonistas de la Reconquista. Como tal, su presencia es más constatable en las fuentes ubicadas en los meridianos de los siglos XII y XIII, en tanto que sus particiones como castigador, legitimador y rescatador se encuentran principalmente focalizadas en el Codex Calixtinus $^{915}$.

Fue la acción del Obispo de Compostela, Diego Gelmírez, quien a través de $L a$ Historia Compostelana dio su forma definitiva al mito, todo ello para engrandecer la influencia del santo en la religiosidad hispana, a la vez que dotaba al obispo de una muy útil arma política que le permitía gozar de la protección providencial para su causa: el enriquecimiento de su diócesis y la obtención de la condición de sede metropolitana en oposición a Toledo ${ }^{916}$. Todo lo anterior culmina al mutar al primitivo Apóstol pescador en un Guerrero Celestial, protector, pero también combatiente ${ }^{917}$. En esencia, una figura celeste que se construyó junto con la historia de la Reconquista y sin la cual difícilmente se puede comprender la historia de la religiosidad hispana ${ }^{918}$.

\footnotetext{
${ }^{913}$ Herbers, Klaus, Política y veneración de santos... op. cit., p. 92.

${ }^{914}$ Márquez Villanueva, Francisco, Santiago: trayectoria de un mito... op. cit., pp. 183, 198; y SánchezAlbornoz, Claudio, España, un Enigma Histórico, Tomo I,... op. cit., p. 275, 279.

${ }^{915}$ Ver gráfico y tabla $\mathrm{N}^{\circ} 5$.

916 Domínguez García, Javier, Memorias del Futuro... op. cit., pp. 24-27, 52, 53; y Herbers, Klaus, Política y veneración de santos... op. cit., pp. 98-101.

${ }^{917}$ Flori, Jean, La Guerra Santa ... op. cit., p. 153.

${ }^{918}$ Episodios como la mencionada batalla de Clavijo, que se popularizó en el siglo XII, fueron parte de la creación de un discurso destinado a fortalecer el papel de la monarquía. Ramiro I, es presentado entonces,
} 
A partir de la Cronica Silense se consolidará la imagen de Santiago como guerrero que descendía de los cielos para apoyar la monarquía, como se relata en torno al cerco de Coimbra por Fernando $\mathrm{I}^{919}$. Una idea que se afianzaría en el Chronicon Mundi, donde Santiago es mostrado derechamente como el protector de la monarquía Castellano-Leonesa. Por ello, según Fernández Gallardo, Lucas de Tuy cierra su obra resaltando cómo Fernando III era un devoto de Santiago y cómo restablece la honra de Compostela al recuperar las campanas de la Catedral, arrebatas por al-Mansur siglos antes $^{920}$.

Pero la imagen de Santiago, si bien fue utilizada por todos los autores a partir de la Silense, no siempre generaba consensos, puesto que el santo y sus influencias se encontraban estrechamente ligados a la diócesis compostelana, y por lo tanto a los juegos de poderes y rivalidades entre los magnates de la Iglesia hispana. Especialmente en lo que se refería al tema del primado peninsular, disputado por Compostela y Toledo - que se identificaba más con el patrocinio de María -. En razón de ello, pero sin olvidar la importancia del mito jacobeo en los intereses políticos y militar del reino, es que Jiménez de Rada, como máxima autoridad religiosa de Toledo, en su De Rebus Hispaniae, procura restar importancia a las apariciones de Santiago y así restar valor a las pretensiones de sus rivales compostelanos ${ }^{921}$.

Independientemente de estas controversias, Santiago fue uno de los santos más populares entre los autores peninsulares y si bien como se aprecia en el gráfico, mucho de los tópicos que se vinculaban al Apóstol fueron concentrados en el Codex Calixtinus, estos continuaron estando presentes en la cronística posterior. En especial en cuanto a sus roles de guerrero y protector ${ }^{922}$.

como un luchador contra los musulmanes, devoto cristiano y de la Iglesia, y más importante aún, un protegido de la Providencia a través de la figura de Santiago. Este no será el único episodio de este tipo; por el contrario, la cronística castellano-leonesa se encuentra plagada de intervenciones jacobeas, siempre vinculadas al poder de los reyes a quienes validaba (De Ayala Martínez, Carlos, Sacerdocio y Reino... op. cit., p. 149; Domínguez García, Javier, Memorias del Futuro... op. cit., p. 89; y Fernández Gallardo, Luis, "Santiago matamoros en la historiografía... op. cit., p. 152).

${ }_{919}^{919}$ Redondo Jarillo, María Cristina, "La Confección de la Figura del Rey... op. cit., pp. 139, 140.

${ }^{920}$ CM 2003, Liber IV, N ${ }^{\circ}$ 101, op. cit., pp. 341, 342; y Fernández Gallardo, Luis, "Santiago matamoros en la historiografía... op. cit., pp. 155, 156.

${ }^{921}$ Fernández Gallardo, Luis, "Santiago matamoros en la historiografía... op. cit., p. 156.

922 En relación a lo anterior, es importante destacar que Santiago, pese a su importancia y popularidad, no era el único en el escenario peninsular. Desde el siglo IX, en diversos monasterios, se rendía culto también a otros santos que cumplieron roles similares al del Apóstol, quienes destacaron en diversos aspectos del escenario de la Reconquista (Herbers, Klaus, Política y veneración de santos... op. cit., p. 34; Goñi Gaztambide, José, Historia de la Bula de Cruzada ... op. cit., pp. 21-33). Sin embargo, ellos no alcanzaron la misma importancia política. 
Gráfico 10: Santos de la Reconquista: Santiago

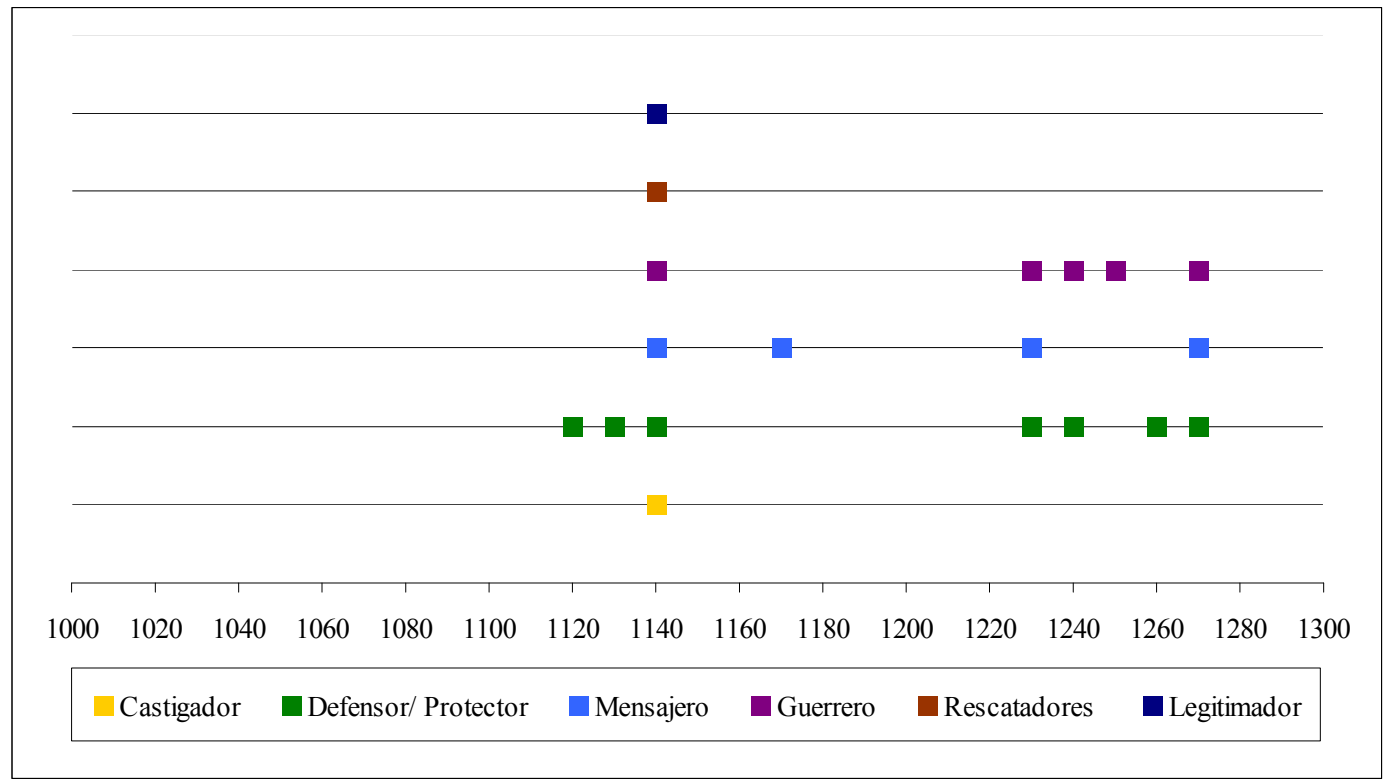

Dada su importancia, como ya mencionamos, fue lógico que, tal como se observa en el gráfico, las apariciones de Santiago abarcaran todas estas esferas de acción, aunque, no con la misma intensidad. Razón por la cual hemos seleccionado ejemplos de distintos textos para ilustrar la manera en que se construyó el discurso jacobeo y como se pretendía a través de este influir en las creencias y prácticas religiosas en Castilla y León $^{923}$.

Protector El "santo protector", corresponde a aquellas acciones donde el Apóstol no aparece fisicamente, aunque se le atribuyen las victorias de las tropas que luchan en su nombre o bien fue gracias a su intervención que algún lugar o persona se libró del mal que la acechaba ${ }^{924}$. Es así que en la Historia Compostelana se narra cómo el santo protegió desde antaño a los titulares de la Catedral, en especial frente a los atropellos, amenazas y abusos que estos sufrían frente a los reyes y autoridades cristianas. Este último aspecto debe ser destacado a la luz del contexto de la obra, puesto que su

${ }^{923}$ Es importante aclarar que las categorías seleccionadas son meramente referenciales y que en la práctica es difícil catalogar de forma estricta los distintos roles del santo, puesto que es frecuente, por ejemplo, que en un mismo episodio lo veamos actuado como mensajero y guerrero, o como protector y guerrero. Es en razón de ello que nos remitiremos solo a aquellos ejemplos donde el actuar del santo este mejor definido o al menos se preste menos a confusiones.

${ }_{924}$ El rol de protector lo consideramos distinto al del guerreo, puesto que a nuestro entender este ultimo se limita a las intervenciones directas y visibles de Santiago, cuando los testigos afirman verlo visto luchando entre los hombres. No obstante, en ocasiones las fuentes no aclaran del todo exactamente cual fue la naturaleza de la aparición, momentos en los que nos vemos obligados a trabajar según nuestros propios criterios clasificatorios. 
promotor, el Obispo Gelmírez, enfrentó duras y frecuentes pugnas contra la reina Urraca y Alfonso de Aragón, por lo que a nuestro entender era lógico que el clérigo utilizase el mito jacobeo como forma de amedrentar a sus adversarios, recordándoles la suerte que había corrido otros que osaron desafiar el patronazgo jacobeo ${ }^{925}$.

Este episodio explica el por qué el sepulcro y la Iglesia sobrevivieron a la embestida del caudillo cordobés, demostrando que Santiago las protegía e incluso despertaba el temor en sus enemigos, sin la necesidad de aparecerse como Guerrero Celeste. También se puede concluir que este relato es una advertencia a los reyes cristianos, como "el Batallador" que en el contexto de sus guerras contra Urraca no dudó en saquear y profanar iglesias. Es pues, lógico, pensar que Gelmírez quería evitar que la rica Catedral fuese víctima de semejante atropello y para ello recurrió a la poderosa imagen de Santiago, así "el aragonés" o cualquier otro que se atreviese a atacar la diócesis debería saber que estaría desafiando al mismo santo.

No obstante los episodios anteriores, los compositores de La Historia Compostelana no olvidaron que las acciones de Santiago no podían limitarse sólo a grandes personajes y acontecimientos, era pues necesario crear la imagen de un santo cercano al común de la gente, puesto que eran ellos los que mayoritariamente peregrinaban y aportaban con sus donaciones al engrandecimiento de la gloria de la catedral. Es por ello que en el texto se describe cómo el Apóstol protegía a los pobres y desvalidos, y velaba por la piedad de sus siervos ${ }^{926}$.

\footnotetext{
${ }^{925}$ Este es el marco que encuadra el relato de Adaulfo II su falsa acusación y el toro, que demostraba cómo Santiago protegía su siervo (HC 1988, Liber I, cap. II, op. cit., pp. 9, 10).

Al relato de Adaulfo, dirigido a los cristianos, se suma la venganza llevada a cabo por Santiago contra las huestes de Al-Mansur, que se atrevieron a profanar la catedral: "Igitur beatissimus Iacobus uolens ne ab ecclesia sua, quam ipsi tante superbie calce oppreserant, impune euaderent, tanto dissenterie morbo eos perscussit, quod, mortuis eorum quam pluribus, perpauci ad propria redierunt. Cumque dux forum Almezor interna consideratione tante ultionis periculo suos acrius percuti conspiceret, quisnam esset ille, cuius aula forum impetu iam fere destructa esset, sui itineris doctores fertur consuluisse. Quorum nimirum resposione, Iacobum scilicet, unum ex discipulis Filii Marie Virginia, [...] ibidem certissime tumulari comperiens ac tante audacia penitudunem gerens fugam obstinate iniit et in fugiendo repentino languore percussus apud Metinacelim, ubi sepultus est, animam suam sinui Mafometh infeliciter commendauit” HC 1988, Liber I, cap. II, op.cit, pp. 13, 14. “Así pues, el santísimo Santiago que no quería que escaparan impunemente de su iglesia, que ellos con tanta soberbia habian pisoteado, los castigó con una enfermedad tan grande de disentería que, muertos la mayoría, sólo algunos pocos regresaron a sus casas. Y como Almanzor comprendió que los suyos habian sido castigados duramente con el escarmiento de tan gran vergüenza, se dice que preguntó a los que guiaban su camino, quién era aquel cuyo palacio ya casi había sido destruido por su ataque. Y al comprender por la respuesta de éstos que allí estaba enterrado con seguridad Santiago, uno de los discípulos del Hijo de la Virgen María, [...], arrepintiéndose de tan gran audacia emprendió sin interrupción la huida, y mientras huía fue atacado por una repentina enfermedad en Medinaceli, donde fue sepultado, y donde entregó su alma infelizmente al seno de Mahoma" HC 1994, Libro I, cap. II, op. cit., p. 75.

${ }^{926}$ Es el caso del obispo Hermenegildo que se caracterizó por cometer abusos y malas obras luego de su elección, siendo el último de ellos el de ordenar arrebatarle a una viuda la única vaca que ella poseía y
} 
En las fuentes también destacan las intervenciones de Santiago como protector de la ruta jacobea. Parte de la ideología del peregrinaje era la creencia de que el camino se encontraba protegido por el santo. Además, la peregrinación era una prueba para el cuerpo y el espíritu del romero, razón por la cual en su viaje no solo debía sortear amenazas físicas como bandidos, sino que también pruebas espirituales. Las rutas de peregrinos eran, según la literatura, lugares místicos y mágicos, que de esta forma procuraba engrandecer las rutas y atraer más peregrinos y sus donaciones ${ }^{927}$.

Analizando con mayor detenimiento la actividad protectora de Santiago, se pueden distinguir distintos tipos de participación. En el primero de ellos, el Apóstol no combate directamente, aunque protege a quienes luchan en su nombre, por lo que los cronistas le atribuyen las victorias contra sus enemigos. En estos episodios, el santo no se aparece, pero envía algún castigo o campeón, contra quienes atacaban Galicia u otros territorios, de forma similar a lo ocurrido con al-Mansur ${ }^{928}$. La diferencia radica en que en ese caso el santo protegió directamente su tumba, mientras que en los que relataremos a continuación, el Apóstol defiende la extensión del territorio. Otra particularidad de este tipo de intervenciones, es que no se debían exclusivamente a amenazas provenientes del Islam, sino que también contra otros tipos de invasores occidentales como los normandos o ingleses ${ }^{929}$.

con la cual alimentaba a sus hijos. Cuando el obispo probó un plato preparado con los intestinos del animal, su vientre reventó matándolo al instante (HC 1988, Libro I, cap II, op. cit., p. 12).

${ }^{927}$ En las fuentes abundan relatos de episodios milagrosos que acrecentaban la fama de las romerías. El Liber Sancti Jacobi nos relata el episodio de un marino, Frisono, que fue salvado de ahogarse por Santiago, durante un ataque de piratas musulmanes (LSJ 1998, Liber II, cap VII, op. cit., p. 166). Por su parte Gonzalo de Berceo, en su obra Milagros de Nuestra Señora, relata un fantástico episodio ocurrido a un romero de Santiago, cuya alma fue salvada del diablo por la intervención de Santiago y la Virgen (MNS, N VIII, 182-219, op. cit., pp. 36-44).

${ }_{928}$ CN 1995, Liber II, N ${ }^{\circ} 32$, op. cit., p. 139; CM, Liber IV, N 38, p. 270; HRH, Libro V, cap. XVI, op. cit., pp. 165, 166; PCG, II, op. cit., p. 449; y CXXR, Libro V, cap. XIX, op. cit., p. 127.

${ }_{929}$ La Historia Compostelana nos relata como durante las luchas de Gelmírez por imponer a Urraca, los rebeldes contratan como mercenarios a una expedición de cruzados ingleses, pero que son derrotados por tropas gallegas gracias a la intercesión de Santiago: "Sed beati Iacobi intercessio a nefasta gente prouinciam suam pessundari et depopulari haud inpune permisit tantumque nefas non inultum remanere uoluit" HC, Libro I, cap LXXVI, op. cit., p. 118. "Pero la intercesión de Santiago no permitió que su tierra fuese inmunemente arruinada y devastada por esta impía gente y no quiso que permaneciera sin castigo tan gran crimen." HC, Libro I, cap LXXVI, op. cit., p. 186.

Otro ejemplo es el relato compartido por las Crónica Najerense, la Historia Compostelana y la crónica de Jiménez de Rada, así como en la Crónica General (CN 1995, Liber II, N 32, op. cit., pp. 137, 138; HRH, Libro V, cap. XI, op. cit., p. 159; y PCG, cap. 727, op. cit., p. 425). Bandas de normandos saquean las costas de Galicia, entonces el conde Gonzalo Sánchez (Guillermo Sánchez según la Najerense), al mando de huestes gallegas, se les enfrenta y los derrota. La victoria es presentada como un castigo de Dios contra los piratas, que fueron vencidos en nombre de Santiago: "Tercio anno cum patratis uastationibus uellent ad propria nauigare, inuocato nomine Domini et beati Iacobi comes Gunsaluus Sancii ocucurrit eis, si posset exterminium uindicare. Et cum prelium iniuissent, Dei gracia et uirtute apostoli qui sine lege uastauerant Dei iundicio sunt prostrati et tam ipsi quam rex eorum in ore gladii ceciderunt, et comes Gunsaluus Sancii eorum nauigia igne consumpsit.” HRH, Liber V, cap. XI, op. cit., p. 159. 
El Apóstol se convierte así, en el protector de su santuario, de Galicia, y finalmente de Hispania. Su radio de acción y participación se va haciendo cada vez más violento, a medida que la guerra peninsular se radicaliza, en los siglos XII y XIII.

\section{Mensajero/Guerrero}

Es precisamente en esta radicalización de la figura del santo que sus roles comienzan a combinarse, haciéndose menos nítidos. Un ejemplo de ésto son los episodios vinculados a Fernando I y la captura de Coimbra. En muchas crónicas se repite el mismo episodio, diferenciándose en pequeños matices. El relato está presente en diversidad de fuentes, convirtiéndose en el principal acontecimiento en relación a sus roles de mensajero y guerrero, a la vez que se transforma en un episodio clave para la construcción del mito jacobeo, puesto que inaugura una nueva representación del santo $^{930}$.

Este primer episodio inaugura la nueva concepción de Santiago, como albo paladín de la cristiandad. El guerrero que lucha por la restauración del cristianismo que, según el mito, él mismo estableció en la Península, y que defiende la tierra que alberga su tumba. Es así como el Apóstol convierte a Compostela en tierra sacra, lo que permite construir el ideal de la Reconquista en una guerra santa, con todos los privilegios y estímulos espirituales que eso implicaba ${ }^{931}$. Es, en resumen, parte de la construcción de un discurso legitimador de la violencia, convirtiéndola en un objetivo religioso que fortalece y valida a sus caudillos.

La historia es casi siempre la misma, un peregrino, unas veces de origen griego, a veces un obispo, pero siempre descrito como un hombre de gran piedad, peregrina a Compostela y allí recrimina a quienes adoran a la figura de Santiago tratándolo como si de guerrero se tratase, puesto que afirma que el santo nunca fue un guerreo montado y que sólo era un simple pescador elegido por Cristo para ser "pescador de hombres"932. Al anochecer, el peregrino es despertado por la aparición de Santiago, quien montado en un caballo, le reprende con las siguientes palabras:

\footnotetext{
“Cuando al cabo de tres años de robar a su antojo se disponían a embarcarse rumbo su patria, el conde Gonzalo Sánchez. Invocando el nombre del Señor y de Santiago, les salió al encuentro por ver si podia vengar la matanza. Y habiéndose trabado combate, con la gracia de Dios y la virtud del apóstol los que habian sido destructores sin tasa fueron vencidos por la decisión de Dios, y tanto ellos como su rey perecieron a punta de espada, y el conde Gonzalo Sánchez prendió fuego a sus naves." HHE, Libro V, cap. XI, op. cit., p. 202.

${ }^{930}$ Fernández Conde, Francisco Javier, La Religiosidad Medieval ... op. cit., pp. 39-40.

931 Abellán, José Luis, Historia critica del pensamiento español, Tomo I, ... op. cit., pp. 241-245.

${ }^{932}$ El relato en cuestión puede observarse en la Crónica Najerense, Libro III; Crónicon Silense; Crónicon Mundi, Libro IV; Crónica General de España y Crónica de veinte reyes, Libro VIII, entre otras.
} 
"Stephane, serve Dei, qui me non militem, sed piscatorem vocari iussiti, eo namque taliter tibi appareo, ut me Deo militare eiusque ahtletam esse, meque in pugna contra Sarracenos Christianos anteire et pro eis victorem existere, amplius non debites. Impetravi enim a Domino, ut universis me diligetibus ac recto corde invocantibus protector sim et ediutor periculis in cunctis" ${ }^{933}$.

A continuación, le indica que las llaves que porta son las de Coimbra, que en esos momentos estaba siendo sitiada por Fernando I, y que al día siguiente él abrirá las puertas de la ciudad para que sea conquistada por los cristianos, lo que implica una participación directa del santo en el combate. Cabe destacar que las crónicas no mencionan la aparición del santo en el cerco, ni ningún otro portento vinculado a él en el sitio mismo de la batalla.

Este relato aparece por primera vez, completamente desarrollado, en la Crónica Najerense y a partir de ese momento es mencionado en distintas crónicas posteriores ${ }^{934}$. En la que se da el relato más detallado es en Liber Sancti Jacobi ${ }^{935}$. Sin importar la precisión o concordancia de las fuentes, el episodio es sumamente significativo, puesto que es él propio Santiago quien se define a si mismo como un guerrero y protector de los cristianos peninsulares. Es cierto que el Apóstol no aparece en medio de un combate, pero se le ve investido de todos los símbolos que caracterizarán sus apariciones $^{936}$, montado en blanco corcel, con ropas resplandecientes y armado ${ }^{937}$. Su función militar queda más clara aún con su afirmación de que él será el que abra las puertas de Coimbra al rey Fernando I, con lo que además certifica al soberano como un

\footnotetext{
933 LSJ 1998, Liber II, Cap XIX, op. cit., p. 175. "Esteban, siervo de Dios, que mandaste que no me llamasen caballero, sino pescador; por eso te me aparezco de esta forma, para que no dudes más de que milito al servicio de Dios y soy su campeón y en la lucha contra los sarracenos precedo a los cristianos y salgo vencedor por ellos. He conseguido del Señor ser protector y auxiliador de todos los que aman y me invocan de todo corazón en todos los peligros.” LSJ 2004, Libro II, Cap XIX, op. cit., p. 376.

${ }^{934}$ Ver gráfico y tabla $\mathrm{N}^{\circ} 5$.

${ }^{935}$ Fernández Gallardo, Luis, "Santiago matamoros en la historiografía... op. cit., pp. 139, 140; Herbers, Klaus, Política y veneración de santos... op. cit., pp. 35-37.

${ }^{936}$ Las mismas que posteriormente darán pasó a la figura de Santiago "matamoros".

${ }^{937}$ De Ayala Martínez, Carlos, Sacerdocio y Reino... op. cit., p. 285.

En el caso del Apóstol Santiago sus repetidas intervenciones militares, atacando a los "moros" y dirigiendo las huestes de ángeles, posteriormente le valdrán el mote de "matamoros", el cual constituirá un arquetipo simbólico. En los siglos siguientes se popularizan las representaciones del santo como un albo caballero y su figura se convertiría en símbolo y estimulo del caballero hispano, al grito de “'Santiago y cierra España!” (Suárez Fernández, Luis, "Santiago: Camino y 'Matamoros”, en Benito Ruano, Eloy (Coordinador), Tópicos y realidades de la Edad Media, Volumen II, Madrid, Real Academia de la Historia, 2002, pp. 312, 325). Finalmente este discurso simbólico será, incluso, trasplantado a América, donde el santo cabalgará contra los indígenas paganos, ahora convertido en "Santiago mataindios".
} 
instrumento de la Providencia, bendito por ella y por lo tanto legitimado a través de la victoria providencial.

El relato tiene varias funciones discursivas complementarias. Contribuye a la definición del mito jacobeo ante quienes puedan dudar de él, debido a la historia conocida del santo. También consolida los rasgos y atributos guerreros del apóstol Santiago, ayudando a posicionarlo como un paladín de la cristiandad, cuya presencia legitima la guerra contra el Islam y a quienes la llevan a cabo. Todo ello en medio de un discurso que apela a las creencias de la religiosidad popular medieval.

\section{Guerrero}

Santiago fue entonces protector y mensajero, pero como ya hemos adelantado, su principal rol fue el de guerrero. Sus diversas apariciones lo convirtieron en uno de los símbolos más significativos de la Reconquista y en uno de los instrumentos más utilizados para legitimar a reyes, guerreros y a la guerra misma ${ }^{938}$.

El santo frecuentemente aparece descrito en distintas fuentes como un caballero montando en un caballo albo y empuñando un estandarte o espada con la que abatía a los "moros". En ocasiones, Jacobo aparecía liderando a legiones de "caballeros blancos" que luchaban junto a los cristianos. Sus visiones solían coincidir con momentos en que los cristianos están siendo superados, por lo que la aparición de Santiago marca un momento de inflexión en el combate, cuando los hispanos obtienen la victoria gracias a la intervención divina. De esta manera se refleja el discurso de instrumentalización de la religiosidad, puesto que se da a entender que los destinos de los guerreros cristianos se encuentran enlazados con los del santo patrono de Compostela, puesto que ambos luchaban por la misma causa, la recuperación de la Tierra Santa de Hispania. Al mismo tiempo, la presencia de las huestes celestiales se convertía en una señal inequívoca de la legitimidad de la guerra y de los caudillos que la dirigían y permitía sostener la creencia de que por ser una guerra justa y sacralizada por los portentos divinos, la muerte en ella era objeto de recompensas celestiales. Todos estos elementos eran claves para la mantención del esfuerzo bélico y, junto con el botín, era el principal atractivo para atraer guerreros de más allá de los Pirineos.

En el escenario peninsular es en la Crónica Silense en la que se observa por primera vez esta representación del Apóstol Santiago como luchador activo y líder de

\footnotetext{
${ }^{938}$ Ver gráfico y tabla ${ }^{\circ} 5$.
} 
legiones celestiales ${ }^{939}$. Complementariamente, diversas crónicas situan la batalla de Clavijo como la primera aparicion de Santiago en su faceta de combatiente activo por la Reconquista. El episodio es narrado en distintas crónicas, las cuales suelen dar más detalles a medida que corresponde a los momentos de mayor actividad reconquistadora, es decir los siglos XII y XIII ${ }^{940}$.

El suceso, si bien tiene múltiples versiones, nosotros optamos por privilegiar la que aparece en la Crónica General, debido a que sintetiza con bastante exactitud los distintos testimonios del milagro. En esta ocasión, es el propio Apóstol Santiago quien se describe a si mismo: "Et por que non dubdes nada en esto que te yo digo ueer medes cras andar y en la lid en un cauallo banco con una senna blanca, et grand espada reluzient en la mano" 941 , para luego continuar con el relato de su participación en la batalla ${ }^{942}$ :

"Otrossi el apóstol sant Yague fue y luego con ellos, assi como les prometiera, et esforçaualos a la batalla, et firie el mismo muy de rezio en los moros, assi semeiaua.

Los cristianos, quando uieron a sant Yahue, fueron muy esforçados, et fiando en ell ayuda de Dios et dell apóstol sant Yague, començaron de ferir en los moros muy de rezio, dando grandes uozes et diziendo: 'Dios, ayuda, et Sant Yague!'”943.

El relato simboliza la unión entre la monarquía, Santiago y la Reconquista, una idea que sería continuada por los cronistas posteriores ${ }^{944}$.

\footnotetext{
${ }^{939}$ García Flores, Antonio, “"Fazer batallas a los moros.... op. cit., p. 270.

940 "Crónicon del Cerratense", en Las Crónicas Latinas de la Reconquista, Tomo I, op. cit., p. 92; HRH, Liber IV, cap. XIII, op. cit., p. 133; y CM, Liber IV, No XVII, op. cit, pp. 238-239.

${ }_{941}$ CGH, cap. 629, op. cit., p. 360.

${ }^{942}$ Este evento seria el origen del llamado "Voto de Santiago", que vinculaba a Ramiro I y su estirpe con la sede Compostelana. Homet, Raquel, "Caracteres de la conciencia histórica.... op. cit., p. 98; y Herbers, Klaus, Política y veneración de santos... op. cit., p. 66.

${ }^{943}$ CGH, cap. 629, op. cit., p. 360.

${ }^{944}$ Un episodio similar es narrado por Gonzalo de Berceo, en su obra: Vida de san Millán de la Cogolla. En esta ocasión, el soberano protagonista es Ramiro II de León y la batalla es la de Simancas, aunque el cronista confunde a los personajes y la época (Berceo, en su relato fusiona la batalla de Clavijo, el voto de Santiago y el tributo de las doncellas con la batalla de Simancas. Por lo tanto el autor confunde a Ramiro de Asturias con Ramiro de León, creando así un solo personaje literario, que además comparte glorias con Fernán Gonçález). La gran diferencia con el relato de Clavijo, es que el autor acompaña al Apóstol Santiago con San Millán de la Cogolla. Ambos santos comparten atributos y luchan como uno solo contra los musulmanes, otorgándole la victoria a los guerreros cristianos (VSM, N 437-439, op. cit., p. 410).

Otro personaje que pareció gozar de la especial protección de Santiago fue el conde Fernán Gonçalez. Distintas fuentes narran cómo el castellano se enfrentó y venció a Al-Mansur con la ayuda de Santiago (PFG, op. cit., pp. 305, 306; CGE, cap.698, op. cit., pp. 400-406; y CXXR, Libro III, cap IV, op. cit., pp. 99, 100). Es así como el Apóstol, en el poema, cumple la misión de validar el condado de Castilla y bendecirlos con la señal inequívoca de la victoria. En palabras de Raquel Homet, el episodio de la aparición de Santiago es un símil de la Batalla de Clavijo, con algunas variantes, como la posición del protagonista que en lugar de rey es un caudillo militar, pero que en común poseen características como la lucha contra los musulmanes presentados como enemigos de la fe (Homet, Raquel, "Caracteres de la conciencia histórica... op. cit., p. 100).
} 
Con el avance de la Reconquista y la paulatina consolidación de los reinos peninsulares, las intervenciones de Santiago se fueron haciendo cada vez menos frecuentes y menos espectaculares, no obstante aún es posible identificar al santo y sus legiones en textos del siglo XIII, auque, en algunos casos haciendo alusión a acontecimientos pretéritos ${ }^{945}$.

Lucas de Tuy rescata una aparición conjunta de Santiago y San Isidoro, de la que fue testigo Alfonso VII, a punto de enfrentarse a fuerzas superiores musulmanas, a la cual nos referiremos en profundidad cuando hablemos del obispo sevillano, pero al respecto adelantaremos que no es gratuito que el Apóstol Santiago, patrono de España y fundador del cristianismo peninsular, aparezca junto a Isidoro, el símbolo del buen visigodo, pieza clave en la creación de la identidad goda y en la cristianización del otrora reino arriano $^{946}$. Ambos personajes apelaban a las raíces de la identidad hispana. Y ahora unidos luchan contra los enemigos de la fe y del pueblo hispano.

Vinculado a lo anterior es el portento que afectó a Alfonso IX de León, reseñado por el mismo cronista. Durante una expedición contra varias localidades musulmanes, el rey leonés se enfrentó a los musulmanes en la batalla de Alfange, ocasión en la cual: "[...] visiblemente aparesçio el bienauenturado Jacobo con muchedumbre de [caualleros] blancos que derribauan los moros con mano valiente [...]"947. El relato también afirma que en la misma campaña, también apareció san Isidoro, para anunciar la pronta captura de Mérida ${ }^{948}$.

Estas últimas apariciones, narradas por "el Tudense", rebelan una vez más como las figuras de los santos fueron utilizadas con propósitos políticos. Con sus apariciones validan la guerra y las políticas de los reinos de Castilla y León, que además se han fusionado de manera definitiva durante la vida del autor de la crónica. Es así como Lucas, utiliza a ambos personajes para consagrar la unidad de los reinos y la misión reconquistadora de sus reyes ${ }^{949}$.

\footnotetext{
${ }^{945}$ Ver gráfico y tabla $\mathrm{N}^{\circ} 5$.

${ }^{946}$ CE, Libro IV, cap. LXXIX, op. cit., p. 394.

${ }_{947}$ CE, Libro IV, cap. XCI, op. cit., pp. 424, 425.

${ }_{948}$ CE, Libro IV, cap. XCI, op. cit., p. 425.

${ }^{949}$ En las crónicas no siempre se es explicito en cuanto a las apariciones de Santiago, no obstante se dan señas que permiten adivinar su presencia. En la Crónica General se rescata un episodio ocurrido luego de la muerte del Cid, cuando 26 caudillos musulmanes atacan Valencia para reconquistarla. En la batalla siguiente los atacantes fueron derrotados cuando aparecieron "sessenta mill cavualleros todos más blancos que vna nieva", encabezados por uno más grande que el resto, que portaba una enseña blanca en una mano y una espada de fuego en la otra (CGE, cap. 956, op. cit., pp. 637, 638). Si bien en el relato no se identifica directamente a Santiago, la descripción del líder de la hueste de jinetes blancos parece corresponde a la del santo. No obstante, dadas las características de la aparición, es factible que también
} 
Otra evidencia significativa de la instrumentalización de las apariciones del Apóstol Santiago, en vista de los fines recién mencionados, es posible de observar en la Crónica General, que afirma que las apariciones de Santiago y los ángeles eran también vistas por los musulmanes. Es el caso de un encuentro dado en el contexto de las campañas de Fernando III:

"Et dizen, asi commo los moros mismos afirmauan después, que parescio y Santiago en vn cauallo blanco et con senna blanca en la mano et con vn espada en la otra, et que andaua y con el vna ligion de caualleros blancos; et dizen que ángeles vieran andar sobre ellos por el ayre; et que estos caualleros blancos les semeiaua que les estroyen mas que ninguna otra gente" ${ }^{\text {"950. }}$.

A nuestro parecer, el relato es un recurso propagandístico, puesto que difícilmente los musulmanes reconocerían a un enviado celeste que protegiera a los cristianos, ya que esto implicaría que los mismos musulmanes se deslegitimarían como religión y como combatientes. Debemos recordar que la Crónica General, así como las crónicas hispanas estaban destinadas a los cristianos y no a los musulmanes. Es por ello que este pequeño relato debía tener como objetivo central dar a entender a los guerreros cristianos que los mismos musulmanes reconocían la justicia de la causa de los reconquistadores y de igual manera reconocían y temían la superioridad militar y religiosa que se manifestaba a través de las apariciones de Santiago.

\section{Mensajero}

En cuanto al rol de Santiago como simple mensajero, es decir sin combinar esta función con otras actividades, como en los casos anteriores, sus apariciones parecen ser menores que las de otros santos, pero no por ello menos importantes, puesto que sus avistamientos para entregar mensajes a los mortales coinciden con momentos decisivos. En cuanto a las fuentes que atribuyen este rol al santo, son principalmente el Codex Calixtinus, además de las crónicas Najerense y el Cronicon Mundi, junto a ellas algunas otras de las postrimerías del siglo como la Crónica General y la de Veinte reyes ${ }^{951}$.

La elaboración del Liber Sancti Jacobi / Codex Calixtinus, contribuyó a la difusión de Compostela y el camino de Santiago en Europa. Este texto convierte a toda la Península en un territorio mágico, fantástico y providencial, pero también narra varios

pueda tratarse de Millán de la Cogolla, sin embargo dado el contexto de la obra no podemos afirmar que se trate de este santo en particular.

${ }_{950}$ CGE. cap. 1044 , op. cit., p. 727.

${ }^{951}$ Ver gráfico y tabla ${ }^{\circ} 5$. 
episodios destinados a exaltar la figura del Apóstol, más no de la diócesis y la catedral que contenía sus reliquias, puesto que ese no era el objetivo de la obra, que en cambio, pretende exaltar el papel de los francos y de Carlomagno - a esa altura también un personaje mitificado - en relación a la providencial lucha contra el Islam en Hispania ${ }^{952}$. Es por ello que destaca el episodio en que se narra en la aparición del Apóstol Santiago al emperador franco, exaltándole a emprender la liberación de la Península y la reposición de la Iglesia cristiana:

"Ego sum, inquit, Iacobus apóstolus [...] cuius corpus in Gallecia, que a Sarracenis adhuc turpe opprimitur, incognitum requiescit. Unde ultra modum moror, cur terram meam a Sarracenis minime liberaste, qui tot urbes tantasque terras adquisisti. Quapropter tibi notifico, quia sicut Dominus potenciorem omnium regum terrenorum te fecit, sic ad preparandum iter deum et deliberandum tellurem meam a manibus Moabitarum te inter omnes, ut tibi coronam eterne retribucionis exinde preparet, elegit." 953

El episodio da pie para narrar la mítica expedición carolingia y validar de esta forma la intervención de los francos en los asuntos hispanos, al mismo tiempo que sirve para elogiar a Carlomagno, que en el texto aparece como un mandadero de la Providencia y protegido de Santiago.

Las crónicas posteriores, que por cierto no recogen la tradición franca, centran su atención en el episodio anteriormente citado con respecto a Fernando I y Coimbra, razón por la cual la función mensajera del santo se diluye en relación a sus participaciones bélicas.

\section{Rescatador}

En el Liber aparecen con alguna frecuencia intervenciones del santo vinculadas a la protección expresada como el rescate de cautivos que previamente habían recurrido a Santiago. Estas narraciones se encuentran principalmente en la obra franca, no obstante nosotros las hemos incluido como categoría dado que representan una realidad de la

\footnotetext{
${ }^{952}$ Herbers, Klaus, Política y veneración de santos... op. cit., p. 58.

953 LSJ 1998, Liber IV, cap I, op. cit., p. 201. "Yo soy - contesto - Santiago apóstol [...] y cuyo cuerpo descansa ignorado en Galicia, todavía vergonzosamente oprimida por los sarracenos. Por esto me asombro enormemente de que no hayas liberado de los sarracenos mi tierra, tú que tantas ciudades y tierras has conquistado. Por lo cual te hago saber que así como el Señor te hizo el más poderoso de los reyes de la tierra, igualmente te ha elegido entre todos para preparar mi camino y liberar mi tierra de manos de los musulmanes y conseguirte por ello una corona de inmarcesible gloria." LSJ 2004, Libro IV, cap I, op. cit., p. 414.
} 
frontera hispánica y que además los relatos del Liber fueron incorporados como parte integral del mito jacobeo ${ }^{954}$. Los relatos consisten en una serie de episodios en los que se explica cómo el santo protegía a quienes luchaban contra los "moros", pero especialmente cómo amparaba a los peregrinos que se dirigían a su tumba. Todo ello con la evidente intención de fortalecer la peregrinación y la fama de las reliquias.

A modo de ejemplo, presentamos algunos episodios. En el primero de ellos se narra cómo veinte hispanos son capturados por los musulmanes y llevados cautivos a Zaragoza. En el calabozo oran a Santiago, quien durante la noche los libera de sus ataduras, abre las puertas de la ciudad y los guía hasta territorio cristiano ${ }^{955}$. Este relato es parte de un tópico temático muy propio de la Península y consiste en narraciones de rescates llevadas a cabo por algún santo, dónde los medios se caracterizan por su mundanidad. Es decir, el santo no realiza actos fantásticos en la liberación, como derribar muros o trasladar a las personas, limitándose, casi siempre, a facilitar la fuga, a través de la entrega de herramientas o haciendo dormir a los guardias, protegiendo a los fugitivos durante la huida.

En otros episodios se narra cómo un peregrino de Barcelona es cautivado a su regreso de Compostela. El cautivo es vendido como esclavo en trece ocasiones, pero nadie podía retenerlo ya que Santiago rompía sus cadenas, en cumplimiento a una petición que el barcelonés le había hecho durante su romería ${ }^{956}$.

Respecto a la función como ente castigador, se encuentra en combinación con otros roles, pero destacando el hecho de que suele ser encontrada en los textos del siglo XII, en episodios como el castigo a los acusadores del Obispo Ataulfo II o la muerte de Hermenegildo. En ambos casos, lo que observamos es al santo sancionando a aquellos que ultrajan a sus siervos y por lo tanto también protegiendo a aquellos que habían sido objetos de injusticia.

Todo ello contribuyó a convertir al Apóstol Santiago en un santo de conocimiento y devoción común, cuya imagen sabiamente utilizada servía tanto para validar a algún monarca mediante su protección, como para intimidar a los enemigos de la corona o de Compostela. Un campeón que se encontraba al alcance de todos y cuya leyenda fue un elemento importante en la creación de un espíritu peninsular, pero también en la introducción de ideas e influencias respecto a la guerra y las relaciones con el resto de Europa.

\footnotetext{
${ }^{954}$ Ver gráfico y tabla ${ }^{\circ} 5$.

${ }^{955}$ LSJ 1998, Liber II, cap I, op. cit., p. 161.

${ }^{956}$ LSJ 1998, Liber II, cap XXII, op. cit., p. 177.
} 
Tabla 10: Santos de la Reconquista: Santiago

\begin{tabular}{|c|c|c|c|c|c|c|c|}
\hline & Castigador & $\begin{array}{l}\text { Defensor/ } \\
\text { Protector }\end{array}$ & Mensajero & Guerrero & Rescatadores & Legitimador & Fuentes \\
\hline \multicolumn{8}{|l|}{1000} \\
\hline \multicolumn{8}{|l|}{1110} \\
\hline 1120 & & $X$ & & & & & - CS/L p. 136 \\
\hline 1130 & & $X$ & & & & & $\begin{array}{l}\text { - HC Libro I p. } 63 \text { Cap. } 2 \text { p. } \\
71,73,75 \text { Cap. } 15 \text { p. } 96,97 \\
\text { Cap. } 76 \text { p. } 186 \text { Libro } 3 \text { Cap. } \\
18 \text { p. } 521\end{array}$ \\
\hline 1140 & $\mathrm{X}$ & $\mathrm{X}$ & $\mathrm{X}$ & $\mathrm{X}$ & $\mathrm{X}$ & $\mathrm{X}$ & $\begin{array}{l}\text { - CAI Libro II } \mathrm{n}^{\circ} 22 \text { p. } 102, \\
\mathrm{n}^{\circ} 26 \text { p } 103, \mathrm{n}^{\circ} 69 \text { p. } 116 \\
\text { - LSJ Libro I Cap. } 15 \text { p. } 16, \\
\text { Cap. } 16 \text { p. } 168, \text { Cap. } 20 \text { p. } \\
\text { 245, Libro II Cap. } 1 \text { pp. } 331, \\
\text { 332, Cap. } 7 \text { pp. } 345,346, \\
\text { Cap. } 19 \text { pp } 375,376, \text { Cap. } 22 \\
\text { p. } 383 \text {, Libro IV Cap. } 1 \text { p. } \\
414\end{array}$ \\
\hline \\
\hline 1160 & & & & & & & \\
\hline 1170 & & & $X$ & & & & $\begin{array}{l}\text { - CN Libro III n }{ }^{\circ} 7 \text { pp. } 165 \text {, } \\
166 .\end{array}$ \\
\hline \multicolumn{8}{|l|}{1180} \\
\hline \multicolumn{8}{|l|}{1190} \\
\hline \multicolumn{8}{|l|}{1200} \\
\hline \multicolumn{8}{|l|}{1210} \\
\hline \multicolumn{8}{|l|}{1220} \\
\hline 1230 & & $\mathrm{X}$ & $X$ & $X$ & & & $\begin{array}{l}\text { - CM Libro IV Cap. } 17 \\
\text { p.290, Cap. } 18 \text { p. } 292 \text {, Cap. } \\
51 \text { pp. } 349,350 . \text { Cap. } 79 \text { p. } \\
\text { 394, Cap. } 91 \text { pp } 424.425 \\
\text { - MSI Cap } 32 \text { p. } 53 \text {, Cap. } 5 \\
\text { p. } 125\end{array}$ \\
\hline 1240 & & $\mathrm{X}$ & & $X$ & & & $\begin{array}{l}\text { - HRH Libro IV Cap. } 13 \text { p. } \\
\text { 177, Libro V Cap. } 11 \text { p. } 202 \text {, } \\
\text { Cap. } 12 \text { p. } 203 \text {, Cap. } 16 \text { pp. } \\
207,208 .\end{array}$ \\
\hline 1250 & & & & $X$ & & & $\begin{array}{l}\text { - PFG n }{ }^{\circ} 404-412 \text { p. } 290, \mathrm{n}^{\circ} \\
546-548 \text { pp. } 305,306 .\end{array}$ \\
\hline 1260 & & $\mathrm{X}$ & & & & & $\begin{array}{l}\text { - MNS Cap. } 8 \text { pp. } 40-42 . \\
\text { - VSM Libro II n } 437-449 \\
\text { pp. } 410-412\end{array}$ \\
\hline 1270 & & $X$ & $X$ & $\mathrm{X}$ & & & $\begin{array}{l}\text { - CGE. Cap. } 629 \text { pp. } 359 \text {, } \\
360 \text { Cap. } 698 \text { p. } 401 \text {, Cap. } \\
726 \text { p. } 425 \text {, Cap. } 807 \text { p. } 487 \text {, } \\
\text { Cap. } 1044 \text { p. } 727 \quad \text { - CC p. } \\
92 \\
\text { - CXXR Libro III Cap. } 4 \text { p. } \\
\text { 100, Libro VIII Cap. } 6 \text { p. } 168\end{array}$ \\
\hline \multicolumn{8}{|l|}{1280} \\
\hline \multicolumn{8}{|l|}{1290} \\
\hline 1300 & & & & & & & \\
\hline
\end{tabular}




\section{III.2.d.- San Isidoro}

Como ya se ha adelantado, San Isidoro de Sevilla, también cumplió un rol gravitante dentro del imaginario religioso hispano medieval. El obispo visigodo, junto con Santiago, compartió el lugar como símbolo de la lucha contra el Islam y de la reconstrucción del antiguo reino cristiano peninsular ${ }^{957}$. Es en ese sentido que los cronistas, influenciados por el "goticismo" llevarán a San Isidoro desde los altares a la frontera.

San Isidoro siempre se mantuvo en la memoria hispánica medieval, vinculado al recuerdo de la unidad política y el apogeo cultural del Reino Visigodo. Esta imagen comenzó a cambiar a partir del siglo XI, cuando en Sevilla, se repotenció el culto al santo y luego en 1063 su cuerpo fue trasladado a León, momento en que su figura se vinculó a la monarquía leonesa y se comenzaron a recopilar milagros y portentos vinculados al santo visigodo ${ }^{958}$. Posteriormente es a partir del siglo XII que la imagen de San Isidoro experimenta la consolidación de su figura, ya no como intelectual y teólogo, sino como "enviado celeste"959. Al igual que Santiago, el santo sevillano experimenta una radical trasformación, que coincide con el avance de la Reconquista, las luchas entre León y Aragón y la necesidad de consolidar el poder de los monarcas y la iglesia local.

Es así como se puede aprecia en el gáfico número 6, la mayor parte de las apariciones de San Isidoro se pueden encontrar principalmente en las crónicas entre los años 1220 y 1240 . Son especialmente los textos de Lucas de Tuy y Jiménez de Rada los que desarrollan las intervenciones del santo visigodo, en especial en su rol de legitimador del cristianismo y los monarcas hispanos. Encontrándose en algunos testimonios significativos, también en las crónicas Silense, Najerense, General y de Veinte reyes. De ellas se puede concluir que en los momentos de mayor actividad reconquistadora, San Isidoro regresó para acompañar a los monarcas en sus luchas,

${ }^{957}$ Ver gráfico y tabla ${ }^{\circ} 3$.

958 La trasladación de las reliquias de Isidoro desde la musulmana Sevilla hasta León fue un hito fundamental en la devoción de santo y un claro ejemplo de la importancia política del culto a las reliquias. Fernando I supo hacer un destacado uso de los santos despojos y de la devoción popular hacia ellos. Al apoderarse de las reliquias del sevillano sabía que estaba accediendo a una herramienta poderosa, que protegía su reino, pero además legitimaba sus actos. Si Isidoro había sido símbolo del catolicismo y la intelectualidad visigodas, era lógico que aquellos que se proclamaban como continuadores del extinto reino contase con la patronato del obispo, que además que con su presencia paralizaba la ciudad de León, convirtiéndola en un foco espiritual que podía rivalizar con Compostela (Fernández Conde, Francisco Javier, La Religiosidad Medieval... op. cit., p. 40; y De Ayala, Carlos, "Fernando I y la sacralización... op. cit., pp. 88-95.

${ }_{959}$ Martín, José Carlos, “El corpus hagiográfico... op. cit., pp. 222- 225. 
simbolizando que el antiguo santo visigodo, por medio de su protección, reconocía a los monarcas como miembros de su linaje y justos reclamadores de las tierra de los $\operatorname{godos}^{960}$.

\section{Gráfico 11: Santos de la Reconquista: Isidoro}

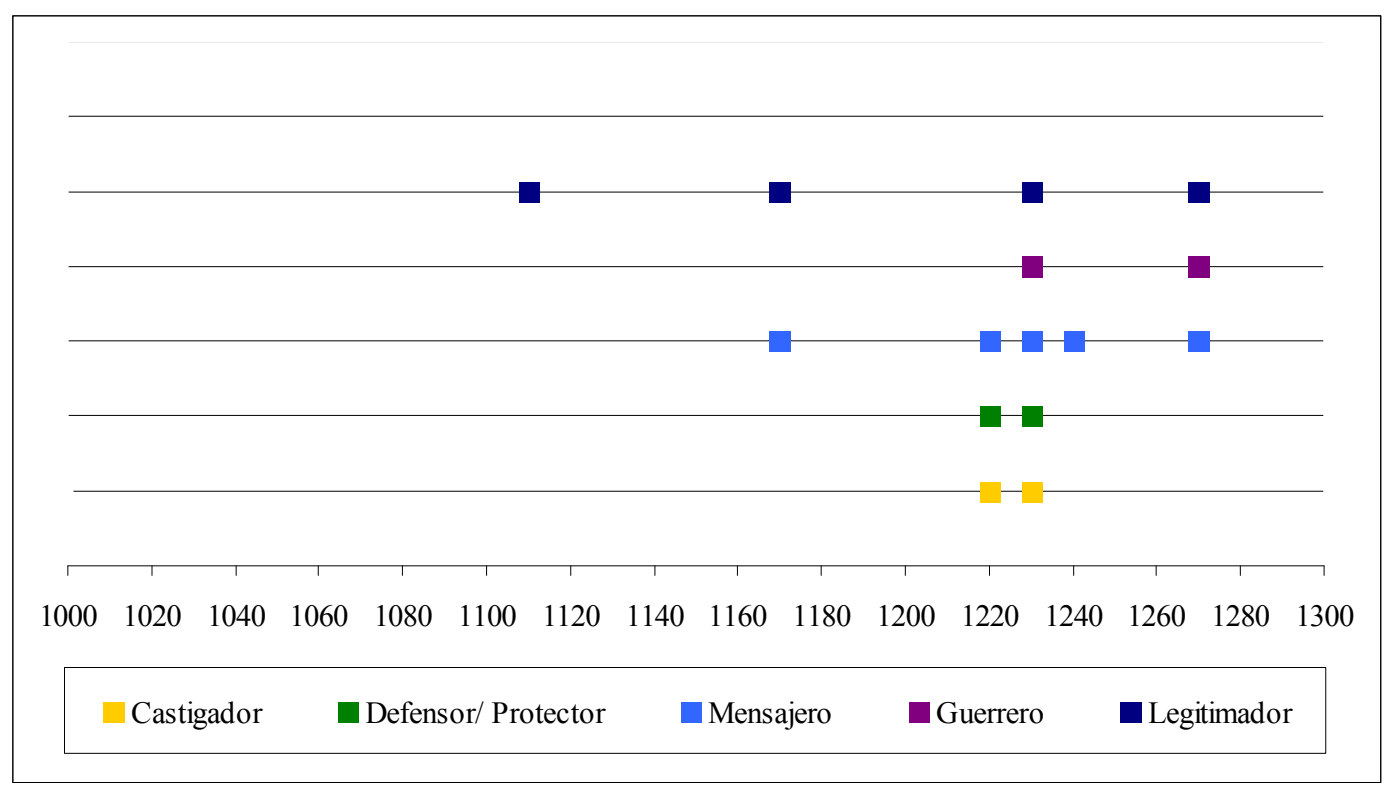

San Isidoro se presenta, entonces, como un santo principalmente legitimador, mientras que sus otros roles de protector, guerrero, mensajero y castigador, no se encuentran muy bien definidos, abarcando distintas categorías al mismo tiempo. No obstante, trataremos de ejemplificar estas distintas actuaciones providenciales.

\section{Legitimador}

Para que la figura de San Isidoro se adaptase al rol legitimador, era necesario construir un mito que señalase sus potestades. Dicho mito se estructuró a partir de la milagrosa aparición de sus reliquias en la Sevilla andalusí.

Al igual que en el caso de Santiago, muchas crónicas se hacen eco del milagroso suceso, pero su punto de partida parece estar en la Crónica Silense. En el texto, así como otros que le sucedieron, se relata cómo Fernando I - mismo rey favorecido por la acción de Santiago en el cerco de Coimbra - deseaba hacer traer desde Sevilla, los cuerpos de algunos mártires, para exaltar la gloria de la ciudad de Léon que estaba destinada a convertirse en su capital, de tal forma que la tierra donde se asentaba su

\footnotetext{
${ }^{960}$ Ver gráfico y tabla ${ }^{\circ} 6$.
} 
trono estuviese sacralizada y de paso obtener un contrapeso a la creciente influencia de Compostela $^{961}$.

Se acordó con el líder musulmán de Sevilla la entrega del cuerpo de Santa Justa y se envió en su búsqueda a Aluito, Obispo de León, junto al Obispo de Astorga y una delegación de magnates ${ }^{962}$. Los emisarios son autorizados por el rey de la ciudad para buscar los restos, pero pasan los días y los despojos no son hallados. Una noche se aparece en sueños al Obispo Aluito, San Isidoro, quien le indica dónde se encuentra su tumba y le ordena que lleven sus restos a León en lugar de los de la santa ${ }^{963}$.

Los emisarios encuentran el cuerpo de San Isidoro, del cual, según la Crónica de veinte reyes, emanaba un bálsamo milagroso, de propiedades curativas, y emprenden el viaje de regreso a León ${ }^{964}$.

Como última prueba de la santidad del cuerpo, según Lucas de Tuy, la historia toma tintes dramáticos. Los sevillanos, al conocer los milagros de las reliquias, deciden robarlos y envían un grupo de guerreros a perseguir a los cristianos. Es entonces cuando San Isidoro interviene, confundiendo la mente de los musulmanes, quienes en vez de atacar a los emisarios, los saludan y regresan a Sevilla. En el camino de regreso recobraron el juicio y retomaron la persecución, pero esta vez es Dios el que interviene

\footnotetext{
${ }^{961}$ Fernández Conde, Francisco Javier, La Religiosidad Medieval ... op. cit., p. 40.

962 CN, Liber III, N 10, op. cit., p. 164; CM, Liber IV, cap. LV, op. cit., pp. 291; HRH, Liber VI, cap. XII, op. cit., p. 192; y CXXR, Libro VIII, cap. IX, op. cit., p. 171.

963 "Interea dum residens sella sustentare paulisper fessa membra atque recitans secum necio quid de Psalmis, opprimeretur sommo prae nimio labore vigiliarum, ei apparuit quidam vir comptus veneranda canitie, amictus infula pontificali que alloquens eum tali voce, ait: Scio quidem venisse te cum tuis sociis ad hoc, ut ducatis vobiscum transferentes hinc corpus beatissimae virginia Justae. Sed quoniam non est divinae voluntatis ut haec civitas desoletur abscesuu humus virginia, immensa pietas Dei non patiens remitiere vos vacuos, est donatum vobis deum corpus, tollentes quod remeate ad propria. Quem quum reventas vir interrogaret, quis esset qui talia sibi injungeret, ait. Ego sum doctor Hispaniarum Isidorus antistes hujusmondi urbis. Dicens haec evanuit ab oculis cernetis." CS 1913. op. cit., p. 152. "Entre tanto como sentado en la silla sustentase un poco los cansados miembros y recitando consigo no sé que de los salmos, fuese oprimido por el sueño por el mucho trabajo de las vigilias, se le apareció cierto varón adornado de veneranda canicie, vestido con la infula pontificia y hablándole con tal voz, le dice: Sé cierto haber venido tú con tus socios para esto, que conduzcáis con vosotros trasladando de aqui el cuerpo de la beatísima virgen Justa. Mas porque no es de la divina voluntad que esta ciudad sea desolada con la retirada de esta virgen, la inmensa piedad de Dios no sufriendo enviaros vacios, es donado á vosotros mi cuerpo, llevando el cual volved al propio país. Al cual como reverendo varón interrogara, quién fuese el que tales cosas le mandase, dice: Yo soy el doctor de las Españas Isidoro prelado de esta urbe. Diciendo esto se desvaneció de los ojos del espectador." CS. en Las Crónicas latinas de la Reconquista, Tomo II, op. cit., p. 152.

964 Según José Carlos Martín, en su articulo ya citado, es posible que todo el capítulo del traslado del cuerpo de Isidoro fuese una historia inventada, puesto a que es posible Fernando I había pactado la entrega con al-Mu'tadid, ello en razón de que para los cluniacenses - que ya influyera en la Corte leonesa - fuese más útil el cuerpo de Isidoro que el de santa Justa, con el fin de aumentar el poder de la diócesis de León. En razón de que a mayor poder de la reliquia más era el poder para quien al poseyera. Además Isidor era un símbolo de la unidad de Hispania y por lo tanto fácil de instrumentalizar para los planes de Fernando I.
} 
haciendo invisibles a los cristianos, por lo que, al no poder encontrarlos, los musulmanes regresan a Sevilla ${ }^{965}$.

Quizás el hecho más interesante del relato radica en que es el propio santo el que ordena el rescate y traslado de su cuerpo. Lo que bien puede ser interpretado como su voluntad por bendecir a León y a sus monarcas y consagrarse como su protector ${ }^{966}$.

Como evidencia el gráfico número 6, pese al contexto del mito, y a sus similitudes con los relatos jacobeos, San Isidoro, a diferencia de Santiago, no fue una figura caracterizada por su acción bélica, siendo sus principales funciones la de ser un mensajero, legitimador y un protector. Funciones que en muchos casos, como ya mencionamos, se sobreponen entre si, en las distintas fuentes.

\section{Mensajero}

En su rol de mensajero, San Isidoro se aparece a distintos personajes para advertirles de peligros o anunciar victorias ${ }^{967}$. En esas situaciones, sus intervenciones siguen los mismos parámetros que las de Santiago, es decir, sus apariciones vienen a reconfortar y proteger a los líderes cristianos, convirtiéndose así en símbolos de validación. Un primer ejemplo de ésto es relatado por Jiménez de Rada, quien en su crónica narra cómo el santo sevillano se le aparece al rey Fernando I para anunciarle su pronta muerte ${ }^{968}$. El hecho puede ser interpretado como una señal del favor divino hacia el rey, puesto que el anuncio de su propia muerte era una recompensa por sus actos en vida ya que le permitía preparase para el buen morir ${ }^{969}$. De esta forma, San Isidoro cumple el rol de premiar al monarca y señalar la bendición de Dios sobre el soberano y su estirpe.

En una situación similar, San Isidoro bendice con su anuncio a Alfonso VI. El suceso se produce durante la campaña del rey contra Toledo, cuando san Isidoro, rodeado de una corte de ángeles, se apareció ante Cibrían, Obispo de León,

\footnotetext{
${ }^{965}$ MSI, cap IV, op. cit., pp. 10.

966 El episodio de Isidoro es similar a lo que ocurría con Santiago, quien según distintas versiones, también se convierte voluntariamente en protector de Hispania, lo que quedaría demostrado en los mensajes que envía para que su cuerpo sea redescubierto, entre otras señales.

${ }^{967}$ Ver gráfico y tabla ${ }^{\circ} 6$.

${ }^{968}$ HRH, Liber VI, cap. XIII, op. cit., pp. 193, 194.

${ }^{969}$ En su relato Jiménez de Rada dedica especial atención a relatar la muerte de Fernando I, describiendo con todo detalle como el rey se hizo acompañar de los clérigos, realizó penitencia y oraciones, recibió los sacramentos y oró ante la tumba de Isidoro, para finalmente morir en estado de gracia. Destaca además el hecho de que "el Toledano" acompañe su relato con piadosas descripciones sobre la agonía del rey, como son, por ejemplo, el que participase en los maitines, a pesar de su debilidad, o que se hiciese conducir a la iglesia para despojarse de las insignias reales atente el sepulcro de Isidoro. Todo ello para construir una narración en extremo laudatoria que se sella con la afirmación de que a su muerte el rey "reddidit Deo spiritum inmaculatum".
} 
vaticinándole que, gracias al favor divino, la ciudad se entregaría al rey, y que gracias a su intercesión, los “moros" serían expulsados, restituyendo a Toledo su honra cristiana. Como señal de veracidad, el santo le comunica al obispo que dentro de un mes él morirá y que quince días después de su deceso, la antigua capital visigoda se entregaría a Alfonso $^{970}$.

El anuncio es más que simbólico, puesto que es el santo más importante de la Hispania visigoda el que comunica la pronta reconquista de la antigua capital del reino, por medio de un soberano que mediante este acto, según las crónicas, señala la recuperación del espíritu del extinto reino germano. Por tanto, todo el episodio es parte de un discurso legitimador que pretendía enlazar a Alfonso VI con la tradición gótica y para ello se instrumentaliza la imagen del doctor de Hispania, que es precisamente un símbolo de la unificación religiosa de los godos y de la santidad de Hispania.

\section{Legitimador /Mensajero}

Posteriormente, el sucesor de Alfonso VI, Alfonso VII, recibiría en distintas ocasiones la visita de San Isidoro. La primera de ellas se produjo durante la expedición a Almería. En esa ocasión el santo se aparece al rey y le promete la victoria contra los musulmanes $^{971}$. Lo interesante de este suceso, es que es un testimonio tardío, aportado por Jiménez de Rada y que no aparece en la Chronica Adefonsis Imperatoris, por lo que todo parece indicar que el episodio es parte del discurso goticista de "el toledano". No obstante, nosotros consideramos más significativa la segunda aparición, relatada por Lucas de Tuy, en el contexto de la campaña de Alfonso contra el castillo de Montoso. Durante el cerco de la fortaleza, el rey cristiano se ve agobiado. Debido a la disminución de sus huestes, ha quedado en desventaja con respecto a los musulmanes, que ahora amenazaban con cercarlo a él. Alfonso ruega a Dios por auxilio y estando en eso es vencido por el sueño, momento en que se le aparece san Isidoro y le anima a luchar prometiéndole la victoria ${ }^{972}$.

\footnotetext{
${ }^{970}$ CE, Libro IV, cap. LXX, op. cit., p. 375; y MSI, Capítulo XVI, op. cit., p. 27.

${ }^{971}$ HRH, Liber VII, cap. XI, op. cit., p. 232.

972 "[...] y apareciéndole vn varon cano de hermosas canas, vestido de vestidura obispal, cuya cara resplandeçia como el sol muy claro, çerca del qual, en la mano derecha, se blandía vn cuchillo de fuego que cortaua de amos cabos, y hablandole blanda y mansamente, por estas palabras, le dixo: 'Alfonso, ¿por qué dubdas?; todas las cosas son possibles al emperador Christo, nuestro Dios; mas ¿vees tú esta muchedunbre de moros?; en amanesciendo, como fumo se desfará delante de tu cara, porque yo, que soy de tu linaje, soy dado por guarda a ti y a los que vernan si anduuieredes delante dél en fee non fingida y coraçon acabado.' Dixole el emperador: ‘Quién eres tú, padre sancto, que tales cosas me fablas?' 'Yo soy —dixo él-Ysidoro, doctor de las Españas, succesor en graçia y en predicaçión del bienauenturado
} 
Lo significativo de esta aparición, es que San Isidoro se presenta con todos los atributos de santidad, como un rostro resplandeciente y una espada de fuego - un elemento muy vinculado con el imaginario de los guerreros de Dios -. Además comparte el espacio y misión con Santiago, de quien se declara su sucesor. San Isidoro no sólo vaticina la victoria del emperador, sino que además valida su ascendencia al presentarse como miembro de su mismo linaje, es decir, es un reconocimiento a la herencia goda del soberano y también a su ascendencia cristiana. Fusionando entonces, tres grandes virtudes constructoras del poder real, la herencia, la religión y la bendición de Dios, en este caso, recibida a través de San Isidoro.

\section{Mensajero / Protector}

Después de estas apariciones, ninguno de los sucesores de Alfonso VII fue bendecido por alguna intervención de San Isidoro, al menos no de manera tan espectacular. Habrá que esperar hasta Fernando III para que el santo visigodo vuelva a intervenir directamente ${ }^{973}$. El episodio es rescatado por Lucas de Tuy, Jiménez de Rada y replicado en la Crónica General y la Crónica de veinte reyes. En todas estas fuentes, el suceso que se relata es muy similar: San Isidoro se aparece al tesorero de su iglesia en León - en otras ocasiones el protagonista es un sacristán - para anunciarle que una fuerza de andalusíes atacará Ciudad Rodrigo y que debía avisarle de ello al rey Fernando III"974: "Set dicitur sanctus isidorus custodi sacrorum sue ecclesie aduentum predicti principis et Arabum reuelasse, ut et ipse regi Fernando similiter reuelaret; et rex Fernandus audiens egit gracias, in continenti properans ad subsidium absessorum" "975. El clérigo notificó al soberano quien salió al auxilio de la ciudad “confiado en el Señor", llegando justo a tiempo para salvar a la urbe, asestando una fuerte derrotada a los atacantes y tomando gran cantidad de cautivos.

Significativo es el hecho de que, a diferencia de sus antecesores, el rey Fernando III nunca vió directamente al santo. Sin embargo, su aparición y mensaje le son útiles al soberano, puesto que le permiten una victoria que contribuye a su consolidación en el poder.

\footnotetext{
Jacobo Apostólo; esta mano derecha es de esse Apostólo Jacobo, defenssor de España." Y dichas estas cosas, la visión se arrebató." CE, Libro IV, cap. LXXIX, op. cit., p. 394.

${ }^{973}$ Ver gráfico y tabla ${ }^{\circ} 6$.

${ }^{974}$ MSI, cap. XLIV, op. cit., p. 83; HRH, Liber VII, cap. XXI, op. cit., 243; PCG, cap. 994, op. cit., p. 674; y CXXR, Libro XIII, cap. XI, op. cit., p. 275.

${ }^{975}$ HRH, Liber VII, cap. XXI, op. cit., p. 243. "Pero se cuenta que San Isidoro anuncio al sacristán de su iglesia la llegada del citado noble y los árabes, para que él se lo anunciara a su vez de la misma forma al rey Fernando; y al enterarse éste, dio gracias, corriendo al punto a socorrer a los asediados." HEH, Libro VII, cap. XXI, op. cit., p. 290.
} 


\section{Protector / Castigador}

Lucas de Tuy, en su recopilación de milagros sobre San Isidoro, rescata diversos episodios en los cuales, si bien el santo tiene una intervención más beligerante, estas son descritas dentro de su faceta de protector. En otras palabras, el santo no solía protagonizar cabalgatas, ni participar directamente en batallas, pero sí castigaba a quienes atentaban contra su Iglesia o contra la fe en general, fuesen estos musulmanes o cristianos.

Respecto a los musulmanes, destacan dos episodios. El primero se vincula con el sepulcro del santo en Sevilla y el segundo se relaciona con las acciones de Miramamolín. En el primer relato se narra que debido a que los cristianos de la ciudad acostumbraban a rezar en la iglesia del santo, el líder almohade ordenó la destrucción del recinto, cuyas piedras fueron usadas para la construcción de mezquitas. Pero el santo se vengó del ultraje cuando un alfaquí subió al minarete construido con las piedras de su tumba, el clérigo cayó y murió. Lo mismo ocurrió con un segundo alfaquí. Finalmente un anciano y respetado alfaquí, comenzó a difamar a San Isidoro, pero cuando subió a la torre fue levantado por los aires y arrojado al suelo, de manera que nadie más se atrevió a subir al minarete ${ }^{976}$.

El segundo ejemplo nos narra que Miramamolín, ordenó excavar en la tumba del santo en búsqueda de un tesoro, pero a los obreros se les pasmaron los brazos y cuando lo volvieron a intentar sus huesos se quebraron aparatosamente. El caudillo ordenó traer nuevos obreros, pero cuando éstos empezaron su trabajo se les reventaron las entrañas, ante lo cual, los musulmanes desistieron de profanar el sepulcro ${ }^{977}$.

Las grotescas muertes de los musulmanes y que bien pueden tener una intencionalidad infamante, contrastan con los castigos más dignos, pero no por eso menos duros, contra los cristianos que se hubiesen atrevido a agredir la memoria de San Isidoro.

"El Tudense" relata dos episodios de esta índole, ambos relacionados con las luchas entre Alfonso VII y Alfonso de Aragón. En el primer suceso, el santo descarga su ira debido a que el rey de Aragón y el conde Enrique de Portugal habían saqueado su iglesia. Al primero de ellos, lo castigó a través de horribles pesadillas que lo perturbaron, en tanto que al portugués le envío una fiebre permanente, así como dio muerte a sus dos caballos predilectos. Posteriormente, la furia del santo continuó,

\footnotetext{
${ }^{976}$ MSI, caps. XX, XXI, op. cit., pp. 34-36.

${ }^{977}$ MSI, caps. XX, XXI, op. cit., pp. 34-36.
} 
ensañándose contra el "Batallador", puesto que, según refiere el autor, el rey encontró la muerte en la batalla de Fraga, en castigo a sus profanaciones en contra de San Isidoro ${ }^{978}$.

Estas sanciones en contra de magnates cristianos, deben de ser entendidos como una forma de demostrar el favoritismo de la providencia hacia Alfonso VII, en esos momentos rey de Castilla y León, y por lo tanto, siguen en la línea de validar a los gobernantes de esos reinos, de igual forma que lo hará en los siguientes casos a tratar.

"El Tudense" también nos narra cómo el Obispo de Sevilla protegió a Alfonso IX de León y, posteriormente, a su hijo Fernando III. En el primer caso, San Isidoro ayudó al rey leonés a apoderase de Mérida y se les apareció a los habitantes de Zamora para anunciarles que debían auxiliar al monarca. Con respecto al rey Fernando III, la ayuda celestial es descrita más detalladamente. El portento ocurre en el marco del acceso al trono de León por parte del hijo de Alfonso IX. Un noble, don Diego, se opone al nuevo monarca y se atrinchera en la iglesia de San Isidoro anexa al palacio real. Pero San Isidoro envía una enfermedad a don Diego. Al reconocer el noble la naturaleza de su mal, decide rendirse ${ }^{979}$.

Estos dos episodios, estrechamente relacionados, son quizás el ejemplo más claro de las intenciones de Lucas de Tuy, por validar al rey Fernando III, a través del uso de la figura de San Isidoro, como parte de la devoción popular en Castilla y León. El cronista comienza narrando la victoria de Alfonso sobre Mérida, gracia a la protección providencial del santo visigodo, para luego relatar, cómo es que el rey Fernando logra ocupar el trono de su padre ${ }^{980}$. Un acto legal y legítimo en vista de que nuevamente San Isidoro interviene para proteger al rey neutralizando a sus enemigos. De esta manera, la guerra, el linaje y la religión, son unidos claramente como los elementos de legitimación real, a través de los milagros de San Isidoro.

El último milagro a destacar en la obra de Lucas de Tuy, no hace referencia directa al poder real, ni a la guerra de Reconquista, pero es clave para la configuración de San Isidoro como paladín de la cristiandad contra el Islam en Hispania. El episodio en cuestión narra el mítico viaje de Mahoma - descrito por el autor como un "hereje endiablado, lleno de grandes pecados y maldades" $" 981$ - a Hispania en tiempos de San

\footnotetext{
${ }^{978}$ MSI, caps. XXVII, XXIX, op. cit., pp. 45, 47.

${ }_{979}$ MSI, cap. V, op. cit., pp. 125, 126.

980 Muñoz Fernández, Ángela, "Cultos, Devociones y Advocaciones Religiosas en los Orígenes de la Organización Eclesiástica Cordobesa (siglos XIII-XIV)", en Cabrera, Emilio (Coordinador), Andalucía entre Oriente y Occidente (1236-1492)... op. cit., p. 139; De Ayala Martínez, Carlos, Sacerdocio y Reino en la España ... op. cit., p. 286.

${ }^{981}$ MSI, cap. IX, op. cit., p. 133
} 
Isidoro. Al enterarse el obispo, envía a sus hombres a arrestar a Mahoma, pero el diablo advirtió a Mahoma del peligro, quien escapa y regresa a África. El relato termina con la narración de cómo, gracias a san Isidoro, Hispania fue salvada de la doctrina de Mahoma $^{982}$.

Este último episodio convierte a San Isidoro en un paladín, y más concretamente, en un "Anti-Mahoma". El santo habría sido el primer cristiano en enfrentar y derrotar al Islam, demostrando su debilidad ante lo que los cronistas entendían como "la verdadera" fe. Un discurso que se engloba dentro de la construcción ideológica de la guerra de Reconquista en los siglos XII y XIII.

Como se puede apreciar en el gráfico y tabla número 6, la mayoría de los relatos en torno a San Isidoro se encuentran concentrados en las obras de Lucas de Tuy y Jiménez de Rada, durante el siglo XIII. Un hecho que coincide con las grandes campañas de la Reconquista, desde Las Navas a las victorias del rey Fernando III. Pero también se producen en el momento de consolidación de la ideología "gótica". Es en estos eventos que debemos interpretar el "renacimiento" de la figura de San Isidoro. El obispo visigodo, precursor del cristianismo y valuarte de la Iglesia en Hispania. Se trata de un santo godo y por lo tanto símbolo de un discurso político, religioso y "nacional", que servía para validar a los reyes, sus reinos y acciones. De esta forma, San Isidoro y Santiago, conforman una dupla santa al servicio de la Reconquista castellano leonesa.

${ }^{982}$ MSI, cap. IX, op. cit., pp. 133-135. 
Tabla 11: Santos de la Reconquista: Isidoro

\begin{tabular}{|c|c|c|c|c|c|c|c|}
\hline & Castigador & \begin{tabular}{|l} 
Defensor/ \\
Protector
\end{tabular} & Mensajero & Guerrero & Rescatadores & Legitimador & Fuentes \\
\hline \multicolumn{8}{|c|}{\begin{tabular}{|l|l}
1000 & \\
\end{tabular}} \\
\hline 1110 & & & & & & $\mathrm{X}$ & - CS/L p.152 \\
\hline \multicolumn{8}{|l|}{1120} \\
\hline \multicolumn{8}{|l|}{1130} \\
\hline \multicolumn{8}{|l|}{1140} \\
\hline \multicolumn{8}{|l|}{1150} \\
\hline \multicolumn{8}{|l|}{1160} \\
\hline 1170 & & & $\mathrm{X}$ & & & $\mathrm{X}$ & $\begin{array}{l}\text { - CN Libro III } n^{\circ} 10 \\
\text { p. } 169\end{array}$ \\
\hline \multicolumn{8}{|l|}{1180} \\
\hline \multicolumn{8}{|l|}{1190} \\
\hline \multicolumn{8}{|l|}{1200} \\
\hline \multicolumn{8}{|l|}{1210} \\
\hline 1220 & $X$ & $X$ & $X$ & & & & $\begin{array}{l}\text { - MSI Cap. } 4 \text { p. } 10, \\
\text { Cap. } 20 \text { pp. } 34,35,3,3 \\
\text { Cap. } 23 \text { pp. } 38,39,3 \\
\text { Cap. } 27 \text { p.45, Cap. } 5 \\
\text { pp. } 125,126, \text { Cap.9 } \\
\text { pp. 133-135. }\end{array}$ \\
\hline 1230 & $X$ & $X$ & $X$ & $X$ & & $\mathrm{X}$ & $\begin{array}{l}\text { - CM Libro IV Cap } \\
\text { 53 pp.351-353, Cap } \\
\text { 55 p. 356, Cap 70 p. } \\
\text { 375, Cap. } 73 \text { p. } 387, \\
\text { Cap. } 79 \text { p. } 394, \text { Cap. } \\
\text { 91 p. } 425 \text {, Cap. } 92 \text { p. } \\
\text { 426 } \\
\text { - MSI Cap. } 4 \text { p. } 10, \\
\text { Cap. } 16 \text { pp. } 27,28, \\
\text { Cap. } 20 \text { pp. } 34,35, \\
\text { Cap. } 21 \text { pp. } 35,36, \\
\text { Cap. } 32 \text { p. } 53, \text { Cap. } 44 \\
\text { p. } 83, \text { Cap. } 5 \text { p. } 125\end{array}$ \\
\hline 1240 & & & $\mathrm{X}$ & & & & $\begin{array}{l}\text { - HRH Libro VI Cap. } \\
13 \text { p. } 236 \text {, Libro VII } \\
\text { Cap. } 11 \text { p. } 278 \text {, Cap } \\
21 \text { p. } 290 .\end{array}$ \\
\hline \multicolumn{8}{|l|}{1250} \\
\hline \multicolumn{8}{|l|}{1260} \\
\hline 1270 & & & $X$ & $X$ & & $X$ & $\begin{array}{l}\text { - CGE Cap. } 994 \text { p. } \\
\text { 673, } 674 \\
\text { - CXXR Libro VIII } \\
\text { Cap. } 9 \text { p. } 171 \text {, Libro } \\
\text { XIII Cap. } 11 \text { p. } 275 \\
\end{array}$ \\
\hline 1280 & & & & & & & \\
\hline 1290 & & & & & & & \\
\hline 1300 & & & & & & & \\
\hline
\end{tabular}




\section{III.2.e.- Santa María}

Una figura del cristianismo universal que destaca en el escenario peninsular es la Virgen María, que por sus apariciones y popularidad, bien puede rivalizar con otros patronos como Santiago y San Isidoro ${ }^{983}$, con la salvedad de que, a diferencia de ellos, sus intervenciones se limitan esencialmente a la protección en distintas variantes, como la liberación de cautivos, la solución de amenazas fronterizas y la salvaguarda lugares $\operatorname{atacados}^{984}$.

Tal como se aprecia en el siguiente gráfico, las intervenciones de la Virgen se hicieron muy frecuentes en el siglo XIII, siendo protagonista del ciclo alfonsí, no obstante su accionar puede ser observado ya en las crónicas del ciclo asturiano. En su rol como protectora, esta relación entre Santa María y los combatientes hispanos, se encuentra en los orígenes mismos de la Reconquista en la batalla de Covadonga ${ }^{985}$. Señalando este aspecto como su principal caracterización en los relatos cronísticos, en tanto que otros roles como el de rescatador, guerrero, legitimador y guerrero se encuentran prácticamente ausentes hasta la aparición de las obras alfonsíes, razón por la cual nos centraremos en la faceta de protectora de la Virgen.

\footnotetext{
${ }^{983}$ Ver gráfico y tabla ${ }^{\circ} 4$

${ }^{984}$ Lomax, Dereck, La Reconquista, op. cit., p. 138.

Vinculado a la popularidad de María y a su posición destacada dentro de la devoción hispánica, se destaca el hecho de fue considerada patrona de Toledo. Sobre este tema, Klaus Herbers, en su texto Política y veneración de santos en la Península Ibérica. Desarrollo del "Santiago político", detalla las disputas entre la iglesia de esta ciudad y Compostela, por lograr imponer el patronazgo de sus respectivos santos y además asegurar el primado de Hispania. Una disputa que fue especialmente intensa en el siglo XII y que solo se logró cuando el IV Concilio de Letrán dio la primacía a la ciudad del Tajo.

Desde Toledo se acusó a Compostela de tratar de imponer unas reliquias robadas, además de que su arzobispado era de reciente data (1124) y en cambio la diócesis toledana podía ostentar esa categoría desde el tiempo de los visigodos. Ambas diócesis trataron de influir en los monarcas, buscando aliados para sus disputas y para ello fueron claves las acciones de los cronistas, que con sus relatos contribuían a acrecentar la fama de los santos y sus diócesis, convirtiendo así una disputa religiosa, en un conflicto político, que se servia de lo militar.

${ }^{985}$ El episodio de Covadonga aparece en casi todas las crónicas de los siglos XII y XIII, así como en anteriores. Para esta reseña nos hemos basado en las siguientes: Crónica de Alfonso III, Versión a Sebastian, op. cit., p. 204, Cronicon Mundi, Libro IV, cap IV, op. cit., pp. 276, 277; y Crónica General, Libro II, p. 322-324.
} 
Gráfico 12: Santos de la Reconquista: La Virgen María

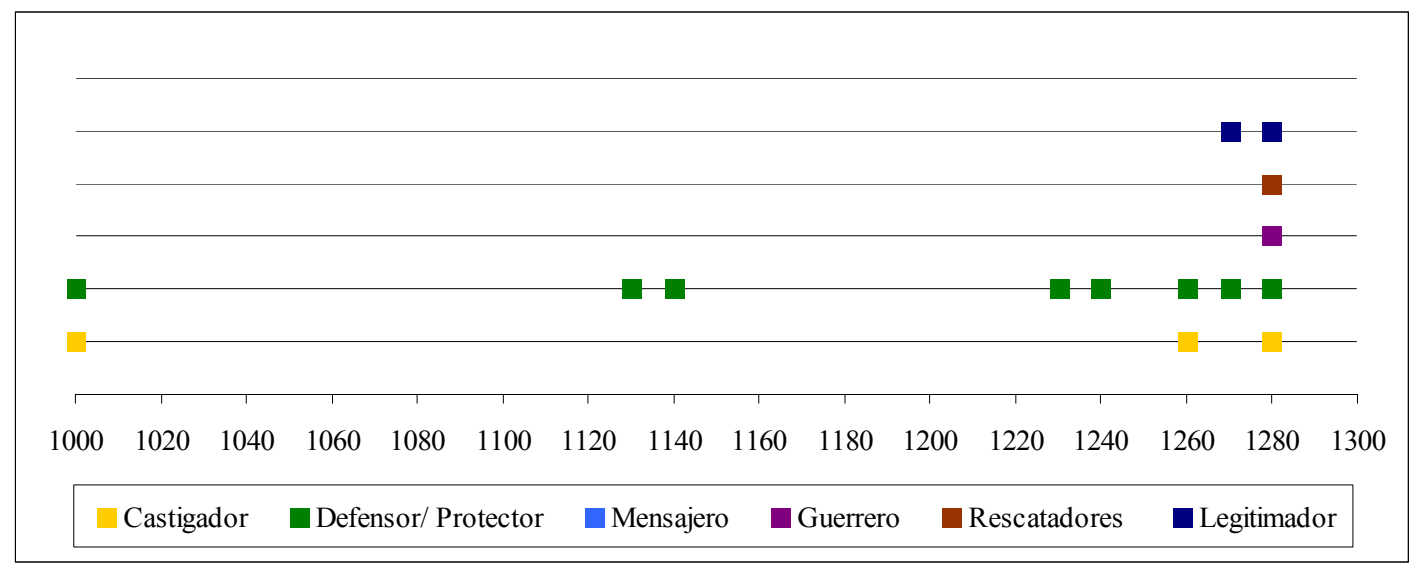

La batalla de Covadonga señala claramente el rol de la Virgen en la guerra, puesto que ella - quien no se le aparece a Pelayo, ni interviene directamente - protege a quienes se refugiaban al amparo de su templo, pero sin tomar una acción agresiva, puesto que los proyectiles se devuelven, pero no son lanzados por la Virgen. Finalmente, su intervención cesa cuando los atacantes se retiran y es Dios, quien realiza la acción punitiva y violenta. De esta manera, los cronistas consagran la figura de Santa María como la madre protectora, la que amparaba a sus fieles, al mismo tiempo que evitaban manchar su imagen con la sangre de sus enemigos.

Este milagro se encuentra enlazado con las raíces míticas de la Reconquista y por lo tanto es observable en prácticamente todas las crónicas que rescatan el mito de Pelayo, convirtiendo así, a la Virgen María, en la valedora de la monarquía asturiana y de sus sucesores.

María, según la Naiarensis, también intervino en la lucha fraticida entre García III y Ramiro I de Aragón ${ }^{986}$. En esta ocasión la Virgen se aparece en sueños a García anunciándole su victoria sobre su hermano:

"Garcias uero sollicitus de pugna, confidens in Domino, dum in quídam ecclesia paruula que intra caueam loco quod nunc est Naiarensem monasterium erat in honore Beate Marie uirginis dicata pernoctans, sompno correptus dormiuit et futurum bellum se uicturum per sompnium Domino reulante cognouit ${ }^{987}$.

\footnotetext{
986 El relato de la Naiarensis proviene originalmente, tal como nos recuerda Klinka, de la Historia Silensis (Klinka, Emmanuelle, “Chronica naiarensis: de la traición... op. cit.).

${ }_{987}$ CN, 1995, Liver III, N 3, op.cit., pp. 151, 152. "garcía, preocupado por el combate, confiando en el Señor, mientras oraba de noche en una iglesia pequeñita consagrada a Santa maría la Virgen - que está dentro de una cueva en el lugar en el que ahora se asienta el monasterio de Nájera -, rendido por el sueño se quedó dormido y en sueños supo por revelación divina que ganaría la guerra que iba a tener lugar”. CN, 2003, Libro III, n³, op. cit., pp. 159, 160.
} 
El relato valida así la victoria de García sobre su hermano y legitima su reinado. Al mismo tiempo que explica las vinculaciones que tendría el condado castellano con María y su culto, expresado a través de monasterios como el de Santa María la Real.

Jiménez de Rada también destaca la ayuda de la Virgen en otro de los grandes hitos bélicos de la Reconquista, Las Navas de Tolosa. En esta ocasión, la Virgen tampoco tiene un rol protagónico como guerrera, pero sí como protectora de los combatientes. Es así como el arzobispo nos relata que: "Erat autem in uexillis regum imago beate Marie Virginis, que Toletane prouincie et tocius Hispanie samper tutrix extitit et patrona" ${ }^{\text {988 }}$. Esta referencia a la Virgen y a su relación con los símbolos del poder no es un detalle menor, puesto que aparte del episodio del pastor y las múltiples referencias a Dios, María es la única personalidad providencial identificada en el contexto de la batalla y el cronista utiliza su mención para aforar su patronazgo sobre Toledo, pero también sobre toda España, en claro detrimento de Santiago y Compostela.

En cuanto a los otros roles de la Virgen, fueron Gonzalo de Berceo, en su Milagros de Nuestra Señora, y Alfonso X, en sus Cantigas, quienes aportaron gran cantidad de episodios - de los cuales sólo seleccionamos unos ejemplos representativos - dedicados a glorificar a Santa María, como protectora de los cristianos hispanos, pero siempre evitando relacionarla con la realización directa de actos violentos, consolidando así su figura e influencias como parte integral de la religiosidad política y militar hispana $^{989}$. Ambos autores rescatan episodios similares. En el milagro XVI, del texto de Berceo, se relata cómo un niño judío que había comulgado, vio una aparición de la Virgen de la cual se enamoró. Su padre al saberlo "Pessóli esto mucho al mal aventurado, Como si lo toviesse muerto o degollado: Non sabia con gran ira que fer el endiablado, Fazie figuras malas como endemoniado" ${ }^{990}$. El relato continúa con el padre arrojando a su hijo a un horno, donde la Virgen, impide que se queme y luego el pueblo, reconociendo el milagro, hace lo mismo con el judío, que muere abrasado ${ }^{991}$.

Por lo anterior, es palpable la relación entre Santa María y los niños, entendidos como el símbolo de la inocencia. Otro ejemplo de ello se aprecia en la Cantiga 323, donde se narra cómo, previo a la caída de Coria en manos de los benimerines, un niño

\footnotetext{
${ }^{988}$ HRH, Liber VIII, cap. X, op. cit., p. 273. "En los estandartes de los reyes figuraba la imagen de Santa María Virgen, que siempre fue protectora y patrona de la provincia de Toledo y de toda España." HHE, Libro VIII, cap. X, op. cit., p. 322.

${ }^{989}$ Ver gráfico y tabla $\mathrm{n}^{\circ} 7$.

${ }^{990}$ MNS, XVI, $\mathrm{N}^{\circ} 361$, op. cit., p. 72.

${ }^{991}$ MNS, XVI, N $352-377$, op. cit., pp. 70-74.
} 
muere y su familia debe abandonar el hogar dejando el cadáver expuesto a los saqueadores. Cuando los africanos se retiran y la familia regresa a su morada encuentran la casa intacta y al niño vivo, quien les narra que "una señora" había estado con él y lo había protegido de los "moros"992.

En el mismo texto de Berceo, en el milagro XVIII, se relata cómo en la Catedral Toledo, durante la fiesta de la Asunción, una imagen de la Virgen comenzó a llorar y luego habló para alertar a los cristianos sobre un grupo de rabinos que se burlaba de Cristo, crucificando una efigie de cera suya ${ }^{993}$. Los cristianos ingresaron a la judería, allanaron las casas de los principales rabinos y dándoles muerte por la profanación ${ }^{994}$.

En otras ocasiones, la acción de la Virgen, es similar a la de Covadonga. En ese sentido en las Cantigas destacan dos episodios. En el primero de ellos, la Virgen María protege a la ciudad de Constantinopla, en ese momento atacada por fuerzas musulmanas ${ }^{995}$. Y en la misma línea del caso anterior, se encuentra el relato del cerco al castillo de Chincoya. Los defensores, apremiados por la superioridad de los musulmanes fueron a buscar una imagen de la Virgen y la colocaron sobre el muro, reclamándole su protección:

“'Ontr' as amēas, dizendo: I 'Se tu es Madre de Deus, / 75. deffend' aqueste castello I e a nos, que somos teus, / e guarda a ta capela | que non seja encreus / mouros en poder, nen façan I a ta imagen arder.'

Poder á Santa Mariah I grande d' os seus acorrer...

E leixárona dizendo: | 'Veremo lo que fáras.' / 80. Entonç' os conbateadores I tornaron todos atrás; / e tres mouros que entraran, I chus negros que Satanas, / no castelo, os de dentro I os fezeron en caer Poder á Santa Maria I grande d' os seus acorrer [... $]^{1996}$.

A primera vista, llama la atención la actitud de los cristianos, que en una suerte de desafío exigen a la Virgen protegerlos, pero que también confían tanto en ella que abandonan las murallas. Sus ruegos son escuchados y los asaltantes de los muros caen

\footnotetext{
992 CSM, Cantiga 323. op. cit.

993 "Oid - dixo - cristianos, una extraña cosa: la gent de iudaismo, sorda e cegaiosa, Nunqua contra don Cristo no fo más porfiosa. Secundo que nos dizen las sanctas Escripturas, Finieron en don Cristo mui grandes travesuras: Taiava essa cuita a mí las assaduras: Mas en ellos quebraron todas las sus locuras. [...] 419. Los que mala nacieron falssos e traidores, Agora me renuevan los antigos dolores, En grand priesa me tienen e en malos sudores, En cruz está mi Fijo, luz de los peccadores”. MNS, XVIII, N416, 418, op. cit., p. 82.

${ }^{994}$ MNS, XVIII, N413-430, op. cit., p. 82-85; y CSM, Cantiga 12, op.cit, p. 137.

${ }_{995}$ CSM, Cantiga 28, op.cit, pp. 183-187.

${ }^{996}$ CSM, Cantiga 184, op.cit, p. 599.
} 
ultimados, mas en ningún momento se dice que es la Virgen quien los liquida - de hecho las muertes no se explican - pero sí se afirma que los musulmanes se retiran al reconocer que el castillo estaba protegido por Santa María. Un episodio que, a nuestro juicio, nuevamente resalta a la madre de Cristo como pulcra, protectora y validadora de la lucha de los cristianos.

Este milagro se vincula con una particular situación producida por los avances de la Reconquista. A medida que las fuerzas cristianas iban ocupando las tierras andalusíes, se multiplicaban los relatos de hallazgos de imágenes de la Virgen, unas veces esculturas en otras pinturas, pero a las que siempre se les daba la misma interpretación. Representaban el antiguo dominio cristiano sobre esas tierras, las mismas que eran sacralizadas por las imágenes halladas, que además vaticinaban la pronta reconquista del territorio. A ello se sumaban los relatos, como el de la Cantiga 184, que convertían a estas imágenes en manifestación físicas de la protección y amparo que la Virgen hacía sobre los cristianos y sus recintos ${ }^{997}$.

Tal como se aprecia en el gráfico número 7, como ente protector la Virgen no podía dejar de lado a quiénes más sufrían las penas de la guerra, los cautivos. En estas ocasiones los milagros de liberación por ella protagonizados se asemejan a los protagonizados por Santo Domingo, puesto que en la mayoría de los casos los cautivados son gente modesta y alejada de la profesión de las armas. Así, las situaciones de liberación son similares: un cautivo desolado ruega a Santa María por ayuda y la Virgen se le aparece para darle la libertad, a través de diferentes medios ${ }^{998}$. Dentro de sus liberaciones destaca el relato de la Cantiga 325, en donde una manceba cautivada debe elegir, entre la conversión al Islam y riquezas, o el cautiverio que le ofrece su ama $^{999}$. Lo notable de este milagro es el doble peligro que amenazaba a la cautiva. Puesto que si no accedía a los deseos de sus captores quedaría condenada a una vida de miserias y si lo hacía y apostataba se condenaría. Es así como la intervención de la Virgen no sólo salva su cuerpo, sino que también su alma.

También en la obra alfonsí, aunque en menor medida, se relata cómo la Virgen ayudaba a los guerreros en acciones ofensivas, es decir en una faceta guerrera. Ejemplo de ello se aprecia en la Cantiga 374, en donde se narra cómo un grupo de incursores en territorios andalusíes, los llamados almogávares, atribuyen su mala fortuna a sus

\footnotetext{
${ }^{997}$ Rodríguez Molina, José, "Santos Guerreros en la Frontera... op. cit., p. 456; García Flores, Antonio, “"Fazer batallas a los moros... op. cit., pp. 270, 271; y González Jiménez, Manuel, "La Frontera de Granada... op. cit., p. 230.

${ }_{998}$ Ejemplo de ello se puede observar en las Cantigas 83, 176, 215, 277 y 325, entre otras.

${ }^{999}$ CSM, Cantiga 325, op.cit, p. 193.
} 
pecados. Por ello hicieron una vigilia dedicada a Santa María y prometieron a la Virgen lo mejor del botín. Gracias a ello fueron recompensados por la Virgen que les otorgó el éxito en su siguiente incursión ${ }^{1000}$. Como se puede apreciar en este episodio, si bien la Virgen protege a quienes cometen violencia contra los musulmanes, ella no participa directamente de la misma, limitándose a ser facilitadora de la victoria, con lo que su rol de madre benefactora no violenta quedaba intacto ${ }^{1001}$.

Alfonso X también incorporó relatos, donde él era coprotagonista junto a la Virgen. Ejemplo de ello se observa en relación a la revuelta mudéjar, cuando los "moros" de Jerez se apoderan de la ciudad y prenden fuego a la capilla de la guarnición, que contenía una imagen de Santa María. El rey sueña con la imagen de la Virgen en llamas, que suplica por su honra y la de su hijo. Situación que lleva a Alfonso a recuperar la ciudad y restablecer la capilla e imagen quemadas. En otra ocasión, en la Cantiga 366, se le atribuye a la Virgen María la recuperación de la enfermedad que afectaba al rey, y que le impedía hacer frente a la amenaza que implicaba la ofensiva de los musulmanes ${ }^{1002}$.

Estos episodios, si bien son parte de la devoción mariana de Alfonso X, también se pueden explicar debido a la necesidad de asociar su compungido reinado a un fuerte patronazgo que contribuyese a sostener su cuestionado poder y para ello que mejor protector que la madre de Dios, un personaje que ya ostentaba una larga relación como valedora y protectora de los monarcas hispanos en su lucha contra el Islam, y al cual buena parte de los monarcas de Castilla y León mostraron su devoción através de la restauración o fundación de Iglesias y Monasterios con su nombre o dirigiéndose a ella en momentos de necesidad.

\footnotetext{
${ }^{1000}$ Cantiga 374 en González Jiménez, Manuel, "La Frontera de Granada en las Cantigas... op. cit., p. 237.

${ }^{1001}$ En la Cantiga 99 se narra como María protegió a un poblado cristiano y desbando a los musulmanes que pretendían atacarlo, siendo esta una de las contadas ocasiones en que se vincula a la Virgen de forma directa con un hecho del tipo bélico, aunque no s especifica como es que María realizó el milagro.

1002 Procter, Evelyn, Alfonso X of Castile... op. cit., pp. 34, 35.
} 
Tabla 12: Santos de la Reconquista: La Virgen María

\begin{tabular}{|c|c|c|c|c|c|c|c|}
\hline & Castigador & $\begin{array}{l}\text { Defensor/ } \\
\text { Protector }\end{array}$ & Mensajero & Guerrero & Rescatadores & Legitimador & Fuentes \\
\hline 1000 & & $\mathrm{X}$ & & & & & $\begin{array}{l}\text { - CAIII Rotense } n^{\circ} 9 \text { p. } \\
\text { 204. CAIII Sebastian } n^{\circ} \\
9 \text { p. } 205 .\end{array}$ \\
\hline \multicolumn{8}{|l|}{1110} \\
\hline \multicolumn{8}{|l|}{1120} \\
\hline 1130 & & $\mathrm{X}$ & & & & & - HC Libro I p. 63 \\
\hline 1140 & & $\mathrm{X}$ & & & & & $\begin{array}{l}\text { - CAI Libro II } n^{\circ} 22 \text { p. } \\
102 n^{\circ} 26 \text { p. } 103\end{array}$ \\
\hline \multicolumn{8}{|l|}{1150} \\
\hline \multicolumn{8}{|l|}{1160} \\
\hline \multicolumn{8}{|l|}{1170} \\
\hline \multicolumn{8}{|l|}{1180} \\
\hline \multicolumn{8}{|l|}{1190} \\
\hline \multicolumn{8}{|l|}{1200} \\
\hline \multicolumn{8}{|l|}{1210} \\
\hline \multicolumn{8}{|l|}{1220} \\
\hline 1230 & & $X$ & & & & & $\begin{array}{l}\text { - CM Libro IV Cap } 4 \\
\text { pp. } 276,277\end{array}$ \\
\hline 1240 & & $X$ & & & & & $\begin{array}{l}\text { - HRH Libro VIII Cap. } \\
10 \text { p. } 322\end{array}$ \\
\hline \multicolumn{8}{|l|}{1250} \\
\hline 1260 & $\mathrm{X}$ & $\mathrm{X}$ & & & & & $\begin{array}{l}\text { - MNS Cap. } 16 \text { pp.70- } \\
74 \text {, Сap. } 18 \text { pp. } 82-84 .\end{array}$ \\
\hline 1270 & & $\mathrm{X}$ & & & & $\mathrm{X}$ & - CGE Cap.568 p. 323 \\
\hline 1280 & $\mathrm{X}$ & $\mathrm{X}$ & & $X$ & $\mathrm{X}$ & $X$ & $\begin{array}{l}\text { - CSM n } 12 \text { p. } 137, \mathrm{n}^{\circ} \\
28 \text { pp. } 183-187, \mathrm{n}^{\circ} 325, \\
\text { pp. } 192,193, \mathrm{n}^{\circ} 329 . \mathrm{n}^{\circ} \\
83 \text { pp. } 340,341, \mathrm{n}^{\circ} 99 \\
\text { p. } 383, \mathrm{n}^{\circ} 176 \text { p. } 577, \\
\mathrm{n}^{\circ} 185 \text { p. } 599, \mathrm{n}^{\circ} 215 \text { p. } \\
675, \mathrm{n}^{\circ} 227 \text { p. } 704, \mathrm{n}^{\circ} \\
373 \text { p. } 310,311,366\end{array}$ \\
\hline 1290 & & & & & & & \\
\hline 1300 & & & & & & & \\
\hline
\end{tabular}




\section{III.2.f.- Santos de la frontera}

Si bien pueden contarse dentro de las figuras celestes más importantes, los santos Santiago e Isidoro no son los únicos en el escenario de la Reconquista. Las características de este proceso propiciaron la aparición de otras figuras, las que comparten características en común encontradas en personajes nativos de Hispania, los que, en algunos casos, fueron contemporáneos a la lucha y recuperación de los territorios cristianos. En otras palabras, son personajes hispánicos, más que visigodos, que vivieron entre los siglos VI y XI y que a su muerte fueron convertidos, por la devoción popular, en santos protectores de aquellos que vivían en la frontera.

Entre estos "Santos de la frontera", destacan - dentro del escenario castellano leonés - especialmente los hermanos San Facundo y San Primitivo, San Millán de la Cogolla y Santo Domingo de Silos ${ }^{1003}$. En su conjunto, estos santos se caracterizan por realizar sus intervenciones en los escenarios fronterizos, concentrandose especialmente en la liberación y protección de cautivos.

Los "Santos de la Frontera" son figuras populares a las que se les encomendaba la protección de aquellos que caían en las manos de los musulmanes. Especialmente se trata de cautivos provenientes de sectores aldeanos o no combatientes y que además parecían no tener los recursos para gestionar su propia liberación. Son por lo tanto, santos vinculados a los grupos más populares de la población, quienes eran los más afectados por la dinámica de guerra propia de las cabalgatas. En relación a ello podemos inferir que los santos de la frontera son la contraparte más humilde de los santos Isidoro y Santiago, potentados celestiales que solían acudían en ayuda de reyes y magnates en el contexto de grandes hechos como batallas y conquistas. Por el contrario, los santos: Millán, Domingo y otros, protegen al personaje simple, de una de las principales amenazas de la cotidianidad de la Reconquista, la captura y el sometimiento al infiel.

En vista de lo anterior, es posible plantear que estas figuras celestes son parte activa del discurso de la Reconquista. Como sabemos en la dinámica de la lucha en Hispania no bastaba con la derrota del Islam, era necesario ocupar el espacio con cristianos, para así lograr la posesión efectiva del territorio. Era pues necesario garantizar la protección de aquellos que se aventuraban a ocupar los territorios. Parte de esa protección era física y venía dada por las milicias y guerreros. No obstante tambien era fundamental dar una protección ideológica y espiritual. Es allí donde se explica el

${ }^{1003}$ Ver gráfico y tabla ${ }^{\circ} 4$ 
surgimiento del culto de estos santos, que se popularizan entre los siglos XI y XIII, momentos en que la actividad de la Reconquista se acrecentó ${ }^{1004}$. La Iglesia, a través de hagiografías, ayudó a popularizar a estos santos, estableciendo la creencia de que, aquellos que vivían en la frontera, contaban con la protección celeste. De esta forma se pretendía estimular al establecimiento de colonos que sirvieran a los intereses de la repoblación, impulsando a la monarquía y favoreciendo las donaciones e influencias para los monasterios e iglesias que contuviesen sus reliquias.

\section{III.2.g.- Santo Domingo de Silos}

Uno de los santos vinculados a la frontera y a las situaciones relacionadas, como el cautiverio, fue Santo Domingo de Silos. Como se aprecia en el siguiente gráfico, sus apariciones son atestiguadas inicialmente en torno al año 1110, en la Vita Dominici Silensis, la cual coincide con la época inmediatamente posterior a la irrupción almorávides y con la muerte de Alfonso VI, es decir la ralentización de la Reconquista y el establecimiento de una etapa netamente fronteriza. Luego de una larga interrupción, Santo Domingo vuelve a aparecer en las fuentes, específicamente a partir del Cronicon Mundi, convirtiéndose en un personaje recurrente en los textos posteriores, especialmente en los trabajos hagiográficos de Gonzalo de Berceo y Pero Marin. En dichas obras, el santo es presentado esencialmente como "el rescatador de cautivos" por excelencia, coincidiendo su nueva popularidad, con la reactivación de la guerra peninsular y, por lo tanto, el aumento de eventos como el cautiverio, sirviendo así como estímulo y consuelo para los guerreros cristianos ${ }^{1005}$.

\footnotetext{
1004 García de la Borbolla, Ángeles, "Santo Domingo de Silos, el santo de la frontera. La imagen de la santidad a partir de las fuentes hagiográficas castellano-leonesas del siglo XIII", en Anuario de Estudios Medievales, 31-1, 2001, [pp. 127-145], pp. 138, 139; Herbers, Klaus, Política y veneración de santos... op. cit., p. 34; Lida de Malkiel, María Rosa, La Idea de la Fama en la Edad Media Castellana, Madrid, Fondo de Cultura Económica, 1952, pp. 134, 135; y Calderón Ortega, José Manuel y Francisco Javier Díaz González (Compiladores), Vae Victis... op. cit., pp. 276, 277.

${ }^{1005}$ El santo habría sido originario de Navarra, donde nació alrededor del año 1000, es decir poco tiempo antes del colapso del Califato. Ingreso a la orden benedictina en el monasterio de san Millán, desde donde tuvo que salir debido a sus disputas con el rey García Sánchez III de Navarra. Debido a ello se traslado a Castilla donde se radicó en el monasterio de san Sebastián de Silos (Posteriormente llamado de Santo Domingo), bajo la protección de Fernando I, que lo puso como abad del mismo, cargo que ocupó hasta su muerte en 1073.
} 
Gráfico 13: Santos de la Reconquista: Santo Domingo de Silos

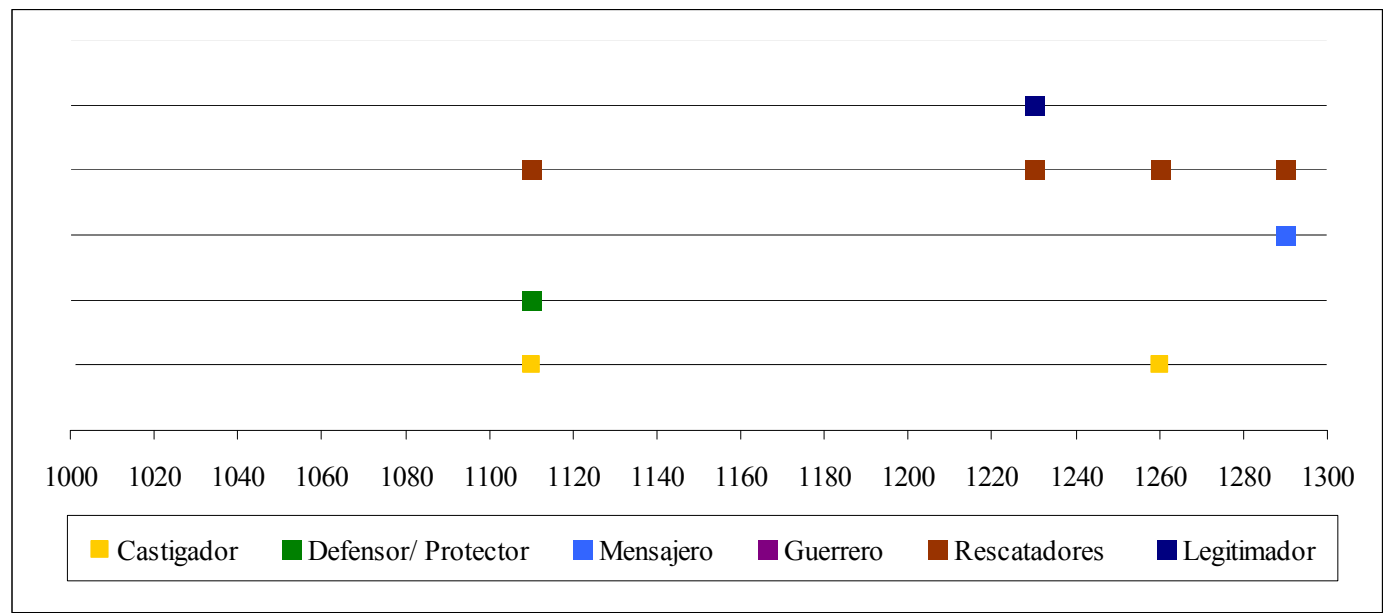

Ya durante su vida, según autores como Grimaldo y Gonzalo de Berceo, el santo se caracterizó por su vida piadosa y su preocupación por los cautivos cristianos, a muchos de los cuáles ayudó a liberar. Luego de su muerte, Santo Domingo continuó con esa piadosa misión, apareciéndosele a los cautivos, para ayudarles a escapar. De acuerdo con García de la Borbolla, la importancia de Santo Domingo, en relación a los cautivos, se puede apreciar en el texto de Pero Marín, en dónde de un total de noventa y un milagros, sólo nueve no se vinculan al tema del cautiverio. Todo el resto están dedicados a narrar episodios de liberación, siendo las víctimas, en su mayoría, caballeros o campesinos capturados ${ }^{1006}$.

De esta forma, el santo se convirtió en un importante símbolo religioso, cuyas acciones contribuyeron a la gloria de Silos. A continuación se exponen algunos ejemplos de las providenciales acciones de Santo Domingo, ocurridas tanto durante su vida, como después de su muerte.

En una ocasión, los musulmanes cautivaron a un tal "Domingo" y lo sometieron a duro cautiverio: "Metiéronlo en fierros, en dura cadena, De lazrar, é fanme dábanle fiera pena, Dábanle yantar mala, é non buena la çena, Cambríe si gelo diesen, de grado pan d'avena" ${ }^{1007}$. A cambio de su libertad los captores exigieron un importante rescate que parecía imposible de pagar, razón por la cual sus familiares acudieron a Santo Domingo de Silos. El abad les entregó un caballo para que, con su venta, obtuviesen los recursos para el rescate. Luego, los familiares, el santo y los monjes, rezaron por el éxito de la operación. El relato continúa narrando cómo Dios escuchó los

\footnotetext{
${ }^{1006}$ García de la Borbolla, Ángeles, "La Espiritualidad de los Cautivos...op. cit., pp. 260, 261.

1007 VSD, $\mathrm{N}^{\circ} 354-371$, op. cit., pp. 246-250.
} 
ruegos y libero al cautivo: "Abriéndose los fierros en que yaçíe travado, El corral nol" retovo, que era bien çerrado: Tornó á sus parientes de los fierros cargado. Façíese él mismo d'ello maravillado". Como colorario, se relata cómo el ex-cautivo llegó a Silos y allí narró su odisea, revelando que el momento de su milagrosa liberación coincidió con la hora en que el santo oraba por su liberación ${ }^{1008}$.

Milagrosa también, fue la forma en que Santo Domingo evitó la huida de unos musulmanes cautivos que estaban al servicio del monasterio. Ellos habían roto sus cadenas, y se habían dado a la fuga escondiéndose en una cueva. En ese momento, la Providencia le advirtió en sueños a Santo Domingo de lo ocurrido. Entonces, el abad reunió a los monjes y luego de cumplir con la obligación de las primeras oraciones, les ordenó iniciar la persecución de los cautivos. Pese al gran esfuerzo realizado, los persecutores no los pudieron encontrar, y ahí es cuando Santo Domingo, “confiando enteramente en el Señor, y con la guía del Espíritu Santo", se dirigió directamente a la cueva en donde se encontraban los cautivos, quienes fueron así recapturados ${ }^{1009}$.

Con posterioridad a la muerte del santo, se multiplican sus milagros, ahora como enviado de la Providencia. Por lo general, sus intervenciones se relacionaron directamente con el rescate de cautivos y siguen más o menos el mismo patrón mencionado con anterioridad ${ }^{1010}$. Lo realmente significativo es la forma en que muchos cautivos fueron liberados, puesto que se trataba de milagros bastante "simples y poco espectaculares".

A modo de ejemplo, se refieren a continuación dos episodios, de entre las docenas que existen. El primer caso se trata de un tal Pedro, que fue capturado durante una cabalgata. Cargado de cadenas, fue encerrado en una cueva, allí el cautivo rezó a Dios, suplicando ayuda. Durante la noche se le apareció Santo Domingo, que se identifica como: "Yo so faire Domingo, pecador de verdat, En la casa de Silos fui yo dicho abat. Dios grant merçed me fizo por su piedad, Que me puso en guarda sobre la christiandat, Que saque los cativos de la catividad, Los que á él se claman de toda voluntad" ${ }^{\text {"1011. A }}$ continuación, Santo Domingo le indicó a Pedro que al día siguiente lo liberaría cuando sus cadenas se abrirían solas. ${ }^{1012}$.

\footnotetext{
${ }^{1008}$ VSD, No $354-371$, op. cit., pp. 246-250.

${ }^{1009}$ VDS, $\mathrm{N}^{\circ}$ XVI, op. cit., pp. 282-285.

1010 En la VDS se describen, entre las paginas 357 y 517, distintos relatos de liberación de cautivos, algunos de los cuales se observan en otros textos hagiográficos como la obra de Berceo o de Pero Marin, pero en todos ellos se puede observar un denominador común en la forma de la liberación.

${ }^{1011}$ VSDS, $\mathrm{N}^{\circ} 716,717$, op. cit., p. 314.

1012 VSDS, $\mathrm{N}^{\circ} 716,717$, op. cit., p. 314.
} 
Otro milagro, es el que protagonizó otro cautivo llamado Servando. En el relato nuevamente se repite el esquema, el pobre cristiano es encadenado, humillado y sometido a un trato de abusos y hambre. El cautivo ora a Dios y en la noche se le aparece Santo Domingo, quien luego de despejar las dudas de cautivo, lo libera: “diolí un madero, De fuste era todo, non fierro nin azero, molió todos los fierros con ese dulz madero [...]". Al llegar a las murallas, el fugitivo se vió paralizado por no tener con qué escalarlas, pero nuevamente recibió la ayuda de Santo Domingo, quien: "[...] que de suso sedie, Echóli una soga, á mano la tenie, Ciñóse bien el preso, que de yuso yazíe, El cabo de la soga el otro lo ternié". Así, el santo subió al cautivo, quien pudo continuar con su huida, ya que los guardias de las puertas estaban dormidos. ${ }^{1013}$.

Con respecto a los casos anteriores, curiosa es la liberación que relata Pero Marin, entre tantas otras, puesto que en esta ocasión se trata de un caso de cautiverio entre cristianos. Es lo ocurrido con un tal Pascual de Encino, que debido a una deuda, se encontraba preso del merino Sancho Martínez. Al igual que los cautivos en manos de los musulmanes, Pascual se encomendó a Dios y Santo Domingo acudió en su ayuda, liberándolo de forma similar a como se liberaba a los cautivos de los musulmanes ${ }^{1014}$.

La simplicidad o mundanidad de los milagros, quizás se debieron a que en realidad se trató de escapes comunes, pero que tanto la piedad del prófugo o bien la creencia popular convirtieron en episodios maravillosos. Bien podría tratarse de relatos construidos por los cronistas y hagiógrafos con el propósito de glorificar al santo y beneficiar al monasterio que contenía sus reliquias. Además de ello, nosotros no podemos negarnos a una instrumentalización política de la devoción popular, pues como ya dijimos anteriormente, los santos de la frontera ayudaban a suplir los temores y las carencias de los habitantes fronterizos y de esta forma contribuían a la repoblación territorial, según las necesidades de la guerra y la corona.

A las liberaciones de Santo Domingo se sumaban otros milagros, como la curación de enfermos, lo que también es atestiguado en diversas obras hagiográficas. Por lo tanto, el santo reunía una serie de potestades, entre ellas era liberador, justiciero en el sentido de que liberase o auxiliase a cristianos en desgracia por causa de otros cristianos - y taumaturgo. Es decir, poseía una seria de virtudes que la tradición cristiana y popular relacionaban con la santidad y que por lo tanto eran esenciales de difundir

${ }^{1013}$ VSDS, $\mathrm{N}^{\circ}$ 652-662, op. cit., pp. 302-306.
${ }^{1014} \mathrm{MR}, \mathrm{N}^{\circ}$ 1090-1110, op. cit., pp. 77, 78. 
para validar la figura del santo y de esa manera poder fomentar su culto y su instrumentalización al servicio de los intereses de la Reconquista ${ }^{1015}$.

Tabla 13: Santos de la Reconquista: Santo Domingo de Silos

\begin{tabular}{|c|c|c|c|c|c|c|c|}
\hline & Castigador & \begin{tabular}{|l} 
Defensor/ \\
Protector \\
\end{tabular} & Mensajero & Guerrero & Rescatadores & Legitimador & Fuentes \\
\hline \multicolumn{8}{|c|}{ 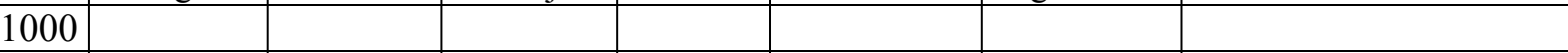 } \\
\hline 1110 & $X$ & $\mathrm{X}$ & & & $\mathrm{X}$ & & $\begin{array}{l}\text { - VDS Libro I Cap. } 16 \\
\text { p. } 283 \text {, Libro II Cap. } 21 \\
\text { pp. } 357-361 \text {, Libro III } \\
\text { Cap. } 36 \text { p. } 517-519 .\end{array}$ \\
\hline \multicolumn{8}{|l|}{1120} \\
\hline \multicolumn{8}{|l|}{1130} \\
\hline \multicolumn{8}{|l|}{1140} \\
\hline \multicolumn{8}{|l|}{1150} \\
\hline \multicolumn{8}{|l|}{1160} \\
\hline \multicolumn{8}{|l|}{1170} \\
\hline \multicolumn{8}{|c|}{1180} \\
\hline \multicolumn{8}{|l|}{1190} \\
\hline \multicolumn{8}{|l|}{1200} \\
\hline \multicolumn{8}{|l|}{1210} \\
\hline \multicolumn{8}{|l|}{1220} \\
\hline 1230 & & & & & $\mathrm{X}$ & $\mathrm{X}$ & - CM Prologo pp. 4-7 \\
\hline \multicolumn{8}{|l|}{1240} \\
\hline \multicolumn{8}{|l|}{1250} \\
\hline 1260 & $\mathrm{X}$ & & & & $\mathrm{X}$ & & $\begin{array}{l}\text { - VSD Cap. } 2 \mathrm{n}^{\circ} 366- \\
373, \text { pp. } 249,250, \\
\text { Cap. } 3 \mathrm{n}^{\circ} 652-662 \text { pp. } \\
302-304, \mathrm{n}^{\circ} 707-729 \\
\text { pp. } 312.316 .\end{array}$ \\
\hline \multicolumn{8}{|l|}{1270} \\
\hline \multicolumn{8}{|l|}{1280} \\
\hline 1290 & & & $\mathrm{X}$ & & $\mathrm{X}$ & & $\begin{array}{l}-\mathrm{MR} \mathrm{n}^{\circ} 28, \mathrm{n}^{\circ} 1090- \\
1110 \text { pp. } 77,78\end{array}$ \\
\hline 1300 & & & & & & & \\
\hline
\end{tabular}

1015 Es importante recordar que no solo Santo Domingo tenía estas virtudes, ya que eran comunes para otros santos como los ya estudiados Santiago e Isidoro, así como para otros como san Millán y la Virgen María, solo por nombrar algunos. 


\section{III.2.h.- San Millán de la Cogolla}

Otro santo que gozó de reputación como protector de cautivos fue San Millán de la Cogolla. Éste fue un ermitaño que, si bien habría vivido en el siglo VI, comenzó a ganar una notable fama a partir del siglo X, razón por la cual lo asociamos a los "santos de frontera", no obstante los relatos escritos en torno a su figura se concentran en el siglo XIII ${ }^{1016}$. Acciones que fueron narradas por Braulio de Zaragoza, autor de la Vida de San Millán de la Cogolla, y por Gonzalo de Berceo, quien compuso un texto del mismo nombre, incluido en su serie de hagiografías redactadas en la segunda mitad del siglo XIII ${ }^{1017}$. Nosotros nos centraremos primeramente en sus manifestaciones como guerrero que incluso lo llevaron a rivalizar con Santiago por el patronazgo de Castilla y a compartir algunos de sus símbolos como el luchar montado y armado de espada y en segundo lugar su actuar como liberador de cautivos ${ }^{1018}$.

\section{Gráfico 14: Santos de la Reconquista: San Millan de la Cogolla}

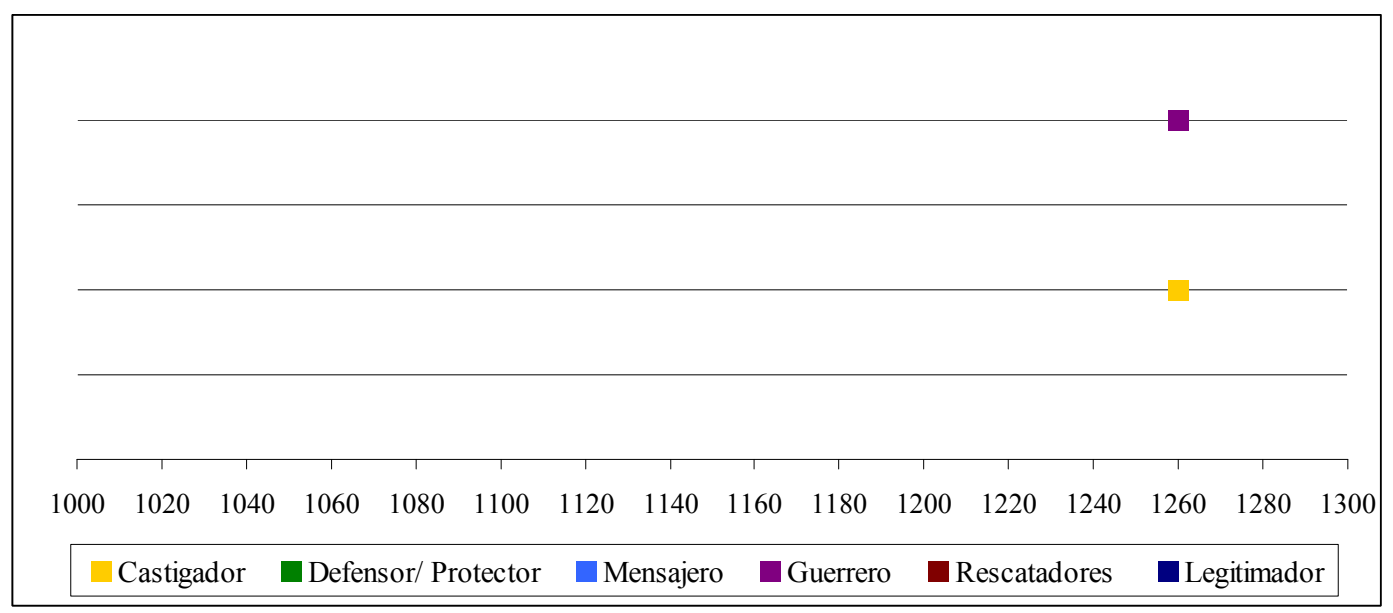

En la batalla de Simancas, Ramiro II habría realizado votos a Santiago, en tanto que su aliado, Fernán Gonçalez, los hizo a San Millán ${ }^{1019}$. Por esta razón, según Berceo,

\footnotetext{
${ }^{1016}$ Ver gráficos y tablas $n^{\circ} 4$ y 9.

1017 Berceo relata varias liberaciones de cautivos junto con otros milagros en su Vida de san Millán, en cuanto al texto de Braulio de Zaragoza, nosotros optamos por incluirlo de nuestro análisis por ser una obra de un periodo muy distante a nuestro marco cronológico de estudio.

1018 Muñoz Fernández, Ángela, “Cultos, Devociones y Advocaciones... op. cit., p. 139; Lomax, Derek, La Reconquista ... op. cit., p. 138; y Lida de Malkiel, María Rosa, La Idea de la Fama ... op. cit., p. 197.

1019 VSM, N³62-489, op. cit., pp. 397-421.
} 
ambos santos hicieron su aparición durante el enfrentamiento justo en el momento en que las huestes cristianas comenzaban a flaquear ${ }^{1020}$ :

“438 Vinien en dos caballos plus blancos que cristal, / Armas quales non vió nunca omne mortal: / El uno tenie croza, mitra pontifical, /El otro una cruz, omne non vió tal.

$[\ldots]$

447. El que tenie la mitra é la croza en la mano, /Esi fue el apóstol de Sant Juan ermano, / El que la cruz tenie é el capiello plano, / Ese fué Sant Millán el varón cogollano." 1021

La relación entre Millán y Gonzáles implicó que este santo se vinculase con los orígenes independientes del condado castellano y, que por lo tanto, se convirtiese en su patrono, en contraparte a Santiago y San Isidoro, quienes estuvieron más vinculados a la tradición leonesa. Una rivalidad que se acrecentó luego de la unificación de los reinos en el siglo XIII, sin embargo, ello no pejudicó la popularidad de Santiago.

Como guerrero y santo de la frontera, Millán también fue un importante combatiente contra el "mal" en general. Especialmente destacables son sus actos como exorcista y protector de los desvalidos. Es en este último rol que el ermitaño demuestra su poder contra aquellos que pretendían dañarlo y entorpecer su ayuda a los desamparados. Es así como dos hombres que intentaron robarle una bestia, con la cual el santo acarreaba leña para los pobres, fueron duramente castigados "Ovieron sendos ojos de las quebrados, Tanto que sendas nueçes cabrían en los forados", sanción que, pese a sus súplicas, el santo no intercedió ante Dios para que se les perdonara ${ }^{1022}$. Este último caso, que si bien es el único de esta índole en la narración, bien puede explicarse por razones prácticas, puesto que se encuentra en la línea de aquellas historias destinadas a crear un aura protectora en torno a la Iglesia y a sus representantes, siendo una advertencia para los mismos cristianos con respecto a la inviolabilidad de la Iglesia, la cual solía estar bastante expuesta en la frontera, no tanto por las tropelías de los musulmanes, sino más bien por la rapiña de los cristianos, quienes, en más de una ocasión, se hicieron de sus bienes para poder financiar sus campañas de reconquista.

\footnotetext{
${ }^{1020}$ Ver nota número 946 en el subcapítulo dedicado a Santiago.

${ }^{1021}$ VSM, $\mathrm{N}^{\circ} 438,447$, op. cit., pp. 410-412.

1022 VSM, N ${ }^{\circ} 271,278$, op. cit., pp. 378-380.
} 
Tabla 14: Santos de la Reconquista: San Millan de la Cogolla

\begin{tabular}{|l|l|l|l|l|l|l|l|}
\hline & Castigador & $\begin{array}{l}\text { Defensor/ } \\
\text { Protector }\end{array}$ & Mensajero & Guerrero & Rescatadores & Legitimador & Fuentes \\
\hline 1110 & & & & & & & \\
\hline 1130 & & & & & & & \\
\hline 1160 & & & & & & & \\
\hline 1190 & & & & & & & \\
\hline 1210 & & & & & & & \\
\hline 1230 & & & & & & & \\
\hline 1260 & & $\mathrm{X}$ & & $\mathrm{X}$ & & & - VSM Libro III $\mathrm{n}^{\circ}$ \\
\hline 1290 & & & & & & & \\
\hline
\end{tabular}

\section{III.2.i.- Otros santos y mensajeros celestes}

Junto a los santos antes referenciados, existieron otros cuyas menciones son menores, pero que cumplieron los mismos roles y atendieron a las mismas necesidades que otras figuras providenciales más populares. Por lo general, el actuar de estos santos se vinculaba a la actividad fronteriza y se les puede localizar en las crónicas de los siglos XII y XIII ${ }^{1023}$. A continuación se presentan algunos de los casos más destacables de estos bienaventurados.

\section{Gráfico 15: Santos de la Reconquista: Otros santos y mensajeros celestes}

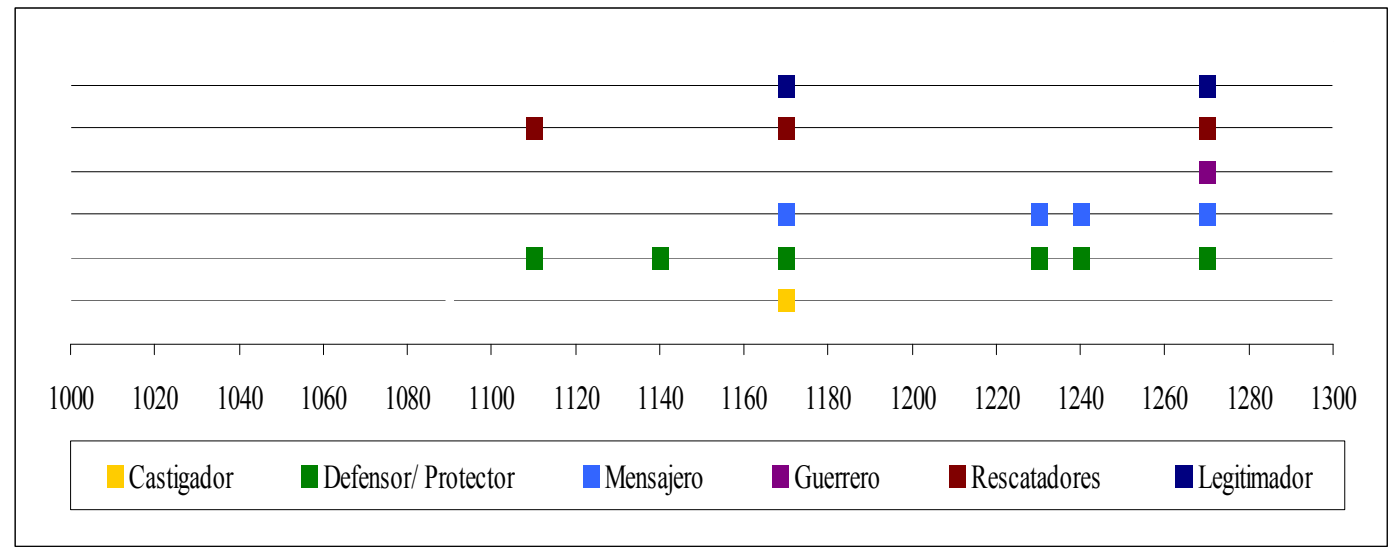

Los más antiguos de estos santos de la frontera son los hermanos Facundo y Primitivo, martirizados en el siglo IV, cuya historia esta relatada en el Crónica anónima de Sahagún, puesto que fue sobre su tumba que se levantó el monasterio y villa que dan

\footnotetext{
${ }^{1023}$ Ver gráfico y tabla $n^{\circ} 4$
} 
nombre a la crónica ${ }^{1024}$. Las reliquias eran una fuente de poder e influencia en la Europa Medieval, razón por la cual no es de extrañar que los hermanos obrasen milagros que glorificaban al monasterio, precisamente cuando éste se encontraba enfrascado en las luchas contra los burgueses, en el contexto de la agitación entre León y Aragón luego de la muerte de Alfonso VI.

El milagro en cuestión es protagonizado por San Facundo y trata sobre un mancebo que fue capturado por un burgués, quien lo cargó de cadenas y lo encerró en un oscuro calabozo, custodiado por cuatro caballeros y tres perros. Durante la noche, el Santo Varón se le apareció al mancebo. La visión consoló al cautivo y le indico abrir la puerta de su celda, para luego hacerle salir caminando tranquilamente mientras perros y guardias dormían profundamente. El fugitivo se dirige al monasterio de Sahagún donde fue acogido por los monjes que rompen sus cadenas y aseguran su libertad ${ }^{1025}$.

Como se puede apreciar, el relato y conducta de la aparición repite un patrón común con las intervenciones de otros santos, como Santo Domingo. Un débil capturado por sus enemigos, que es arrojado a un calabozo oscuro y que en su desolación recibe, de noche, la visita de un santo, quien le indica cómo escapar.

Junto con estos guerreros celestiales las fuentes mencionan las apariciones y milagros de otras figuras celestes, comunes al conjunto del cristianismo occidental. Tal es el caso de figuras como San Pedro o distintos ángeles, entre los que destaca el arcángel Gabriel. Pero en su conjunto, todos ellos cumplían un rol similar, animar a los guerreros de la Reconquista y legitimar la violencia mediante su intervención ${ }^{1026}$.

Entre las apariciones de raíces cristianas comunes figura la de San Pedro. El Apóstol habría jugado un rol clave en la vida de Alfonso VI ${ }^{1027}$. En un episodio de la Chronica Najerense se narra que cuando el futuro rey se encontraba retenido por su hermano Sancho, habría sido visitado por San Pedro quien le anunció su pronta liberación y futura ascensión al trono de su padre, para luego aparecerse ante Sancho y ordenándole liberar a su hermano bajo amenaza de muerte ${ }^{1028}$.

\footnotetext{
1024 CAS, Crónica I, op. cit., pp. 9, 10.

1025 CAS, Crónica I, op. cit., pp. 102-106. Es importante recordar que este y otros milagros aparecidos en la Crónica de Sahagún deben ser enmarcados en el contexto de las pugnas entre los monjes y los burgueses, por lo que estos portentos tenían como objetivo el de fortalecer la imagen del Monasterio y validar providencialmente su posición ante sus adversarios.

${ }^{1026}$ Ver tabla $\mathrm{n}^{\circ} 10$.

${ }^{1027}$ De Ayala Martínez, Carlos, Sacerdocio y Reino... op. cit., pp. 302.

1028 "Quibus assidue orationi por eo incumbentibus, ecce quidam nocte clauieger celi Beatus Petrus apostulus per quendam episcopum Aldefonso innotuit qualiter instancia precum sancti Hugonis suorumque pulsatus, in breui ipsum proprie redderet potestati, et in regnum paternum nichilominus sublimaret. Transactis itaque paucis diebus, rursus idem celi clauiger regi Santio nocte terribiliter
} 
La visita del Apóstol, según la tradición, elegido por Cristo como base de la Iglesia y guardián de las puertas del cielo, es un ejemplo más del uso de la devoción popular por razones políticas. Sólo un hombre justo y piadoso podría contar con tan importante patrono, que en esencia lo convertiría en un protegido de la Providencia, una imagen, que como ya sabemos, se procuró crear en torno a Alfonso. En relación a esta intencionalidad existían razones más bien políticas que explican el auxilio de San Pedro y no de algún otro enviado más vinculado a la tradición hispánica, como los santos Santiago e Isidoro. La misma crónica nos revela que previamente Alfonso había pedido ayuda a Hugo abad de Cluny y que gracias a él se produjo la providencial intervención. Un detalle significativo puesto que el abad representaba a la misma orden que luego el monarca favorecería una vez recuperado su trono y fortalecido su reino. Es en ese sentido que se explica la intervención de Pedro, un santo "extranjero" pero popular entre la orden borgoñona, por lo que su intervención bien podría ser un símbolo de la alianza entre el futuro conquistador de Toledo y la orden franca.

San Pedro validaba así a Alfonso y sus lazos con Cluny, pero además el rey, posteriormente, enfrentó una etapa de tensiones con Roma, por lo que la mística relación con San Pedro, bien pudo ser la demostración discursiva de una relación y reconciliación entre el soberano y la Iglesia, puesto que al fin y al cabo el Pontífice, no es sino el sucesor de San Pedro. Los ángeles también hacen frecuentes apariciones en el escenario de la Reconquista, aunque su rol suele ser secundario, puesto que sus intervenciones suelen ser como escoltas o acompañantes de otras personalidades celestes como San Isidoro y Santiago ${ }^{1029}$. Por lo general en las intervenciones en batalla de estos santos, se les muestra acompañados por legiones de "caballeros blancos", a veces derechamente identificados como ángeles. Es en este rol que los miembros de la corte celeste suelen aparecer en escenario militar europeo y así lo podemos atestiguar en distintos episodios de las cruzadas, a modo de ejemplo. A veces los ángeles se identificaban claramente, especialmente Miguel, en su rol de jefe de las milicias

apparuit et mortem illi gruissimam, nisi fratrem dimitteret, intemptauit. Surgens ergo ocius uehementius exturbatus, uocatis setellitibus, ad fratem uadi; a uinculis illum soluit; quo illum libeat, ire mandat. Et sic lectum petit denuo dormiturus" $\mathrm{CN}$ 1995, Liber III, $\mathrm{N}^{\circ}$ 15, op. cit., p. 173. "Mientras éstos andaban reclinados en continua oración por él, he aqui que una noche el portero del cielo, san Pedro apóstol, le comunica por mediación de un obispo a Alfonso de qué manera, instado por el apremio de los ruegos de san Hugo y los suyos, lo devolvería a su majestad e incluso lo elevaría al poder de su padre. Así pues, al cabo de unos pocos días el portero del cielo se le presentó con aspecto terrible, de noche, al rey Sancho y lo amenazó con una muerte dolorosísima a menos que liberara a su hermano. Al instante se levanta lleno de turbación y tras llamar su guardia se presenta ante su hermano, lo suelta de las cadenas y le ordena que se marche a donde le plazca, y asi vuelve a la cama para seguir durmiendo." CN 2003, Libro III, $\mathrm{N}^{\circ}$ 15, op. cit., p. 177.

${ }^{1029}$ Ver gráfico y tabla $n^{\circ} 10$. 
celestiales. Para el caso hispánico, los ángeles ocupan un rol secundario, dentro de la diversidad de enviados celestes, pero la creencia en ellos queda de manifiesto en algunos episodios, el referido a la derrota de Alfonso "el batallador", cuando se nos dice que ni Gabriel el "más importante mensajero de Dios" ni Miguel, "príncipe de la milicia celeste", ayudaron al rey en Fraga ${ }^{1030}$.

Los ángeles son, por lo tanto, ejemplos de los roles de mensajeros, protectores y guerreros principalmente, y como se aprecia en el gráfico y tabla número 10, sus apariciones, al igual que las de los restantes enviados celestes, coinciden con los ciclos de mayor actividad bélica, en especial durante los reinos de Alfonso VI, Alfonso VII, Alfonso VIII y Fernando III.

Sin duda, la aparición angelical más importante en las crónicas fue la del famoso "pastor de la Navas", figura sobre la cual vale la pena detenerse, en especial dada la importancia que las crónicas contemporáneas y posteriores le asigna al personaje ${ }^{1031}$.

Durante la marcha hacia el campo de batalla de las Navas de Tolosa, después de las capturas de Malagón y Calatrava, los ejércitos cruzados vieron bloqueado su camino, por los musulmanes, en el paso de La Losa. El hecho causó una crisis entre los cristianos, cundió el desanimo y las divisiones. Incluso, según algunos testimonios, Alfonso VIII propuso dar por cumplidos los votos y dirigir las huestes contra el Alfonso IX de León, ante lo cual los demás caudillos amenazaron con abandonarlo e incluso se le amenazó con sanciones eclesiásticas ${ }^{1032}$.

Fue en este contexto cuando se produjo la aparición del misterioso pastor. El suceso es tratado en distintas crónicas, las que coinciden más o menos en sus detalles, más no en su interpretación, puesto que entre más distante a los hechos más providencialistas se vuelven los relatos ${ }^{1033}$.

Según los cronistas, mientras los caudillos cristianos discutían respecto a qué hacer, apareció un "hombre simple, un rústico" que pidió hablar con Alfonso VIII. En la reunión le da cuenta de un paso desconocido y no vigilado. Los cristianos rápidamente ocuparon el paso y pudieron proseguir su marcha. Después de ello, el pastor desapareció misteriosamente sin reclamar recompensas por su acción.

\footnotetext{
${ }^{1030}$ CEA, Libro I, N55, op.cit, p. 80; y CAI, Liber I, N 55, op. cit., pp. 45, 46.

${ }^{1031} \mathrm{Si}$ bien las crónicas no se ponen de acuerdo respecto a si el pastor era o no un ángel, nosotros hemos decidido tratarlo como tal, puesto que hay coincidencias en las fuentes respecto a tratarlo como un enviado de Dios cuya aparición fue providencial, así como su misteriosa desaparición una vez terminada su misión.

1032 CLRC 1999 N ${ }^{\circ}$ 22, op. cit., p. 51; HHE, Libro VIII. Cap. VII, op. cit., pp. 317; CGE, Cap. 1016, op. cit., pp. 698; y CXXR, Libro. XIII. Cap. XXXI, op. cit., p. 283.

${ }^{1033}$ Ver gráfico y tabla $\mathrm{n}^{\circ} 10$.
} 
No pasó mucho tiempo para que esta aparición se rodeara de un aura milagrosa, siendo señalado como un enviado del cielo o un ángel, incluso se le relaciona con San Isidoro. Al estudiar los relatos se puede apreciar que entre más tardía la crónica, más mística se convierte la figura del pastor ${ }^{1034}$. Jiménez de Rada, el único testigo directo de los hechos, toma la postura más cauta y lo reduce a un simple hombre enviado por Dios, pero los autores posteriores fueron construyendo un mito en torno a la figura, hasta convertirla en un ángel enviado del cielo ${ }^{1035}$. Ello en razón de que la mentalidad providencialista del momento exigía que en una cruzada, y en especial una de la envergadura de las Navas de Tolosa, debiera haber eventos o apariciones que ratificasen la santidad de la causa y la bendijesen con las señales de la Providencia. Razón, por lo que además, el pastor de las Navas, no sería el único milagro de la expedición ${ }^{1036}$.

Es importante notar, que a diferencia de otros enviados celestes, el pastor no cumple la función de estratega ni de animar a los cristianos. Simplemente se limita a señalar un camino, dejando en manos de los cruzados la decisión sobre la forma de obrar y por lo tanto es también merito de ellos la victoria que se obtendría. Por ello es posible observar una relación distinta respecto a interacción con la Providencia, puesto que ahora los hombres parecen ser mucho más autónomos y responsables por sus acciones.

\footnotetext{
${ }^{1034}$ Lucas de Tuy al referirse a él dice: "[...] presentose por divina inspiración al rey Alfonso un hombre, a modo de pastor de ovejas, que les enseñó un camino ancho". Según Jiménez de Rada era un hombre simple que "[...] resultó cierto como un enviado de Dios, que se sirve de las escorias del mundo [...]". Alfonso VIII, apenas habla de él en su carta al Papa, y se limita a decir que: "[...] nuestros magnates que iban en la vanguardia, guiados por un rústico que Dios nos envió impensadamente, encontraron alli mismo otro paso bastante fácil". La Crónica Latina, más tardía, continúa con la tradición, pero inclinándose aun más por el providencialismo y lo describe como: "Se cree por los que juzgan con rectitud que no era 'un puro hombre', sino alguna virtud divina, que en tanta angustia, ayudó al pueblo cristiano, ya que por una parte, tantos adalides, tantos pastores, tantos hermanos de Calatrava discurrían a menudo por aquellos lugares y, sin embargo, ninguno de ellos sabía algo de aquel lugar, y por otra, no compareció posteriormente el pastor", con lo que da a entender que el mismo paso fue abierto por Dios (CE, Libro IV, cap. LXXXIII, op. cit., p. 415; HHE, Libro VIII, cap. VIII. op. cit., p. 318; Carta de Alfonso VIII a Inocencio III en González, Julio, El Reino de Castilla en la época de Alfonso VIII, III Documentos... op.cit, p. 566; y CLRC 1999, № 23, op. cit., p. 52). Alfonso X en su crónica, es más ambiguo y dice: "[...] assi Dios omnipotent, por cuya gracia spiritual se enderesçaua el fecho, enui alli entonçes al rey don Alffonsso un omne del pueblo, assaz uil de uestido et de persona, que auie andado de tiempo antes curiando ganando en aquellas montannas et tomando coneios e liebres; et aquel pastor mostro al rey don Alffonsso la carrera assaz ligera de todo en todo, pora sobir por una cuesta del costado desse mont; et aun dixo quel non conuinie de tirarse nin de esconderse de la uista de los enemigos, mas aun que ueyendolo ellos et non nos podiendo embargar nin estoruar nin nos tener danno, que podriemos uenir al logar conuinient a la batalla.” CGE, cap. 1016, op. cit., p. 698.

Por su parte la Crónica de veinte reyes dice al respecto: "Cuenta la estoria que ellos estando en este pensamiento, llegó vn omne bueno por la merçed de Dios, en semejança de pastor, que demandaua por los rreyes amuy gran priesa. Mas commo quier quel pastor semejase, çierto era ángel mandadero de Dios." CXXR, Libro XIII, cap. XXXI, op. cit., p. 283.

1035 García Fritz, Francisco, Las Navas de Tolosa ... op. cit., p. 413.

${ }^{1036}$ García Fritz, Francisco, "La Conquista de Andalucía... op. cit., p. 55.
} 
Quizás la principal virtud del pastor es precisamente lo modesto de su actuar, puesto que gracias a este oscuro personaje es posible proseguir la victoria ${ }^{1037}$. Nosotros nos aventuramos a postular que el pastor cumple también el rol de ser un ejemplo de humildad, de cómo Dios está en las grandes y pequeñas acciones y, más importante aún, un recordatorio a los soberanos de la importancia del favor de la Providencia y la relevancia de mantenerse en una actitud humilde en la victoria. Una idea que reaparecerá al final de la campaña cuando el Dios castigue a los cruzados por su codicia y vanidad ${ }^{1038}$.

Según lo observado en las fuentes cronísticas, el episodio del pastor corresponde a la última gran intervención de los enviados celeste en la Reconquista - eso en el entendido de que el pastor puede ser clasificado así - puesto que para mediados del siglo XIII los cronistas, si bien reproducen las apariciones más antiguas de los santos Santiago, Isidoro, María, entre otros, no suelen agregar nuevas intervenciones. Sólo unos pocos eventos pueden ser clasificados de totalmente nuevos y se vinculan a la época del reinado de Fernando III y Alfonso IX, pero son excepcionales. Al parecer los santos, como parte del discurso providencialista, tendieron a disminuir sus participaciones en tanto que los monarcas y algunos magnates cobraron más protagonismo. Eran ellos los que ahora actuaban directamente en comunión con Dios, sin necesidad de tantos intercesores, una situación que fue de la mano con los cambios en las concepciones del poder político que afectaron a la Península y a Europa, los cuales se evidenciaron durante el siglo XIII.

1037 Manuela Gracía Pardo, "El pastor de Las Navas de Tolosa. La realidad y la leyenda" en Toro Ceballos, Francisco y José Rodríguez Molina (Coordinadores), IV Estudios de Frontera... op. cit., pp. 219, 220.

${ }^{1038}$ Según las fuentes, una vez asegurado el triunfo, los cruzados se encaminaron a la población de Úbeda para cercarla. Allí los defensores ofrecieron una fianza de piezas de oro para levantar el cerco (la cantidad varía según las fuentes). Inicialmente el rescate tentó a los reyes cristianos, pero los Arzobispos y demás autoridades religiosas lo prohíben tajantemente, por lo que la ciudad fue capturada por asalto y su población sometida (HHE, Libro VIII, cap. XII, op. cit., p. 325; CLRC. N 25, op. cit., p. 63; y CGE, cap. 1021, op.cit, p. 705).

Las crónicas dan a entender que la codicia demostrada por los reyes cristianos, sumado al hecho de que se vanagloriaban de su victoria, motivó la última intervención divina, cuando una peste azotó a la hueste cristiana, obligándola a abandonar la campaña y regresar a Toledo (HHE, Libro VIII, cap. XII, op. cit., p. 325; CLRC. $\mathrm{N}^{\circ}$ 25, op. cit., p. 65, cap. 1021, op.cit, p. 705). Jiménez de Rada es bastante explicito al respecto al afirmar que: "Y como ya la gracia de Dios se estaba marchitando por causa de los excesos de los hombre, los cristianos, presa de su avaricia, se dedicaban a los delitos y los robos, por lo que el Señor les colocó un freno en sus bocas y los golpeó con enfermedades a ellos y sus animales de tiro, y apenas habia en las tiendas quien pudiera atender a su camarada o a su señor." (HHE, Libro VIII, cap. XII, op. cit., p.325). 
Tabla 15: Santos de la Reconquista: Otros santos y mensajeros celestes

\begin{tabular}{|c|c|c|c|c|c|c|c|c|}
\hline Otros & $\begin{array}{l}\text { Fecha } \\
\text { aprox. }\end{array}$ & Castigador & $\begin{array}{l}\text { Defensor/ } \\
\text { Protector }\end{array}$ & Mensajero & Guerrero & Rescatadores & Legitimador & Fuentes \\
\hline & 1090 & & & & & & & \\
\hline \multirow[t]{3}{*}{$\begin{array}{l}\text { San } \\
\text { Facundo y } \\
\text { Primitivo } \\
\end{array}$} & 1110 & & $X$ & & & $X$ & & $\begin{array}{l}- \text { CAS n }^{\circ} \\
69 \text { p. } 102\end{array}$ \\
\hline & 1120 & & & & & & & \\
\hline & 1130 & & & & & & & \\
\hline \multirow[t]{3}{*}{$\begin{array}{l}\text { Arcángel } \\
\text { Miguel }\end{array}$} & 1140 & & $X$ & & & & & $\begin{array}{l}\text { - CAI } \\
\text { Libro II n } \\
6 \text { p. } 97\end{array}$ \\
\hline & 1150 & & & & & & & \\
\hline & 1160 & & & & & & & \\
\hline \multirow[t]{6}{*}{ San Pedro } & 1170 & $X$ & $X$ & $X$ & & $X$ & $X$ & $\begin{array}{l}\text { - CN Libro } \\
\text { III n }{ }^{\circ} 15 \mathrm{p} . \\
177\end{array}$ \\
\hline & 1180 & & & & & & & \\
\hline & 1190 & & & & & & & \\
\hline & 1200 & & & & & & & \\
\hline & 1210 & & & & & & & \\
\hline & 1220 & & & & & & & \\
\hline $\begin{array}{l}\text { Pastor de } \\
\text { las Navas }\end{array}$ & 1230 & & $X$ & $X$ & & & & $\begin{array}{l}\text { - CLRC } \\
n^{\circ} 23 \text { p. } 52\end{array}$ \\
\hline \multirow[t]{3}{*}{$\begin{array}{l}\text { Pastor de } \\
\text { las Navas }\end{array}$} & 1240 & & $X$ & $X$ & & & & \begin{tabular}{|l|} 
- HRH \\
Libro VIII \\
Cap. 8 \\
p.318. \\
- CM Libro \\
IV p. 415. \\
\end{tabular} \\
\hline & 1250 & & & & & & & \\
\hline & 1260 & & & & & & & \\
\hline \multirow[t]{4}{*}{$\begin{array}{l}\text { Fray } \\
\text { Pelayo, } \\
\text { Ángeles } \\
\text { guerros, } \\
\text { Pastor de } \\
\text { las Navas }\end{array}$} & 1270 & & $X$ & $X$ & $X$ & $X$ & $X$ & $\begin{array}{l}\text { - CGE Cap. } \\
\text { 698 pp. } \\
400,401, \\
\text { Cap. } 956 \\
\text { pp. 637, } \\
638, \\
\text { Cap.1016 } \\
\text { pp. 697, } \\
696 . \text { Cap. } \\
1016 \text { p. } \\
698 \\
\text { - CXXR } \\
\text { Libro XIII } \\
\text { Cap.31 p. } \\
\text { 283. } \\
\end{array}$ \\
\hline & 1280 & & & & & & & \\
\hline & 1290 & & & & & & & \\
\hline & 1300 & & & & & & & \\
\hline
\end{tabular}




\section{III.3.- Las dadivas divinas y los rituales de la guerra}

\section{III.3.a.- Las dádivas divinas: recompensas espirituales, indulgencias}

La concepción militar providencialista fue trasversal durante la Edad Media y se mantuvo vigente en Europa, aún cuando la guerra fuese entre cristianos ${ }^{1039}$. Ello fue acompañado a su vez por la formulación de una ritualidad religiosa para belica, que partiendo de la tradición clasica se consolidó en la Edad Media y que en algunos casos incluso pueden observarse en la actualidad ${ }^{1040}$.

Parte integral de las prácticas y discurso de la Reconquista eran las recompensas espirituales y los rituales religiosos. En el siguiente capítulo analizaremos cada uno de estos elementos, centrándonos en su uso como estímulo para la lucha y como herramienta al servicio de los intereses políticos y religiosos de la guerra peninsular.

Dentro de las distintas aristas que servían para justificar la guerra de Reconquista existía un elemento que fundamental, que es inseparable del discurso religioso; nos referimos a las promesas de recompensas espirituales para aquellos que participaron de la lucha.

Se sabe también que el conjunto de la población -plebeyos, aldeanos y burguesestambién obtenía ganancias a través de la conquista y el botín que nutría los mercados, activaba el comercio y permitía el acceso a las riquezas de al-Andalus. Pero, además de todas estas ganancias materiales, existía un sustrato cultural que afectaba a toda la sociedad; nos referimos a la creencia sostenida de que la Reconquista era una lucha religiosa contra los enemigos de Dios, y que por tanto merecía recompensas espirituales. Esta creencia no puede ser omitida, porque constituía un importante aliciente para los combatientes, en especial entre aquellos sectores más influenciables por el discurso religioso. Si bien se puede poner en duda que las recompensas espirituales eran un incentivo valido para los campesinos y villanos involucrados en la lucha, sí es factible afirmar que el hábil uso de las creencias religiosas podía ser un estímulo tan valioso como las promesas de obtención de riquezas y botín.

\footnotetext{
${ }^{1039}$ Lida de Malkiel, María Rosa, La Idea de la Fama... op. cit., pp. 115, 116.

${ }^{1040}$ En muchos lugares de América Latina todavía subsisten muchos rituales religioso-militares que tienen su origen en la tradición hispana medieval. En países como Chile, que es un estado laico, hasta el día de hoy se practican ceremonias religiosas destinadas a bendecir los estandartes, cuarteles y navíos de las FF.AA. Mientras que el Ejército reconoce el patronazgo de la Virgen del Carmen, cuya imagen es escoltada por los militares en las procesiones que se realizan cada año, el 16 de julio. Si bien estos rituales no se acompañan de oraciones para destruir a los enemigos, ni se invoca a Dios para guiar las armas, siguen siendo un testimonio de una tradición cristiano-militar, que podemos remontar a San Agustín, Orosio, Isidoro y otros pensadores medievales.
} 
En el aspecto religioso, el conjunto de los grupos sociales, en Europa y la Península, estaban impulsados por sus creencias fruto de la relación histórica entre el cristianismo y la violencia. Lo que según Jean Flori, se materializaba en: el perdón de los pecados confesados; la obtención de la indulgencia; la promesa de protección y de remuneraciones divinas y la asimilación del martirio para aquellos que muriesen en campaña $^{1041}$.

Esta realidad es apreciable en todo el escenario europeo; las huestes de cruzados en viaje a Tierra Santa estaban constituidas, entre otros, de campesinos, villanos y desposeídos que se enrolaban bajo la cruz con la esperanza de alcanzar la Gracia y de ser posible, de hacerse con alguna fortuna material. Sin embargo esta última podía ser esquiva, en cambio la Gracia, ya sea como perdón de los pecados o a través del martirio, estaba garantizada por la Iglesia.

En esencia, los sectores más bajos de la sociedad que acudían a la guerra pensando en las recompensas espirituales, no hacían más que seguir la ya extensa tradición cristiana de ofrecer consuelos divinos a aquellos que por su condición, difícilmente podrían mejorar sus condiciones de vida ${ }^{1042}$. Esto no significaba que los ejércitos de la Reconquista estuvieran plagados de miserables, pero sí que muchos de quienes luchaban en ellos tenían como principal motivación las promesas celestiales, en conjunto con de sus deseos de botín.

Para el caso peninsular, estas asociaciones entre guerra y recompensas espirituales tuvieron una asimilación más tardía, y si bien se evidencian señales de su existencia con anterioridad al siglo VIII, no es sino hasta mediados del siglo XII -coincidiendo con el inicio del avance decisivo de la Reconquista- que esta idea permeó al conjunto de la sociedad y comenzó a ser testimoniada en crónicas y otras fuentes. No obstante, como se aprecia en el siguiente gráfico, debemos aclarar que el asunto de las indulgencias no fue una temática destacada en las crónicas, en comparación con otros aspectos, siendo relativamente pocos los autores que se detuvieron mayormente en este aspecto. Una situación que contrasta con la preocupación papal sobre este tema y las diversas instancias en que fueron concedidas bulas de cruzadas y decretos de indulgencia -ya

\footnotetext{
${ }^{1041}$ Flori, Jean, Guerra Santa, Yihad, Cruzada... op. cit., pp. 271, 272.

${ }^{1042}$ Desde los orígenes del cristianismo, la nueva religión apunto a las clases más bajas de la sociedad. El "sermón de la montaña", prometía las recompensas espirituales a los pobres, desvalidos y marginados de la sociedad (Mateo 5:1-12). Una idea que fue inmortalizada por los apóstoles y que se tradujo que en los comienzos de las predicaciones por el Imperio Romano, el cristianismo se hiciese fuerte entre las clases más bajas de la sociedad, que veían en esas promesas una suerte de compensación por lo duro de sus vidas y la poca alentadora expectativas de pasar la inmortalidad en el Hades.
} 
fuesen parciales o totales- otorgadas a los guerreros peninsulares, como queda atestiguado en la documentación pontificia elaborada durante los siglos XII y XIII, y recopiladas por Mansilla, Domínguez, Quintana y Rodríguez ${ }^{1043}$.

\section{Gráfico 16: Idulgencias}

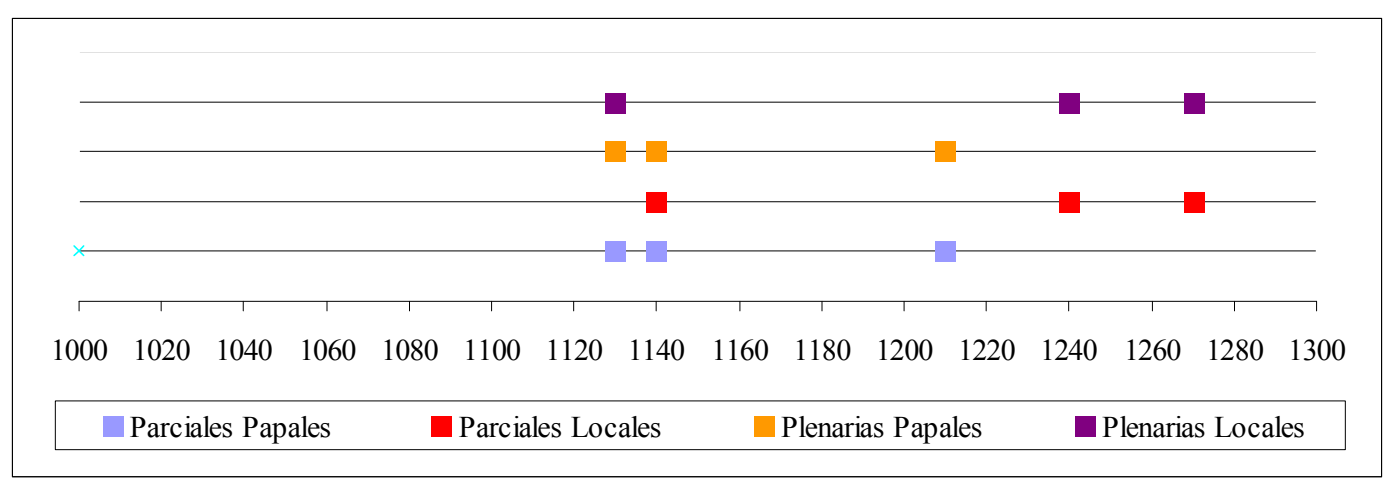

Desde el siglo XII la consolidación de la concepción de cruzada, coincidió con la situación recién descrita. A partir de 1096, el Papado comenzó a fortalecer los conceptos vinculados a la guerra santa cristiana, tales como sus causas, la forma de combatir en ellas, las garantías que daba a los guerreros por su participación, y por supuesto, las recompensas que derivaban de arriesgar la vida en la defensa de la fe ${ }^{1044}$. En algunas fuentes hispanas del período se puede apreciar la mención directa a recompensas espirituales acompañadas por promesas de botín, como es el caso del Poema de Almería que narra cómo las autoridades religiosas arengaban a las tropas con promesas de diversa índole:

\section{"[25] Pontifices omnes Legionis sive Toleti, exemplo gladio divino corporeoque,}

\footnotetext{
1043 Al respecto ver: Mansilla, Demetrio, La documentación pontifica hasta Inocencio... op. cit.; del mismo autor, la también ya citada La documentación pontificia de Honorio III... op.cit.; Domínguez Sánchez, Santiago, Documentos de Gregorio IX... op.cit.; Quintana Prieto, Augusto, La documentación pontificia de Inocencio IV (1234-1254), Roma, Instituto de historia eclesiástica, 1987, Tomos I y II; Rodríguez de Lama, Idelfonso, La documentación pontificia de Alejandro IV (1254-1261), Roma, Instituto de historia eclesiástica, 1976; del mismo autor, La documentación pontificia de Urbano IV (1261-1264), Roma, Instituto de historia eclesiástica, 1981; y de Santiago Domínguez Sánchez, Documentos de Clemente IV (1265-1268) Referentes a España, León, Universidad de León, 1996; Documentos de Gregorio X (1272-1276) Referentes a España, León, Universidad de León, 1997; Documentos de Nicolás III (1277-1280) Referentes a España, León, Universidad de León, 1999; Documentos de Nicolás IV (1288-1292) Referentes a España, León, Universidad de León, 2009; Documentos de Bonifacio VIII (1294-1303) Referentes a España, León, Universidad de León, 2006.

${ }^{1044}$ Goñi Gaztambide, José, Historia de la Bula de Cruzada ... op. cit., pp. 187-189. El mismo autor en las páginas 51 y 52 de su libro postula la posibilidad de que fuese Alejandro II, con su patrocinio en la campaña de Barbastro, el primer pontífice en otorgar indulgencias de cruzada en España. Una posibilidad que García Fitz postula como un hecho en su articulo "la Reconquista: un estado de la cuestión", publicado en Clio \& Crimen, $\mathrm{n}^{\mathrm{o}}$ 6, 2009, pp. 142-215.
} 
orant maiores [invitantque] minores,

ut veniant cuncti fortes ad proelia tuti.

Crimina persolvunt, voces ad sidera tollunt,

[30] mercedem vitae spondent cunctis utriusque.

Argenti dona promittunt, cumque corona

quidquid habent Mauri rursus promittitur auri" ${ }^{1045}$.

Según la cita, el mensaje era claro: quien arriesgase su vida o sus recursos al servicio de las causas de la Iglesia vería su esfuerzo recompensado, siendo un importante estímulo para una sociedad creyente, piadosa y temerosa de Dios.

Como ya se mencionó en estos casos las recompensas más habituales eran las indulgencias plenarias o parciales, aunque las fuentes no suelen hacer mayores diferencias entre ellas. El perdón de los pecados fue el estímulo más comúnmente aceptado y utilizado, puesto que se demuestra una gran versatilidad en su uso. En ocasiones, en una campaña la indulgencia se ofrecía a los guerreros, pero también a quienes aportasen con materiales, dinero u oraciones. Lo que implicaba que el esfuerzo bélico se hacía extensivo a toda la sociedad y no sólo a pequeños grupos de guerreros, lo que bien podría revelar una intención por “popularizar” la campaña. Además, de esta forma se aseguraba no sólo a los hombres sino también los recursos materiales necesarios.

Si bien una indulgencia parcial podría no parecer gran cosa, en el contexto de una sociedad altamente temerosa de la condenación, que además vivía imbuida en un discurso y una iconografía que permanentemente se la recordaba, no se puede despreciar el impacto que estas indulgencias debieron tener.

La entrega de indulgencias es una práctica que comenzó en el siglo XI, haciéndose cada vez más frecuentes las referencias a ellas en las crónicas a partir del siglo XII, con los grandes avances de la Reconquista en Hispania. Sin embargo, en el escenario peninsular se contaba con fórmulas similares; las llamadas "peregrinaciones penitenciales" o las "absoluciones generales", que la jerarquía eclesiástica otorgaba a quienes luchasen contra los musulmanes o prestasen servicios a la Iglesia ${ }^{1046}$.

${ }^{1045}$ CAI, Poema de Almeria, 25, 30, op. cit., p. 167. "Los obispos de Toledo y León en su totalidad, tras desenvainar la espada divina y la material/ [40] ruegan a los mayores y animan a los jóvenes a que todos acudan al combate, valientes y seguros. Perdonan los pecados, elevan sus voces al cielo y aseguran a todos la recompensa en ésta y en la otra vida. Prometen premios en plata y, con la victoria, / [45] se promete a su vez todo el oro que tienen los moros." CEA, Poema de Almería. 40, 45, op. cit., p. 132.

${ }_{1046}$ Martín Martín, José Luis, "Algunas prácticas clericales... op. cit., pp. 410; y Fernández Conde, Javier, Historia de la Iglesia en España. II-2 ${ }^{\circ}$... op. cit., p. 297. 
Respecto al modo como operaba el sistema de indulgencias, hay que aclarar que cuando éstas eran parciales, podían ser otorgadas por alguna alta autoridad eclesiástica, como los obispos locales, y por lo general respondían a situaciones precisas. En el caso de la Península Ibérica las crónicas no diferencian de forma explícita entre un tipo de indulgencia y otra; no obstante, es posible distinguirlas por el contexto en que utilizaron o por las características de la campaña convocada. Por lo general, según las crónicas, estos eventos solían corresponder a las etapas previas de una campaña, o bien ante situaciones de emergencia. Quizás el ejemplo más conocido para el caso hispano se encuentra en los acontecimientos que precedieron a la formación de la orden de Calatrava, un evento que ya se ha relatado, pero consideramos necesario reiterarlo ${ }^{1047}$.

Como es sabido, en 1158, los templarios a cargo de la protección de la villa de Calatrava, reconocieron su incapacidad de defenderla ante la acometida musulmana y por ello se la devolvieron a Sancho III. Al llamado a defender la fortaleza hecho por el monarca respondió Raimundo, abad de Fitero, quien pidió hacerse cargo de la defensa junto con sus monjes, entre los que destacaba uno llamado Diego Velazquez, que había sido guerrero. Ante la falta de una solución mejor se les otorgó lo que pedían, y para ayudarlos el primado de Toledo ofreció indulgencias a todos aquellos que contribuyesen a la obra ${ }^{1048}$ :

"Et el primas, pues que lo oyo, gradesçiolo a Dios por quel semeio que era a su seruiçio de Dios, et diole luego su ayuda de sus cosas; demas fizolo predicar luego por Toledo et por los pueblos et dezir que todos aquellos que en ayuda de Calatraua fuessen que les perdonaua todos los peccados conffessados. Et fizosse desta soltura tan gran sueno por la çipdad de Toledo et por tierra, et tan grand muebda, que en la çipdad de Toledo apenas fue y ninguno de los toledanos que non fuesse en ayuda de Calatrana, o por su persona misma, o que non diesse y su cauallo et sus armas et su auer, et lo non enuiasee alla en ayuda"1049.

Como se logra apreciar la respuesta al ofrecimiento de indulgencias fue notable, destacando el hecho de que no sólo acudieron guerreros, sino que además se produjeron donaciones de caballos, armas y dineros, lo que parece demostrar un intento por

\footnotetext{
${ }^{1047}$ Goñi Gaztambide, José, Historia de la Bula de Cruzada ... op. cit., pp. 88, 89.

${ }^{1048}$ La Crónica General reproduce el episodio tomado de la Historia de Rebus Hispaniae, Liber VII, cap. XIV, op. cit., pp. 234-236.

${ }^{1049}$ CGE, cap. 987, op. cit., p. 667.
} 
popularizar la campaña; es decir, convertirla en un evento donde todos podrían participar y compartir las recompensas, sin importar su condición social ${ }^{1050}$.

Finalmente, los musulmanes desistieron de sus intenciones y la ciudad se salvó. Por su parte, los monjes para mantener su promesa de defender la villa, acabaron por fundar la Orden de Calatrava.

En cuanto a las indulgencias de tipo plenarias, su otorgamiento se restringía principalmente al Papa o a sus delegados, y habitualmente las encontramos asociadas a Bulas y documentos pontificios. Por lo mismo su otorgamiento estaba vinculado a ocasiones especiales y particularmente a las cruzadas, tornandose, con el paso del tiempo, muy populares y versátiles, e incluso hicieron a las indulgencias extensibles a los pecados pasados y no confesados ${ }^{1051}$.

En la Historia Compostela aparece uno de los primeros ejemplos hispánicos de un documento ofreciendo indulgencias plenarias a quienes combatiesen a los musulmanes. La fuente corresponde a una carta emitida por Diego Gelmírez en su calidad de legado pontificio, dirigida para su divulgación a todas las autoridades eclesiásticas y políticas de la Península. En ella el arzobispo exhorta a la lucha contra los musulmanes y promete indulgencia para aquellos que acudiesen en persona o bien contribuyesen enviando hombres o ayudas económicas a la campaña. Destaca también el hecho de que en su epístola, el arzobispo asegure la protección de todos aquellos que acudiesen a su llamado, amenazando con la excomunión y el anatema a quienes se atreviesen a causar algún mal a los combatientes o sus bienes ${ }^{1052}$.

Otro ejemplo puede observarse en la epístola del Papa Calixto, citada en el Liber Sancti Jacobi ${ }^{1053}$ :

"Hoc idem et nos corroboramos et affirmamus, ut omnes qui aut in Yspania, aut in iherosolimitanis horis, ad expugnandum gentem perfidam, ut superius diximus, elevato signo dominice crucis in humeris perrexerint, ex parte Dei et sanctorum apostolorum Petri el Pauli et Iacobi, omniumque sanctorum, et nostra benedictione

\footnotetext{
${ }^{1050}$ Fernández Conde, Javier, Historia de la Iglesia en España. II-2 ${ }^{\circ}$... op. cit., p. 36.

${ }^{1051}$ Flori, Jean, La Guerra Santa ... op. cit., pp. 317, 318.

1052 HC 1988, Liber II, cap. LXXVIII, op. cit., pp. 378-380.

1053 Concordamos con lo planteado por el profesor García Fitz en su articulo ya citado "La Reconquista: un estado de la cuestión" en el sentido de que pese a la documentación pontificia y en especifico la bula de Urbano II de julio de 1089, referente a Tarragona, en la península no parece existir evidencia de documentos de este tipo hasta mediados del siglo XII, cuando aparecen las primeras menciones en fuentes cronísticas como al Chronica Adefonsi, la Historia Compostellana y el Pseudo Turpin. Según García Fitz, si bien entre los peninsulares ya existía la noción de que quien muriese en lucha contra el Islam recibiría la salvación, al parecer no había claridad con respecto a la situación del guerrero cristiano en general, en cuanto a penitencias y absoluciones. Con respecto a la epístola de Urbano II recién referida ver Goñi Gaztambide, José, Historia de la Bula de Cruzada... op. cit., p. 57.
} 
apostolica ab omnibus peccatis de quibus sacerdotibus suis confessi et penitentes fuerint, absolvantur et benedicantur, et in celestibus regnis una cum sanctis martiribus qui ab inicio christianitatis usque ad finem seculi martirii palman ibi acceperunt vel accepturi sunt, coronari mereantur" ${ }^{1054}$.

En estos dos documentos, y específicamente el último, donde se aprecia su calidad de plenaria, destaca -al igual que en el episodio de Calatrava- la aclaración de que era necesaria la confesión como paso previo para recibir la indulgencia. Este hecho posiblemente refleja la intencionalidad de la Iglesia de mantener cierto control sobre quienes respondían a sus llamados, puesto que los obligaba a reconocer la autoridad de la Iglesia y sus sacramentos, ya que sin la confesión no podrían alcanzar nunca las recompensas espirituales prometidas. De esta forma, la indulgencia exigía el sometimiento a la jerarquía eclesiástica y a los procedimientos de Roma.

El gráfico número 11 nos demuestra que es a partir del siglo XII, por su agitada actividad bélica, fue el momento en que se registran más llamados a cruzadas y concesiones de indulgencias en Hispania. Notorio es también el hecho de que tras la gran mayoría de otorgamientos de indulgencias se encontraba la solicitud de los monarcas al Papado, quienes con el fin de asegurar el éxito de sus campañas recurrían a la ya asentada idea de cruzada, pudiendo obtener a través de las promesas de indulgencia, los refuerzos humanos y materiales que necesitaban en sus campañas.

En otros casos, la convocatoria de una cruzada respondió a una acción cuidadosamente planificada, como el caso de las Navas de Tolosa. Es sabido que la iniciativa de la campaña se le atribuye a Alfonso VIII, que solicitó al Papado la promulgación de una bula de cruzada y la protección respectiva. Inocencio III respondió a la solicitud y encomendó la difusión de la campaña al arzobispo toledano Rodrigo Jiménez de Rada y a los obispos de Tarragona y Coimbra, quienes tenían facultades para sancionar a cualquiera que violase las paces con el rey de Castilla mientras durase

\footnotetext{
1054 LSJ 1998, Libro IV, Appendix D, op. cit., p. 229. "Esto también Nos corroboramos y confirmamos: que todos los que marchen como arriba dijimos, con el signo de la cruz del Señor en los hombros, a combatir al pueblo infiel en España o Tierra Santa, sean absueltos de todos sus pecados de que se hayan arrepentido y confesado a sus sacerdotes y sean bendecidos por parte de Dios y de los santos apóstoles San Pedro y San Pablo y Santiago, y de todos los santos, y con nuestra apostólica bendición; y que se merezcan ser coronados en el reino celestial, junto con los santos mártires que desde el principio de la cristiandad hasta el fin de los siglos recibieron o han de recibir la palma del martirio." LSJ 2004, Libro IV, cap. XXVI, op. cit., p. 522.
} 
la campaña. Un hecho que se vio reforzado con la concesión de una bula de cruzada en mayo de 1212 y la promesa de indulgencia plenaria a los combatientes ${ }^{1055}$.

El otorgamiento de la bula implicaba la obtención de un potente instrumento ideológico. La campaña se convertía así en una guerra santa, cuyo principal objetivo, en palabras de García Fitz, era la restauración de la Iglesia y de la fe oprimida por los musulmanes. En otras palabras, se entendía como una causa noble que además se enraizaba en la percepción del otro como el representante del mal y enemigo natural de la cristiandad. Por otra parte, lo que era más importante, convertía a Alfonso VIII en un instrumento de Dios, puesto que la lucha no era por razones personales, ni por Castilla, sino por la $\mathrm{fe}^{1056}$. De modo que bajo ese concepto, el soberano se veía protegido antes sus enemigos y validado frente a sus aliados ${ }^{1057}$.

Gracias a la bula, Alfonso pudo pactar treguas con todos sus adversarios. Ello sumado a la esperanza de botín, confluyó para que los reyes de Navarra y Aragón; Sancho VII y Pedro II se sumasen a la campaña, aunque con escasos recursos, en tanto que el rey de Portugal, Alfonso II, si bien no asistió personalmente, dio libertad de acción a sus vasallos que quisiesen unirse a la campaña. A ellos se sumaron las órdenes peninsulares que unieron sus huestes a las de Alfonso, que convocó a las milicias de

1055 Hay indicios de que el Papa no confiaba plenamente en los resultados de la próxima campaña. Al parecer el Pontífice dudaba de lo oportuno de la misión y en especial temía la merma que esta nueva cruzada podía generar entre los combatientes provenzales que luchaban contra los albigenses. Razón por la cual el pontífice aconsejó a Alfonso VIII aceptar una tregua si es que ésta era ofrecida por los Almohades y postergar la campaña para un momento más propicio (Huici Miranda, Ambrosio, Las grandes batallas de la Reconquista... op. cit., p. 229). Pero al perseverar el castellano en sus intenciones, el pontífice emitió una serie de documentos mediante los cuales patrocinaba la campaña, aunque, sin comprometer el envío de un legado o de recursos extraordinarios. Respecto a estos documentos, Mansilla, en su recopilación de documentos pontificios hasta Inocencio III, reúne entre otros: un mandato al arzobispo de Sens para prestar auxilio a Alfonso VIII (Letrán, 31 de enero de 1212), Notificación al rey de castilla sobre el mandato anterior (Letrán 4 de febrero de 1212), Ordena a los arzobispos de Toledo y Compostela a obligar a los reyes hispanos a hacer la paz y unirse contra el Islam (Letrán, 5 de abril de 1212), manda realizar rogativas en Roma por el éxito de la cruzada (Letrán, 16 de mayo de 1212).

${ }^{1056}$ García Fritz, Francisco, Las Navas de Tolosa... op. cit., pp. 390, 412-415; y Fernández Conde, Javier, Historia de la Iglesia en España. II-2 ${ }^{\circ}$... op. cit., pp. 32, 33.

${ }^{1057}$ La trasformación de la campaña en una cruzada fue quizás un elemento crucial para su éxito. No sólo se entendía como una guerra justa según la tradición jurídica vigente en Europa, sino que también era una lucha santa, que apelaba a las prácticas y creencias religiosas más importantes, en especial el perdón de los pecados. En una sociedad altamente piadosa, la idea de asegurar la salvación de sus almas era un estímulo potente, que se reforzaba en la visión del Islam como un ente maligno, percepción que apelaba a los sentimientos caballerescos y que terminó por convertir cualquier tipo de enfrentamiento con los musulmanes - independientemente si se hacían en respuesta a una bula o no- en un esfuerzo que producía recompensas espirituales. Esta es una de las razones que explican el porque los ultramontanos acudieron en masa al llamado pontificio y del monarca castellano, continuando con así con una tradición de cruzada, iniciada, tiempo atrás, por el llamado de Urbano II (García Fritz, Francisco, Las Navas de Tolosa ... op. cit., pp. 407, 419-421). 
todo el reino para la gran batalla. De esta forma se forjó una gran alianza peninsular, algo inédito en la guerra de Reconquista ${ }^{1058}$.

Pero Alfonso VIII estaba decidido a la victoria, y aprovechó la Bula de Cruzada para enviar al Arzobispo de Toledo -Rodrigo Jiménez de Rada- a la Corte de Felipe II en Francia para invitarlo a unirse a la campaña, bajo las promesas de expiación cruzada y botín. Sin embargo, el monarca franco no estuvo dispuesto a arriesgarse en las lejanas tierras andaluzas, menos aún cuando se desarrollaba la cruzada albigense en sus territorios. No obstante, Jiménez logró convencer a numerosos señores francos, entre ellos los obispos de Narbona, Burdeos y Nantes ${ }^{1059}$.

Finalmente, la presencia de los francos no fue un factor determinante en la victoria, puesto que se retiraron antes de la batalla; no obstante, la proclamación de la cruzada y sus promesas fueron fundamentales para que Alfonso pudiese actuar sin temor de sus enemigos cristianos y pudiese reunir una multitud de guerreros venidos de los distintos reinos hispanos.

Tiempo después, para 1230, Fernando III asestaba fuertes golpes a los andalusíes, mientras que su padre Alfonso IX hacía lo mismo en Extremadura. Por ello Gregorio IX, autorizó a Jiménez de Rada -en ese momento legado pontificio para la guerra peninsular- para que otorgase indulgencias a quienes se uniesen o apoyasen materialmente las expediciones. Posteriormente permitió al legado absolver de la excomunión a los cruzados sancionados, fortaleciendo así la idea de la cruzada como expiación de los pecados ${ }^{1060}$.

En muchas ocasiones la ayuda del Papa no sólo se limitaba a las indulgencias, puesto que a solicitud de los soberanos, no fue poco frecuente que les otorgara el uso de las décimas de la Iglesia o incluso algunos aportes extraordinarios, como los veinte mil áureos por tres años que Gregorio IX le otorgó a Fernando III para el repoblamiento y aseguramiento de la recién conquistada Córdoba. En forma casi pasarela, en 1240, mientras la frontera estaba en paz y para no perder el esfuerzo bélico, el Papa concedió

\footnotetext{
${ }^{1058}$ Por su parte Alfonso IX, se limito a aceptar la tregua, pero se negó a acudir mientras su primo no le devolviese los territorios y castillos conquistados e incluso aprovechó la campaña para recuperar algunos de ellos, pero solo en territorio de León para no exponerse a la excomunión.

${ }^{1059}$ CXXR, Libro XIII, cap. XXVIII, op. cit., pp. 281, 282.

Según las crónicas, se logró convocar alrededor de 40 a 60 mil hombres. Aunque las cifras modernas los han reducido a entre 15.000 y 30.000 , siendo de igual forma un número significativo de hombres para la época (García Fitz, Francisco, Castilla y León frente al Islam ... op. cit., pp. 361-366).

${ }^{1060}$ Goñi Gaztambide, José, Historia de la Bula de Cruzada... op. cit., p. 154; y De Ayala Martínez, Carlos, "Fernando III: Figura, significado y contexto... op. cit., p. 24.
} 
indulgencia especial a quienes se uniesen a las luchas de las órdenes de Alcántara y Calatrava contra los "moros" 1061 .

A la muerte de Fernando III, Alfonso $\mathrm{X}$ tambien solicitó y recibió ayuda pontificia para su proyectada “campaña del Estrecho". Inocencio IV ordenó a los obispos de Cartagena y Zamora absolver de la excomunión a todos quienes se uniesen a la hueste, costearan el envío de combatientes o aportasen económicamente a la empresa. Para este momento la práctica de las indulgencias estaba tan arraigada en el pensamiento militar hispano, que cuando estallaron las revueltas mudéjares en 1264, la primera reacción de Alfonso $\mathrm{X}$ fue desempolvar dos antiguas bulas de cruzada para asegurar el flujo de hombres y recursos para controlar la amenaza. Esta medida le permitió ganar tiempo, mientras que desde Roma, Clemente IV despachaba cuatro nuevas bulas. En ellas el Papa cubría todas las necesidades del monarca, prometiendo veinte días de indulgencia para quienes rezasen por el triunfo cristiano. Así también, se ordenaba al clero otorgar las centésimas de Tierra Santa para financiar la campaña contra los rebeldes, a la vez que se mandaba al Obispo de Sevilla predicar la cruzada en Hispania, Genova y Pisa. Finalmente, se otorgaban indulgencias plenarias en forma triple: una indulgencia parcial a los que aportasen con bienes o navíos, además de una protección apostólica, y la remisión de usuras e inmunidad para los cruzados. Además se facultaba a los legados predicar la cruzada y conceder cien días de indulgencias a quienes acudiesen al oír el llamado; además se autorizaba a conmutar los votos de ayuno y peregrinación a cambio de colaborar en la lucha, y finalmente se prometía a los predicadores que difundiesen la noticia durante un año, los mismos privilegios y garantías que a los cruzados ${ }^{1062}$.

En su conjunto, la Revuelta Mudéjar nos revela hasta qué punto se habían instrumentalizado las indulgencias al servicio de la causa de la Reconquista. Puesto que incluso para una situación apremiante como una revuelta interna, era necesario recurrir a ellas para garantizar el éxito material y humano de la empresa.

No obstante los ejemplos anteriores, las promesas de indulgencias no parecen ser un elemento fundamental dentro discurso cronístico. Es cierto que la población demostraba un fuerte interés en la salvación y el perdón de los pecados, pero al parecer no fue una herramienta a la cual los cronistas recurriesen a menudo; tampoco el

${ }^{1061}$ González Jiménez, Manuel, Fernando III el Santo ... op. cit., p. 178; y Domínguez Sánchez, Santiago, Documentos de Gregorio IX..., op. cit., pp. 726, 727.

${ }^{1062}$ Goñi Gaztambide, José, Historia de la Bula de Cruzada ... op. cit., pp. 155, 156, 187-189, 192, 193. Para un conocimiento detallado de estas fuentes, recomendamos remitirse a la ya citada obra de Santiago Domínguez Sánchez, Documentos de Clemente IV (1265-1268). 
aparataje jurídico hacía eco de esta situación. Un aspecto bastante decidor a este respecto es que las primeras fuentes que hablan sobre el tópico de las indulgencias son de alrededor de la década de 1130, como la Historia Compostelana y el Codex Calixtinus, en un momento en que la influencia franca ya era notable en el reino leonés y se habían experimentado los primeros grandes avances territoriales por parte de Alfonso VI, así como los efectos de la invasión almorávide. No será hasta la década de 1210 que el discurso cronístico vuelva a incorporar el tema de las indulgencias, coincidiendo con la reactivación de la expansión reconquistadora, presentándose con más frecuencia en los textos de los siglos posteriores. Sin embargo, continuó mostrándose como un elemento secundario en comparación con otros argumentos más recurrentes como lo eran el botín, la lucha contra el Islam usurpador y la exaltación hispánica.

Tabla 16: Idulgencias

\begin{tabular}{|l|l|l|l|l|l|}
\hline & $\begin{array}{l}\text { Parciales } \\
\text { Papales }\end{array}$ & $\begin{array}{l}\text { Parciales } \\
\text { Locales }\end{array}$ & $\begin{array}{l}\text { Plenarias } \\
\text { Papales }\end{array}$ & $\begin{array}{l}\text { Plenarias } \\
\text { Locales }\end{array}$ & Fuente \\
\hline 1000 & & & & & \\
\hline 1090 & & & & & \\
\hline 1100 & & & & & \\
\hline 1110 & & & & & \\
\hline 1120 & & & & & \\
\hline 1130 & $\mathrm{X}$ & & $\mathrm{X}$ & $\mathrm{X}$ & \begin{tabular}{l} 
- HC Libro I Cap 39 $\mathrm{p} .146$. Libro II Cap 78 pp. \\
\hline 1140
\end{tabular} \\
\hline 1150 & $\mathrm{X}$ & $\mathrm{X}$ & $\mathrm{X}$ & & $\begin{array}{l}\text { - CAI [PA] 40 pp.132. } \\
\text { - LSJ Libro Libro IV Cap 26 pp. 521, 522 }\end{array}$ \\
\hline 1160 & & & & & \\
\hline 1170 & & & & & \\
\hline 1180 & & & & & \\
\hline 1190 & & & & & \\
\hline 1200 & & & & & \\
\hline 1210 & $\mathrm{X}$ & & $\mathrm{X}$ & & - AT I p. 350, 351 \\
\hline 1220 & & & & & \\
\hline 1230 & & & & & \\
\hline 1240 & & $\mathrm{X}$ & & $\mathrm{X}$ & - HRH Libro VII Cap 14 p. 282 \\
\hline 1250 & & & & & \\
\hline 1260 & & & & & \\
\hline 1270 & & $\mathrm{X}$ & & $\mathrm{X}$ & - CGE Cap. 987 p. 667 \\
\hline 1280 & & & & & \\
\hline 1290 & & & & & \\
\hline 1300 & & & & & \\
\hline
\end{tabular}




\section{III.3.b.- Martirio}

Otro elemento, que si bien no se reproduce mayormente en las crónicas, sí se repite abundantemente en bulas y epístolas -como por ejemplo en la ya citada del Papa Calixto-, es la mención al martirio. Ésta era considerada la más gloriosa forma de alcanzar las recompensas celestiales, pero quizás no la más deseada, puesto que implicaba el deceso del beneficiario. No obstante, el martirio era considerado la forma de muerte más cristiana de todas, puesto que significaba la entrega total a la Iglesia y a la comunidad de creyentes, siguiendo el ejemplo de Cristo y de los primeros cristianos. Quien muriese bajo el martirio, inmediatamente alcanzaría la gloria en los cielos: la máxima recompensa a la que cualquier hombre podía aspirar ${ }^{1063}$.

De esta manera, de forma similar a lo ocurrido con las indulgencias, la concepción del martirio experimentó un importante auge a partir de las cruzadas, como se evidencia en los anteriormente mencionados escritos de Bernardo de Claraval ${ }^{1064}$.

Bajo los nuevos preceptos de la cruzada, el caballero debía alegrarse si obtenía la victoria en el nombre de Dios, pero aún más si moría, ya que así alcanzaría el gozo y la gloria al unirse con Dios, siendo esta muerte más apetecible que cualquier victoria. En otras palabras, el martirio no era un sacrificio, sino una recompensa, y la mayor de todas. Es por eso que se convertían en la meta para todo guerrero.

Pero ya antes de la obra de Bernardo, la idea ya había calado hondo en relación a la lucha en Hispania. Ya hemos visto cómo el Papa Calixto incorporó las promesas de

\footnotetext{
${ }^{1063}$ La idea del martirio, experimentó una evolución en la cosmología cristiana. En un estado inicial en el tiempo de las persecuciones romanas, el mártir encontraba su muerte, condenado por el sólo hecho de ser cristiano. Con el paso del tiempo esta concepción fue mutando hasta aplicarse a quienes sucumbían en la defensa de la Iglesia. Finalmente, esta muerte no tenía porqué ser provocada por una actitud meramente defensiva, puesto que la evolución de los conceptos de guerra en el cristianismo permitieron considerar mártires a aquellos que morían luchando contra los enemigos de la fe sin importar donde ello ocurriese. Esta última idea se popularizó a partir de finales del siglo XI, siendo prácticamente imposible separarla de la idea de la guerra santa cristiana (Rodríguez García, José Manuel, "Cruzados y fronterizos. Discusión sobre el Carácter Cruzado de la Guerra en la Frontera, 1214-1314”, en Toro Ceballos, Francisco y José Rodríguez Molina (Coordinadores), III Estudios de Frontera... op. cit., pp. 581; y Goñi Gaztambide, José, Historia de la Bula de Cruzada... op. cit., p. 38).

Maribel Fierro nos recuerda en su texto De muerte violenta. Política, religión y Violencia en el alAndalus, que la idea del martirio no era ajena para el Islam. La doctrina Maliki afirmaba que quien moría por Alá ascendía directamente al cielo y gozaba de una situación especial entre el resto de los creyentes. Esto debido a que su sacrificio implicaba el perdón por todas sus faltas y le garantizaba la eternidad en gozo y paz.

${ }_{1064}$ ENMT, I, op. cit., p. 41. Para un análisis de estos aspectos de la obra de Bernardo, ver el subcapítulo I.2.b.- De la Guerra santa a la Cruzada, y la nota número 186 de esta tesis.
} 
recibir las palmas martirio a aquellos que bajo el signo de la cruz y con sus pecados confesados, muriesen en la lucha contra los musulmanes ${ }^{1065}$.

Urbano II también hizo promesas a los fieles hispanos, a quienes se dirigió para exhortarlos a la lucha contra los sarracenos. En una epístola, el pontífice incita a los peninsulares a esforzarse en su lucha contra el Islam, al igual que lo hacían quienes partían a Tierra Santa. Y al igual que ellos, se les prometía que todo aquel que muriese en campaña: "conseguirá el perdón de sus pecados y la vida eterna por la gracia misericordiosa de Dios" ${ }^{1066}$. Todo ello para evitar que los hispanos, impulsados por el fervor cruzado, abandonasen su propio frente de batalla en la Península.

El gráfico número 12 nos señala, que al igual que en el caso de las indulgencias, al parecer, las promesas de martirio tampoco se manifestaron mayormente en las crónicas, siendo bastante escasas las referencias explícitas a ello, a exepción de las obras de influencia franca, como el Codex Calixtinus. Posteriormente, en las crónicas hispanas escritas entre los años 1220 y 1270, la idea del martirio volvería a aparecer, ahora vinculada a la expansión y radicalización de la Reconquista, aunque sin convertirse en un argumento central para el estímulo de los guerreros.

\section{Gráfico 17: Martirio}

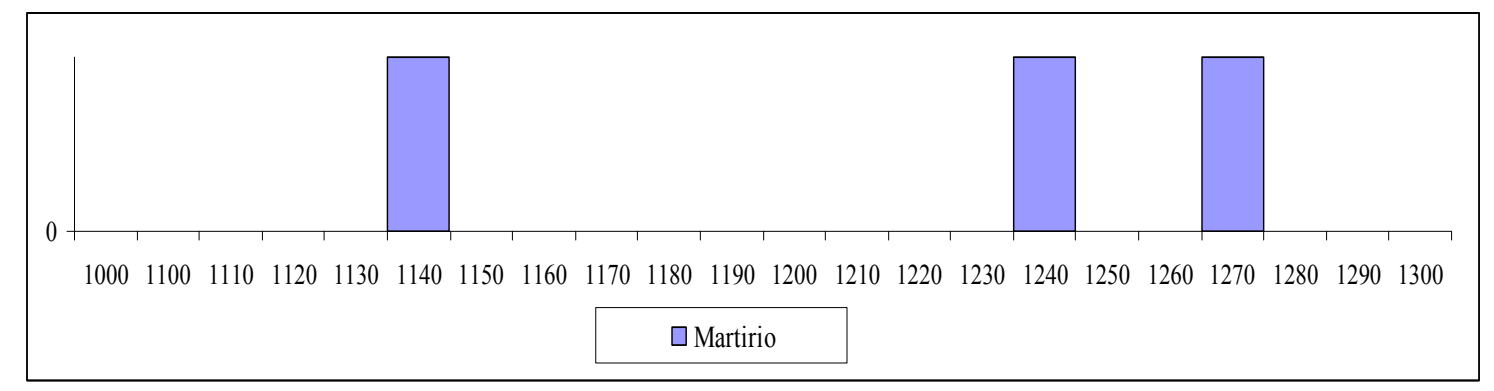

Pero, incluso en estos casos la mención a la muerte en guerra como vía para la salvación no se trataba de forma explícita, limitándose a la inclusión de algunas referencias discursivas menores, que en ocasiones se pierden dentro de la retórica cronística. Ese es el caso, de la Crónica Latina que comenta la batalla de Alarcos, en la cual la idea del martirio y recompensa eterna se pierde en medio de las intenciones líricas del autor: "[...] humani sanguinis dies prodiga Mauros mittit ad Tartara,

\footnotetext{
1065 LSJ 1998, Libro IV, Appendix D, op. cit., p. 229.

${ }^{1066}$ Urbano II, Carta 20, Epistolae et privilegia, en Flori, Jean, Guerra Santa, Yihad, Cruzada... op. cit., p. 315.
} 
Christianos transmittit ad eterna palacia" ${ }^{\not 1067}$. Frente a esto cabe preguntarse si es que dicha referencia hace eco de una idea ya arraigada en la mentalidad guerrera hispana, o bien se trata solamente de un discurso literario para resaltar las diferencias entre los guerreros cristianos y musulmanes.

En la Crónica de veinte reyes, se nos revela un buen ejemplo del uso de las ideas del martirio en la mentalidad caballeresca hispánica. El episodio en cuestión ocurre cuando una multitud de musulmanes al mando del rey de Granada atacan Martos, que en ese momento se encontraba sin defensa debido a la partida de sus caballeros hacia otras tierras. Por ello, la esposa del Conde Alvar Peres, que se encontraba en el lugar, dirige las defensas de la localidad. En su auxilio llega don Tello, sobrino del Conde, acompañado por unos pocos caballeros, aunque insuficientes para romper el cerco. Mientras los guerreros cristianos dudan en su manera de proceder, uno de los caballeros, de nombre Diego Peres de Vargas, exhorta a sus compañeros a lanzar una carga y romper las filas enemigas, haciendo en ello claras referencias al martirio:

"E los que non pudieramos pasar moriremos e saluaremos nuestras almas, e yremos a la iglesia del paraíso, e conpliremos nuestro debdo, aquello que todo cauallero fijodalgo deue conplir, e esto es fazer derecho e perder miedo alli do lo deue omne perder, ca, sy asy ymos de aquí syn más [...]"1068

Los caballeros lograron romper las líneas granadinas y penetrar en el castillo, por lo que los sitiadores decidieron abandonar el cerco. Si bien el discurso de Diego Peres se puede vincular con los ideales de caballería y de fama -por el honor y el rescate de la dama en apuros-, es notoria la mención a la "iglesia del paraíso" como destino de quienes cayeran en la refriega. Esto no es más que la apelación a la creencia de que al morir combatiendo a los musulmanes, por ser una causa justa, cumplían su deber para con su Señor, su rey y su fe. Por tanto, su recompensa sería la vida eterna.

De forma aún más tardía -escapándose de nuestro marco de estudio, pero prudente de mencionar por su claridad-, en el siglo XIV, don Juan Manuel sintetiza e incluye los usos de la idea del martirio en su Libro de los Estados. En el capítulo XXX de la parte primera, enlaza la guerra justa y la Reconquista con el martirio:

“Et tiene[n] los buenos christianos que la razón por que Dios consintió que los cristianos oviesen reçebido de los moros tanto mal, es por que ayan razón de

${ }^{1067}$ CLRC 1997, $\mathrm{N}^{\circ} 13$, op. cit., p. 46. "Se lucha con fuerza por ambos bandos. El día pródigo en sangre humana, envía moros al tártaro y trasladó cristianos a los eternos palacios" CLRC 1999, N 13, op. cit., p. 39.

${ }^{1068}$ CXXR, Libro XV, cap., VI, op. cit., p. 320. 
aver con ellos guerra derechureramente, por los que en ella muriesen, aviendo conplido los mandamientos de sancta Eclesia, sean mártires, et sean las sus ánimas, por el martirio, quitas del pecado que finieren" ${ }^{1069}$.

Posteriormente, en el capítulo LXXVI de la primera parte del mismo libro, el autor procura aclarar, seguramente teniendo en vista las realidades de la convivencia fronteriza, que no se debía considerar mártires a todos los que cayesen en lucha contra los musulmanes, sino que sólo a aquellos que muriesen en el contexto de una campaña autorizada, excluyendo así las campañas de pillaje $\mathrm{u}$ otras actividades predatorias que pudiesen alterar las relaciones fronterizas ${ }^{1070}$. Esto demuestra que si bien el martirio es un elemento presente en las ideas de la nobleza y guerreros castellanos, éste no podía convertirse en un estímulo para el fanatismo guerrero; por el contrario, debía someterse a la planificación práctica de la guerra peninsular.

Es así como las recompensas divinas como las indulgencias y el martirio fueron una forma secundaria pero eficiente de exaltar el ardor guerrero de los hispanos. En ello, a la monarquía le cupo encauzar tal ímpetu hacia objetivos prácticos en el marco de la Reconquista. Así, poder político y poder religioso utilizaron la piedad y creencias de los hispanos para asegurar la continuación de la guerra contra el Islam y evitar el cese de los hombres y recursos necesarios para la empresa. Por esa misma razón era necesario recordar permanentemente a los combatientes que su empresa era una causa religiosa, situación por la que era necesario mantener y enriquecer de manera permanente una ritualidad religiosa militar.

${ }^{1069}$ LDLE I Parte, Cap. XXX, op. cit., p. 117.

${ }^{1070}$ Hay que recordar que para la época de don Juan Manuel la Reconquista experimentaba una etapa de ralentización caracterizada por los pactos y las treguas, por lo que es lógico concluir que el autor, como parte de la elite política, procurar desincentivar las acciones militares particulares que pudiesen contradecir las decisiones y estrategias reales. 
Tabla 17: Martirio

\begin{tabular}{|l|l|l|}
\hline & Martirio & \multicolumn{1}{|c|}{ Fuente } \\
\hline 1000 & & \\
\hline 1090 & & \\
\hline 1100 & & \\
\hline 1110 & & - CAI [PA] 40 pp.133, 134 \\
\hline 1120 & & - LSJ Libro Libro IV Cap 26 p. 522. \\
\hline 1130 & & \\
\hline 1140 & & \\
\hline 1150 & & \\
\hline 1160 & & \\
\hline 1170 & & \\
\hline 1180 & & \\
\hline 1190 & & - HRH Libro VIII Cap.5 pp. 312, 313 \\
\hline 1200 & & \\
\hline 1220 & & - CGE Cap. 1015 p. 695 \\
\hline 1230 & & - CXXR Libro XIV Cap. 25 p. 313, Libro XV \\
\hline 1240 & & Cap. 6 p. 320. \\
\hline 1250 & & \\
\hline 1260 & & \\
\hline 1270 & & \\
\hline 1280 & & \\
\hline 1290 & & \\
\hline 1300 & & \\
\hline
\end{tabular}




\section{III.3.c.- Rituales bélico-religiosos en occidente}

Desde tiempos pretéritos, la guerra se rodeó de una ritualidad religiosa particular, con el consabido objetivo de atraer la gracia de los dioses o de la Providencia hacia cada uno de los bandos en disputa ${ }^{1071}$.

La forma común de realizar estas rogativas se traduce en la práctica de "ritos", los que se comprenden como fórmulas -más o menos rígidas- llevadas a cabo por algún guía espiritual (chaman o sacerdote) con el fin de atraer la bendición de una deidad; en síntesis el rito es siempre parte de la práctica y la concepción religiosa de una cultura. Una característica esencial del rito, según Durkheim, es que se crea y recrea de forma periódica y permanente, a lo que Eliade agrega un profundo sentido de renovación del acto primordial ${ }^{1072}$. Es decir, cumplen la función de repetir un acto inaugural de orígenes místicos que dan sentido a una realidad, sirviendo por ello para señalar el fin o el comienzo de una etapa, resultando fundamentales para marcar y comprender el paso del tiempo ${ }^{1073}$. Entonces, los rituales forman parte del orden cósmico y terrenal, por lo tanto, se hacen necesarios para el desenvolvimiento de la vida cotidiana. Al fin y al cabo, en todas las sociedades los ritos forman parte integral de las vidas de las personas. Vemos así ritos de fecundidad, de nacimiento, de transición a la adultez, de muerte, etc., así como ritos que señalan el momento de la siembra, de la cosecha, de la recolección, de la cacería, de la matanza, del verano, del invierno, etc.

En relación a ello debemos observar que los pueblos del Mediterraneo tambien fueron culturas de cultos y ritos altamente reglamentados ${ }^{1074}$. Por su parte los germanos

${ }^{1071}$ Por lo general entendemos los ritos como solicitudes a la divinidad mediante ofrendas o peticiones para rogar por su intervención en un determinado acontecimiento (Rubio Hernández, Rogelio, Antropología... op. cit., p. 57). Estas rogativas son comunes a todas las civilizaciones humanas, siendo utilizadas para responder a distintas necesidades, tales como la de lluvia, de cosechas, o de enfrentar algún mal como podían ser ataques enemigos o enfermedades.

${ }^{1072}$ En el capítulo "Ritos" del Diccionario razonado del occidente medieval de Le Goff y Schmitt, este ultimo define el rito sencillamente como "una sucesión ordenada de gestos, de sonidos (palabras y músicas) y de objetos, desencadenada por la acción de un grupo social con fines simbólicos" y que incluye el desarrollo simultaneo del tiempo y el espacio, así como múltiples dimensiones como gestos, palabras, emblemas, instrumentos, ordenados en una serie de acciones de orden jerárquico repetidas solemnemente, distintos a la ceremonia, que correspondería a una manifestación impuesta y a diferencia del rito, prácticamente carente de emoción. Schmitt, Jean-Claude, "Ritos", en Le Goff, Jacques y JeanClaude Schmitt (Editores), Diccionario razonado.... op. cit., pp. 688, 689; y Eliade, Mircea, El mito del eterno retorno. Arquetipos y repetición, Buenos Aires, Alianza, 1972, p. 15.

1073 Durkheim, Emile, Las formas elementales de la vida religiosa. El sistema totémico en Australia, Madrid, Akal, 1992, pp. 33, 389; y Eliade, Mircea, El mito... op. cit., p. 15.

${ }^{1074}$ Los romanos crearon una serie de rituales jurídico-religiosos vinculados a guerra justa. Incluyendo juramentos, sacrificios y la participación destacada de sacerdotes y embajadores. Todo ello con el fin de asegurar los auspicios divinos, sin los cuales la victoria sería imposible. (Kakarieka, Julios, "Los orígenes... op. cit., pp. 269, 277-281). 
también crearon estructuras de gran carga ritual. Fue así como el cristianismo primitivo fue adaptando sus raíces hebraicas y combinándolas con los rituales de los pueblos paganos con los que entró en contacto.

Pieza clave en las prácticas rituales fueron los sacerdotes, eran ellos los que, por estar dotados de un carisma particular, podían comunicarse directamente e incluso influir en la divinidad. Autores como Max Weber y Jean Markale hablan incluso de la potestad de los sacerdotes para obligar a la divinidad a satisfacer sus ruegos ${ }^{1075}$.

En esencia, la práctica de ciertos ritos fue común para los pueblos indoeuropeos y para todas las culturas humanas desde América hasta Asía, sin importar el grado de desarrollo de sus civilizaciones todos elaboraron sistemas de interacción con la divinidad, donde los ritos son piezas fundamentales.

En el mundo medieval la Iglesia procuró monopolizar la ritualidad, anteponiendo los ritos religiosos y sagrados dirigidos por ella, controlando así las relaciones entre los hombres y la divinidad ${ }^{1076}$.

Al igual que otros ceremoniales, los ritos bélicos fueron comunes a todas las civilizaciones, y habitualmente se realizaban antes y después de la batalla. Solían ser ofrendas y sacrificios, muchas veces acompañados de la interpretación de augurios que buscaban conocer la voluntad de los dioses. Luego de la victoria se repetían los sacrificios, como acción de gracias, siendo habitual la entrega de parte del botín y de prisioneros a las deidades. Gastón Bouthoul agrega, que los rituales previos al combate cumplían la función de ritos funerarios anticipados o instancias de purificación destinados a la preparación para la buena muerte ${ }^{1077}$.

Debemos tener en consideración que a medida que el cristianismo fue aceptando la violencia como parte de su cosmovisión, fue necesario que se creasen o adaptasen algunos ritos destinados a completar la sacralización de la lucha cristiana ${ }^{1078}$.

El fortalecimiento de la Iglesia y el colapso de Roma lograron que la religiosidad cristiana permeara todas las esferas culturales de la convulsa Europa, de manera que las oraciones, como símbolo de la verdadera fe, se convirtieron en un arma más.

\footnotetext{
1075 Weber, Max, Economía y Sociedad.... op. cit., p. 343. Respecto a Markale solo hemos usado como referencia su obra El cristianismo celta: orígenes y huellas de una espiritualidad perdida, por ilustrar de manera grafica algunos de los planteamientos de Weber.

1076 Schmitt, Jean-Claude, "Ritos", en Le Goff, Jacques y Jean-Claude Schimitt (Editores), Diccionario razonado... op. cit., p. 692.

1077 Bouthoul, Gastón, La Guerra ... op. cit., p. 10.

${ }^{1078}$ Keen, Maurice, La Caballería... op. cit., pp. 72, 73.
} 
Esto explica porqué en el siglo VIII se atestiguan oraciones específicas para implorar la derrota de los enemigos del Papado, o porqué los francos y Carlomagno hacían rezar, ayunar y hacer procesiones a sus soldados antes de enfrentarse a los sajones paganos ${ }^{1079}$.

Todo lo anterior es parte de ese largo y relativamente exitoso proceso mediante el cual la Iglesia trató de encauzar la violencia durante todo el medievo. Parte de este fue la asignación y consagración de los roles sociales, en especial de los bellatores, para quienes se creó una ritualidad propia que consideraba su investidura, su consagración y la entrega de sus armas, procurando simbolizar con ellos la alianza entre los guerreros y la Iglesia, una situación que se hizo cada vez más relevante a partir del siglo XI con el posterior surgimiento de las ordenes de caballería ${ }^{1080}$. El caballero debía regir su vida por la fe y ser un ejemplo de ella, razón por la cual no fueron poco frecuentes las representaciones de guerreros armados en medio de rituales religiosos, siendo muy frecuente las imágenes de caballeros en oración.

En lugares donde la lucha se realizaba contra grupos considerados enemigos de la fe, como el Islam en el caso de la Península Ibérica, estos ritos adquirían una relevancia particular, puesto que eran la prueba palpable de la alianza entre el poder político que llevaba a cabo la guerra y el poder religioso que la sacralizaba.

En nuestro caso, los ritos y rituales que nos interesan son aquellos vinculados a la actividad bélica, que pueden ser detectados en las primeras crónicas de la Reconquista, en especial en aquellas vinculadas a la batalla de Covadonga. Para el siglo XII se puede observar una mayor descripción de rituales bélicos, posiblemente influenciados por la consolidación de las ideas de cruzada y la presencia franca en la Península. En otras palabras, la mayor consideración de los rituales bélico-religiosos en las crónicas coincide con la consolidación de una ideología bélica europea y con el fortalecimiento de la figura del monarca como líder bélico y militar del reino.

En el escenario peninsular, y particularmente en el castellano y leonés, es que se pueden testimoniar los diferentes rituales bélico-religiosos, que hemos catalogado como ritos de preparación al combate -dentro de ellos los del buen morir-, los de gratitud por

\footnotetext{
${ }^{1079}$ García Villoslada, Ricardo, Historia de la Iglesia Católica en sus cuatro grandes edades ... op. cit., p. 428; y Flori, Jean, Guerra Santa, Yihad, Cruzada... op. cit., p. 125.

${ }^{1080}$ García-Guijarro Ramos, Luis, Papado, cruzadas y órdenes militares... op. cit., p. 42, 43; y Flori, Jean, La caballería...op. cit., p. 87.
} 
la victoria y los de purificación. A continuación se tratarán en mayor detalle algunos ejemplos de ellos ${ }^{1081}$.

\section{III.3.d.- Ritos de preparación al combate}

Los ritos de preparación para el combate tenían una doble finalidad, ambas ya enunciadas: la primera, atraer la gracia de la divinidad para que diese el triunfo a quienes lo suplicaban, y el segundo servir de preparación colectiva para la eventual muerte. En el cristianismo en general y en Hispania en particular, estos ritos se practicaban en forma habitual antes de la lucha por lo que incluso pueden ser catalogados de la contraparte religiosa de la arenga que daban los caudillos ${ }^{1082}$. Esto se debe a que aparte de las funciones ya mencionadas, los ritos previos a la lucha, como la bendición de estandartes y armas, las liturgias, confesiones, eucaristías y bendiciones a los guerreros, eran también parte de la difusión del discurso político-religioso ${ }^{1083}$. En las oraciones se apelaba a la tradición veterotestamentaria, recordando a los héroes bíblicos que con la ayuda de Dios sortearon toda suerte de obstáculos y vencieron a sus enemigos ${ }^{1084}$. Las prédicas y los ritos funcionaban como el recordatorio de que eran guerreros cristianos que luchaban por su fe contra los adversarios de su religión; contra los otros, los sirvientes del mal ${ }^{1085}$.

${ }^{1081}$ En las crónicas estos ritos no cuentan con una categorización clara y muchas veces se confunden, razón por la cual nosotros hemos optado por dividirlos de acuerdo a ciertas características y funcionalidad, no obstante algunos de ellos pueden corresponden y ser estudiados en mas de una categoría.

${ }^{1082}$ Sobre el tema de la arenga Francisco García Fitz, en los últimos años ha dedicado algunos estudios al respecto, entre los cuales recomendamos su artículo "La arenga militar en la historiográfica de las cruzadas: la ideología patente", ya citada anteriormente.

${ }^{1083}$ Alvira Cabrer, Martín, "Guerra e ideología en la España del siglo XIII: la conquista de Mallorca según la crónica de Bernat Desclot”, en En la Edad Media, 19, 1996, [pp. 37-50], p. 43.

${ }^{1084}$ Como en otros casos, los rituales de preparación para el combate no fueron exclusivos del mundo cristiano, por el contrario son comunes a muchas religiones, entre ellas el Islam. Ya se han indicado otros ejemplo de ello, por ejemplo el Islam en sus orígenes experimentó la influencia del judaísmo, y por lo tanto, parte de sus raíces son comunes a las del cristianismo, motivo por el cual es posible observar similitudes entre algunos ritos y formas. No es de extrañar entonces que los musulmanes practicasen costumbres destinadas a asegurar la gracia divina en el combate, tal cual nos cuenta Ibn 'Idari en su tardía crónica, al relatar el ceremonial que presidió el inicio de la campaña de al-Malik, contra los catalanes: " $E l$ día viernes, a las 8 [noches] andadas de ša'bān del año este [12 de junio de 1003], Abd al-Malik cabalgó hacia la mezquita aljama en la capital de Córdoba, a fin de asistir a [la ceremonia de] anudamiento de los estandartes para esta expedición, conforme la costumbre de los emires de al-Andalus que le precedieron" (CCC, op. cit., p. 13).

${ }^{1085}$ Por lo anterior, al igual que en otros tipos de ritos, previo al combate era fundamental la participación de los clérigos. De ellos era la misión de realizar las ceremonias y exaltar la piedad de los guerreros, no obstante tenían prohibido combatir, puesto que derramar sangre era impropio de ellos y su cargo. Un rol que Tomas de Aquino sintetiza en su Summa Teologica de la siguiente manera: "sed ut iuste pugnantibus spiritualiter subveniant suis exhotationibus et absolutionibus et aliis huiusmodi spiritualibus subventionibus" (ST, Tomo VII, Cuestión 40, articulo 2. op. cit., pp. 1080, "para prestar socorro 
Las fuentes hispano cristianas de los siglos XII y XIII, en general no son muy descriptivas en cuanto a estos rituales de preparación al combate, limitándose a menciones generales, donde el ritual en sí queda relegado a un segundo lugar; en tanto que se procuraba describir con mayor detalle las fórmulas de la oración. Esto en razón, quizás, de lo que realmente interesaba al cronista era relatar la lucha y sus resultados, pues eso era lo que demostraba la grandeza de la causa y los acontecimientos ${ }^{1086}$.

En todo caso, estos ritos se centran especialmente en formulas de liturgias y oraciones, así como también en actos colectivos de confesión y arrepentimiento de los pecados. Siendo - como nos indica el siguiente gráfico- los relatos vinculados a los actos litúrgicos los más abundantes, en especial entre los años 1130 y 1140 y luego durante el periodo entre 1220 y 1270.

\section{Gráfico 18: Ritos de preparación al combate}

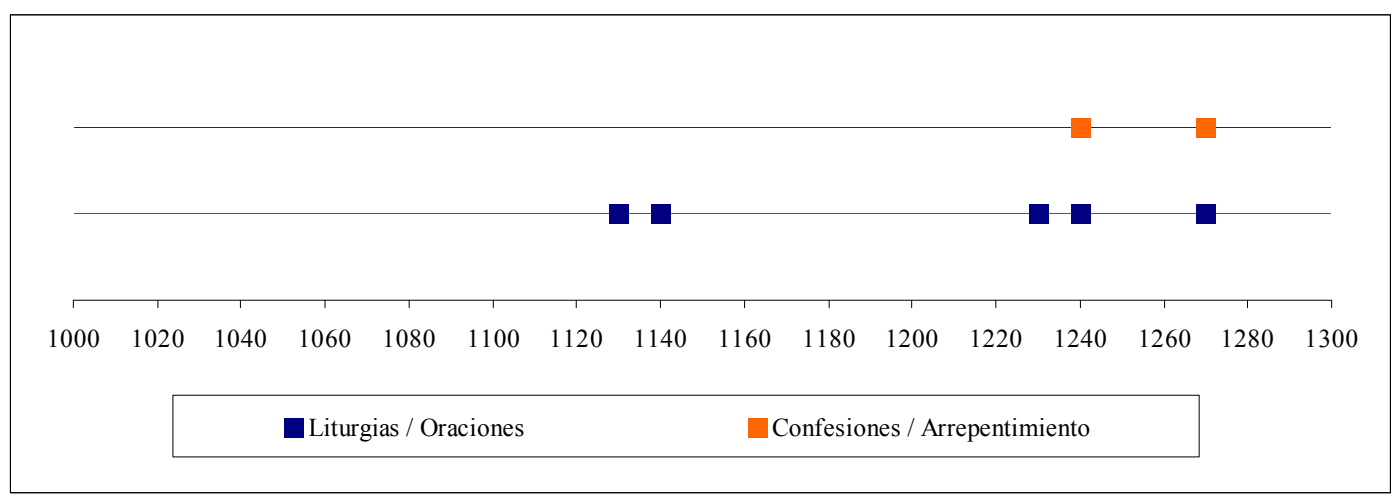

Por lo general, estos ritos litúrgicos pueden dividirse en dos grandes grupos. En el primero se encuentran aquellos que se realizaban al inicio de la campaña y que podían ser parte de una planificación anticipada. En estos casos la dinámica solía ser más o

espiritual con sus oraciones y absoluciones y otros auxilios espirituales a aquellos que combaten justamente").

La presencia de clérigos fue común en las huestes medievales y los ritos que dirigían eran parte integral de la realidad bélica, abarcando funciones espirituales y morales. Es decir los clérigos debían orar por los que combatían pero también eran los garantes de las recompensas divinas en estas circunstancias, puesto que también debían auxiliar con sus absoluciones, es decir el perdón de los pecados. Además el santo, es claro en recordar el concepto de justicia vinculado a la lucha, como una forma de recalcar que los clérigos solo podían actuar y realizar los rituales, cuando la causa por la que se combatía contase con el patrocinio de la Iglesia, algo especialmente importante en Hispania. Donde además fue especialmente evidente, pero no exclusivo, el hecho de que algunos altos clérigos como abades y obispos se veían obligados a actuar como caudillos militares y dirigir tropas, debido a las obligaciones vasallaticas que abarcaban sus altos cargos. Pero incluso en esos casos se pretendía que el clérigo evitase verse directamente involucrado en la lucha (Martín Martín, José Luis, "Algunas prácticas clericales... op. cit., p. 409; Flori, Jean, La Guerra Santa ... op. cit., p. 57; y Lomax, Derek. La Reconquista ... op. cit., p. 138). ${ }^{1086} \mathrm{Si}$ bien en las crónicas las confesiones y actos de contrición tienen pocas menciones, no hay que olvidar que estas prácticas suelen ser parte importante de la liturgia y por lo tanto pueden estar incluidas de forma tácita en las referencias a estos rituales. 
menos la misma, la cual es magistralmente narrada por Sánchez-Albornoz y que sintetizamos a continuación. Cuando se decidía iniciar una campaña, se designaba a un clérigo para que portase la cruz a modo de estandarte. A continuación el rey y sus magnates se dirigían a la iglesia mayor donde los esperaban reunidos la hueste y autoridades. Luego se oficiaba una misa, en la cual se oraba por el triunfo de la campaña. A veces durante su transcurso se bendecían los estandartes y enseñas, y al finalizar la liturgia, los clérigos consagraban a la tropa, que luego se ponía en marcha, usualmente entonando himnos religiosos que progresivamente eran reemplazados por trompetas y bocinas mientras los guerreros se alejaban de la urbe. ${ }^{1087}$ Este mismo rito era más o menos similar en distintas partes de Europa ${ }^{1088}$.

En ocasiones la campaña podía ser precedida por ritos más particulares, que se vinculaban con la devoción personal de los caudillos. Ese fue el caso de Fernando I, que en 1064, como preparación para su campaña con el objetivo de conquistar Coimbra, peregrinó a Santiago de Compostela para rogar al santo por el éxito de su empresa $^{1089}$.

En el segundo grupo encontramos los ritos de preparación realizados en los momentos previos al combate. Cuando el tiempo lo permitía y si había clérigos presentes, estos ritos se realizaban de forma similar a los recién reseñados, a veces agregándose confesiones y absoluciones individuales o colectivas. Pero en otros, cuando el combate era fruto de una acción sorpresiva o no planificada, el rito era improvisado por los caudillos de las huestes, quienes usualmente reunían a su tropa para dirigir una oración común, en la cual se invocaba a los santos protectores ${ }^{1090}$.

En estos relatos las confesiones y actos de contrición tienen pocas menciones, no obstante eran parte importante de la liturgia, por lo que su ausencia pueda deberse a que se entendiesen que estaban tácitamente incluidas en la descripción general del ritual. En otros casos, cuando la preparación al combate recaía en algún caudillo laico, las fuentes permiten concluir que los ritos de contrición efectivamente se encontraban ausentes ${ }^{1091}$.

1087 Sánchez-Albornoz, Claudio, Una ciudad de la España cristiana... op. cit., pp. 108-111; Goñi Gaztambide, José, Historia de la Bula de Cruzada... op. cit., pp. 33, 34; y Bronisch, Alexander Pierre, Reconquista y guerra santa... op. cit., pp. 99, 100.

${ }^{1088}$ Lida de Malkiel, María Rosa, La Idea de la Fama... op. cit., pp. 224, 225.

1089 Márquez Villanueva, Francisco, Santiago: trayectoria de un mito... op. cit., p. 187; y De Ayala Martínez, Carlos, Sacerdocio y Reino... op. cit., p. 285.

${ }^{1090}$ Martín Martín, José Luis, “Algunas prácticas clericales... op. cit., pp. 414, 415.

${ }^{1091}$ Ejemplo de ello son apreciables en la Chronica Adefonsi Imperatoris, cuando se nos relata como fue frecuente que previo al combate las huestes leonesas invocasen a la trinidad hispánica: Dios o Cristo, María y Santiago (Klinka, Emmanuelle, "Protagonismos y relación historiográfica... op. cit.). Esto lo que ocurre en el choque entre las fuerzas de Córdoba y Sevilla y las milicias Ávila y Segovia, estas ultimas: 
Es significativo que los caudillos y guerreros cristianos dirijan sus oraciones respetando la jerarquización celeste, rogando primero a Cristo, luego a la Virgen y, finalmente, al Apóstol Santiago, atribuyéndoles a cada uno diferentes funciones, ofreciéndoles recompensas y donaciones, para asegurar con ello su protección. Una metodología de oración que representa la continuación de una relación con lo divino originada en el mundo antiguo, en el que los hombres exigían a las deidades su favor a cambio de ofrendas ${ }^{1092}$. Munio Alfonso, difícilmente fue conciente de estar replicando una formula pre-cristiana y, posiblemente, el cronista tampoco cayó en cuenta de ello, pero, probablemente, sabían que el ritual reafirmaba la fe de los guerreros al recordarles a los inspiradores de la lucha, los patronos y combatientes celestes que derrotaban a los enemigos de la Iglesia y que los protegerían porque ellos, los toledanos, actuaban piadosamente.

"[...] et clamaverunt ad Deum caelorum et terrea et ad Sanctam Mariam et ad Sanctum Iacobum in oratione, ut eos adiuvaret et defenderet." (CAI, Liber II, $\mathrm{n}^{\circ}$ 117, op. cit., p. 91. "[...] e invocaron en sus oraciones al Dios de los cielos y de la tierra, a Santa María y a Santiago para que les ayudasen y defendieses." CEA, Libro II, N²2 (117), op. cit., p. 102). Lo mismo hicieron, poco después, las huestes bajo el mando de Rodrigo González previo a su batalla contra las fuerzas de Sevilla: "Christiani autem, ex Toto corde, clamabant ad Dominum Deum et ad Beatam Mariam et Sanctum Iacobum ut forum miserentur et obliviscerentur peccata regum et eorum et parentum." (CAI, Liber II, $\mathrm{n}^{\circ}$ 121, op. cit., p. 94. "A su vez, los cristianos invocaban de todo corazón a Dios Nuestro Señor, a Santa María y Santiago, para que se compadecieran de ellos y olvidasen los pecados de los reyes, los suyos y los de sus padres." CEA, Libro II, $\mathrm{N}^{\circ} 26$ (121), op. cit., p. 103). Otro caso, de la misma crónica, es el del conocido Munio Alfonso, que invocaba a la Providencia antes de enfrentarse a una fuerza superior de enemigos: "Venerunt ergo in praedictum locum et ibi fixere suos papiliones et cuncti, flexis genibus clamaverunt ad Dominum in oratione et dixerunt: 'O Ihesu Nazarene, qui pro nobis pependisti in ligno et sanguinem tuum pro nobis fudisti; ecce Moabites et Agareni, inimici tui et nostri, convenerunt adversus nos ut nos disperdant: sed tu miserere et eripe nos. O magna Virgo Virginum, intercede pro nobis ad filium tuum Dominum nostrum Iesum Christum, et si nos liberaveris, ex omnibus quae nobis dedisti aut dederis, fideliter dabimus ecclesiae tuae in Toleto fundatae decimas. Sancte Iacobe, apostole Christi, defende nos in proelio, ut non pereamus in tremendo indicio Sarracenorum." CAI, Liber II, $\mathrm{N}^{\circ} 162$, op. cit., p. 128. "Llegaron al citado lugar, fijaron alli sus tiendas de campaña y todos, tras doblar sus rodillas, invocaron al Señor en oración diciendo: "Oh Jesús Nazareno, que por nosotros estuviste colgado del madero y por nosotros derramaste tu sangre, he aqui que los moabitas y los agarenos, enemigos tuyos y nuestros, se han unido contra nosotros para perdernos. Compadécete de nosotros y libranos. Oh magna Virgen entre las vírgenes, intercede por nosotros ante tu hijo, nuestro Señor Jesucristo, y, si nos liberas, fielmente daremos a tu iglesia construida en Toledo los diezmos de todo lo nos has dado o nos des. Santiago, apóstol de Cristo, defiéndenos en el combate, para que no perezcamos con la terrible sentencia de los musulmanes." CEA, Libro II, $\mathrm{N}^{\circ} 69$ (164), op. cit., p. 116.

${ }^{1092}$ Un ejemplo de esta particular relación entre los dioses y hombres en el mundo clásico, se encuentra en una de las obras inaugurales de Occidente: La Iliada. En su canto primero se nos narra como el sacerdote de Apolo, Crises, luego de haber sido desairado por los aqueos y sus reyes se dirige al dios recordándole los favores que le debía en razón de los sacrificios ofrecidos: "33 Así dijo. El anciano sintió temor y obedeció el mandato. Fuese en silencio por la orilla del estruendoso mar; y, mientras se alejaba, dirigía muchos ruegos al soberano Apolo, a quien parió Leto, la de hermosa cabellera: 37 -jÓyeme, tú que llevas arco de plata, proteges a Crisa y a la divina Cila, a imperas en Ténedos poderosamente! ;Oh Esminteo! Si alguna vez adorné tu gracioso templo o quemé en tu honor pingües muslos de toros o de cabras, cúmpleme este voto: ¡Paguen los dánaos mis lágrimas con tus flechas!”. Si bien este tipo de demandas o exigencias a la deidad no son posibles de hallar en el contexto que estudiamos, si es factible observar una relación con la divinidad basada en la reciprocidad, es decir la protección a cambio de tributos como oraciones y donaciones materiales. Homero, La Ilíada, Canto I, Barcelona, Edicomunicación, 1997, p. 22 
Usualmente, mientras se luchaba en el frente, en la retaguardia la Iglesia procuraba la realización de procesiones, misas y actos religiosos colectivos, en los cuales se rezaba y rogaba por el éxito de la guerra. Estas prácticas servían para unir al conjunto de la población en torno a la victoria. Así, la religiosidad popular, a través de sus rituales, se convertía en un elemento de unión en torno a la guerra y a los monarcas o caudillos que la conducían ${ }^{1093}$.

La derrota también desencadenaba una serie de rituales destinados a conjurar el peligro, rogando a Dios y a los santos por el perdón de los pecados -que supuestamente habían atraído la desgracia-, y pidiendo misericordia por el pueblo cristiano. Ello se enmarca en la ya descrita dinámica del castigo y perdón que cruzaba la religiosidad medieval. Al respecto, Rodríguez de la Peña nos recuerda un ejemplo de ello en la Chronica Adefonsi ${ }^{1094}$. Según esta, en el marco de las guerras entre Urraca y Alfonso, Alí rey de Marruecos atacó y puso cerco Toledo. Allí la población y los clérigos se volcaron a las iglesias suplicando a la Providencia que los librase de los almorávides, del cautiverio, de la muerte, de la profanación y del ultraje ${ }^{1095}$. Para ello las rogativas, procesiones y oraciones fueron la herramienta adecuada. Como sabemos la ciudad no fue conquistada, y su población se salvó, hecho que seguramente reforzó la piedad de los toledanos y la confianza tanto en Dios como en la Iglesia, siendo esta última la que intercedió por ellos, vigorizando así la practica de los rituales y religiosidad fronteriza.

Relacionados con los resultados adversos de la guerra -como parte integral de los usos y costumbres del cristianismo- se encuentran los ritos vinculados con el "buen morir". Estos son básicamente la unción, la confesión y la comunión de los guerreros. Estos rituales se solían agrupar en la antigua práctica de la extremaunción, y estaba destinado a aquellos que se encontraban gravemente enfermos o agónicos ${ }^{1096}$. El rito ayudaba entonces a preparar el alma del desahuciado para iniciar la transición hacia la muerte y enfrentar el juicio de la Providencia.

\footnotetext{
${ }^{1093}$ Quizás el ejemplo más conocido de este tipo de prácticas lo podemos en contra en el ya citado caso de Inocencio III con respecto a la campaña de Las Navas de Tolosa.

1094 Rodríguez de la Peña, Manuel Alejandro, "Añadiendo muertos a los muertos.... op. cit., p. 58; y CAE, Liber II, $\mathrm{n}^{\circ} 102$, op. cit., pp. 79, 80.

${ }^{1095}$ CAE, Liber II, n 101, op. cit., pp. 78, 79.

${ }^{1096}$ El rito de la extremaunción es de antigua data, aunque no hay certeza de su origen. Comúnmente se atribuye su concepción a la interpretación de la Epístola de Santiago, 5, 14-15: “¿Está enfermo alguno entre vosotros? Llame a los presbiteros de la Iglesia, que oren sobre él y le unjan con óleo en el nombre del Señor. Y la oración de la fe salvará al enfermo, y el Señor hará que se levante, y si hubiera cometido pecados, le serán perdonados".
} 
No obstante, pese a su aparente importancia, las crónicas son extremadamente parcas en cuanto a estos ritos, limitándose a algunas menciones aisladas y vinculadas a episodios concretos como las cabalgatas de Alfonso VII y la campaña de las Navas de Tolosa $^{1097}$.

\section{Gráfico 19: Ritos de preparación para la muerte}

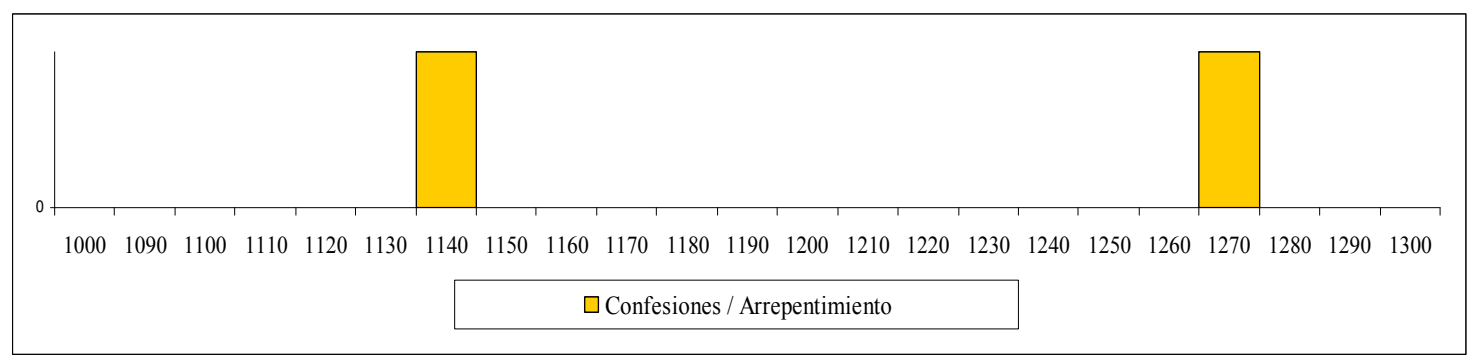

En vista de la relevancia de estos ritos es patente la necesidad de que estuviesen incluidos en la preparación bélica. En parte, los rituales de preparación del combate descritos en el apartado anterior, cumplían ese rol, siendo una especie de predisposición colectiva para la muerte, a la que todo guerrero estaba expuesto. Pero también, en ocasiones críticas, cuando las huestes cristianas habían sido sobrepasadas o la derrota y muerte se veían inminentes, se producían preparaciones especiales para el buen morir. En estos casos lo que sucedía no era un rito realmente estructurado, sino que la realización de distintas prácticas, que normalmente giraban en torno a la confesión. Muchas veces en estas circunstancias, cuando no había sacerdotes entre los guerreros, eran los caudillos los que ordenaban la realización de estas prácticas y preparaban a sus hombres para morir. Evidentemente, este tipo de situaciones se daba en casos extremos, puesto que su realización era el reconocimiento implícito de la derrota y señal inequívoca de que la moral y espíritu de combate se habían derrumbado ${ }^{1098}$.

Un ejemplo de estos ritos y que se ciñe con claridad a las situaciones de emergencia, es el que relata la Chronica Adefonsi Imperatoris. En esta ocasión se narra cómo una parte de la hueste real se separó del grueso del ejército para saquear los alrededores por su cuenta. Allí fueron son atacados por lo musulmanes y acorralados por la crecida del Guadalquivir. Ante la imposibilidad de poder ayudarlos, Alfonso y el

\footnotetext{
1097 Ver gráfico y tabla $\mathrm{n}^{\circ} 14$.

1098 Estas prácticas también eran comunes en otras partes de Europa, por lo que el escenario castellanoleonés no constituyó una excepción en este sentido. En la Península en general, en razón de la guerra contra el Islam, los ritos religiosos tenían un significado particular, puesto que reafirmaban una y otra vez la peculiaridad de este conflicto.
} 
resto del ejército los abandonaron a su suerte, sin antes incitar a los guerreros acorralados a que se preparasen a morir cristianamente:

"Quibus principes responderunt: 'Vos videtis, quia magnum chaos firmatum est inter nos et vos: nec vos poteritis transire ad nos, nec nos possumus ire ad vos'. Et iterum principes: 'Confitemini alterutrum peccata vestra et orate et communicate de pane benedicto, quod habetis vobiscum, et Deus miserebitur animarum vestrarum"1099.

En este episodio queda claro de qué manera operaban los ritos de preparación a la muerte en caso de premura, puesto que eran los mismos guerreros quienes, en un acto colectivo, debían confesarse y comulgar para enfrentar cristianamente su destino, siendo además la invocación a ello la única ayuda que podían recibir de sus compañeros, que a falta de recursos materiales sólo podían apelar a las prácticas rituales.

El caso citado pertenece a fuentes compuestas en torno de los años 1140, coincidiendo con la influencia franca en las crónicas hispanas, así como tambien a un período de crisis en la Reconquista, cuando el proceso estaba prácticamente estancado debido a la irrupción de los almorávides y los ataques a poblaciones y los reveses militares fueron más comunes.

En el siglo XIII los rituales de preparación al combate siguieron siendo mencionados en las fuentes, pero al igual que en la etapa anterior, no fueron parte central del relato ${ }^{1100}$. Ejemplo de ello lo podemos apreciar en el ya mencionado caso de las Navas de Tolosa, donde los ritos previos a la batalla son descritos parcamente. Según los testimonios, luego del episodio del pastor las huestes cristianas arribaron al llano de las Navas de Tolosa y se prepararon para la batalla. El domingo 15 de julio se celebraron misas y a medianoche, en medio del júbilo general, los hombres se confesaron y comulgaron, luego de lo cual los cristianos se pusieron en marcha hacia el

1099 CAI, Liber II, N ${ }^{\circ}$ 133, op. cit., p. 105. "Los jefes militares les respondieron: 'Veis que un gran abismo se ha establecido entre vosotros y nosotros. Ni vosotros podréis atravesar adonde nosotros, ni nosotros podemos ir adonde vosotros'. Y de nuevo les dijeron los jefes militares: 'Confesad vuestros pecados unos a otros, orad y comulgad con el pan bendito que tenéis con vosotros y Dios se apiadará de vuestras almas" CEA, Libro II, №38 (133), op. cit., p. 107.

1100 Aparte de los casos mencionados, las fuentes posteriores no hacen una referencia explicita al fenómeno de la preparación al buen morir. Nosotros solo detectamos un caso posterior, en el capítulo XXII de la Crónica de veinte reyes, cuando durante una cabalgata liderada por Alvar Pérez, la hueste cristiana se vio obligada a presentar batalla contra Aben Hut que había apellidado a los andalusíes contra los cristianos. En esa ocasión la crónica dice que "Los christianos fueron todos confesados, los que pudieron aver clérigo, e los que non vnos con otros." (CXXR, Libro XIV, cap. XXII, op. cit., p. 307).

Ver gráfico y tabla $\mathrm{n}^{\circ} 14$. 
campo de batalla ${ }^{101}$. Finalmente los obispos y clérigos recorrieron el campamento arengando a los guerreros, reiterándoles recordándoles los beneficios aparejados a las indulgencias de la cruzada y amenazando con la excomunión a aquellos que dejasen la batalla para recoger el botín ${ }^{1102}$.

Por su parte, la conducta de los religiosos, quienes daban exhortaciones e instrucciones a los guerreros de cómo comportase en la lucha, confirma el espíritu cruzado de la campaña. Ellos, como jefes espirituales recordaban a la población las recompensas celestiales que podrían ser obtenidas, y además disponían de las gracias espirituales concedidas por el Inocencio III, que señalaban la supremacía de la autoridad religiosa y recalcaban a los hombres que eran soldados de Cristo y, por lo tanto, estaban sujetos a sus designios.

La búsqueda de la Gracia de la Providencia en la batalla y de la buena muerte fueron necesidades apremiantes para el hombre medieval. En el caso de los guerreros la situación era especialmente significativa, puesto que su rol violento muchas veces los acercaba al pecado y a la condenación. En ese sentido los ritos eran parte del recordatorio permanente de la causa cristiana y por ende, manifestación patente de las ideologías involucradas en la guerra peninsular. Los caudillos guerreros eran ante todo líderes cristianos y en ese aspecto eran los encargados de velar por el alma de sus guerreros. Es en este sentido que los líderes de la Reconquista cumplieron un rol religioso y militar, que queda evidenciado en las fuentes.

${ }^{1101}$ HRH, Liber VIII, cap. IX, op. cit., p. 270. "Alrededor de la medianoche del día siguiente estalló el grito de júbilo y de la confesión en las tiendas cristianas y la voz del pregonero ordenó que todos se aprestaran para el combate del Señor. Y así, celebrados los misterios de la Pasión del Señor y hecha confesión, recibidos los sacramentos, tomadas las armas, salieron a la batalla campal." HHE, Libro VIII, cap. IX, op. cit., p. 319.

${ }^{1102}$ CLRC 1997, No 24, op. cit., pp. 61, 62; CXXR, Libro. XIII. cap. XXXI, op. cit., p. 284; y Alvira Cabrer, Martín, "La muerte del enemigo... op. cit., p. 418. 
Tabla 18: Ritos de preparación al combate

\begin{tabular}{|c|c|c|c|}
\hline & $\begin{array}{l}\text { Liturgias / } \\
\text { Oraciones }\end{array}$ & $\begin{array}{l}\text { Confesiones / } \\
\text { Arrpentimiento }\end{array}$ & Fuentes \\
\hline \multicolumn{4}{|c|}{1000} \\
\hline \multicolumn{4}{|l|}{1090} \\
\hline \multicolumn{4}{|l|}{1100} \\
\hline \multicolumn{4}{|l|}{1110} \\
\hline \multicolumn{4}{|l|}{1120} \\
\hline 1130 & $\mathrm{X}$ & & - HC Libro I Cap. 49 p. 158 \\
\hline 1140 & $\mathrm{X}$ & & $\begin{array}{l}\text { - CAI Libro II n }{ }^{\circ} 26 \text { p. } 103 n^{\circ} 69 \text { p. } \\
116 n^{\circ} 93 \text { p. } 124\end{array}$ \\
\hline \multicolumn{4}{|l|}{1150} \\
\hline \multicolumn{4}{|l|}{1160} \\
\hline \multicolumn{4}{|l|}{1170} \\
\hline \multicolumn{4}{|l|}{1180} \\
\hline \multicolumn{4}{|l|}{1190} \\
\hline \multicolumn{4}{|l|}{1200} \\
\hline \multicolumn{4}{|l|}{1210} \\
\hline \multicolumn{4}{|l|}{1220} \\
\hline 1230 & $\mathrm{X}$ & & - CLRC n $^{\circ} 24$ p. 53 \\
\hline 1240 & $\mathrm{X}$ & $\mathrm{X}$ & - HRH Libro VIII Cap. 9 p. 319 \\
\hline \multicolumn{4}{|l|}{1250} \\
\hline \multicolumn{4}{|l|}{1260} \\
\hline 1270 & $\mathrm{X}$ & $\mathrm{X}$ & $\begin{array}{l}\text { - CXXR Libro XIII Cap. 31-32 p. } \\
284 .\end{array}$ \\
\hline \multicolumn{4}{|l|}{1280} \\
\hline \multicolumn{4}{|l|}{1290} \\
\hline 1300 & & & \\
\hline
\end{tabular}


Tabla 19: Ritos de preparación para la muerte

\begin{tabular}{|l|l|l|}
\hline & Confesiones / Arrepentimiento & Fuentes \\
\hline 1000 & & \\
\hline 1090 & & \\
\hline 1100 & & \\
\hline 1120 & & \\
\hline 1130 & $\mathrm{X}$ & - CAI Libro II n 38 p. 107 \\
\hline 1140 & & - LSJ Libro IV Cap 21 p. 493 \\
\hline 1150 & & \\
\hline 1160 & & \\
\hline 1170 & & \\
\hline 1180 & & \\
\hline 1190 & & \\
\hline 1200 & & \\
\hline 1210 & & \\
\hline 1220 & & \\
\hline 1230 & & \\
\hline 1240 & & \\
\hline 1250 & & \\
\hline 1260 & & \\
\hline 1270 & & \\
\hline 1280 & & \\
\hline 1290 & & \\
\hline 1300 & & \\
\hline
\end{tabular}




\section{III.3.e.- Ritos de Victoria}

En oposición a los ritos vinculados a la preparación de la campaña o de una posible derrota, encontramos los denominados "ritos de victoria", que suelen estar descritos con mayor detalle en las crónicas. En ellas usualmente se narran estos episodios con sus pormenores, incluyendo los momentos exactos de su realización, sus protagonistas y otros elementos, como himnos y salmos que se hacían en su trascurso. La realización de estos rituales se entendía también como un acto de piedad, que agradecía a la Providencia por la victoria. El no realizar este rito, según las mismas crónicas, se consideraba un acto de soberbia, que podía ser castigado de diversas maneras, incluyendo la derrota en un futuro enfrentamiento ${ }^{1103}$.

Hemos podido observar que la descripción de dichos ritos de victoria se encuentra presente en las primeras crónicas de la Reconquista, vinculadas al triunfo de Pelayo. Lo que es una novedad, es que a partir de la década de 1120, estas prácticas son descritas como si se tratase de una obligación directamente relacionada con las costumbres piadosas de los guerreros, siendo posible observarlas - como se evidencia en el siguiente gráfico - de manera más o menos permanente, en las décadas posteriores y en especial a partir de 1220 cuando la Reconquista avanza significativamente con Fernando III.

Estos ritos pueden dividirse en tres grandes actos, que no siempre se pueden observar conjuntamente. Se trataba de simples oraciones, que eran las más comunes, liturgias y triunfos. De las crónicas se desprende que estas dos solían darse en forma conjunta y que de hecho la liturgia venia a ser la parte concluyente de la celebración triunfal $^{1104}$.

\footnotetext{
${ }^{1103}$ Un ejemplo de las consecuencias de esta falta de humildad y gratitud por parte de los vencedores es lo ocurrido con las milicias salmantinas y que se relata en la CAI, Libro II, $\mathrm{N}^{\circ}$ 29, op. cit., p. 104.

${ }^{1104}$ Ver gráfico y tabla $\mathrm{n}^{\circ} 15$.
} 


\section{Gráfico 20: Ritos de victoria}

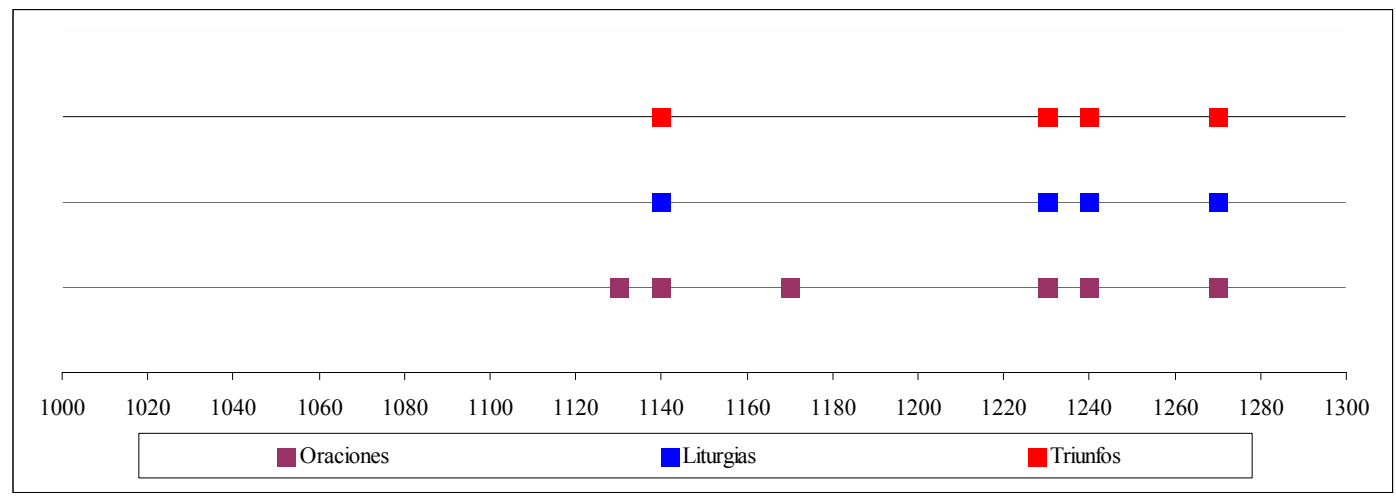

Los ritos de victoria, que bien pueden ser comprendidos como una acción de gracias, se solían dar en dos instancias. Primeramente, se realizaba inmediatamente después de concluido el combate, y se efectuaba en el mismo lugar de los hechos ${ }^{1105}$. En este caso consistían en la ejecución de una oración comunitaria y en la entonación de himnos, habitualmente el Te Deum laudamus, dirigido por los clérigos o caudillos. El tradicional cántico de alabanza y gratitud se entonaba en pleno campo, rodeados de los despojos de la batalla, lo que contribuía a darle un tono dramática a la escena, que exaltaba la solemnidad y gloria del acto. No obstante, en esas circunstancias, este rito era también una acción rutinaria, impulsado por la costumbre. Esta simpleza del acto de victoria, cambiaba cuando el triunfo correspondía a una conquista significativa y a cuya cabeza se encontraba alguien de suma importancia como el rey, entonces el ritual se hacia más sofisticado

Una crónica muy generosa en la descripción de estos rituales es la Chronica Adefonsi Imperatoris, que describe la ceremonia que sucede inmediatamente luego de la rendición y captura del castillo de Oreja:

"Postremo autem die mensis, summo mane, datum est castellum et impletae sunt turres militum christianorum, et elevata sunt vexilla regalia super excelsam turrem [Sed] hi qui tenebant vexilla, clamabant excelsa voce et dicebant 'Vivat Adefonsus imperator Legionis et Toleti!' Hoc audientes et videntes episcopi et totus clerus et omnes qui erant in castra, levaverunt manus suas ad celum et dixeunt: 'Te Deum laudamus, te Dominum confitemur', etc" ${ }^{\text {1106. }}$.

\footnotetext{
${ }^{1105}$ Martín Martín, José Luis, “Algunas prácticas clericales...”, op. cit., pp. 418, 419.

${ }^{1106}$ CAI, Liber II, $\mathrm{N}^{\circ} 154$, op. cit., p. 120. "El ultimo día del mes, muy de mañana, se entregó el castillo, se llenaron de caballeros cristianos las torres y se izaron los estandartes reales sobre una torre alta. $Y$ los que portaban los estandartes gritaban en voz alta y decían ';Viva Alfonso, emperador de León y Toledo!'. Al oír y ver esto, los obispos, el clero completo y todos los que estaban en el campamento,
} 
Es interesante que se relate que antes de la acción de gracias se realizaba un acto de fuerte simbolismo político: los guerreros primero elevaban las banderas del reino y alaban a su rey, y sólo a continuación los clérigos iniciaban la acción de gracias. Al parecer la intención del autor de la crónica era exaltar a Alfonso como artífice de la victoria y a continuación señalar, por medio de la intervención clerical, que el rey estaba al servicio de Dios, aunque no por ello renunciaba a su gloria.

La batalla de las Navas de Tolosa no fue la excepción en el contenido de esas fórmulas rituales. Luego de la victoria y rodeados de despojos, las crónicas narran que los clérigos entonaron el Te Deum laudamus. Consumado el piadoso requisito, se autorizó a los guerreros a recoger el inmenso botín, que incluía armas, telas, animales, entre otros despojos, descritos por los cronistas, que destacan lo inusual de la cantidad de riqueza reunida, siendo una digna recompensa material por tan magno esfuerzo ${ }^{1107}$. Este fue un episodio vívidamente descrito por la Crónica General:

"[...] el arçobispo et los obispos, que y eran con ell, et los abades et frayres et la otra clerezia, que y eran con ellos, alçadas las manos et la uozes al çielo, con lagrimas de sanctidad et con cantico de alabança, salieron en esta razon, cantando con gran alegria aquel cantico que dizen en la iglesia: Te Deum laudamus, te Dominum confitemur, et quiere esto assi dezir en el castellano : 'A ti, Dios, alabamos, a ti, Sennor, confessamos', et dixieron este cantico todo, cantandol fasta cabo" ${ }^{\prime 108}$.

En el Cronicon Mundi y en la Crónica General, se relata la celebración triunfal de la captura de Sevilla por Fernando III. Al igual que en el caso anterior, el ceremonial se realizó en el mismo campo de batalla, en este caso en la ciudad conquistada. El relato corresponde a una entrada triunfal, donde según la obra de "el Tudense" se destacan los aspectos providenciales de la victoria, reflejados en los patronos a los que se les agradece su intercesión; la Virgen María y el Apóstol Santiago ${ }^{1109}$. En tanto que la Crónica General resalta el rito de victoria en sí:

"[...] quando ese noble et bienaventurado rey don Fernando, de que la estoria tantos bienes a contado, entro en esa dicha noble çipdat de Seuilla, capital de todo

levantaron sus manos al cielos y entonaron el 'Te Deum laudamus, te Dominum confitemur', etcétera." CEA, Libro II, No 59 (154), op. cit., p. 113.

${ }^{1107}$ HRH, Libro VIII. Cap. XI, op. cit., p. 275; y CXXR, Libro. XIII. Cap. XXXV, op. cit., p. 286.

${ }^{1108}$ CGE, cap. 1019 , op. cit., p. 702.

${ }^{1109}$ CE, Libro IV, Cap. C, op. cit., p. 442. 
ese sennorio del Andaluzia, o fue reçebido con muy Grant proçesion de obispos et de toda la clerecía et de todas las otras gentes, con muy grandes alegrias et con muy grandes bozes, loando et bendiciendo et dando graçias a Dios, et alabando los fechos del rey don Fernando; et entro asi desta gisa ese bienaventurado rey don Fernando dentro en la yglesia de Sancta Maria" ${ }^{1110}$.

En este caso, al igual que en el anterior, destaca la exaltación de la figura del "bienaventurado" rey Fernando, para luego narrar la participación de los clérigos. De ello se puede concluir que es posible, que a semejanza de lo ocurrido con Alfonso VII, la intención del cronista fuera la exaltación de la figura regia, que además en este caso se vincula con la intención de Alfonso X de exaltar su propio linaje.

Junto con esta instancia de celebración victoriosa, se podía realizar un segundo ritual de victoria y gratitud, por lo general mucho más espectacular. Acontecía generalmente cuando las huestes volvían a su punto de partida; es decir, a la ciudad desde donde habían partido los guerreros, o bien cuando se procedía a ocupar una ciudad conquistada $^{1111}$. En las crónicas habitualmente se describe el regreso de las mesnadas del rey, por lo que el escenario de estas celebraciones solían ser ciudades como Toledo, León o Burgos. Estos eventos que recuerdan a los tradicionales triunfos romanos $^{1112}$, correspondían a un rito cívico-religioso, puesto que la entrada de los guerreros y la exposición del botín y cautivos, solían estar acompañados por gestos religiosos que por lo general culminaban en una liturgia de acción de gracias, simbolizando la alianza entre Dios y los guerreros cristianos. Nuevamente encontramos en la Chronica Adefonsi Imperatoris, abundantes testimonios de estas celebraciones posteriores a la victoria, en los cuales la profusión de detalles y magnitud del acto varía según quien protagonizace el relato. Por ejemplo, se dice que Rodrigo Fernández, jefe de los ejércitos toledanos, derrotó a las fuerzas moras de Texufin y que al regreso de la hueste a la ciudad, cargados de botín, cautivos y animales, fueron "recitando un himno y bendiciendo a Dios porque es bueno, porque su misericordia es eterna". A continuación la crónica relata otra victoria del mismo caudillo, agregando en esta ocasión, que a su entrada a Toledo se entonó el Te Deum laudamus ${ }^{1113}$.

${ }^{1110}$ CGE, cap. 1125 , op. cit., p. 767.

${ }^{1111}$ Martín Martín, José Luis, “Algunas prácticas clericales...”, op. cit., pp. 418, 419.

1112 Calderón Ortega, José Manuel y Francisco Javier Díaz González (Compiladores), Vae Victis... op. cit., p. 112.

${ }^{1113}$ CAI, Libro II, N $128-129$, op. cit., pp. 99-101.

En otras ocasiones, pareciera ser que la magnitud del evento era mucho mayor, como cuentan los relatos de las victorias de Munio Alfonso, en particular cuando venció en batalla campal a dos reyes andalusíes: 
La victoria de las Navas también es escenario para la realización de un desfile triunfal y un ritual de acción de gracias, esto pese a que el último episodio de la campaña -que describen los cronistas- corresponde a la peste que afectó a la hueste cruzada y que fue interpretada como un castigo. Al regresar a Toledo, Alfonso VIII fue recibido por todo el clero de la ciudad con una gran procesión que lo escoltó junto con el pueblo hasta la Catedral. La escena es descrita como un acto multicultural y de gran colorido: "[...] do fueron bien rreçebidos de chistianos e de moros e de judios, que salieron fuera de la villa con juglares e con intrumentos, e los arçobispos con toda su clerezía con gran proçesión, loando a Dios quánta merçed les fiziera e que los traya sanos e con gran onrra"1114.

Así, los toledanos y en extensión el conjunto de Castilla, se hacían parte de la victoria y de la Gracia divina, simbolizando paralelamente la restauración del orden espiritual gracias a la bendición de la Providencia, manifestada en el triunfo cristiano y la derrota de los musulmanes.

Los distintos ejemplos de las diferentes fórmulas de los rituales de triunfo y que se hacían extensivos a cualquier gran victoria, tenían varios objetivos: primero el reconocimiento explícito de que toda victoria venía dada por Dios, y que los guerreros

"[169] Et factus est dies crastinus, tunc Munio Adefonsi et sui socii, moverunt castra et venerunt Toletum, et ingresi sunt in civitatem per portam de Alcantara, et praecedebant eos vexilla regalia erecta, et in summitate hastarum capita rerum, et deinde milites nobiles captivi in catenis; post haec, populus Sarracenus ligatis manibus a tergo; sequebantur eos pedites christianorum trahentes equos regum et mulos et mulas ducum et principum et militum cum suis sellis optimis laboratis ex auro et argento. Deinde mulos et mulas, quos vocant azemillas, et camellos oneratos armis et ex omnibus expollis.

[170] Et sic venerunt ante fores ecclesiae Sanctae Mariae, ubi erat praesens imperatrix domna Berengaria uxor imperatoris, et archiepiscopus Toletanus domnus Raymundus et omnis cleros et omnes milites civitatis et totus populus, qui venerant ad videndum miraculum et victoriam. Sed postquam viderunt capita regum Sarracenorum in summitate hastarum, in quibus erant vexilla, regalia erecta, omnes mirati sunt, et intraverunt ecclesiam Sanctae Mariae cum gaudio magno cantantes et dicentes 'Te Deum laudamus, te Dominum confitemun' usque in finem. Et data benedictione ab archiepiscopo, omnes, abierunt in tabernacula sua". CAI, Libro II, n 169-170, op. cit., pp. 132, 133. "(169) Y llegó el día siguiente. Entonces Munio Alfonso y sus compañeros levantaron el campamento, llegaron a Toledo y entraron en la ciudad por la Puerta de Alcántara; delante de ellos iban los estandartes reales en alto y las cabezas de los reyes en las puntas de las lanzas, después los caballeros nobles cargados de cadenas, a continuación la población musulmana con las manos atadas a la espalda. Les seguían los peones de los cristianos llevando los caballos de los reyes y los mulos y mulas de los caudillos, jefes militares y caballeros con sus magníficas sillas repujadas de oro y plata, a continuación los mulos y mulas que llaman acémilas y los camellos cargados de armas y de toda clase de despojos.

(170) Y llegaron de tal modo ante las puertas de la iglesia de Santa María, donde estaban presentes la emperatriz doña Berenguela, esposa del emperador, el arzobispo de Toledo don Raimundo, todo el clero, todos los caballeros de la ciudad y el pueblo entero, que habian acudido a ver el prodigio y la victoria. $Y$ después que vieron las cabezas de los reyes musulmanes en las puntas de las lanzas, en las que estaban izadas las enseñas reales, todos quedaron admirados y entraron en la iglesia de Santa María cantando y entonando con enorme alegría el 'Te Deum laudamus, te Dominum confitemun' hasta el final. Y después que se dio la bendición, el arzobispo y todos se marcharon a sus viviendas." CEA, Libro II, N 74 (169)75 (170), op. cit., p. 118.

${ }^{1114}$ CXXR, Libro. XIII. Cap. XXXVI, op. cit., p. 287. 
no eran más que los ejecutores de la voluntad divina. En este sentido, era considerado también un acto de humildad y sometimiento a Dios. Asimismo, era un acto de reconocimiento a la autoridad de las Iglesia como el representante de la Providencia, puesto que a ella se le entregaban parte del botín de la batalla y era dentro de sus recintos sagrados donde se llegaba a la etapa cúlmine del rito. Por su parte, el desfile era una forma de promover la gloria y fama de los guerreros vencedores: el pueblo los veía y los reconocía como sus campeones, tributándoles los honores correspondientes, lo que era un hecho significativo cuando el líder de la hueste era el soberano. Así, el pueblo se hacía partícipe de estos hechos, celebrando el triunfo y siendo testigos de sus frutos. El desfile triunfal era, entonces, un significativo acto de propaganda, donde el brazo armado dirigido por el poder real en comunión con la Iglesia actuaban unidos, siguiendo la voluntad de Dios, quien con la victoria los legitimaba.

Además de las formas rituales que se han mencionado, hubo otras maneras de agradecer los triunfos militares, que no eran propiamente ritos de victoria, como es el caso de la peregrinación emprendida por Alfonso IX de León a Santiago de Compostela. Este rey murió en 1230 cuando se dirigía como peregrino a Galicia para agradecer por su victoria y conquista de Cáceres y otras localidades ${ }^{1115}$. Si bien este episodio no es en sí una ceremonia triunfal, es significativo puesto que el acto reforzaba la imagen del rey victorioso como devoto de Santiago, robusteciendo así la alianza entre el brazo armado y la religión.

En definitiva, existió un aumento de descripciones sobre los rituales de preparación para el combate a partir de la segunda mitad del siglo XIII, cuando la actividad bélica incrementó y se consolidaron los discursos religiosos que convertían a la Reconquista en una guerra santa.

1115 O'Callaghan, Joseph, Reconquest and Crusade... op. cit., p. 89. 
Tabla 20: Ritos de victoria

\begin{tabular}{|c|c|c|c|c|}
\hline & Oraciones & Liturgias & Triunfos & Fuentes \\
\hline \multicolumn{5}{|c|}{\begin{tabular}{l|l}
1000 \\
\end{tabular}} \\
\hline \multicolumn{5}{|l|}{1090} \\
\hline \multicolumn{5}{|l|}{1100} \\
\hline \multicolumn{5}{|l|}{1110} \\
\hline \multicolumn{5}{|l|}{1120} \\
\hline 1130 & $\mathrm{X}$ & & & - HC Libro I Cap. 39 p. 146 Cap. 103 pp. 246, 247 \\
\hline 1140 & $\mathrm{X}$ & $\mathrm{X}$ & $\mathrm{X}$ & $\begin{array}{l}\text { - CAI Libro II n } 34 \text { p. } 105 n^{\circ} 61 \text { pp. } 113,114 n^{\circ} 69 \\
\text { pp. } 116,117 n^{\circ} 75 \text { p. } 118\end{array}$ \\
\hline \multicolumn{5}{|r|}{ m } \\
\hline \multicolumn{5}{|l|}{1160} \\
\hline 1170 & $\mathrm{X}$ & & & - CN Libro II n²0 p. 128 \\
\hline \multicolumn{5}{|l|}{1180} \\
\hline \multicolumn{5}{|l|}{1190} \\
\hline \multicolumn{5}{|l|}{1200} \\
\hline \multicolumn{5}{|l|}{1210} \\
\hline \multicolumn{5}{|l|}{1220} \\
\hline 1230 & $\mathrm{X}$ & $\mathrm{X}$ & $\mathrm{X}$ & $\begin{array}{l}\text { - CM Libro IV Cap } 94 \text { p. } 430 \text { CLRC. } n^{\circ} 26 \text { p. } 56, n^{\circ} \\
50 \text { p. } 82, n^{\circ} 73 \text { p. } 102\end{array}$ \\
\hline 1240 & $\mathrm{X}$ & $\mathrm{X}$ & $\mathrm{X}$ & - HRH Libro IX Cap. 16 p. 350, Cap. 17 p. 351. \\
\hline \multicolumn{5}{|r|}{ 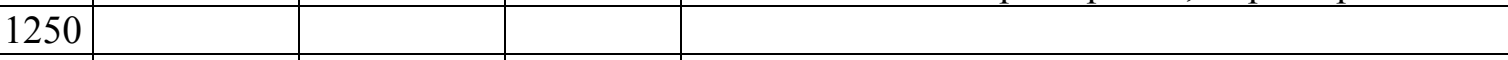 } \\
\hline \multicolumn{5}{|l|}{1260} \\
\hline 1270 & $\mathrm{X}$ & $\mathrm{X}$ & $\mathrm{X}$ & $\begin{array}{l}\text { - CGE Cap. } 871 \text { p. } 541, \text { Cap. } 1046 \text { p.733 } \\
\text { - CXXR Libro XIV Cap. } 25 \text { pp. } 312,313 .\end{array}$ \\
\hline \multicolumn{5}{|r|}{ ( } \\
\hline \multicolumn{5}{|l|}{1290} \\
\hline 1300 & & & & \\
\hline
\end{tabular}




\section{III.3.f.- Ritos de purificación de los lugares conquistados}

Estrechamente vinculados a los ritos de victoria, se encuentran los de purificación. Éstos quizás fueron los que tuvieron una mayor carga simbólica, puesto que fueron procedimientos rituales que se realizaban en las mezquitas de las ciudades andalusíes capturadas, destinados a convertirlos en centros de adoración cristiana. Dicho de otro modo, se trataba de "limpiar" y trasformar el recinto para eliminar cualquier vestigio del Islam. Este acto era fundamental dentro del imaginario hispano, puesto que señalaba de forma evidente el triunfo del cristianismo sobre la religión de Mahoma. Los cronistas, como símbolo de la victoria, solían aprovechar el momento para denostar a los musulmanes y su fe.

En ocasiones el rito de purificación era acompañado por lo que podríamos llamar los "ritos de ocupación", un conjunto de prácticas que combinaban elementos tanto políticos como religiosos destinados a celebrar y hacer patente el triunfo de las armas y reyes cristianos, simbolizado el fin del dominio musulmán sobre alguna urbe y su territorio $^{1116}$.

Estos ritos, que bien pueden ser la culminación de los rituales de victoria, hacen su aparición ya completamente definidos en las crónicas del siglo XII, específicamente en la Chronica Adefonsi Imperatoris, describiéndose de forma más intensa en los textos del siglo siguiente ${ }^{1117}$. Un hecho que se explica debido a que fue en este período cuando, la Reconquista realizó importantes avances, apoderándose de ciudades que por siglos habían sido epicentros de al-Andalus, en forma paralela que el discurso bélico y religioso se radicalizaba. Este rito es entonces la prueba definitiva de la recuperación del espacio cristiano, el mismo que en la cosmovisión hispana antes había sido de los visigodos $^{1118}$. Es, por lo tanto, también un rito de restauración de índole político y religioso $^{1119}$.

\footnotetext{
${ }^{1116}$ Mircea Eliade hace referencia a este tipo de ritos en relación a la ocupación efectiva de un territorio, conformando lo que el llama un "ritual de toma de posesión, el cual no es sino una copia del acto primordial de la creación del mundo". Una práctica que se puede observar en la India y también en los conquistadores lusos y españoles cuando tomaban posesión en nombre de Jesucristo. Para el autor la instalación de una cruz equivalía a un acto que justificaba la ocupación y su consagración al cristianismo señalaba un nuevo nacimiento para la localidad, siendo una especie de bautismo territorial. (Eliade, Mircea, El mito del eterno retorno... op.cit, pp. 19, 20.

1117 Ver gráfico y tabla $n^{\circ} 16$.

1118 Con el fin de la Reconquista este rito continuaría evolucionado, ya que seria trasplantado a América, donde, siguiendo los mismos patrones, los conquistadores lo utilizarán para apoderase y apropiarse de los templos indígenas en lugares como los imperios Aztecas e Incas.

1119 Muñoz Fernández, Ângela, “Cultos, Devociones y Advocaciones... op. cit., p. 135, 137.
} 
Gráfico 21: Ritos de purificación de los lugares conquistados

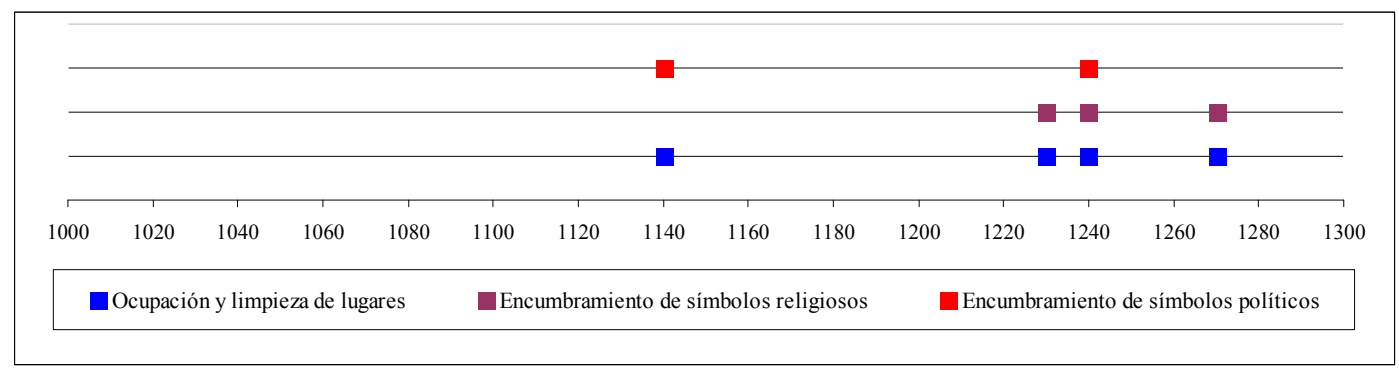

En ese mismo sentido es que podemos encuadrar estos rituales dentro de las señales que demuestran una paulatina y creciente radicalización de la guerra peninsular, puesto que sus descripciones coinciden con las que señalan la expulsión de los musulmanes de las ciudades reconquistadas. En contraste, es significativo que en los siglos anteriores no se hiciera alusión explicita a estas prácticas. Es el caso de la ocupación de Toledo por Alfonso VI, donde no parece que se le diera una mayor importancia a la "purificación de los espacios religiosos". Sobre este episodio, las crónicas nos dicen que el emperador se apropió de las mezquitas de la ciudad, pero no se hace una referencia a algún ritual en particular para consagrar esos espacios de culto $^{1120}$. Lo anterior no significa que esas prácticas no existiesen, pero sí revela que no eran consideradas trascendentes para los cronistas del siglo XI, quienes estaban más preocupados de exaltar la expansión del reino de Alfonso que de denostar a los "moros".

Estos ritos de purificación, al igual que los otros referidos, servían para recalcar la alianza entre la Iglesia y el poder político. La Iglesia era colaboradora esencial del esfuerzo bélico, y por lo tanto era necesario que compartiese la victoria desde un lugar destacado, sacralizando el triunfo y compartiendo los beneficios del mismo. Esto último en razón de que la conquista de una ciudad muchas veces implicaba la restauración o creación de una nueva sede eclesiástica, la que se veía beneficiada por donaciones provenientes del botín. De esta forma se estrechaba la alianza entre monarquía y religión a través de rituales que apelaban a la religiosidad de los cristianos peninsulares.

\footnotetext{
${ }^{1120}$ La "conquista" de Toledo aparece en prácticamente todas las crónicas que mencionan a Alfonso VI, pero solo en los textos del siglo XII y posteriores el episodio es narrado con profusión de detalles. Aun así las referencias se concentran en el proceso de captura de la ciudad y el pacto de rendición de la misma. Jiménez de Rada es de los pocos autores que hacen alguna referencia a la ocupación de la Catedral y al ritual relacionado, pero lo hace en el contexto de la acción emprendida por Bernardo y para narrar la reacción del rey al respecto, por lo que el relato no entrega muchos detalles en cuanto al ritual de purificación, limitándose a afirmar que el arzobispo "borró los vestigios de la suciedad de Mahoma" (HHE, Libro VI, cap. XXIV, op. cit., p. 250). La Crónica General repite el relato de "el Toledano", por lo que tampoco aporta mucho más sobre el episodio (CGE, cap. 871, op. cit., p. 541).
} 
La victoria era mucho más que la ampliación del reino; era la expansión de la fe. La restauración de las iglesias era, por ende, la imposición de la verdadera religión sobre la "fe demoníaca" de los musulmanes ${ }^{121}$.

El ritual de purificación en sí, según las crónicas, era bastante sencillo, pero de una enorme carga simbólica. Por lo general, se relata su realización como algo inmediatamente posterior a la conquista de una ciudad, y casi siempre referido a la ocupación y conversión de la mezquita mayor en Catedral. A continuación se podrán apreciar algunos ejemplos de esto, presentes en distintas crónicas.

El primer caso al que se hace referencia, describe la ocupación de Coria por las huestes de Alfonso VII. La ciudad se entregó al emperador luego de una rendición pactada. El siguiente pasaje narra cómo se realizó el rito de purificación:

"[161] Postquam autem reddita est civitas imperatori, mundata est ab inmunditia barbaricae gentis et contaminatione Mahometis, et destructa omni spurcitia paganorum civitatis illus et templi sui. Dedicaverunt ecclesiam in honore Sanctae Mariae semper virginis et omnium sanctorum, et ordinaverunt ibi episcopum virum religiosum nomine Navarronem sicuti antiquitus fuerat sedes episcopales tempore Ildefonsi arquiepiscopi et Recaredi regis, quando tota illa terra christianorum erat, a Mediterraneo usque ad more Occeanum"1122.

En el relato se aprecian varios elementos propagandísticos relevantes. Primero, la exaltación de la victoria propiamente tal; luego la forma de referirse al enemigo vencido y a su religión. Los musulmanes eran tachados de "pueblo bárbaro" y "herejes", no sólo eso, sino que también como "paganos". Epítetos de una importante carga simbólicareligiosa, puesto que se pretendía dar una imagen de los andalusíes como un pueblo inferior y alejado de Dios, en consecuencia, sujetos de guerra justa, a los que la Iglesia manda derrotar en el cumplimiento de designios divinos ${ }^{1123}$. Así la limpieza y designación de una nueva Iglesia se convertía en un símbolo de superioridad sobre el otro y, además, en señal inequívoca de la victoria del rey y del cristianismo.

\footnotetext{
${ }^{1121}$ García Fitz, Francisco. "La Conquista de Andalucía... op. cit., p. 58; y Muñoz Fernández, Ángela, op. cit., p. 137.

${ }_{1122}$ CAI, Liber II, n 161 , op. cit., p. 125. “(161) Después que la ciudad fue devuelta al emperador, se limpió de la impureza del pueblo bárbaro y de la herejía de Mahoma y, tras hacer desaparecer toda la suciedad de los paganos de aquella ciudad y su templo, consagraron una iglesia en honor de Santa María siempre virgen $y$ de todos los santos y ordenaron alli obispo a un hombre religioso por nombre Navarrón, en vista de que antiguamente había sido sede episcopal en tiempo del arzobispo Idelfonso y del rey Recaredo, cuando todo aquel territorio pertenecía a los cristianos desde el Mediterráneo hasta el mar Océano." CEA, Libro II, Nº6 (161), op. cit., p. 115.

${ }^{1123}$ García-Serrano, Francisco, La creación de identidad en la frontera medieval hispana y la visión del otro: mudéjares y judios, Madrid, CEU Ediciones, 2009, p. 81.
} 
El episodio también contiene otro elemento discursivo importante, la idea de restauración de una sede episcopal. El relato nos dice que apenas consagrado el templo se nombró a un obispo, para así devolverle a Coria el status que había gozado durante el reino de Recaredo. En otras palabras, se recalca el hecho de que los cristianos estaban recuperando tierras otrora visigodas y cristianas, reclamando lo que -según el discursolegítimamente les pertenecía. Este territorio iba desde el Mediterráneo al Atlántico, devolviendo, entonces, el orden natural a las cosas. Todo ello también servía para reafirmar el linaje de Alfonso, como parte de la estirpe de los godos y señor natural de su heredad.

El ritual de purificación no escapó de la atención de los musulmanes, puesto que Ibn 'Idari lo incluyó en su crónica al narrar la captura de Medinaceli por los catalanes. El cronista difiere en algunos aspectos en la descripción del rito, al que describe de la siguiente manera: "El primer lugar de la ciudad en el que entraron fue en su [mezquita] aljama, entonces rociaron sus muros con vino (sic), tocaron en ella campanas (nāqūs) y trasformaron su alquibla [... "1124. Al autor no se le escapa la significación y simbolismo del acto. Claro está que el cronista, no acompaña la descripción con acciones de gracias ni denostaciones a Mahoma o el Islam, pese a lo cual deja en claro la trascendencia del ritual como una señal de victoria, aunque sea sólo militar y política. En la Crónica Latina de los Reyes de Castilla, el ritual de purificación es narrado con más detalles, en dos ocasiones distintas. La primera referida a la captura de Capilla, guardando bastantes semejanzas con el episodio de Coria:

"Archiepiscopus uero Toletanus et episcopus Palentinus et alii niri religiosi, qui cum episcopis erant, mezquitam Maurorum omni spurcicia mahometice susperstitionis per uirtutem Domini nostri Iesu Christi et uictoriosissime Crucis eius purgatam dedicauerunt ecclesiam Domino Iesu Christo, missam et diuina officia cum magno gaudio celebrantes" ${ }^{\text {1125. }}$.

Una situación similar es la que sucedió luego de la captura de Córdoba por Fernando III -narrada por la misma fuente-, aunque en esta ocasión destaca la descripción detallada del uso de agua con sal para lavar la Mezquita y las ignominiosas palabras al referirse al culto musulmán:

1124 CCC, op. cit., p. 88.

1125 CLRC 1997, N50, op. cit., p. 94. "El arzobispo toledano, el obispo palatino y otros hombres religiosos que con los obispos estaban purificaron la mezquita de los moros de toda mancha de superstición mahometana por virtud de Nuestro Señor Jesucristo, celebrando la Misa y los divinos oficios con gran gozo". CLRC 1999, N50, op. cit., p. 82. 
"[...] intrauerunt in mezquitam et preparantes, que necesaria erant ad hoc, ut ecclesia fieret de mezquita, expulsa Mahometi superstitione uel spurcicia, santificauerunt locum per aspersionem aque cum salibus benedicte, et quod prius erat cubile diaboli facta ecclesia Iesu Christi, uocata nomine Genetricis ipsius gloriose" ${ }^{\text {1126. }}$.

Es a partir de la conquista de Córdoba que las fuentes suelen explayarse sobre el ritual realizado por Fernando III al apropiarse de la ciudad ${ }^{1127}$. En crónicas, como las de "el Tudense" y de "el Toledano", encontramos desarrollada la narración del ritual, difiriendo en algunos de sus detalles o en la importancia que se les da a los mismos. Ambos relatos se inician con la entrada de Fernando III a la ciudad para luego proseguir con la narración de la limpieza de la mezquita y su posterior consagración a Santa María. Lucas resalta el detalle de que junto con lo anterior, se recuperaron las campanas de Compostela, que habían sido arrebatadas por al-Mansur siglos antes ${ }^{1128}$. En tanto que Jiménez de Rada destaca al hecho de que el rey ordenase hacer exaltación de la cruz en el mismo lugar donde se solía invocar al perfidus Mahoma ${ }^{1129}$.

Es sobre este mismo detalle que se concentra la descripción de los hechos en la Crónica General:

"Et en la fiesta de los apostoles sant Pedro et sant pablo, la çipdat de Cordoua, a que la estoria llama patriçia de las otras çipdades, esto es patrona et enxienplo de las otras pueblas de Andalozia, fue aquel dia alinpiada de las suziedades de Mahomad, et fue dada al rey don Fernando, et el entrego della; et el rey don Fernando mando luego poner la cruz en la mayor torre o el nombre falso de Mahomat solie ser llamado et alabado, et començaron luego los cristianos todos con gozo et alegria a llamar 'iDios, ayuda!' Et el rey luego man a mano, mando poner la su senna real çerca la cruz de Nuestro Sennor Dios, et començo lugo boz de gozo et de alegria a sonar et seer oyda en las tiendas de los iustos, esto es de los fieles de Cristo; et aquellas bozes fazien los obispos con toda la clerezia, cantando et diziendo: 'Te Deum laudamus', con el muy noble rey don Fernando et con la

\footnotetext{
${ }^{1126}$ CLRC 1997, №73, op. cit., p. 117. “[...] entraron en la mezquita, y, preparando lo que era necesario para que de mezquita se hiciera iglesia, expulsaron la superstición o herejía musulmana y santificaron el lugar por la aspersión del agua bendita con sal, y lo que antes era cubil diabólico fue hecho iglesia de Jesucristo, llamada en el nombre de su gloriosa madre.” CLRC 1999, №73, op. cit., p. 102.

1127 González Jiménez, Manuel, Fernando III el Santo... op. cit., p. 158.

${ }_{1128}$ CE, Libro IV, cap. XCIV, op. cit., p. 430.

${ }^{1129}$ HRH, Libro IX, cap. XVI, op. cit., p. 297, 298.
} 
yglesia et la fe del rey del çielo que entraua alli quella ora con el rey Fernando et con ellos" $" 1130$.

El episodio -que también es reseñado en la Crónica de veinte reyes ${ }^{131}$ - no sólo hace referencia a la purificación de la mezquita mayor y su transformación en templo cristiano, sino que también a la restauración simbólica de las iglesias en honra de Castilla y León, algo ya parcialmente logrado con la recuperación de las campanas compostelanas. También nos describe un ritual de purificación distinto y de enorme carga simbólica. Alfonso, al elevar la cruz y sus enseñas en la torre mayor, realizaba un doble acto, al establecer su autoridad sobre la antigua capital califal -la misma desde la cual se acosó a los cristianos durante el siglo $\mathrm{X}$ y anteriores- En tanto que con la elevación de la cruz, el rey pretendía demostrar a la vez el triunfo de su fe y la purificación completa de la ciudad.

No sólo la mezquita será transformada en un espacio consagrado cristianamente, sino que la conquista de la urbe se convertía en una señal inequívoca del triunfo de las armas reales al servicio de la Iglesia. Es entonces la ciudad entera la que fue lavada y consagrada.

Los ritos de purificación fueron parte esencial del discurso y de la propaganda con la cual se pretendió dirigir las prácticas religiosas en Castilla y León. Fueron señales indelebles y magníficas del éxito de las armas cristinas. Un éxito que sólo había sido posible de lograr con el apoyo de la Providencia, misma razón por la cual la victoria legitimaba al monarca y sus actos. De la misma manera que el agua lavaba los pecados en el bautismo y simbolizaba la vida cristiana, el lavado de las mezquitas reflejaba el renacer de la Iglesia victoriosa. Renacer puesto que la ocupación de los musulmanes no había logrado eliminar a la fe cristiana dentro del al-Andalus, pero sí someterlo. Las campanadas e himnos de la victoria señalaban, en el imaginario y en el discurso, el despertar del letargo en el cumplimiento de la voluntad divina y la derrota de los enemigos de Dios.

Las recompensas espirituales y los ritos religiosos vinculados a la guerra son claros exponentes de la religiosidad hispana y cómo ésta fue orientada al servicio de la causa de la Reconquista. Sobre el primer aspecto, las fuentes indican que las promesas de Salvación, si bien son parte integral del relato cronístico en especial a partir de la primera mitad del siglo XII, no pareciesen ser un elemento esencial en la promoción y

\footnotetext{
${ }^{1130}$ CGE, cap. 1046, op. cit., p. 733.

${ }^{1131}$ CXXR, Libro, XIV, cap. XXV, op. cit., pp. 312, 313.
} 
justificación de las guerras contra el Islam. Sólo entre las décadas de 1130 y 1140 existe un uso frecuente de las promesas espirituales como parte del discurso bélico, aunque estas están ligadas a crónicas de fuerte influencia franca, que además coinciden con uno de los momentos de crisis de la Reconquista, especialmente para los reinos de León y Castilla, la época en que las ideas de cruzada y de guerra santa ya se habían popularizado en Occidente.

Como se ha expresado anteriormente, esto no significa que en el escenario castellano-leonés las promesas de indulgencia o de martirio no tuviesen eco en las huestes de guerreros y en la población general, pero sí que dadas las características de la guerra peninsular y sus ramificaciones políticas y económicas, los guerreros posiblemente fuesen motivados, también, por otras causas, como la adquisición de tierras y de botín. Esto explicaría por qué los estímulos espirituales sólo son apreciables en las principales épocas de crisis o expansión militar, coincidiendo con la necesidad de atraer refuerzos a las fronteras hispánicas. En otras palabras, este tipo de recompensas se instrumentalizaron como un elemento secundario, específicamente para la divulgación de la guerra, obedeciendo a la necesidad de santificar el conflicto para así poder contar con las ventajas materiales e ideológicas que ello implicaba.

Por su parte, los ritos religiosos vinculados a los hechos militares constituyeron una práctica, más arraigada en la realidad hispánica. No obstante, que las crónicas sólo comienzan a describirlos con detalle en las primeras décadas del siglo XII. Estos rituales respondían a una necesidad del pueblo cristiano en general, que era la de buscar o asegurar la ayuda y el favor divino. Eran prácticas que se manifestaban en todos los estamentos sociales, y que en muchas ocasiones, ocurrían espontáneamente, aunque impulsadas por la costumbre; como las oraciones realizadas en momentos de peligro extremo, o para agradecer luego de superada una amenaza. En otras ocasiones, se realizaban para purificar lugares o para celebrar victorias, en cuyo caso correspondían a episodios planificados con una clara intención propagandística.

Finalmente, los rituales terminaron por servir a distintos fines; el primero y más sencillo era el de consolar a los guerreros cristianos, pero también reforzar su fe. En segundo lugar, también servían a los poderes políticos y religiosos como símbolos de su poder y como permanente recordatorio de las razones espirituales de su lucha, puesto que estas fórmulas fueron convertidas en un símbolo más de legitimación, en una señal evidente de que Dios había concedido la victoria a su pueblo, y que sólo reconociendo este hecho alcanzaría el triunfo definitivo. 
Tabla 21: Ritos de purificación de los lugares conquistados

\begin{tabular}{|c|c|c|c|c|}
\hline & $\begin{array}{l}\text { Ocupación y } \\
\text { limpieza de } \\
\text { lugares }\end{array}$ & $\begin{array}{l}\text { Encumbramiento } \\
\text { de símbolos } \\
\text { religiosos. }\end{array}$ & $\begin{array}{l}\text { Encumbramiento } \\
\text { de símbolos } \\
\text { políticos }\end{array}$ & Fuentes \\
\hline \multicolumn{5}{|c|}{1000} \\
\hline \multicolumn{5}{|l|}{1090} \\
\hline \multicolumn{5}{|l|}{1100} \\
\hline \multicolumn{5}{|l|}{1110} \\
\hline \multicolumn{5}{|l|}{1120} \\
\hline \multicolumn{5}{|l|}{1130} \\
\hline 1140 & $\mathrm{X}$ & & $X$ & $\begin{array}{l}\text { - CAI Libro II n }{ }^{\circ} 59 \text { p. } 113 n^{\circ} \\
66 \text { p. } 115\end{array}$ \\
\hline \multicolumn{5}{|l|}{1150} \\
\hline \multicolumn{5}{|l|}{1160} \\
\hline \multicolumn{5}{|l|}{1170} \\
\hline \multicolumn{5}{|l|}{1180} \\
\hline \multicolumn{5}{|l|}{1190} \\
\hline \multicolumn{5}{|l|}{1200} \\
\hline \multicolumn{5}{|l|}{1210} \\
\hline \multicolumn{5}{|l|}{1220} \\
\hline 1230 & $\mathrm{X}$ & $\mathrm{X}$ & & $\begin{array}{l}\text { - CM Libro IV Cap } 94 \text { p. } 430 \\
\text { - CLRC n }{ }^{\circ} 50 \text { p. } 82, n^{\circ} 73 \text { p. } \\
102\end{array}$ \\
\hline 1240 & $\mathrm{X}$ & $\mathrm{X}$ & $X$ & $\begin{array}{l}\text { - HRH Libro IX Cap. } 16 \text { p. } \\
\text { 350, Cap. } 17 \text { p. } 351 .\end{array}$ \\
\hline \multicolumn{5}{|r|}{ 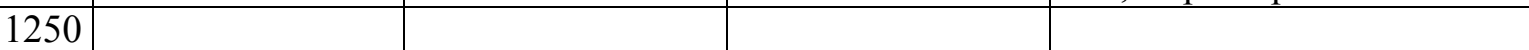 } \\
\hline \multicolumn{5}{|l|}{1260} \\
\hline 1270 & $\mathrm{X}$ & $\mathrm{X}$ & & $\begin{array}{l}\text { - CGE Cap. } 871 \text { p. 541, Cap. } \\
1046 \text { p. } 733 \\
\text { - CXXR Libro XIV Cap. } 25 \\
\text { pp. } 312,313 .\end{array}$ \\
\hline 1280 & & & & \\
\hline 1290 & & & & \\
\hline 1300 & & & & \\
\hline
\end{tabular}




\section{III.4.- Los Reyes modélicos: Siglos XII y XIII}

Habiendo identificado en los capítulos previos los distintos tópicos que se asociaban al poder y obra del rey, así como las características que idealmente debía poseer el monarca, y el contexto en que éstas evolucionaron y se aplicaron, podemos enfocarnos en el análisis de los que hemos denominado "reyes modélicos", entre los siglos XII y XIII; nos referimos a Alfonso VI, Alfonso VII, Alfonso VIII, Fernando III $\mathrm{y}$ Alfonso $\mathrm{X}^{1132}$. Ello con el objeto de atestiguar como los cronistas y las fuentes trataron a estos monarcas, convirtiéndolos en la materialización del ideal real expresado en las ya descritas virtudes reales.

\section{III.4.a.- Alfonso VI (1065-1109)}

Sin duda, en nuestro periodo de estudio, uno de los reyes que se convirtió en un paradigma real fue Alfonso VI. Como veremos a continuación, este monarca fue trasformado en un modelo que trascendió con los siglos; en él los cronistas concentraron todas las virtudes del buen rey; su linaje visigodo, su piedad cristiana, su sentido se justicia, la protección de sus súbditos, la expansión territorial, la restauración eclesiástica y la victoria sobre los enemigos de la Iglesia.

Como se puede apreciar en el siguiente gráfico, si bien son las fuentes prácticamente contemporáneas a la vida del rey las que se más se extienden sobre sus atributos, es relevante que en los siglos siguientes la imagen del monarca seguía presente, pero centrando sus virtudes en su faceta de justiciero, pacificador y protegido por Dios. Estas virtudes se consolidaron por sobre otras características, que en un primer momento, en torno a los años 1110, parecían más relevantes como su rol de guerrero o su calificación como piadoso y continuador del linaje visigodo. Es decir, a nuestro entender, a medida que avanzaron los años y consecuentemente se fue consolidando la figura del monarca hispano, los cronistas tuvieron un mayor interés por resaltar aquellos atributos vinculados a la imagen del buen monarca, más que a la del guerrero conquistador.

\footnotetext{
${ }^{1132}$ Es importante aclarar que no consideramos a Alfonso X exactamente como un rey modélico, no al menos en cuanto a las características que iremos desarrollando a lo largo de este capítulo, puesto que somos conscientes que su reinado culminó en un conflicto civil, donde el monarca fue cuestionado e invalidado por importantes sectores de su reino. No obstante la razón para incluirlo en este listado es el rol que el monarca jugó en cuanto a la consolidación de la figura del rey. En otras palabras, la figura de Alfonso X nos interesa y la colocamos en nuestra categoría del rey modélico, no por sus actos, sino que por su aporte en la creación del modelo que estudiamos, el cual se mantendría vigente, incluso después de la coronación de su díscolo hijo, Sancho IV.
} 


\section{Gráfico 22: Virtudes Alfonso VI}

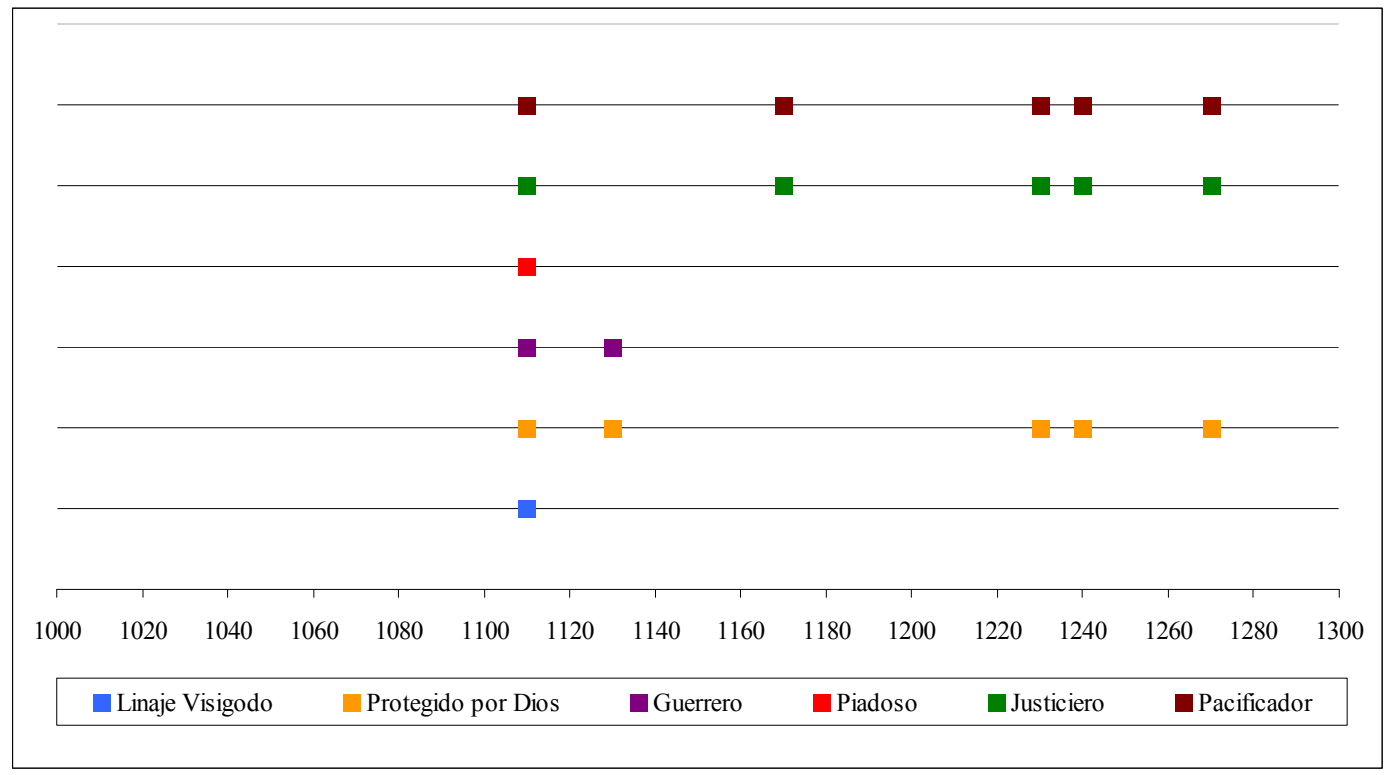

Una crónica que resulta significativa al respecto es la ya mencionada Silense, en la cual su autor procura convencer al lector sobre el linaje godo de Alfonso VI, para lo cual relata su genealogía ${ }^{1133}$. El objetivo de esta operación se entiende porque fue este rey leonés el que se apoderó de Toledo, la antigua capital de los godos. Un acto más que simbólico, que procuraba demostrar de manera práctica la validación dinástica del monarca: "Adelfonsus igitur, ex illustri Gotorum prosapia ortus, fuit magna vi et consilio et armis, quod inter mortales vix inuenitur; namque alterum ex timore occisionis, atque alterum ex audatia fortitudinis processiosse uidemus"

No sólo se destaca la ascendencia goda de Alfonso VI, sino que también su alianza con la divinidad, ya que de la Silense, según José Luis Martín, se desprende que el anterior destierro del conquistador de Toledo en dicha ciudad se debió a la voluntad divina, que de esta forma le permitió acceder a los secretos de la urbe y conocer sus debilidades para su conquista ${ }^{135}$. El relato reafirma la idea del apoyo divino al señalar cómo Isidoro y Santiago, actuaron en beneficio de los ancestros del rey, apareciéndoseles para llevar mensajes y realizar milagros en beneficio de los monarcas de León. De esta forma, la crónica procura validar a Alfonso VI, un rey que accedió al

1133 Le Morvan, Gaël, Reinos e imperio: la Historia legionensis... op. cit., http://espania.revues.org/21681 (junio de 2013).

${ }^{1134}$ HS 1959, 8, op. cit. p. 119. "Pues Alfonso fue oriundo de la ilustre prosapia de los godos, dotado de magna fuerza ya en el consejo, ya en las armas, lo cual entre los mortales apenas se encuentra. Pues lo uno parece proceder del temor de la muerte y lo otro de la audacia de la fortaleza." HS 1913, 8, op. cit., pp. 21, 22.

${ }^{1135}$ Martín, José Luis, "Reconquista y cruzada... op. cit., pp. 230, 231. 
trono luego de fuertes luchas intestinas, a través de la apelación de un linaje que se remonta a Pelayo -el modelo del visigodo virtuoso- y a la ayuda divina recibida ${ }^{1136}$. Es decir, tradición y religión son las bases en las que se sustenta el poder de Alfonso, quien gracias a sus conquistas y nuevas relaciones con la Iglesia, simbolizó el retorno de la gracia divina, que había sido perdida por el pecado de los soberanos visigodos.

Definitivamente, los clérigos-cronistas tuvieron un rol clave en la exaltación de la figura de Alfonso VI, así como en la de sus antecesores ${ }^{1137}$. Ello en virtud de la preocupación del soberano por fortalecer sus lazos con la Iglesia a través de donaciones, pero aún más importante, mediante la refundación y restauración de las antiguas sedes eclesiásticas a medida que se apoderaba de nuevos territorios. Así, los cronistas pretendían señalar al soberano como el responsable de la recuperación del antiguo orden de los visigodos ${ }^{1138}$.

Si bien es cierto que durante el reinado de Alfonso VI los cristianos lograron importantes avances territoriales, y el poder del reino se incrementó -al punto de pactar con Roma e imponerse sobre la nobleza local por el asunto de la liturgia mozárabe-, también hay que recordar que en la esfera privada el rey no estuvo exento de faltas ${ }^{1139}$. Mantuvo una relación con una princesa musulmana, Zaira, con quien incluso engendró un hijo que se convirtió en heredero de su corona, algo que dudosamente fue bien visto por la Iglesia. A esto debe sumarse su tortuoso acceso al trono luego de la muerte de su hermano Sancho, y la prisión de su otro hermano, García. Además, los últimos años de su reinado se vieron marcados por la invasión almorávide en 1086 y el consiguiente retroceso de la frontera hasta el río Tajo. En forma paralela, la muerte de su primogénito

${ }^{1136}$ Corral, Fernando Luis, "Y sometió a su autoridad... op.cit, http://e-spania.revues.org/21696 (junio 2013).

${ }^{1137}$ En esa línea de validación también se puede enmarcar la Crónica Najerense, que exalta a la nueva dinastía castellana, justificando las luchas fraticidas y asesinato de los primogénitos. A Fernando I y su hijo Alfonso VI se les describe como protagonistas de estos actos violentos, pero al mismo tiempo se destacan sus obras y actos piadosos, además de las señales divinas que consagraban sus victorias, lo que vendría a validarlos por sobre a las turbulentas formas en que adquirieron sus coronas. (Klinka, Emmanuelle, "Chronica naiarensis: de la traición... op. cit.,).

${ }_{1138}$ Reglero de la Fuente, Carlos, "Restauración diocesana y memoria regia en León y Castilla", en Martínez Pascual, Rodríguez, Ana, La construcción medieval de la memoria... op. cit., pp. 93, 95; y Le Morvan, Gaël, Reinos e imperio: la Historia legionensis... op. cit., http://e-spania.revues.org/21681 (junio de 2013).

${ }^{1139}$ Respecto a la Liturgia Mozárabe, la forma en que, según la tradición, el rey zanjó el asunto sirvió para trasmitir la imagen del rey como restaurador, pacificador y organizador de sus dominios. Esto en razón de que gracias a la "conquista" de Toledo y la pacificación interior de sus territorios, Alfonso VI se consolidó como la máxima autoridad de su reino, capaz de imponerse a todos sus oponentes; él era el conquistador y el guerrero, así como también quien imponía el orden e impartía la justicia, por lo que era a su voluntad a la que el reino debía someterse. Una realidad que además se entendía inseparable de la nueva alianza entre el monarca y la Iglesia de Roma, la administradora de la fe y guía de la cristiandad. Al respecto ver: De Ayala Martínez, Carlos, Sacerdocio y reino... op. cit., capítulos IX - X. 
desencadenó una crisis sucesoria difícilmente resuelta con el matrimonio de su hija Urraca con Alfonso de Aragón. Pese a todo ello, los cronistas convirtieron al rey en un ideal monárquico, caracterizado por sus múltiples virtudes. A nuestro parecer, si bien es cierto que esta forma de representación comenzó en vida del rey y, por lo tanto, bajo su influencia, sostenemos que a su muerte se mantuvo esta línea representativa, llegando a convertirse en una figura incluso más importante que la de Pelayo ${ }^{1140}$.

Como se observa en el gráfico 17, para los cronistas, entre las virtudes de Alfonso no sólo se destacaban su cercanía a Dios y su ascendencia, sino que también su calidad de combatiente ${ }^{1141}$. Por ejemplo la Historia Compostellana representa al soberano como un guerrero ejemplar, un verdadero héroe que combatía a la cabeza de sus tropas, a las que procuraba darles el ejemplo: "Ipse prior in hostes ruebat, prior hostium cuneos prosternebat et milites suos ad eadem animabat, illos obuiam ire Agarenis et militari exercitio uiriliter desudare ad sui exemplar instruebat." 1142

De acuerdo a este testimonio, se desprende que esta actitud valiente del soberano lo confirmó como la síntesis del buen rey, lo que sirvió además para explicar su conducta temeraria en batalla fundada en su confianza de estar protegido por Dios. Incluso el cronista llega a afirmar que a la muerte del rey, el espíritu guerrero de los castellanos disminuyó, y que se volvieron cobardes, perdiendo su antigua valentía ${ }^{1143}$.

Otra de las crónicas donde observamos esta idealización es la Crónicas anónimas de Sahagún, que realiza una detallada descripción del virtuoso Alfonso VI:

"En el año de la Encarnación del Señor de mill e sesenta e seis, después que el muy noble rey don Alfonso [VI], fijo del rei don Fernando [I] e de la reina doña Sancha, obo el señorío e dignidad del reino de España, varón, por çierto, en las cosas belicosas mui noble guerrero; en disponer bien su reino, proveído e discreto; en el juiçio, muy derecho; en los negoçios seglares, astuto e entendido;

\footnotetext{
${ }^{1140}$ A medida que avanzan los años durante nuestro periodo de estudio, podemos constatar como el mito de Covadonga va cediendo espacio narrativo al reinado de Alfonso VI. Esto no significo que las hazañas de Pelayo fuesen omitidas, pero si que los espacios dedicados a su relato se volverán más reducidos y parcos, en tanto que la descripción de los acontecimientos vinculados Alfonso se harán más extensos. Algo similar ocurrirá, después, entorno a la figura de Alfonso VIII y las Navas de Tolosa.

${ }^{1141}$ Ver gráfico y tabla $\mathrm{n}^{\circ} 17$.

1142 HC 1988, Liber I, cap. LXXXIII, op.cit., p. 132. “Él mismo se lanzaba contra el enemigo el primero, el primero derribaba las filas de los enemigos y animaba a sus soldados a hacer lo mismo, él les enseñaba a ir contra los agarenos y esforzarse valerosamente en el ejercicio militar siguiendo su ejemplo." HC 1994, Libro I, cap. LXXXIII, op.cit., p. 201.

${ }^{1143}$ HC 1988, Liber I, cap. LXXXIII, op.cit., p. 132. "Pero, muerto el rey Alfonso, que era modelo de honradez y escudo de los castellanos, todo en aquéllos cambió a peor: los castellanos se entregaron a la desidia y a la pereza, el lujo y la codicia destruyó su valentía y el anterior valor quedó oculto por el miedo que se iba apoderando de ellos y cuanto más los invitaba la necesidad al estrépito de la guerra, tanto más deseaban alejarse del combate y esconderse lo más lejos posible, no se afanaban ni en defender lo suyo, ni en conseguir luchando lo ajeno." HC 1994, Libro I, cap. LXXXIII, op.cit., p. 201.
} 
mas en las cosas eclesiásticas, religioso e piadoso; en ensalçar y magnificar su reino, muy singular; a los enemigos e malfechores, muy justiçiero e espantoso; a los varones eclesiásticos o a otros sus allegados, muy manso e benigno; en las cosas contrarias, prudente e fuerte; e en las prósperas e vienandantes, templado e manso" ${ }^{, 144}$.

Recordemos que este testimonio fue elaborado por los monjes de Sahagún, que tenían sobradas razones para exaltar la figura del monarca que había sido su benefactor. No obstante, es interesante ver cuáles son las virtudes que resaltan del soberano. En primer lugar destacan sus dotes guerreras. Alfonso, pese a sus postreras derrotas, logró apoderarse de vastos territorios andalusíes, acrecentando su fortuna y de paso las donaciones a la Iglesia y a los monjes cluniacenses. También destacan su sentido de la justicia, calificándolo de "muy derecho" e implacable con los "malfechores"; un atributo no menor si consideramos que el rey representaba la voluntad divina y que la justicia era uno de los atributos esenciales de los reyes del Antiguo Testamento. Sólo un rey justo podía ser considerado legítimamente elegido por Dios ${ }^{1145}$.

No bastando estas virtudes, también se menciona que el rey era entendido en asuntos seglares, y piadoso en los religiosos, destacándose así como un hombre "instruido y entregado a la piedad religiosa". Algo que también se puede concluir al observar que se le describe como "manso y benigno" en relación a los eclesiásticos, así como "mesurado y templado" para los asuntos del reino, sin importar la gravedad de las situaciones $^{1146}$. Esta última característica exalta su figura, también en relación con otros modelos bíblicos como Saúl, cuya ira llevó a alejarse de Dios y pretender la eliminación del modélico David ${ }^{1147}$.

Esta misma crónica también hace referencia a la situación del reino luego de la desaparición de Alfonso, y describe las luchas de los burgueses de la localidad en el marco de las guerras entre Urraca y Alfonso I. Esta parte del relato permite hacer una comparación entre el "virtuoso" reinado de Alfonso VI y el "desgobierno" producido por las pugnas de los dos soberanos; Urraca y Alfonso de Aragón, que enfrascados en sus luchas permitieron los atropellos contra el monasterio y los monjes. La crónica es

\footnotetext{
${ }^{1144} \mathrm{CAS}, \mathrm{I}^{\circ}, \mathrm{n}^{\circ} 6$, op. cit., p. 13.

${ }^{1145}$ Al respecto ver en la segunda parte de esta tesis el capítulo II.4.- Las virtudes del rey: Construcción de un ideal monárquico.

${ }^{1146}$ CAS, $\mathrm{I}^{\circ}, \mathrm{n}^{\circ} 6$, op. cit., p. 13.

${ }_{1147} \mathrm{~A} 1$ respecto ver en la segunda parte de esta tesis el capítulo II.4.- Las virtudes del rey: Construcción de un ideal monárquico.
} 
especialmente dura con el rey de Aragón, al que caracteriza como "bárbaro cruel"1148, y le acusa de aliarse con sarracenos, violar monjas y ultrajar conventos, hacer daños a las iglesias e irrespetar a los clérigos:

"Pero el rei quedo en Galiçia façiendo grandes crueldades e despoblando las villas, rovando los monasterios, socavando los altares, perdiendo las ánimas, así de los suyos como de los estraños, matando onbres, dando denusto e faciendo enjurias a los clérigos, monjes e monjas" ${ }^{\prime 149}$.

Esta demonización del aragonés responde a la doble intencionalidad de exaltar el propio reino y al territorio a través de la figura del rey virtuoso; en este caso Alfonso VI en contraste con las acciones del "Batallador", un extranjero que pretendía el trono leonés, sobre el cual no tenía legítimos derechos ${ }^{1150}$. Por otra parte, hace un contraste

${ }^{1148}$ CAS, $\mathrm{I}^{\circ}, \mathrm{n}^{\circ} 20$, op. cit., p. 33 .

1149 CAS, $\mathrm{I}^{\circ}, \mathrm{n}^{\circ} 20$, op. cit., p. 33.

${ }^{1150}$ Como es sabido la muerte del infante Sancho en la batalla de Uclés, obligó a Alfonso VI a buscar un esposo para su hija Urraca, puesto que ella había enviudado de Raimundo de Borgoña, y su hijo aún no estaba en edad de asumir el trono. El candidato más factible era Alfonso de Aragón, pariente de la infanta; situación que de inmediato generó la oposición de gran parte del clero leonés. Al respecto, existen abundantes testimonios que se caracterizan por la dureza con la que se refieren a dicha unión; por ejemplo, en la Historia Compostellana se nos dice al respecto: "Interea spretro rege Aragonensi, cui incesta coniugii copula Vrracha regina inheserat" y luego agrega en relación a la disputa entre ambos conyugues: "si cum esset ei proxima consanguinitatis linea iunctus, uir eius est nominandus" (HC 1988, Liber I, cap. XLVIII, op. cit., p. 87). Aún más duras son las palabras de la Crónicas anónimas de Sahagún, atribuidas a Bernardo de Toledo, aunque debemos recordar que ambos textos fueron compuestos por personas e instituciones directamente afectadas por este conflicto: "mucho les contradixo, amonestándoles que tal maldad non presumiesen acavar, ca semejante ayuntamiento non era digno de seer llamado matrimonio, mas estupro e fornicaçión prohibida, muchas begadas trayedo a la memoria aquel dicho de León papa, conbiene saber: 'Mucho es difíciles aquellas cosas seer acavadas con buen fin que obieron mal prinçipio"” (CAS, Crónica I, N 18, op.cit, p. 27).

Desde Roma Calixto II, hermano del anterior esposo de Urraca y tío del futuro rey Alfonso VII, también se manifestó contrario a la unión. Pese a ello, el matrimonio se llevó a cabo, solamente para terminar en una rápida ruptura de la pareja debido a la intervención de los potentados civiles y religiosos de ambos reinos y una larga lucha entre ambos para imponerse el uno sobre el otro (Pallares, Portela, op. cit., pp. 156, 157. De Ayala Martínez, Carlos. Sacerdocio y Reino... op. cit., p. 370).

En el intertanto, el conjunto del clero leonés, especialmente los monjes cluniacenses y los prelados se tornaron en grandes enemigos del aragonés, y no dudaron en ayudar a la reina en su lucha abriendo sus arcas para financiar a su ejércitos. Una actitud que se justificaba por los saqueos y ultrajes que las huestes aragonesas, en alianza con algunos musulmanes, habían cometido contra iglesias y monasterios en León (CAS, Crónica I, N²0, op. cit., pp. 33, 34).

Este tipo de situaciones provocaron la intervención del Papa Pascual II, quien en el año 1113 envío una bula exhortando a las autoridades eclesiásticas a lograr la paz, pero también excomulgando a todos aquellos que hubiesen atentado contra las propiedades de la Iglesia. Pese a ello la crisis continuó, obligando al Pontífice a convocar a los obispos hispanos a un Concilio en 1116, en el cual exhortó a la búsqueda de la paz y a un arreglo entre los bandos en disputa (De Ayala Martínez, Carlos, Sacerdocio y Reino... op. cit, p. 379, 390, 393).

El conflicto, si bien se apaciguó, continuó vigente, incluso después de la muerte de Urraca en 1126 y de la coronación de Alfonso VII. Este rey aumentó notablemente el poder e influencia de la Iglesia, puesto que la institución había sido determinante en la oposición del matrimonio entre Urraca y Alfonso, jugando un rol fundamental en el divorcio y el conflicto que le siguió. 
entre dos modelos reales, en especial en cuanto a sus respectivas relaciones con la Iglesia.

Otra crónica interesante en cuanto a la exaltación de la figura del Alfonso VI es la conocida Crónica de Pelayo, de mediados del siglo XII, donde la figura del rey es exaltada por las obras realizadas durante su reinado, diciéndose de él:

"Este Alfonso fue defensor paternal de todas las iglesias de España y por ello se mostró ante todo católico y los agentes del mal nunca se atrevieron a mostrarse ante él; todos los poderosos, nobles o no, ricos o pobres, no osaron nunca promover el mal. Fue tanta la ordenada paz que floreció en su tiempo que una mujer sola, aunque fuese cargada de oro y plata [podía circular] por toda España sin encontrar ni en los campos ni en los montes, ni en lugares habitados o despoblados, quien la tocase o hiciese daño. Los mercaderes y peregrinos que deambulaban por el reino lo hacían sin ningún temor de que nadie les desposeyese de lo que llevaban, aunque sólo valiese un óbalo" ${ }^{1151}$.

Las virtudes de Alfonso relatadas por Pelayo hacen halago de la paz y prosperidad del reino, que sólo podían ser alcanzadas por la Gracia, que así premiaba la devoción que se dice tenía el rey. El obispo no es el único en destacar la paz al interior del reino leonés,: el mismo episodio se repite en crónicas posteriores, tales como la Crónica Najerense $^{1152}$, Cronicon Mundi ${ }^{1153}$, Historia de Rebvs Hispaniae ${ }^{1154}$ Crónica General $^{155}$ y la Crónica de veinte reyes ${ }^{1156}$, convirtiéndose en parte central de las descripciones del reinado de Alfonso VI.

Una semblanza aun más elogiosa sobre Alfonso VI es la que elabora Jiménez de Rada, que dedica el cap XXI del libro VI de su crónica a alabar al rey, considerándolo un referente en cuanto a sus acciones militares, religiosas y de gobierno en general:

"Hic fuit strenuitate maxima nobilis, uirtute excelsus, gloria singularis ; habundauit in diebus eius iusticia, finem accepit seruitus, consolationem lacrime, augmentum fides, dilatationem patria, audaciam populus, confusus est inimicus, obmutuit gladius, cessauit Arabs, timuit Affer; ploratus ululatus Hispanie usque ad istummansit absque consolatore; dextera eius presidium patrie, munimentum absque timore, fortitudo dine perturbatione, protectio pauperum, uirtus magnatum;

${ }^{1151}$ COP, op. cit., pp. 179, 180.

${ }^{1152}$ CN 2003, Libro III, $n^{\circ} 23$, op. cit., p. 183

${ }^{1153}$ CE, Libro IV, cap. LXVIII, op. cit., pp. 371, 372.

${ }^{1154}$ HHE, Libro VI, cap. XXI, op. cit., p. 246.

${ }^{1155}$ CG, cap. 846, op. cit., pp. 519, 520.

${ }^{1156}$ CXXR, Libro X, cap. I, op. cit., pp. 201, 202. 
magnitudo cordis eius Infra angustias Asturiarum non potuit contineri, et elegit laborem indiuiduum comitem uite sue; delicias miseriam reputabat deputans uite sue, in quo belli pericula non agebat. Rex accrescens magnanimus Adelfonsus, rex accrescens sedit in forti; arcus eius confisus in Domino inuenit graciam in occulis Creatoris; magnificauit eum in timore inimicorum et in populo suo elegit eum zelare fidem, dilatare regnum, exterminare inimicos, concluyere aduersarios, multiplicare ecclesias, restaurare sancta, restituere dissipata" ${ }^{1157}$.

Los diversos cronistas coinciden en destacar que una vez en el trono, el rey gobernó con justicia y equidad, relatando su reinado como una época dorada ${ }^{1158}$. Este hecho nos permite plantear la existencia cronística de una "pax alfonsina", que si bien fue de corta duración -limitándose sólo al reinado de Alfonso (1072-1109)-, sirvió para construir un rey modélico en oposición a la actitud de reyes pasados y futuros, en especial en relación al reinado de Urraca, tan vapuleado por los cronistas. Es en ese aspecto que resulta interesante constatar que el Obispo de Oviedo realiza en su crónica, aunque de forma indirecta, una comparación entre Alfonso, el "buen rey", y Bermudo II (985-999), a quien describe como prototipo del tirano. Un soberano injusto, rencoroso, perseguidor de obispos, libertino y licencioso, que es castigado por Dios a través de sequías, las incursiones de al-Mansur y finalmente por la enfermedad que terminó por postrar al rey. En suma, una serie de pecados que lo hizo merecedor del castigo divino y del desprecio de la Iglesia. Evidentemente, su figura contrastaba con la de Alfonso VI, de quien se omite el detalle de su relación con Zaira y se relata la historia del prodigioso anuncio de su muerte a través del milagro de las piedras de las que fluyó agua en la Iglesia de san Isidoro en León ${ }^{1159}$. Un hecho que aparece en numerosas fuentes y que claramente pretende demostrar la aprobación divina respecto al monarca, consagrándolo como un modelo regio.

\footnotetext{
${ }^{1157}$ HRH, Liber VI, cap. XXI, op. cit., pp. 202, 203. “Su nobleza se conjugaba con su valentía; sobresalía por su virtud; su gloria no tuvo par. En su reinado reverdeció la justicia, la esclavitud halló su fin, las lágrimas, su consuelo, la fe, su expansión, la patria, su engrandecimiento, el pueblo, su confianza; el enemigo fue aniquilado, las armas callaron, el árabe desistió, el africano se aterrorizó; el llanto y los lamentos de España no encontraron consuelo hasta su llegada; su diestra era la garantía de la patria, la salvaguardia sin miedo, la fortaleza sin menoscabo, la protección de los pobres, el valor de los poderosos. Las estrecheces de Asturias no fueron capaces de contener la grandeza de su corazón y escogió el esfuerzo como único compañero de su vida; despreciaba los placeres, encontraba deleite y gozo en los peligros de la guerra, pareciéndole que malgastaba los días de su vida que no pasaba entre ellos. Alfonso, rey poderoso y magnánimo, rey poderoso que nada teme; su arco, confiando en el Señor, halló gracia ante los ojos del Creador, que lo engrandeció con el temor de sus enemigos, acabar con los rivales, multiplicar las iglesias, reconstruir los lugares sagrados, reedificar lo destruido."HHE, Libro VI, cap. XXI, op. cit., p. 246.

${ }^{1158}$ Ver gráfico y tabla ${ }^{\circ} 17$.

${ }^{1159}$ COP, op. cit., pp. 172-176, 180.
} 
Sobre este milagro que anuncia la muerte del soberano existen abundantes versiones en distintas crónicas ${ }^{1160}$. En este caso citamos la de la Crónica Najerense, uno de los relatos más extensos $\mathrm{y}$, a nuestro parecer, de los más interesantes, por las conclusiones que obtiene del "milagro":

"Octauo autem ante mortem eius die natiuitatis Sancti Iohannis Babtiste apud Legionem in ecclesia Sancti Ysidori magnum fecit miraculum Deus omnipotens, nam in lapidibus qui sunt ante altare sancti Ysidori, in quibus sacerdos missam celebrans pedes tenet, non per iuncturas set per medium petrarum cepit manare aqua continue ab hora sexta ipsius diei cotidie usque in eam horam dominice diei, uidentibus et presentibus Petro Legionensi et Pelagio Ouetensi episcopis, una cum clero et populo et maxima nobilium multitudine circunstante. Quarta autem die scilicet Dominica predicti episcopi pontificalibus induti uestibus una cum clero et populo, facta processione, accensis cereis, de ecclesia Sancte Marie usque ad altare sancti Ysidori uenerunt uocem dantes cum lacrimis et Dei mirabilia collaudantes. Peracto sermone ab episcopo Ouetensi et peracta missa, accedentes predicti episcopi ad aquam illam et ex ea biberunt et aliis, ut biberent, dederunt; et quod erat residuum aque in uase uitreo posuerunt per multum temporis in testimonium reseruandum. Hoc Signum nichil aliud portendebat nisi luctus et tribulaciones que Yspanie post eius obitum euenerunt. Ideoque plorauerunt lapides ut ad fletum homines commouerent." 1161

Es interesante notar que el episodio no se vinculaba directamente a la persona del rey, puesto que Alfonso VI no se encontraba presente en el lugar de los hechos. No obstante, unánimemente se interpretó el milagro como un anuncio vinculado al monarca y como el inicio de una era de dificultades y desgracias producto de su

${ }^{1160}$ HHE, Libro VI, cap. XXXIV, op. cit., pp. 263, 264; CE, Libro IV, cap. LXXI, op. cit., pp. 381, 382; y CXXR, Libro X, cap. LXXXVIII, op. cit., p. 245.

${ }^{1161}$ Chronica Naierensis, Liber III, N 23, Cvra et Studio Juan A. Estevéz Sola, Tvrnholti, Brepols, 1995 pp. 180, 181. "Ocho días antes de su muerte, en la festividad de la natividad de San Juan Bautista, Dios Todopoderoso realizó un gran milagro en la iglesia de San Isidoro de León, pues en las piedras que están ante el altar de San Isidoro, en las que el sacerdote al celebrar la misa pone los pies, no por las juntas sino que de las mismas piedras comenzó a manar agua sin parar desde las doce de ese día hasta la misma hora del domingo, día a día, viéndolo y estando presente los obispos Pedro de León y Pelayo de Oviedo, junto con el clero y el pueblo, y una gran muchedumbre de nobles a su alrededor. Al cuarto día, esto es, el domingo, los mencionados obispos, revestidos de las vestiduras pontificales, junto con el clero y el pueblo, en procesión, con velas encendidas, vinieron desde la iglesia de Santa María hasta el altar de San Isidoro dando voces entre lágrimas y alabando juntos las maravillas de Dios. Acabado el sermón y la misa por parte del obispo de Oviedo, se acercaron los mencionados obispos al agua y bebieron de ella y a los demás dieron de beber; lo que quedó del agua lo pusieron en un vaso de cristal para que se guardara como recuerdo durante mucho tiempo. Esta señal no mostraba otra cosa sino el luto y las tribulaciones que sucedieron en Hispania después de su muerte. Tanto lloraron las piedras que conmovieron a los hombres hasta el llanto." CN, 2003, Libro III, № 23, op. cit., pp. 183, 184. 
próxima desaparición. Esto sin duda reforzó su imagen como soberano virtuoso, justo y protegido por Dios. También es notorio el hecho de que la manifestación divina se realizase en forma de agua, puesto que tanto en el Antiguo como Nuevo Testamento ésta se vincula a la divinidad y a la legitimación de los conductores del pueblo. Recordemos que para el caso de Moisés, el agua aparece en dos momentos claves de su conducción del pueblo de Israel; en la muy conocida separación de las aguas del mar Rojo, y cuando hace brotar agua de la roca para dar de beber a su pueblo ${ }^{1162}$.

En el caso de Cristo, él mismo se define como "agua de vida" que sacia la sed en un sentido de eternidad, a lo que se suman los relatos del agua que brotó de su pecho cuando fue herido estando en la cruz, episodio del cual se desprende el mito del Santo Grial $^{1163}$.

En cuanto al agua que brota en Toledo, esta se convirtió en una reliquia que quedó profundamente vinculada a la figura del conquistador Alfonso VI, de forma similar a lo que ocurría con los santos y sus vestigios ${ }^{1164}$.

1162 "Respondió Yahveh a Moisés: 'Pasa adelante del pueblo, llevando contigo algunos de los ancianos de Israel; lleva también en tu mano el cayado con que golpeaste el Río y vete, que alli estaré yo ante ti, sobre la peña, en Horeb; golpearas la peña, y saldrá de ella agua para que beba el pueblo. Moisés lo hizo así a la vista de los ancianos de Israel." (Éxodo. 17: 5).

1163 Juan. 4: 5, 19: 31.

${ }^{1164}$ Fernand Cabrol y Henri Leclercq (et.al) en su obra Dictionnaire d'archéologie chrétienne et de liturgie, en su tomo IV, analizan en profundidad la importancia del agua en las culturas del Mediterráneo. Ya para los antiguos hebreos el agua tenía una profunda carga simbólica como instrumento de purificación. Los baños y aspersiones eran parte integral de la ritualidad religiosa, siendo el agua uno de los mayores símbolos de la pureza. A semejanza de los judíos, egipcios, griegos y romanos también daban una importancia ritual al agua como símbolo de vida y purificación, En estas culturas el agua como símbolo purificador solía compartir el espacio con el fuego, siendo ambos elementos, mitológicamente opuestos, parte integral de las prácticas religiosas, observable especialmente en los rituales vinculados a la transición, como los matrimonios y rituales funerarios. El agua como renacimiento también era parte importante de los cultos vinculados a la agricultura y la vida, razón por al cual también vemos su uso en los actos fundacionales de ciudades y templos (Cabrol, Fernand y Henri Leclercq (et.al), Dictionnaire d'archéologie chrétienne et de liturgie, Tome Quatriéme, Paris, Librairie Letouzey et Ané, 1921, pp. 1680-1684). Dado este contexto el ritual cristiano del bautismo puede ser interpretado como la reutilización y reinterpretación del antiguo simbolismos del agua, dado sus componentes simbólicos de renacimiento, la limpieza o pureza y vida.

Es por esta misma carga simbólica que el agua que surge de las piedras de Toledo, en relación a la próxima muerte de Alfonso VI, apela a una conciencia colectiva. El agua era vida y muerte, pureza y pecado. Cabrol y Leclercq nos recuerdan que el agua también tiene una acepción cristiana como "agua bendita" directamente vinculada con la figura de algunos santos. Emanaciones que brotaban de aquellos lugares directamente relacionados con la santidad y a las cuales se les atribuían propiedades curativas y milagrosas. Una creencia popular que llevaba a crear conexiones directas entre algunas personas "predilectas de Dios" y el líquido vital que brotaba de forma milagrosa. (Cabrol, Fernand y Henri Leclercq (et.al), Dictionnaire d'archéologie... op. cit., pp. 1684, 1685) Dado lo anterior, es posible preguntarnos, si es que los cronistas, al menos inicialmente, no habrían tendido la intención de convertir a Alfonso en una figura santificada. Los relatos afirman que el agua de la catedral fue guardada como reliquia, pero las referencias terminan allí, puesto que ninguna de las crónicas que mencionan el portento vuelven a ser referencia a él o a que ocurrió con el agua milagrosa.

Para el momento en que se compuso el relato, a mediados del siglo XII, en Castilla y León existía una fuerte influencia franca. Allende los Pirineos la práctica de la unción estaba arraigada y fuertemente vinculada a la imagen de la realeza, si bien los reyes francos eran ungidos con un óleo 
También es posible atribuir otros significados no excluyentes al portento del agua, pero antes debemos recordar que esta historia fue escrita con posterioridad al fallecimiento de Alfonso VI, por hombres que atestiguaron los conflictos que marcaron el reinado de su heredera Urraca. En ese contexto, el agua bien podría representar el "llanto" de las piedras de la catedral, un lamento por el futuro del reino pronto a quedar huérfano. Una señal poderosa cuando se considera que el milagro ocurre en la misma edificación que simbólicamente es el centro espiritual de Toledo, que a su vez fue el centro del espíritu restaurador godo. A partir de este "milagro" podemos interpretar el potente mensaje de los cronistas, para los que la muerte del monarca es anunciada por el llanto de los cimientos espirituales de la antigua capital; un lamento por la partida del rey restaurador, que trajo la paz y grandeza a su reino y un símbolo de las congojas que a partir de ese momento azotaran a todos sus territorios.

Es así como Alfonso, en el discurso, sintetiza la herencia visigoda: el buen guerrero, la piedad y devoción religiosa y la justicia. Una serie de virtudes que lo convirtieron en un paradigma, que además tenía la ventaja de ser un personaje verdadero y conocido. Los cronistas supieron convertir su imagen en un modelo, no obstante que en muchos casos no se ocultaron sus defectos, aunque se procuró que estos apareciesen disminuidos en comparación con sus virtudes ${ }^{1165}$. Todo ello en consideración de que prácticamente todas las semblanzas laudatorias de Alfonso VI fueron escritas con posterioridad a su muerte, en una época en la que su reino se veía sacudido por guerras y conflictos ${ }^{1166}$. La lucha contra el Islam se había estancado y alAndalus parecía un bloque sólido bajo el mandato de los almorávides, mientras que las guerras entre Aragón y León se volvían casi crónicas, y Urraca trataba de imponerse a

sagrado, la monarquía misma, discursivamente, se remitía a Clodoveo y a su bautismo con agua como símbolo legitimador, ¿acaso no es posible que los cronistas leoneses hubiesen sido influenciados por este modelo? y que a partir de él quisiesen convertir a Alfonso, el reconquistador de Toledo, en el fundador santificado de una nueva estirpe real. No lo sabemos y la respuesta a esta pregunta escapa a las posibilidades de esta investigación. Lo cierto es que el episodio, si bien fue repetido en la cronística posterior, quedo reducido a una simple anécdota acotada en su interpretación y trascendencia.

${ }_{1165}$ Inés Calderón en su texto "La memoria de los reyes de León (1157-1230)", pone en evidencia la existencia de una memoria colectiva por parte de los cronistas, dada su costumbre de exaltar algunos soberanos o aspectos de los mismos, mientras se procuraba ocultar a los considerados como "malos reyes". Así se fortalecían los modelos de conducta y las cualidades legitimadoras, un hecho que era respaldado por los mismos soberanos deseosos de glorificar su ascendencia. Esta situación explica, por ejemplo, el ostracismo en que los cronistas dejaron a Urraca, a la que se suele señalar como un ejemplo de mal gobernante.

Esta actitud en cuanto al uso de la memoria llevaba aparejada la práctica de actos de fuerte simbolismo, siendo uno de los más importantes los vinculados a la sepultura real. La autora nos pone el ejemplo de Alfonso VII que para exaltar las antiguas glorias, en especial las de su abuelo Alfonso VI, se hizo sepultar en Toledo, ciudad que a su vez representaba la "restauración" goda.

1166 Sobre la datación de las crónicas aludidas en referencia a Alfonso V, ver el capítulo correspondiente en la segunda parte de esta misma tesis. 
sus múltiples rivales internos. En dicho contexto no nos parece extraño que la figura del difunto monarca se convirtiese en un icono de las glorias pasadas, de tiempos mejores y que se pretendiese crear a partir de su imagen un modelo regio, para que sus sucesores enmendasen el camino.

Tabla 22: Virtudes Alfonso VI

\begin{tabular}{|c|c|c|c|c|c|c|c|}
\hline & $\begin{array}{l}\text { Linaje } \\
\text { Visigodo }\end{array}$ & $\begin{array}{l}\text { Protegido } \\
\text { por Dios }\end{array}$ & Guerrero & Piadoso & Justiciero & Pacificador & Fuente \\
\hline \multicolumn{8}{|l|}{1000} \\
\hline \multicolumn{8}{|l|}{1090} \\
\hline 1110 & $X$ & $X$ & $X$ & X & $X$ & $X$ & $\begin{array}{l}\text { - CS/L p. } 21,22 \\
\text { - CAS I } \text { n }^{\circ} 6 \text { p. } 13 .\end{array}$ \\
\hline \multicolumn{8}{|l|}{1120} \\
\hline 1130 & & $X$ & $X$ & & & & $\begin{array}{l}\text { - HC Libro I Cap. } 83 \text { p. } \\
201 . \\
\text { - COP pp. } 172 \text { - } 176 \text {, } \\
179,180\end{array}$ \\
\hline 1140 & & & & & & & \\
\hline 1150 & & & & & & & \\
\hline \multicolumn{8}{|l|}{1160} \\
\hline 1170 & & & & & $X$ & $X$ & $\begin{array}{l}\text { - CN Libro III n }{ }^{\circ} 23 \text { pp. } \\
180-183\end{array}$ \\
\hline 1180 & & & & & & & \\
\hline 1190 & & & & & & & \\
\hline \multicolumn{8}{|l|}{1200} \\
\hline \multicolumn{8}{|l|}{1210} \\
\hline \multicolumn{8}{|l|}{1220} \\
\hline 1230 & & X & & & $X$ & $X$ & $\begin{array}{l}\text { - CM Libro IV, Cap. } 68 \\
\text { pp. } 371,372 . \text { Cap. } 71 \\
\text { p. } 381,392 .\end{array}$ \\
\hline 1240 & & $X$ & & & $X$ & $X$ & $\begin{array}{l}\text { - HRH Libro VI, Cap. } \\
21, \text { pp. } 202,203,246 . \\
\text { Cap. } 24 \text { pp. } 263,264 .\end{array}$ \\
\hline 1250 & & & & & & & \\
\hline \multicolumn{8}{|l|}{1260} \\
\hline 1270 & & $X$ & & & $X$ & $X$ & $\begin{array}{l}\text { - CGE Cap. 846, pp. } \\
\text { 519, } 520 . \\
\text { - CXXR, Libro X, cap. } \\
\text { 1, pp. } 201,202 \text {, Cap. } \\
88 \text { p. } 245 .\end{array}$ \\
\hline 1280 & & & & & & & \\
\hline 1290 & & & & & & & \\
\hline 1300 & & & & & & & \\
\hline
\end{tabular}


III.4.a.- Alfonso VII (1126-1157)

Dentro del estudio de la figura de este monarca, un texto clave es la Chronica Adefonsi Imperatoris, por estar dedicada monográficamente a la figura de Alfonso VII, que al igual que su abuelo Alfonso VI, se hizo llamar emperador, gobernando los reinos de León y Castilla y realizando importantes campañas contra los musulmanes.

Como se observa en el siguiente gráfico, de forma similar que en la cronística dedicada a Alfonso VI, inicialmente los testimonios se concentraron en trasmitir la imagen del monarca como un guerrero piadoso y protegido por Dios. Pero a partir de la primera mitad del siglo XIII a estas virtudes se incorporó la característica de rey justiciero, creándose una imagen del soberano centrada en su representación como un guerrero piadoso, que protegido por Dios rigió a su reino con justicia.

\section{Gráfico 23: Virtudes Alfonso VII}

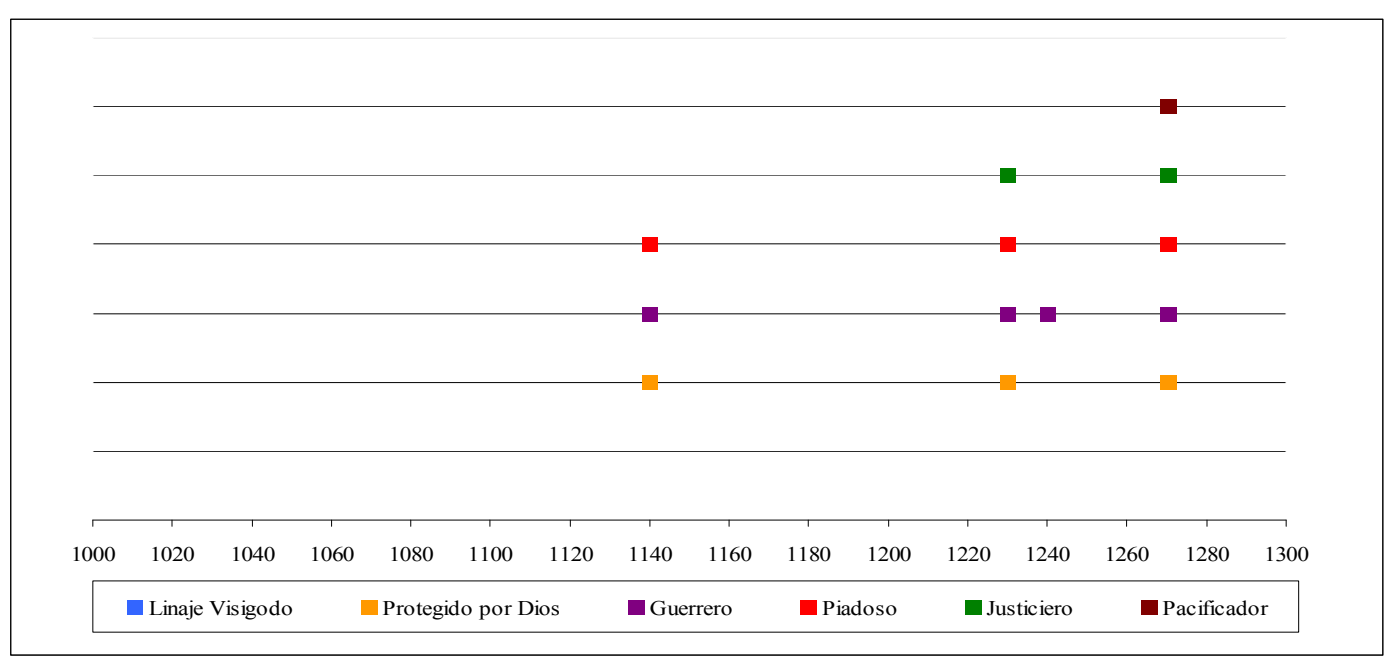

En la primera parte de la Chronica Adefonsi se relatan las luchas entre Alfonso VII y Alfonso I, con la clara intención de exaltar al leonés, mientras se critica abiertamente al rey de Aragón, destacando así una comprensión dualista, donde el primero simboliza las virtudes positivas, mientras que el aragonés sintetiza un conjunto de aspectos negativos ${ }^{1167}$. No obstante, a diferencia de otros modelos de exaltación monárquica, en la Chronica no se hace una semblanza concreta del emperador, sino que por el contrario, sus virtudes y atributos se encuentran dispersos por toda la obra,

${ }^{1167}$ Klinka, Emmanuelle, "Protagonismos y relación historiográfica... op. cit. 
mezclados con los relatos de los hechos. Sólo en su última parte, el Poema de Almería, encontramos una descripción del monarca más o menos compacta:

"[1] Convenere duces Hispani Francigenaeque:

per mare per terras Maurorum bella requirunt.

Dux fuit Imperii cunctorum rex Toletani.

Hic Adelfonsus erat, nomen tenet imperatoris,

[5] facta sequens Catoli, cui competit aequiparari.

Gente fuere pares, armorum vi coaequales.

Gloria bellorum gestorum par fuit horum.

Extitit et testis Maurorum pesima pestis,

quos maris aut Festus non protegit, aut sua tellus" ${ }^{1168 .}$

En el texto se hace una comparación directa entre Alfonso y Carlomagno, personaje que durante el Medioevo se convirtió en el paradigma del buen rey; prudente, piadoso y defensor de la Iglesia contra los infieles y paganos ${ }^{1169}$. El hecho de que se muestren ambos soberanos nos permite constatar la creciente influencia franca en el reino leonés, producto de la propagación de Cluny y el arribo de personajes ultrapirenaicos a la Península como fue el caso de Raimundo de Borgoña, el padre de Alfonso. Notable también es el hecho que el eje de la comparación se encuentre en la capacidad bélica de ambos monarcas en relación al Islam, dejando claro que la victoria sobre ellos señalaba la fortaleza y grandeza de los reyes cristianos.

La importancia de la Chronica Adefonsi no sólo reside en lo ya referido, sino que también en el perfeccionamiento del discurso validador de los reyes en cuanto a la guerra y la protección divina, algo atestiguable ya en las primeras líneas de la Crónica cuando se celebra el arribo al trono de Alfonso, como producto de la disposición divina:

“Adefonsus vero, filius Rius et Raymundi ducis, qui post eam, quia promisum de supernis misumque feliciter, Deo dispensante, regnavit, sequenti die postquam est mater eius, eiam iuvenis decem et novem annorum, beato iubilei anni

${ }^{1168}$ CAI, Poema de Almeria, I, 1, 5, pp. 165, 166. “[...] Reuniéronse los caudillos hispanos y francos: /[15] por mar y tierra desean guerrear con los moros. El caudillo de todos fue el rey del imperio toledano; éste era Alfonso, que ostenta el título de emperador siguiendo las hazañas de Carlos, al que corresponde equiparle: fueron iguales en carácter, parejos en la fuerza de sus armas, /[20] igual fue la gloria de las guerras realizadas por ellos. / Y testigo de ello fue la perversa peste de los moros, a los que no protegieron las agitadas aguas del mar o su propia tierra [...]" CEA, Poema de Almería, op. cit, pp. $131,132$.

${ }^{1169}$ Duby, Georges, La Época de las Catedrales... op. cit., p. 23. 
tempore, ducente Domino, in Legionensi civitate, unde regnum ducitur, venit."

En la misma línea de exaltación providencialista se pueden señalar que en, al menos dos episodios narrados, podemos observar cómo los enemigos del emperador temen enfrentarse a él al reconocer a Dios detrás de sus actos, y de esta forma el rey se impone a sus adversarios sin luchar:

"Cum autem videret rex Aragonensis illa acies minimas esse et viros, qui in eis erant, validos animis et instructos armis, et se videret cum multis milibus militum et petitum, vocavit principes et duces populi et episcopos, qui secum erant, et petiit consilium a beis quid facere deberet. Sed episcopus Pampilonensium, qui nomen erat Petrus, dixit regi: 'Domine, si iubes, ego loquar ad te.' Et respondit ei rex: 'Loquere, Domine.' Et dixit: 'Vides illam gentem minimam? Nos est pauca, sed multa. Deus enim est cum illa, et Deus est defensor eius. Non quaerit quae aliena sunt, sed quae sua.. Pacem diligit, pacem quaerit: omnis enim amator pacis Dominum diligit. Non est dificile apud Deum concludere multos in manibus paucorum: victoria belli non est in multitudine exercitus, sed de coelo fortitudo est. Rex: reminiscere pacti quod pepigisti in praeterito anno regi Legionis dare ei Castrum Silici et Naiaram et Omnia castella et civitates, quas tulisti matri suae reginae dominae Urracae, et ita vive cum meo pacifice. Oh rex: ne pugnes cum eo; si enim pugnas cum eo, rictus es et mortuus, et omnes qui tecum sunt"1171.

En este episodio observamos el intento del cronista por confrontar dos modelos regios: el virtuoso materializado por Alfonso VII y su némesis encarnada en el

${ }^{1170} \mathrm{CAI}$, Liber I, $\mathrm{N}^{\circ}$ 1, op. cit, p. 4. "Alfonso, hijo suyo y del duque Raimundo, que por disposición divina, como promesa felizmente enviada de los cielos, reinó tras ella al día siguiente de morir su madre, vino por inspiración divina a la ciudad de León, desde donde se gobierna el reino, cuando ya era un joven de veintiún años, en el bienaventurado momento del año jubilar." CEA, Libro I, $\mathrm{N}^{\circ} 1$, op. cit., p. 63.

${ }^{1171}$ CAI, Liber I, $\mathrm{N}^{\circ} 15$, op. cit, pp. 16, 17. "Al ver el rey de Aragón que aquellas tropas eran muy poco numerosas y que los hombres que en ellas habia eran valientes y estaban provistos de armas y viéndose él con muchos miles de caballeros y peones, llamó a sus nobles consejeros, a los caudillos del pueblo y a los obispos que estaban con él y les pidió consejo sobre qué debía hacer. Entonces el obispo de Pamplona, cuyo nombre era Pedro, le dijo al rey: 'Señor, si me lo ordenas, yo te hablare'. El rey le respondió: 'Habla, señor'. Y dijo: ¿Juzgaras que aquel ejército es poco numeroso? No es poco, sino mucho. Dios está con él y Dios es su defensor. No reclama lo que le es ajeno, sino lo que es suyo; ama la paz, busca la paz. Pues todo amante de la paz ama a Dios. Con la ayuda de Dios no es dificil que muchos terminen en manos de pocos. La victoria en la guerra no reside en la multitud de un ejército, sino que la fuerza procede del cielo. Acuérdate, rey, del pacto que estableciste el año pasado con el rey de León: darle Castrogeriz, Nájera y todos los castillos y ciudades que arrebataste a su madre la reina doña Urraca y de este modo vivir en paz con él. Rey, no luches con él. Pues, si luchas con él, date por vencido y muerto tú y todos los que están contigo." CEA, Libro I, N 115, op. cit., pp. 68, 69. 
aragonés. Las dudas del rey de Aragón y la advertencia que le hace el Obispo Pedro señalan claramente una supremacía bélica de los guerreros del emperador -aunque sus huestes estuviesen en desventaja numérica-, lo que viene a señalar la superioridad moral leonesa, que además deslegitimaba a Alfonso I al negársele la gracia divina, y por lo tanto condenándolo a la perdición de él y de su pueblo.

A lo anterior se agregan otros episodios tales como que Alfonso VII en distintas ocasiones pide y recibe el amparo de María, en cuya iglesia el monarca fue coronado $^{1172}$. Siendo aun más significativa su relación con Santiago. Previo a su enfrentamiento con García de Navarra, Alfonso peregrina a Compostela y una vez iniciada la expedición el leonés encara con solo treinta caballeros al navarro y sus huestes, que huyen ante la presencia de su adversario, para, posteriormente firmar la paz y someterse a Alfonso. Entendiéndose, a partir de este episodio, que las victorias del emperador se debieron a la protección del Patrono de España, que junto con Dios y la Virgen, componían la trinidad protectora del reino y su soberano ${ }^{1173}$.

Un último episodio que quisiéramos destacar de la Chronica Adefonsi Imperatoris, es el referido a la narración de una cabalgata dirigida por el monarca. En esa ocasión, una parte de la hueste cruzó el Guadalquivir sin que el rey lo hubiese ordenado para realizar pillajes, obteniendo un enorme botín. Pero antes de que pudiesen regresar fueron atrapados por la crecida del río. Ante la imposibilidad de ayudarlos el emperador se marcho con el resto de su tropa:

"[132] Dum ista gerentur, quaedam pars gentis Extremature transierunt flumen quod vocatur Goadalquivir sine praecepto imperatoris et principum eius, et abierunt in terram Sarracenorum et fecerunt multas praedas et incendia, et reversi sunt ad eumdem locum ubi prius transierant flumen, et per pigritiam et abundantiam divitiarum, quas acceperant, non transierunt flumen et manserunt ibi. Media autem nocte, facta est magna inundatio pluviae, et aqua nimium crevit. Mane autem facto, illa gens neque natando neque aliquo potuit transire flumen.

[133] Imperator vero, praevidens ea, quae futura erant, cum propria militia a longe abiit, ne viderent mortis gentis suae [...]"1174

${ }^{1172}$ CAI, Liber I, N 1, op. cit, p. 4; y Klinka, Emmanuelle, "Protagonismos y relación historiográfica... op. cit.

${ }_{1173}$ CAI, Liber I, No 88-91, op. cit, pp. 90, 91; y Klinka, Emmanuelle, "Protagonismos y relación historiográfica... op. cit.

1174 CAI, Liber II, N 132, 133, op. cit, pp. 104, 105. “37 (132) Mientras sucedia esto, una parte del ejército de Extremadura atravesó el río llamado Guadalquivir sin la orden del emperador ni de sus jefes militares, marcharon al territorio de los musulmanes, perpetraron numerosos botines e incendios $y$ regresaron al mismo lugar donde anteriormente habian atravesado el río y permanecieron allí. Pero a media noche se produjo una gran inundación provocada por la lluvia, y el río creció demasiado. Y por la 
El relato continúa narrando cómo los extremeños clamaron por ayuda y finalmente fueron masacrados por los musulmanes, salvándose sólo uno de los guerreros cristianos $^{1175}$.

El episodio puede ser interpretado como una advertencia para aquellos que, bajo las órdenes del monarca, actuaban contra sus deseos movidos por intereses particulares puesto que la crónica da a entender que la codicia fue la causa de la perdición de la hueste- y finalmente fueron castigados por ello. En esencia, este es un discurso que pretende asegurar la lealtad y sometimiento al monarca ${ }^{1176}$.

Los diversos actos bélicos protagonizados por Alfonso, en la Chronica Adefonsi, son complementados o incluso se podría decir equilibrados, por la asignación de diversas virtudes al monarca, principalmente sus deseos de paz y otorgar el perdón a quienes, siendo sus súbditos, lo ofenden. Siendo significativo de ello uno de los actos inaugurales de su reinado, cuando ofrece el perdón a aquellos señores que atrincherados en una torre se negaban a reconocerlo como a su rey ${ }^{1177}$. Un episodio que junto con los anteriores que vinculaban al monarca con las disposiciones divinas, vino a señalar los atributos virtuosos del soberano y su relación con la providencia.

A la muerte de Alfonso VII en 1157, los reinos de Castilla y León se separaron, lo que dio pie a un nuevo periodo castellanista. Durante el reinado de Alfonso VIII, estas ideas se exacerbaron, buscando una mayor distanciación con León, que para ese entonces se había convertido en el gran rival castellano y con el cual se mantenían constantes conflictos ${ }^{1178}$. La cancillería castellana jugó un rol importante en este contexto, reforzando la imagen del rey a través de la intitulación. Luego del enlace matrimonial de Alfonso con Leonor Plantagenet, en 1170, los textos oficiales comienzaron a utilizar la formula de Rex Hispaniarum, mismo título que usaba Fernando II de León. Esto refleja la competencia entre ambos territorios, pero también el deseo del castellano por reforzar su poder ante influencias externas. Posteriormente,

mañana aquel ejército no pudo atravesar el río nadando ni mediante ningún otro sistema. 38 (133) El emperador, previendo lo que iba a suceder, marchó lejos con su propio ejército para no contemplar la muerte de su gente." CEA, Libro II, No 37 (132)-39 (134) op. cit., pp. 106, 107.

1175 CEA, Libro II, No 37 (132)-39 (134) op. cit., pp. 106, 107.

${ }^{1176}$ Un episodio similar es el mencionado sobre los caballeros que fueron derrotados por desobedecer al rey en la campaña contra Jerez. Al respecto ver CEA, Libro I, $\mathrm{N}^{\circ}$ 38, op. cit, pp. 75, 76; y Klinka, Emmanuelle, "Protagonismos y relación historiográfica... op. cit.

${ }^{1177}$ CEA, Libro I, N 3, op. cit, p. 64; y Klinka, Emmanuelle, "Protagonismos y relación historiográfica... op. cit.

${ }^{1178}$ Maravall, José Antonio, El concepto de España...op.cit, pp. 315-318; Gárate Córdoba. Espíritu y milicia... op. cit., p. 37; y Linehan, España, 1157-1300... op. cit., pp. 28, 29-64, 65. 
se impuso la fórmula de Rey de Castilla y Toledo, que tenía la ventaja de consolidar una nueva visión con respecto al espacio y la tradición del reino ${ }^{1179}$.

Tabla 23: Virtudes Alfonso VII

\begin{tabular}{|c|c|c|c|c|c|c|c|}
\hline & \begin{tabular}{|l|} 
Linaje \\
Visigodo \\
\end{tabular} & $\begin{array}{l}\text { Protegido } \\
\text { por Dios }\end{array}$ & Guerrero & Piadoso & Justiciero & Pacificador & Fuente \\
\hline 1000 & & & & & & & \\
\hline 1090 & & & & & & & \\
\hline 1100 & & & & & & & \\
\hline 1110 & & & & & & & \\
\hline 1120 & & & & & & & \\
\hline 1130 & & & & & & & \\
\hline 1140 & & $\mathrm{X}$ & $\mathrm{X}$ & $\mathrm{X}$ & & & $\begin{array}{l}\text { - CAI, Libro I, n } \mathrm{n}^{\circ} \mathrm{p} \text {. } \\
63, \mathrm{n}^{\circ} 3 \text { p. } 64, \mathrm{n}^{\circ} 27 \mathrm{p} \text {. } \\
72 . \mathrm{n}^{\circ} 88-91 \text { pp. } 90, \\
91 . \mathrm{n}^{\circ} 115, \text { pp. } 63,68, \\
69,132[\mathrm{PA}] \mathrm{I}, 1,5 \\
\text { pp. } 165,166 .\end{array}$ \\
\hline 1150 & & & & & & & \\
\hline 1160 & & & & & & & \\
\hline 1170 & & & & & & & \\
\hline 1180 & & & & & & & \\
\hline 1190 & & & & & & & \\
\hline 1200 & & & & & & & \\
\hline 1210 & & & & & & & \\
\hline 1220 & & & & & & & \\
\hline 1230 & & $\mathrm{X}$ & $\mathrm{X}$ & $\mathrm{X}$ & $\mathrm{X}$ & & - CLRC n $^{\circ} 5$ p. 31 \\
\hline 1240 & & & $\mathrm{X}$ & & & & $\begin{array}{l}\text { - HRH, Libro VII Cap } \\
4 \text { p. } 270,271\end{array}$ \\
\hline 1250 & & & & & & & \\
\hline 1260 & & & & & & & \\
\hline 1270 & & $\mathrm{X}$ & $\mathrm{X}$ & $\mathrm{X}$ & $\mathrm{X}$ & $X$ & $\begin{array}{l}\text { - CGE Cap. } 968-982 \\
\text { pp. } 649 \text { a } 662 . \\
\text { - CXXR Libro XIII, } \\
\text { Cap } 1-16 \text { p. } 259-266\end{array}$ \\
\hline 1280 & & & & & & & \\
\hline 1290 & & & & & & & \\
\hline 1300 & & & & & & & \\
\hline
\end{tabular}

${ }^{1179}$ Estepa, Carlos, "Memoria y poder real bajo Alfonso VIII (1158-1214)”, en Martínez Sopena, Pascual y Ana Rodríguez (Editores), La construcción medieval de la memoria regia ... op. cit., p. 202; Estepa Diez, Carlos, "El Reino de Castilla de Alfonso VIII (1158-1214)", en Álvarez Borge, Ignacio, Carlos Estepa Diez y José María Santamarta Luengos, Poder Real y Sociedad: Estudios sobre el reinado de Alfonso VIII (1158 - 1214), León, Universidad de León, 2011, p. 34, 35; y Rodríguez, Ana, "Memoria y curia regia en Castilla en la primera mitad del siglo XIII", en Martínez Sopena, Pascual y Ana Rodríguez, La construcción medieval de la memoria regia ... op. cit., p. 204. 
Sin duda alguna la imagen de Alfonso VIII se encuentra estrechamente vinculada a la batalla de las Navas de Tolosa. Episodio que, como podemos observar en el gráfico número 18, sirvió para definir la imagen del soberano por medio de cuatro pilares de igual relevancia; un rey guerrero, piadoso, protegido por Dios y justiciero. Así los cronistas procuraron trasmitir la imagen de un monarca equilibrado en función de la Reconquista entendida como una causa esencialmente religiosa ${ }^{1180}$.

\section{Gráfico 24: Virtudes Alfonso VIII}

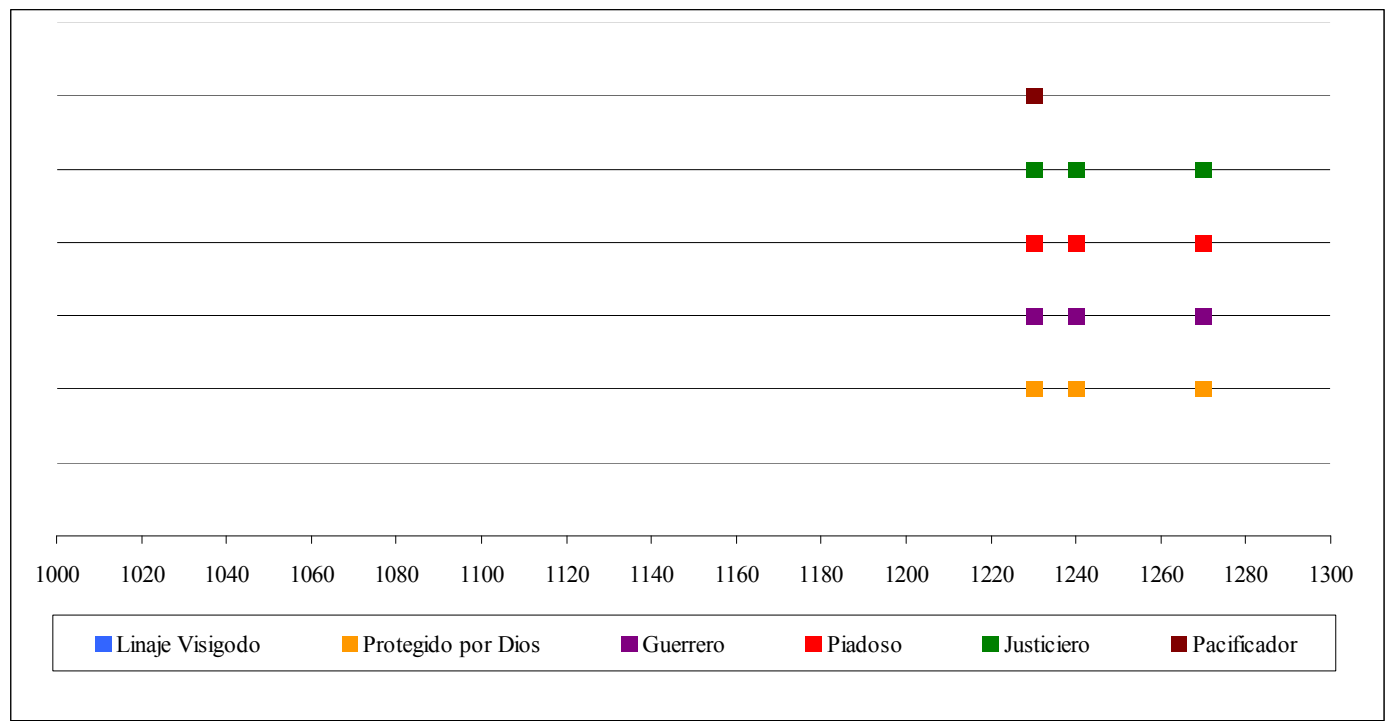

Los cronistas destacan que el triunfo de rey de Castilla en las Navas de Tolosa era una victoria para toda la cristiandad, y así fue reconocida por el mismo Papa que la celebró en Roma ${ }^{181}$. Castilla se convertía así en un Estado cristiano que había llevado a cabo una cruzada exitosa contra el Islam y su rey, Alfonso VIII, en un elegido por Dios para derrotar a sus enemigos, como atestigua la Crónica Latina ${ }^{1182}$ : "Rex gloriosus et

\footnotetext{
${ }^{1180}$ Ver gráfico y tabla $\mathrm{n}^{\circ} 18$.

1181 Mansilla, Demetrio, La documentacion pontificia hasta Inocencio III... op. cit., p. 519.

${ }^{1182} \mathrm{La}$ intitulación da buena cuenta de esto, puesto que la cancillería procuró mencionar y destacar las distintas acciones exitosas del monarca, es decir su triunfo en sus funciones reales, que lo validaban como soberano y cristiano. Es así como en la documentación se destaca su conquista de Cuenca (1177), la curia de Carrión (1188) y Las Navas de Tolosa (1212). Pero también sus triunfos sobre sus competidores hispanos, como la victoria sobre Navarra y los conflictos resueltos con León. El mismo Alfonso procuró trasmitir esta imagen de éxito a su linaje, siendo especialmente destacable el hecho de que su primogénito, Sancho, pese a su corta existencia, desde un comienzo recibió el titulo de rey en la documentación castellana. Así, mediante el uso de la intitulación, Alfonso, procuró reforzar su carisma como rey victorioso y heredarlo a su descendencia como una forma de asegurar la perpetuidad de su reino
} 
nobilis, hoste superbissimo deuicto et prostrato, receptus est in Toleto cum exultatione et gaudio ab uniuersis populis clamantibus et dicentibus: Benedictus qui uenit in nomine Domini" ${ }^{1183}$.

Para construir esta imagen del "rex gloriosus", Alfonso debió recorrer un largo camino, comenzando por su difícil minoría ${ }^{1184}$. Alrededor de 1169 y 1170, Alfonso alcanzó la mayoría de edad y pudo iniciar formalmente su reinado, siendo su primera prioridad validarse a través de imponerse sobre la nobleza y recuperar la posición de Castilla frente a sus vecinos. Pero ello era sólo parte de su proceso de validación; la verdadera prueba era la reconquista de las tierras de sus ancestros cristiano-visigodos. Una prueba fundamental que le brindaría legitimación al joven rey como un monarca bendito por la Providencia. Es por ello que Alfonso inició una doble ofensiva; por un lado inició la lucha militar contra sus enemigos cristianos, y por el otro reactivó la guerra contra los musulmanes ${ }^{1185}$.

En la batalla de Alarcos del 19 de julio de 1195, las huestes castellanas fueron derrotadas, y el mismo rey estuvo a punto de perder la vida. Lo que según los cronistas habría sido la intención del monarca, pero sus propósitos fueron abortadas por sus

(Estepa Diez, Carlos. "El Reino de Castilla de Alfonso VIII (1158-1214), en Álvarez Borge, Ignacio y otros. Poder Real y Sociedad... op. cit., p. 49, 57; Rodríguez, Ana. "Légitimation Royale Et Discours... op. cit., pp. 161; y Sirantoine, Hélène, "La Cancillería regia en época de Fernando III... op. cit., p. 180).

Inés Calderón en su trabajo "La memoria de los reyes de León (1157-1230)” nos recuerda que en León la Cancillería llevó a cabo una acción similar, centrándose en las figuras de Fernando II y Alfonso IX. Ambos monarcas fueron presentados como modelos ejemplares, dotados de virtudes como la justicia, sabiduría, valentía, piedad y victoria militar. Este último aspecto fue el más destacado por la diplomacia cancilleresca, quizás en oposición a la obra de su símil castellana.

${ }^{1183}$ CLRC 1997, N 25, op. cit., p. 64. "El rey glorioso y noble, vencido y humillado el soberbio enemigo, fue recibido en Toledo con alegría y gozo por todo el pueblo que aclamaba y decía: Bendito el que viene en el nombre del Señor." CLRC 1999, № 25, op. cit., p. 56.

${ }^{1184}$ Como es sabido, el hijo de Sancho III, era aun un niño cuando en 1158 murió su padre, lo que implico que Castilla se viese envuelta en una serie de luchas entre el bando de los De Castro y los De Lara, que se disputaban el tutelaje del rey niño. Este periodo de inestabilidad fue aprovechado por Sancho IV de Navarra y Fernando II de León para apoderarse de tierras castellanas (La Rioja y Tierra de Campos, respectivamente) e influir en el reino. Ello en razón de las rivalidades existentes entre los reinos cristianos en el siglo XII, que pugnaban por extender sus territorios a costa de sus vecinos cristianos y el alAndalus. Todo ello, además, contribuyó a ralentizar la actividad reconquistadora de Castilla, lo que significo que el peso de la guerra recayó sobre las milicias y señores de la frontera.

${ }^{1185}$ El castellano primero, en alianza con Alfonso II de Aragón, derrotó a Sancho IV de Navarra en 1173, acción gracias a la cual logró neutralizar a este rival, lo que a su vez le permitió dirigir su esfuerzo bélico contra Cuenca, arrebatándosela a los musulmanes en 1177. De esta forma, con su poder ya consolidado, el rey castellano firma con su par aragonés el tratado de Cazola en 1179, en el cual se realiza la división teórica de Navarra y las áreas de expansión hacia el sur de ambos reinos.

En 1188, Alfonso VIII se reunió con su primo Alfonso IX, que acababa de asumir el trono leones luego de la muerte de su padre Fernando II. La concordia pactada fue rota por el castellano, cuando aprovechándose de la debilidad del nuevo rey le arrebató varias localidades, reiniciando el conflicto entre los reinos cristianos. 
consejeros que lo obligaron retirarse ${ }^{186}$. Un episodio, quizás exagerado, pero que sirvió a los cronistas para destacar el valor del monarca:

"[...] supplicauerunt ei exiret et uitam suam seruaret, quoniam iratus uidebatur Dominus Deus populo Christiano. Nolens autem eos audite malebat gloriosa morte uitam finire quam rictus de bello recedere; sui uero intelligentes periculum inminere toti Ispanie ipsum de prelio quasi inuitum et renitentem eduxerunt." 1187

En 1212 Alfonso retomó la ofensiva, poniendo en marcha la exitosa campaña de las Navas de Tolosa. Para ello reunió un enorme contingente en Toledo, resultando en un episodio que sirvió a cronistas como Jiménez de Rada para destacar una nueva virtud del rey la generosidad ${ }^{1188}$ : "Nec erat qui posset alicuius rei causari deffectum, cum et ipsa ciuitas sui habundancia occurerent et prodiga manus nobilis principis omnibus ad omnia necesaria ministraret" ${ }^{1189}$. La Crónica General agrega que Alfonso VIII se mostró pródigo en regalos y títulos para recibir a los caballeros ${ }^{1190}$.

Junto a lo anterior, Jiménez de Rada, destaca otras características del rey, sin llegar a hacer una semblanza extensa sobre el mismo. El cronista hace constantes referencias a que la Gracia se encontraba con Alfonso y se refiere a él como un rey glorioso, noble y "confortado por la virtud del Altísimo"1191

\footnotetext{
${ }^{1186}$ La derrota de Alarcos fue el primer gran revés cristiano en campo abierto desde la batalla de Uclés en 1108, y puso en entredicho la legitimidad de Alfonso VIII, que luego de ella debió enfrentarse nuevamente a sus vecinos cristianos que buscaban resarcir sus antiguas perdidas, al mismo tiempo que trataban de contener la ofensiva almohade (García Fitz, Francisco, Las navas de Tolosa ... op. cit., pp. $120,121)$

${ }^{1187}$ CLRC, 1997, № 13, op. cit., pp. 46, 47. "[...] le suplicaron que se alejase y preservara su vida ya que el Señor Dios se mostraba airado con el pueblo cristiano. Pero no quería oirlos y prefería acabar la vida con muerte gloriosa a retroceder, vencido, de la batalla. Los suyos, dándose cuenta que el peligro era inminente para toda España, lo apartaron del combate, casi de mala gana y a regañadientes." CLRC, 1999, $\mathrm{N}^{\circ} 13$, op. cit., p. 39.

${ }^{1188}$ Toledo si bien era, por su ubicación, un lugar propicio para reunir a las huestes, también era la antigua capital visigoda y un símbolo de la Reconquista que englobaba el recuerdo del Reino Visigodo y sus glorias y la restauración del cristianismo.

${ }^{1189}$ HRH, Liber VIII, cap. I, op. cit., p. 259. "Y no había quien pudiera quejarse de la falta de nada, ya que no sólo la propia ciudad aportaba por su riqueza, sino que además la generosa mano del noble príncipe atendía a todos en lo preciso." HHE, Libro VIII, Cap. I, op. cit., p. 308.

${ }^{1190}$ CGE, cap. 1012, op. cit., p. 691.

${ }^{1191}$ HHE, Libro VII, cap. XXVI, op. cit., pp. 296, 297.

Jiménez de Rada fue uno de los grandes promotores de la figura de Alfonso VIII, a quien colocaba como un modelo real dadas sus actuaciones bélicas y las relaciones que mantuvo con la nobleza de su reino. (Arizaleta, Amaia, "Ut lector agnosceret: discurso y recepción de la obra de Rodrigo Jiménez de Rada (primera mitad del siglo XIII)", en Cahiers de linguistique et de civilisation hispaniques médiévales, $\mathrm{N}^{\circ}$ 26, 2003, [pp. 163-186], pp. 167-169, 170).

Ver gráfico y tabla $\mathrm{N}^{\circ} 18$.
} 
Es sabido que la jornada de las Navas resultó en una gran victoria cristiana, y colocó a Alfonso en una posición sumamente ventajosa, puesto que no sólo había borrado la vergüenza de Alarcos, sino que además había logrado superar una de las pruebas más difíciles de la mentalidad y práctica guerrera medieval: el conquistar el éxito en una batalla campal. El rey se apresuró en difundir su triunfo, por lo que envío cartas a Inocencio III comunicándole los pormenores de la campaña, y siendo especialmente explícito con respecto a la gratitud hacia la ayuda divina, a quien atribuía toda la gloria. Noticias que fueron respondidas por el Pontífice en el mismo tenor providencialista $^{1192}$.

Gracias a lo anterior Alfonso se convirtió en el gestor y ejecutor de una alianza que había obtenido una brillante victoria, gracias a la cual pudo consolidar su poder al interior de la Hispania cristiana. Un hecho que se materializó con el posterior acuerdo de paz alcanzado con Alfonso IX de León. ${ }^{1193}$. Alfonso se convierte gracias a su esfuerzo y victoria en rex christianissimus, una imagen asociada, según Nieto Soria, a los motivos discursivos que lo llevaron a medirse contra los almohades: el amor a la cristiandad y el deseo de servir a Dios ${ }^{1194}$. Su victoria, consideramos, lo convierten en un modelo de rey cristiano, una imagen que será explotada por los cronistas que construían el discurso político peninsular y que la harían trasmisible a la estirpe real.

Al beligerante Alfonso le sucedió -luego de un breve interregno- su nieto, Fernando III, que protagonizó una de las etapas de mayor expansión sobre el alAndalus; la Campaña del Guadalquivir. Al momento de su muerte, el Islam peninsular había quedado confinado a unos pocos territorios, mientras que él era reconocido como el soberano más poderoso de la Península.

Ambos monarcas, Alfonso VIII y Fernando III, se convirtieron en los nuevos modelos monárquicos en Castilla y luego en León ${ }^{1195}$. Sus actos y conductas

\footnotetext{
1192 González, Julio, El Reino de Castilla en la época de Alfonso VIII, III Documentos... op. cit., p. 566; y Mansilla, Demetrio, La documentación pontificia hasta Inocencio III... op . cit., pp. 519-521.

${ }_{1193}$ Linehan, Peter, España, 1157-1300. Una sociedad desorganizada por la guerra... p. 84; y Nieto Soria, José Manuel, "Fundamentos Ideológicos del Poder Real... op. cit., p. 81.

${ }^{1194}$ Nieto Soria, José Manuel, "Imágenes religiosas del rey y del poder real en la Castilla del siglo XIII", En la España Medieval, Tomo V, Ed. Universidad Complutense, Madrid, 1986, p. 717.

A estas características, otros autores agregan que Alfonso VIII vino a señalar otros nuevos atributos reales vinculados a virtudes como la sapiencia y modestia, mismas que son destacadas por Jiménez de Rada y Lucas de Tuy. Al respecto ver Rodríguez de la Peña, Manuel Alejandro, "Rex institutor scholarum: La dimensión sapiencial de la realeza en la cronística de León-Castilla y los orígenes de la Universidad de Palencia”, en Hispania Sacra, LXII, 126, 2010, [pp. 491-512], pp. 497, 498.

${ }^{1195}$ En el caso de Fernando III, como veremos en las páginas siguientes, fue necesario realizar algunos cambios prácticos en el discurso cronístico en consideración a la ya tradicional rivalidad entre Castilla y León, con el fin de reforzar la imagen del soberano único de los reinos reunidos.
} 
permitieron equipararlos con Alfonso VI, puesto que ambos habían propinado duras derrotas al Islam, protegido a la Iglesia y "recuperado las antiguas tierras de los visigodos"1196. Ambos son puestos como ejemplos de piedad y de devoción, en especial Fernando III, quien se convirtió en un modelo de castidad. Esta piedad era entendida directamente como la lucha contra el Islam, al servicio de la Iglesia, y por lo tanto influenciada por el espíritu cruzado ${ }^{1197}$.

Tabla 24: Virtudes Alfonso VIII

\begin{tabular}{|c|c|c|c|c|c|c|c|}
\hline & $\begin{array}{l}\text { Linaje } \\
\text { Visigodo }\end{array}$ & \begin{tabular}{|l}
$\begin{array}{l}\text { Protegido } \\
\text { por Dios }\end{array}$ \\
\end{tabular} & Guerrero & Piadoso & Justiciero & Pacificador & Fuente \\
\hline 1090 & & & & & & & \\
\hline 1100 & & & & & & & \\
\hline 1110 & & & & & & & \\
\hline 1120 & & & & & & & \\
\hline 1130 & & & & & & & \\
\hline 1140 & & & & & & & \\
\hline 1150 & & & & & & & \\
\hline 1160 & & & & & & & \\
\hline 1170 & & & & & & & \\
\hline 1180 & & & & & & & \\
\hline 1190 & & & & & & & \\
\hline 1200 & & & & & & & \\
\hline 1210 & & & & & & & \\
\hline 1220 & & & & & & & \\
\hline 1230 & & $X$ & X & $X$ & X & $X$ & $\begin{array}{l}\text { - CM Libro IV Cap. } 83 \text { p. } \\
406 \\
\text { - CLRC n } 13 \text { pp. } 46,47 . \\
n^{\circ} 25 \text { p. } 56\end{array}$ \\
\hline 1240 & & X & X & $X$ & X & & $\begin{array}{l}\text { - HRH Libro VII, Cap. } 26 \\
\text { pp. } 296,297 . \text { Libro VIII, } \\
\text { Cap } 1 \text { p. } 303.308,311\end{array}$ \\
\hline 1250 & & & & & & & \\
\hline 1260 & & & & & & & \\
\hline 1270 & & $X$ & $X$ & $X$ & $X$ & & $\begin{array}{l}\text { - CGE Cap. } 991 \text { p. } 672 \text {, } \\
\text { Cap. } 1012 \text {, p. } 691 \\
\text { - CXXR Libro XIV Cap. } 9 \\
\text { p. } 274\end{array}$ \\
\hline 1280 & & & & & & & \\
\hline 1290 & & & & & & & \\
\hline 1300 & & & & & & & \\
\hline
\end{tabular}

${ }^{1196}$ Nieto Soria, José Manuel, Fundamentos Ideológicos... op. cit., pp. 78, 80.

1197 Es de destacar, que para la época en cuestión, incluso el éxito de una campaña militar no era tan importante como la capacidad del monarca por entregarse de lleno a la lucha contra los enemigos de la fe, como fue el caso de Luís IX de Francia, contemporáneo y primo de Fernando III, que pese a sus sonados fracasos en la VII y VIII cruzada fue convertido en un ejemplo de rey cristiano y finalmente llevado a los altares. 
III.4.a.- Fernando III (1217-1252) 1198

Fernando III marca la culminación de la imagen del rey modélico, en gran parte gracias a la acción historiográfica de su hijo Alfonso $\mathrm{X}$, que procuró convertir a su padre en un referente que pudiese validarlo.

Como veremos a continuación, la historiografía cronística rodeó a Fernando III de una larga lista de virtudes que se pueden desglosar a partir de los grandes tópicos ya mencionados. Como se evidencia en el gráfico número 19, se trato de un rey guerreo, profundamente piadosos, preocupado de imponer la paz en su reino y que frecuentemente se encontró bajo la protección de la Providencia. Una imagen laudatoria que fue establecida por cronistas como Lucas de Tuy, pero que fue perpetuada por Alfonso X y sus sucesores.

\section{Gráfico 25: Virtudes Fernando III}

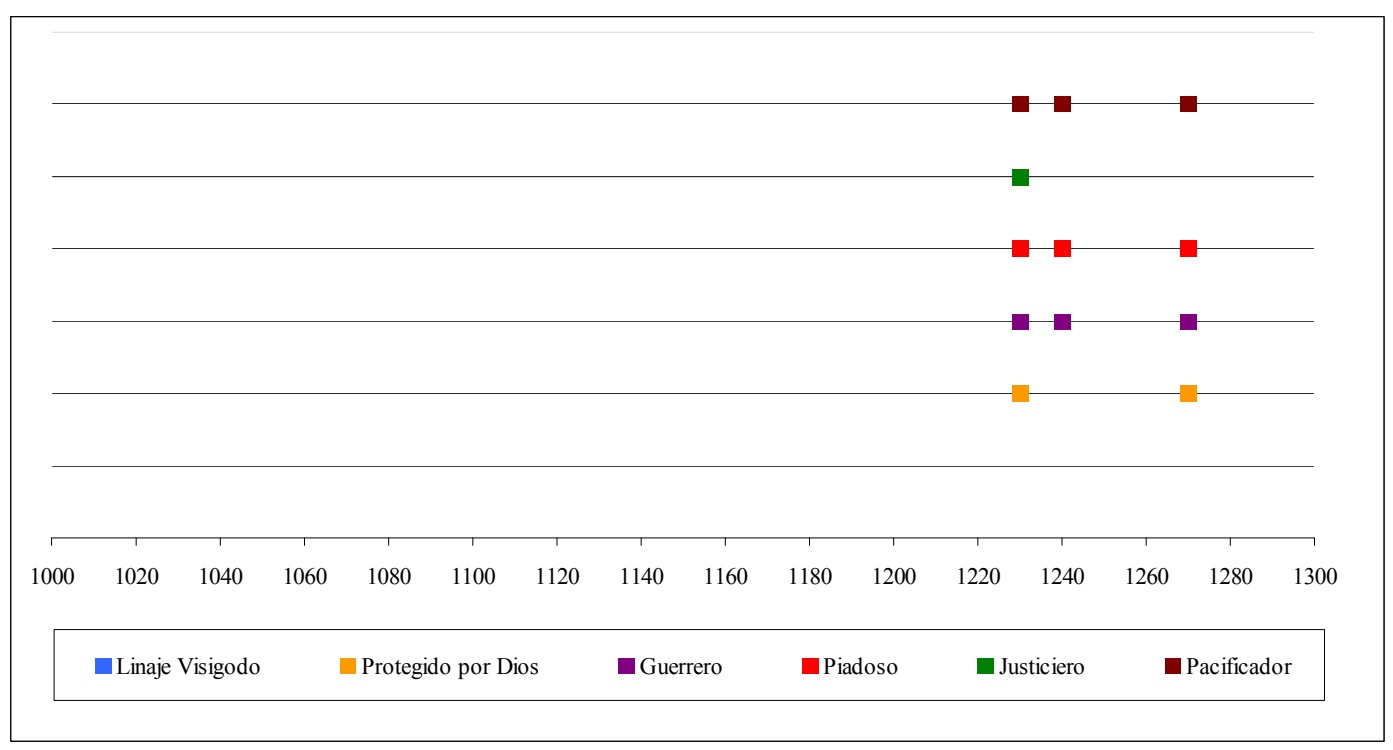

En ese contexto, el texto más significativo fue el Setenario, que aunque no pertenece al género cronístico sirve de punto de partida para analizar esta última figura arquetípica. La obra en su ley V, De las vertudes ssiete que puso Dios en el rrey don Ffemando, enumera siete virtudes que poseía el monarca y que coinciden con las virtudes teologales y cardinales; fe, esperanza, caridad, justicia, mesura, nobleza y

${ }^{1198}$ Fernando III fue rey de Castilla a partir de 1217 y en 1230 recibió también la corona de León. Nosotros consideramos el análisis del rey desde el momento que recibió su primer reino y por lo tanto comienza a simbolizar los ideales monárquicos. 
fortaleza, las que a su vez son complementadas con los dones del Espíritu Santo: saber, entendimiento, consejo, seso, piedad y temor de Dios ${ }^{199}$. Este cúmulo de dones convertía al rey en el modelo virtuoso por excelencia, puesto que ese grado de perfección sólo era posible si se contaba con la protección y guía de $\operatorname{Dios}^{1200}$.

En la Crónica General, al igual que en el Setenario, Alfonso X convierte a su padre en un paradigma de buen gobernante, colocando su piedad, sus servicios a la Iglesia y el consecuente favor de Dios como los elementos centrales de su semblanza. A los que agrega otras virtudes propiamente monárquicas, como son su valentía, su capacidad guerrera, la justicia con que regía a su pueblo, la creación de fueros y leyes, y su respeto y generosidad con los nobles y vasallos ${ }^{1201}$. Un rey amado y respetado por todo su pueblo, así como también por sus enemigos ${ }^{1202}$.

1199 Nieto Soria, José Manuel, "Imágenes religiosas... op. cit., p. 719; y Bizzarri, Hugo y Adeline Rucquoi, "Los espejos de Príncipes en Castilla.... op. cit., p. 20.

1200 "Fe ouo el rrey don Ffernando muy conplidamiente en Nuestro Sennor, segunt de suso es dicho, para creer en él en todas las maneras que Santa Eglesia manda. Esperança ouo ssienpre de auer el ssu bien en este mundo, commo lo ouo demientra que en él visco, e después en el otro; porque oy en día muestra Dios que la su merçet que atendie auer del, que la ouo muy conplidamiente. Amor de caridat ouo del otrosí; ca non tan sol amiente lo amó Dios, mas a todas las otras cosas que lo amauan o que eran del amadas. Justicia amo mucho e la ouo conplidamiente, galardonando los bienes e escarmentando los males. Mesura puso tanta en él que ningún omne non podríe más auer en sí que en él auye. Nobleza de coraçón auye en él muy grande para desdennar e despreciar las cosas malas e viles e de pagarse de onrrar las nobles. De ffortaleza era muy conplido; ca desque entendiese que la cosa que auya de ffazer era derecha, non se camiaría della por omne del mundo nin por amor nin por desamor, nin por cosa quel diesen nin le prometiesen a dar.

Esto ouo en ssi naturalmiente ssin otras buenas costunbres e maneras quel dio Dios tantas e tales que todo omne ssería acabado para auerlas.” Alfonso X, Setenario, Ley V, Edición e Introducción de Kenneth H. Vanderford, Buenos Aires, Universidad de Buenos Aires, 1945, p. 11.

${ }^{1201}$ Carlos de Ayala propone que en este aspecto, Alfonso X fue un continuador de las ideas de su padre, quien habría centrado sus esfuerzos en la consolidación de la unidad castellano-leonesa, como primer paso para la conformación de un imperio (De Ayala Martínez, Carlos, "Fernando III: Figura, significado y contexto... op. cit., p. 24).

1202 "Diz la estoria que este rey don Fernando, pues que tanto ouo puiado et ouo ganado tal prez et ouo su onrra llegada al logar que uos contado auemos, et fue mucho amado et mucho conprido de Dios - et de los terrenales - [...] Pues por morir desta manera que el morio, tan alto et tan amado et seyendo tan reçelado, muy buena le era a el la muerte et mucho onrrada; et con muy tenprada sazon le vino. [...] Et que mucho omne del quisiese decir, los sus fechos le dan testimonio ende. Mas este rey tanto punno en los vsos de todas bondades guisar et obrar siempre en toda la su uida, que nombre conplido de todo buen prez gano en sus grandes conquistas fazer et en todos otros bienes conplidos, quales nin cuantos omne contar non podrie: en heredar caballeros et ricos omnes, ordenes, iglesias, adalides, almogauares, et a todos quantos otros el razon auie de fazer merced; en dar buenos fueros et franquezas et grandes libertades; en ser muy iustiçiero et non menguar y alli o deuie. [...] Este fue rey mucho mesurado et conplido de toda cortesía; et de buen entendimiento, muy sabidor; et muy brauo et muy sannudo en los logares ol conuenie, muy leal et muy verdadero en todas cosas que lealtad debiese seer guardada. Pero que muchol temien los moros, era dellos mucho amado; esto era por la grant lealtad que en el auien siempre fallada. Et enxalçador de cristianismo, abaxador de paganismo, mucho olmidoso contra Dios, mucho obrador de sus obras et muy husador dellas, muy católico, muy eclesiástico, mucho amador de la yglesia, muy rreçelador de en ninguna razon yr contra ella nin pasar contra los sus mandamientos. Rey de todos fechos granados, segunt que en la estoria es ya contado et departido en muchos logares que saco de Espanna el poder et el apremiamiento de los contrarios de la fe de Cristo, et les tollio el sennorio et los torno al suyo a quantos al su tiempo eran. [...] En Dios touo su tienpo, sus oios et su coraçon, por 
Es sabido que bajo Fernando III, Castilla y León se unieron de forma definitiva, y los cronistas reforzaron en sus textos la idea de comunidad y unión que sirviese a las políticas reales. No obstante, al menos en un primer momento, existió una corriente cronística que se abocó a la exaltación de cada uno de los reinos. Pieza emblemática de esta tendencia fue la Crónica Latina de los reyes de Castilla, cuyo objetivo primordial fue la exaltación de los antecesores de Fernando III en el trono castellano, con la intención de validar el linaje del rey y del reino y así facilitar su dominio sobre León.

En relación al mismo problema se procuró producir, con dispar éxito, crónicas más generales e inclusivas. Este papel recayó en Lucas de Tuy y en Jiménez de Rada, por sus cercanías con ambos reinos. Sus historias sirvieron de base para la Crónica general de Alfonso X, que vino a ser la primera crónica "oficial" del reino unido de Castilla y León.

Lucas escribió bajo el mandato de Berenguella, la madre de Fernando III. La reina procuró que la obra del obispo reflejase las virtudes de un buen rey para que sirviese de modelo a su hijo. Es por ello que el cronista convirtió al soberano en un nuevo paradigma, en el que sintetizó todos aquellos elementos que debía poseer un rey, pero también aquellos que debían legitimarlo, en especial el respaldo de la Iglesia $^{1203}$. Es así que Lucas procura mencionar y exaltar a los antecesores de Fernando III, destacando a su vez la actitud piadosa de Fernando, poniéndolo como ejemplo de un buen siervo de Dios. También se explaya largamente sobre sus conquistas y victorias sobre los musulmanes, para así recalcar la idea de que se encontraba bajo la protección divina $^{1204}$. Por último, es de destacar la semblanza que hace de Fernando, en la que se resumen todas las ideas arriba expresadas, destacando primero su prestancia física, así como sus características positivas como su piedad católica, su prudencia y humildad, virtudes que lo distinguían del resto de los hombres de su edad: "Hic autem rex Fernandus grauissima adolescencia uenustatus, non, ut illa etas assolet, lasciuiam amplaxatus est mundi, sed pius, prudens, humilis, catholicus et benignus senilibus se

que el siempre fue tenudo del ayudar et guiar en todos sus fechos, et del adelantar et puiar en todas ondras." CGE, cap. 1131, op. cit, p. 771.

1203 Alfonso, Isabel, Julio Escalona y Georges Martin, "Lucha política condena y legitimación... op. cit., p. 23, 34 .

${ }_{1204}$ En contraste a la exaltación que hacen de Fernando como enemigo de los musulmanes, los cronistas omiten mayor información respecto a la negativa del soberano por involucrase en los esfuerzos de la cruzada oriental y sus frecuentes roces con la Iglesia peninsular en razón de la retención de rentas eclesiásticas y nombramientos episcopales. (De Ayala Martínez, Carlos, "Fernando III: Figura, significado y contexto... op. cit., pp. 21-23). 
moribus decorauit." ${ }^{205}$ Aspectos que el cronista da a entender, respondían a las influencias de quienes rodeaban al monarca, en especial su madre y sus consejeros: "Etenim ita obediebat prudentissime Berengarie regine matri sue, quamuis esset regni culminare sublimatus, ac si esset puer humillimus sub ferula magistrali. Habebat secum prudentissimos cathólicos uiros, quibus tam ipse quam mater totum suum consilium comittebant ${ }^{\prime 1206}$.

Mención aparte merece la descripción de su lucha contra los herejes y enemigos de la fe católica, los cuales el rey procuraba perseguir y eliminar: "In tantum regnum sibi subditum succensus igne catholice ueritas strenue rexit, ut inmicus fidei Christiane totis uiribus persequeretur, et quoscumque reperiebat hereticos, flammis exureret et ipse uice famulorum ignem et ligna in eis comburendis ministrabat ${ }^{1207}$. Una caracterización que llama la atención en relación a que, en la misma, en contraste, no se hacen referencias a sus luchas contra los musulmanes. En cuanto a sus enemigos, su actitud habría sido las de la rectitud, justicia y misericordia, algo que reflejaría su estirpe regia: "Aderat illi in humilitate iusta seueritas, qua reprobos puniebat, et in seueritate iusta misericors et Clemens humilitas, qua prostatis. Eius regalis animus auaricia numquam potuit inflammari, siquidem uisum est, quod requieuerit super eum spiritus sapiencie, qui fuit Adelfonso rege Castelle auo suo, et spiritus fortitudinis et clemencie, qui erat Adefoso rege Legionensi patre ipsius" ${ }^{\prime 208}$.

Por ultimo, Lucas de Tuy, destaca las excepcionales virtudes matrimoniales de Fernando, al alabar la lealtad de tuvo hacia su esposa Beatriz, reina de gran linaje, con la que engendró varios hijos que asegurarían la continuación de su estirpe: "Quid plura? Quod de nullo regum precedencium legitur, omnino irreprehensibilis fuit, quantum nobis scire datum est, et thorum coniugalem unquam minime uiolauit. Duxit namque

${ }^{1205} \mathrm{CM}$, Liber IV, No 93, op. cit., pp. 332, 333. "Mas este rey Fernando, fermosado de muy noble mançebia, no, como aquella edad suele, abraçó la loçania del mundo, mas honrrola seyendo piadoso, prudente, humilde, catholico y benigno." CE, Libro IV, $\mathrm{n}^{\circ}$ 93, op. cit., pp. 417-418.

${ }^{1206}$ CM, Liber IV, N 93, op. cit., pp. 332, 333. "Y con semejables bienes se honrró; y asi obedecía a la muy sabia Berenguella su madre, aunque era enxalçado en la alteza del reyno, como si fuese muy humilde moço so la palmatoria del maestro. Tenía consigo varones católicos muy sabios, a los quales encomendaua él y su madre todo consejo;" CE, Liber IV, N 93, op. cit., pp. 417-418.

1207 CM, Liber IV, N 93, op. cit., pp. 332, 333 "[...] asi que él, encendido con fuego de la verdad católica, [en tanto] noblemente rigio el reyno a ssí subjecto, que los enemigos de la fee christiana perseguia con todas [sus] fuerças, e cualesquiera hereges que hallava, quemava con fuego, en el fuego y las brasas y la llama aparejava para que los quemar." CE, Liber IV, No 93, op. cit., pp. 417-418.

${ }^{1208}$ CM, Liber IV, $\mathrm{N}^{\circ}$ 93, op. cit., pp. 332, 333 Tenía tanta humilldad y deecha crueldad contra los malos, que los feria, y en la justa crueldad tenía humildad misericordiosa y clemente, por la qual perdonaba a los enemigos vencidos; y su real coraçon nunca se pudo ynflamar de avariçia, assi que fue visto que folgó sobrél [el] spiritu de sabiduria que fue en Alfonso rey de Castilla, su abuelo, y el espiritu de fortaleza y clemencia que era Alfonso su padre, rey de Leon. CE, Liber IV, N 93, op. cit., pp. 417418. 
uxorem ex imperiali genere Romanorum Deo deuotissiman feminam nomine Beatricem, ex qua genuit Adelfonsum, Fredericum, Fernandum, Philippum, Henricum, Sancium, Emanuelem, Alienor, Berengariam et Mariam" ${ }^{209}$.

Finalmente el cronista termina alabando la actitud del monarca con respecto al respeto a la Iglesia y afirmando como gracias al rey se imponía la paz en su reino: “Omnibus etiam ecclesiis ita Omnia sua iura seruauit, ut nullus esset qui audelet eas uel in aliquo molestare. In tanta pace regnum sibi subditum rexit, ut mayores uel minores in aliorum res insurgere non auderent ${ }^{, 1210}$.

Como se desprende de lo anterior, esta semblanza de Fernando III viene a renovar el paradigma del buen rey hispano. Es de notar que en ella aparecen repetidas muchas de las buenas características atribuidas a Alfonso VI en las, ya mencionadas, Crónicas de Sahagún y del Obispo Pelayo, aunque también aparecen nuevos elementos ${ }^{1211}$. De ambos soberanos se destaca un sentido de justicia y mesura, siendo implacables perseguidores de sus enemigos, pero también justos en la victoria. Se menciona asimismo el buen juicio de los monarcas en la administración de su reino, destacando sus relaciones con la Iglesia; a ambos se les define como respetuosos de los clérigos, defensores de la Iglesia y hombres piadosos. Por último, debemos hacer notar que tanto en el caso de Alfonso como de Fernando se insinúa que sus reinos estuvieron caracterizados por la paz interior y la prosperidad, y que transmitieron un estado de bienestar a todos sus súbditos.

Respecto a los nuevos elementos, estos son inseparables del contexto político de la crónica de Lucas de Tuy. Fernando es el monarca de un nuevo reino nacido de la unión de dos realidades políticas antagónicas; es por ello que el cronista agrega el elemento "familiar" en su crónica. Primero se hace referencia a un consejo, "habebat secum prudentissimos catolicos uiros, quipus tam ipse quam Mater totum suum consilium comittebant'. Este puede ser entendido como un conjunto de asesores eclesiásticos que darían sustento religioso a las decisiones del monarca, al mismo tiempo que simbolizarían la alianza entre el rey y la Iglesia. El "Tudense" también hace una

${ }^{1209} \mathrm{CM}$, Liber IV, N 93, op. cit., pp. 332, 333 “¿Qué es más? De lo que [en] ningun rey passado se leye, fue de todo en todo sin reprension quanto nos es dado de saber, y nunca poco ni más ensuziió el lecho conjugal. Vbo por muger, del linaje de los emperadores de Roma, a Beatriz, fembra muy deuota a Dios, de la qual engendró a Alfonso, Fabrique, Fernando, Felipe, Enrrique, Sancho, Manuel, Leonor, Beringuella, [e] Maria." CE, Liber IV, n 93, op. cit., pp. 417-418.

${ }_{1210} \mathrm{CM}$, Liber IV, $\mathrm{N}^{\circ}$ 93, op . cit., pp. 332, 333. "[...] y guardó todos los derechos a las iglesias, asi que non auia alguno que osase en cosa enojarla. En tanta paz rigió el reyno a sí subjeto, que mayores ni menores no se osauan mouer para tomar las cosas de los otros." CE, Liber IV, n 93, op. cit., pp. 417418.

${ }^{1211}$ Ver gráfico y tabla n ${ }^{\circ} 17$. 
mención directa al padre y al abuelo del rey (Alfonso IX y Alfonso VIII respectivamente), los antiguos monarcas de Castilla y León, para quienes sólo tiene palabras de elogio -los describe como hombres clementes, sabios y de fortaleza-, pretendiendo sintetizar las virtudes de ambos reyes en el nuevo monarca del reino unido. Por último, no deja de ser llamativa la preocupación por recalcar las relaciones maritales y filiares del rey. La mención y elogios a Berenguela se entienden dado a que ella fue la promotora de la crónica, como el mismo Lucas lo reconoce ${ }^{1212}$ : “Ascritus preceptos gloriosissime ac prudentisime Yspaniarum Regine domine Berengarie, que ut cronicorum libros a beato Ysidoro et a quibusdam aliis peritis de historia regum Yspanorum et quorundam aliorum editos sibi scriberem imperauit ${ }^{\prime 1213}$.

La reina, además, fue en parte responsable de la ascensión al trono de su hijo, sobre quien mantuvo gran influencia durante toda su vida ${ }^{1214}$. Vinculado a lo anterior, también es interesante el espacio dedicado a la relación de Fernando con su esposa, la reina Beatriz, destacando que nunca le fue infiel, "[...] et thorum coniugalem unquam minime uiolauit" ${ }^{\prime 215}$. Esta dedicación conyugal fue un nuevo elemento destinado a mostrar la virtud del rey, puesto que demuestra el respeto por mujer y por su legítimo matrimonio. Una gran diferencia en comparación con otros reyes hispánicos anteriores, donde la lujuria era un mal común y que se creía era castigada con derrotas militares. Por último, la individualización de su descendencia también nos habla del deseo de demostrar el origen legítimo de esta, como dignos sucesores y continuadores del linaje de sus ancestros: los "legítimos" dueños de las tierras que Fernando estaba conquistando.

1212 Tanto en la Crónica Latina, como en el Cronicon Mundi, el rol de Berenguella como consejera y estrecha colaborado de Fernando III nos es destacado en forma reiterada. En el primer texto la reina merece párrafos laudatorios específicos (ver CLRC, $\mathrm{N}^{\circ} 33,35,36,37,43$ y 66, entre otros), en tanto que el "Tudense" procura recordar permanentemente como Berenguella se encuentra junto a Fernando, como consejera, en algunos de los principales episodios de la vida del rey, como por ejemplo los episodios vinculados a la posesión del trono leones y los problemas que se debieron sortear. Otro tanto se puede decir de la Crónica General, donde se repiten muchos de estos relatos, como el capítulo 1038 donde se nos dice que con respecto al rey "[...] et todo esto andandolo guisando, con Dios, muy sabiamente en todas las cosas, la muy noble reyna donna Berenguella, su madre." (CGE, cap. 1038, op. cit., p. 722).

1213 CM, Praefatio, op. cit., p. 4. "Constreñido y forçado por los mandamientos de la muy gloriosa y muy sabia reyna de las Españas doña Verenguela, me mando que escriviese los libros compuestos de los coronistas por Santo Ysidoro y por otros sabios de la estoria de los reyes españoles" CE, Prohemio, op. cit., p. 3.

${ }^{1214}$ Evidencia de ello la podemos encontrar en la Crónica Latina, donde se cuenta, entre otros episodios, cómo Fernando III, en 1224 reunió a su consejo para anunciarles su intención de emprender la guerra contra los musulmanes. El rey inicio sus palabras alabando a su madre, llamándola "Carissima genetrix et domina dulcísima", recordando cómo ella le había entregado el trono: "[...] quid michi prodest fregnum Castelle, quod uestra liberalitas a se, uelud sibi de iure debitum, abdicauit mihique concessitur [...]" (CLRC, 1997, N 43, op. cit., p. 85).

${ }^{1215}$ CM, Liver IV, $\mathrm{N}^{\circ}$ 93, op. cit., p. 333. 
Sobre Fernando III, al igual que Lucas, Jiménez de Rada, también destaca su moderación y la paz y tranquilidad que caracterizó su reinado, haciendo mención expresa a la influencia de su madre en este punto, pero que finalmente en ello siguió la pauta de su abuelo: “[...] ut regnum et patriam iuxta morem aui sui nobilis Aldefonsi in pace et modestia gubernaret usque ad regni sui uicesimun quintum annum"1216. Así resalta la nobleza de la ascendencia del rey, estableciéndose la continuidad de un linaje virtuoso y agradable a Dios.

Si bien Lucas y Jiménez representan un giro en la cronística hispana, nuestra investigación nos permite constatar que unos pocos años antes, el autor de la ya mencionada Crónica Latina de los reyes de Castilla ya había destacado a Fernando III y su linaje como reyes modélicos, fuertemente vinculados a la divinidad. En el caso concreto de Fernando, el cronista es claro en señalar que el rey era un instrumento al servicio de Dios. Por ejemplo al decirnos en relación a la decisión del rey, en contra de la opinión de sus consejeros, de dirigirse a la guerra en Murcia, el cronista explica el episodio afirmando que el monarca se encontraba tocado por el espíritu del Señor: "Rex uero, in quem Spiritus Domini irruerat, ductos saniori consilio, tanquam a Domini Spiritu, pospositis, ne dicam spretis, omnium uoluntatibus et consiliis, Toledo festinanter exiuit, et versus partes illas gloriosus miles Christi cepit ire ${ }^{, 1217}$.

Es así como a partir de este relato sostenemos que la "posesión" divina de Fernando no sólo lo llevó a lograr sus objetivos en esta campaña, sino que también demostró un gran grado de compromiso divino en la causa del rey, quien se convirtió en un instrumento de Dios. Este hecho se relata con claras reminiscencias veterotestamentarias, algo que no se ve en las crónicas anteriores, al menos no de manera tan explícita.

\footnotetext{
${ }^{1216}$ HRH, Liber IX, cap. X, op. cit., p. 290. “[...] llevó con paz y moderación las riendas del reino y de la patria hasta el año vigésimoquinto de su reinado, siguiendo la pauta de su abuelo el noble Alfonso." HHE, Libro IX, cap. X, op. cit., p. 341.

1217 CLRC 1997, $\mathrm{N}^{\circ}$ 48, op. cit., p. 91. "Pero el rey, en quien había irrumpido el Espíritu del Señor, guiado por un consejo más saludable, como del Espíritu del Señor, dados de lado por no decir despreciados los pareceres y consejos de todos, salió rápidamente de Toledo y se dirigió a aquellas tierras." CLRC 1999, $\mathrm{N}^{\circ}$ 48, op. cit., p. 79.
} 
Tabla 25: Virtudes Fernando III

\begin{tabular}{|c|c|c|c|c|c|c|c|}
\hline & \begin{tabular}{|l|} 
Linaje \\
Visigodo
\end{tabular} & $\begin{array}{l}\text { Protegido } \\
\text { por Dios }\end{array}$ & Guerrero & Piadoso & Justiciero & Pacificador & Fuente \\
\hline \multicolumn{8}{|c|}{\begin{tabular}{|l|l|l|}
1000 & \\
\end{tabular}} \\
\hline \multicolumn{8}{|l|}{1090} \\
\hline \multicolumn{8}{|l|}{1100} \\
\hline \multicolumn{8}{|l|}{1110} \\
\hline \multicolumn{8}{|l|}{1120} \\
\hline \multicolumn{8}{|l|}{1130} \\
\hline \multicolumn{8}{|l|}{1140} \\
\hline \multicolumn{8}{|l|}{1150} \\
\hline \multicolumn{8}{|l|}{1160} \\
\hline \multicolumn{8}{|l|}{1170} \\
\hline \multicolumn{8}{|l|}{1180} \\
\hline \multicolumn{8}{|l|}{1190} \\
\hline \multicolumn{8}{|l|}{1200} \\
\hline \multicolumn{8}{|l|}{1210} \\
\hline \multicolumn{8}{|l|}{1220} \\
\hline 1230 & & $X$ & $X$ & $\mathrm{X}$ & $X$ & $\mathrm{X}$ & $\begin{array}{l}\text { - CM Libro IV Cap. } \\
83 \text { pp. } 417,418 \text { Cap } \\
93 \text { pp. } 427,428 . \text { Cap. } \\
97 \text { pp. } 433-436 \\
\text { - CLRC n }{ }^{\circ} 43 \text { p. } 74 n^{\circ} \\
53 \text { p. } 85,\end{array}$ \\
\hline 1240 & & & $X$ & $X$ & & $\mathrm{X}$ & $\begin{array}{l}\text { - HRH. Libro IX, } \\
\text { Cap. 10, p. } 341\end{array}$ \\
\hline \multicolumn{8}{|l|}{1250} \\
\hline \multicolumn{8}{|l|}{1260} \\
\hline 1270 & & $X$ & $X$ & $X$ & & $X$ & $\begin{array}{l}\text { - CGE Cap. } 1034 \text { p. } \\
\text { 718, Cap } 1038 \text { p. } 722 \text {, } \\
\text { Cap. } 1131 \text { p. } 771 . \\
\text { - CXXR Libro XV } \\
\text { Cap. } 80-83 \text { pp. } 346- \\
\text { 348 }\end{array}$ \\
\hline 1280 & & & & & & & \\
\hline 1290 & & & & & & & \\
\hline 1300 & & & & & & & \\
\hline
\end{tabular}


En la segunda mitad del siglo XIII, prácticamente todos los factores utilizados para la creación del modelo real se encuentran sintetizados en las obras alfonsíes. El reinado de Alfonso X marca un hito en la proyección de la figura del monarca hispano, puesto que el rey aplicó una política que podríamos denominar de "construcción institucional", que partiendo de la tradición cronística anterior, procuró crear todo un aparato legal fundamentado en la costumbre y en la ley con el fin de asegurar las bases jurídicas del poder real, y también, para compatibilizar su realidad local con sus aspiraciones imperiales. Todo ello mientras mantenía tensas relaciones con la nobleza local, las que terminarían en un conflicto abierto encabezado por su hijo el futuro Sancho $\mathrm{IV}^{1218}$. No obstante -como observamos en el siguiente gráfico- en lo que se refiere estrictamente a la labor cronística, la figura de Alfonso X es apenas mencionada, en parte debido a que se encuentra eclipsada por los relatos respecto a Fernando III, misma razón que nos explica el hecho de que las pocas referencias a Alfonso se enmarquen en el contexto de las campañas de su padre.

\section{Gráfico 26: Virtudes Alfonso X}

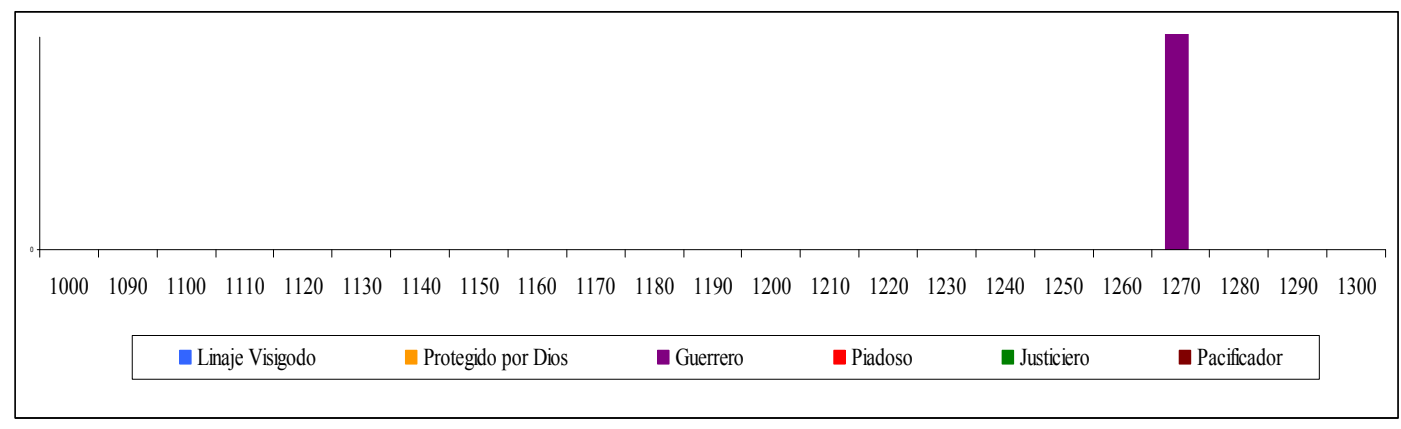

Con la obra del "rey sabio" se consolidó un discurso que ya estaba lo suficientemente elaborado como para convertirse en ley ${ }^{1219}$. Es por ello que consideramos prudente remitirnos con cierto detalle a la obra alfonsina en sus dos vertientes: cronística y jurídica, resaltando el hecho de que la obra alfonsí era tributaria de la tradición cronística anterior.

\footnotetext{
1218 Sobre el reinado de Alfonso X, su ideología y aspiraciones, ver la segunda parte de esta tesis.

1219 Alfonso X no solo se concentró en los aspectos legales de la legitimación, puesto que en sus textos Espéculo y la Crónica General también reforzó la imagen del rey virtuoso a través de las caracterizaciones y enumeraciones de virtudes que poseían algunos personajes, en especial su padre Fernando III.
} 
En relación a la Crónica General, debemos recordar que en esencia fue producto de la edición de distintas obras previas, incluyendo algunos trabajos de Isidoro y las crónicas de Lucas de Tuy y de Jiménez de Rada, por lo que los modelos regios que allí aparecen siguen los mismos principios ya conocidos, es decir la exaltación de la justicia, de la piedad, de la valentía y la defensa de la Iglesia y de la fe. Es así como al final de la obra, en el espacio dedicado a Fernando III, nuevamente vemos una alabanza a su persona, como una síntesis de todas aquellas virtudes, pero con un énfasis mucho mayor en su misión reconquistadora. Es simbólico que estas ideas, según la crónica, fuesen expresadas por el mismo Fernando a modo de últimas palabras e instrucciones finales sus herederos:

"Ssennor te dexo de toda la tierra de la mar aca, que los moros del rey Rodrigo de Espanna ganado ovieron; et en tu sennorio finca toda: la una conquerida, la otra tributada. Sy la en este estado en que te la yo dexo la sopieres guardar, eres tan buen rey commo yo; et sy ganares por ti mas, eres meior que yo; et si desto menguas, non eres tan bueno commo yo." 1220

A través esta sentencia, se puede aventurar que la conquista territorial se había convertido en la máxima misión real y su principal fuente de validación, por sobre las virtudes tradicionales. Sin embargo, esto debe ser matizado a la luz de otra vertiente de los talleres alfonsíes; nos referimos a las obras jurídicas, en el que la definición del monarca y sus poderes ocupa una parte central. En ese sentido es que la escuela alfonsí realizó su gran innovación, la que podemos resumir como, la expresión jurídica de las ideas tradicionales presentes en las crónicas; la creencia de que la monarquía era el reflejo terrenal del orden divino, en que el rey recibía sus poderes de Dios y era su representante en la tierra.

De esta forma convertía al soberano en una entidad casi sagrada e intocable y establecía una serie de penas para quienes le ofendiesen. Un aspecto que debe ser comprendido en consideración a los conflictos del rey con la nobleza. Alfonso debía validarse como soberano, y al parecer sus éxitos militares no fueron suficientes para ello, por lo mismo sus juristas se dieron la tarea de recalcar el origen divino del poder del monarca y de esa manera tratando de influenciar directamente las creencias de sus súbditos.

$\overline{{ }^{1220} \text { CGE, cap. 1132, op. cit., pp. } 772,773 .}$ 
Veamos ahora cómo los textos alfonsíes expresan, a nuestro parecer, estas ideas a través de los siguientes gráficos.

\section{Gráfico 27: Deberes del Pueblo en Relación a su rey}

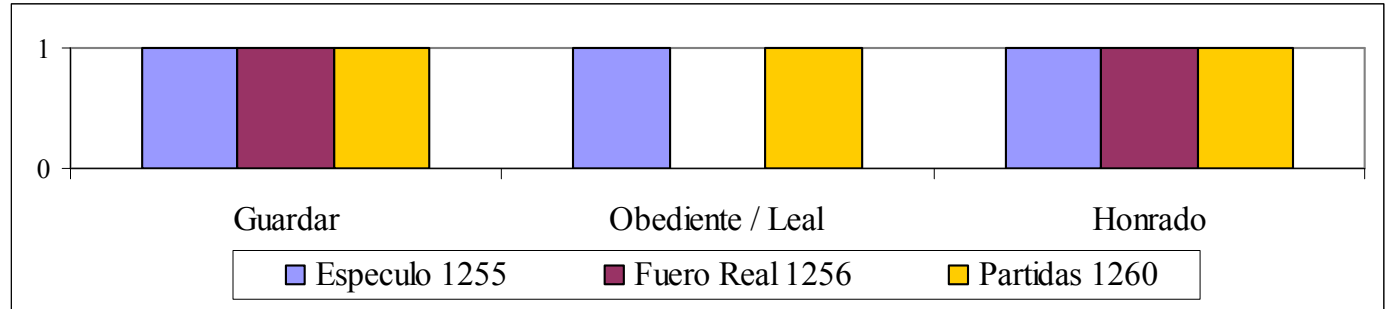

\section{Gráfico 28: Virtudes Militares del rey}

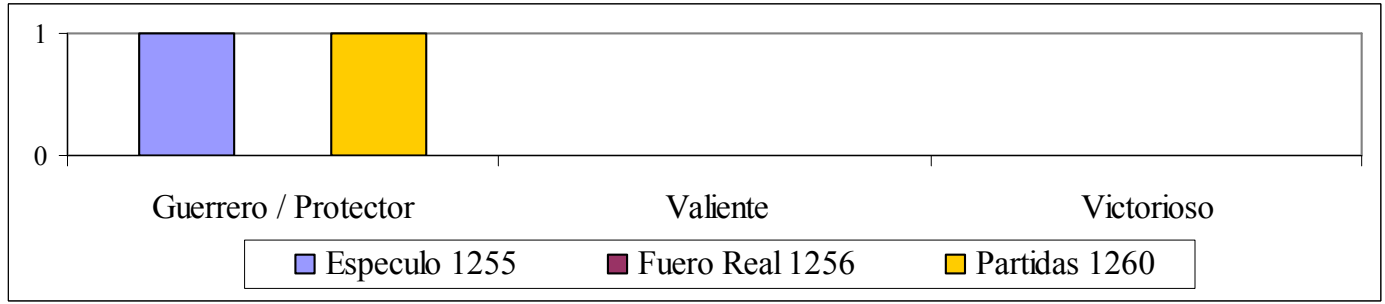

\section{Gráfico 29: Virtudes Judiciales del rey}

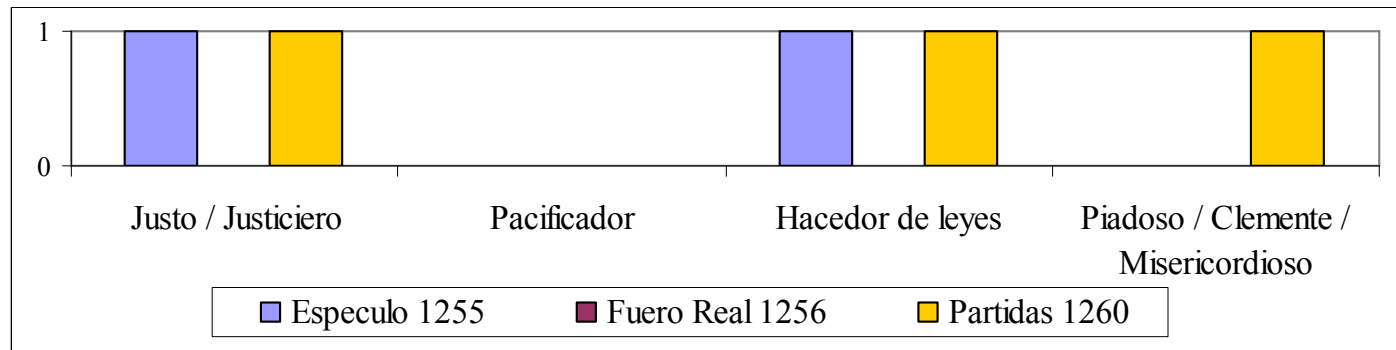

\section{Gráfico 30: Virtudes Religiosas del rey}

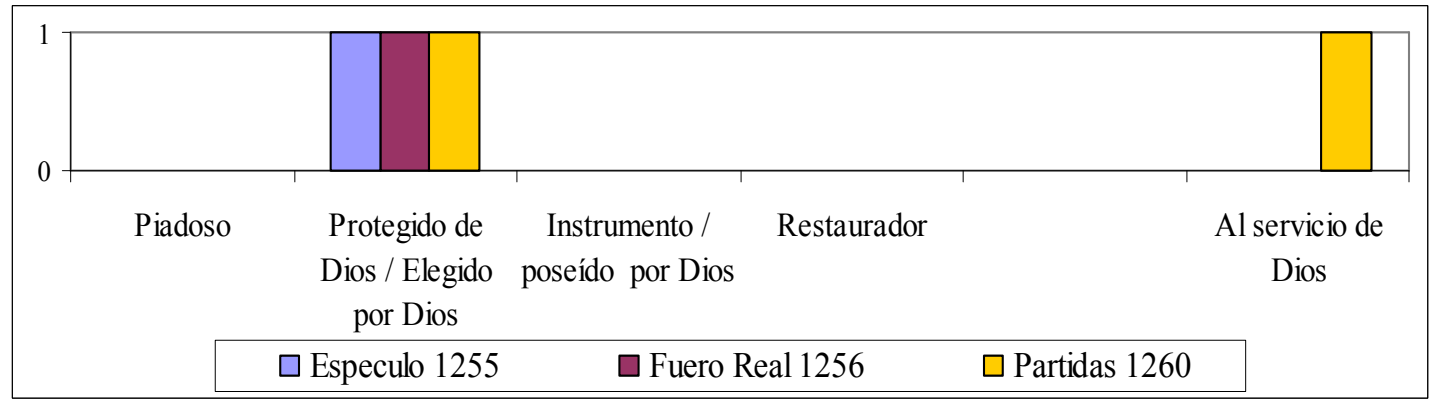


Gráfico 31: Virtudes Morales del rey

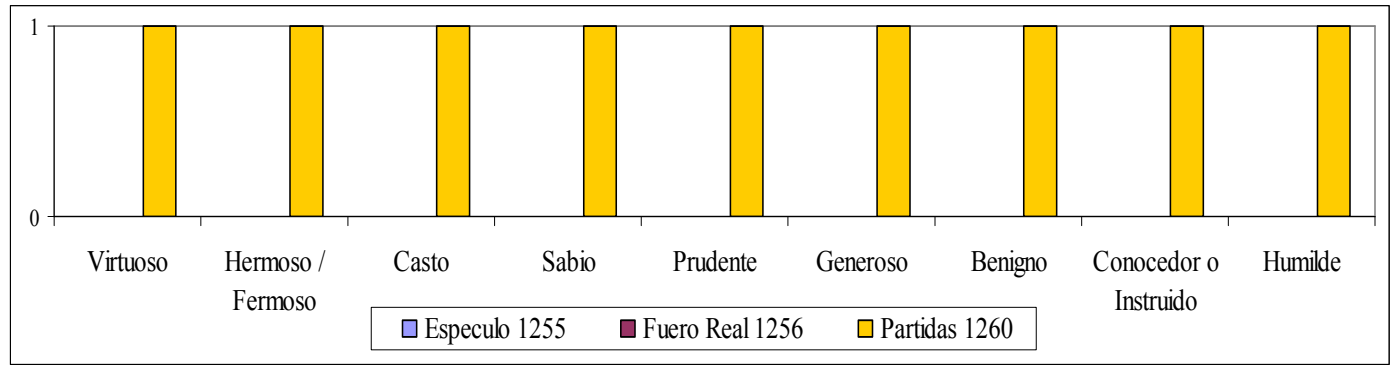

Como se puede observar en los textos jurídicos, existió una intención por reglamentar las esferas de acción del soberano y guiar su conducta. En ese sentido las tres obras se complementan, observándose además, como las Partidas tendieron a englobar a las obras anteriores.

\section{Espéculo}

El primer texto alfonsí en relación a la tematica juridica-real fue el Espéculo (1255 aprox.). En el Libro II se realiza una definición del rey y todo aquello vinculado a su persona. Primeramente se distingue que el monarca tiene dos naturalezas; una espiritual y la otra jurídica, dos concepciones con distintos orígenes. La primera naturaleza encuentra sus raíces en los profetas y santos; es decir, en las Escrituras y en la tradición religiosa, mientras que la segunda se debe a los conocedores del derecho; a los juristas anteriores y contemporáneos al rey. Cada una de estas naturalezas corresponde a una forma distinta de validación, pero coinciden en la función justiciera del soberano como su principal misión y símbolo de su comunión con Dios:

"Sspiritualmiente de-l col. b zimos que el rrey es alma del pueblo e es sennor señalado porque está ffazendado en toller ssus yerros de ssu tierra; e rrey es mayor ssobre todo ssu regno por quien todos los del rregno reciben dono de Dios en sser vna cosa" ${ }^{1221}$.

En el primer título del libro primero de la misma obra, se trata el tema de las leyes y de su naturaleza. Allí podemos apreciar una clara intención de relacionar al rey con la función de hacer justicia, puesto que se dice que sólo los reyes o emperadores pueden formular leyes, excluyendo totalmente a otros poderes en dicha tarea, como a la Corte y a la Iglesia:

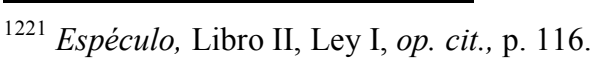


"Ninguno non puede facer leyes sinon emperador o rey o otro por su mandamiento dellos. E si otros las fezieren sin su mandato non deven aver nombre leyes nin deben seer obdedecidas nin guardadas por leyes nin deven valer en ningún tiempo"1222.

En el Espéculo, Alfonso X también se reserva el derecho de aplicar y enmendar las leyes, aunque para esto afirma que es necesario recurrir al consejo de "homes sabidores" $" 1223$. Curiosamente, a nuestro entender, esta forma no parece hacer referencia a la Corte o la Curia, sino que a los juristas reales, personajes cercanos y leales al soberano. Esto podría deberse a la intención de Alfonso X por limitar las atribuciones de los nobles.

La función jurídica del rey es una de sus principales atributos y fuentes de poder. El "rey sabio" conocía esta situación, y trató de normar estas atribuciones, basadas en la tradición. El monarca era consciente de la importancia de controlar el aparato jurídico del reino para validarse ante la díscola nobleza, asegurar el favor del pueblo y demostrar su posición como delegado de Dios en su reino.

Esta función jurídica también obligaba en algunos aspectos al soberano, puesto que debía actuar como reflejo de Dios, ya que Él era el máximo referente de la justicia. Por ello Alfonso desarrolla en la Segunda Partida, las virtudes y deberes del buen soberano, entre las que destacan el comer y beber de forma mesurada, prescindir de la codicia, evitar el trato con mujeres "viles" que podrían corromper su linaje, evitar las palabras y denuestos contra sus mayores o contra Dios y los santos, preservar su salud y evitar la ira y la saña, procurar el estudio y el conocimiento de los hombres, ser generoso pero evitando el derroche, ser además hábil en la guerra y en la caza, y finalmente dedicar tiempo a oír o leer cantares de gesta, romances, libros y practicar el ajedrez u otros juegos de similar índole ${ }^{1224}$. En suma, el rey debía ser un hombre de actitud humilde, piadosa, generosa, además de un hábil guerrero y estudioso; es decir, un cúmulo de valores que lo convertían en un modelo a seguir, pero que al mismo tiempo le garantizaba total independencia en materia política.

En este mismo sentido, los juristas alfonsíes centralizaron el poder en la persona del rey como el líder natural para una comunidad ${ }^{1225}$. Este postulado nos recuerda el ya

\footnotetext{
${ }^{1222}$ Ibid.

${ }^{1223}$ Procter, Evelyn, Curia y Cortes... op. cit., pp. 217, 218.

${ }^{1224}$ LST, Partida II, Titulo V, Leyes I a XXI; y González Jiménez, Manuel, Alfonso X el Sabio. 12521284, Palencia, La Olmeda, 1993, pp. 200-202.

${ }^{1225}$ Procter, Evelyn, Curia y Cortes... op. cit., pp. 217, 218.
} 
mencionado relato bíblico de Saúl, en el cual el propio pueblo de Israel solicita un rey para que los conduzca y juzgue. De esta forma, los juristas alfonsíes vinculan la institución monárquica castellano leonesa con la tradición bíblica del Antiguo Testamento, y por lo tanto con la voluntad de Dios. Pero para que no quedasen dudas al respecto, el Espéculo expresa claramente la idea central de que todo el aparataje jurídico alfonsino estaba vinculado a la divinidad:

"Onrrado deue sseer el rey conmo aquél que tiene logar de Nuestro Ssennor Dios en tierra para ffazer iustiçia en ssu rregno quanto en el temporal e porque lieua nombre de Nuestro Ssennor en quantol dizen rrey e porque Ihesu Christo los onrró en que quisso nasçer de linage de los rreys. Otrossí deue sseer onrrado el rrey porque es ssennor ssobre ${ }^{13 v}$ ssobre [sic] todos los de ssu tierra e porque es puesto para ffazer bien a ssus gientes e para guardarlos de mal, ${ }^{1226}$.

La novedad del pensamiento político alfonsí radica en que el rey y sus juristas sostuvieron la total independencia del poder real, incluso respecto del pontificado, estableciendo que el rey sólo se encontraba sometido a Dios. Una ideología que encontraba sus raíces en la "teoría de las dos espadas", pero interpretada de tal forma que asegurase la autonomía del rey y su hegemonía sobre todos los aspectos de su reino $^{1227}$. Esto explicaría la utilización de un discurso propagandístico por parte de Alfonso $\mathrm{X}$, quien se presentó como vicario de Dios para legitimar su reinado y dar soporte a sus aspiraciones reales.

Más significativo es el hecho de que la cita anterior aparezca bajo el titulo "Por qué razón deue sseer el rey onrrado", dejando establecido que sólo el rey justo puede mandar y ser obedecido con propiedad ${ }^{1228}$.

Es así como los juristas alfonsíes se esforzaron por consolidar la idea de que el rey era el alma de su pueblo; es decir, que en él residían los principios fundamentales sobre los que se sostenía el reino y así los súbditos podrían identificarse como parte de un colectivo. En esencia, el rey se consideraba la cabeza del reino, aunque el monarca y el reino eran consideradas dos entidades separadas, puesto que el reino debía sobrevivir al rey, en su acepción individual ${ }^{1229}$. Aun así, es de notar que en el Espéculo también se presentan limitaciones al poder real, dándose a entender que el rey debía aplicar su

\footnotetext{
${ }^{1226}$ Espéculo, Libro II, Titulo I, Ley V, op. cit., p. 117

${ }^{1227}$ González Jiménez, Manuel, Alfonso X... op. cit., pp. 197, 198; Rucquoi, Adeline, "El Rey Sabio... op. cit., p. 82; y Villacañas Berlanga, José Luís, La Formación de los Reinos ... op.cit, p. 643.

${ }_{1228}$ Procter, Evelyn, Curia y Cortes... op. cit., p. 117.

${ }^{1229}$ González Jiménez, Manuel, Alfonso X el Sabio... op. cit., p. 199.
} 
poder con justicia para proteger a sus súbditos. Esta es una idea constante en la filosofía jurídica vinculada a Alfonso X; en ella el rey ejerce la justicia como representante de Dios, y por lo tanto debe respetar las virtudes cristianas y no abusar de su poder.

La Biblia y las crónicas dan abundantes testimonios de reyes y caudillos castigados por sus actos injustos; Saúl y David son algunos ejemplos, pero también lo fueron los últimos reyes visigodos como Witiza, y soberanos posteriores como Alfonso "el Batallador".

Con todo ello, según esta perspectiva, el rey que actúe con justicia, y por lo tanto como justo representante de Dios, se convierte en una figura inviolable. El Espéculo dedica varias leyes a detallar cómo el rey debe ser respetado y de qué males debe ser guardado, concretamente en el Libro II, títulos $1^{\circ}$ y $2^{\circ}$. Una protección que se hace extensiva a la reina, debido a que por su cercanía con el rey, podemos inferir, podía convertirse en un instrumento para dañarlo, razón por la cual el texto incluye los distintos males -los concernientes al alma y al cuerpo- que podrían afectar a la reina y cómo debía ser guardada de estos, teniendo como eje la idea de la honra y lealtad ${ }^{1230}$ :

"Onde dezimos que cualquier que tal trayçión ffeziesse con su rryna, mugier de ssu ssennor, o gela consseiase ffazer o gela encobriesse, es traydor conocido, quier ssea varón quier mugier, e deua tal pena en el cuerpo e en el auer commo quien mata ssu rrey"1231.

Finalmente el texto en su libro III establece las formas en que debía ser servido el rey y los castigos que recaerían sobre aquellos que atentaran en su contra o lo desobedecieran, puesto que era "ssu ssennor natural"1232, y por lo tanto existía un deber superior hacia su persona. Pese a lo cual era necesario exponer las penas que acarreaba la desobediencia, como una forma más eficiente de estimular el servicio regio y asegurar las lealtades. Esto se hacía recalcando la idea de que Dios, el rey y el reino se encontraban profundamente vinculados, y que todos debían ser protegidos de la misma manera.

\footnotetext{
${ }^{1230}$ Espéculo, Libro II, Titulo III, Ley I-III, op. cit., p. 127-129.

1231 Espéculo, Libro II, Titulo III, op. cit., p. 127.

1232 Nieto Soria, José Manuel, Fundamentos Ideológicos... op. cit., pp. 93, 94; y Procter, Evelyn, Curia y Cortes... op. cit., p, 197.
} 


\section{El Fuero Real y las Partidas}

A continuación del Espéculo, los talleres alfonsinos produjeron el Fuero Real (1255 aporx.), como un intento de unificar los distintos fueros que existían en el reino. Por ello, al ser un texto de carácter más práctico se prestó menos para las innovaciones político-jurídicas, por lo que no presenta grandes cambios en relación al Espéculo. Se centra especialmente en la obligación de obedecer al rey y recalca la figura del soberano como cabeza del pueblo por voluntad divina, estableciendo la idea de que un ataque al rey era equivalente a agredir el orden de Dios ${ }^{1233}$.

"Et puso al Rey en su logar, caabeca et comienço de todo el pueblo, assí como puso Sí mismo cabeça et comienço de los Angeles el de los Archangeles. Et diol poder de guiar su pueblo. Et mandó que todo el pueblo en uno, et cada uno omne por sí recibiesse et obdedeciese los mandamientos de su Rey, et que lo amassen, et quel temiesen, et quel guardasen, tan bien su fama et su ondra como su cuerpo mismo" ${ }^{, 234}$.

Por su parte, las Siete Partidas constituyeron la obra jurídica más importante de Alfonso X, que por estar destinada a ser un documento "imperial” incorporó algunos conceptos de las nuevas corrientes ideológicas europeas y realizó un estudio más profundo respecto de la figura del monarca. En ellas se hacen una interesante distinción ente las figuras del emperador y del rey, asignándole a cada uno sus propias características en relación a sus orígenes, y compartiendo la idea de que ambos reciben su poder por delegación divina, y que por lo tanto están obligados a ejercer justicia y defender a la Iglesia ${ }^{1235}$. Respecto al emperador, se deja en claro que su poder estaba por encima de todos, a excepción del Papa en temas espirituales. Respecto al rey, las Partidas repite las ideas del Espéculo, pero con la novedad de que incorpora las ideas de Aristóteles y la Política -posiblemente influenciado por las nuevas corrientes neoaristotélicas- para reafirmar la idea de que la administración de justicia era una de las principales funciones del monarca ${ }^{1236}$.

1233 Fuero Real. Alfonso X el Sabio, op.cit, Libro I, Titulo II, pp. 5, 6. Nieto Soria, Fundamentos Ideológicos... op. cit., p. 59. Morán Remedios y Eduardo Fuentes, "Ordenamiento, legitimación y potestad... op. cit., pp. 223 y 224. En este ultimo trabajo, los autores nos recuerdan el rol del derecho como elemento de legitimación y como Alfonso X, para contrarrestar la oposición de la nobleza y alto clero a sus proyectos, procuró buscar el respaldo de las distintas ciudades mediante el otorgamiento y ordenamiento de leyes y fueros.

${ }^{1234}$ FR, Libro I, Titulo II, op. cit., p. 6.

1235 LSP, Partida II, Titulo I, Ley I a IX, pp. 3-10.

${ }^{1236}$ Bizzarri, Hugo y Rucquoi, Adeline, "Los espejos de Príncipes... op. cit., p. 21; y Morán Remedios y Eduardo Fuentes, “Ordenamiento, legitimación y potestad... op. cit., pp. 208-211. 
En su afán por imponer estas reformas, Alfonso debía someter a los estamentos de la sociedad que poseían sus propios privilegios y derechos, es decir caballeros y nobles. A ellos les recalcó que el poder de rey venía dado por Dios y que por ello revelarse contra el monarca era un acto sacrílego. Pero era necesario crear bases sólidas para estos argumentos, y con ese fin se impuso la idea de que si Dios delegaba su poder en el rey, sólo éste podía otorgar potestades a otros hombres; en este caso a los caballeros. Así se forjaba la concepción de que la nobleza estaba en una suerte de deuda con el monarca y que sólo a él debían sus privilegios y prerrogativas; las mismas que podían ser revocadas bajo este mismo principio ${ }^{1237}$.

Así, las disposiciones alfonsíes contradecían una concepción práctica sumamente arraigada en la realidad europea: la lealtad del guerrero y su misión como algo esencialmente religioso y no político. Alfonso muta mucho de los elementos religiosos en elementos éticos, no obstante, éstos a su vez se inspiran en una cosmovisión cristiana y por lo tanto de raíces religiosas comunes. Por otra parte, debemos recordar que Alfonso fue uno de los más claros representantes de la consolidación del poder real en la Península, y que las Partidas se enmarcan en el fecho imperio, razones que

${ }^{1237}$ Dentro de esta nueva concepción, el estamento de los caballeros era el que más vinculado quedaba al monarca, puesto que su rol social estaba enfocado básicamente a la defensa del rey y del reino. Por lo tanto un atentado contra el monarca se consideraba una suerte de acto contranatural que los podía deslegitimar. Es por ello que, según Carlos Heusch, Alfonso X fue el primero en establecer de forma jurídica la investidura de los caballeros. En el escenario peninsular, estos ritos que eran de antigua data, recién fueron formalizados y reglamentados por Alfonso X. El rey procuró mantener algunas costumbres como la vigilia de las armas, y aunque se mantienen en el rito fórmulas religiosas como el juramento, se da a entender que el acto en sí es un asunto entre el caballero y su rey, quien es el que además lo ordena, por lo que es al monarca y por extensión al reino, a quienes el guerrero debe toda su lealtad. Algo que queda en evidencia cuando en la Partida describe quién puede nombrar caballeros y los juramentos que son parte de la ceremonia (Heusch, Carlos, La caballería castellana en la baja edad media. Textos y contextos, Montpellier, Université de Montpellier III, 2000, pp. 20, 21).

En la Partida Segunda, que pretende regular la relación entre el monarca y la nobleza, en el Título XXI se incluye una larga definición de la figura del caballero, sus orígenes, deberes y características (Villacañas Berlanga, José Luis, La Formación de los... op. cit., p. 672). En el texto, si bien la figura del monarca sólo aparece referenciada su intencionalidad era la de legitimar los poderes y atribuciones del soberano. Él se imponía como protector de su pueblo y de la Iglesia, existiendo una clara intención de asimilar la figura del rey con su territorio y habitantes, por lo tanto cuando en la "Ley IX" obliga a los caballeros a ser leales y en el preámbulo dice "Defensores son uno de los tres estados porque Dios quiso que se mantuviese el mundo [...] (LST, Partida II, Titulo XXI, p. 197), apelando así a la idea de un ordenamiento superior.

Respecto a la potestad de nombrar caballeros, el texto deja en claro que sólo otros caballeros podían hacerlo, a excepción del rey o su hijo, que poseían ese derecho por naturaleza, esto porque se consideraba asunto de interés del reino: "pero algunos hi hobo que tovieron que el rey ó su fijo el heredero maguer caballeros non fuesen, que bien lo podrían facer por razon del regno, porque ellos son cabeza de la caballeria" (LSP, II Partida, Titulo XXI, Ley XI, op. cit., p. 205). Esta última expresión deja en claro no sólo quién podía armar caballeros, sino a quien éstos debían toda su lealtad. Lo que reafirmaba en los mencionados juramentos: "[...] et facerle jurar estas tres cosas: la primera que non rezele morir por su ley si meester fuere: la segunda por su señor natural: la tercera por su tierra" (LSP, II Partida, Titulo XXI, Ley XIV, op. cit., p. 209. 
explican porqué el rey quería dirigir la lealtad de la elite militar exclusivamente hacia su persona.

Una medida que contravenía la ya larga tradición de la Curia y amenazaba directamente las prerrogativas de los magnates y de la nobleza, lo que resultó en una creciente oposición por parte de estos sectores. En esencia, Alfonso pretendía convertir la figura del rey en el eje sobre el cual girara la relación entre el pueblo y el territorio $^{1238}$. Para ello buscó el apoyo de los concejos urbanos, en el conocimiento de que las oligarquías locales serían una pieza importante del reino dado su poder económico y militar. En tanto en las ciudades, las elites locales sabían que necesitaban del rey y sus garantías, razón por la cual apoyaron sus proyectos reformadores. Alfonso intentó consolidar esta situación a través de las leyes, dedicándole al "pueblo" un apartado especial en Las Partidas, específicamente en la II, Títulos XII al XVI. Leyes donde no sólo norma las relaciones entre el pueblo y el monarca, sino que además define quiénes constituían este pueblo"1239: "Pueblo tanto quiere decir como ayuntamiento de gentes de todas maneras de aquella tierra do se allegan. E desto non sale ome ni mujer, ni clérigo ni lego". Se distingue así de la nobleza, fortaleciendo el carácter identitario de este grupo. Junto a ello, el soberano, además les aseguraba una serie de garantías tales como el respeto a sus vidas y propiedades. Todo ello pretendía trasmitir la nobleza y justicia del rey, y por lo tanto la conveniencia de respaldar al monarca ${ }^{1240}$. Es decir, que el rey era el ente que aglutinaba y mantenía unido al reino y no la nobleza, que debía someterse a él. Es importante recordar que estos preceptos tenían como trasfondo las intenciones imperiales de Alfonso, y por lo tanto pretendían proyectarse más allá de Castilla y de la nobleza local.

Es por ello, que creemos que Alfonso X buscó validar sus aspiraciones, creando a través de un sistema jurídico, una vinculación directa entre Dios y la figura del monarca o emperador. El rey sabía que sus aspiraciones imperiales no eran compartidas por parte importante de la nobleza y del clero local, y que sus intenciones de centralizar el sistema jurídico también afectaban los antiguos derechos forales, lo que le obligó a ir modificando sus ideas a través de los distintos códigos que elaboró en un vano intento de apaciguar a sus opositores. Si bien las ideas de Alfonso no eran nuevas, y se basaban en la tradición jurídica medieval, el "rey sabio" innovó al plasmar en leyes escritas esta

1238 Funes, Leonardo, El modelo historiográfico alfonsí: una caracterización, London, Department of Hispanic Studies, Queen Mary and Westfield Collage, 1997, pp. 10, 11.

${ }^{1239}$ González Jiménez, Manuel, Alfonso X el Sabio... op. cit., pp. 250, 251; y Maravall, José Antonio, Estudios de Historia del pensamiento... op. cit., pp. 134, 137

${ }^{1240}$ LST, Partida II, Titulo XXI, Titulo XXI, p. 197. 
tradición. Sin duda, Alfonso necesitaba controlar la totalidad de su reino e imponerse sobre todos los poderes señoriales si quería llevar a cabo sus planes imperiales.

Sin embargo, sus esfuerzos en el plano jurídico no fueron suficientes, y como ya hemos mencionado, acabó por entrar en confrontación directa contra buena parte de la nobleza; enfrentamiento en el que los concejos también tomaron parte decantándose por uno u otro bando. Es por esta razón que una de las primeras medidas tomadas por el triunfante Sancho IV fue la de atraer a los nobles y representantes de la Iglesia para asegurarles sus antiguas prerrogativas, al mismo tiempo que fortalecía sus lazos con los concejos, facilitando el nombramiento de caballeros villanos y convocando nuevamente a las Cortes ${ }^{1241}$.

Es en vista de lo anterior que podemos concluir que los juristas alfonsíes expresaron de forma legalista los elementos que legitimaban y convertían al monarca no sólo en un ideal regio, sino que en la máxima autoridad política, jurídica y religiosa del reino. Es en ese sentido que se exaltaba la idea de la justicia como virtud principal, siempre ligada al convencimiento de que el soberano era el representante de Dios. Por lo mismo él debía defender a la Iglesia, y guardarse de cometer arbitrariedades.

La elaboración de la figura del monarca en Castilla y León es el resultado de un largo proceso, pero también de la construcción consciente de un discurso político sustentado en la tradición gótica, el linaje, la guerra y la religión. El monarca de la Reconquista no era ya un visigodo, pero utilizó la construcción ideológica-religiosa de ese pueblo para sustentar su poder. Se hizo propio el discurso de los visigodos como un pueblo bendecido por Dios, razón de sus victorias, pero que su orgullo lo llevó al pecado y al castigo divino. Sus sucesores, los monarcas nacidos en el Reino de Asturias, cumplían así la bíblica misión de alcanzar el perdón de Dios mediante actos nobles, en especial la lucha contra los enemigos de la Iglesia. La Reconquista se convirtió así en un una misión divina, liderada por los monarcas como legados de la Providencia en la tierra. Si bien esto representa una construcción discursiva, es innegable que apeló a un conocimiento común arraigado en las elites políticas y religiosas del reino, que permitió a los reyes - con la ayuda de juristas y cronistas- construir un nuevo modelo de poder que legitimara su poder, alinear a la aristocracia y al mismo tiempo asegurar la recuperación de las tierras del centro y sur peninsular.

Fue así como los monarcas castellanos y leoneses, gracias a la elaboración de importantes textos jurídicos y cronísticos, se convirtieron en figuras emblemáticas que

${ }^{1241}$ Nieto Soria, José Manuel, Sancho IV 1284-1295, Palencia, La Olmeda, 1994, pp. 60, 61, 201-208. 
simbolizaron las virtudes del pueblo cristiano, y sobre este planteamiento se estructuró el discurso político y religioso que legitimó la expansión territorial hacia el sur. Por lo mismo, el soberano debía ser un ejemplo reconocible por todos los componentes de la sociedad, que garantizase el orden y justicia en sus reinos para asegurase el favor divino.

En esencia, los monarcas supieron utilizar la tradición cristiana y visigoda para tomar control sobre las dos grandes vertientes del poder político medieval; el control de las almas a través de la idea de delegación divina, y el sometimiento de los hombres al monarca mediante la síntesis de virtudes y atributos que lo convirtieron en un modelo destacado por sobre sus congéneres.

Tabla 26: Virtudes Alfonso X

\begin{tabular}{|l|l|l|l|l|l|l|l|}
\hline & $\begin{array}{l}\text { Linaje } \\
\text { Visigodo }\end{array}$ & Protegido por Dios & Guerrero & Piadoso & Justiciero & Pacificador & Fuente \\
\hline 1200 & & & & & & & \\
\hline 1210 & & & & & & & \\
\hline 1220 & & & & & & & \\
\hline 1230 & & & & & & & \\
\hline 1240 & & & & & & & \\
\hline 1260 & & & & & & & \\
\hline 1270 & & & $X$ & & & & CGE Cap. \\
\hline 1280 & & & & & & & \\
\hline 1290 & & & & & & & \\
\hline 1300 & & & & & & & \\
\hline
\end{tabular}

Tabla 27: Deberes del Pueblo en Relación a su rey

\begin{tabular}{|c|c|c|c|c|}
\hline & Guardar & $\begin{array}{l}\text { Obediente / } \\
\text { Leal }\end{array}$ & Honrado & Fuente \\
\hline $\begin{array}{l}\text { Espéculo } \\
1255\end{array}$ & $\mathrm{X}$ & $\mathrm{X}$ & $X$ & $\begin{array}{l}\text { Libro II, Titulo } 1 \text { Ley } 1^{\circ}-11^{\circ} \text {. Titulo } 2 \text { Ley } 1^{\circ}- \\
4^{\circ}\end{array}$ \\
\hline $\begin{array}{l}\text { Fuero Real } \\
1256\end{array}$ & $\mathrm{X}$ & & $\mathrm{X}$ & Libro I, Titulo $2^{\circ}$ \\
\hline $\begin{array}{l}\text { Partidas } \\
1260\end{array}$ & $X$ & $X$ & $X$ & Partida II, Titulo 13 , Ley $1^{\circ}-26^{\circ}$ \\
\hline
\end{tabular}


Tabla 28: Virtudes Militares del rey

\begin{tabular}{|l|c|l|l|l|}
\hline & $\begin{array}{l}\text { Guerrero } \\
\text { Protector }\end{array}$ & Valiente & Victorioso & Fuente \\
\hline $\begin{array}{l}\text { Espéculo } \\
1255\end{array}$ & $\mathrm{X}$ & & & Libro II, Titulos 1 - 16 \\
\hline $\begin{array}{l}\text { Fuero Real } \\
1256\end{array}$ & & $\mathrm{X}$ & & Libro I, Titulo 2 \\
\hline $\begin{array}{l}\text { Partidas } \\
1260\end{array}$ & $\mathrm{X}$ & & & Partida II, Titulo 5, Ley 19 \\
\hline
\end{tabular}

Tabla 29: Virtudes Judiciales del rey

\begin{tabular}{|l|c|l|l|l|l|}
\hline & $\begin{array}{l}\text { Justo } \\
\text { Justiciero }\end{array}$ & Pacificador & $\begin{array}{l}\text { Hacedor de } \\
\text { leyes }\end{array}$ & $\begin{array}{l}\text { Piadoso / Clemente / } \\
\text { Misericordioso }\end{array}$ & Fuente \\
\hline $\begin{array}{l}\text { Espéculo } \\
1255\end{array}$ & $\mathrm{X}$ & $\mathrm{X}$ & & $\begin{array}{l}\text { Libro I, Titulo 1, Ley 3, } \\
\text { Libro II Titulo 1, Ley 1 }\end{array}$ \\
\hline $\begin{array}{l}\text { Fuero Real } \\
1256\end{array}$ & $\mathrm{X}$ & & & & \\
\hline $\begin{array}{l}\text { Partidas } \\
1260\end{array}$ & $\mathrm{X}$ & & $\mathrm{X}$ & $\mathrm{X}$ & $\begin{array}{l}\text { Libro I, Titulo 2 }{ }^{\circ} 4^{\circ}, 6^{\circ} \\
\text { Titulo 3, Titulo 4, Titulo } \\
\text { 5, Titulo 12 }\end{array}$ \\
\hline
\end{tabular}

Tabla 30: Virtudes Religiosas del rey

\begin{tabular}{|l|c|c|l|l|l|l|}
\hline & Piadoso & $\begin{array}{l}\text { Protegido de } \\
\text { Dios / Elegido } \\
\text { por Dios }\end{array}$ & $\begin{array}{l}\text { Instrumento / } \\
\text { poseído por } \\
\text { Dios }\end{array}$ & Restaurador & $\begin{array}{l}\text { Al servicio de } \\
\text { Dios }\end{array}$ & Fuente \\
\hline $\begin{array}{l}\text { Espéculo } \\
1255\end{array}$ & $\mathrm{X}$ & $\mathrm{X}$ & & & & $\begin{array}{l}\text { Libro II, Titulo } \\
\text { 1, Ley 1 }\end{array}$ \\
\hline $\begin{array}{l}\text { Fuero Real } \\
1256\end{array}$ & $\mathrm{X}$ & $\mathrm{X}$ & & & & Libro I, Titulo 2 \\
\hline $\begin{array}{l}\text { Partidas } \\
1260\end{array}$ & $\mathrm{X}$ & $\mathrm{X}$ & & & $\mathrm{X}$ & $\begin{array}{l}\text { Partida II, Titulo } \\
\text { 2. }\end{array}$ \\
\hline
\end{tabular}

Tabla 31: Virtudes Morales del rey

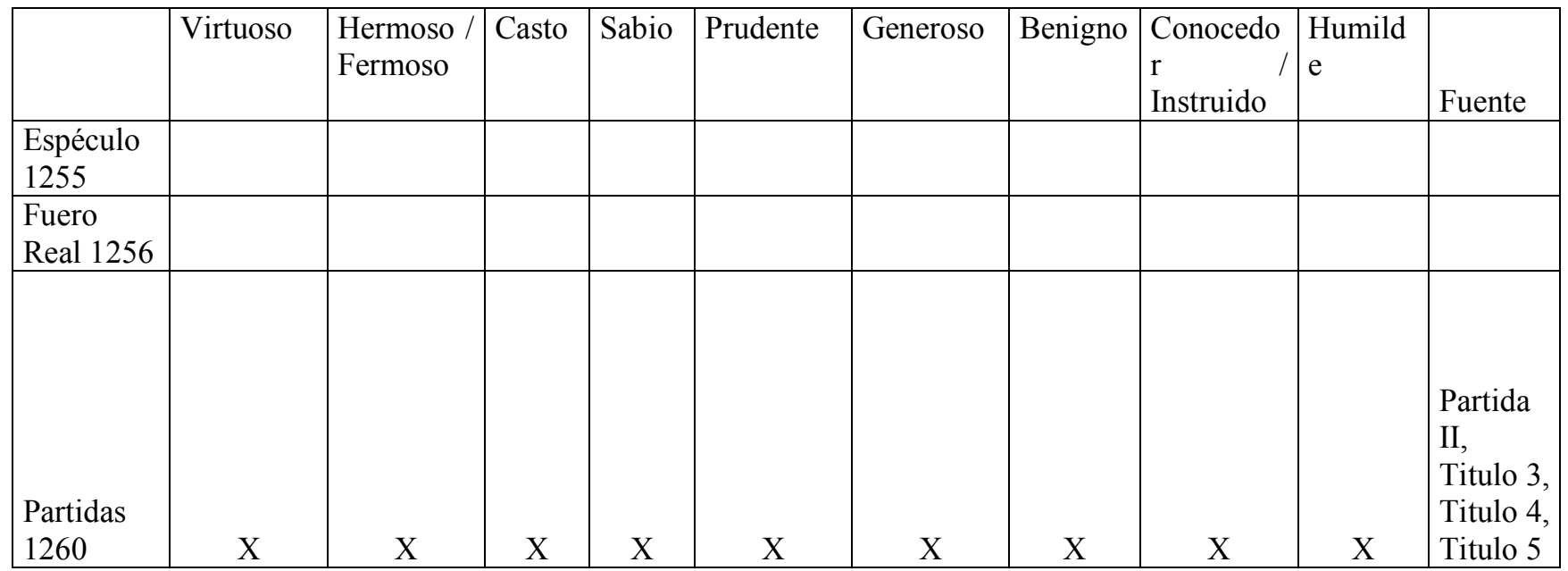




\section{CONCLUSIONES}

\section{La palabra}

Qué buen idioma el mío, qué buena lengua heredamos de los conquistadores torvos... Estos andaban a zancadas por las tremendas cordilleras, por las Américas encrespadas, buscando patatas, butifarras, frijolitos, tabaco negro, oro, maiz, huevos fritos, con aquel apetito voraz que nunca más se ha visto en el mundo... Todo se lo tragaban, con religiones, pirámides, tribus, idolatrías iguales a las que ellos traían en sus grandes bolsas... Por donde pasaban quedaba arrasada la tierra... Pero a los bárbaros se les caían de la tierra de las barbas, de las herraduras, como piedrecitas, las palabras luminosas que se quedaron aquí resplandecientes... el idioma. Salimos perdiendo... Salimos ganando... Se llevaron el oro y nos dejaron el oro... Se lo llevaron todo y nos dejaron todo... Nos dejaron las palabras. $^{1242}$

Las palabras que refiere el poeta son las que componen el lenguaje y reflejo la importante herencia cultural que trasmitieron. Ellos a su vez eran los herederos de un discurso que colocaba a sus tierras de origen y a su estirpe como señalados por la providencia y cuya sociedad e instituciones se estructuraron a partir de su lucha contra el Islam occidental. Nosotros hemos pretendido ilustrar como se fue consolidando esta visión de la realidad hispano cristiana en el marco de la Reconquista, a través de la descomposición de los tópicos y continuidades presentes en el discurso cronístico.

Un ejercicio que debe enmarcarse dentro del contexto de los siglos XII y XIII en el escenario castellano-leonés. Es en función de lo anterior que la presente tesis está articulada en tres niveles complementarios de análisis, los que además corresponden a los tres partes que la componen:

1.- La presentación del contexto general de la Reconquista en Castilla y León, y la construcción de los conceptos de Guerra Santa y Cruzada, así como su posterior aplicación en el escenario peninsular.

${ }^{1242}$ Neruda, Pablo, "La palabra", en Confieso que he vivido. http://www.lainsignia.org/2003/agosto/ cul_019.htm (agosto de 2014) 
2.- La construcción de la cronística hispana medieval en Castilla y León en los siglos XII y XIII. La identificación y caracterización de los elementos centrales del discurso cronístico en torno a la figura del monarca.

3.- Los tópicos constitutivos del discurso cronístico y su uso en cuanto elemento de reafirmación y expansión de la monarquía castellana.

Por lo tanto las conclusiones que se presentan responden a los objetivos de estudio de cada una de estas partes, en cuanto al estudio del discurso cronístico y sus usos en función de los intereses de la monarquía castellana.

Se han presentado y explicado las características generales que enmarcan el proceso de la Reconquista durante los siglos XII y XIII, así como los antecedentes del mismo, centrándonos especialmente en la construcción de una concepción de sociedad cristiana en oposición al-Andalus.

Lo anterior se ha manifestado en un esfuerzo por sintetizar el desarrollo político que sigue a estos acontecimientos a partir de la identificación de determinados procesos y eventos que son los que señalan los hitos principales de la Reconquista para Castilla y, secundariamente, para León, observando cómo estos han ido de la mano con el desarrollo de un discurso presente en una serie de testimonios cronísticos, hagiográficos y jurídicos.

Así hemos observado cómo durante los siglos XII y XIII, se produce un significativo avance territorial de la Reconquista, en conjunto con la conformación de los reinos de Castilla y León como entidades individuales con sus propias características e intereses. En ambos casos, la expansión territorial y la ocupación del espacio los obligó a adaptar y formular las instituciones del reino y de la frontera, conjuntamente a la visión que se tenía del Islam en razón de la coexistencia propia de la frontera.

Se ha mostrado cómo las crónicas y cronistas, sometidos a los avatares de la Reconquista, fueron parte esencial en la construcción de un discurso identitario puesto al servicio de las causas políticas, religiosas y militares de los monarcas de Castilla y León, en el proceso de la construcción de los reinos peninsulares. Junto con ellos los 
hagiógrafos contribuyeron a la creación de un discurso identitario, útil a la validación de los monarcas y sus intenciones en cuanto a sus reinos y la expansión territorial. Esto se logró a través del uso de una serie de tópicos, que si bien pudieron desarrollarse en los siglos XII y XIII, son el producto de una larga tradición cronística que supo adaptarlos y utilizarlos según variaron las condiciones de la Reconquista.

Es así como la Hispania medieval es el fruto de una construcción que incluyó a todos los reinos cristianos que la conformaron y que se basó en la idea de una época pretérita gloriosa y una grandeza que se iniciaba en la tradición latina y que fue reforzada por el ideal godo y una concepción providencialista de su fortuna. Este modelo ideológico entró en crisis a partir de la irrupción musulmana en el siglo VIII, pero rápidamente fue rescatado y reinterpretado por la tradición que se mantiene en los reinos cristianos que surgieron en el norte. Se trataba ahora de recuperar las tierras que por tradición y "designio divino" les pertenecían a los visigodos y a sus herederos. Fue así como las crónicas astures dieron paso a los cronistas de Castilla y León, donde observamos el rescate del linaje tradicional, pero reconstruido inicialmente a partir de la imagen del visigodo ideal, Pelayo, un campeón de la fe y de su pueblo, que con la ayuda de Dios y bajo el liderazgo de sus reyes podría enmendar su camino, recuperar sus tierras y restaurar la Iglesia profanada por el Islam. En esencia un discurso religioso que fue usado como un instrumento al servicio de los intereses de las elites cristianas.

De este modo las crónicas, oficiales u oficiosas, los hagiógrafos y juristas fueron construyendo un discurso destinado a convertir a la Reconquista en un ideal que servía a los intereses de validación de la expansión territorial de los reinos cristianos, que bajo el liderazgo de sus reyes y el amparo de la Providencia buscaba la recuperación del solar visigodo, lo que a la postre terminó por convertirse en el sello identitario peninsular.

Pero este discurso debió convivir con la realidad propia de una dinámica fronteriza, donde la coexistencia con el Islam implicaba permanentes intercambios y transacciones y donde muchas veces el discurso debía someterse a realidades prácticas. Es así como la documentación foral y jurídica revelan una sociedad diversa, compuesta por distintas culturas obligadas a compartir el mismos espacio y donde el comercio y el mestizaje eran realidades y en muchos casos necesidades.

Fue por ello que los cronistas y otros autores, permanentemente debieron sostener y reforzar el discurso de la Reconquista, en especial en los momentos de crisis -como los retrocesos en la Reconquista-, cuando parecía que Dios había abandonado a los cristianos. Era pues necesario recordar a los guerreros que el Islam era su enemigo y que 
la restauración de la Iglesia hispana era una misión sagrada. Misma que recayó en la figura del soberano, sobre la cual se amalgamaron los ideales y virtudes de la sociedad cristiana peninsular.

Si bien la figura del soberano en Castilla y León originalmente se basaba en su origen gótico, en especial en la figura de Pelayo, progresivamente adoptó otros modelos, en especial la memoria de Alfonso VI. Así, los tópicos que simbolizaban la esencia de la figura monárquica se mantuvieron, demostrando la capacidad de adaptación del discurso cronístico. El rey debía ser un guerrero señalado por la Providencia, que regía sus actos en justicia, respetando su tradición y herencia cristiana.

La capacidad de adaptación del discurso lo hizo permeable a ideas importadas, como fue la cruzada y tópicos afines, tales como la peregrinación, indulgencias y martirio, aunque siempre como un componente secundario del discurso. Junto con ello, entre los siglos estudiados, también se observa un frecuente uso de los santos como parte del discurso, pero con la característica de que se trató de figuras que podían ser vinculadas al pasado mítico o real de Hispania, y que se encontraban al servicio de los ideales de la Reconquista, misma razón por la cual sus apariciones fueron perdiendo protagonismo en la medida de que se consolidaba la figura del monarca. En la misma línea se encuentran los rituales asociados a la guerra, los que comienzan a hacerse más presentes en las fuentes a partir del siglo XIII, especialmente relacionados a las grandes conquistas y victorias vinculadas con Alfonso VIII y Fernando III. Lo anterior viene a ilustrar el proceso de cambios que rodeó a la Reconquista en los siglos XII y XIII, cuando el discurso reconquistador ya se encontraba integrado a la cosmovisión de las elites peninsulares y en cambio se hacia necesario resaltar la figura del monarca como el "factor humano" central del proceso. Era necesario incorporar nuevas formas de simbolizar el poder del monarca, a través de sus victorias y la exaltación de las mismas, pero sin perder de vista el elemento providencialista, que finalmente validaba todas las acciones de los monarcas.

Todo lo anterior evidencia cómo durante los siglos XII y XIII, sin olvidar la tradición gótica y sobre el ideal de la Reconquista, se puede atestiguar una intencionalidad por construir un modelo monárquico basado en personajes contemporáneos, cuya existencia y méritos no estaban en discusión gracias a la forma en que los cronistas trataron su memoria y a las crónicas que estos mismos monarcas promovieron. 
Finalmente, al respecto de este discurso y su evolución varias fueron las preguntas, que surgidas durante el trascurso de nuestra investigación, nos sirvieron de guía y que ahora creemos poder responder.

1.- ¿Es posible afirmar la existencia de un discurso consciente y atestiguable en las fuentes estudiadas?

Al respecto nosotros consideramos que efectivamente existió un discurso de validación, compuesto de una serie de tópicos claramente identificables y que este se vio reflejado principalmente en las crónicas de los siglos XII y XIII. Si bien es cierto que el origen del discurso es anterior a estos siglos, fue durante este periodo, dada la gran actividad reconquistadora y la consolidación de las instituciones monárquicas y religiosas, que su presencia se hace más evidente en las fuentes.

Elemento esencial de este discurso fue la construcción de un ideal de monarca, caracterizado por una serie de tópicos virtuosos. Entre los que, según observamos en los gráficos presentados, se observa una preocupación por destacar las virtudes religiosas, en especial la piedad, la función restauradora de la Iglesia y la trasmisión de la convicción de que el monarca y sus actos se encontraban protegidos por Dios. Ello complementado por las virtudes bélicas, que son una referencia constante y que ayudan a equilibrar la imagen del monarca como hombre religioso y defensor de su fe. Lo que a su vez explica la preocupación de los cronistas por referir la función jurídica del rey y destacar la justicia de sus actos, una virtud propia de los grandes monarcas de la antigüedad bíblica.

En cuanto a las virtudes morales, la preocupación por constatarlas en las fuentes se hace más evidente entre las décadas de 1220 y 1240, como parte de la intención de trasmitir una imagen más acabada del monarca como un hombre virtuoso y digno.

Lo anterior, sin perder de vista que entre los siglos XII y XIII existe un importante vació en la producción de todo tipos de fuentes, entre las décadas de 1180 y 1220 , coincidente con el momento ralentización de la Reconquista producto de la unificación del al-Andalus bajo los almorávides y los conflictos entre los distintos reinos hispanos. Es precisamente, luego de superada esta situación a comienzos del siglo XIII, que las fuentes retoman su labor, señalando una imagen mucho más completa y consolidada del monarca y el ideal de la Reconquista. 
2.- Aclarado lo anterior queda el asunto de la conciencia de este discurso, es decir si su existencia y utilización fue un acto consciente por parte de los cronistas o se trató más de una práctica ya arraigada y por lo tanto incorporada a la escritura cronística.

Este es un tema cuya respuesta implica una mayor dificultad, puesto que el concepto de conciencia siempre pude implicar cierta ambigüedad, en especial cuando nos referimos a una práctica social. No obstante nosotros creemos que para los cronistas, hagiógrafos, juristas, en suma la elite intelectual de Castilla, sí existía una conciencia de este discurso, pero comprendido como un conjunto de ideas matrices, originadas en la tradición, que eran parte de la cosmovisión y comprensión que de sí mismos y su realidad tenían los autores. Los cronistas y la sociedad que representaban habían sido formados en esta tradición y por ende eran herederos de este discurso, sus tópicos y sus fórmulas, $\mathrm{y}$ procuraron perpetuarlo como una forma de identificación social. No obstante tuvieron la virtud de ir adaptándolo y reconstruyéndolo según el contexto del momento, es así como podemos observar que si bien las ideas providencialistas, o del linaje se mantienen, se puede testimoniar, por ejemplo, cómo la figura de los santos se va modificando en su forma de actuar cediendo más protagonismo a los monarcas, o bien, cómo el linaje de Pelayo se va diluyendo para dar lugar a modelos más contemporáneos como Alfonso VI. En el mismo sentido se puede constatar cómo para el siglo XIII, las animosidades entre León y Castilla dan paso a la exaltación de los linajes de Alfonso VIII y Alfonso IX con el fin de exaltar la figura de su descendiente común, Fernando III como monarca de ambos reinos.

Una pieza clave en la trasmisión consciente de este discurso fue el que le cupo a la Iglesia Hispana y concretamente a algunos prelados de alto rango estrechamente vinculados a la monarquía, en especial durante el siglo XIII. Tal es el caso de los obispos Lucas de Tuy, Jiménez de Rada y Juan de Osma, todos ellos autores de crónicas que directamente procuraban validar la monarquía y sus acciones a través de la exaltación de los mismos. A estos esfuerzos les antecedieron otros autores que sin ser directamente miembros de la corte o pertenecer al alto clero, compusieron textos que directa o indirectamente favorecieron el discurso de validación, tal fue el caso de Diego Gelmírez, la Crónica de Sahagún o la Adefonsi Imperatoris.

Todos ellos contribuyeron a la difusión de los tópicos de validación de la monarquía y la Reconquista en general, al reiterar en sus obras las mismas ideas y principios, ajustándolos y adaptándolos a las circunstancias del momento, pero sin alterar su significancia cultural. 
En virtud de aquello se puede afirmar que la sistematización de datos, constatable en los gráficos, ilustra el hecho de que a partir de la década de 1230 se puede observar cómo los cronistas resaltan la figura de reyes más recientes, por sobre la ascendiente directamente visigoda. La cual no parece ser un hito sobresaliente en las fuentes, no obstante es importante recordar que la mayoría de las primeras crónicas hacen referencia a la pérdida del Reino Visigodo y la necesidad de lograr su restauración, junto con realizar un relato prácticamente lineal que a través de Pelayo señalaba la continuidad visigoda. Un pensamiento que se expresaba en el tópico de la restauración como uno de los más constantes en los relatos de las virtudes reales.

A lo anterior se debe agregar que en las fuentes de los siglos XII y XIII, si bien no suele haber asociaciones dinásticas explícitas entre los visigodos y los reyes contemporáneos, el lamento por el reino perdido y su restauración es una constante manifestada a través del relato de Covadonga y la memoria de los reyes asturianos, en especial aquellos que se enfrentaron y lograron vencer al adversario musulmán.

Es en ese mismo sentido que las crónicas revelan que los cronistas, al parecer, nunca perdieron de vista los objetivos políticos de las elites que representaban, es decir la expansión territorial y la consolidación monárquica con respecto a sus vecinos andalusíes y cristianos.

3.- Puesto que para los siglos XII y XIII el discurso parece ser parte integral de la cultura de los cronistas, es pertinente cuestionar la originalidad e intencionalidad del mismo. En otras palabras $i$ se trataba de un acto original tanto en su significado como en sus tópicos, o más bien consistía en la reiteración y edición de ideas más antiguas?

Nosotros creemos que lo apropiado es considerar que el discurso, para los siglos XII y XIII, era parte integral de la formación cultural de los cronistas, estando integrado a su forma de comprender su realidad. Por lo tanto la cuestión no es si este respondía a una suerte de plan maestro, sino que si existía una intención en la forma en que el discurso se adaptaba o reinterpretaba según se modificaban las circunstancias y necesidades de la Reconquista. A ese respecto creemos que sí existió una intencionalidad e incluso una instrumentalización, en el sentido de utilizar el discurso, así como la reiteración de tópicos culturales en los mismos, como una manera de perpetuar la trasmisión de una forma de comprensión de la realidad enfocada al servicio 
de los intereses de las elites, respecto a aspectos políticos, religiosos, militares y de expansión territorial, que constituían un todo sobre el cual se articulaba la construcción del reino castellano.

En vista de ello, consideramos que es posible cuestionar la originalidad de este discurso, ello en razón de que el origen del mismo es anterior a los siglos XII y XIII y que algunos de sus tópicos, como el goticismo, son incluso previos a la irrupción musulmana, o bien no son originarios de la Península, pero fueron incorporados al lenguaje cronístico peninsular. Inclusive algunos de sus aspectos tienen un origen más antiguo, como es el caso de la guerra religiosa o la figura del monarca. No obstante, nosotros creemos que sí existe un cierto grado de originalidad en el uso que se hizo de estos tópicos y cómo se fueron incorporando nuevas acepciones de los mismos para adaptarlos a las circunstancias de la Reconquista, tanto para los siglos por nosotros estudiados como para la totalidad del proceso reconquistador. Fue así como el discurso cronístico se construyó sobre un conjunto de conceptos y tópicos de diversa data, los cuales fueron identificados por los cronistas y utilizados concientemente por ellos, fueron evolucionando en su uso y acepción, configurando así un discurso original en cuanto al uso e implicancia de los tópicos, más que con respecto a su introducción y significado.

4.- Puesto que el discurso fue generado por miembros de las elites intelectuales y políticas, y se trata, además de textos escritos, solo accesibles para una minoría ¿Quiénes eran el "público objetivo" al que iba dirigido y por ende, cuál era su verdadero impacto en la sociedad castellana?

Respecto a esta interrogante, consideramos que el discurso cronístico debe ser asumido como un producto generado por la elite, para la elite. Ello por tratarse las crónicas de relatos escritos que su público objetivo era un reducido grupo al interior de las capas más altas de la sociedad. No obstante, también debemos considerar que se trataba de narraciones en muchos casos que recogían una tradición más antigua, parte integrante de la cultura, y que por lo tanto podían ser reproducidas verbalmente para grupos mayores no alfabetizados. Esto es especialmente aplicable para el caso de las hagiografías, entendidas como representantes de una cultura más "popular", dada su temática providencialista y piadosa, protagonizada por santos, reyes populares $\mathrm{o}$ personajes provenientes de sectores campesinos o villanos. 
Respecto al uso de los santos en los relatos de los siglos XII y XIII, los gráficos nos demuestran que, si bien se advierte una presencia constante de ellos, son Santiago e Isidoro de Sevilla los que tienen una mayor notoriedad. Y que en su conjunto, entre las décadas de 1220 y 1280, se puede constatar un aumento en la cantidad de referencias respecto a la aparición o participación de los santos, en especial en los roles de guerreros, protectores y legitimadores, coincidiendo con la etapa de reactivación y aceleración de la Reconquista bajo el mandado de los reyes de Castilla y León.

En las fuentes se puede observar que las ideas del providencialismo, aplicable para el conjunto del pueblo hispano, giran en torno al binomio de las ideas de castigo y protección divina, comenzando desde los relatos de la pérdida del Reino Visigodo hasta las victorias cristianas del siglo XIII. Concentrándose ambos tópicos en las fuentes entre los años 1220 y 1280. Algo similar ocurre en cuanto a la figura del monarca. En cambio, entre los años 1100 a 1180, existe una mayor concentración de estos tópicos referidos a personajes particulares, tendiendo a hacerse menos frecuente y espaciados a partir del primer tercio del siglo XIII, cuando las ideas providencialistas se concentran en torno a los monarcas.

En forma complementaria, las recompensas espirituales, las indulgencias, en sus distintas formas, se concentran en dos periodos distintos, primeramente de forma intensa entre los años 1120 y 1140, coincidiendo con la amenaza almorávide y la necesidad de incentivar la lucha por la defensa del solar hispano, y posteriormente, entre 1200 y 1280, en esta ocasión con menciones más distanciadas y esporádicas y en muchos casos vinculadas a las Navas de Tolosa.

Por lo anterior creemos que se trata de un discurso creado por las elites para el servicio de sus intereses reconquistadores y de consolidación monárquica, pero que debía ser extensivo para el conjunto de la población. Por ello no solo debía apelar a altos intereses, sino que también incluir motivaciones culturales universales como la idea de salvación espiritual, el pecado o la identidad, así como también a motivos más temporales como la fama y el botín y la riqueza, este ultimo, por cierto, se trataba de un tema transversal a todos los grupos de la sociedad lo que queda evidenciado por las referencias y normativas que se observan al respecto en las crónicas, hagiografías y textos jurídicos. 
6.- Por ultimo cabe preguntarnos si este discurso, con todas sus características, fue realmente efectivo en cuanto a la satisfacción de los intereses monárquicos y reconquistadores.

A nuestro parecer este último aspecto resulta efectivo, y no solo en sus orígenes, sino que proyectado en el tiempo, puesto que ayudó a configurar una identidad castellana y luego hispana, a partir de los tópicos constituyentes del discurso de la Reconquista, lo que podríamos denominar una suerte de autoconvencimiento de una identidad castellano-leonesa.

No obstante, durante el periodo de nuestro estudio también se hace evidente la necesidad permanente de reafirmar este discurso a través de las crónicas y las hagiografías. Era imperioso que los tópicos se impregnaran en la conciencia del auditorio de estas obras y los motivase permanentemente en razón de, como nos muestran los textos jurídicos, en la práctica existía una coexistencia con el Islam que hacía difícil de aplicar las ideas de aniquilación o segregación total, evidenciándose así que el discurso permanentemente debía imponerse a la realidad práctica, y para ello se construyó un relato ideal e idealizante.

Por todo lo anterior, podemos concluir que, en esencia la realidad de la Reconquista propició que en los reinos de Castilla y León se crease un discurso de validación real propio, que si bien fue receptor de las influencias ideológicas y mentales europeas, se desarrolló con sus propias particularidades, según evolucionaron las circunstancias y necesidades en los reinos hispanos. Como parece evidenciar la recopilación y análisis de los datos en torno a la figura del monarca y la memoria de este en las diversas fuentes estudiadas. Es así como, sin olvidar el mito de Pelayo, para los siglos XII y XIII la imagen del monarca se construye sobre modelos idealizados, partiendo de la persona de Alfonso VI, que es uno de los más completos respecto a sus virtudes, especialmente en las fuentes comprendidas entre 1100 y 1130 , no obstante, con el avanzar del tiempo pareciera existir un mayor interés en rescatar su imagen en torno a los tópicos de pacificador, justiciero y protegido por Dios, los mismos que serán resaltados en los restantes monarcas modélicos.

Con respecto a Alfonso VIII, en razón de los sucesos acontecidos durante y después de su reinado, que las referencias respeto a él se concentran, entre 1220 y 1280 , especialmente en destacar su rol de guerrero, pero también se trasmite la imagen global 
de una figura monárquica bastante equilibrada en sus virtudes, siendo presentado como un buen monarca de los reinos unidos de Castilla y León.

Alfonso VIII y Fernando III, son presentados de forma bastante similar, destacando su sentido de justicia, así como su piedad religiosa, pero especialmente en su calidad de guerreros de la fe. Lo que no es de extrañar dada la vinculación del primero con la trascendental batalla de las Navas de Tolosa y las enormes conquistas del segundo, asociadas a la ocupación de ciudades tan importantes en el imaginario simbólico como Córdoba y Sevilla.

Todas estas características fueron concentradas por Alfonso X tanto en su labor cronística como jurídica, donde si bien no hace mayores referencia sobre sí mismo, salvo en su faceta de guerrero, se presenta un relato lineal desde los monarcas visigodos hasta Fernando III, resaltando una larga estirpe de reyes caracterizados por los tópicos virtuosos de ser guerreros defensores de su fe, justicieros y protegidos por la Providencia.

Las ideas y tópicos que constituyeron el discurso cronístico, pero también hagiográfico y jurídico, de la Reconquista, sirvieron para perfilar la noción de que en la Península existía una unidad cultural propia e individual, basada en su tradición visigoda, cristiana y guerrera, de la cual emanan los fundamentos de lo que después seria la conciencia de una idea de nación, la misma que se comenzaría a consolidar a partir de los Reyes Católicos y la expansión de ultramar. 


\section{BIBLIOGRAFÍA}

\section{I.- Fuentes Primarias}

1. “Annales Toledanos”, en Las crónicas latinas de la Reconquista, Volumen I, estudios prácticos de latín medieval por A. Huici, España, Establecimiento Tip, Hijos de F. Vives Mora, 1913,

2. “Crónica del Obispo de Oviedo don Pelayo", en Casariego, J.A., Crónicas de los Reinos de Asturias y León, León, Everest, 1985.

3. Alfonso X el Sabio, Cantigas de Santa María, Cantiga 83, editadas por Walter Mettmann, Madrid, Ediciones Xerais de Galicia, 1981.

4. ---------, Cantigas de Santa María. Códice Rico de El Escorial, Ms. escurialense T.I.1. Introducción, versión castellana y comentarios de José Filgueira Valverde, Madrid, Castalia, 1985.

5. - --------, Fuero Real, Edición, estudio y glosario de Azucena Palacios Alcaine, Barcelona, PPU, 1991.

6. ----------, Setenario, Ley V, Edición e Introducción de Kenneth H. Vanderford, Buenos Aires, Universidad de Buenos Aires, 1945.

7. Alighieri, Dante, La divina comedia, Madrid, Millenium, 1999.

8. Aquino, Tomás de, Suma Teológica, Parte II-II (a), Madrid, Biblioteca de Autores Cristianos, 1990.

9. ----------, Suma Teológica, Traducción y Anotaciones de Francisco Barbado Viejo O.P., Madrid, Biblioteca de Autores Cristianos, 1959.

10. Aristóteles, Política, Madrid, Alianza, 1998.

11. Biblia de Jerusalén, Bilbao, Desclée de Brouwer, 1975.

12. Cantar de Mío Cid, edición, prologo y notas de Alberto Montaner, Estudio preliminar de Francisco Rico, Barcelona, Centro para la Edición de los Clásicos Españoles, 2007. 
13. Cantigas de Santa María de Alfonso X el Sabio, Rey de Castilla, Estudio Preliminar por Matilde López Serrano, Madrid, Editorial Patrimonio Nacional, 1974.

14. Chonica latina regum castellae, Corpus Christianorum, Continuatio Mediaevalis, LXXIII, Chronica Hispana Saecvli XIII, Turnholti, Typographi Brepols Editores Pontificii, MCMXCVII.

15. Chronica Adefonsi Imperatoris, Edición y estudio por Luis Sánchez Belda, Madrid, CSIC., Escuela de Estudios Medievales, 1950.

16. Chronica Naierensis, Chronica Hispana saeculi XII. Pars II, Cura et studio Juan A. Estévez Sola, Brepols, Turnhout, 1995.

17. Cicerón, Los oficios o los deberes, México D.F., Porrúa, 1998.

18. Claraval, Bernardo de, Elogio de la Nueva milicia templaria, Madrid, Siruela, 2005.

19. Crónica de Alfonso X, según el Ms. II/2777 de la Biblioteca del Palacio Real, edición, trascripción y notas por Manuel González Jiménez, Murcia, Real Academia de Alfonso X el Sabio, 1999.

20. Crónica de Veinte Reyes, Burgos, Ayuntamiento de Burgos, 1991.

21. Crónica del Emperador Alfonso VII, Introducción, traducción, notas e índices por Maurilio Pérez González, León, Universidad de León, 1997.

22. Crónica Latina de los Reyes de Castilla, edición de Luis Charlo Brea, Madrid, Akal, 1999.

23. Crónica mozárabe de 754, Edición crítica y traducción por José Eduardo López Pereira, Zaragoza, Anubar, 1980.

24. Crónica Najerense, Edición de Juan A. Estévez Sola Tres Cantos, Madrid, Akal, 2003.

25. Crónicas Anónimas de Sahagún, Edición crítica, nota e índice por Antonio Ubieto Artera, Zaragoza, Anubar, 1987.

26. Crónicas asturianas: Crónica de Alfonso III (Rotense y "A Sebastián"), Crónica albeldense (y "profética"), Introducción y edición crítica de Juan Gil Fernández; 
traducción y notas de José L. Moralejo, estudio preliminar de Juan I. Ruiz de la Peña, Oviedo, Universidad de Oviedo, 1985.

27. Domínguez Sánchez, Santiago, Documentos de Bonifacio VIII (1294-1303) Referentes a España, León, Universidad de León, 2006.

28. ----------, Santiago, Documentos de Clemente IV (1265 - 1268) Referentes a España, León, Universidad de León, 1996.

29. --------, Santiago, Documentos de Gregorio IX (1227 - 1241) Referentes a España, León, Universidad de León, Secretariado de Publicaciones, 2004.

30. ----------, Santiago, Documentos de Gregorio X (1272 - 1276) Referentes a España, León, Universidad de León, 1997.

31. --------, Santiago, Documentos de Nicolás III (1277-1280) Referentes a España, León, Universidad de León, 1999.

32. ---------, Documentos de Nicolás IV (1288-1292) Referentes a España, León, Universidad de León, 2009.

33. Don Juan Manuel, El Libro de los Estados, Edición de Ian R. Macpherson y Robert Brian Tate, Madrid, Editorial Castalia, 1991.

34. El Corán, Edición preparada por Julio Cortés, Barcelona, Herder, 2009.

35. El Cronicón del Silense, en Las Crónicas Latinas de la Reconquista, Tomo II, Estudios prácticos de latín medieval por Ambrosio Huici, Valencia, Establecimiento tipográfico Hijos de F. Vives Mora, 1913.

36. El Fuero de Coria, Estudio histórico-jurídico por José Maldonado y Fernández del Torco; trascripción y fijación del texto por Emilio Sáez; con prólogo del Excmo. Sr. D. José Fernández Hernando, Instituto de Estudios de Administración Local, 1949.

37. El fuero de Cuenca, $2^{\mathrm{a}}$ Edición, Introducción, traducción y notas de Alfredo Valmaña Vicente, Cuenca, Torno, 1978.

38. El libro de los doze sabios o Tratado de la nobleza y lealtad [ca. 1237], Real Academia Española de la Lengua (Anexos del Boletín de la RAE, XXIX), Madrid 1975, páginas 71-118. En: http://www.filosofia.org/aut/001/12sabios.htm. 
39. Espéculo. Leyes de Alfonso X, Edición y análisis crítico por Gonzalo Martínez Diez, Ávila, Fundación Sánchez Albornoz, 1985.

40. Foucher de Chartres, Histoire des Croisades, Chap. 1, Paris, Ed. Guizot, 1825, http://books.google.cl/books?id=J00PAAAAQAAJ\&pg=PA7\&focus=viewport\&o utput=text.

41. Gil de Zamora, Juan, De preconiis Hispanie o Educación del príncipe, traducción y estudio José-Luis Martín, Jenaro Costas, Ayuntamiento de Zamora, 1996.

42. González, Julio, Reinado y Diplomas de Fernando III, Tomos I, II, III, Córdoba, Publicaciones del monte de piedad y caja de ahorros de Córdoba, 1980-1986.

43. Gonzalo de Berceo, Milagros de Nuestra Señora; Vida de santo Domingo de Silos; Vida de san Millán de la Cogolla; Vida de santa Oria; Martirio de san Lorenzo, Prólogo y versión moderna de Amancio Bolaño e Isla, México, Porrua, 1969.

44. Guibert de Nogent, Histoire des Croisades, II, Paris, Éd. Guizot, 1825, En http://books.google.cl/books?id=GkQPAAAAQAAJ\&printsec=frontcover\&source $=$ gbs_ge_summary_r\&cad $=0 \# \mathrm{v}=$ onepage $\& \mathrm{q} \& \mathrm{f}=$ false $(28$ enero del 2014. 14:50 horas).

45. Guillaume de Tyr, Histoire des Croisades, I, Paris, Éd. Guizot, 1824, vol. I, en http://jmarin.jimdo.com/fuentes-y-documentos/las-cruzadas/el-llamado-a-laprimera-cruzada-seg\% $\%$ C3\%Bn-diversos-autores/.

46. Hipona, Agustín de, De civitate Dei, en http://www.augustinus.it/ latino/cdd/index $2 . h t m$.

47. --------- La Ciudad de Dios, traducción de Santos Sartamarta del Río, Madrid, Biblioteca Homo Legens, 2006.

48. ------- Obras completas de San Agustín. XXXI. Escritos antimaniqueos $\left(2^{\circ}\right)$ Contra Fausto, Introducción, Traducción, Notas e Índices de Pío de Luis, Madrid, Biblioteca de Autores Cristianos, 1993.

49. Historia Compostelana, Edición de Emma Falque, Madrid, Akal, 1994.

50. Historia Compostella, Cura et Studio Emma Falque Rey, Brepols, Turnholti, 1988. 
51. Historia Silense, Edición crítica e introducción por Dom Justo Pérez de Urbel y Atilano González Ruiz-Zorrilla, Madrid, Escuela de Estudios Medievales, 1959.

52. Homero, La Ilíada, Barcelona, Edicomunicación, 1997.

53. Ibn 'Idari al-Marrakusi, La caída del Califato de Córdoba y los reyes de Taifas, estudio, traducción y notas de Felipe Maillo Salgado, Salamanca, Universidad de Salamanca, 1993.

54. Jiménez de Rada, Rodrigo, Historia Arabvm, Introducción, Edición crítica, notas e índice de José Lozano Sánchez, Sevilla, Universidad de Sevilla, 1993.

55. ------- Historia de los hechos de España, Introducción, traducción, notas e índices de Juan Fernández Valverde, Madrid, Alianza, 1989.

56. --------- Opera Omnia, Pars I, Historia de revus Hispaniae, Corpus Christianorum, Continuatio Mediaevalis, LXXII, Turnholti, Typographi Brepols Editores Pontificii, MCMLXXXVIII.

57. La "Vita Dominici Siliensis" de Grimaldo, estudio, edición crítica y traducción de Vitalino Valcarcel. Logroño, Instituto de Estudios Riojanos, 1982.

58. Las siete partidas del rey don Alfonso el Sabio, Cotejadas con varios códices antiguos por la Real Academia de la Historia, Tomo III, Madrid, Imprenta Real, 1807.

59. Liber Sancti Jacobi “Codex calixtinus", Traducción de Abelardo Moralejo, Casimiro Torres y Julio Feo, Galicia, Xunta de Galicia, 2004.

60. Liber Sancti Jacobi: Codex Calixtinus, Edición de K. Herbers y M. Santos Noia, Galicia, Xunta de Galicia, D.L. 1998.

61. López Guil, Itzíar, Libro de Fernán Gonçález, Madrid, CSIC., Instituto de la Lengua española, 2001.

62. Los "Miraculos romançados" de Pero Marín, edición crítica, introducción e índices por Karl-Heinz Antón, Abadía de Silos, 1988.

63. Los Anales Toledanos I y II, Edición de Julio Porres Martín-Cleto, Toledo, Instituto provincial de Investigaciones y Estudios Toledanos, Diputación Provincial de Toledo, 1993. 
64. Lumbreras Valiente, Pedro, Los fueros municipales de Cáceres su derecho publico, Cáceres, Ayuntamiento de Cáceres, 1974.

65. Mansilla, Demetrio, La documentación pontificia de Honorio III (1216 - 1227), Roma, Instituto Español de Historia Eclesiástica, 1965.

66. --------- La documentación pontificia hasta Inocencio III (965-1216), Roma, Instituto Español de Estudios Eclesiásticos, 1955.

67. Marín, José, Textos históricos: desde el Imperio Romano hasta el siglo VIII, Santiago de Chile, RIL, 2003.

68. Orderic Vital, Histoire de Normandie, Libro IX, Ed. Guizot, 1826, Paris, vol. III, en http://jmarin.jimdo.com/fuentes-y-documentos/las-cruzadas/el-llamado-a-laprimera-cruzada-seg\% $\%$ C3\%BAn-diversos-autores/.

69. Orosio, Paulo, Historia contra los paganos, Estudio preliminar, versión y notas de Enrique Gallego-Blanco, Barcelona, Puvill Libros, 1983.

70. Primera Crónica General de España, Editada por Ramón Menéndez Pidal con un estudio actualizador de Diego Catalán, $2^{\circ}$ tomo de la tercera reimpresión, Madrid, Gredos, 1977.

71. Quintana Prieto, Augusto, La documentación pontificia de Inocencio IV (12341254), Roma, Instituto de historia eclesiástica, 1987, Tomos I y II.

72. Robert le Moine, Histoire de la Première Croisade, Paris, Ed. Guizot, 1825, En http://remacle.org/bloodwolf/historiens/robertlemoine/croisade1.htm

73. Rodríguez de Lama, Ildefonso La documentación pontificia de Alejandro IV (1254-1261), Roma, Instituto de historia eclesiástica, 1976.

74. -------- La documentación pontificia de Urbano IV (1261-1264), Roma, Instituto de historia eclesiástica, 1981,

75. Santa Biblia, Reina-Valera, Edición de Estudio, Bogotá, Sociedades Bíblicas Unidas, 1995.

76. Sevilla, Isidoro de, Etimologías, Versión castellana total, por vez primera, e introducciones particulares de don Luis Cortés y Góngora, Introducción general e índices científicos del prof. Santiago Montero Díaz, Madrid, Biblioteca de Autores Cristianos, 1951. 
77. --------- Las historias de los godos, vándalos y suevos, Estudio, edición crítica y traducción de Cristóbal Rodríguez Alonso, León, Centro de Estudios e investigación "San Isidoro", 1975.

78. Synodicon Hispanum, dirigido por Antonio García García, Madrid, Biblioteca de Autores Cristianos, 1981, Volúmenes I, III, V.

79. Tudensis, Lucae, Opera Omnia, Chronicon Mundi, Cura et studio Emma Falque, Corpus Christianorum, Continuatio Mediaevalis, LXXIV, Bélgica, Brepols Publishers, 2003.

80. Tuy, Lucas de, Crónica de España, Primera edición del texto romanceado, conforme a una copia de la Academia preparada y prologada por Julio Puyol, Madrid, 1926.

81. ---------- Milagros de san Isidoro, traducción de Juan de Robles (1525), Trascripción, prólogo y notas de Julio Pérez Llamazares (1947), León, Universidad de León, 1992. 


\section{II.- Bibliografía}

1. Abela, Jaime, "Las técnicas de Análisis de Contenido: Una revisión actualizada", en http://public.centrodeestudiosandaluces.es/pdfs/S200103.pdf

2. Abellán, José Luis, Historia critica del pensamiento español. Tomo I. Metodología e introducción histórica, Madrid, Espasa-Calpe, 1979.

3. Alfonso Antón, Isabel, "El cuerpo del delito y la violencia ejemplar" en Fierro, Maribel. Francisco García Fitz (editores), El cuerpo derrotado: Cómo trataban musulmanes y cristianos a los enemigos vencidos (Península Ibérica, SS. VIIIXIII), Madrid, CSIC., 2008.

4. Alonso Álvarez, Raquel, "La obra histórica del obispo Pelayo de Oviedo (10891153) y su relación con la Historia legionensis (llamada silensis)", en e-Spania [En línea], 14, diciembre2012, mis en ligne le 13 septembre 2012. URL: http://espania.revues.org/21586; DOI: 10.4000/e-spania.21586.

5. Alonso Álvarez, Raquel, "Los promotores de la Orden del Císter en los reinos de Castilla y León: familias aristocráticas y damas nobles.”, en Anuario de Estudios Medievales, Vol. 37/2, 2007, [pp. 653-710].

6. Alphandéry, Paul. La cristiandad y el concepto de cruzada, México, Unión Tipográfica Editorial Hispano Americana, 1962.

7. Alvar, Carlos, La poesía trovadoresca en España y Portugal, Madrid, Cupsa, D.L, 1977.

8. Álvarez Borge, Ignacio, La Plena Edad Media, Siglos XII-XIII, Madrid, Ed. Síntesis.

9. Alvira Cabrer, Martín, “'Senhor, per les nostres peccatz'. Guerra y pecado en la Edad Media”, en Carrasco Manchado, Ana Isabel y María del Pilar Rábade Obradó (Coordinadores), Pecar en la Edad Media, Silex, Madrid, 2008.

10. ---------, "Del sepulcro y los sarracenos meridionales a los herejes occidentales", en Baloup, Daniel y Philippe Josserand (Editores), Regards Croisés sur la Guerre Sainte. Guerre, Idéologie et Religion Dans L'espace Méditerranéen Latin (XI-XIII Siècle), CNRS-Université de Toulouse-Le Mirail, 2006. 
11. ----------, "El desafío del Miramamolín antes de la Batalla de las Navas de Tolosa (1212), fuentes, datación y posibles orígenes", Al-Qantara, Vol. XVIII, Fasc. 2, 1997, [pp. 463-490].

12. ----------, “Guerra e ideología en la España del siglo XIII: la conquista de Mallorca según la crónica de Bernat Desclot”, en En la España Medieval, 19, 1996, [pp. 37 $50]$.

13. ----------, “La muerte del enemigo en pleno medioevo cifras e ideología (el modelo de las Navas de Tolosa)", en Hispania, Revista Española de Historia, Vol. LV/ II, $\mathrm{N}^{\mathrm{o}} 190,1995$, [pp. 403-423].

14. Alvira Cabrer, Martín, "Las cruzadas y la España medieval”, en Historia 16, 229, 1995 [pp. 82-90].

15. ----------, Guerra e ideología en la España medieval: cultura y actitudes históricas ante el giro de principios del siglo XIII: batallas de Las Navas de Tolosa (1212) y Muret (1213), Tesis inédita, Madrid, Universidad Complutense, 2003.

16. Arias Guillén, Fernando, "Honor y Guerra. La tensión entre realidad bélica y el discurso ideológico en la cronística castellana de la primera mitad del siglo XIV”, en Hispania, vol. LXIX, N²32, 2009, [pp. 307-330].

17. Arizaleta, Amaia, "La Chronica regum Castellae: aledaños de la ficción", en eSpania [En ligne], 2 | diciembre 2006, mis en ligne le 14 décembre 2006, URL: http://e-spania.revues.org/517; DOI: 10.4000/e-spania.517.

18. ---------, “Topografías de la memoria palatina: los discursos cancillerescos sobre la realeza (Castilla, siglos XII y XIII)”, en Fernández de Larrea, Jon Andoni y José Ramón Díaz de Durana (Editores), Memoria e Historia. Utilización política en la Corona de Castilla al final de la Edad Media, Madrid, Silex, 2010.

19. --------, “Ut lector agnosceret: discurso y recepción de la obra de Rodrigo Jiménez de Rada (primera mitad del siglo XIII)", en Cahiers de linguistique et de civilisation hispaniques médiévales, № 26, 2003, [pp. 163-186].

20. Ballesteros Beretta, Antonio, Alfonso X el Sabio, Barcelona, El Albir, 1984.

21. Ballesteros Gaibrois, Manuel "La conquista de Jaén por Fernando III el santo", en Cuadernos de Historia de España, $\mathrm{N}^{\circ}$ 20, 1953, [pp. 63-138]. 
22. Baloup, Daniel y Philippe Josserand, "Du Jourdain au Tage", en Baloup, Daniel y Philippe Josserand (Editores), Regards Croisés sur la Guerre Sainte. Guerre, Idéologie et Religion Dans L'espace Méditerranéen Latin (XI-XIII Siècle), Toulouse, CNRS-Université de Toulouse-Le Mirail, 2006,

23. Barbero, Abilio y Marcelo Vigil, La Formación del Feudalismo en la Península Ibérica, Barcelona, Crítica, 1978.

24. ----------, Sobre los orígenes sociales de la Reconquista, Barcelona, Ariel, 1988.

25. Bardin, Laurence, El análisis de contenido, Madrid, Akal, 2002.

26. Barkai, Ron, "Diálogo Filosófico-Religioso en el seno de las tres culturas ibéricas”, en Santiago-Otero, Horacio (Editor), Diálogo Filosófico-Religioso entre Cristianismo, Judaísmo e Islamismo durante la Edad Media en la Península Ibérica, Actes du Colloque international de San Lorenzo de El Escorial, Société Internationale pour l'Étude de la Philosophie Médiévale, Brepols, 1994.

27. ---------, El enemigo en el espejo. Cristianos y musulmanes en la España medieval, Madrid, Rialp, 2007.

28. Baró Pozos, Juan, "El Concejo de la Villa de Santander en la Baja Edad Media", en El Fuero de Santander y su Época, Actas del Congreso Conmemorativo de su VIII Centenario, Santander, Diputación regional de Cantabria. Ayuntamiento de Santander, Universidad de Cantabria, 1989.

29. Bautista, Francisco, "Escritura cronística e ideología histórica", en e-Spania [En línea], 2 | décembre 2006, Puesto en línea el 16 agosto 2010. URL: http://espania.revues.org/429; DOI: 10.4000/e-spania.429.

30. --------, “Genealogía y leyenda", en e-Spania [En línea], 7 | juin 2009, Puesto en línea el 16 agosto 2010, URL: http://e-spania.revues.org/18086; DOI: 10.4000/espania. 18086.

31. Beceiro Pita, Isabel, "La legitimación del linaje a través de los ancestros", en Fernández de Larrea, Jon Andoni y José Ramón Díaz de Durana (Editores), Memoria e Historia. Utilización política en la Corona de Castilla al final de la Edad Media, Madrid, Silex, 2010. 
32. Benítez Guerrero, Carmen, La imagen del rey en la cronística castellana. Propaganda y legitimación durante la primera mitad del siglo XIV, Madrid, La Ergástula, 2014.

33. Benito Ruano, Eloy, "España y las cruzadas", en Anales de historia antigua y medieval, 1951-1952, [pp. 92-120].

34. ----------, "La historiografía de la alta edad media. Ideología y Estructura", Cuadernos de Historia de España, XVII, Buenos Aires, Universidad de Buenos Aires, Instituto de Investigaciones Históricas, 1952, [pp. 50-104].

35. ---------, "Las órdenes militares y la idea de cruzada", en Hispania: Revista Española de Historia, $\mathrm{N}^{\circ} 15,1956$, [pp. 3-15].

36. Bermejo, José Luis, "Orígenes Medievales en la Idea de Soberanía”, en Revista de Estudios Políticos, 200-201, 1975, [pp. 283-290].

37. -------, Máximas, Principios y Símbolos Políticos, Madrid, Centro de Estudios Constitucionales, 1986.

38. ---------, "En torno al Imperio Hispano Medieval”, en Anuario de Historia del Derecho español, № 59, 1989, [pp. 737-750].

39. Bertelli, Sergio, “«Religio Regis» la propaganda del poder real”, en Medievalismo, Año 8, N 8, Madrid, 1998, [pp. 9-18].

40. Bishko, Charles, "Fernando I y los orígenes de la alianza castellano-leonesa con Cluny”, en Cuadernos de Historia de España, No XLVII, 1968, [pp. 31-135] y N XLVIII, 1969, [pp. 50-116].

41. Bizzarri, Hugo Oscar, "La idea de Reconquista en el Libro de los doze Sabios", en Revista de Filología Española, Tomo LXXVI, Enero-Junio 1996, Fascículos $1^{\text {º }}$ $2^{\circ}$, CSIC, Madrid, 1996, [pp. 5-29].

42. Bloch, Marc, Los reyes taumaturgos, México DF, FCE, 1993.

43. Bodelón, Serafín, Literatura latina de la Edad Media en España, Madrid, Akal, 1989.

44. Boesch, Sofía, "Santidad", en Le Goff, Jacques y Jean-Claude Schmitt (Editores), Diccionario razonado del occidente medieval, Madrid, Akal, 2003.

45. Bonassie, Pierre y otros, Las Españas Medievales, Barcelona, Crítica, 2001. 
46. Bouthol, Gaston, El Fenómeno Guerra, Barcelona, Plaza \& Janes, 1971.

47. ---------, La Guerra, Barcelona, Oikos-tau, 1971.

48. ----------, Las Mentalidades, ¿Qué sé?, No 21, Barcelona, Oikos-tau, 1971.

49. Bresc, Henri, Pierre Guichard y Robert Mantran, Europa y el Islam en la Edad Media, Barcelona, Crítica, 2001.

50. Bronisch, Alexander Pierre, "En Busca de la Guerra Santa", en Baloup, Daniel y Philippe Josserand (Editores), Regards Croisés sur la Guerre Sainte. Guerre, Idéologie et Religion Dans L'espace Méditerranéen Latin (XI-XIII Siècle), CNRSUniversité de Toulouse-Le Mirail, 2006.

51. ---------, "La ideología asturiana y la historiografía en la época de Fernando III", en De Ayala Martínez, Carlos y Martín Ríos Saloma (Editores), Fernando III, tiempo de cruzada, Madrid, Silex, 2012.

52. ----------, Reconquista y guerra santa: La concepción de la guerra en la España cristiana desde los visigodos hasta comienzos del siglo XII, Granada, Universidad de Granada, 2006.

53. Brundage, James, "Holy War and the Medieval Lawyers", en Murphy, Thomas Patrik (Editores), The holy war, Ohio, Columbus, 1976.

54. Cabrillana Ciézar, Nicolás, Santiago Matamoros: historia e imagen, Málaga, Diputación de Málaga, Servicio de Publicaciones, 1999.

55. Cabrol, Fernand y Henri Leclercq (et.al), Dictionnaire d'archéologie chrétienne et de liturgie, Tome Quatriéme, Paris, Librairie Letouzey et Ané, 1921.

56. Calderón Medina, Inés, "La Memoria de los reyes de León (1157-1230)", en Martínez Sopena, Pascual y Ana Rodríguez (Editores), La construcción medieval de la memoria regia, Valencia, Publicacions de la Universitat de València, 2011.

57. Calderón Ortega, José Manuel y Francisco Javier Díaz González (Compiladores), Vae Victis: Cautivos y prisioneros en la Edad Media hispánica, Alcalá de Henares, Universidad de Alcalá, 2012, pp. 93 y ss.

58. Calderón, Inés, "La memoria de los reyes de León", en Estepa Díez, Carlos y otros, Poder real y sociedad: estudios sobre el reinado de Alfonso VIII (11581214), Universidad de León, León, 2011. 
59. Canal Sánchez-Pagín, José María, “Crónica Silense o Crónica domnis sanctis?”, en Cuadernos de Historia de España, LXIII-LXIV, 1980, [pp. 94-103].

60. ----------, “Elías, canónigo rótense, posible autor de la Chronica Adefonsi Imperatoris", en Anuario de Estudios Medievales, 30/2, 2000, [pp. 735-757].

61. Cardini, Franco, “Guerra y cruzada”, en Le Goff, Jacques y Jean-Claude Schmitt (Editores), Diccionario razonado del occidente medieval, Madrid, Akal, 2003.

62. Carrasco, Juan y otros, Historia de las Españas Medievales, Barcelona, Ed. Crítica, 2002.

63. Carrillo de Albornoz y Galbeño, Juan, "Fernando III. Sus Campañas. (El Conquistador y la conquista)", en Archivo Hispalense Revista Histórica, Literaria y Artística. 2.a Época, Año 1994. Tomo LXXVII. Núms. 234-235-236, [pp.137$155]$.

64. Casagrande, Carla y Silvana Vecchio, "Pecado", en Le Goff, Jacques y JeanClaude Schmitt (Editores), Diccionario razonado del occidente medieval, Madrid, Akal, 2003.

65. Catalán, Diego, La estoria de España de Alfonso X: creación y evolución, Madrid, Universidad Complutense de Madrid, Seminario Menéndez Pidal, 1992.

66. Charouiti Hasnaoui, Milouda, "El Dualismo conceptual de la frontera legendaria e histórica en las fuentes árabes”, en Toro Ceballos, Francisco y José Rodríguez Molina. (Coordinadores), IV Estudios de Frontera. Historia, Tradiciones y leyendas en la Frontera, Jaén, Diputación Provincial de Jaén, 2003

67. Cipollone, Giulio, "Esclavitud y Liberación en la Frontera", en Toro Ceballos, Francisco y José Rodríguez Molina (Coordinadores), Estudios de Frontera Alcalá La Real y el Arcipreste de Hita, Diputación Provincial de Jaén, Alcalá la Real, 1996.

68. Contamine, Philippe, La Guerra en la Edad Media, Barcelona, Labor, 1984.

69. Cook, Chris, Diccionario de términos históricos, Segunda Edición, Madrid, Alianza, 2006.

70. Cooper, J. C., Diccionario de símbolos, Barcelona, Gustavo Gili, 2007.

71. Corral, Fernando Luis, "'Y sometió a su autoridad todo el reino de los leoneses': formas de ejercicio del poder en la Historia Silense o cómo Alfonso VI llegó al 
trono”, en e-Spania [En ligne], 14 | décembre 2012, mis en ligne le 13 septembre 2012, URL: http://e-spania.revues.org/21696; DOI: 10.4000/e-spania.21696.

72. Costas Rodríguez, Jenaro, Fernando III a través de las crónicas medievales, Zamora, Ayuntamiento de Zamora, Centro de la UNED de Zamora, 2001.

73. Crespo, Juan Bautista, "La 'Estoria de España' y las crónicas generales", en Fernández-Ordóñez, Inés (ed.), Alfonso X el Sabio y las Crónicas de España, Valladolid, Universidad de Valladolid, Centro para la Edición de los Clásicos Españoles, 2001.

74. Cyrille, Aillet, Les Mozarabes. Christianisme, islamisation et arabisation en péninsule ibérique (IXe - XIle siècle), Madrid, Casa de Velázquez, 2010.

75. De Ayala Martínez, Carlos, "Fernando I y la sacralización de la Reconquista", Anales de la Universidad de Alicante, Historia Medieval, 17, 2011, [pp. 67-116].

76. ----------, "Fernando III: Figura, significado y contexto en tiempo de cruzada", en De Ayala Martínez, Carlos y Martín Ríos Saloma (Editores), Fernando III, tiempo de cruzada, Madrid, Silex, 2012.

77. --------, "Las órdenes militares castellano-leonesas y la acción de frontera en el siglo XIII", en Identidad y Representación de la Frontera en la España Medieval (siglos XI-XIV), Seminario celebrado en la Casa de Velázquez y la Universidad Autónoma de Madrid, Madrid, 2001.

78. --------, Las órdenes militares hispánicas en la Edad Media (siglos XII-XV), Madrid, Marcial Pons Historia, 2007.

79. ---------, Carlos, Sacerdocio y Reino en la España Altomedieval. Iglesia y poder político en el Occidente peninsular, siglos VII-XII, Madrid, Sílex, 2008.

80. De la Montaña Conchiña, Juan Luis, "Frontera y Sociedad en la Transtierra Extremeña (siglos XII-XIII)”, Estudios de Frontera Alcalá La Real y el Arcipreste de Hita, Diputación Provincial de Jaén, Alcalá la Real, 1996.

81. De Moxó, Salvador, Feudalismo, señorío y nobleza en la Castilla medieval, Madrid, Real Academia de la Historia, 2000.

82. De Pange, Jean, Le roi très Chretien, Paris, Librairie Arthème Fayard, 1949. 
83. Demurger, Alain, Caballeros de Cristo. Templarios, hospitalarios, teutónicos y demás órdenes militares en la Edad Media (Siglos XI a XVI), Universidad de Granada, Universitat de Valencia, Granada, 2005.

84. Deyermond, Alan, Historia de la literatura española. 1, La Edad Media, Barcelona, Ariel, 1979.

85. Díaz y Díaz, Manuel, De Isidoro al siglo XI. Ocho estudios sobre la vida literaria peninsular, Barcelona, El Albir, 1976.

86. Diccionario de la Lengua Española, XXII Edición, Madrid, Real Academia Española, 2001.

87. Díez Borque, José María (Editor), Historia de las literaturas hispánicas no castellanas, Madrid, Taurus, 1980.

88. Domínguez García, Javier, De Apóstol matamoros a Yllapa mataindios: dogmas e ideologías medievales en el (des)cubriminsto de América, Salamanca, Universidad de Salamanca, 2008.

89. ----------, Memorias del futuro: Ideología y ficción en el símbolo de Santiago Apóstol, Madrid, Iberoamericana, 2008.

90. Domínguez Rodríguez, Ana y Pilar Treviño Gajardo, Las Cantigas de Santa María Formas e imágenes, España, AyN Ediciones, 2007.

91. Duby, Georges, La Época de las Catedrales, arte y sociedad 980-1420, Madrid, Cátedra, 1993.

92. --------, Los tres órdenes o lo imaginario del feudalismo, Barcelona, Argot, 1983.

93. Durkheim, Emile, Las formas elementales de la vida religiosa. El sistema totémico en Australia, Madrid, Akal, 1992.

94. Eliade, Mircea, El mito del eterno retorno. Arquetipos y repetición, Buenos Aires, Alianza, 1972.

95. ---------, Lo Sagrado y lo Profano, Barcelona, Labor, 1985.

96. --------, Mito y Realidad, Barcelona, Labor, 1991.

97. Erdman, Carl, The origin of the idea of Crusade, Oxford, 1977.

98. Estepa Diez, Carlos, "El reino de Castilla de Alfonso VIII (1158-1214)", en Álvarez Borge, Ignacio, Carlos Estepa Diez y José María Santamarta Luengos, 
Poder Real y Sociedad: Estudios sobre el reinado de Alfonso VIII (1158 - 1214), León, Universidad de León, 2011.

99. -----------, “Memoria y poder real bajo Alfonso VIII (1158-1214)”, en Martínez Sopena, Pascual y Ana Rodríguez (Editores), La construcción medieval de la memoria regia, Valencia, Publicacions de la Universitat de València, 2011.

100. ----------, “Memoria y poder real bajo Alfonso VIII”, en Estepa Díez, Carlos y otros, Poder real y sociedad: estudios sobre el reinado de Alfonso VIII (11581214), Universidad de León, León, 2011.

101. Estévez Sola, Juan Antonio, "Chronica Naierensis e Historia Silensis", en eSpania [En línea], 7 | juin 2009, Puesto en línea el 21 noviembre 2011, consultado el 04 octubre 2013. URL: http://e-spania.revues.org/18048; DOI: 10.4000/espania. 18048.

102. Fernández Chaves, Flory, "El análisis de contenido como ayuda metodológica para la investigación”, en Ciencias Sociales, Junio, Vol. II, Nº 96, Universidad de Costa Rica, [pp. 35-54].

103. Fernández Conde, Francisco Javier, Historia de la Iglesia en España, II-2 ${ }^{\circ}$ La Iglesia en la España de los siglos VIII al XIV, Madrid, Ed. Católica, 1982.

104. ----------, La Religiosidad Medieval en España. Plena Edad Media (siglos XIXIII), Trea, Oviedo, 2005.

105. Fernández Ordóñez, Inés, "La composición por etapas de la Chronica latina regum Castellae (1223-1237) de Juan de Soria”, en e-Spania [En ligne], 2 | décembre 2006, mis en ligne le 14 décembre 2006, URL: http://espania.revues.org/283; DOI: 10.4000/e-spania.283

106. Fernández Ubiña, José, Cristianos y militares. La iglesia antigua ante el ejército y la guerra, Granada, Universidad de Granada.

107. Fletcher, Richard, La cruz y la media luna. Las dramáticas relaciones entre el cristianismo y el Islam desde Mahoma hasta Isabel la Católica, Barcelona, Península, 2005.

108. ----------, The episcopate in the Kingdom of León in the twelfth century, Oxford, Oxford University Press, 1978. 
109. Flori, Jean, "La crónica como hecho ideológico: el caso de la Estoria de España de Alfonso X", en La Corónica, A journal of medieval hispanic languages: Literatures \& Cultures, Vol. XXXII, N³, 2004, [pp. 69-90].

110. -----------, Caballeros y caballería en la Edad Media, España, Paidos Ibérica, 2001.

111. ----------, El modelo historiográfico alfonsí: Una Caracterización, London, Department of Hispanic Studies, Queen Mary and Westfield College, 1997.

112. ----------, Guerra Santa, Yihad, Cruzada. Violencia y Religión en el Cristianismo y el Islam, Granada, Universidad de Granada, Universitat de València, 2004.

113. ----------, La Guerra Santa. La formación de la idea de cruzada en el Occidente cristiano, Granada, Trota, Universidad de Granada, 2003.

114. Foronda, François, "Sociedad política, propaganda monarquía y el régimen en Castilla del Siglo XIII. En torno al libro de los doze sabios", en Edad Media. Revista de Historia, $\mathrm{N}^{\circ}$ 7, 2006, [pp. 10-37].

115. Gacto Fernández, Enrique, Temas de Historia del derecho: Derecho Medieval, Sevilla, Universidad de Sevilla, 1977.

116. Gárate Córdoba, José María, Espíritu y milicia en la España medieval, Madrid, Publicaciones Españolas, 1967.

117. García Caneiro, José y Francisco Javier Vidarte, Guerra y filosofía: concepciones de la guerra en la historia del pensamiento, Valencia, Tirant lo Blanch, 2002.

118. García de Cortázar, José Ángel, Sociedad y organización del espacio en la España medieval, Granada, Editorial Universidad de Granada, 2004.

119. García de la Borbolla, Ángeles, "La Espiritualidad de los Cautivos de Santo Domingo en la obra de Pero Marín”, en II Estudios de Frontera. Actividad y Vida en la Frontera, Diputación Provincial de Jaén, 1998.

120. ---------, "Santo Domingo de Silos, el santo de la frontera: La imagen de la santidad a partir de las fuentes hagiográficas castellano-leonesas del siglo XIII", en Anuario de Estudios Medievales, 31-1, 2001, [pp. 127-145].

121. García de Valdeavellano, Luis, El Feudalismo Hispánico, Barcelona, Crítica, 1981. 
122. García Fitz, Francisco, “¿’De exterminandis sarracenis’? El trato dado al enemigo musulmán en el reino de Castilla-León durante la plena edad media”, en Fierro, Maribel y Francisco García Fitz (Editores), El cuerpo derrotado: Cómo trataban musulmanes y cristianos a los enemigos vencidos (Península Ibérica, SS. VIIIXIII), Madrid, CSIC., 2008.

123. ------------, “El discurso militar en la historiografía de las cruzadas: la ideología patente”, en Iglesias Zoido, Juan Carlos (Editor), Retórica e Historiografía. El discurso militar en la historiografia desde la Antigüedad hasta el Renacimiento, Madrid, Ediciones Clásicas, Cáceres, Universidad de Extremadura, 2007.

124. -----------, "La conquista de Andalucía en la cronística castellana del siglo XIII: Las mentalidades historiografías en los relatos de la conquista", en Cabrera, Emilio, Andalucía entre Oriente y Occidente (1236-1492), Actas del V Coloquio Innternacional de Historia Medieval de Andalucia, Córdoba, Excma. Diputación Provincial de Córdoba, 1988.

125. ------------, "La didáctica militar en la literatura castellana (Segunda mitad del siglo XIII y primera del XIV)", en Anuario de Estudios Medievales, 19, CSIC., 1989, [pp. 271-283].

126. --------, “La Reconquista: un estado de la cuestión”, en Clio \& Crimen, n 6, Extremadura, 2009, [pp. 142-215].

127. ------------, “Las guerras de cada día en la Castilla del siglo XIV”, en Edad Media. Revista de Historia, 8, 2007, [pp. 151-181].

128. -----------, Castilla y León frente al Islam: Estrategias de expansión y Tácticas militares (Siglos XI - XIII), Sevilla, Universidad de Sevilla, 2001.

129. ---------, La edad Media. Guerra e ideología, justificaciones jurídicas y religiosas, Madrid, Silex, 2003.

130. ---------, La Reconquista, Granada, Universidad de Granada, 2010.

131. ----------, Las Navas de Tolosa, Barcelona, Ariel, 2008.

132. ----------, Relaciones Políticas y Guerra. La experiencia castellano - leonesa frente al Islam. Siglos XI-XIII, Sevilla, Universidad de Sevilla, 2002.

133. García Flores, Antonio, “'Fazer batallas a los moros por las vecindades del reyno’. Imágenes de enfrentamientos entre cristianos y musulmanes en la Castilla 
medieval", en Identidad y Representación de la Frontera en la España Medieval (siglos XI-XIV), Seminario celebrado en la Casa de Velázquez y la Universidad Autónoma de Madrid, Madrid, 2001.

134. García Moreno, Luis A., El fin del reino visigodo de Toledo: decadencia y catástrofe, una contribución a su crítica, Madrid, Universidad Autónoma, 1975.

135. García Pardo, Manuela, "La Redención de Cautivos: Una muestra de la religiosidad popular medieval en Úbeda", en V Estudios de Frontera, funciones de la red castral fronteriza, Alcalá la Real, Diputación Provincial de Jaén, 2003

136. García Pelayo, Manuel, El Reino de Dios, Arquetipo Político, Revista de Occidente, Madrid, 1959.

137. García Ramila, Ismael, "Inocencio III y la cruzada de las navas de Tolosa", en Revista de Archivos Bibliotecas y Museos, N XLVIII, 1927, [pp. 455-464].

138. García Sanjuán, Alejandro, "Formas de sumisión del territorio y tratamiento de los vencidos en el derecho islámico clásico”, en Fierro, Maribel y Francisco García Fitz (Editores), El cuerpo derrotado: Cómo trataban musulmanes y cristianos a los enemigos vencidos (Península Ibérica, SS. VIII-XIII), Madrid, CSIC, 2008.

139. García Villoslada, Ricardo, Historia de la Iglesia Católica en sus cuatro grandes edades: Antigua, Media, Nueva y Moderna, Madrid, Biblioteca de Autores Cristianos, 1958.

140. García y García, Antonio, Iglesia, Sociedad y Derecho, Salamanca, Publicaciones Universidad Pontificia de Salamanca, 2000.

141. García-Gallo de Diego, Alfonso, "La obra legislativa de Alfonso X, hechos e hipótesis", en Anuario de Historia del Derecho español, N 54, 1984, [pp. 97$162]$.

142. García-Guijarro Ramos, Luis, Papado, cruzadas y órdenes militares, siglos XIXIII, Cátedra, Madrid, 1995.

143. García-Serrano, Francisco, "La creación de identidad en la frontera medieval hispana y la visión del otro: mudéjares y judíos", en Rodríguez de la Peña, Alejandro, Hacedores de Frontera. Estudios sobre el contexto social de la frontera en la España medieval, Madrid, CEU Ediciones, 2009. 
144. -----------, La creación de identidad en la frontera medieval hispana y la visión del otro: mudéjares y judios, Madrid, CEU Ediciones, 2009.

145. Gil, Juan, "La Historiografía”, en Historia de España Menéndez Pidal, Tomo XI, Madrid, Espasa Calpe, 1995.

146. Glick, Thomas, Islamic and Christian Spain in the Early Middle Ages, Leiden, Koninklijke Brill NV, 2005, p. 8

147. Godoy, Cristina y Josep Vilella, "De la Fides Ghotica a la Ortodoxia Nicena: Inicio de la Teología Política Visigótica”, en González Blanco, Antonio. Antigüedad y Cristianismo, Monografias históricas sobre la Antigüedad Tardía: Los Visigodos, Historia y Civilización. Actas de la Semana Internacional de Estudios Visigóticos. Madrid-Toledo-Alcalá de Henares, 1986.

148. Gómez Redondo, Fernando, "Historiografía medieval. Constantes evolutivas de un género", en Anuario de Estudios Medievales. Vol. 19, 1989, [pp. 3-15].

149. ------------, “La construcción del modelo de Crónica real”, en Fernández Ordóñez, Inés, Alfonso X el Sabio y las crónicas de España, Valladolid, Universidad de Valladolid, Centro para la Edición de los Clásicos Españoles, 2001.

150. González Antón, Luis, España y las Españas, Madrid, Alianza, 1997.

151. González Jiménez, Manuel, "Historia política y estructura de poder. Castilla y León. La Historia medieval en España. Un balance historiográfico (1968 - 1998)”, XXV Semana de Estudios Medievales Estella, 14 a 18 de julio de 1998.

152. ---------, Alfonso X el Sabio. Historia de un reinado, 1252 - 1284, Palencia, Diputación Provincial de Palencia, La Olmeda, 1993.

153. González, Julio, "La Crónica Latina de los Reyes de Castilla", en Homenaje a Don Agustín Millares Carlo, 2 V, Gran Canaria, Caja Insular de Ahorros de Gran Canaria, 1975.

154. ---------, El reino de Castilla en la época de Alfonso VIII, 3 vols., Madrid, Escuela de Estudios Medievales, 1960.

155. --------, Reinado y Diplomas de Fernando III, Córdoba, Publicaciones del Monte de Piedad y Caja de Ahorros de Córdoba, 1983.

156. Goñi Gaztambide, José, Historia de la Bula de Cruzada en España, Vitoria, Editorial del Seminario, 1958. 
157. Gordo Molina, Ángel, “Alfonso VII, sucesión e Imperium. El príncipe cristiano en la Chronica Adefonsi Imperatoris y el diplomatario regio como modelo de virtud. Fuentes cronísticas e imagen del soberano de León”, en Tiempo y Espacio, Año 15, Vol.18. Universidad del Bio-Bio, Chillán, 2007, [pp.115-144], en http://www.ubiobio.cl/miweb/webfile/media/222/Tiempo/2007/ALFONSO\%20VI I,\%20 SUCESI\%C3\%93N\%20E\%20IMPERIUM.pdf.)

158. -----------, “El reinado de la 'indomable' reina Urraca I de León. El mito que hace historia. Fuentes, soberanía, prejuicios y religión”, parte de la investigación patrocinada por el Instituto de Estudios Zamoranos "Florián de Ocampo" titulado: "La Reina Urraca I (1109-1126) La práctica del concepto de Imperium Legionense en la primera mitad del siglo XII".

159. -----------, “Estructuras Regias en el Reino de León. La Preparatio en la Elevación al Trono Imperial de Urraca I y Alfonso VII. Factores diferenciadores y de estabilidad en el gobierno", en Cerda, José Manuel (Editor), El Mundo Medieval, Legado y Alteridad, Santiago de Chile, Universidad Finis Terrae, 2009

160. ----------, “Las intitulaciones y expresiones de la 'Potestas' de la reina Urraca I de León: trasfondo y significado de los vocativos 'Regina' e 'imperatrix' en la primera mitad del siglo XII”, en Intus - legere, Vol. 1, No 9, 2006, [pp. 77-92].

161. ----------, "Papado y monarquía en el reino de León. Las relaciones político religiosas de Gregorio VII y Alfonso VI en el contexto del Imperium Legionense y la implantación de la reforma pontifical en la Península Ibérica", en Studi medievali, Anno 49, Fasc. 2, 2008, [pp.519-559].

162. Gozalbes Cravioto, Enrique, "Reflexiones sobre el concepto Antiguo y Medieval de Frontera", en Toro Ceballos, Francisco y José Rodríguez Molina (Coordinadores), III Estudios de Frontera. Convivencia, Defensa y Comunicación en la Frontera, Jaén, Diputación Provincial de Jaén, 2002

163. Gracía Pardo, Manuela, "El pastor de Las Navas de Tolosa. La realidad y la leyenda", en Toro Ceballos, Francisco y José Rodríguez Molina (Coordinadores), IV Estudios de Frontera, Historia, Tradiciones y leyendas en la Frontera, Jaén, Diputación Provincial de Jaén, 2002. 
164. Granda Gallego, Cristina, "Otra imagen del guerrero cristiano (su valoración positiva en testimonios del Islam)", en En la España Medieval, 8, 1986, [pp. 471480],

165. Grassotti, Hilda, "El deber y el derecho de hacer guerra y paz en León y Castilla", en Cuadernos de Historia de España, N 59-60, 1976, [pp. 221-296].

166. -----------, "Para la historia del botín y de las parias en castilla y León", Cuadernos de Historia de España, $\mathrm{N}^{\circ}$ XXXIX-XL, 1964, [pp. 43-132].

167. ------------, ‘Don Rodrigo Ximénez de Rada, gran señor y hombre de negocios en la Castilla del siglo XIII", en Cuadernos de Historia de España, N 55-56, 1972, [pp. 1-302].

168. Guenée, Bernard, "Historia", en Le Goff, Jacques y Jean-Claude Schmitt (Editores), Diccionario razonado del occidente medieval, Madrid, Akal, 2003.

169. Guglielmi, Nilda y Adeline Rucquoi (Coordinadoras), El discurso político en la Edad Media $=$ Le discours politique au Moyen Age, Buenos Aires, Consejo Nacional de Investigaciones Científicas y Técnicas, Paris, Centre National de la Recherche Scientifique, 1995.

170. Guiance, Ariel, "Morir por la patria, morir por la fe: La ideología de la muerte en la Historia de Rebus Hispaniae", en Cuadernos de Historia de España, LXXIII, Buenos Aires, Instituto de Historia de España, 1991, [pp. 75-104].

171. Guichard, Pierre, "Islam", en Le Goff, Jacques y Jean-Claude Schmitt (Editores), Diccionario razonado, Madrid, Akal, 2003.

172. Heers, Jacques, Historia de la Edad Media, Barcelona, Labor, 1984.

173. ----------, La primera Cruzada, Barcelona, Andrés Bello, 1997.

174. Herbers, Klaus. Política y veneración de santos en la Península Ibérica. Desarrollo del "Santiago Político", Pontevedra, Fundación Cultural Rutas del Románico, 2006.

175. Heusch, Carlos, La caballería castellana en la baja edad media. Textos y contextos, Montpellier, Université de Montpellier III, 2000.

176. Hindley, Geoffrey, Las cruzadas. Peregrinaje armado y guerra santa, Ediciones B, Argentina, 2004. 
177. Hobsbawm, Eric y Terence Ranger (Editores), La invención de la tradición, Barcelona, Crítica, 2002.

178. Homet, Raquel, "Caracteres de la conciencia histórica: los sueños y visiones en la Estoria de España", en En la España Medieval, N²5, 2002, [pp. 85-112].

179. Huici Miranda, Ambrosio, Las grandes batallas de la Reconquista durante las invasiones africanas (Almorávides, Almohades y Benimerines), Madrid, Instituto de Estudios Africanos, CSIC, 1956.

180. Iradiel, Paulino y otros, Historia Medieval de la España Cristiana, Madrid, Ed. Cátedra, 1989.

181. Isla Frez, Amancio, "La construcción de la monarquía en León, siglos X y XI: Historia y Leyes", en Martínez Sopena, Pascual y Ana Rodríguez (Editores), La construcción medieval de la memoria regia, Valencia, Publicacions de la Universitat de València, 2011.

182. --------, "Una historia leonesa, su perfil y sus costuras", en Edad media. Rev. Hist., $\mathrm{N}^{\circ} 12,2011$ [pp. 143-157].

183. ----------, Ejército, Sociedad y Política en la Península Ibérica entre los siglos VII y XI, CSIC., Madrid, 2010.

184. Izquierdo Benito, Ricardo y Francisco Ruiz Gómez, Las órdenes militares en la Península Ibérica, volumen I. Edad Media, Cuenca, Ediciones de la Universidad de Castilla-La Mancha, Cortes de Castilla-La Mancha, 2000.

185. Jiménez Vicente, María del Carmen, La razón de Estado en Alfonso X el Sabio. Paulo Orosio en la Primera Crónica General. Salamanca, Universidad de Valladolid, 1993.

186. Kakarieka, Julios, "Los orígenes de la doctrina de la guerra justa. Cicerón y la tradición romana", en Arbea, Antonio, Giuseppina Grammatico y Héctor Herrera Cajas, Cicerón, un alma ardiente, Santiago de Chile, Universidad Metropolitana de Ciencias de la Educación, Centro de Estudios Clásicos, 1994.

187. Kantorowicz, Ernst H., Los dos cuerpos del rey: un estudio de teología política medieval, Madrid, Alianza, 1985.

188. Keegan, John, Historia de la guerra, Barcelona, Planeta, 1995. 
189. Keen, Maurice (ed.), Historia de la Guerra en la Edad Media, Madrid, A. Machado Libros, 2005.

190. ------, La caballería, Madrid, Alianza, 2001.

191. Klinka, Emmanuelle, "Chronica naiarensis: de la traición a la exaltación”, en $e$ Spania [En línea], 7 / juin 2009, http://e-spania.revues.org/18934; DOI: 10.4000/espania.18934.

192. ----------, "Protagonismos y relación historiográfica en la Chronica Adefonsi Imperatoris", en e-Spania [En línea], 15 | juin 2013, Puesto en línea el 21 junio 2013. URL: http://e-spania.revues.org/22279; DOI: 10.4000/e-spania.22279.

193. Lacarra de Miguel, José María, “Acerca de la atracción de pobladores en las ciudades fronterizas de la España cristiana (siglos XI-XII)", en En la España Medieval, № 2, 1982 Madrid, [pp. 485-498].

194. Lacarra, María Eugenia, El poema de Mio Cid: realidad histórica e ideología, Madrid, Ediciones José Porrúa Turanzas, 1980.

195. Ladero Quesada, Miguel Ángel, “Comunicación y propaganda de creencias, opiniones e ideas en la Europa de los siglos XIV y XV", en Revista de la Universidad Complutense de Madrid, N 3, 1981, [pp. 193-211].

196. ------------, “La financiación de la guerra por la Monarquía castellana (12521515)", en Revista de Historia Militar, Número Extraordinario 3, 2007, [pp. 1338].

197. -----------, "Patria, nación y Estado en la Edad Media", en Revista de Historia Militar, Número Extraordinario 1, 2005, [pp. 33-58].

198. Le Goff, Jacques, "Rey", en Le Goff, Jacques y Jean-Claude Schmitt (Editores), Diccionario razonado del occidente medieval, Madrid, Akal, 2003.

199. ------------, La civilización del occidente medieval, Paidos, Barcelona, 1999.

200. -----------, Lo maravilloso y lo cotidiano en el Occidente medieval, Barcelona, Gedisa, 2002.

201. Le Morvan, Gaël, "Reinos e imperio: la Historia legionensis (llamada silensis) y la reivindicación leonesa de la herencia visigótica", en e-Spania [En ligne], 14 | décembre 2012, mis en ligne le 13 septembre 2012, URL: http://espania.revues.org/21681; DOI: 10.4000/e-spania.21681. 
202. Lida de Malkiel, María Rosa, La Idea de la Fama en la Edad Media Castellana, Madrid, Fondo de Cultura Económica, 1952.

203. Liddell Hart, Basil, La estrategia de aproximación indirecta. Las guerras decisivas en la historia, Barcelona, Iberia - Joaquín Gil, 1946.

204. Linehan, Peter, "Fechas y sospechas sobre Lucas de Tuy", en Anuario de Estudios Medievales. №32, 2002, [pp. 19-38].

205. ----------, “La documentación pontificia de Honorio III (1216-1227): unas adiciones a la Regesta de D. Demetrio Mansilla", en Anthologica Annua, 16, 1968, [pp. 385-408].

206. -----------, “Lucas de Tuy, Rodrigo Jiménez de Rada y las Historias alfonsíes”, en Fernández Ordóñez, Inés, Alfonso X el Sabio y las crónicas de España, Valladolid, Universidad de Valladolid, Centro para la Edición de los Clásicos Españoles, 2001.

207. ----------, España, 1157-1300. Una sociedad desorganizada por la guerra, Historia de España, VII, Barcelona, Crítica, 2008.

208. -----------, Historia e historiadores de la España Medieval, Salamanca, Universidad de Salamanca, 2011.

209. -----------, History and the historians of medieval Spain, Oxford, Clarendon Press, 1993.

210. -----------, La Iglesia en León a mediados del Siglo XIII, León, Centro de Estudios e Investigación "San Isidoro", 1975.

211. ---------, La Iglesia Española y el Papado en el S. XIII, Salamanca, Universidad Pontificia de Salamanca, 1975.

212. -----------, Past and present in Medieval Spain, Hampshire, Variorum, 1992.

213. Llorca, Bernardino, Historia de la Iglesia Católica: en sus cuatro grandes edades: Antigua, Media, Nueva, Moderna. II, Edad Media (800-1303): la cristiandad en el mundo europeo y feudal, Madrid, Editorial Católica, 1963.

214. Lomax, Derek, La Reconquista, Barcelona, Crítica, 1984.

215. López Noguero, Fernando, "El análisis de contenido como método de investigación”, en Revista de Educación, 4, 2002, [pp. 167-179]. 
216. Lourie. "Society organizad for war: medieval Spain", en Past and present, $\mathrm{N}^{\circ} 35$, 1966, [pp. 54-76].

217. Lumbreras Valiente, Pedro, Los fueros municipales de Cáceres su derecho publico, Cáceres, Ayuntamiento de Cáceres, 1974.

218. Mackay, Angus, La España de la Edad Media: Desde la Frontera hasta el Imperio (1000-1500), Madrid, Cátedra, 2000.

219. Madero, Marta, Manos Violentas, Palabras Vedadas. La injuria en Castilla y León (siglos XIII-XV), Madrid, Taurus, 1992.

220. Maíllo Salgado, Felipe, “De la formación social tributaria ¿y mercantil? Andalusí”, en Anales de Historia antigua, medieval y moderna, № 35-36, 2003, Universidad de Buenos Aires, [pp. 175-184].

221. ---------, "La Guerra santa según el derecho malikí. Su preceptiva. Su influencia en el derecho de las comunidades cristianas del medioevo hispano", en Stvdia Historica $H^{a}$ Medieval, Vol. I, No 2, 1983, [pp. 29-66].

222. -----------, Un análisis del discurso histórico: La ideología. (Lección teóricometodológica), Salamanca, Imprenta Comercial Salmantina, 1980.

223. Mantran, Robert, La expansión musulmana (siglos VII al XI), Barcelona, Editorial Labor, 1982.

224. Maravall, José Antonio, "La idea de Reconquista en España durante la Edad Media", en Arbor: Ciencia, pensamiento y cultura, 28, 1954, [pp. 1-37].

225. ----------, El concepto de España en la Edad Media, Madrid, Centro de Estudios Constitucionales, 1997.

226. -----------, Estudios de Historia del Pensamiento Español, Madrid, Ediciones Cultura Hispánica, 1983.

227. Marín, José, Cruzada, Guerra santa y Yihad. La Edad Media y Nosotros, Valparaíso, Instituto de Historia, Pontificia Universidad Católica de Valparaíso, 2003.

228. Márquez Villanueva, Francisco, Santiago: trayectoria de un mito, Barcelona, Bellaterra, 2004. 
229. Martín Martín, José Luis, “Algunas prácticas clericales en ámbitos fronterizos”, en Iglesia y frontera. V Jornadas de Historia en la Abadía. Homenaje a José Rodríguez Molina, Alcalá la Real, Diputación de Jaén, Servicio de Publicaciones, 2005.

230. ------------, "Espacios eclesiásticos y construcción de fronteras en la Península Ibérica, siglos IX-XII”, en Domínguez Sánchez, Santiago y Klaus Herbers (coords.), Roma y la península Ibérica en la Alta Edad Media la construcción de espacios, normas y redes de relación, León, Universidad de León, 2009.

231. ---------, "La Frontera como entorno legendario", en Toro Ceballos, Francisco y José Rodríguez Molina (Coordinadores), IV Estudios de Frontera. Historia, Tradiciones y leyendas en la Frontera. Jaén, Diputación Provincial de Jaén, 2002.

232. -----------, "Los fueros de la Transierra posibilidades y limitaciones en la utilización de una fuente histórica", en En la España medieval, № 2, 1982 (Ejemplar dedicado a: En memoria de Salvador de Moxó (I)), [pp. 691-705]

233. -----------, "Los Obispos de Extremadura en la Edad Media", en Revista de estudios extremeños, Vol. 47, № 1, 1991. [pp. 67-98].

234. Martin, Georges, "El modelo historiográfico alfonsí y sus antecedentes", en Fernández Ordóñez, Inés, Alfonso X el Sabio y las crónicas de España, Valladolid, Universidad de Valladolid, Centro para la Edición de los Clásicos Españoles, 2001.

235. -----------, "La Historia legionensis (llamada silensis) como memoria identitaria de un reino y como autobiografía", en e-Spania [En ligne], 14 | décembre 2012, mis en ligne le 13 septembre 2012, URL: http://e-spania.revues.org/21740; DOI: 10.4000/e-spania.21740.

236. -----------, “La invención de Castilla. Rodrigo Jiménez de Rada, Historia de rebus Hispaniae, V. Identidad patria y mentalidades políticas", en Séminaire interdisciplinaire de recherches sur'l Espagne medievales (SIREM), 2006.

237. -----------, "Linaje y legitimidad en la historiografía regia hispana de los siglos IX al XIII”, e-Spania [En ligne], 11 | juin 2011, mis en ligne le 18 mai 2011, consulté le 11 octobre 2014. URL: http://e-spania.revues.org/20335; DOI: 10.4000/espania. 20335 
238. Martín, José Carlos, "El corpus hagiográfico latino en torno a la figura de Isidoro de Sevilla en la Hispania tardoantigua y medieval (SS. VII-XIII)", en Veleria. Revista de Prehistoria, Historia Antigua, Arqueología y Filología Clásicas, Vitoria, Universidad del País Vasco, 2005, [pp. 187-228].

239. Martín, José Luís, "La pérdida y reconquista de España a la luz de las crónicas y del romancero", en Actas del III Curso de Cultura Medieval. Repoblación y reconquista, Centro de Estudios Románicos Aguilar del Campoo, septiembre de 1991.

240. ------------, "Los milagros de la Virgen: Versión latina y romance", en Espacio, Tiempo y Forma, Serie III, H. Medieval, T. 16, 2003, [pp. 177-213].

241. -----------, "Reconquista y cruzada", en Studia Zamorensia. Segunda Etapa, Volumen III, UNED, Zamora 1996, [pp. 215-241].

242. ------------, La Península en la Edad Media, Barcelona, Teide, 1976.

243. Martínez Díez, Gonzalo, "Las capitulaciones de Fernando III con las ciudades musulmanas conquistadas", en Archivo Hispalense Revista Histórica, Literaria y Artística, 2.a Época, Año 1994, Tomo XXXVII, Núms. 234-235-236, [pp. 267286].

244. Martínez Martínez, Julio Gerardo: Acerca de las guerras y la paz. Los ejércitos, las estrategias y las armas, según el Libro de las Siete partidas, Cáceres, Universidad de Extremadura, 1984.

245. Martínez, Pascual, "Los consejos, la tradición foral y la memoria regia en Castilla y León”, en Estepa Díez, Carlos y otros, Poder real y sociedad: estudios sobre el reinado de Alfonso VIII (1158-1214), Universidad de León, León, 2011.

246. Melo Carrasco, Diego, "Las treguas entre Granada y Castilla durante los siglos XIII a XV”, en Revista de Estudios Históricos-Jurídicos, XXXIV, 2012, Pontificia Universidad Católica de Valparaíso, Valparaíso, [pp. 237-275].

247. Menéndez Pidal, Ramón, Los Españoles en la Historia, Madrid, Espasa Calpe, 1991.

248. Mínguez, José María, "Pervivencia y transformaciones de la concepción y practica del poder en el reino de León (Siglos X y XII)", en Studia historica. Historia medieval, $\mathrm{N}^{\circ} 25,2007$, [pp. 15-65] 
249. , Alfonso VI. Poder, expansión y reorganización interior, Donostia-San Sebastian, Nerea, 2000.

250. La España de los siglos VI al XIII: Guerra Expansión y Trasformaciones. En busca de una frágil unidad, Donostia, Nerea, 2008.

251. -----------, La Reconquista, España, Historia 16, 1989.

252. Mitre Fernández, Emilio, “¿Un sentimiento de comunidad hispánica? La historiografía peninsular", en Historia de España Menéndez Pidal, Tomo XVI, Madrid, Espasa Calpe, 1994.

253. ------------, “Alfonso X: historiografía y tradiciones compilatorias del medievo europeo", en III Curso de Cultura Medieval. Repoblación y reconquista, Centro de Estudios Románicos Aguilar del Campoo, 1991.

254. ---------, "La historiografía sobre la Edad Media", en Andrés-Gallego, J. (Coordinador), Historia de la historiografía española, Madrid, Encuentro, 1999.

255. -----------, "Reflexiones sobre noción de frontera tras la conquista de Toledo (1085): Fronteras reales y fronteras mentales", en Cuadernos de Historia de España, № 69, 1987, [pp. 197-216].

256. -----------, Alvira Cabrer, Martín, “Ideología y guerra en los reinos de la España Medieval", en Revista de Historia Militar, 2001, No 1 Extraordinario, [pp. 291334].

257. ---------, Historia y pensamiento histórico: estudio y antología, Madrid, Cátedra, 1997.

258. ----------, Historiografía y mentalidades históricas en la Europa Medieval, Madrid, Universidad Complutense, 1982.

259. ----------, Iglesia y vida religiosa en la Edad Media, Madrid, Istmo.

260. ------------, Iglesia, herejía y vida política en la Europa Medieval, Madrid, Biblioteca de Autores Cristianos, 2007.

261. , La España medieval, Madrid, Istmo, 1999.

262. ----------, La España medieval: Sociedades, estados, culturas, Madrid, Istmo, 1984. 
263. Molina, Luis y Alberto Montaner, "El Cantar de Mio Cid y su supuesta autoría árabe”, en Al-Qantara, XXXI, 1, 2010, [pp. 311-323].

264. Mollero García, Jesús M., "La Frontera Castellana en tiempos de Alfonso VII: Nobleza y organización del espacio", en II Estudios de Frontera. Actividad y Vida en la Frontera, Alcalá la Real, Diputación Provincial de Jaén, 1997.

265. Monsalvo, José María, "Notas sobre los primeros espacios de la Reconquista (Primera Mitad S. VIII) en la cronística cristiana pleno medieval: De la Historia Silense a la Estoria de España”, en Mínguez Fernández, José M. y Gregorio del ser Quijano (Editores), La Península en la Edad Media treinta años después. Estudios dedicados a José Luis Martín, Salamanca, Ediciones Universidad de Salamanca, 2006.

266. Montgomery Watt, W, Historia de la España islámica, Madrid, Alianza, 2007.

267. Morán, Remedios y Eduardo Fuentes, "Ordenamiento, legitimación y potestad normativa: Justicia y moneda", en Nieto Soria, José Manuel, Orígenes de la monarquía hispánica, propaganda y legitimación (ca. 1400-1520), Madrid, Dykinson, 1999.

268. Muñoz Fernández, Ángela, “Cultos, Devociones y Advocaciones Religiosas en los Orígenes de la Organización Eclesiástica Cordobesa (siglos XIII-XIV)”, en Emilio Cabrera. Andalucía entre Oriente y Occidente (1236-1492), Actas del V coloquio internacional de historia medieval de Andalucía, Excma. Diputación Provincial de Córdoba, 1988.

269. Nieto Soria, José Manuel, "Del rey oculto al rey exhibido: Un síntoma de las trasformaciones políticas en la castilla bajo medieval”, en Medievalismo, 2, 1992 [pp. 5-27].

270. -----------, “Ideología y poder monárquico en la Península”, en La Historia medieval en España. Un balance historiográfico (1968 - 1998) XXV Semana de Estudios Medievales Estella, 14 a 18 de julio de 1998, Pamplona Gobierno de Navarra, Departamento de Educación y Cultura, 1999.

271. -------------, “Imágenes religiosas del rey y del poder real en la Castilla del siglo XIII”, En la España Medieval, Tomo V, Ed. Universidad Complutense, Madrid, 1986. 
272. "Imágenes religiosas del rey y del poder real en la Castilla del siglo XIII”, en La España Medieval, Tomo V, Ed. Universidad Complutense, Madrid, 1986.

273. ------------, “La ideología política bajo medieval en la historiografía española”, en Hispania, revista española de historia, L/2, № 175, 1990, [pp. 667-681].

274. -----------, “Origen divino, espíritu laico y poder real en la Castilla del siglo XIII”, en Anuario de Estudios Medievales, Vol., 27/1, 1997, [pp. 43-101].

275. -----------, “Religión y política en la Castilla bajomedieval: Algunas perspectivas de análisis en torno al poder real", en Cuadernos de Historia de España, $\mathrm{N}^{\circ} 76$, 2000, [pp. 99-120].

276. -----------, Fundamentos Ideológicos del Poder Real en Castilla (Siglos XIII-XVI), Madrid, Eudema, 1988.

277. ------------, Propaganda y opinión pública en la historia, Valladolid, Universidad de Valladolid, 2007.

278. ------------, Sancho IV 1284-1295, Palencia, La Olmeda, 1994.

279. Nogales Rincón, David, "Los espejos de príncipe en Castilla (Siglos XIII-XV): Un modelo literario de la realeza bajo medieval", en Medievalismo, 16, 2006, [pp. 939].

280. Noth, Albrecht, Heiliger Krieg und Heiliger Kampf in Islam und Chistetum. Breiträge zur Vorgeschchte und Geschichte der Kreuzzüge, Bonn, 1966.

281. O'Callaghan, Joseph, Las Cortes de Castilla y León. 1188-1350, Valladolid, Ámbito, Cortes de Castilla y León, 1989.

282. ------------, Reconquest and Crusade in Medieval Spain, Philadelphia, University of Pennsylvania Press, 2003.

283. Oliver Pérez, Dolores, El Cantar de Mio Cid: Génesis y autoria árabe, Almería, Fundación Ibn Tufayl de Estudios Árabes, 2008.

284. Orcástegui, Carmen y Esteban Sarasa, La historia en la Edad Media. Historiografia e historiadores en Europa Occidental: siglos V-XIII, Madrid, Cátedra, 1991 
285. Orlandis, José, "Legados de la España Visigótica”, en Nuño González, Jaime (Coordinador), II Curso de Cultura Medieval: Alfonso VIII y su Época. Centro de Estudios del Románico, Aguilar del Campoo, 1990.

286. Ortega, José Manuel y Francisco Javier Díaz González (Compiladores), Vae Victis: Cautivos y prisioneros en la Edad Media hispánica, Alcalá de Henares, Universidad de Alcalá, 2012.

287. Ortega, Juan Fernando, "La paz y la guerra en el pensamiento agustiniano", en Revista Española de Derecho Canónico. Enero-abril 1965. Vol. XX. Num. 58, [pp. 5-35].

288. Palacios Martín, Bonifacio, "Alfonso VIII y su política de frontera en Extremadura", en Anuario de Estudios Medievales, Vol. 19, 1989, [pp. 155-167].

289. ------------, "Las Milicias de Extremadura y la Conquista de Andalucía”, en Cabrera, Emilio, Andalucía entre Oriente y Occidente (1236-1492), Actas del V coloquio internacional de historia medieval de Andalucía, Excma. Diputación Provincial de Córdoba, 1988.

290. Palacios Ontalva, Santiago, "Fortalezas y Guerra Santa. Un estudio comparado de algunos aspectos de su funcionalidad en las fronteras de la Cristiandad", en Espacio, Tiempo y Forma, Serie III, H. Medieval, t. 14, 2001, [pp. 193-217].

291. Palacios Ontalva, Santiago, "Imagen e identidad del musulmán en tiempos de Fernando III. El enemigo desde la perspectiva cruzada”, en De Ayala Martínez, Carlos y Martín Ríos Saloma (Editores), Fernando III, tiempo de cruzada, Madrid, Silex, 2012.

292. Pallares, María del Carmen y Ermelindo Portela, La Reina Urraca, Donostia, Editorial Nerea, 2006.

293. Palomeque Torres, Antonio, "Contribución al estudio del ejército en los estados de la Reconquista", en Anuario de historia del derecho español, Tomo XV, Madrid, 1944, [pp. 205-351].

294. Paniagua Lortau, Ana Belén, "Consideraciones sobre la imagen de los musulmanes en la Gran Crónica de Alfonso XI", en Toro Ceballos, Francisco y José Rodríguez Molina (Coordinadores), IV Estudios de Frontera, Historia, Tradiciones y leyendas en la Frontera, Jaén, Diputación Provincial de Jaén, 2002. 
295. Partner, Peter, El Dios de las batallas: Las guerras santas desde la Biblia hasta nuestros días, Madrid, Anaya, 2002.

296. Pascua Echegaray, Ester, "Hacia la formación política de la monarquía medieval: Las relaciones entre la monarquía y la Iglesia castellanoleonesa en el reinado de Alfonso VII", en Hispania: Revista Española de Historia, Vol. 49, ํ172, 1989, [pp. 397-441].

297. ----------, Guerra y pacto en el siglo XII. La consolidación de un sistema de reinos en Europa Occidental, Madrid, Biblioteca de Historia: 31, CSIC., 1996.

298. Penelas, Mayte, "Introducción a la doctrina malikí sobre el martirio", en Fierro, Maribel (Editora), De muerte violenta. Política, religión y Violencia en el alAndalus, Madrid, CSIC, 2004.

299. Pérez de Tudela Velasco, María Isabel, "El concepto de pecado como arma de control político: el matrimonio de Alfonso IX de León y Berenguella de Castilla”, en Carrasco Manchado, Ana Isabel y María del Pilar Rábade Obradó, (Coordinadores), Pecar en la Edad Media Silex, Madrid, 2008.

300. ------------, "La consideración ética de la guerra y el uso de la violencia en la España Medieval”, en En La España Medieval, 2007, vol. 30 7-25, [pp. 7-25].

301. Pernoud, Régine, Los Templarios, Madrid, Siruela, 2005.

302. Piñuel Raigada, José Luis, "Epistemología, metodología y técnicas del análisis de contenido", en Estudios de Sociolingüística, 3(1), 2002, [pp. 1-42].

303. Pizarroso Quintero, Alejandro, Historia de la Propaganda, notas para un estudio de la propaganda política y de guerra, Madrid, Eudema, 1993.

304. Porras Arboledas, Pedro Andrés, "Derecho a Guerra y paz en la España medieval", en Revista de Historia Militar, 2001, № Extraordinario, Instituto de Historia y Cultura militar, [pp. 335-359].

305. Porrinas González, David, “Masacre o Clemencia? La conducta del Cid hacia los enemigos vencidos", en Fierro, Maribel y Francisco García Fitz (Editores), El cuerpo derrotado: Cómo trataban musulmanes y cristianos a los enemigos vencidos (Península Ibérica, SS. VIII-XIII), Madrid, CSIC., 2008.

306. ----------- "La caballería y la guerra en la Edad Media castellano-leonesa: El libro del caballero Zifar y su contexto”, En Medievalismo 15, 2005, [pp. 39-70]. 
307. Powers, James F., A society organized for war. The Iberian Municipal Militias in the Central Middle Ages, 1000-1284, University of California Press, 1999.

308. Procter, Evelyn, Alfonso X of Castile, patron of literature and learning, Oxford, Oxford University Press, 1941.

309. ----------, Curia y Cortes en Castilla y León 1072-1295, Madrid, Cátedra, 1988.

310. Ratzinger, Joseph, Benedicto XVI, Jesús de Nazaret, Buenos Aires, Planeta, 2010.

311. Recuero Astray, Manuel José, Alfonso VII (1126-1157), Burgos, Serie de los Reyes de León y Castilla, Vol. XIX, 2004.

312. -----------, Orígenes de la Reconquista en el occidente peninsular, Coruña, Universidade da Coruña, 1996.

313. Redondo Jarillo, María Cristina, "La Confección de la Figura del Rey guerrero en las Crónicas Asturleonesas (Siglos VIII-XII)” en Miscelánea Medieval Murciana, 2008, XXXII, [pp. 131-141].

314. Reglero de la Fuente, Carlos, "Restauración diocesana y memoria regia en León y Castilla”, en Martínez Sopena, Pascual y Ana Rodríguez (Editores), La construcción medieval de la memoria regia, Valencia, Publicacions de la Universitat de València, 2011.

315. Reilly, Bernard, Cristianos y Musulmanes, 1031-1157, Historia de España, VI, Barcelona, Crítica, 1992.

316. ----------, El Reino de León y Castilla bajo el Rey Alfonso VI, 1065-1109, Toledo, Instituto Provincial de Investigaciones y Estudios Toledanos, 1987.

317. Reuter, Timothy, Warriors and churchmen in the high middle ages, London and Rio Grande, Hambledon Press, 1992.

318. Riano Rodríguez, Timoteo, "Propósito de Pero Abat al escribir el Cantar de Mío Cid: Motivaciones geopolíticas", en Actas del Congreso Internacional del Cid, poema e historia (12-16 de julio, 1999).

319. Riley-Smith, Jonathan, ¿Qué fueron las cruzadas?, Barcelona, Acantilado, 2012.

320. --------, The first crusade and the idea of crusading, Philadelphia, University of Pennsylvania Press, 1997. 
321. The first crusaders: 1095-1131, Cambridge, Cambridge University press, 1997.

322. Ríos Saloma, Martín, "Usos políticos e historiográficos del concepto de Reconquista", en Anales de la Universidad de Alicante, Historia Medieval, $\mathrm{N}^{\circ} 17$, 2011, [pp. 41-65].

323. Rodríguez de la Peña, Manuel Alejandro, “Añadiendo muertos a los muertos: el destino de los vencidos en la frontera al-Andalus en la cronística latina pleno medieval", presente en la obra colectiva Hacedores de Frontera. Estudios sobre el contexto social de la frontera en la España Medieval, Madrid, CEU Ediciones, 2009.

324. ----------, “Ideología política y crónicas monásticas: La concepción cluniacense de la realeza en la España del siglo XII", Anuario de Estudios Medievales, 30/2, 2000, [pp. 681-734].

325. ---------, "Rex institutor scholarum: La dimensión sapiencial de la realeza en la cronística de León-Castilla y los orígenes de la Universidad de Palencia”, en Hispania Sacra, LXII, 126, 2010, [pp. 491-512].

326. ----------, Los Reyes Sabios. Cultura y poder en la Antigüedad Tardía y la Alta Edad Media, Madrid, Actas, 2008.

327. Rodríguez García, José Manuel, “Cabezas cortadas en Castilla - León, 11001350”, en Fierro, Maribel y Francisco García Fitz (Editores), El cuerpo derrotado: Cómo trataban musulmanes y cristianos a los enemigos vencidos (Península Ibérica, SS. VIII-XIII), Madrid, CSIC., 2008.

328. -----------, “Cruzados y fronterizos. Discusión sobre el carácter cruzado de la guerra en la frontera, 1214-1314”, en Toro Ceballos, Francisco y José Rodríguez Molina (Coordinadores), III Estudios de Frontera. Convivencia, Defensa y Comunicación en la Frontera, Alcalá la Real, Diputación Provincial de Jaén, 2000.

329. --------, "El Yihad: Visión y respuesta andalusí a las campañas cristianas en la época de Alfonso X, el sabio”, en Medievalismo, 2000, 10, [pp. 69-98].

330. ----------, "Fernando III y sus campañas en el contexto cruzado europeo, 12171252”, en Archivo Hispalense Revista Histórica, Literaria y Artística. $2^{\mathrm{a}}$ Época, Año 1994. Tomo LXXVII. Núms. 234-235-236, [pp. 205-217]. 
331. , Idea y realidad de cruzada en tiempos de Alfonso X El sabio (12521284), Tesis doctoral, Salamanca 2010, pp. 124-126: http://gredos.usal.es/jspui/bitstream/10366/76558/2/DHMMC_Rodriguez_Garcia_ JM_Idea_y_realidad_2.pdf

332. Rodríguez Hernández, Juan Pedro, "El Diablo en 'Los Milagros de Nuestra Señora' de Gonzalo de Berceo", en Espacio, Tiempo y Forma, Serie III, H/ Medieval, T. 17, 2004, [pp. 519-532].

333. Rodríguez López, Ana, “De rebus Hispaniae frente a la Crónica latina de los reyes de Castilla: virtudes regias y reciprocidad política en Castilla y León en la primera mitad del siglo XIII", en Cahiers de linguistique et de civilisation hispaniques medievales, $\mathrm{N}^{\circ} 26,2003$, [pp. 133-150].

334. -----------, "La política eclesiástica de la monarquía castellano-leonesa durante el reinado de Fernando III (1217-1252)", en Hispania Revista Española de Historia, $\mathrm{N}^{\circ} 168$, Madrid, 1988, [pp. 7-48].

335. -----------, "La preciosa transmisión, memoria y curia regia en Castilla en la primera mitad del siglo XIII”, en Estepa Díez, Carlos y otros, Poder real y sociedad: estudios sobre el reinado de Alfonso VIII (1158-1214), Universidad de León, León, 2011.

336. ------------, “Légitimation Royale Et Discours Sur La Croisade En Castille Aux XII Et XIII Siecles”, en Journal des savants, 2004, N¹, [pp. 129-163].

337. ----------, "Memoria y curia regia en Castilla en la primera mitad del siglo XIII", en Martínez Sopena, Pascual y Ana Rodríguez (Editores), La construcción medieval de la memoria regia, Valencia, Publicacions de la Universitat de València, 2011.

338. ------------, “Modelos de legitimidad política en la Chronica regum Castellae de Juan de Osma”, en e-Spania [En línea], 2 | décembre 2006, Puesto en línea el 25 junio 2007, URL: http://e-spania.revues.org/433; DOI: 10.4000/e-spania.433.

339. -----------, “Sucesión regia y legitimidad política en Castilla en los siglos XII y XIII. Algunas consideraciones sobre el relato de las crónicas latinas castellanoleonesas”, en Alfonso, Isabel, Julio Escalona y Georges Martin (Coordinadores), Lucha Política. Condena y legitimación en la España medieval, Annexes des Cahiers de linguistique et de civilisation hispanique medievales, Vol. 16, 2004. 
340. Rodríguez Molina, José, “Alcalá la Real. Comunicación, Defensa y Convivencia en la Frontera", en Toro Ceballos, Francisco y José Rodríguez Molina (Coordinadores), III Estudios de Frontera. Convivencia, Defensa y Comunicación en la Frontera, Alcalá la Real, Diputación Provincial de Jaén, 2000.

341. -----------, "Historia, tradiciones y leyendas en la frontera", en Toro Ceballos, Francisco y José Rodríguez Molina (Coordinadores), IV Estudios de Frontera, Historia, Tradiciones y leyendas en la Frontera, Jaén, Diputación Provincial de Jaén, 2002.

342. ----------, "La Frontera de Granada, siglos XIII-XV”, en Toro Ceballos, Francisco y José Rodríguez Molina (Coordinadores), III Estudios de Frontera. Convivencia, Defensa y Comunicación en la Frontera, Alcalá la Real, Diputación Provincial de Jaén, 2000.

343. -----------, "Santos Guerreros en la Frontera”, en Toro Ceballos, Francisco y José Rodríguez Molina (Coordinadores), IV Estudios de Frontera, Historia, Tradiciones y leyendas en la Frontera, Jaén, Diputación Provincial de Jaén, 2002.

344. Rodríguez Velasco, Jesús D., "La historia como base argumentativa de la literatura ético-política en Europa, ca. 1100-1350”, en Epos. Revista de Filología. 12, 1996. [pp. 177-205].

345. Rojas Donat, Luis, Orígenes Históricos del Papado, Chillan, Universidad del BíoBío, 2006.

346. Rousset, Paul, Historie d'une idéologie. La Croisade, Lausanne, 1983.

347. -----------, Les origins et les caracteres de la première croisade, Neuchatel, 1945.

348. Rubio Hernández, Rogelio, Antropología: Religión, mito y ritual, Madrid, Universidad Nacional de Educación a Distancia, 1988.

349. Rucquoi, Adeline y Hugo Bizzarri, "Los Espejos de Príncipes en Castilla: entre Oriente y Occidente", en Cuadernos de Historia de España, LXXIX, 2005, [pp.7$30]$.

350. -----------, "El Rey Sabio: Cultura y poder en la monarquía medieval castellana", en III Curso de Cultura Medieval, Repoblación y Reconquista, Aguilar de Campoo, Centro de Estudios del Románico, 1993.

351. Runciman, Steven, Historia de las Cruzadas, Madrid, Alianza, 1994. 
352. Russell, Frederick, The Just War in the Middle Ages, Cambridge, 1975.

353. Sánchez Alonso, B., Historia de la historiografia española. Tomo I. Hasta la publicación de la Crónica de Ocampo (...-1543), Madrid, Consejo Superior de Investigaciones científicas, 1947.

354. Sánchez Prieto, Ana Belén, Guerra y guerreros en España según las fuentes canónicas de la Edad Media, Madrid, Servicio de Publicaciones del E.M.E., 1990.

355. Sánchez Salor, Eustaquio, "El Providencialismo en la Historiografía CristianoVisigótica en España", en Anuario de Estudios Filológicos V Universidad de Extremadura, Cáceres, 1982, [pp. 179-192].

356. Sánchez, Tomas Antonio, Poetas castellanos anteriores al siglo XV, Madrid, Biblioteca de Autores Españoles, Atlas, 1966.

357. Sánchez-Albornoz, Claudio, España, un Enigma Histórico, Tomo I, Buenos Aires, Sudamericana, 1971.

358. --------, Investigaciones sobre historiografia hispana medieval (siglos VIII al XII), Buenos Aires, Instituto de Historia de España, 1967.

359. Santiago-Otero, Horacio, La Biblia en la península ibérica durante la Edad Media (siglos XII-XV): el texto y su interpretación, Coimbra, Arquivo da Universidade de Coimbra, 2001.

360. Schmitt, Jean-Claude, "Ritos", en Le Goff, Jacques y Jean-Claude Schmitt (Editores), Diccionario razonado del occidente medieval, Madrid, Akal, 2003.

361. Simon, Cristopher, Riley-Smith, Jonathan, y Marie-Loise Jeanetta (Editores), The Crusades: Idea and Reality 1095-1274, Londres, 1981.

362. Sirantoine, Hélène, "La Cancillería regia en época de Fernando III: Ideología, discurso y práctica", en De Ayala Martínez, Carlos y Martín Ríos Saloma (Editores), Fernando III, tiempo de cruzada, Madrid, Silex, 2012.

363. Sot, Michel, "Peregrinaciones", en Le Goff, Jacques y Jean-Claude Schmitt (Editores), Diccionario razonado del occidente medieval, Madrid, Akal, 2003.

364. Soto Rábanos, José María, "Reflexiones sobre el discurso cristiano a judíos y musulmanes en los sínodos castellanos, siglos XIII-XV”, en IV Jornadas de Historia en la Abadía de Alcalá la Real, Diputación provincial de Jaén, Jaén, 2003. 
365. Suárez Fernández, Luis, "Los fundamentos medievales de la nación española”, en Benito Ruano, Eloy (Coordinador), Tópicos y realidades de la Edad Media, III, Madrid, Real Academia de la Historia, 2000-2002.

366. ----------, "Santiago: Camino y «Matamoros»", en Benito Ruano, Eloy (Coordinador), Tópicos y realidades de la Edad Media, II, Madrid, Real Academia de la Historia, 2002.

367. Tolan, John, Sarracenos. El Islam en la imaginación medieval europea, Valencia, Universitat de Vàlencia, 2007.

368. Torres Sevilla, Margarita, "La propaganda del poder y sus técnicas en las crónicas leonesas y castellanas (Siglos IX-XIII)”, en Aragón en la Historia, N 18, 2004, [pp. 57-82].

369. Torró, Joseph, "De Bona Guerra. El ambiguo estatuto del cautivo musulmán en los países de la corona de Aragón (Siglos XII-XIII)", en Fierro, Maribel y Francisco García Fitz (Editores), El cuerpo derrotado: Cómo trataban musulmanes y cristianos a los enemigos vencidos (Península Ibérica, SS. VIIIXIII), Madrid, CSIC., 2008.

370. Toynbee, Arnold, Guerra y Civilización, Buenos Aires, Alianza, 1952.

371. Tuliani, Mauricio, "La idea de Reconquista en un manuscrito del la Crónica General de Alfonso X el sabio", en Studia Historica. Historia Medieval. Vol. 12, 1994, [pp. 3-23].

372. Ullmann, Walter, Historia del pensamiento político en la Edad Media, Barcelona, Ariel, 2006.

373. Vaca Lorenzo, Ángel, "La guerra en la historia", Décimas Jornadas de Estudios Históricos, organizadas por el departamento de Historia Medieval, Moderna y Contemporánea, Universidad de Salamanca, Salamanca, 1999.

374. Valdeón Baruque, Julio, La Reconquista. El concepto de España: unidad y diversidad, Madrid, Espasa, 2006.

375. Vallvé Bermejo, Joaquín, "El tiempo de los moros", en Benito Ruano, Eloy (Coordinador), Tópicos y realidades de la Edad Media, III, Madrid, Real Academia de la Historia, 2000-2002.

376. Vara Thorbeck, Carlos, El lunes de Las Navas, Jaén, Universidad de Jaén, 1999. 
377. Villacañas Berlanga, José Luis, La Formación de los Reinos Hispánicos, España, Ed. Espasa Calpe, 2006.

378. Villar García, Luis Miguel, La Extremadura Castellano-Leonesa, guerreros, clérigos y campesinos (711-1252), Valladolid, Junta de Castilla y León, 1986.

379. Villey, Michel, La cruisade. Essai sur la formation d'une théorie juridique, París, 1942.

380. Vovelle, Michel, Ideologías y mentalidades, Barcelona, Ariel, 1985.

381. Weber, Max, Economía y Sociedad. Esbozo de sociología comprensiva, México, Fondo de Cultura Económica, 1983.

382. Zamora, Patricio, "El Rey Sagrado, Arquetipo Político-Religioso. Concepción y Representación en las fuentes del poder sagrado de la Edad Media”, Intus Legere, $\mathrm{N}^{\circ} 4,2001$, [pp. 123-139].

383. -----------, “Espejos de lo sagrado: Genealogía y antropología del poder en la monarquía francesa (Siglos VI-IX)”, Intus-Legere, 8, 2005, en http://edadmedia.cl/wordpress/wp-content/uploads/2011/04/ReySagradoII

Espejos.pdf 


\section{PRIMERA PARTE: CONTEXTO HISTÓRICO}

\section{I.1.- El Cristianismo y el Islam dos culturas enfrentadas en el marco peninsular}

I.1.b.- El 711, debacle y leyenda negra

p. 561

I.1.d.- Siglos XII-XIII. Avanza la reconquista y la intolerancia

p. 562

\section{I.3.- La Guerra Santa y la Cruzada, el caso hispano medieval}

I.3.a.- Discusiones en torno al uso de los conceptos:

De Asturias a la Reconquista

p. 565

I.3.b- Reconquista, Monarquía e Iglesia

p. 567

\section{SEGUNDA PARTE: LAS FUENTES: LA CONSTRUCCIÓN DE INSTRUMENTOS IDEOLÓGICOS}

II.1.- La historiografía medieval, fusión de lo clásico y lo "bárbaro": el caso hispano.
II.1.a.- Panorama general.
p. 570
II.1.b.- La historiografía de la Reconquista: Siglos VIII-X
p. 570

\section{II.2.- Las Crónicas y la hagiografía en el discurso de la Reconquista}

$\begin{array}{ll}\text { II.2.a.- Cronistas, crónicas: vidas y contextos } & \text { p. } 571\end{array}$

II.2.c.- La demonización del Islam: proceso ideológico y realidad práctica p. 572

II.2.d.- El caso de Mahoma: la construcción de una imagen malévola p. 574

II.2.e.- El escenario fronterizo y algunos intentos de comprensión del Islam p. 574

$\begin{array}{ll}\text { II.2.f.- Las matanzas: la muerte instrumentalizada p. } 575 & \end{array}$

II.2.g.- Botín, aspectos materiales y humanos p. 583

II.2.h.- La imagen de los musulmanes y el ordenamiento de la

frontera en Alfonso X: Realidad y práctica p. 586 


\section{II.3.- La figura del rey y la Reconquista}

II.3.b.- El caso hispano, los monarcas visigodos p. 590

$\begin{array}{ll}\text { II.3.c.- Los monarcas de la Reconquista } & \text { p. } 591\end{array}$

II.4.- Las virtudes del rey: Construcción de un ideal monárquico

$\begin{array}{ll}\text { II.4.a.- Linaje visigodo y continuidad p. } 592 & \text { p }\end{array}$

$\begin{array}{ll}\text { II.4.b.- Virtudes religiosas p. } 595 & \text { p }\end{array}$

$\begin{array}{ll}\text { II.4.c.- Validación bélica } & \text { p. } 595\end{array}$

$\begin{array}{lr}\text { II.4.d.-Validación jurídica } & \text { p. } 596\end{array}$

\section{TERCERA PARTE: LOS TÓPICOS}

\section{III.1.- EI Dios de la guerra}

III.1.b.- Providencialismo hispano-visigodo p. 599

III.1.c.- Pecado y castigo p. 603

III.1d.- El siglo XIII. Dios y los hombres, consolidación y cambios p. 606

III.2.- Los santos guerreros al servicio de la causa cristiana

$\begin{array}{ll}\text { III.2.c.- Santiago p. } 611 & \text { p } 600\end{array}$

$\begin{array}{ll}\text { III.2.d.- San Isidoro p. } 620 & \text { p }\end{array}$

III.2.e.- Santa María p. 629

III.2.g.- Santo Domingo de Silos p. 633

III.2.h.- San Millán de la Cogolla p. 634

III.2.i.- Otros santos y mensajeros celestes p. 634

III.3.- Las dadivas divinas y los rituales de la guerra

III.3.a.- Las dádivas divinas: recompensas espirituales, indulgencias $\quad$ p. 636

$\begin{array}{ll}\text { III.3.b.- Martirio p. } 638 & \text { p. }\end{array}$

III.3.d.- Ritos de preparación al combate p. 638

III.3.e.- Ritos de Victoria p. 640

III.3.f.- Ritos de purificación de los lugares conquistados p. 642

III.4.- Los Reyes modélicos: Siglos XII y XIII

III.4.a.- Alfonso $V I \quad$ p. 646

III.4.a.- Alfonso VII p. 652

III.4.a.- Alfonso VIII p. 656

III.4.a.- Fernando III p. 657

$\begin{array}{lr}\text { III.4.a.- Alfonso } X & \text { p. } 659\end{array}$ 


\section{Presentación.}

Los siguientes anexos corresponden a una selección representativa de distintos fragmentos de crónicas, hagiografías y textos jurídicos, que testimonian diversos aspectos del discurso y su evolución durante nuestro periodo de estudio.

Si bien algunos de los siguientes anexos ya han sido citados en el cuerpo de la tesis, hemos incluido otros que no lo fueron por razones de espacio o bien por la continuidad del relato. Es importante recalcar que nuestra recopilación no pretende abarcar todas las referencias a los tópicos en las fuentes, puesto que ello escapa a nuestras capacidades, pero sí ilustrar a través de algunos ejemplos su presencia en los textos. En razón de ello es que los anexos han sido ordenados siguiendo la cronología de la producción de las fuentes, en tanto que se ha procurado colocar los distintos relatos de un mismo episodio, con el fin de resaltar como los cronistas procuraron repetir algunos relatos para así destacar los tópicos que los componían, así como la adaptación de los mismos según los contextos. Algo que se puede observar en la extensión de la narración o bien en algunos de los testimonios utilizados. 


\section{PRIMERA PARTE: CONTEXTO HISTÓRICO}

\section{I.1.- El Cristianismo y el Islam dos culturas enfrentadas en el marco peninsular}

\section{I.1.b.- $E l$ 711, debacle y leyenda negra}

Crónica Mozárabe del 754. Mahoma como caudillo del Islam

"Sarraceni in Era DCLVI, anno imperii Eraclii VII, Siriam, Arabiam et Mesopotamiam furtim magis quam virtute Mammet eorum ducatore rebellia adortante sibi uindicat atque non tantum publicis irruptionibus quantum clanculis incursationibus perseuerando uicinas prouincias uastant. Sicque quoquo modo arte fraude non uirtute cunctas adiacentes imperii ciuitates stimulant et postmodum iugum a ceruice excutientes aperte rebellant. Qui et in era DCLVI, anno imperii Eraclii VII, regnum inuadunt, quod crebro et uario euentu belligerantes fortiter uindict." ${ }^{1243}$

Crónica Mozárabe del 754. Destrucción y devastación en tierras hispanas "Sicque non solum ulteriores Spaniam, sed etiam et citeriores usque ultra Cesaragustam antiquissimam ac florentissiman, seniores et potentes seculi cruci aiudicat, iubenes atque lactantes pugionibus trucidat. Sicque dum tali terrore cunctos stimulat pacem nonnulle ciutates que residue erant iam coacte proclamitant adque suadendo et inridendo astu quoddam nec mora petita condonat. Sed ubi enpetrata territi metu recalcitrant, ad montana temti iterum effugientes fame et diversa morte periclitant. Adque in eandem infelicem Spaniam Cordoba in sede dudum Patricia, que semper extitit pre ceteras adyacentes ciuitates opulentissima et regno Uuisegothorum primitibas inferebat delicias, regnum efferum conlocant." 1244

${ }^{1243} \mathrm{CM} 754, \mathrm{n}^{\circ}$ 8, op. cit., p. 28. "Los sarracenos, en la era de 656, año séptimo del imperio de Eraclio, inducidos por Mahoma, su caudillo, a la rebelión, se apropian más por astucia que por fuerzas de Siria, Arabia y Mesopotamia, y devastan las provincias, no tanto con una invasión declarada cuanto por sus reiteradas algaradas. Así, con habilidad y engaños, no por fuerzas, ataca a las ciudades fronterizas del imperio, y luego sacudiéndose el yugo de su cerviz se rebelan abiertamente. Y ya en la era de 656, año séptimo del imperio de Heraclio, invaden su reino y pretenden hacerse con él luchando enérgicamente con múltiples y variados resultados." CM 754, nº 8, op. cit., p. 29.

${ }^{1244}$ CM 754, n 54, op. cit., pp. 70, 72. "Y así, con la espada, el hambre y la cautividad devasta no sólo la España ulterior sino también la citerior hasta más allá de Zaragoza, ciudad muy antigua y floreciente, poco ha desprovista de defensas porque asi lo quiso Dios. Con el fuego deja asoladas hermosas ciudades, reduciéndolas a cenizas; manda crucificar a los señores y nobles y descuartiza a puñaladas a los jóvenes y lactantes. De esta forma, sembrando en todos el pánico, las pocas ciudades restantes se ven obligadas a pedir la paz, e inmediatamente, complacientes y sonriendo, con cierta astucia conceden las 
Crónica Mozárabe del 754. Victoria cristiana

"Tunc Abdirrahaman supra fatum Eudonem ducem insequens, dum Turniensem eclesiam palatia diruendo et eclesias ustulando depredare desiderat, cum consulem [Francie interioris] Austrie nomine Carrulum, uirum ab ineunte etate belligerum et rei militaris expertum, ab Eudone premonitum, sese infrontat. Ubi dum pene per septem dies utrique de pugne conflictu excruciant, sese postremo in aciem parant atque dum acriter dimicant, gentes septentrionles in hictu oculi, ut paries inmobiles permanentes sicut et zona rigoris glacialiter manent adstricti, Arabes gladio enecant."

Crónica Najerense. Origen de los sarracenos.

"23. Abraham annorum $C$ genuit Yssac ex Sarra libera, nam primum ex ancilla Agar genuerat Ysmahel a quo Ysmahelitarum genus, qui postea Agareni, ad ultimum Sarraceni sunt dicti."1246

\section{I.1.d.- Siglos XII-XIII. Avanza la reconquista y la intolerancia}

\section{Historia Compostelana. Identificación del invasor en la Batalla de Sagrajas}

"Transacto abhinc ferme triennio Moabite, quos estus solis facit Ethiopibus similes, castra et oppida Toledo subiacentia acrius solito inuaserunt et, interfectis hominibus, qui forum abstabant fortitudini, quia robore militum suorum uallati nulla hostium spicula formidabant, ibi quasi in summa positi trasquillitate sua tentoria firmauerunt."1247

condiciones pedidas. Pero asustados, rechazan la paz lograda, huyen por segunda vez en desbandada a las montañas y mueren de hambre y otras causas.

Así, sobre esta España desdichada, en Córdoba, ciudad que de antiguo llevaba el título de Patricia, que siempre fue la más rica entre otras ciudades próximas y que dio al reino visigodo los primeros frutos delicados, establecen un reino bárbaro." CM 754, n 54, op. cit., pp. 71, 73.

1245 CM 754, n 80, op. cit., pp. 98, 100. "Continuando Abderramán la persecución del mencionado duque Eudo, mientras se detiene a destruir palacios y quemar palacios y quemar iglesias, e intenta saquear la diócesis de Tours, se encuentra con Carlos, cónsul de Austria, hombre belicoso desde su infancia y muy versado en asuntos militares, de antemano advertido por Eudo. Después de atormentarse durante casi siete dias unos y otros con pequeños enfrentamientos militares, al fin se despliegan en batalla, y en dura pelea, permaneciendo las gentes septentrionales inmóviles como una pared y manteniéndose en bloque como el hielo en época invernal (o en una región polar), pasan a espada en un abrir y cerrar de ojos a los árabes." CM 754, n 80, op.cit., pp. 99, 101.

${ }^{1246}$ CN 1995, Liber I, n²3, op. cit., p. 10. "23. Abraham a los 100 años engendró a Isaac de Sara, que era mujer libre, pues primero de la esclava Agar había engendrado a Ismael, de quien procede el pueblo de los ismaelitas, quienes luego fueron llamados agarenos y por último sarracenos". CN 2003, Libro I, $\mathrm{n}^{\circ} 23$, op. cit., p. 46.

1247 HC 1988, Liber I, Cap. XXIX, op. cit., p. 57. "Pasados desde entonces casi tres años, los almorávides, a los que el calor del sol hace semejantes a los etiopes, atacaron con más fuerza de lo acostumbrado los campamentos y poblaciones cercanas a Toledo y, muertos los hombres que se oponían 
Chronica Adefonsi Imperatoris. La efectividad devastadora de la cabalgata

"Et inde rex movit castra et coepit ire per campaniam Codubae[sic], a dextris et a siniestris preadando, et occupavit totam illam terram et praedavit eam, et misit post se ignem et fecit magnam captivationem et pervenit ad fluvium qui dicitur Goadalquivir, quo transfretato, ex altera parte dimiserunt Cordubam et Carmonam a sinistra, Sibiliam vero, quam antiqui vocabant Hispalim relinquentes a dextera. Eratque in diebus messis unde et succendit omniasata, et omnes vineas et oliveta et ficulnea fecit incide $;[\ldots]^{\prime 1248}$

Chronica Adefonsi Imperatoris. La efectividad devastadora de la cabalgata "[...] et cecidit timor illius super omnes habitantes in terra Moabitarum et Agarenorum, sed et ipsi Moabitae et Agareni, praeoccupati timore magno, reliquerunt civitates et castella minora et miserunt se in castellis fortissimis et in civitatibus munitis; in montibus et speluncis montium et in cavernis petram, et in insulis maris absconderunt se."1249

Chronica Adefonsi Imperatoris. Andalusíes buscan la paz con Alfonso VII

"Moabitae medullas terrae comedunt et posesiones nostras; aurum et argentum nobis tollunt; uxores nostras et filios nostros opprimunt: pugnemus ergo contra eos et occidamus eiiciamusque dominium forum a nobis, quia non est nobis pars in domo regis Texufini neque hereditas in filiis Ali et patris eius Iuzeph'. Alii autem dicebant: 'Faciamus in primis pactum et pacem cum imperatore Legiones et Toleti et demus ei tributa regalia sicut patres nostri dederunt patribus suis'. Quod bonum visum est in

a su bravura, puesto que defendidos por la fuerza de sus soldados no temían a las flechas de los enemigos, plantaron allí su campamento como si estuvieran colocados en lugar seguro". HC 1994, Libro I, cap. XXIX, op. cit., p. 125.

${ }^{1248}$ CAI, Liber I, n 35, op. cit., p. 32. "El rey levanto alli el campamento, empezó a moverse por la campiña de Córdoba saqueando a diestro y sinistro, ocupó todo aquel territorio, lo saqueó, lo incendio a sus espaldas, hizo gran número de prisioneros y llegó al río llamado Guadalquivir. Después de atravesarlo, desde la otra orilla se alejaron dejando a la izquierda Córdoba y Carmona y a la derecha Sevilla, que los antiguos llamaban Hispalis. Era la época de la recolección, por lo que hizo incendiar todos los sembrados y cerrar todas las viñas, olivos e higueras. El temor a él se apoderó de todos los habitantes del territorio de los moabitas y agarenos, más también los aludidos moabitas y agarenos, invadidos por un gran temor, abandonaron las ciudades y castillos secundarios y se refugiaron en los castillos más fortificados y en las ciudades amuralladas; se escondieron en las montañas, en las cuevas de las montañas, en las cavernas de las rocas y en las islas del mar" CEA, Libro I, $\mathrm{n}^{\circ} 35$, op. cit., pp. 74, 75.

${ }^{1249}$ CAI, Liber I, n 36, op. cit., p. 32. "El temor a él se apoderó de todos los habitantes del territorio de los moabitas y agarenos, mas también los aludidos moabitas y agarenos, invadidos por un gran temor, abandonaron las ciudades y castillos secundarios y se refugiaron en los castillos más fortificados y en las ciudades amuralladas; se escondieron en las montañas, en las cuevas de las montañas, en las cavernas de las rocas y en las islas del mar." CEA, Libro I, n³6, op. cit., p. 74. 
occulis forum, et ut essent parati in proemio contra Marrochinos. Deinde, conversi in synagogis suis, orabant patentes miserationes Mahometis pseudoprophetae eorum, ut adiuvaret coeptus et actus eorum; et mittentes nuntios, vocabant regem Zafadolam et omnem semen regum Agarenorum ut venirent et bellarent contra Moabitas" ${ }^{250}$.

Crónica Latina de los Reyes de Castilla. La efectividad devastadora de la cabalgata

"Denigrata est facies illius nobilis civitatis, florentis et uirentis, super carbones; emarcuit terra; squalebant arua; decidit, decidit gloria prima." 1251

Crónica de Veinte Reyes. Cabalgata de Fernando Magno contra Sevilla

"E después quél ouo todas sus cosas hordenadas e asosegadas por todo su rreyno allegó muy grant huste e fue correr tierra de moros, e començó de destruyr a fierro e a fuego villas e castillos, aldeas, e todo caunto fallaua, e tanto mal les fizo que por fuerça ouo de venir a él Abenhabet, rrey de Córdoua e de Seuilla, con grandes aueres, rrogándole que tomase aquel auer e que por onrra de su rreyno non quisiese más mal fazerle en la tierra de lo que avía fecho, mas quell tomase por su vasallo e su pechero asy commo tomara a los otros reyes moros d'España."1252

${ }^{1250}$ CAI, Liber II, n 188, op. cit., pp. 148, 149. “'Los moabitas consumen las entrañas de la tierra nuestras posesiones, nos quitan el oro y la plata, oprimen a nuestras esposas y a nuestros hijos. Luchemos, pues, contra ellos, matémoslos y sacudámonos su dominio, puesto que no tenemos parte en el palacio del rey Texufin ni herencia entre los hijos de Ali y de su padre Yusef'. Por su parte, otros decian: 'Ante todo hagamos una alianza de paz con el Emperador de León y Toledo y démosle tributos reales, de la misma manera que nuestros padres se los dieron a sus padres'. Les pareció bien a sus ojos esto y el hecho de estar preparados para una guerra contra los de Marrakech. Después, tras dirigirse a sus mezquitas, oraban pidiendo la compasión de Mahoma, su falso profeta, para que les ayudase en sus empresas y acciones. Y mediante embajadas llamaban al rey Zafadota y a toda la estirpe de los reyes agarenos para que viniesen y guerreasen contra los moabitas." CEA, Libro II, $\mathrm{n}^{\circ} 92$ (188) op. cit., pp. $123,124$.

${ }^{1251}$ CLRC 1997, $\mathrm{n}^{\circ}$ 46, op. cit., p. 89. "La faz de aquella noble ciudad, floreciente y vigorosa, se ennegreció como el carbón, la tierra se marchitó y los campos languidecieron: cayó, cayó su gloria primera". CLRC 1999, n 46, op. cit., p. 78.

${ }_{1252}$ CXXR, Libro VIII, cap. VIII, op. cit., p. 170. 


\section{I.3.- La Guerra Santa y la Cruzada, el caso hispano medieval}

\section{I.3.a.- Discusiones en torno al uso de los conceptos: De Asturias a la Reconquista}

Historia Compostelana. Los métodos de guerra contra el Islam

"[...] nec parcit gladius eorum a maiori usque ad minorem: templa quoque eorum comburere ac diruere et in eis feda relatu facere non erubescunt ${ }^{\text {"1253 }}$.

Chronica Adefonsi Imperatoris. Poema de Almería. Estímulos espirituales y materiales para la guerra.

“[25] Pontifices omnes Legionis sive Toleti, exempto gladio divino corporeoque, orant maiores [invitantque] minores, ut veniant cuncti fortes ad proelia tuti. Crimina persolvunt, voces ad sidera tollunt, [30] mercedem vitae spondent cunctis utriusque. Argenti dona promittunt, cumque corona quidquid habent Mauri rursus promittitur auri. Pontificum clangor tantus fuit et pius ardor nunc promittendo, nunc lingua vociferando, [35] ut vix iam teneri possent a matre teneri. A canibus cervus velut in sylvis agitatus desiderta, fontes dimittens, undique montes, plebs Hispanorum sic proelia sarracenorum exoptans, aeque non dormit nocte dieque. [40] Tuba salutaris resonat per climata mundi; vox Almariae cunctis est agnita dirae."1254

Cronicon Mundi. Hispania como tierra santificada.

"Exceptis omnibus hiis temporalibus bonis, omnipotens Deus in tantum Yspaniam celestibus ditauit donis, ut prothomartyris apostolorum Iacobi corpus sibi trasnmitteret perpetuo carius amplectendum, et doctorem gencium Paulum illi contulerit specialius in spiritu uenerandum. Etenim cum Romanis idem apostolus scriberet, dixit se per eos transitum facturum et uenturum ad Yspanias. Quod utrum in corpore uenerit, licet quedam scriptura, que uidetur autentica, eum testatur uenisse corporaliter, nos tamen

${ }^{1253}$ HC 1988, Liber I, CIII, 3, op. cit., p. 176. “[...] y su espada no perdona desde el mayor al más pequeño; tampoco se avergüenzan de quemar y derruir sus templos y de hacer en ellos cosas indignas de ser relatadas". HC 1994, Libro I, CIII, 3, op. cit., p. 246.

${ }^{1254}$ CAI, Poema de Almería, op. cit. pp. 167, 168. "Los obispos de Toledo y León en su totalidad, tras desenvainar la espada divina y la material, / [40] ruegan a los mayores y animan a los jóvenes a que todos acudan al combate, valientes y seguros. Perdonan los pecados, elevan sus voces al cielo y aseguran a todos la recompensa en ésta y en la otra vida. Prometen premios en plata y, con la victoria, / [45] se promete a su vez todo el oro que tienen los moros. Tan ingente fue el clamor de los obispos y su ardor religioso, ya con promesas, ya hablando a voz en grito, que a duras penas los pequeños podian ser retenidos por sus madres. Como el ciervo acosado por los perros en los bosques / [50] echa de menos las fuentes al abandonar los montes por doquier, asi el pueblo de los hispanos, ansiando en la misma forma combatir con los musulmanes, no duerme ni de día ni de noche. La trompeta salvadora resuena por las regiones del mundo. El nombre de la cruel Almería es conocido de todos." CEA, Poema de Almería, op. cit. pp. 132-133. 
ignoramus. Firmiter credimus eum promissum suum etsi non in corpore tamen in spiritu compleuisse, quia ueritatis apostolus mentiri non potuit. Teneat ergo Roma corpus apostoli Pauli; et Yspania quadam prerogatiua eius spiritus patrociniis se perfrui glorietur. Accedit ad Yspaniam anthonomasice decorandam quod illos duos insigenes martires et leuitas, scilicet Laurencium et Vincencium genuit, quorum fama et sanctitate ubique Christi ecclesia roboratur. Que patria uel que ciuitas ut Legio urbs Yspanie tale quid protulit? Que Christi martirem Marcellum centurionem cum beatissima uxore Nona et duodecim filiis centurionibus et Christi martiribus edidit, quorum sanguine et fide plebs catholica roboratur? Nomina eorum hec sunt: Claudius, Lepercus, Victorius, Facundus, Primitiuus, Emeterius, Celedonius, Seruandus, Germanus, Faustus, Ianuarius et Marcialis. Vt autem ad presens omittam infinitam aliorum sanctorum multitudinem, quorum martirio et doctrina Yspania fulget, ueniam ad Seuerianum Cartaginensem ducem, qui de uxore Theodora illos tres doctores inclitos, Leandrum scilicet archiepiscopum Yspalensem et Isidorum archipresulem, ambos primates Yspanie, atque Fulgencium episcopum, omnes Christi confessores, filios meruit obtinere. [...] Sed pretermittendi non sunt sanctissimi Dominicus sanctissimum ordinem Predicatorum instituit, sancto Spiritu suggerente, et Antonius beatissimo patri Francisco in ordine pauperum beatorum sanctitate successit primus. Sanctus etiam Dominicus, Cluniacensis ordinis abbas de Silos, in liberandis de carcere Sarracenorum captiuis gloriam pre ceteris sanctis reportare uidetur."1255

1255 CM, Praefatio, op. cit., pp. 5, 6, 7. "Allende de todos estos temporales bienes, en tanto el todopoderoso Dios enriquescio a España de çelestiales dones, porque inbiase el cuerpo del prothomartir Santiago porque perpetuamente él lo tuuiese abraçado en carne; e diole para que veniese en espíritu más spiritualmente al doctor de la gente sant Pablo, porque como ese mismo apostol escriuiese a los Romanos que pasrian por ellos o vernian a las Españas, asi aya venido en cuerpo; aunque vna escriptura, que paresce ya aprouada, da testimonio de aver venido corporalmente; mas nos no lo sabemos firmemente; creemos él aver cumplido su promesa y signo en el cuerpo e en el spiritu sancto, porque el apostol, que es verdad, no pudo mentir; pues tenga Roma el cuerpo de sant Pablo apostol, o glorifiquese España de vsar de los padrones de su espiritu por vna ventaja. Allégase por exçelencçia para honrrar a España que engendró aquellos dos muy señalados martires leuitas, conviene a saber: Sant Laurente \& sant Viceynte, por la fama de los quales y por su santidad a do quiera la yglesia de Ihu Xpo se fortifica. ¿Qué tierra, o qué çibdad, asi como Leon, çibdad de España, traxo tal cosa?; la qual pario el martir de Ihu Xpo Marcello centurio, con la bien auenturada Nona, muger suya, e doze fijos suyos, centuriones e martires de Ihu Xpo, por la sangre de los quales y fee, el pueblo catholico se esfuerça; los nonbres dellos son Claud[i]o, Luperçio, Vitorio, Facundo, Primitiuo, Emeterio, Celidonio, Seruando, Germano, Fausto, Januario e Marcial. Mas porque yo al presente dexe la ynfinita muchedunbre de los otros sanctos, por doctrina de los quales España resplandesce, verne a Severiano, duque de Cartajena, que meresçio tener de su muger Theodora por fijos aquellos tres nobles doctores, conuiene a saber: a Leandro, arçobispo de Seuilla; Ysidoro, arçobispo, ambos primados de España, e a Fulgençio, obispo, todos confesores de Ihu Xpo.” [...]

Mas non es de pasar aquesto que fizieron el muy sancto Domingo y Antonio, los quales en nuestros tiempos acrescentaron las obras de los apostoles; Sancto Domingo establesçio por espiritu sancto la muy sancta orden de los predicadores, y Santo Antonio, primeramente, sucedio en sanctidad al muy bien auenturado Sant Francisco en la orden de los pobres bienauenturados; Sancto Domingo, abbad 


\section{I.3.b- Reconquista, Monarquía e Iglesia}

Historia Compostelana. Carta del Papa Pascual a los clérigos y laicos del reino de Alfonso.

“P. episcopus seruus seruorum Dei clericis et laicis Al. Regnum habitantibus salutem et apostolicam benedictionem.

Magnum uestre salutis dispendium facitis, quod Apostolice Sedis preceptos obedire contempnitis. Scripsimus enim uobis preterito tempore, ne Iherosolimitane expeditionis occasione partes uestras desereretis, que Maurorum et Mohabitarum cotidianis incursionaribus impugnantur; non parum enim in discessu uestro illorum tyrannidem occidentalibus partibus formidamus. Qua de re nos partium uestratum tam clericos quam laicos, quos lidere potuimus, a Ierosolimitana profectione desistere et ad patriam suam redire precipimus. Latores quoque presentium, Munionem et Didacum et Nunonem cum sequacibus suis, a nobis coactos redire sciatis. Vnde etiam uestre dilectioni precipimus, ne quis eos pro reditu hoc infamare aut calumpniis aliquibus presuma tempere. Vobis ergo omnibus iterata preceptione precipimus, ut in uestris partibus persitentes Mahobitas et Mauros totis uiribus impugnetis, ibi largiente Deo uestras penitentias peragatis, ibi sanctorum apostolorum Petri et Pauli et apostolice eorum ecclesie remissionem et gratiam percipiatis. Datum Laterani VIII Kal. Aprilis" ${ }^{\prime 256}$.

de Silos, de la orden del cluniaco, parescese traer más gloria que los otros sanctos en librar los captiuos de la cárçel de los moros." CE, Prologo, op. cit., pp. 4, 5, 6.

${ }^{1256}$ HC 1988, Liber I, XXXIX, op. cit., pp. 77, 78. "Pascual, obispo, siervo de los siervos de Dios, a los clérigos y laicos que viven en el reino de Alfonso, salud y bendición apostólica.

Gran daño hacéis a vuestra salvación porque os negáis a obedecer los preceptos de la sede apostólica. Pues os hemos escrito hace tiempo que no abandonaseis vuestras tierras, las cuales son atacadas por las frecuentes incursiones de moros y almorávides, para peregrinar a Jerusalén; pues en vuestra ausencia, no poco tememos la tiranía de aquellos sobre las regiones occidentales. Por lo cual hemos ordenado, tanto a los clérigos como a los laicos de vuestras tierras que hemos podido ver, que desistan de la marcha a Jerusalén y que regresen a su patria. Sabed también que los portadores de la presente, Munio, Diego y Nuño con sus compañeros, han sido obligados por nosotros a regresar. Por ello, ordenamos a vuestra caridad que ninguno se atreva a infamarlos por este regreso o a acusarles con alguna reclamación. Así pues, ordenamos a todos vosotros con repetido precepto que permanezcáis en vuestras tierras y luchéis con todas vuestras fuerzas contra los almorávides y moros, y alli por la generosidad de Dios, hagáis vuestras penitencias y allí recibáis el perdón y la gracia de los apóstoles Pedro y Pablo y de su apostólica Iglesia. En Letrán a 25 de marzo". HC 1994, Libro I, XXXIX, op. cit., pp. 146, 147. 
Liber Sancti Jacobi / Codex Calixtinus. Calixto II declarará la paridad entre las cruzadas orientales y la Reconquista

"Idcirco dilectio vestra, filioli mei, queso, intelligat quanta auctoritas sit ire ad Yspanias causa expugnandi Sarracenos, quantaque mercede qui illuc libenter perrexerint, remunerabuntur. Fertur namque quod Karolus Magnus, Galliorum rex famosissimus, magis pre ceteris regibus itinera yspanica innumeris laboribus gentes perfidas expugnando disposuit, et beatus Turpinus archiepiscopus remensis, consocius eius, coadunato tocius Gallie et Lotharingie omnium episcoporum concilio apud Remis, urbem Galliorum, a vinculis omnium peccatorum suorum cunctos qui in Yspania ad expugnandum gentem perfidam, et ad augmentum christianitatem, captivosque christianos ad liberandum, et ad accipiendum ibi pro divino amore martirium, tunc ierunt et post ituri erant, ut in gestis eius scribitur, divina auctoritate corroboratus relaxavit. Hoc idem omnes apostolici qui postea usque ad nostrum tempus fuere, corroboraverunt, testante beato Urbano papa, illus- / tri viro, qui in concilio Claromontis, regionis Gallie, adstantibus circiter C. episcopis, hoc idem asseruit, quando ytinera itherosolimitana disposuit, ut codex itherosolimitane ystorie refert. Hoc idem e nos corroboramus et affirmamus, ut omnes qui aut in Yspania, aut in itherosolimitanis horis ad expugnandum gentem perfidam, ut superius diximus, elevato signo dominice crucis in humeris perrexerit, ex parte Dei et sanctorum apostolorum Petri et Pauli et Iacobi, omniumque sanctorum, et nostra benedictione apostolica ab omnibus peccatis de quibus sacerdotibus suis confessi et penitentes fuerint, absolvantur et benedicantur, et in celestibus regnis una cum sanctis martiribus qui ab inicio christianitatis usque ad finem seculi martirii palmam ibi acceperunt vel accepturi sunt, coronari mareantur. Numquam profecto fuit tanta necessitas olim illum ire sicuti est hodie. Qupropter rogantes universaliter precepimus, ut omnes episcopi et prelati in sinodis et conciliis suis et ecclesiarum dedicacionibus hoc super cetera apostolica mandata precipue annunciare non desinant, presbiteris suis etiam exortantes, ut in ecclesiis suis gentibus laicis renuncient." ${ }^{1257}$

1257 LSJ, Liber IV, Apendix D, op. cit., pp. 228, 229. "Por esto os suplico, hijos míos, que entienda vuestra caridad cuánta importancia tiene el ir a España a pelear con los sarracenos y con cuántas gracias serán remunerados los que voluntariamente alli fueren. Pues ya es sabido que Carlomagno, rey de los galos, el más famoso sobre todos los demás reyes, estableció la cruzada en España, combatiendo con innumerables trabajos a los pueblos infieles, y que su compañero el bienaventurado Turpín, arzobispo de Reims, según se cuenta en su gesta, robustecido con la autoridad de Dios, en un concilio de todos los obispos de toda la Galia y Lorena reunidos en Reims, ciudad de los galos, concedió indulgencia plenaria a todos los que entones fueron y a los que en lo sucesivo vayan a combatir a España al pueblo infiel, a aumentar la cristiandad, liberar a los cautivos cristianos, y a sufrir alli el martirio por amor de 
I Concilio de Letrán. Penas al incumplimiento de votos en la guerra

"En cuanto a los que se han puesto las cruces en los vestidos haciendo voto de ir a Jerusalén o a España y después las han dejado, les ordenamos en virtud de la autoridad apostólica, que vuelvan a tomarlas y se pongan en ruta desde la Pascua próxima hasta la siguiente; de lo contrario les prohibimos la entrada en la iglesia y la celebración de todo servicio divino en sus tierras, excepto el bautismo de los niños y la penitencia de los moribundos." 1258

Dios. Todos los varones apostólicos que, después, hasta nuestro tiempo hubo, corroboraron esto mismo y es testigo el santo papa Urbano, ilustre varón, que en el concilio de Clermont en la Galia, con asistencia de cien obispos, aseguró esto mismo, cuando dispuso la cruzada de Jerusalén, según consta el códice de la historia jerosolimitana. Esto mismo también Nos corroboramos y confirmamos: que todos los que marchen como arriba dijimos, con el signo de la cruz del Señor en los hombros, a combatir al pueblo infiel en España o Tierra Santa, sean absueltos de todos sus pecados y que se hayan arrepentido y confesado a sus sacerdotes, y sean bendecidos por parte de Dios y de los santos apóstoles San Pedro, San Pablo y Santiago, y de todos los santos, y con nuestra apostólica bendición; y que se merezcan ser coronados en el reino celestial, junto con los santo mártires que desde el principio de la cristiandad hasta el fin de los siglos recibieron o han de recibir la palma del martirio. Nunca hubo en verdad en otro tiempo tanta necesidad de ir allá, como en la actualidad. Por lo cual encarecida y universalmente mandamos a todos los obispos y prelados en sus sinodos y concilios y en las solemnidades de las iglesias no dejen de anunciar principalmente, y sobre los demás mandatos apostólicos, esto; exhortando también a sus presbiteros a que en las iglesias lo comuniquen a sus feligreses. Y si hacen esto gustosamente sean remunerados en el cielo con igual recompensa que los que van allá." LSJ (2004) Libro IV, Cap. XXVI, op. cit., pp. 521-522.

${ }^{1258}$ Primer Concilio de Letrán, Canon XIII, en Goñi Gaztambide, José, op. cit., 76, 77. 


\section{SEGUNDA PARTE: LAS FUENTES: LA CONSTRUCCIÓN DE INSTRUMENTOS IDEOLÓGICOS}

\section{II.1.- La historiografía medieval, fusión de lo clásico y lo "bárbaro": el caso hispano.}

\section{II.1.a.- Panorama general.}

Historia contra los paganos. Alianza entre política monárquica y la Iglesia

“En verdad, ¿quién puede regular y ordenar nuestras acciones más sabiamente y con más firmeza que Aquel que previó lo que tenía que hacerse y ejecutó lo previsto? Por esto, el hecho de que todo poder y todo gobierno proceden de Dios es sentido por los que no son ilustrados, y reconocido por los que lo son." 1259

\section{II.1.b.- La historiografía de la Reconquista: Siglos VIII-X}

Crónica Mozárabe del 754. La desdicha de Hispania

"55.- Quis enim narrare quet tanta pericula? Quis dimunerare tam infortuna naufragio? Nam si omnia menbra uerterentur in linguam, omnino nequaquam Spanie ruinas uel eius coth tanque mala dicere poterit humana natura. Sed ut in brebi cuncta legenti renotem pagella, relictis seculi inumerabilibus ab Adam usque nunc claribus, quas per infinitis regionibus et ciuitatibus crudelis intulit mundus iste inmundus, quidquid historialiter capta Troia perrulit, quidquit Iherosolima predicta per prophetarum eloquia baiulabit, quidquid Babilonia per scripturarum eloquia substulit, quidquid postremo Roma apostolorum nouilitate decorta martirialiter confecit, omnia et coth ut Spania comdam deliciosa et nunc misera effecta tam in honore quam etiam in dedecore experibit ${ }^{\prime 1260}$.

\footnotetext{
${ }^{1259}$ HCP, Libro II, cap. I, op. cit., p. 65. (También referenciado en: III.1.a.- Providencialismo: Dios juez y parte en los hechos de los hombres)

${ }^{1260}$ CM 754, Cap. VII, op. cit., pp. 72, 74. "55.- ¿¿Quién podrá, pues, narra tan grandes peligros?! ¿¿Quién podrá enumerar desastres tan lamentables?! Pues aunque todos sus miembros se convirtiesen en lengua, no podría de ninguna manera la naturaleza humana referir la ruina de España ni tantos y tan grandes males como ésta soportó. Pero para contar al lector todo en breves páginas, dejando de lado los innumerables desastres, que desde Adán hasta hoy causó, cruel, por innumerables regiones y ciudades, este mundo inmundo, todo cuanto según la historia soportó la conquistada Troya, lo que aguantó Jerusalén, según vaticinio de los profetas, lo que padeció babilonia, según el testimonio de las
} 
Chronica Albendensia. Visión providencialista de la lucha.

"Sarraceni euocati Spanias occupant regnemque Gotorum capiunt, quem aduc usque ex parte pertinaciter possedunt. Et cum eis Xpiani die noctuque bella iniunt et cotidie conflictur, dum predestinatio usque diuina dehinc eos expelli crudelit iubeat."1261

\section{II.2.- Las Crónicas y la hagiografía en el discurso de la Reconquista II.2.a.- Cronistas, crónicas: vidas y contextos}

Crónica del Obispo de Oviedo don Pelayo. Ascenso al trono de Alfonso VI.

“Enterado de esto el rey Alfonso regresó rápidamente [de Toledo], recobró su reino [León] y el de su hermano [Castilla]. Y tras no muchos días se apoderó, por medio de artimañas y sin lucha, del reino [Galicia] de su hermano García, al que arrestó y tuvo en prisiones más de veinte años, y allí se le debilitó la sangre, cayó en cama, murió y fue enterrado en León."1262

Historia Compostelana. Visión providencialista del obispado de Gelmírez.

"Nun cuero ipsius reuerendi episcopi successus, quos in hoc honore habuit, et aduersa, que in eodem uiriliter pertulit, atque ea, que ipse ad Dei honorem et sue ecclesie utilitatem Domino cooperante discrete et sapienter peregit, describere et ad posterorum memoriam reucare diuina preueniente gratia aggrediar." 1263

Escrituras, y, en fin, todo cuanto Roma enriquecida por la dignidad de los apóstoles alcanzó por sus mártires, todo esto y más lo sintió España tanto en su honra, como también de su deshonra, pues antes era atrayente, y ahora está hecha una desdicha." CM 754, Cap. VII, op. cit., pp. 73, 75.

1261 Chronica Albendensia, Cap. XIV, 34, en Crónicas asturianas... op. cit., p. 171. "Los sarracenos ocupan España y se apoderan del reino de los godos, que todavía retienen en parte de manera pertinaz. $Y$ con ellos los cristianos día y noche afrontan la batalla y cotidianamente luchan, hasta que la predestinación divina ordene que sean cruelmente expulsados de aqui'. Crónica Albeldense, Cap. XIV, 34, op. cit., p. 171.

1262 COP, op. cit., p. 178.

${ }^{1263}$ HC 1998, Libro I, cap. III, op. cit., p. 17. "Y ahora con la ayuda de la divina gracia empezaré a describir y recordar a las generaciones venideras los éxitos que el reverendo obispo tuvo en el desempeño de su cargo y las adversidades que sufrió con valentía en el mismo y lo que él en persona con la cooperación del Señor llevó a cabo con discreción y sabiduría para honor de Dios y utilidad de su iglesia.” HC 1994, Libro I, cap. III, 3, op. cit., p. 79. 
Historia de Rebus Hispanie. Providencialismo en la preparación de las Navas de Tolosa.

"Et sic factum est per omnipotentis Dei graciam, qui solo nutu omnia disponebat, ut nulla seditio, nulla perturbatio exorta fuerit, que potuerit belli negocium impedire, licet per hostem humani generi fuerit sepius atemptatum". ${ }^{264}$

Historia de Rebus Hispanie. Providencialismo en la deserción de los ultramontanos.

"Set quoriam humani generis inimicus non cessat christianis actibus inuidere, misit Sathan in exercitum caritatis et corda emulancium conturbauit, et qui ad certamen fidei se acinserant, retrorsum a bono proposito abierunt. Omnes enim fere ultramontani comuni proposito atatuerunt ut relictis crucis signaculis, omissis etiam belli laboribus, ad prpria remearent." 1265

Crónica de Alfonso X. Visión providencialista de los actos de los reyes.

“[...] conuiene que los fechos de los reyes, que tienen lugar de Dios en la tierra, sean fallados en escripto, señaladamente de los reyes de Castilla e de León, que por la ley de Dios e por acrecentamiento de la santa fee católica tomaron muchos trabajos e se posyeron a grandes peligros en las lides que ouieron con los moros echándolos de Espanna." 1266

\section{II.2.c.- La demonización del Islam: proceso ideológico y realidad práctica}

Cronicón Burguense. Almanzor asociado al demonio.

“Era millesima cuadragesima; mortuus est Almanzor et est sepultus in inferno."

Historia Compostelana. Los almorávides y andalusíes según Diego de Gelmírez “[...] quos estus solis facit Ethiopibus similes"

\footnotetext{
${ }^{1264}$ HRH, Liber VIII. Cap. I., op. cit., p. 259. "Y por gracia de Dios todopoderoso, que con su solo gesto lo disponía todo, se llevó a cabo de tal manera que no surgió ninguna querella, ningún alboroto que pudiera malograr la empresa de la batalla, aunque el enemigo del género humano lo intentase más de una vez.”HHE, op. cit., Libro VIII. Cap. I., p. 308.

${ }^{1265}$ HRH, Libro VIII, Cap. VI, op. cit., p. 265. "Pero como el enemigo del género humano no deja de malquerer las obras cristianas, introdujo a Satán en el ejército de caridad y encizañó los corazones de los envidiosos; y quienes se habian aprestado para la contienda de la fe dieron marcha atrás en sus buenas intenciones. Pues casi todos los ultramontanos, dejadas las enseñas de la cruz, abandonados también los trabajos de la batalla, tomaron la determinación de regresar a sus tierras."HHE, Libro VIII, Cap. VI, op. cit., p. 314.

${ }^{1266}$ CAX 1999, op. cit., p. 3.

1267 Cronicón Burguense, en Huici M., Ambrosio, Las crónicas latinas...op. cit., Tomo I. p. 34.
} 
“[...] ne forte Hismahelitarum subdola uersutia qualibet machinatione seu ingenii calliditate $[\ldots]^{\prime 1269}$.

Historia Compostelana. El politeísmo musulmán según Diego de Gelmírez

"Regnum etenim Toleti, castella, ciuitates et oppida, que ultra decursum Dorri fluminis esse noscuntur, in quibus christiane professionis religio tenetur et obseruatur, a cultura Pentium numina iana colentium penitus euacuauit,"1270.

Historia Compostelana. Ignorancia de los musulmanes

"[...] uerissimis atque euidentissimis argumentis astruebat gentiles ignorantie nube cecatos uarioque desusos errore". ${ }^{1271}$

Crónica Najerense. El demonio y la superstición árabe

"[...] set, ut uariis demonum erroribus nonnulli illaqueantur mahometica supersiticiosa secta $[\ldots]^{, 1272}$.

Cronicon Mundi. La muerte del Almanzor.

"Et Canatanazor perdio Almazor el tambor, id est, in Canatanazor perdidit Almazor timpanum siue sistrum, hoc est, leticiam suam. Veniebant as eum barbari Cordubenses et cum appropinquarent ei, euanescebat ab occulis eorum et iterum in alio loco apparens eaden plagens repetebat. Hunc credimus diabolum fuisse, qui Sarracenorum plangebat deiectionem. Almazor autem ab ea die, qua succubuit, noluit comedere neque bibere et ueniens in ciuitatem que dicitur Medinacelem, mortuus est et ibidem sepultus."1273

${ }^{1268}$ HC 1988, Liber I, cap XXIX, op. cit., p. 57. "A los que el calor del sol hace semejantes a los etiopes". HC 1994, Liber I, cap XXIX, op. cit., p. 125.

${ }^{1269}$ HC 1988, Liber I, cap. XXXIII, op. cit., p. 63. "Para evitar que la malicia astucia de los ismaelitas pudiera tomarla con alguna maquinación o engaño de su ingenio [...]” HC 1994, Libro I, cap. XXXIII, op. cit., p. 132.

${ }^{1270}$ HC 1988, Liber I, cap. XLVI, op. cit., p. 84. "Pues apartó por completo del culto de los gentiles, que adoran dioses vacios, el reino de Toledo, los castillos, las ciudades y fortalezas que están más allá del río Duero, en los cuales se profesa y observa la religión cristiana”, HC 1994, Libro I, cap. XLVI, op. cit., p. 152.

${ }^{1271}$ HC 1988, Liber II, cap. L, op. cit., p. 308. "Con muy veraces y evidentes argumentos afirmaba que los gentiles estaban cegados por la nube de la ignorancia y que estaban engañados por muchos errores", HC 1994, Libro II, cap. L, op. cit., p. 384.

${ }_{1272}$ CN 1995, Liber II, no 17, op. cit., pp. 110, 111. "[...] como otros tantos que por las diferentes argucias de los demonios caían en la trampa de la supersticiosa secta de Mahoma [...]" CN Libro II, ${ }^{\circ}$ 17, op. cit., p. 123.

${ }^{1273}$ CM, Liber IV, n 39, op. cit., p. 271. "En Calatanaçor perdio Almançor el atambor"; que quiere dezir que en Calatanaçor perdio Almançor el pandero, que es su alegría; venien(do) a él todos los 
Historia Rebus Hispaniae. La falta de inteligencia árabe

"Huius temporibus nephandus Mahomat nequiciam secte sue stultis populis predicauit ${ }^{1274}$.

Crónica de Veinte Reyes. Actos demoniacos de los musulmanes.

“Amigos, los moros son omnes que saben muchos escantamentos e llaman los diablos por esperimentos que fazen, e algun moro astroso que sabe fazer aquestas cosas fizo aquella visión venir por espantarnos con esta artería. E mas, como sodes omnes entendidos, bien deuedes saber que el diablo non nos puede fazer ningund mal, ca le tolló el poder nuestro señor Ihesu Christo, e acomendémonos [a] aquel solo Dios que fizo todas las cosas del mundo, que es poderoso de dar e de toller a quien él quiere, e non demos nada por tales cosas (e) desde oy."1275

\section{II.2.d.- El caso de Mahoma: la construcción de una imagen malévola}

Anales Complutenses. Mahoma como pseudoprofeta.

"In era sexcentesima quinquagesima sexta prophetavit Mafomet pseudos-propheta $[\ldots]^{\prime 1276}$.

\section{II.2.e.- El escenario fronterizo y algunos intentos de comprensión del Islam}

Historia Rebus Hispaniae. Comparación del califa de Bagdad y el Sumo Pontífice

"Auentumerth autem asciuit quendam, qui Almohadi uocabatur et erat in Machometi doctrina ualde peritus, et cepit librum Machometi, qui dicitur Alchoranus, exponere et docere et caliphe de Baldac, qui est Papa Arabum et descendit generationis linea de

barbaros de Cordoua, e como se allegase[n] a él, desfaziase ante sus ojosy llorando a ellos otra vez [aparesçia e] lo tornaua a dezir. Este creemos que fue el diablo que lloraua la cayda de los moros. Mas Almançor, desde esse dia que fue vençido, nunca quiso comer nin beuer, y veniendo en la çibdad que se dice Medinaceli morio". CE, Libro IV, n 39, op. cit., p. 330-331.

${ }^{1274}$ HRH, Liber II, Cap. XVII, op. cit., pp. 65, 66. "Durante su reinado el maldito Mahoma predicó la maldad de su secta a los pueblos de poco seso.” HHE., Libro II, Cap. XVII, op. cit., p. 111.

${ }^{1275}$ CXXR, Libro III, cap. IV, op. cit., p. 99.

1276 Anales Complutenses, en Huici, Ambrosio, Las Crónicas latinas... op. cit., Tomo I, pp. 40. "En la seiscentésima quincuagésima sexta profetizó Mahoma, falso profeta [...]." Anales Complutenses, en Huici, Ambrosio, Las Crónicas latinas... op. cit., Tomo I, pp. 40. 
semine Machometi, contraria predicare, similiter contra Almorauides, qui tunc culmen regni in Affrica optinebant, rebellia adhortari." 1277

Historia Rebus Hispaniae. Virtudes de Abenthut

"Erat autem Abenhut de genere Abohaget olim regis Cesarauguste, et cum fere monarchus in cismarina Vandalia haberetur, audacia, largitate, justicia, ueritate, prout gentis eius infedelitas seu uersucia tolerat, preminebat."1278

Fuero de Coria. Limitaciones al comercio con al-Andalus.

"234. Qui pan levar a tierra de moros.

Todo ome que pan llevar a tierra de moros, ho miel, ho queso, ho manteca, ho armas, ho cavallo, qui lo fallar tomelle quanto truxier sin calonna, e adula el cuerpo a los alcaldes, e fagan delle justiçia, e pierda quanto ovier."1279

Fuero de Cuenca. Limitaciones al comercio con al-Andalus.

“4.- El que venda alimentos a los sarracenos.- Cualquiera que venda o suministre armas o alimentos a los moros, sea despeñado, si se le puede probar; pero si no, sálvese con doce vecinos y sea creído; o juré él solo y responda el reto, lo que más le plazca al Consejo. Llamamos alimentos al pan, al queso y a todo lo que se pueda comer, excepto los ganados vivos". ${ }^{1280}$

\section{II.2.f.- Las matanzas: la muerte instrumentalizada}

Historia Compostelana. Ensañamiento de cristianos contra musulmanes

"Ducenti uiri mari belloque promti cursu uelifero Hismaelitarum terram inuadunt.

Pro acceptis itaqui olim dampnis atque contumeliis equipolentia et amplius Hismahelitis rependunt: incendunt domos, et segetes in areis (erat enim tempus

${ }^{1277}$ HRH, Liber VII, cap. X, op. cit., p. 231. "Aventumerth se ganó a un tal Almohadi, persona muy docta en la doctrina de Mahoma, y comenzó a predicar y enseñar el libro de Mahoma, que se llama Alcorán, y a defender ideas opuestas a las del califa de Bagdad, que es el Papa de los árabes y desciende de Mahoma por línea directa, y de la misma forma comenzó a instigar levantamientos contra los almorávides, que entonces poseian el poder en Africa”. HHE, Libro VII, cap. X, op. cit., p. 277.

${ }^{1278}$ HRH, Liber IX, cap. XIV, op. cit., p. 294. "Por su parte Abenhut pertenecía a la familia de Abohaget, otrora rey de Zaragoza, y considerándose como monarca en la Andalucía peninsular, hacía gala de generosidad, justicia y verdad, en la medida en que lo permite la deslealtad y la artería de ese pueblo". HHE, Libro IX, cap. XIV, op. cit., p. 346.

${ }_{1279}$ FC, Libro III, n ${ }^{\circ} 234$, op. cit., p. 71.

${ }^{1280}$ FCc, cap. XIII, n ${ }^{\circ}$ 4, op. cit., p. 124. 
triturationis), arbores, uineas succidunt, nec parcit gladius eorum a maiori usque ad minorem: templa quoque eorum comburere at diruere et in eis feda relatu facere non erubescunt. Naues eorum honeriferas aut ueligeras captiuos Christianos deffere assuetas capiunt, destruunt, comburunt. Tandem saciato gladio nauibusque suis auro, argento, spoliis honeratis, concinentes laudem Deo et beato Iacobo ad propria cum gaudio reuertuntur." 1281

Chronica Adefonsi Imperatoris. Revancha cristiana.

"[...] et habuit cum eis misterium consilii sui, dixitque omnem intentionem suam in eo esse ut iret in terram Sarracenorum ad debellandum eos et accipere sibi vindictam de rege Texufino et de caeteris regibus Moabitarum, qui venerant in terram Toleti et occiderant multos duces chistianorum et destruxerant castellum quod dicitur Acecha usque ad fundamentum, et omnes cristianos quos ibi invenerant, perdiderant gladio." 1282 .

Chronica Adefonsi Imperatoris. Ensañamiento de cristianos contra musulmanes "[...] et multae cohortes praedatoriae ambulaverunt per deis multos a longe, et praedaverunt totam terram de Iaem et Baezae et Ubetae et Anduger et multarum aliarum civitatum, et miserunt ignem in omnibus villis quascumque inveniebant, et synagogas eorum destruxerunt, et libros legis Mahometi combuserunt igne: omnes viri doctores legis quicumque inventi sunt, gladio trucidati sunt; vineas et oliveta et ficulneas et omnes arbores fecerunt incidi, et omnis locus quemcumque pedes eorum calcaverunt vastatus remansit. Post multos vero dies reversi sunt ad imperatorem in castra, portantes secum magnam multitudinem captivorum virorum ac mullurum et parvulurum, munera auri et argenti et vestes pretiosissimas et omnes locupletationes

${ }^{1281}$ HC 1988, Liber I, cap. CIII, op. cit., pp. 176. "Doscientos hombres, preparados para el mar y la guerra, atacan con sus barcos de vela la tierra de los ismaelitas. Devuelven a los ismaelitas lo equivalente y más por los daños y ultrajes recibidos en otro tiempo: incendian las casas y las mieses en las eras (pues era el tiempo de la siega), cortan los árboles, las viñas, y su espada no perdona desde el mayor al más pequeño; tampoco se avergüenzan de quemar y derruir sus templos y de hacer en ellos cosas indignas de ser relatadas". HC 1994, Libro I, cap. CIII, op. cit., pp. 246.

${ }^{1282}$ CAI, Liber I, $\mathrm{n}^{\circ} 33$, op. cit., p. 30, 31. "[...] y trato con ellos su plan secreto diciendo que toda su intención estaba en ir al territorio de los musulmanes para vencerlos y tomarse venganza del rey Texufin $y$ de los demás reyes moabitas, que incluso en persona habian venido al territorio de Toledo, matando a muchos caudillos de los cristianos, destruyendo hasta los cimientos el castillo llamado Aceca y pasando a cuchillo a todos los cristianos de alli habian encontrado" CEA, Libro I, n 33, op .cit., p. 74. 
eorum et totam supellectilem et magnos greges equorum et equarum et boum et vaccarum et ovium et caprarum."1283

Chronica Adefonsi Imperatoris. Cabezas como trofeos.

"Capita vero regum suspenderunt in summitate hastarum in quibus erant vexilla regalia, et capita ducum et principum suspensa sunt in singulis hastis. Corpora regum iussit Munio Adefonsi involvi in pannis sericis optimis, et posuit ea in quoddam campo viridi, et reliquia cum eis Sarracenos qui ea custodirent usque inde tollerentur." 1284

Chronica Adefonsi Imperatoris. Cabezas como trofeos.

“[174] Iussit autem Munio Adefonsi suspendi capita regum et caetera capita principum et ducum in summa arce Toletti, ut omnibus christianis, Moabitis et Agarenis manifestum sigum esset auxilii Dei. Transactis autem aliquot diebus, imperatrix, misericordia magna mota, iussit capita regum deponi, et praecepit Iudaeis et Sarracenis medicis ea ungere myrrha et aloes, et involvi in pannis optimis et mittere in arcis laboratis ex auro et argento. Deinde imperatrix honorifice misit ea in Cordobam reginis uxoribus eorum regum. Facta est autem haec victoria a Deo in Era centesima octuagesima prima post millesiman, in mense martio (82)." 1285

\footnotetext{
1283 CAI, Liber II, n 131, op. cit., p. 103, 104. "Numerosos escuadrones dedicados al pillaje se alejaron durante muchos días, saquearon todo el territorio de Jaén, Baeza, Úbeda, Andújar y de otras muchas ciudades, prendiendo fuego a todas las villas que encontraban, destruyeron sus mezquitas y entregaron al fuego los libros de la ley de Mahoma. Mataron a golpe de espada a todos los doctores de la ley que encontraron. Hicieron cortar las viñas, olivos, higueras y todos los árboles, y todo lugar que hollaron sus pies quedó devastado. Y después de muchos días regresaron al campamento ante el emperador llevando consigo una gran multitud de cautivos, hombres, mujeres y niños, regalos de oro y plata, vestidos muy valiosos, todas sus riquezas, todo su ajuar y grandes rebaños de caballos, yeguas, bueyes, vacas, ovejas y cabras." CEA, Libro II, n 36 (131), op. cit., p. 106.

${ }^{1284}$ CAI, Liber II, $n^{\circ} 168$, op. cit., pp. 131, 132. "Colgaron las cabezas de los reyes en la punta de las lanzas, en las que estaban los estandartes reales, y en cada una de las lanzas se suspendieron las cabezas de los caudillos y jefes militares. Munio Alfonso mando envolver los cuerpos de los reyes en espléndidos paños de seda, los puso en una llanura verde y dejó con ellos a los musulmanes para que los custodiasen hasta que fueran retirados de alli." CEA, Libro II, n 73 (168) op. cit., pp. 117, 118.

${ }^{1285}$ CAI, Liber II, n 79 (174), op. cit., p.135. "79 (174) Por otra parte, Munio Alfonso mandó colgar las cabezas de los reyes y las demás cabezas de los príncipes y caudillos en la parte más alta de la ciudadela de Toledo, para que todos los cristianos, moabitas y agarenos tuviesen un testimonio manifiesto de la ayuda de Dios. Pero, pasados algunos días, la emperatriz, movida por una gran compasión, mandó bajar las cabezas de los reyes y ordenó a los médicos judios y musulmanes ungirlas con mirra y áloe, envolverlas en los mejores paños y ponerlas en cofres repujados de oro y plata. Después la emperatriz las envió con todos los honores a Córdoba a las reinas esposas de estos reyes. Dios proporcionó esta victoria en el mes de marzo del año 1143." CEA. Libro II, n 79 (174), op. cit., p. 119.
} 
Chronica Adefonsi Imperatoris. Muerte y mutilación de Munio Alfonso.

"Venit autem Farax adali et amputavit caput eius et brachium dextrum cum humero, et manun et pedem eius dextrum, cum tibia, et expoliavit eum armis; et truncum corporis eius involvit in linteaminibus mundis; et multa capita militum christianorum praeciderunt. Et miserunt capuz Munionis Adefonsi in Cordubam, in domun uxoris Azuel, et in Sibiliam, in domun regis Abencetae; deinde trans mare, in domun regis Texufini, ut annuntiaretur in omnen terram Moabitarum et Agarenorum. Brachium et pedem Munionis Adefonsi, et capita aliorum militum suspenderunt super excelsam turrem quae est super Calatravam." 1286

Crónica Najerense. Matanza ordenada por Fernando I

"Lameccenses quoque Mauri partim gladiis obtruncati, partim uero ob diuersa ecclesiarum opera ansis ferreis sunt constricti" ${ }^{1287}$.

Crónica Latina de los Reyes de Castilla. Matanzas de los francos

"Mouentes igitur castra in nomine Domini Iesu Christi profecti sunt uersus Malagon, quod in momento et uelud in ictu oculi rapuerunt de manibus Maurorum, concidentes in frusta quotquot ibi reperti sunt ${ }^{, 1288}$.

Cronicon Mundi. Prácticas de amedrentamiento de Alfonso VI en el cerco a Córdoba "Sequenti uero die ipsum Abaldella iussit rex Adefonsus uidentibus Mauris qui erant super murum Cordube, frustratim (s)cindi et igne cremari, quia occiderat Benabet socerum regis. De illis etiam qui capti fuerant cum illo et erant familiares eius, igne comburi iussit. Vnde territi Sarraceni de soliendo tributo cum rege Adelfonso firmiter pepigerunt et illi et argenti, lapidum preciosorum et sericarum uestium, inmensos

${ }^{1286}$ CAI, Liber II, $\mathrm{n}^{\circ}$ 183. op. cit., p. 142. "El adalid Farax llegó y cortó su cabeza, el brazo derecho con el hombro, la mano y su pie derecho con la pierna, le despojó de sus armas y envolvió su cuerpo mutilado en lienzos limpios. Cortaron muchas cabezas de los caballeros cristianos, y enviaron la cabeza de Munio Alfonso a Córdoba, al palacio de la esposa de Azuel, y a Sevilla, al palacio del rey Avenceta, después al otro lado del mar al palacio del rey Texufín, con el fin de que se conociese en todo el territorio de los moabitas y de los agarenos. El brazo y el pie de Munio Alfonso y las cabezas de los demás caballeros los colgaron sobre una alta torre que hay en Calatrava." CEA, Libro II, $\mathrm{n}^{\circ} 88$ (183), op. cit., pp. 121, 122.

${ }^{1287}$ CN 1995, Liber III, n 6, op. cit., p. 157. "Los moros de Lamengo fueron en parte decapitados con las espadas, y en parte atados con cadenas de hierro para los trabajos en la construcción de iglesias." $\mathrm{CN}$ 2003, Libro III, n 6, op. cit., p. 164.

${ }^{1288}$ CLRC 1997, Liber II, $\mathrm{n}^{\circ}$ 22, op. cit., p. 58. "Levantaron pues los campamentos en nombre del Señor Jesucristo y marcharon hacia Malagón, que en un momento y como en un abrir y cerrar de ojos tomaron de la mano de los moros, matando inútilmente a cuantos alli encontraron". CLRC 1999, Libro II, $\mathrm{n}^{\circ} 22$, op. cit., p. 50. 
thesauros abtulerunt, et reuersus est rex Adefonsus in patriam cum multis opibus et gloria magna"1289.

Historia Rebus Hispaniae. Matanza ordenada por Ordoño I

"Et sic uictor et inclitus ad eos quos in obsidione dimiserat, est reuersus, et VII die postquam rediit, irruptione municionem accepit; omnibus qui inerant interfectis et ciuitate usque ad fundamenta subuersa, ad propria rediit cum triumpho" ${ }^{1290}$.

Historia Rebus Hispaniae. Matanza ordenada por Ordoño II

"In inicio autem regni rex Ordonius collecto exercitu Talaueram oppidum animosus obsedit; uenientesque Arabes ut obsessis fierent in succursum, et ipsi pugna prostrati et obsessi frustrati utrique gladio perierunt; et directo oppido que ibi erant regis Ordonii prede cesserunt, et principem exercitus Cordubensis captum adduxit, qui multis predis et captiuorum catheruis eius gloriam subsequentibus in regnum suum reuertitur gloriose, 1291 .

Historia Rebus Hispaniae. Matanza ordenada por Fernando III "[...] alia uice duxit exercitum per Giennum circa festum sancti Iohannis, quod propter sui fortitudinem non potuit expugnari; et inde procedens cepit Pegum et captis incolas et occisis munitionem funditas desolauit, et ueniens ad oppidum quod Alhama dicitur, captis habitatoribus et occisis locum destruccione simili dissipauit ${ }^{\prime 1292}$.

${ }^{1289} \mathrm{CM}$, Liber IV, $\mathrm{n}^{\circ}$ 71, op. cit., p. 307. “[...] e entonçes, al dia siguiente, mando el rey Alfonso, veyendolo los moros que estauan sobre el muro de Cordoua, fazer en pedaços y quemarlo, porque auia muerto a Benabeth, y de aquellos que auian seydo captiuos en la batalla, que eran sus familiares, mandolos quemar en fuego; onde espantados los moros, pleytaron firmemente con el rey de pagar los tributos, y offresçieronle grandes tesoros de oro y plata y de piedras preçiosas y de vestiduras de seda, $y$ tornose a su tierra con muchas riquezas y gran gloria." CE, Libro IV, cap. LXXI, op. cit., p. 380.

${ }^{1290} \mathrm{HRH}$, Liber IV, cap. XIV, op. cit., 135. "Y de esta forma, victorioso y enaltecido, volvió junto a los que habia dejado en el asedio, y a los siete días de su regreso conquistó al asalto la fortaleza; una vez ejecutados todos los que la ocupaban y arrasada la ciudad hasta los cimientos, regresó triunfalmente a su tierra."HHE, Libro IV, cap. XIV, op. cit., p. 179.

${ }^{1291}$ HRH, Liber IV, cap. XXII, op. cit., p. 145. "Al comienzo de su reinado el rey Ordoño, formado un ejército, sitió con gran coraje la fortaleza de Talavera; y cuando llegaron los árabes para socorrer a los sitiados, no sólo fueron éstos derrotados en combate y quedaron los asediados sin esperanzas, sino que unos y otros fueron pasados a cuchillo, y, saqueada la fortaleza, los que alli vivían engrosaron el botín del rey Ordoño, y se llevó prisionero al jefe del ejército cordobés y regresó cubierto de gloria a su reino con ingente botín y largas columnas de prisioneros que rubricaban su gloria.” HHE, Libro IV, cap. XXII op. cit., p. 188.

${ }^{1292}$ HRH, Liber IX, cap. XII, op. cit., p. 293. "[...] en otra ocasión condujo a su ejército hacia Jaén por la festividad de San Juan, pero no pudo conquistarla a causa de sus grandes defensas; y partiendo desde allí tomó Priego y, apresados y pasados a cuchillo sus moradores, demolió la fortaleza hasta los cimientos, y dirigiéndose al castillo que se llama Alhama, arrasó el lugar con el mismo sistema tras apresar y pasar a cuchillo a sus habitantes.” HHE, Libro IX, cap. XII, op. cit., p. 345. 
Historia Rebus Hispaniae. Matanza de Albelda.

"Et sic victor et melitus ad eos quos in obsidione dimiserat, est reuersus, et VII die postquam rediit, irruptione municionem accepit; omnibus qui inerant interfectis et ciuitate usque ad fundamenta subuersa, ad propria rediit cum triumpho."1293

Historia de Rebus Hispaniae. Matanza de Malagón.

"[...] licet qui erant in arce satis uiriliter se defenderent, instancia temen ultramontanorum, que magna strenuitate feruebat, pro Christi nomine mori desiderans uirtutem resistencium et munitionis presidium in nomine Domini minorauit cepitque Malachonem, omnibus qui inerant interfectis" ${ }^{294}$.

Crónica General de España. Prácticas de amedrentamiento del Cid en el cerco a Valencia

"Et aquel que el Çid podie fallar que salie de la villa, mandaual quemar ante todo el pueblo en lugar o lo viessen los moros; et quemo en vn dia XVII dellos. Et echaua otros a los perros que los despedaçauan biuos.",1295

Crónica General de España. Matanza de cautivos.

"El infante tenie la çaga et traye y quinientos moros catiuos que desa caualgada tomaron, et enbil don Aluar Perez dezir; que traya la delantera, que fezies descabeçar los catiuos todos; et fezieronlo asi. ",1296

Crónica de Veinte Reyes. Matanza de Fernando III

"E llegó a Jahén e pusieron y luego fuego a vna torre, e murieron y muchos moros quemados e despeñáuanse e rrecogienlos en las lanças."1297

\footnotetext{
${ }^{1293}$ HRH, Liber IV, cap. XIV, op. cit., p. 135. "Y de esta forma, victorioso y enaltecido, volvió junto a los que había dejado en el asedio, y a los siete días de su regreso conquistó al asalto la fortaleza; una vez ejecutados todos los que la ocupaban y arrasada la ciudad hasta los cimientos, regresó triunfalmente a su tierra."HHE, Libro IV, cap. XIV, op. cit., p. 179.

${ }^{1294}$ HRH, Liber VIII, cap. V, op. cit., p. 264. "[...] aunque los que estaban en la fortaleza se defendieron muy bravamente, sin embargo el empuje de los ultramontanos, que ardía de valerosa pasión, en su afán por morir por la fe de Cristo quebrantó el valor de los defensores y la solidez de la fortificación en nombre del Señor y se apoderó de Malagón, matando a todos los de adentro." HHE, Libro VIII, cap. V, op. cit., p. 313.

${ }^{1295}$ CGE, cap. 915 , op. cit., p. 586.

${ }^{1296}$ CGE, cap. 1043, op. cit., p. 726.

${ }^{1297}$ CXXR, Libro XIV, cap. VIII, op. cit., p. 300.
} 
Crónica de Alfonso X. Decapitación de Nuño González de Lara

"Et Aben Yuçaf mostró que le pesaua de la muerte de don Nuño, ca dezié que lo quisiera tomar biuo. Et mandól cortar la cabeça e enbióla al rey de Granada, et enbióle dezir que tomase su parte de aquella cabalgada. Et el rey de Granada enbiól dezir que era pagado con aquella parte que él le enbiaua, pero quel pesó mucho con la muerte de don Nuño, ca éste fizo mucho porque él fuese rey. E esta cabeça enbiólla (sic) a Córdoua e enbió dezir que la enterrasen con el cuerpo." 1298

Crónica de Alfonso X. Muerte y mutilación de Sancho, Arzobispo de Toledo "E fue preso el arzobispo e muertos muchos de los cristianos. E teniendo[lo] desnudo de las armas e de las otras vestiduras que leuaua, aquellos moros que eran los mayoles dixeron que lo leuarían al rey de Granada. Et Hamejamalit e Vzmén dixieron que ellos lo leuarían [a] Abén Yuçaf, ca, fasta que ellos pasaron aquende la mar, nunca el rey de Granada nin los suyos supieron por quáles partes pasaua el río de Gualdalquivir. Et sobre esto fueron los moros en tiempo de aver muy grant pelea entre sí. Et quanto esto vió el arrayaze Abén Macar, dio de las espuelas al caballo e fue al arzobispo do estaua desnuyo (sic) e diól con vna azagaya por ençima del onbro que le entró el cuerpo e matoló. Et dixo:

- 'Non quiera Alá que por vn perro se maten tantos buenos commo aquí están' -

E cortáronle la cabeça e la mano en que tenié el aniello e mouieron ende con su presa et fuéronse."1299

Crónica de los Reyes de Castilla. Derrota de los caballeros de Santiago.

"[...] é á ellos que se tornaban ya, parecieron cerca del castillo de Moclin, cient caballeros de moros, é desque los vido este maestre don Gonzalo Ruiz Giron, commo era ome de grand corazon, non atendío ninguno de los otros, ni áun á la su gente mesma, é frésenlos acometer con muy poca gente, é los moros, que los vieron, comenzaron de fuir, é leváronle á una celada en que estaban dos mill caballeros de moros. É desque fué descubierta la celada, acogieron en pos dellos, é diéronle feridas á este Gonzalo Ruiz, de que murió después, é fueron en pos de la otra gente, é llegaron

${ }_{1299}^{1298}$ CAX, cap. LXII, op. cit., p. 179.

1299 CAX, cap. LXIII, op. cit., p. 182. 
cerca de las tiendas del rey, é mataron ese día entre caballeros é omes de pié dos mill é ochocientos, é murieron y todos los más de los frailes de la órden de Santiago [...]”. ${ }^{1300}$

La caída del Califato de Córdoba y los reyes de Taifas. Conquista del Castillo de San Martín

“Detuvo su corcel en el patio de la fortaleza que miró con atención; luego llegase al lugar en el que se había separado a las gentes [23] de la fortaleza. Se dirigió hacia [el grupo formado por] los hombres, que ya se habian levantado en consideración a él, mientras esperaban de su clemencia que los llevaría cautivos. [Él] los miró y les aplicó la sentencia con el [mismo] veredicto [emitido contra] Sa'd b.Mu'ād - Dios esta satisfecho con él -. Hizo un signo a los soldados que estaban a su alrededor; [estos] entonces los pasaron a cuchillo y los hicieron perecer en un momento. Enseguida ordenó la distribución de los prisioneros a los fronterizos voluntarios de la guerra santa (ah lar-ribāt) y a los cabalgadores de los grupos irregulares (fursāan al-wufüd), conforme a la costumbre."1301

La caída del Califato de Córdoba y los reyes de Taifas. Ultraje y devastación de los francos.

"[...] tomando todo lo que se le presentaba y castigando por lo que se le ocultaba, y a veces perdió la vida el musulmán por esto y así descansó; otras veces su término lo retrasó para una situación peor que esa, dado que los enemigos de Dios, entonces, apetecian violar a las mujeres de sus prisioneros y a sus hijas en su presencia, extremándose en las ofensas; abusaban de la casada y desfloraban a la virgen ante el marido de aquélla y el padre de ésta aherrojado, y el que no se complacía de entre ellos en hacer eso las daba a sus esclavos para que se divirtieran con ellas."1302

La caída del Califato de Córdoba y los reyes de Taifas. Los andalusíes masacran a los francos.

"Cuando los cristianos vieron eso con sus propios ojos salieron desde otro lado, por otra puerta, y cargaron como un solo hombre contra el campamento de los musulmanes; pero los muslines los persiguieron y los mataron como quisieron, y no se salvó de ellos sino poca gente de aquellos cuyo fin se aplazó. Hicieron prisioneros a

${ }^{1300}$ CRC, cap. LXXIV, op. cit., p. 58.

${ }_{1301}$ CCC, op. cit., pp. 29, 30.

1302 CCC, op. cit., p. 189. 
todos los que estaban en ella, sus familiares e hijos, y se mató, de los enemigos de Dios, a unos mil caballeros y a cinco mil infantes, y no fueron alcanzados de la comunidad musulmana sino unos cincuenta. Los musulmanes se adueñaron de la ciudad y la lavaron de la suciedad del politeísmo y la pulieron de la herrumbre de la mentira."1303

\section{II.2.g.- Botín, aspectos materiales y humanos}

Chronica Adefonsi Imperatoris. Descripción del botín.

"[...] et reversae sunt universae praedatoriae cohortes cum magnis victoriis, portantes secum multa milia Sarracenorum captivorum et maximam multitudinem camelorum, equorum et equarum, boum et vaccarum, arietum et ovium, hircorum et caprarum, quae erant regum et regitarum, et alias opes plurimas" ${ }^{\prime 304}$.

Chronica Adefonsi Imperatoris. Victoria de Rodrigo Fernández

"[128] Ut autem vidit eos Toletanus princeps, dixit christianis: 'Ne timueritis multitudinem eorum, et impetum eorum ne formidetis: mementote qualiter rex domnus Adefonsus et patres nostri bellando ce perunt Toletum et omne regnum usque ad flumen Dorii; et nunc clamemus in caelum et miserebitur nostri Deus noster, et Deus conceret eos ante faciem nostram hodie' (62). Et paratis aciebus militum et peditum et ballistorum ex utraque parte, commiserunt bellum, et ceciderunt multa milia Sarracenorum, et placuit Deo. Et rex Texufinus victus est, et fugiit de campo ipse et omnis exercitus eius, et christiani acceperunt aurum multum et argentum et equos et mulos et amellos et opes magnas, et conversi venerunt Toletum et dicebant hymnum et benedicebant Deum, quoniam bonus est quoniam in saeculum misericordia eius (63)."1305

\footnotetext{
1303 CCC, op. cit., p. 190.

${ }^{1304}$ CAI, Liber I, n' 39, op. cit., p. 34. "Y todas las tropas dedicadas al pillaje regresaron con grandes victorias llevando consigo muchos miles de prisioneros musulmanes y un número muy grande de camellos, de cabras, y yeguas, de bueyes, vacas, carneros y ovejas, de machos cabrios y cabras, que eran de los reyes y reinas, y otras muchísimas riquezas". CEA, Libro I, $\mathrm{n}^{\circ} 39$, op. cit., p. 76.

${ }^{1305}$ CAI, Liber II, n’ 128, op. cit., pp. 99, 100. "33 (128). Cuando los vio el jefe militar de Toledo, dijo a los cristianos: 'No temáis su número ni os aterroricéis de su ímpetu. Recordad cómo el rey don Alfonso y nuestros padres tomaron luchando Toledo y todo su reino hasta el rio Duero. Ahora clamemos al cielo, nuestro Dios se compadecerá de nosotros y Dios los aplastará hoy en nuestra presencia'. Dispuestas las tropas de caballeros, peones y ballesteros por ambas partes, entablaron combate y cayeron muchos miles de musulmanes con el beneplácito de Dios. El rey Texufin fue vencido y huyó del campo de batalla él y todo su ejército y los cristianos cogieron mucho oro y plata, caballos, mulos, camellos y grandes riquezas y regresaron a Toledo recitando un himno y bendiciendo a Dios porque es bueno, porque su misericordia es eterna." CEA, Libro II, n 128, op. cit., pp. 105.
} 
Chronica Adefonsi Imperatoris. Descripción del botín

"Vineas et oliveta et ficulneas et omnes arbores fecerunt incidi, et emnis locus quemcumque pedes forum calcaverunt vastatus remansar. Post multos vero dies reversi sunt ad imperatorem in castra, portantes secum magnam multitudem captivorum virorum ac mulierum et parvolorum, munera auri et argenti el vestes pretiosissimas et omnes locupletationes forum et totam supellectilem et magnos greges equarum et equarum et boum et vaccarum et ovium et caprarum"1306.

Crónica Latina de los Reyes de Castilla. Negociaciones en Córdoba.

"E contrario suadebatur regi ut acceptaret conditionem et non curaret de personis Maurutum uel de mobilibus dummodo ciuitatem posset habere sanam et integram, siquidem quasi pro certo sciebatur, quia Cordubenses conduxerant, quia si dominus noster Fernandus rex nollet acceptare conditionem, desperantes de uita, omne preciosum, quod esset in ciuitate, destruerent, mezquitam scilicet et pontem, aurum et argentum absconderent, panos sericos ymo totam ciuitatem igni succederent, semetipsos morti traderent." 1307

Cronicon Mundi. Botín como estímulo de campaña

"Erat quedam nobilissima et opulentissima ciuitas barbarorum in maritimis Mediterranei maris Almeria, quam imperator Adefonsus depredatis omnibus aliis opidis barbarorum obsedit et etiam Ianuenses et Venetos per mare ad obsidionem illius urbis conuocauit. Cepit eam imperator catholicus in ore gladii et omnes thesauros ipsius dedit Venetis et Ianuensibus et ciuitatem retinuit sibi. Captiuos autem Sarracenos dedit Raymundo comiti Barchilonensi, qui uenerat ad absidionem urbis, et licet thesauri essent infiniti, imperator nichil sibi retinuit" ${ }^{\prime 1308}$

\footnotetext{
${ }^{1306}$ CAI, Liber II, $\mathrm{n}^{\circ} 131$, op. cit., p. 104. "Hicieron cortar las viñas, olivos, higueras y todos los árboles, $y$ todo el lugar que hollaron sus pies quedó devastado. Y después de muchos días regresaron al campamento ante el emperador llevando consigo una gran multitud de cautivos, hombre, mujeres y niños, regalos de oro y plata, vestidos muy valiosos, todas sus riquezas, todo su ajuar y grandes rebaños de caballos, yeguas, bueyes, vacas, ovejas y cabras". CEA, Libro II, n 36 (131), op cit., p. 106.

1307 CLRC 1997, n 73, op. cit., p. 116. "Otros, al contrario, insinuaban al rey que aceptara la condición y no se preocupase de las personas de los moros ni de los bienes muebles con tal de que pudiera obtener la ciudad sana e integra, pues de cierto se sabía que los cordobeses habian decido que, si nuestro rey Fernando no quería aceptar la condición, desesperados de la vida, destruirían todo lo que de valor hubiese en la ciudad, a saber, la mezquita y el puente, esconderían el oro y la plata y quemarian las telas de Siria, es más, toda la ciudad, y a sí mismos se darían la muerte”. CLRC 1999, n 73, op. cit., p. 101.

${ }^{1308} \mathrm{CM}$, Liber IV, $\mathrm{n}^{\circ}$ 74, op. cit., p. 311. "Hera vna muy noble y muy abastecida çibdad de los barbaros, en los mares mediterraneos, que se dize Almería, la cual çcercó el emperador Alfonso robando los otros villajes de los barbaros; y llamó para la çerca de aquella çibdad a los genoueses y veneçianos por la mar; y tomo el emperador en boca de cuchillo, todos sus tesoros y diolos a los veneçianos y gonoueses, y
} 
Historia Rebus Hispaniae. El botín en las Navas de Tolosa

"In campo autem qui uoluerunt rapere plurima inuenerunt, aurum, scilicet, argentum, uestes preciosas, suppellectilia serica et multa alia preciosísima ornamenta, necnon et pecunias multas et uasa preciosa, que omnia pro maiori parte pedites et aliqui milites de Aragonia habuere. Maiores enim et quos fidei zelus et legis reurencia et amor strenuitatis nobilitauerat, hec omnia contempnentes usque ad noctem persecucioni uiriliter intenderunt, presertim cum precedente die Toletanus pontifex sub interminatione anathematis inhibuisset, ne quis prede campi insisteret, si diuina providencia uictoriam concedere dignaretur."1309

Crónica de Veinte Reyes. Captura de cautivos

"E leuaron los cristianos muchos catiuos e muchos despojos, e tornáronse para sus tierras rricos e honrrados". ${ }^{1310}$

\section{Las Siete Partidas. Definición y normativas respecto del cautivo}

"Mas cativos son llamados por derecho aquellos que caen en prisión de homes de otra creencia; ca estos los matan despues que los tienen presos por despreciamineto que han á su ley, ó los tormentan de muy cruas penas, ó se sirven dellos como siervos metiéndolos á tales servicios que querrian ante la muerte que la vida: et sin todo esto non son señores de los que han pechándolo á aquellos que les facen todos estos males ó los venden quando quieren."

$[\ldots]$

“Quitar deben los homes á los que yacen en cativo por quatro razones: la primera porque place mucho á Dios de haber home dolor de su cristiano, ca segunt él dixo asil debe home amar como á sí mesmo quanto a la fe: la segunda por mostrar hi piedad natural que deben los homes haber daquellos que mal reciben, porque son de una natura et de una forma: la tercera por razon de haber gualardon de Dios et de los

retubo para sí la çibdad; mas los captiuos moros diolos a Remon, conde de Barçelona, que auia venido a la çerca de la çibdad, y maguera que tesoros sin cuento auia auido, el emperador no tomó para sí cosa". CE, Libro IV, cap. LXXVIII, op. cit., pp. 392, 393.

${ }^{1309}$ HRH, Liber VIII, cap. XI, op. cit., p. 275. "A su vez, los que quisieron pillar encontraron muchísimas cosas en el campo, esto es, oro, ricos vestidos, atalajes de seda y muchos otros ornamentos valiosísimos, $y$ además mucho dinero y vasos preciosos, de lo que en su mayor parte se apoderaron los infantes $y$ algunos caballeros de Aragón. Pues los grandes y aquellos a los que había ennoblecido el amor a la fe, el respeto a la ley y el afán de valentía, continuaron bravamente la persecución hasta la noche dando de lado a todo eso, debido sobre todo a que el día anterior el Arzobispo de Toledo había prohibido, bajo amenaza de excomunión, dedicarse al saqueo del campo si la divina providencia se dignaba a conceder la victoria." HHE, Libro VIII, cap. XI, op. cit., p. 324.

${ }^{1310}$ CXXR, Libro I, Cap V, op. cit., p. 83. 
homes quandol fuere meester; ca bien asi como él querri seer acogido si yoguiese en cativerio; otrosí debe él acorrer al que en él fuese: la quarta por facer daño a sus enemigos cobrando los que tienen preso de su parte sácandolos de su poder; ca esta cosa en que yace pro et honra á los que lo facen, et los otros reciben en ello perdida et mengua." 1311

\section{II.2.h.- La imagen de los musulmanes y el ordenamiento de la frontera en Alfonso X: Realidad y práctica}

Crónica General de España. Linaje de Mahoma

“466. Del linnage onde uino Mahomat.

Cuenta la estoria que los moros uienen del linnage de Agar et de Ysmael su fijo que fue fiio de Abraham, de Ysmael salio Caydar, de Caydar salio Nepti, de Nepti salio Alhumesca, de Alhumesca salio Eldano, de Eldano salio Munher, de Munher salio Escicip, de Escicip salio Jaman, de Jaman salio Auttit, de Auttit salio Attinan, de Attinan salio Mahat, de Mahat salio Nizar, de Nizar salio Muldar, de Muldar salio Hyndaf, de Hyndaf salio Mutiric, de Mutiric salio Humela, de Humela salio Quinana, de Quinana salio Melic, de Melic salio Feyr, de Feyr salio Galib, de Galib salio Luhey, de Luhey salio Murra, de Murra salio Quelib, de Quelib salio Cuztey, de Cuztey salio Abdilmenef; este Abdilmenef ouo dos fijos que ouieron nombre ell uno Escim el otro Abdiscemiz, de Escim el primero fijo salio Abdelmutalib, de Abdelmutalib salio Abdalla. Este Abdalla morando de souno con su muger Emina, fija que fue de Hayub et de Halima, en la uilla que dizen Yatrib que es acerca de Meca, concibio dun fijo a que dixieron Mahomat."1312

Crónica General de España. Los ángeles lavan el corazón de Mahoma.

"Esse anno dozeno del regnado del rey Leouegildo, auiendo ya Mahomat quatro annos de su nascencia, dixo aquel iudio estrellero mintiendo, que uinieron dos angeles et que sacaran el coraçon a Mahomat et ge lo fendieran por medio, et quel tiraran dell un quaio de sangre negra, et dise que ge lo lauaran muy bien con agua muy clara et flemosa [...] e que ell un angel daquellos dixo all otro: 'si este coraçon fuere puesto en

\footnotetext{
${ }^{1311}$ LSP, Partida II, Titulo XXIX, Ley I, op. cit., p. 327., Partida II, Titulo XXIX, Ley II, op. cit., p. 328.
} ${ }^{1312}$ CGE, cap. 466 , op. cit., p. 261. 
peso con los corazones de quantos omnes a en Arauia, mas pesara el solo que todos ellos'. E el judio mintiendo dixo quel dixiera esto sant Grabiel arcangel en uision". ${ }^{1313}$

Crónica General de España. Mahoma como hereje y poseído

"Este Mahomat era omne fermoso et rezio e muy sabidor en las artes a que llaman magicas, e en aqueste tiempo era el ya uno de los mas sabios de Arauia et de affrica. Este Mahomat otrossi uiene del linnage de Ysmael, fijo de Abraham, assi como lo auemos ya contado ante desto en esta estoria, e començó de seer mercador, ca era omne pobre et lazrado, e yua muy amenudo con sus camellos a tierra de Egipto et de Palestina; et moraua allá con los judios et los cristianos que y auie una sazon dell anno, e mayormientre con un monge natural de Anthiochia, que auie nombre Johan, que tenie el por su amigo et era herege; e daquel monge malo aprendio el muchas cosas tan bien de la nueua ley como de la vieia pora deffender se contra los iudios et los cristianos quando con ellos departiesse, ca todo lo que aquel monge le demostraua, todo era contra Dios et contra la ley, et todo a manera de heregia. [...]

Mahomat, quando aquello uio, començo de coytar la mucho et de costrennir la por sus coniuraciones et sus espiramientos que se el sabie, de guisa que non lo entendiesse ella, diziendol con tod esto que ell era Messias, el que los judios atendien que auie de uenir. Los judios, quando oyron et supieron aquello que el dizie, uinien se pora ell a compannas de cada logar, et aguardauan lo et creyen le de quanto les el dizie, otrossi los ysmaelitas et los alaraues uinien se pora ell, et acompannauan le et aguardauan le, ca tenien por marauilla lo quell oyen dezir et fazer. E el començaua les de predigar et de fazer enfintosamientre nueuas leys, e traye los en aquellas malas et descomulgadas leys otoridades de la uieia ley et de la nueua, e destruye el por esta guisa la ley de Nuestro Sennor Dios, assi que muchas uezes auien razon los cristianos et los iudios de desputar con los moros. E dio aquel Mahomat tal ley et tal mandamiento a aquellos que creyen los que les dizie: que tod aquel que otra cosa predicasse nin dixiesse, si non aquello que el dizie, que luego lo descabeçassen. [...]

E alli estando, predicaua et dizie mintiendo todas estas cosas que auemos dichas, et aun otras muchas que son de riso et de escarnio et de falsedad; et fazie a todos creer que Grabiel ge las dixiera; e por tal que el pudiesse bien atar con prisiones de muerte a aquellos pueblos de los reuellados que ell engannara et pudiesse encrobir el uenino de

${ }^{1313}$ CGE, cap. 469, op. cit., p. 262. 
la su nemiga, predicaua les siempre un Dios solo. E Meca era estonces a aquel tiempo tenida en grand onrra et en grand alteza por los muchos ydolos que y auie."1314

Crónica General de España. Explicación de la composición del Corán "E despues que se leuantarua dalli predigauales et dauales leys que touiessen, las que ellos llamaron por au arauigo zoharas, que son tanto como 'mandamientos', e destas zoharas les fizo ell un grand libro departido por capitulos, al que ellos llaman alcoran, et tanta nemiga et tanta falsedad escriuio ell en aquellas zoharas, esto es mandamientos, que uerguença es a omne de decirlo nin de oyrlo, et mucho mas de seguirlo; e pero estas zoharas le recibieron aquellos pueblos malauenturados seyendo beldos de la ponçon del diablo et adormilados en el peccado de la lujuria, e oy en dia los tienen et estan muy firmes en su porfia e non se quieren llegar nin acoger a la carrera de la verdadera fe nin ayer en si la ley de Dios nin el su enseñamiento."1315

Crónica General de España. Muerte de Mahoma

"[...] vn su disciplo que auie nonbre Albimor quiso prouar si resuscitarie Mahomat de muert a uida a tercer dia assi dixiera, ca ell auie dicho que despues que los diez annos fuessen conplidos de su regnado que morrie, et desi que resuscitarie al tercer dia; e por ende aquel su disciplo destempro un uenino et diogelo a beuer muy encubiertamientre. Mahomat, assi como lo beuio, mudosse le luego a soora toda la color, e por que ell entendio que su muerte era ya llegada, dixo a aquellos moros que estauan y con el que por agua serian saluos et aurien perdon de sus peccados. Assi como lo dixo, dio luego ell alma al diablo, et murio. E sus disciplos guardaron bien el cuerpo cuedando que resuscitarie al tercer dia, assi como les el dixiera; mas pues que ellos uiron que non resuscitana et que fedie ya muy mal, desampararonle et fueronse su uia. Dezi a cabo de los onze dias pues que el muerto, uino Albimor, aquel su disciplo, ueer de como yazie, e segund cuenta don Lucas de Thuy, fallol tod el cuerpo comido de canes. Albimor cogio estonces todos los huessos del et soterrolos en Medina rasul, que quiere dezir en el lenguage de Castiella tanto como 'la cibdad de los mandaderos'.,"1316

\footnotetext{
1314 CGE, cap. 478-493, op. cit., pp. 265-273.

1315 CGE, cap. 493, op. cit., p. 274.

${ }^{1316}$ CGE, cap. 494, op. cit., p. 274.
} 
Las Siete Partidas. Descripción del "moro".

"[...] una manera de gentes que creen que Mahomat fue profeta et mandadero de Dios; et porque las obras et los fechos que él fizo non muestran del tan grant santidad por que a tan santo estado pudiese llegar, por ende la su ley es como denuesto de Dios". ${ }^{1317}$

Las Siete Partidas. Reglamentación de la convivencia.

"Et decimos que deben vevir los moros entre los cristianos en aquella misma manera que deximos en el titulo ante deste que lo deben facer los judios, guardando su ley et non denostando la nuestra. Pero en las villas de los cristianos non deben haber los moros mezquita, nin facer sacrificios públicamente ante los homes: et las mezquitas que habien antiguamente deben seer del rey, et puédelas él dar a quien quisiere. Et como quier que los moros non tengan buena ley, pero mientras vivieren entre los cristianos en seguranza dellos, non les deben tomar ni robar lo suyo por fuerza; et cualquier que contra esto ficiere mandamos que peche doblado todo lo que les asi tomaren."1318

Las Siete Partidas. Evangelización de los musulmanes.

"Por buenas palabras et convenibles predicaciones se deben trabajar los cristianos de convertir a los moros para facerles creer la nuestra fe et para aducirlos a ella, et non por fuerza nin por premia; ca si voluntad fuese de nuestro señor Dios de los aducir a ella o de gela facer creer por fuerza, él los apremiare, que ha poder acabado de lo facer; mas el non se paga del servicio que facen los homes amidos, sinon de aquel que lo face de su grado et sin premia ninguna: et pues que el non les quiere apremiar nin forzar, por esto defendemos que ninguno non los apremie nin les faga fuerza ninguna sobre esta razon." 1319

Crónica de Alfonso X. Los rebeldes mudéjares de Jerez

"E commo quier que el rey tenía dellos muy gran sanna por lo que finieron, pero [por] la gran guerra que tenía començada con el rey de Granada et con los moros de aquén la mar [et] otrosy que avía nuevas que Jaco[b] Abuyuçaf, rey de Marruecos, se aperçibía para pasar aquén la mar con todo su poder, e por cobrar esta villa ante que aquello fuese, touo por bien de cobrar aquella villa e dexar salir los moros a saluo."1320

\footnotetext{
${ }^{1317}$ LSP, Partida VII, Titulo XXV, op. cit., p. 675.

${ }^{1318}$ LSP, Partida VII, Titulo XXV, Ley I, op. cit., pp. 675, 676.

${ }^{1319}$ LSP, Partida VII, Titulo XXV, Ley II, op. cit., p. 676.

${ }^{1320}$ CAX, cap. XIV, op. cit., p. 38.
} 


\section{II.3.- La figura del rey y la Reconquista}

\section{II.3.b.- El caso hispano, los monarcas visigodos}

III Concilio de Toledo. Rechazo del arrianismo

"Por lo mismo, santísimos Padres, ofrezco al eterno Dios, por vuestra mano, como un santo y expiatorio sacrificio, a estos nobilísimos pueblos, que por nuestra diligencia se han ganado para el Señor, pues será para mí una inmarcesible corona y gozo en la retribución de los justos, si estos pueblos que por nuestros ciudadanos corrieron a la unidad de la Iglesia, permanecen firmes y constantes en la misma. Y así como disposición divina nos fue dado a nosotros traer estos pueblos a la unidad de la Iglesia de Cristo, del mismo modo os toca a vosotros instruirlos en los dogmas católicos, para que instruidos totalmente con el conocimiento de la verdad, sepan rechazar acertadamente el error de la perniciosa herejía y conservar por la caridad en camino de la verdadera fe, abrazando con deseo cada día más ardientemente la comunión de la Iglesia católica." 1321

Historia de los Godos, Vándalos y Suevos. Hispania como recompensa al esfuerzo y fruto de victoria.

"Iure itaque te iam pridem aurea Roma caput gentium concupiuit et liceo te sibimet eadem Romuela uirtus primun uictrix desponderit, denuo tamen Gothorum florentissima gens post multiplices in orbe uictorias certatim rapit et amauit, fruiturque hactenus inter regias infulas et opes largas imperri felicitate securas."1322

Historia de los Godos, Vándalos y Suevos. La piedad visigoda.

"Post hoc igitur uotum adgressi urbem omnibus et mors et captiuitas indulta est, qui ad sanctorum limina confugerunt. Sed et qui extra loca martyrum erant et nomen Chisti et sanctorum nominauerunt, et ipsis simili misericordia pepercerunt." ${ }^{, 1323}$

${ }^{1321}$ III Concilio de Toledo, en Emilio Mitre, Iglesia y vida religiosa en la Edad Media, Madrid, Istmo, pp. 84,85 .

${ }^{1322}$ HGVS, op. cit., pp. 170. "Y por ello, con razón, hace tiempo que la áurea Roma, cabeza de las gentes, te deseó y, aunque el mismo Poder Romano, primero vencedor, te haya poseído, sin embargo, al fin, la floreciente nación de los godos, después de innumerables victorias en todo el orbe, con empeño te conquistó y te amó y hasta ahora te goza segura entre ínfulas regias y copiosisimos tesoros en seguridad y felicidad de imperio." HGVS, op. cit., p. 171.

${ }^{1323}$ HGVS, $\mathrm{n}^{\circ} 15$, op. cit., p. 194. " $Y$ así, después de esta promesa, cuando atacaron la ciudad, concedieron el indulto de la muerte y del cautiverio a todos los que se refugiaron en los lugares sagrados, y también perdonaron con igual misericordia a los que se hallaban fuera de los templos martiriales y pronunciaron el nombre de Cristo o los santos." HGVS, nº 15, op. cit., p. 195. 
Historia de los Godos, Vándalos y Suevos. Conversión de Recaredo.

“Aera DCXXIIII, anno III imperio Maurici, Leunigildo defuncto filius eius Recaredus regno est coronatus, cultu praeditus religiones et paternis moribus longe dissimilis: namque ille inrreligiosus et bello promptissimus, hic fide pius et pace praeclarus, ille armorum artibus gentis imperium dilatans, hic gloriosus eandem gentem fidei trophaeo sublimans. In ipsis enim regni sui exordios catholicam fidem adeptus totius Gothicae gentis populos inoliti errores labe deterja ad cultum rectae fidei reuocat."1324

\section{II.3.c.- Los monarcas de la Reconquista}

Crónica de Alfonso III, versión Ad Sebastianvm. La leyenda negra de Witiza

"Era DCCXXXVIIII post Egicani discessum Uutiza ad solium patris reuertitur Toleto. Iste quidem probrsus et moribus flagitiosus fuit, et 'sicus equus et mulus, in quibus non est intellectus', cum uxoribus et concubinis plurimis se coinquinauit. Et ne aduersus eum censura eclesiastica consurgeret, concilia dissoluit, canones obserauit omnemque religiones ordinem depranarit. Episcopis, presbiteris et diaconibus uxores habere preceptos. Istud quidem scelus Yspanie causa pereundi fuit. Et quia reges et sacerdotes legem Domini derelinquerunt, Omnia agmina Gotorum Sarracenorum gladio perierunt. Interea Uuittiza post regni an. X morte propria Toleto discessit era DCCXLVIIII."1325 Crónica de Alfonso III, versión Rotensis. Impiedad del pueblo godo

"Et quia derelinquerunt Dominum ne seruirent ei in justicia et ueritatem, derelicti sunt a Domino ne auitarent terram desiderauilem"1326

${ }^{1324}$ HGVS, n’ 52, op. cit., p. 260. "En la era DCXXIIII, en el año tercero del imperio de Mauricio, muerto Leovigildo, fue coronado rey su hijo Recaredo. Estaba dotado de un gran respeto a la religión y era muy distinto de su padre en costumbres, pues el padre era irreligioso y muy inclinado a la guerra; él era piadoso por la fe y preclaro por la paz; aquél dilataba el imperio de su nación con el empleo de las armas, éste iba a engrandecerlo más gloriosamente con el trofeo de la fe. Desde el comienzo mismo de su reinado, Recaredo se convirtió, en efecto, a la fe católica y llevó al culto de la verdadera fe a toda la nación gótica, borrando asi la mancha de un error enraizado.” HGVS, n 52, op. cit., p. 261.

${ }^{1325}$ CAIII, versión Ad Sebastianvm...op. cit., pp. 119, 121. "En la era 739, tras el fallecimiento de Egica, Vitiza vuelve a Toledo para ocupar el trono de su padre. Este fue en verdad un hombre deshonesto y de escandalosas costumbres, y cual el caballo o el mulo, en los que no hay entendimiento, se contaminó con numerosas esposas y concubinas. Y para que no se levantara la censura eclesiástica contra él, disolvió los concilios, cerró los cánones, y vició todo el orden religioso. A los obispos, presbiteros y diáconos les ordenó que tuvieran esposas. En verdad este crimen fue la causa de la perdición de España. Y puesto que reyes y sacerdotes abandonaron la ley del Señor, todos los ejércitos de los godos perecieron por la espada de los sarracenos. Entretanto Vitiza, tras diez años de reinado, falleció de muerte natural en Toledo, en la era 749." CAIII, versión A Sebastián... op. cit., p. 199

${ }^{1326}$ CAIII, versión Rotensis, $\mathrm{n}^{\circ}$ 7, op. cit., pp. 120, 122. "Y como abandonaron al Señor, para no servirle en justicia y en verdad, fueron abandonados por el Señor, de manera que no habitaran la tierra deseable" CAIII, versión Rotense, $\mathrm{n}^{\circ}$ 7, op. cit., p. 200. 
Crónica Najerense. Pecados de Witiza y del pueblo visigodo.

"Concilia dissoluit, canones sigillauit, uxores et concubinas plurimas accepit et, ne aduersus eum concilium fieret, episcopis, presiteris seu diachonibus uxores habere precepit. Istud namque Yspanie causa pereundi fuit."1327

Cronicon Mundi. Pecados de Witiza y del pueblo visigodo.

"Et ne aduersus eum insurgeret sancta ecclesia, episcopis, presbiteris, diaconibus et ceteris ecclesie Christie ministris, carnales uxores lasciuus rex habere precepit, et ne obedirent Romano pontifici, sub mortis interminationes prohibuit. Istud quidem causa pereundi Yspanie fuit. ",1328

\section{II.4.- Las virtudes del rey: Construcción de un ideal monárquico}

\section{II.4.a.- Linaje visigodo y continuidad}

Poema de Fernán González. El origen de los godos

"Escogyeron España toda de mar a mar,

nin vylla nin castello no s' pudo anparar.

Áfryca e Turonia ovyeron por mandar:

omnes fueron arteros, Dios los quiso guïar.

Fueron de Sancty Spýritus los godos espyrados,

los malos argumentos todos fueron fallados:

conosçieron que eran los ýdolos pecados,

cuantos creién por ellos eran mal engañados.

$[\ldots]$

Resçibyeron los godos del ánima vautysmo,

Fueron luz e estrella de tod' el cristianismo;

alçaron cristiandad, vaxaron paganismo:

el cond' Ferrán Gónçález fyzo aquesto mismo" ${ }^{\text {1329. }}$

${ }^{1327}$ CN 1995, Liber I, n²09, op. cit., p. 94. "Y para que contra él concilio ninguno se realizara, ordenó a los obispos, presbiteros y diáconos tener mujeres. Esta fue la causa de la perdida de Hispania." CN 2003, Libro I, n 209, op. cit., p. 107.

${ }^{1328}$ CM, Liber III, Cap. LXIII, op. cit., 217, 218. "Y por que se non leuantase contra él la sancta yglesia, mandó este rey a los obispos y clérigos y diaconos y a los otro sministros de la yglesia de christo que huuiesen mas anchamente mugeres carnales, e vedoles que non obedesçiesen al papa romano so pena de muerte. Y esto fue çiertamente causa de perescer España." CE, Libro III, Cap. LXIII, op. cit., p. 264.

${ }^{1329}$ PFG, (19 - 24) op. cit., p. 247. 
Crónica de Alfonso III, versión Ad Sebastianvm. Continuación visigoda.

"IN NOMINE DOMINI NOSTRI IHESU XP̃I INCIPIT CRÓNICA UISEGOTORUM A TEMPORE UUAMBANI REGIS USQUE NUNC IN TEMPORE GLORIOSI GARSEANI REGIS DIUE MEMORIE ADEFONSI FILIO COLLECTA ${ }^{\prime 1330 .}$

Crónica Latina de los Reyes de Castilla. Validación por ascendencia.

"Defuncto comite Fernando Gundissalui, qui Primus tenuit comitatum in Castella post subuersionem populi Christiani tempore Roderici, regis Gotorum, factam in Yspaniis, succesit ei filius eius, comes Garsias Fernandi, cui succesit filius, comnes Sancius, cuius filius, Garsias infans, interfectus fuit apud Legionem, cum iuisset ut duceret in uxorem filiam regis uel cuiusdam comitis, per quosdam Legionenses"1331.

Historia Rebus Hispaniae. Descripción y exaltación de los visigodos

“Libertatem semper bello quam pace pocius seruauerunt. In bellandi necessitate uires precibus pretulerunt, et in armis spectabiles, hastis et iaculis, arcubus et sagitis, ensibus atque clauis, equestri et pedestri prelio confligebant. Cura tamen equorum carior illis fuit. Telis et iaculis pro recreatione preludere affectabant. Ludorum certamina usu gerebant in armorum experiencia. Solo naualis belli exercicio caruerunt usque ad tempora Sisebuti, sub quo ad tantam gloriam peruenerunt ut uictoriarum insigniis non solum terras, set et ipsa maria subsulcarent. Fuerunt autem naturaliter magnanimi et audaces, ingenio faciles et subtiles, in proposito prouidi et constantes, gestu et habitu aprobandi, uiribus prepollentes, statura ardui et proceri, duri uulneris, manu prompti, corpore ualidi, menbris apti, disposicione compositi, coloris albi."1332

1330 CAIII, versión Ad Sebastianvm...op. cit., p. 115. "EN NOMBRE DE NUESTRO SEÑOR JESUCRISTO, EMPIEZA LA CRÓNICA DE LOS VISIGODOS, COMPILADA DESDE EL TIEMPO DEL REY WAMBA HASTA AHORA, EL TIEMPO DEL GLORIOSO REY GARCIA, HIJO DE ALFONSO, DE SANTA MEMORIA" CAIII, versión A Sebastian... op. cit., p. 195.

1331 CLRC, 1997, n 1, op. cit., p. 35. "Cuando murió Fernán-González, el primer conde de Castilla después de la derrota que los cristianos sufrieron en España en tiempos de Rodrigo, rey de los godos, le sucedió su hijo el conde Garcia-Fernández; a éste el suyo, el conde Sancho. Un hijo de este Sancho, el infante García, cuando fue a León para casarse con una hija del rey o de un conde, cayó muerto a mano de ciertos leoneses." CLRC, 1999, $\mathrm{n}^{\circ}$ 1, op. cit., p. 25.

${ }^{1332}$ HRH, Liber I, cap. IX, op. cit., p. 24. "Protegieron siempre su libertad más con la guerra que con la paz. En el trance del combate preferían la fuerza a las negociaciones, y al luchar eran de admirar manejando todo tipo de armas: lanzas y picas, arcos y flechas, espadas y mazas, a pie y a caballo. Sentían, con todo, una mayor predilección hacia los caballos. Con los dardos y las picas se divertían simulando los prolegómenos de la lucha. La experiencia de estos juegos la aplicaban luego al ejercicio de las armas. Solamente les faltó práctica en el combate naval hasta la época de Sisebuto, bajo el que alcanzaron tal gloria que recorrieron no sólo las tierras sino también los mares con las hazañas de sus victorias. Pese a todo fueron de un natural generoso y valiente, de inteligencia rápida y profunda, de intención precavida y tenaz, de maneras y porte más que regular, de fuerza sobresaliente, de estatura 
Historia Rebus Hispaniae. Luchas fraticidas entre los godos.

"Post mortem itaque regis optimi Ferdinandi tres filii eius et due filie remanserunt, Sancius, Aldefonsus, Garsias, Vrraca et Geloyra. Set licet ipse regnum filiis diuisisset et partem suam unicuique assignasset, quia omnis potestas impaciens est consortis et quia reges Hispanie a feroci Gothorum sanguine contraxerunt ne maiores aliquem uelint parem nec minores superiorem, sepius inter Gothos regalia funera fraterno sanguine maduerunt. Rex itaque Sancius Castelle et Nauarre finibus non contentus, inhumanitatis Gothice successor et heres, et sanguinem fratrum sitire et ad eorum regna cepit cupidus anelare, ut nichil fratribus uel sororibus de hiis que pater dederat remaneret, set solus totum ambiciosus haberet.",1333

Historia Rebus Hispaniae. Castigo de los visigodos.

"Et quia diuina gracia protectionis manum elongauerant ab Hispanis, gens illa uitrix, gens illa nobilis, gens Gothorum cui se dederant Asia et Europa et eius fugacibus Vandalis Orbis cesserat Africanus, triumphis Arabicis incuruatur."1334

Crónicon Mundi. Ascendencia de Fernando III.

"[...] quod requieuerit super eum spiritus sapiencie, qui in Adefonso rege Castelle auo suo, et spiritus fortitudinis et clemencie, qui erat in Adefonso rege Legionense patre ipsius" ${ }^{\prime 335}$.

elevada y esbelta, resistentes a las heridas, rápidos de acción, poderosos de cuerpo, hábiles de manejo, proporcionados de figura, de tez clara." HEH, Libro I, cap. IX, op. cit., p. 75.

${ }^{1333}$ HRH, Liber VI, cap. XIV, op. cit., p. 194, 195. "Pero por más que el padre había repartido el reino entre ellos y le había asignado una parte a cada uno, como ningún poder admite ser compartido y como los reyes de España deben a la feroz sangre de los godos el que los poderosos no soporten a nadie igual ni los débiles a nadie superior, con bastante frecuencia las exequias de los reyes se empaparon con la sangre del hermano entre los godos. Así, el rey Sancho, al que le parecían poco los reinos de Castilla y de Navarra, digno sucesor y heredero de la crueldad goda, empezó a sentir sed de la sangre de sus hermanos y a ambicionar más de lo normal los reinos de éstos, siendo su obsesión que a sus hermanos y hermanas no les quedara nada de lo que su padre les había dejado, sino que, codicioso, fuera él solo el dueño de todo." HHE, Libro VI, cap. XIV, op. cit., p. 237, 238.

${ }^{1334} \mathrm{HRH}$, Liber III, cap. XX, op. cit., p. 103. "Y como la gracia de Dios habia apartado de los hispanos su mano protectora, aquel pueblo triunfador, aquel pueblo noble, el pueblo de los godos a quien se habian rendido Asia y Europa y que había hecho huir a los vándalos, ante quienes se había inclinado las tierras de África, es doblegado por la victoria de los árabes.” HHE, Libro III, cap. XX, op. cit., p. 147.

${ }^{1335} \mathrm{CM}$, Liber IV, n’ 93, op. cit., p. 333. "[...] assi que fue visto que folgó sobrél [el] spiritu de sabiduria que fue en Alfonso rey de Castilla, su abuelo, y el espiritu de fortaleza y clemençia que era en Alfonso su padre, rey de León.” CE, Libro IV, cap. LXXXV, op. cit., p. 418. 
Crónica General de España. Virtudes del rey.

"Mas este rey tanto punno en los vsos de todas bondades quisar et obrar sienpre en toda la su uida, que nonbre conplido de todo buen prez gano en sus grandes conquistas fazer et en todos otros bienes conplidos, quales sin quantos omne contar non podrie: en heredar caualleros et ricos omnes, ordenes eglesias, adaliles, almogauares, et a todos quantos otros el razon auie de fazer merçed; en dar buenos fueros et franquezas et grandes libertades; en ser muy iustiçiero et non menguar y alli o deuie. Non fue omne que viese rey que asy sopiesse onrrar a qui el ondrar deuiese, nin que asy acogiese nin recibiese a todo omne segunt el reçibimiento que perteneciese fazer. Este fue rey mucho mesurado et conplido de toda cortesia; et de buen entendimiento, muy sabidor; et muy brauo et muy sannudo en los logares ol conuiene, muy leal et muy verdadero en todas cosas que lealtad deuiese seer guardada. Pero que muchol temien los moros obrador, era dellos mucho amado; esto era por la grant lealtad que en el auien sienpre fallada. Et enxalçador de cristianismo, abaxador de paganismo, mucho omildoso contra Dios, mucho obrador de sus obras et muy husador dellas, muy catholico, muy ecclesiastico, mucho amador de la yglesia, muy rreçelador de en ninguna razon yr contra ella nin pasar contra los sus mandamientos." 1336

\section{II.4.b.- Virtudes religiosas}

Crónica Sampiro. Alfonso III y la restauración eclesiástica

“Quoque tempore ejes est ampliata ecclesia; namque populantur a christianis urbes portugallensis, bracharensis, vesensis, flaviensis, auriensis et secundum sententiam canonicam ordinantur episcopi et producitur populando usque ad flumen Tagum"1337.

\section{II.4.c.- Validación bélica.}

Historia Rebus Hispaniae. Victorias del rey Ramiro

"Post hec autem rex Ranimirus nolens ociosus a Dei seruicio inueniri, aggressus est loca Arabum et tam in uillis quam in agris cuncta que reperiit, etiam Anagarum incencio concremauit." 1338

\footnotetext{
${ }^{1336}$ CGE, cap. 1131, op. cit., p. 771.

1337 CSEA, op. cit., pp. 243, 245. "También en tiempo de él fue ampliada la iglesia; pues se pueblan por los cristianos las urbes de Oporto, Braga, Viseo, Chaves, Orense y según la sentencia canónica se ordenan obispos y se extiende poblando hasta el río Tajo". CSEA, op. cit., pp. 244, 246.
} 
La "Vita Dominici Siliensis” de Grimaldo. Descripción del rey García

"Igitur in eo tempore Garsias rex, filius Sancii regis Maioris, frater Fredelandi regis tenentis imperium prouincie Legionensium, obtinebat regnum prouincie Nagarensis; uir certe corpore decorus, actibus clarus, sermone directus, armis strenuus et usu milicie bellicosus, ut testantur frecuentes et nobiles ac memorabiles ipsius uictorie super spurcissiman gentem Agarenorum facte et insuper restitutio Calagurritane ciuitatis, que quondam fuit, auctoritate scripturarum, sedes pontificalis."1339

\section{II.4.d.-Validación jurídica}

Cronica de Alfonso III, versión Rotensis. Muerte de Alfonso I

"Nec hoc miraculum silebo, quod uerius factum esse cognosco. Quumque spiritum emisisset intempeste noctis silentia *** [sic] cum officiis palatinis corpus custodissent, subito in aera auditur a cunctis uox angelorum psallentium: 'Ecce quomodo tollitur iustus et nemo considerat; et uiri iusti tolluntur et nemo percibit corde. A facie iniquitatis sublatus est iustus; erit in pace sepultura eius'. Hoc uerum esse cognoscite et nec fabulosum putetis:' alioquin tacere magis quam falsa promere maluissem'.,1340

Cronicon Mundi. Advertencias respecto a justicia real.

"Rex dicitur a regendo, quod se et alios bene regat; cui specialius quinque sunt necesaria: primo uidelicet creatorem et regem suum, Patrem et Filium et Spiritum sanctus, unum uerum Deum in unitate subtancie et in trinitate personarum agnoscere; secundo fidem catholicam moribus et uerbis confiteri; tercio regnum in pace omnimode

${ }^{1338}$ HRH, Liber IV, cap. XIII, op. cit., p. 133. "Tras estos hechos, el rey Ramiro, que no quería permanecer inactivo en el servicio de Dios, atacó los dominios de los árabes e incendió todo lo que encontró a su paso, tanto poblados como sembrados, incluida Nájera". HHE, Libro IV, cap. XIII, op. cit., p. 177.

${ }^{1339}$ VDS, Liber I, cap. V, op. cit., 216, 218. "Es el caso que, por aquel entonces, el rey García, hijo del rey Sancho el Mayor, hermano del rey Fernando, que regía el reino de León, ocupaba el trono de Nájera; hombre, ciertamente, de belleza corporal, esclarecido en sus hechos, claro en su modo de hablar, soldado activo y valiente en la práctica de la guerra, como atestiguan sus frecuentes, célebres y famosas victorias obtenidas sobre la infame gente de los agarenos, así como la reconquista de la ciudad de Calahorra, que otrora fue sede episcopal, según consta en escrituras". VDS, Libro I, cap. V, op. cit., pp. 217, 219.

${ }^{1340}$ CAIII, versión Rotensis, $\mathrm{n}^{\circ} 15$, op. cit., pp. 132, 134. "Y no callaré un milagro que en verdad sé que ocurrió. Como hubiera exhalado su espíritu durante el silencio de la noche cerrada ***, y como los oficiales palatinos velaban su cuerpo, súbitamente se oyó por todos en los aires la voz de los ángeles que cantaban: 'He aqui cómo desaparece el justo y nadie repara en ello; y los varones justos desaparecen y nadie se da cuenta en su corazón. De la presencia de la iniquidad ha sido apartado el justo; en la paz estará su sepultura'. Sabed que esto es verdad, y no lo reputéis fabuloso; de otro modo hubiera preferido callar antes que contar falsedades." CAIII, versión Rotense, n 15, op. cit., 208. 
conseruare; cuarto sine acceptione personarum unicuique iusticiam exibere; quinto uero hostes uiriliter, contemptis cunctis laboribus, expugnare. Princeps enim dalicatus pocius flectitur ad carnis ludibrio preagenda, quam ad hostium onstinatam fortitudinem feriendam. Princeps delicatus uino madet, lenitur blandiciis meretricum, dissoluitur luxuria et susurronibus libenter aponit aurem [...] Semper sollicitatur princeps sapiens, ne suis excessibus in temporalibus aut spiritualibus paciatur populus sibi subditus detrimentum; nam plerumque pro peccatis principum ira Dei in populos incandescit, et quotquot eius culpa dilapsi fuerint in peccatum, de illis Deo redditurus est rationem." 1341

Libro de los doze sabios. Las características del rey.

"Que el príncipe o rey o regidor que no es sañudo a los malos ni muestra los yerros a los que lo merecen, y no da por el mal pena y por el bien galardón no es digno de regimiento, que regidor de reino tanto quiere decir como pastor de las ovejas, que ha de dar vía por donde usen y vayan, destruidor de los malos, enmendador de los malos usos y costumbres, rehacedor de los bienes, igualador de las discordias, veces con saña, veces con buena palabra, enseñador de las virtudes, destruidor de los pecados, y pena de la maldad y gloria de la bondad, defendimiento de pueblo, poblador de tierra, pértiga de justicia. Y por ende le es cumplidera la saña contra los malos y crueles y desordenados en sus hechos, que el príncipe o señor en quien no hay saña o crueldad cuando cumple no puede bien regir reino, que cada uno se atreve a mal obrar en esfuerzo de no ser castigado. Y más temor pone la saña del rey o del regidor que es conocido por justicia que la justicia que hace o manda hacer, y más la debe mostrar a los grandes que a los pequeños, que ganado lo más, lo menos es cosa vencida. Y muy gran castigo es al pueblo ver quebrantada la soberbia de los grandes que ser sometidos a justicia. Razón clara y muy conocida es de que las obras pasadas dan testimonio. IX

${ }^{1341}$ CM, Praefatio, op. cit., p. 3,4. "El rey se diriua o desciende desta palabra regir, porque bien rija a sí ya los otros; al qual, más especialmente que a otro, çinco cosas son necesarias, conuiene a saber: primeramente, conosçer al criador y a su Rey, padre y fijo y spiritu sancto, vn viuo Dios en vnidad de sustancia e trinidad de personas; segundamente, les es necesario confesar la fee católica por costumbres y palabras; terceramente, le es necesario que de todo en todo guarde su reyno en paz; lo cuarto, dar justicia a cada vna de las personas sin afección; lo quinto, varonilmente despreciando sus enemigos, con todos trabajos batallar, porque el principe delicado más ayna se inclina a tractar los escarnios e los ruegos de la carne, que a ferir la fortaleza de los enemigos. El principe delicado mójase con vino, afalágase con blanduras de malas mugeres, sueltase por lujuria, de buena mente da la oreja a los maldicientes parleros [...] El prinçipe sabio siempre es cydadoso que el pueblo subiecto a él, por sus excesos en las cosas temporales o spirituales non padezca daño, porque muchas vezes, por los peccados de los principes, la yra de Dios escomiença a caer (y) [en] los pueblos y qualquier cosa de peccado en que por su culpa cayeren dara dello cuenta." CE, Prologo, op. cit., pp. 1, 2. 


\section{$[\ldots]$}

El miedo no es yerro mas naturaleza derecha: publicarlo es gran mengua, encubrirlo es nobleza de corazón. Antes hablando con las sus compañas y esforzándolos como compañero, debe ser el primero que tomare la lanza, y decir decires de osadía. Y como ya habemos dicho, y el esfuerzo tuvo las glorias mundanales y es hermano de la fortuna. Pero no sea tanto compañero que se atrevan a él y con palabra grida y sañuda deseche a los que se atrevieren a él fuera de razón, que de todas las cosas el medio y templanza es la mejor, según antes dijimos en el tratado de templanza. XI'. ${ }^{1342}$

${ }^{1342}$ LDS, op. cit., IX, XI. 


\section{TERCERA PARTE: LOS TÓPICOS}

\section{III.1.- El Dios de la guerra}

\section{III.1.b.- Providencialismo hispano-visigodo}

Crónica de Alfonso III, versión Rotense. Pelayo como restaurador godo.

"Pelagius dixit: 'Spes nostra Xps est quod per instum modicum monticulum quem conspicis sit Spanie salus et Gotorum gentis exercitus reparatus. Confido enim quod promissio Domini impleatur in nobis quod dictum est per Dauid: 'Uisitauo in uirga iniquitates eorum et in flagellis peccata eorum; misericordia autem meam non abertam ab eis'. Et nunc ex oc fidens in misericordia Ihesu Xpi hanc multitudinem despicio et minime pertimesco. Prelium ergo quam tu minas nobis, habemus aduocatum aput Patrem Dominum Ihesum Xpm, qui ab istis paucis potens est liuerare nos." ${ }^{1343}$

Crónica de Alfonso III, versión Ad Sebastianvm. Pelayo como restaurador godo.

"Confidimus enim in Domini misericordia quod am insto modico monticulo quem conspicis sit Yspanie salus et Gotorum gentis exercitus reparatus, ut in nobis conpleatur ille profeticus sermo qui dicit: 'Uisitabo in uirga iniquitates eorum et in flagellis peccata eorum; misericordiam autem meam auferam ab eis'. Igitur etsi sententiam seueritatis per meritum excepimus, eius misericordiam in recuperatione ecclesie seu gentis et regni uenturam expectamus. Unde hanc multitudinem paganorum spernimus et minime pertimescimus." 1344

\footnotetext{
${ }^{1343}$ CAIII, versión Rotensis, $\mathrm{n}^{\circ}$ 9, op. cit, pp. 126. “A esto respondió Pelayo: 'Cristo es nuestra esperanza de que por este pequeño monte que tú ves se restaure la salvación de España y el ejército del pueblo godo. Pues confio en que se cumpla en nosotros la promesa del Señor que fue dicha por David: 'Revisaré con la vara sus iniquidades, con el látigo sus pecados; pero mi misericordia no la apartaré de ellos'. Y ahora yo, fiado en la misericordia de Jesucristo, desdeño a esa multitud y no la temo en absoluto. En el combate con que tú nos amenazas, tenemos por abogado ante el Padre al Señor Jesucristo, que poderoso es para librarnos de esos pocos."CAIII, versión Rotense, n 9, op. cit, pp. 204.

${ }^{1344}$ CAIII, versión versión Ad Sebastianvm, n 9, op. cit., pp. 127. "Pues confiamos en la misericordia del Señor, que desde este pequeño monte que tú ves restaure la salvación de España y el ejército del pueblo godo, para que en nosotros se cumplan aquellas palabas proféticas que dicen: 'Revisaré con la vara sus inequidades y con el látigo sus pecados, pero mi misericordia no la apartaré de ellos'. Por ello, aunque hemos recibido merecidamente una severa sentencia, esperamos que venga su misericordia para la recuperación de la Iglesia y del pueblo y del reino. Por esto despreciamos a esa multitud de paganos y en absoluto los tememos." CAIII, versión a Sebastian, n 9, op. cit., pp. 205.
} 
Crónica del Obispo de Oviedo don Pelayo. Milagro de Teresa de León.

“A esta, su hermano Alfonso, muerto ya su padre, la entregó, contra la voluntad de ella, en matrimonio a un pagano rey de Toledo, para así estar en paz con él. Pero como ésta [Teresa] era cristiana le dijo al rey pagano [en la noche de bodas]: 'No me toques pues eres un rey pagano y si lo haces te golpeará y dará muerte un ángel del Señor'. Pero el rey tomó esto a broma y yació por una vez con ella; y en el momento, tal como ella anunciara, el ángel del Señor lo derribó. Al sentirse morir llamó a sus fámulos y consejeros y les mandó que dispusiesen camellos cargados de oro, plata, piedras preciosas y ricas vestimentas, y que con todos esos presentes la enviasen [a Teresa] a León, donde ella vivió algún tiempo vistiendo hábitos monásticos". ${ }^{1345}$

Crónica Najerense. Providencialismo en la batalla de Covadonga.

"Set in hoc non defuere Domini magnalia. Nam cum lapides egressi essent a fundibalis et ad domum Sancte Marie Virginis peruenisent, qui intus est in coua, super mittentes reuertebantur et Caldeos fortiter trucidabant. Et quia Dominus non dinumerat astas et cui uult porrigit palmam, egressis Christianis de coua ad pugnam, Caldei conuersi sunt in fugam, et in duas diuisi sunt turmas. Ibique statim Oppa episcopus comprehensus est, Alchaman interfectus. In eodem namque loco CXXIIII milia ex Caldeis interfecti sunt. Sexaginta uero et tria milia, qui remanserunt, in uertice montis Aseube ascenderunt atque per locum Amossa ad Libanam descenderunt. Set nec ipsi Domini euaserunt uindictam. Cumque per uerticem montis pergerent, qui est super ripam fluminis cui nomen est Deua, iuxta uilliam que dicitur Causegaudia, sic iuditio Domini actum est ut mons ipse a fundamento se reuoluens LXIII milia uirorum in flumine proiecit, et ibi eos omnes mons ipse oppressit, ubi nunc ipse fluuius, dum limites suos requirit, ex eis multa signa euidenter ostendit." 1346

\footnotetext{
${ }^{1345}$ COP, op. cit., pp. 174, 175.

${ }^{1346}$ CN 1995, Libro II, $\mathrm{n}^{\circ}$ 5, op. cit., pp. 101. "Pero no faltaron en esto los milagros del Señor. Pues tan pronto como las piedras eran lanzadas desde los fenéboles y llegaban a la iglesia de Santa María, que está dentro de la cueva, volvían sobre las que las habían lanzado y a los caldeos destrozaban con fuerza. $Y$ como el Señor no cuenta las lanzas sino que a quien quiere extender su palma, saliendo los cristianos de la cueva para luchar, los caldeos emprendieron la huida y en dos bandas se dividieron. Al instante alli es capturado el obispo Opas, Alcamán es asesinado. De hecho en aquel preciso lugar fueron asesinados ciento veinticuatro mil caldeos. Los sesenta y tres mil que quedaron subieron al monte Auseva y por el paso de Amuesa descendieron a La Liébana. Pero tampoco estos escaparon a la venganza del Señor. Mientras iban avanzando por la cima del monte, que está sobre la ribera del río cuyo nombre es Deva, junto a la villa qu ellaman Cosgaya, asi sucedió por juicio del Señor que el propio monte revolviéndose desde sus cimientos lanzó al río a los sesenta y tres mil hombres, y el propio monte los aplastó allí a todos ellos, lugar en el que ahora el tal río, cuando retoma sus orillas, muchas señales de ellos deja a la luz.” CN 2003, Libro II, n 5, op. cit., pp. 115, 116.
} 
Crónica General de España. Profecía del fin del reino visigodo

"E el rey mando la abrir, et non fallaron en ella sinon un panno en que estauan escriptas letras ladinas que dizien assi: que quando aquellas cerraduras fuessen crebantadas et ell arca et el palacio fuessen abiertos et lo que yazie fuesse uisto, que yentes de tal manera como en aquel panno estauan pintadas que entrarien en Espanna et la conqueririen et serien ende sennores. El rey quando aquello oyo, pesol mucho por que el palacio fiziera abrir, e fizo cerrar ell arca et el palacio assi como estauan de primero. En aquel palacio estauan pintados omnes de caras et de parescer et de manera et de uestido assi como agora andan los alaraues, e tienen sus cabeças cubiertas de tocas, et seyen en cauallos, et los uestidos dellos eran de muchos colores, $e$ tenien en las manos espadas et ballestas et sennas alçadas. E el rey et los altos omnes fueron mucho espandados por aquellas pinturas que uiran."1347

Crónica General de España. Señales divinas: la cruz de Alfonso de Casto

"E el uiniendo pora su palacio de la iglesia o fuera a oyr misa, fallosse con dos angeles que uinien en guisa de peregrino quel dixieron que eran orebzes. El rey quando lo oyo plogol mucho con ellos, et dixole que fiziessen una cruz la mas fremosa que ellos pudiesen; et dioles oro et piedras preciosas et casa apartada en que labrassen. [...] El rey, luego que lo sopo, fue pora ella corriendo, e quando uio aquella claridad tan grand et la cruz fecha et acabada tan ayna et de tan alta obra et tan maravillosa, et non estando y los orebzes, rendio gracias a Dios por ende, ca entendio que fecho de Dios era". 1348

Crónica General de España. Milagro de Teresa de León.

"Pero este fecho daquel casamiento non fue con plazer de donna Teresa, cal peso mucho; et pues que la ovieron leuada a Toledo et el quiso passar a ella como uaron a su mugier, dixol ella: 'yo so cristiana et tu eres moro; digote que me non tangas, ca non quiero auer tal ayuntamiento con omne de otra ley; ca bien sepas tu que si me tanxieres, que te matara ell angel de mio Sennor Ihesu Cristo en que yo creo et fio. '. El rey moro non dio nada por lo que ella dizie, et aun touolo por escarnio, et trauo della et por fuerça cumplio y su voluntat; et luego all ora le firio ell angel del nuestro Sennor Dios de que cuedo el ser muerto de tod en todo. Et llamo luego sus omnes, et dioles de

1347 CGE, cap. 553, op.cit, p. 307.

${ }^{1348}$ CGE, cap. 616 , op. cit., p. 349. 
oro et de plata et de pannos preciados et de otras noblezas muchas con ellos, et mandolo poner en sus bestias, et enuiolas cargadas de mucho algo con donna Teresa, et que la leuassen a su hermano el rey don Alffonso."1349

Crónica de Veinte Reyes. Milagro de Teresa de León.

"Pero este casamiento non fue con plazer de la dueña, e pues que ge la ouieron leuada a toledo, quiso el moro auer con ella su plazer. La dueña le dixo: 'Yo só christiana e tú eres moro, non ha menester que me tengas, ca yo non quiero auer compaña con omne de otra ley. E dígote que sy en mí pusieres la mano o me pecar fizieres que te matará luego el ángel de aquell mío señor Ihesu Christo en que yo creo'. El moro non dio nada por esto que ella dezía e tóuolo en desdén e trauó della e fizo s voluntad con ella. Mas luego a la ora le firió el ángel del nuestro Señor Dios de vna tan grande enfermeat, donde cuido ser muerto. E llamó sus omnes e mandóles cargar muchos camellos de oro e de plata e de paños preçiados e de otras noblezas e enbió todo aquello de sovno con la dueña para León a su hermno el rrey don Alfonso."1350

Crónica de Veinte Reyes. Anuncio de la victoria de Fernán González.

"Por çierto sepas que guiará Dios la tu fazianda; asy vençerás todo el poder de Almaçor, auerás grand batalla con los moros e vençerlos has, e mataras y tantas que non avrá cuenta, e cobrarás vna grand partida de la tierra, e verterás mucha sanghe de rreyes e de grandes omes. E la tu buena andaca será tan grande que por todo el mun/do será sonada la tu caballería."1351

Crónica latina de los Reyes de Castilla. Conquista de Toledo.

"Recepto nuncio, predictus rex in continenti reuersus est et, disponente Deo, regnum paternum plene adeptus est. Inspirauit ei Dominus consilium salutare ut obsideret Toletum, cuius statum ad plenum nouerat, utpote qui eius interiora et secretiora, dum ibi moram faceret, non perfuctiore fuerat perscrutatus. Multis igitur annis eam impugnauit prudenter, singulis annis segetes uastando et fructus omnes destruendo. Tandem uirtute diuina compulsi, Mauri Tolletani tradiderunt ciuitatem suam predicto regi Alfonso, ipsum recipientes honorifice in dominum et in regem, adiecta conditione

\footnotetext{
${ }^{1349}$ CGE, cap 761, op. cit., p. 452.

${ }^{1350}$ CXXR, Libro VI, cap. III, op. cit., p. 134.

${ }^{1351}$ CXXR, Libro II, cap VI, op. cit., pp. 89.
} 
quod liceret eis remanere in ciuitate, retinere domos et possessiones suas, et quod seruirent ei sicut regi." 1352

\section{III.1.c.- Pecado y castigo}

Cronicón Albeldense. Lamento por España.

"Quidem terra Gog designatur Spania sub regimine gothorum: in qua ismaelitae propter delicta gentis gothicae sunt ingressi et eos conciderunt gladio atque fecerunt tributarios sibi sicuti patet praesenti tempore. Vero quod idem propheta dicit iterum ad Ismaelem. Quia dereliquisti Dominum et ego te derelinquam et tradam in manu Gog et reddet vicem tibi postquam eos afflixeris. CCLXX tempora tibi facient, sicut ei fecisti Nostra spes est Christus quod completis proximiori tempore CCLXX annis de quo sunt ingressi Hispaniam, inimici redigantur ad nihilum et pax Christi reddatur sanctae ecclesiae; quia tempora ponuntur pro annis. $" 1353$

Crónica de Alfonso III. Version Rotense. Los godos fueron abandonados por Dios. "Sed suorum peccatorum classe oppressi et filiorum Uitizani fraude delecti in fuga sunt uersi. Quo exercitus fugatus usque ad internicionem eo pene est deletus. Et quia derelinquerunt Dominum ne seruirent ei in iustitia et ueritatem, derelicti sunt a Domino ne auitarent erram desiderauilem." 1354

${ }^{1352}$ CLRC 1997, n², op. cit, p. 36. “Cuando recibió el mensaje, el rey Alfonso volvió con toda rapidez y, por la providencia de Dios, obtuvo en su totalidad el reino paterno. El Señor Dios le inspiró el saludable consejo de que sitiara Toledo, cuya situación conocía perfectamente, puesto que, mientras vivió alli, había escudriñado totalmente a fondo sus interiores y lugares apartados. Durante muchos años la impugnó juiciosamente, devastando y destruyendo año tras año las mieses y los frutos todos. Finalmente, los moros toledanos, movidos por la virtud divina y con la condición de que les fuera permitido permanecer en la ciudad, retener sus casas y posesiones y que le sirvieran como rey, entregaron la ciudad al rey Alfonso, a quienes recibieron con honor como rey y señor." CLRC 1999, n 2, op. cit, p. 27. ${ }^{1353}$ CA, op. cit., pp. 192, 193. "Cierto por la tierra de Gog es designada España bajo el régimen de los godos; en la cual los ismaelitas por los delitos de la gente gótica ingresaron y los mataron con la espada é hicieron tributarios para sí como es patente en el presente tiempo. Pues lo que el mismo profeta dice otra vez á Ismael. Porque dejaste al Señor y yo te dejaré y entregaré en mano de Gog y te devolveré la vez á ti después que los afligieres. 270 tiempos te harán como le hiciste. Nuestra esperanza es Cristo que cumplidos en próximo tiempo 270 años desde que ingresaron en España, los enemigos sean reducidos á la nada y la paz de Cristo se devuelva á la santa iglesia; porque la palabra tiempos se pone por años." CA, op. cit., pp. 192, 193.

${ }^{1354}$ CAIII, versión Rotensis, 7, op. cit., pp. 120, 122. "Pero, aplastados por la muchedumbre de sus pecados y traicionados por el fraude de los hijos de Vitiza, fueron puestos fuga. Puesto en fuga el ejército, fue destruido casi hasta el exterminio. Y como abandonaron al Señor, para no servirle en justicia y en verdad, fueron abandonados por el Señor, de manera que no habitaran la tierra deseable". CAIII, versión Rotense, 7, op. cit., p. 200. 
Crónica Anónima de Sahagún. Lamento por España.

"Mas mereçiéndolo los grandes pecados de la gente gótica e permitiémdolo la justa sentençia del muy alto señor, España fue ferida e metida al cuchillo muy cruel de los ynfieles, por lo qual el dicho lugar e capilla, en la que los miembros de los dichos santos mártires folgavan, fasta el suelo derrivada."1355

Crónica Anónima de Sahagún. Demonización del rival, Alfonso de Aragón

"Su cara era arrugada e magra; los dientes, escabrosos e ormientos; e sus ojos, turbados manantes sangre; la su barba, pelada en la haz e pocos pelos e quasi ferida e quemada. E como fuese así de feo en la figura de la cara, mui más feo era en el corazón e voluntad, ca los sus mesmos cavalleros que le seguían, afirmavan que escondidamente avía dado fee al demonio, e el ánima con el cuerpo al diablo avía dado $[\ldots]{ }^{\prime}{ }^{1356}$

Chronica Adefonsi Imperatoris. Castigo providencial.

"Verumtamen noluit eam recipere, quia Deus induraverat cor eius ut venirent super eum omnia mala quae ipse fecerat super cristianos in terra Legionis et Castellae et super gentem suam, sicut et postea venerunt ${ }^{1357}$.

Chronica Adefonsi Imperatoris. Derrota de Alfonso "el batallador".

"Hoc videntes episcopi et clerici et omnis populus christianorum, coeperunt rogare Dominum Deum ut eos eriperet de manibus Sarracenorum et ne reminisceretur peccatorum regis nec parentum suorum vel qui cum eo erant, et ut ab ipso mitius corriperentur. Sed, peccatis exigentibus, orationes eorum non sunt exauditae ante Deum, quia Gabriel Archangelus, summus nuntius Dei, non tulit eas ante tribunal Christi nec Michael, princeps militae caelestis, misus est a Deo ut eos adiuvarent in bello" 1358 .

${ }_{1355}^{1356}$ CAS, Crónica I, n 3, op. cit., p. 10.

${ }_{1356}^{1356}$ CAS, Crónica I, n ${ }^{\circ 9}$, op. cit., p. 87.

${ }^{1357}$ CAI, Liber I, n ${ }^{\circ}$ 53, op. cit., p. 44. "Sin embargo, él no quiso aceptarla porque Dios había endurecido su corazón para que cayeran sobre él, como después cayeron, todos los males que él había hecho contra los cristianos en el territorio de León y Castilla y contra su propio pueblo." CEA, Libro I, n ${ }^{\circ}$ 53, op. cit., p. 80 .

${ }_{1358}$ CAI, Liber I, $\mathrm{n}^{\circ} 55$, op. cit., pp. 45, 46. “Al ver esto, los obispos, clérigos y todo el pueblo de los cristianos empezaron a rogar a Dios Nuestro Señor que los arrancase de las garras de los musulmanes, que no se acordarse de los pecados del rey, de sus parientes o de quienes estaban con él y que los castigase con suficiente benignidad. Pero, en castigo por sus pecados, sus oraciones no fueron atendidas ante Dios, porque el arcángel Gabriel, el más importante mensajero de Dios, no le llevó ante el tribunal 
Chronica Adefonsi Imperatoris. Muertes providenciales.

"Heu!, consulis, peccatis exigentibus, sagitta per cratem machinae ictum faciens, sonuit, relictaque in ipsa crate arundine, in collum consulis ferrum ligno vacuum, percusit et, galeam loricamque penetrando, vulnus effecit."

$[\ldots]$

"Mortuus est autem Munio Adefonsi, quem alcaydem Toleti satis memoravimus, et omnes viros bellatores qui cum eo erant, pro peccato magno quod fecit contra Deum, scilicet quia occidit suam filiam, quam habebat legitimae coniugis, quia ludebat cum quoddam iuvine, et non fuit misertus filiae suae sicut Dominus misericors erat in omnibus proeliis quaecumque faciebat." 1359

Crónica Najerense. Dios elimina a Aureliano.

“112. aurelianus regnauit annos V. Hic persequutionem aduersus Christianos efficiens fulmine corripitur et nec mora occiditur." 1360

Historia Rebus Hispaniae. Los pecados de Witiza se extienden al conjunto de los godos "Set quoniam humani generis inimicus humano generi non desinit inuidere, seminauit in potestate superbiam, in religione accidiam, in pace discordiam, in habundancia luxuriam, in sollercia ignauiam adeo ut sicut populus, sic et sacerdos, sicut impii, sic et princeps." $" 1361$

de Cristo, ni Miguel, príncipe de la milicia celeste, fue enviado por Dios para ayudar en la guerra." CEA, Libro I, nº 55, op. cit., p. 80.

${ }^{1359}$ CAI Liber II, $\mathrm{n}^{\circ}$ 137, op. cit., p. 108. “ $; A y$ !, en castigo por los pecados del gran señor, la flecha silbó haciendo impacto a traves del cañizo de la maquina y, tras perder la varilla en el propio cañizo, el hierro, libre de la madera, golpeó en el cuello del gran señor y le hirió atravesando el casco y la loriga." CEA, Libro II, $\mathrm{n}^{\circ} 42$ (137) op. cit., pp. 108.

CAI Liber II, $\mathrm{n}^{\circ} 185$, op. cit., p. 144. "Murió Munio Alfonso, al que hemos mencionado bastante como alcaide de Toledo, y todos los guerreros que estaban con él por culpa de un gran pecado que cometió contra Dios, a saber, porque mató a su propia hija, la que tenía de su esposa legítima, a causa de sus amoríos con un joven, y no fue compasivo con su hija, de la misma manera que el Señor era misericordioso con él en todas las batallas que emprendía [...]." CEA, Libro II, n 90(185) op. cit., pp. 122.

${ }^{1360}$ CN 1995, Liber I, n 110-112, op. cit., p. 41. 112. "Aureliano reinó cinco años. Éste, por perseguir a los cristianos, es alcanzado por un rayo y al punto muere." CN 2003, Libro I, ${ }^{\circ} 110-112$, op. cit., p. 61.

${ }^{1361}$ HRH, Liber III, cap. XVI, op. cit., pp. 97, 98. "Pero como el enemigo de la raza humana no cesa de mirarla con malos ojos, esparció la altanería sobre el poder, la indiferencia sobre la religión, el enfrentamiento sobre la paz, la lujuria sobre la riqueza, la indolencia sobre la diligencia hasta el punto de que tal como obraba el pueblo, asi también el sacerdote, y como los pecadores, así también el rey". HHE, Libro III, cap. XVI, op. cit., p. 141. 
Historia Rebus Hispaniae. Pelayo como señalado por la Providencia.

"Et dum tot dispendiis Hispaniam dissecarent, Deus omnipotens in ira sua misericordie non oblitus Pelagium quasi cintillam modicam in suo conspectu uoluit conseruare [...] inueniensque plurimos qui metu ad edicta Arabum properabant, spiritu fortitudinis et spe in Domino confortauit, quia etsi propter peccata flagellat filios pestilentes, in fine tamen non obliuiscitur misereri." 1362

Crónica General de España. Los pecados de Witiza y los visigodos.

"Assi en esta guisa como dezimos fue toda Espanna llena de nemiga et de peccado et de sobeiania de mal por el rey Witiza que mouio los oios de Nuestro Sennor Dios a sanna, ca todos los omnes de la tierra auien corrompida su carrera et ensuçiada su uida; e al que era bueno nol preciauan una paia, et al derechurero quanto a una espina de sebe, esto es sarça". 1363

Crónica de Veinte Reyes. Legitimidad monárquica y castigo al pueblo

"Mas al cabo, por los pecados de la Christiandat, fueron los christianos vençidos e fuxeron muchos dellos, non los persiguiendo ninguno. El rrey don Alfonso mantouo la batalla él solo, synon con muy pocos, fasta la noche e tan de rrezio lidiaua que moro ninguno non se le osaua parar delante [...]". ${ }^{1364}$

\section{III.1d.- El siglo XIII. Dios y los hombres, consolidación y cambios}

\section{Crónica Latina de los Reyes de Castilla. Felonía de Alfonso IX}

"Rex uero Legionis, qui ibat in auxilium regis Castelle, uenit Toletum et consilio quorumdam satellitum Sathane conuersus est in arcum prauum querens occasiones quibus disceredet ab amico, et de amico factus est crudelissimus inimicus, nempe

\footnotetext{
${ }^{1362}$ HRH, Liber IV, cap. I, op. cit., 115. "Y mientras destrozaban España con tantas acometidas, Dios todopoderoso, no olvidándose en su ira de la misericordia, quiso preservar bajo sus ojos a Pelayo como una pequeña ascua. [...] Y encontrando a muchos que andaban huidos por miedo a la tiranía de los árabes, los confortó con su espíritu de resistencia y con la esperanza en el Señor, porque aunque castiga a sus hijos corrompidos a causa de sus pecados, sin embargo al final no deja de apiadarse." HHE Libro IV, cap. I, op. cit., pp. 159, 160.

${ }_{1363}$ PCG, cap. 551, op. cit., p. 305

${ }^{1364}$ CXXR, Libro X, cap. XXXIX, op. cit., p. 222.
} 
manebat alta mente repositum quod ei contingerat in curia, de qua supra facta est mentio, in Carrione celebrata" 1365.

Crónica Latina de los Reyes de Castilla. Soberbia de Alfonso VIII.

"Ignis ascensus uidebatur in furore Domini et elationem animi, si qam conceperat rex nobilis ex gloria precedenti, deprimere videbatur, ut intelligeret rex prudens et nobilis quod regnum filiorum hominum in manu Dei est et cuicumque uoluerit dabit illud" ${ }^{\text {"1366. }}$.

Crónica Latina de los Reyes de Castilla. Fernando III impulsado por el Espíritu de Dios.

“70. Irruit igitur Domini Spiritus in rege, et ponens spem suam in Domino Iesu Christo aures suas obturauit ne audiret consilium eorum, qui, uelud incantatores, uerbis et persuasibilibus factum tam nobile impedire machinabantur, alegantes yemis asperitatem, que solito pluiis amplius inundabat, uiarum pericula, fluminum inundationem, raritatem nobilium qui secum tunc aderant, tanti discriminis euentum dubium et, quod plus omnibus erat formidandum, multitudopopuli Cordubensis innumera, qui ceteris Mauris cismarinis ab antiquo strenuitate et armorum exertitio precelebat, cum quibus erat certamem ineundum super propriis personis et ciuitate tam nobile, terra natiuitatis sue, pro uxoribus et liberis et super omnibus que posidebant. [...] Sed $<_{S}>$ pretis his omnibus et pro nichilo habitis, miles Christi fortissimus rex Fernandus mane sequenti exiuit Venauentum in multa festinancia; matrem, que tunc erat apud Legionem, de longe salutauit per nuncium, qui nunciaret ei fideliter ea que acciderant et firmum propositum filii, quod nulla ratione poterat inmutari." ${ }^{, 1367}$

1365 CLRC 1997, n 14, op. cit., p. 47. "El Rey de León, que iba en ayuda del rey de Castilla, llegó a Toledo y por consejo de algunos satélites de Satanás se convirtió en arco de maldad, buscando ocasiones para apartarse del amigo, y de amigo se hizo enemigo cruel, pues guardaba en la profundidad de su alma de lo que sucediera en las Cortes celebradas en Carrión, de las que anteriormente se hizo mención". CLRC 1997, n 14, op. cit., p. 47.

${ }^{1366}$ CLRC 1997, n 14, op. cit., p. 48. "El fuego de la ira del Señor parecía crecer y abatir la soberbia, que quizá tuviese el noble rey por su gloria anterior, para que entendiera el prudente y noble rey que el reino de los hombres está en manos de Dios y lo da a quien quiere". CLRC 1999, n 14, op. cit., p. 40.

${ }^{1367}$ CLRC 1997, no 70, op. cit., p. 111, 112. "70. Irrumpió, pues, el Espíritu del Señor en el rey, y, poniendo su esperanza en Jesucristo, el Señor, endureció sus oídos para no oír el consejo de los que, como encantadores, intentaban con persuasivas palabras impedir hecho tan noble, alegando la aspereza del invierno -que inundaba con lluvias más de lo acostumbrado-, los peligros de los caminos, las inundaciones de los ríos, los pocos hombres que con él estaban, el dudoso éxito de riesgo tan grande, y, lo que era más de temer, la innumerable multitud del pueblo cordobés, que sobrepasaba desde la antigüedad a los restantes moros cismarinos en valor y ejercicio de las armas, con los que habia que entablar un combate sobre sus propias vidas y ciudad tan noble, tierra de su nacimiento, en favor de sus esposas e hijos y sobre todo lo que poseían. [...] 
Crónica Latina de los Reyes de Castilla. Dios castiga a los cruzados por su soberbia.

"Proposuerant ulterius procedere, sed Deus, cuius uoluntati resistere nemo potest, impediuisse uidebatur. Occulta quidem sunt iudicia Dei: Fortase aliquid elationis et superpie contraxerunt Christiani ex victoria supradicti belli, cum soli Deo, non sibi, atribuere debuissent. Nam cum aliquot diebus moram fecissent in obsidione predicte uille, tot et tantos de Christianis inuasit multiplex infirmitatum uarietas et precipue fluxus uentrium, quod pauci remanserunt sani, qui, si necessitas postularet, contra hostes se defendere possent. Eadem et tempestate tanta mortalitas accidit in hiis qui remanserant de bello, quod in autumno illo magna pars maiorum et seniorum in uillis et ciuitatibus uite terminum dederunt." 1368

Historia Rebus Hispaniae. Protección providencial de los cruzados

"Set quia humana artificia contra Dei prouidenciam nichil ualent, sic Deus uoluit ut paucissima uel nulli fere illis tribulis lederentur; et gracie Dei manu supposita transiuimus flumen Anam et castramentati fuimus in circuitu Calatraue" ${ }^{\text {1369. }}$.

Historia Rebus Hispaniae. Deserción de los ultramontanos.

"Set quoniam humani generis inimicus nos cessat christianis actibus inuidere, misit Sathan in exercitum caricatis et corda emulancium conturbauit, et qui ad certamen fidei se accinxxerant, retrorsum a bono proposito abierunt. Omnes enim fere ultramontani comuni proposito statuerunt ut relictis crucis signaculis, omissis etaim belli laboribus, ad propria remearent" ${ }^{\prime 1370}$.

Pero, despreciadas todas estas cosas y como nada consideradas, el soldado de Cristo, fortísimo rey Fernando, a la mañana siguiente salió de Benavente con mucha prisa; saludó de lejos a su madre, que entonces estaba en León, por medio de un emisario que debía anunciarle fielmente lo que sucedía y el firme propósito del hijo, que por ninguna razón cambiaría." CLRC 1999, $\mathrm{n}^{\circ}$ 70, op. cit., p. 98.

${ }_{1368}$ CLRC 1997, $\mathrm{n}^{\circ}$ 25, op. cit., p. 63. "Habian determinado avanzar más, pero Dios, cuya voluntad nadie puede resistir, lo impidió. Ocultos son en verdad los juicios de Dios. Quizá los cristianos pecaron de vanagloria y soberbia atribuyéndose a ellos mismos y no a Dios el mérito de la victoria en la guerra. $Y$ así, cuando descansaban algunos días en el asedio de la citada villa, a tales y tantos cristianos invadió una múltiple variedad de enfermedades y principalmente un flujo de vientre que quedaron pocos sanos para defenderse de los enemigos si la necesidad lo requiriera."CLRC 1999, n 25, op. cit., p. 55.

${ }^{1369}$ HRH, Liber VIII, cap. V, op. cit., p. 264. "Pero como las invenciones de los hombres nada pueden hacer contra la providencia de Dios, la voluntad de Dios fue que escasisimos, o casi ninguno, se hiriera con aquellos abrojos; y sobre la mano de la Gracia de Dios, a modo de puente, atravesamos el río Guadiana y acampamos en derredor de Calatrava" HHE, Liber VIII, cap. V, op. cit., p. 313.

${ }^{1370}$ HRH, Liber VIII, cap. VI, op. cit., p. 265. "Pero como el enemigo del género humano no deja de malquerer las obras cristianas, introdujo a Satán en el ejército de caridad y encizaño los corazones envidiosos; y quienes se habian aprestado para la contienda de la fe dieron marcha atrás en sus buenas intenciones. Pues casi todos los ultramontanos, dejadas las enseñas de la cruz, abandonados también los trabajos de la batalla, tomaron en común la determinación de regresar a sus tierras." HHE, Libro VIII. cap. VI, op. cit., p. 314. 
Historia Rebus Hispaniae. Milagro del estandarte de la Catedral.

"Crux uero Domini, que coram Toletano pontifice consueuerant baiulari, preferente eam Dominico Pascasii canonico Toletano, per agarenorum acies miraculose transiuit, et ibídem illeso baiulo sine suis usque finem belli, Sicut Domino placuit, perdurauit." 1371

Historia Rebus Hispaniae. Milagrosa y gran mortandad entre los almohades "Erant autem Agareni, qui iuxta supradictum atrium inuenti sunt, statura proceri, pinguedini dilatati et, quod mirabile est dictu, licet iarecent in omnibus partibus corporis detruncati et iam a pauperibus spoliati, in toto campo nec signum sanguinis poterat inueniri. Quibus peractis, nostri gracie Dei terminum nolentes imponere, per omnes partes usque ad noctem eos infatigabiliter sunt secuti, et secundum estimationen creduntur circiter CCti milia interfecta. De nostris autem uix deffuere XXV."1372

Historia Rebus Hispaniae. Cerco de Úbeda y oferta de rescate.

"Hoc factum fuit feria VI ${ }^{a}$ post bellum. Igitur II feria, VIII ${ }^{\circ}$ scilicet die post bellum, agressi sunt ciuitatem inuocato nomine christiano; et sicut Domino placuit, ex ea parte ubi instabant Aragonenses, quidam armiger Lupi Ferrencii de Luna murum ascendit et in eius ascensu corda resistencium languerunt et se regis gracie spoponderunt; super hoc itaque habito frequenti tractatu, primo optulerunt Sarraceni mille milia aureorum ut ciuitas eis integra remaneret, quod et aliqui acceptarunt, dolentibus admodum regibus, dissimulantibus tamen Procter instanciam magnatorum. Demun Toletano, Narbonensis et ceteris pontificibus auctoritate pontificali pacta huiusmodi prohibentibus, factum est ut ciuitas funditus euerteretur, Sarracenis ad uitam seruatis, captiuitati nichilomunis mancipatis". ${ }^{1373}$

${ }^{1371}$ HRH, Liber VIII, cap. X, op. cit., p. 273. "La cruz del Señor, que solía tremolar delante del arzobispo de Toledo, pasó milagrosamente entre las filas de los agarenos llevada por el canónigo de Toledo Domingo Pascasio, y allí, tal como quiso el Señor, permaneció hasta el final de la batalla sin que su portador, solo, sufriera daño alguno."HHE, Libro VIII. Cap. X, op. cit., p. 322.

${ }^{1372}$ HRH, Liber VIII, cap. X, op. cit., p. 274. "A su vez, los agarenos que fueron hallados junto al ya mencionado palenque eran de elevada estatura, de gran obesidad y, cosa sorprendente, aunque quedaron tremendamente mutilados y ya habian sufrido el pillaje de los pobres, no se podía descubrir en todo el campo ni un rastro de sangre. Concluido lo cual, no queriendo los nuestros poner límites a la gracia de Dios, se dedicaron a perseguirlos sin descanso por todas partes hasta la noche, $y$, según cálculos, se cree que fueron muertos unos doscientos mil. En cambio, los nuestros apenas sufrieron veinticinco bajas." HHE, Libro VIII, cap. X, op. cit., p. 323.

${ }^{1373}$ HRH, Liber VIII, cap. XII, op. cit., p. 276. "Así pues, el lunes, es decir, el octavo día después de la batalla, atacaron la ciudad invocando el nombre de Cristo; y fue voluntad del Señor que un escudero de Lope Fernández de Luna escalara la muralla por la parte donde arremetían los aragoneses, y ante su escalo se vinieron abajo los ánimos de los de dentro y dieron palabra de encomendarse a la gracia del 
Historia Rebus Hispaniae. Dios castiga a los cruzados por su soberbia.

"Et iam Dei gracia propter luxum hominum tepescente, Christiani cupiditate illecti intendebant iniuriis et rapinis, unde et Dominus imposuit frenum ori eorum et percussit eos infirmitatibus et iumenta, et uix erat in tabernaculis qui comilitoni posset socio uel domino ministrae."1374

Crónica General de España. Cruce del Guadiana.

"Mas porque las arterias de los omnes non ualen nada, quan engannosas et sotiles quier que sean, contra lo que Dios faze et quiere guardar, muy pocos o fascas ningunos fueron dannados daquellos cardos o abroios de los moros. Et puso Dios la su mano sobrellos, et passamos nos en saluo el ryo de Guadiana, et fincamos las tiendas aderredor de Calatraua." 1375

Crónica General de España. Deserción de los ultramontanos.

"Entre tod esto, porque ell enemigo de los omnes, et este el diablo, que nunca queda de inuidiar los buenos fechos de los omnes, metiosse en la huste de los fieles de Cristo et de la su caridad, et conturuio los coraçones de los enuidiosos que se auien guisado pora yr a esta batalla. Et fizolos arredar de yr, et fizoles desuiar de la buena postura que auien fecha: ca por la mayor parte todos los trasmontanos de comunal postura establesçieron que tolliessen las sennales de la cruç que auien tomadas de que se cruçaran pora esta batalla, et que dexassen los trabaios de su lit, et se tornassen pora sus tierras". ${ }^{1376}$

Crónica General de España. Milagro de los muertos en torno al Palenque.

"Et eran los moros que fueron fallados çercal sobredicho corral muy luengos de cuerpos et muy gruessos omnes; et lo que es marauilla pora dezirlo: maguer que yazien

rey; y tras parlamentar largamente sobre ello, los sarracenos ofrecieron en primer lugar un millón de áureos a cambio de la indemnidad de la ciudad, lo que algunos aceptaron con gran contrariedad de los reyes, que sin embargo disimularon con el gran interés de los nobles. Finalmente, al prohibir tal acuerdo los arzobispos de Toledo, Narbona y los demás con su autoridad pontificia, se quedó en que la ciudad fuera arrasada hasta sus cimientos, perdonándosele la vida a los sarracenos y haciéndolos prisioneros." HHE, Libro VIII, cap. XII, op. cit., p. 325.

${ }^{1374}$ HRH, Liber VIII, cap. XII, op. cit. p. 276. "Y como ya la gracia de Dios se estaba marchitando por causa de los excesos de los hombres, los cristianos, presa de su avaricia, se dedicaban a los delitos y a los robos, por lo que el Señor les colocó un freno en sus bocas y los golpeó con enfermedades a ellos y a sus animales de tiro, y apenas si habia en las tiendas quien pudiera atender a su camarada o a su señor." HHE, Libro VIII, cap. XII, op. cit., p. 325.

${ }^{1375}$ CGE, cap. 1015, op. cit., p. 695.

${ }^{1376}$ CGE, cap. 1015, op. cit., p. 696. 
destorpados de todos sus cuerpos et de todos sus miembros, et despojados todos, que los despoiaran los pobres, pero por tod esso, en tod el campo de la batalla ninguna sennal de sangre non pudo seer fallada."1377

Crónica General de España. Dios castiga a los cruzados por su soberbia.

“Et por la sebeiania de los omnes esfriandosse ya la gracia de Dios, tanto los tenie enlazados la cobdiçia, que por ella entendien ya a fazer tuertos et robos; onde Nuestro Sennor Dios, por poner freno et estoruo a la cobdiçia dellos, firio con enfermedades a ellos et a sus bestias, assi que apenas auie en todas las sus tiendas uno que pudiesse servir all otro, nin cauallero a cauallero, nin aun sirvient a sennor, pora darle lo que mester fuesse." 1378

Crónica de Veinte Reyes. Portentos previos a la batalla.

“[...] aparesçió en el çielo vna cruz muy fermosa de oro de muchos colores e vieron los cristianos e touiéronlo por buena señal [...]". 1379

Crónica de Veinte Reyes. Dios castiga a los cruzados por su soberbia.

"[...] mas non quiso Dios que los chistianos saliesen ende onrrados, que non eran de vn coraçón nin ayudaron a su señor commo deuían, e fueron vençidos e malandantes e murieron y muchos cristianos". ${ }^{1380}$

\section{III.2.- Los santos guerreros al servicio de la causa cristiana}

\section{III.2.c.- Santiago}

Historia Compostelana. Narración histórica de la diócesis de Compostela "[...] sed sicut Leo Papa in epistola, quam de eius passione et ipsius corporis in Hispaniam translatione, ad Hispanos destinauit, affirmat: Integrum corpus cum capite extra ciuitatem proiicientes canibus auibusque atque feris deuorandum consumendumque exposuerunt. Sed illis discipuli ab illo uiuente premoniti quatenus corpus suum in Hispánicam regionem transferrent tumulandum, totum corpus cum capite, teste Leone Papa, concturno tempore arrepientes litus adusque maris citato

\footnotetext{
${ }^{1377}$ CGE, cap. 1019 , op. cit., pp. 702, 703.

1378 CGE, cap. 1021, op. cit., p. 705.

${ }^{1379}$ CXXR, Libro XIII, cap. XXXII, op. cit., p. 284.

${ }^{1380}$ CXXR, Libro. XIII, cap. XXV, op. cit., p. 280.
} 
calle peruenerunt; dumque ibi de auigio, quo in Hispaniam transmearent, solliciti essent, nauim sibi diuinitus apparatam in littore maris inuenerunt, quam Deo gratias unanimiter referentes, sacratísimo corpore imposito, ouanter conscederunt et, Scilla cum Caribdi atque periculosis Sirtibus, manu Domini gubernante, deuitatis, primum ad Hiriensem portum felici nauigio peruenerunt, deinde uenerabile corpus ad lucum, qui tunc Liberum domun uacabatur, nunc autem Compostella dicitur, deferentes ipsum corpus sub marmoreis arcubus eclesiástico more ibidem sepelierunt."1381

Liber Sancti Jacobi /Codex Calixtinus. Hispania, tierra bendita por la Providencia "Sed nec preces matris, quibus sedem regni fillis poposcerat, cassate sunt, quia ut quidam sapiens in himnidicis laudibus astruit, Iohanni Asia que est a dextera, beato vero Iacobo Hispania que est a sinistra, in divisione provinciarum contigerunt. Unde beatus Iacobus, ut creditur, sua ammonicione post passionem suma a discipulis in Hispania est transvectus, et in fine Gallecie, qui nunc Compostella nuncupatur, honorifice est sepultus, ut non solum Hispanos, qui sibi in sorte contigerant suo patrocinio regerent, verum etiam corporis sui thesauro confortaret. Gaude ergo Hispania tanto illustra iubare, tripudia, supersticiones exuta errore. Gaude, quia per adventum tanti hospitis beluinam ferocitatem deposuisti et humilis Christi iugo cervices prius indomitam supposuisti. Plus enim tibi contulit beati Iacobi humilitas, quam omnium regum tuorum immanitas. Illa etinem te sublevavit ad celum; isti te depresserunt ad baratrum. Illi te coinquinaverunt idolis sacrificando; illa te mundificavit cultum veri Dei tradendo". ${ }^{1382}$

${ }^{1381}$ HC 1988, Liber I, cap I, op. cit., pp. 7, 8. “[...] según afirma el papa León en la carta dirigida a los hispanos en la que habla de su pasión y traslado de su cuerpo a Hispania: Arrojando el cuerpo entero con la cabeza en las afueras de la ciudad, lo dejaron a merced de los perros, las aves y las fieras para que fuera devorado y consumido. Pero sus discípulos, a los que él había ordenado en vida que llevaran su cuerpo a Hispania para enterrarle, recogieron el cuerpo con la cabeza durante la noche, según atestigua el papa León, llegaron hasta la orilla del mar con paso apresurado y, al buscar allí un barco para hacer el viaje a Hispania, encontraron en la playa una nave que les había sido preparada por Dios, en la cual se hicieron a la mar llenos de gozo dando gracias a Dios de manera unánime tras embarcar el sacratísimo cuerpo, y después de evitar Escila y Caribdis junto con las peligrosas Sirtes, siguiendo el rumbo de la mano del Señor, arribaron a bordo del afortunado navío primero al puerto de Iria y luego llevaron el venerable cuerpo al lugar que entonces se llamaba Liberum donum y que ahora se llama Compostela, donde lo sepultaron siguiendo el rito eclesiástico bajo unos arcas de mármol" HC 1994, Libro I, cap I, op. cit., pp. 67, 68.

1382 LSJ 1998, Liber I, cap. XV, op. cit., pp. 81, 82. "Pero aun la petición de su madre de una sede especial en el reino, para sus hijos, no fue en vano, pues como dijo un sabio poeta en los versos del himno en su honor, a Juan le tocó Asia, que está a la derecha; a Santiago, España, que está a la izquierda en la división de las provincias. Por lo cual Santiago, según es tradición, por su indicación fue trasladado después de su martirio por sus discípulos a España y en la extremidad de Galicia, que ahora se llama Compostela, fue honoríficamente sepultado, no solo para regir con su patrocinio a los españoles que le habian tocado en suerte, sino por confortarlos con el tesoro de su cuerpo. Regocíjate, España, 
Liber Sancti Jacobi /Codex Calixtinus. Santiago libera a un grupo de cautivos.

"Quorum irremediabilis pene voces beatus Iacobus exaudiens, in obscuritate carceris sic eos alloquens refulsit: Ecce adsum, quem vocastis.Qui tante audicionis claritate succinti, ora, que pre magnitudine doloris in genibus fixa tenebantur, erigentes, ad eius virtutis ungento, eorum vincla perfregit. Preterea sue potencie dextera captivorum manibus conserta, de ergastulo tanti periculi divinitus erepti ad portas civitatis eo duce pervenerunt. Porte vero, crucis facto signo, apostolici reverencie egressionem ultronee adeo ministrarunt, quod pristine adiuncionis rigorem, egressis eis, reformarunt. Quos beatus Iacobus apostolus longo delapso spacio post gallicinum, iam fere resultante lucis spiculo eos, procedendo ad quoddam castellum, quod sub Christianitatis tutamine tenebatur, perduxit. Ubi etiam se ab eis advocari precipiens, celos visibiliter conscendit. Cuius quidem precepcione cum magno vocis strepitu eum advocantes, apertis foribus, interius sunt suscepti. Altera autem die inde egredientes, ad propria redire conantur. Post paucum vero temporis quidam eorum beati Iacobi limina petens in festivitate translacionis eiuscem apostoli que aput nos die III Kalendarum Ianuarii annue celebratur, hec omnia sic facta fuisse, ut scripsimus, omnibus nunciavit. A Domino factum est istut et est mirabile in oculis nostris (Ps 117, 23; Mt 21, 42). Regi ergo suppremo sit decus et gloria in secula seculorum. Amen."1383

Liber Sancti Jacobi /Codex Calixtinus. Santiago se presenta como caballero.

"Stephane, serve Dei, qui me non militem, sed piscatorem vocari iussiti, eo namque taliter tibi appareo, ut me Deo militare eiusque ahtletam esse, meque in pugna contra Sarracenos Christianos anteire et pro eis victorem existere, amplius non debites.

ensalza con semejante fulgor; salta de gozo, pues has sido salvada del error de la superstición. Alégrate, ya que por la visita de este huésped dejaste la ferocidad de las bestias y sometiste tu cerviz, antes indómita, al yugo de la humildad de Cristo. Mayores bienes te proporciono la humildad de Santiago que la ferocidad de todos tus reyes. Aquella te levantó hasta el cielo; éstos te hundieron en el abismo. Ellos te mancillaron con el sacrificio de los ídolos; aquélla te purificó, enseñándote el culto al verdadero Dios." LSJ 2004, Liber I, cap. XV, op. cit., p. 168.

1383 LSJ 1998, Liber II, cap I, op. cit., p. 161. "Santiago, escuchando sus llamadas casi irremediables, apareció radiante en la oscuridad de la cárcel, hablándoles así: Heme aquí a quien llamasteis. Y obligados por la claridad de tan inaudita grandeza, alzaron sus rostros, que por la fuerza del dolor tenían fijos en las rodillas, y cayeron postrados a sus pies. Más Santiago, condolido en sus entrañas, les rompió las ligaduras derramando el bálsamo de su virtud. Trabando además la diestra de su poder con las manos de los cautivos y sacándolos milagrosamente de prisión tan peligrosa, llegaron con tal guía a las puertas de la ciudad. A su vez las puertas, hecha la señal de la cruz, ofrecieron salida en honor del Apóstol tan espontáneas, que así que hubieron ellos salido restablecieron el rigor de su anterior unión. El apóstol Santiago, pasado largo tiempo después de cantar el gallo y casi al asomar los rayos de la aurora, llegó con ellos, yendo él delante, a cierto castillo que estaba bajo guardia de cristianos, donde mandándoles también que le invocasen, subió visiblemente a los cielos." LSJ 2004, Libro II, Cap. I, op. cit., pp. 331, 332. 
Impetravi enim a Domino, ut universis me diligetibus ac recto corde invocantibus protector sim et ediutor periculis in cunctis" ${ }^{\prime 384}$.

Liber Sancti Jacobi /Codex Calixtinus. Santiago frente a Carlomagno

“Ego sum, inquit, Iacobus apóstolus [...] cuius corpus in Gallecia, que a Sarracenis adhuc turpe opprimitur, incognitum requiescit. Unde ultra modum moror, cur terram meam a Sarracenis minime liberaste, qui tot urbes tantasque terras adquisisti. Quapropter tibi notifico, quia sicut Dominus potenciorem omnium regum terrenorum te fecit, sic ad preparandum iter deum et deliberandum tellurem meam a manibus Moabitarum te inter omnes, ut tibi coronam eterne retribucionis exinde preparet, elegit." 1385

Liber Sancti Jacobi /Codex Calixtinus. Santiago protege a un peregrino.

"Qui cum ab apostolo tantum peteret, ut eum a captione inimicorum suorum liberaret, si forte in ea caderet, ad propria reversus, negotii causa Siciliam perrectus, a Sarracenis in mari captus est. Quid plura? Per nundinas et foros tredecies venditur et emitur. Qui vero eum emebant, beato Iacobo catenas et vincula eius conterente, tenere nequibant." 1386

Crónica Najerense. Victoria de Guillermo Sánchez en honor a Santiago.

“Tercio uero anno remeantibus illis ad propria Deus, quem occulta non latent, retribuit ultionem. Sicut enim illi plebem Christianam in captiuitatem miserunt et multos gladio interfecerunt ita et illi, priusquam a finibus Galletie exirent, multa mala perpessi sunt. Comes namque Guillemus Santionis in nomine Domini et honore Sancti Iacobi apostoli,

${ }^{1384}$ LSJ 1998, Liber II, Cap XIX, op. cit., p. 175 “Esteban, siervo de Dios, que mandaste que no me llamasen caballero, sino pescador; por eso te me aparezco de esta forma, para que no dudes más de que milito al servicio de Dios y soy su campeón y en la lucha contra los sarracenos precedo a los cristianos y salgo vencedor por ellos. He conseguido del Señor ser protector y auxiliador de todos los que aman y me invocan de todo corazón en todos los peligros.” LSJ 2004, Libro II, Cap XIX, op. cit., p. 376.

${ }^{1385}$ LSJ 1998, Liber IV, cap I, op. cit., p. 201. "Yo soy - contesto - Santiago apóstol [...] y cuyo cuerpo descansa ignorado en Galicia, todavía vergonzosamente oprimida por los sarracenos. Por esto me asombro enormemente de que no hayas liberado de los sarracenos mi tierra, tú que tantas ciudades y tierras has conquistado. Por lo cual te hago saber que asi como el Señor te hizo el más poderoso de los reyes de la tierra, igualmente te ha elegido entre todos para preparar mi camino y liberar mi tierra de manos de los musulmanes y conseguirte por ello una corona de inmarcesible gloria." LSJ 2004, Libro IV, cap I, op. cit., p. 414.

${ }^{1386}$ LSJ 1998, Liber II, cap XXII, op. cit., p. 177. "Y habiendo pedido solamente al Apóstol que le librase del cautiverio de sus enemigos, si por azar cayese en él, una vez vuelto a su casa marchó a Sicilia, por causa de negocios y fue apresado en el mar por sarracenos. ¿Qué más? Por ferias y mercados fue vendido y comprado trece veces. Pero los que le compraban no podían tenerle sujeto, porque Santiago les rompia las cadenas y ligaduras.” LSJ 2004, Libro II, Cap. XXII, op. cit., p. 383. 
cuius terram deuastanerant, exiuit cum exercitu magno obuiam illis et cepit preliari cum illis. Dedit illis Deus uictoriam et omnem gentem ipsam simul cum rege suo gladio interfecit. Classes eorum igne cremauit diuina clementia adiuuante."1387

Cronicon Mundi. Batalla de Clavijo.

"Exercitus autem regis Ranimiri paulatim cepit terga prebere usque dum peruenerunt in collem qui Caluillum uocatur. Clausit nox obscurisima diem et in una mola omnes Christiani congregati sunt totam noctem in lacrimis et in orationibus peragentes. Rex autem Ranimirus aiquantulum dormire cepit, et apparens ei beatus Iacobus apostolus ait illi: 'Dominus noster Iesus Christus alias prouincias aliis fratribus nostris apostolis distribuens totam Yspaniam mee tutele deputauit atque mea muniuit protectione'. Post hec apostolus manu sua manum regis astringens dixit illi: 'Confortare et esto robustus. Ego enim sum Iacobus apostolus Christi et uenio in auxilium tet superabis mane auxilio Dei Sarracenorum, a quibus obsessus es, hanc innumerabilem multitudinem. Multi tamen ex tuis, quibus iam parata est eterna requies, sunt in isto prelio coronam martirii suscepturi. Et ne dubites super hoc: uidebitis me in equo albo deferentem maximum album uexillum. Summo igitur mane facta peccatorum uestrorum confessione et accepta corporis et sanguinis Domini comunione, armata manu non dubitetis inuadere castra barbarorum nomen Domini inuocantes et meum. Pro certo enim noueris eos in ore gladii ruituros'. Quibus dictis apostolus discessit. Rex autem Ranimirus ad se reuersus uocatis episcopis, abbatibus et magistratibus eis retulit uisionem. Qui gratias agentes Deo fecerunt, ut sibi fuerat preceptum, et bellum barbaris intuerunt. Beatus autem Iacobus apparuit sicut promiserat, Christianos animando ad pugnam et Sarracenos fortiter feriendo. Christiani autem, ut uiderunt beatum Iacobum, in Domino roborati ceperunt magnis uocibus concidendo gladiis Sarracenos clamare dicentes: 'Adiuua nos Deus et beate Iacobe'. Tunc uicti Sarraceni fugerunt et ceciderunt ex illis fere LXX

\footnotetext{
${ }^{1387}$ CN 1995, Liber II, n 32, op. cit., p. 137, 138. “Al tercer año, mientras volvían a su patria, Dios, a quien no se le ocultaba lo escondido, les pagó con su venganza. Pues al igual que ellos pusieron en cautiverio al pueblo cristiano y a muchos mataron con la espada, así también ellos, antes de que hubieran salido de los límites de Galicia, muchos males sufrieron. En efecto, el conde Guillermo Sánchez, en nombre del Señor y en honor de Santiago apóstol, cuya tierra habrían devastado, salió a su encuentro con un gran ejército y comenzó a luchar con ellos. Dios les concedió la victoria y a todo ese pueblo mató junto con su rey. Quemó sus barcos con fuego ayudado de la clemencia divina." CN 2003, Libro II, $\mathrm{n}^{\circ} 32$, op. cit., p. 145.
} 
milia. Tunc cepit rex Calagurram et quedam alia castra et reuersus est cum gloria magna."

Cronicon Mundi. Derrota de Almanzor

“"En Canatanazor perdio Almanzor el tambor", id est, in Canatanazor perdidit Almazor

timpanum siue sistrum, hoc est, leticiam suam. Veniebant ad eum barbari Cordubenses

et cum appropnquarent ei, euanescebat ab occulis eorum et iterum in alio loco apparens eadem plangens repetebat. Hunc credimus diabolum fuisse, qui Sarracenorum plangebat deiectionem. Almazor autem ab ea die, qua succubuit, noluit comedere neque bibere et ueniens in ciuitatem que dicitur Medinacelem, mortuus est et ibidem sepultus."1389

Cronicon Mundi. Santiago en Batalla.

"[...] visiblemente aparesçio el bienauenturado Jacobo con muchedumbre de [caualleros] blancos que derribauan los moros con mano valiente [...]".

${ }^{1388}$ CM, Liber IV, n XVII, op. cit, pp. 238-239. "Mas la hueste del rey Ramiro començo poco a poco dar las espaldas, fasta que venieron a vn monte que llaman Clavijo; y çerró el dia una noche muy escura, y todos los christianos se llegaron en vna muela, passando toda la noche en lagrimas y en oraçiones. Mas el rey Ramiro començo a dormir algund poco y aparesçiole el bienauenturado aposto Jacobo y dixole: 'Mi Señor Ihesu Christo partio a los otros mis hermanos apostolos las otras prouinçias y ordenó a mi guarda de toda España y guarneçiola al mi amparo'; e despues desto, apretando el apostol la mano del rey, dixo: 'Confortate y sey robusto, porque yo soy Jacobo, apostolo de Christo, que vengo en tu ayuda; vençeras mañana, con la ayuda de Dios, a los moros que [te] tienen ençerrado con esta muchedumbre [no] contable; mas muchos de los tuyos, a los quales es aparejada durable folgança, recibiran corona de martirio en esta batalla. No dubdes sobre esto: mañana me veras en vn cauallo blanco; pues de grande mañana, desde que fizierdes la confesion de vuestros peccados y tomardes la comunion del cuerpo y sangre de nuestro Señor, non dubdeys de [a] cometer a las huestes de los sarraçines con mano armada, llamando el nonbre del Señor y mio. Por çierto sepas que caeran en boca de cuchillo'. Las quales cosas dichas, partiose el Apostol. El rey Ramiro, tornando en sí y llamando sus obispos y abbades, contoles la vision, los quales, dando graçias a Dios, fizieron como les auia seydo mandado y dieron batalla a los barbaros; y Sanctiago apareçioles como les auia prometido, animando a los christianos a la batalla y feriendo reziamente a los sarrazines; mas los christianos, como veyan a Sanctiago, esforçados en el Señor, començaron con grandes vozes a llamar, derrocando los moros por cuchillo, diziendo: 'Ayudenos Dios y Señor Sanctiago'; entonçes los sarraçines vençidos, fuyeron, y fueron muertos de ellos poco menos de sesenta mill. Entonçes tomó el rey Ramiro (largura y tomó) a C[a]lagur[r] a y algunos otros lugares y castillos y tornose con gran gloria." CM, Libro IV, cap XVII, op. cit, pp. 291, 292.

${ }^{1389}$ CM, Liber IV, n 38, op. cit., p. 270. "En Calatanaçor perdio Almançor el atambor'; que quiere dezir que en Calatanaçor perdio Almançor el pandero, que es su alegria; venien(do) a él todos los barbaros de Cordoua, e como se allegase(n) a él, desfaziase ante sus ojos y llorando a ellos otra vez [aparesça e] lo tornaua a dezir. Este creemos que fue el diablo que llorana la cayda de los moros. Mas Almançor, desde esse dia que fue vençido, nun quiso comer nin beuer, y veniendo en la çibdad que se dize Medinaceli morio [...]" CE, Libro IV, cap. 38, op. cit., p. 329.

${ }^{1390}$ CE, Libro IV, cap. XCI, op. cit., pp. 424, 425. 
Cronicon Mundi. Aparición de Santiago e Isidoro a Alfonso VII.

"Pues como asi se hubiesen, y los christianos temiesen de tanta muchedunbre de ynfieles, el emperador Alfonso, sentado en la tienda y estando apremiado, tomole el sueño y aparesçiole vn varon cano de fermosas canas, vestido de vestidura obispal, cuya cara resplandeçia como el sol muy claro, çerca del qual, en la mano derecha, se blandia vn cuchillo de fuego que cortaua de amos cabos, y hablandole blanda y mansamente, por estas palabras, le dixo: 'Alfonso, ¿por qué dubdas?; todas las cosas son possibles al emperador Christo, nuestro Dios; mas, ¿ves tu esta muchedunbre de moros?; en amanesciendo, como fumo se desfará delante de tu cara, porque yo, que soy de tu linaje, soy dado por guarda a ti y a los que vernan si anduuieredes delante dél en fee non fingida y coraçon acabado’. Díxole el emperador: ‘¿Quién eres tu, padre sancto, que tales cosas me fablas?' 'Yo soy-dixo él-Ysidoro, doctor de las Españaas, succesor en graçia y en predicaçion del bienauenturado Jacobo Apostolo; esta mano derecha es de esse Apostolo Jacobo, defenssor de España'. y dichas estas cosas, la vision se arrebató." 1391

Cronicon Mundi. Santiago anuncia la captura de Mérida.

"[...] que, çiertamente, en essa batalla, visiblemente aparesçio el bienauenturado Jacobo con muchedumbre de [caualleros] blancos que derribauan los moros con mano valiente; y tanbien el bienauenturado sidoro confessor aparesçio en Çamora a algunos ante que Merida fuesse tomada nin fuese fecha la batalla, y dixoles que se aquexaria con hueste de sanctos a la batalla del rey Alfonso y en su ayuda, e que le daria la dicha çibdad y le daria vençmiento campal de los moros."1392

Cronicon Mundi. Devolución de las campanas a Compostela

"Inuente sunt ibi campane, quas ob insigne ab ecclesia sancti Iacobi apostoli rex Cordubensis olim detulerat Almazor, et rex catholicus Fernandus fecit eas Sarracenorum humeris ad ecclesiam santi Iacobi reportati." 1393

\footnotetext{
${ }^{1391}$ CE, Libro IV, cap. LXXIX, op. cit., p. 394.

1392 CE, Libro IV, cap. XCI, op. cit., p. 425.

${ }^{1393}$ CM, Liber IV, n' 101, op. cit., pp. 341. "Y fallaron ende las campanas que en otro tiempo Almançor, rey de Cordoua auia traydo de la yglesia de Sanctiago, y el rey Fernando fizolas leuar en los onbros de los moros a la yglesia del Apostol Sanctiago.” CE, Libro IV, cap. XCIV, op. cit., p. 430.
} 
Historia Rebus Hispaniae. Batalla de Clavijo.

"Cumque in nocte de certamine dubitaret, apparuit et beatus Iacobus confortans eum, ut certus de uictoria sequenti die bellum Arabibus instauraret. Cumque diluculo surrexisset, uisionem episcopis et magnatibus reuelauit; qui pro uisione gracias exoluentes ad pugnam omnes se comuniter perauerunt apostoli oraculo robotari. Set et ex alia parte Sarraceni de multitudine confidentes ad prelium processerunt. Hinc inde itaque conserto prelio, Sarraceni confusione turbati Christianorum gladis terga dederunt, ita quod ex eis fere $L X X^{a}$ milia ceciderunt. In quo bello beatus Iacobus in equo albo uexillum album manu baiulans fertur apparuisse. Tunc rex Ranimirus cepit Albaydam, Clauigium, Calagurram et multa alia que regno adiecit. Ex tunc, ut fertur, hec inuocatio inoleuit: Deus adiuna, et sancte Iacoe. Tunc etiam uota et donaria beato Iacobo persoluerunt et in aliquibus locis non ex tristicia aut necessitate, set deuotiones uoluntaria adhuc soluunt.",1394

Historia Rebus Hispaniae. Santiago protege su sepulcro.

"Cumque ad maritima peruenisset, etiam ciuitatem et ecclesiam beati Iacobi deuastauit, set fulgure territus ab eo loco, ubi esse corpus apostoli credebatur, abstinuit, quod tamen proposuerat uiolare. Nichilominus tamen campanas minores in signum uictorie secum tulit et in mezquita Cordube pro lampadibus collocauit, que longo tempore ibi fuerunt. Almançor autem cum suo exercitu percussus a Domino pro scelere sacrilegii dignam sustinuit ultionem, nam qui sanctum locum apostoli prophanarat, inmunda sui plaga, scilicet, dissenteria, fere totus exercitus est consumptus; reliqui morte subitanea perierunt." $" 1395$

\footnotetext{
${ }^{1394}$ HRH, Liber IV, cap. XIII, op. cit., p. 133. "Y como Ramiro anduviera indeciso por la noche acerca del combate, se le apareció Santiago animándole a que, seguro de su victoria, entablara combate con los árabes al día siguiente. Con la primera luz del día comunicó su visión los obispos y magnates, quienes, dando gracias por la visión, se aprestaron en común para la lucha confortados por la promesa del apóstol. Pero también desde el otro bando salieron al combate los sarracenos confiados en su superioridad numérica. Iniciada de esta forma la batalla por una y otra parte, los sarracenos, sacudidos por el desconcierto, dieron la espalda a las espadas de los cristianos, de modo que perecieron casi setenta mil de ellos. Se cuenta que en esta batalla apareció Santiago sobre un caballo blanco haciendo tremolar un estandarte blanco. Entonces el rey Ramiro se apoderó de Albelda, Clavijo, Calahorra y otros muchos lugares que agregó a su reino. Después aquel día, según se cuenta, se utilizó esta invocación: ¡Dios, ayuda, y Santiago! También entonces ofrendaron a Santiago exvotos y regalos, y en algunos lugares todavía los ofrecen sin estar acuciados por la desgracia o la pobreza, sino por espontánea devoción.” HHE, Libro IV, cap XIII, op. cit., p. 177.

${ }^{1395}$ HRH, Liber V, cap. XVI, op. cit., p. 165. "Y habiendo llegado a las tierras cercanas al mar, destruyó también la ciudad y la iglesia de Santiago, pero, espantado por un rayo, no se atrevió a hollar el lugar donde se creía que estaba el cuerpo del apóstol, aunque se había propuesto profanarlo. Lo que sí hizo, en cambio, fue llevarse con él, como señal de su victoria, las campanas menores, y las utilizó como lámparas en la mezquita de Córdoba. Sin embargo, Almanzor y su ejército, golpeados por el Señor,
} 
Crónica General de España. Santiago se presenta como caballero.

"Et por que non dubdes nada en esto que te yo digo ueer medes cras andar y en la lid en un cauallo banco con una senna blanca, et grand espada reluzient en la mano" [...].

"Otrossi el apóstol sant Yague fue y luego con ellos, assi como les prometiera, et esforçaualos a la batalla, et firie el mismo muy de rezio en los moros, assi semeiaua. Los cristianos, quando vieron a sant Yahue, fueron muy esforçados, et fiando en ell ayuda de Dios et dell apóstol sant Yague, començaron de ferir en los moros muy de rezio, dando grandes uozes et diziendo: 'Dios, ayuda, et Sant Yague!.",1396

Crónica General de España. Santiago protege su sepulcro.

"Mas ante que el se partiesse de tierra de Santyague fue ferido el con toda su campanna de maiamiento de Dios; et por el peccado dell atreuimiento et de las suziedades que el fazie en la eglesia de sant Yague, cayo en el una de las mas suzias enfermedades que podrie ser, et es aquella que dizen los fisicos diarria; et diaria es dolor del uientre que rompe las entrannas et faze en los omnes la malazon tan fuerte, que mueren los omnes ende. Et Almançor et todos los de la su hueste, de guisa fueron consomidos et desfechos los cuerpos que todos murieron ende, sinon muy pocos; et los que escaparon cuenta la estoria que murieron despues muerte subitanna."1397

Crónica General de España. Aparición de Santiago vista por musulmanes

“Et dizen, asi commo los moros mismos afirmauan después, que parescio y Santiago en vn cauallo blanco et con senna blanca en la mano et con vn espada en la otra, et que andaua y con el vna ligion de caualleros blancos; et dizen que ángeles vieran andar sobre ellos por el ayre; et que estos caualleros blancos les semeiaua que les estroyen mas que ninguna otra gente" 1398 .

Crónica de Veinte Reyes. Santiago protege su sepulcro.

"E después que llegó a la marisma, corrió e astragó la çibdat e la tierra toda aderredor de Santiago, e al cabo entró mucho atreuidamente en la iglesia del buen apóstol Santiago por quebrantar el monimento donde él yazía, e fue y muy mal espantado por

sufrieron un castigo acorde con el sacrilegio que habian cometido, pues casi todo el ejército que habia profanado el santo lugar del apóstol fue aniquilado por una peste asquerosa de por sí, esto es, la disentería. Los demás perecieron de forma repentina." HHE, Libro V, cap. XVI, op. cit., pp.207, 208.

${ }^{1396}$ CGE, cap. 629, op. cit., p. 360.

${ }^{1397}$ CCG, cap. 754, op. cit., p. 449.

1398 CGE. cap. 1044, op. cit., p. 727. 
vn rrayo que firió y çerca dél, pero tomó las canpanas menores e leuólas por señal de aqull su vençimiento, e púsolas después por lánparas en la mezquita de Córdoua, e estouieron y luengo tienpo fasta en el tienpo del rrey don Ferrando el Terçero. E después desto, mandó Almançor poner fuego a la iglesia de Santiago e quemóla toda. Mas ante que se él fuese de tierra de Santiago, tomó Dios dél grant vengança e de toda su hueste, ca por el pecado del grand atreuimiento e de los lixos quél fizo en la iglesia de Santiago, cayó en todos ellos vna de las más suzias enfermedades que en el omne pudo / ser, e era aquella enfermedat la que llaman los fisicos diarría, e tan maltrechos fueron ende que todos los más murieron, a los que ende escaparon murieron después muerte sopitaña."1399

Crónicon del Cerratense. Batalla de Clavijo.

“Era nuevecentésima septuagésima segunda; el rey Ramiro trabó batalla con los sarracenos, ayudándole visiblemente Santiago, y arrancó un grave yugo de las cervices de los cristianos; porque hasta aquel día les daban cien vírgenes para ser burladas." 1400

\section{III.2.d.- San Isidoro}

Crónica Silense/Legionense. Traslación de san Isidoro.

"Interea dum residens sella sustentare paulisper fessa membra atque recitans secum necio quid de Psalmis, opprimeretur sommo prae nimio labore vigiliarum, ei apparuit quidam vir comptus veneranda canitie, amictus infula pontificali que alloquens eum tali voce, ait: Scio quidem venisse te cum tuis sociis ad hoc, ut ducatis vobiscum transferentes hinc corpus beatissimae virginia Justae. Sed quoniam non est divinae voluntatis ut haec civitas desoletur abscesuu humus virginia, immensa pietas Dei non patiens remitiere vos vacuos, est donatum vobis deum corpus, tollentes quod remeate ad propria. Quem quum reventas vir interrogaret, quis esset qui talia sibi injungeret, ait. Ego sum doctor Hispaniarum Isidorus antistes hujusmondi urbis. Dicens haec evanuit ab oculis cernetis." 1401

\footnotetext{
${ }^{1399}$ CXXR, Libro V, cap. XIX, op. cit., p. 127.

1400 "Crónicon del Cerratense", en Las Crónicas Latinas de la Reconquista, Tomo I, op. cit., p. 92.

${ }^{1401}$ CS 1913. op. cit., p. 152. "Entre tanto como sentado en la silla sustentase un poco los cansados miembros y recitando consigo no sé que de los salmos, fuese oprimido por el sueño por el mucho trabajo de las vigilias, se le apareció cierto varón adornado de veneranda canicie, vestido con la infula pontificia y hablándole con tal voz, le dice: Sé cierto haber venido tú con tus socios para esto, que conduzcáis con
} 
Crónica Najerense. Traslación de san Isidoro.

"Interea, dum sella residens fessa membra paulisper sustentaret atque secum nesccio quid de psalmis recitans pre nimio uigiliarum labore sompno opprimeretur, apparuit ei quidam uir ueneranda canitie comptus pontificali infula amictus, eumque tali uoce alloquens ait: 'scio quidem te cum sociis tuis ad hoc uenisse, ut corpus beatissime uirginis Iuste hinc transferentes uobiscum ducatis; set quoniam non est diuine uoluntatis ut hec ciuitas abscessu huius uirginis desoletur, inmensa Dei pietas, uos remittere uacuos non paciens, corpus meum donat uobis, quod tollentes ad propria remeate'. Quem cum reuerendus uir interrogaret quis esset qui talia sibi iniungeret, ait: 'ego sum Yspaniarum doctor huiuce ubis antistes, Ysidorus'. Et hec dicens ab occulis cernentis euanuit." 1402

Historia Rebus Hispaniae. Traslación de san Isidoro.

"Postea adeo regem Hispalis infestauit, ut corpus beati Isidori permitteret inde leuari, quod a duobus episcopis, Aluito Legionensi et Ordonio Astoricensi multis miraculis coruscantibus, translatum est ab Hispali Legionem."1403

Historia Rebus Hispaniae. Isidoro como mensajero y protector.

"Set dicitur sanctus Isidorus custodi sacrorum sue ecclesie aduentum predicti principis et Arabum reuelasse, ut et ipse regi Fernando similiter reuelaret; et rex Fernandus audiens egit gracias, in continenti properans ad subsidium absessorum" ${ }^{1404}$.

vosotros trasladando de aqui el cuerpo de la beatísima virgen Justa. Mas porque no es de la divina voluntad que esta ciudad sea desolada con la retirada de esta virgen, la inmensa piedad de Dios no sufriendo enviaros vacios, es donado á vosotros mi cuerpo, llevando el cual volved al propio país. Al cual como reverendo varón interrogara, quién fuese el que tales cosas le mandase, dice: Yo soy el doctor de las Españas Isidoro prelado de esta urbe. Diciendo esto se desvaneció de los ojos del espectador." CS, en Las Crónicas latinas de la Reconquista, Tomo II, op. cit., p. 152.

${ }^{1402} \mathrm{CN}$, Liber III, n 10, op. cit., p. 164. "En ese momento, mientras sentado en una silla reposaba un poco sus cansados miembros y recitando para sí no se qué salmo el sueño lo tenía rendido por el excesivo esfuerzo de la vigilia, se le apareció un hombre adornado de una venerable canicie, ceñido con la infula pontifical, que hablándole con estas palabras le dice: 'Sé ciertamente que estás venido con tus compañeros para esto: para llevaros, sacándolo de aquí, el cuerpo de la santísima virgen Justa; pero puesto que no es de la voluntad divina que la ciudad quede desolada por la partida de esta virgen, la inmensa piedad de Dios no consiente que os vayáis de vacio y os entrega mi cuerpo, llevándoos el cual volved a vuestra patria'. Cuando el reverendo varón le preguntó quién era quien tales órdenes le daba, le dijo: 'Yo soy Isidoro, el doctor de las Hispanias, el obispo de esta ciudad'. Y diciéndole esto, desapareció de la vista de quien lo estaba mirando." CN 2003, Libro III, n 10, op. cit., p. 169.

${ }^{1403}$ HRH, Liber VI, cap. XII, op. cit., p. 192. "Luego, acosó hasta tal punto al rey de Sevilla, que le permitió llevarse de alli el cuerpo de San Isidoro, que fue trasladado desde Sevilla a Toledo por dos obispos, Alvito de León y Ordoño de Astorga, que eran ilustres por muchos milagros [...]" HHE, Libro VI, cap XII, op. cit., p. 235.

${ }^{1404}$ HRH, Liber VII, cap. XXI, op. cit., p. 243. "Pero se cuenta que San Isidoro anuncio al sacristán de su iglesia la llegada del citado noble y los árabes, para que él se lo anunciara a su vez de la misma forma al rey Fernando; y al enterarse éste, dio gracias, corriendo al punto a socorrer a los asediados." HEH, Libro VII, cap. XXI, op. cit., p. 290. 
Historia Rebus Hispaniae. Isidoro anuncia su muerte a Fernando I.

"Set iam uite sibi termino inminente apparuit ei beatus Isidorus et diem sui obitus intimauit; et cum cepisset post modicum infirmari, fecit se Legionem adduci, et IX kalendas Ianuarii, die Sabbati, ingressus est ciuitatem et ex more corpora sanctorum flexis genibus adorauit, petens et supplicans ut cum dies obitus iam instaret, anima eius ab angelis duceretur." 1405

Historia Rebus Hispaniae. Isidoro se aparece a Alfonso VII.

"Apparuit autem in nocte santus Isidorus confortans imperatorem et in congressu crastino se pollicens aduitorem. Igitur luce crastina apparente, inito prelio, iuxta promissum sancti Isidori optinuit imperator, et fugatis auxiliis Mauri oncole, quia resistere non ualebant, eius dominio se dederunt et ei urbis presidium tradiderunt, quod ipse in continenti repleuit bellatoribus et incolis christianis, et remanserunt Mauri subditi sub tributo; et propter miraculum ecclesiam sancti Isidori conuentu regularium ordinauit et donariis plurimis adornauit."1406

Historia Rebus Hispaniae. Isidoro alerta sobre el ataque a Ciudad Rodrigo "Set dicitur sanctus Isidorus custodi sacrorum sue ecclesie aduentum predicti principis et arabum reuelasse, ut et ipse regi Fernando simiiliter reuelaret, et rex Fernandus audiens egit gracias, in continenti properans ad subsidium obsessorum. Set quia ciuitas nondum erat munis munita, populatores quadrigas et scrinia, dolia, archas et lectos et lignamina omnia in ciruiru posuerunt, quibus usque ad aduentum regis hostibus restiterunt. Rex autem ueniens, inuictus animo, confisus in Domino et oraculo confortatus, cum obsessoribus concertauit, et maxima eorum multitudine interfecta que vix poterat numerari, alios egit fuga, alios retiniuit in captura; et munita Ciuitate Roderici quieuit terra a preliis diebus multis." 1407

${ }^{1405}$ HRH, Liber VI, cap. XIII, op. cit., pp. 193, 194. “Cuando ya su vida tocaba a su fin, se le apareció San Isidoro y le reveló el día de su muerte; y como al poco tiempo sintiese los primeros síntomas, se hizo conducir a León y entró en ésta el sábado 24 de diciembre, y siguiendo su costumbre, oró de rodillas ante los cuerpos de los Santos pidiéndoles y suplicándoles que, como ya se aproximaba el día de su muerte, su alma fuera llevada por los ángeles." HHE Libro VI, cap. XIII, op. cit., p. 236.

${ }^{1406}$ HRH, Liber VII, cap. XI, op. cit., p. 232. "Entonces se apareció San Isidoro en medio de la noche dando ánimos al emperador y asegurándole su ayuda en el combate del día siguiente. Y así, empezada la batalla tan pronto como amaneció, el emperador alcanzó la victoria de acuerdo con la promesa de San Isidoro, y al emprender la huida los que habían acudido de lejos, los moros del lugar, como eran incapaces de hacerle frente, se le rindieron y le entregaron la fortaleza de la ciudad [...]" HHE, Liber VII, cap. XI, op. cit., p. 278.

${ }^{1407}$ HRH, Liber VII, cap. XXI, op. cit., p. 243. "Pero se cuenta que San Isidoro anunció al sacristán de su iglesia la llegada del citado noble y de los árabes, para que él se lo anunciara a su vez de la misma 
Cronicon Mundi. Traslación de san Isidoro.

"Tunc apparuit ambobus apiscopis orantibus Christi confessor Ysidorus et ostendit eis sui corporis locum, precipiens et eum deferrent ad ciuitatem Legionensem decorandam. Sed cum ex licencia regis Benabet tumulus beatissimi doctoris Yspaniarum Ysidori aperiretur, balsami ros de ossibus illius axalauit et arbores et homines qui aderant, perfudit." $" 1408$

Cronicon Mundi. Isidoro anuncia la captura de Toledo.

"[...] porque en la noche siguiente, como el obispo se diesse al sueño, passadas las dos partes de la noche, aparesçiole Ysidoro, el confessor de Christo, vestido de vestidura arçobispal y çercado de compaña de muchos angeles, [e] con blanda palabra y cara muy alegre, dixole: 'Alegrate, hermano Çibrian, que las tus oraçiones yo las leué ante el Señor y alcançé que despues de vn mes de dias, dexada la carga de la carne, te alegres con nosotros en la durable gloria; y por esso, de mi parte, embiarás mensajero al rey diziendole que despues de quinze dias, le dará el Señor a Toledo, la muy noble çibdad de las Españas, porque yo seré presente, y echando los moros yo restituyre la çibdad que non se pude combatir a la honrra christiana, la qual adelante no será dada en las manos de los moros, y cantarse ha en ella cantar de alegria de Ihesu Christo, y a la Virgen, engendradora de Dios, Maria Reyna del çielo, se glorificará en ella; e venirte ha a ti oy esta señal: que vn mançebo de tu compañia te dira a la hora de la terçia que el rey Alfonso se parte de la çerca de la dicha çibdad; agora, pues, (faza) $[\ldots]^{\prime 1409}$

Milagros de San Isidoro. Traslación de san Isidoro.

“[...] y como los cristianos vieron venir así los moros airados para ellos, y conocieron que venían para quitarles el cuerpo santo, y que eran tan pocos que no se lo podrían

forma al rey Fernando; y al enterarse éste, dio gracias, corriendo al punto a socorrer a los asediados. Pero como la ciudad no estaba todavía fortificada con murallas, sus habitantes colocaron en derredor carros, baúles, tinajas, arcas, lechos y toda clase de maderos, con lo que pudieron resistir a los enemigos hasta la llegada del rey. En cuanto llegó éste seguro de su victoria, confiado en el Señor y animado por la revelación, arremetió contra los atacantes y, después de dar muerte a tantos que apenas se podian contar, a unos los puso en fuga y a otros los mantuvo en cautiverio; y una vez fortificada Ciudad Rodrigo, la tierra se vio libre de combates durante mucho tiempo." HHE, Libro VII, cap XXI, op. cit., p. 290, 291.

${ }^{1408}$ CM, Liber IV, n'. LV, op. cit., pp. 291. "Entonçes aparesçió el confessor de Ihesu Christo Ysidoro a entrambos los obispos orantes, y demostroles el lugar de su cuerpo por que lo traxesen para honrrar la cibdad de Leon.Y (aun) de liçencia del rey Benabeth, como se abriese el luzillo del doctor de las Españas, bienauenturado Ysidoro, baporó de sus huesos olor balssamo y derramosse por los omes y arboles que estauan en derredor." CE, Libro IV, cap LV, op. cit., p. 356.

${ }^{1409}$ CE, Libro IV, cap. LXX, op. cit., p. 375. 
impedir, comenzaron a pedir de todo corazón y con muchas lágrimas, y muy devotamente, al mismo San Isidro que los socorriese en aquella necesidad, y para ello les alcanzara la misericordia de Dios. Y así como llegaron a ellos los moros mudóseles el pensamiento, y alteróseles la voluntad y el juicio de tal manera que del todo olvidaron el propósito que traían, y no acordándose de ello ni a qué venían, halláronse tan confusos que no supieron que hacer, sino saludar alegremente a los dichos cristianos e hicieron gran reverencia al cuerpo santo, y donde venían a ofenderlos, les hicieron mucha honra y placer; y así se tornaron los moros para su ciudad de Sevilla, y después que iban lejos del santo cuerpo comenzaron a pensar y hablar entre sí la causa de su venida, y acordándose de ella, volvieron con muy mayor furia en pos de los cristianos, y corrieron tanto que los volvieron a alcanzar, y cuando llegaron cerca de ellos plugó a Dios, que nunca pudiérase verlos, y andaban los moros como ciegos, de acá para allá, perdidos, que no sabian que hacer de sí, por manera, que así turbados, con gran vergüenza y confusión se hubieron de tornar para Sevilla: y como los cristianos los veían asi andar ciegos y perdidos habian tan grandísimo placer y consolación, y daban por ello tantas gracias a Dios y a su glorioso confesor San Isidro, que no hay persona, que lo pueda decir.",1410

Milagros de San Isidoro. Isidoro anuncia la captura de Toledo.

“Tenían en aquel tiempo los moros, por los pecados de los cristianos, ocupada la real ciudad de Toledo, y procuró mucho por recobrarla el noble rey de los católicos D. Alonso con el ejército de los godos, y con todas sus fuerzas y muchos trabajos y gastos insistió en ello, y la tuvo sitiada por espacio de siete años y más."1411

Milagros de San Isidoro. Isidoro protege su sepulcro.

"Y mandó guardar con grande diligencia aquel santo lugar para que ningún cristiano pudiera entrar en él; y mandó, asimismo derribar y destruir aquella santa iglesia y edificios sagrados muy hermosos y de gran altura, que alli había hecho el glorioso confesor San Isidro; e hizo el malaventurado rey llevar las piedras de los dichos santos edificios para hacer los muros de la ciudad, y las mezquitas y templos de Mahoma, para que pereciere del todo la memoria de aquel santo templo de N. Señor y de su bendito confesor. Y como edificasen de las dichas sagradas piedras una torre de una

${ }^{1410}$ MSI, cap. IV, op. cit., pp. 10.
${ }^{1411}$ MSI, cap. XVI, op. cit., p. 27. 
mezquita, que parecía ya tener su altura grande y perfecta, un sacerdote de aquellos infieles, al cual ellos llaman almodono o alfaquí subió a la dicha torre para invocar ciertas cosas diabólicas con sus desdichadas voces, según la costumbre de ellos; y así como comenzó a decir sus palabras malditas, luego cayó de lo más alto de la torre al suelo, y se deshizo en pedazos, y así murió malaventuradamente; y muerto aquel, tornó luego otro a subir a la misma torre, para acabar lo que el primero había comenzado, y también cayó luego, y murió de la misma suerte que el otro; y como todos los presentes estuviesen maravillados y espantados de aquello y hablasen entre sí, diciendo si por ventura venía de Dios aquella venganza por amor de San Isidro, un alfaquí viejo, que era tenido entre todos los alfaquies por el más sabio en la secta de Mahoma, viendo aquello se enfadó mucho, y encendido de tanta furia, que comenzó a decir contra San Isidro muchas palabras injuriosas y grandes blasfemias, y luego subió a la torre susodicha con grande prisa, y comenzó a cantar sus malaventuradas palabras, temblando y con temor; y después que así hubo cantado un poco, ensalzando el nombre de su Mahoma, con todos los loores que eél podía, no tardó la venganza de la ira de nuestro Señor, porque luego fué el malaventurado alfaqui arrebatado de encima de la torre donde estaba, y levantando un pocomás alto, y de alli dió tan gran caída y tan recia, que todos sus miembros y huesos fueron desmenuzados: y como los moros lo vieron, quedaron muy espantados y tuvieron tan gran temor, que jamás osaban llegar a la dicha torre, ni acercarse a ella."

$[\ldots]$

"Y los dichos criados del rey fueron luego y llevaron muchos obreros para cavar en el dicho lugar, y encomenzando a cavar y cortar la tierra con sus azadones y otros instrumentos, súbitamente se les pasmaron los brazos a todos, y aún a algunos de ellos se les quebrantaron de manera que no pudieron más cavar ni hacer cosa alguna: y como los criados del rey vieron aquello, fueron luego a decírselo, y él fué muy airado de ello, les dijo: tomad otros obreros, y llevadlos allí, y si de su voluntad no quisiesen cavar, dadles de palos hasta que caven la tierra. Y tornaron los dichos criados del rey al santo lugar con los otros obreros y comenzaron a darles palos y azotes porque cavasen, y luego, súbitamente les tomó a los dichos criados, camareros del rey, que hacian aquello, un dolor de torzón tan grande que les hacía dar las mayores voces y gemidos del mundo, y asi gimiendo y clamando echaron luego por sus partes bajas sus 
miserables entrañas de todo punto con muy grande sonido, y así murieron malaventuradamente." 1412

Milagros de San Isidoro. Isidoro castiga a Enrique de Portugal y Pedro de Aragón. “[...] y así usando Dios de su justicia, hirió luego al rey Don Pedro susodicho de pura enfermedad, en tal manera que comenzando a dormir le venía una terrible congoja y despertaba clamando con gran temor así como si alguno le quisiera matar; velando, no podía holgar ni reposar, y en sueños era sacudido y molestado con grandes temores y espantos, porque así fatigado y punido, con la venganza de Dios cada día muriese. Prometía restituir al templo de Dios los tesoros que le había robado, conociendo que por aquello le daba Dios esas penas, pero no tenía de qué pudiese pagar ni cumplir lo que así debía. Así mismo, el conde Don Enrique susodicho, viniendo para Astorga, le comprendió la ira de Dios y el cuchillo de su justicia, porque así como mandó e hizo arrancar el oro y piedras preciosas del cobertor o tapadero del arca del cuerpo santo de San Isidro, que llevaba consigo, y en aquellas tablas del dicho cobertor, que así quedaron desguarnecidas, echasen cebada para comer a dos caballos que el dicho conde llevaba, muy escogidos, hermosos y muy ligeros, de quién el mucho se fiaba para sus guerras y caminos, luego los caballos fueron rotos del vientre y se cayeron muertos en el suelo y como el conde vió aquello conoció que era la venganza de Dios que venía sobre él por cuanto había sido muy cruel y codicioso sobre el sagrado túmulo y tesoros del bienaventurado confesor San Isidro, y luego le tomó una fiebre cotidiana, de la cual ningún médico le pudo curar mientras vivió, y de día a él y a los suyos les sucedian peor las cosas, y les venían muchas cosas de desastres y caídas y malas venturas en todo."

$[\ldots]$

"Y como el dicho rey Don Pedro era hombre recio y animoso, juntó su ejército contra los moros, y fué a pelear con ellos cerca de la villa de Fraga, y permitió Dios, por sus pecados del dicho rey que los cristianos de su ejército fuesen desbaratados y vencidos de los moros; así que los cristianos se pusieron en huída, recibiendo mucho daño, y el rey Don Pedro sobredicho fué perdido en aquella batalla, de manera que jamás le pudieron ver, ni hallar muerto ni vivo, y así se cumplió bien y muy presto lo que de él habia dicho San Isidro al susodicho caballero Don Gutierre Fernández."1413

\footnotetext{
${ }^{1412}$ MSI, caps. XX, XXI, op. cit., pp. 34-36.

${ }^{1413}$ MSI, caps. XXVII, XXIX, op. cit., pp. 45, 47.
} 
Milagros de San Isidoro. Isidoro castiga a don Diego por oponerse a Fernando III "[...] y estando puestos en esta tribulación y angustia no les faltó la misericordia de Dios por los méritos de San Isidro, el cual hirió luego al dicho Don Diego de una muy grande enfermedad, y daba grandes voces diciendo que San Isidro, por ayudar al rey Don Fernando quería matarle a él, porque había ocupado su iglesia y torre contra el servicio del rey; y junto con esto tenía el caballero tan grandísimo dolor en los ojos, que le parecía que se los arrancaban de su lugar, y así le fatigó San Isidro tan fuertemente que de puro temor y necesidad, con acuerdo de la dicha condesa, su madre, hubo de devolver al prior y convento de San Isidro su iglesia y torre libremente, y más les pagó todos los daños que les había hecho y les hizo juramento sobre los santos Evangelios que de alli adelante sería siempre caballero y vasallo de San Isidro, y hecha la dicha satisfacción y juramento luego en la misma hora fué sano."1414

Milagros de San Isidoro. Isidoro alerta sobre el ataque a ciudad Rodrigo "Y acaeció que estando él una noche después de maitines así orando como solía, apareciósele San Isidro, y díjole así: Martino, ve luego al rey Don Fernando y salúdalo de mi parte, y dile que digo yo, que se vaya luego a prisa para Ciudad Rodrigo, porque viene grande multitud de moros a tomar aquella ciudad, y yo seré con él, y el bienaventurado apóstol Santiago, y los moros serán quebrantados y desbaratados y huirán de la faz del rey. Yo soy Isidro, patrono tuyo, y no tardes en ir, porque el rey hará luego con voluntad agradable lo que de mi parte le dirás."1415

Milagros de San Isidoro. Leyenda de Isidoro y Mahoma.

"La primera fué, que nuevamente se había levantado un hereje endiablado, lleno de grandes pecados, y maldades, que se decía Mahoma, el cual con su boca de víbora emponzoñaba, predicando opiniones falsísimas, nunca oídas, inficionaba y engañaba a los que le oían.

“Como San Isidro oyó aquellas cosas fué muy triste, y envió luego ciertos criados y oficiales suyos de justicia que le trajesen a Mahoma, y si no quisiese venir de su voluntad, que le tragesen preso y atado, y dióles el mismo San Isidro los lazos con que le habian de atar, para comprimir o apremiar sus maleficios, porque no se pudiese soltar con ellos. Como el diablo supo aquello acordó de fallarles la causa de su venida,

\footnotetext{
${ }^{1414}$ MSI, cap. V, op. cit., pp. 125, 126.

1415 MSI, cap. XLIV, op. cit., p. 83.
} 
porque no tuviese efecto la intención y mandamiento de San Isidro: y tomó luego el demonio figura de ángel bueno, y dijole así: Oh mi amado Mahoma, sábete ahora que viene nuestro enemigo Isidro, el cual es un engañador y adversario nuestro y de los nuestros en todas las cosas; por ende, conviene que luego, sin ninguna dilación, te vayas de España y de sus confines, porque tú, ni aún los ángeles de Dios, no podemos sufrir la presencia de este Isidro. Respondióle Mahoma y dijo: ¿Cómo puede ser, o qué novedad es esta, que los ángeles de Dios no pueden sufrir la presencia de un hombre mortal? Replicó el demonio y dijo así: En ninguna manera digas que esto es cosa nueva, antes cree y afirma que es de las primeras y más antiguas cosas que acaecieron en el mundo, porque el primer hombre, conviene a saber, Adán, hecho a la imagen y semejanza de Dios, a quien todas las cosas del mundo fueron sometidas y le fueron dados los ángeles para que lo guardasen, fué lanzado del paraíso por el engaño que el demonio le hizo, y los ángeles de Dios no le pudieron ayudar ni aprovechar cosa alguna: además, Jesucristo, profeta muy grande, siendo fatigado del diablo y apremiado de mucha necesidad, oró y pidió a Dios que le librase de la muerte, porque no podría sufrir las persecuciones del diablo.

“Como Mahoma oyó aquellas palabras fué muy espantado, y luego, a la hora, fuyó, y se pasó a las partes de África, y allí con sus maldades y abominables predicaciones engaño innumerable multitud de gentes de los ismaelitas: y aquellos que San Isidro había enviado a prender a Mahoma buscáronle por los lugares de España donde andaban predicando, y fueron en seguimiento de él hasta la mar, y como no le pudieron haber a él, prendieron a algunos de los suyos y trajéronlos a San Isidro, al cual, según parece somos en gran obligación todas las naciones de España y de sus confines, pues con su presencia y virtud maravillosa en su tiempo lanzó y quitó de nuestras partes aquella endiablada y pestilencial doctrina de Mahoma, que la mayor parte del mundo ha inficionado por los pecados de las gentes, y así quedamos nosotros libres de ella por los méritos de este nuestro Santo glorioso."1416

Crónica General de España. Isidoro alerta sobre el ataque a Ciudad Rodrigo

"Et la puebla de la çipdad non era aun çercada de muros, et, segund lo cuenta ell arçobispo don Rodrigo, los pobladores del logar tomaron entonçes apriessa, como uarones, carros, carretas et carrales, cubas, uassas, arcas, lechos, uigas, cabrios et las otras maderas que auer pudieron que pora ello fuessen, et pusieronlo todo en çerco

${ }^{1416}$ MSI, cap. IX, op. cit., pp. 133-135. 
aderredor de la puebla, por estoruo de los enemigos et por guarda de si otrossi et de su puebla, fasta que llegasse el rey don Fernando." 1417

Crónica de Veinte Reyes. Traslación de san Isidoro.

"Entonçes, aparesçió el bendito confesor de Ihesu Christo, Ysidrio, e amos los obispos o yazían en su oraçión, e demostróles el lugar donde estauan el cuerpo, e díxoles que le leuasen para León. Los christianos, abriendo la sepoltura por mandado de Abenhabet, salió luego vn olor tan sabroso en manera de bálsammo de sus huesos que a todos los que y estauan aderredor prestó mucho e dio grand salud."1418

Crónica de Veinte Reyes. Isidoro alerta sobre el ataque a Ciudad Rodrigo

"Mas vino Sant Ysidrio en vision quel thesorero del monesterio de los que avíe otro su nonbre Ysidrio e díxole commo un príncipe venie con grand poder de moros sobre la Çibdat Rrodrigo, e él que lo dixiese al rrey don Ferrndo. Quando el rrey don Ferrando lo oyó, agradesçiólo a Dios e fuese quanto pudo para allá, e porque la villa non era avn çercada, los omnes que y eran toaron carretas e cubas e arcas e lechos e quanta madera pudieron auer pusiéronlo todo en derredor e defendiéronse desta guisa fasta que vino el rrey." 1419

\section{III.2.e.- Santa María}

Crónica Najerense. García III ora a Santa María.

"Garcias uero sollicitus de pugna, confidens in Domino, dum in quídam ecclesia paruula que intra caueam loco quod nunc est Naiarensem monasterium erat in honore Beate Marie uirginis dicata pernoctans, sompno correptus dorminit et futurum bellum se uicturum per sompnium Domino reulante cognouit" ${ }^{1420}$.

\footnotetext{
${ }^{1417}$ CGE, cap. 994, op. cit., p. 674.

${ }^{1418}$ CXXR, Libro VIII, cap. IX, op. cit., p. 171.

${ }^{1419}$ CXXR, Libro XIII, cap. XI, op. cit., p. 275.

${ }^{1420}$ CN, 1995, Liver III, n’ 3, op. cit., pp. 151, 152. "García, preocupado por el combate, confiando en el Señor, mientras oraba de noche en una iglesia pequeñita consagrada a Santa María la Virgen - que está dentro de una cueva en el lugar en el que ahora se asienta el monasterio de Nájera -, rendido por el sueño se quedó dormido y en sueños supo por revelación divina que ganaría la guerra que iba a tener lugar.” CN, 2003, Libro III, n³, op. cit., pp. 159, 160.
} 
Historia Rebus Hispaniae. La Virgen protege al portador de su estandarte.

"Erat autem in uexillis regum imago beate Marie Virginis, que Toletane prouincie et tocius Hispanie samper tutrix extitit et patrona"1421.

Milagros de Nuestra Señora. La Virgen protege a un niño converso.

“Tomó a su hijo,

tal como estaba calzado y vestido,

y lo arrojó al fuego.

¡Dios castigue al padre que tal hace con un hijo!

La madre empezó a gritar y a arañarse

las mejillas con sus uñas.

En poco tiempo se juntó mucha gente

aturdida por las voces que daba la mujer.

El fuego, aunque horrible, tuvo piedad del niño,

no le tocó ni a la ropa.

Se salvó el pequeñín

¡Este gran milagro hizo Dios!’”. ${ }^{422}$

Milagros de Nuestra Señora. La Virgen denuncia a los rabinos que profanaban una imagen.

"Vallamos sin tardanza a las casas

de los rabinos más nombrados y algo hallaremos;

'no tratemos de ir a almorzar ahora, ya lo haremos después,

'si no queremos que la Gloriosa se enoje con nosotros'.

Se pusieron en movimiento clérigos y pueblo

y fueron al barrio de la judería; Cristo y la Virgen los guiaron

y pronto descubrieron la traición.

Hallaron en casa del rabino más honorable

un cuerpo de hombre, hecho en cera;

estaba crucificado como Nuestro Señor

con grandes clavos y la llaga en el costado.

${ }^{1421}$ HRH, Liber VIII, cap. X, op. cit., p. 273. "En los estandartes de los reyes figuraba la imagen de Santa María Virgen, que siempre fue protectora y patrona de la provincia de Toledo y de toda España." HHE, Libro VIII, cap. X, op. cit., p. 322.

${ }^{1422}$ MNS, XVI, n $352-377$, op. cit., pp. 70-74. 
Cuanta ofensa hicieron a nuestro Señor

allí la repitieron para deshonra nuestra.

Los mataron a todos aunque con pena profunda.

¿Gracias al Señor, lo que a él hicieron se hizo con ellos!”1423

Cantigas de Santa María. La Virgen denuncia a los rabinos que profanaban una imagen.

"E a voz, come chorando, | dizia: 'Ay Deus, ai Deus,

com'é mui grand' e provada | e perfia dos judeus

que meu Fillo mataron, seendo seus,

e aynda non queren con ele paz.'

O que Santa María mais desprez [...]"1424

Cantigas de Santa María. Sitiados reclamando la protección de la Virgen

“'Ontr' as amēas, dizendo: I 'Se tu es Madre de Deus, / 75. deffend' aqueste castello I e a nos, que somos teus, / e guarda a ta capela I que non seja encreus / mouros en poder, nen façan $\mid$ a ta imagen arder.'

Poder á Santa Mariah I grande d' os seus acorrer...

E leixárona dizendo: | 'Veremo lo que fáras.' / 80. Entonç' os conbateadores | tornaron todos atrás; / e tres mouros que entraran, I chus negros que Satanas, / no castelo, os de dentro $\mid$ os fezeron en caer

Poder á Santa Maria I grande d'os seus acorrer [...]"1425.

Cantigas de Santa María. La Virgen rescata a una cautiva.

"Esta con outra cativa | jazian en prijon forte

dua moura que o demo | fillou pera sy en sorte,

que enfermidade grande | adusse mui tost' a morte;

mais enante que morresse | amba-las chamar fazia.

Con dereit' a virgen santa $\mid$ á nome Strela do Dia...

E consellou-lles que fossen | mouras e crischaidade

leixassen, e fossen fora $\mid$ daquela catividade,

e lles faria grand' algo | e dar-lles-ya herdade,

e que con mouros mui ricos | a ambas casa-las faria.

Con dereit' a Virgen santa | á nome Strela do Dia...

${ }^{1423}$ MNS, XVIII, n ${ }^{\circ}$ 413-430, op. cit., pp. 82-85.

${ }^{1424}$ CSM, Cantiga n ${ }^{\circ} 12$, op. cit, p. 137.

${ }^{1425}$ CSM, Cantiga n ${ }^{\circ} 184$, op. cit, p. 599. 
E se fazer non quisesse [n] | esto, logo nas cadeas

ambas mete-las faria $\mid$ e dar-lles tan g[ra]ndes peas

que lles non ficassen saos | coiros nen nervos ven veas,

e demais, sobre tod' esto, | escabeça-las farias.

Con dereit' a Virgen santa | á nome Strela do Dia...

A hua disse medo | que o faria de grado;

mais a outra mui sannuda |disse: 'son non é penssado,

ca mia alma e meu corpo | todo ei acomendado

a a egreija da Madre | de Deus que é en Tudia.'

Con dereit' a Virgen santa | á nome Strela do Dia...

A moura con mui gran sanna | mandou-as log'essa ora

no carcer deitar ontranbas; | mais aquela sen demora

adormeceu, e a Virgen | lle dise: Sal acá fora

deste logar e trei migo, | ca eu te porrei na via.'

Con dereit' a Virgen santa $\mid$ á nome Strela do Dia...

Pois a cativa esperta |foi, achou-ss' en uu camyo

ancho e chao, sen pedras, | e andou-o mui festynno,

que pan non comeu bocado | nen beveu agua nen vyo,

ata que preto de Silve | foi quando aluzeçia.

Con dereit' a Virgen santa $\mid$ á nome Strela do Dia [...]"1426

\section{III.2.g.- Santo Domingo de Silos}

Vida de santo Doningo de Silos. Sobre el cautiverio y liberación de Domingo

"Abriéndose los fierros en que yaçíe travado, El corral nol' retovo, que era bien çerrado: Tornó á sus parientes de los fierros cargado. Façíese él mismo d'ello maravillado". ${ }^{1427}$

${ }_{1426}$ CSM, Cantiga n ${ }^{\circ} 325$, op. cit, p. 193.

${ }^{1427}$ VSD, n ${ }^{\circ} 354-371$, op. cit., pp. 246-250. 
Vida de santo Domingo de Silos. Liberación de Pedro.

"Yo so faire Domingo, pecador de verdat, En la casa de Silos fui yo dicho abat. Dios grant merçed me fizo por su piedad, Que me puso en guarda sobre la christiandat, Que saque los cativos de la catividad, Los que á él se claman de toda voluntad". ${ }^{1428}$

Vida de santo Domingo de Silos. Domingo libera a Servando

"[...] diolí un madero, De fuste era todo, non fierro nin azero, molió todos los fierros con ese dulz madero

$[\ldots]$

que de suso sedie, Echóli una soga, á mano la teníe, Ciñóse bien el preso, que de yuso yazíe, El cabo de la soga el otro lo ternie". ${ }^{1429}$

Milagros Romanceados de Pero Marin. Domingo rescata a Pascual de Encino. “Como saco a pascual de ençiso de poder del merino de Sancho m(artine)z

En la era sobredicha. Veno aq(ui) Pascual de ençiso dixo q(eu)l apusiera(n) q(ue) furtura vna yegua. \& q(ue)l p(ri)siera ochoa lopez. merino de Sancho m(a)r(tine(z) de leyua. esta(n)do preso. q(ue) daua fiadores de q(ua)nto ma(n)das su fuero. o el Rey. o Sancho m(a)r(tine(z). \& no(n) gelos q(ui)siero(n) coger. \& leuaro(n) le al Castiello. \& pusiero(n) vna escalera q(uel metiessen en la Carçel muy fonda. \& p(re)gu(n)taro(n) le si auia parie(n)tes. quel fiassen. dixo q(ue) a dios. \& a S(an)ta M(aria). \& a S(an)to Domi(n)go de Silos. \& a ssant M(artin). dixol el merino. pues essos te acorrera(n). \& metiero(n) le en carçel. \& el fizo su or(aci)on. \& acome(n)dosse a ellos. quel ouiessen m(er)çet. Et el Sabbado p(ri)m(er)o de q(ua)resma. domi(n)go amanesçie(n)t vio muy g(ran)t claridat en la carçel. \& desp(er)to. \& fallo los fierros fuera de los pies q(ue)brados. \& q(ua(ndo fue de dia viose yuso fuera de la torre. al çinto q(ue) dize(n) de S(an)ta maria çerca dela egl(es)ia. \& fues pora una egl(es)ia q(ue) dize(n) sant paulino. \& fallo un om(n)e. q(ue) tenia aq(ue)lla egl(es)ia. \& acome(n)dol los fierros. \& fues a cornago. \& moro alla.VII. setmanas. \& depues torno por los fierros. \& veno aq(ui) co(n) ellos. Sabbado .VIII. dias de Deziembre. \& viniero(n) co(n) el de su Logar varones \& mugieres mas de treynta q(ue)lo otorgaro(n) todo."1430

\footnotetext{
${ }^{1428}$ VSD, n ${ }^{\circ} 716,717$, op. cit., p. 314.

${ }^{1429}$ VSD, $\mathrm{n}^{\circ}$ 652-662, op. cit., pp. 302-306.

${ }^{1430} \mathrm{MR}, \mathrm{n}^{\circ} 1090-1110$, op. cit., pp. 77, 78.
} 


\section{III.2.h.- San Millán de la Cogolla}

Vida de San Millan de la Cogolla. San Millán y el voto de Ramiro II.

"El bienaventurado rey don Ramiro tomó / consejo muy cuerdo, pagar un tributo / a Santiago para ponerlo de su parte / en una lid tan dura."

“El conde Fernán González con todo su / ejército, llegó al campo de batalla; / oyeron lo que se decía acerca del voto / y todos convinieron en que era cosa bien hecha.

Entonces, se reunieron en consejo los castellanos / con su jefe el conde, y éste dijo:/ 'amigos y hermanos, los leoneses / 'obraron como buenos cristianos.

'Tomaron una buena desición estos / 'ilustres varones, dejando ejemplo para las / 'generaciones futuras; no podrían tomar mejores / 'determinaciones; dad por segura la derrota de las bestias.

'Pero ahora quiero abriros mi corazón: / 'deseo que también nosotros hagamos un voto / 'semejante: pagar a san Millán el mismo tributo / 'que otorga al apóstol el rey de León." 1431

Vida de San Millan de la Cogolla. Santiago y San Millán en la batalla de Simancas “438 Vinien en dos caballos plus blancos que cristal, / Armas quales non vió nunca omne mortal: / El uno teníe croza, mitra pontifical, /El otro una cruz, omne non vió tal. $[\ldots]$

447. El que tenie la mitra é la croza en la mano, /Esi fue el apóstol de Sant Juan ermano, / El que la cruz tenie é el capiello plano, / Ese fué Sant Millán el varón cogollano." 1432

\section{III.2.i.- Otros santos y mensajeros celestes}

Chronica Adefonsi Imperatoris. Ángeles guerreros

"Et ecce, ultione divina disponente, venerunt acies paratae Moabitarum et Agarenorum in circuitu castrorum et coeperunt pugnare et mittere super eos multas lanceas et sagittas et tela et petras, et occidere multam gentem et bestias. Hoc videntes episcopi et clerici et omnis populus christianorum, coeperunt rogare Dominum Deum ut eos eriperet de manibus Sarracenorum et ne reminisceretur peccatorum regis nec parentum

${ }^{1431}$ VSM, n 362-489, op. cit., pp. 397-421.

${ }^{1432}$ VSM, n 438, 447, op. cit., pp. 410-412. 
suorum vel qui cum eo erant, etut ab ipso mitius corriperentur. Sed, peccatis exigentibus, orationes eorum non sunt exauditae ante Deum, quia Gabriel Archangelus, summus nuntius Dei, non tulit eas ante tribunal Christi nec Michael, princeps militiae caelestis, misus est a Deo ut eos adiuvaret in bello."1433

Crónica Najerense. San Pedro se aparece a Alfonso VI y le anuncia su pronta liberación.

“Quibus assidue orationi por eo incumbentibus, ecce quídam nocte clauieger celi Beatus Petrus apostulus per quendam episcopum Aldefonso innotuit qualiter instancia precum sancti Hugonis suorumque pulsatus, in breui ipsum proprie redderet potestati, et in regnum paternum nichilominus sublimaret. Transactis itaque paucis diebus, rursus idem celi clauiger regi Santio nocte terribiliter apparuit et mortem illi gruissimam, nisi fratrem dimitteret, intemptauit. Surgens ergo ocius uehementius exturbatus, uocatis setellitibus, ad fratem uadi; a uinculis illum soluit; quo illum libeat, ire mandat. Et sic lectum petit denuo dormiturus." 1434

${ }^{1433}$ CAI. Liber I, n 55, op. cit., pp. 45, 46. "55. Y e aquí que, por disposición de la venganza divina, las tropas dispuestas de los moabitas y agarenos llegaron en derredor del campamento, comenzaron a luchar, a enviar contra ellos muchas lanzas, flechas, dardos y piedras y a matar muchos soldados y animales. Al ver esto, los obispos, clérigos y todo el pueblo de los cristianos empezaron a rogar a Dios Nuestro Señor que los arrancase de las garras de los musulmanes, que no se acordase de los pecados del rey, de sus parientes o de quienes estaban con él y que los castigase con suficiente benignidad. Pero, en castigo por sus pecados, sus oraciones no fueron atendidas ante Dios, porque el arcángel Gabriel, el más importante mensajero de Dios, no las llevó ante el tribunal de Cristo, ni Miguel, príncipe de la milicia celeste, fue enviado por Dios para ayudarles en la guerra." CEA, Libro I, $\mathrm{n}^{\circ} 55$, op. cit, p. 80.

${ }^{1434} \mathrm{CN}$ 1995, Liber III, $\mathrm{n}^{\circ}$ 15, op. cit., p. 173. "Mientras éstos andaban reclinados en continua oración por él, he aqui que una noche el portero del cielo, san Pedro apóstol, le comunica por mediación de un obispo a Alfonso de qué manera, instado por el apremio de los ruegos de san Hugo y los suyos, lo devolvería a su majestad e incluso lo elevaría al poder de su padre. Así pues, al cabo de unos pocos días el portero del cielo se le presentó con aspecto terrible, de noche, al rey Sancho y lo amenazó con una muerte dolorosísima a menos que liberara a su hermano. Al instante se levanta lleno de turbación y tras llamar su guardia se presenta ante su hermano, lo suelta de las cadenas y le ordena que se marche a donde le plazca, y así vuelve a la cama para seguir durmiendo." $\mathrm{CN} 2003$, Libro III, $\mathrm{n}^{\circ} 15$, op. cit., $\mathrm{p}$. 177. 


\section{III.3.- Las dadivas divinas y los rituales de la guerra \\ III.3.a.- Las dádivas divinas: recompensas espirituales, indulgencias}

Historia Compostelana. Gelmírez exhorta a la lucha y promete indulgencias.

"Quisquis autem huius militie particeps fieri uoluerit omnium suorum

peccatorumrecordetur et ad ueram confessionem et ueram penitentiam uenire festinet

et, postea acceptis armis, ad castra Christi in Dei obsequium et suorum peccatorum remissionem procedere non differat. Quod si ita fecerit, nos et nostri fratres uenerabiles coepiscopi, abbates et alie religiose persone in concilio, quod iuxta domini Pape edictum XV Kal. Februarii Deo auctore Compostelle celebrauimus, nobiscum residentes eum ab omibus suis peccatis, que a fonte baptismatis usque ad hodiernum diem diabolo instigante perpetrauit, Omnipotenti Dei et beatorum apostolum Petri et Pauli atque Iacobi omniumque sactorum auctoritate absoluimus. Illis uero, qui his Christi castris interesse noluerint uel non potuerint, per obedientiam precipimus et intercidimus, ut nullum malum terris et honoribus siue aliis rebus eorum, quamdiu in Dei seruitio permanserint, temerario ausu inferre neque eorum personas siue facultates capere aut inquietare ullo modo presumant. Quod si nostrum edictum in hoc, contempserint, auctoritate Dei Patris Omnipotentis et Filii et Spiritus Sancti et beatorum apostolorum Petri et Pauli atque Iacobi omniumque sanctorum eos excomunicamus et anathematizamus et a liminibus Sancte Ecclesie sequestramus, ita ut, si infirmi fuerint, non uisitentur, donec satisfaciant, et, si mortui fuerint, non sepeliantur. Et si quis princeps uel dominus solidatas aut alia beneficia eis contulerit, dator et acceptor anathema sit." 1435

\footnotetext{
${ }^{1435}$ HC 1988, Liber II, cap. LXXVIII, op. cit., pp. 379-380. "Y todo aquel que quisiere participar en esta milicia, haga examen de todos sus pecados y apresúrese de ir a la verdadera confesión y verdadera penitencia y, tomando después las armas, no se retrase en marchar a los campamentos de Cristo para servicio de Dios y remisión de sus pecados. Y si asi lo hiciere, nos y nuestros venerables hermanos coepíscopos, abades y otras personas religiosas reunidos con nosotros en el concilio que hemos celebrado, según el mandato del Papa, el 18 de enero con la autoridad de Dios, lo absolvemos por la autoridad de Dios omnipotente y de los santos apóstoles Pedro y Pablo y Santiago y de todos los santos, de todos sus pecados, que desde la fuente del bautismo hasta el día de hoy haya cometido por instigación del diablo.

Y a aquellos que no quisieren o no pudieren acudir a los campamentos de Cristo, en obediencia ordenamos y prohibimos que se atrevan con temeraria osadía a causar ningún mal en las tierras y señoríos o en otros bienes de éstos, mientras que permanezcan en el servicio de Dios, ni tomar o inquietar de ningún modo sus personas o posesiones. Y si en esto menospreciaran nuestro edicto, por la autoridad de Dios omnipotente, Padre, Hijo y Espiritu Santo y de los santos apóstoles Pedro y Pablo y de Santiago y de todos los santos los excomulgamos y anatematizamos y les apartamos de los límites de la Santa Iglesia d manera que, si estuvieran enfermos, no sean visitados hasta que den satisfacción, y si murieran, no sean enterrados. Y si algún príncipe o señor le concediere soldadas $u$ otros beneficios, sean excomulgados el que los dé y el que los acepte.” HC 1994, Libro II, cap. LXXVIII, op. cit., pp. 454.
} 
Chronica Adefonsi Imperatoris. Poema de Almería. Recompensas espirituales.

"[25] Pontifices omnes Legionis sive Toleti,

exemplo gladio divino corporeoque,

orant maiores [invitantque] minores,

ut veniant cuncti fortes ad proelia tuti.

Crimina persolvunt, voces ad sidera tollunt,

[30] mercedem vitae spondent cunctis utriusque.

Argenti dona promittunt, cumque corona

quidquid habent Mauri rursus promittitur auri" ${ }^{\text {1436. }}$

Crónica General de España. Defensa de Calatrava.

"Et el primas, pues que lo oyo, gradesçiolo a Dios por quel semeio que era a su seruiçio de Dios, et diole luego su ayuda de sus cosas; demas fizolo predicar luego por Toledo et por los pueblos et dezir que todos aquellos que en ayuda de Calatrana fuessen que les perdonaua todos los peccados conffessados. Et fizosse desta soltura tan gran sueno por la çipdad de Toledo et por tierra, et tan grand muebda, que en la çipdad de Toledo apenas fue y ninguno de los toledanos que non fuesse en ayuda de Calatraua, o por su persona misma, o que non diesse y su cauallo et sus armas et su auer, et lo non enuiasee alla en ayuda". ${ }^{1437}$

Liber Sancti Jacobi /Codex Calixtinus. Equiparación de las cruzadas orientales con la Reconquista.

"Hoc idem et nos corroboramos et affirmamus, ut omnes qui aut in Yspania, aut in iherosolimitanis horis, ad expugnandum gentem perfidam, ut superius diximus, elevato signo dominice crucis in humeris perrexerint, ex parte Dei et sanctorum apostolorum Petri el Pauli et Iacobi, omniumque sanctorum, et nostra benedictione apostolica ab omnibus peccatis de quibus sacerdotibus suis confessi et penitentes fuerint, absolvantur et benedicantur, et in celestibus regnis una cum sanctis martiribus qui ab inicio

${ }^{1436}$ CAI, Poema de Almería, 25, 30, op. cit., p. 167. “Los obispos de Toledo y León en su totalidad, tras desenvainar la espada divina y la material/ [40] ruegan a los mayores y animan a los jóvenes a que todos acudan al combate, valientes y seguros. Perdonan los pecados, elevan sus voces al cielo y aseguran a todos la recompensa en ésta y en la otra vida. Prometen premios en plata y, con la victoria, / [45] se promete a su vez todo el oro que tienen los moros." CEA, Poema de Almería. 40, 45, op. cit., p. 132.

${ }^{1437}$ CGE, cap. 987, op. cit., p. 667. 
christianitatis usque ad finem seculi martirii palman ibi acceperunt vel accepturi sunt, coronari mereantur" ${ }^{\prime 1438}$.

\section{III.3.b.- Martirio}

Liber Sancti Jacobi / Codex Calixtinus. Calixto II declarará la paridad entre las cruzadas orientales y la Reconquista

Ver anexo en: I.3.b- Reconquista, Monarquía e Iglesia

Crónica de Veinte Reyes. Martirio como arenga militar.

"E los que non pudieramos pasar moriremos e saluaremos nuestras almas, e yremos a la iglesia del paraíso, e conpliremos nuestro debdo, aquello que todo cauallero fijodalgo deue conplir, e esto es fazer derecho e perder miedo allí do lo deue omne perder, ca, sy asy ymos de aquí syn más [...]”. 1439

\section{III.3.d.- Ritos de preparación al combate}

Chronica Adefonsi Imperatoris. Alí rey de Marruecos ataca Toledo

"[101] Dum ista bella geruntur, archiepiscopus domnus Bernardus, Toletanae ecclesiae, cum clericis et monachis et senibus et mulieribus et pauperibus, postrati in terra in ecclesia Sanctae Mariae, unanimiter rogabant Dominum Deum et Sanctam Mariam ut peccata regum ne reminiscerentur et populorum, ne ipsi darentur in captivitatem et gladium, et mulieres in divisionem, et infantes eorum in praedam, et civitas eorum in exterminium, et sancta lex Dei in opprobium et in pollutionem et conculcationem (46)." 1440

\footnotetext{
${ }^{1438}$ LSJ 1998, Libro IV, Appendix D, op. cit., p. 229. “Esto también Nos corroboramos y confirmamos: que todos los que marchen como arriba dijimos, con el signo de la cruz del Señor en los hombros, a combatir al pueblo infiel en España o Tierra Santa, sean absueltos de todos sus pecados de que se hayan arrepentido y confesado a sus sacerdotes y sean bendecidos por parte de Dios y de los santos apóstoles San Pedro y San Pablo y Santiago, y de todos los santos, y con nuestra apostólica bendición; y que se merezcan ser coronados en el reino celestial, junto con los santos mártires que desde el principio de la cristiandad hasta el fin de los siglos recibieron o han de recibir la palma del martirio." LSJ 2004, Libro IV, cap. XXVI, op. cit., p. 522.

${ }_{1439}$ CXXR, Libro XV, cap., VI, op. cit., p. 320.

1440 CAI, Liber II, n 101, op. cit., pp. 78, 79. "6 (101). Mientras estas guerras se llevaban a cabo, el arzobispo de la iglesia de Toledo don Bernardo junto con los clérigo, monjes, ancianos, mujeres y pobres, postrados en tierra en la iglesia de Santa María, rogaban unánimemente a Dios Nuestro Señor y a Santa María que no recordasen de nuevo los pecados de los reyes y de sus pueblos, que ellos no fueran entregados al cautiverio y a la muerte, las mujeres al ultraje, sus niños a la rapiña, su ciudad al
} 
Chronica Adefonsi Imperatoris. Incitación del rey Alfonso VII a que su hueste muera cristianamente

"Quibus principes responderunt: 'Vos videtis, quia magnum chaos firmatum est inter nos et vos: nec vos poteritis transire ad nos, nec nos possumus ire ad vos'. Et iterum principes: 'Confitemini alterutrum peccata vestra et orate et communicate de pane benedicto, quod habetis vobiscum, et Deus miserebitur animarum vestrarum" ${ }^{\text {"1441 }}$.

Historia Rebus Hispaniae. Víspera de la batalla de las Navas de Tolosa.

"Sequenti uero die circa mediam noctem uox exultationis et confessionis insonuit in tabernaculis christianis et per uocem preconis inclamatum est ut omnes ad bellum Domini se armarent. Celebrati itaque Dominice passionis misteriis et facta confessione, sumptis sacramentis, acceptis armis, ad campi certamina processerunt [...]."1442

Crónica Latina de los Reyes de Castilla. Víspera de la batalla de las Navas de Tolosa. "24. Surgunt igitur Christiani post mediam noctem, in qua hora Christus, quem collebant, uictor surrexit a morte, et auditis missarum solemniis, recreati uiuificis sacramentis Corporis et Sanguinis Dei nostri Iesu Christi, munientes se signo Crucis, sumunt celeriter arma bellica, et gaudentes currunt ad prelium tanquam ad epulas inuitati. Non illos retardant fragosa et saxosa loca, non concaua uallium neque prerupta montium. Feruntur in hostem parati mori uel uincere."1443

exterminio y la sagrada ley de Dios al oprobio, la profanación y el desprecio.” CEA, Libro II, n 101, op. cit., p. 97.

${ }^{1441}$ CAI, Liber II, n 133, op. cit., p. 105. "Los jefes militares les respondieron: 'Veis que un gran abismo se ha establecido entre vosotros y nosotros. Ni vosotros podréis atravesar adonde nosotros, ni nosotros podemos ir adonde vosotros'. $Y$ de nuevo les dijeron los jefes militares: 'Confesad vuestros pecados unos a otros, orad y comulgad con el pan bendito que tenéis con vosotros y Dios se apiadará de vuestras almas". CEA, Libro II, n 38 (133), op. cit., p. 107.

${ }^{1442}$ HRH, Liber VIII, cap. IX, op. cit., p. 270. "Alrededor de la medianoche del día siguiente estalló el grito de júbilo y de la confesión en las tiendas cristianas y la voz del pregonero ordenó que todos se aprestaran para el combate del Señor. Y así, celebrados los misterios de la Pasión del Señor y hecha confesión, recibidos los sacramentos, tomadas las armas, salieron a la batalla campal [...]." HHE, Libro VIII, cap. IX, op. cit., p. 319.

${ }^{1443}$ CLRC 1997, no 24, op. cit., pp. 61. "24. Se levantan, pues, los cristianos después de la media noche en la hora en que Cristo, a quien daban culto, se levantó vencedor de la muerte y, tras la celebración solemne de la Misa, recreados con los vivificantes sacramentos del Cuerpo y de la Sangre de Jesucristo, nuestro Dios, y fortalecidos con el signo de la Cruz, toman rápidamente las armas bélicas y corren gozosos a la batalla como invitados a un banquete. No los retardan ni la dificultad y lo pedregoso de los terrenos ni las concavidades de los valles ni las escabrosidades de los montes, llegan al enemigo preparados a morir o vencer". CLRC 1999, n² 24, op. cit., pp. 53. 
Crónica de Veinte Reyes. Víspera de la batalla de las Navas de Tolosa.

“E don Rodrigo, arçobispo de Toledo, e todos los otros perlados andauan por la hueste predicando e otorgando perdones a todos aquellos que de buen coraçón entrasen en la batalla. E mandaron que se guisasen e comulgasen para otro día lunes cómmo entrasen en la batalla."

\section{III.3.e.- Ritos de Victoria}

Chronica Adefonsi Imperatoris. Victorias de Rodrigo Fernández.

"[128] Ut autem vidit eos Toletanus princeps, dixit christianis: 'Ne timueritis multitudinem eorum, et impetum eorum ne formidetis: mementote qualiter rex domnus Adefonsus et patres nostri bellando ce perunt Toletum et omne regnum usque ad flumen Dorii; et nunc clamemus in caelum et miserebitur nostri Deus noster, et Deus conceret eos ante faciem nostram hodie' (62). Et paratis aciebus militum et peditum et ballistorum ex utraque parte, commiserunt bellum, et ceciderunt multa milia Sarracenorum, et placuit Deo. Et rex Texufinus victus est, et fugiit de campo ipse et omnis exercitus eius, et christiani acceperunt aurum multum et argentum et equos et mulos et amellos et opes magnas, et conversi venerunt Toletum et dicebant hymnum et benedicebant Deum, quoniam bonus est quoniam in saeculum misericordia eius (63). [129] Et rursus secunda vice, Rodericus Fernandi, princeps Toletanus, congregato exercitu, abiit in terram Moabitarum et Agarenorum; et reges eorum exierun obviam ei in loco qui dicitur Serpia, et princeps Toletanus victor extitit, et accepit magna spolia Sarracenorum, et reversus est in Extrematura cum gaudio magno. Et iterum tertio, Toletanus princes, congregatis suis agminibus, abiens in terram inimicorum, fecit multas strages et occidit multos Moabitas et Agarenos. Namreges eorum, congregata magna multitudine militum et peditum, venerunt ad eum in loco qui dicitur Silvia et, inito certamine, terga verterunt Moabitae et Agareni et ceciderunt multa milia eorum et caeteri fugerunt huc et illuc. Et Toletanus princeps victor extitit in campo, et christiani acceperunt magna spolia eorum et reversi sunt Toletum cum gaudio magno et laetitia cantantes 'Te Deum laudamus, te Dominum confitemur' usque in finem. "1445

${ }^{1444}$ CXXR, Libro. XIII. cap. XXXI, op. cit., p. 284.

1445 CAI, Libro II, $\mathrm{n}^{\circ}$ 128-129, op. cit., pp. 99-101. "33 (128). Cuando los vio el jefe militar de Toledo, dijo a los cristianos: "No temáis su número ni os aterroricéis de su ímpetu. Recordad cómo el rey don Alfonso y nuestros padres tomaron luchando Toledo y todo su reino hasta el río Duero. Ahora clamemos al cielo, nuestro Dios se compadecerá de nosotros y Dios los aplastará hoy en nuestra presencia". Dispuestas las tropas de caballeros, peones y ballesteros por ambas partes, entablaron combate $y$ 
Chronica Adefonsi Imperatoris. Captura del castillo de Oreja

"Postremo autem die mensis, summo mane, datum est castellum et impletae sunt turres militum christianorum, et elevata sunt vexilla regalia super excelsam turrem [Sed] hi qui tenebant vexilla, clamabant excelsa voce et dicebant 'Vivat Adefonsus imperator Legionis et Toleti!' Hoc audientes et videntes episcopi et totus clerus et omnes qui erant in castra, levaverunt manus suas ad celum et dixeunt: 'Te Deum laudamus, te Dominum confitemur', etc" ${ }^{\prime 1446}$.

Crónica General de España. Acción de gracias tras la victoria de las Navas de Tolosa "[...] el arçobispo et los obispos, que y eran con ell, et los abades et frayres et la otra clerezia, que y eran con ellos, alçadas las manos et la uozes al çielo, con lagrimas de sanctidad et con cantico de alabança, salieron en esta razon, cantando con gran alegria aquel cantico que dizen en la iglesia: Te Deum laudamus, te Dominum confitemur, et quiere esto assi dezir en el castellano : 'A ti, Dios, alabamos, a ti, Sennor, confessamos', et dixieron este cantico todo, cantandol fasta cabo", ${ }^{1447}$

\section{Crónica General de España. Captura de Sevilla}

"[...] quando ese noble et bienaventurado rey don Fernando, de que la estoria tantos bienes a contado, entro en esa dicha noble çipdat de Seuilla, capital de todo ese sennorio del Andaluzia, o fue reçebido con muy Grant proçesion de obispos et de toda la clerecía et de todas las otras gentes, con muy grandes alegrias et con muy grandes

cayeron muchos miles de musulmanes con el beneplácito de Dios. El rey Texufín fue vencido y huyó del campo de batalla él y todo su ejército y los cristianos cogieron mucho oro y plata, caballos, mulos, camellos y grandes riquezas y regresaron a Toledo recitando un himno y bendiciendo a Dios porque es bueno, porque su misericordia es eterna.

34 (129). De nuevo por segunda vez Rodrigo Fernández, jefe militar de los toledanos, tras reunir un ejército, marchó al territorio de los moabitas y de los agarenos, los reyes de éstos salieron a su encuentro en el lugar llamado Serpa y el jefe militar de los toledanos resultó vencedor, tomó grandes despojos de los musulmanes y regresó a Extremadura con gran alegría. Y de nuevo por tercera vez el jefe militar de Toledo, marchando al territorio de los enemigos después de haber reunido a sus tropas, causó muchos estragos y mató a numerosos moabitas y agarenos. Efectivamente, sus reyes, tras reunir una gran multitud de caballeros y peones, vinieron a su encuentro en el lugar llamado Silves y, una vez iniciada la lucha, los moabitas y agarenos volvieron la espalda, cayeron muchos miles de ellos y los restantes huyeron por acá y por allá. El jefe militar de Toledo resultó vencedor en el campo de batalla, los cristianos tomaron numerosos despojos suyos y regresaron a Toledo con gran gozo y alegría cantando el 'Te Deum laudamus, te Dominum confitemur' hasta el final." CEA, Libro II, $\mathrm{n}^{\circ} 128-129$, op. cit., pp. 105-106.

${ }^{1446}$ CAI, Liber II, $\mathrm{n}^{\circ} 154$, op. cit., p. 120. "El ultimo día del mes, muy de mañana, se entregó el castillo, se llenaron de caballeros cristianos las torres y se izaron los estandartes reales sobre una torre alta. $Y$ los que portaban los estandartes gritaban en voz alta y decían ';Viva Alfonso, emperador de León y Toledo!'. Al oír y ver esto, los obispos, el clero completo y todos los que estaban en el campamento, levantaron sus manos al cielos y entonaron el 'Te Deum laudamus, te Dominum confitemur', etcétera." CEA, Libro II, $\mathrm{n}^{\circ} 59$ (154), op. cit., p. 113.

${ }^{1447}$ CGE, cap. 1125 , op. cit., p. 767. 
bozes, loando et bendiciendo et dando graçias a Dios, et alabando los fechos del rey don Fernando; et entro asi desta gisa ese bienaventurado rey don Fernando dentro en la yglesia de Sancta Maria". ${ }^{1448}$

Crónica de Veinte Reyes. Recibimiento de Alfonso VIII

“[...] do fueron bien rreçebidos de chistianos e de moros e de judios, que salieron fuera de la villa con juglares e con intrumentos, e los arçobispos con toda su clerezía con gran proçesión, loando a Dios quánta merçed les fiziera e que los traya sanos e con gran onrra". 1449

\section{III.3.f.- Ritos de purificación de los lugares conquistados}

\section{Chronica Adefonsi Imperatoris. Ocupación de Coria}

"[161] Postquam autem reddita est civitas imperatori, mundata est ab inmunditia barbaricae gentis et contaminatione Mahometis, et destructa omni spurcitia paganorum civitatis illus et templi sui. Dedicaverunt ecclesiam in honore Sanctae Mariae semper virginis et omnium sanctorum, et ordinaverunt ibi episcopum virum religiosum nomine Navarronem sicuti antiquitus fuerat sedes episcopales tempore Ildefonsi arquiepiscopi et Recaredi regis, quando tota illa terra christianorum erat, a Mediterraneo usque ad more Occeanum" ${ }^{, 1450}$.

Crónica Latina de los Reyes de Castilla. Ocupación de Capilla

“Archiepiscopus uero Toletanus et episcopus Palentinus et alii uiri religiosi, qui cum episcopis erant, mezquitam Maurorum omni spurcicia mahometice susperstitionis per uirtutem Domini nostri Iesu Christi et uictoriosissime Crucis eius purgatam dedicauerunt ecclesiam Domino Iesu Christo, missam et diuina officia cum magno gaudio celebrantes" ${ }^{\prime 1451}$.

\footnotetext{
1448 CGE, cap. 1125 , op. cit., p. 767.

1449 CXXR, Libro. XIII. Cap. XXXVI, op. cit., p. 287.

${ }^{1450}$ CAI, Liber II, $n^{\circ} 161$, op. cit., p. 125. "(161) Después que la ciudad fue devuelta al emperador, se limpió de la impureza del pueblo bárbaro y de la herejía de Mahoma y, tras hacer desaparecer toda la suciedad de los paganos de aquella ciudad y su templo, consagraron una iglesia en honor de Santa María siempre virgen $y$ de todos los santos y ordenaron alli obispo a un hombre religioso por nombre Navarrón, en vista de que antiguamente habia sido sede episcopal en tiempo del arzobispo Idelfonso y del rey Recaredo, cuando todo aquel territorio pertenecía a los cristianos desde el Mediterráneo hasta el mar Océano." CEA, Libro II, nº 66 (161), op. cit., p. 115.

1451 CLRC 1997, n 50, op. cit., p. 94. "El arzobispo toledano, el obispo palatino y otros hombres religiosos que con los obispos estaban purificaron la mezquita de los moros de toda mancha de
} 
Crónica Latina de los Reyes de Castilla. Ocupación de la mezquita de Córdoba "[...] intrauerunt in mezquitam et preparantes, que necesaria erant ad hoc, ut ecclesia fieret de mezquita, expulsa Mahometi superstitione uel spurcicia, santificauerunt locum per aspersionem aque cum salibus benedicte, et quod prius erat cubile diaboli facta ecclesia Iesu Christi, uocata nomine Genetricis ipsius gloriose" ${ }^{, 452}$.

Historia Rebus Hispaniae. Celebracion de la victoria de las Navas de Tolosa.

"Hiis et aliis in hunc modum dictis ipse Toletanus ett alii pontifices, qui simul aderant, cum lacrimis deuotionis in laudis canticum eleuatis uocibus proruperunt dicentes: Te Deum laudamus, te Dominum confitemur. Erant etiam ibi Tellius Palentinus episcopus, Rodericus Segontinus, Menendus Oxomensis, Dominicus Placentinus, Petrus Abulensis, multi etiam alii clerici Domino cantica decantes. Campus autem sic strage Agarenorum plenus erat, ut etiam in robustissimis equis uix super eorum cadauera absque periculo transiremus.",1453

Historia Rebus Hispaniae. Ocupación de Córdoba "[...] tandem affecta pugnis et inedia, uicta reditur et inuita, et uite tantummodo conseruati inclusi Arabes exierunt, et in festo apostolorum Petri et Pauli a sordibus Machometi patricia ciuitas expurgatur. Set rex in turri maiori, ubi solebat nomen perfidi inuocari, precepit lignum crucis uiuifice exaltari, et ceperunt omnes cum gaudio et lacrimis Deus adiuua conclamare, et subsequenter regale uexillum iuxta crucem dominicam collocari, et cepit in iustorum tabernaculis gaudii et leticie uox audiri, clero cum pontificibus aclamante: Te Deum laudamos, te Dominum confitemur."1454

superstición mahometana por virtud de Nuestro Señor Jesucristo, celebrando la Misa y los divinos oficios con gran gozo". CLRC 1999, n 50, op. cit., p. 82.

${ }^{1452}$ CLRC 1997, $\mathrm{n}^{\circ}$ 73, op. cit., p. 117. "[...] entraron en la mezquita, y, preparando lo que era necesario para que de mezquita se hiciera iglesia, expulsaron la superstición o herejía musulmana y santificaron el lugar por la aspersión del agua bendita con sal, y lo que antes era cubil diabólico fue hecho iglesia de Jesucristo, llamada en el nombre de su gloriosa madre." CLRC 1999, n 73, op. cit., p. 102.

${ }^{1453}$ HRH, Libro VIII. Cap. XI, op. cit., p. 273, 274. "Una vez dichas estas palabras y otras de ese tenor, el propio toledano y otros obispos que se encontraban con él, iniciando un canto de alabanza entre lágrimas de devoción, rompieron a entonar 'Te Deum laudamus, te Dominum confitemur'. También se encontraban alli los obispos Tello de Palencia, Rodrigo de Sigüenza, Menendo de Osma, domingo de Plasencia, Pedro de Ávila y otros muchos clérigos entonando los cánticos del Señor. Por otra parte, el campo de batalla se encontraba tan atiborrado por el desastre de los agarenos que, incluso con los más poderosos caballos, no costaba trabajo pasar sin problemas sobre sus cadáveres." HHE, Libro VIII. Cap. XI, op. cit., p. 323.

${ }^{1454}$ HRH, Liber IX, cap. XVI, op. cit., p. 298, 299. "[...] finalmente víctima de los ataques y la fatal de víveres, quedo vencida y doblegada, y con la sola concesión de la vida salieron los árabes sitiados, y la ciudad patricia es purificada de las abominaciones de Mahoma en la festividad de los apóstoles Pedro y Pablo. Pero el rey ordenó que se hiciera exaltación de la cruz redentora en la torre mayor, desde donde 
Cronicon Mundi. Ocupación de Córdoba

" $Y$ entró el rey a Cordoua con gran gloria y alegria y desterrada toda la suciedad de Mahomath, los sagrados pontifiçes acabaron diuinales misterios en essa çibdad en la fiesta de los Apostoles Pedro y Paulo, a honrra de nuestro Señor Ihesu Christo y Maria su madre, Reyna de los çielos; y aquel grande oratorio de los sarraçines honrraronlo al nombre de Maria, madre de Dios; y fallaron ende las campanas que en otro tiempo Almançor, rey de Cordoua, auia traydo de la yglesia de Sanctiago, y el rey Fernando fizolas leuar en los ombros de los moros a la yglesia del Apostol Sanctiago."1455

Cronicon Mundi. Conquista de Sevilla.

"Y fue sonada la boz de los christianos alabantes a Dios del cielo y a la [muy bienauenturada] Maria su madre Virgen, y al bienauenturado Jacobo Apostolo, y boz de gemido y aullido y de lloro de los moros. Mas como el dia del domingo vieniesse, dia de nuestra redençion, y todos los christianos con su principe fiziessen los misterios diuinales alabando a Dios y a la muy bienauenturada Virgen Maria su madre, y al apostol Jacobo, patron y defenssor de toda España, el nuestro rey catholico Fernando, a buelta con su muger doña Juana, vinieron a la puerta de la çibdad que les auia seydo aseñalada, çercados y aconpañados de nobles varones de su reyno."1456

Crónica General de España. Ocupación de la mezquita de Córdoba

"Et en la fiesta de los apostoles sant Pedro et sant pablo, la çipdat de Cordoua, a que la estoria llama patriçia de las otras çipdades, esto es patrona et enxienplo de las otras pueblas de Andalozia, fue aquel dia alinpiada de las suziedades de Mahomad, et fue dada al rey don Fernando, et el entrego della; et el rey don Fernando mando luego poner la cruz en la mayor torre o el nombre falso de Mahomat solie ser llamado et alabado, et començaron luego los cristianos todos con gozo et alegria a llamar 'iDios, ayuda!' Et el rey luego man a mano, mando poner la su senna real çerca la cruz de Nuestro Sennor Dios, et començo lugo boz de gozo et de alegria a sonar et seer oyda en las tiendas de los iustos, esto es de los fieles de Cristo; et aquellas bozes fazien los

se acostumbraba a invocar el nombre del maldito, y todos prorrumpieron a exclamar entre el gozo y el llanto 'Dios, ayuda', y acto seguido plantaron el estandarte del rey junto a la cruz del Señor, y en los aposentos de los justos comenzó a oírse la voz del gozo y la alegría, mientras el clero y los obispos entonaban a gritos Te Deum laudamus, Te Dominum confitemur". HHE, Libro IX, cap XVI, op. cit., p. 350.

${ }^{1455}$ CE, Libro IV, cap. XCIV, op. cit., p. 430.

${ }^{1456}$ CE, Libro IV, Cap. C, op. cit., p. 442 
obispos con toda la clerezia, cantando et diziendo: 'Te Deum laudamus', con el muy noble rey don Fernando et con la yglesia et la fe del rey del çielo que entraua alli quella ora con el rey Fernando et con ellos". ${ }^{1457}$

Crónica de Veinte Reyes. Ocupación de Córdoba

“E en la fiesta de los apostoles Sant Pedro e Sant Pablo la çibdat de Cordoua, aquella estoria llama patriça de las otras çibdades, esta padrona e enxemplo / de las otras del Andaluzía, fue aquell día alinpiada de las suziedades de Maomat e fue dada al rrey don Ferrando e él entregado della. El rrey don Ferrando mandó luego poner la cruz en la mayor torre, donde el nonbre del falso Maomad solía ser llamado e alabado, e començaron luego todos los christianos con gozo e con alegría a llamar: ¡Dios ayuda! El rrey luego, mano a mano, mando poner la su seña rreal çerca la cruz de nuestro señor Dios, e començaron luego boz de gozo e de alegría a sonar e seer oydas en las tiendas de los justos, esto es de los fieles de Ihesu Christo. E aquellas bozes facian todos los obispos con la clerezía toda, e diziendo: 'Te Deum laudamus' con el muy noble rrey don Ferrando e con la iglesia e con la fe del Rrey del çelo, que entraua allí aquella oraçión del rrey don Ferrando con ellos. Mas la estoria va contando las nobles conquistas del rrey don Ferrando Cuenta de las obras de piadat que este don Ferrando fizo."1458

La caída del Califato de Córdoba y los reyes de Taifas. Ocupación de Coria “El primer lugar de la ciudad en el que entraron fue en su [mezquita] aljama, entonces rociaron sus muros con vino (sic), tocaron en ella campanas (nāqūs) y trasformaron su alquibla $[\ldots]$... 1459

${ }^{1457}$ CGE, cap. 1046, op. cit., p. 733.

${ }^{1458}$ CXXR, Libro, XIV, cap. XXV, op. cit., pp. 312, 313.

${ }^{1459}$ CCC, op. cit., p. 88. 


\section{III.4.- Los Reyes modélicos: Siglos XII y XIII III.4.a.- Alfonso VI}

\section{Crónica Anónima de Sahagún. Virtudes de Alfonso VI}

“En el año de la Encarnación del Señor de mill e sesenta e seis, después que el muy noble rey don Alfonso [VI], fijo del rei don Fernando [I] e de la reina doña Sancha, obo el señorío e dignidad del reino de España, varón, por çierto, en las cosas belicosas mui noble guerrero; en disponer bien su reino, proveído e discreto; en el juiçio, muy derecho; en los negoçios seglares, astuto e entendido; mas en las cosas eclesiásticas, religioso e piadoso; en ensalçar y magnificar su reino, muy singular; a los enemigos e malfechores, muy justiçiero e espantoso; a los varones eclesiásticos o a otros sus allegados, muy manso e benigno; en las cosas contrarias, prudente e fuerte; e en las prósperas e vienandantes, templado e manso". ${ }^{1460}$

\section{Historia Compostelana. Alfonso VI como guerrero ejemplar}

"2. Tempore siquidem nobilissimi regis A., regis Fredenandi f., milites Castellani bellorum studio maxime desudabant et periculi atque laboris pacientes erant, et quanto frequentius militaria negotia exercebat, tanto animosiores et ad arma promptiores in bella ruebant: hostes prosternendo, hostium spolia rapiendo triumphum, laudem, militie famam sibi acquirebant. Illos utique Hyspania sibi preclariores elegerat et ad bella fortiores mittere non formidabat, tunc nimirus temporis rex A. illorum dux atque princeps erat et uirtutis sue atque probitatis formam in eos quasi in specialores et precordialiores heredes transferre studebat. Ipse prior in hostes ruebat, prior hostium cuneos prosternebat et milites suos ad eadem animabat, illos obuiam ire Agarenis et militari exercitio uiriliter desudare ad sui exemplar instruebat. Verum enimuero mortuo rege A., qui prbitatis Compostellanorum lampas et clipeus existebat, illis omnia in deterius conuersa sunt: Castellani desidie et ignauie dediti sunt, luxus et cupiditas eorum audaciam detriuit et pristina animositas ingruente formidolositate latuit et quanto magis rei necessitas eos ad belli strepitum inuitabat, tanto magis bello abesse et remotius latere cupiebant, nec sua defendere, nec aliena militanter acquirere studebant." 1461

\footnotetext{
${ }^{1460} \mathrm{CAS}, \mathrm{I}^{\circ}, \mathrm{n}^{\circ}$ 6, op. cit., p. 13.

${ }^{1461}$ HC 1988, Liber I, cap. LXXXIII, op.cit, p. 132. "Ciertamente en tiempos del muy noble rey Alfonso, hijo del rey Fernando, los soldados castellanos se esforzaban mucho en el arte de la guerra y soportaban el peligro y el esfuerzo, y cuanto más frecuentemente se ocupaban de los asuntos militares, tanto más
} 
Crónica Silense/legionense. Linaje visigodo de Alfonso VI

"Adelfonsus igitur, ex illustri Gotorum prosapia ortus, fuit magna vi et consilio et armis, quod inter mortales vix inuenitur; namque alterum ex timore occisionis, atque alterum ex audatia fortitudinis processiosse uidemus". ${ }^{1462}$

\section{Crónica del Obispo de Oviedo don Pelayo. Alfonso VI como pacificador}

“Este Alfonso fue defensor paternal de todas las iglesias de España y por ello se mostró ante todo católico y los agentes del mal nunca se atrevieron a mostrarse ante él; todos los poderosos, nobles o no, ricos o pobres, no osaron nunca promover el mal. Fue tanta la ordenada paz que floreció en su tiempo que una mujer sola, aunque fuese cargada de oro y plata [podia circular] por toda España sin encontrar ni en los campos ni en los montes, ni en lugares habitados o despoblados, quien la tocase o hiciese daño. Los mercaderes y peregrinos que deambulaban por el reino lo hacían sin ningún temor de que nadie les desposeyese de lo que llevaban, aunque sólo valiese un óbalo". ${ }^{463}$

\section{Crónica Najerense. Virtudes de Alfonso VI}

"23. Tantut fuit terribilis quod nullus malefactor se auderet eius conspectui presentare. Nullus princeps, nullus miles, nullus maiorinus, nullus iudex, nullus diues, nullus pauper de regno eius audebat in proximum litem aut rixam mouere aut in aliquo inquietare. Set tanta pax fuit in debus eius quod quelibet muliercula sola portaret aurum uel argentum per omnem terram regni eius, ita quod non inueniret qui eam tangeret inuitam aut aliquid dampni uel molestie illi auderet facere. Negociatores uero etiam et peregrini per totum eius regnum euntes nichil sibi uel suis rebus timebant. Ne

animosos y más rápidamente se precipitaban a las armas en los combates: derribando a los enemigos, arrebatando sus despojos, adquirían para sí triunfo, gloria y fama militar. España los tenía por los más preclaros y no temía enviarlos como los más valientes a la guerra, pues entonces el rey Alfonso era su caudillo y príncipe y se afanaba por transferirles como muy especiales y queridos herederos el ejemplo de su valor y su honradez. Él mismo se lanzaba contra los enemigos el primero, el primero derribaba las filas de los enemigos y animaba a sus soldados a hacer lo mismo, él les enseñaba a ir contra los agarenos y esforzarse valerosamente en el ejercicio militar siguiendo su ejemplo.

Pero, muerto el rey Alfonso, que era modelo de honradez y escudo de los castellanos, todo en aquéllos cambió a peor: los castellanos se entregaron a la desidia y a la pereza, el lujo y la codicia destruyó su valentía y el anterior valor quedó oculto por el miedo que se iba apoderando de ellos y cuanto más los invitaba la necesidad al estrépito de la guerra, tanto más deseaban alejarse del combate y esconderse lo más lejos posible, no se afanaban ni en defender lo suyo, ni en conseguir luchando lo ajeno."HC 1994, Libro I, cap. LXXXIII, op .cit., p. 201.

${ }^{1462}$ HS 1959, 8, op. cit. p. 119. "Pues Alfonso fue oriundo de la ilustre prosapia de los godos, dotado de magna fuerza ya en el consejo, ya en las armas, lo cual entre los mortales apenas se encuentra. Pues lo uno parece proceder del temor de la muerte y lo otro de la audacia de la fortaleza." HS 1913, 8, op. cit., pp. 21, 22.

${ }^{1463}$ COP, op. cit., pp. 179, 180. 
autem ullo tempore a bonis uaccaret operibus, omnes pontes qui sunt de Lucronio usquein Sanctum Iacobum ipse de suo fecit. Pater pauperum, ecclesiarum defensor extitit et patronus. Maurorum strnuissimus expugnator, quamuis multas ab eis contumelias passus est et incursus, tamen dum uixit per annos singulos ab illis accepit tributa et munera constituta."1464

Crónica Najerense. Milagro en torno a la muerte de Alfonso VI.

"Octauo autem ante mortem eius die natiuitatis Sancti Iohannis Babtiste apud Legionem in ecclesia Sancti Ysidori magnum fecit miraculum Deus omnipotens, nam in lapidibus qui sunt ante altare sancti Ysidori, in quibus sacerdos missam celebrans pedes tenet, non per iuncturas set per medium petrarum cepit manare aqua continue ab hora sexta ipsius diei cotidie usque in eam horam dominice diei, uidentibus et presentibus Petro Legionensi et Pelagio Ouetensi episcopis, una cum clero et populo et maxima nobilium multitudine circunstante. Quarta autem die scilicet Dominica predicti episcopi pontificalibus induti uestibus una cum clero et populo, facta processione, accensis cereis, de ecclesia Sancte Marie usque ad altare sancti Ysidori uenerunt uocem dantes cum lacrimis et Dei mirabilia collaudantes. Peracto sermone ab episcopo Ouetensi et peracta missa, accedentes predicti episcopi ad aquam illam et ex ea biberunt et aliis, ut biberent, dederunt; et quod erat residuum aque in uase uitreo posuerunt per multum temporis in testimonium reseruandum. Hoc Signum nichil aliud portendebat nisi luctus et tribulaciones que Yspanie post eius obitum euenerunt. Ideoque plorauerunt lapides ut ad fletum homines commouerent."1465

${ }^{1464}$ CN 1995, Liber III, n’ 23, op. cit., p. 179, 180. “23. Tan terrible fue que ningún malhechor se atrevía a presentarse ante su cara. Ningún príncipe, ningún caballero, ningún merino, ningún juez, ningún rico, ningún pobre de su reino se atrevía a promover combate por riña con su prójimo o inquietarlo en algo. Sino que tan grande fue la paz en sus tiempos que cualquier muchachita sola podía llevar oro o plata por toda la tierra de su reino de tal manera que no encontraba quien la tocara contra su voluntad o se atreviera a hacerle ni daño ni molestia alguna. Tampoco los comerciantes y peregrinos que marchaban por su reino temían por su integridad o la de sus cosas. Para que en ningún momento faltaran las buenas obras, todos los puentes que hay desde Logroño hasta Santiago los hizo a sus propias expensas. Fue padre de los pobres, protector y defensor de las iglesias. Esforzadísimo luchador contra los moros, aunque soportó muchas afrentas de ellos y muchas incursiones, sin embargo mientras vivió recibió de ellos año a año los tributos y los regalos establecidos." CN 2003, Libro III, $\mathrm{n}^{\circ} 23$, op. cit., p. 183.

${ }^{1465} \mathrm{CN}$, Liber III, $\mathrm{n}^{\circ} 23$, op. cit., pp. 180, 181. "Ocho días antes de su muerte, en la festividad de la natividad de San Juan Bautista, Dios Todopoderoso realizó un gran milagro en la iglesia de San Isidoro de León, pues en las piedras que están ante el altar de San Isidoro, en las que el sacerdote al celebrar la misa pone los pies, no por las juntas sino que de las mismas piedras comenzó a manar agua sin parar desde las doce de ese día hasta la misma hora del domingo, día a día, viéndolo y estando presente los obispos Pedro de León y Pelayo de Oviedo, junto con el clero y el pueblo, y una gran muchedumbre de nobles a su alrededor. Al cuarto día, esto es, el domingo, los mencionados obispos, revestidos de las vestiduras pontificales, junto con el clero y el pueblo, en procesión, con velas encendidas, vinieron desde la iglesia de Santa María hasta el altar de San Isidoro dando voces entre lágrimas y alabando juntos las 
Historia Rebus Hispaniae. Virtudes de Alfonso VI

"Nunc ad gestorum eius principia redeamus. Hic fuit strenuitate maxima nobilis, uirtute excelsus, gloria singularis ; habundauit in diebus eius iusticia, finem accepit seruitus, consolationem lacrime, augmentum fides, dilatationem patria, audaciam populus, confusus est inimicus, obmutuit gladius, cessauit Arabs, timuit Affer; ploratus ululatus Hispanie usque ad istum mansit absque consolatore; dextera eius presidium patrie, munimentum absque timore, fortitudo sine perturbatione, protectio pauperum, uirtus magnatum; magnitudo cordis eius Infra angustias Asturiarum non potuit contineri, et elegit laborem indiuiduum comitem uite sue; delicias miseriam reputabat deputans uite sue, in quo belli pericula non agebat. Rex accrescens magnanimus Adelfonsus, rex accrescens sedit in forti; arcus eius confisus in Domino inuenit graciam in occulis Creatoris; magnificauit eum in timore inimicorum et in populo suo elegit eum zelare fidem, dilatare regnum, exterminare inimicos, concluyere aduersarios, multiplicare ecclesias, restaurare sancta, restituere dissipata" ${ }^{\text {1466. }}$.

Historia Rebus Hispaniae. Milagro en torno a la muerte de Alfonso VI.

"Et quia Deus omnipotens eius opera acceptarat, eius obitum pronosico flebili uoluit intimare; octauo etenim die, in natiuitate sancti Iohannis, hora $V I^{a}$, de lapidibus qui erant in altaris grandibus cementati, non ex terra uel ex iuncturis, set ex ipsa substancia lapidum cepit aqua cunctis uidentibus emanare, et tribus diebus continue emanauit."1467

maravillas de Dios. Acabado el sermón y la misa por parte del obispo de Oviedo, se acercaron los mencionados obispos al agua y bebieron de ella y a los demás dieron de beber; lo que quedó del agua lo pusieron en un vaso de cristal para que se guardara como recuerdo durante mucho tiempo. Esta señal no mostraba otra cosa sino el luto y las tribulaciones que sucedieron en Hispania después de su muerte. Tanto lloraron las piedras que conmovieron a los hombres hasta el llanto." CN, 2003, Libro III, $\mathrm{n}^{\circ} 23$, op. cit., pp. 183, 184.

${ }^{1466}$ HRH, Liber VI, cap. XXI, op. cit., pp. 202, 203. "Volvamos ahora a los comienzos de sus hazañas. Su nobleza se conjugaba con su valentía; sobresalia por su virtud; su gloria no tuvo par. En su reinado reverdeció la justicia, la esclavitud halló su fin, las lágrimas, su consuelo, la fe, su expansión, la patria, su engrandecimiento, el pueblo, su confianza; el enemigo fue aniquilado, las armas callaron, el árabe desistió, el africano se aterrorizó; el llanto y los lamentos de España no encontraron consuelo hasta su llegada; su diestra era la garantía de la patria, la salvaguardia sin miedo, la fortaleza sin menoscabo, la protección de los pobres, el valor de los poderosos. Las estrecheces de Asturias no fueron capaces de contener la grandeza de su corazón y escogió el esfuerzo como único compañero de su vida; despreciaba los placeres, encontraba deleite y gozo en los peligros de la guerra, pareciéndole que malgastaba los días de su vida que no pasaba entre ellos. Alfonso, rey poderoso y magnánimo, rey poderoso que nada teme; su arco, confiando en el Señor, halló gracia ante los ojos del Creador, que lo engrandeció con el temor de sus enemigos, acabar con los rivales, multiplicar las iglesias, reconstruir los lugares sagrados, reedificar lo destruido." HHE, Libro VI, cap. XXI, op. cit., p. 246.

${ }^{1467}$ HRH, Liber VI, cap XXXIV, op. cit., p. 218. "Y como Dios todopoderoso había acogido con agrado sus obras, quiso anunciar su muerte con un triste vaticinio; pues ocho días antes de ésta, en la natividad de San Juan, a la hora sexta, empezó a brotar agua, a la vista de todos, de las piedras que había en las 
Cronicon Mundi. Virtudes de Alfonso VI

Cómo el dicho rey Alfonso recibió el reyno y juró y fue noble rey.

Despues desto, los nobles castellanos y pamploneses como no huuiese alguno de linaje real que pudiesen tener por señor, venieron apriessa al rey Alfonso e fizieronle rey, mas poniendo esta condiçion: que primero jurasse que nunca auia seydo en consejo de la muerte del rey Sancho su hermano; y como no hubiesse alguno que osase tomar el dicho juramento, el sobredicho Ruy Diaz, noble cauallero, tomole juramento, por lo qual el rey Alfonso syempre lo ouo en aborrescimiento. Mas despues quel rey Alfonso reçibio los reynos de sus hermanos, (y) fizo llamar reyna a la muy sabia Orraca su hermana, por cuyo sabio consejo aparejaua qualesquier cosas que en el reyno se auian de fazer. Tan bien e sabiamente traxo el rey Alfonso el gouierno del reyno, que todos los poderosos, nobles, ricos e pobres que auia en el reyno estauan en folgança, en tal manera, que no osaua mouer el vno contra el otro varaja nin fazer algun mal; era padre y defenssor de todas las yglesias y en todas las cosas honrrador de la religion catholica; [tan] espantable fue a todos los que mal fazian, que nunca osauan paresçer en acatamiento del rey; tanta paz fue en los dias que él reynó, que aunque fuesse vna muger con oro e plata en la mano por todo su reyno, tan bien en montes, como en canpos, (que) no fallaria alguno que le mal fiziese; assy los camineros e peregrinos que passauan por sus reynos, ninguna cosa les empeçia, porque no auia alguno que los osase enojar; y estudió en fazer grandes puentes que eran desde Logroño fasta Sanctiago." $" 1468$

Cronicon Mundi. Milagro en torno a la muerte de Alfonso VI.

“Mas al octauo dia antes que moriesse, fizo Dios en la çibdad de Leon en la yglesia de Sant Ysidro vna gran señal, en el nasçimiento de Sant Juan Baptista, a la hora sexta: que las piedras que estan delante el altar de Sant Ysidro, adonde tiene el saçerdote los pies quando se dize la missa, no por las junturas de las piedras, [mas] por la meytad de ellas començó a manar agua, veyendolo los çibdadanos grandes y pequeños, a buelta con los obispos Pedro de Leon y Pelayo de Obiedo; esto acaesçió en tres dias, jueves y viernes y sabbado; mas en el quarto dia, que era domingo, los sobredichos obispos se bestieron de vestiduras obispales, y toda la orden eclesiastica, cubierta de sacras vestimentas, cada vno leuando en la mano çirios, a buelta con muchedumbre de

gradas del altar, no de la tierra o de las junturas, sino del mismo interior de las piedras, y estuvo brotando sin interrupción durante tres dias." HHE, Libro VI, cap. XXXIV, op. cit., pp. 263, 264.

${ }^{1468}$ CE, Libro IV, cap. LXVIII, op. cit., pp. 371, 372. 
çibdadanos y pueblo, faziendo procession desde [la yglesia de Sancta Maria hasta] el altar de Sancto Ysidoro confessor, [entraron en la iglesia de Sancto Ysidoro] dando vozes, con lagrimas, y alabando las marauillas de nuestro Señor. Pues acabado assi el sermon por el sobredicho obispo de Ouiedo y dicha la missa por Pedro de Leon obispo, allegaron los sobredichos obispos al lugar adonde era el agua y beuieron della, y a buelta todo el pueblo, y despues de esto, cessaron las aguas de correr; mas mandaron que de aquella agua se guardase por testimonio en vasos, maguer que a honrra del bienauenturado Ysidoro muchos enfermos fueron curados... empero escriuanos señalaron esta señal, que paresçe mostrar los lloros que despues vinieron a toda la Yglesia y a España despues de la muerte del sobredicho rey Alfonso, por eso que los sabios pensaron que significauan las piedras llorantes."1469

\section{Crónica General de España. Virtudes de Alfonso VI}

"Et este fue el rey don Alffonsso el sesto, et dezienle por connoscencia de sobrenombre 'el rey don Alffonso el Brauo', assí como lo cuenta la estoria; et aun por otro sobrenombre 'el rey don Alffonsso el de las particiones'. Este rey don Alffonso luego en comienço de su regnado, mando llamar a su hermana donna Vrraca, et porque era ella muy sesuda duenna et de my buen entendimiento, fazie el con conseio della quanto auie de fazer et de enderençar en el regno; pero que gelo tenien todos por non bien, cal estaua mal. Segund dize don Luchas de Thuy, este rey don Alffonso el sesto mantouo sus regnos tan sabiamientre que quantos so el su sennorio eran, tanbien los ricos como los pobres, todos uiuien en paz et en folgura con ell, de guisa que non osaua ninguno tomar arma uno contra otro, nin boluer pelea, nin fazer mal ninguno por los oios de la faz. Este rey don Alffonso fue muy hardit et muy atreuudo en armas, assi que si noble era por linnage et alto por poder, et eralo el tod esto, mas aun muy mas noble et mas alto era de coraçon et de fechos."

\section{Crónica de Veinte Reyes. Virtudes de Alfonso VI}

"Este rrey don Alfonso mantouo su rreyno tan bien e tan sabiamente que todos quantos y eran, asy rricos omnes commo caualleros, commo todos los otros pueblos que eran en su tierra, todos veuían en paz e en folgura, en guisa que ninguno non osaua solamente tomar arma contra otro, nin boluer pelea nin fazer otro mal. Él fue mucho ardit e

\footnotetext{
${ }^{1469}$ CE, Libro IV, cap. LXXI, op. cit., pp. 381, 382.
}

${ }^{1470}$ CGE, cap. 846, op. cit., pp. 519, 520. 
mucho esfforçado en armas, e sy era noble e alto de linaje e de poder mucho más noble era de coraçón e de maneras e de fechos; en los sus días tanto avondó en justiçia en su tierra que sy vna muger sola leuase por todo el rreyno oro o plata, asy por yermo commo por poblado, non fallaría ninguno quel quisiese pesar nin ge lo dezían, ca tan espantoso era él a los malos que ninguno non osaua yr antél. Demientra quel fue biuo nunca los de su tierra ouieron a fazer seruidunbre a otro señor ninguno. Él fue consolador de los que llorauan e acreçentamiento de fe, padre e defendedor de las iglesias e de los monesterios, e esffuerço de los pueblo, garnimiento sin pauor, fortaleza syn themor, cubrimiento de pobres, esffuerço de rricos omnes; él despreçiaua su jornal e preçiaua por lidiar e avía sabor en ello, e quando non lidiaua tenía que su tienpo era perdido; él fue rrey de grant coraçón, e aviendo en Dios sienpre fiuzia ganó la de su gracia e ensalçol sobre todos sus enemigos."1471

Crónica de Veinte Reyes. Milagro en torno a la muerte de Alfonso VI.

"E el rrey don Alfonso yaziendo doliente, asy commo vos deximos, ocho días ante que fuese señaladamente el día de sant Juan Babtista, fizo Dios milagro señalado en la iglesia de Sant Isidro de León, e fue éste: que manó agua de las piedras en aquell lugar donde el clérigo tenie los pies quando dezie la misa, e non salie de entre las junturas de las piedras nin de la tierra en derredor, mas por medio de las pie/dras quebraua, e manó estos tres días, jueues, viernes e sábado. Entonçes era en León don Pedro, obispo dese mesmo lugar, e don Pelayo de Ouiedo, e quando ellos vieron aquel milagro tan grande, tomáronse otro día domingo con toda la clerezía e con todo el pueblo de la çibdat, e fueron vestidos asy commo conuiene a obispos en proçesión desde la iglesia cathedral fasta el altar de Sant Ysidrio donde aquel lugar contesçiera. E pues que la misa ouo cantada el obispo de León, e el obispo de Oviedo ouo fecha su proçesión e predicaçión, allegáronse todos a aquell lugar e asy los obispos commo los otros todos, loando a Dios e llorando de los ojos, beuieron de aquell agua de manar. Pero mandaron los obispos guardar de aquella agua en rredomas de vidrio por testimonio de aquell milagro. E quando ellos oyeron la muerte del rrey, entendieron luego que el manar de las piedras non era ál, synon lloro e quebranto de toda España."1472

${ }^{1471}$ CXXR, Libro X, cap. I, op. cit., pp. 201, 202.

${ }^{1472}$ CXXR, Libro X, cap. LXXXVIII, op. cit., p. 245. 


\section{III.4.a.- Alfonso VII}

Chronica Adefonsi Imperatoris. Alfonso VII, rey por disposición divina

“Adefonsus vero, filius Rius et Raymundi ducis, qui post eam, quia promisum de supernis misumque feliciter, Deo dispensante, regnavit, sequenti die postquam est mater eius, eiam iuvenis decem et novem annorum, beato iubilei anni tempore, ducente Domino, in Legionensi civitate, unde regnum ducitur, venit."

Chronica Adefonsi Imperatoris. Alfonso VII perdona a unos rebeldes.

"[3] Post multas autem collocutiones, rex ad eos qui adhuc in turribus rebelles erant, duos comites praedictos, Adefonsum et Suarium, cum Didaco episcopo misit dicens: 'Pacifice vos suscipiam et eritis magni in regno meo si turres michi sine bello tradideritis'. At illi, qui in turribus erant, postquam se turres non reddere multoties iureiurando asseruerunt, hunc et regnare super se nolle se adiecerunt."1474

Chronica Adefonsi Imperatoris. Alfonso VII protegido por la Providencia "Cum autem videret rex Aragonensis illa acies minimas esse et viros, qui in eis erant, validos animis et instructos armis, et se videret cum multis milibus militum et petitum, vocavit principes et duces populi et episcopos, qui secum erant, et petiit consilium ab eis quid facere deberet. Sed episcopus Pampilonensium, qui nomen erat Petrus, dixit regi: 'Domine, si iubes, ego loquar ad te.' Et respondit ei rex: 'Loquere, Domine.' Et dixit: 'Vides illam gentem minimam? Nos est pauca, sed multa. Deus enim est cum illa, et Deus est defensor eius. Non quaerit quae aliena sunt, sed quae sua.. Pacem diligit, pacem quaerit: omnis enim amator pacis Dominum diligit. Non est dificile apud Deum concludere multos in manibus paucorum: victoria belli non est in multitudine exercitus, sed de coelo fortitudo est. Rex: reminiscere pacti quod pepigisti in praeterito anno regi Legionis dare ei Castrum Silici et Naiaram et Omnia castella et civitates, quas tulisti

${ }^{1473}$ CAI, Liber I, n 1, op. cit., p. 4. "Alfonso, hijo suyo y del duque Raimundo, que por disposición divina, como promesa felizmente enviada de los cielos, reinó tras ella al día siguiente de morir su madre, vino por inspiración divina a la ciudad de León, desde donde se gobierna el reino, cuando ya era un joven de veintiún años, en el bienaventurado momento del año jubilar." CEA, Libro I, $\mathrm{n}^{\circ}$ 1, op. cit., p. 63. ${ }^{1474}$ CAI, Libro I, n 3, op cit., pp. 6, 7. "3. Y tras muchas entrevistas, a los que aún permanecian rebeldes en las torres el rey les envió a los dos condes aludidos, Alfonso y Suero, junto con el obispo Diego con el siguiente mensaje: 'Os recibiré en paz y seréis grandes en mi reino, si me entregáis sin lucha las torres'. Mas los que estaban en las torres, después de asegurar repetidamente bajo juramento que no entregaban las torres añadieron que además no querían que él reinase sobre ellos." CEA, Liber I, n 3, op. cit, p. 64. 
matri suae reginae dominae Urracae, et ita vive cum meo pacifice. Oh rex: ne pugnes cum eo; si enim pugnas cum eo, rictus es et mortuus, et omnes qui tecum sunt ${ }^{\prime 1475}$.

Chronica Adefonsi Imperatoris. Cabalgata y revés de Alfonso VII.

"[132] Dum ista gerentur, quaedam pars gentis Extremature transierunt flumen quod vocatur Goadalquivir sine praecepto imperatoris et principum eius, et abierunt in terram Sarracenorum et fecerunt multas praedas et incendia, et reversi sunt ad eumdem locum ubi prius transierant flumen, et per pigritiam et abundantiam divitiarum, quas acceperant, non transierunt flumen et manserunt ibi. Media autem nocte, facta est magna inundatio pluviae, et aqua nimium crevit. Mane autem facto, illa gens neque natando neque aliquo potuit transire flumen.

[133] Imperator vero, praevidens ea, quae futura erant, cum propria militia a longe abiit, ne viderent mortis gentis suae, et circa horam tertiam diei populus ille, elevans occulos suos, vidit magnas paratas acies Moabitarum et Agarenorum, militum et peditum, venientes ut eos perderent et, terrefacti, audatiam bellandique scientiam pariter amiserunt. Et clamaverunt ad Toletanum principem et ad comitem Rodericum, ut eorum misererentur. Quibus principes responderunt: 'Vos videtis, quia magnum chaos firmatum est inter nos et vos: nec vos poteritis transire ad nos, nec nos possumus ire ad vos'. Et iterum principes: 'Confitemini alterutrum peccata vestra et orate et communicate de pane benedicto, quod habetis vobiscum, et Deus miserebitur animarum vestrarum'.

[134] Tunc christiani, fide et armis bene instructi, occiderunt omnes Sarracenos captivos quos-cumque ceperant, tam viros quam parvulos et mulieres, et bestias quas habebant secum. Et, continuo, illa gens Sarracenorum irruit super eos, et omnes christiani mortui sunt, et non remansit ex eis nisi quidam miles christianus, qui misit se in aquam et exivit trans flumen inter christianos: et omnes christiani et Sarraceni qui id

${ }^{1475}$ CAI, Liber I, n 15, op. cit., pp. 16, 17. “Al ver el rey de Aragón que aquellas tropas eran muy poco numerosas y que los hombres que en ellas habia eran valientes y estaban provistos de armas y viéndose él con muchos miles de caballeros y peones, llamó a sus nobles consejeros, a los caudillos del pueblo y a los obispos que estaban con él y les pidió consejo sobre qué debía hacer. Entonces el obispo de Pamplona, cuyo nombre era Pedro, le dijo al rey: 'Señor, si me lo ordenas, yo te hablare'. El rey le respondió: 'Habla, señor'. Y dijo: ¿Juzgaras que aquel ejército es poco numeroso? No es poco, sino mucho. Dios está con él y Dios es su defensor. No reclama lo que le es ajeno, sino lo que es suyo; ama la paz, busca la paz. Pues todo amante de la paz ama a Dios. Con la ayuda de Dios no es dificil que muchos terminen en manos de pocos. La victoria en la guerra no reside en la multitud de un ejército, sino que la fuerza procede del cielo. Acuérdate, rey, del pacto que estableciste el año pasado con el rey de León: darle Castrogeriz, Nájera y todos los castillos y ciudades que arrebataste a su madre la reina doña Urraca y de este modo vivir en paz con él. Rey, no luches con él. Pues, si luchas con él, date por vencido y muerto tú y todos los que están contigo." CEA, Libro I, n 115, op. cit., pp. 68, 69. 
miraculum viderunt, mirati sunt. Sarraceni vero, tollentes multa capita christianorum et spolia, abierunt. His ita peractis, consules moventes castra venerunt ad imperatorem et narraverunt ei omnia quaecumque acciderant, et imperator factus est tristis, et venit Toletum et unusquisque in terram suam (66)."1476

\section{Chronica Adefonsi Imperatoris. Poema de Almería. Descripción de Alfonso VII}

\section{"[1] Convenere duces Hispani Francigenaeque:}

per mare per terras Maurorum bella requirunt.

\section{Dux fuit Imperii cunctorum rex Toletani.}

Hic Adelfonsus erat, nomen tenet imperatoris,

[5] facta sequens Catoli, cui competit aequiparari.

Gente fuere pares, armorum vi coaequales.

Gloria bellorum gestorum par fuit horum.

Extitit et testis Maurorum pesima pestis,

quos maris aut Festus non protegit, aut sua tellus"1477.

1476 CAI, Liber II, n 132-134, op. cit., pp. 104-106. “37 (132). Mientras sucedia esto, una parte del ejército de Extremadura atravesó el río llamado Guadalquivir sin la orden del emperador ni de sus jefes militares, marcharon al territorio de los musulmanes, perpetraron numerosos botines e incendios $y$ regresaron al mismo lugar donde anteriormente habian atravesado el rio, y por desgana y por la abundancia de las riquezas que habían cogido no atravesaron el río y permanecieron allí. Pero a media noche se produjo una gran inundación provocada por la lluvia, y el río creció demasiado. Y por la mañana aquel ejército no pudo atravesar el río nadando ni mediante ningún otro sistema.

38 (133). El emperador, previendo lo que iba a suceder, marchó lejos con su propio ejército para no ver la muerte de su gente. Alrededor de la tercera hora del día aquella muchedumbre, levantando su vista, vio dispuestas grandes tropas de moabitas y agarenos, de caballeros y peones, que venían a matarlos, y, aterrados, perdieron al mismo tiempo su audacia y conocimientos de la guerra y llamaron a gritos al jefe militar de Toledo y al conde Rodrigo para que se apiadasen de ellos. Los jefes militares les respondieron: 'Veis que un gran abismo se ha establecido entre nosotros y vosotros. Ni vosotros podréis atravesar adonde nosotros, ni nosotros podemos ir adonde vosotros'. Y de nuevo les dijeron los jefes militares: 'Confesad vuestros pecados unos a otros, orad y comulgad con el pan bendito que tenéis con vosotros, y Dios se apiadará de vuestras almas'.

39 (134). Entonces los cristianos, bien provistos de fe y armas, mataron a todos los musulmanes cautivos que habian apresado, tanto varones como niños y mujeres, y los animales que tenían consigo. $Y$ al instante el ejército de los musulmanes cayó sobre ellos y todos los cristianos murieron, no quedando de ellos sino un caballero cristiano, que se lanzó al agua y emergió al otro lado del río entre los cristianos, $y$ todos los cristianos y musulmanes que vieron este milagro quedaron admirados. Los musulmanes se marcharon llevándose consigo muchas cabezas de cristianos y sus despojos. Una vez así acabado esto, los grandes señores levantando el campamento vinieron ante el emperador, le contaron todo lo que habia sucedido y el emperador se entristeció, volviendo él a Toledo y cada uno a su territorio." CEA, Libro II, $\mathrm{n}^{\circ} 37$ (132)-39 (134) op. cit., pp. 106, 107.

${ }^{1477}$ CAI, Poema de Almería, I, 1, 5, op. cit., pp. 165, 166. “[...] Reuniéronse los caudillos hispanos y francos: / [15] por mar y tierra desean guerrear con los moros. El caudillo de todos fue el rey del imperio toledano; éste era Alfonso, que ostenta el título de emperador siguiendo las hazañas de Carlos, al que corresponde equiparle: fueron iguales en carácter, parejos en la fuerza de sus armas, / [20] igual fue la gloria de las guerras realizadas por ellos. / Y testigo de ello fue la perversa peste de los moros, a los que no protegieron las agitadas aguas del mar o su propia tierra [...]" CEA, Poema de Almería, op. cit., pp. 131, 132. 


\section{III.4.a.- Alfonso VIII}

Crónica latina de los Reyes de Castilla. El valor de Alfonso VIII.

"[...] supplicauerunt ei exiret et uitam suam seruaret, quoniam iratus uidebatur Dominus Deus populo Christiano. Nolens autem eos audite malebat gloriosa morte uitam finire quam rictus de bello recedere; sui uero intelligentes periculum inminere toti Ispanie ipsum de prelio quasi inuitum et renitentem eduxerunt."

Crónica latina de los Reyes de Castilla. Alfonso VIII entra triunfante en Toledo.

"Rex gloriosus et nobilis, hoste superbissimo deuicto et prostrato, receptus est in Toleto cum exultatione et gaudio ab uniuersis populis clamantibus et dicentibus: Benedictus qui uenit in nomine Domini" ${ }^{1479}$.

Historia Rebus Hispaniae. Generosidad de Alfonso VIII.

"Nec erat qui posset alicuius rei causari deffectum, cum et ipsa ciuitas sui habundancia occurerent et prodiga manus nobilis principis omnibus ad omnia necesaria ministraret" ${ }^{\prime 1480}$.

Crónica General de España. Generosidad de Alfonso VIII.

“[...] de las villas mayores et de los castiellos uinieron alli otrossi campannas grandes et muy abondadas de cauallos et de armas, et muy guisadas de todas las cosas que era mester pora leuar en hueste: vianda, lorigas de cuerpos et cauallos, perpuntes, et de todas las otras cosas que pertenesçien pora deffender sus cuerpos en la batalla et lidiar bien - et estas cosas de que ellos uinieron muy guarnidos eran tantas, que serie mucho de contar, assi que entre todos ellos non auie y ninguno que minguado fuesse de ninguna cosa, mas an ellos dauan liberalmientre de sus cosas a los otros et fazienlas con ellos comunales pora todos-et magar que en sus villas et en sus çibdades uiuien

1478 CLRC, 1997, n 13, op. cit., pp. 46, 47. “[...] le suplicaron que se alejase y preservara su vida ya que el Señor Dios se mostraba airado con el pueblo cristiano. Pero no quería oírlos y prefería acabar la vida con muerte gloriosa a retroceder, vencido, de la batalla. Los suyos, dándose cuenta que el peligro era inminente para toda España, lo apartaron del combate, casi de mala gana y a regañadientes." CLRC, 1999, n 13, op. cit., p. 39.

${ }^{1479}$ CLRC 1997, $\mathrm{n}^{\circ} 25$, op. cit., p. 64. "El rey glorioso y noble, vencido y humillado el soberbio enemigo, fue recibido en Toledo con alegría y gozo por todo el pueblo que aclamaba y decía: Bendito el que viene en el nombre del Señor." CLRC 1999, n² 25, op. cit., p. 56.

${ }^{1480} \mathrm{HRH}$, Liber VIII, cap. I, op. cit., p. 259. "Y no había quien pudiera quejarse de la falta de nada, ya que no sólo la propia ciudad aportaba por su riqueza, sino que además la generosa mano del noble príncipe atendia a todos en lo preciso." HHE, Libro VIII, Cap. I, op. cit., p. 308. 
por gouernamiento et mantenimiento de un prinçep, pero del comienço de la su yent ouieron natura de auer uso de armas et nobleza de caualleria, et ganaron de antiguo nonbre de caualgar dandose siempre a ello, de guisa que todauia fizieron muchos buenos fechos et grandes contra moros, et otrossi a las uezes contra cristianos entre ssi mismos unos contra otros, et fizieronlo ellos assi et usaronllo sus parientes apuestamente todauia."

\section{III.4.a.- Fernando III}

Crónica latina de los Reyes de Castilla. Fernando poseído y aconsejado por el Espíritu del Señor

"Rex uero, in quem Spiritus Domini irruerat, ductos saniori consilio, tanquam a Domini Spiritu, pospositis, ne dicam spretis, omnium uoluntatibus et consiliis, Toledo festinanter exiuit, et versus partes illas gloriosus miles Christi cepit ire ${ }^{, 1482}$.

\section{Cronicon Mundi. Semblanza de Fernando III}

"Hic autem rex Fernandus grauissima adolescencia uenustatus, non, ut illa etas assolet, lasciuiam amplaxatus est mundi, sed pius, prudens, humilis, catholicus et benignus senilibus se moribus decorauit. Etenim ita obediebat prudentissime Berengarie regine matri sue, quamuis esset regni culminare sublimatus, ac si esset puer humillimus sub ferula magistrali. Habebat secum prudentissimos cathólicos uiros, quibus tam ipse quam mater totum suum consilium comittebant. In tantum regnum sibi subditum succensus igne catholice ueritas strenue rexit, ut inmicus fidei Christiane totis uiribus persequeretur, et quoscumque reperiebat hereticos, flammis exureret et ipse uice famulorum ignem et ligna in eis comburendis ministrabat. Aderat illi in humilitate iusta seueritas, qua reprobos puniebat, et in seueritate iusta misericors et Clemens humilitas, qua prostatis. Eius regalis animus auaricia numquam potuit inflammari, siquidem uisum est, quod requienerit super eum spiritus sapiencie, qui fuit Adelfonso rege Castelle auo suo, et spiritus fortitudinis et clemencie, qui erat Adefoso rege Legionensi patre ipsius. Quid plura? Quod de nullo regum precedencium legitur, omnino irreprehensibilis fuit, quantum nobis scire datum est, et thorum coniugalem unquam

${ }^{1481}$ CGE, cap. 1012, op. cit., p. 691.

1482 CLRC 1997, n 48, op. cit., p. 91. "Pero el rey, en quien había irrumpido el Espíritu del Señor, guiado por un consejo más saludable, como del Espíritu del Señor, dados de lado por no decir despreciados los pareceres y consejos de todos, salió rápidamente de Toledo y se dirigió a aquellas tierras." CLRC 1999, n 48, op. cit., p. 79. 
minime uiolauit. Duxit namque uxorem ex imperiali genere Romanorum Deo deuotissiman feminam nomine Beatricem, ex qua genuit Adelfonsum, Fredericum, Fernandum, Philippum, Henricum, Sancium, Emanuelem, Alienor, Berengariam et Mariam. Omnibus etiam ecclesiis ita Omnia sua iura seruauit, ut nullus esset qui audelet eas uel in aliquo molestare. In tanta pace regnum sibi subditum rexit, ut mayores uel minores in aliorum res insurgere non auderent."1483

Historia Rebus Hispaniae. Fernando III pacificador "[...] ut regnum et patriam iuxta morem aui sui nobilis Aldefonsi in pace et modestia gubernaret usque ad regni sui uicesimun quintum annum ${ }^{\text {"1484 }}$.

\section{Crónica General de España. Virtudes de Fernando III}

"Diz la estoria que este rey don Fernando, pues que tanto ouo puiado et ouo ganado tal prez et ouo su onrra llegada al logar que uos contado auemos, et fue mucho amado et mucho conprido de Dios - et de los terrenales - [...] Pues por morir desta manera que el morio, tan alto et tan amado et seyendo tan reçelado, muy buena le era a el la muerte et mucho onrrada; et con muy tenprada sazon le vino. [...] Et que mucho omne del quisiese decir, los sus fechos le dan testimonio ende. Mas este rey tanto punno en los vsos de todas bondades guisar et obrar siempre en toda la su uida, que nombre conplido de todo buen prez gano en sus grandes conquistas fazer et en todos otros bienes conplidos, quales nin cuantos omne contar non podrie: en heredar caballeros et

${ }^{1483}$ CM, Liber IV, n 93, op. cit., pp. 332, 333. "Mas este rey Fernando, fermosado de muy noble mançebia, no, como aquella edad suele, abraçó la loçania del mundo, mas honrrola seyendo piadoso, prudente, humilde, catholico y benigno. Y con semejables bienes se honrró; y asi obedecía a la muy sabia Berenguella su madre, aunque era enxalçado en la alteza del reyno, como si fuese muy humilde moço so la palmatoria del maestro. Tenía consigo varones católicos muy sabios, a los quales encomendaua él y su madre todo consejo; asi que él, encendido con fuego de la verdad católica, [en tanto] noblemente rigio el reyno a ssi subjecto, que los enemigos de la fee christiana perseguia con todas [sus] fuerças, e cualesquiera hereges que hallava, quemava con fuego, en el fuego y las brasas y la llama aparejava para que los quemar. Tenía tanta humilldad y deecha crueldad contra los malos, que los feria, y en la justa crueldad tenía humildad misericordiosa y clemente, por la qual perdonaba a los enemigos vencidos; $y$ su real coraçon nunca se pudo ynflamar de avariçia, assi que fue visto que folgó sobrél [el] spiritu de sabiduria que fue en Alfonso rey de Castilla, su abuelo, y el espiritu de fortaleza y clemencia que era Alfonso su padre, rey de Leon; ¿Qué es más? De lo que [en] ningun rey passado se leye, fue de todo en todo sin reprension quanto nos es dado de saber, y nunca poco ni más ensuziió el lecho conjugal. Vbo por muger, del linaje de los emperadores de Roma, a Beatriz, fembra muy deuota a Dios, de la qual engendró a Alfonso, Fabrique, Fernando, Felipe, Enrrique, Sancho, Manuel, Leonor, Beringuella, [e] Maria; y guardó todos los derechos a las iglesias, asi que non auia alguno que osase en cosa enojarla. En tanta paz rigió el reyno a sí subjeto, que mayores ni menores no se osauan mouer para tomar las cosas de los otros". CM, Liber IV, n 93, op. cit., pp. 332, 333.

${ }^{1484}$ HRH, Liber IX, cap. X, op. cit., p. 290. "[...] llevó con paz y moderación las riendas del reino y de la patria hasta el año vigésimoquinto de su reinado, siguiendo la pauta de su abuelo el noble Alfonso." HHE, Libro IX, cap. X, op. cit., p. 341. 
ricos omnes, ordenes, iglesias, adalides, almogauares, et a todos quantos otros el razon auie de fazer merced; en dar buenos fueros et franquezas et grandes libertades; en ser muy iustiçiero et non menguar y alli o deuie. [...] Este fue rey mucho mesurado et conplido de toda cortesía; et de buen entendimiento, muy sabidor; et muy brauo et muy sannudo en los logares ol conuenie, muy leal et muy verdadero en todas cosas que lealtad debiese seer guardada. Pero que muchol temien los moros, era dellos mucho amado; esto era por la grant lealtad que en el auien siempre fallada. Et enxalçador de cristianismo, abaxador de paganismo, mucho olmidoso contra Dios, mucho obrador de sus obras et muy husador dellas, muy católico, muy eclesiástico, mucho amador de la yglesia, muy rreçelador de en ninguna razon yr contra ella nin pasar contra los sus mandamientos. Rey de todos fechos granados, segunt que en la estoria es ya contado et departido en muchos logares que saco de Espanna el poder et el apremiamiento de los contrarios de la fe de Cristo, et les tollio el sennorio et los torno al suyo a quantos al su tiempo eran. [...] En Dios touo su tienpo, sus oios et su coraçon, por que el siempre fue tenudo del ayudar et guiar en todos sus fechos, et del adelantar et puiar en todas ondras. $" 1485$

\section{III.4.a.- Alfonso $X$}

Crónica General de España. Alabanza y continuidad de lo dispuesto por Fernando III "Ssennor te dexo de toda la tierra de la mar aca, que los moros del rey Rodrigo de Espanna ganado ovieron; et en tu sennorio finca toda: la una conquerida, la otra tributada. Sy la en este estado en que te la yo dexo la sopieres guardar, eres tan buen rey commo yo; et sy ganares por ti mas, eres meior que yo; et si desto menguas, non eres tan bueno commo yo." 1486

Espéculo. Función justiciera del soberano

"Sspiritualmiente de-/ col. b zimos que el rrey es alma del pueblo e es sennor señalado porque está ffazendado en toller ssus yerros de ssu tierra; e rrey es mayor ssobre todo ssu regno por quien todos los del rregno reciben dono de Dios en sser vna cosa". ${ }^{487}$

\footnotetext{
${ }^{1485}$ CGE, cap. 1131 , op. cit, p. 771.

${ }^{1486}$ CGE, cap. 1132, op. cit., pp. 772, 773.

1487 Espéculo, Libro II, Ley I, op. cit., p. 116.
} 
Espéculo. El rey como hacedor de leyes.

"Ninguno non puede facer leyes sinon emperador o rey o otro por su mandamiento dellos. E si otros las fezieren sin su mandato non deven aver nombre leyes nin deben seer obdedecidas nin guardadas por leyes nin deven valer en ningún tiempo". ${ }^{1488}$

Espéculo. El Rey y la divinidad en la justicia

“Onrrado deue sseer el rey conmo aquél que tiene logar de Nuestro Ssennor Dios en tierra para ffazer iustiçia en ssu rregno quanto en el temporal e porque lieua nombre de Nuestro Ssennor en quantol dizen rrey e porque Ihesu Christo los onrró en que quisso nasçer de linage de los rreys. Otrossí deue sseer onrrado el rrey porque es ssennor ssobre ${ }^{13 v}$ ssobre [sic] todos los de ssu tierra e porque es puesto para ffazer bien a ssus gientes e para guardarlos de mal". ${ }^{1489}$

Fuero Real. Atacar al rey es atacar a Dios.

"E desí, ordenó la cort terrenal en aqulla misma guisa et en aquella manera que era ordenada la Suya en el cielo. Et puso al Rey en su logar, cabeca et comienço de todo el pueblo, assí como puso Sí mismo cabeça et comienço de los Angeles et de los Archangeles. Et diol poder de guiar su pueblo. Et mandó que todo el pueblo en uno, et cada uno omne por sí recibiesse et obedeciesse los mandamientos de su Rey, et que lo amassen et que lo temiessen et quel guardassen, tan bien su fama et su ondra como su cuerpo mismo. Ca la Sancta Scriptura diz que non es ninguno mayor enemigo que aquel que dann la fama del otro. E diz, en otro logar, que tod ome que de los fechos et d elos dichos del Prinçeps algun mal retrae que es descomulgado et deue auer la pena de aquél que faze sacrilegio et iaze en culpa a todo el pueblo." 1490

Las siete partidas. De emperadores y reyes.

"Ley I

Qué cosa es emperador, et por qué ha asi nombre, et por que convino que fuese, et qué lugar tiene.

Imperio es grant dignidat, et noble et honrada sobre todas las otras que los homes pueden haber en este mundo temporalmente. Ca el señor á quien Dios tal honra da es

\footnotetext{
${ }^{1488}$ Espéculo, Libro II, Ley I, op. cit., p. 116.

${ }^{1489}$ Espéculo, Libro II, Titulo I, Ley V, op. cit., p. 117.

${ }^{1490}$ Fuero Real, Libro I, Titulo II, op. cit., p. 6.
} 
rey et emperador, et á él pertenesce segunt derecho et el otorgamiento quel ficieron las gentes antiguamente de gobernar et de mantener el imperio en justicia, et por eso es llamado emperador, que quier tanto decir como mandador, porque al su mandamiento deben obedescer todos los del imperio: et él non es tenudo de obedescer á ninguno, fueras ende al papa en las cosas espirituales. Et convino que un home fuese emperador, et hobiese este poderio en tierra por muchas razones: la una por toller desacuerdo de entre las gentes et ayuntarlas en uno, lo que non podrien facer si fuesen muchos los emperadores, porque segunt natura el señorio non quiere compañero nin lo ha menester, como quier que en todas guisas convien que haya homes bonos et sabidores quel consejen et le ayuden; la segunda para facer fueros et leyes por que se judguen derechamente las gentes de su señorio; la tercera para quebrantar los soberbiosos, et los torticeros et los malfechores, que por su maldat ó por su poderio se atreven á facer mal ó tuerto á los menores; la quarta para amparar la fe de nuestro señor Iesu Cristo, et quebrantar los enemigos della. Et otrosi dixieron los sabios que el emperador es vicario de Dios en el imperio para facer justicia en lo temporal, bien así como lo es el papa en lo espiritual.

Ley II

Qué poder ha el emperador, et cómo debe usar del imperio.

El poderio que ha el emperador es en dos maneras, la una de derecho, et la otra de fecho; et aquel que ha segund derecho es este, que puede facer ley et fuero nuevo et mudar el antiguo, si entendiere que es á pro comunal de su gente; et otrosi quando fuese escuro ha poder de lo esclarescer; et puede otrosi toller la costumbre usada quando entendiere que era dañosa, et facer otra que fuese buena. Et aun ha poderio de facer justicia et escarmiento en todas las tierras del imperio quando los homes ficiesen por qué, et otro ninguno non lo puede facer sinon aquellos á qui lo él mandase, ó á quien fuer otorgado por previllejo de los emperadores. Et otrosi él ha poderio de poner portadgos, et otorgar ferias nuevamente en los lugares que entendiere que lo debe facer, et non otro home ninguno, et por su mandado et por su otorgamiento se debe batir moneda en el imperio, et maguer muchos grandes señores lo obedescen non la puede ninguno facer en su tierra, si non aquellos á quien él otorgase que la ficiesen; et él solo es otrosi poderoso de partir los términos de las provincias et de las villas, et por su mandado deben facer guerra, et tregua et paz. Et quando acaesce contienda sobre los previllejos que él dió, ó los otros emperadores que fueron ante que él, tal pleito como este él lo debe librar et otro non. Et aun ha poderio de poner adelantados et 
jueces en las tierras que judguen en su lugar segunt fuero et derecho, et puede tomar dellos yantares, et trebutos et censo en aquella manera que lo acostumbraron antiguamente los otros emperadores. Et como quier que los homes del imperio hayan señorio enteramente en las cosas que son suyas de heredat, con todo eso quando alguno usare dellas contra derecho ó como non debie, él ha poder de lo endereszar et escarmentr como toviere por bien. Otrosi decimos que quando el emperador quisiese tomar heredamiento ó alguna otra cosa á algunos para sí ó para darlos á otri, como quier que él sea señor de todos los del imperio para ampararlos de fuerza et para mantenerlos en justicia et en derecho, con todo eso non puede él tomar á ninguno lo suyo sin su placer, si non ficiese tal cosa por que lo debiese perder segunt ley. Et si por aventura gelo hobiese á tomar por razon que el emperador hobiese menester de facer alguna cosa en ello que se tornase á pro comunal de la tierra, tenudo es por derecho del dar ante buen camio por ello que vala tanto ó mas, de guisa que él finque pagado á bien vista de homes buenos. Ca maguer los romanos, que antiguamente ganaron con su poder el señorio del mundo, ficiesen emperador et otorgasen todo el poder et el señorio que habien sobre las gentes para mantener et defender derechamente el pro comunal de todos, con todo eso non fue su entendimiento del facer señor de las cosas de cada uno, de manera que las podiese tomar á su voluntad, sinon tan solamente por alguna de las razones que desuso son dichas. Et este poder ha el señor luego que es scogido de todos aquellos que han poderio de lo escoger ó de la mayor parte, seyendo fecho rey en Alemaña en aquel lugar do se costumbraron á facer antiguamente los que fueron escogidos para emperadores.

Ley III

Qué poderio debe haber el emperador de fecho.

Poderoso debe el emperador ser de fecho, de manera que el su poder sea tan complido et asi ordenado, que pueda mas que los otros de su señorio para apremiar et costreñir á los que lo non quisiesen obedescer. Et para haber tal poder como este ha mester que se enseñoree de las caballerias et que las parta, et que las acomiende á tales cabdiellos que lo amen et que las tengan por él et de su mano, de manera que conoscan á él por señor, et á los otros que los cabdiellan por guiadores. Otrosi debe seer poderoso de los castiellos, et de las fortalezas et de los puertos del imperio, et mayormente de aquellos que estan en frontera de los bárbaros et de los otros regnos sobre que el emperador non ha señorio, porque en su mano et en su poder sea todavia la entrada et la salida del imperio. Otrosi deben haber homes señalados, et sabidores, et entendudos, et leales et 
verdaderos quel ayuden et le sirvan de fecho en aquellas cosas que son menester para su conseio et para facer justicia et derecho á la gente, ca él solo non podria veer nin librar todas las cosas, por que ha mester por fuerza ayuda de otros en quien se fie que cumplan en su lugar, usando del poder que dél reciben en aquellas cosas que él non podrie por sí complir. Otrosi dixeron los sabios que el mayor poderio et mas complido que el emperador puede haber de fecho en su señorio es quando él ama á su gente et él es amado della, et mostraron que se puede ganar et ayuntar este amor faciendo el emperador justicia derechamente á los que la hobieren menester, et habiendo á las vegadas merced en las cosas que con alguna razon guisada la puede facer, et honrando su gente de palabra et de fecho: et mostrándose por poderoso et por amador puede cometer et facer grandes fechos et cosas granadas á pro del imperio. Et aun dixeron que maguer el emperador amase á su gente et ellos á él, que se podrie perder aquel amor por tres razones; la primera quando él fuese torticero manifiestamente, la segunda quando despreciase et aviltase los homes de su señorio, la tercera quando él fuese tan cruo contra ellos, que hobiesen á haber dél grant miedo demas.

Ley IV

Cómo el emperador debe usar de su poderio.

Dos temporales son, segunt dixieron los sabios antiguos, en que los emperadores deben usar de las cosas que son mester para enderezamiento de lo que han de facer en cada uno destos tiempos; et el uno es tiempo de paz, et el otro de guerra. Et en el tiempo de paz se deben aparejar et anteveer todas las cosas que les son menester para en tiempo de guerra, porque las tengan prestas et se puedan mejor ayudar dellas quando les fuese menester. Otrosi deben en ese mismo tiempo entender en enderezamiento de su gente et de su tierra, ayudándose de leyes et de fueros derechos, et usando dellos contra los soberbios et los torticeros, dando su derecho á cada uno. Otrosi deben enderezar et ordenar sus rentas et todo lo suyo de manera que lo hayan bien parado, et que se puedan ayudar dello; ca maguer la riqueza del imperio sea muy grande, si bien parada non fuese, poco se podrá el señor aprovechar della. Débese otrosi trabajar en buena manera de ayuntar algun tesoro de que se pueda acorrer quando algunt granado et honrado fecho se le descubriese á so hora, porque lo pudiese mas ligeramente acometer et acabar. Otrosi dixieron los sabios antigos que el emperador debe usar en tiempo de guerra de armas et de todas aquellas cosas de que se pueda ayudar contra sus enemigos por mar et por tierra, et aun mostraron que se debie aconsejar el emperador en fecho de guerra con los homes honrados, et con los caballeros, et con los otros que 
son sabidores della, et que han hi á meter las manos quando menester fuere, et debe usar de su poderio por conseio dellos, bien asi como se guia por conseio de los sabidores de derecho para toller las contiendas que nacen entre los homes.

Ley $V$

Qué cosa es rey, et cómo es puesto en lugar de Dios.

Vicarios de Dios son los reyes cada uno en su regno puestos sobre las gentes para mantenerlas en justicia et en verdad quanto en lo temporal, bien asi como el emperador en su imperio. Et esto se muestra complidamente en dos maneras: la primera dellas es espiritual segunt lo mostraron los profetas et los santos, á quien dió nuestro Señor grcia de saber las cosas ciertamente et de facerlas entender; la otra es segunt natura, asi como mostraron los homes sabios que fueron como conoscedores de las cosas naturalemnte: et los santos dixeron que el rey es señor puesto en la tierra en lugar de Dios para complir la justicia et dar á cada uno su derecho, et por ende lo llamaron corazon et alma del pueblo; ca asi como el alma yace en el corazon del home, et por ella vive el cuerpo et se mantiene, asi en el rey yace la justicia, que es vida et mantenimiento del pueblo de su señorio. Et bien otrosi como el corazon es uno, et por él reciben todos los otros miembros unidat para seer un cuerpo, bien asi todos los del regno, maguer sean muchos, porque el rey es et debe seer uno, por eso deben otrosi todos ser unos con él para servirle et ayudarle en las cosas que él ha de facer. Et naturalmente dixieron los sabios que el rey es cabeza del regno; ca asi como de la cabeza nacen los sentidos por que se mandan todos los miembros del cuerpo, bien asi por el mandamiento que nace del rey, que es señor et cabeza de todos los del regno, se deben mandar, et guiar et haber un acuerdo con él para obedescerle, et amparar, et guardar et endereszar el regno onde él es alma et cabeza, et ellos los miembros.

Ley VI

Qué quiere decir el rey, et por qué es asi llamado.

Rey tanto quiere decir como regidor, ca sin falla á él pertenesce el gobernamiento del regno, et segunt dixieron los sabios antigos, señaladamente Aristóteles en el libro que se llama Politica, en el tiempo de los gentiles el rey non tan solamente era guiador et cabdiello de las huestes, et juez sobre todos los del regno, mas aun era señor sobre las cosas espirituales que estonce se facien por reverencia et por honra de los dioses en que ellos creien, et por ende lo llamaban rey, porque regie tambien en lo temporal como en lo espiritual. Et señaladamente tomó el rey nombre de nuestro señor Dios, ca asi como él es dicho rey sobre todos los otros reyes, porque dél han nombre, et él los 
gobierna et los mantiene en su lugar en la tierra para facer justicia et derecho; asi ellos son tenudos de mantener et de gobernar en justicia et en verdat á los de sus señorio. Et aun otra manera mostraron los sabios por que el rey es asi llamado, et dixieron que rey tanto quier decir como regla, ca bien asi como por ella se conoscen todas las torturas et se endereszan, asi por el rey son conoscidos los yerros et enmendados.

Ley VII

Por qué convino que fuese rey, et qué lugar tiene.

Complidas et verdaderas razones mostraron los sabios antiguos por que convino que fuese rey demas daquellas que desuso deximos del emperador. Et como quier que ante fablamos del emperador por la honra del imperioque del rey; pero antiguamente fueron primero los reyes que los emperadores. Et una de las razones que mostraron por qué convino que fuese rey es esta, que todas las cosas que son vivas traen consigo naturalmente todo lo que han mester et que les conviene, et non han mester que otri gelo acarree dotra parte. Ca si son de vestir, ellas se son vestidas de suyosé, las unas de péñolas et las otras de cabellos, et las otras de cuero, et las otras de escamas et de conchas, cada una dellas segunt su natura, porque non han mester que texan para seer vestidas. Otrosi para defenderse las unas traen picos, et las otras dientes, et las otras uñas, et las otras cuernos, et las otras aguijones ó espinas, por que non les conviene de buscar otras armas con que se defiendan. Otrosi lo que comen et beben cada una lo falla segunt que le es mester, de guisa que non han de buscar quien gelo adobe, nin cosa con que les sepa bien, nin lo han á comprar, nin han á labrar por ello; mas el home de todo esto non ha nada para sí á menos de ayuda de muchos que lo busquen et le alleguen aquellas cosas quel convienen, et este ayudamiento non puede seer sin justicia, la que non podrie ser fecha sinon por mayorales á quien hobiesen los otros á obedescer. Et estos seyendo muchos, non podrie seer que algunas vegadas non se desacordasen, porque naturalmente las voluntades de los homes son departidas, et los unos quieren valer mas que los otros; et por ende fue mester por derech fuerza que hobiesen uno que fuese cabeza dellos, por cuyo seso se acordasen et se guiasen, asi como todos los miembros del cuerpo se guian et se mandan por la cabeza, et por esta razon convino que fuesen reyes, et los tomasen los homes por señores. Otra razon hi ha escripta segun dicho de los profetas et de los santos por que fueron los reyes; et esta es que la justicia que nuestro señor Dios habie á dar en el mundo porque los homes viviesen en paz et en amor, que hobiese quien la ficiese por él en las cosas temporales, dando á cada uno su derecho segunt su merescimiento. Et tiene el rey lugar de Dios pra 
facer justicia et derecho en el reyno en que es señor, bien asi como desuso deximos que lo tiene el emperador en el imperio, et aun demas que el rey lo tiene por heredamiento, et el emperador por eleccion.

Ley VIII

Quál es el poderio del rey, et cómo debe usar dél.

Sabida cosa es que todos aquellos poderes que desuso deximos que los emperadores han et deben haber en las gentes de su imperio, que esos mismos han los reyes en las de sus regnos, et mayores; ca ellos non tan solamente son señores de sus tierras mientras viven, mas aun á sus finamientos las pueden dexar á sus herederos, porque han el señorio por heredat, lo que non pueden facer los emperadores que lo ganan por eleccion, asi como desuso deximos. Et demas el rey puede dar villa ó castillo de su regno por heredamiento á quien se quisiere, lo que non puede facer el emperador, porque es tenudo de acrecentar su imperio et de nunca menguarlo, como quier que los podrie bien dar á otro por servicio quel hovbiese fecho, ó que prometiese de facer por ellos. Otrosi decimos quel rey se puede servir et ayudar de las gentes del regno quandol fuere menester en muchas maneras que lo non podrie facer el emperador. Ca el emperador por ninguna cuita quel venga non puede apremiar á los del imperio quel den mas daquello que antiguamente fue acostumbrado de dar á los otros emperadores, si de su grado non lo quisieren facer; mas el rey puede demandar et tomar del regno lo que usaron los otros reyes que fueron ante que él, et aun mas á las sazones que lo hobiese tan grant mester para pro comunal de la tierra, que lo non pueda escusar; bien asi como los otros homes que se acorren al tiempo de la cuita de lo que es suyo por heredamiento. Otrosi decimos que el rey debe usar de su poderio en aquellos tiempos et en aquella manera que desuso deximos que lo puede et debe facer el emperador.

Ley $I X$

En quántas maneras se gana el regno derechamente.

Verdaderamente es llamado rey aquel que con derecho gana el señorio del regno, et puédese ganar por derecho en estas quatro maneras: la primera es quando por heredamiento hereda los regnos el fijo mayor, á alguno de los otros que son mas propincos parientes á los reyes al tiempo de su finamiento; la segunda es quando lo gana por avenencia de todos los del regno que lo escogen por señor, non habiendo pariente que deba heredar el señorio del rey finado por derecho; la tercera razon es por casamiento, et esto es quando alguno casa con dueña que es heredera de regno, que maguer él non venga de linage de reyes, puédese llamar rey despues que fuere 
casado con ella; la quarta es por otorgamiento del papa ó del emperador queando alguno dellos face reyes en aquellas tierras en que han derecho de lo facer: et los que ganan los regnos en alguna de las maneras que desuso deximos son dichos verdaderamente reyes, et deben siempre mas guardar la pro comunal de su pueblo que la suya misma, porque el bien et la riqueza dellos es como suyo, et otrosi deben amar et honrar á los mayores, et á los medianos et á los menores, á cada uno segunt su estado, et placerles con los sabios, et alegrarse con los entendudos, et meter amor et acuerdo entre su gente, et ser justicieros dando á cada uno su derecho, et deben fiar mas en los suyos que en los estraños, porque ellos son sus señores naturales, et non por premia."1491

${ }^{1491}$ LSP, Partida II, Titulo I, Ley I-IX, pp. 3-10. 